Engineered Barrier Development for a Nuclear Waste Repository Located in Basalt

An Integration of Current Knowledge

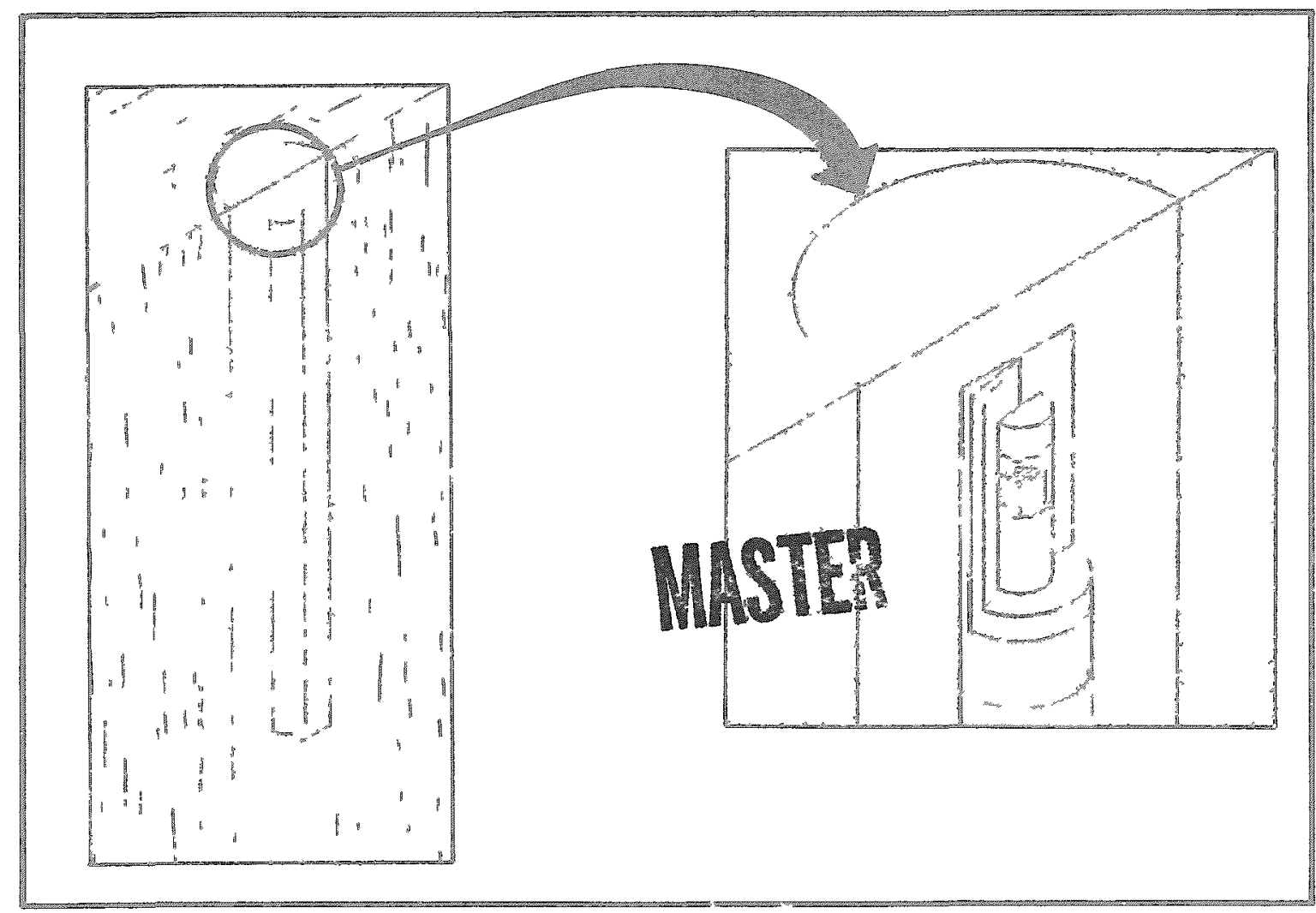

Propared ror the United Stanss

Deparimen of Energy

Under Conirad OE-ACOG-TTRLOU⿴囗十

Pockwell lntemational

Rockwell Hamiord Operâtions

Energy Systems Group 


\section{DISCLAIMER}

This report was prepared as an account of work sponsored by an agency of the United States Government. Neither the United States Government nor any agency Thereof, nor any of their employees, makes any warranty, express or implied, or assumes any legal liability or responsibility for the accuracy, completeness, or usefulness of any information, apparatus, product, or process disclosed, or represents that its use would not infringe privately owned rights. Reference herein to any specific commercial product, process, or service by trade name, trademark, manufacturer, or otherwise does not necessarily constitute or imply its endorsement, recommendation, or favoring by the United States Government or any agency thereof. The views and opinions of authors expressed herein do not necessarily state or reflect those of the United States Government or any agency thereof. 


\section{DISCLAIMER}

Portions of this document may be illegible in electronic image products. Images are produced from the best available original document. 


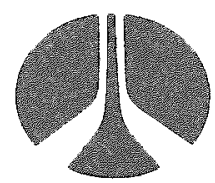

\section{Rockwell International \\ Rockwell Hanford Operations \\ Energy Systems Group \\ Richland, WA 99352}

\section{OHSCLAMMEF}

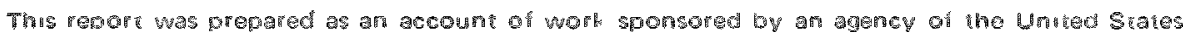

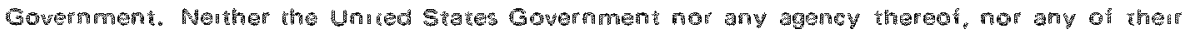

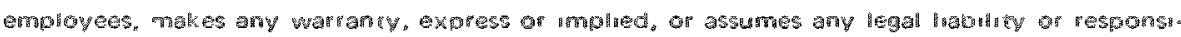

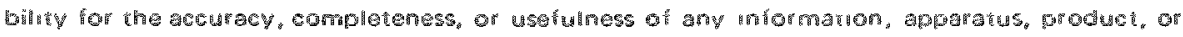

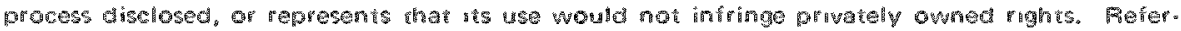

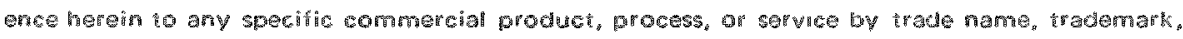

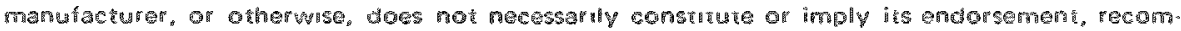

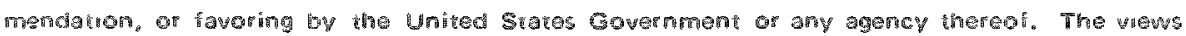
and optrions of auhhors expressed heran do not necgssar Sraces sovernment on any agency horeot.

ASALLABLE WOMTHE

NATIONAL TECHNICAL INFORMATION SERVICE

SFRUNGFIELD, VA, 221EI

PFICE: MICROFICHE W.00

PAPEB COPY 17.00 
RHO-BWI-ST-7

Distribution Catagories

UC $-11 /$ UC -70

\title{
ENGINEERED BARRIER DEVELOPMENT FOR A NUCLEAR WASTE REPOSITORY IN BASALT: \\ AN INTEGRATION OF CURRENT KNOWLEDGE
}

\author{
Principal Author \\ M. J. Smith
}

\section{Authors}

G. J. Anttonen

G. S. Barney

E. L. Moore

W. E. Coons

A. F. Noonan

F. N. Hodges

J. E. O'Rourke

R. G. Johnston

W. W. Schulz

J. D. Kaser

R. M. Manabe

S. C. McCare

C. L. Taylor

B. J. Wood

M. I. Wood

\section{Engineered Barriers Group}

Scientific Technologies

Basalt Waste Isolation Project

May 1980

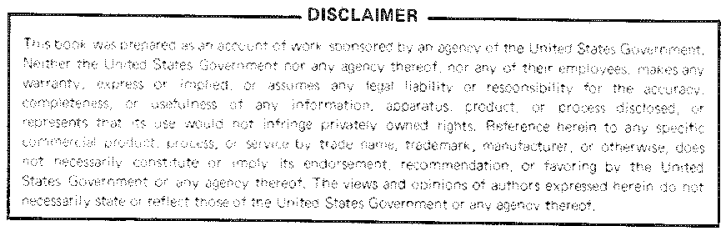

Rockwel1 International

Rockwell Hanford Operations

Energy Systems Group

Richland, Washington 99352 


\title{
RHO-BWI-ST-7
}

\author{
DISTRIBUTION
}

This report has been distributed according to the categories "Environmental Control Technology and Earth Sciences," UC-11, and "Nuclear Waste Management, "UC-70, as given in the Standard Distribution for Unclassified Scientific and Technical Reports, TID -4500 . 
RHO-BWI-ST-7

SECTION ACKNOWLEDGMENTS

Executive Summary

1.0 Introduction to the Report

2.1 Introduction to Multiple Barriers

2.2 Functions of the Engineered Barriers System

2.3 Rock Characteristics and Geologic Setting

2.4 Groundwater Composition

2.5 Repository Conditions

2.6 Waste Forms

2.7 The Canister and Overpack

2.8 Backfills and Other Engineered Barriers

2.9 Waste-Basalt Interactions

2.10 Sorption Studies

2.11 Preliminary Modeling of the Near-Field Environment

3.1 Introduction to Borehole Plugging

3.2 Concepts

3.3 Description of the Environment

3.4 Selection of Candidate Plug Materials

3.5 Emplacement Machines
AUTHOR

J. D. Kaser

M. J. Smith

M. J. Smith

W. E. Coons

E. L. Moore

M. J. Smith

A. F. Noonan

M. I. Wood

R. M. Manabe

F. N. Hodges

R. G. Johnston

W. E. Coons

E. L. Moore

W. W. Schulz

M. I. Wood

W. W. Schuiz

W. E. Coons

G. S. Barney

B. J. Wood

M. I. Wood

F. N. Hodges

F. N. Hodges

F. N. Hodges

F. N. Hodges

G. J. Anttonen

J. E. O'Rourke

C. L. Taylor

S. C. McCare 1 
Section Acknowledgments (continued)

3.6 Laboratory Testing

G. J. Anttonen

J. E. O'Rourke

C. L. Taylor

S. C. McCare1

3.7 Preconceptual Plug Design

G. J. Anttonen

J. E. O'Rourke

C. L. Taylor

S. C. McCarel

3.8 Borehole Plugging Field Tests

F. N. Hodges 
Rockwell Haniord Operations

Energy Systems Group

P.O. Box 800

Richland, WA 99352

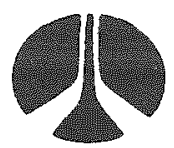

Rockwell

International

August 1980

ENGINEERED BARRIER DEVELOPMENT FOR A NUCLEAR WASTE REPOSITORY

IN BASALT: AN INTEGRATION OF CURRENT KNOWLEDGE

This document represents a compilation of data and interpretive studies conducted as part of the engineered barriers program of the Basalt Waste Isolation Project. The overall objective of these studies is to provide information on barrier system designs, emplacement and isolation techniques, and chemical reactions expected in a nuclear waste repository located in the basalts underlying the Hanford Site within the state of Washington.

This report is being given a broad distribution extending throughout the scientific community to ensure that input and comments are received regarding the information contained herein. If you have any comments or suggestions regarding the information contained in this report, please contact Dr. Raul A. Deju, Director of the Basalt Waste Isolation Project, Rockwell Hanford Operations, Post Office Box 800, Richland, Washington, 99352.

Sincerely,

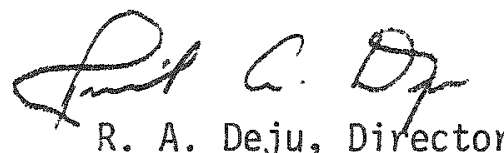

Basalt Waste Isolation Project

RAD/dks 


\section{EXECUTIVE SUMMARY}

The United States is developing systems of engineered barriers to provide additional protection against unacceptable radionuclide releases from nuclear waste repositories, in view of the complexity and uncertainty in predicting the long-term reliability of geologic formations as barriers to radionuclide migration from the repositories. The engineered barriers will be designed to provide this additional protection, taking into account the properties of the waste, the waste canister, and the repository environment. Specifically, the barrier system will be designed to protect the canister from corrosion and mechanical rupture and, as a backup function, to sorb or fix any radionuclide that could conceivably be released from the waste in the unlikely event of canister failure and leaching of the waste by groundwater.

The multiple barriers activity of the Basalt Waste Isolation Project aims at specifying for each candidate waste form an effective site specific barrier system for use in a repository in basalt. In order to accomplish this objective, the following information is being gathered:

- Definition of acceptable limits for the release of radionuclides to the biosphere and development of other system performance criteria based on applicable government regulations

- Determination of the attenuating effect of the surrounding geologic formations upon radionuclides released from waste to the biosphere

- Definition of the environment expected in the repository

- Assessments of barrier materials performance in the repository environment.

When the above information is assembled, alternative barrier system designs can be generated and an acceptable design specified for each waste form. Performance must be extrapolated with confidence into the future which requires modeling of time-dependent behavior based upon established physical and chemical relationships. 
In order to $\mathrm{plan}$ an efficient research and development program to gather required information, preliminary barrier system designs will be generated to define problems, to identify the specific information required, to establish the required accuracy of the information, and to assess the relative importance of the information collected.

While the concept of an engineered barrier system has been described in general terms in the past (Westerman, 1979; DOE and USGS, 1979), a more detailed concept has been developed by the Basalt Waste Isolation Project as a basis for defining a supporting reseach and development program. This concept of a five-component system comprised of waste form, canister, buffer, overpack, and backfi11, is shown in Figure 2-3 and is discussed in Section 2.2.2. This conceptual system is not necessarily a final design approach, but has been chosen as a specific starting point for developing an optimum system. The component barriers and their time-dependent functions are outlined in Table 2-1. The borehole wall grout and the retrieval sleeves shown in Figure 2-3 are provided as operational conveniences and are not considered important barriers against radionuclide release.

The geologic characteristics of the Columbia River basalts in southeastern Washington, which are being studied as candidate rock formations for a high-level nuclear waste repository, are discussed in Section 2.2. These Miocene basalts are at least 1,500 $\mathrm{m}$ thick and are overlain by up to $200 \mathrm{~m}$ of Pliocene and Pleistocene fluvial and glaciofluvial sediments. The chemical composition of the basalts is being determined to aid in making stratigraphic correlations and to provide the basis for determining waste-groundwater-rock interactions. Chemical compositions including both major elements and trace elements have been determined and used to clarify several stratigraphic relationships.

The mineralogy of the major basalt flows has been described. The mineral components of basalt are generally simple and the relative abundance of mineral phases is useful for making stratigraphic correlations and in predicting the hydrothermal reactivity of basalt. The primary minerals occurring in varying proportions with glass are plagioclase solid solutions, augite, pigeonite, ilmenite, magnetite, and 
olivine. Basalts with a large fraction of glassy phases are expected to undergo hydrothermal reactions more readily than basalts containing less glassy phases and more crystalline mineral phases.

The principal secondary minerals formed by the alteration of basalt by groundwater are clays and zeolites. The secondary minerals, which are found in fractures, interbeds, and vesicles, control radionuclide migration through basalt because of their sorptive capacity. The identification, composition, and distribution of secondary minerals have been worked out with the aid of electron microprobe and $X$-ray diffraction analysis of basait samples.

The geochemical characteristics of the groundwaters found in the deep basalts are discussed in Section 2.4. Several studies have been completed describing in detail the hydrologic properties and hydrochemical data of important aquifers within the Columbia Plateau basalt system. (ARHCO, 1976; Deju and Others, 1977; Deju and Fecht, 1979; Gephart and Others, 1979a, 1979b).

Preliminary chemical compositions for groundwater in water-bearing horizons within the Columbia River basalts in the Pasco Basin have been determined. From these measurements, it has been determined that as distance from the major recharge area increases, calcium and magnesium content decreases, sodium and total dissolved solids increase, and sulfate decreases. Based on chemical analysis, a synthetic groundwater recipe has been developed for hydrothermat interaction and corrosion experiments.

The near field of the repository is not only controlled by the nature of the rock and the entrained water, but also by the temperature and pressure conditions at depth. The repository conditions expected in a deep basalt layer are discussed in Section 2.5. Preliminary calculations show that the average repository temperature wi11 increase to $185^{\circ} \mathrm{C}$ in 50 years if the repository is filled with a mixture of 10-year-old pressurized water and boiling water reactor spent fuel elements at an initial thermal loading of $10 \mathrm{~kW} /$ acre. As expected, temperature peaks in the basalt become lower and occur later as distance from the repository increases. 
At a repository depth of $1,000 \mathrm{~m}$ the 7 ithostatic pressure is expected to be 300 bars. The hydrostatic pressure at the same depth would be approximately 100 bars. The equilibrium pressure of water in a confined aquifer would be between the lithostatic pressure and the hydrostatic pressure. The pressure in a repository prior to backfilling will be slightly above atmospheric pressure. After backfilling, the fluid pressure will rise to equilibrium pressure at a rate controlled by the influx of groundwater, by expansion or compaction of backfill and rock, and possibly by formation of steam.

The interaction of hot groundwater and the basalt in the heated zone of the repository may temporarily acidify the groundwater, affecting the performance and selection of the barrier materials. It is expected that the groundwater pH will return to near the pre-repository value as the repository cools down.

The Eh, or redox, potential of the groundwater to a large extent controls the oxidation state of radionuclides dissolved in the groundwater. The Eh of the Grande Ronde Basalt groundwater is calculated to be in the range of -0.50 to -0.54 .

The performance of waste forms under repository conditions must also be characterized to devise a system of engineered barriers. Waste form chemistry and physics are discussed in Section 2.6. Waste forms presently being considered include packed spent power reactor fuel elements and various stable solids incorporating high-level waste from spent fuel reprocessing as backups. The latter waste forms include glass, tailored ceramics, and various composite solids.

After carefully assessing the environment in a repository in basalt, the Basalt Waste Isolation Project's engineered barriers group utilized this information to screen canister materials, overpacks, and backfills to obtain preliminary lists of materals for further testing. Earlier materials studies, the basis for selection, and the resulting candidate engineered barriers are discussed in Sections 2.7 and 2.8 .

Other highlights of the Basalt Waste Isolation Project's engineered barrier effort include preliminary studies on waste form-basalt interaction (Section 2.9), sorption studies to examine the extent of 
potential transport of radionuclides (Section 2.10), and modeling of geochemical changes in the near-field environment (Section 2.11). Important conclusions from the sorption studies are as follows:

- The site for the repository should be selected so that sorption of radionuclides and flow path length are maximized. The reducing properties of the basalt will be important in determining the mobility of technetium, neptunium, and uranium. The reduced forms (TC(IV), Np(IV), and U(IV)) of each of these radionuclides is less mobile than their oxidized form normally found in solutions which are in contact with the atmosphere. $\mathrm{Fe}$ (II) in the basalt appears to be capable of reducing technetium and neptunium to an immobile oxidation state.

- Secondary minerals lining fissures in basalt have a higher sorption capacity than the basalt for most radionuclides. Therefore, to minimize radionuclide transport, any fissures in the basalt formation chosen for the repository should be lined (or preferably plugged) with secondary minerals.

- The repository should be placed as far away as possible from porous interbeds which may contain aquifers. These would likely be the main conduits for radionuclide transport from a breached repository to the biosphere. Results of preliminary sorption studies on interbed material (tuff and sandstone) show, however, that migration of many radionuclides will be strongly retarded in the interbeds.

The repository will be sealed after the operational period of repository history. Sealing is accomplished by plugging the tunnels, rooms, access shafts, and boreholes with materials designed to prevent intrusion of water into the repository either from the surface or from adjacent aquifers. A secondary function of plugs will be to retard the migration of radionuclides as a backup to the engineered barriers placed around each canister.

Because the plug system performs several functions such as: preventing water flow; preventing radionuclide migration; supporting the tunnels and shafts; and, because the plugs must perform reliably in 
openings of several sizes and orientations, the overall plug system will be complex and use several materials placed in multiple zones. Since the plugs must remain effective for periods on the order of 10,000 years, the materials selected should have demonstrated survival for like periods of time in similar environments. For this reason, natural geologic materials have received the most attention. Cements and grouts will be used as primary sealants to provide structural integrity and the backfill will consist chiefly of clay and crushed basalt. The plug may be instrumented to detect water and radiation.

No single material will satisfy all the requirements of plug design, so a combination of materials will be used. Materials were selected on the basis of compatibility with the repository environment and a documented history of long-term survival in similar environments. Another important selection factor was the availability of information on properties and methods of emplacement. A preliminary screening of materials was made on the basis of these criteria. The screening process resulted in the following list of candidate materials:

Major Components

Basalt

Smectite clay-bentonite

clinoptilolite

Mullite

\section{Steatite}

Type II \& V portiand cement

Type $V$ hydrothermal cement-silica mixture

Grey expansion hydrothermal cement

Portland pozzolan cement

Grave 1

Sand

silt
Additives

Diatomaceous earth--silica source

Quartz--silica source

Smectite clays--expansive agent, ion exchange material, permeability reducer.

Vermiculite--expansive agent and ion exchange material

Clinoptilolite--ion exchange material

Phillipsite--ion exchange material

Magnetite--radiation shield

Hematite--radiation shield

Barite--radiation shield

Lead--radiation shield

Aluminum powder--expansive agent

Ferric hydroxide--pH control 
A preliminary list of candidate machines has been developed and are described in Section 3.5. These candidate machines are currentiy being studied further as more information is accumulated on pluging techniques and plug material properties.

Portable compactors or concrete pump systems appear attractive for tunnel plugs. Portable compactors, concrete wireline, and pump systems are suitable for shaft plugs while a combination of an oil and gas well gravel pack plant, rotary drilling, reverse circulation mud plant, and grout pump systems appear attractive for plugging of boreholes.

A testing program has been initiated to evaluate candidate borehole plugging materials. Initial geochemical tests are being carried out on candidate materials to determine their stability under repository conditions. Mechanical, thermal, and fluid transport properties are being measured. Test plans and procedures are described in detail in Sections 3.6 and 3.8 .

Three field tests of borehole plugging materials and machinery are currentiy planned:

- Shallow borehole test

- Intermediate depth borehole test

- Deep borehole test.

The tests will be carried out in sequence, so that the scale and complexity of the test increases with increasing experience. Monitoring of plug performance is planned for a considerable period following construction. Remote instrumentation will be installed to determine short-term and long-term performance of the plugs under test. 


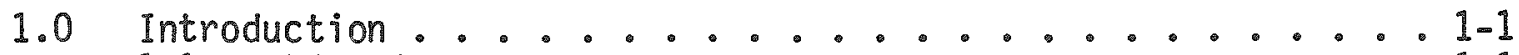

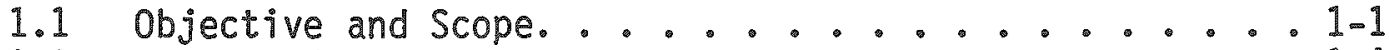

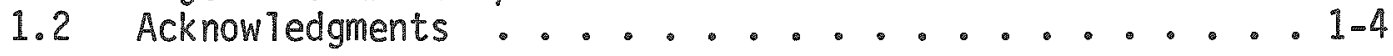

2.0 Multiple Barriers. .................... 2-1

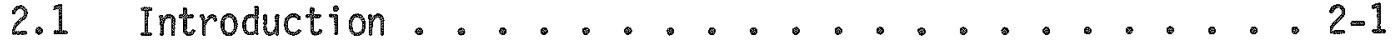

2.1.1 Barrier Selection. ................ 2-1

2.1.2 Definition of Repository Conditions......2-3

2.2 Functions of the Engineered Barrier Systems. ..... 2-6

2.2.1 General Design GoaT. .......... 2-7

2.2 .2 System Description .......... 2-7

2.2.3 System Criteria............ 2-12

2.2.4 Functions of the Engineered Barrier System . . 2-13

2.3 Rock Characteristics and Geologic Setting.......2-21

2.3.1 Introduction ............ 2-21

2.3.2 Chemical Composition of Pasco Basin Basalts. . 2-28

2.3.3 Mineral Composition of Pasco Basin Basalts . . 2-45

2.3.4 Composition of Interbeds in the Pasco Basin. . 2-69

2.3.5 Sumnary. .................. 2-72

2.4 Groundwater. . . . . . . 2- . $2-75$

2.4.1 Introduction ........... 2-75

2.4.2 Hydrogeologic Setting. ....... 2-76

2.4.3 Hydrologic Parameters and Testing Methods... 2-78

2.4.4 Physical and Chemical Groundwater Data .... 2-79

2.4.5 Interpretation ........... 2-89

2.4.6 Specification of a Reference Grande Ronde

Groundwater Composition. ........ 2-. 2-97

2.5 Repository Conditions. . . . . . . . . . . . 2-104

2.5 .1 Temperature. .............. 2-107

2.5 .2 Pressure ................. 2-113

$2.5 .3 \quad E h$ and $\mathrm{pH} . \ldots \ldots 2-119$

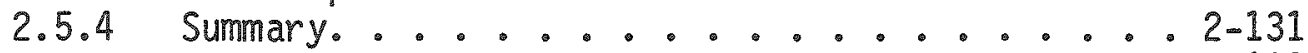

2.6 Waste Forms. . . . . . . . 2-133

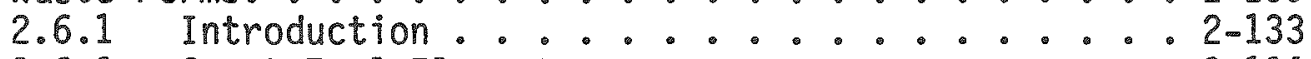

2.6.2 Spent Fuel Elements. . . . .... 2-134

2.6.3 High-Level Liquid Wastes and Calcines. .... 2-151

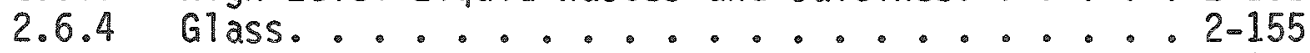

2.6 .5 Tailored Ceramics. .......... 2-166

2.6.6 Waste Form Performance in a Hydrotherma]

2.6.7 A Comparison of Emplaced Nuclear Waste and

2.6.8 Uranium Ore Body Toxicities. . . . . 2-205

2.6.9 Considerations in the Development of Engineered Barrier Requirements for Nuclear Waste Forms

in a Basalt Environment. ......... 2-213 
2.7 The Canister and Overpack. .......... 2-217

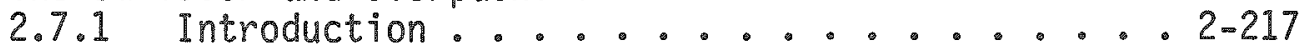

2.7.2 Survey of Materials Evaluation Studies....2-218

2.7.3 Evaluation of Previous Work. ...... 2-240

2.7.4 General Criteria Governing the Selection of

2.5 Candidate Canister and Overpack Materials. . . 2-243

2.7.5 The Canister as a Long-Lived Waste Isolation

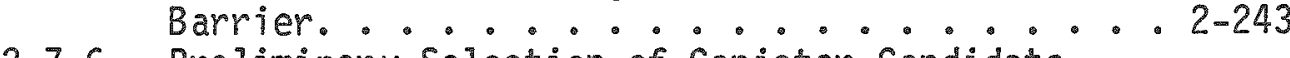

2.7.6 Preliminary Selection of Canister Candidate

2.7 Materials. . . . . . . . 2-248

2.7.7 The Overpack as a Long-Lived Waste Isolation

2.7 Barrier. . . . . . . 2-256

2.7.8 Preliminary Selection of Candidate Overpack

Materials. ............. 2-256

2.8 Backfi11 and Other Engineered Barriers ..... 2-258

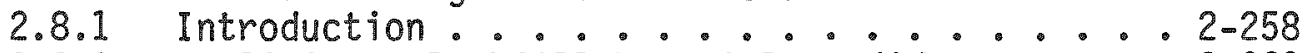

2.8.2 Preliminary Backfill Material Candidates ... 2-260

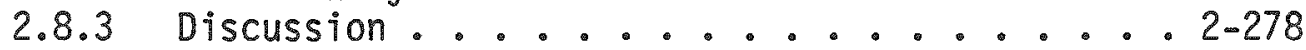

2.8.4 Other Engineered Barrier System Components . . 2-284

2.9 Waste-Basalt Interactions. ........... 2-288

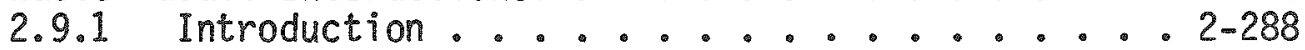

2.9.2 Spent FueT-Basalt-Water Interactions .... 2-289

2.9.3 Borosilicate Glass-Basalt-Water Interactions . 2-296

2.9.4 Supercalcine-Basalt-Water Interactions .... 2-303

2.9.5 Summary of Waste-Rock-Water Interactions and Implications for Siting a Repository

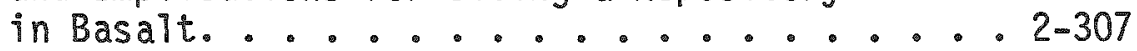

2.10 Sorption Studies ............................

2.10 .1 Introduction ................ 2-311

2.10.2 Measurement Methods. . . . . . . 2-313

2.10.3 Identification of Key Radionuclides. ..... 2-319

2.10.4 Results of Radionuclide Distribution

Measurements ........... 2-323

2.10 .5 Pariculate Transport ....... 2-337

2.10.6 Effects of Radiation on Sorption ...... 2-338

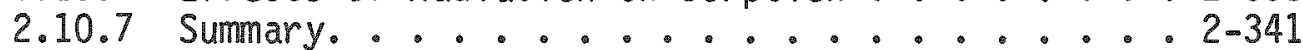

2.11 Modeling of the Near-Field Environment .....2-345

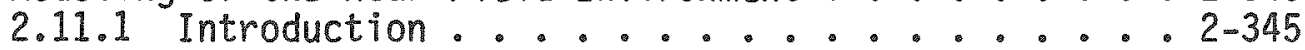

2.11.2 The EQ3/EQ6 Mass Transfer Simulation Code. . . 2-346

2.11.3 Groundwater-Basalt Interactions in the

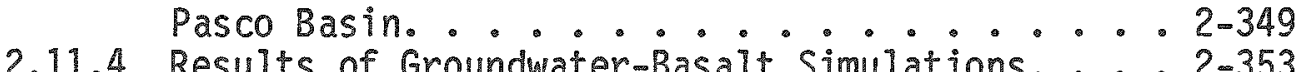

2.11 .5 Waste-Basalt-Groundwater Interactions. . $2-357$

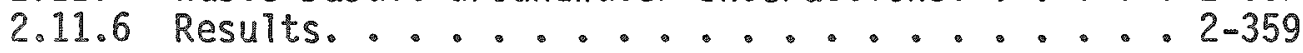

2.11 .7 Future Work. ......... 2- . 2559

2.11.8 Thermodynamic Data Base Development..... 2-361

3.0 Borehole Plugging. ...................

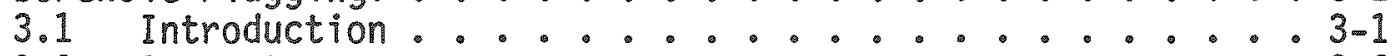

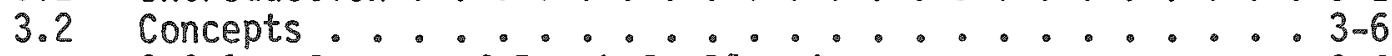

3.2.1 System of Borehole Plugging. ...... 3-6

3.2.2 General Methodology for Borehole Plug

Validation .................. 6 
3.2.3 Borehole Plug--Generalized Criteria and

Constraints............... 3-10

3.3 Description of the Environment ...............

3.3.1 Plug Environment .......... 3-12

3.3.2 Geotectonic Environment. ....... 3-14

3.3.3 Physical Environment ......... 3-15

3.3.4 Additional Characterization of the Plug

Environment. . . . . . 3-19

3.4 Selection of Candidate Plug Materials. ....... 3-43

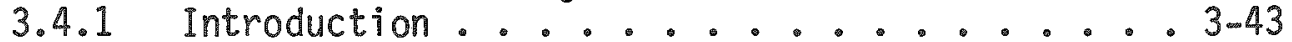

3.4.2 Materials Selection Methodology...... 3-44

3.4.3 Materials Selection Process........ 3-49

3.4 .4 Conclusion ................ 3-61

3.5 Emplacement Machines .............. 3-62

3.5.1 Candidate Machines ........ 3-63

3.5.2 Machine Selection............. 3-63

3.6 Laboratory Testing ............. 3- . . . . .

3.6.1 Geochemical Testing. ......... 3-72

3.6.2 Physical Testing .......... 3-84

3.7 Preconceptual Plug Design. .......... 3-139

3.7.1 Candidate PTugging Schemes ........ 3-141

3.7.2 Analysis of Plugging Schemes ....... 3-170

3.7.3 Expert Evaluation and Judgment ...... 3-202

3.7.4 Preconceptual Plugging Systems ...... 3-206

3.8 Borehole Plugging Field Tests. ........ 3-213

3.8.1 Shallow (First) Borehole Plugging Test .... 3-213

3.8.2 Second Borehole Plugging Test........ 3-214

3.8.3 Advanced Field Demonstration ....... 3-214

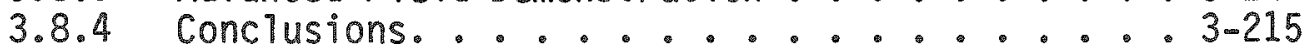

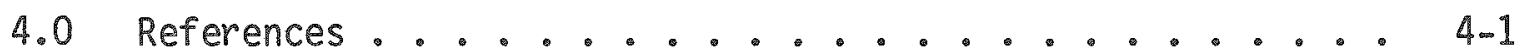

TABLES:

2-1 Barrier Function Versus Time. ........... 2-11

2-2 Applicable Criteria That May Affect Waste Package/

Engineered Barrier Design ........... 2-14

2-3 Average Major-Elenent Compositions of Columbia River

Basalt Chemical Types ..............2-30

2-4 Approximate Major-Element Composition of Basalt Formations

in the Pasco Basin. ................ 2-31

2-5 X-Ray Fluorescence Analyses of the Umtanum Flow .... 2-32

2-6 Variations in Major Element Composition of Museum Flow and Flow $E$ at Sentinel Gap and across the Pasco Basin . . 2-34

2-7 Average X-Ray Fluorescence Analyses of Saddle Mountains Basalt in the Pasco Basin ......... 2-37 
2-8 Major Element Compositions of the Umatilla, Wilbur Creek, and Ice Harbor Members of the Saddle Mountains Formation. 2-38

2-9 Approximate Average Trace Element Composition of Basalt

Formations in the Pasco Basin........... 2-39

2-10 Average Trace Element Composition of Selected Flows

at the Grande Ronde Type Section. ........... 2-40

2-11 Trace Element Analyses of Members of the Wanapum

Formation ..................... 2-41

2-12 Average Trace Element Composition of Members

of the Saddle Mountains Basalt. .......... 2-41

2-13 Atomic Absorption Trace Element Analyses of Saddle

Mountains Basalt at Gable Mountain and Gable Butte. . . 2-42

2-14 Mean Concentrations (ppm) of Trace Elements Measured

in the Umatilla Reference Powder........... 2-43

2-15 Average Electron Microprobe Analyses of Minerals and

Glass from Selected Flows at the Grande Ronde Basalt

Type Section................. 2-. 47

2-16 Average Electron Microprobe Analyses of Minerals and Glass from Selected Group B "Lower" Yakima Basalt Flows (Possible Schwana Sequence) .......... 2-48

2-17 Average Electron Microprobe Analyses of Minerals and

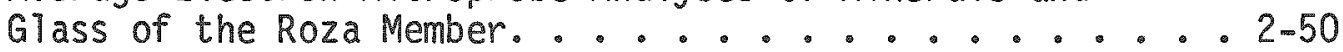

2-18 Compositions of Mean Hanford Clay and Zeolite with Structural Formulas .................... 2-57

2-19 Percent of Fracture and Vesicle Samples Containing a Specific Secondary Mineral Found by X-Ray Diffraction . . 2-62

2-20 Relative Volume Estimates (SEM) of Major Secondary Phases in vesicles from $D C-2, D C-6, D H-5 \ldots$ 2-67

2-21 Depths at which Clinoptilolite and Mordenite First Appear as reported from X-Ray Diffraction Data ....... 2-69

2-22 Features of the Groundwater Flow Systems beneath the Pasco Basin ............... 2-71

2-23 Basalt Formations in the Pasco Basin. ....... 2-73

2-24 Summary Characteristics of Pasco Basin Basait

Formations................. 2-74 
2-25 Important Primary and Secondary Phases in Pasco Basin Basalts ................. 2- . 75

2-26 Basalt Lithology Given as a Percentage of Formation Thickness Drilled in Borehole DC-1......... 2-78

2-27 Representative Hydrautic Properties of the Unconfined Aquifer ............... 2-82

2-28 Hydrautic Properties of the Saddle Mountains Aquifers . . 2-82

2-29 Hydraulic Properties of the Wanapum and Grande Ronde

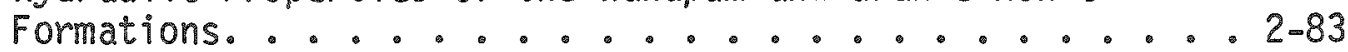

2-30 Average Composition and Range in Concentration of Major Chemical Constituents within Groundwater in the Unconfined Aquifer at Hanford. ............... 2-86

2-31 Range and Median Values of Trace Elements for Unconfined Groundwater at the Hanford Site ......... 2-87

2-32 Average Composition and Range in Concentration of Major Chemical Constituents within Groundwater of the Mabton

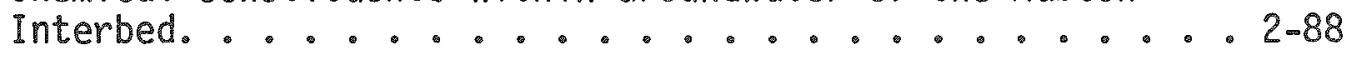

2-33 Average Composition and Range in Concentration of Major Chemical Constituents within Springs in the Rattlesnake

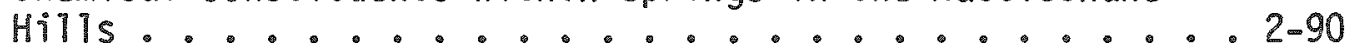

2-34 Range and Median Values of Trace Elements for Groundwater within the Mabton Interbed of the Hanford Site...... 2-91

2-35 Average Composition and Range in Concentration of Major Chemical Constituents within Groundwater of the Upper Wanapum Basalt. ............ 2-92

2-36 Trace Element Concentrations for Groundwater in the Priest Rapids Member of the Upper Wanapum Basalt. . . . 2-94

2-37 Radioisotopic Analyses for Groundwater within the Priest Rapids Member of the Upper Wanapum Basalt, Hanford Site. ............... 2-. . . .

2-38 Major Inorganic Composition of Groundwater for Selected Wells Completed in the Grande Ronde Basalt. ...... 2-95

2-39 Trace Elements for Groundwater within Confined Aquifers of the Grande Ronde Basalt on the Hanford Site. . . . . 2-96

2-40 Set of Simultaneous Equations Used to Calculate $\left[\mathrm{H}_{3} \mathrm{SiO}_{4}^{-}\right]$, $\left[\mathrm{H}^{+}\right],\left[\mathrm{OH}^{-}\right],\left[\mathrm{CO}_{3}^{-2}\right]$, and $\left[\mathrm{HCO}_{3}^{-}\right] \ldots \ldots . . \ldots 2-100$ 
2-41 Equilibrium Constant Values Calculated as a Function of Temperature on the Basis of Thermodynamic Data .... 2-101

2-42 Estimated Anionic Species Concentrations for Grande

Ronde Groundwater .............. 2-103

2-43 Hydraulic Properties of the Aquifer Systems beneath the

Hanford Site. ................ 2-104

2-44 Average Composition and Range in Concentration of Major Chemical Constituents within Groundwater for Formations beneath the Hanford Site. ............. 2-106

2-45 Summary of Repository Equilibrium Conditions. ..... 2-131

2-46 Assumptions for Spent Fuel Canister Inventory

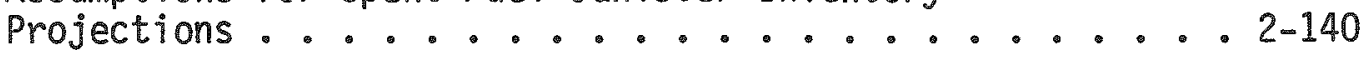

2-47 Elemental Abundances in Spent Fuel. ....... 2-145

2-48 Reported Fission-Product Phase Chemistry in Spent Fue 1. . 2-147

2-49 Simulated Spent Fuel Fission Products Formulation . . . 2-149

2-50 Reference High-Level Waste Composition, Wt\% Oxides. ... 2-153

2-51 Reference Waste Giass Compositions. ......... 2-157

2-52 Crystalline Phase in Waste Glass Formulations . . . . 2-159

2-53 Typical Waste GTass Compositions. . . . . . . 2-161

2-54 Heat Generation Rates of Simulated PW-4b Waste Glass

$72-68 \ldots \ldots 2-164$

2-55 Phase Formulation of Supercalcine SPC-2 ...... 2-171

2-56 Composition of Supercalcine SPC-2 ......... 2-172

2-57 Phase Formulation of Supercalcine SPC-4 ...... 2-173

2-58 Composition of Supercalcine SPC-4 ........ 2-174

2-59 Phase Formulation of High-Sodium Supercalcine 77-2. . . 2-176

2-60 Phase and Chemical Compositions of SYNROC Ceramics. . . 2-181

2-61 Potential Radionuclide Substitutions in SYNROC A

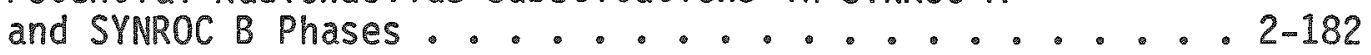

2-62 Estimated Solubility of Uranite $\left(\mathrm{UO}_{2}\right)$ at 750 Bars

Pressure and Low Oxygen Fugacity.......... 2-188 
2-63 Compositions of Residual Solutions from Experiments Reacting Simulated Spent Fuel with Distilled Water at

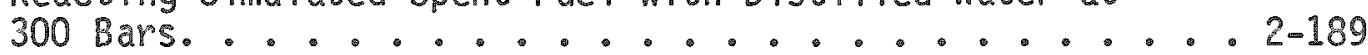

2-64 Compositions of Residual Solutions from Experiments Reacting Simulated PNL 76-68 Glass in Distilled Water

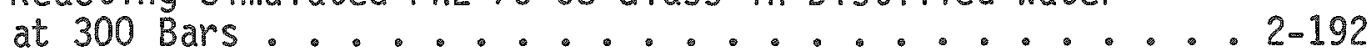

2-65 Comparison of the Compositions of Residual Solutions from Experiments Reacting Alternative Waste Forms with Distilled Water at 300 Bars .................... 2-200

2-66 A Summary of Major Characteristics of Waste Forms . . . 2-215

2-67 Nominal Chemical Composition (Wt\%) of Candidate Canister Alloys--Sandia Laboratories. ........ 2-227

2-68 Test Solutions for Canister Corrosion Studies--

Sandia Laboratories .............. 2-228

2-69 Corrosion Rates of Candidate Canister Materials in Brines and Seawater at $250^{\circ} \mathrm{C}--$ Sandia Laboratories .... 2-229

2-70 Candidate Materials for Long-Lived Spent Fuel Disposal

Barrier Systems ............... 2-232

2-71 Nominal Composition (Wt\%) of Alloys Tested in Simulated

High-Temperature Geothermal Brines. ........ 2-235

2-72 Effect of Alloy Composition on Uniform Corrosion. ... 2-236

2-73 Comparison of Alternate Alloys with Carbon Steels in Oxygen-Free Brines--6.89 MPa. ......... 2-237

2-74 General Criteria Governing the Preliminary Selection of Candidate Canister Materials .......... 2-244

2-75 General Criteria Governing the Selection of Candidate Overpack Materials............. 2-245

2-76 Corrosion Rates at $250^{\circ} \mathrm{C}$ for Candidate Canister Alloys in Simulated Brines and Seawater ........2-250

2-77 Weldability of Candidate Canister Alloys for a Repository Located in Basalt. . . . . . . . . 2-252

2-78 Preliminary List of Candidate Canister Alloys for a Repository Located in Basalt. ........... 2-252

2-79 Preliminary List of Candidate Overpack Alloys . . . . 2-257

2-80 Functions and Functional Properties of the Backfill Component ................. 2-259 
2-81 The $230^{\circ} \mathrm{C} \mathrm{d}^{2}$ Values for Fracture Mineralization and and Synthetic Groundwater ............. 2-265

2-82 The $60{ }^{\circ} \mathrm{C} \mathrm{K}_{d^{\prime}}$ Values for Fracture Mineralization and Synthetic Groundwater ................2-266

2-83 Retention Times in 1-Meter-Thick Clay Barrier for Various Nuclides. ............ 2-268

2-84 Retardation Factors in 1-Meter-Thick Clay/Quartz and Clinoptilolite Barriers for Various Nuclides. ..... 2-270

2-85 Sorption of $\mathrm{TCO}_{4}^{-}, \mathrm{I}^{-}$, and $\mathrm{IO}_{3}^{-}$by Various Rocks and

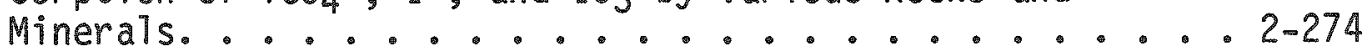

2-86 Sorption of $\mathrm{Np}(\mathrm{V})$ from Water by Various Rocks and Minerals. .............. 2-277

2-87 Preliminary List of Preferred Backfill Candidate Materials ............... 2-280

2-88 Compositions of Residual Solutions from Experiments Reacting Simulated Spent Fuel in Distilled Water. . . . 2-290

2-89 Compositions of Residual Solutions from Experiments Reacting Simulated Spent Fuel at $100^{\circ} \mathrm{C} . . . . . .2-295$

2-90 Compositions of Residual Solutions from Experiments Reacting Simulated PNL 76-68 Glass in Distilled Water at $3000^{\circ}$...................... 2-297

2-91 Leachability of Simulated PNL 76-68 Glass Using Distilled Water and in the Presence of Basalt (near $300^{\circ} \mathrm{C}$ ). . . 2-298

2-92 Compositions of Residual Solutions from Experiments Reacting Simulated PNL 76-68 Glass in Distilled Water at $100{ }^{\circ} \mathrm{C} . \ldots . \ldots 2-\ldots . \ldots 2$

2-93 Composition of Residual Solutions from Experiments

Reacting Supercalcine and Basalt. ........ 2-304

2-94 Composition of Residual Solutions Reacting from Experiments on Supercalcine and Distilled Water at $100^{\circ} \mathrm{C}, 300$ Bars. . 2-306

2-95 Likely Engineered Barrier Design Requirements for Several Waste Forms ...................... 208

2-96 Comparison of $K_{d}$ Values Obtained by Nine Laboratories for Identical Controlled Experiments. ........ 2-314

2-97 Effects of Various Procedures on $K_{d}$ Measurement .... 2-315

2-98 Light Water Reactor Plant Waste from Uranium Fuels

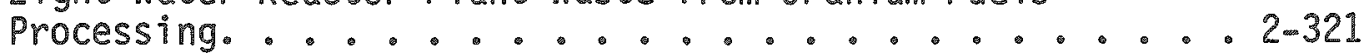


2-99 Recommended Concentration Guide Values (in Water) for Radionuclides in Liquid Water Reactor Plant Waste from Uranium Fuels Reprocessing. ........... 2-322

2-100 Effect of Temperature on $k_{d}$ Values $(\mathrm{ml} / \mathrm{g}$ ) for Umtanum

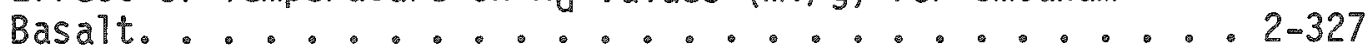

2-101 Characteristics of Three Columbia Plateau Basalts (20 to 50 Mesh)................ 2-329

2-102 Comparison of $K_{d}$ Values $(\mathrm{ml} / \mathrm{g})$ for Three Columbia Plateau Basalts at 230 C............ 2-330

2-103 Sorption Properties of Fresh and Altered Basalt .... 2-331

2-104 Transport Velocities, Retardation Factors, and $\mathrm{K}_{\mathrm{d}}$ Values for Three Thirsty Canyon Tuff Samples....... 2-334

2-105 Migration of Kaolin Particles through Crushed Basalt

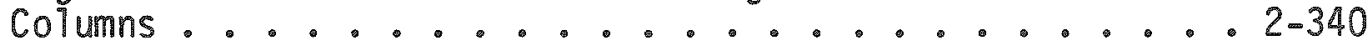

2-106 Selected $k_{d}$ values.................... 2-342

2-107 Composition of Reactant Phases Used in EQ3/EQ6 Near-Field Simulations ................... 2-350

2-108 Surface-Water Compositions (mg/l) Used as the Initial Groundwater Composition in the EQ3/EQ6 Near-Field

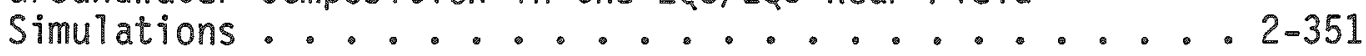

2-109 Simulated Groundwater Compositions Which Best Reproduce Actual Groundwater Compositions as a Function of Increasing Depth or Extent of Reaction (Z) ................ 2-354

2-110 Moles of Secondary Minerals Produced in Simulated BasaltGroundwater Reactions $(Z=0.02) \ldots \ldots$ 2-356

2-111 Mole Fractions of Principal Oxides in Light Water Reactor Fuels Cycle Waste Used in Groundwater/Basalt/Spent Fuel

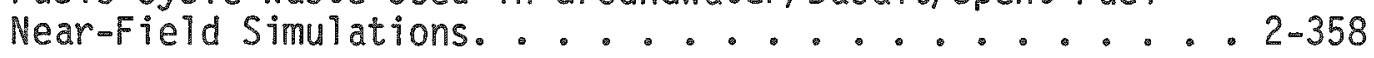

2-112 Chemical Compositions of Average Hanford Smectite and

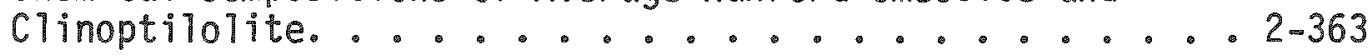

3-1 Generalized Physical Characteristics of Basalt. .... 3-13

3-2 Estimated Composition of Groundwater from the Lower Confined Aquifer (Grande Ronde) at $45^{\circ} \mathrm{C}$. . . . . . 3-17

3-3 Preliminary Definition of Plug Types and Plug

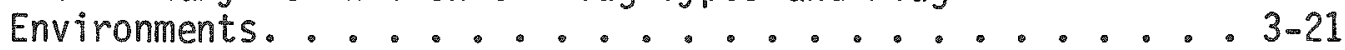

3-4 Characteristics of Starting Materials (Ground to -200 Mesh). . ........... 3-45 
3-5 Preferred Candidate Plug Materials. ......... 3-46

3-6 Decision Analysis and the Selection of Candidate Plug

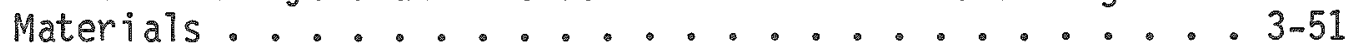

3-7 Materials for Consideration ............. 3-52

3-8 Candidate Borehole Plugging Machinery . . . . . 3-64

3-9 Results of Matrix Ratings ............ 3-71

3-10 Materials and Materials Mixtures for Preliminary

Hydrothermal Screening Tests........... 3-81

3-11 Specimens Used in the Geochemical Testing Program . . . 3-82

3-12 Cement Curing Procedures........... 3-84

3-13 Testing Procedures Applied to Cementitious Mixtures . . . 3-88

3-14 Summary of Test Results for Cement Mortars Cured at

Elevated Temperatures ................... 39

3-15 Summary of Test Results for Portland Pozzolan Cement

Mortars Containing Different Aggregate Types. ..... 3-95

3-16 Materials Used in Performance Tests for Cementitious

Mixtures................ 3-95

3-17 Natural Materials Used in Screening Tests on Compacted

Earth Materials . . . . . . . . . . . 3-107

3-18 Testing Procedures Applied to Compacted Earth

Materials . . . . . . . . . . 3-108

3-19 Summary of Bond Strength Data for Selected Clay/

Sand Mixtures ................. 3-123

3-20 Qualitative Results of Thixotropy Tests on Clay

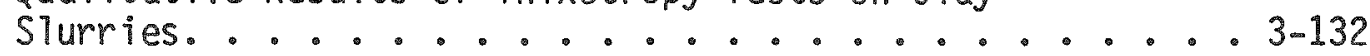

3-21 Summary of Data and Test Results for Preplacement and

Slurry Injection of Aggregate ............ 3-136

3-22 Summary of Data and Test Results for Premixed Slurry

and Aggregate .................. 3-137

3-23 Proposed Value of Design Parameters ........ 3-196

3-24 Summary of Dominance Computations for Tunnels . . . . 3-197

3-25 Summary of Dominance Computations for Shafts. ..... 3-198 
RHO-BWI-ST-7

3-26 Surmary of Dominance Computations for Boreholes ..... 3-199

3-27 Judgmental Evaluation of Candidate Monolithic and

Multiple-Zone Plugs by Professionals. ........ 3-205

FIGURES:

1-1 Generalized Concept of Engineered Barriers in Basalt. . . 1-3

2-1 Selection Process for an Engineered Barrier System. ... 2-2

2-2 Required Components of an Engineered Barrier System as a Function of Time ................ 2-5

2-3 Engineered Barrier System Emplacement Concept . . . . . 2-8

2-4 Typical Engineered Barrier System Emplacement Concept . . . 2-10

2-5 Distribution of Columbia River Basalt in Washington,

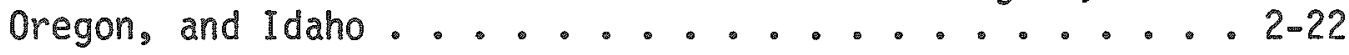

2-6 Approximate Areal Extent of the Pasco Basin Showing the Hanford Site. ................. 2-23

2-7 Simplified Cross-Sectional View across the Pasco Basin Taken from Figure 2-6.............. 2-24

2-8 Hanford Site in the Pasco Basin and Locations of Boreholes Indicated and Referred to in the Text ..... 2-25

2-9 Physical Characteristics Recognized in a Typical Columbia River Basalt Flow ............. 2-27

2-10 Pasco Basin Stratigraphic Nomenclature. ....... 2-29

2-11 Position of the Umtanum Member Relative to Other Units Recognized in the Upper Grande Ronde Basalt at DC-2, $D C-3, D C-4$, and $D C-8 \ldots \ldots 2-33$

2-12 Graph of Feldspar Compositions from the Umatilla Formation ....................... 2-51

2-13 X-Ray Diffraction Patterns for the Commonly Occurring Secondary Minerals............... 2-56

2-14 Compositions of All Clays (Mostly Smectite) Formed Prior to Deposition of Zeolite or Silica....... 2-58

2-15 Compositions of First and Second Generations of Secondary Zeolite ............. 2-59 
2-16 Ion Exchange Ratios in Zeolites as a Function of Depth at $D C-6 \ldots \ldots 2-61$

2-17 Clinoptilolite Rosettes on a Surface of Cristobalitel Quartz................ 2-63

2-18 A Typical Crystallization Sequence for Secondary Minerals................. 2-64

2-19 Broken Secondary Quartz Sphere Exposing Interior Smectite Nodules Deposited during Quartz Growth in DC-6 Basalt Sample. . . . . . . . . . . 2 2-65

2-20 Sample Showing Dissolution of Silica Followed by Precipitation of Smectite or Simultaneous Crystallization of Two Phases ................ 2-66

2-21 Approximate Distribution of Major Secondary Minerals as a Function of Depth .............. 2-68

2-22 Depths at which Mordenite (M) and Clinoptilolite (C) First Appear in Core Samples DH-5, DC-2, and DDH-3. . . 2-70

2-23 Generalized Diagram of Drill Stem Testing Apparatus . . . 2-80

2-24 Compositions of Groundwaters in the Pasco Basin .... 2-98

2-25 Measured Downhole Fluid Temperatures at the Center of the Umtanum Flow in Various Test We11s....... 2-109

2-26 Heat Production Profile for a Canister of Reprocessed Nuclear Waste and for Major Heat-Producing Isotopes within the Waste. ......................

2-27 Temperature Profiles Resulting from Burial of a 2:1 Mixture of 10-Year-01d Pressurized Water Reactor and Boiling Water Reactor Spent Fuel Elements at a Depth of $1,000 \mathrm{~m}$ in the Columbia River Basalts ........ 2-112

2-28 Temperatures above the Repository as a Function of Time, after the Emplacement of a 2:1 Mixture of 10-Year-01d Pressurized Water Reactor and Boiling Water Reactor Spent Fue T Elements .............. 2-113

2-29 Schematic Illustration of Different Types of Potential Repository Pressures and Their Relationships. . . . . 2-115

2-30 Divariant Curve (Liquid-Vapor) for Water $\left(\mathrm{H}_{2} \mathrm{O}\right) \ldots \ldots$ 2-117

2-31 I17ustration of Differential Thermal Analysis Curves

for Some Smectites................ 2-120

2-32 Variation Trend of Solution pH as a Function of Time...2-123 
2-33 Control of Hydrothermal Groundwater pH by Silicic Acid.. . 2-125

2-34 pH Versus 1/T for Groundwater in Equilibrium with

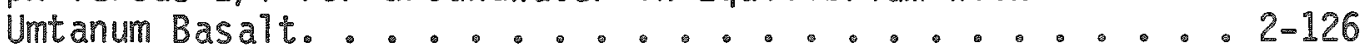

2-35 Stability Relations of Iron Oxides, Sulfides, and

Carbonate in Water at $250^{\circ} \mathrm{C}$ and 1 Atmosphere Total

Pressure. ................. 2-130

2-36 Typical Light Water Reactor Fuel Element. ....... 2-135

2-37 Typical Light Water Reactor Fuel Assembiies ...... 2-137

2-38 Decay Heat as a Function of Time for Typical

Pressurized Water Reactor and Boiling Water Reactor

Spent Fue 1 Canisters. .............. 2-138

2-39 Projected Spent Fuel Canister Inventories Based on

Low, Medium, and High Growth Projections for Nuclear

Electric Generation Capacity. .......... 2-141

2-40 Cross Section of a Typical 0xide Fuel Pellet from

High-Burnup Light Water Reactor or Fast Breeder

Reactor Fue ............... 2-142

2-41 Centerline Temperatures of a Reference Canister Containing

72-68 Waste Glass, Cooled in Air and Water........ 2-163

2-42 Conceptual Flow Diagram for Supercalcine Processing . . 2-168

2-43 Multibarrier Concept for Isolating High-Level Waste ... 2-179

2-44 Solubility of $\mathrm{UO}_{2}$ in Water as a Function of Temperature;

$\mathrm{fO}_{2}$ in the Experiments Buffered by the Equilibrium

between $\mathrm{UO}_{2}$ and $\mathrm{UO}_{3}$ under oxidizing Conditions...... 2-185

2-45 The Approach to Equilibrium Using a Hydrogen Diffusion

Membrane................ 2-186

2-46 Scanning Electron Micrograph of a Section through the

Product of a 4-Week Hydrothermaliy Treated Treatment

of a PNL 76-68 Glass Specimen ........... 2-194

2-47 Composition-Distance Profile for Leached PNL 76-68

G7ass Sphere Shown in Figure 2-46....... 2-195

2-48 Solution Concentrations of Various Ions from PNL 76-68

Glass as a Function of Time at $300{ }^{\circ} \mathrm{C}, 300$ Bars in

Deionized Water ................ 2-197

2-49 Waste Ion Concentrations in Solution as a Function

of Time from Supercalcine-Ceramic SPC-4 at $300^{\circ} \mathrm{C}$,

300 Bars in Deionized Water. 
2-50 Relative Toxicities of Various Natural Ores to Nuclear Wastes Using Low-Grade Uranium Ore as a Basis for Comparison. .................2-209

2-51 Thermal Power of a Spent Fuel Canister Containing One Pressurized Water Reactor Assembly Compared to a Canister of High-Level Waste From Similar Fuel Containing 2.5 Metric Tons of Uranium (MTU) ...... 2-211

2-52 Comparison of the Characteristic Parameters of Unreprocessed and Reprocessed Spent Fue 1. . . . . . 2-212

2-53 Swedish Titanium Canister-Backfill Concept for Geologic Disposal of Vitrified High-Level Waste........ 2-220

2-54 Swedish Copper Canister and Backfill Concept for Disposal of Spent Fuel Rods ........... 2-222

2-55 Swedish Alumina Canister and Backfill Concept for Disposal of Spent Fuel Rods ........... 2-224

2-56 Engineered Barrier System Incorporating (a) Minimum Barrier Components and (b) Maximum Barrier Components . . 2-247

2-57 Variation in Swelling Pressure (PS) as a Function

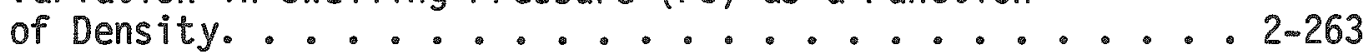

2-58 Variation in Permeability (k) as a Function of Density................. 2-264

2-59 Fixation of $\mathrm{TCO}_{4}{ }^{-}$and $\mathrm{SeO}_{4}{ }^{-2}$ by $\mathrm{PbO}$ as a Function of Anion/Pbo Mole Ratio...............2-275

2-60 Stable Regions of Some Metals and Oxides Pertinent to Nuclear Waste Disposal in Basalt. ......... 2-286

2-61 Solubility of $\mathrm{UO}_{2}$ as a Function of $\mathrm{pH}$ and Oxygen

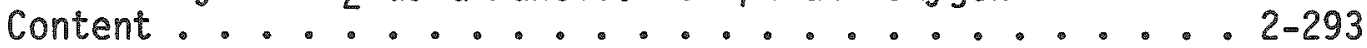

2-62 Dissolution of Crushed Basalt, pH 4.5 ..... 2-325

2-63 A Typical Sorption Isotherm for Sorption of a Solute from Solution .................. 2-326

2-64. Dependence of Cesium Sorption by Basalt on Cesium Concentration ............... 2-327

2-65 Sorption of $99 \mathrm{TC}$ (Initially $\mathrm{TCO}_{4}^{-}$) and $237 \mathrm{~Np}$ (Initial7y $\mathrm{NpO}_{2}^{+}$) in Rock-Water Systems Purged of

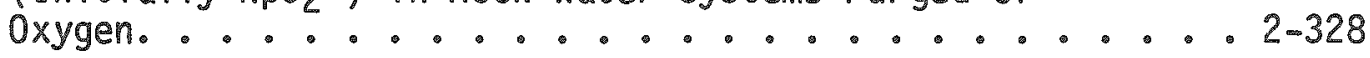

2-66 Relative Migration Rates for Plutonium and Americium in Los Alamos Tuff. 
2-67 Distribution of Activated Kaolin throughout the Basalt Column after Particulate Flow Experiments. ...... 2-339

2-68 Local Equilibrium Mass-Transport as Modeled by the EQ3/EQ6 Mass Transfer Simulation Code. ........ 2-347

2-69 Solution Species Concentrations and Solids Precipitating during Reaction of Groundwater with Basalt ...... 2-352

2-70 Dissolution of Spent Fuel and Basalt by Groundwater in Spent Fuel/Basalt/Groundwater Near-Field Simulations. . 2-360

3-1 Schematic of Repository Plugging .......... 3-7

3-2 Materials Selection Process. .......... 3-50

3-3 Boreholes Drilled from the Surface ........ 3-73

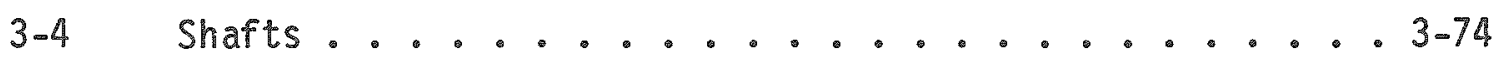

3-5 Subsurface Boreholes (Plug far from Large Working Area). . 3-75

3-6 Subsurface Boreholes (Plug near to Large Working Area) . 3-76

3-7 Small Tunnel ................ 3-. . . . . . .

3-8 Large Tunnel with Short Plug . . . . . . . . 3-78

3-9 Large Tunnel with Long Plug. ........... 3-79

3-10 Compressive Strength of Cement Mortar Mixtures Cured at Elevated Temperatures ........... 3-...90

3-11 Effect of Increasing the Content of -325 Mesh, Polished, Leafing-Type Aluminum Powder or Expansion Characteristics of Fresh Grout .................... 3-92

3-12 Compressive Strength of Cement Mixtures Containing a Water-Reducing Agent (P Tastiment) and Aluminum Powder at Elevated Curing Temperatures......... 3-93

3-13 Performance of Cement Mixtures Containing Portland Type V Silica Flour and Three Types of Fine Aggregate. . 3-94

3-14. Summary of Grout Performance for High Temperature Locations $\left(T \geq 100^{\circ} \mathrm{C}\right) \ldots . . . . . . . .3-97$

3-15 Summary of Grout Performance for Moderate Temperature

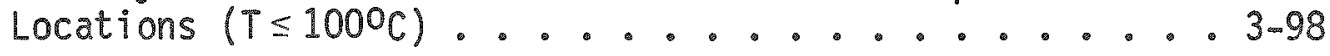

3-16 Summary of Grout Performance Expansive Grout for Relatively Low Temperature Locations $\left(T \leq 50^{\circ} \mathrm{C}\right)$..... 3-99 
3-17 Summary of Concrete Performance for High Temperature Locations $(T \geq 1000 \mathrm{C}) \ldots . . . . . . .200$

3-18 Summary of Concrete Performance for Moderate Temperature Locations $(T \leq 1000 \mathrm{C}) \ldots \ldots$....................

3-19 Summary of Concrete Performance Expansive Concrete for Low Temperature Locations ........... 3-102

3-20 Index Properties of Various Clay Minerals . . . . . 3-110

3-21 Compaction Curves for Candidate Clay/Sand Mixtures. . . 3-112

3-22 Swelling Pressure of Bentonite/Sand Mixtures. . . . . 3-114

3-23 Unconfined Compressive Strength of Clay/Sand Mixtures . . 3-115

3-24 Young's Modulus of Clay/Sand Mixtures ......... 3-116

3-25 Bond Strength of $\mathrm{Clay} / \mathrm{Sand}$ Mixtures at Ambient Temperatures....................... 3-121

3-26 Bond Strength Sliding Strain Curves for Clay/Sand Mixtures Containing Wyoming Bentonite and Glaciofluvial

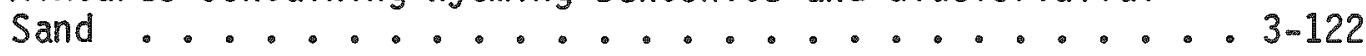

3-27 Consolidation Curve of Clay/Sand Mixtures Containing $10 \%$ Oregon Bentonite and 90\% Glaciofluvial Sand .... 3-125

3-28 Consolidation Curves of Clay/Sand Mixtures Containing $60 \%$ Oregon Bentonite and 50\% Glaciofluvial Sand .... 3-126

3-29 Densities of Clay S7urries. . . . . . . . 3-129

3-30 Flow Time of Clay Slurries. . . . . . . . 3-130

3-31 Variation of Solids Content ( $2 \%$ and $4 \%$ ) of Clay Slurries. . 3-133

3-32 Variation of Solids Content (6\% and $8 \%$ ) of Clay Slurries. - 3-134

3-33 Boreholes from the Surface. ............. 3-145

3-34 Boreholes Drilled from the Surface: Precompressed Soil Plug Scheme for Boreholes .......... 3-146

3-35 Boreholes Drilled from the Surface: Copper Plug for Boreholes ........................ 347

3-36 Stiff Clay/Sand Plug for Shafts ........... 3-149

3-37 Concrete Plug (1) for Shafts................ 3-150

3-38 Concrete Plug (2) for Shafts........... 3-151 
3-39 Boreholes Drilled from the Surface: the Use of a

Cement Retainer Plug in Cased Hole......... 3-152

3-40 Borehole Originating Underground (Plug near to Large

Working Area) ................. 3-153

3-41 Boreholes Drilled from the Surface. . . . . . . 3-155

3-42 Boreholes Drilled from the Surface: Borehole Plug of

Pre-Compressed Bentonite Pellets with Gravel Pack . . . . 3-156

3-43 Boreholes Drilled from the Surface: Basalt Plug for

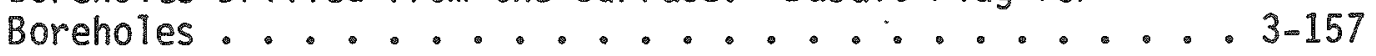

3-44 Boreholes Dritled from the Surface: Continuous Melt

for Boreholes ................. 3-158

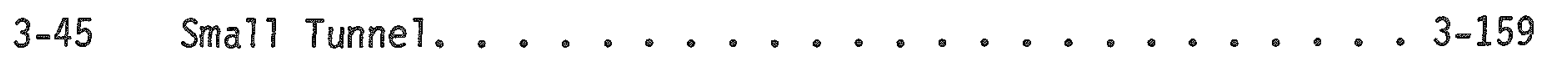

3-46 Masoned Block Plugs for Tunnels ........... 3-160

3-47 Large Tunnet. ................... 3-161

3-48 Large TunneT with a Long Plug .......... 3-162

3-49 Solid Basalt Rock Plugs for Tunnels and Shafts. . . . . 3-163

3-50 Multiple-Zone Metal and Cement Grout Plugs for Boreholes. - 3-164

3-51 Multiple-Zone Concrete and Block, and Zoned Earth Plugs . . 3-165

3-52 Multiple-Zone, Mortared Block Arch and Concrete Plug. ... 3-166

3-53 Muttiple-Zoned Plugs for Tunnets. ......... 3-167

3-54 Multiple-Zoned Plugs with Cutoffs for Tunnels . . . . 3-168

3-55 Zone of Elastic Stress Relief .......... 3-175

3-56 Relation between Support Types and Possible Deformation

Criteria.......................... 177

3-57 Modeling Conditions No. 1 ........... 3-180

3-58 Flow through Plug of Permeability $10^{-9} \mathrm{~cm} / \mathrm{sec} \ldots . . .3-182$

3-59 Flow through Plug of Permeability $10^{-9} \mathrm{~cm} / \mathrm{sec}$ with

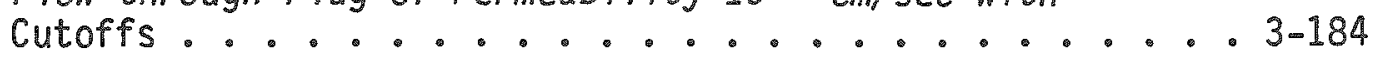

3-60 Flow through Plug of Permeability $10^{-8} \mathrm{~cm} / \mathrm{sec}$ with

Cutoffs .................... 3-185

3-61 Length of Plug (Idealized Numerical Mode1). . . . . 3-186 
3-62 Stress Distribution around Tunnel and Shaft ...... 3-189

3-63 Thermoelastic Response of a Confined Concrete Plug. . . . 3-190

3-64 Thermoelastic Response of an Unconfined Concrete Plug . . . 3-192

3-65 Thermomechanical Stresses in the Surrounding Basalt

Rock at the Plug Interface.............. 3-193

3-66 Migration of Radionuclides across a Hypothetical Plug . . 3-195

3-67 Preconceptual Design of Tunnel Plugs. . . . . . . 3-208

3-68 Preconceptual Design of Shaft Plugs ........ 3-210

3-69 Preconceptual Design of Borehole Plugs. . . . . . 3-212 
RHO-BWI-ST-7

1.0 INTRODUCTION 


\subsection{INTRODUCTION}

\subsection{OBJECTIVE AND SCOPE}

Until recentiy, the United States philosophy for geologic isolation of high-level nuclear wastes placed great emphasis on the host rock acting as the primary barrier for the containment of radionuclides (Batch and Heath, 1979). Recognizing the complexity of predicting long-term stability of geologic formations and the resultant uncertainty in their functioning as long-term barriers to radionuclide migration, the United States has (since 1977) adopted a multiple barriers approach to high-level nuclear waste storage and disposal. This approach involves the concept of engineered barriers (i.e., waste form, canister, buffer, overpack, backfill, emplacement hole liner, borehole plug, etc.) acting in concert with the natural barriers (geologic strata, distance to biosphere, etc.) in a sufficiently conservative manner to prevent unacceptable release of radionuclides to the biosphere. Such an approach has been widely accepted and endorsed by both the U.S. Government agencies and the general scientific community. Published reports have stated that:

\footnotetext{
"Multiple and redundant components (engineered barriers to isolate waste or substantially inhibit radionuclide movement are called for to compensate for uncertainties in assessing the long-term performance (of the) repository system." (NRC, 1980.)

"A systems approach should be used to select the geologic environment, repository site, and waste form. A systems approach recognizes that, over thousands of years, the fate of radionuclides in a repository will be determined by the natural geologic environment, by the physical and chemical properties of the medium chosen for waste emplacement, by the waste form itself, and other engineered barriers. If carefully selected, these factors can and should provide multiple, and to some extent independent, natural and engineered barriers to the release of radionuclides to the biosphere." (IRG, 1979.)

"With the expansion of effort came the realization that total isolation in the immediate waste repository probably cannot be guaranteed, and the recognition that a series of barriers--both engineered and natural--to waste migration could offer the level of protection needed to compensate for the uncertainties in predicting long-term waste isolation." (DOE and USGS, 1980.)
} 
"Protection against possible release of radionuclides goes beyond the two levels of containment provided by the solid (waste) form itself. A satisfactory method for disposing of high-level nuclear wastes will be one that uses a sequence of muTtiple barriers..." (NAE and NAS, 1979.)

"...the safe disposal of nuclear waste in a mined geologic repository is an acceptable approach. This disposal method is based on a series of engineered and natural1y occurring barriers to the environment (biosphere)..." (ANS, 1979.)

A generalized engineered barrier concept for disposal of spent fuel or high-level nuclear waste in a geologic repository is illustrated in Figure 1-1. In this system, the high-level waste form or spent fuel in a container is encapsulated in a suitable metallic or ceramic canister. In some cases, depending on the inertness of the waste form in the repository environment, the resulting assembiy may be sealed (overpacked) in a second canister. Overpacked waste canisters are inserted into holes bored into the repository floors or walls. As shown in Figure 1-1, it may be desirable to grout hole walls to seal fracture cracks caused by boring or drilling operations. After emplacement of the radioactive material, holes are backfilled with materials (e.g., clay minerais) for sorbing mobile radionuclides and/or intrusive groundwater. Once operations cease and retrievability is no longer desired, the shafts, tunnels, and boreholes are sealed and the waste is considered to be in final storage. The waste form-canister-overpack-backfill "waste package" makes up the engineered barrier system. The final barriers in this defense-in-depth system are the natural geologic strata. For a repository excavated in Columbia $P$ lateau basalt, the natural barriers include both fresh and altered basalt, secondary minerals which fill vugs, and interbed materials. Consistent with the engineered barrier requirement for geologic isolation of nuclear waste, an engineered barriers program has been organized within the Basalt Waste Isolation Project. It comprises the borehole plugging activity and the muitiple barriers activity. As its name implies, the former study involves selection, testing, demonstration, and evaluation of materials and machines for sealing man-made openings--boreholes, sharts, and tunnels--in or near a nuclear waste repository located in Columbia Plateau basalt. The objective of the multiple barriers activity is to 


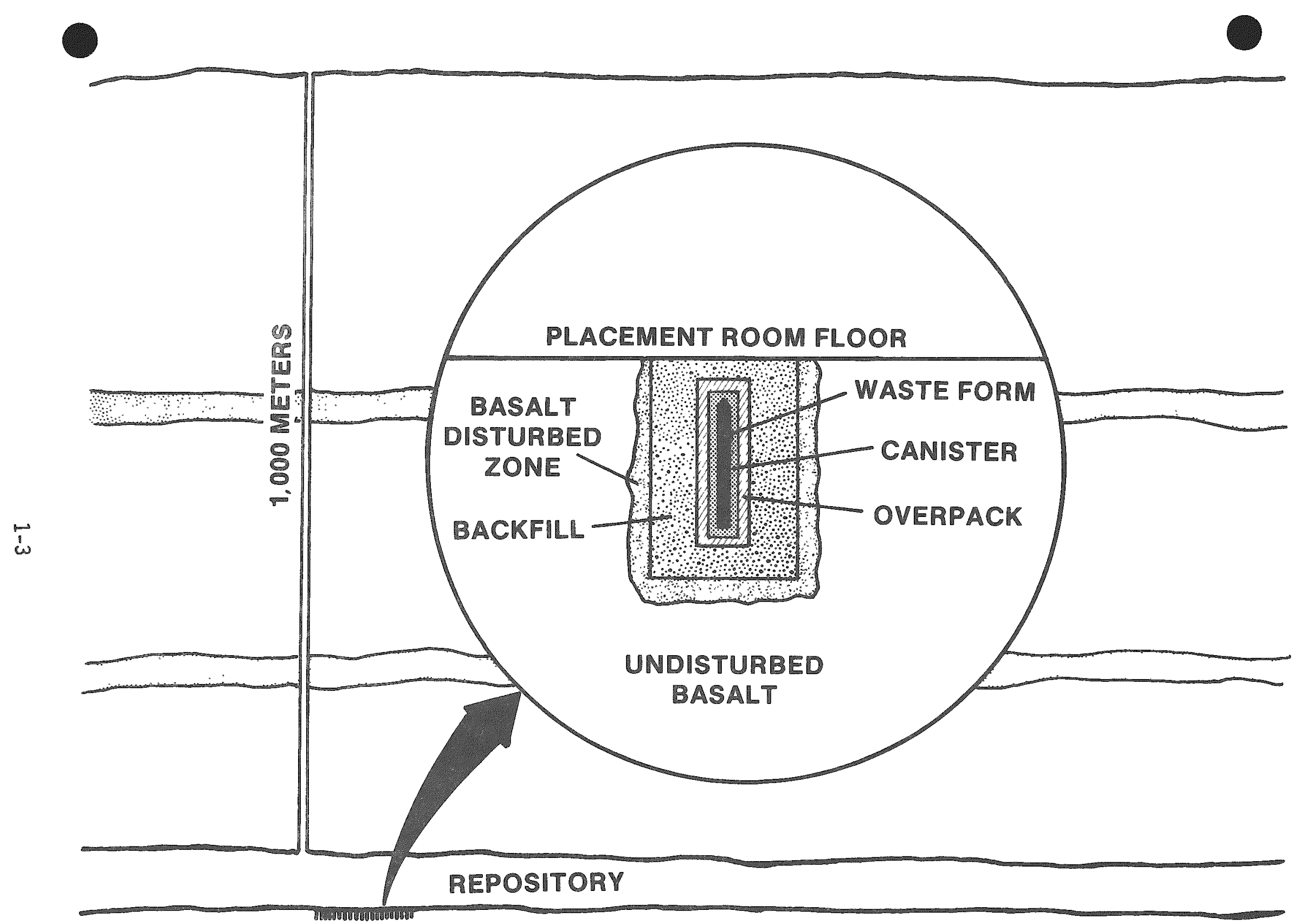

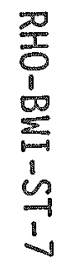

FIGURE 1-1. Generalized Concept of Engineered Barriers in Basalt. 
specify, for each candidate high-level waste form, a system of engineered barriers which together with the natural barriers--basalt, secondary minerals, and interbed/interflow materials--will effectively prevent or retard the migration of radionuclides to the biosphere. Although borehole plugs certainly constitute part of an overall "multiple barriers system," it is convenient to consider the borehole plugging activity separately from those of the other engineered barriers, as is done in this report.

The engineered barriers program of the Basalt Waste Isolation Project was organized and began operations in mid-1977. During the time since its inception, considerable progress has been made toward achieving the engineered barriers and borehole plugging programs' goals and objectives. The purpose of this report is to summarize the present status of the Basalt Waste Isolation Project's engineered barriers program, including important technical achievements made to date and their relation and significance to overall Basalt Waste Isolation Project objectives and schedules. Multiple barrier and borehole plug concepts and methodologies for defining acceptable barrier systems are addressed, as are also the principal experimental tasks, studies, and demonstration programs.

\subsection{ACKNOWLEDGMENTS}

The authors wish to express their appreciation to the Project Director, R. A. Deju, and the Associate Director, R. J. Gimera for their review comments and guidance in organizing this report. Thanks are also extended to the many persons who contributed their time to technically review portions of this document.

The authors are indebted to members of the geosciences and hydrology groups of the Basalt Waste Isolation Project who provided much valuable information concerning the geology and hydrology of the Pasco Basin. Recognition is also extended to $W$. I. Winters of the Systems Engineering Department who provided technical support required to complete this report. 
Special thanks are given to D. B. Mill for the preparation and coordination of plates and figures and to J. A. Foley for her tireless efforts devoted to completing draft contributions. Particular appreciation is also extended to J. M. Hofstedt for the technical editing and organizational assistance needed to prepare this document for publication.

Some of the information used and referred to in this document was obtained from Rockwe 11 Hanford Operations' subcontractors. When appropriate, these references have been properly acknowledged throughout the text. Particular thanks are extended to L. L. Ames of Battelle, Pacific Northwest Laboratory; L. V. Benson and L. S. Teague of Lawrence Berkeley Laboratory, University of California; B. E. Scheetz and colleagues at the Materials Research Laboratory, The Pennsylvania State University: and Woodward-Clyde Consultants for their many contributions. 
RHO-BWI-ST-7

2.0 MULTIPLE BARRIERS 


\section{RHO-BWI-ST-7}

\subsection{MULTIPIEE BARRIERS}

\subsection{INTRODUCTION}

As noted in the preceding chapter, an engineered system of multiple and redundant components (canisters, buffer, overpack, and backfi11) to isolate waste or substantially inhibit radionuclide movement is called for in present regulations to overcome uncertainties in assessing the long-term performance of a repository system. A program to select and qualify an assemblage of engineering components suitable for a repository in basalt is being conducted as part of the Basalt Waste Isolation Project.

The environment expected in a repository located in basalt is being characterized to assess the effect of the rock, the entrained groundwater, and the waste form on defining the near-field environment. As a part of this characterization task, a set of reference repository conditions is being assembled that constitutes the basis for engineered barriers testing and validation. These provide the basis for the design and development of engineered barrier systems that must function during the operating, thermal, and geologic control periods of repository life. These barrier systems must then be qualified by demonstrating compliance with established criteria to meet repository licensing requirements. The selection of barrier systems for consideration is expected to follow the logic contained in Figure 2-1.

\subsubsection{Barrier Selection}

The first step in barrier selection is to define the necessary barrier components required to meet established performance criteria for the operating, thermal, and geologic periods. The nature and number of barrier components chosen is dictated by the specific waste form selected and the geologic environment which controls system stability. It is important to consider the temporal nature of the repository and the multitude of environments to which a barrier will be subjected. The barrier system must then be matched with the job and the conditions expected for its operating life. For the purpose of illustration, consider storage of spent fuel elements in basalt. In tests using simulated spent fuel, some 


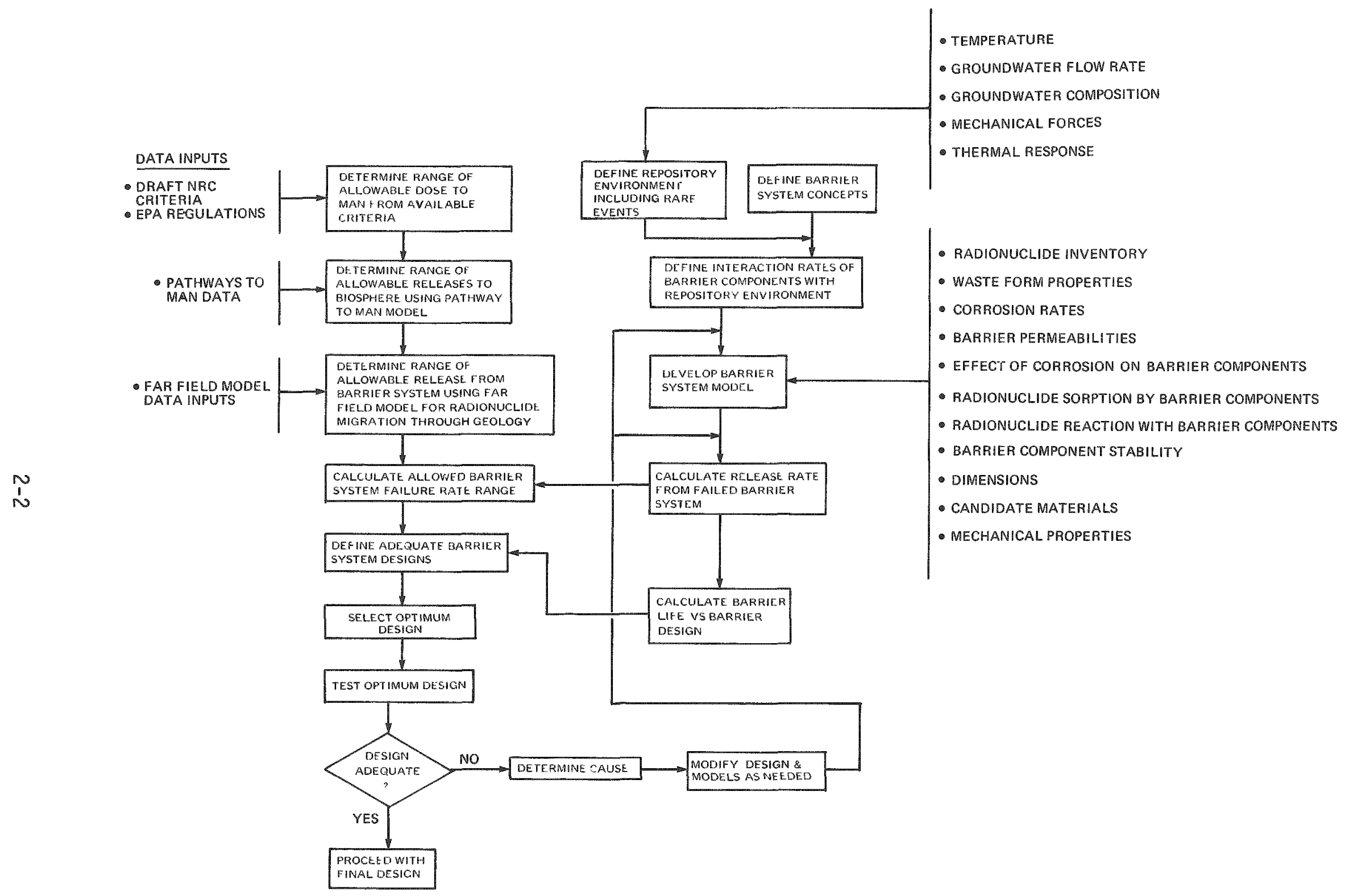

FIGURE 2-1. Selection Process for an Engineered Barrier System. 
components of the waste form appear to be leachable if exposed to heated water. It also appears that the leachable components are reactive to sodium feldspar. This information regarding the reactivity of spent fuel leads to several conclusions:

- Spent fuel must be isolated from groundwater.

- A backfill will likely be required to guard further against waste dispersal in the event of container failure and groundwater incursion.

- A major component of the backfill will probably be sodium feldspar, which will immobilize cesium by reaction to form pollucite and will also fix strontium and rubidium.

If the assumption is made that spent fuel will be delivered to a repository in a standard canister (probably steel), an additional preliminary conclusion can be made:

- Physical isolation of the fue is likely to require sitespecific overpacking to prevent corrosion and failure of the canister.

\subsubsection{Definition of Repository Conditions}

In order to compose a preliminary list of barrier materials, it is first necessary to determine reference conditions (see Fig. 2-1) in an operating repository. These conditions may be estimated by modeling (e.g. temperature contouring), experimentation (e.g., hydrothermal solution composition), and/or field measurements (e.g., ambient groundwater compositions and temperatures).

Some of these conditions depend on repository design, while others are intrinsic to geologic storage. For instance, spent fuel stored in basalt at Hanford is calculated to raise the surrounding rock to a temperature of $250^{\circ} \mathrm{C}$ at peak thermal output (Hardy and Hocking, 1978). However, the maximum temperature could be reduced by increased canister spacing or through decreased waste loading. In contrast, groundwater reaction with silicate glass generates acid and will depress solution $\mathrm{pH}$ (Bischoff and Dickson, 1976; Barnes and Scheetz, 1979). This chemical 
process will occur as long as magnesium-rich clay is formed as a reaction product. It is important to distinguish those parameters which are adjustable in order to make informed decisions later in the material selection process. Presentiy at Hanford, the parameters in an operating repository in basalt considered to affect barrier material selection include:

$\begin{array}{ll}\text { Temperature } & =\left(660 \text { to } 250^{\circ} \mathrm{C}\right) \\ \text { Pressure } & =(100 \text { to } 300 \text { bars }) \\ \text { Oxygen Fugacity } & =\left(\mathrm{Ni}-\mathrm{NiO}^{\circ} \text { to } \mathrm{Fe}_{3} \mathrm{O}_{4}-\mathrm{Fe}_{2} \mathrm{O}_{3} \text { contro } 1\right) \\ \text { Groundwater } \mathrm{pH} & =(2.0 \text { to } 10.1) \\ \begin{array}{l}\text { Presence of } \\ \text { Aqueous Complexing }\end{array} & =\left(\mathrm{Cl}^{-}, \mathrm{F}^{-}, \mathrm{SO}_{4}^{-2}\right) \\ \text { Agents } & \end{array}$

Reflecting on the range of these parameters, the wisdom of considering engineered barriers as an integrated system becomes clear. It is unlikely that a single encapsulation material can be depended on to survive through all repository conditions. It seems more prudent to design a set of barriers with each component designed to perform a specific function and operate during a specific period of repository life. The components of an engineered barrier system at two different times in repository history are illustrated in Figure 2-2. The radionuclides of concern in the thermal and geologic time periods are shown in Figure 2-2.

As discussed above, the selection of an engineered barrier system develops from the realization that repository conditions change with time. For instance, in the thermal period, groundwater $\mathrm{pH}$ will be low, oxygen fugacity may be high, and temperature will be high. During this time period, emphasis is placed on protecting an iron-based canister and isolating the highly soluble radionuclides, cesium and rubidium, from the groundwater. At this time, overpack and buffer components are of special importance because early conditions are likely to corrode the canister and promote dissolution of waste. Later in repository history, the temperature will have dropped, the $\mathrm{pH}$ will have risen, and an iron-based canister will be much more stable. In addition, short-lived cesium and 


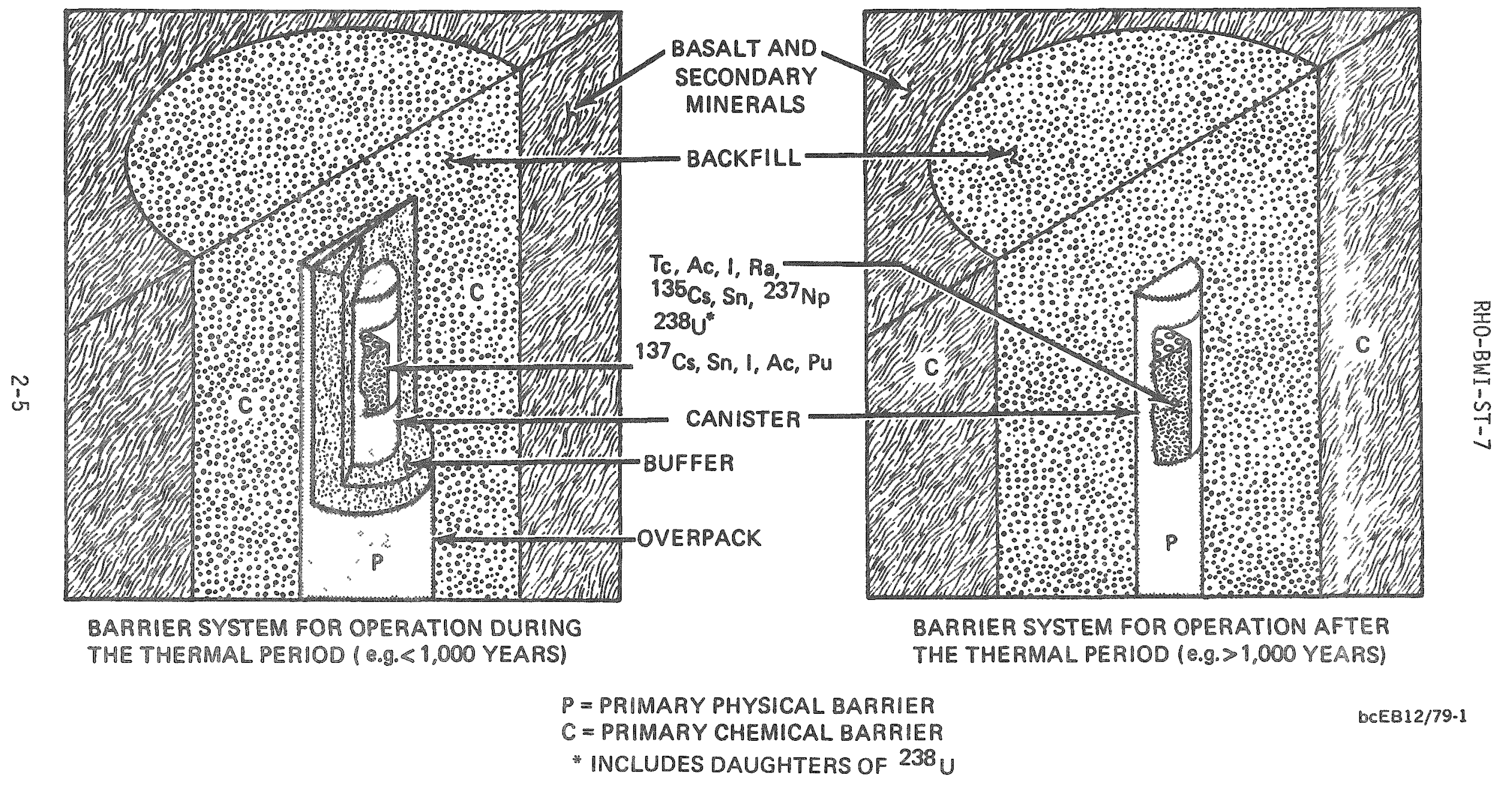

FIGURE 2-2. Requried Components of an Engineered Barrier System as a Function of Time. 
strontium will have decayed to innocuous levels, reducing general waste form solubility problems. During the geologic controls period, the importance of canister and waste form solubility is emphasized and the geology replaces backfill as the primary chemical barrier to dispersal of waste materials. Using this reasoning, a total barrier system can be conceived for effective operation throughout repository life. For spent fuel in basalt, likely components (and materials) include:

- Canister - Probably steel (assumption)

- Buffer - Graphite, powdered metals (titanium, aluminum, iron), bentonite, feldspar, carbonates

- Overpack - Titanium, noble metals, zirconium, copper, aluminum, alumina, specialized alloys (e.g., Hastelloy)

- Backfill - Bentonite, clay, quartz, zeolites, basalt, basalt glass, sodium feldspar, bornite.

These candidate materiais have been selected, as discussed in subsequent sections, on the basis of presently available data, indicating that they possess the prerequisite qualities demanded by the component function. These candidates can be screened to eliminate clearly unreasonabie choices and then are examined for stability. The best candidate can then be selected on the basis of expected repository performance.

\subsection{FUNCTIONS OF THE ENGINEERED BARRIER SYSTEMS}

While the concept of an engineered barrier system designed to provide redundancy in waste isolation has received firm support, the function of such a system has been described only in general terms (Westerman, 1979; DOE and USGS, 1979). More detailed functional criteria are necessary to act as the basis for continued research supporting engineered barrier development for a nuclear waste repository in basalt. The primary purpose of this section, therefore, is to define those functions in greater detail. A concise statement of the function of each barrier in a conceptual system is given, accompanied by a brief discussion intended to convey the basis for the statement and to give examples of candidate materials which might be selected to meet the engineered barrier design goal. As an introduction to the discussion, a conceptual engineered 
barrier system is defined, and the operating philosophy is briefiy discussed. Proposed critcria which will intuence the design of the engineered barrier system are identified.

\subsubsection{General Design Goal}

The engineered barrier system must be a practical system designed to meet the need for protection of public health and safety. It must meet this need in a cost-effective manner within the envelope of performance criteria presentiy being proposed and promulgated by cognizant federal agencies. These criteria are needed, but they should not motivate a research and development effort that pursues the development of ideal engineered barrier systems and ignores the cost of inordinately long deveTopment programs.

It is the goal of the Basalt Waste Isolation Project to develop acceptable, basalt-specific, engineered barrier systems which are waste form specific and qualifiable in terms of being cost effective and functionally acceptable for emplacement in a repository located in basalt.

\subsubsection{System Description}

Currently, technology development is not sufficiently advanced to permit a precise engineered barrier system design description for a nuclear waste repository in basalt. An understanding of the chemical interactions occurring among the basalt, groundwater, waste form, and other components of the engineered barrier system within the repository environment is needed. However, for the purpose of this illustration, a five-component barrier system has been selected and is depicted in Figure 2-3. These components encompass the several types that may be required for an effective barrier system. A grouted region and retrieval sleeve are also shown in Figure 2-3. The grouted region represents one means of stabilizing the basait disturbed during emplacement hole drilling. The grout would exhibit some water-retardant properties, but is not considered an engineered barrier component here. The use of the retrieval sleeve reflects the need for a means of facilitating waste retrieval, if required, during the operational period of the repository. This sleeve 


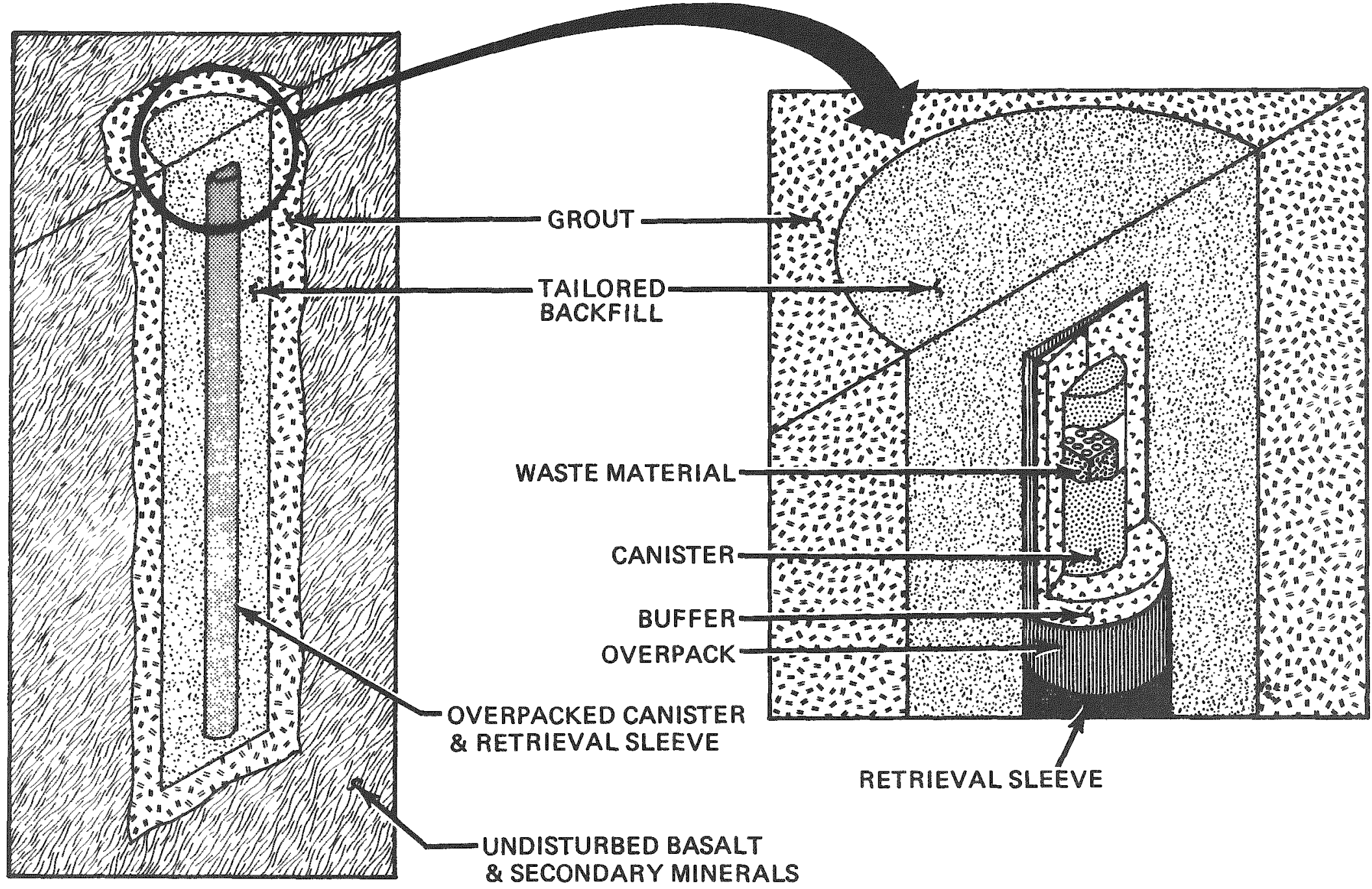

FIGURE 2-3. Engineered Barrier System Emplacement Concept. 
would be designed for short-term service and would not constitute a long-term barrier to water intrusion, thus it is also not considered a barrier component for the present discussion.

Depicted in Figure 2-4 is one potential scheme for emplacing the engineered barrier system in a repository in basalt. The merger of the engineered and natural barrier systems to form the multiple barrier system required for effective nuclear waste isolation is also illustrated.

The operating basis for the engineered barrier system can best be described in terms of the repository history, which can be divided into two fundamental periods based on the prevailing conditions at the time. The early history (e.g., <1,000 years) is defined as the thermal period. It is that interval of time during which the ambient geothermal gradient is perturbed by the heat produced by radionuclide decay, including the portion of time before closure when the repository is under institutional control. Late repository history is the period of geologic control. It is defined as the interval of time after the thermal period when geologic conditions have returned to a static, natural, thermal condition and prior to decay of radionuclides to innocuous levels. The different environmental conditions existing during these two time periods give rise to separate problems--different engineered barrier functions and different materiais requirements. The engineered barrier functions are tabulated in Table 2-1 against the repository operating history. The functions of the geology (basalt) are included to show the relationship between the engineered barriers and the natural barriers.

As noted in Table 2-1, the waste form and canister have functions prior to emplacement in the repository. The waste form acts to retain the radionuclides, while the canister provides physical support and protection for the waste form during handiing and transportation. Thereafter, for the life of the repository, the waste form continues to function in the same manner, while the role of the canister and remaining engineered barriers varies with the operating period. Also, during the repository operating period, the geology prevents access of the waste form to man. 


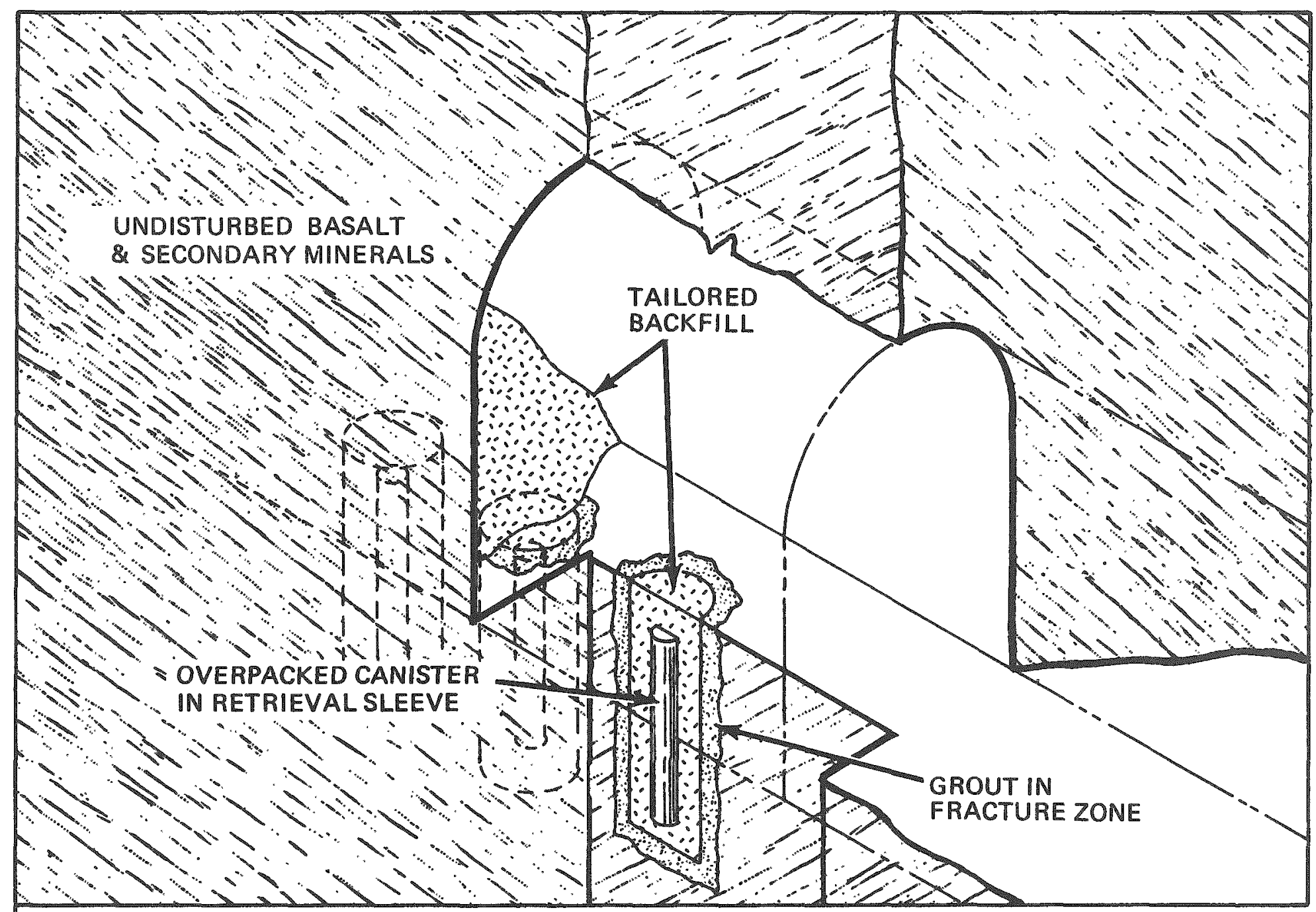


RHO-BWI-ST-7

TABLE 2-1. Barrier Function Versus Time.

\begin{tabular}{|c|c|c|c|}
\hline Item & Barrier & Operating Period & Function \\
\hline \multirow[t]{3}{*}{1} & $\begin{array}{l}\text { Geology } \\
\text { (Basalt) }\end{array}$ & Thermal Perioda & $\begin{array}{l}\text { Supp lementary chemical } \\
\text { barrier to radionuclide } \\
\text { migration }\end{array}$ \\
\hline & & Geologic Controlb & $\begin{array}{l}\text { Primary chemical barrier } \\
\text { to radionuclide migration }\end{array}$ \\
\hline & & Repository Lifec & $\begin{array}{l}\text { Physical isolation of } \\
\text { waste material from man }\end{array}$ \\
\hline \multirow[t]{3}{*}{2} & Backfill & Thermal Period & $\begin{array}{l}\text { Primary chemical barrier } \\
\text { to radionuclide migration }\end{array}$ \\
\hline & & & $\begin{array}{l}\text { Inhibits groundwater } \\
\text { intrusion }\end{array}$ \\
\hline & & Geologic Control & $\begin{array}{l}\text { Secondary chemical } \\
\text { barrier }\end{array}$ \\
\hline 3 & Overpack & Thermal Period & $\begin{array}{l}\text { Primary physical barrier } \\
\text { to groundwater intrusion } \\
\text { Aids in retrievability }\end{array}$ \\
\hline 4 & Buffer & Thermal Period & $\begin{array}{l}\text { Chemically inhibits } \\
\text { canister corrosion in } \\
\text { event of failed overpack }\end{array}$ \\
\hline \multirow[t]{4}{*}{5} & Canister & Pre-Emp lacement & $\begin{array}{l}\text { Provides physical } \\
\text { support and protection } \\
\text { for waste form }\end{array}$ \\
\hline & & Thermal Period & $\begin{array}{l}\text { Supplement to overpack } \\
\text { preventing groundwater } \\
\text { intrusion }\end{array}$ \\
\hline & & & Permit retrievability \\
\hline & & Geologic Control & $\begin{array}{l}\text { Primary physical barrier } \\
\text { to groundwater intrusion }\end{array}$ \\
\hline 6 & Waste Form & $\begin{array}{l}\text { Pre-Emplacement and } \\
\text { Repository Life }\end{array}$ & $\begin{array}{l}\text { Retards release of radio- } \\
\text { nuclides in the event of } \\
\text { containment failure }\end{array}$ \\
\hline
\end{tabular}

aThermal Period $=$ Time before 1,000 years of operation.

bGeologic Control = Time after 1,000 years of operation.

CRepository Life $=$ Thermal period + geologic control.

dPre-Emplacement $=$ Time from canister filling to emplacement in the repository. 
During the thermal period, the canister, overpack, and backfill act to retard or prevent groundwater intrusion to the waste form, with the overpack functioning as the primary physical barrier and the backfill and canister functioning in supplementary roles. In the event of a premature failure of the overpack, the buffer acts to modify (Eh and pH control) the groundwater chemistry to decrease corrosion of the canister. Should the canister aiso become breached, the tailored backfill then functions as the primary chemical barrier to radionuclide migration, with the basalt functioning in a redundant role as a chemical barrier: During the early part of the thermal period, the period of retrievability, the overpack and canister also allow retrieval, if such an operation is required.

Canisters which have survived the thermal period will continue to function as primary physical barriers to water intrusion during the period of geologic control. In the event of canister failure, as groundwater reacts with the waste form, the basalt will function as the primary chemical barrier and the backfill will function as a secondary chemical barrier to radionuclide migration to the biosphere.

The functions of the conceptualized engineered barrier system and each of its components, together with examples of candidate materials, are discussed in greater detail in Section 2.2.4.

\subsubsection{System Criteria}

The engineered barrier system must be designed to meet certain criteria to be acceptable from the viewpoints of health and safety and protection of the environment. The need for such criteria was recognized early in the National Waste Terminal Storage Program before the advent of the engineered barrier concept as it is known today. The waste form and canister that comprised the waste package were addressed in early criteria development activities. Draft acceptance criteria were written that identified the constraints the waste package must meet to be compatible with handing and transportation facilities, as well as the geologic repository they were to support. The draft waste package acceptance criteria were based on the then perceived restrictions on physical dimensions, weight, shape, thermal power, etc. and were needed 
to support conceptual design activities associated with a geologic repository to be located in a salt formation. These criteria were, by necessity, semi-quantitative since much of the data influencing waste package design were yet to be developed.

The lack of an adequate data base motivated the Office of Nuclear Waste Isolation, as coordinator of the National Waste Terminal Storage Program, to broaden criteria development activities. Under its direction, qualitative statements are being prepared which define the general program policies and criteria intended to provide direction for a.11 National Waste Terminal Storage Program efforts. The Office of Nuclear Waste Isolation's waste package criteria are generic, and it is their intent that site-specific data be developed by each repository program to permit the development of waste package (engineered barrier system) acceptance and design criteria.

In addition to the draft criteria being developed for the U.S. Department of Energy by the Office of Nuclear Waste Isolation, other federal agencies have proposed criteria which will influence the disposal of radioactive waste (NRC, 1979b, 1980; EPA, 1979). To iTlustrate the breadth of the criteria that will affect engineered barrier system design, those applicable are tabulated in Table 2-2.

\subsubsection{Functions of the Engineered Barrier System}

2.2.4.1 Overall Function. The function of the engineered barrier system is to limit release of hazardous materials associated with nuclear waste to levels below established limits by means of an integrated system of physical and chemical barriers acting in concert with the geology.

2.2.4.2 Basis and Discussion. In Section 2.2.2, the engineered barrier system is described as a multi-component array which acts to inhibit hazardous release of commercial nuclear waste materials. A sequence of engineered barriers is required for maximum safety of the subsurface storage of nuclear waste even in the event of a worst credible repository failure; however, the components are not completely redundant to each other and cannot be designed to be completely redundant. Rather, some 
TABLE 2-2. Applicable Criteria That May Affect Waste Package/Engineered Barrier Design.

\begin{tabular}{|c|c|}
\hline Source & Requirements \\
\hline $\begin{array}{l}10 \text { CFR 50, } \\
\text { Appendix } F \text { (1979) }\end{array}$ & $\begin{array}{l}\text { Liquid high-level waste must be solidified within } \\
5 \text { years of its generation and transferred to a } \\
\text { federal repository within } 10 \text { years of its } \\
\text { generation. The solid waste must be chemically, } \\
\text { radiolytically, and thermally stable to prevent } \\
\text { excessive pressurization of the canister from the } \\
\text { canning to } 90 \text { days after receipt at the federal } \\
\text { repository }\end{array}$ \\
\hline $\begin{array}{l}10 \text { CFR } 60 \text {, } \\
\text { Subpart E, } \\
\text { Proposed Draft } 10 \\
\text { (March, 1980) }\end{array}$ & $\begin{array}{l}\text { Engineered barrier system to provide reasonable } \\
\text { assurance of containment for at least the first } \\
1,000 \text { years after decommissioning } \\
\text { Maintain retrievability option for the duration } \\
\text { of the operational period plus } 50 \text { years }\end{array}$ \\
\hline $\begin{array}{l}40 \text { CFR 191, } \\
\text { Subpart B, } \\
\text { Proposed Draft } 7 \\
\text { (November 1979) }\end{array}$ & $\begin{array}{l}\text { Requires a system of multiple passive barriers } \\
\text { with each barrier designed to isolate the waste } \\
\text { Requires design to permit waste recovery in } \\
\text { future years } \\
\text { Must be designed to deter unintentional intrusion } \\
\text { by man. } \\
\text { Requires zero release from the engineered barrier } \\
\text { system for first } 1,000 \text { years. From } 1,000 \text { to } \\
10,000 \text { years, release should be limited to that } \\
\text { associated with } 1 \text { death }\end{array}$ \\
\hline
\end{tabular}

components are supportive to others, enhancing the likelihood of reliable system performance.

There are two subsystems within the engineered barrier system. Physical containment of the hazardous material is provided by the canister and overpack and is enhanced by the buffer. Redundant chemical containment is provided by a backfill specifically tailored for the waste form and surrounding formations of a nuclear repository in basalt. This system will operate to restrict release in the event of failure of the physical barriers. Because the containment mechanisms of the two systems are so different (i.e., physical isolation as opposed to chemical reaction), it is unlikely that both systems could be rendered inoperative by a single, worst-case accident. 
As conceived, the engineered barrier system must be tailored to meet the needs imposed by waste form leachability (which requires it to be waste-form specific) while simultaneously maintaining compatibility with the geologic environment (which requires it to be site specific). These requirements are necessary to ensure that the system adequately prevents excessive release of hazardous material to the biosphere. To perform this function, it is required that each system be specifically designed to meet the needs of each repository and each waste form. A final design constraint is that barrier components should not interact so as to diminish performance of either subsystem.

2.2.4.3 Waste Form Function. The function of the waste form is to immobilize radionuclides associated with nuclear fuels by containment as part of a solid, such as glass or ceramic. For the purpose of this report, clad unreprocessed fuel is considered a waste form.

2.2.4.4 Basis and Discussion. The waste form is a solid, such as glass or ceramic, matrix which incorporates the hazardous materials from nuclear fuel thereby facilitating handling, storage, and transportation. Several waste forms have been proposed, but all fall into one of three categories: (1) spent fue 1; (2) glass; and (3) tailored ceramics. Each of these forms has its virtue, being favored for either technica?, economic, or non-proliferation reasons. It is the position of the Basalt Waste Isolation Project that an acceptable system can be designed for any given waste form, but that the waste form choice will affect the complexity, therefore the cost, feasibility, and size of a subsurface repository.

As an example of a waste form that may require greater reliance on an engineered barrier system, consider spent fuel, which is the waste form specified by national policy and is the waste form receiving most attention by the Basalt Waste Isolation Project. Its merits include high waste loading and no fabrication expense. However, preliminary evidence indicates a possible susceptibility of some components to hydrothermal leaching, most notably cesium, strontium, and rubidium (Johnson, 1977). Therefore, in order to conform to draft regulatory criteria (NRC, 1980), it would be necessary to engineer a system which protects or mitigates chemical degradation of the waste form. 
There are two ways to inhibit dispersal of radionuclides from spent fuel: prevent access of water to the waste or remove dissolved waste components from contaminated groundwater by reaction with a backfill material. For redundancy, the operation of both mechanisms is required and will result in the need for a more sophisticated canister/overpack/ backfill engineered barrier system which, in turn, may affect the cost and size of repository construction.

In contrast, consider the prospect of a highly leach-resistant waste form. By itself, it may be an effective barrier to radionuclide release, with the potential to function acceptably from the time of emplacement to beyond the thermal period of a repository. An engineered barrier system based on such a waste form may consist of only a canister plus backfill. However, there will be additional fabrication costs and these may be considerable if the waste form is not sufficiently flexible to accommodate the variations in composition inherent to a reprocessed waste stream.

In summary, the waste form is an integral part of the engineered barrier system. While an acceptable system can be designed regardless of the waste form selected, waste form choice will directly affect the size and cost of both the repository and associated barrier system. It is the plan of the Basalt Waste Isolation Project to develop a basalt-specific, engineered barrier system for spent fuel which is the waste form specified by national policy. Secondary consideration is being given to basalt-specific systems for alternate waste forms (e.g., borosilicate glass, supercalcine, and SYNROC) as a contingency in the event a decision to reprocess spent fuel is made.

2.2.4.5 Canister Function. The function of the canister is to provide physical support and protection for the waste form during solidification, handiing, and shipping and to act as the primary physical barrier to water intrusion following the thermal period in the repository.

2.2.4.6 Basis and Discussion. Since the inception of the national waste management effort, the waste canister has been viewed as a primary containment vessel designed to safely contain solidified waste during solidification and a period of interim storage, during handiing and shipping, and for a period of time after disposal in a geologic 
repository. The canister may contain a filler to keep the canister from collapsing under the pressures expected in a closed repository. The canister design life has been extended from the earlier requirement of 10 years' interim storage at the reprocessing facility plus 90 days after geologic disposal (NRC, 1979b), to the 100-year requirement for interim storage in a retrievable surface storage facility (ARHCO, 1974), and to the present multi-hundred year requirement for geologic disposal (NRC, 1980). With each incremental increase in design life requirements, the need for increased level of support for materials evaluation studies is recognized.

Today, the canister must bear a significantly greater burden of geologic waste isolation. The "head end" activities (design and fabrication quality assurance/quality control requirements, waste management system facility licensing requirements, transportation requirements, waste solidification processing requirements, possible requirements for a period of interim storage in water, etc.) plus the longevity requirements 211 have substantial impact on the material performance requirements and the need for mutually complementary engineered barriers to meet the requirements for waste isolation.

As an example, the design life requirements for the waste canister may extend beyond the thermal period of the repository and well into the period of geologic containment ( $>1,000$ years). During the thermal period, principal reliance for prevention of groundwater intrusion will be on the backfill and overpack, thus protecting the canister and enabling it to function at a later time. Following the thermal period and assuming failure of the overpack, the groundwater will be more benign (lower temperature and higher $\mathrm{pH}$ ) and will be anoxic due to the reducing capability of the basalt. Corrosion rates will also be much lower.

The list of candidate materials suitable for an anoxic environment may contain titanium-base, iron-base, nickel-base, and copper-base al7oys. Material evaluation studies incorporating these alloy systems have yielded results which are quantitatively applicable to the choice of canister materials for use in a repository in basalt. Braithwaite and Molecke (1979) have conducted corrosion studies to identify canister materials suitable for use in repositories in bedded salt and seabed 
sediments. Three alloys (TiCode-12, Hastelloy C-276, and 90-10 Cupronickel) were identified for further study. Incone1 625, Incoloy 825, and lead were considered as aiternative candidate metals. Other studies by Shannon (1977) yielded results similar to Braithwaite and Molecke's (1979) studies. Hastelloy C-276, Inconel 625, Inconel 600, Incoloy 825, and several titanium-base alloys were resistant to $250^{\circ} \mathrm{C}$ oxygen-free brine solutions.

Material corrosion in low-ionic strength groundwaters typical of a repository in basalt is anticipated to be less than in brines or seawater; therefore the above noted alloys can also be considered as candidate materials suitable for service in basalt environments.

2.2.4.7 Buffer Function. The functions of a buffer are to prolong canister life in the event of overpack failure by producing a chemical environment less conducive to canister corrosion and to improve thermal conductivity between the canister and overpack.

2.2.4.8 Basis and Discussion. The buffer is a mechanical mixture of specialized components designed to extend the life of a canister which otherwise might not survive through the thermal period. Emplaced between the canister and overpack, the buffer operates in the event of minor overpack failure and modifies or controls the local environment.

For example, assume a rupture in the overpack that is sma11, but sufficient to permit entry of groundwater. During the thermal period, it is possible that the groundwater $\mathrm{pH}$ may be as low as 4 due to hydrothermal reactions between the host rock and the groundwater. Under the oxygen fugacity imposed by geologic systems and with acid solutions, it is likely that an iron-based canister would corrode rapidiy. However, given an environment where groundwater flow is restricted, a material which absorbs water, raises $\mathrm{pH}$, and depresses oxygen fugacity wil1 greatiy extend canister life. Once the canister survives the thermal period, it will need minimal support from the buffer because conditions will have returned to high $\mathrm{pH}$ and low temperature. Under these conditions, even an iron-based canister is resistant to corrosion. 
Candidate buffer materials must be compatible with the canister/ overpack assembly and must be chosen to moderate conditions imposed by the geology which are unfavorable to canister life. Therefore, candidate buffer materiais are necessarily specific to the canister/overpack and to the repository geology. For the case of an iron-based canister in a basalt environment, buffer materials include graphite, powdered iron, aluminum and/or titanium, swelling clays, lime, and carbonates. These materials have been chosen for moderation of oxygen fugacity (graphite, powdered iron, and/or titanium) or groundwater pH (Time, carbonates, aluminum), or because of their ability to inhibit groundwater intrusion (aluminum, swelling clays). In addition, graphite and metals are good thermal conductors and can be expected to aid heat transport out of the waste package.

It is unlikely that the buffer will be composed entirely of a single material given the several purposes for which it is intended. It is more likely that the buffer will be a composite material which is sized and pre-formed to fill most of the volume between the canister and overpack. 2.2.4.9 Overpack Function. The functions of the overpack are to act as a barrier to the intrusion of groundwater through the thermal period of the repository and to provide a means for retrievability of the waste through the retrieval period.

2.2.4.10 Basis and Discussion. The overpack will be a highly corrosionresistant metal or ceramic material. Because of shipping weight and size restrictions, the buffer and overpack will likely be added to the waste canister in packaging facilities located at the repository. It is anticipated that fabrication specifications will not be as restrictive as those for the canister because the overpack will not function as a primary barrier for waste containment and will not be transported across the country. However, it must be designed with sufficient strength to allow handiing and permit retrieval should the need arise during the retrieval period.

The overpack (whose principal function is prevention of water intrusion) will be designed to perform this function from its emplacement through the thermal period (zero to $\sim 1,000$ years) of the repository. During this period, the groundwater will tend to be more corrosive due to 
the higher temperature and possibly lower pH. For the first 100 years, during the period of institutional control, the repository will be open. Groundwater will be accessible to oxygen, and oxidizing conditions may prevail during a portion of this segment of the thermat period. Gradually, the crushed basalt in the backfill will promote anoxic conditions and alloys suitable for service in both oxidizing and anoxic environments would be considered candidates for overpacks. TiCode-12, a titanium-base alloy, is currently a prime candidate for overpacks by the Basalt Waste Isolation Project. It requires a source of oxygen to preserve its passive oxide coating. Under anoxic conditions, the source of oxygen is supplied by the reduction of water by titanium metal.

other candidates being considered for service in both environments are the nickel-base alloys, Hastelloy C-276, Inconel 625, and Incoloy 825. The copper-base alloy, 90-10 Cupronickel, exhibits unacceptable corrosion resistance in oxidizing environments, thus it is only usefur in anoxic environments. However, further testing under environmental conditions expected in a repository in basalt may prove them to be suitable candidates for overpack fabrication.

2.2.4.11 Tailored Backfill Function. The functions of a tailored backfill are to provide thermal continuity between the overpack and the wall rock, aid emplacement (i.e., alignment) of the canister/overpack assemblage, and act as the primary chemical barrier to radionuclide migration. The backfill will also lend structural support to the repository and inhibit access of water to the canister.

2.2.4.12 Basis and Discussion. The backfill is a crushed material which will be packed around the canister and used to fill the repository and borehole excavations. Rather than simply filling the hole and/or repository with previousiy mined rock, it may be preferable to tailor the material to act as an engineered barrier.

It is conceivable that the backfill will act as a primary barrier to groundwater intrusion. This requires that the material be easily compacted and/or that it swells to absorb pore volume. It is imperative to design the backfill to promote reaction with hazardous materials that might disperse from a failed canister/overpack system. Thus, use of 
materials which absorb cesium, rubidium, strontium, and transuranic elements could be a prerequisite.

A final consideration is that the backfill materials must have moderate thermal stability. Although the backill is intended to operate throughout the life of the repository, the most likely period for failure of physical containment is during the thermal period. Therefore, it is critical that the backfill be both stable and operative between temperatures of $65^{\circ}$ and $300^{\circ} \mathrm{C}$. While both temporary sorption and permanent retention are desirable qualities, an idealized backfi11 wi11 react irreversibly with waste components, permanently trapping them in a crystaliine framework.

The backfill may be compacted and pre-formed into suitable shapes before placement in the boreholes. This procedure may simplify placement of canisters and canister retrieval. Pre-formed backfills acting as sleeves should aid in canister/overpack placement. This sleeve then becomes the chemical barrier to radionuclide release, a barrier to groundwater intrusion. Materials being considered by the Basait Waste Isolation Project as candidate components of the backfill include swelling clays to retard groundwater intrusion), crushed basalt and sodium feldspars (reactive extraction of cesium, rubidium, and strontium), and zeolites, titanates, and bornite (sorb radionuclides).

\subsection{ROCK CHARACTERISTICS AND GEOLOGIC SETTING}

\subsubsection{Introduction}

The Pasco Basin in southeastern Washington (Fig. 2-5, 2-6, and 2-7) is a structural and topographic depression containing a section of Columbia River basalt of Miocene age at least $1,500 \mathrm{~m}$ thick. This basalt is overlain by up to $200 \mathrm{~m}$ of Pliocene and Pleistocene fluvial and glaciofluvial sediments. The U.S. Government-owned Hanford Site is centrally located in the Pasco Basin (Fig. 2-8) which has been studied in detail since 1976 as part of the National Waste Terminal Storage Program.

Early geological investigators of the Columbia River basalt (Russell, 1903; Smith, 1901, 1903; Waring, 1913) documented the vast accumulation of continental basaltic rock in the northwestern part of the United 


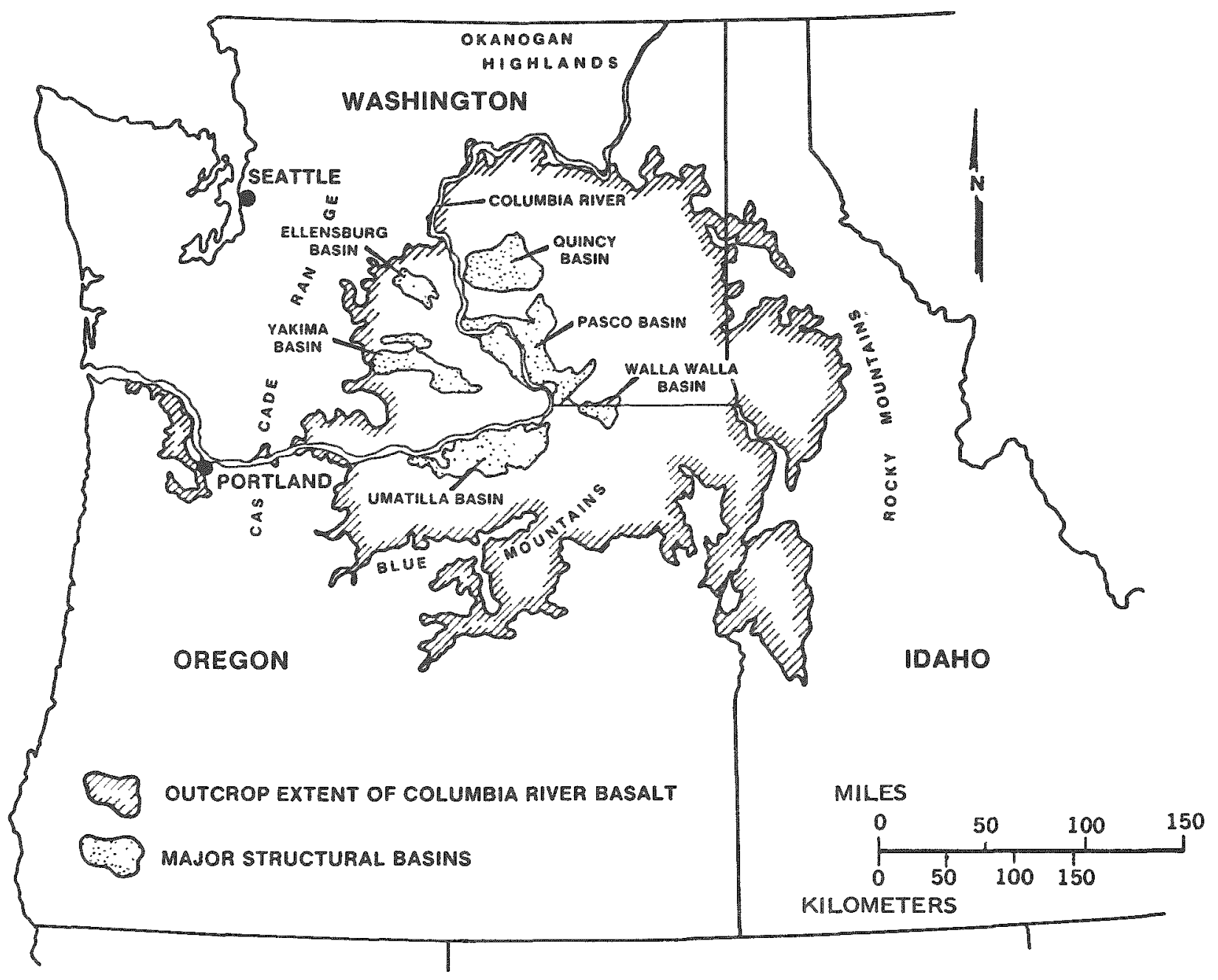

FIGURE 2-5. Distribution of Columbia River Basalt in Washington, Oregon, and Idaho (after Tal7man and Others, 1979). 


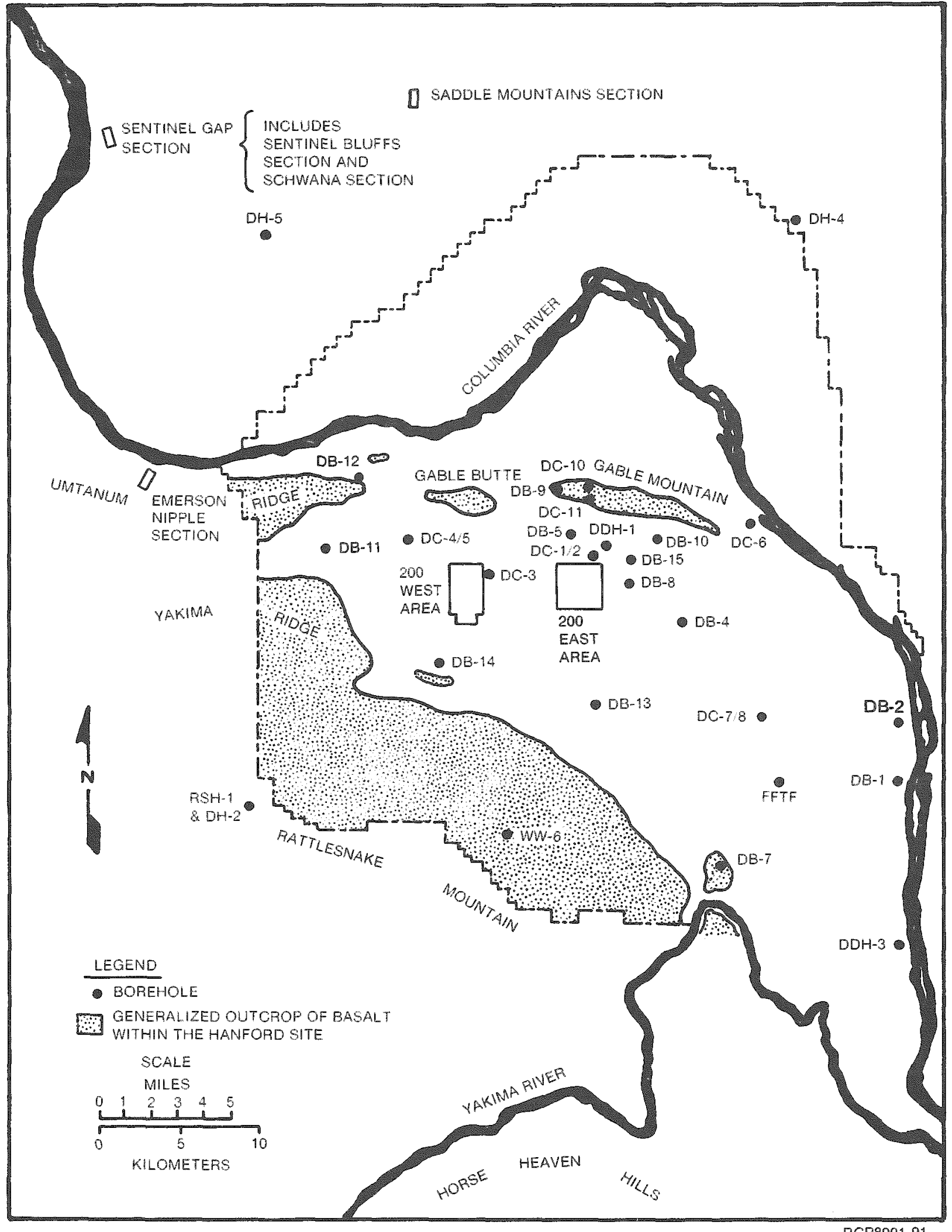

RCP8001-91

FIGURE 2-8. Hanford Site in the Pasco Basin and Locations of Boreholes Indicated and Referred to in the Text (after Myers/Price and Others, 1979). 
States. Later, Laval (1957) and Mackin (1961) were among the first geologists to successfully correlate the many basalt flows in the region using gross physical characteristics. More recentiy, Waters (1961) and Schmincke (1964), Wright and Others (1973), and Swanson and Others (1979) were able to apply geochemical and microscopic petrology to distinguish major groups of Columbia River basalt. Swanson (1967) was able to apply these techniques and lithologic properties to describe the basalt flows in still greater detail (Fig. 2-9). In 1968, these and other modern analytical techniques were used by the AtTantic Richfield Hanford Company on behalf of the U.S. Government to begin an intensive investigation of the basalt flows underlying the Hanford Site. Numerous publications were produced utilizing petrographic, geochemical, and geophysical techniques to identify and correlate basalt flows between bore holes and outcrops (Brown and Ledgerwood, 1973; Myers, 1973).

With the establishment of the National Waste Terminal Storage Program in 1976, increased emphasis was once again placed on the detailed examination of the Columbia Plateau basalts to determine their suitability for the terminal storage of radioactive waste. In 1977, largely due to the completion of earlier studies (Ledgerwood and Deju, 1976; ARHCO, 1976), support was given by the U.S. Department of Energy to evaluate in greater detail that portion of the Pasco Basin underiying the Hanford Site. Since that time the Basalt Waste Isolation Project staff of Rockwell Hanford Operations (successor to Atlantic Richfield Hanford Company) has conducted these studies. This complex project has been outlined (Deju, 1978a; Deju and Others, 1978a) and includes the combined efforts of several programs (systems integration, geology, hydrology, engineered barriers, and engineered testing).

The purpose of the engineered barriers program is to design and evaluate the effectiveness of a multiple barriers system for nuclear waste isolation. In order to perform this task it is necessary to characterize fresh and altered basalt and interbed material in the Pasco Basin to understand and thus be able to predict chemical reactions at depth in the environs of the proposed repository. Some basalt character ization work has recently been reported (Myers/Price and Others, 1979; 


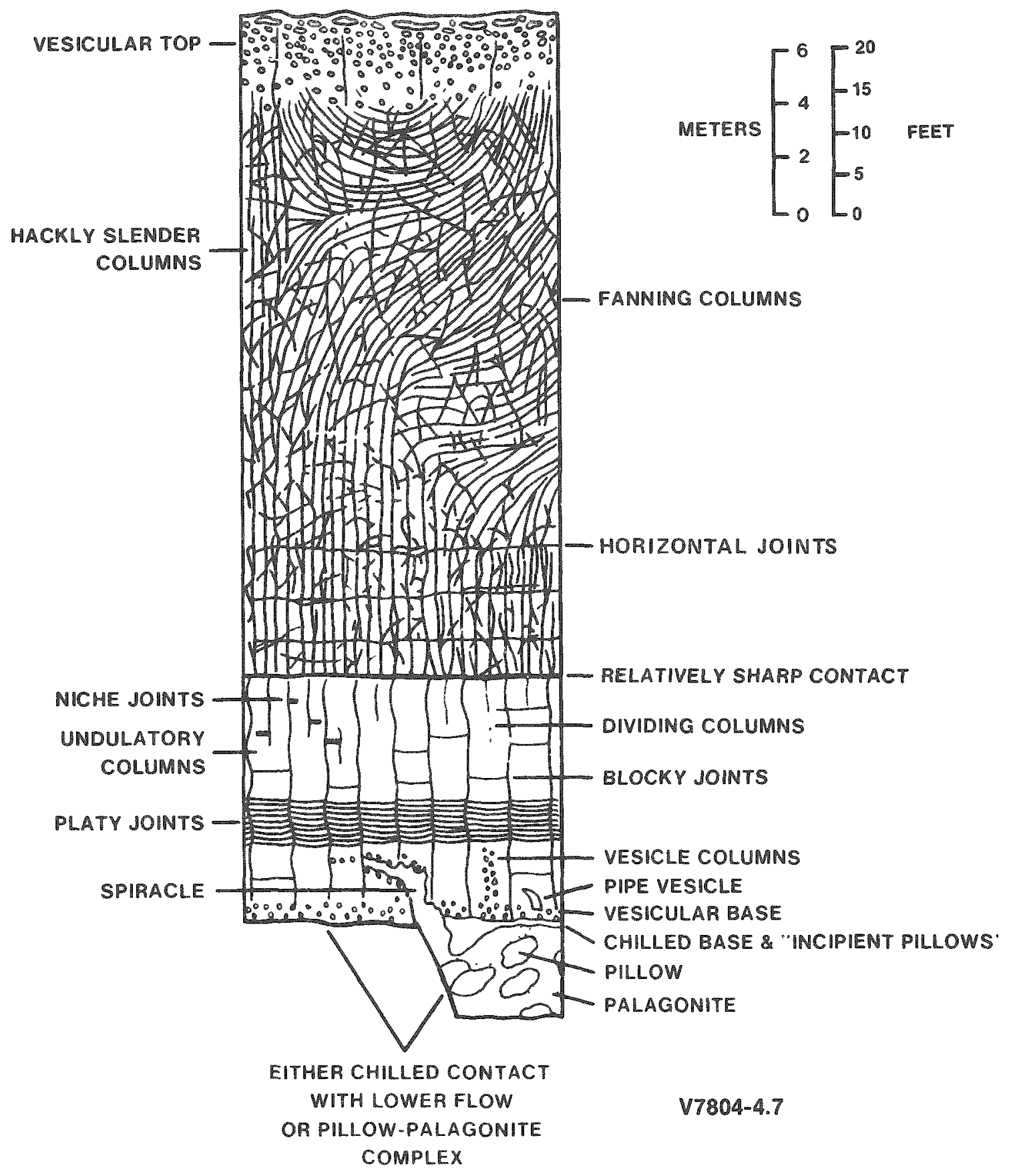

FIGURE 2-9. Physical Characteristics Recognized in a Typical Columbia River Basalt Flow (after Swanson, 1967). 
Ames, in press) as well as secondary mineralization studies (Benson and others, 1978, 1979; Ames, in press). X-ray fluorescence analyses of core hole and basalt outcrop samples have been obtained and detailed petrographic and microchemical studies are planned which should confirm existing stratigraphic nomenclature (Myers/Price and Others, 1979; Long and Others, 1980) (Fig. 2-10).

\subsubsection{Chemical Composition of Pasco Basin Basalts}

A knowledge of the major and minor element chemistry of the unaltered basalts in the Pasco Basin is essential to increase the probability of correctly correlating basalt flows and provide the basis for conducting valid hydrothermal experiments simulating reactions in and adjacent to the repository during and following the thermal period. The average major-element composition of selected Columbia River basalt chemical types presented in Table 2-3 probably approximates that of their stratigraphic equivalents in the Pasco Basin underlying the Hanford Site. These major units have been described in some detail (Myers/Price and Others, 1979) and will be reviewed in conjunction with correlation studies performed outside the basin.

2.3.2.1 Major Element Chemistry. The assumed approximate major-element composition of basalt formations in the Pasco Basin computed from Table 2-3 is presented in Table 2-4. More chemical information is available and required for the Grande Ronde Basalt because the flows are chemically and physically similar and selected flows in that formation are being considered as potential repository host rock (i.e., the Umtanum). Because of their chemical similarity, analyses of the Grande Ronde and other basalt flows have been used in conjuction with paleomagnetic and borehole geophysical log data to support rock stratigraphic correlations at depth. Magnetostratigraphic correlations are based on between-flow differences in magnetic-inclination values and on polarity changes. Borehole geophysical logs are useful for measuring changes in the physical properties of the rocks (e.g., density log, sonic log) and measuring certain chemical changes (e.g., gamma-ray log). Gamma-ray logs are particularly useful for identifying certain rock types by measuring 


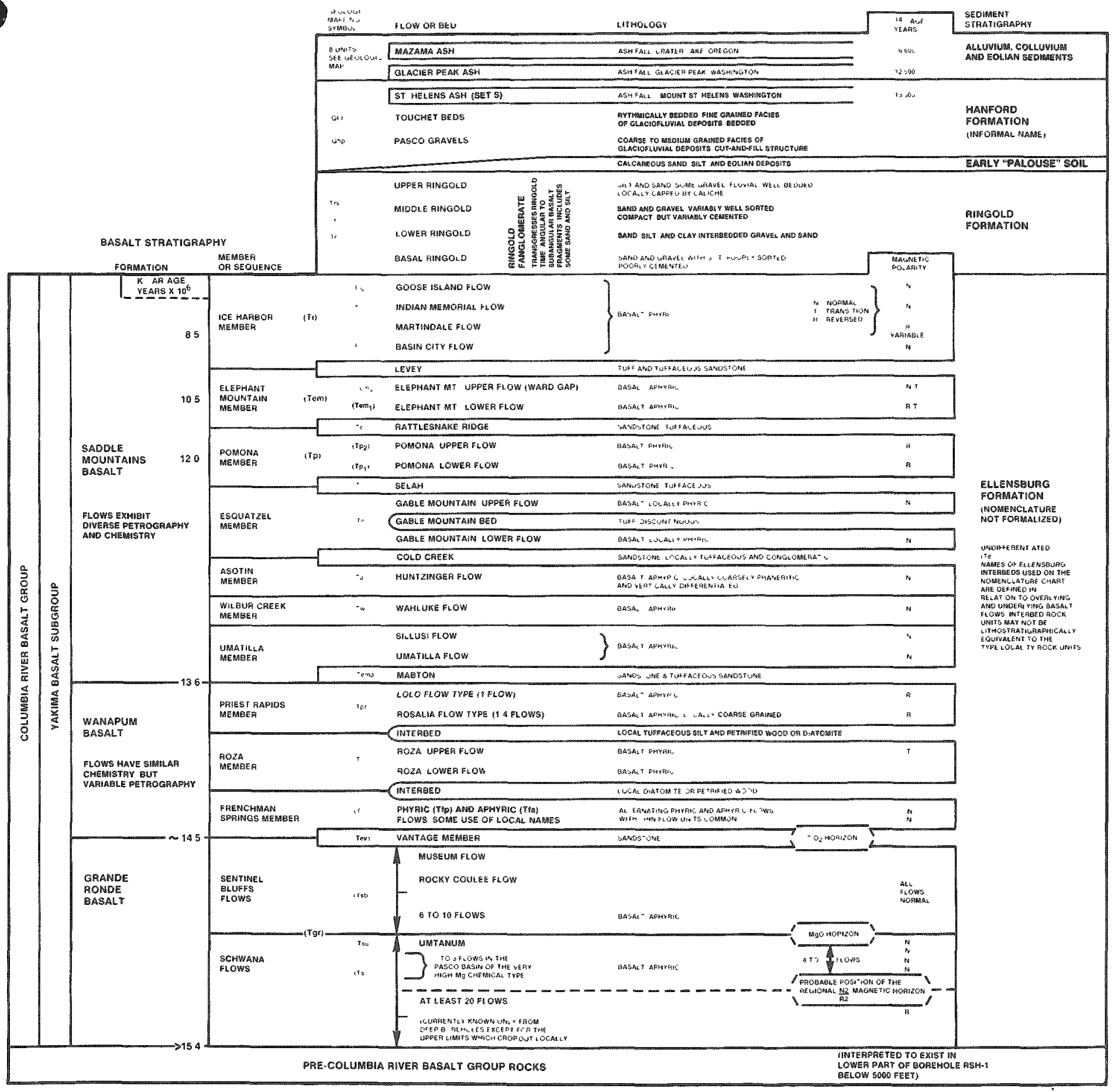

FIGURE 2-10. Pasco Basin Stratigraphic Nomenclature. 
TABLE 2-3. Average Major-Element Compositions of Columbia River Basalt Chemical Types.

(After Swanson and Others, 1979.)

\begin{tabular}{|c|c|c|c|c|c|c|c|c|c|c|c|c|c|c|}
\hline \multirow{5}{*}{$\begin{array}{l}\text { Membersa } \\
\text { Flowsb } \\
\text { Thickness (m)c }\end{array}$} & \multicolumn{13}{|c|}{ Formations } & \\
\hline & \multicolumn{3}{|c|}{ Grande Ronde } & \multicolumn{4}{|c|}{ Wanapum Basalt } & \multicolumn{7}{|c|}{ Saddle Mountains Basalt } \\
\hline & 1 & 2 & 3 & 4 & 5 & 6 & 7 & 8 & 9 & 10 & 11 & 12 & 13 & 14 \\
\hline & 8 & 20 & 3 & 8 & 3 & 2 & 2 & 2 & 1 & 1 & 2 & 1 & 2 & 3 \\
\hline & 300 & 770 & 30 & 200 & 60 & 35 & 35 & 45 & 15 & 30 & 15 & 40 & 30 & 20 \\
\hline $\begin{array}{l}\text { (wt\%) } \\
\mathrm{SiO}_{2}\end{array}$ & 53.78 & 55.94 & 54.37 & 52.29 & 51.19 & 50.27 & 50.09 & 54.70 & 54.41 & 50.72 & 54.16 & 51.88 & 51.08 & 47.89 \\
\hline $\mathrm{Al}_{2} \mathrm{O}_{3}$ & 14.45 & 14.04 & 15.28 & 13.21 & 14.07 & 13.69 & 14.31 & 14.10 & 14.51 & 16.23 & 13.84 & 14.88 & 13.54 & 13.41 \\
\hline Feod & 11.35 & 11.77 & 9.46 & 14.38 & 13.91 & 15.04 & 13.78 & 12.63 & 11.07 & 9.64 & 12.60 & 10.55 & 14.75 & 15.72 \\
\hline MgO & 5.25 & 3.36 & 5.91 & 4.04 & 4.39 & 4.29 & 5.18 & 2.71 & 4.51 & 8.19 & 3.91 & 6.96 & 4.28 & 5.43 \\
\hline $\mathrm{CaO}$ & 9.07 & 6.88 & 9.79 & 7.90 & 8.48 & 8.31 & 8.88 & 6.14 & 8.32 & 10.70 & 7.71 & 10.67 & 8.34 & 9.41 \\
\hline $\mathrm{Na}_{2} \mathrm{O}$ & 2.83 & 3.14 & 2.80 & 2.67 & 2.72 & 2.67 & 2.57 & 3.20 & 2.69 & 2.22 & 2.66 & 2.36 & 2.45 & 2.39 \\
\hline $\mathrm{K}_{2} \mathrm{O}$ & 1.05 & 1.99 & 0.77 & 1.41 & 1.22 & 1.16 & 1.07 & 2.68 & 1.77 & 0.51 & 1.70 & 0.64 & 1.25 & 0.89 \\
\hline $\mathrm{TiO}_{2}$ & 1.78 & 2.27 & 1.17 & 3.17 & 3.13 & 3.55 & 3.15 & 2.80 & 1.95 & 1.45 & 2.82 & 1.62 & 3.52 & 3.57 \\
\hline$P_{2} O_{5}$ & 0.28 & 0.43 & 0.29 & 0.71 & 0.67 & 0.81 & 0.78 & 0.88 & 0.56 & 0.18 & 0.41 & 0.25 & 0.59 & 1.06 \\
\hline MnO & 0.19 & 0.19 & 0.16 & 0.22 & 0.23 & 0.21 & 0.19 & 0.17 & 0.21 & 0.17 & 0.19 & 0.17 & 0.20 & 0.23 \\
\hline Totale & 100.01 & 100.01 & 100.00 & 100.00 & 100.00 & 100.00 & 100.00 & 100.01 & 100.00 & 100.01 & 100.00 & 99.98 & 100.00 & 100.00 \\
\hline
\end{tabular}

Members: 1 High-Mgo Grande Ronde; 2 Low-Mg0 Grande Ronde; 3 Very high-Mgo Grande Ronde; 4 Frenchman Springs; 5 Roza;.6 Priest Rapids

(Rosalia Chemical Type); 7 Priest Rapids (Lolo Chemical Type); 8 Umatilla; 9 Wilbur Creek; 10 Asotin; 11 Esquatzel; 12 Pomona; 13 Elephant Mountain; 14 Ice Harbor (Average of the Basin City, Martinstale (Ice Harbor I) and the Goose Island (Ice Harbor II) Chemical Types).

bapproximate number of flows in the Pasco Basin (average thickness, $20-25$ meters).

CApproximate average thickness in meters of basalt memebers in the Pasco Basin.

$\mathrm{dFeO}_{\mathrm{Fe}} \mathrm{Fe}_{2} \mathrm{O}_{3}$, reported as $\mathrm{FeO}$

eResults normalized to $100 \%$. 
gamma emission from the naturally occurring radioactive isotopes, primarily $40_{K}$. Therefore, clay-rich interbeds and basalt flows either markedly higher or lower in $\mathrm{K}_{2} \mathrm{O}$ content are readily recognized.

TABLE 2-4. Approximate Major-Element Composition of Basalt Formations in the Pasco Basin.*

\begin{tabular}{l|c|c|c|c}
\hline Wt\% & $\begin{array}{l}\text { Grande } \\
\text { Ronde }\end{array}$ & Wanapum & $\begin{array}{c}\text { Saddle } \\
\text { Mountains }\end{array}$ & $\begin{array}{c}\text { Total } \\
\text { Sequence }\end{array}$ \\
\hline $\mathrm{SiO}_{2}$ & 55.29 & 51.65 & 52.22 & 54.23 \\
$\mathrm{Al}_{2} \mathrm{O}_{3}$ & 14.49 & 13.53 & 14.44 & 14.09 \\
$\mathrm{FeO}^{* *}$ & 11.58 & 14.30 & 12.24 & 12.18 \\
$\mathrm{Mg0}$ & 3.97 & 4.26 & 5.17 & 4.17 \\
$\mathrm{Ca0}$ & 7.58 & 8.15 & 8.84 & 7.84 \\
$\mathrm{Na}_{2} 0$ & 3.04 & 2.67 & 2.60 & 2.92 \\
$\mathrm{~K}_{2}{ }^{0}$ & 1.69 & 1.31 & 1.38 & 1.58 \\
$\mathrm{TiO}_{2}$ & 2.10 & 3.20 & 2.47 & 2.35 \\
$\mathrm{P}_{2} 0_{5}$ & 0.37 & 0.72 & 0.55 & 0.46 \\
$\mathrm{MnO}^{2}$ & 0.19 & 0.22 & 0.18 & 0.19 \\
\hline
\end{tabular}

*Values calculated from the average compositions of Columbia River basalt chemical types and approximate unit thicknesses. $\star * \mathrm{FeO}+\mathrm{Fe}_{2} \mathrm{O}_{3}$, reported as $\mathrm{FeO}$.

The Grande Ronde Basalt in the Pasco Basin has been broadly divided into two units based on its major element chemistry. The upper Sentinel Bluffs sequence of at least 13 flows, totaling nearly $300 \mathrm{~m}$, is chemically characterized by its relatively high-Mgo content ( $5 \% \mathrm{MgO}$ ). The lower stratigraphic sequence, the Schwana, consists of at least 25 flows of markedly lower MgO content (3.5\% MgO). The contact between these two major sequences, referred to as the "Mgo horizon," is a major chemical marker throughout the Pasco Basin. Within the Schwana sequence there is a single low- $\mathrm{K}_{2} \mathrm{O}$ flow which contains from 5 to $6 \% \mathrm{MgO}$ (also referred to as the very high-MgO flow).

Boreholes just north of the Hanford Site have penetrated at least $800 \mathrm{~m}$ of the Schwana sequence intersecting from 15 to 25 separate flows. Chemical stratigraphic correlations have identified 5 chemical stratigraphic units of the low-Mgo type. These units were correlated primarily on the basis of vertical variations in $\mathrm{TiO}_{2}$ and $\mathrm{MgO}$ content. The 
central and southern Pasco Basin boreholes reveal the $10 \mathrm{w}-\mathrm{K}_{2} \mathrm{O}$ (very high-Mgo) flow interlayered within the upper Schwana about 60 to $80 \mathrm{~m}$ below the Mgo horizon. The Umtanum flow, still within the Schwana sequence, directly overlies the low- $K_{2} 0$ flows in most areas within the central and southern portions of the basin (Fig. 2-11). X-ray fluorescence analyses of Umtanum basalt from core samples $D C-2, D C-4$, and $D C-8$ are presented in Table $2-5$.

TABLE 2-5. X-Ray Fluorescence Analyses of the Umtanum Flow. 2

\begin{tabular}{|c|c|c|c|c|}
\hline \multirow[b]{2}{*}{ Wt\% } & \multicolumn{3}{|c|}{ Core Sample } & \multirow[b]{2}{*}{ Average } \\
\hline & $D C-2(3)^{C}$ & $D C-4(2)^{C}$ & $D C-8(2)^{C}$ & \\
\hline $\begin{array}{l}\mathrm{SiO}_{2} \\
\mathrm{Al}_{2} \mathrm{O}_{3} \\
\mathrm{FeO}^{3} \\
\mathrm{MgO} \\
\mathrm{CaO} \\
\mathrm{Na}_{2} \mathrm{O} \\
\mathrm{K}_{2} \mathrm{O} \\
\mathrm{TiO}_{2} \\
\mathrm{P}_{2} \mathrm{O}_{5} \\
\mathrm{MnO}\end{array}$ & $\begin{array}{r}54.90 \\
14.31 \\
13.34 \\
3.50 \\
7.29 \\
2.35 \\
1.55 \\
2.18 \\
0.35 \\
0.22\end{array}$ & $\begin{array}{r}54.62 \\
14.62 \\
13.00 \\
3.45 \\
7.28 \\
2.72 \\
1.58 \\
2.16 \\
0.35 \\
0.22\end{array}$ & $\begin{array}{r}55.14 \\
14.10 \\
13.14 \\
3.40 \\
7.15 \\
2.69 \\
1.66 \\
2.16 \\
0.34 \\
0.22\end{array}$ & $\begin{array}{r}54.89 \\
14.34 \\
13.16 \\
3.45 \\
7.24 \\
2.59 \\
1.60 \\
2.17 \\
0.35 \\
0.22\end{array}$ \\
\hline TOTAL & 99.99 & 100.00 & 100.00 & 100.00 \\
\hline
\end{tabular}

aAll analyses normalized to $100 \%$.

$\mathrm{bFeO}+\mathrm{Fe}_{2} \mathrm{O}_{3}(2.00 \%)$ reported as $\mathrm{FeO}$.

CNumber of analyses ().

The Sentinel Bluffs sequence, remarkably constant in thickness across the basin $(220$ to $300 \mathrm{~m})$, directly overlies the Umtanum and the Mgo horizon. The sequence seems to be of one chemical type, high-Mgo, in which no stratigraphic units can be easily identified. However, major element analyses of flows exposed at the type locality (Museum flow and Flow E) were tested for vertical chemical variability and found to be somewhat different chemically. The Museum flow appears somewhat enriched in $\mathrm{SiO}_{2}, \mathrm{TiO}_{2}, \mathrm{FeO}$, and possibly $\mathrm{K}_{2} \mathrm{O}$ relative to $\mathrm{Flow} \mathrm{E}$. When the data are compared with average analyses of core samples taken from the central Pasco Basin there is no statistical difference between major element analyses demonstrating lateral as well as vertical chemical continuity of at least some flows in the Sentinel Bluffs sequence (Table 2-6). 


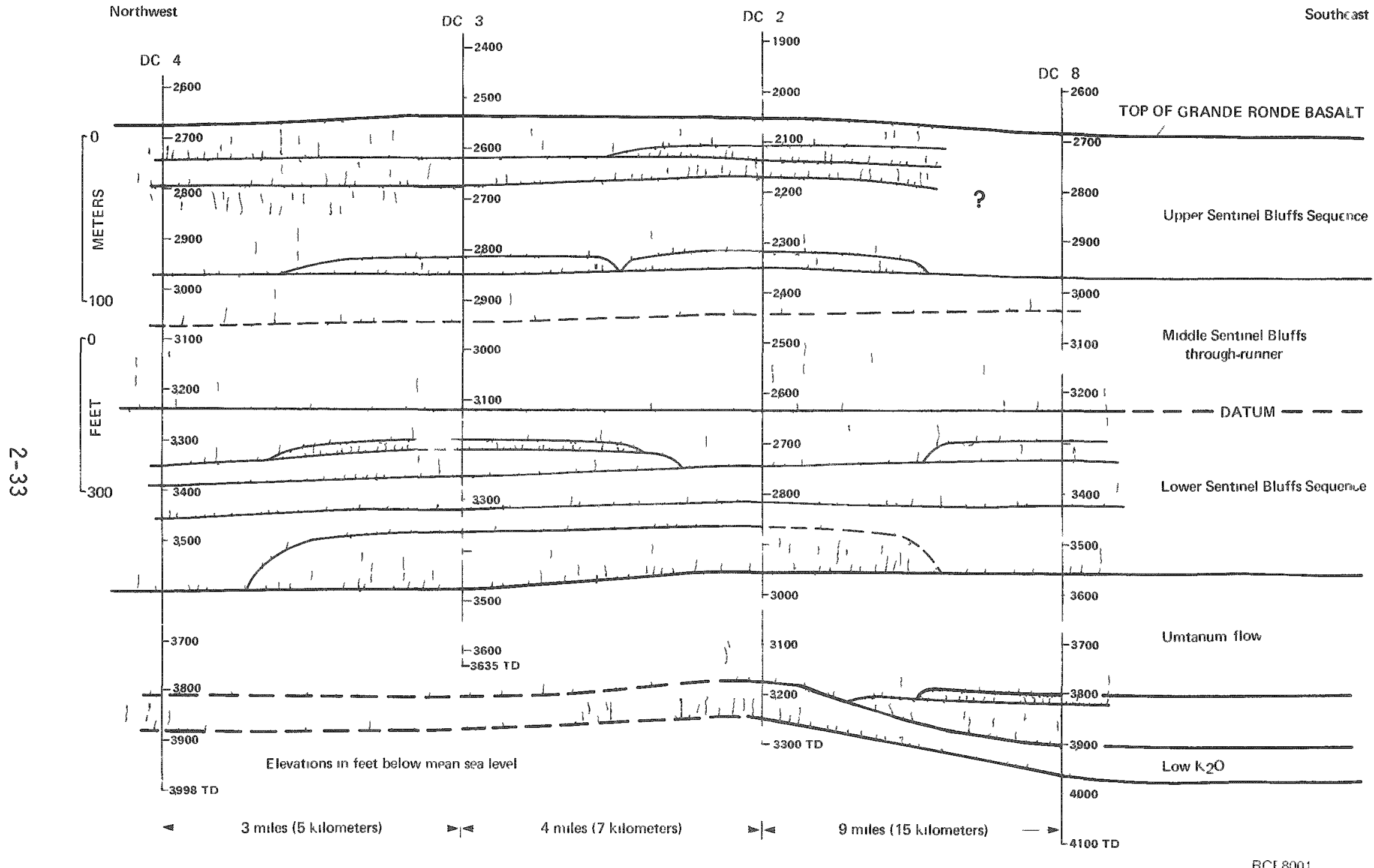

Southeast

FIGURE 2-11. Position of the Umtanum Member Relative to Other Units Recognized in the Upper Grande Ronde Basalt at $D C-2, D C-3, D C-4$, and $D C-8$ (after Myers/Price and 0thers, 1079). Location of boreholes is shown in Figure 2-8. 
TABLE 2-6. Variations in Major ETement Composition of Museum Flow and Flow $E$ at Sentinel Gap and across the Pasco Basin.

(After Myers/Price and Others, 1979.)

\begin{tabular}{|c|c|c|c|c|c|c|c|c|}
\hline \multirow{3}{*}{ Wt\% } & \multicolumn{4}{|c|}{ Museum Flow } & \multicolumn{4}{|c|}{ Flow $E$} \\
\hline & \multicolumn{2}{|c|}{ Sentinel Bluff } & \multicolumn{2}{|c|}{ Pasco Basin } & \multicolumn{2}{|c|}{ Sentinel Bluff } & \multicolumn{2}{|c|}{ Pasco Basin } \\
\hline & $A V *$ & $\mathrm{SD}^{\text {*t }}$ & AV & SD & $A V$ & SD & AV & SO \\
\hline $\begin{array}{l}\mathrm{SiO}_{2} \\
\mathrm{Al}_{2} \mathrm{O}_{3} \\
\mathrm{TiO}_{2} \\
\mathrm{FeO} \\
\mathrm{CaO}_{2} \\
\mathrm{MgO} \mathrm{K}_{2} \mathrm{O}_{2} \\
\mathrm{P}_{2} \mathrm{O}_{5}\end{array}$ & $\begin{array}{r}54.19 \\
14.52 \\
1.69 \\
9.97 \\
8.41 \\
4.76 \\
1.23 \\
0.28\end{array}$ & $\begin{array}{l}0.37 \\
0.25 \\
0.07 \\
0.17 \\
0.12 \\
0.34 \\
0.07 \\
0.02\end{array}$ & $\begin{array}{r}54.20 \\
15.05 \\
1.69 \\
9.55 \\
8.59 \\
4.79 \\
1.15 \\
0.29\end{array}$ & $\begin{array}{l}0.48 \\
0.39 \\
0.06 \\
0.47 \\
0.33 \\
0.29 \\
0.24 \\
0.02\end{array}$ & $\begin{array}{r}53.50 \\
14.80 \\
1.89 \\
10.54 \\
8.33 \\
4.89 \\
0.95 \\
0.28\end{array}$ & $\begin{array}{l}0.42 \\
0.23 \\
0.06 \\
0.31 \\
0.14 \\
0.35 \\
0.17 \\
0.02\end{array}$ & $\begin{array}{r}53.38 \\
14.80 \\
1.91 \\
10.56 \\
8.53 \\
4.64 \\
1.07 \\
0.28\end{array}$ & $\begin{array}{l}0.31 \\
0.32 \\
0.05 \\
0.26 \\
0.19 \\
0.19 \\
0.13 \\
0.01\end{array}$ \\
\hline
\end{tabular}

$* A V=$ Average.

$* * S D=$ Standard Deviation.

In the Pasco Basin the Wanapum Basalt contains, in stratigraphically ascending order, the Frenchman Springs and Roza Members, which appear to contain flows of one chemical type, overlain by the Priest Rapids Member which contains flows of two chemical types. These basalt flows total approximately $300 \mathrm{~m}$ in the central and southern portions of the basin.

Because of chemical similarities, correlation of the Wanapum Basalt units across the Pasco Basin has been particularly difficult. Packer and Petty (1979), however, have measured polarity and inclination variations of the 12 Wanapum units penetrated by $D C-2$ and have been able to distinguish the three important members. The uppermost Priest Rapids flows display reverse polarity, followed by a unit with a flat inclination, probably the Roza Member, followed in turn by the underlying Frenchman Springs Member, which displays normal polarity with variations in the inclination distinguishing separate flows.

The Frenchman Springs Member measures about $200 \mathrm{~m}$ in thickness in the central part of the Pasco Basin. The unit contains from three flows on the flanks of the basin to possibly ten near the center. Chemical stratigraphic correlations have not yet proven successful because the flows are 
chemically similar. However, variations in paleomagnetic inclination combined with borehole geophysical log data offer good potential for correlation studies. The major element composition of the Frenchman Springs Member reported by Price (1978) from the data of ARHCO (1976) and Tatman (1972) is in wt\%: $\mathrm{SiO}_{2}, 52.5 ; \mathrm{Al}_{2} \mathrm{O}_{3}, 13.2 ; \mathrm{FeO}, 14.6$; $\mathrm{MgO}, 4.7$; $\mathrm{CaO}, 7.9 ; \mathrm{Na}_{2} \mathrm{O}, 2.9 ; \mathrm{K}_{2} \mathrm{O}, 1.1 ; \mathrm{MnO}, 0.23 ;$ and $\mathrm{TiO}_{2}, 2.6$. This average composition of sections exposed on the northwest periphery of the Pasco Basin near Vantage, Washington is probably representative of the stratigraphic equivalent in the basin. It is also similar to the Frenchman Springs chemical type for all Columbia River basalt (see Table 2-3), although the basin flows appear somewhat higher in $\mathrm{MgO}$ and $\mathrm{Na}_{2} \mathrm{O}$ and lower in $\mathrm{TiO}_{2}$.

The Roza Member, averaging possibly $60 \mathrm{~m}$ in the central part of the basin, contains two or possibly three separate yet chemically similar flows. Although the Roza Member is chemically similar to the Frenchman Springs Member, it can be distinguished on the basis of paleomagnetic data. The average major element composition of this unit in the Pasco Basin is probably similar to that of the type section near Yakima, Washington, also analyzed by ARHCO (1976) and Tatman (1972). The reported average composition of this unit as reported by Price (1978) in wt\% is: $\mathrm{SiO}_{2}, 51.5 ; \mathrm{Al}_{2} \mathrm{O}_{3}, 13.3 ; \mathrm{FeO}, 14.3 ; \mathrm{MgO}, 4.8 ; \mathrm{CaO}, 8.2 ; \mathrm{Na}_{2} \mathrm{O}$, $2.8 ; \mathrm{K}_{2} \mathrm{O}, 1.2 ; \mathrm{MnO}, 0.23 ; \mathrm{TiO}_{2}, 2.8 ;$ and $\mathrm{P}_{2} \mathrm{O}_{5}, 0.61$. This analysis appears practically identical to that of the Frenchman Springs in the Pasco Basin, which demonstrates some of the uncertainties of chemical stratigraphic correlations. This analys is resembles that of the Roza chemical type (see Table 2-3) although it is somewhat lower in $\mathrm{Al}_{2} \mathrm{O}_{3}$, but higher in MgO relative to the reference analysis.

The uppermost member of the Wanapum Basalt, the Priest Rapids Member, has been reported to consist of at least two and locally four flows of two chemical types, the Lolo chemical type (Wright and Others, 1973) and the Rosalia chemical type (Swanson and Others, 1979). The stratigraphically lower Rosalia flows are relatively thick $(30$ to $40 \mathrm{~m}$ ) in the northern portion of the basin and pinch out towards the southeast. The upper Lolo flows are from 30 to $40 \mathrm{~m}$ thick in the central part of the 
basin and thin out towards the north. From the reported chemical analyses, the Rosalia chemical type flows appear enriched in $\mathrm{FeO}, \mathrm{TiO}_{2}$, and possibly alkalies, but somewhat depleted in $\mathrm{CaO}, \mathrm{MgO}$, and $\mathrm{Al}_{2} \mathrm{O}_{3}$ relative to the Lolo flows. The average compositions are comparable to the Rosalia and Lolo reference chemical types recognized for all Columbia River basalt (see Table 2-3).

The Saddle Mountains Basalt units, totaling an average thickness of about $200 \mathrm{~m}$ in the central portion of the Pasco Basin, consist of seven important members. The stratigraphically lowermost unit, the Umatilla Member, is overlain by the Wilbur Creek, Asotin, Esquatze1, Pomona, Elephant Mountain, and Ice Harbor Members, respectively. Many of these units, several of which contain more than one flow, appear chemically similar, reducing the probability of successfully correlating these flows on the basis of chemistry. However, Fecht (1978) has been able to use the major element chemistry, specifically the ratio $\mathrm{CaO}: \mathrm{TiO}_{2}$ to distinguish the Asotin, Esquatze1, Pomona, and Elephant Mountain Members in the Gable Mountain and Gable Butte area (Table 2-7). Asotin and Pomona Members were found to have a higher $\mathrm{CaO}: \mathrm{TiO}_{2}$ ratio than either Esquatzel or Elephant Mountain. The more recent X-ray fluorescence analyses of Fecht (1978) are considered superior to the earlier atomic absorption work (ARHCO, 1976) and are similar to the chemical types recognized for these flows throughout the region.

Chemical stratigraphic correlations also seem possible using the ratio $\mathrm{CaO}: \mathrm{TiO}_{2}$ for the underlying Umatilla and Wilbur Creek units as we 11 as the uppermost Ice Harbor flows (Table 2-8). The Umatilla analysis presented in Table 2-8 is the $\mathrm{X}$-ray fluorescence average analysis of a basalt reference sample taken from Finiey Quarry, Washington, in the Pasco Basin. Only slightly different from the Umatilla chemical type, it is considered representative of the unit throughout the basin. The composition of the wilbur creek unit in the Pasco Basin, also known as the Wahluke flow, approximates that of the Wilbur Creek chemical type. The average Ice Harbor analysis appears similar to the average Ice Harbor chemical type (see Table 2-3) with the exception of $\mathrm{SiO}_{2}$ and $\mathrm{K}_{2} \mathrm{O}$. 
TABLE 2-7. Average X-Ray Fluorescence Analyses of Saddle Mountains Basalt in the Pasco Basin.*

(After Fecht, 1978.)

\begin{tabular}{|c|c|c|c|c|}
\hline$w t \%$ & $\begin{array}{l}\text { Asotin (2)** } \\
\text { (Huntzinger Flow) }\end{array}$ & $\begin{array}{l}\text { Esquatzel } \\
\text { Flow }(2) * *\end{array}$ & $\begin{array}{l}\text { Pomona } \\
\text { Flow }(4) * *\end{array}$ & $\begin{array}{c}\text { Elephant Mt } \\
\text { Flow }(2)^{* *}\end{array}$ \\
\hline $\mathrm{SiO}_{2}$ & 50.42 & 52.41 & 51.57 & 50.82 \\
\hline $\mathrm{Al}_{2} \mathrm{O}_{3}$ & 16.55 & 14.23 & 15.52 & 13.98 \\
\hline $\mathrm{TiO}_{2}$ & 1.42 & 3.02 & 1.61 & 3.58 \\
\hline $\mathrm{FeO}$ & 10.01 & 13.91 & 10.75 & 14.76 \\
\hline Mno & 0.18 & 0.21 & 0.19 & 0.21 \\
\hline $\mathrm{CaO}$ & 11.39 & 7.76 & 10.77 & 8.35 \\
\hline MgO & 7.82 & 3.85 & 6.70 & 4.27 \\
\hline $\mathrm{K}_{2} \mathrm{O}$ & 0.10 & 1.80 & 0.49 & 1.34 \\
\hline $\mathrm{Na}_{2} \mathrm{O}$ & 1.89 & 2.42 & 2.16 & 2.33 \\
\hline $\mathrm{P}_{2} \mathrm{O}_{5}$ & 0.21 & 0.39 & 0.24 & 0.36 \\
\hline TOTAL & 99.99 & 100.00 & 100.00 & 100.00 \\
\hline $\mathrm{CaO}: \mathrm{TiO}_{2}$ & 8.0 & 2.6 & 6.7 & 2.3 \\
\hline
\end{tabular}

*Samples from Gable Mountain, cores DC-10 and DC-11. $* *$ Number of analyses ( ) normalized to $100 \%$.

2.3.2.2 Minor Element Chemistry. Most trace element analyses of the Columbia River basalt units have been conducted in the last several years using type locality basalt sections and other exposed units outside the Pasco Basin proper (ARHCO, 1976; Camp, 1976; Camp and Others, 1978; Reide1, 1978; Price, 1978; Additon and Sei1, 1979). The average trace element composition of the basalt formations in the Pasco Basin measured by ARHCO (1976), calculated using sequence thicknesses of approximately $1,100,300$, and $200 \mathrm{~m}$, respectively, is presented in Table 2-9. The Grande Ronde and Wanapum Formations are similar for these selected trace elements, while the Saddle Mountains composition shows some major differences. Three flows, namely Asotin (Huntzinger), Pomona, and Ice Harbor, contain over $100 \mathrm{ppm}$ chromium accounting for the high average chromium value for Saddle Mountains. The high barium value is attributed to the Umatilla unit which was found to contain nearly 3,800 ppm barium. Another 
TABLE 2-8. Major Element Compositions of the Umatilla, Wilbur Creek, and Ice Harbor Members of the Saddle Mountains Formation.

\begin{tabular}{|c|c|c|c|}
\hline$w t \%$ & Umati $17 a^{*}$ & Wilbur Creek** & Ice Harbor*** \\
\hline $\mathrm{SiO}_{2}$ & 52.54 & 53.8 & 50.2 \\
\hline $\mathrm{Al}_{2} \mathrm{O}_{3}$ & 13.79 & 14.0 & 12.2 \\
\hline $\mathrm{Fe}_{2} \mathrm{O}_{3}$ ( $\left.\mathrm{T} \mathrm{Fe}\right)$ & 13.73 & & \\
\hline $\mathrm{FeO}(\mathrm{T} \mathrm{Fe})$ & & 12.1 & 15.2 \\
\hline MgO & 2.95 & 5.2 & 5.8 \\
\hline $\mathrm{CaO}$ & 6.40 & 8.2 & 9.8 \\
\hline $\mathrm{Na}_{2} \mathrm{O}$ & 3.20 & 2.8 & 2.4 \\
\hline $\mathrm{K}_{2} \mathrm{O}$ & 2.52 & 2.0 & 1.0 \\
\hline $\mathrm{TiO}_{2}$ & 2.76 & 1.8 & 3.4 \\
\hline $\mathrm{P}_{2} \mathrm{O}_{5}$ & 0.90 & & \\
\hline Mno & 0.19 & 0.19 & \\
\hline $\mathrm{BaO}$ & 0.35 & & \\
\hline TOTAL & 99.33 & 100.09 & 100.0 \\
\hline $\mathrm{CaO}: \mathrm{TiO}_{2}$ & 2.3 & 4.6 & 2.9 \\
\hline
\end{tabular}

*Average analysis of the Umatilla reference sample (Additon and Sei7, 1979).

**From Price (1978), normalized to $100 \%$ data.

anomalous value, $64 \mathrm{ppm}$ tantalum for Saddle Mountains, is attributed to the I ce Harbor I flow which was reported to contain $38 \mathrm{ppm}$ tantalum, but this should be regarded as possibly a spurious value. The trace element analyses presented in Table 2-9 are considered good approximations for the three formations. More recent high-quality X-ray fluorescence analyses and instrumental neutron activation analyses of selected flows extends the list of trace elements (Tables 2-10 through 2-14).

An examination of major, minor, and selected trace element analyses of flows in the Grande Ronde Basalt type section in southeastern Washington showed that a chemical break occurs. Camp (1976) termed flows below this chemical break members of "Group $A$ " and flows above this break members of "Group B". It has been suggested by Camp and Others (1978) that the "Group A" flows are similar to the high-MgO Grande Ronde and the 
TABLE 2-9. Approximate Average Trace Element Composition of Basalt Formations in the Pasco Basin.*

\begin{tabular}{l|c|c|c|c}
\hline (ppm)** & Grande Ronde & Wanapum & Saddle Mountains & Total Sequence \\
\hline $\mathrm{SC}$ & 34 & 36 & 31 & 34 \\
$\mathrm{Cr}$ & 27 & 30 & 68 & 32 \\
$\mathrm{Co}$ & 38 & 36 & 39 & 38 \\
$\mathrm{Ba}$ & 770 & 700 & 1,332 & 824 \\
$\mathrm{Hf}$ & 4.5 & 4.7 & 6.9 & 4.8 \\
$\mathrm{Ta}$ & 2.2 & 1.4 & 6.4 & 2.6 \\
$\mathrm{La}$ & 26 & 27 & 34 & 6.4 \\
$\mathrm{Sm}$ & 5.9 & 7.9 & 7.0 & 2.2 \\
Eu & 2.0 & 2.4 & 2.9 & 1.2 \\
$\mathrm{~Tb}$ & 1.2 & 1.2 & 1.5 & 4.1 \\
\hline $\mathrm{Th}$ & 3.8 & 4.4 & 5.6 & \\
\hline
\end{tabular}

*Calculated from atomic absorption data of ARHCO (1976) using assigned Pasco Basin unit thicknesses (see Table 2-3). **Parts per million.

chemistry of the "Group B" flows resembles the low-MgO Grande Ronde chemical type. Price (1978) has suggested that the "Group B" basalts of the type section correlate with the Schwana sequence. It is possible that the Meyer Ridge flow of the "Group B" sequence could be the chemical stratigraphic equivalent of the high-MgO flows (Sentinel Bluffs sequence) of the Grande Ronde in the Pasco Basin.

Selected trace element analyses of the Grande Ronde Basalt at the type locality are reported by Reidel (1978). The elements studied (zirconium, strontium, rubidium, barium, vanadium, scandium, nickel, chromium, copper, and yttrium) were determined using X-ray fluorescence analytical techniques. Additional trace elements (1 anthanum, cerium, samarium, europium, terbium, ytterbium, lutetium, cobalt, hafnium, thorium, tantalum, and cesium) were measured using instrumental neutron activation analysis (Price, 1977; Reidel, 1978). These trace element analyses of the Grande Ronde as reviewed by Camp and Others (1978) are presented in Table 2-10. The data show that the "Group B" sequence of

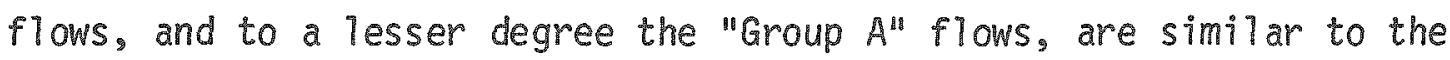
average of selected trace elements of the Grande Ronde Basalt in the Pasco Basin (see Table 2-9). This is particularly the case for barium, 
TABLE 2-10. Average Trace Element Composition of Selected Flows at the Grande Ronde Type Section.*

\begin{tabular}{|c|c|c|c|}
\hline \multirow{2}{*}{$\operatorname{XRF}(\mathrm{ppm}) * *$} & \multicolumn{3}{|c|}{ Flows } \\
\hline & Meyer Ridge & "Group A" & "Group B" \\
\hline $\mathrm{Zr}$ & 163 & 207 & 196 \\
\hline$s r$ & 347 & 338 & 332 \\
\hline $\mathrm{Rb}$ & 35 & 37 & 42 \\
\hline $\mathrm{Ba}$ & 350 & 481 & 623 \\
\hline V & 308 & 381 & 369 \\
\hline Sc & 45 & 38 & 37 \\
\hline $\mathrm{Ni}$ & 118 & 63 & 48 \\
\hline $\mathrm{Cr}$ & 145 & 54 & 24 \\
\hline $\mathrm{Cu}$ & 173 & 161 & 96 \\
\hline Y & 8 & 18 & 17 \\
\hline$(\mathrm{ppm}) * *$ & & & \\
\hline La & 18.2 & 22.5 & 23.9 \\
\hline $\mathrm{Ce}$ & 24.7 & 49.9 & 50.2 \\
\hline Sm & 4.5 & 6.2 & 6.4 \\
\hline Eu & 1.5 & 2.0 & 2.1 \\
\hline $\mathrm{Tb}$ & 0.8 & 1.1 & 1.1 \\
\hline $\mathrm{Yb}$ & 3.6 & 5.2 & 4.7 \\
\hline $\mathrm{Lu}$ & $N D * *$ & 0.60 & 0.61 \\
\hline Co & 36 & 37 & 37 \\
\hline $\mathrm{Cr}$ & 141 & 63.3 & 26.4 \\
\hline $\mathrm{Hf}$ & 3.5 & 4.7 & 4.6 \\
\hline Th & 3.4 & 3.5 & 4.6 \\
\hline $\mathrm{Ta}$ & 1.5 & 1.3 & 1.6 \\
\hline Cs & 0.5 & 0.8 & 1.2 \\
\hline
\end{tabular}

*Calculated from data of Camp and Others, 1978.

**XRF $=$ X-ray fluorescence analysis; INA = Instrumental neutron activation anaTysis; ND = Not determined. 
TABLE 2-11. Trace Element Analyses of Members of the Wanapum Formation. a

\begin{tabular}{c|c|c|c}
\hline ppmb & $\begin{array}{c}\text { Frenchman } \\
\text { Springs }\end{array}$ & Roza & Priest Rapids \\
\hline Sc & 35 & 35 & 38 \\
Cr & 32 & 43 & 15 \\
Co & 35 & 38 & 39 \\
Ba & 728 & 652 & 658 \\
Hf & 4.7 & 4.8 & NDC \\
Ta & 1.4 & 1.6 & ND \\
La & 28 & 24 & 28 \\
Sm & 7.8 & 7.9 & 8.1 \\
Eu & 2.2 & 2.4 & 2.8 \\
Tb & 1.1 & 1.3 & ND \\
Th & 4.1 & 6.3 & 3.9 \\
\hline
\end{tabular}

aCalculated from data of Price (1978), ARHCO (1976), and Tatman (1972).

bparts per million.

$\mathrm{C}_{\mathrm{ND}}=$ Not determined.

TABLE 2-12. Average Trace Element Composition of Members of the Saddle Mountains Basalt.

(After ARHCO, 1976.)

\begin{tabular}{|c|c|c|c|c|c|c|c|c|c|}
\hline \multicolumn{10}{|c|}{ Member } \\
\hline \multirow{2}{*}{ ppm*t } & \multicolumn{5}{|c|}{ High-Ti } & \multicolumn{4}{|c|}{ Low-Ti } \\
\hline & UM* & ES* & $E M *$ & $I H *$ & $A V *$ & WC* & $A S *$ & $\mathrm{PO*}$ & $A V *$ \\
\hline Sc & 25 & 29 & 33 & 42 & 32 & 26 & 28 & 33 & 29 \\
\hline $\mathrm{Cr}$ & 7 & 20 & 27 & 101 & 39 & 36 & 177 & 103 & 105 \\
\hline Co & 25 & 45 & 48 & 42 & 40 & 38 & 41 & 42 & 40 \\
\hline $\mathrm{Ba}$ & 3,796 & 822 & 703 & 1,066 & 1,597 & 1,050 & 584 & 50 & 561 \\
\hline Hf & 11.2 & 7.1 & 6.3 & $\begin{array}{r}8.7 \\
1\end{array}$ & 8.3 & $\begin{array}{r}7.5 \\
-3.5\end{array}$ & 4.8 & 3.1 & 5.1 \\
\hline $\mathrm{Ta}$ & 2.7 & ND* & ND & 38 & 20 & 1.7 & 1.1 & 1.0 & 1.3 \\
\hline La & 48 & 37 & 37 & 42 & 41 & $\mathrm{ND}$ & 25 & 20 & 22 \\
\hline$S m$ & 10.5 & 7.3 & 9.0 & 3.3 & 7.5 & 6.8 & 5.3 & 4.7 & 5.6 \\
\hline Eu & 4.4 & 2.3 & 2.9 & 5.4 & 3.8 & 1.9 & 1.6 & 1.5 & 1.7 \\
\hline $\mathrm{Tb}$ & 1.7 & ND & NO & 3.1 & 2.4 & 1.2 & 1.0 & 1.1 & 1.1 \\
\hline & 6.3 & 8.3 & 6.2 & 5.4 & 6.6 & 3.2 & 4.0 & 5.5 & 4.2 \\
\hline $\mathrm{CaO}: \mathrm{TiO}_{2}$ & 2.3 & 2.8 & 2.7 & 2.9 & & 4.6 & 5.9 & 6.3 & \\
\hline
\end{tabular}

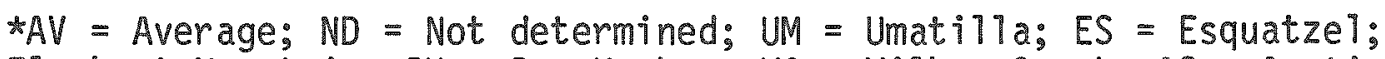
$E M=$ Elephant Mountain; IH = Ice Harbor: WC = Wilbur Creek; $A S=$ Asotin; PO = Pomona.

**Parts per million. 
TABLE 2-13. Atomic Absorption Trace Element Analyses of Saddle Mountains Basalt at Gable Mountain and Gable Butte.

(After Fecht, 1978.)

\begin{tabular}{|c|c|c|c|c|c|c|}
\hline \multirow{3}{*}{$\begin{array}{c}\mathrm{CaO}: \mathrm{TiO}_{2} \\
\text { ppmc }\end{array}$} & \multicolumn{3}{|c|}{ Low-Ti Flows } & \multicolumn{3}{|c|}{ High-Ti Flows } \\
\hline & $A-1001^{a}$ & $A-1004^{a}$ & $A V^{b}$ & $A-1017^{2}$ & $A-1020^{a}$ & $A V^{b}$ \\
\hline & 7.1 & 6.3 & 6.7 & 2.6 & 2.7 & 2.6 \\
\hline $\mathrm{Ba}$ & 1,371 & 882 & 1,126 & 870 & 570 & 720 \\
\hline $\mathrm{Zn}$ & 91 & 87 & 89 & 163 & 134 & 148 \\
\hline Co & 44 & 45 & 44 & 45 & 38 & 42 \\
\hline $\mathrm{Pb}$ & 20 & 20 & 20 & 29 & 24 & 26 \\
\hline Cu & 112 & 74 & 93 & 20 & 20 & 20 \\
\hline $\mathrm{Cr}$ & 177 & 179 & 178 & 30 & 30 & 30 \\
\hline$N i$ & 35 & 14 & 24 & 21 & 14 & 18 \\
\hline $\mathrm{Rb}$ & 65 & 60 & 62 & 11 & 15 & 13 \\
\hline
\end{tabular}

asamp le number.

$\mathrm{b}_{\mathrm{AV}}=$ Aver age.

CParts per million. 
TABLE 2-14. Mean Concentrations (ppm) of Trace Elements Measured in the Umatilla Reference Powder.

(After Additon and Sei\}, 1979.)

\begin{tabular}{|c|c|c|c|}
\hline Element & Concentration & Element & Concentration \\
\hline$B$ & 6 & $\mathrm{Nd}$ & 48 \\
\hline $\mathrm{Be}$ & 4 & $\mathrm{Ni}$ & 11 \\
\hline $\mathrm{Ce}$ & 91 & $\mathrm{~Pb}$ & 13 \\
\hline $\mathrm{Cl}$ & 0.015 & $\mathrm{Rb}$ & 43 \\
\hline Co & 28.8 & s & 0.0690 \\
\hline Cs & 0.56 & Sc & 27.62 \\
\hline $\mathrm{Cu}$ & 21 & Sm & 9.96 \\
\hline Dy & 9.13 & $s r$ & 256 \\
\hline Eu & 4.04 & $\mathrm{Ta}$ & 1.28 \\
\hline Ga & 24 & $\mathrm{~Tb}$ & 1.45 \\
\hline Gd & 8.7 & Th & 7.51 \\
\hline$H f$ & 10.5 & $\mathrm{Tm}$ & 0.86 \\
\hline $\mathrm{H}_{2} \mathrm{O}+(\mathrm{wt} \%)$ & 0.80 & U & 1.46 \\
\hline $\mathrm{H}_{2} \mathrm{O}-(\mathrm{Wt} \%)$ & 0.45 & v & 232 \\
\hline La & 46 & Y & 48 \\
\hline Li & 8 & $Y_{b}$ & 4.3 \\
\hline Lu & 0.64 & $\mathrm{Zn}$ & 136 \\
\hline $\mathrm{Nb}$ & 39 & $\mathrm{Zr}$ & 460 \\
\hline
\end{tabular}


RHO-BWI -ST-7

scandium, and chromium, which Asaro and others (1978) have shown to be useful elements for chemical stratigraphic correlations. The trace element data also suggest that the Meyer Ridge flow is not the chemical stratigraphic equivalent of the high-Mgo flows of the Grande Ronde in the Pasco Basin.

Average trace element compositions of the flows of the three principal members of the Wanapum Formation are presented in Table 2-11. Certain trace elements are useful for distinguishing separate flows of this sequence, particularly chromium, but also barium and thorium to a lesser degree. For example, the Priest Rapids IV unit contains over 80 ppm chromium whereas the lower units I through III contain less than $20 \mathrm{ppm}$ chromium. The Roza flow contains the highest average chromium (43 ppm) although one of the three Frenchman Springs flows, Sand Hollow, also contains over 40 ppm chromium, distinguishing it from the sentinel Gap and Gingko units which average about 25 ppm chromium. Barium is slightly enriched in all three Frenchman Springs units relative to both Roza and Priest Rapids whereas Roza is enriched in thorium compared to the other two.

Within the Saddle Mountains Basalt certain trace elements are useful for distinguishing high-from low-Ti basalts (see Table 2-12). The high-Ti flows appear notably enriched in barium, hafnium, lanthanium, samarium, europium, and thorium, but appear somewhat depleted in chromium relative to the low-Ti basalts. Fecht (1978) studied trace element trends of high- and low-Ti basalts at Gable Mountain and Gable Butte and a)though he did not show the high-Ti flows to be enriched in barium, he showed them to be somewhat enriched in zinc and lead but depleted in copper, chromium, and rubidium (see Table 2-13). One certainty regarding the barium distribution is the fact that the Umatilla unit is remarkably enriched and contains at least 0.35 wt\% $\mathrm{BaO}$ as reported by Additon and Seil (1979). A complete listing of the trace elements measured in the Umatilla reference sample, for many elements probably representative of the entire sequence of flows in the basin, is presented in Table 2-14. 
RHO-BWI-ST-7

\subsubsection{Mineral Composition of Pasco Basin Basalts}

Recent studies concerned with the mineral chemistry of the Pasco Basin basalt core samples have been conducted by Ames (in press) and the Basalt Waste Isolation Project staff. Correlation studies have been conducted by Reidel (1978), Jones and Landon (1978), and Price (1978). It has been shown that the primary mineralogy is generalty simple and the relative abundance of phases and textural considerations is usualty helpful for stratigraphic correlations. The primary minerals occurring in varying proportions with glass are normally members of the plagioclase solid solution series ( $\left.\mathrm{NaAlSi}_{3} \mathrm{O}_{8}-\mathrm{CaAl}_{2} \mathrm{Si}_{2} \mathrm{O}_{8}\right)$, augite $(\mathrm{Mg}, \mathrm{Fe}, \mathrm{Ca}, \mathrm{Al})_{2}$ $(\mathrm{Si}, \mathrm{Al})_{2} \mathrm{O}_{6}$, pigeonite $(\mathrm{Mg}, \mathrm{Fe}, \mathrm{Ca})(\mathrm{Mg}, \mathrm{Fe}) \mathrm{Si}_{2} \mathrm{O}_{6}$, ilmenite $\left(\mathrm{FeTiO}_{3}\right)$, magnetite $\left(\mathrm{Fe}_{3} \mathrm{O}_{4}\right)$, and the olivine solid solution series $\left(\mathrm{Mg}_{2} \mathrm{SiO}_{4}-\mathrm{Fe}_{2} \mathrm{SiO}_{4}\right)$.

The composition and abundance of crystalline phases and glass in a particular flow, as well as its lateral and vertical phase variation, are important parameters used to project the chemical and physical integrity of a rock unit. For example, glass is more reactive than minerals in a hydrothermal setting and the relative abundance of glass has also been shown to determine the amount and type of shrinkage fractures present (Long, 1978). These become important hydrological considerations affecting groundwater flow rates and ultimately basalt-waste-engineered barrier interactions. Therefore, it becomes very important to know the compositions of the basaltic glasses and the crystalline phases, as well as their relative abundance.

\subsubsection{Primary Minerais. The work of Ames (in press) presents a} general overview of the major element chemistry of the primary minerals for basalts in the Pasco Basin. Plagioclase, a principal silicate phase, shows some chemical variation overall and in single crystals. A typical sample from $\mathrm{DDH}-3$ core showed a chemical range for plagioclase of from $\mathrm{An}_{44}$ to $\mathrm{An} n_{70}$ with $53 \%$ of the crystals identified as labradorite and 47\% as andesine. A common trend recognized throughout the flows is that the larger crystais are more calcic (1abradorite and bytownite) while the small matrix crystals are sodic (0ligoclase and andesine). All of the pyroxenes are in the augite compositional range except for a few subcalcic and ferroaugite grains. Also in the DDH-3 core sample, ilmenite and 
ilmenite-magnetite mixtures were found to be the principal opaque phases. The minor phase, olivine, ranges in chemical composition from $\mathrm{Fa}_{50}$ to $\mathrm{Fa}_{75^{\circ}}$ *

When possible, the compositions of primary minerals are reported here in the context of their relative abundance and textural occurrence to reflect the overall lithology. As expected, a disproportionate amount of data are available on the Grande Ronde Basalt, much of which has been correlated to the Pasco Basin from studies conducted outside the basin proper.

The average mineral and glass composition of selected flows from the Grande Ronde type section may approximate the major element phase chemistry of the Pasco Basin basalts (Table 2-15). The volume percent of each of the major phases for all flows at the type section are listed and used to calculate the overall weighted average composition which probably approximates the composition of the Grande Ronde Basalt at that locality. Although alteration products account for between 5 and 6 vo $7 \%$ of the basalts, and glass roughly 15 vol\%, the combined figure of $21 \%$ was used as the "glass" contribution (this assumes glass to be the only altered material). The calculated composition compares favorably with the average Grande Ronde determined from bulk samples from the region (see Table 2-3). The comparatively high $\mathrm{TiO}_{2}$ value calculated from average mineral analyses may suggest that more titanium-magnetite than ilmenite occurs in the basalts sampled at the type locality, which would also account for the somewhat lower $\mathrm{FeO}$ and MnO values. Also, the somewhat lower $\mathrm{Na}_{2} \mathrm{O}$ value may suggest that the average plagiociase composition for the entire sequence is actually more sodic, which would raise the $\mathrm{SiO}_{2}$ and lower both the $\mathrm{Al}_{2} \mathrm{O}_{3}$ and $\mathrm{CaO}$ values and/or there may actually be sodium present in some of the basalt glass. Also, the true abundance of pyroxene may actually be less than estimated, which would lower both the $\mathrm{CaO}$ and MgO values.

It has been suggested that in the Pasco Basin the low-MgO Schwana sequence of flows, also referred to as the low-MgO high- $\mathrm{K}_{2} \mathrm{O}$ "Tower" Yakima, may be chemically correlated with the Group B "Tower" Yakima

$$
{ }^{*} \text { An }=\text { Anorthite }\left(\mathrm{CaAl}_{2} \mathrm{Si}_{2} \mathrm{O}_{8}\right) ; \mathrm{Fa}=\text { Fayalite }\left(\mathrm{Fe}_{2} \mathrm{SiO}_{4}\right) \text {. }
$$


TABLE 2-15. Average Electron Microprobe Analyses of Minerals and Glass from Selected Flows at the Grande Ronde Basalt Type Section.

(After Camp and Others, 1978.)

\begin{tabular}{|c|c|c|c|c|c|c|c|c|}
\hline \multirow[b]{2}{*}{ Wt\% } & \multicolumn{8}{|c|}{ Mineral } \\
\hline & $\begin{array}{c}\text { Fe]dspar } \\
\text { (41)a }\end{array}$ & $\begin{array}{r}\text { Augite } \\
(20) a\end{array}$ & $\begin{array}{l}\text { Pigeonite } \\
\text { (8) } a\end{array}$ & $\begin{array}{l}\text { I7menite } \\
\text { (4) } a\end{array}$ & $\begin{array}{c}\text { Ti-Magnetite } \\
\text { (4)a }\end{array}$ & $\begin{array}{l}\text { Olivine } \\
\text { (2)a }\end{array}$ & $\begin{array}{l}\text { Glass } \\
21 b\end{array}$ & AVC \\
\hline $\mathrm{SiO}_{2}$ & 55.2 & 53.6 & 53.8 & 0.70 & 1.0 & 38.2 & 74.2 & 54.1 \\
\hline $\mathrm{A}_{2} 203$ & 27.2 & 2.0 & 0.20 & 0.50 & 1.8 & & 13.9 & 14.6 \\
\hline $\mathrm{FeO}$ & 0.70 & 13.5 & 21.8 & 46.5 & 65.2 & 44.7 & 1.5 & 10.4 \\
\hline MgO & & 13.8 & 18.0 & 1.3 & 1.1 & 16.2 & 2.7 & 5.2 \\
\hline $\mathrm{CaO}$ & 10.4 & 16.7 & 4.8 & 0.20 & 0.20 & 0.30 & 1.1 & 8.2 \\
\hline $\mathrm{Na}_{2} \mathrm{O}$ & 5.4 & & & & & & & 2.21 \\
\hline $\mathrm{K}_{20}$ & 0.50 & & & & & & 6.8 & 1.63 \\
\hline Mno & & & & 0.20 & 0.40 & 0.60 & & 0.04 \\
\hline $\mathrm{TiO}_{2}$ & & 0.20 & 0.30 & 50.6 & 30.4 & & 0.30 & 3.4 \\
\hline$P_{205}$ & & 0.40 & 0.30 & & & & 0.20 & 0.15 \\
\hline
\end{tabular}

avolume percent.

bGiass and alteration products.

$\mathrm{C}_{\mathrm{AV}}=$ Average calculated chemical composition for these flows. 
Basalt flows identified in eastern Washington (Price, 1978). A comparison of the petrographic character of the Group $B$ flows of the Grande Ronde area with the Schwana flows indicates that these units are lithologically similar (Myers, 1973). Therefore, the relative abundance and compositions of phases in Group B flows are probably a good approximation of the lithology of the Schwana sequence in the basin (Table 2-16).

TABLE 2-16. Average Electron Microprobe Analyses of Minerals and Glass from Selected Group B "Lower" Yakima Basalt Flows (Possible Schwana Sequence).

(After Price, 1978.)

\begin{tabular}{|c|c|c|c|c|c|c|}
\hline \multirow{2}{*}{ Wt\% } & \multicolumn{6}{|c|}{ Mineral } \\
\hline & $\begin{array}{l}\text { Feldspar } \\
(43)^{a}\end{array}$ & $\begin{array}{l}\text { Augite } \\
(20)^{2}\end{array}$ & $\begin{array}{c}\text { Pigeonite } \\
(9)^{a}\end{array}$ & $\begin{array}{c}\text { Ti-Magnetite } \\
(8)^{2}\end{array}$ & $\begin{array}{l}\text { Glass } \\
(20)^{b}\end{array}$ & AVC \\
\hline $\mathrm{SiO}_{2}$ & 54.0 & 53.5 & 54.3 & 1.0 & 73.5 & 53.6 \\
\hline $\mathrm{Al}_{2} \mathrm{O}_{3}$ & 26.9 & 2.4 & 0.20 & 1.5 & 13.9 & 15.0 \\
\hline Feo & 0.80 & 13.6 & 19.9 & 65.0 & 1.4 & 10.3 \\
\hline $\mathrm{MgO}$ & & 13.7 & 20.1 & 1.2 & 3.4 & 5.3 \\
\hline $\mathrm{CaO}$ & 10.3 & 16.3 & 4.9 & 0.30 & 1.2 & 8.4 \\
\hline $\mathrm{Na}_{2} \mathrm{O}$ & 5.6 & & & & & 2.4 \\
\hline$k_{2} 0$ & 0.5 & & & & 8.2 & 1.9 \\
\hline Mno & & & & 0.30 & & 0.02 \\
\hline $\mathrm{TiO}_{2}$ & & 0.20 & 0.30 & 30.6 & 0.30 & 2.6 \\
\hline $\mathrm{P}_{2} \mathrm{O}_{5}$ & & 0.50 & 0.30 & & 0.20 & 0.17 \\
\hline
\end{tabular}

avolume percent.

bGlass and alteration products.

$C_{A V}=$ Average calculated chemical composition for these flows.

The average composition basalts, computed for Group B "lower" Yakima, however, show similar differences compared to the major-element bulk composition (see Table 2-3) as previously noted for the Grande Ronde type locality. $\mathrm{SiO}_{2}, \mathrm{Na}_{2} \mathrm{O}, \mathrm{MnO}$, and $\mathrm{P}_{2} \mathrm{O}_{5}$ are comparatively low whereas $\mathrm{CaO}$, $\mathrm{MgO}$, and $\mathrm{TiO}_{2}$ are high. It seems most likely that the mineral compositions approximate those of the minerals in the Pasco Basin equivalent flows but that the actual volume percentages are incorrect and 
RHO-BWI-ST-7

difficult to estimate because of the fine-grained textures and optical similarities between certain minerals. Thus, it is concluded that estimated volume percentages reported are only approximations and cannot be used to compute flow compositions.

The Sentinel Bluffs, or high-MgO sequence of flows, are generally fine- to medium-grained, aphyric to phyric, some with distinctive plagioclase microphenocrysts. In the vicinity of the Grande Ronde type section, Camp and Others (1978) and Price (1978) have noted the chemical similarity of the Meyer Ridge flow to that of the high-MgO flows of the Sentinel Bluffs units in the Pasco Basin. They have also pointed out the difference in polarity between the two and the unlikelihood of their being stratigraphic equivalents.

The three to eight basalt flows of the Frenchman Springs Member (Wanapum Basalt) are alternating beds of dense, fine-grained aphyric rocks containing plagioclase phenocrysts up to $2 \mathrm{~cm}$ across and fine- to medium-grained glass-rich flows. Also, as much as $5 \%$ by volume occurs in some units.

The Roza Member in the Pasco Basin has been geochemically correlated with flows of the "Roza chemical type" originating from fissures in the Chief Joseph swarm area (Price, 1974). These are fine- to medium-grained rocks containing evenly distributed plagioclase phenocrysts 0.5 to $2.0 \mathrm{~cm}$ across. The composition of phases from the Roza flow in the studied area (Table 2-17) may be representative of the comparable flows in the Pasco Basin.

The Priest Rapids Member is typically gray-green in color, aphyric with rare plagioclase phenocrysts up to $1 \mathrm{~cm}$ across. The unit normal7y displays a fine-grained, glassy, and dense texture which shows conchoidal fracture. Price (1978) reports that the composition of the Anatone flow within the Grande Ronde type area most closely resembles the Priest Rapids unit within the Pasco Basin. The two flows, however, exhibit different stratigraphic positions.

The Umati1la Formation (Saddle Mountains Basait) in the Pasco Basin is typically $45 \mathrm{~m}$ thick, black and alassy, and aphyric with rare plagioclase phenocrysts $0.7 \mathrm{~cm}$ across. Glass content may be as high as 
TABLE 2-17. Average Electron Microprobe Analyses of Minerals and GTass of the Roza Member.

(After Price, 1978.)

\begin{tabular}{l|c|c|c|c|c|c}
\hline \multirow{2}{*}{ Wt\% } & \multicolumn{7}{|c|}{ Minera } \\
\cline { 2 - 7 } & $\begin{array}{c}\text { Feldspar } \\
(45)^{\mathrm{a}}\end{array}$ & $\begin{array}{c}\text { Augite } \\
(27)^{\mathrm{a}}\end{array}$ & $\begin{array}{c}\text { I Imenite } \\
(4)^{\mathrm{a}}\end{array}$ & $\begin{array}{c}\text { Ti-Magnetite } \\
(4)^{\mathrm{a}}\end{array}$ & $\begin{array}{c}\text { Glass } \\
(20)^{\mathrm{b}}\end{array}$ & AVC \\
\hline $\mathrm{SiO}_{2}$ & 56.1 & 53.1 & 0.70 & 0.90 & 74.7 & 54.6 \\
$\mathrm{AT}_{2} \mathrm{O}_{3}$ & 26.2 & 1.7 & 0.40 & 1.7 & 14.5 & 15.2 \\
$\mathrm{FeO}^{\mathrm{MgO}}$ & 1.0 & 13.2 & 40.9 & 70.0 & 1.6 & 8.8 \\
$\mathrm{MaO}$ & 11.8 & 12.9 & 2.0 & 1.5 & 0.80 & 3.8 \\
$\mathrm{Na}_{2} \mathrm{O}$ & 4.3 & & & & 2.2 & 10.7 \\
$\mathrm{~K}_{2} \mathrm{O}$ & 0.5 & & & & 5.4 & 3.0 \\
$\mathrm{MnO}$ & & & 0.40 & 0.60 & & 0.22 \\
$\mathrm{TiO}_{2}$ & & 0.80 & 56.0 & 25.4 & 0.60 & 3.6 \\
\hline
\end{tabular}

avolume percent.

$\mathrm{B}_{\mathrm{G}} \mathrm{lass}$ and alteration products.

$\mathrm{c}_{\mathrm{AV}}=$ Average calculated chemical composition for these flows.

$60 \%$ by volume, producing excellent conchoidal fractures. The upper several meters are typically red and orange scoriaceous material. The Puffer Butte flow in the Grande Ronde area and the Umatilla flow in the Pasco Basin are probable stratigraphic equivalents (Price, 1978).

A detailed study of the mineralogy of the Umatilla unit in the basin shows that the feldspar crystals vary in composition from bentonite to orthoclase (Fig. 2-12), some with pronounced compositional variations (Ames, in press). The feldspars have also been found to contain, on rare occasion, BaO content in excess of 3 wt\%. Most Umatilla pyroxene is augite, some of which is moderately zoned with iron content higher on the crystal edges and lower towards the centers. Ilmenite, titaniummagnetite, apatite, and pyrite were also recognized.

The Wilbur Creek Member consists of one flow averaging $30 \mathrm{~m}$ in thickness. The basalt is typically fine-grained and glassy with rare plagioclase phenocrysts up to $1 \mathrm{~cm}$. The mineralogy has not been described. 


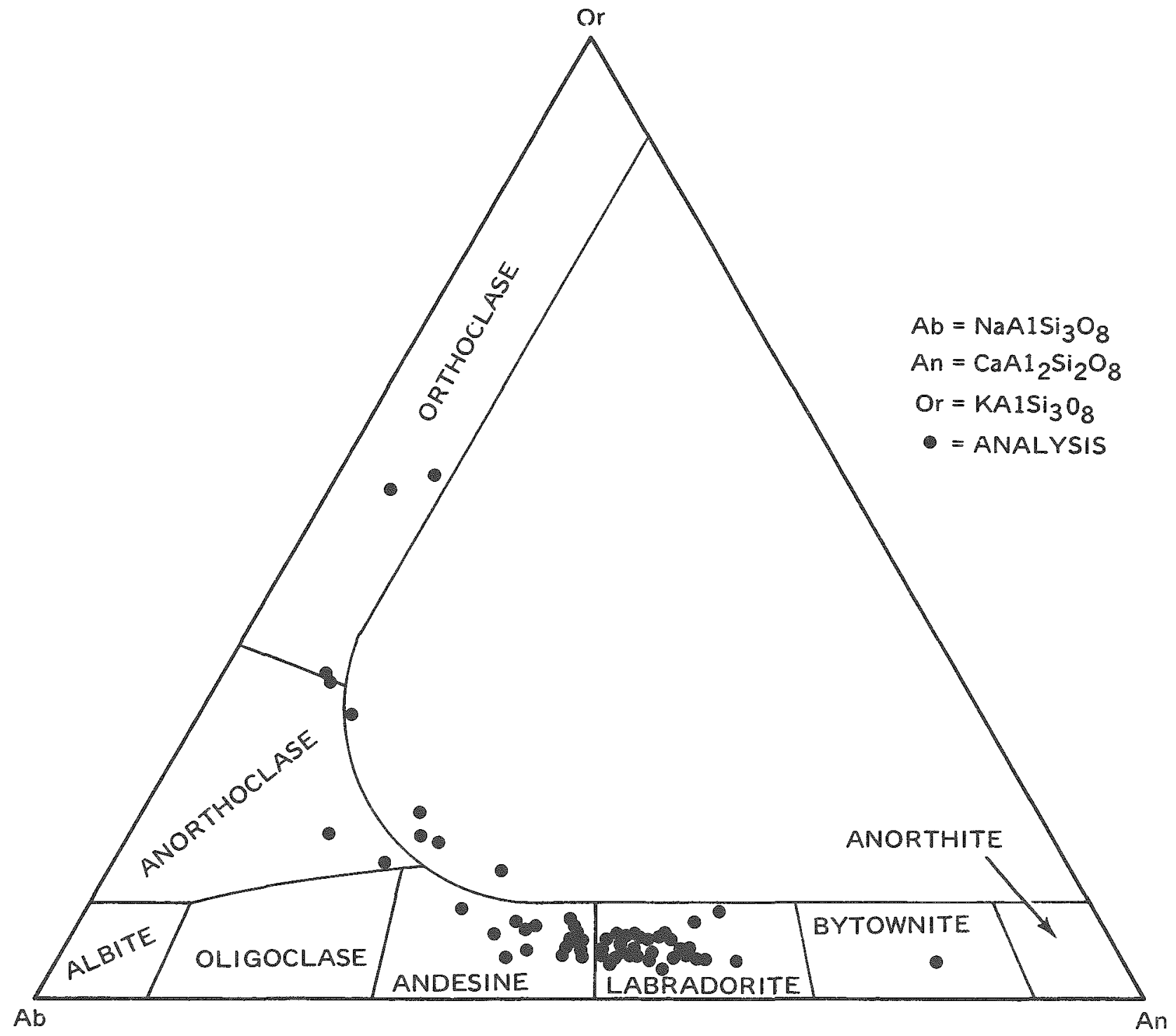

RCP8002-36

FIGURE 2-12. Graph of Feldspar Compositions from the Umatilla Formation (after Ames, in press). $A n=$ anorthite; $A B=$ albite; $0 r=$ orthoclase. 
The Asotin Member, which consists of generally one flow, known as the Huntzinger, in the Pasco Basin, averaging possibly $30 \mathrm{~m}$ in thickness. It is generally black and ophitic with phenocrysts of plagioclase up to $1 \mathrm{~cm}$ across and olivine up to $0.5 \mathrm{~cm}$. Price (1978) has pointed out that the Asotin Member in the Grande Ronde area has the same stratigraphic position and polarity as the Huntzinger flow within the Pasco Basin. However, the Huntzinger flow appears to be one of the few flows of the Columbia Plateau which shows intraflow chemical and petrographic variations (Ward, 1976) and it is uncertain if the mineral chemistry of the Asotin Member of the Grande Ronde area resembles that of the stratigraphic equivalent in the basin.

The Esquatzel Member averages $15 \mathrm{~m}$ in thickness and is restricted to the central and eastern Pasco Basin; its source being somewhere to the east. The unaltered rock is finemgrained and contains plagioclase phenocrysts up to $1.5 \mathrm{~cm}$ across. The phase compositions have not been described in detail.

The Pomona unit has 2 or possibly 3 flows averaging about $40 \mathrm{~m}$ in thickness. The lower portion of the unit shows well-developed colonnade and entablature with a glassy to pumaceous upper 2 to $10 \mathrm{~m}$. Both upper and lower portions of the unit are fine- to medium-grained and microvesicular. The upper unit contains plagioclase and olivine phenocrysts up to $5 \mathrm{~mm}$ across whereas the lower portion of the unit has mostly plagioclase phenocrysts. It has been observed that in general, the Pomona feldspar compositions are higher in caicium content than the overall average for the entire sequence of flows (Ames, in press). More than $80 \%$ of the feldspar grains were found to be of labradorite composition compared with just 50\% in DDH-3, for example. The pyroxene grains in the Pomona flow were also found to be unusual in that many are asymmetrically zoned. Through detailed minor element analyses (manganese and chromium), Ames (in press) showed that of the silicate phases present, the highest chromium concentrations were found in the earliest formed high-Mg pyroxene (average $689 \mathrm{ppm}$ ). 
The two Elephant Mountain flows which together average 20 to $30 \mathrm{~m}$ in the basin are typically fine to coarse grained, glassy, and occasionally diktytaxitic. The lower flow has a vesicular texture grading into columnar joints. The flows are high in apatite content and contain pyroxene and $\mathrm{plagioclase}$ microphenocrysts.

The two Ice Harbor units are found only in the southeastern part of the Pasco Basin. The total thickness of the flows is not known although the upper Goose Island unit is known to exceed $20 \mathrm{~m}$. Goose Is land has a microvesicular, hackly upper $3 \mathrm{~m}$, an interior colonnade of wel1-developed horizontal joints, and a 1-m vesicular base. The overall texture is vesicular, characterized by sparse plagioclase and iron-titanium oxide phenocrysts. The lower unit exhibits a slightly phyric to felty texture, aligned microvesicles, and plagioclase, augite, and olivine microphenocrysts.

2.3.3.2 Secondary Minerals. The distribution and compositions of secondary minerals occurring in the Pasco Basin basalts have been reported by Benson (1978), Benson and Others (1979), and Ames (in press). It has been shown that the basaltic glass and groundmass (i.e., that adjacent to vesicles and fractures) have experienced the greatest degree of alteration. The principal secondary minerals formed are clays and zeolites, which occur in nearly equal abundance, silica, and minor amounts of other secondary phases.

Chemically the clays are hydrous silicates (principally of aluminum and magnesium) which, on heating, lose adsorbed and constitutional water (Deer and 0thers, 1967). The three-1ayered clay mineral groups that occur in the Columbia River basalt are smectite, illite, and vermiculite, in order of decreasing abundance. These minerals have characteristic basal spacings of approximately $15 \AA$ (smectite), $10 \AA$ (i17ite), and $14.5 \AA$ (vermiculite). Chemical composition may vary according to the extent of replacement of silicon, aluminum, and magnesium by other cations, the nature and quantity of inter-layered cations, and the water content. The clays also differ from one another in their cation exchange properties according to the nature of their interlayer cations and residual surface charges. 
The mixed-1ayered smectite clays recognized are montmorillonite, beidellite, and nontronite, di-octahedral end-members of a solid solution series. These di-octahedral clays fill two-thirds, or slightly more, of the octahedral position $(Y)$ with $\mathrm{Al}^{+3}-\mathrm{Mg}^{+2}$ (montmorillonite), $\mathrm{Al}^{+3}$ (beidellite), or $\mathrm{Fe}^{+3}$ (nontronite) and present an approximate generalized chemical formula of:

$$
(\mathrm{Ca}, \mathrm{Na})_{0.66}\left(\mathrm{Al}^{+3}, \mathrm{Mg}^{+2}, \mathrm{Fe}^{+3}, \mathrm{Fe}^{+2}\right)_{4-6}(\mathrm{Si}, \mathrm{AT})_{8} \mathrm{O}_{20}(\mathrm{OH})_{4} \cdot \mathrm{nH}_{2} \mathrm{O} \text {. }
$$

Iron-rich illite contains potassium as the principal interlayer cation rather than calcium and sodium as in the case of smectite. The generalized formula for iron-rich illite recognized in the Pasco Basin basalts is approximately the following:

$$
\mathrm{K}_{2}\left(\mathrm{AT}, \mathrm{Mg}, \mathrm{Fe}^{+3}, \mathrm{Fe}^{+2}\right)_{4}(\mathrm{Si}, \mathrm{AT})_{8} \mathrm{O}_{2} \mathrm{O}(\mathrm{OH})_{4} \cdot \mathrm{nH}_{2} \mathrm{O} \text {. }
$$

Only trace amounts of vermiculite have been recognized; the primary chemical difference between it and the smectites and illite is that $\mathrm{Mg}$ is the principal interlayer cation.

The zeolites are hydrated aluminosilicates of the alkalies and alkaline earths (Deer and Others, 1967). They are noted for their reversible dehydration, ion exchange, and molecular absorption properties. The principal zeolite mineral recognized is heulandite (or clinoptilolite) with the chemical formula:

$$
\left(\mathrm{Ca}, \mathrm{Na}_{2}\right)\left(\mathrm{Al}_{2} \mathrm{Si}_{7} \mathrm{O}_{18}\right) \cdot 6 \mathrm{H}_{2} \mathrm{O}
$$

Clinoptilolite, although sometimes confused with heulandite, is a separate species somewhat enriched in silica. Minor amounts of mordenite $\left(\mathrm{Na}_{2}, \mathrm{~K}, \mathrm{Ca}\right)\left(\mathrm{Al}_{2} \mathrm{Si}_{1} \mathrm{O}_{24}\right) \cdot 7 \mathrm{H}_{2} \mathrm{O}$ have been recognized as a prominent secondary mineral in the Pasco Basin basalts. Also, trace amounts of the following zeolites have been recognized throughout the basalts:

Name

Phillipsite

Harmotome

Chabazite

Erionite
Chemical Formula

$$
(\mathrm{Ca}, \mathrm{Na}, \mathrm{K})_{3}\left(\mathrm{Al}_{3} \mathrm{Si}_{5} \mathrm{O}{ }_{16}\right) \cdot 6 \mathrm{H}_{2} \mathrm{O}
$$$$
\mathrm{Ba}\left(\mathrm{AT}_{2} \mathrm{Si}_{6} \mathrm{O} 16\right) \cdot 6 \mathrm{H}_{2} \mathrm{O}
$$$$
\mathrm{Ca}\left(\mathrm{Al}_{2} \mathrm{Si}_{4} \mathrm{O}{ }_{12}\right) \cdot 6 \mathrm{H}_{2} \mathrm{O}
$$$$
\left(\mathrm{Na}_{2}, \mathrm{~K}_{2}, \mathrm{Ca}, \mathrm{Mg}\right)_{4.5}\left(\mathrm{Al}_{9} \mathrm{Si}_{27} \mathrm{O}_{72}\right) \cdot 27 \mathrm{H}_{2} \mathrm{O} \text {. }
$$ 
Other important secondary minerals include the silica polymorphs quartz, tridymite, cristobalite, and the amorphous variety opal. Also reported in the basalts in trace amounts are gypsum $\left(\mathrm{CaSO}_{4} \cdot 2 \mathrm{H}_{2} \mathrm{O}\right)$, calcite $\left((\mathrm{Ca}, \mathrm{Mg}, \mathrm{Fe}, \mathrm{Mn}) \mathrm{CO}_{3}\right)$, and pyrite $\left(\mathrm{FeS}_{2}\right)$.

The identification of secondary minerals has been accomplished primarily using 3 complimentary analytical techniques (i.e., XRF; scanning electron microscopy (SEM); and electron microprobe analysis (EMP)). X-ray diffraction patterns have been used successfully for identifying minerals and their relative abundance by approximating the integrated area of the most intense peak of each mineral by its halfwidth multiplied by its peak height. X-ray diffraction patterns for the commonly occurring secondary minerals are shown in Figure 2-13. SEM studies coupled with energy dispersive $X$-ray analysis (EDAX) data are used successfully to correlate crystal morphology with mineral composition. EMP analyses are used to confirm SEM-EDAX studies and help distinguish the principal zeolites (i.e., heulandite and clinoptilolite), the various clay minerals, and their distribution in multi-layered assemblages.

Identifying the various clay minerals becomes a formidable task. Initial X-ray diffraction analyses are normally sufficient to distinguish the small amounts of illite and vermiculite from the more abundant smectite group minerals. However, distinguishing the smectite group members (i.e., montmorillonite, beidellite, and nontronite) usually requires dehydration curves and $X$-ray powder patterns before and after treatment by heating and application of organic liquids. Ames (in press) has successfulty determined the relative abundance of the smectite members using these techniques. Briefly, the procedure requires generating a diffractogram of an oriented sample mounted on a glass slide treated with ethylene glycol and warmed. If smectite group minerals are present, a strong peak will appear at 17A.. A smal1 quantity of the sample is then treated with potassium ions (usually either $\mathrm{KCl}$ or $\mathrm{KOH}$ ) and another diffractogram produced. The montmorillonite fraction shows a potassium based peak at about 14 to $15 A$ whereas that of the nontronite collapses further to 12 to $14 \AA$. With heating, the nontronite fraction 


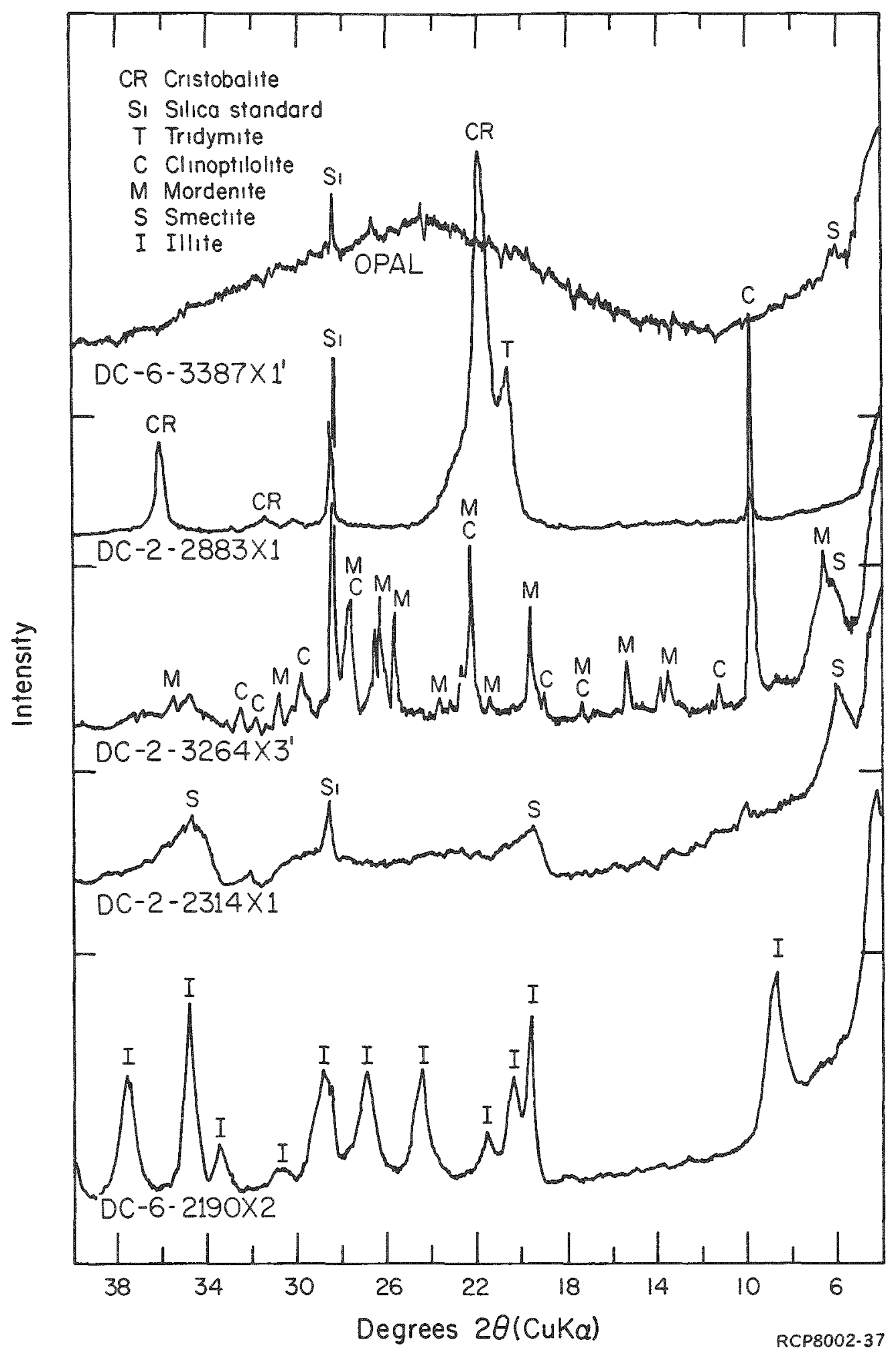

FIGURE 2-13. X-Ray Diffraction Patterns for the Commonly Occurring Secondary Minerals (after Benson and Others, 1979). 
collapses further to the $10 \AA$ illite spacing. The beidellite structure, however, also collapses under these conditions. Therefore, chemical composition, normal7y determined with the electron microprobe, becomes essential information to accurately determine the relative abundance of these phases. With the exception of specific references, these mixed-layer clays will be grouped and referred to as "smectite" in this section because of their structural and chemical complexity.

The principal secondary zeolite mineral(s) encountered in the basalts are heulandite and clinoptilolite. The two are difficult to distinguish in X-ray diffraction patterns although relative intensities of the $9.0 \AA$ and $4.0 \AA$ peaks are useful; clinoptilolite has the larger $4.0 \AA$ and heulandite the larger $9.0 \AA$ peak. Chemical analysis (EMP) has proven to be the most useful technique for distinguishing the two zeolites. Based on the molecular ratio Si:Al $(2.75$ to 3.25 for heulandite and 4.25 to 5.25 for clinoptilolite) and the molar ratio of monovalent to divalent cations (i.e., (Na+k) greater than calcium in clinoptilolite), the zeolites analyzed are mostly clinoptilolite (Benson and Others, 1979). With few exceptions, all zeolites discussed below will be referred to as clinoptilolite.

The clays and zeolites found in the Pasco Basin basalts have a considerable range in composition as determined by the electron microprobe studies of Benson and Others (1979). The average compositions with ranges are illustrated in Figures 2-14 and 2-15. The zeolites and clays are both hydrated silicates, thus the difference between the summations of the average oxides determined and $100 \%$ is attributed to the presence of water. The average compositions with structural formulas are presented in Table 2-18.

TABLE 2-18. Compositions of Mean Hanford Clay and Zeolite with Structural Formulas.

(After Benson and Others, 1979.)

\begin{tabular}{|c|c|c|c|c|c|c|c|c|c|}
\hline \multirow[b]{2}{*}{ Smectite } & $\mathrm{SiO}_{2}$ & $\mathrm{Al}_{2} \mathrm{O}_{3}$ & $\mathrm{Fe}_{2} \mathrm{O}_{3}$ & $\mathrm{CaO}$ & BaO & $\mathrm{Na}_{2} \mathrm{O}$ & $\mathrm{K}_{2} \mathrm{O}$ & Mgo & $\mathrm{H}_{2} \mathrm{O}$ \\
\hline & $\begin{array}{l}50.20 \\
\left(\mathrm{si}_{3} .6\right.\end{array}$ & $\begin{array}{c}5.88 \\
0.36)\end{array}$ & $\begin{array}{c}24.07 \\
.23 \mathrm{Fe}^{+}\end{array}$ & $\begin{array}{r}1.67 \\
+2 \\
+2\end{array}$ & $\begin{array}{l}0.06 \\
\text { 2) } \\
(\mathrm{Cad}\end{array}$ & $\begin{array}{c}1.68 \\
\text { Na. } 0.46 \mathrm{~K}\end{array}$ & 5) $\begin{array}{r}1.26 \\
0_{10}\end{array}$ & $2^{6.93}$ & 8.25 \\
\hline Clinoptilolite & $\begin{array}{l}68.51 \\
\text { (si29. }\end{array}$ & $\begin{array}{c}12.34 \\
16.34 F\end{array}$ & 4) $\begin{array}{c}0.13 \\
\text { (CaO }\end{array}$ & $\begin{array}{c}1.13 \\
\text { Ba0.07! }\end{array}$ & \multicolumn{4}{|c|}{$\left(\mathrm{Si}_{29.84 \mathrm{Al}} 6.34 \mathrm{Fe} \mathrm{T}_{04}\right)\left(\mathrm{Ca}_{0.53} \mathrm{Ba} 0.07 \mathrm{Na} 2.61 \mathrm{~K} 1.68 \mathrm{MgO} .01\right) 0_{72} 9.44 \mathrm{H}_{2} \mathrm{O}$} & 11.34 \\
\hline
\end{tabular}



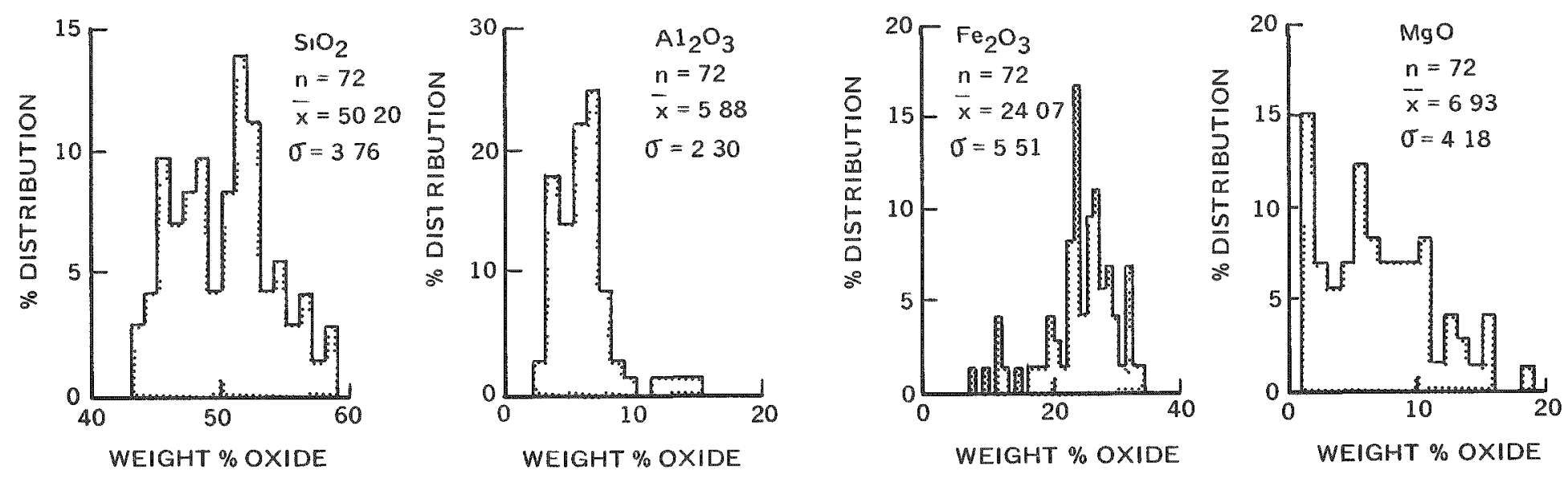

I
Un
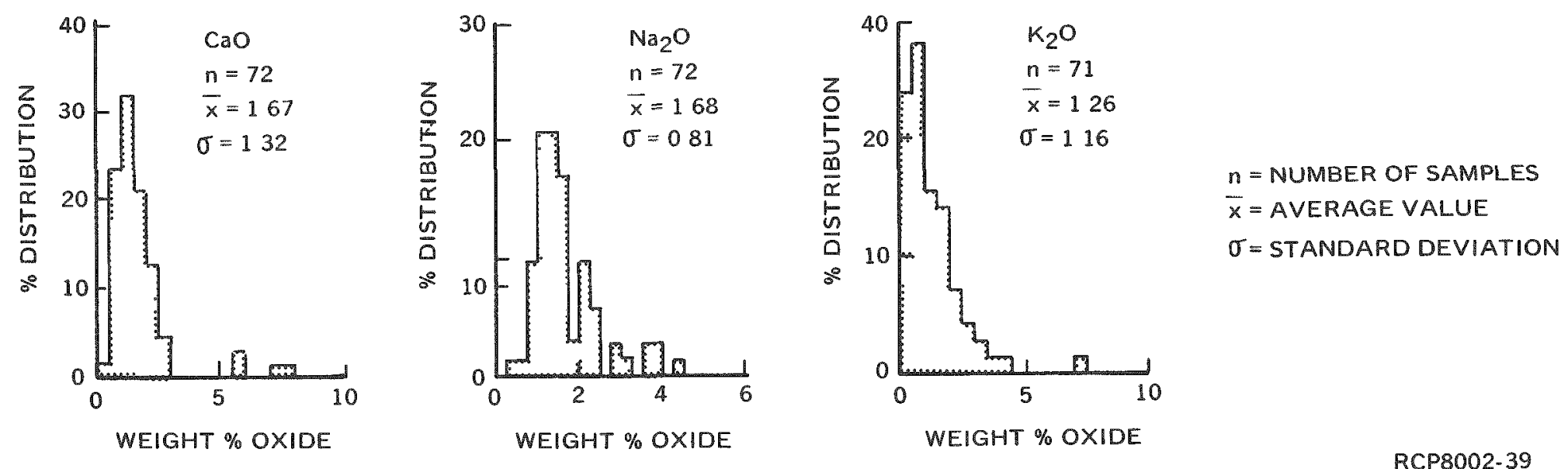

FIGURE 2-14. Compositions of All Clays (Most7y Smectite) Formed Prior to Deposition of Zeolite or Silica (after Benson and Others, 1979). 

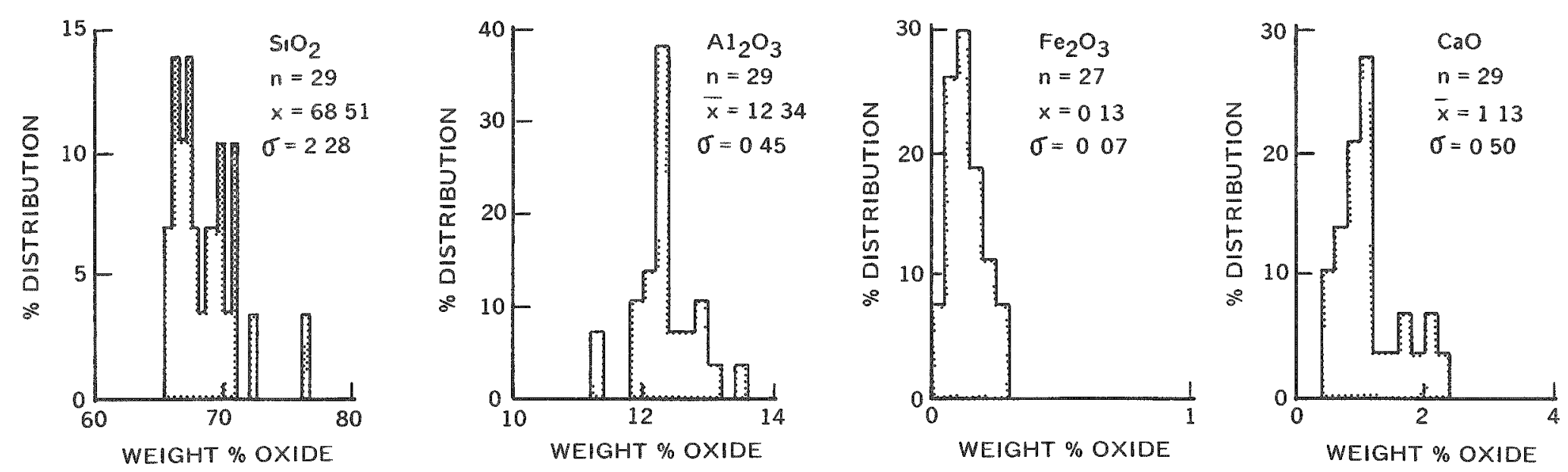

In
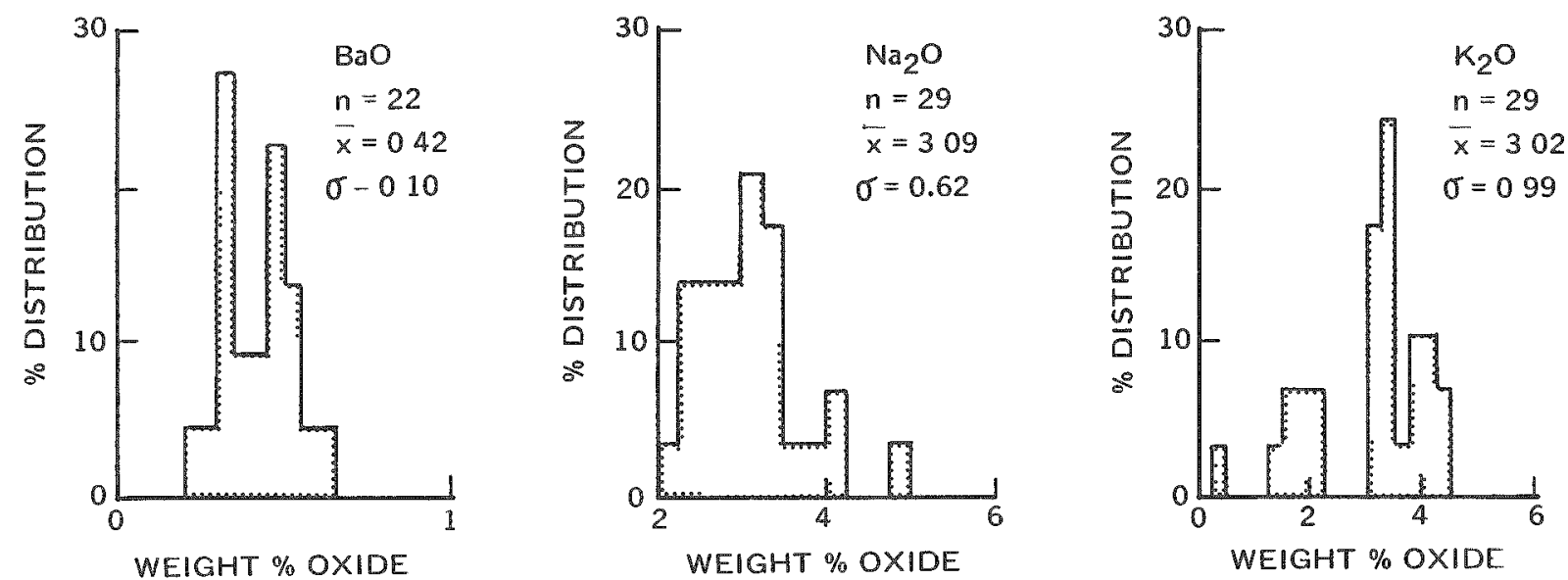

$n=$ NUMBER OF SAMPLES

$\bar{x}=$ AVERAGE VALUE

$\sigma=$ STANDARD DEVIATION

RCP8002 38

FIGURE 2-15. Compositions of First and Second Generations of Secondary Zeolite (after Benson and Others, 1979). 
Electron microprobe analyses of the zeolites have shown distinct compositional trends as a function of depth. There is a definite increase in the Ca:Na ratio below $1,100 \mathrm{~m}$ (Fig. 2-16). This is the approximate depth at which the zeolite mordenite appears and may suggest dissolution and replacement of the earlier formed clinoptilolite by the more stable mordenite. It is also the approximate depth at which calcite reappears after occurring only in the upper $400 \mathrm{~m}$.

Microprobe traverse studies were also conducted by Benson and Others (1979) of several secondary mineral assemblages. Their general observations are as follows:

- Single generations of clay in vesicles and fractures appear homogeneous whereas single generations of clinoptilolite are somewhat heterogeneous.

- In vesicles and fractures having multiple generations of clay or clinoptilolite, chemical composition often changes significantly from generation to generation.

- Multiple generations of clay from fractures at the same depth appear to exhibit similar compositional variations.

- Muttiple generations of clays from vesicles at the same depth also show similar compositional variations from generation to generation.

- There are considerable differences between the compositions of individual generations of clay from either vesicle or fracture samples. No overall systematic trend in composition as a function of distance from vesicle or fracture walls has been found to exist.

It is apparent that the basalt vesicles exhibit a more complex mineralogy than do the fractures. The fractures generally contain clinoptilolite, smectite, and silica with small amounts of illite and pyrite, whereas the vesicles also contain minor amounts of the zeolites erionite, chabazite, and phillipsite with vermiculite, gypsum, and calcite. The layered precipitation sequence recognized in both vesicles 
RHO-BWI-ST-7

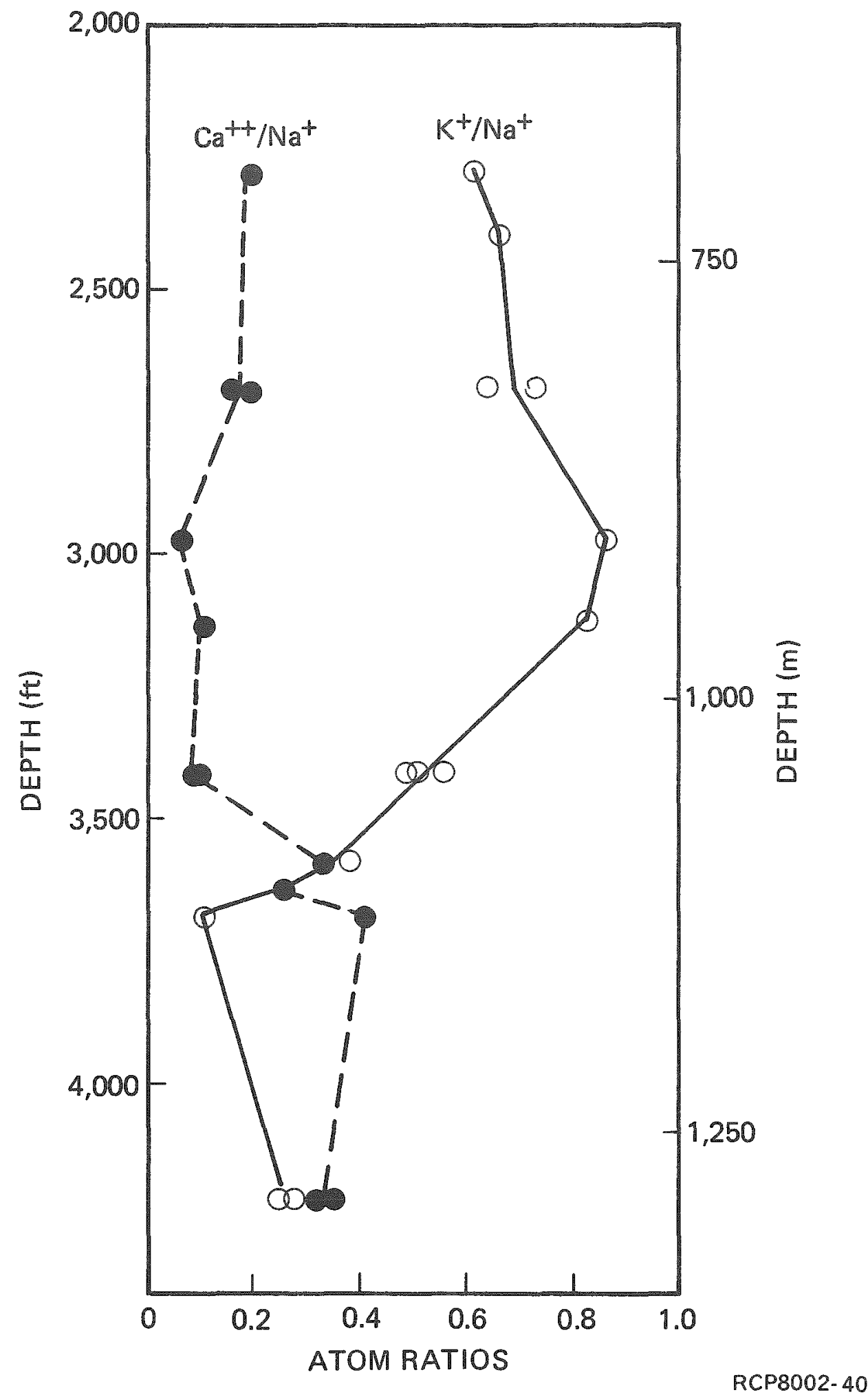

FIGURE 2-16. Ion Exchange Ratios in Zeolites as a Function of Depth at DC-6 (after Benson and Others, 1979). Well Tocation is shown in Figure 2-8. 
and fractures, however, seems to be the same. For the assemblages, the sequence is usually clay, clinoptilolite, and silica followed by clay. Benson and Others (1979) showed that clay is the first mineral to form in $96 \%$ of the fractures and $94 \%$ of the vesicles. Clinoptilolite makes up the difference and is the second phase to form in fractures $81 \%$ of the time and in vesicles $97 \%$ of the time. For assemblages having additional layers, silica followed by clinoptilolite is in the sequence $100 \%$ of the time in fractures and $67 \%$ of the time in vesicles (Fig. 2-17 and 2-18). Clay was again precipitated after zeolite in the remaining $33 \%$ of the vesicles. It is also recognized that the assemblages are sometimes reversed in no apparent, systematic manner and intergrown (Fig. 2-19). Dissolution followed by reprecipitation of one or more secondary minerals is also recognized as a common occurrence ( $F i g .2-20$ ).

Further abundance and distribution studies of the secondary mineral (Benson and Others, 1979) shows that clinoptilolite occurs in approximately $78 \%$ of the fractures and vesicles, smectite in $76 \%$, quartz in $39 \%$, cristobalite in $36 \%$, and tridymite in $15 \%$. The percentage occurrence of secondary minerals found in fractures and vesicles sampled from boreholes $D C-2, D C-6$, and $D H-5$ are listed in Table 2-19. These samples were alt

TABLE 2-19. Percent of Fracture and Vesicle Samples Containing a Specific Secondary Mineral Found by X-Ray Diffraction.

(After Benson and Others, 1979.)

\begin{tabular}{l|r|r|r|r|r|r|r|r}
\hline \multirow{2}{*}{$\begin{array}{c}\text { Secondary } \\
\text { Mineral }\end{array}$} & \multicolumn{3}{|c|}{37} & Fracture Samp les & \multicolumn{3}{c|}{127 Vesicle Samples } \\
\cline { 2 - 9 } & DC-2 & DC-6 & DH-5 & AV* & DC-2 & DC-6 & DH-5 & AV* \\
\hline Clinoptilolite & 50 & 86 & 80 & 71 & 88 & 70 & 90 & 80 \\
Mordenite & 0 & 0 & 0 & 0 & 6 & 14 & 0 & 9 \\
Smectite & 75 & 100 & 20 & 81 & 67 & 64 & 15 & 57 \\
Illite & 0 & 14 & 0 & 7 & 2 & 32 & 5 & 16 \\
Cristobalite & 38 & 14 & 60 & 29 & 59 & 20 & 40 & 39 \\
Quartz & 44 & 29 & 20 & 33 & 31 & 52 & 35 & 41 \\
Tridymite & 38 & 5 & 0 & 17 & 12 & 18 & 15 & 15 \\
\hline
\end{tabular}

*Average taken for all cores. 


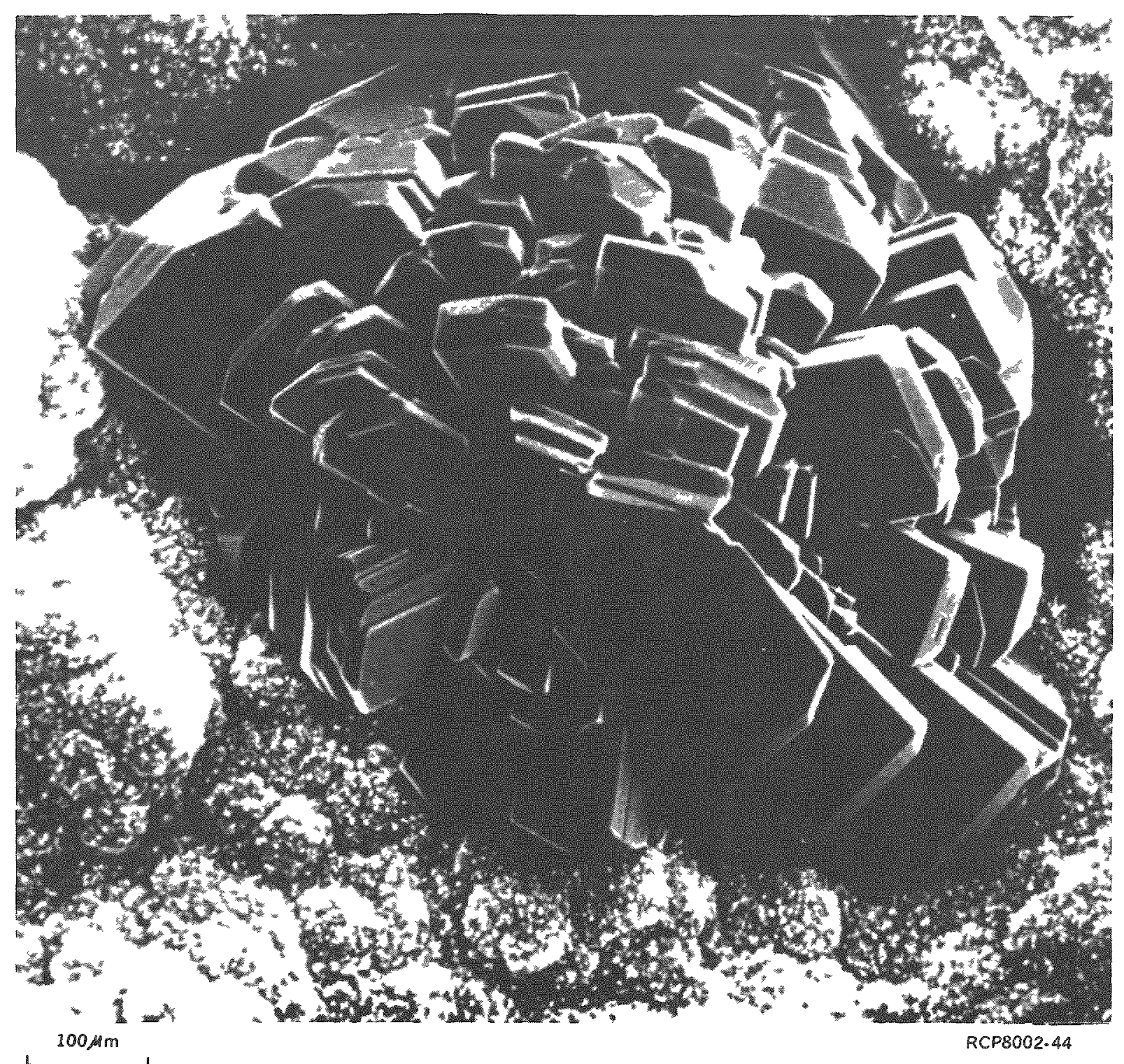

FIGURE 2-17. Clinoptilolite Rosettes on a Surface of Cristobalite/ Quartz (after Benson and Others, 1979). Taken from a basalt sample at DC -6 . 


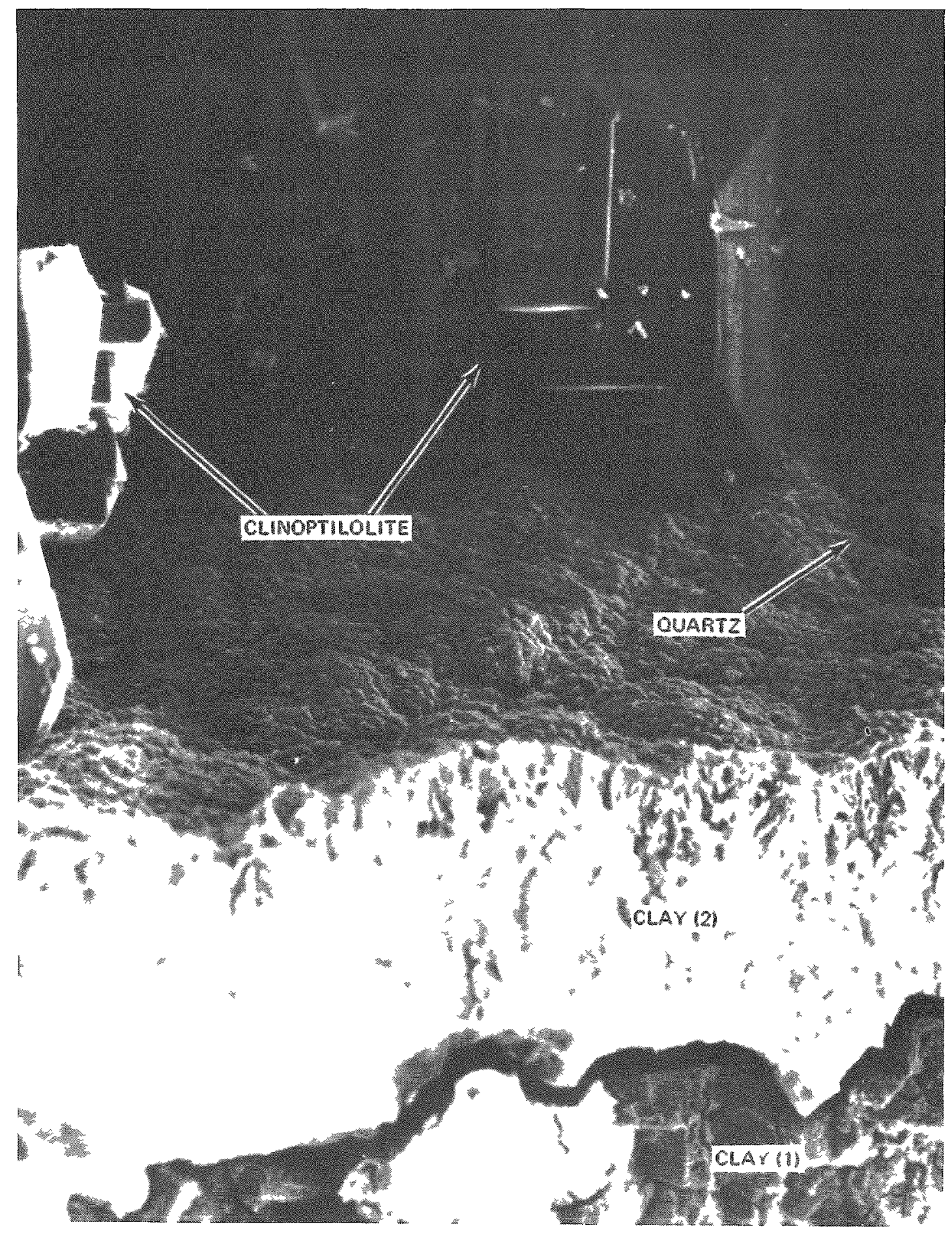

FIGURE 2-18. A Typical Crystallization Sequence for Secondary Minerals. The initial clay, at bottom, shows dessication cracks and is separating from the second clay layer. The surface of the second clay layer is coated with a layer of quartz followed by large well-developed clinoptilolite crystals (after Benson and 0thers, 1979). 


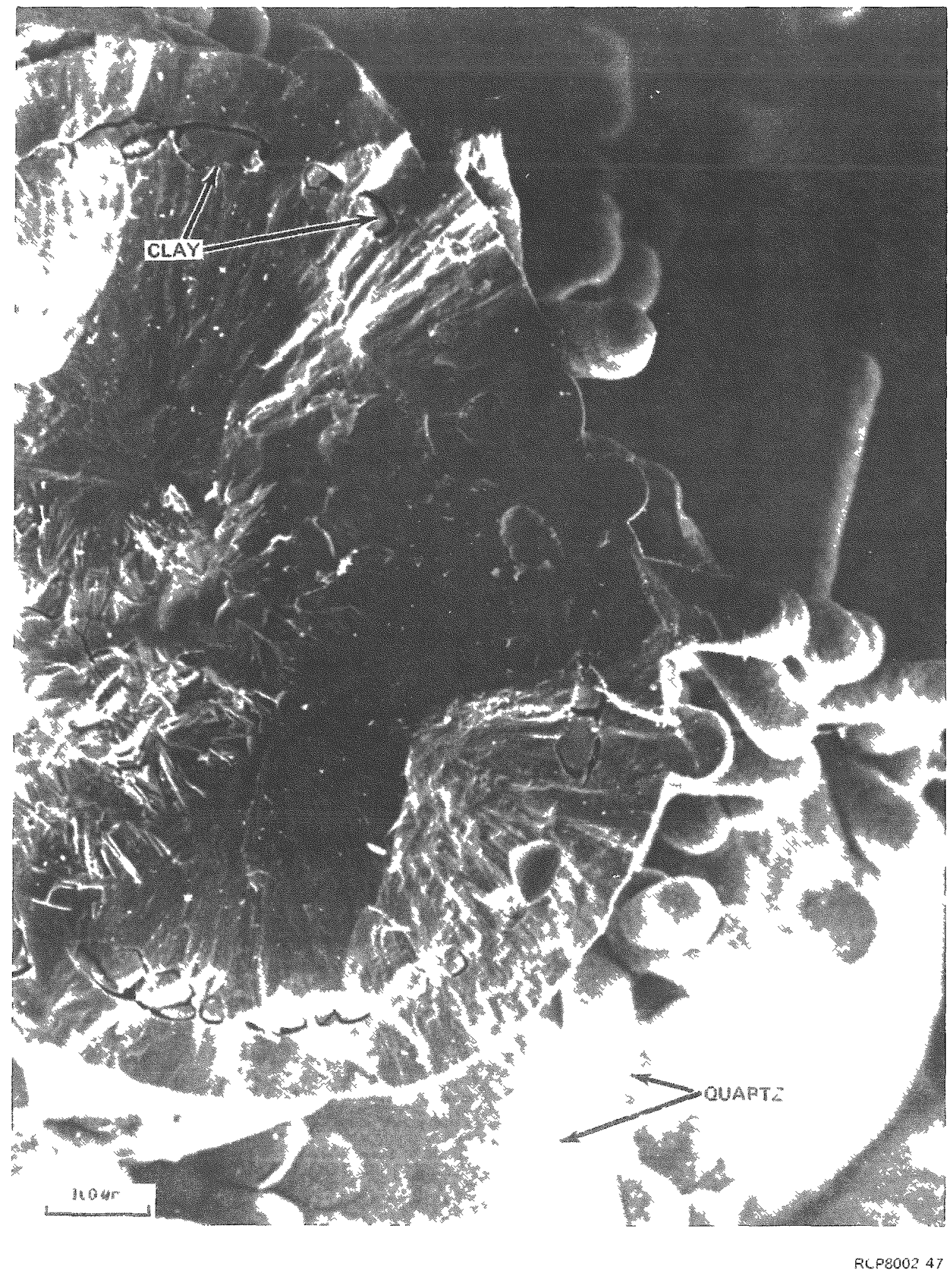

FIGURE 2-19. Broken Secondary Quartz Sphere Exposing Interior Smectite Nodules Deposited during Quartz Growth in DC-6 Basalt Sample (after Benson and Others, 1979). 


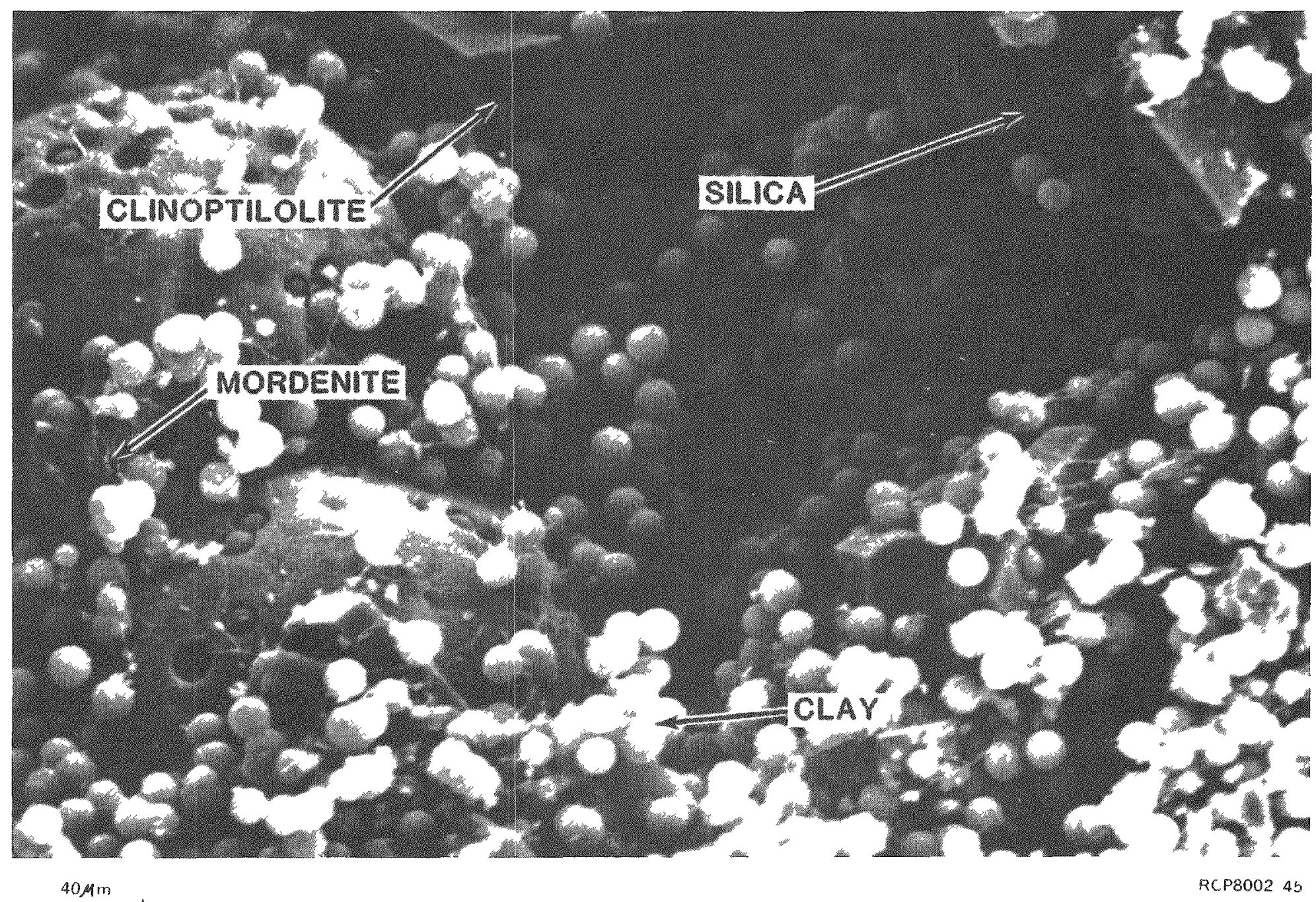

FIGURE 2-20. Sample Showing Dissolution of Silica Followed by Precipitation of Smectite or Simultaneous Crystallization of Two Phases. Larger spheres are silica and smaller spherules are smectite. The tabular crystals are clinoptilolite and the fibers are probably mordenite, (after Benson and Others, 1979). 
taken from below $600 \mathrm{~m}$ so as to include only true authigenic secondary phases. Although it is apparent that silica occurs as commonly as zeolite and clay, its relative abundance is considerably less. A summary of SEM volume estimates of these major secondary phases in vesicle samples also taken from boreholes $D C-2, D C-6$, and DH-5 shows silica to be less abundant than either zeolite or clay (Table 2-20). Point counting volume estimates in fractures from a section of $D C-6(1,000$ to $1,250 \mathrm{~m})$ shows that in fractures clay (75\%) is more abundant than zeolite (20\%) and both are much more abundant than silica (5\%).

TABLE 2-20. Relative Volume Estimates (SEM) of Major Secondary Phases in Vesicles from $D C-2, D C-6$, and $D H-5$.

\begin{tabular}{l|c|c|c|c}
\hline Minera7 & $\begin{array}{c}D C-2 \\
(670-970 \mathrm{~m})\end{array}$ & $\begin{array}{c}\text { DC }-6 \\
(600-1,080 \mathrm{~m})\end{array}$ & $\begin{array}{c}\mathrm{DH}-5 \\
(800-860 \mathrm{~m})\end{array}$ & AV* \\
\hline Clay & 35 & 39 & 20 & 32 \\
Zeolite & 55 & 33 & 42 & 43 \\
Silica & 10 & 28 & 38 & 25 \\
\hline
\end{tabular}

$*$ AV $=$ Average.

The major secondary mineral distribution data of Ames (in press) and Benson and Others (1979) as a function of depth are presented in Figure 2-21. Of the clay group minerais, smectite seems to occur throughout the sampled section, although it is possibly less abundant below $900 \mathrm{~m}$, whereas illite occurs unevenly through the section. Quartz occurs throughout a 11 cores. Cristobalite, which occurs as often as quartz throughout the section, is the dominant silica phase in the 600- to 1,000-m interval (opal reported from $\mathrm{DH}-4$ and $\mathrm{DH}-5$ is probably cristobalite, according to Benson and Dthers, 1979). Small amounts of tridymite and opal probably occur throughout the section. Clinoptilolite occurs in 2.11 samples below about $400 \mathrm{~m}$ but is absent at shallower depths. Dissolution of clinoptilolite is indicated below about $950 \mathrm{~m}$, the approximate depth at which mordenite first appears. However, both clinoptilolite and mordenite occur in all samples studied below $950 \mathrm{~m}$. The depths at which mordenite and clinoptilolite first appear in samples studied from $D H-4, D H-5, D C-2, D C-6$, and $D D H-3$ are given in Table 2-21. 


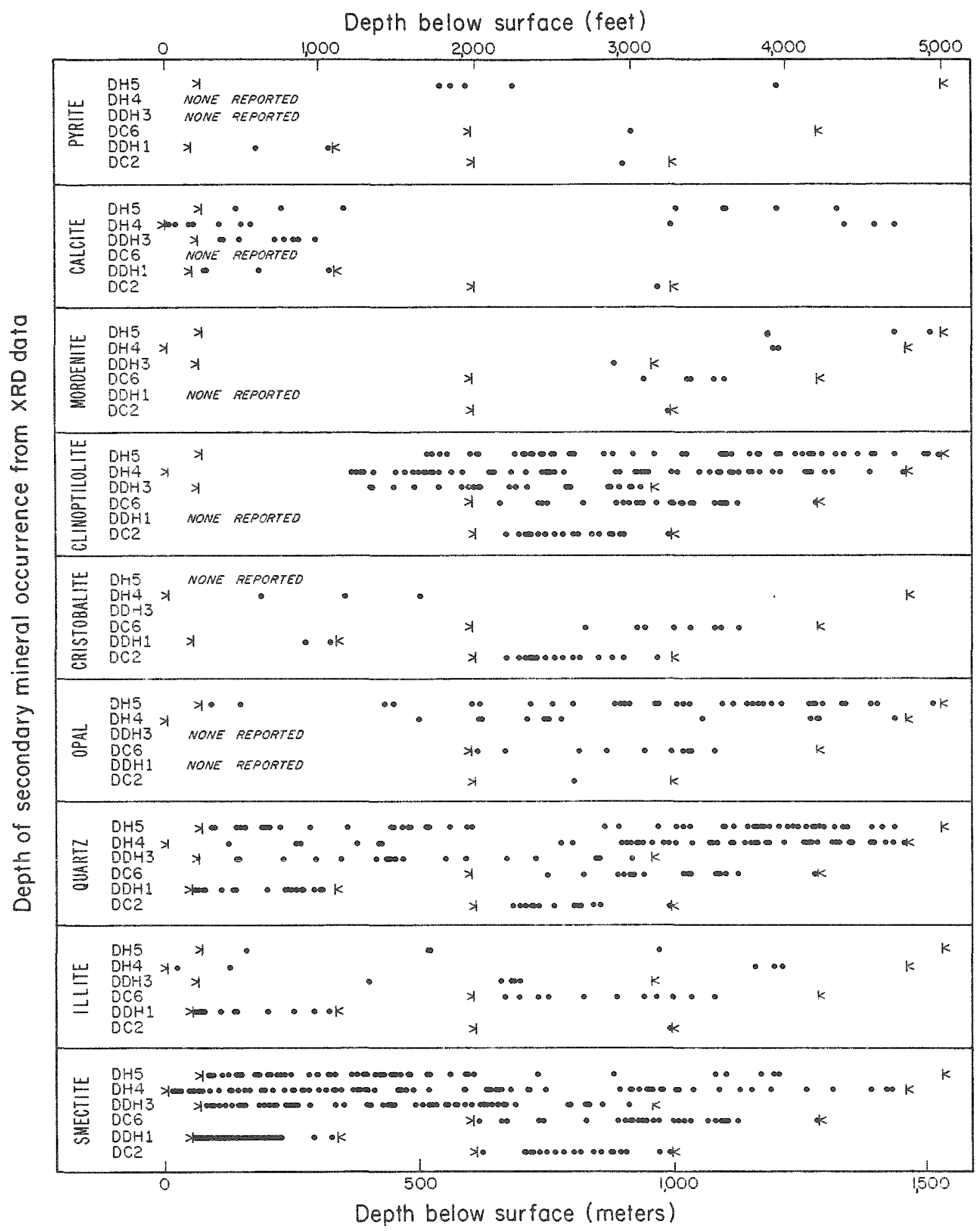

RCP8002-41

FIGURE 2-21. Approximate Distribution of Major Secondary Minerals as a Function of Depth (after Benson and Others, 1979). Data from DDH-1, $\mathrm{DDH}-3, \mathrm{DH}-4$, and $\mathrm{DH}-5$ are from Ames (in press): data from $\mathrm{DC}-2$ and $\mathrm{DC}-6$ are from Benson and 0thers (1979). ( $* k$ ) indicates interval of core sampled. Well locations are shown in Figure 2-8. 
TABLE 2-21. Depths at which Clinoptilolite and Mordenite First Appear as Reported from X-Ray Diffraction Data.

(After Benson and Others, 1979; Ames, in press.)

\begin{tabular}{l|c|c}
\hline Sample Location & $\begin{array}{c}\text { Morden ite } \\
\text { (depth } \text { in } \mathrm{m} \text { ) }\end{array}$ & $\begin{array}{c}\text { CTinoptilolite } \\
\text { (depth in } \mathrm{m} \text { ) }\end{array}$ \\
\hline DH-4 (Ames) & 1,194 & 315 \\
DH-5 (Ames) & 1,193 & 515 \\
DC-2 (Benson) & 995 & $\begin{array}{c}\text { Probably between } \\
400-500 \text { meters }\end{array}$ \\
DC-6 (Benson) & 942 & 407 \\
DDH-3 (Ames) & 882 & 4 \\
\hline
\end{tabular}

When these data are plotted on a structural cross-section of the basin (DH-5, DC-2, and DDH-3), there appears to be no structural or stratigraphic control which influences the zeolite distribution (Fig. 2-22). Rather, these horizons appear to be more a function of depth indicating the regions of phase stability (i.e., clinoptilolite, 400 to $950 \mathrm{~m}$; mordenite, below about $950 \mathrm{~m}$ ). As additional data is obtained, the distribution (stability fields) of these and other secondary phases will be confirmed.

\subsubsection{Composition of Interbeds in the Pasco Basin}

A brief review of the groundwater hydrology of the Pasco Basin was reported by Gephart (in BWIP, 1979b). In the basin, the aquifers referred to as confined (Table 2-22) are those permeable interbeds occurring between low-permeable basalt flows which act as aquitards. In genera1, these units occur in the Wanapum and Saddle Mountains Basalt. The unconfined aquifer is the shallowest near-surface hydrologic system of limited areal extent contained completely within the Pasco Basin.

The major confined aquifers occurring throughout the basin, all of which are informally assigned to the Ellensburg Formation, are the Vantage Sandstone in the Wanapum Basalt and the Mabton, Cold Creek, Selah, Rattlesnake Ridge, and Levy Members in the Saddle Mountains Basalt (see Fig. 2-10 for stratigraphic position). The interbed material is mostly tuffaceous siltstone although quartzose sands, conglomerates, and wellsorted vitric tuffs also occur. 


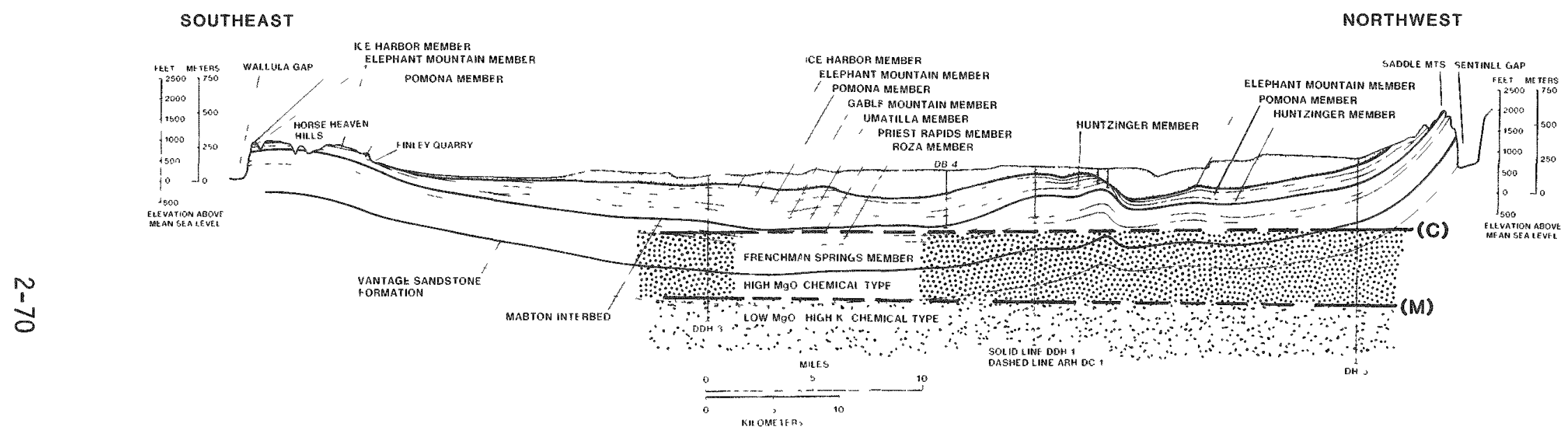

(C) FIRST APPEARANCE OF CLINOPTILOLITE ( $400 \mathrm{~m})$

(M) FIRST APPEARANCE OF MORDENITE ( $\sim 950 \mathrm{~m})$

FIGURE 2-22. Depths at which Mordenite (M) and Clinoptilolite (C) First Appear in Core Samples $\mathrm{DH}-5, \mathrm{DC}-2$, and $\mathrm{DDH}-3$ (Refer to Table 2-21). 
TABLE 2-22. Features of the Groundwater Flow Systems beneath the Pasco Basin.

(After Gephart in BWIP, 1979b.)

\begin{tabular}{|c|c|c|c|c|}
\hline Flow System & Geologic Unit & $\begin{array}{l}\text { Recharge } \\
\text { within the } \\
\text { Pasco Basin }\end{array}$ & $\begin{array}{l}\text { Discharge } \\
\text { within the } \\
\text { Pasco Basin }\end{array}$ & $\begin{array}{l}\text { Groundwater } \\
\text { Contributions from } \\
\text { Outside the Pasco Basin }\end{array}$ \\
\hline \multirow[t]{2}{*}{$\begin{array}{l}\text { Unconfined } \\
\text { Aquifer }\end{array}$} & $\begin{array}{l}\text { Hanford and } \\
\text { Ringold } \\
\text { Formations }\end{array}$ & Major & Major & Minor \\
\hline & $\begin{array}{l}\text { Saddle Mountains } \\
\text { Basalt }\end{array}$ & Major & Major & Minor \\
\hline \multirow{2}{*}{$\begin{array}{l}\text { Confined } \\
\text { Aquifers }\end{array}$} & Wanapum Basalt & Minor & Possible & Major \\
\hline & $\begin{array}{l}\text { Grande Ronde } \\
\text { Basalt }\end{array}$ & Minor & Possible & Major \\
\hline
\end{tabular}

The Vantage Sandstone is the fine-grained micaceous quartzose sand that marks the contact between the Grande Ronde and Wanapum Basalts in most of the Pasco Basin. The thickness of this marker bed is between 0 and $8 \mathrm{~m}$ with its greatest thickness in the northwestern portion of the basin $(8 \mathrm{~m}$ at $\mathrm{DH}-5)$. The unit pinches out to $4 \mathrm{~m}$ at DC-4 where it is composed of black clay, clayey sandstone, and loosely consolidated sand. Locally within the basin the Vantage interbed is absent but represented by Grande Ronde saprolite.

The Mabton interbed is a major unit occurring between the Wanapum and Saddle Mountains Basalt. It is the most extensive and voluminous interbed within the Pasco Basin. It is a tuffaceous silt characterized by red and purple opal near the top, occurring in thicknesses in excess of $50 \mathrm{~m}$ in the northwestern part of the basin. It generally thins away from this area with thicknesses of $25 \mathrm{~m}$ having been measured at $\mathrm{DC}-2$. Vertical lithologic changes have been recognized within the basin. From top to bottom the unit consists of: (1) a well-indurated lapilli tuffstone, locally baked; (2) a fine-grained tuffaceous, clayey, quartzitic sandstone; and, (3) a loosely consolidated, quartzitic or arkosic sand or sandstone with interlayered volcaniclastic sediments. 
The Saddle Mountains Basalt contains several major interbeds. The lowermost Cold Creek interbed, occurring between the Asotin and Esquatzel units, ranges from 0 to $35 \mathrm{~m}$ in thickness and is restricted to the cold creek syncline area. The unit is composed of tuffaceous to arkosic sandstone with a middle conglomerate of well-rounded and closely-packed basalt cobbles in a black basaitic sandstone.

The Selah interbed occurs locally in the Pasco Basin in variable thicknesses stratigraphically between the Esquatzel and Pomona Members. It is a clean and well-sorted vitric tuff, locally silty and sandy with some chert at the Pomona contact. Its distribution also parallels the Cold Creek synciine beneath the Hanford Site, where it is probabiy at least $20 \mathrm{~m}$ thick.

The Rattlesnake Ridge interbed is a tuffaceous silt and sandstone also thickest along the Cold Creek synclinal axis, but occurring throughout the basin. It occurs between the Pomona and Elephant Mountain Members. Like the Cold Creek interbed, it has a thick cobble conglomerate facies of mostly basaltic clasts.

The uppermost interbed in the Saddle Mountains section, the Levy interbed, occurs between the Elephant Mountain and Ice Harbor Members. It is generally a tuffaceous siltstone unit from 0 to $6 \mathrm{~m}$ thick occurring in the eastern part of the Pasco Basin.

Minor interbeds within the Saddle Mountains Basalt include a vitric tuff 1 to $2 \mathrm{~m}$ thick separating two flows of the Esquatzel Member (Gable Mountain Bed) and a thin, 15-cm clay layer separating the Wilbur Creek (?) and Umatilla flows.

\subsubsection{Summary}

The Pasco Basin is located in the Columbia Plateau of southeastern Washington. As the structural and topographic low point of the province during an extended period of lava extrusion ( 6.0 to 16.5 million years before present), the Pasco Basin contains a voluminous accumulation of continental basalt with a maximum thickness in excess of $1,500 \mathrm{~m}$. The basalt alters to mostly clay and zeolite phases with high ion-absorption and swelling potential. Because of these favorable geologic conditions 
the Pasco Basin has been proposed as a possible site for the deep geologic disposal of high-level radioactive wastes.

Primarity on the basis of chemistry and paleomagnetic properties, the Pasco Basin basalt units have been divided into three major formations; the Grande Ronde, Wanapum, and Saddle Mountains (Table 2-23). The

TABLE 2-23. Basalt Formations in the Pasco Basin.

\begin{tabular}{l|c|c|c|c}
\hline \multicolumn{1}{c|}{ Formation } & $\begin{array}{c}\text { Volume } \\
(\%)\end{array}$ & $\begin{array}{c}\text { Thickness } \\
(\mathrm{m})\end{array}$ & $\begin{array}{c}\text { Basalt } \\
\text { Flows }\end{array}$ & $\begin{array}{c}\text { Age } \\
\text { (million years) }\end{array}$ \\
\hline Saddle Mountains & $\sim 12$ & $\sim 200$ & $\sim 10$ & $\sim 6.0-13.6$ \\
Wanapum & $\sim 20$ & $\sim 330$ & $\sim 15$ & $\sim 13.6-14.0$ \\
Grande Ronde & $\sim 68$ & $\sim 1,100$ & $\sim 30$ & $\sim 14.0-16.5$ \\
\hline
\end{tabular}

lowermost Grande Ronde Basalt occupies the basin below about $650 \mathrm{~m}$ and accounts for nearly $70 \%$ of the total basalt accumulation in the basin. Approximately $300 \mathrm{~m}$ of "high-Ti" Wanapum Basalt with 2 to 3 discontinuous interbeds occur immediately above the Grande Ronde. The uppermost Saddle Mountains Basalt was deposited above the Wanapum during the waning period of volcanism ( 6 and 13.6 milition years before present). This final protracted period of volcanism was interrupted by several extended periods of quiescence during which the major interbeds were deposited. These interbeds are the major sedimentary aquifers in the Pasco Basin.

Chemical and mineralogical data suggest that basalt horizons in the Grande Ronde are well suited for hosting a repository. Chemically, the basin basalts increase in silica and alkali content with increasing depth: the highest values recognized in the low-Mgo Schwana sequence of the Grande Ronde. This chemical trend is reflected in the increase of available free silica and alkalies in the groundwater fluids available for secondary mineral formation. The stable silica- and alkali-rich zeolite and smectite clay phases formed at this depth have a high cation exchange capacity, providing for effective radionuclide capture if required. Also, the glass from which these phases are formed when exposed to percolating solutions occurs in relatively greater abundance in the Grande Ronde Basalts (Tabie 2-24). 
TABLE 2-24. Summary Characteristics of Pasco Basin Basalt Formations.

\begin{tabular}{|c|c|c|c|}
\hline & Lithology & Minerology & Chemistry \\
\hline $\begin{array}{l}\text { Wanapum } \\
\text { Basalt }\end{array}$ & $\begin{array}{l}\text { Medium-grained; } \\
\text { plagioclase phyric }\end{array}$ & $\begin{array}{l}\text { 0livine-bearing; } \\
\text { variable petrography }\end{array}$ & $\begin{array}{l}\text { Relatively high } \\
\text { FeO and } \mathrm{TiO}_{2}\end{array}$ \\
\hline $\begin{array}{l}\text { Saddle } \\
\text { Mountains } \\
\text { Basalt }\end{array}$ & $\begin{array}{l}\text { Variable; aphyric } \\
\text { fine- to medium- } \\
\text { grained }\end{array}$ & $\begin{array}{l}\text { Olivine \& plagioclase } \\
\text { phyric }\end{array}$ & $\begin{array}{l}\text { More diverse } \\
\text { than other }\end{array}$ \\
\hline $\begin{array}{l}\text { Grande Ronde } \\
\text { Basalt }\end{array}$ & $\begin{array}{l}\text { Fine-grained, } \\
\text { glass-rich; dense }\end{array}$ & $\begin{array}{l}\text { Olivine } 0.5 \% \text { rare } \\
\text { plagioclase and } \\
\text { pyroxene phenocrysts }\end{array}$ & $\begin{array}{l}\text { Low Mgo \& high } \\
\text { chemical types: } \\
\text { high-Si basalt } \\
\text { formation }\end{array}$ \\
\hline
\end{tabular}

Two major flows in the Grande Ronde, the Umtanum in the upper Tow-MgO sequence, and the middle Sentinel Bluffs "through runner" in the high-Mgo sequence, appear to be good repository host inits. Both flows occur below the zone at which high-silicon zeolites first appear (clinoptilolite, $400 \mathrm{~m}$ ) and are dense, continuous flows of nearly uniform thickness. The Umtanum is approximately $70 \mathrm{~m}$ thick (900 to $970 \mathrm{~m}$ in depth at DC-2) and the Sentinel Bluffs "through runner" is about $80 \mathrm{~m}$ thick $(710$ to $800 \mathrm{~m}$ in depth at $D C-2)$. Both of these units are, therefore, found at a depth where the naturally occurring secondary minerals possess high ion-absorption and swelling properties.

For the reasons noted above, crushed Grande Ronde Basalt would also serve as an ideal component of an engineered barriers design, namely backfill material. The Umtanum flow, for example, is characterized by relatively high glass content (40 to $60 \%$ ) and is aphyric. Crushed Umtanum basalt would be particularly susceptible to alteration in the presence of percolating groundwater, markedly so at elevated temperatures. Basalt fracture studies at depth suggest that crushed and altered Umtanum "backfill" could produce significant amounts of clay and zeolite (Table 2-25). If significant alteration occurred, the secondary phases produced could provide the mechanical strength, cation-exchange capacity, and swelling properties desired. If the system remains relatively "dry," the basalt backfill component will likely remain mechanically and thermodynamically stable, even at elevated temperatures. In either case, an 
TABLE 2-25. Important Primary and Secondary Phases

in Pasco Basin Basalts.

\begin{tabular}{l|c|l|l|c}
\hline \multicolumn{2}{c|}{ Primary Basalt Minerals } & \multicolumn{3}{c|}{ Secondary Mineral Distribution (Vo1\%) } \\
\hline \multicolumn{1}{c|}{ Phase } & Vol\% (Range) & Phase & Vesicles & Fractures \\
\hline Feldspar & $\sim 40(4-60)$ & Smectite & $\sim 32$ & $\sim 75$ \\
Clinopyroxene & $\sim 30(4-40)$ & Clinoptilolite & $\sim 43$ & $\sim 20$ \\
Opaques & $\sim 10(1-15)$ & Silica & $\sim 25$ & $\sim 5$ \\
01ivine & Tr*(0-4) & & & \\
Glass & $\sim 20(T r-85)$ & & & \\
\hline
\end{tabular}

$* T r=$ Trace.

engineered barriers design incorporating a backfill material composed at least in part of crushed Grande Ronde Basalt would utilize the geochemical advantage provided by the basalts.

\subsection{GROUNDWATER}

\subsubsection{Introduction}

In 1968, the Atlantic Richfield Hanford Company, a prime contractor for the Hanford Site, began an intensive investigation of the hydrologic systems underlying the Hanford Site. These studies were concerned mainly with the areal distribution, hydraulic conductivity, and transmissivity of groundwater across the Hanford Site in the unsaturated and unconfined aquifer systems overlying the Columbia River basalt (Deju and Summers, 1975; Sunmers and Deju, 1974). These studies were initiated mainly to assess radionuclide migration away from surface waste disposal sites as part of the Hanford nuclear waste management program (Taliman and Others, 1979).

In 1976, with the establishment of the National Waste Terminal Storage Program, these studies were extended to include the hydrologic regimes present in the Columbia River basalt in an effort to establish 
the feasibility of a deep geologic repository for radioactive waste in the Columbia Plateau. These studies were conducted by Rockwell Hanford Operations' Basalt Waste Isolation Project. Particular emphasis was placed on the Pasco Basin because of the voluminous accumulation of continental basalt contained within the basin, the already established siting of the government-owned Hanford Site in the Pasco Basin, the semi-arid climate of the region, and the relative impermeability of the basalts (Deju and 0thers, 1977). Several important studies have been completed describing the hydrologic properties and hydrochemical data of important interbed and basalt interflow aquifers found within the basin (ARHCO, 1976; Deju and Others, 1977; BWIP, 1979a; Gephart and Others, 1979a, 1979b).

This section is a summary of available hydrologic and chemical data on groundwaters in the Pasco Basin. More detailed information can be found in Gephart and Others (1979b). This information is needed to assess the effect groundwater will have on the chemical reactions in the near-field environment of a nuclear waste repository in basalt.

\subsubsection{Hydrogeologic Setting}

As discussed in the preceding section, the Hanford Site is located within the Pasco Basin, which is a structural and topographic basin containing at least $1,500 \mathrm{~m}$ of Columbia River basalt of Miocene age overtain by from 0 to $200 \mathrm{~m}$ of fluvial, glaciofluvial, and eolian sediments of Pliocene and Pleistocene age. The basin is structurally situated between the east-west and northwestern trending anticlines and synclines of the Yakima Fold system (see Fig. 2-6).

The relative stratigraphic positions of the four hydrologic systems (i.e., unsaturated or "vadose" zone, unconfined, and upper and lower confined aquifer systems) are defined (Gephart and 0thers, 1979b). The uppermost unsaturated zone typically includes parts of the upper and middle Ringold Formation, as well as portions of the overlying Hanford formation (informal name) and more recent eolian sediments (see Fig 2-10). The unconfined aquifer system extends from the water table to the first 
impermeable rock 1ayer. The upper confined aquifer system extends from the permeable units of the lower Ringold Formation through the Saddle Mountains Basalt which includes several interbeds and basalt interflow contacts. The Wanapum and Grande Ronde Basalt interbeds and interflow contacts represent the lower confined hydrologic systems and contain chemically distinct groundwater. Aquifers in the Wanapum Basalt may contain water of "transitional" composition. Evidence suggests that in certain areas hydraulic communication exists between the unconfined lower Ringold aquifer and the Rattlesnake Ridge confined aquifer (Ledgerwood and Deju, 1976; Newcomb, 1972). The degree of intercommunication and groundwater transfer between other aquifers is not yet fully understood.

The lithology of an aquifer dictates its porosity and hydrautic conductivity. The higher the hydraulic conductivity, the greater the ease with which water migrates through it. Sediments in the unsaturated and unconfined aquifers are highly permeable loess and sands mantiling the Hanford formation which is also composed mostly of permeable fluvial sands and gravels. The Ringold Formation, Pliocene in age, contains an upper layer of silts and sands, a middle Ringold unit of sands and grave1s, and a lower Ringold unit of clay and silt (Brown, 1959; Tallman and Others, 1979). The sedimentary interbeds which are most abundant in the Sadde Mountains Basalt (Tabie 2-26) are essentially quartz sandstone (Vantage), vitric tuffs (Selah), and mostiy tuffaceous silts and sands (Levy, Cold Creek, and Mabton). Some clastic sedimentary units, particularly the sandstone portions, are highly porous and show good hydraulic conductivity while the more clay-rich units do not. Another type of water-bearing strata are the basalt interflow contacts separating the individual flows, particularly those that extend across the entire basin. The vesicular top and porous rubble base of a typical basalt flow (see Fig. 2-9), separated by dense and essentially "dry" basalt, provide possible conduits for water migration. The dense central portion of the basalt flows, however, often displays primary and secondary cooling joints which are frequently filled with secondary minerals with usually low hydraulic conductivity. Many of these microfissures are essentially closed with secondary minerals and are impermeable (Long, 1978). A 
summary of hydrologic properties of these basalt interflows, sedimentary interbeds, and the overlying unconfined aquifers will also be reported in this section.

TABLE 2-26. Basalt Lithology Given as a Percentage of Formation Thickness Drilled in Borehole DC-1.*

(After LaSala and Doty, 1971.)

\begin{tabular}{l|c|c|c|c}
\hline \multicolumn{1}{c|}{$\begin{array}{c}\text { Columbia } \\
\text { River } \\
\text { Basalt }\end{array}$} & $\begin{array}{c}\text { Interval } \\
\text { Thickness } \\
\text { (feet) }\end{array}$ & $\begin{array}{c}\text { Interflow of } \\
\text { Basalt }(\%)\end{array}$ & $\begin{array}{l}\text { Vesicular or } \\
\text { Brecciated } \\
\text { Basalt (\%) }\end{array}$ & $\begin{array}{c}\text { Sedimentary } \\
\text { Interbeds (\%) }\end{array}$ \\
\hline Saddle Mountains & 625 & 54 & 4 & 42 \\
Wanapum & 1,120 & 61 & 11 & $28 *$ \\
Grande Ronde & 2,055 & 62 & 32 & 6 \\
\hline
\end{tabular}

* We11 DC-1 location is depicted in Figure 2-6.

**Percentage probably high because LaSala and Doty (1971) reported several weathered basalt zones as tuff.

\subsubsection{Hydrologic Parameters and Testing Methods}

The usual hydrologic parameters measured from aquifers are the ir hydraulic conductivity, storage coefficient, effective porosity, and transmissivity (Gephart and Others, 1979b). Static head measurements are also normally recorded. The hydraulic conductivity is a measure of the ability of a particular rock unit to conduct water under a hydraulic gradient. The transmissivity defines the overall ability of the rock unit to conduct water by taking into account the rock thickness (hydraulic conductivity multiplied by unit thickness). The storage coefficient is defined as the volume of water that an aquifer releases from or takes into storage per unit surface area of aquifer per unit change in the component of head normal to that surface (Todd, 1959). Effective porosity is a measure of the percentage of void space of the connected interstices capable of transmitting water. 
Testing procedures for measuring these parameters vary generally, depending on the aquifer depth. Pumping tests, generally used to depths of no more than $300 \mathrm{~m}$, are the simplest of well tests. These tests involve pumping a well and measuring changes in groundwater drawdown as a function of time. Results permit a determination of the hydrautic conductivity, storage coefficient, and permeability. For deep basalts and interbeds, drill stem, slug injection/withdrawal, and continuous injection tests have been used for determining the hydrauric conductivity, storage coefficient, and other properties. In this case, the test apparatus uses inflatable "packers" to isolate the specific unit being measured. The isolated formation's response to fluid injection and withdrawal can be carefully monitored and parameters determined (Fig. 2-23). Water flow velocity, effective porosity, and dispersivity are usually measured using tracer tests. These tests involve introducing a tracer substance into the aquifer of interest in one well and observing the time required for it to appear in a second well.

\subsubsection{Physical and Chemical Groundwater Data}

The data presented here are abstracted and condensed from a recent study (Gephart and Others, 1979b) which incorporates previous data as well as data collected during fiscal year 1979 by Rockwe 11 Hanford Operations. A more complete display and discussion of these data are found in that report. Presented in the following tables are hydrological data (hydrautic conductivities, transmissivities, and storage coefficients) and hydrochemical data (abundances of major aqueous species, trace elements, and radioisotopes). The data are organized according to the aquifers found in the geologic column beginning with the unconfined aquifers in the youngest formations, the Hanford and Ringold Formations, followed by the confined aquifers in the Saddle Mountains, Wanapum, and Grande Ronde Formations. The amount of data collected is greatest for the unconfined aquifers and decreases with depth.

\subsubsection{Physical Properties of the Aquifer Systems. The unconfined} aquifer system is made up of the Hanford and Ringoid Formations. The unconfined aquifer varies in thickness from 0 to $63 \mathrm{~m}$. In general, the 
RHO-BWI -ST-7

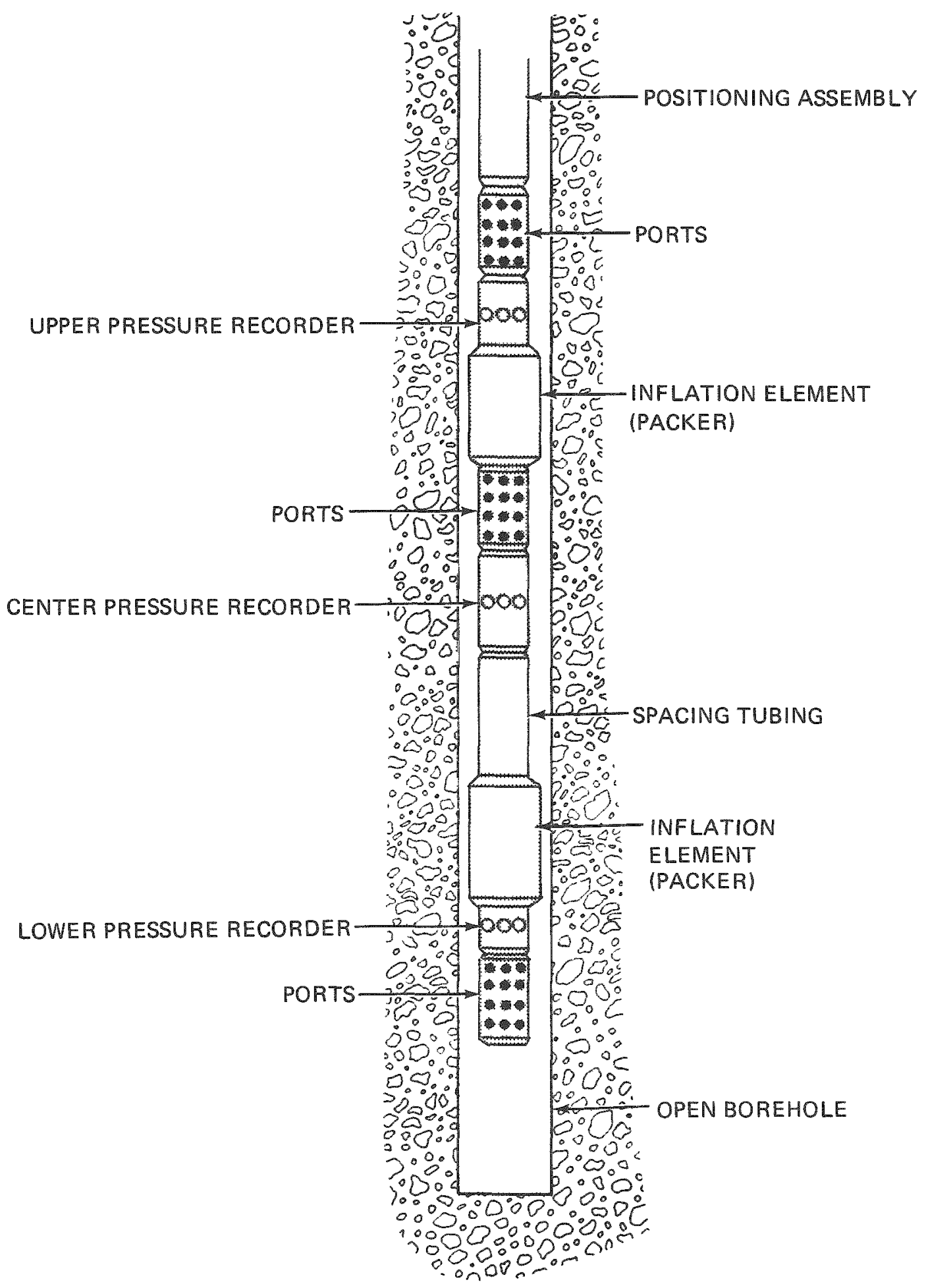

$m w / 80$

FIGURE 2-23. Generalized Diagram of Drill Stem Testing Apparatus (after BWIP, 1979a). 
Ringold Formation makes up the bulk of the aquifer. Within the Pasco Basin, the Hanford formation is thickest on the northern and southern flanks of Gable Mountain. Also, the unconfined aquifer is thickest in the synclinal sections and thinnest in the anticlinal sections.

The unconfined aquifer in the Pasco Basin is bounded by the Saddle Mountains to the north, the Umtanum and Yakima Ridges to the west, Rattiesnake and Horse Heaven Hills to the south, and a broad monocline to the east (see Fig. 2-6). Natural recharge occurs mostly through stream runoff from three sources; Cold Creek and Dry Creek between Rattlesnake Hills and Umtanum Ridge, the Yakima River, and the Columbia River at high stages. An unspecified amount of recharge may come from the basalts and interbeds just below the Ringold. Artificial recharge sources include Tiquid waste disposal ponds on the Hanford Site, primarily U Pond, B Pond, and Gable Mountain Pond. Unconfined aquifer water discharges into the Columbia River north of Richland, Washington and to a lesser extent into the Yakima and Snake Rivers.

The hydrautic properties of the unconfined aquifer are summarized in Table 2-27. The ranges listed result from a compilation of data from a minimum of 35 wells for hydraulic conductivities and transmissivities. Much less storage coefficient data are available and the range listed is essentially an estimate. The Hanford formation has the highest conductivity values since it is composed of the more porous and permeable coarse sand, gravel, and cobble materials. The greater thickness of the Hanford formation along the flanks of Gable Butte and Gable Mountain is reflected in the high transmissivity values for that region.

The uppermost confined aquifers occur in the Saddle Mountains Formation and the greatest amount of data is available for these units. The major aquifers include the Rattlesnake Ridge, Selah, Cold Creek, and Mabton interbeds with the Mabton being the most continuous and therefore the best sampled aquifer.

The ranges of hydraulic conductivities and transmissivities measured in these wells penetrating the Saddle Mountain aquifers are summarized in Table 2-28. The majority of hydraulic conductivities fall in the range of 1 to $100 \mathrm{ft} /$ day. No storage coefficient data are presently available and the values in the table represent standard confined aquifer values. 
TABLE 2-27. Representative Hydrautic Properties of the Unconfined Aquifer.

(After Gephart and Others, 1979b.)

\begin{tabular}{|c|c|c|c|c|}
\hline $\begin{array}{l}\text { Stratigraphic } \\
\text { Interval }\end{array}$ & $\begin{array}{l}\text { Hydraulic } \\
\text { Conductivity } \\
\text { (ft/day) }\end{array}$ & Region & $\begin{array}{c}\text { Transmissivity } \\
(\text { ft } 2 / \text { day })\end{array}$ & $\begin{array}{c}\text { Storage } \\
\text { Coefficients }\end{array}$ \\
\hline $\begin{array}{l}\text { Hanford } \\
\text { Formation }\end{array}$ & $500-20,000$ & $\begin{array}{l}\text { North of Gable } \\
\text { Butte and Gable } \\
\text { Mountain }\end{array}$ & $4,000=25,000$ & \\
\hline $\begin{array}{l}\text { Undifferent- } \\
\text { jated Hanford } \\
\text { and Middle } \\
\text { Ringold Unit }\end{array}$ & $100=7,000$ & $\begin{array}{l}\text { Flank of Gable } \\
\text { Butte and Gable } \\
\text { Mountain and along } \\
\text { paleochannels }\end{array}$ & $40,000-600,000$ & \\
\hline $\begin{array}{l}\text { Middle Ringold } \\
\text { Unit }\end{array}$ & $20-600$ & $\begin{array}{l}\text { Other areas on } \\
\text { the Hanford Site }\end{array}$ & $2,000-40,000$ & \\
\hline $\begin{array}{l}\text { Lower Ringold } \\
\text { Unit }\end{array}$ & $0.11-10.0$ & $\begin{array}{l}\text { Throughout the } \\
\text { unconfined } \\
\text { aquifer }\end{array}$ & & $0.01-0.1$ \\
\hline
\end{tabular}

TABLE 2-28. Hydraulic Properties of the Saddle Mountains Aquifers.

(After Gephart and Others, 1979b.)

\begin{tabular}{l|c|c|c}
\hline $\begin{array}{c}\text { Stratigraphic } \\
\text { Member }\end{array}$ & $\begin{array}{c}\text { Hydraulic } \\
\text { Conductivity } \\
\text { (ft/day) }\end{array}$ & $\begin{array}{c}\text { Transmissivity } \\
\text { (ft2/day) }\end{array}$ & $\begin{array}{c}\text { Storage } \\
\text { Coefficient }\end{array}$ \\
\hline Rattlesnake Ridge & $2.4-103.0$ & $8-4.326$ & \\
Selah & $2.2-23.1$ & $67-462$ & $5 \times 10^{-3}-1 \times 10^{-5}$ \\
Cold Creek & $1.5-181.0$ & $141-8.326$ & $\begin{array}{l}\text { (estimated) } \\
\text { Mabton }\end{array}$ \\
\hline
\end{tabular}

In the Wanapum and Grande Ronde Formations, aquifers are primarity found in interflow zones where the basait is brecciated and fractured. Also, brecciated zones within basalt flows as well as locally occurring interbeds probably act as minor aquifers. Little direct information is known about the areas of recharge and discharge for these aquifers. 
The range of hydraulic conductivities and storage coefficients in the Wanapum and Grande Ronde Formations are shown in Table 2-29. Hydrautic conductivities were measured across high-density, columnar basait sections, and low-density, vuggy, brecciated basalts. Storage coefficients were smaller in the high-density basalts $\left(1 \times 10^{-6}\right.$ to $\left.1.4 \times 10^{-6}\right)$ than in low-density basalts $\left(1 \times 10^{-3}\right.$ to $\left.3 \times 10^{-3}\right)$.

TABLE 2-29. HydrauTic Properties of the Wanapum and Grande Ronde Formations.

(After Gephart and Others, 1979b.)

\begin{tabular}{|c|c|c|c|}
\hline $\begin{array}{l}\text { Stratigraphic } \\
\text { Location }\end{array}$ & $\begin{array}{c}\text { Rock } \\
\text { Character }\end{array}$ & $\begin{array}{l}\text { Hydrautic } \\
\text { Conductivity } \\
\text { (ft/day) }\end{array}$ & $\begin{array}{l}\text { Storage } \\
\text { Coefficients }\end{array}$ \\
\hline $\begin{array}{l}\text { Wanapum } \\
\text { Formation }\end{array}$ & $\begin{array}{l}\text { High-density } \\
\text { Low-density }\end{array}$ & $\begin{array}{l}1.3 \times 10^{4}-2.9 \times 10^{3} \\
4.2 \times 10^{-2}=2.3 \times 10^{-1}\end{array}$ & $\begin{array}{l}6.3 \times 10^{-4} \\
1.8 \times 10^{-3}\end{array}$ \\
\hline $\begin{array}{l}\text { Grande Ronde } \\
\text { Formation }\end{array}$ & $\begin{array}{l}\text { High-density } \\
\text { Low-density }\end{array}$ & $\begin{array}{l}10^{-8}-10^{-3} \\
10^{-5}-10^{2}\end{array}$ & $\begin{array}{c}1.4 \times 10^{-6}-{ }^{-1} \times 10^{-} \\
3 \times 10^{-3}\end{array}$ \\
\hline Umtanum Unit* & $\begin{array}{l}\text { High-density } \\
\text { Low-density }\end{array}$ & $\begin{array}{c}10^{-7}-10^{-8} \\
1.8 \times 10^{-3}-1.6 \times 10^{-4}\end{array}$ & $=$ \\
\hline
\end{tabular}

\subsubsection{Hydrochemical Properties of the Groundwater Systems. An} extensive data set of groundwater compositions in the various aquifer systems in the Pasco Basin is being collected to aid in the determination of the following:

- The origin and source of the groundwater

- Groundwater flow patterns

- Residence and travel time

- Hydrochemical classification

- Rock/groundwater interactions

- Aquifer intercommunication

- Transport mechanisms. 
The data set is greatest for the unconfined aquifers and it decreases with depth. Furthermore much of the data collected in earlier studies is inaccurate because of three major factors:

- Poor field sampling and/or analytical techniques

- Interaquifer mixing in the older, monitoring wells

- Contamination from the drilling fluid.

Validation of chemical analyses of groundwater was accomplished by computing the cation-anion balance for each analysis. Ideally, the sum of the anion equivalences should not differ from the sum of cation equivalences. Analyses were included in these compilations only if the ratio (anion-cation)/cation $\leq 5 \%$. Complete chemical characterization includes the measurement of aqueous species concentrations, trace element concentrations, and stable and radioactive isotope concentrations.

A large number of water samples have been taken from the unconfined aquifer on the Hanford Site. However, many of these samples were taken to monitor the migration of radionuclides and chemical waste within the confined aquifer from cooling water and waste disposal activities. Consequentiy, the data sets of complete chemical analyses are limited. The average composition and range of the major aqueous species are shown in Table 2-30. The most abundant components are bicarbonate, sulfate, calcium, silica, and magnesium. This water is classified as a calcium bicarbonate type. Note that the nitrate concentration exhibits a very 1 arge range of values which can be attributed to artificial recharge from surface waste ponds. Trace element concentration ranges are shown in Tabie 2-31. The most abundant elements are aluminum, barium, boron, iron, manganese, and zinc.

The most extensive hydrochemical data set has been collected from the Saddle Mountains Basalt aquifer system, not only from wells, but also from springs. Within the Saddle Mountains Basalt aquifers, the Mabton interbed is the thickest, most continuous, and best sampled. Consequentiy, a detailed correlation of the chemical and physical properties of this aquifer system has been made. 
Major element concentrations are shown in Table 2-32. Data were compiled from Summers and Schwab (1978) and from yet unpublished analyses obtained by the Basalt Waste Isolation Project's hydrology group. These analyses were done on Mabton interbed samples and are considered representative of groundwater compositions of the entire Saddle Mountains aquifer system. These groundwaters are characterized as the sodium bicarbonate type. However, analyses of spring water sampled from the Rattlesnake Hills area (Table 2-33) show that this water is a calciummagnesium bicarbonate. These data indicate that groundwater composition changes with distance away from the recharge area (near the springs) in the following ways:

- Calcium and magnesium content decreases.

- Sodium content and total dissolved solids content increases.

- Sulfate content decreases.

Isotopic data for the Mabton interbed of the Saddle Mountains Basalt have been shown by Gephart and Others (1979b). These groundwaters contain very low amounts of tritium and their carbon-14 ages average over 15,000 years.

Trace element concentrations for the Mabton interbed are shown in Table 2-34. The most abundant elements are aluminum, boron, barium, iron, and strontium.

The aquifers that lie below the lower Saddle Mountains aquifers are primarily composed of interflow materials. They have not been as extensively sampled as the Mabton interbed. Quantitative chemical data have been compiled from Summers and Weber (1978) and unpublished analyses obtained by the Basalt Waste Isolation Project hydrology group. only those analyses with acceptable cation/anion balances were selected and only 12 well sites produced data that were considered representative of the Wanapum groundwaters. No data have yet been collected from the lower Wanapum aquifers.

Table 2-35 is a summary of the groundwater compositions that are representative of the upper Wanapum aquifer system. Examination of this 
RHO-BWI $-S T-7$

TABLE 2-30. Average Composition and Range in Concentration of Major Chemical Constituents within Groundwater in the Unconfined Aquifer at Hanford.

(After Gephart and Others, 1979b.)

\begin{tabular}{l|c|c}
\hline Anions & Range $(\mathrm{mg} / \mathrm{l})$ & Average $(\mathrm{mg} / \mathrm{l})$ \\
\hline $\mathrm{HCO}_{3}^{-}$ & $56.0-314.0$ & 149.0 \\
$\mathrm{Cl}^{-}$ & $2.7-32.0$ & 11.0 \\
$\mathrm{SO}_{4}^{-2}$ & $2.7-99.0$ & 43.0 \\
$\mathrm{NO}_{3}^{-}$ & $0.1-270.0$ & 27.0 \\
$\mathrm{~F}^{-}$ & $0.1-1.3$ & 0.5 \\
\hline Cations & $2.9-64.0$ & 23.0 \\
\hline $\mathrm{Na}^{+}$ & $2.4-13.0$ & 6.2 \\
$\mathrm{~K}^{+}$ & $14.0-92.0$ & 41.0 \\
$\mathrm{Ca}^{+2}$ & $3.1-29.0$ & 11.0 \\
$\mathrm{Mg}{ }^{+2}$ & $8.8-50.0$ & 35.0 \\
SiO & $203.0-728.0$ & 347.0 \\
Total & & \\
Dissolved & & \\
\hline
\end{tabular}




\section{RHO-BWI-ST-7}

TABLE 2-31. Range and Median Values of Trace Elements for Unconfined Groundwater at the Hanford Site.

(After Gephart and Others, 1979b.)

\begin{tabular}{|c|c|c|}
\hline Trace Element & Range $(\mathrm{mg} / \mathrm{l})$ & Median $(\mathrm{mg} / \mathrm{l})$ \\
\hline $\mathrm{Ag}$ & $<0.010-0.002$ & $<0.010$ \\
\hline$A 1$ & $<0.050-0.470$ & $<0.050$ \\
\hline As & $0.001-0.014$ & 0.005 \\
\hline B & $<0.009-0.150$ & 0.020 \\
\hline $\mathrm{Ba}$ & $0.007-0.100$ & 0.050 \\
\hline $\mathrm{cd}$ & $<0.003-0.140$ & 0.003 \\
\hline $\mathrm{Cn}$ & $0.010-0.120$ & $<0.010$ \\
\hline Co & $<0.002-0.010$ & 0.005 \\
\hline $\mathrm{Cr}$ & $<0.050-0.100$ & 0.007 \\
\hline $\mathrm{Cu}$ & $<0.010-0.047$ & $<0.010$ \\
\hline $\mathrm{Fe}$ & $<0.005-3.9$ & 0.020 \\
\hline$M n$ & $<0.001-0.480$ & 0.010 \\
\hline Mo & $<0.001-0.030$ & 0.007 \\
\hline $\mathrm{Pb}$ & $<0.030-0.017$ & $<0.003$ \\
\hline $\mathrm{Sb}$ & $<0.030$ & $<0.030$ \\
\hline $\mathrm{Se}$ & $0.001-0.012$ & 0.002 \\
\hline $2 n$ & $<0.005-1.6$ & 0.012 \\
\hline
\end{tabular}


RHO-BWI-ST-7

TABLE 2-32. Average Composition and Range in Concentration of Major Chemical Constituents within Groundwater of the Mabton Interbed.

(After Gephart and Others, 1979b.)

\begin{tabular}{|c|c|c|}
\hline Anions & Range (mg/l) & Average $(\mathrm{mg} / \mathrm{l})$ \\
\hline $\mathrm{HCO}_{3}^{-}$ & $169.0-267.0$ & 217.0 \\
\hline $\mathrm{Cl}^{-}$ & $4.3-63.0$ & 20.0 \\
\hline $\mathrm{SO}_{4}^{-}$ & $0.3-18.0$ & 4.0 \\
\hline $\mathrm{NO}_{3}^{-2}$ & $<0.5$ & $<0.5$ \\
\hline$F^{-}$ & $0.1-8.0$ & 2.2 \\
\hline \multicolumn{3}{|l|}{ Cations } \\
\hline $\mathrm{Na}+$ & $36.0-122.0$ & 83.0 \\
\hline$k+$ & $7.7=14.0$ & 11.0 \\
\hline $\mathrm{Ca}^{+2}$ & $0.5-22.0$ & 4.7 \\
\hline $\mathrm{Mg}^{+2}$ & $0.1-12.0$ & 1.8 \\
\hline $\mathrm{SiO}_{2}$ & $56.0-91.0$ & 69.0 \\
\hline $\begin{array}{l}\text { Total } \\
\text { Dissolved } \\
\text { Solids }\end{array}$ & $344.0-505.0$ & 413.0 \\
\hline
\end{tabular}


indicates that groundwater within the upper Wanapum Basalt generally has a low total dissolved solids content (i.e., less than $500 \mathrm{mg} / \mathrm{h}$ ) and is of a mixed cation, primarily sodium-bicarbonate type. It also appears to exhibit the same trends as the Saddle Mountains groundwater in that calcium and magnesium concentrations decrease and sodium concentrations increase with distance from the recharge area. The amount of total dissolved solids also increases (see Tables 2-33, 2-34, and 2-35).

Trace element and isotopic data are very sparse. Two trace element analyses are shown in Table 2-36. The most abundant elements are a) are known for two wells (Table 2-37).

The Grande Ronde Basalt aquifers, like the Wanapum Basalt aquifers, are primarily interfiows. Geochemical data are sparse. Three major element water compositions are shown in Table 2-38. These analyses indicate that Grande Ronde groundwater is chemically distinct from the Saddle Mountains and upper Wanapum groundwater. The differences are as follows:

- $\mathrm{K}^{+}, \mathrm{Mg}^{+}, \mathrm{Ca}^{+2}$, and $\mathrm{HCO}_{3}^{-}$are decreased in the Grande Ronde groundwater

- $\mathrm{CO}_{3}^{+2}, \mathrm{Cl}^{-}, \mathrm{SO}_{4}^{-2}$, and $\mathrm{F}^{-}$are increased in the Grande Ronde groundwater

- Total dissolved solids are increased in the Grande Ronde groundwater.

Trace element abundances are shown from three well samples in Table 2-39 and reflect a wide range of values. The more abundant elements are aluminum, barium, bromine, molybdenum, and zinc. Radioisotopic data are also very sparse. The few data available on $\delta^{18} 0$ values are similar to the Wanapum and Saddle Mountains groundwater.

\subsubsection{Interpretation}

The data presented in preceding sections on the hydrochemical properties of the Pasco Basin groundwaters can be used to interpret the evolution of groundwater composition in this system. In the Saddle 
TABLE 2-33. Average Composition and Range in Concentration of Major Chemical Constituents within Springs in the Rattlesnake Hills.

(After Gephart and Others, 1979b.)

\begin{tabular}{l|r|c}
\hline Anions & Range $(\mathrm{mg} / \mathrm{l})$ & Average $(\mathrm{mg} / \mathrm{l})$ \\
\hline $\mathrm{HCO}_{3}^{-}$ & $71.0-229.0$ & 124.0 \\
$\mathrm{Cl}^{-}$ & $0.1-12.0$ & 5.5 \\
$\mathrm{SO}_{4}^{-2}$ & $10.0-41.0$ & 16.0 \\
$\mathrm{~F}^{-}$ & $0.2-0.64$ & 0.3 \\
\hline Cations & $5.0-19.0$ & \\
\hline $\mathrm{Nat}^{-}$ & $1.5-5.1$ & 9.4 \\
$\mathrm{~K}^{-}$ & $12.0-50.0$ & 2.4 \\
$\mathrm{Ca}^{+2}$ & $4.9-17.0$ & 27.0 \\
$\mathrm{Mg}^{+2}$ & $25.0-61.0$ & 9.7 \\
Si0 & $145.0-410.0$ & 45.0 \\
Total & & 251.0 \\
Dissolved & & \\
\hline Solids & & \\
\hline
\end{tabular}


RHO-BWI-ST -7

TABLE 2-34. Range and Median Values of Trace Elements for Groundwater within the Mabton Interbed of the Manford Site.

(After Gephart and Others, 1979b.)

\begin{tabular}{|c|c|c|}
\hline Trace Element & Range (mg/le) & Median (mg/e) \\
\hline$A T$ & $<0.020-2.170$ & 0.298 \\
\hline B & $<0.005-0.550$ & 0.030 \\
\hline $\mathrm{Ba}$ & $<0.005-0.065$ & 0.019 \\
\hline $\mathrm{Cd}$ & $<0.005-0.009$ & $<0.005$ \\
\hline Co & $<0.005$ & 0.005 \\
\hline $\mathrm{Cr}$ & $<0.005$ & $<0.005$ \\
\hline $\mathrm{Cu}$ & $<0.005$ & $<0.005$ \\
\hline $\mathrm{Fe}$ & $<0.005-4.700$ & 0.275 \\
\hline $\mathrm{Mn}$ & $<0.010$ & $<0.010$ \\
\hline Mo & $<0.010$ & $<0.010$ \\
\hline $\mathrm{Ni}$ & $<0.005-0.030$ & $<0.005$ \\
\hline Sr* & $0.009-0.111$ & 0.071 \\
\hline $\mathrm{Zn}$ & $<0.005-0.093$ & $<0.005$ \\
\hline
\end{tabular}

*Based on only ten analyses. 
TABLE 2-35. Average Composition and Range in Concentration of Major Chemical Constituents within Groundwater of the Upper Wanapum Basalt.

(After Gephart and Others, 1979b.)

\begin{tabular}{|c|c|c|c|}
\hline & Anions & Range (mg/l $)$ & Average $(\mathrm{mg} / \mathrm{l})$ \\
\hline & $\mathrm{HCO}_{3}^{-}$ & $141.0-216.0$ & 177.0 \\
\hline & $\mathrm{Cl}^{-}$ & $3.8-15.0$ & 6.6 \\
\hline & $\mathrm{SO}_{4}{ }^{-2}$ & $0.2-32.0$ & 11.0 \\
\hline & $\mathrm{NO}_{3}^{-}$ & $0.1-2.7$ & 0.5 \\
\hline & $\mathrm{F}^{-}$ & $0.2-2.0$ & 0.7 \\
\hline & \multicolumn{3}{|l|}{ Cations } \\
\hline & $\mathrm{Nat}$ & $17.0-80.0$ & 34.0 \\
\hline & $\mathrm{K}+$ & $5.9-19.0$ & 11.0 \\
\hline & Catt & $1.6-24.0$ & 17.0 \\
\hline & $\mathrm{Mg}++$ & $0.2-15.0$ & 8.8 \\
\hline & $\mathrm{SiO}_{2}$ & $41.0-73.0$ & 57.0 \\
\hline $\begin{array}{l}\text { Total } \\
\text { Dissolved } \\
\text { Solids }\end{array}$ & & $283.0-435.0$ & 324.0 \\
\hline
\end{tabular}


Mountains and Wanapum groundwater, the divalent calcium and magnesium species decrease while the sodium values increase presumably due to ion exchange processes where the $\mathrm{Ca}^{+2}$ and $\mathrm{Mg}^{+2}$ cations are adsorbed to the secondary minerals smectite and clinoptilolite by exchanging with $\mathrm{Na}^{+}$cations which are released into the groundwater. The increase in total dissolved solids reflects the increased residence time in the host basalt which allows the water to react with larger volumes of rock. The decreased $\mathrm{SO}_{4}^{-2}$ content may occur as a result of the chemical reaction

$$
\mathrm{SO}_{4}^{-2}+\mathrm{CH}_{4} \rightarrow \mathrm{HS}^{-}+\mathrm{HCO}_{3}^{-}+\mathrm{H}_{2} \mathrm{O} \text {. }
$$

Glover (1936) has reported the presence of methane $\left(\mathrm{CH}_{4}\right)$ within units of the lower Saddle Mountains Basalt. The completion of this reaction also increases the bicarbonate content of the groundwater.

Several preliminary conclusions can be drawn which enhance the desirability of the selected basalt flows within the Grande Ronde Formation as a repository site. First hydrautic conductivity measurements of the Umtanum flow $\left(10^{-7}\right.$ to $10^{-8} \mathrm{ft} /$ day $)$ indicate that under normal conditions the repository is essentially isolated from the biosphere via groundwater flow for the designed lifetime of the repository. Second, the initial analyses of Grande Ronde groundwater indicate that it is chemically distinct from the Saddle Mountains and upper Wanapum aquifers. These differences are graphically displayed in Figure 2-24. The area of the circles is scaled to the average total dissolved solids contents (in equivalents per million) from the analyses. Note that the Grande Ronde groundwater contains significantly greater amounts of dissolved solids than the upper Wanapum or Saddle Mountains groundwaters. The circles are divided into sections labeled with the appropriate ionic species which graphically represent the average content (in equivalents per million) of that species. The numbers in parentheses indicate the species concentrations in the units of $\mathrm{mg} / \mathrm{l}$. The Saddle Mountains and upper Wanapum groundwater compositions are dominated by $\mathrm{HCO}_{3}^{-}$. In contrast, sodium is the most abundant species in the Grande Ronde groundwater. A7so, the significant abundances of $\mathrm{Cl}^{-}, \mathrm{SO}_{4}^{-2}, \mathrm{~F}^{-}$, and $\mathrm{CO}_{3}^{-2}$ in the Grande Ronde groundwater 
TABLE 2-36. Trace Element Concentrations for Groundwater in the Priest Rapids Member of the Upper Wanapum Basalt.

(After Gephart and Others, 1979b.)

\begin{tabular}{c|c|c}
\hline $\begin{array}{c}\text { Trace } \\
\text { Element }\end{array}$ & $\begin{array}{c}\text { Sample A } \\
(\mathrm{mg} / \mathrm{l})\end{array}$ & $\begin{array}{c}\text { Sample B } \\
(\mathrm{mg} / \mathrm{l})\end{array}$ \\
\hline Al & $<0.05$ & 0.086 \\
B & 0.10 & 0.013 \\
Ba & 0.027 & 0.052 \\
Cd & $<0.005$ & $<0.005$ \\
Co & $<0.005$ & $<0.005$ \\
Cr & $<0.005$ & $<0.005$ \\
Cu & 0.005 & $<0.005$ \\
Fe & 0.228 & 0.181 \\
Mn & $<0.100$ & $<0.10$ \\
Mo & $<0.020$ & $<0.020$ \\
Ni & $<0$ & $<0.005$ \\
Zn & $<0.005$ \\
\hline
\end{tabular}

TABLE 2-37. Radioisotopic Analyses for Groundwater within the Priest Rapids Member of the Upper Wanapum Basalt, Hanford Site. (After Gephart and Others, 1979b.)

\begin{tabular}{|c|c|c|}
\hline \multirow[b]{3}{*}{$\begin{array}{c}\text { Tritium, }{ }^{3} H \\
\left(T . U_{0}\right)^{*}\end{array}$} & \multicolumn{2}{|c|}{ Radioisotopes } \\
\hline & \multicolumn{2}{|c|}{ Data for Two Wells } \\
\hline & $\begin{array}{l}\text { Oxygen Ratio } \\
\delta^{18} \mathrm{SM}^{\mathrm{SM}} \mathrm{W}\end{array}$ & $\begin{array}{l}\text { Carbon-14 } \\
\text { (years) }\end{array}$ \\
\hline $0.17 \pm 0.05$ & -17.7 & $17,542 \pm 490$ \\
\hline $0.11 \pm 0.04$ & -20.8 & $18,100 \pm 570$ \\
\hline
\end{tabular}

*one Tritium Unit (T.U.) $=3.2$ picocuries/ $/$.

* SMOW $=$ Standard mean ocean water. 
TABLE 2-38. Major Inorganic Composition of Groundwater for Selected Wells Completed in the Grande Ronde Basalt.

\begin{tabular}{|c|c|c|c|}
\hline \multirow[b]{2}{*}{ Anions (mg/l) } & \multicolumn{3}{|c|}{ Data Source } \\
\hline & $\begin{array}{l}\text { LaSala and } \\
\text { Doty (1971) }\end{array}$ & $\begin{array}{l}\text { Apps and others } \\
(1979)\end{array}$ & $\begin{array}{c}\text { Gephart and Others } \\
(1979 b)\end{array}$ \\
\hline $\mathrm{HCO}_{3}^{-}$ & $66.0(49)^{2}$ & $88.0(51)^{a}$ & $43.0(90)^{a}$ \\
\hline$* \mathrm{CO}_{3}^{-2}$ & $52.0(101)^{a}$ & $70.0(127)^{\mathrm{a}}$ & $34.0(52)^{a}$ \\
\hline $\mathrm{Cl}^{-}$ & 98.0 & 148.0 & 148.0 \\
\hline $\mathrm{SO}_{4}^{-2}$ & 13.0 & 96.0 & 108.0 \\
\hline$F^{-}$ & 21.0 & $N^{C}$ & 37.0 \\
\hline \multicolumn{4}{|l|}{ Cations (mg/l) } \\
\hline $\mathrm{Nat}$ & 182.0 & 242.0 & 250.0 \\
\hline$k+$ & 3.3 & 3.2 & 1.9 \\
\hline $\mathrm{Ca}^{+2}$ & 0.8 & 1.3 & 1.3 \\
\hline $\mathrm{Mg}^{+2}$ & 0.0 & 2.0 & 0.04 \\
\hline $\mathrm{SiO}_{2}$ & 116.0 & 115.0 & 121.0 \\
\hline $\begin{array}{l}\text { Total } \\
\text { Dissolved } \\
\text { Solids }\end{array}$ & 552.0 & $-b$ & 744.0 \\
\hline $\mathrm{pH}$ & 10.1 & 10.1 & 10.1 \\
\hline
\end{tabular}

a Listed values are corrected for titration of $\mathrm{H}_{3} \mathrm{SiO}_{4}^{-}$during alkalinity determination. Uncorrected concentrations are shown in parentheses.

DTotal dissolved solids not determined due to lack of fluoride concentration.

$C_{N D}=$ Not Determined. 
TABLE 2-39. Trace Elements for Groundwater within Confined Aquifers of the Grande Ronde Basalt on the Hanford Site.

(After Gephart and Others, 1979b.)

\begin{tabular}{|c|c|c|c|}
\hline \multirow[b]{2}{*}{$\begin{array}{c}\text { Trace Elements } \\
\qquad(\mathrm{mg} / \mathrm{l})\end{array}$} & \multicolumn{3}{|c|}{ Data Source } \\
\hline & $\begin{array}{l}\text { Apps and Others } \\
(1979)\end{array}$ & $\begin{array}{l}\text { Apps and 0thers } \\
(1979)\end{array}$ & $\begin{array}{c}\text { Gephart and Others } \\
(1979 b)\end{array}$ \\
\hline $\mathrm{Ag}$ & $<0.010$ & ND* & ND \\
\hline A1 & ND & ND & 0.11 \\
\hline As & $<0.002$ & 0.001 & ND \\
\hline B & NO & ND & 1.39 \\
\hline $\mathrm{Ba}$ & 0.150 & $<0.112$ & $<0.005$ \\
\hline $\mathrm{Br}$ & 0.201 & 0.285 & ND \\
\hline$c d$ & 0.007 & 0.089 & $<0.005$ \\
\hline Co & $<0.017$ & 0.047 & $<0.020$ \\
\hline $\mathrm{Cr}$ & $<0.0002$ & $<0.0004$ & $<0.005$ \\
\hline Cu & 0.050 & 0.060 & $<0.005$ \\
\hline $\mathrm{Fe}$ & 0.017 & 0.015 & 0.054 \\
\hline$M n$ & 0.004 & $<0.009$ & $<0.010$ \\
\hline Mo & 0.270 & 0.31 & 0.310 \\
\hline $\mathrm{Ni}$ & 0.070 & ND & $<0.005$ \\
\hline$S r$ & 0.012 & 0.003 & $<0.005$ \\
\hline $\mathrm{Zn}$ & 0.260 & 0.240 & 0.096 \\
\hline
\end{tabular}

*ND $=$ Not Determined. 
distinguishes it from the upper Wanapum and Saddle Mountains groundwater. These analyses indicate that Grande Ronde groundwater appears to have evolved separately from the upper groundwater and that little or no interaquifer communication has occurred.

\subsubsection{Specification of a Reference Grande Ronde Groundwater Composition}

Reference groundwater compositions and procedures for synthesizing the major groundwater types present in the potential path of radionuclides to the biosphere are being specified based on reported data. To date, the Grande Ronde groundwater composition has been specified first, since water of this composition will first come into contact with the repository system.

Determination of a reference groundwater and specification of a procedure for making the groundwater will allow laboratories supporting the Basalt Waste Isolation Project effort to perform experiments with identical starting solutions. Thus, interlaboratory experimental results can be compared directiy. The use of synthetic groundwater rather than actual groundwater disposes of two problems. First, aliquots of real groundwater are likely to vary in composition due to time-dependent variables and sampling locations. Second, the chemical composition of the groundwater may change during transport to outside laboratories.

of the three Grande Ronde groundwater compositions reported, the composition determined by the hydrology group of the Basalt Waste Isolation Project (Gephart and Others, 1979b) was used to make up a synthetic groundwater composition. The cation concentrations as well as $\mathrm{F}^{-}, \mathrm{Cl}^{-}$, and $\mathrm{SO}_{4}^{-2}$ concentrations determined by Gephart and Others (1979b) were used as reported. However, the $\mathrm{HCO}_{3}^{-}$and $\mathrm{CO}_{3}^{-2}$ concentrations were not measured directly in the samples reported, but were calculated from total alkalinity values. The method of calculation is discussed below.

In Table 2-40 a quantitative definition of alkalinity ( $\mathrm{Eq} .9$ ) is given along with the set of simultaneous equations used to determine carbonate and bicarbonate concentrations and $\mathrm{pH}$ from the reported values. The measured alkalinity computed in equivalents per million is 
0
1
0

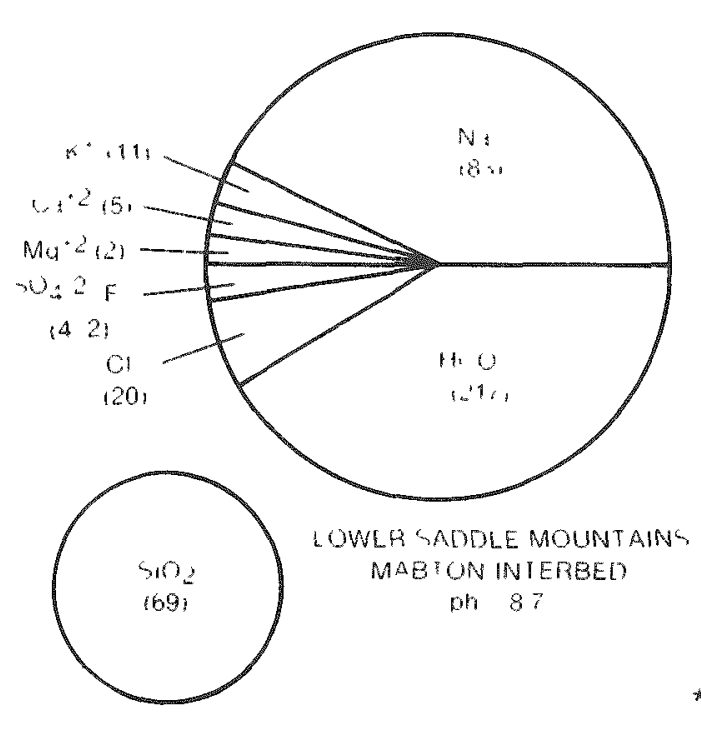

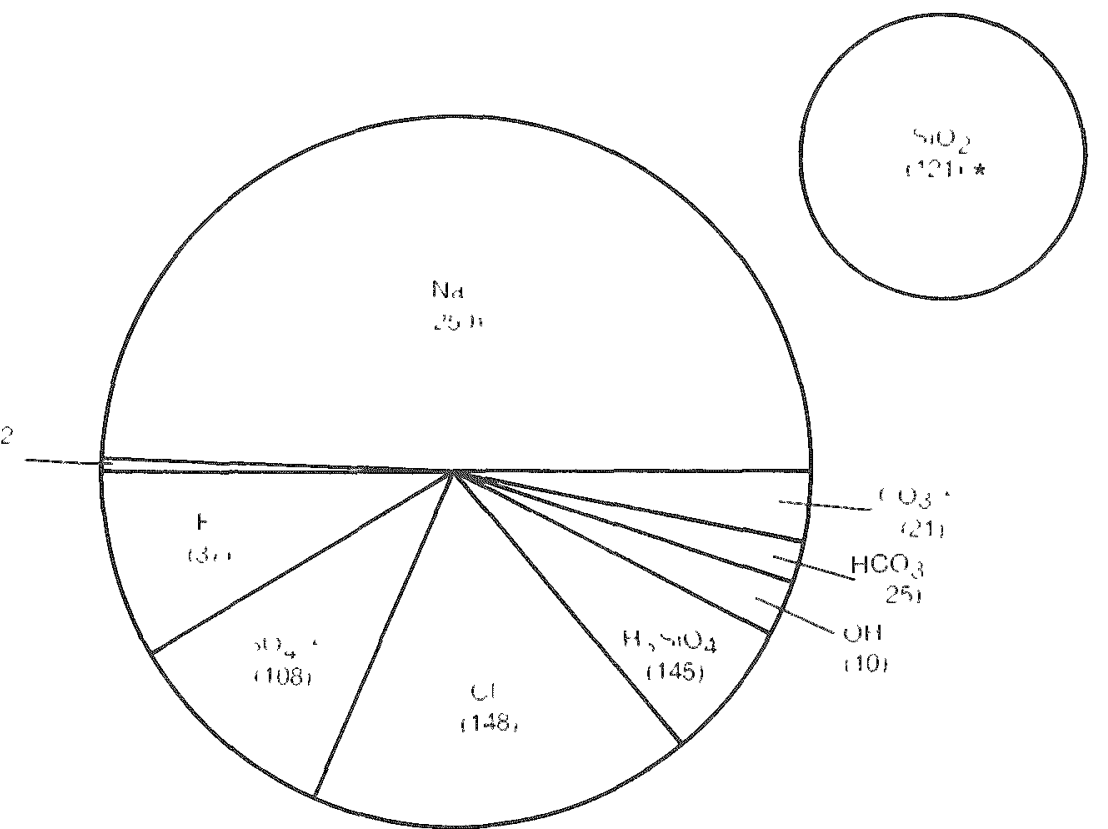

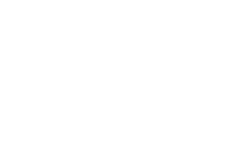$$
\text { IMTANGM }
$$

DH IU I AI $45 \%$

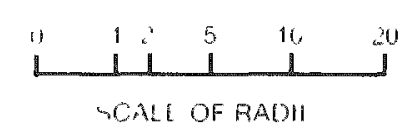

CALL OF RADH

WUTAL OF MILLIEUUIVALENT PIR LITEA

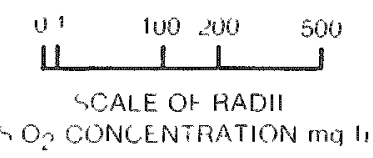

* CONGENTRAIIUNS IN PARENTHE SE ARE EXIMRESSED IN MG

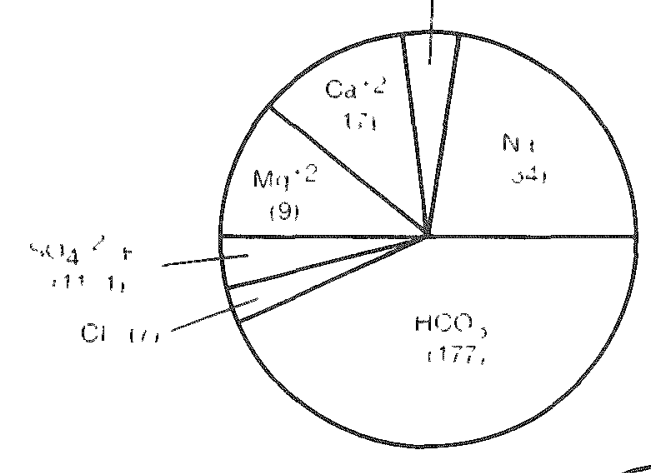

UPPLH WANAPUM PRIEST RAPIDS MEMRER pH 8 :

15,2

FIGURE 2-24. Compositions of Groundwaters in the Pasco Basin. 
3.212. The $\mathrm{H}_{3} \mathrm{SiO}_{4}^{-}$and $\mathrm{OH}^{-}$concentrations were included in the alkalinity equation because in basic solutions with high silica content such as Grande Ronde groundwater these species are found in appreciable quantity and contribute to the titratable alkalinity. Consequently, the first step in calculating carbonate and bicarbonate concentrations was to calculate $\left[\mathrm{H}_{3} \mathrm{SiO}_{4}^{-}\right]$and $\left[\mathrm{OH}^{-}\right]$in moles per liter which were converted to equivalents per million. In Table 2-40, Equation $2 a$ describes the chemical reaction that occurs to produce $\mathrm{H}_{3} \mathrm{SiO}_{4}^{-}$. Equation $2 \mathrm{~b}$ is the definition of the dissociation constant for Equation $2 a$ and Equation $2 \mathrm{c}$ states that aqueous $\mathrm{SiO}_{2}$ occurs as two species, $\mathrm{H}_{4} \mathrm{SiO}_{4}$ and $\mathrm{H}_{3} \mathrm{SiO}_{4}{ }^{-}$. Equation $2 d$ was used to calculate $\left[\mathrm{H}_{3} \mathrm{SiO}_{4}^{-}\right]$and was derived by combining Equations $2 \mathrm{~b}$ and $2 \mathrm{C}$ and rearranging terms. Thus, $\left[\mathrm{H}_{4} \mathrm{SiO}_{4}\right]$ was eliminated from the calculation leaving one unknown, $\left[\mathrm{H}_{3} \mathrm{SiO}_{4}^{-}\right]$. Equation $3 \mathrm{c}$ was used to calculate $\left[\mathrm{OH}^{-}\right]$and was derived by rearranging terms from the definition of the dissociation constant of water (Eq. 3b).

The second step in the total calculation was to subtract $\left[\mathrm{H}_{3} \mathrm{SiO}_{4}{ }^{-}\right]$ and $\left[\mathrm{OH}^{-}\right]$from the total alkalinity in Equation 1 which left two unknowns, $\left[\mathrm{HCO}_{3}^{-}\right]$and $\left[\mathrm{CO}_{3}-2\right]$. The number of unknowns was reduced to one by substituting for $\left[\mathrm{HCO}_{3}^{-}\right]$with its equivalent expression in Equation $4 \mathrm{c}$ leaving on $7 y\left[\mathrm{CO}_{3}^{-2}\right]$. Once $\left[\mathrm{CO}_{3}^{-2}\right]$ was calculated, it was substituted into Equation $4 \mathrm{C}$ and $\left[\mathrm{HCO}_{3}^{-}\right]$was calculated. This step completed the total calculation.

It is important to note that the equations used to calculate the anion concentrations ( $\mathrm{Eq} .2 \mathrm{~d}, 3 \mathrm{c}, 4 \mathrm{c}$ ) all include dissociation constants among their terms. Dissociation constant values vary as a function of temperature. Consequently, the anion concentrations and $\mathrm{pH}$ also vary with temperature which requires that the calculation procedure described above be done for each temperature of interest. For the purposes of Grande Ronde groundwater specification, calculations were performed for three temperatures, $25^{\circ} \mathrm{C}, 45^{\circ} \mathrm{C}$, and $65^{\circ} \mathrm{C}$. The ambient temperature of the proposed repository site is approximately $65^{\circ} \mathrm{C}$ but may be as 1 ow as $45^{\circ} \mathrm{C}$. However, the groundwater to be synthesized in the Taboratory must be prepared and stored at room temperature, $25^{\circ} \mathrm{C}$. Thus, it was necessary to calculate and synthesize a composition with anion concentrations 
TABLE 2-40. Simultaneous Equations Used to Calculate

$\left[\mathrm{H}_{3} \mathrm{SiO}_{4}^{-}\right],\left[\mathrm{H}^{+}\right],\left[\mathrm{OH}^{-?},\left[\mathrm{CO}_{3}^{-2}\right]\right.$, and $\left[\mathrm{HCO}_{3}^{-}\right]$.

(A11 concentrations are measured as moles per liter and converted to $\mathrm{mg} / \mathrm{\&}$ and epm.)

1) Alkalinity $=\left[\mathrm{H}_{3} \mathrm{SiO}_{4}^{-}\right]+\left[\mathrm{OH}^{-}\right]+\left[\mathrm{HCO}_{3}^{-}\right]+2\left[\mathrm{CO}_{3}^{-2}\right]$

2a) $\left[\mathrm{H}_{4} \mathrm{SiO}_{4}\right]=\left[\mathrm{H}_{3} \mathrm{SiO}_{4}{ }^{-}\right]+\left[\mathrm{H}^{+}\right]$

2b) $\mathrm{K}_{4} \mathrm{SiO}_{4}=\left[\mathrm{H}_{3} \mathrm{SiO}_{4}{ }^{-}\right]\left[\mathrm{H}^{+}\right]$

$$
\left[\mathrm{H}_{4} \mathrm{SiO}_{4}\right]
$$

2c) $\left[\mathrm{H}_{4} \mathrm{SiO}_{4}\right]=\left[\mathrm{SiO}_{2}\right]-\left[\mathrm{H}_{3} \mathrm{SiO}_{4}^{-}\right]$

2d) $\left[\mathrm{H}_{3} \mathrm{SiO}_{4}^{-}\right]=\mathrm{K}_{4} \mathrm{SiO}_{4}\left[\mathrm{SiO}_{2}\right]$

$$
\left[\mathrm{H}^{+}\right]+\mathrm{K}_{\mathrm{H}_{4} \mathrm{SiO}_{4}}
$$

3a) $\left[\mathrm{H}_{2} \mathrm{O}\right]=\left[\mathrm{H}^{+}\right]+\left[\mathrm{OH}^{-}\right]$

3b) $\mathrm{K}_{\mathrm{H}_{2} \mathrm{O}}=\left[\mathrm{H}^{+}\right]\left[\mathrm{OH}^{-}\right]$

3c) $\left[\mathrm{OH}^{-}\right]=<\mathrm{KH}_{\mathrm{H}} \mathrm{O}$

$$
\frac{2}{\left[\mathrm{H}^{+}\right]}
$$

4a) $\left[\mathrm{HCO}_{3}^{-}\right]=\left[\mathrm{CO}_{3}^{-2}\right]+\left[\mathrm{H}^{+}\right]$

4b) $\mathrm{KHCO}_{3}^{-}=\left[\mathrm{CO}_{3}^{-2}\right]\left[\mathrm{H}^{+}\right]$

$$
\text { 4c) }\left[\mathrm{HCO}_{3}^{-}\right]=\frac{\overline{\left[\mathrm{COO}_{3}^{-2}\right]\left[\mathrm{H}^{-}\right]}}{\mathrm{K}_{\mathrm{HCO}_{3}^{-}}^{-}}
$$


and $\mathrm{pH}$ at $25^{\circ} \mathrm{C}$ which were equivalent to anion concentrations and $\mathrm{pH}$ at $45^{\circ}$ to $65^{\circ} \mathrm{C}$. The data required to initiate this correction procedure were the $\mathrm{pH}$, alkalinity and temperature at which the $\mathrm{pH}$ and alkalinity were measured in the field. A pH of 10.1 was measured in the field at $45^{\circ} \mathrm{C}$ and anion concentrations were determined at this temperature.

Dissociation constants $(K)$ were determined as a function of temperature on the basis of thermodynamic data taken from Smith and Marte 11 (1976). A list of $K$ values are shown in Table 2-41. The $K$ values are measured at $25^{\circ} \mathrm{C}$ and extrapolated to $45^{\circ}$ and $65^{\circ} \mathrm{C}$ using the Gibbs-Helmholtz relationship

$$
\frac{d \log K}{d T}=\frac{\Delta H}{2.303 R T^{2}}
$$

or $\log K_{2}=\log K_{1}+H\left(T_{2}-T_{1}\right) 2.303 R T_{1} T_{2}$, where temperature $T_{1}=25^{\circ} \mathrm{C}$ and $K_{1}$ is the dissociation constant at $25^{\circ} \mathrm{C}$. The equilibrium constant $K_{2}$ is then calculated for $45^{\circ}$ and $65^{\circ} \mathrm{C}$.

TABLE 2-41. Equilibrium Constant Values Calculated as a Function of Temperature on the Basis of Thermodynamic Data.

(After Smith and Marte11, 1976.)

\begin{tabular}{|c|c|c|c|c|}
\hline \multirow{2}{*}{$-\log K_{j}$} & \multicolumn{3}{|c|}{ Temperature } & \multirow{2}{*}{$\mathrm{H}(\mathrm{Kcal} / \mathrm{mole}) * *$} \\
\hline & $25^{\circ} \mathrm{C}$ & $45^{\circ} \mathrm{C}$ & $65^{\circ} \mathrm{C}$ & \\
\hline $\mathrm{H}_{4} \mathrm{SiO}_{4}$ & 9.86 & 9.63 & 9.43 & 5.0 \\
\hline $\mathrm{HCO}_{3}^{-}$ & $10.33 \pm .01$ & 10.17 & 10.03 & 3.5 \\
\hline $\begin{array}{l}\mathrm{H}_{2} \mathrm{O} \\
\mathrm{pH}\end{array}$ & $\begin{array}{l}13.997 \pm .003 \\
10.26 *\end{array}$ & $\begin{array}{l}13.38 \\
10.10 \% *\end{array}$ & 12.84 & 13.34 \\
\hline
\end{tabular}

*Estimated pH assuming carbonate-bicarbonate buffer. **Measured in field. 
At $45^{\circ} \mathrm{C}$, the calculation of anion concentrations was straightforward since the dissociation constants and $\mathrm{pH}$ were known. However, at $25^{\circ} \mathrm{C}$ the calculation was complicated by the fact that $\mathrm{pH}$ was not measured. Consequently, there were two unknowns in Equation $3 c$ (see Table 2-40) and an estimate of $\mathrm{pH}$ at $25^{\circ} \mathrm{C}$ was made. A comparison of $\mathrm{pH}$ and $\mathrm{K}$ values at $45^{\circ} \mathrm{C}$ showed that $\mathrm{pH}(10.1)$ and $\mathrm{K}_{\mathrm{HCO}_{3}}{ }^{-}$(10.16) were essentially identical and suggested that $\mathrm{pH}$ is buffered by the carbonate bicarbonate equilibrium ( $\mathrm{Eq}$. 4a; Table 2-40). Assuming that pH was similarly buffered at $25^{\circ} \mathrm{C}$, an estimate of $\mathrm{pH}$ was derived by multiplying the $\mathrm{pH}$ to $\mathrm{K}_{\mathrm{HCO}_{3}}$-ratio at $45^{\circ} \mathrm{C}$ by $\mathrm{K}_{\mathrm{HCO}_{3}}{ }^{- \text {at }} 25^{\circ} \mathrm{C}$. This calculation yielded a pH of 10.26. Anion concentrations at $25^{\circ}$ and $45^{\circ} \mathrm{C}$ are listed in Table $2-42$.

The determination of anion concentrations and $\mathrm{pH}$ at $65^{\circ} \mathrm{C}$ was first calculated assuming that the carbonate-bicarbonate reaction was the primary pH buffer. An estimated pH of 9.92 (derived by assuming the ratio of $\mathrm{pH}$ to $\mathrm{K}_{\mathrm{HCO}_{3}}{ }^{-}$at $45^{\circ} \mathrm{C}$ was the same at $65^{\circ} \mathrm{C}$ ) generated an $\mathrm{OH}^{-}$concentration of 1.738 equivalents per million and an $\mathrm{H}_{3} \mathrm{SiO}_{4}^{-}$ concentration of 1.568 equivalents per million. The combined total of 3.306 equivalents per million was in excess of the total alkalinity (3.212). This lead to the impossible conclusion that negative amounts of $\mathrm{CO}_{3}{ }^{-2}$ and $\mathrm{HCO}_{3}^{-}$were in solution. In order to calculate positive amounts of $\mathrm{CO}_{3}^{-2}$ and $\mathrm{HCO}_{3}^{-}$, the $\mathrm{pH}$ had to be less than 9.9.

The implications from the results of these calculations are threefold: (1) $\mathrm{pH}$ at $65^{\circ} \mathrm{C}$ has an upper limit of 9.9 ; (2) the buffering capacity of the carbonate-bicarbonate reaction is reduced at $65^{\circ} \mathrm{C}$; and (3) another buffering reaction must be affecting the $\mathrm{pH}$. As discussed in Section 2.3, experimental evidence (Barnes and Scheetz, 1979) indicates that the dissociation of silicic acid is the primary $\mathrm{pH}$ buffer at $\geq 100^{\circ} \mathrm{C}$ resulting from the low carbon content and increasing dissoloved silica content with increased temperature. Consequent $7 y$, at $65^{\circ} \mathrm{C}, \mathrm{pH}$ may be buffered primarily by the dissociation of silicic acid or by a combination of carbonate-bicarbonate equilibrium and silicic acid dissociation. By assuming that the dissociation of silicic acid is the 
TABLE 2-42. Estimated Anionic Species Concentrations for Grande Ronde Groundwater.

\begin{tabular}{|c|c|c|c|c|}
\hline TOC & 25 & & 45 & \\
\hline Anionic Concentrations & $\mathrm{mg} / \mathrm{l}$ & epm* & $\mathrm{mg} / \mathrm{l}$ & epm \\
\hline $\mathrm{CO}_{3}^{-2}$ & 30 & 1.003 & 13 & .430 \\
\hline $\mathrm{HCO}_{3}^{-}$ & 36 & .589 & 15 & .247 \\
\hline $\mathrm{OH}^{-}$ & 3 & .182 & 9 & .525 \\
\hline $\mathrm{H}_{3} \mathrm{SiO}_{4}^{-}$ & 137 & 1.438 & 192 & 2.010 \\
\hline $\mathrm{Cl}^{-}$ & 148 & 4.174 & 148 & 4.174 \\
\hline $\mathrm{SO}_{4}^{-2}$ & 108 & 2.249 & 108 & 2.249 \\
\hline$F^{-}$ & 37 & 1.947 & 37 & 1.947 \\
\hline TOTAL epm = & & 11.582 & & \\
\hline Cation Concentrations & $\mathrm{mg} / \mathrm{l}$ & epm & $\mathrm{mig} / \mathrm{l}$ & epm \\
\hline $\mathrm{Na}^{+}$ & 250 & 10.875 & 250 & 10.875 \\
\hline$k^{+}$ & 1.9 & .049 & 1.9 & .049 \\
\hline $\mathrm{Ca}^{+2}$ & 1.3 & .065 & 1.3 & .065 \\
\hline $\mathrm{Mg}^{+2}$ & .04 & .033 & .04 & .033 \\
\hline $\mathrm{SiO}_{2}$ & 121 & & 121 & \\
\hline TOTAL epm = & & 11.022 & 11 & 11.022 \\
\hline
\end{tabular}


primary buffer, the lower limit can be placed on the estimated $\mathrm{pH}$ at $65^{\circ} \mathrm{C}$. The $\mathrm{K}_{\mathrm{H}_{4}} \mathrm{SiO}_{4}$ value at $65^{\circ} \mathrm{C}$ is 9.43. An estimate of $\mathrm{pH}$ can also be derived from the empirical relationship determined by Barnes and Scheetz (1979) as a result of hydrothermal experiments in the range $100^{\circ}$ to $300^{\circ} \mathrm{C}$ with simulated Hanford groundwater and Umtanum basalt. The formula is

$$
\mathrm{pH}=\frac{2,640}{\text { TOK }}+1.64
$$

which yields a pH of 9.45 at $65^{\circ} \mathrm{C}$. Thus, the pH of Grande Ronde groundwater is estimated to be in the range 9.4 to 9.9 .

\section{4 .7 Surmary}

The hydrautic properties of the major aquifer units beneath the Hanford Site are summarized in Table 2-43. The unconfined aquifer systems within the Hanford and Ringold Formations are generally characterized by the largest hydraulic conductivity values. Hydraulic conductivity values for most confined aquifer systems are frequently lower.

TABLE 2-43. Hydrautic Properties of the Aquifer Systems beneath the Hanford Site.

(After Gephart and Others, 1979b.)

\begin{tabular}{l|c|c|c}
\hline Aquifer & $\begin{array}{c}\text { Hydrauific } \\
\text { onductivity } \\
\text { (ft/day) }\end{array}$ & $\begin{array}{c}\text { Transmissivity } \\
\text { (ft/day) }\end{array}$ & $\begin{array}{c}\text { Storage } \\
\text { Coefficient }\end{array}$ \\
\hline Unconfined & $10^{-1}-2 \times 10^{3}$ & $2 \times 10^{3}-6 \times 10^{5}$ & $10^{-2}-10^{-1}$ \\
Saddle & $10-10^{2}$ & $8 \times 10-10^{3}$ & $5 \times 10^{-3}-1 \times 10^{-5}$ \\
Mountains & $2.3 \times 10^{-1 *}$ & -- & $6.3 \times 10^{-4}-4.8 \times 10^{-3}$ \\
Wanapum & $1.3 \times 10^{4}$ & - & $1 \times 10^{-6}-3 \times 10^{-3}$ \\
\hline
\end{tabular}

*Values include range from low- to high-density basalt. 


\section{RHO-BWI-ST-7}

The chemical properties of groundwater from the major aquifers beneath the Hanford Site are summarized in Table 2-44. The chemical analyses of groundwater samples to date indicate that two distinct types of groundwater exist. The first type is a calcium magnesium bicarbonate water which is found in the Saddle Mountains and upper Wanapum basalts. The second type is a sodium carbonate-bicarbonate which is found in the Grande Ronde Basalt. This water also distinguished from the Saddle Mountains groundwater by greater abundances of fluoride, chloride, and dissolved silica, and reduced carbon content. Although there is some question as to the correct carbonate and bicarbonate concentrations in the Grande Ronde groundwater, it is clear that at least two distinct groundwater types exist beneath the Hanford Site.

The Grande Ronde groundwater will have the greatest effect on the design and selection of materials for the multiple barrier system since the reference repository horizon is in this formation. In particular, the corrosive effects of the groundwater components on various metals at various temperatures must be considered. Fluoride, chloride, sulfate, and sulfide are species which are potential corrosive agents (see Section 2.7 on canister and overpack materials for a more detailed discussion). The groundwater will also come in contact with backfill materials and the alteration produced in the backfill and in the groundwater composition as a result of chemical interaction must be understood. The effects of chemical alteration on the designed functions of the backfill barrier (sorption, reaction, water exclusion) can then be analyzed and used as criteria in the selection process for primary backfill materials.

\subsection{REPOSITORY CONDITIONS}

The engineered barriers concept dictates that an interdependent system of physical and chemical barriers be constructed within a geologic nuclear waste repository to complement the natural barrier of the mass of rock between the repository and the biosphere. The design of a successful system of barriers requires a high level of understanding of the physical and chemical conditions which will exist in and around a repository throughout its lifetime. Parameters (i.e., those that do not 
RHO-BWI-ST-7

TABLE 2-44. Average Composition and Range in Concentration of Major Chemical Constituents within Groundwater for Formations beneath the Hanford Site.

(After Gephart and Others, 1979b.)

\begin{tabular}{|c|c|c|c|c|}
\hline Anions* & $\begin{array}{l}\text { Hanford and } \\
\text { Ringold Formations }\end{array}$ & $\begin{array}{l}\text { Lower Saddle } \\
\text { Mountains Basalt }\end{array}$ & $\begin{array}{l}\text { Upper Wanapum } \\
\text { Basalt }\end{array}$ & $\begin{array}{c}\text { Grande Ronde } \\
\text { Basalt }\end{array}$ \\
\hline $\mathrm{HCO}_{3}^{-}$ & $\left(56^{149}-314\right)$ & $\left(169^{217}-267\right)$ & $\left(141^{177}-216\right)$ & $\left(43^{66}-88\right)$ \\
\hline $\mathrm{CO}_{3}^{-2}$ & 0 & 0 & 0 & $\left(34^{52}-70\right)$ \\
\hline $\mathrm{Cl}-$ & $\left(2.7^{11}-32\right)$ & $\left(4.3^{20}-63\right)$ & $(3.8-15)$ & $\frac{131}{(98-148)}$ \\
\hline $\mathrm{SO}_{4}^{-2}$ & $\left(2.7^{43}-99\right)$ & $\begin{array}{c}04.0 \\
(0.3-18)\end{array}$ & $\left(0.2^{11}-32\right)$ & $\left(13^{72}-108\right)$ \\
\hline $\mathrm{NO}_{3}{ }^{-}$ & $\left(0.1^{27}-270\right)$ & $\begin{array}{l}<0.5 \\
(<0.5)\end{array}$ & $\left(0.1^{0.5}-2.7\right)$ & ND** \\
\hline$F^{-}$ & $(0.1-1.3)$ & $\left(0.1^{2.2}-8.0\right)$ & $\left(0.2^{0.7}-2.0\right)$ & $\left(21^{29}-37\right)$ \\
\hline \multicolumn{5}{|l|}{ Cations* } \\
\hline $\mathrm{Na}^{+}$ & $\left(29^{23}-64\right)$ & $\left(36^{83}-122\right)$ & $\left(17^{34}-80\right)$ & $(182-250)$ \\
\hline $\mathrm{k}^{+}$ & $\left(2.4^{6.2}-13\right)$ & $\left(7.7^{11}-14\right)$ & $\left(5.9^{11}-19\right)$ & $\left(1.9^{2.5}-3.3\right)$ \\
\hline $\mathrm{Ca}^{+2}$ & $\left(14^{41}-92\right)$ & $\left(0.5^{4.7}-22\right)$ & $\left(1.6^{17}-24\right)$ & $\left(0.8^{1.1}-1.3\right)$ \\
\hline $\mathrm{Mg}^{+2}$ & $(3.1-29)$ & $(1.8=12)$ & $\left(0.2^{8.8}-15\right)$ & $(0.0-2.0)$ \\
\hline $\mathrm{SiO}_{2}$ & $(8.8-50)$ & $\begin{array}{l}69 \\
(56-91)\end{array}$ & $\left(41^{57}-73\right)$ & $\begin{array}{c}117 \\
(115-121)\end{array}$ \\
\hline $\begin{array}{l}\text { Total } \\
\text { Dissolved } \\
\text { Solids }\end{array}$ & $\begin{array}{l}347 \\
(203-728)\end{array}$ & $\left(344^{413}-505\right)$ & $\left(283^{324}-435\right)$ & $\begin{array}{c}648 \\
(552-744)\end{array}$ \\
\hline
\end{tabular}

*Concentrations in $\mathrm{mg} / \mathrm{l}$.

**ND $=$ Not Detected. 
depend upon the amount of material present) such as the base rock temperature, pressure, Eh, and pH will control material stability, chemical reactions, and chemical transport in and around the repository. Therefore, knowledge of such parameters as a function of time is necessary for the proper selection of individual barrier materials, the design and experimental validation of barrier systems and their subsequent modeling. This section is an effort to bring together existing data relevant to physical and chemical conditions that would exist in a nuclear waste repository mined in the basalts beneath the Columbia Plateau. Because several basalt flows, whose depths vary as a function of position within the Pasco Basin, are under consideration as potential repository horizons, $1,000 \mathrm{~m}$ has been chosen as the hypothetical repository depth in the following discussion. The data and conciusions presented are preliminary and will be updated as studies of the basalts and engineered barriers development continue.

\subsubsection{Temperature}

Temperature is an important parameter which must be considered when defining the repository environment, because thermal energy is the primary driving force for chemical reaction and it exerts strong influence on aqueous transport rates. As well as being important, repository temperature is difficult to estimate because it is dependent upon the age, nature, and emplacement configuration of the nuclear waste. The presence of water, voids, or compositional heterogeneity in the rock will also affect repository temperature. Furthermore, the heating resulting from burial of nuclear waste is a consequence of the power generated by radioactive decay. Since the nuclides are continualiy decaying, the power output changes with time. Thus, the prevailing repository temperature is also a function of time.

Consider the earth, which, in some respects, is a natural analog for a radioactive waste repository. The earth's interior is comprised of rock housing small amounts of naturaily occurring radioisotopes (e.g., ${ }^{40} \mathrm{~K},{ }^{87} \mathrm{Rb},{ }^{235} \mathrm{U},{ }^{238} \mathrm{U}$ ). Decay of these isotopes resuits in a release of energy in the form of heat. Because heat tends to migrate 
toward cooler areas, heat flow from the earth's interior to the surface occurs. However, rock is not an efficient thermal conductor, so much of the heat is retained in the interior, giving rise to the so-called geothermal gradient. The actual value of the gradient varies depending on the thermal properties of the rock and the geologic environment. For areas without active igneous activity, this gradient commonly ranges from $20^{\circ}$ to $50^{\circ} \mathrm{C}$ per kilometer of depth (Miyashiro, 1973; Winkler, 1974).

The temperatures existing at depth have been measured directly in wells drilled on the Hanford Site. The data are plotted in Figure 2-25 and yield an estimated geothermal gradient of $\sim 45^{\circ} \mathrm{c} / \mathrm{km}$. This result is within the range of normal crustal gradients. Such data enable estimation of the baseline (i.e., unperturbed) repository temperature for any candidate horizon. At a depth of $1 \mathrm{~km}$, the conceptual depth of a repository at Hanford, the calculation is simple, involving only the multiplication of the gradient times the depth in kilometers and adding the result to the average surface temperature $\left(12^{\circ} \mathrm{C} ; \mathrm{B} 1\right.$ ackwe 11,1978$)$. Thus, at a depth of $1 \mathrm{~km}$, the estimated ambient temperature is $\sim 57^{\circ} \mathrm{C}$. However, it is likely that a mined repository will follow a specific horizon in the rock, and since the basalts of the Pasco Basin are not flat-lying, repository temperatures are bound to vary. Therefore, a reasonable estimate for the maximum temperature within the Umtanum flow is $60^{\circ}$ to $70^{\circ} \mathrm{C}$. This range represents the baseline repository temperature at Hanford. It can be applied in two ways: (1) as a starting reference point for temperature estimates during the thermal period; and (2) the long-term, "steady-state" repository condition that will prevail during geologic control.

Repository temperature estimates for the thermal period are calculated by adding the baseline temperature to the change in the rock temperature produced by radiogenic heating. The radiogenic heating is a function of the power output of waste per unit volume of repository and the thermal conductivity of the rock. This is necessarily a complex function because the power output of the waste changes as the nuclides decay and the efficiency of heat dissipation decreases as thermal resistance is accumulated. 
RHO-BWI-ST -7

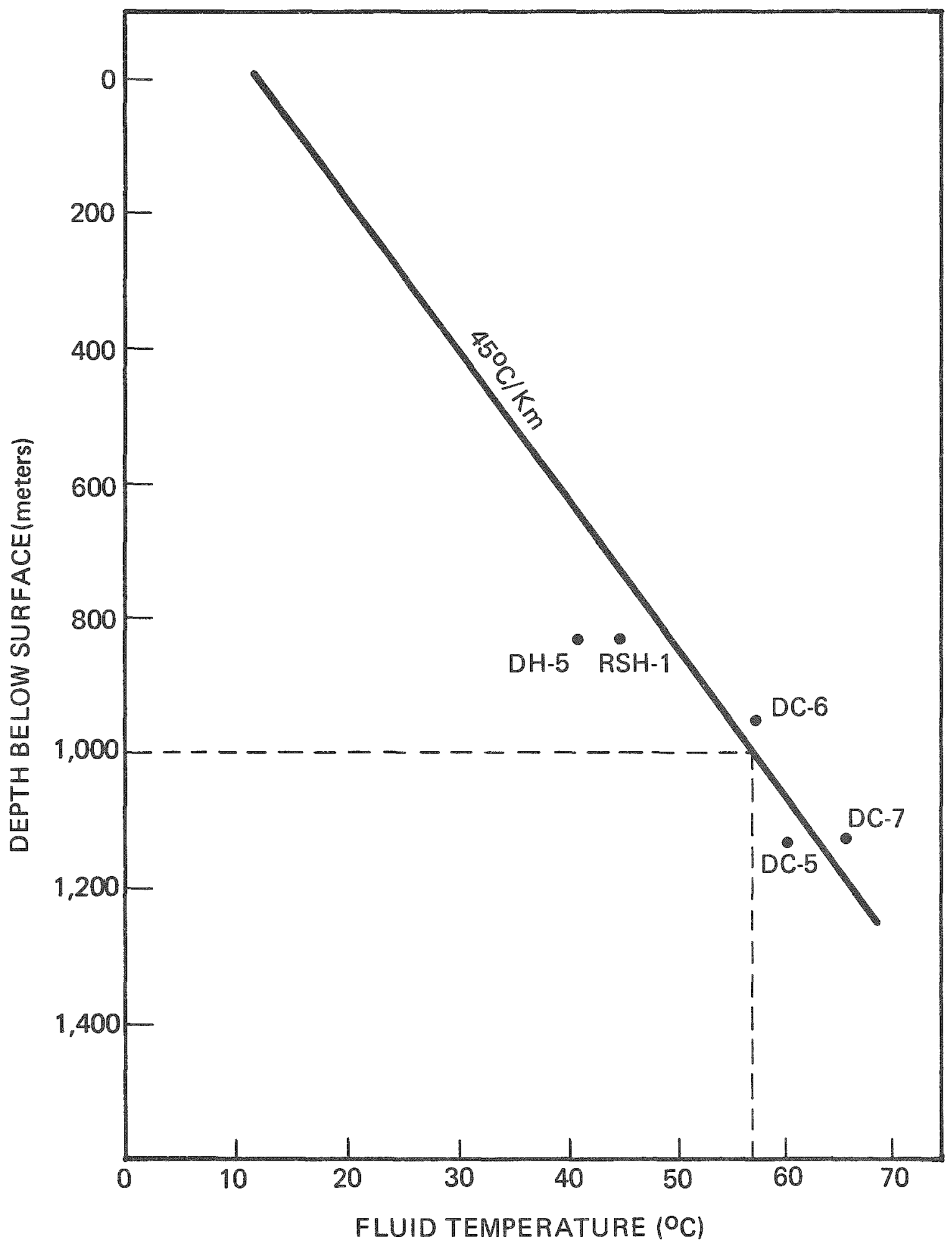

fhEB12/79-1

FIGURE 2-25. Measured Downhole Fluid Temperatures at the Center of the Umtanum Flow in Various Test Wells. 
The calculated thermal output of a container holding the equivalent of six spent fuel assemblies is illustrated in Figure 2-26. Prior to 400 years, most of the heat is produced by decay of energetic, short-lived radioisotopes (e.g., ${ }^{90} \mathrm{Sr},{ }^{90} \mathrm{Y},{ }^{106} \mathrm{Rh},{ }^{134} \mathrm{Cs},{ }^{135} \mathrm{Cs},{ }^{144} \mathrm{Pr}$ ). After 400 years the thermal output results largely from the long-lived actinide isotopes. From this discussion it is clear that the thermal output is directly dependent on whether spent fuel or reprocessed waste is buried. For instance, spent fuel contains a smaller proportion of short-lived isotopes, but is rich in actinides. Thus, its thermal profile will have a relatively small early pulse followed by a relatively large late pulse. In contrast, reprocessing waste is concentrated in fission products (e.g., strontium and cesium) and depleted in actinides. Thus, burial of reprocessing waste will result in a larger early pulse but a smaller late pulse.

The Basalt Waste Isolation Project is presentiy operating under the premise that spent fuel will be the waste form emplaced in a repository. Thermal model calculations for an average basalt have been performed with this in mind and with the additional assumptions of: (1) a spent fuel assembly ratio of $2: 1$ pressurized water to boiling water reactor; (2) a thermal loading of $25 \mathrm{~W} / \mathrm{m}^{2} ;$ (3) an ambient temperature of $55^{\circ} \mathrm{C}$ (Hardy and Hocking, 1978); and (4) a11 heat loss by conduction (i.e., dry conditions). The results of these calculations are illustrated in Figure 2-27 and reveal that even after 5,000 years post emplacement, temperatures wi 77 be in excess of $100^{\circ} \mathrm{C}$ hundreds of meters from the repository.

The continuous variation of temperature with time at three distances from the heat source is shown in Figure 2-28. Peak thermal temperatures are higher and occur earlier nearer to the package. The achievement of thermal maxima in less than 1,000 years is demonstrated in the figure only if the area proximate to the repository is considered. However, if the region more than $200 \mathrm{~m}$ above the repository is considered, the thermal maxima occur after 5,000 years. Two hundred meters is certainly within the "near-field environment;" thus the thermal period of repository history should probably be considered to last at least the 


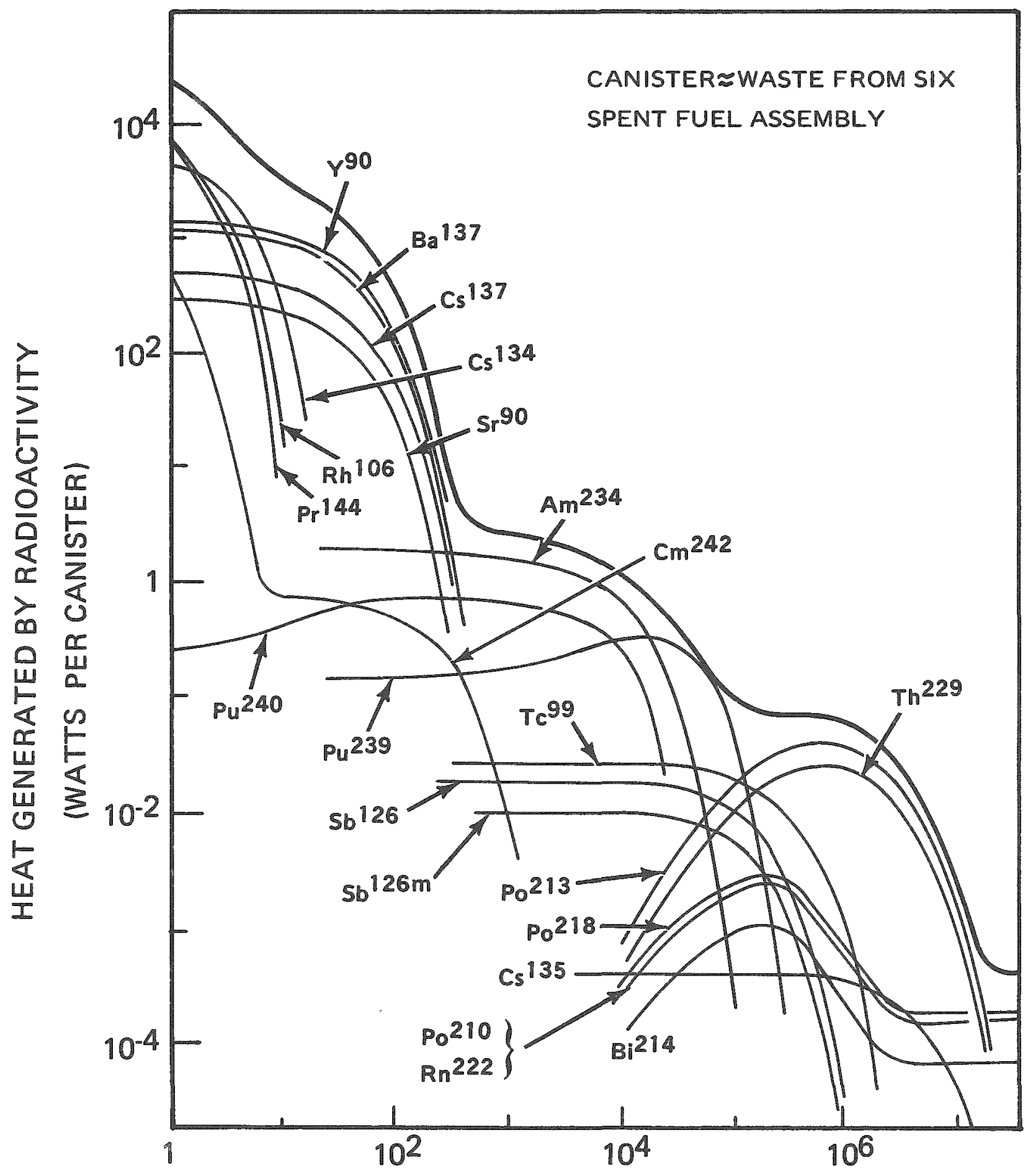

YEARS AFTER REMOVAL FROM REACTOR

FIGURE 2-26. Heat Production Profile for a Canister of Reprocessed Nuclear Waste and for Major Heat-Producing Isotopes within the Waste. Canister content is equivalent to approximately six spent fuel assembijes (after Cohen, 1977b). 


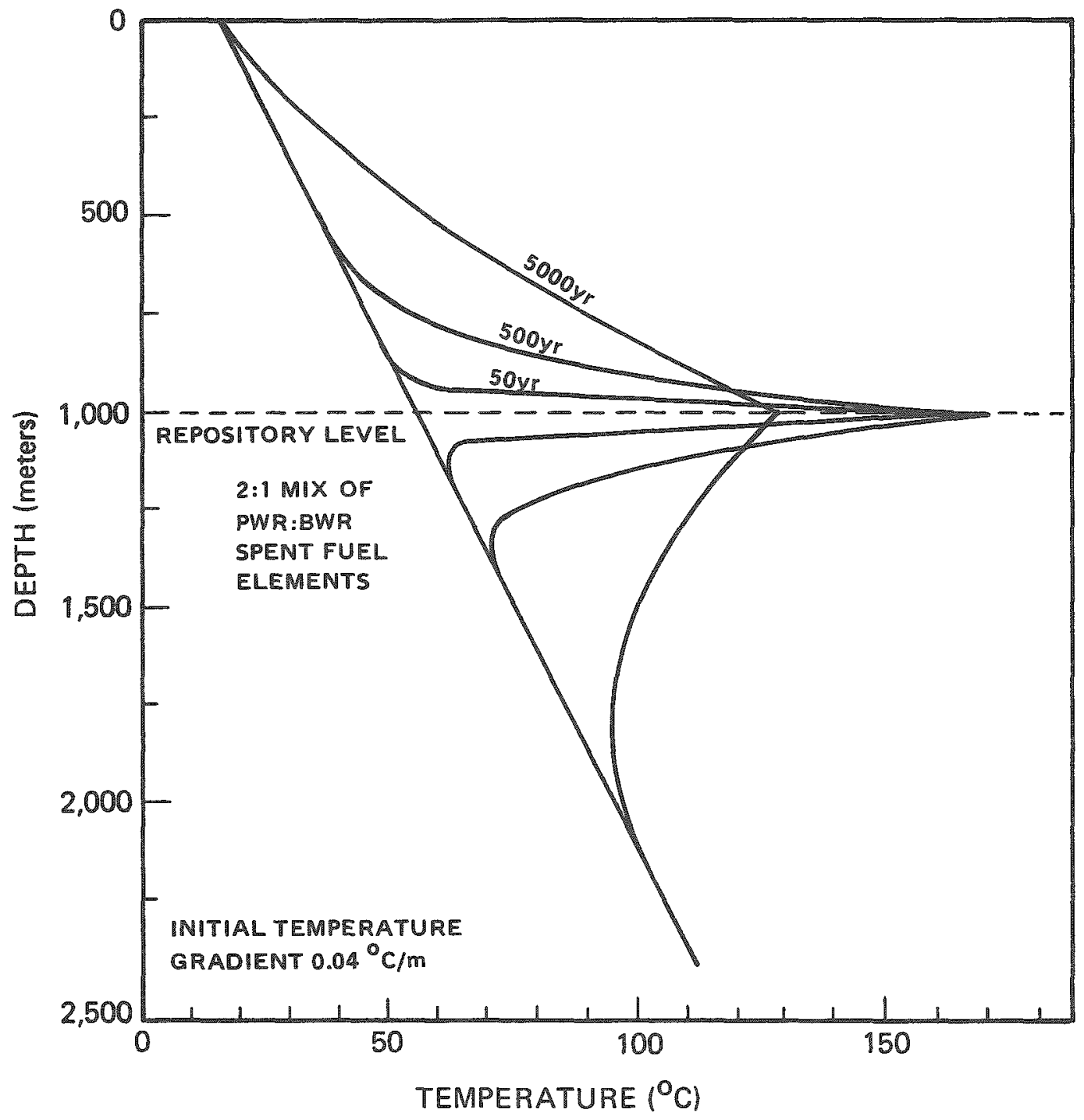

fhEB $12 / 79.5$

FIGURE 2-27. Temperature Profiles Resulting from Burial of a $2: 1$ Mixture of 10-Year-0Id Pressurized Water Reactor and Boiling Water Reactor Spent Fuel Elements at a Depth of $1,000 \mathrm{~m}$ in the Columbia River Basalts. Profiles are indicated for 50, 500, and 5,000 years after burial (after Hardy and Hocking, 1978). 


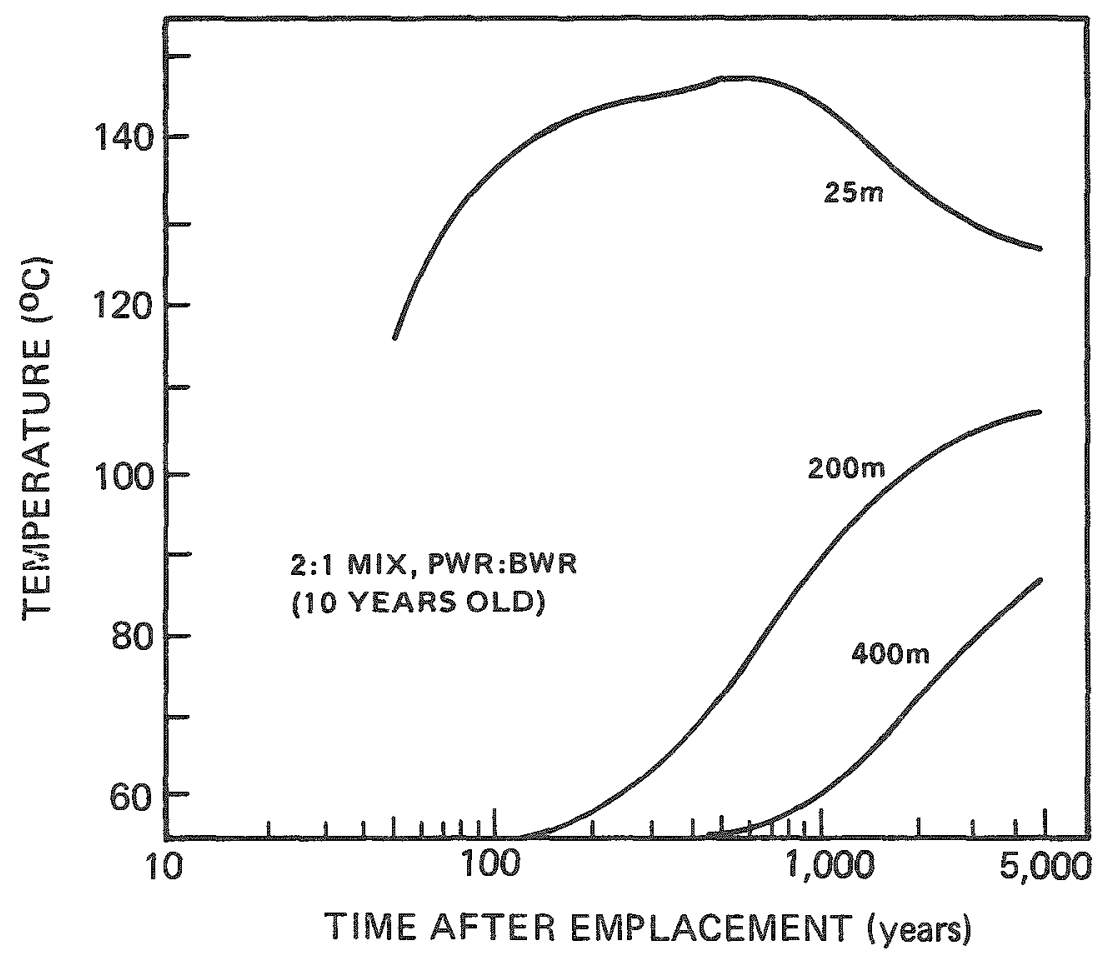

FIGURE 2-28. Temperatures above the Repository as a Function of Time, after the Emplacement of a 2:1 Mixture of 10-Year-01d Pressurized Water Reactor and Boiling Water Reactor Spent Fue 1 Elements (after Hardy and Hocking, 1978).

first 5,000 years following emplacement. The highest calculated temperature during this time period occurs approximately 25 years after emp lacement when a temperature near $270^{\circ} \mathrm{C}$ is reached at the packagerock interface. Therefore, a useful temperature range to consider over all repository history is $60^{\circ}$ to $300^{\circ} \mathrm{C}$.

\subsubsection{Pressure}

Two types of pressure, lithostatic and hydrostatic, are important to discussions of pressure within the earth. Lithostatic pressure at a point within the earth is simply the pressure resulting from the weight 
of the overiying column of rock. Hydrostatic pressure at a point within the earth is the pressure that would exist at the bottom of a body of water with a depth equal to the thickness of the overlying rock column. The difference between lithostatic and hydrostatic pressure is a result of the different densities of rock $\left(0.3 .0 \mathrm{gm} / \mathrm{cm}^{3}\right.$ for basalt) and water $\left(21.0 \mathrm{gm} / \mathrm{cm}^{3}\right)$. The pressure transmitted from grain to grain within a rock is generally equal to the lithostatic pressure. Significant deviations from lithostatic pressure are usually a product of directed stresses and result in deformation of the rock. If a fluid phase (i.e., water) is present within the rock, the pressure within the fluid phase may take any value between the lithostatic and hydrostatic pressures. If the fluid phase is sealed within the rock, the pressure on the fluid will equal the pressure on the rock, usually lithostatic (Fig. 2-29a). If the fluid phase is not sealed within the rock and is in communication with the earth's surface, the pressure within the fluid phase will equal the hydrostatic pressure (Fig. 2-29b). If the fluid phase is not sealed within the rock and is in communication with a higher reservoir rather than the earth's surface, the pressure on the fluid phase will equal the lithostatic pressure on the upper reservoir plus the pressure resulting from the water column leading to the upper reservoir (Figure 2-29c). In this latter case the pressure on the fluid phase will be intermediate between the lithostatic and hydrostatic pressures.

Hydrostatic and lithostatic pressures within a repository mined from basalt at a depth of $1,000 \mathrm{~m}$ are easily calculated from the equation $P=\rho g h(P=$ pressure, $\rho=$ density, $g=$ acceleration due to gravity, $h=$ depth). Assuming a density of $3.0 \mathrm{gm} / \mathrm{cm}^{3}$ for basalt, the lithostatic pressure at a repository depth of $1,000 \mathrm{~m}$ would be approximately 300 bars. The hydrostatic pressure at the same depth would be approximately 100 bars.

Long-term equilibrium pressures within a geologic repository will be of the type described above; however, short-term pressures within the repository will depart considerably from equilibrium. The direction and magnitude of deviations from equilibrium pressures will depend upon the 

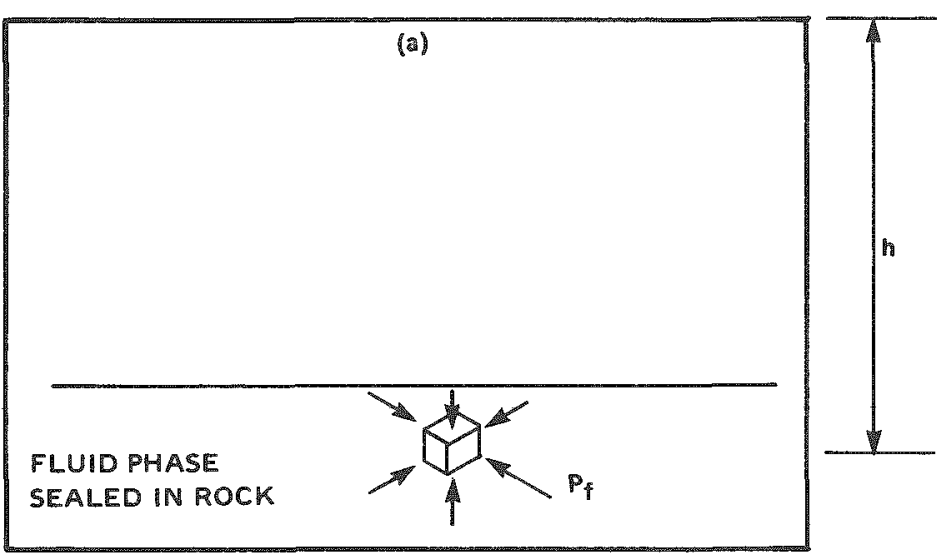

PRESSURE $P_{f}$ ON THE FLUID PHASE IS RESULT OF WEIGHT OF OVERLYING COLUMN OF ROCK OF HEIGHT $h$ (lithostatic) $\left(P_{f}=P_{R} g^{g h}=P_{L}\right)$
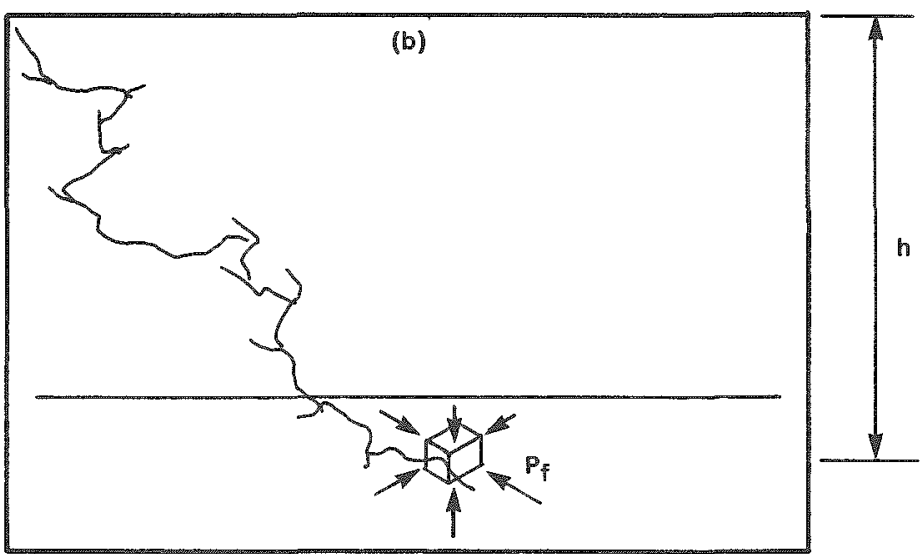

SURFACE

PRESSURE Pf ON FLUID PHASE IS RESULT OF WATER BETWEEN ROCK AND SURFACE AND IS EQUAL TO PRESSURE $\rho_{H}$ CAUSED BY WATER COLUMN OF HEIGHT $h$. (hydrostatic) $\left(P_{f}=P_{H_{2}} O^{g h}=P_{H}\right)$
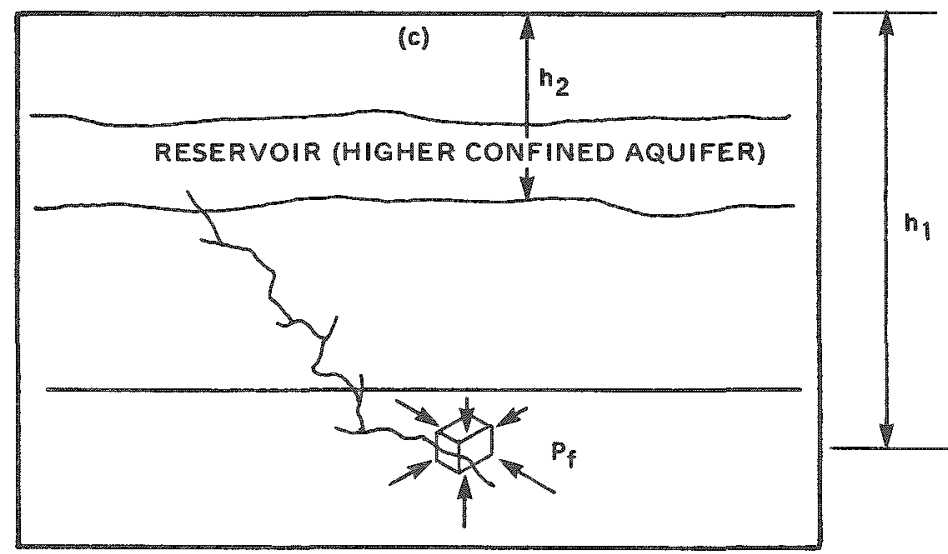

SURFACE

PRESSURE P, ON FLUID PHASE IS RESULT OF PRESSURE CAUSED BY ROCK COLUMN $h_{2}$ PLUS PRESSURE RESULTING FROM WEIGHT OF WATER BETWEEN $h_{2}$ AND $h_{1}$. $P_{f}=\rho_{\mathrm{Agh}}+\rho_{\mathrm{H}_{2}} \mathrm{O} g\left(\mathrm{~h}_{1} \cdot \mathrm{h}_{2}\right)$ $\mathrm{P}_{\mathrm{L}_{\mathrm{S}}}>\mathrm{P}_{\mathrm{f}}>\mathrm{P}_{\mathrm{H}}$

FIGURE 2-29. Schematic IlTustration of Different Types of Potential Repository Pressures and Their Relationships. $P_{f}=$ pressure on fluid phase: $P_{L}=1$ ithostatic pressure: $P_{H}=$ hydrostatic pressure; $P R=$ rock density: $\mathrm{OH}_{2} \mathrm{O}$ = density of water; $\mathrm{g}=$ acceleration due to gravity. 
materials and techniques used in the backfilling of the repository. The long-term approach to equilibrium is controlled by the solid-state flow or creep of the basalt.

The pressure within the repository prior to backfilling and closure will be 1 atmosphere plus the weight of the column of air between sea level and repository depth, a result insignificantly different from 1 atmosphere. After backfilling and sealing of the repository, two different pressure scenarios must be considered, one with non-expanding backfill and the second with expanding backfill. The pressure on solids and any fluid (water or air) trapped in voids or pore spaces immediately after backfilling will be essentially 1 atmosphere in eicher case. In the first case, where the repository is backfilled with non-expanding material, pressure buildup within the repository will be controlled principally by movement of water into the repository from the surrounding rock. Water entering the repository would fill intergranular voids and eventually raise repository fluid pressure to the fluid pressure that exists in the surrounding rock. This final pressure would probably be slightly above normal hydrostatic pressure because the deep aquifers beneath the Hanford Site tend to be confined, artesian systems (Gephart and others, 1979b).

This scenario could be complicated if water were to come in contact with hot canisters or heated material adjacent to canisters and form steam before the pressure has risen sufficiently to block its formation. At temperatures as high as $300^{\circ} \mathrm{C}$ the vapor pressure of water is oniy 86 bars (Fig. 2-30), considerably less than the hydrostatic pressure, thus, steam should not be capable of displacing water from the surrounding rock and escaping from the repository. In the event of steam formation within a sealed repository, pressure would rise rapidly to the liquid-vapor divariant curve and remain on that curve until the continued influx of water into the repository raised the pressure into the liquid field. The pressure buildup should also be aided somewhat by the expansive alteration of crushed basalt within the backfi11. The hydrothermal alteration of basalt will produce clays that occupy a volume considerably 
RHO-BWI-ST-7

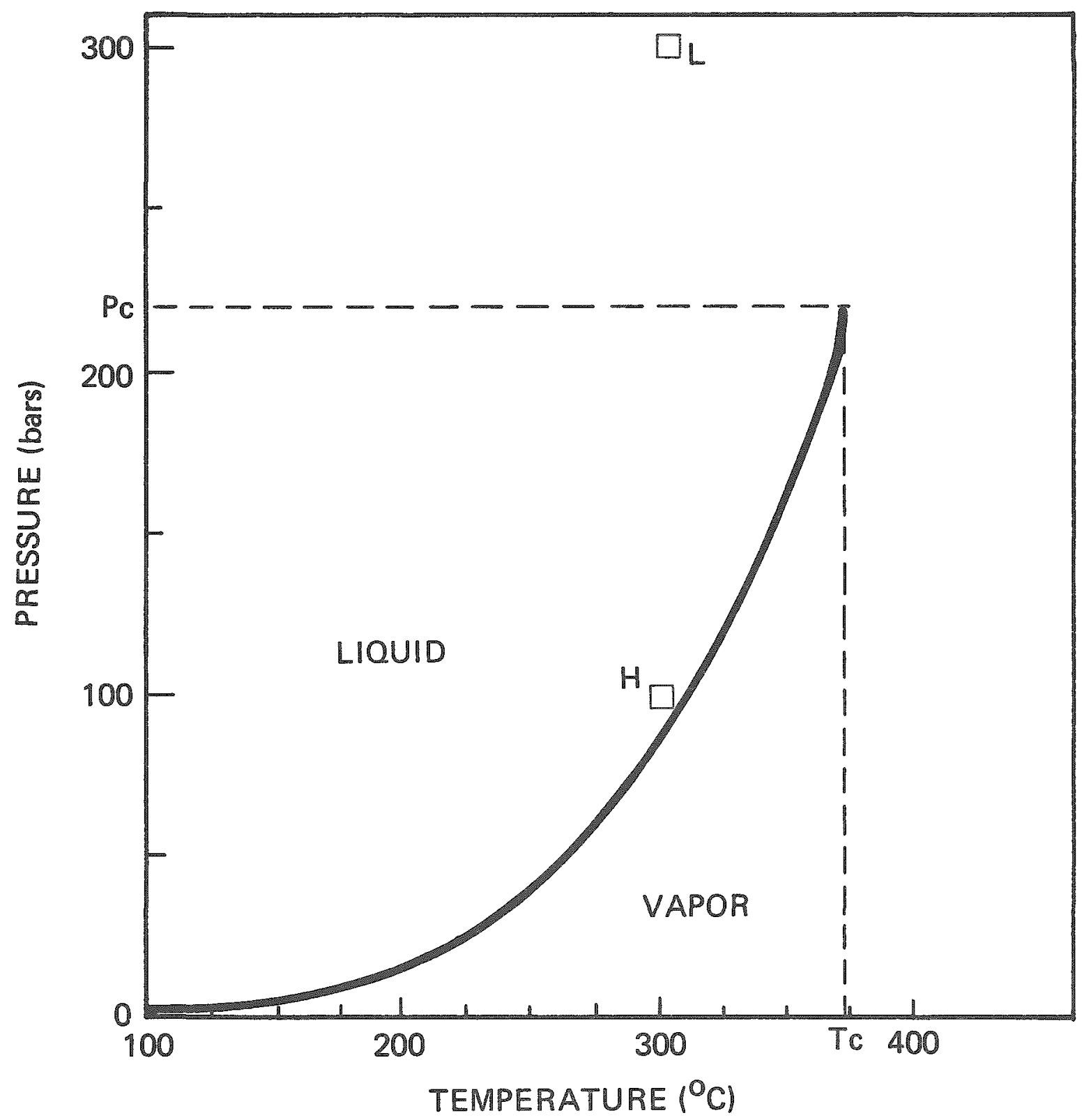

fhEB12/79-6

FIGURE 2-30. Divariant Curve (Liquid-Vapor) for Water $\left(\mathrm{H}_{2} \mathrm{O}\right)$. $P_{c}$ and $T_{c}$ are the critical pressure and the critical temperature. The squares marked $H$ and $L$ indicate the relative positions of hydrostatic pressure $(\mathrm{H})$ and lithostatic pressure $(\mathrm{L})$ at a repository temperature of $300^{\circ} \mathrm{C}$. 
greater than the original basalt. However, reaction kinetics for the alteration of basait are not well known and the rate of reaction will depend to a large degree upon the percentage of glass in the basalt used for backfill. Thus, the degree to which basalt backfill alteration will facilitate the return to pressures cannot be quantitatively evaluated at this time. Two other effects which may be important are the hydrothermal alteration and thermal expansion of basalt adjacent to the repository. Both effects should produce expansion of wall rock into the repository volume and thus work to increase pressure within the repository toward the lithostatic value.

In the second case, in which the repository is backfilled with a mixture in which expanding clay (e.g., bentonite) is a major component, the pressure history within the repository will be dominated by the expansion of the clays. Expansive clays (those belonging to the smectite or montmorillonite clay group) are characterized by their ability to reversibly gain or lose water, resulting in expansion or shrinkage. Water gain or loss at temperatures below $100^{\circ} \mathrm{C}$ involves water loosely bound to the surfaces of the clay particles. Water gain or loss at temperatures between $100^{\circ}$ and $200^{\circ} \mathrm{C}$ involves water loosely bound between the silicate sheets of the clay structure. Differential thermal analysis curves (Deer and others, 1967) for several clays clearly showing the thermal events associated with the loss of interlayer water between $100^{\circ}$ and $200^{\circ} \mathrm{C}$ are shown in Figure 2-31. The data indicate that several bonding sites are involved and that the temperatures at which water losses occur are functions of the chemical composition of the clay. Irreversible loss of water from smectite clays does not occur at temperatures below $300^{\circ} \mathrm{C}$ (Deer and others, 1967). If expanding clay within the backfill has been partiy or completely dehydrated (reversible water on $1 y$ ) prior to emplacement, it will react with any water entering the repository. The resultant expansion will result in a rapid pressure increase within the repository. If sufficient water and clay are available, the expansion should continue until the pressure on the clay is equal to the lithostatic pressure. In addition, because of the low permeability of well-compacted clay, communication between water 
contained in the backfill and water in the surrounding rock will be poor. It is apparent from Figure 2-31, the phase diagram for water in the region of interest, that hydrostatic pressure (100 bars) at 1,000 $\mathrm{m}$ is quite sufficient to keep water in the liquid state at temperatures as high as $300^{\circ} \mathrm{C}$. It should be pointed out that the dehydration temperatures reported for clays are 111 for 1 atmosphere of pressure and must be considerabiy higher at elevated pressures. Furthermore, even if temperatures immediately adjacent to the canisters are high enough to prevent rehydration of the clays, expansion of clays in the cooler portions of the backfill should keep the pressure well within the range of liquid water.

\subsubsection{Eh and $\mathrm{pH}$}

Eh and pH are the two dominant intensive variables in aqueous solutions, where they control both the stability and solubility of solid species and the form taken by species in solution. They are not completely independent, however, and in consideration of stability in aqueous solutions they must be considered together. In the following sections, $\mathrm{pH}$ is considered first because it can be measured directly with reasonable accuracy. Eh is considered next because its value must be inferred from a model that is $\mathrm{pH}$ dependent.

2.5.3.1 $\mathrm{pH}$. $\mathrm{pH}$ is a measure of the activity of hydrogen ions in solution and is defined as the negative logarithm of the hydrogen ion activity, which in dilute solutions is essentially equal to the hydrogen ion concentration. Because of the definition (negative logarithm), low values of $\mathrm{pH}$ correspond to acidic solutions and high values to alkaline solutions. At room temperature $\left(25^{\circ} \mathrm{C}\right)$ a pH of 7 corresponds to neutrality: however, at higher temperatures the neutral point shifts to lower values because of shifts in the ionization constant of water. At $200^{\circ} \mathrm{C}$, for instance, neutrality corresponds to a pH of approximately 6.5 .

Measurements of the pH of groundwaters sampled from the Grande Ronde Formation (Gephart and Others, 1979b) indicate that the pH at $45^{\circ} \mathrm{C}$ is approximately 10.1. Extrapolation of the $\mathrm{pH}$ to higher temperatures indicates that the $\mathrm{pH}$ at $65^{\circ} \mathrm{C}$ is between 9.4 and 9.9 (see Section 2.4.6). The high $\mathrm{PH}$ values found in the Grande Ronde groundwaters are 
RHO-BWI-ST-7

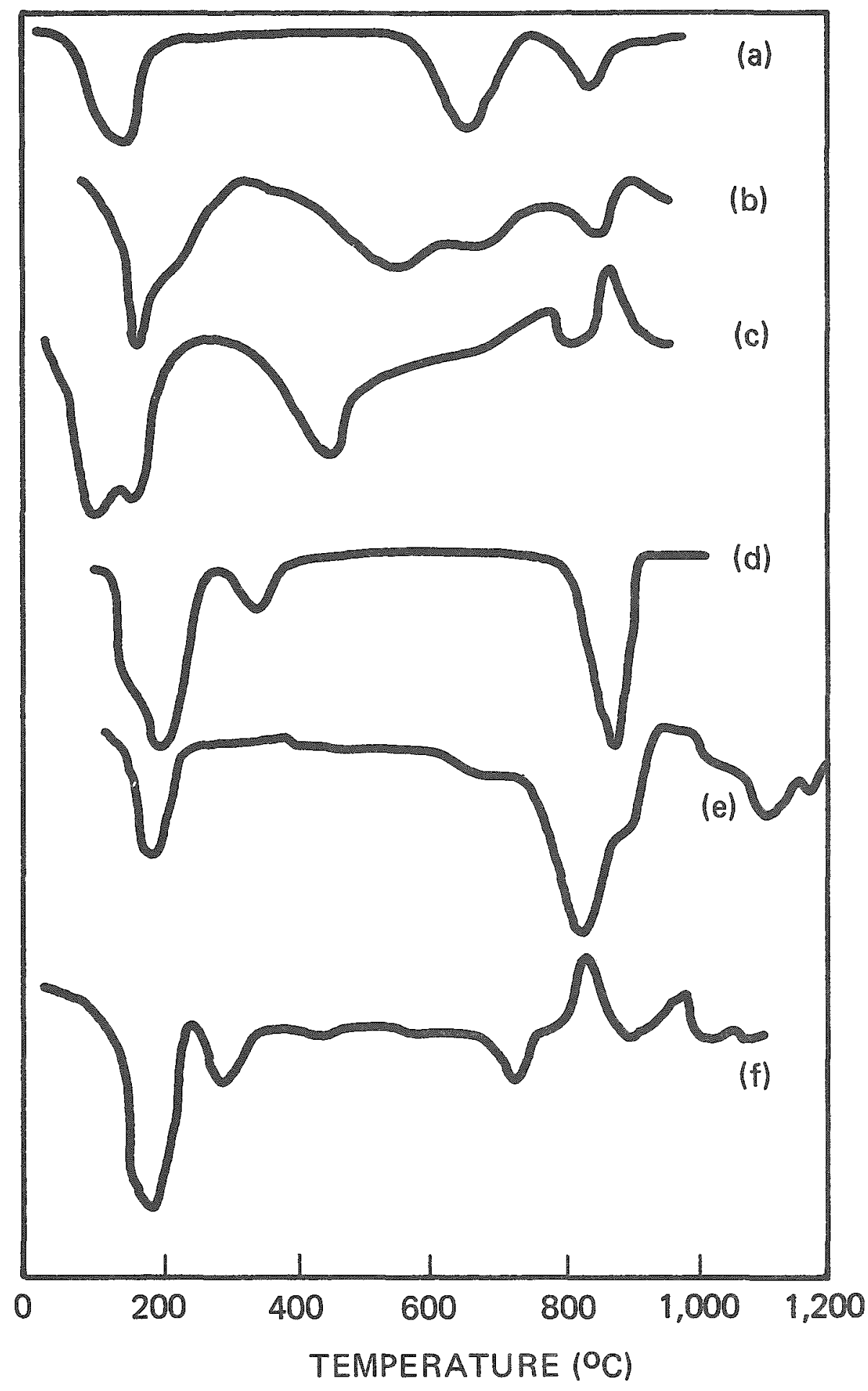

fh EB $1 / 80$

FIGURE 2-31. Illustration of Differential Thermal Analysis Curves for Some Smectites. (a) Montmorillonite, Santa Rita, New Mexico (b) Beide17ite, Beide 11, Colorado (c) Nontronite ("chioropai"), Hungary (d) Saponite, Krugersdorp, Transvaal (e) Hectorite, California (f) Sauconite, Coon Hollow Mine, Arkansas (after Deer and Others, 1967). 
consistent with groundwater isolated from the atmosphere and in contact with silicates and/or carbonates where hydrolysis reactions result in a high pH (Krauskopf, 1967).

Consider, for instance, hydrolysis of the albite component of plagioclase, a mineral contained in basalt. Albite plus water generates the clay, kaolinite, plus sodium hydroxide plus silicic acid.

$\mathrm{NaATSi}_{3} \mathrm{O}_{8}+22 \mathrm{H}_{2} \mathrm{O}=\mathrm{Al}_{4} \mathrm{Si}_{4} \mathrm{O}_{10}(\mathrm{OH})_{8}+4 \mathrm{Na}^{+}+4 \mathrm{HH}^{-}+8 \mathrm{H}_{4} \mathrm{SiO}_{4}$
(albite) + (water) $=$ (kaolinite) + (sodium hydroxide) + (silicic acid)

The product silicic acid dissociates, forming hydrogen ions, and yields a solution $\mathrm{pH}$ which is about 9.4 at $65^{\circ} \mathrm{C}$.

$\mathrm{H}_{4} \mathrm{SiO}_{4}=\mathrm{H}^{+}+\mathrm{H}_{3} \mathrm{SiO}_{4}^{-} ; \mathrm{Ka}=9.43$ at $65^{\circ} \mathrm{C}$ (Smith and Marte11, 1976)

The Hanford groundwater is saturated with respect to silica (Gephart and Others, 1979b) and is depleted in other dissolved solids. The combined result is a groundwater with a pH controlled (i.e., buffered) largely by dissociation of silicic acid.

The pH range appropriate to tests simulating ambient repository conditions is 9.4 to 9.9. However, this pH range will shift downward when the natural geotherm is perturbed by burial of nuclear waste.

At elevated temperatures, two processes affect pH: precipitation of clay from solution; and hydrolysis of silicates. Precipitation of clay occurs as the groundwater is heated and results in a decrease in $\mathrm{pH}$ because of consumption of $\mathrm{OH}^{-}$and generation $\mathrm{H}^{+}$. On the other hand, hydrolysis of silicates involves the production of clay by solid-liquid reaction. In contrast to precipitation, the hydrolysis reaction causes a rise in $\mathrm{pH}$ (Krauskopf, 1967). To gain a clearer understanding of the difference between these two processes, consider the reactions below.

$$
\begin{aligned}
& 6 \mathrm{Mg}^{+2}+8 \mathrm{SiO}_{2}+10(\mathrm{OH})^{-}=\mathrm{Mg}_{6} \mathrm{Si}_{8} \mathrm{O}_{20}(\mathrm{OH})_{4}+2 \mathrm{H}_{2} \mathrm{O}+2 \mathrm{H}^{+} \\
& \text {(dissolved components) }=\text { (smectite } \mathrm{clay})+ \text { (water) }+ \text { (hydrogen ion) } \\
& 4 \mathrm{NaATSi}_{3} \mathrm{O}_{8}+6 \mathrm{H}_{2} \mathrm{O}=\mathrm{Al}_{4} \mathrm{Si}_{4} \mathrm{O}_{10}(\mathrm{OH})_{8}+8 \mathrm{SiO}_{2}+(4 \mathrm{Na})^{+}+4(\mathrm{OH})^{-} \\
& \text {(albite) }+ \text { (water) }=\text { (kaolinite clay) }+ \text { (dissolved solids) }+ \text { (hydroxide) }
\end{aligned}
$$


Equation 3 involves the direct precipitation of clay from groundwater. This reaction consumes hydroxide, leaving an excess of hydrogen ion and resulting in a decrease in $\mathrm{pH}$.

Equation 4 is another form of Equation 1 and describes the hydrolysis of silicate. In natural basalt, glass is the most reactive phase and would likely contribute most to elevation of $\mathrm{pH}$. However, glass is non-crystalline with a variable stoichiometry, therefore any illustrative example using glass as a reactant is unnecessarily confusing. For increased clarity, Equation 4 is written as the hydrolysis of albite. The equation shows that reaction of water and silicates to yield clay will produce $\mathrm{OH}^{-\infty}$ ions (equivalent to consuming $\mathrm{H}^{+}$ions). The result is a decrease in hydrogen ion activity and consequent rise in groundwater pH.

Precipitation and hydrolysis may occur simultaneously. The two reactions occur at different rates and have opposite effects. Therefore, the combined result is a complex variation of groundwater $\mathrm{pH}$ with time. The trend commonly observed during hydrothermal experiments reacting "natura 1" waters with basalt is shown in Figure 2-32. Early pH depression results from precipitation of clay from the heated water. This reaction is favored kinetically and precedes reaction of the silicate and groundwater. Later, precipitation slows and the dominant effect is produced by the hydrolysis reaction. The characteristic result is rise of groundwater $\mathrm{pH}$ with an asymptotic approach to steady state.

It is important to note that the extent of $\mathrm{pH}$ depression is dependent on temperature, water composition, and the water:solid ratio. Some of these relations are depicted in Figure $3-32$. Note that minimum pH is produced when the water:solid ratio is infinite (1ower curve). Also, note that waters with abundant dissolved salts (e.g., seawater) enhance pH depression over solutions of low ionic strength (e.g., Hanford groundwater). This effect is great enough to overwhelm the results of increased temperature. For instance, $\mathrm{PH}$ depressions observed using Hanford groundwater are less exteme at $500^{\circ} \mathrm{C}$ than those produced in similar experiments at $200^{\circ} \mathrm{C}$ using seawater. 


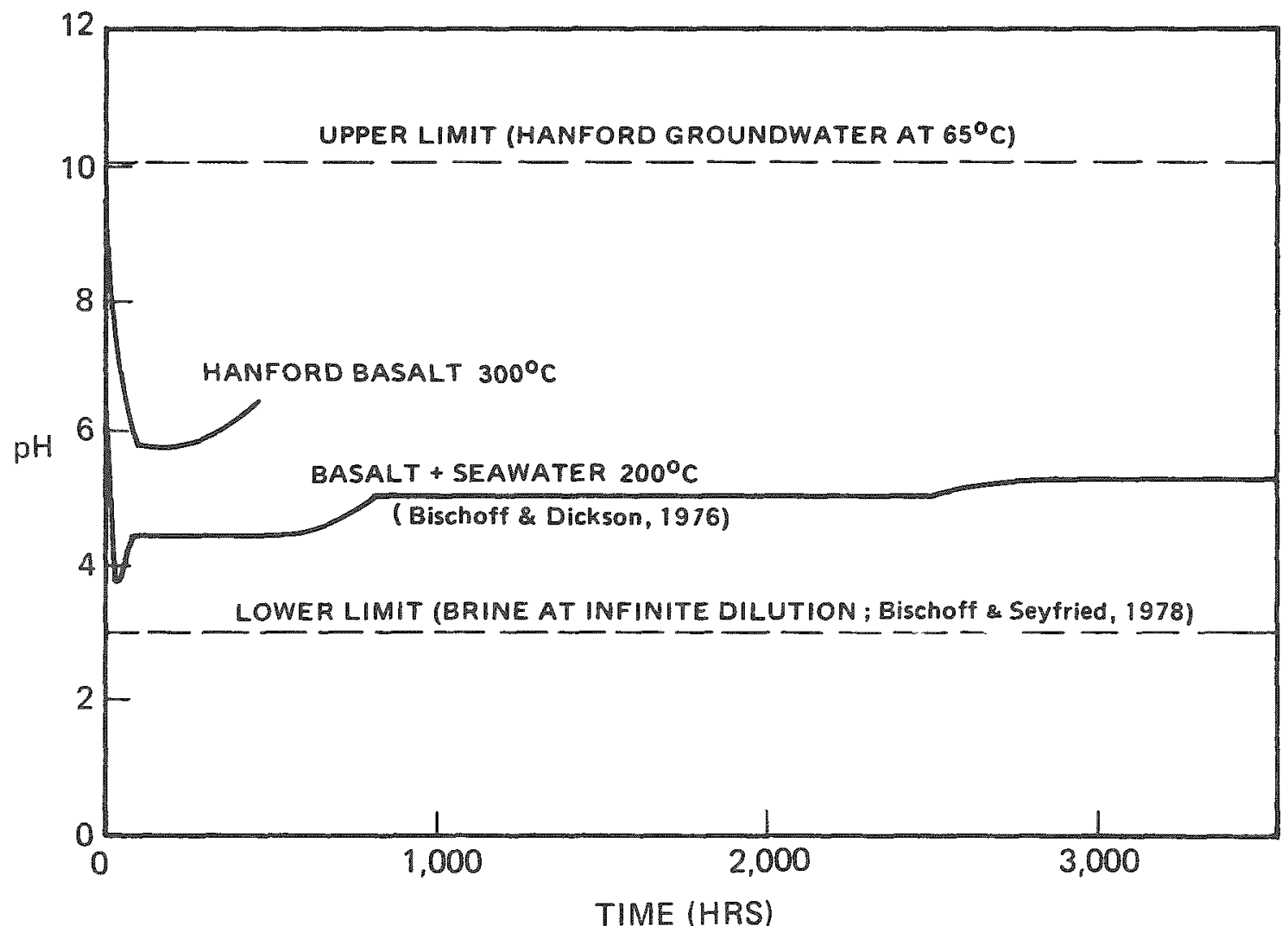

FIGURE 2-32. Variation Trend of Solution pH as a Function of Time.

Increased temperature and water:solid ratios also decrease $\mathrm{pH}$. At elevated temperatures precipitation of clay is enhanced and $\mathrm{pH}$ depression is increased. Similarly, at high water:rock ratios, processes which occur predominately in the liquid phase prevail over processes requiring both solid and liquid. Thus, at high water:rock ratios, $\mathrm{pH}$ depression is increased. At low water: rock ratios, solid-liquid reactions control pH. In these cases, pH depression is minimized (or not observed) and steady state is rapidly approached. The experimentally determined variation of equilibrium $\mathrm{pH}$ with temperature for low water:rock ratio is shown in Figure 2-33. The linear trend is a good match with the trend calculated for silicic acid dissociation. 
Figure 2-34 extrapolates the experimental trend to lower temperatures and compares the result with measurements made directly in wells on the Hanford Site. The good correspondence confirms that Hanford groundwater pH is controlled by dissociation of silicic acid. Furthermore, repository groundwater $\mathrm{pH}$ will continue to be controlled by the silicic acid buffer even during the thermal period. The linear trend, as determined experimentally, allows prediction of steady-state groundwater pH from the equation:

$$
\mathrm{pH}=\frac{2,640}{T^{0} \mathrm{~K}}+1.64 .
$$

This calculation will yield a reliable estimate of repository groundwater $\mathrm{pH}$ when groundwater flow rates are low and the effective water:rock ratio is small.

In summary, ambient geologic pH is controlled largely by dissociation of silicic acid and is in the range 9.4 to 9.9. This range is applicable to a repository environment during the period of geologic control. Heated groundwater changes the $\mathrm{pH}$, depending on temperature and the water: rock ratio. In stagnant or slowly flowing environments the $\mathrm{pH}$ at any temperature can be estimated from Equation 5. In free-flowing systems (i.e., high water:rock ratio), pH will be below that calculated from Equation 5. The minimum $\mathrm{pH}$ that can occur in a repository at Hanford will be no lower than 3 (see Fig. 2-32). It is expected that future experimentation will result in upward revision of this estimate because it is based on seawater/basalt relations.

2.5.3.2 Eh. Eh is a measure of the electric potential (volts) necessary to cause oxidation or reduction of a material. Consequently, the prevailing Eh of a system can be used to determine the stable oxidation state of polyvalent elements. 
RHO-BWI -ST -7

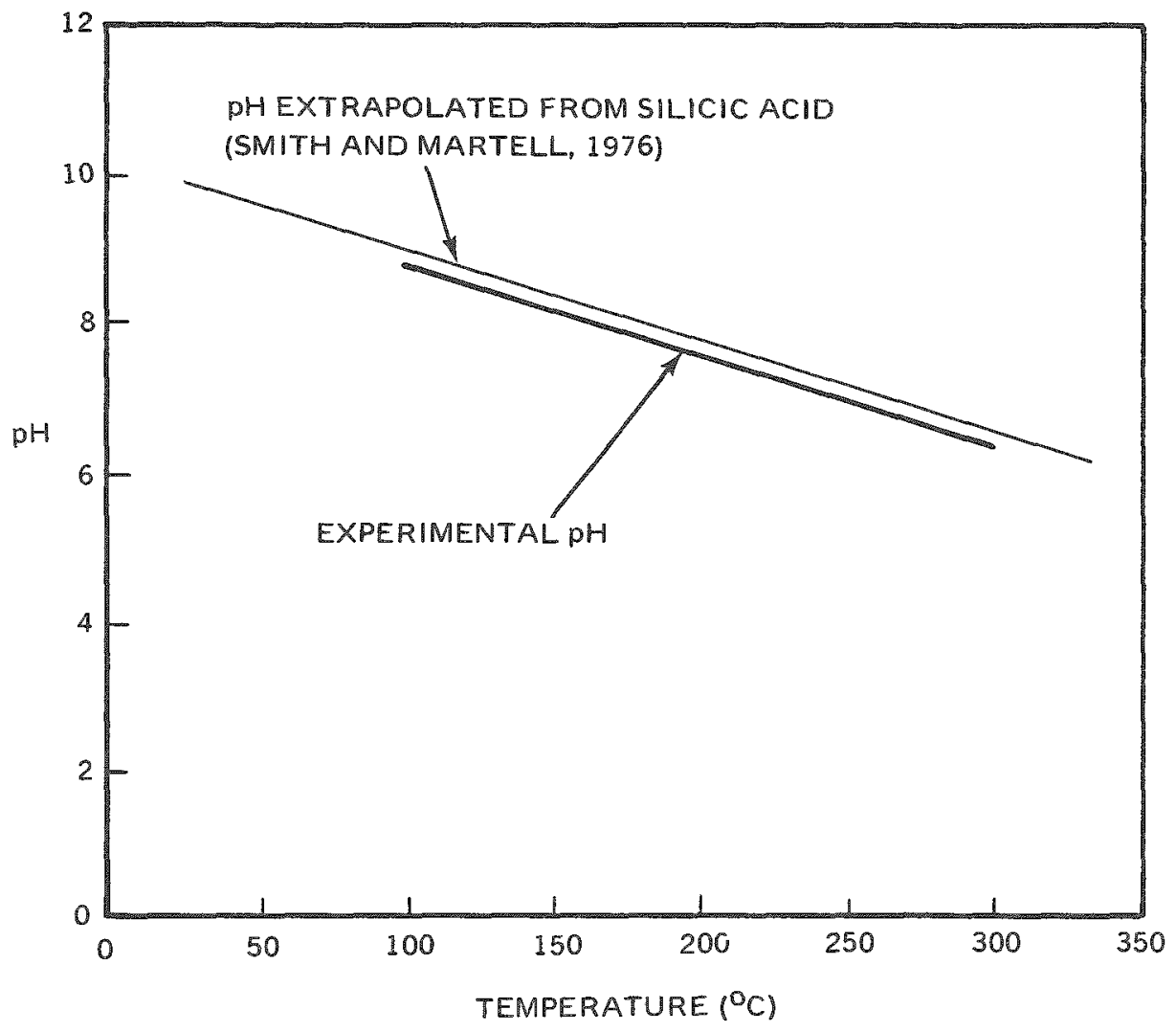

FIGURE 2-33. Control of Hydrothermal Groundwater pH by Silicic Acid.

Eh is generally applied to aqueous systems and is therefore constrained by the oxidation-reduction relations of water:

$$
\begin{array}{cc}
2 \mathrm{H}_{2} \mathrm{O}=\mathrm{O}_{2}+4 \mathrm{H}^{+}+4 \mathrm{e}^{-} & \text {(oxidation) } \\
2 \mathrm{H}^{+}+2 \mathrm{e}^{-}=\mathrm{H}_{2} & \text { (reduction) }
\end{array}
$$

( $e^{-}$refers to an electron in aqueous solution). 
RHO-BWI-ST-7

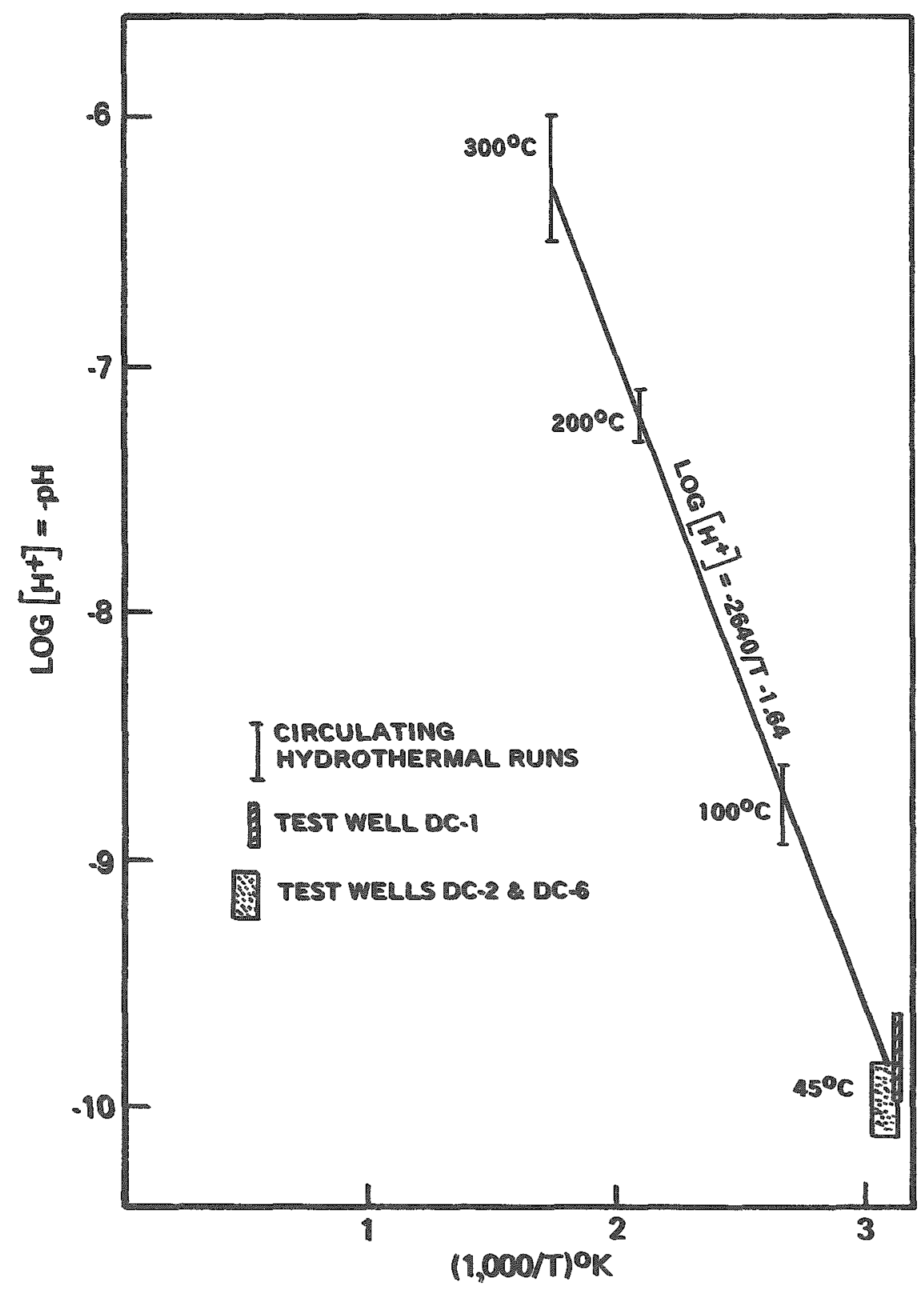

FIGURE 2-34. pH Versus 1/T for Groundmater in Equillibrium with Untanum Basalt. 
As mentioned previously, Eh is measured in volts. For convenience, the hydrogen half cell reaction is defined as having a value of zero at alt temperatures.

$$
2 \mathrm{H}^{+}+2 \mathrm{e}^{-}+\mathrm{H}_{2}\left(E \mathrm{Ch}^{0}=0.0 \mathrm{~V}\right) \text {. }
$$

This reference is then used as a basis for measurement of any half cell of interest. For instance:

$$
\begin{aligned}
& \mathrm{Fe}^{+3}+\mathrm{e}^{-} \rightarrow \mathrm{Fe}^{+2}\left(\mathrm{Eh}^{0}=+0.77 \mathrm{~V} \text { at } 25^{\circ} \mathrm{C}\right) \\
& \mathrm{Fe}^{+2}+2 \mathrm{e}^{-} \rightarrow \mathrm{Fe}^{0}\left(\mathrm{Eh}^{0}=-0.44 \mathrm{~V} \text { at } 25^{\circ} \mathrm{C}\right)
\end{aligned}
$$

A positive value results from a half cell with a potential that is more oxidizing than the hydrogen half cell and a negative value results from one that is more reducing.

In the laboratory, Eh can be measured directly under carefully controlled conditions. However, field measurement of natural Eh is so imprecise as to be virtually meaningless (Morris and Stumm, 1967). Therefore, natural Eh conditions are often inferred indirectly.

There are two elementary methods for estimating the Eh of a geologic environment. The more rigorous of the two is by thermodynamic calculation. The more direct method is by comparing observed mineral assemblages with experimental data. To be directiy applicable, the experimental materials and conditions should be appropriate to the geologic environment of interest. Otherwise, estimations of Eh will be only qualitative.

Calculation of repository Eh begins with the assumption that iron-bearing minerals in the rock control oxygen fugacity. Because the compositions of minerals change from rock to rock, there is no unique oxygen fugacity associated with a given rock type. Instead, there are generally recognized ranges. For basalt, the appropriate oxygen fugacity range is defined by the reactions:

$$
\mathrm{Ni}+1 / 2 \mathrm{O}_{2}=\mathrm{NiO} \quad \text { (NNO buffer; Huebner and Sato, 1970) }
$$

$3 \mathrm{Fe}_{2} \mathrm{SiO}_{4}+\mathrm{O}_{2} \rightarrow 2 \mathrm{Fe}_{3} \mathrm{O}_{4}+3 \mathrm{SiO}_{2}$ (QFM buffer; Eugster and Wones, 1962) 
For simplicity, it is usually assumed that the solids are present as the pure phase (i.e., activity $=1$ ). Then the equilibrium constant for each reaction can be derived as follows:

$$
\begin{gathered}
k_{6}=\frac{\mathrm{aNiO}}{\left(\mathrm{aN}_{1}\right)\left(\mathrm{fO}_{2}\right)^{1 / 2}}=\frac{1}{\sqrt{\mathrm{FO}_{2}}} \\
k_{7}=\frac{\left(\mathrm{aFe}_{3} \mathrm{O}_{4}\right)^{2}\left(\mathrm{aSiO}_{2}\right)^{3}}{\left(\mathrm{aFe}_{2} \mathrm{SiO}_{4}\right)^{3}\left(\mathrm{fO}_{2}\right)}=\frac{1}{\mathrm{fO}_{2}} .
\end{gathered}
$$

A numerical result for each $K$ can be obtained through tabulated thermodynamic data (Robie and Others, 1978) using the relationship:

$$
\Delta G=-R T \operatorname{Tn} K \text {. }
$$

The equations for determining oxygen fugacity at any temperature for the two buffers are:

$$
\begin{array}{rlr}
\log \mathrm{fO}_{2}(\mathrm{~atm})= & 9.36-24,930 / \mathrm{T}^{\circ} \mathrm{K} & \text { (NNO) } \\
& \text { and } & \\
\log \mathrm{fO}_{2}(\mathrm{~atm})=9.0-25,680 / \mathrm{T}^{\circ} \mathrm{K} & \text { (OFM). }
\end{array}
$$

The oxygen fugacity is related to Eh through the reaction describing oxidation of water (see above). To complete the Eh calculation, it is also necessary to know pH at the desired temperature. For a repository at Hanford, pH can be calculated from Equation 5.

The results of the above calculations may be fed into the expression below to determine Eh at any temperature and oxygen fugacity.

$$
\begin{aligned}
& E h(\text { volts })=1.23+4.96 \times 10^{-5}\left(T^{O} K\right) \log f_{2}-1.984 \times 10^{-4}\left(T^{0} K\right) \mathrm{pH}- \\
& \left(T^{0} \mathrm{~K}-298\right) 9.196 \times 10^{-4} . *
\end{aligned}
$$

The Eh range for a closed repository at Hanford is from -0.45 to $-0.55 \mathrm{~V}$ depending on temperature.

\footnotetext{
*The Tast term of this expression is required in order to ensure that the hydrogen reference electrode remains $0.00 \mathrm{~V}$ at all temperatures. Application of this expression to determining $\Delta G$ or $K$ from half cell potentials requires deletion of the last term.
} 
No experiments have yet been conducted using site-specific reactants to determine the stability relations of secondary mineral assemblages. However, Eh may be approximated by referring to data gathered for appropriate mineral assemblages. Equilibria within the iron-oxygencarbonate system at $25^{\circ} \mathrm{C}$ are illustrated in Figure 2-35. The minerals pyrite, magnetite, and siderite are shown to coexist over a limited range of $\mathrm{Eh} / \mathrm{pH}$ space, and this mineral assemblage (i.e., pyrite, magnetite, carbonate) has been identified in Columbia River basalt taken from the Hanford Site.

The total Eh range wherein pyrite, magnetite, and siderite (i.e., carbonate) coexist is estimated as $\sim-0.36$ to $\sim-0.41 \mathrm{~V}$. This approximation cannot be rigorousiy applied because the experimental conditions, notably temperature and carbonate content, do not agree well with Hanford conditions. However, the result is sufficientiy close to the Eh calculated from thermodynamics to verify that Eh is controlled by the geology.

The reducing conditions imposed by the geology are conducive to metal (i.e., canister and overpack) stabilities and favor formation of insoluble transuranic oxides. In addition. Eh is so low that the hydrogen pressure in equilibrium with liquid water at 300 bars total pressure is in the range 2.5 to 8.9 atmospheres. This is significant because it may inhibit the radiolysis of water.

Radiolysis results from radiation-induced dissociation of water. The species produced (e.g., $\mathrm{H}_{2} \mathrm{O}_{2}, \mathrm{HO}_{2}^{-}, \mathrm{OH}^{-}$) are generally short-lived but strongly oxidizing. For this reason, radiolysis is a major concern when predicting canister (or overpack) life. However, the presence of hydrogen may cause the radicals to recombine quickly, thus mitigating corrosion and perhaps negating the effects of radiolysis altogether (Stobbs and Swallow, 1962).

The previous discussion has dealt exclusively with estimations of equilibrium Eh. More oxidizing conditions are certain to result from repository excavation and subsequent backfilling. These conditions will be temporary, lasting only until the air trapped between particles of 
RHO-BWI-ST -7

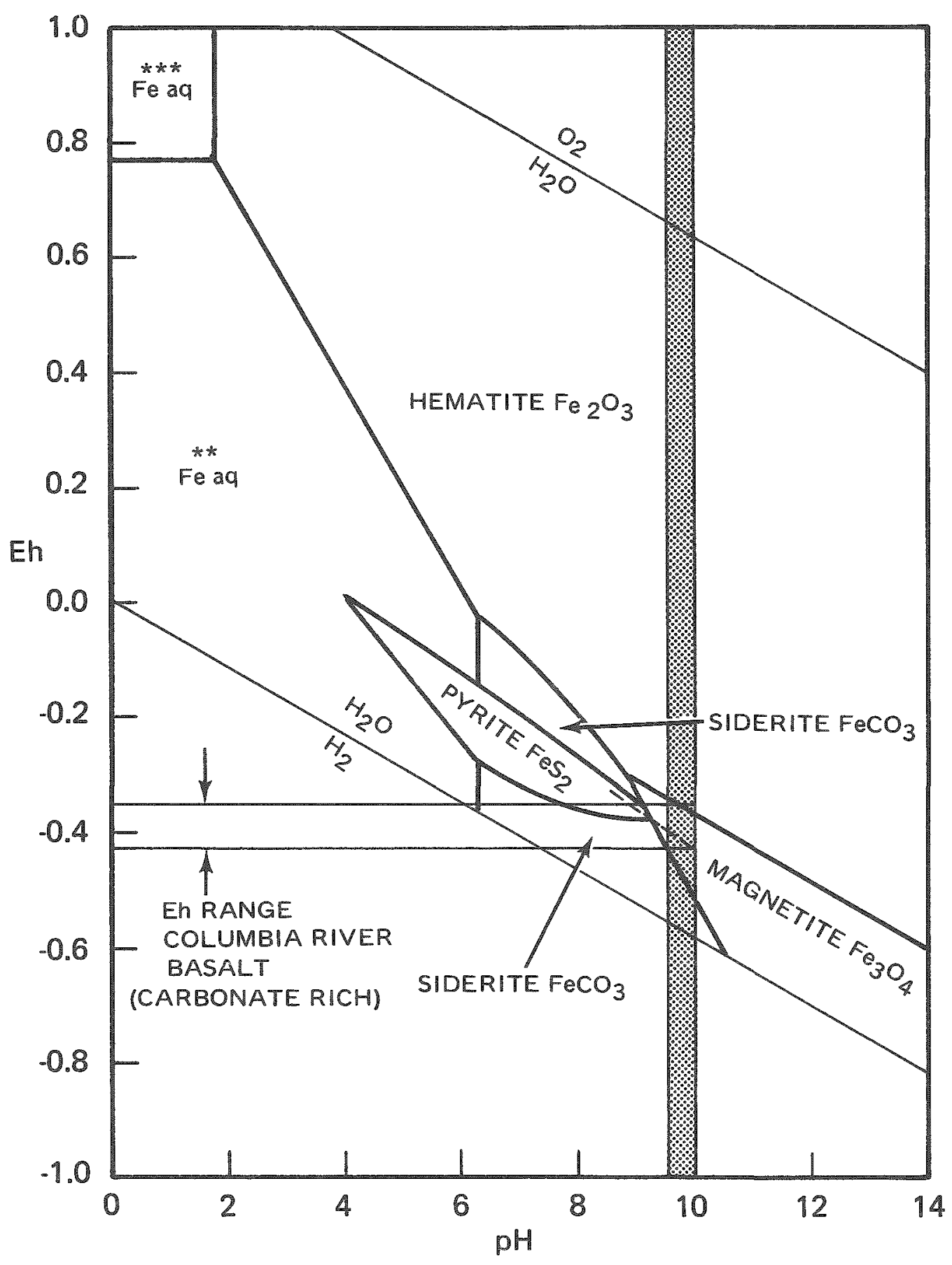

MEASURED AMBIENT REPOSITORY $\mathrm{pH}$

(Data from Garrels and Christ, 1965)

FIGURE 2-35. Stabi7ity Relations of Iron Oxides, Sulfides, and Carbonate in Water at $25^{\circ} \mathrm{C}$ and 1 Atmosphere Total Pressure. Total dissolved sulfur $=10^{-6}$ moles per liter. Total dissolved carbonate $=10^{0}$. Note elimination of $\mathrm{FeS}$ field by $\mathrm{FeCO}_{3}$ under strongly reducing conditions, and remarkable stability of pyrite in presence of small amount dissolved sulfur. 
backfill is exhausted by reaction with the rock. The exact rate of oxygen consumption by basalt (or backfill) will be directly dependent on the surface area of the solid and the temperature prevailing at the air-particle interface. However, detailed knowledge of the specific reaction kinetics is lacking and this prevents making a confident estimate of how long Eh will be outside of geologic control. A crude guess of the time required to bring repository Eh from air $(+0.54 \mathrm{~V})$ to geologic equilibrium $(-0.45$ to $-0.54 \mathrm{~V})$ is hundreds of years.

\subsubsection{Summary}

The anticipated range of environmental conditions in a closed repository at the Hanford Site is sumarized in Table 2-45. These conditions are 211 affected by temperature which has been assumed to range between $65^{\circ} \mathrm{C}$ at ambient and $300^{\circ} \mathrm{C}$ at the canister surface during the maximum thermal peak. The high temperature is computed from the assumed canister spacings advocated in the Basalt Waste Isolation Project preconceptual repository design. Therefore, the high-temperature limits and hence, the range in other dependent parameters, is subject to alteration in design. These ranges should be considered maximal and subject to downward revision.

TABLE 2-45. Summary of Repository Equilibrium Conditions.

\begin{tabular}{|c|c|c|c|c|}
\hline & $\begin{array}{l}\text { Temperature } \\
\left({ }^{\circ} \mathrm{C}\right)\end{array}$ & $\begin{array}{c}\text { Equilibrium } \\
\text { pH }\end{array}$ & $\begin{array}{c}\log \text { oxygen } \\
\text { Fugacity }(\mathrm{atm})\end{array}$ & $E h(V)$ \\
\hline$\frac{\text { Period of }}{\text { Coologic }}$ & 65 & 9.4 & -64.5 to -67.15 & -0.51 to $=0.55$ \\
\hline \multirow[t]{5}{*}{ Thermal Period } & 100 & 8.7 & -57.8 to -60.0 & -0.49 tc -0.53 \\
\hline & 150 & 7.9 & -49.6 to -51.8 & -0.48 to -0.53 \\
\hline & 200 & 7.2 & -43.3 to -45.4 & -0.47 to -0.52 \\
\hline & 250 & 6.7 & -38.3 to -40.2 & -0.48 to -0.52 \\
\hline & 300 & 6.2 & -34.1 to -35.9 & -0.45 to $=0.51$ \\
\hline$\frac{\text { Operating }}{\text { Period }}$ & 65 & 9.6 & -0.7 & +0.54 \\
\hline
\end{tabular}


The variation of temperature with time is non-linear. Initial temperature will be $265^{\circ} \mathrm{C}$ and rise to a maximum near $270^{\circ} \mathrm{C}$ after about 25 years. Thereafter, temperatures will drop slowiy because the rock represents a 1 arge thermal mass. After 1,000 years, canister skin temperature may fall as little as $15^{\circ} \mathrm{C}$ from the maximum, with 5,000 years required to drop to $125^{\circ} \mathrm{C}$.

Pressure during repository history will vary from 1 to 300 atmospheres. One atmosphere pressure will prevail while the repository is open. Immediately thereafter, pressure will depend on the packing efficiency of the backfill. U1timately, pressure will return to that defined by the rock load (300 atmospheres). However, after closure, the water pressure will vary between that defined by the hydrostatic head (w100 atmospheres) and the load pressure (300 bars). Thus, a conservative estimate is 300 bars.

Ambient groundwater $\mathrm{pH}$ is in the range 9.4 to 9.9, and is probably controlled by dissociation of silicic acid. The equilibrium $\mathrm{pH}$ under hydrothermal conditions will also be controlled by silicic acid dissociation and can be predicted at any temperature from:

$$
\mathrm{pH}=\frac{2,640}{T^{0} \mathrm{~K}}+1.64 \text {. }
$$

The $\mathrm{pH}$ under hydrothermal conditions may be subject to transient depressions caused by precipitation of smectite and influenced by the water: rock ratio (i.e., flow rate). High flow rates will cause a maximum $\mathrm{pH}$ depression, which at $300^{\circ} \mathrm{C}$ may be as $1 \mathrm{ow}$ as $\mathrm{pH}=4.0$.

Equilibrium oxidation potential (Eh) is controlled by oxygen exchange with the repository host rock. Under geologic control, Eh will be in the range -0.45 to $-0.54 \mathrm{~V}$ depending on temperature. The equilibrium Eh can be calculated from: $\quad c h=1.23+4.96 \times 10^{-5}\left(T^{O} \mathrm{~K}\right)\left(\log \mathrm{fO}_{2}\right)-1.984 \times 10^{-4}$ $\left(T^{0} \mathrm{~K}\right)(\mathrm{pH})-\left(\mathrm{T}^{\mathrm{O}} \mathrm{K}-298\right) 9.196 \times 10^{-4}$. Eh will vary between that determined by water equilibrated with atmosphere $(+0.54 \mathrm{~V})$ and that controlled by the geology $(-0.45 \mathrm{~V}$ to $-0.54 \mathrm{~V})$. The range is a consequence of excavation and closure which will trap air (and oxygen) between particles of backfill and temperature. The time necessary to consume the trapped 


\section{RHO-BWI -ST - 7}

oxygen cannot yet be estimated, but it is certain that geologic control will prevail during the greatest part of repository history.

\subsection{WASTE FORMS}

\subsubsection{Introduction}

The physical and chemical properties of the waste form, together with those of the repository host rock, will determine the nature and number of engineered barriers required to prevent release of unacceptable amounts of radionuciides to the biosphere. The engineered barriers system must not only be compatible with the repository conditions (e.g., temperature, pressure, and rock/groundwater chemistry), but also with the waste form that it surrounds. Accurate, detailed characterization of the waste forms and their interactions with other engineered barriers and natural materials are necessary to the development of viable barrier systems.

High-level waste forms are typically defined as stable solids in which the radioactive by-products of power generation, both fission products and irradiated material, are immobilized. In a broader sense, this definition includes the depleted $\mathrm{UO}_{2}$ fuel elements themselves. Current national policies preclude the reprocessing of spent fuel elements in the United States to recover usable uranium and plutonium, dictating that spent fuel elements be disposed of in the nuclear waste repository. Therefore, the primary waste form for which engineered barriers must be developed is spent fuel. Engineered barrier development for the major waste forms arising from solidification of reprocessing wastes must also be conducted as a backup to development work for the spent fuel barrier package. Such efforts will minimize overall program delays in the event of a policy change to permit or require reprocessing of spent nuclear fuel.

Several different waste form types have been proposed for the solidification of nuclear wastes which arise from the reprocessing of spent fuel elements. Waste forms under development by various agencies (Mendel and Others, 1977; Ringwood, 1978; McCarthy, 1975a, 1977a) include 
several types of vitrified (glass) solids, tailored ceramic materials such as supercalcine and SYNROC, and the so-called "multiple barrier" waste forms. Extensive research programs have been undertaken on these waste forms. Vitreous solids have received the most attention, aithough considerable effort is now being expended by researchers on the development of ceramic and multiple barrier solids.

In this section, the physical and chemical compositions of the various high-level waste forms will be discussed in detail. The strengths and weaknesses of each major waste form will be discussed. Emphasis will be placed on waste form properties that are relevant to disposal in a repository in basalt.

\subsubsection{Spent Fuel Elements}

2.6.2.1 Reactor Types and Waste Inventories. Light water reactor fue consists of uranium dioxide pellets contained in sealed zircaloy tubes, as shown in Figure 2-36. These tubes, or fuel elements, are mounted in arrays called fuel assemblies. An average fuel assembly from a pressurized water reactor will spend approximately three years in the reactor core before it requires replacement. The total burnup (amount of $235 U+{ }^{239} \mathrm{Pu}+{ }^{238} U$ fissioned) is dependent upon a number of factors (ERDA, 1976), but averages 33,000 MW-days per metric ton for pressurized water reactor fue 7 . This value corresponds to a consumption of $76 \%$ of the ${ }^{235} U$ originally present in the fuel. Some ${ }^{238} U$ is consumed in the process, either by fast-neutron fission or by transmutation into ${ }^{239} \mathrm{Pu}$ (Cohen, $1977 \mathrm{a}$ and $1977 \mathrm{~b}$ ). A portion of the ${ }^{239} \mathrm{Pu}$ also fissions prior to fuel discharge, with $54 \%$ of the total fissions occurring in plutonium near the end of the fuel's useful lifetime.

Currenily, about $37 \%$ of the light water reactors (25 reactors out of a total of 67) presently operating in the United States are boiling water reactors (Anonymous, 1979). The average boiling water reactor requires approximately $20 \%$ more uranium than does a comparable pressurized water reactor. Boiling water reactor fuel is burned at a lower power rate than 


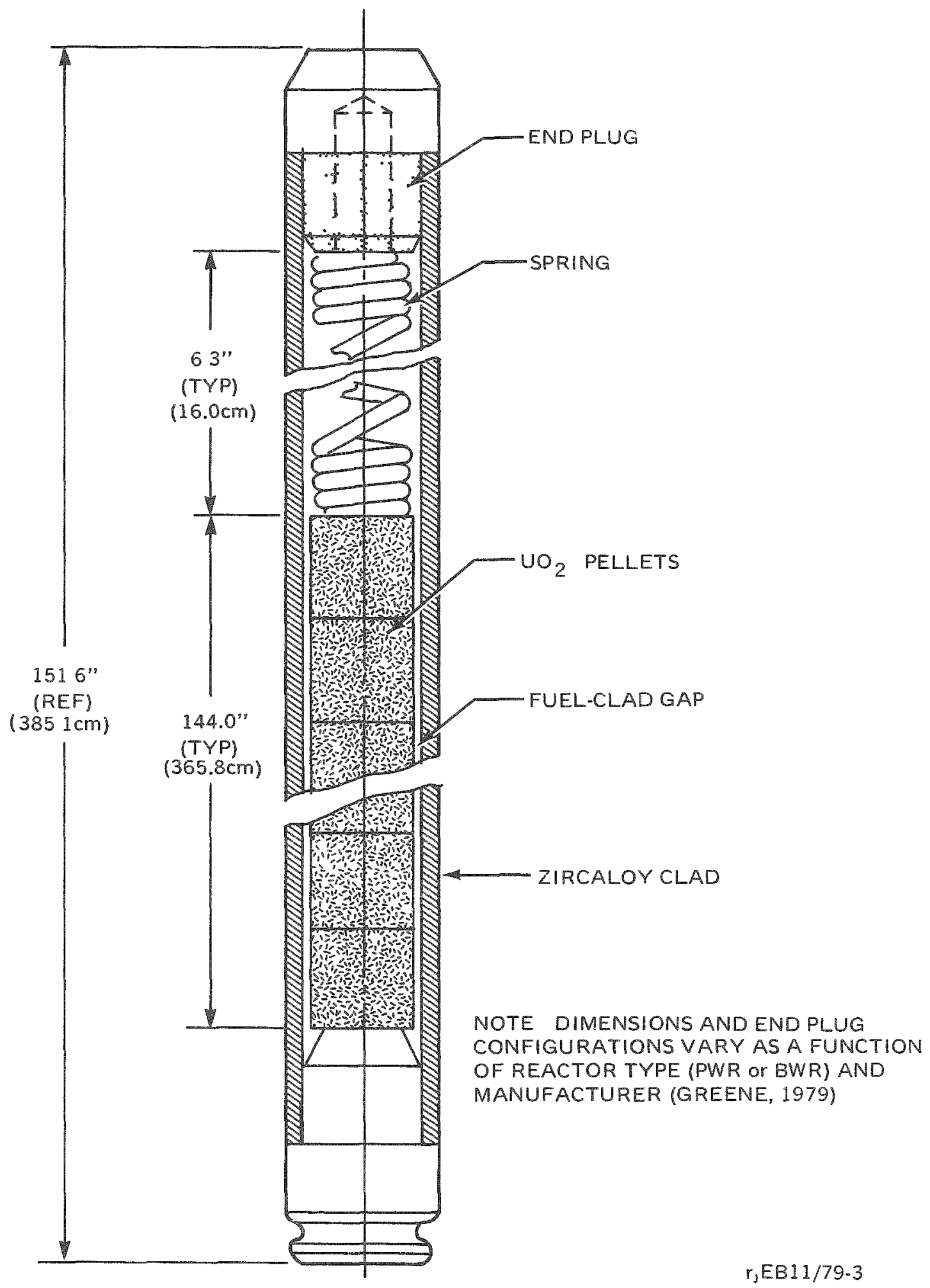

FIGURE 2-36. Typical Light Water Reactor Fuel Element. 
pressurized water reactor fuel, achieving an average burn-up of 27,500 MW days per metric ton before discharge (BWIP, 1979a). An average boiling water reactor fuel assembly provides 4 years' service before it must be repiaced.

Individual pressurized water reactor and boiling water reactor fuel assemblies are quite different physically. These differences have had effects on canister design for spent fuel disposal and will aiso affect emplacement strategies. The physical characteristics of referenced fuel assemblies are shown and listed in Figure 2-37.

Various packaging arrangements for disposal of spent fuel assemblies are currently being evaluated. Packaging intact assemblies is the simplest approach, though it is relatively inefficient from the standpoint of the number of canisters required. Typical canister designs for intact assemblies are sized to hold one pressurized water reactor assembly or three boiling water reactor assemblies. The package design presently baselined for conceptual design of a repository in basalt is based upon disassembly of spent fuel elements and packaging fuel pins from three pressurized water reactors or seven boiling water reactors into a $30.5-\mathrm{cm}$ in diameter canister. Roughiy $60 \%$ of a11 spent fue 1 assemblies will be boiling water reactor assemblies, provided the 2:1 pressurized water reactor:boiling water reactor ratio of total reactors currently operational, under construction, and on order (Anonymous, 1979) is maintained. For canisters of disassembled fuel elements, this translates to approximately 58\% of the canisters containing pressurized water reactor spent fuel assemblies.

The contents of the boiling water reactor and pressurized water reactor canisters described above are similar in heat output, total fuel content, and, as will be described in the spent fuel chemistry section, fission product content. The heat generation curves for typical boiling water reactor and pressurized water reactor canisters are shown in Figure 2-38. Spent fuel canisters containing 10-year-old or older boiling water reactor and pressurized water reactor fuel have comparable thermal outputs and probably do not need to be distinguished from one another. The values plotted in Figure 2-38 are for burnups of 33,000 MW days per metric ton and 28,000 MW days per metric ton for pressurized 

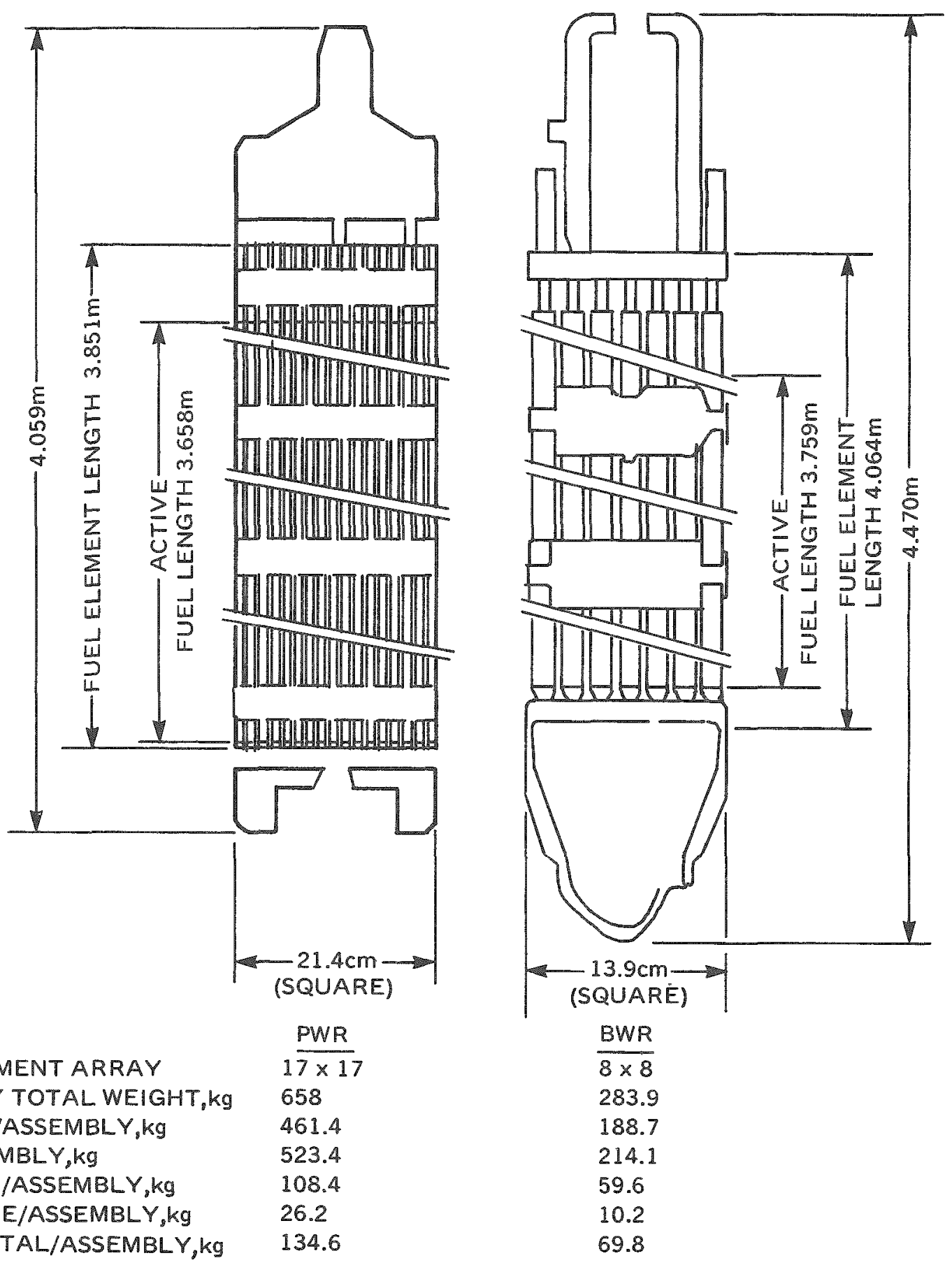


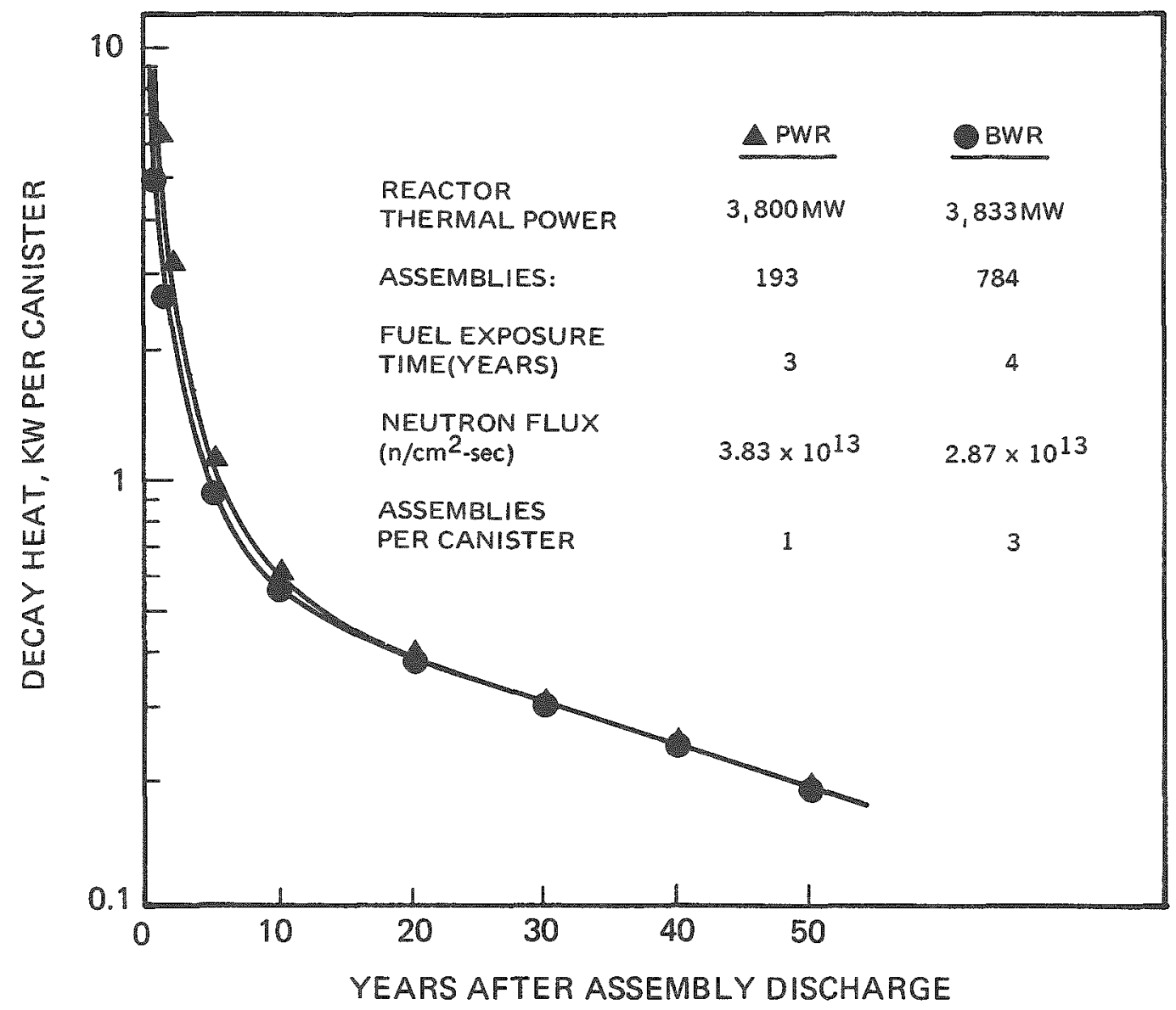

rjEB12/79-2

FIGURE 2-38. Decay Heat as a Function of Time for Typical Pressurized Water Reactor and Boiling Water Reactor Spent Fuel Canisters (after NAE and NAS, 1979).

water reactor and boiling water reactor fuel, respectively. Decay heat in the fuel assemblies is almost directly proportional to burnup or reactor exposure time for cooling periods greater than about 5 years (Greene, 1979).

Projections of spent fuel inventories have declined within recent years, concurrent with declining projections of installed nuclear generating capacity. The most current optimistic estimate of installed nuclear generating capacity in the year 2000 is 300 gWe (DOE, 1979b: clark and Reynolds, 1979). This estimate yields a maximum cumulative 
inventory of 70,000 canisters by the year 2010. Half of these have been assumed to be designated for disposal at a repository at Hanford. For a $2: 1$ ratio of pressurized water reactor to boiling water reactor canisters and $21.34 \mathrm{~kg}$ uranium per canister, the value listed above corresponds to 95,000 metric tons of uranium fuel consumed. Projected high, median, and low installed nuclear generating capacities are presented in Table 2-46, along with assumptions for calculating the number of resulting canisters for both the spent fuel assembly disposal and spent fuel pin disposal (disassembly of fuel assemblies) options. Projected canister inventories to the year 2010, based upon packaging freshly discharged fuel, are presented for the fuel pin disposal option in Figure 2-39. The total number of canisters available for disposal in the year 2010 will be the inventory present in the year 2000, as 10-year aging prior to disposal is required. This corresponds to about 70,000 canisters containing spent fuel pins which would require disposal in the year 2010. This estimate may vary as much as $10 \%$ due to variations in the estimated generating capacity growth curve in the 1980 to 1995 time frame from author to author. Note that this option would multiply the heat output of pressurized water reactor and boiling water reactor spent fuel canisters to 3.0 and 2.3 times, respectively, that of the values shown in Figure $2-38$. 2.6.2.2 The Physical State of Spent Fuel. The fuel pellets in spent fuel elements are heterogeneous, both physically and chemically, due to the steep thermal gradient across the individual pellets during irradiation. Physically, significant restructuring occurs within the pellets, often within a few hours of irradiation (DeHalas and Horn, 1963). Voids in the fuel pellet migrate up the thermal gradient via a fuel-evaporation/condensation mechanism, forming long columnar grains of $\mathrm{UO}_{2}$. In some fuel, such as the fast breeder reactor fuel pellet seen in schematic in Figure $2-40$, these migrating voids form a central cavity in the pellet. The migration rates are highly temperature and thermal gradient dependent. This dependency results in a sharply defined outer boundary for the columnar grains (Hoyt and Rhee, 1979). Restructuring effects similar to those shown in Figure $2-40$ are also seen in light water reactor spent fuel. Several other structural features are also illustrated in Figure 2-40. Equiaxed grain growth occurs both adjacent 
TABLE 2-46. Assumptions for Spent Fue T Canister Inventory Projections. Nuclear Generating Capacity (gWe)

(After DOE, 1979b; Clark and Reynolds, 1979.)

\begin{tabular}{c|c|c|c}
\hline Year & Low & Mid & High \\
\hline 1985 & 102 & 114 & 118 \\
1990 & 142 & 152 & 171 \\
1995 & 186 & 208 & 225 \\
2000 & NF* & NF & 300 \\
\hline
\end{tabular}

${ }_{\text {NHF }}=$ Not Forecast.

Spent fuel assemblies generated/gWe-year. $=90.8$ (BWIP, 1979a).

Pressurized water reactor:boiling water reactor ratio $=2: 1$.

Boiling water reactor assemblies discharged:

pressurized water reactor assemblies discharged $=3: 2$.

One canister contains pins from 3 pressurized water reactor or 7 boiling water reactor assemblies.

Initial spent fuel assembly inventory $(1978)=19,417$

(Greene, 1979).

A linear growth rate was projected for new generating capacity beyond 1995 for the low and median growth cases of 11 and 13 gWe/year, resuectively. For the high growth case, a linear growth rate of $18 \mathrm{gWe} /$ year was projected beyond the year 2000.

To obtain number of canisters resulting if intact spent fuel assemblies are packaged in canisters containing 3 from a pressurized water reactor or 7 from a boiling water reactor, multiply the number of canisters at time $t$ in Figure $2-39$ by 2.74 . 


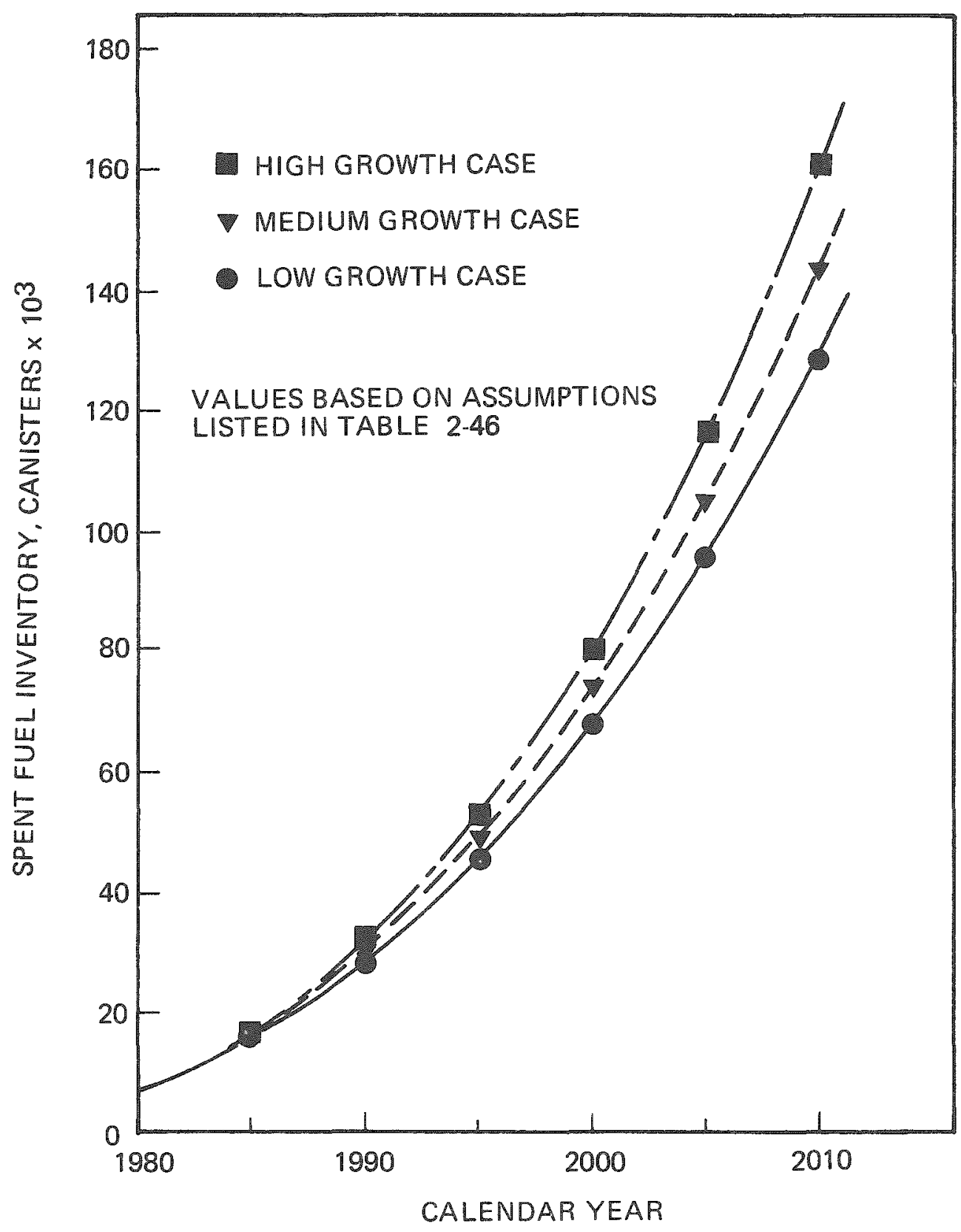

FIGURE 2-39. Projected Spent Fuel Canister Inventories Based on Low, Medium, and High Growth Projections for Nuclear Electric Generation Capacity (after Clark and Reynolds, 1979). 


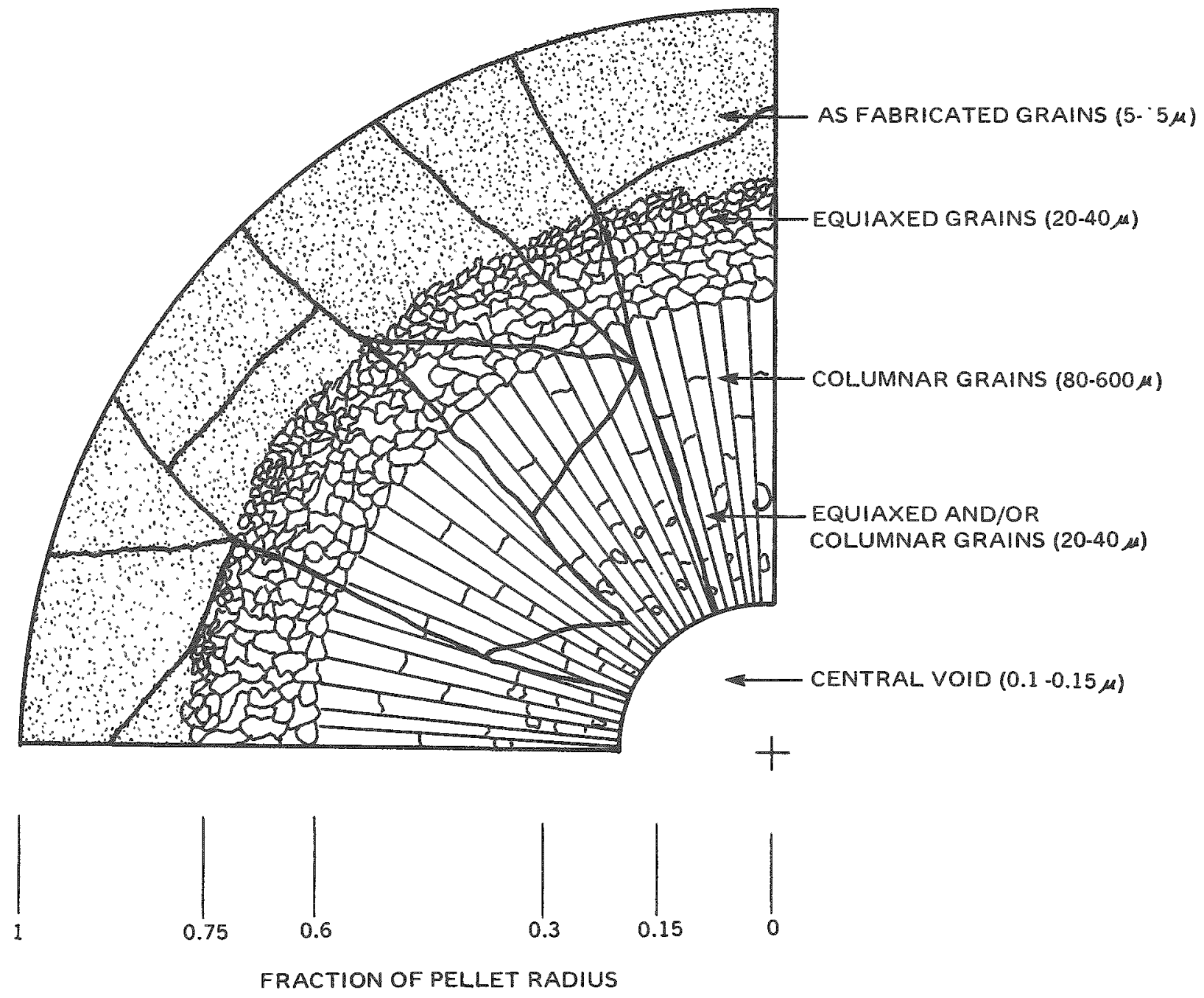

NOTE: APPROXIMATE VALUES HAVE BEEN GIVEN FOR THE POSITION OF RADIAL GRAIN ZONES AND FOR AVERAGE GRAIN SIZES; HOWEVER, ACTUAL VALUES WILL VARY DEPENDING UPON REACTOR TYPE, FUEL PELLET DIAMETER, AMOUNT OF BURNUP. AND FUEL HEAT RATING.

rj12/79-1

FIGURE 2-40. Cross Section of a Typical Oxide Fuel Pellet from High-Burnup Light Water Reactor or Fast Breeder Reactor Fuel. (after Hoyt and Rhee, 1979). 
to the outer region of the columnar grains and adjacent to the pellet's central void. This grain growth is the result of the high temperatures and relativeiy small thermal gradients in these regions. Many of the inner equiaxed grains are replaced by columnar grains later in the fuel's lifetime. Grain growth does not take place in the outer, cooler regions. Also, significant cracking occurs throughout the pellets. The pellets may, in addition, deform slightly during reactor operation, becoming pinched towards the center and expanding at the ends. Extreme examples of this effect may cause local deformations in the fuel element cladding, giving the element a bamboo-like appearance (01ander, 1976).

Light water reactor fuel pellets are typically contained, or clad, in zircaloy tubes. The cladding of irradiated fuel may become weakened or damaged in several ways while in service in a reactor. Weaknesses may be created by abrasion, either during the periodic shuffling of fuel elements during refueling or due to small vibrations of the rods during reactor operation (Andrews and Others, 1979; Sofer and Woods, 1979). Some physical restructuring of the cladding material may occur during its service life, as well as chemical attack by some of the fission product elements. These events typically do not breach fuel pins, although occasional failures do occur. For instance a maximum of $0.3 \%$ fuel pin failures have occurred in fuel manufactured by Combustion Engineering, Inc., Windsor, Connecticut, in early pin assembly designs (Andrews and Others, 1979). Current fuel pins have recorded less than one failure per 10,000 rods, or less than $0.01 \%$. No evidence of fuel rod degradation or failure after deposition in water basin storage has been observed (Johnson, 1977).

Chemical interaction of the cladding material with fission product phases is one mechanism which has been cited as causing cladding breach within reactors. Iodine has been found to induce stress corrosion cracking in zircaloy at temperatures as low as $325^{\circ} \mathrm{C}$ (Cubicciotti and Jones, 1978). Such events have been cited as being responsible for occasional in-service failures of light water reactor fuel elements. Cesium, cadmium, and iron have also been found to embrittle zircaloys 
(Cubicciotti and Sanecki, 1978). Zircaloy which has been damaged in this manner may be prone to micro-cracking during handling, thereby reducing the reliability of the cladding as a back-up barrier in the event of a canister breach in the repository.

2.6.2.3 The Chemistry of Spent Fuel. Spent light water reactor fuel is basically heavily sintered $\mathrm{UO}_{2}$ which contains about $4.5 \%$ of fission product elements and actinides (produced by neutron capture). Many of these elements remain in solid solution with $\mathrm{UO}_{2}$ and are distributed throughout the fuel in amounts proportional to the local amount of burnup. other fission products form metallic inclusions (sometimes called ingots) within the fuel matrix. Some form oxide phases distinct from $\mathrm{UO}_{2}$, while others are present as gases. A listing of the relative elemental abundances in spent fuel at 150 days after removal from the reactor is presented in Table 2-47. This table also shows the relative abundances of elements in spent fuel at 1,10,100,1,000, and 10,000 years.

The specific behavior of a given fission product in light water fuel depends upon many variables and, consequently, is very difficult to predict. The behavior depends on: (1) the birth location of the fission product in the fuel pellet; (2) the fission product concentration, which increases with burnup; (3) the temperature distribution within the fuel (and hence, the thermal conductivity of the fuel, which changes as a function of burnup and fuel ratio): (4) the oxygen-to-metal ratio, which increases with burnup and affects fission product thermodynamic properties; and (5) the large number of possible fission product compounds (Hoyt and Rhee, 1979). Therefore, a variety of fission product distributions and phases can be expected in spent fuel.

In genera1, the burnup, fission product content, and plutonium content in irradiated $\mathrm{UO}_{2}$ fuel is greatest in the outer, non-restructured regions of the pellet (Poncelet, 1965; Megerth, 1969). This phenomenon occurs independently of migration effects in light water reactor fuel. Cesium has been observed to migrate to the unrestructured region of the fuel, accumulating primarily at the grain boundaries ( $0 i$ and Naito, 1964; Banham and Others, 1968). Americium, neodymium, and curium also tend to concentrate in the pellet periphery. Short-range radial migration of 
TABLE 2-47. Elemental Abundances in Spent Fuel. (After Bel1, 1973.)

\begin{tabular}{|c|c|c|c|c|c|c|}
\hline \multirow[b]{2}{*}{ Element } & \multicolumn{6}{|c|}{ Grams per Metric Ton Uranium Charged to Reactor* } \\
\hline & g/MTU & $1 y r$ & $10 \mathrm{yr}$ & $100 \mathrm{yr}$ & $1,000 \mathrm{yr}$ & $10,000 \mathrm{yr}$ \\
\hline $\mathrm{He}$ & $3.53 E-1$ & $4.50 E-1$ & $6.34 E-1$ & $1.15 E 0$ & $1.95 E 0$ & $3.54 E 0$ \\
\hline $\mathrm{Ge}$ & $3.71 E-1$ & $3.71 E-1$ & $3.71 E-1$ & $3.71 E-1$ & $3.71 E-1$ & $3.71 E-1$ \\
\hline As & $8.46 E-2$ & $8.46 E-2$ & $8.46 E-2$ & $8.46 E-2$ & $8.46 E-2$ & $8.46 E-2$ \\
\hline Se & $5.21 E 1$ & $5.21 E 1$ & $5.21 E 1$ & $5.21 E 1$ & $5.20 E 1$ & $5.15 \mathrm{E} 1$ \\
\hline $\mathrm{Br}$ & $1.53 \mathrm{EI}$ & $1.53 \mathrm{EI}$ & $1.53 \mathrm{E} 1$ & $1.53 \mathrm{E1}$ & $1.54 E 1$ & $1.59 E 1$ \\
\hline $\mathrm{Kr}$ & $3.75 \mathrm{E} 2$ & $3.73 \mathrm{E} 2$ & $3.62 E 2$ & $3.47 E 2$ & $3.47 E 2$ & $3.47 E 2$ \\
\hline $\mathrm{Rb}$ & $3.34 E 2$ & $3.36 E 2$ & $3.48 E 2$ & $3.62 E 2$ & $3.63 \mathrm{E2}$ & $3.63 E 2$ \\
\hline Sr & $8.96 E 2$ & $8.80 E 2$ & $7.75 \mathrm{E} 2$ & $3.96 \mathrm{E} 2$ & $3.50 E 2$ & $3.50 E 2$ \\
\hline$\gamma$ & $4.70 \mathrm{E} 2$ & $4.67 E 2$ & $4.67 E 2$ & $4.67 E 2$ & $4.67 E^{2}$ & $4.67 E 2$ \\
\hline $\mathrm{Zr}$ & $3.67 E 3$ & $3.68 \mathrm{E} 3$ & $3.78 E 3$ & $4.16 E 3$ & $4.21 E 3$ & $4.21 E 3$ \\
\hline $\mathrm{Nb}$ & $1.32 E 2$ & $3.19 E-1$ & $4.08 E-3$ & $3.46 E-2$ & $3.41 E-1$ & $3.40 E 0$ \\
\hline Mo & $3.44 E 3$ & $3.47 E 3$ & $3.47 E 3$ & $3.47 E^{2}$ & $3.47 E 3$ & $3.47 E 3$ \\
\hline TC & $8.41 E 2$ & $8.41 E 2$ & $8.41 E 2$ & $8.41 E 2$ & $8.39 E 2$ & $8.14 E 2$ \\
\hline Ru & $2.27 E 3$ & $2.21 E 3$ & $2.15 \mathrm{E} 3$ & $2.15 E 3$ & $2.15 E 3$ & $2.17 E 3$ \\
\hline Rh & $3.85 E 2$ & $3.88 E 2$ & $3.88 E 2$ & $3.88 E 2$ & $3.88 E 2$ & $3.88 \mathrm{E} 2$ \\
\hline $\mathrm{Pd}$ & $1.29 E 3$ & $1.35 \mathrm{E} 3$ & $1.41 E 3$ & $1.41 E 3$ & $1.41 E 3$ & $1.41 \mathrm{E3}$ \\
\hline $\mathrm{Ag}$ & $5.97 E 1$ & $5.97 E 1$ & $5.97 E 1$ & $5.97 E 1$ & $5.97 \mathrm{E} 1$ & $6.00 E 1$ \\
\hline $\mathrm{Cd}$ & $8.38 E 1$ & $8.38 E 1$ & $8.38 E 1$ & $8.38 E 1$ & $8.38 E 1$ & $8.38 E 1$ \\
\hline In & $1.23 E 0$ & $1.23 \mathrm{EO}$ & $1.23 E 0$ & $1.23 E 0$ & $1.23 \mathrm{EO}$ & $1.23 E 0$ \\
\hline sn & $5.10 E 1$ & $5.10 E 1$ & $5.10 E 1$ & $5.10 E 1$ & $5.09 E 1$ & $4.98 E 1$ \\
\hline $\mathrm{Sb}$ & $1.75 \mathrm{EI}$ & $1.58 \mathrm{EI}$ & $1.05 \mathrm{E} 1$ & $9.96 E 0$ & $9.96 E 0$ & $9.96 E 0$ \\
\hline Te & $5.64 E 2$ & $5.65 E 2$ & $5.70 \mathrm{E} 2$ & $5.71 E 2$ & $5.71 E 2$ & $5.72 E 2$ \\
\hline$I$ & $2.68 E 2$ & $2.70 E 2$ & $2.70 \mathrm{E2}$ & $2.70 E 2$ & $2.70 E 2$ & $2.70 E 2$ \\
\hline $\mathrm{Xe}$ & $5.45 E 3$ & $5.45 \mathrm{E} 3$ & $5.45 E 3$ & $5.45 E 3$ & $5.45 E 3$ & $5.45 E 3$ \\
\hline $\mathrm{Cs}$ & $2.73 E 3$ & $2.65 E 3$ & $2.31 E 3$ & $1.46 \mathrm{E} 3$ & $1.33 E 3$ & $1.33 E 3$ \\
\hline $\mathrm{Ba}$ & 1.39E3 & $1.47 \mathrm{E} 3$ & $1.81 E 3$ & $2.66 E 3$ & $2.78 \mathrm{E} 3$ & $2.78 \mathrm{E} 3$ \\
\hline La & $1.27 \mathrm{E} 3$ & $1.27 E 3$ & $1.27 \mathrm{E3}$ & $1.27 \mathrm{E} 3$ & $1.27 E 3$ & $1.27 \mathrm{E} 3$ \\
\hline $\mathrm{Ce}$ & $2.72 E 3$ & $2.58 E 3$ & $2.48 \mathrm{E} 3$ & $2.48 \mathrm{E} 3$ & $2.48 E 3$ & $2.48 \mathrm{E} 3$ \\
\hline $\mathrm{Pr}$ & $1.20 E 3$ & $1.20 E 3$ & $1.20 E 3$ & $1.20 E 3$ & $1.20 E 3$ & $1.20 E 3$ \\
\hline $\mathrm{Nd}$ & $3.87 E 3$ & $4.01 E 3$ & $4.11 E 3$ & $4.11 E 3$ & $4.11 E 3$ & $4.11 E 3$ \\
\hline $\mathrm{Pm}$ & 1.06E2 & $8.10 E 1$ & $7.49 E 0$ & $=\infty$ & $=-\infty$ & $-m$ \\
\hline $\mathrm{Sm}$ & $8.04 E 2$ & $8.28 E 2$ & $8.99 E 2$ & $8.86 E 2$ & $8.67 E 2$ & $8.67 E 2$ \\
\hline Eu & 1. $80 E 2$ & $1.77 \mathrm{E} 2$ & $1.62 E 2$ & $1.52 E 2$ & $1.70 \mathrm{E} 2$ & $1.70 \mathrm{E} 2$ \\
\hline $\mathrm{Gd}$ & 1.02E2 & $1.05 E 2$ & $1.23 E 2$ & $1.52 E 2$ & $1.53 E 2$ & 1.53E2 \\
\hline$T b$ & $1.81 E 0$ & $1.78 \mathrm{EO}$ & $1.78 \mathrm{EO}$ & $1.78 E 0$ & $1.78 \mathrm{EO}$ & $1.78 \mathrm{EO}$ \\
\hline Dy & $1.02 E 0$ & $1.09 E 0$ & $1.12 \mathrm{EO}$ & $1.12 E 0$ & $1.12 E 0$ & $1.12 E 0$ \\
\hline$U^{\prime \prime}$ & $9.55 E 5$ & $9.55 E 5$ & $9.55 E 5$ & $9.55 E 5$ & $9.57 E 5$ & $9.64 E 5$ \\
\hline $\mathrm{Np}$ & $4.82 E 2$ & $4.82 E 2$ & $4.83 E 2$ & $4.89 E 2$ & $5.21 E 2$ & $5.30 E 2$ \\
\hline Pu & $8.95 \mathrm{E} 3$ & $1.00 E 4$ & $1.16 \mathrm{E4}$ & $1.45 E 3$ & $1.45 E 4$ & $1.65 \mathrm{E} 4$ \\
\hline Am & $1.36 \mathrm{E} 2$ & $1.36 E 2$ & $1.37 E 2$ & $1.33 E 2$ & $9.33 E 1$ & $3.69 E 1$ \\
\hline $\mathrm{Cm}$ & $3.90 E 1$ & $3.33 E 1$ & $2.33 E 1$ & $2.66 E 0$ & $1.83 E 0$ & $9.00 E 0$ \\
\hline
\end{tabular}

${ }^{*}$ power $=30 \mathrm{MW} / \mathrm{metric}$ ton: Exposure $=33,000 \mathrm{MW}$-days $/$ metric ton. * 150 days after fuel discharge from reactor. 
fission products such as barium and strontium also occurs due to the movement of short-lived precursors. Ruthenium and niobium are frequently found in high concentrations near the fuel center, at the periphery of the columnar grain zone, and in smaller concentrations in the equiaxed grain zone. The fission products iodine, tritium, krypton, and xenon, as well as volatile oxides of such elements as cesium and niobium are particularly mobile.

Fission products and actinides have been observed in a variety of chemical states in spent fuel. Some may be found in more than one chemical form, such as metal and oxide. Unambiguous phase identification data are not always the basis for such determinations. In many cases chemical state is inferred from chemical analysis of an interesting point in the fuel matrix coupled with other observations.

A number of fission products remain in solid solution with $\mathrm{UO}_{2}$. These elements include the actinides and the rare earth elements (0'Boyle and Others, 1969; Leitnaker, 1974). Some Sro may also go into solid solution with $\mathrm{UO}_{2}$ at elevated temperatures (Sari and Others, 1979). Metal1ic inclusions have been found to contain molybdenum, ruthenium, technetium, palladium, rhodium, silver, and occasionally cesium (Jeffrey, 1967; Ewart and Taylor, 1976). The ingots typically contain several elements rather than one or two.

Fission product oxide chemistry is complex, and may vary not only from fuel to fuel but within individual fuel pellets as well. The discrete fission product phases which have been reported are listed in Table 2-48. Many of the phases are found in the periphery of the $\mathrm{UO}_{2}$ fuel pellets, while others have been reported as complex solid solutions, such as $(\mathrm{Ba}, \mathrm{Sr})\left(\mathrm{Zr}, \mathrm{U}_{3} \mathrm{Mo}\right) \mathrm{O}_{3}$ (Sari and Others, 1979). In hyperstoichiometric fuels $\left(\mathrm{UO}_{2+x}\right)$, ternary oxides containing hexavalent uranium (such as $\mathrm{Cs}_{2} \mathrm{UO}_{4}$ ) may be stable (Cubicciotti and Sanecki, 1978). Other evidence suggests that fission product elements such as barium and strontium form a variety of oxide phases across the radius of the fuel pellet (Koizumi and Others, 1974). Such experiments suggest that $B a O$ and SrO are the stable oxides of these fission products through much of the columnar grain zone and in 
RHO-BWI-ST-7

TABLE 2-48. Reported Fission-Product Phase Chemistry in Spent Fue .**

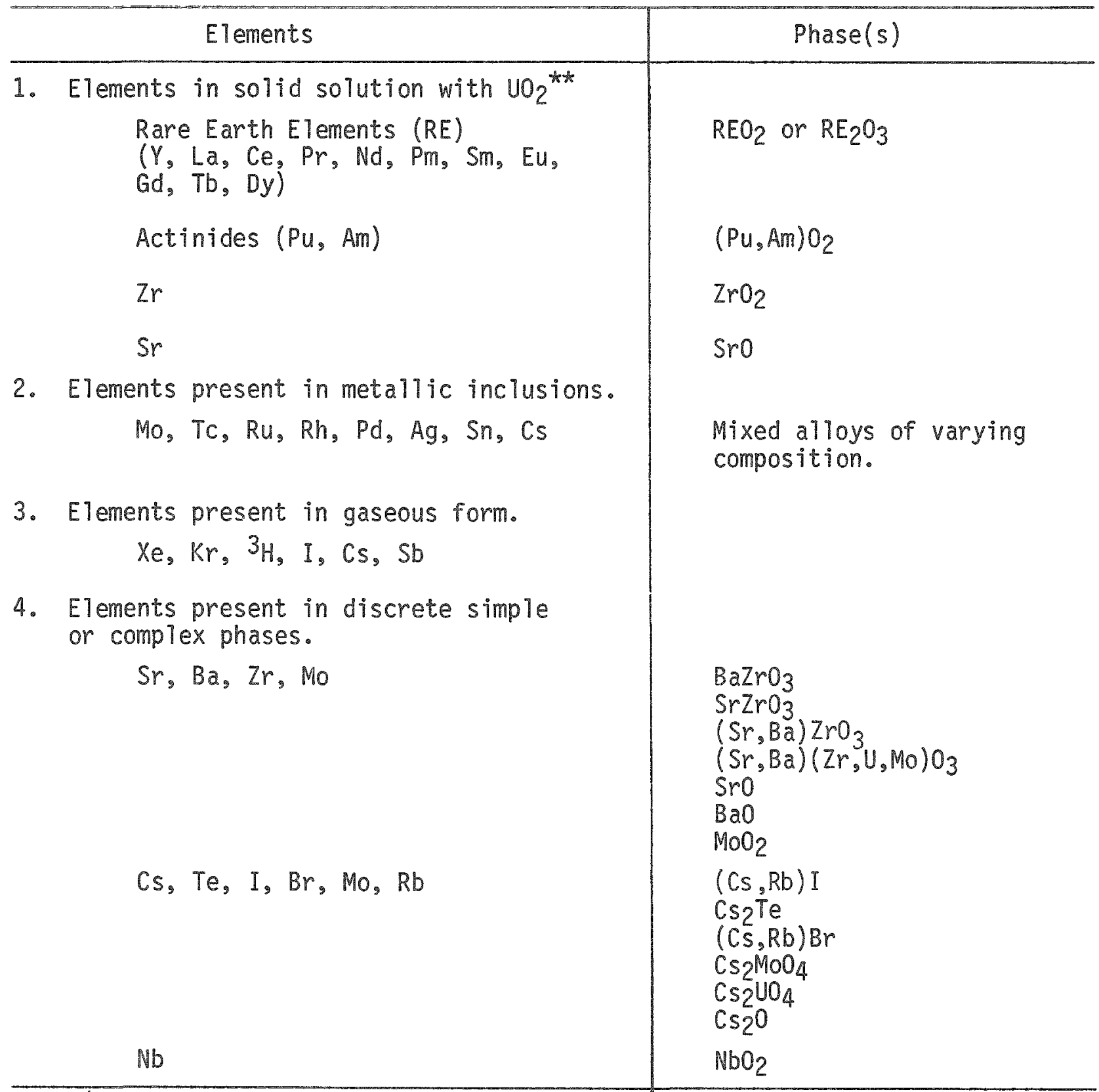

"Cubicciotti and Sanecki, 1978; Leitnaker, 1974; Lindemer, 1977; Davies and Ewart, 1971; O'Boyle and Others, 1969; Jeffrey, 1967; Koizumi and Others, 1974; Sari and Others, 1979; Ewart and Taylor, 1976.

${ }^{* *}$ A given fission product may be present in more than one phase, depending upon its location in the fuel pellet and the elements present in the locale (see text). 
the outer fringes of the pellets. $(\mathrm{Ba}, \mathrm{Sr}) \mathrm{ZrO}_{3}$ is stable from about 0.5 is stable from about 0.5 pellet radii (columnar grain zone) across the equiaxed grains into the original matrix. The individual zirconates, as well as $(\mathrm{Ba}, \mathrm{Sr})(\mathrm{U}, \mathrm{Zr}) \mathrm{O}_{3}$ are also stable in this area. Barium and strontium are most concentrated in the equiaxed grains and in the periphery of the pellet.

Volumes of material describing fission product distributions in irradiated oxide fuels have been written. Comparatively little work has been done which reports unambiguous descriptions of the chemical state of fission products in irradiated $\mathrm{UO}_{2}$ fuel. Much of the reported work has been performed on mixed oxide fuels, where fission product corrosion of cladding is a serious problem. Such fuels have both different oxygen contents (hypo or hyperstoichiometric), different burnups, and different fission product spectra. Data on the chemical state of fission products in irradiated $\mathrm{UO}_{2}$ fuel have become particularly important for the synthesis of simulated spent fuel now that the storage and disposal of spent fuel elements is part of national policy. The information is also necessary to provide additional insight into the potential for spent fuel leaching.

\subsubsection{Simulated Spent Fuel. Simulated spent fuel for experimental} testing in contact with basalt and prototype engineered barriers has been synthesized according to the recipe and procedures developed by McCarthy and others (1978a). The recipe for the simulated spent fuel fission product array is shown in Table 2-49. The fission product mix, which requires thorough mixing in excess water, drying at $90^{\circ} \mathrm{C}$ after boil-down on a stirrer hot plate, denitration at $400^{\circ} \mathrm{C}$, and a thorough grinding after denitration, is fired at $600^{\circ} \mathrm{C}$ under flowing hydrogen to obtain the reduced fission product mixture characteristic of spent fuel. The reduced fission product mix is combined with $\mathrm{UO}_{2}$ to give a 96.5 wt\% $\mathrm{UO}_{2}$ (approximately $1 \%$ of which is a stand-in for $\mathrm{PuO}_{2}$ ), 3.5\% fission product stoichiometry. This mixture has typically been sintered in evacuated tubes at $1,100^{\circ} \mathrm{C}$ for many hours in attempts to encourage the formation of phases reported in spent fuel. 
TABLE 2-49. Simulated Spent Fuel Fission Products Formulationa (Burnup of $33,000 \mathrm{MWd} / \mathrm{MTU}$ ).

(After McCarthy and Others, 1978a.)

\begin{tabular}{|c|c|c|c|c|}
\hline Element & Atomic \% & Formulation for a $100 \mathrm{Meq}^{\mathrm{b}}$ Batch & oxide & Wt\% oxide \\
\hline $\mathrm{Zr}$ & 16.51 & $4.408 \mathrm{~g} \mathrm{ZrO}\left(\mathrm{NO}_{3}\right) \cdot 2 \mathrm{H}_{2} \mathrm{O}$ & $\mathrm{ZrO}_{2}$ & 14.3 \\
\hline Mo & 14.80 & $2.131 \mathrm{~g} \mathrm{MoO}_{3}$ & $\mathrm{MoO}_{3}$ & 14.9 \\
\hline Nd $(P m)^{c}$ & 11.37 & $4.980 \mathrm{~g} \mathrm{Nd}\left(\mathrm{NO}_{3}\right)_{3} \cdot 6 \mathrm{H}_{2} \mathrm{O}$ & $\mathrm{NdO}_{1.5}$ & 13.4 \\
\hline Ru & 9.19 & $27.5 \mathrm{ml} 10 \%$ Ru nitrate solution & $\mathrm{RuO}_{2}$ & 8.5 \\
\hline Cs & 8.41 & $1.640 \mathrm{~g} \mathrm{CsNO}_{3}$ & $\mathrm{CsO}_{0.5}$ & 8.3 \\
\hline $\mathrm{Ce}$ & 7.94 & $3.454 \mathrm{~g} \mathrm{Ce}\left(\mathrm{NO}_{3}\right)_{3} \cdot 6 \mathrm{H}_{2} \mathrm{O}$ & $\mathrm{CeO}_{2}$ & 9.5 \\
\hline Pd & 4.98 & $5.3 \mathrm{~m} 110 \%$ Pd Nitrate solution & $\mathrm{PdO}$ & 4.2 \\
\hline$s r$ & 4.21 & $0.893 \mathrm{~g} \mathrm{Sr}\left(\mathrm{NO}_{3}\right)_{2}$ & sro & 3.1 \\
\hline $\mathrm{Ba}$ & 4.21 & $1.099 \mathrm{~g} \mathrm{Ba}\left(\mathrm{NO}_{3}\right)_{2}$ & $\mathrm{BaO}$ & 4.5 \\
\hline La & 3.74 & $1.619 \mathrm{~g} \mathrm{La}\left(\mathrm{NO}_{3}\right)_{3} \cdot 6 \mathrm{H}_{2} \mathrm{O}$ & $\mathrm{LaO}_{1.5}$ & 4.3 \\
\hline $\operatorname{Pr}$ & 3.58 & $1.564 \mathrm{~g} \operatorname{Pr}\left(\mathrm{NO}_{3}\right)_{3} \cdot 6 \mathrm{H}_{2} \mathrm{O}$ & $\mathrm{PrO}_{1.5}$ & 4.1 \\
\hline Sm & 2.18 & $0.968 \mathrm{~g} \mathrm{Sm}\left(\mathrm{NO}_{3}\right)_{3} \cdot 6 \mathrm{H}_{2} \mathrm{O}$ & $\mathrm{Smo}_{1.5}$ & 2.6 \\
\hline$\gamma$ & 2.18 & $0.835 \mathrm{~g} \mathrm{Y}\left(\mathrm{NO}_{3}\right)_{3} \cdot 6 \mathrm{H}_{2} \mathrm{O}$ & $\mathrm{YO}_{1.5}$ & 1.7 \\
\hline Te & 1.87 & $0.299 \mathrm{~g} \mathrm{TeO}_{2}$ & $\mathrm{TeO}_{2}$ & 2.1 \\
\hline $\mathrm{Rh}$ & 1.56 & $1.61 \mathrm{ml} 10 \% \mathrm{Rh}$ nitrate solution & $\mathrm{RhO}_{1.5}$ & 1.4 \\
\hline $\mathrm{Rb}$ & 1.56 & $0.231 \mathrm{~g} \mathrm{RbNO}_{3}$ & $\mathrm{RbO}_{0.5}$ & 1.0 \\
\hline $\mathrm{Gd}(\mathrm{Eu}, \mathrm{Am}, \mathrm{Cm})$ & 1.09 & $0.492 \mathrm{~g} \mathrm{Gd}\left(\mathrm{NO}_{3}\right)_{3} \cdot 6 \mathrm{H}_{2} \mathrm{O}$ & $\mathrm{GdO}_{1.5}$ & 1.4 \\
\hline $\mathrm{Ag}$ & 0.31 & $0.050 \mathrm{~g} \mathrm{AgNO}_{3}$ & $\mathrm{AgO}_{\mathrm{O}}$ & 0.4 \\
\hline $\mathrm{Cd}$ & 0.31 & $0.040 \mathrm{~g} \mathrm{CdO}$ & $\mathrm{CdO}$ & 0.3 \\
\hline & & & & 100.0 \\
\hline
\end{tabular}

a Tc, I, $K r$, and $\mathrm{Xe}$ are not inciuded.

bMilliequivalent.

$\mathrm{C}_{\text {Elements in }}$ parentheses indicate that the preceding element is a stand-in. 
The fission product composition listed in Table 2-49 is a fairly accurate simulation of the actual fission product content of spent fuel, with stand-in elements replacing some radioactive or extremely expensive elements. However, both the physical structure of the simulated spent fuel and its chemical phase composition (when prepared as described above) are significantly different from actual spent fuel. The simulated product is homogeneous, both physically and chemically, and rather friable. Actual spent fuel pellets, as described earlier in this section, are physically and chemically heterogeneous due to the high temperatures which they experience in the reactor and the steep thermal gradient across the pellet. Irradiated $\mathrm{UO}_{2}$ pellet fragments are probabiy rather strong if uncracked. In addition, the fission product phases are not well simulated by the preparation conditions described above. Attempts are now under way at The Pennsylvania State University to prepare a better simulation of fission product phases in simulated spent fuel by employing hot isostatic pressing of simulated spent fuel at $1,300^{\circ} \mathrm{C}$ and $276 \mathrm{MPa}$ in an evacuated iron crucibie. The process replaces the last step in the procedure specified by Mccarthy and others (1978a). Spent fuel formulations on which hot isostatic pressing was performed under the reducing conditions imposed by the iron crucible may better simuiate the actual phase array in irradiated $\mathrm{UO}_{2}$.

The actual phases in spent fuer, and to some degree the inhomogeneity of irradiated $\mathrm{UO}_{2}$, may also be simulated by the addition of fine metal shot and fragments of presynthesized, we 11-characterized fission product phases. The feasability of this approach has yet to be tested. However, the final product would still be relatively homogeneously mixed, but would more accurately simulate inclusions of fission product phases. The grain structure, fission product distribution, and effects of radioisotopes in the spent fuel are probably not amenable to accurate simulation. Therefore, experiments with actual spent fuel will be required to study any waste-barrier-rock interactions which are a strong function of these unique properties. 


\subsubsection{High-Level Liquid Wastes and Calcines}

If spent fuel is reprocessed by the PUREX (Cleveland, 1970) or similar methods to recover uranium and plutonium for reuse, a solution of fission product nitrates plus some suspended solids results as a by-product. Such a solution is not an ideal medium for the long-term storage of high-level radioactive waste. The liquid is highly corrosive, easily dispersible to the environment by water transport, and occupies a large volume. It is, therefore, highly advantageous to solidify the liquid waste, substantially reducing or eliminating the problems discussed above.

The liquid waste may be converted to solid form with a significant volume reduction by any of a variety of rapid evaporation processes. These processes typically employ temperatures in the range of $503^{\circ}$ to $700^{\circ} \mathrm{C}$ (McCarthy, 1975a; Bonner and Others, 1976) causing partial decomposition of hydrates and nitrates during the drying process. The product, which is called calcine, takes the form of a fine powder if spray calcination has been used, or of granules in the case of fluidized bed calcination.

Calcine generally appears amorphous when examined by X-ray diffraction. The amorphous nature of the product arises from the low temperature and short duration of processing. Calcines also typically possess high surface areas, which in turn imply high reactivity and susceptibility to leaching by water. A number of the oxides present in calcine are highly water soluble, a further disadvantage. If left unconsolidated, calcine may be easily dispersed by the action of wind and water. Such properties make unmodified calcine a poor choice for the permanent disposal of high-level waste in any geologic media.

Calcination of high-level waste is now perceived as the first step in the production of solid waste forms by more complex processes. Prototype waste processing methods (McCarthy, 1977a; Mende1, 1978) have been designed to solidify modified calcines into monolithic, wel1-consolidated, compact forms. Basic calcines (without additives) used as precursors for 
glassy and supercalcine waste forms have been primarily based on six PUREX-type wastes, respectively labeled PW-4b, PW-7, PW-7a, PW-8a, and PW-9. The compositions of these high-level wastes are listed in Table $2-50$.

The PW-4b high-level waste formulation corresponds to waste from an optimized reprocessing plant operation, in which little uranium or plutonium is lost to the waste stream (Mendel and 0thers, 1977). It is also low in inerts or reprocessing chemicals. PW-4b is a clean, or low sodium, waste (McCarthy, 1977a). Researchers at Pacific Northwest Laboratory (Mendel and Others, 1977) consider this waste stream representative of that proposed for General Electric Company's Midwest Fuel Recycle Plant, and a suitable substitute for high-level waste which may be generated by the Exxon Corporation's fuel reprocessing plant.

The PW-7a waste is similar to that which was planned for the Allied General Nuclear Services' plant in Barnwe11, South Carolina. This waste is a combination of high-level waste and intermediate-level waste, which is responsible for the high sodium and phosphorus content. Excess gadolinium has been added to this waste stream as a burnable poison for criticality control. Uranium and plutonium contents of the waste are higher than those in PW-4b, due to lower expected separation efficiencies (99.0\% vs. 99.9\%). The PW-7 composition is a low-sodium version of $\mathrm{PW}-7 \mathrm{a}$.

PW-7C is an updated PW-7a waste which reflects recent changes in regulations, expected burnup, and mixing ratios of high-level waste and intermediate-level waste (Ross and others, 1978). The large increase in $\mathrm{Gd}_{2} \mathrm{O}_{3}$ was due to regulation changes. The $\mathrm{PW}-7 \mathrm{C}$ composition represents waste from the early years of reactor operation in which fuel burnup, and thus the fission product content, is lower. The shearing operation in the fuel chop and leach process adds the zirconium fines to the waste stream. Additional intermediate-level waste increases the $\mathrm{Na}_{2} \mathrm{O}$ and $\mathrm{U}_{3} \mathrm{O}_{8}$ concentrations over that in $\mathrm{PW}-7 \mathrm{a}$, and adds $\mathrm{MnO}_{2}$.

The PW-8a waste is typical of the high-level waste currently stored at Nuclear Fuel Services, West Lake, New York (McCarthy, 1977a). It is 
TABLE 2-50. Reference High-Level Waste

Compositions, wt\% Oxides.

(After McElroy, 1975; Ross and Others, 1978.)

\begin{tabular}{|c|c|c|c|c|c|c|c|}
\hline & & $P W=4 b$ & PW-7 & $P W-7 a$ & $P W-7 c$ & PW-8a & PW-9 \\
\hline \multirow[t]{8}{*}{ Inerts } & $\mathrm{Na}_{2} \mathrm{O}$ & $=$ & 0.18 & 9.06 & 9.50 & 15.08 & 10.12 \\
\hline & $\mathrm{Fe}_{2} \mathrm{O}_{3}$ & 3.70 & 4.62 & 3.98 & 3.63 & 29.21 & 2.61 \\
\hline & $\mathrm{Cr}_{2} \mathrm{O}_{3}$ & 0.84 & 0.53 & 0.45 & 0.05 & 1.24 & 0.60 \\
\hline & NiO & 0.35 & 0.22 & 0.19 & 0.02 & 0.61 & 0.24 \\
\hline & $\mathrm{P}_{2} \mathrm{O}_{5}$ & 1.65 & 4.10 & 8.36 & 7.03 & 1.44 & 1.16 \\
\hline & $\mathrm{MnO}_{2}$ & - & - & - & 0.32 & - & - \\
\hline & $\mathrm{Gd}_{2} \mathrm{O}_{3}$ & - & 15.83 & 13.65 & 30.71 & - & - \\
\hline & $\mathrm{ZrII}$ Fine $\left(\mathrm{ZrO}_{2}\right)$ & - & - & - & 0.40 & - & - \\
\hline \multirow[t]{22}{*}{ Fission Products } & $\mathrm{Rb}_{2} \mathrm{O}$ & 0.87 & 0.54 & 0.47 & 0.33 & 0.38 & 0.73 \\
\hline & sro & 2.59 & 1.62 & 1.40 & 0.86 & 1.14 & 2.10 \\
\hline & $\mathrm{Y}_{2} \mathrm{O}_{3}$ & 1.46 & 0.91 & 0.79 & 0.52 & 0.64 & 1.18 \\
\hline & $\mathrm{ZrO}_{2}$ & 12.11 & 7.55 & 6.52 & 4.50 & 5.31 & 9.66 \\
\hline & $\mathrm{MoO}_{3}$ & 12.67 & 7.91 & 6.82 & 4.69 & 5.55 & 10.34 \\
\hline & $\mathrm{TC}_{2} \mathrm{O}_{7}$ & 3.16 & 1.97 & 1.70 & 1.24 & 1.39 & 2.31 \\
\hline & $\mathrm{RuO}_{2}$ & 7.28 & 4.54 & 3.92 & 2.57 & 3.19 & 6.43 \\
\hline & $\mathrm{Rh}_{2} \mathrm{O}_{3}$ & 1.17 & 0.73 & 0.63 & 0.48 & 0.52 & 0.91 \\
\hline & Pdo & 3.63 & 2.27 & 1.95 & 1.47 & 1.59 & 3.44 \\
\hline & $\mathrm{Ag}_{2} \mathrm{O}$ & 0.22 & 0.13 & 0.12 & 0.07 & 0.09 & 0.14 \\
\hline & $\operatorname{cdo}$ & 0.24 & 0.15 & 0.13 & 0.08 & 0.10 & 0.24 \\
\hline & $\mathrm{TeO}_{2}$ & 1.78 & 1.11 & 0.96 & 0.65 & 0.78 & 1.46 \\
\hline & $\mathrm{Cs}_{2} \mathrm{O}$ & 7.05 & 4.40 & 3.80 & 2.37 & 3.09 & 5.80 \\
\hline & $\mathrm{BaO}$ & 3.84 & 2.39 & 2.07 & 1.64 & 1.68 & 3.31 \\
\hline & $\mathrm{La}_{2} \mathrm{O}_{3}$ & 3.62 & 2.26 & 1.95 & 1.34 & 1.59 & 3.09 \\
\hline & $\mathrm{CeO}_{2}$ & 8.14 & 5.08 & 4.38 & 2.73 & 3.57 & 6.97 \\
\hline & $\mathrm{Pr}_{6} \mathrm{O}_{11}$ & 3.63 & 2.26 & 1.95 & 1.30 & 1.59 & 3.12 \\
\hline & $\mathrm{Nd}_{2} \mathrm{O}_{3}$ & 11.07 & 6.91 & 5.96 & 4.31 & 4.85 & 9.45 \\
\hline & $\mathrm{Pm}_{2} \mathrm{O}_{3}$ & 0.30 & 0.19 & 0.16 & 0.03 & 0.13 & 0.26 \\
\hline & $\mathrm{Sm}_{2} \mathrm{O}_{3}$ & 2.26 & 1.41 & 1.22 & 0.98 & 0.99 & 1.94 \\
\hline & $\mathrm{Eu}_{2} \mathrm{O}_{3}$ & 0.49 & 0.31 & 0.26 & 0.17 & 0.21 & 0.42 \\
\hline & $\mathrm{Gd}_{2} \mathrm{O}_{3}$ & 0.34 & 0.21 & 0.18 & 0.10 & 0.15 & 0.29 \\
\hline \multirow[t]{6}{*}{ Actinides } & $\mathrm{U}_{3} \mathrm{O}_{8}$ & 2.86 & 17.86 & 15.40 & 15.37 & 12.54 & 9.72 \\
\hline & $\mathrm{NpO}_{2}$ & 2.12 & 1.32 & 1.14 & 0.20 & 0.93 & 1.21 \\
\hline & $\mathrm{PuO}_{2}$ & 0.02 & 0.16 & 0.14 & 0.15 & 0.19 & 0.14 \\
\hline & $\mathrm{Am}_{2} \mathrm{O}_{3}$ & 0.44 & 0.28 & 0.24 & 0.17 & 0.19 & 0.44 \\
\hline & $\mathrm{Cm}_{2} \mathrm{O}_{3}$ & 0.10 & 0.06 & $\underline{0.05}$ & $\underline{0.01}$ & 0.04 & $\underline{0.17}$ \\
\hline & TOTAL & 100.01 & 100.01 & 100.02 & 99.99 & 100.00 & 100.00 \\
\hline
\end{tabular}


a7so a "dirty" (high sodium) waste resulting from a combined highlevel/intermediate-level waste stream. Excess iron in $\mathrm{PW}-8 \mathrm{a}$ resulted from the use of thin, mild steel, basket liners in the chopped fuel transfer process, which were dissolved along with the fuel (Mendel and others, 1977).

These waste compositions may be expected to vary somewhat from the values given. The fission product content, which is based on a burnup of $33,000 \mathrm{MW}$ days per metric ton uranium, will vary as a function of actual fuel burnup. The PW-9 waste, calculated for a burnup of 40,000 MW days per metric ton uranium, represents such a variation. It is also a relatively clean waste with moderate sodium and uranium concentrations. Startup and shutdown of reprocessing plants for inspection, maintenance, and material accountability inventories will generate larger volumes of intermediate-level waste. Changes in the types and amounts of reprocessing chemicals will also influence the composition of the waste stream to varying degrees. Waste compositions which account for such changes have been defined by McETroy (1974a and 1974b, 1975, 1976).

A number of other possible waste streams may become important if nuclear fuel reprocessing occurs in the United States. Such wastes could include the THOREX wastes from the processing of urania-thoria fuels, and wastes from $\mathrm{UO}_{2}-\mathrm{PuO}_{2}$ fast breeder reactor fuels. The fission product spectra of such fuels differ somewhat from that of $\mathrm{UO}_{2}$ light water reactor fuel due to both plutonium or thorium fission and different burnups. Fast breeder reactor fuels, for instance, are projected to reach burnups of 50,000 MW days per metric ton uranium/plutonium. Comparatively litile research has been conducted on waste forms for high-level waste streams from these options.

For high-level waste from commercial pressurized water reactors, calcine appears to be $v$ able only as a processing step rather than as an end product waste form. Some research is currently under way at Idaho National Engineering Laboratory on the pelletization of calcined defense fuel wastes (Lamb and Cole, 1979). This work has yielded promising 
results for calcines now stored at Idaho Falls, Idaho. However, the process has been given little attention by researchers developing solid waste forms for commercial high-level waste. The waste form may also not be applicable to these wastes.

\subsubsection{G1 ass}

2.6.4.1 The GTass Waste Form Concept. G1ass has probably received more study as a potential solid for high-level waste immobilization than all other waste forms combined in the 20 years which have passed since its first proposal (Mende1, 1978). The concept has attracted much attention due to its relative engineering simplicity, low cost, and apparent strengths. Among the strengths of glass are its ability to dissolve a wide variety of elements in the glass-forming network, its monolithic form when poured and cast, and its physical strength and resistance to leaching in at least some of the proposed repository environments (Mende1, 1978). A glass waste form is also insensitive to many of the fluctuations in waste stream composition which may occur in a reprocessing plant, and its stability is not greatly affected by radiation damage as some crystal structures are.

Most glass-melting operations are perceived as a two-step operation. The Tiquid waste is calcined by either spray or fluidized bed calcination techniques to drive off water and nitrates. The calcine is blended with a glass-forming material (frit) and is melted. The melter may be either an in-can type, in which the canister itself is the melt container, or a continuous melter whose contents are periodically emptied into a canister. As an option, the properly mixed liquid waste stream may also be added directly to some melters. Drying, denitration, and glass melt formation occur simultaneously in such a device. Another option, which is a precursor to the more complex, multiple barriers waste form, is to produce small glass spheres by methods such as dropping beads of molten glass onto a cooled rotating metal disc. The multiple barriers waste form is described in more detail in Section 2.6.5.

\subsubsection{The Chemistry of Waste Glass Formulations. A large number of} glass formulations have been developed and tested for various waste 
streams both in the United States and abroad. The formulations have included phosphate, borosilicate, and aluminosilicate glasses, as well as glass ceramics. Most of the radioactive waste glasses which have been developed to the point of process application are borosilicate glasses (Mende 1, 1978). Borosilicate glass has been chosen as the reference glass waste form in the United States because of its low dissolution rate in water (at 1 atmosphere pressure and temperatures less than $100^{\circ} \mathrm{C}$ ) and good physical integrity. Borosilicate glass can accommodate a wide variety of waste elements, is relatively slow to devitrify under anhydrous conditions, and is stable to radiation effects (McElroy and Burns, 1979). Radioactive waste elements usually constitute 25 to 35 wt\% of the waste glass. At the Pacific Northwest Laboratory, many glass formulations, including melts containing actual high-level waste, have been prepared and extensively characterized. Several of the borosilicate formulations have been used as reference materials in solid waste performance tests at Pacific Northwest Laboratory, The Pennsylvania State University, and other Taboratories across the nation.

The chemistries of four Pacific Northwest Laboratory simulated high-level waste glasses are given in Table 2-51, including the designation numbers and compositions of the glass-making frits required by each particular waste stream. These formulations were developed for several of the high-level waste compositions described in Section 2.6.3. Several hundred grams of fully radioactive waste glass with the compositions listed in Table 2-51 have also been prepared and are undergoing testing (Ross and Others, 1978; Bradley, 1978; Wald and Westsik, 1979). In addition, two test canisters of radioactive borosilicate waste glass were produced in early 1979 as part of the Nuclear Waste Vitrification Project (MCElroy and 0thers, 1979a). Borosilicate waste glasses such as these are roughiy analogous to Pyrex in composition ( $82 \% \mathrm{SiO}_{2}, 12 \% \mathrm{~B}_{2} \mathrm{O}_{3}, 4 \% \mathrm{Na}_{2} \mathrm{O}$ ) and melting temperatures. Boron lowers the melting (and, therefore, the processing) temperature of the glass by lowering its viscosity and increases the solubility of many waste elements in silica-based glass.

Ideally, all waste elements should be soluble in waste glasses. In practice, this is not the case. Palladium metal and $\mathrm{RuO}_{2}$ are usually 
RHO-BWI-ST-7

TABLE 2-51. Reference Waste Glass Compositions. $\left(W t \%^{*}\right)$

(After Ross and Others, 1978.)

\begin{tabular}{|c|c|c|c|c|}
\hline Glass Code & $72-68$ & $76-68$ & $77-260$ & $77-107$ \\
\hline Waste Type & $P W-4 b$ & PW-8a & $\mathrm{PW}-7 \mathrm{C}$ & PW-9 \\
\hline Frit Code & $73-1$ & $76-101$ & $77-269$ & $77-268$ \\
\hline $\mathrm{SiO}_{2}$ & 27.3 & 40.0 & 36.0 & 38.0 \\
\hline $\mathrm{B}_{2} \mathrm{O}_{3}$ & 11.1 & 9.5 & 9.0 & 13.0 \\
\hline $\mathrm{Na}_{2} \mathrm{O}$ & 4.0 & 7.5 & 8.0 & 2.0 \\
\hline $\mathrm{K}_{2} \mathrm{O}$ & 4.0 & - & 2.0 & 4.0 \\
\hline Zno & 21.3 & 5.0 & - & 5.0 \\
\hline $\mathrm{CaO}$ & 1.5 & 2.0 & 1.0 & 2.0 \\
\hline MgO & 1.5 & - & - & - \\
\hline sro & 1.5 & - & - & - \\
\hline $\mathrm{BaO}$ & 1.5 & - & - & - \\
\hline $\mathrm{TiO}_{2}$ & - & 3.0 & 6.0 & 3.0 \\
\hline $\mathrm{Al}_{2} \mathrm{O}_{3}$ & - & - & 2.0 & - \\
\hline CuO & - & - & 3.0 & - \\
\hline Waste & 26.3 & 33.0 & 33.0 & 33.0 \\
\hline
\end{tabular}

*Normalized to $100 \%$. 
present in the amorphous matrix as crystalline inclusions, and rarely, if ever, dissolve in the glass (Mendel and others, 1977; Turcotte and Wald, 1978). Also present in melts of 72-68 glass were $\left(\mathrm{Ce}, \mathrm{Zr}, \mathrm{RE}^{+3}\right) \mathrm{O}_{2-x}$ ( $R E=$ rare earth elements) and a trace of spinel-structure $(\mathrm{Zr}, \mathrm{Ni})$ $(\mathrm{Fe}, \mathrm{Cr})_{2} \mathrm{O}_{4}$

A glass may partially crystallize or devitrify under certain conditions. In such an occurrence, atoms in the random, glassy network rearrange themselves forming an ordered crystalline structure which is more thermodynamically stable than the glass. The rate of devitrification is both time and temperature dependent. Measurable waste glass devitrification typically occurs only between $500^{\circ}$ and $950^{\circ} \mathrm{C}$ (Mendel, 1978). Above this range, crystals other than those mentioned in the preceding paragraph redissolve in the glass. Below $500^{\circ} \mathrm{C}$, crystallization is diffusion-limited because of the high viscosity of the glass matrix, and hence, is very slow.

A number of crystalline phases have been consistently observed in nuclear waste glass formulations which have devitrified. Crystallites of these phases are large compared to those of the phases which never dissolve, and may cause damage (microcracking) in the glass structure. Significant quantities of $(\mathrm{Cs}, \mathrm{Sr}, \mathrm{Ba}) \mathrm{MOO}_{4}, \mathrm{Zn}_{2} \mathrm{SiO}_{4}$, and $\mathrm{Ca}_{2} \mathrm{RE}_{8}\left(\mathrm{SiO}_{4}\right)_{6} \mathrm{O}_{2}$ (apatite) crystals have been observed in devitrified samples of 72-68 glass (Mendel and Others, 1977: Turcotte and Wald, 1978).

The devitrification phases observed in the other reference glass formulations varied significantly from those reported for $72-68 \mathrm{glass}$. These differences may be attributed to both variation of the additives and differences in the waste streams under consideration. For example, in isothermal treatments in the $600^{\circ}$ to $900^{\circ} \mathrm{C}$ range, crystals of the phase NiFeSi,0, slowly grew into the 76-68 glass matrix (Ross and Mendel, 1979). Approximately 30 wt\% (as estimated by $x$-ray diffraction) of the glass crystallized as this phase during 1 year of annealing at $750^{\circ} \mathrm{C}$ (McElroy and others, 1979a). The devitrification products observed in the four reference glass formulations are summarized in Table $2-52$.

Measurable anhydrous devitrification occurs in a relatively narrow range of annealing temperatures for these glass formulations. The center 
TABLE 2-52. Crystalline Phases in Waste Glass Formulations.*

\begin{tabular}{|c|c|c|c|}
\hline Glass & Phase & Max Wt\% & Occurrence \\
\hline \multirow[t]{7}{*}{$72-68$} & $\mathrm{RuO}_{2}$ & 1.4 & Melt Insoluble \\
\hline & $(\mathrm{Ni}, \mathrm{Zr})(\mathrm{Fe}, \mathrm{Cr})_{2} \mathrm{O}_{4}$ & trace & Melt Insoluble \\
\hline & $\mathrm{Pd}$ & 3.0 & Melt Insoluble \\
\hline & $\left(\mathrm{Ce}, 2 r, \mathrm{RE}^{+3}\right) \mathrm{O}_{2-x}$ & 5.0 & Melt Insoluble \\
\hline & $\mathrm{Zn}_{2} \mathrm{SiO}_{4}$ & 14.0 & Devitrification Product \\
\hline & $\left(\mathrm{Ca}, \mathrm{Sr}_{2}, \mathrm{Ba}\right) \mathrm{MOO}_{4}$ & 6.0 & Devitrification Product \\
\hline & $\mathrm{Ca}_{2}\left(\mathrm{RE}^{3+}\right)_{8}\left(\mathrm{SiO}_{4}\right)_{6} \mathrm{O}_{2}$ & 3.0 & Devitrification Product \\
\hline \multirow[t]{7}{*}{$76-68$} & $\mathrm{RuO}_{2}$ & $\sim 2.0$ & Melt Insoluble \\
\hline & $\mathrm{NiFe}_{2} \mathrm{O}_{4}$ & $\sim 2.0$ & Melt Insoluble \\
\hline & $\mathrm{Pd}$ & trace & Melt Insoluble \\
\hline & $\left(C e, U, R E^{+3}\right) O_{2}$ & $\sim 2.0$ & Devitrification Product \\
\hline & $\mathrm{NaFeSi}_{2} \mathrm{O}_{6}$ & $\approx 30.0$ & Devitrification Product \\
\hline & $\mathrm{CaMoO}_{4}$ & trace & Devitrification Product \\
\hline & $(\mathrm{Ce}, \mathrm{RE}) \mathrm{PO}_{4}$ & trace & Devitrification Product \\
\hline \multirow[t]{7}{*}{$77-107$} & $\mathrm{RuO}_{2}$ & NR* $* \hbar$ & Melt Insoluble \\
\hline & $\mathrm{NiFe}_{2} \mathrm{O}_{4}$ & NR & Melt Insoluble \\
\hline & $\mathrm{Pd}$ & NR & Melt Insoluble \\
\hline & $\mathrm{CeO}_{2}$ & NR & Devitrification Product \\
\hline & $\mathrm{CaMOO}_{4}$ & NR & Devitrification Product \\
\hline & $\mathrm{TiO}_{2}$ & NR & Devitrification Product \\
\hline & $\mathrm{NdBSiO}_{5}$ & NR & Devitrification Product \\
\hline \multirow[t]{6}{*}{$77-260$} & $\mathrm{RuO}_{2}$ & NR & Melt Insoluble \\
\hline & $\mathrm{NiFe}_{2} \mathrm{O}_{4}$ & NR & Melt Insoluble \\
\hline & $\mathrm{Pd}$ & NR & Melt Insoluble \\
\hline & $\mathrm{CeO}_{2}$ & NR & Devitrification Product \\
\hline & $\mathrm{Gd}_{2} \mathrm{Ti}_{2} \mathrm{O}_{7}$ & NR & Devitrification Product \\
\hline & $\mathrm{Ca}_{3} \mathrm{Gd} 7\left[\mathrm{SiO}_{4}\right]_{5}\left(\mathrm{PO}_{4}\right) \mathrm{O}_{2}$ & NR & Devitrification Product \\
\hline
\end{tabular}

*Turcotte and Wald, 1978; Ross and Others, 1978; Ross and Mendel, 1979; MCEIroy and Others, 1979a; Wald and Westsik, 1979. **Not reported. 


\section{RHO-BWI-ST-7}

of the range, which spans about $300^{\circ} \mathrm{C}$, lies at about $750^{\circ} \mathrm{C}$ for short anneals, and at 650 to $700^{\circ} \mathrm{C}$ for anneals of several months (Ross and Mende1, 1979). Melt insolubles constitute from 4 to $7 \%$ of the four reference waste glass formulations (Wald and Westsik, 1979). Devitrification on slow cooling or during extended annealings of these glass formulations has yielded a maximum of $45 \%$ crystalline material in the devitrified specimens (of 72-68 and 77-260), with 76-68 glass being the most devitrification-resistant of the glass specimens studied. No devitrification has been observed in samples annealed at temperatures less than $500^{\circ} \mathrm{C}$. Fully radioactive analogs of the formulations described above devitrify in a similar manner to the simulated specimens, and contain the same melt-insoluble phases (Wald and Westsik, 1979), atthough in lesser quantities.

The formation of crystallites within the glass matrix may significantly alter properties such as leach resistance. For instance, the leachability of 72-68 glass was significantly increased by microcracking due to devitrification (Ross and others, 1978). The chances for waste glass devitrification are greatest during the first 100 years after its production, when the decay heat loads are the largest. The effects of devitrification on waste glass properties are discussed in more detait in the next section.

A variety of other waste glass formulations have been studied by various researchers. The average compositions of various types of waste glasses are presented in Table 2-53. Much interest has focused on the phosphate glasses, although a number of problems have inhibited their development (Mendel, 1978). These formulations produce low-melting giasses, which eases some processing requirements. However, phosphate solutions exhibit high ruthenium volatilities during denitration, and the melt is extremely corrosive. Phosphate glasses also devitrify rapidiy when held at temperatures greater than $500^{\circ} \mathrm{C}$, with a 1,000 -fold increase in the leach rate of the glass occurring as a result.

Aluminosilicate glasses and glass-ceramics have also been studied as waste forms. Aluminosilicate glasses have excellent chemical durability, but process considerations (very high melting point) and limited waste loading (Jess than 10 wt\%) have turned development of waste glasses in 
TABLE 2-53. Typical Waste Glass Compositions.

(After Mende1, 1978.)

\begin{tabular}{|c|c|c|c|c|}
\hline \multirow[b]{2}{*}{ Oxides } & \multicolumn{4}{|c|}{ Glass Composition, Wt\% } \\
\hline & Borosilicate & $\begin{array}{l}\text { Alumino- } \\
\text { silicate }\end{array}$ & $\begin{array}{l}\text { Glass- } \\
\text { Ceramic }\end{array}$ & Phosphate \\
\hline $\mathrm{SiO}_{2}$ & $25-50$ & $33-40$ & $32-60$ & $0-6$ \\
\hline $\mathrm{B}_{2} \mathrm{O}_{3}$ & $9-22$ & - & $1-11$ & - \\
\hline $\mathrm{P}_{2} \mathrm{O}_{5}$ & $0-2$ & - & - & $30-55$ \\
\hline Alkali Metal Dxides & $8-19$ & $18-22$ & $0-13$ & $5-25$ \\
\hline Alkaline Earth 0xides & $0-6$ & $13-16$ & $2-33$ & - \\
\hline $\mathrm{Fe}_{2} \mathrm{O}_{3}, \mathrm{Cr}_{2} \mathrm{O}_{3}, \mathrm{NiO}$ & $1-20$ & - & - & $0-30$ \\
\hline $\mathrm{Al}_{2} \mathrm{O}_{3}$ & $0-10$ & $26-30$ & $10-24$ & $0-35$ \\
\hline $\mathrm{TiO}_{2}$ & $0-3$ & - & $0-3$ & - \\
\hline Zno & $0-22$ & - & $0-13$ & - \\
\hline CuO & $0-3$ & - & - & - \\
\hline $\mathrm{PbO}$ & $0-50$ & - & - & $0-30$ \\
\hline $\mathrm{Gd}_{2} \mathrm{O}_{3}$ & $0-12$ & - & - & - \\
\hline Fission Products & 30 & 5 & 20 & 30 \\
\hline Actinides & 10 & 1 & 7 & 10 \\
\hline
\end{tabular}

other directions (Mende 1, 1978). Glass-ceramics have aiso begun to receive modest consideration. A glass-ceramic is basically a glass which has a tendency to crystallize. The glass is crystallized under controlled conditions forming very small, uniformly sized crystals embedded in a glass matrix. The crystal phases can be tailored to achieve the desired properties. Glass ceramics have a higher thermal stability and are tougher than ordinary glasses. However, many questions remain to be answered about the stability of such a waste form under long-term repository storage. For instance, tests with some glassceramic waste forms have indicated that only 50 to $60 \%$ crystallinity can be achieved, with the residual glassy phase exhibiting poorer leach behavior than that of a comparable glass waste form (Rusin, 1980). 
2.6.4.3 Physical Properties of Waste Glass. From a process standpoint, a low melting point is desirable in radioactive waste glasses. Typical glass formulations have been designed to have melting points in the $950^{\circ}$ to $1,150^{\circ} \mathrm{C}$ range. This temperature range reduces corrosion in the melter and limits volatilization from the glass melt during processing, while ensuring that a minimum amount of insoluble crystalline phases is formed in the final solid. Such considerations produce a more uniform, leach-resistant product.

The temperature of a waste glass canister at its surface and the thermal profile through it will significantly influence any reactions which take place between stored glass and intruding groundwater in the repository system. Such reactions may be particularly severe should they occur early in the thermal history of the canister. The absolute temperature of a waste giass canister will depend upon factors such as the irradiation history of the spent fuel and its type, the age of the waste at vitrification, and the waste loading of the giass (Mendel and others, 1977). The temperature profile across the canister will vary as a function of waste package conductivity, composition, and size. The thermal history during processing is also important. Cracks caused by quenching the hot glass/canister combination, which may be inevitable due to gross differences between the conductivity of the glass and its canister (Ross and Others, 1978), offer greatly increased surface area for reaction with intruding groundwater in the event of canister breach.

Thermal profiles have been caiculated for reference waste glass/canister systems. If the 72-68 glass is taken as a reference case, the heat generation rate as a function of time will be that listed in Table 2-54. This glass formulation, when poured into a $30.5-\mathrm{cm}$ inner dianeter, 3-m-1ong canister with 8 internal fins $6.4 \mathrm{~mm}$ thick (Mendel and others, 1977), produced the centerline thermal profile as a function of time shown in Figure 2-41 if the waste is 1 year old at vitrification. As illustrated by the figure, the thermal profile of the canister as the waste ages varies in different media, such as air or water. 
RHO-BWI-ST -7

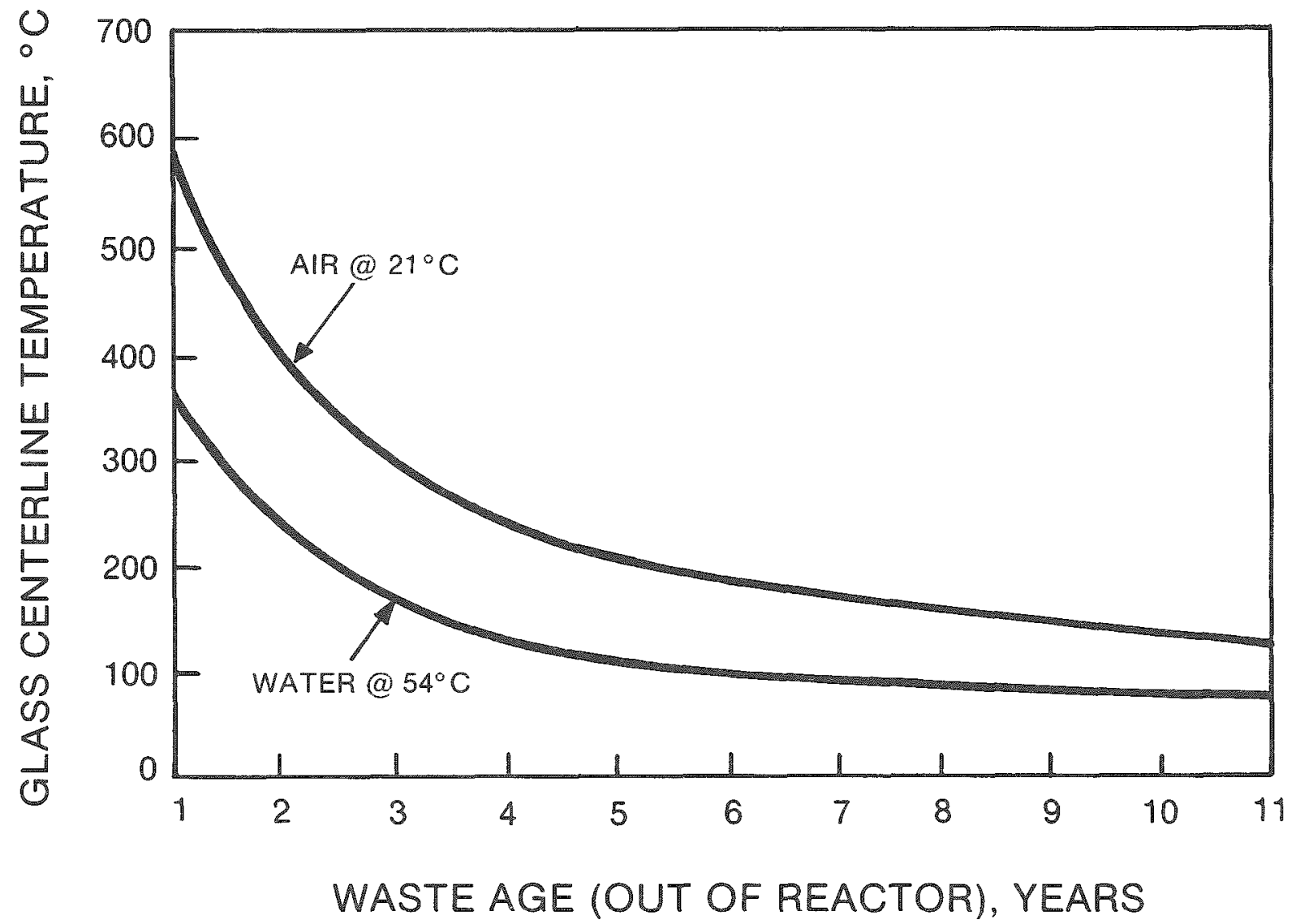

FIGURE 2-41. Centerline Temperatures of a Reference Canister Containing 72-68 Waste G1ass, Cooled in Air and Water. Canister: $30.5 \mathrm{~cm}$ diameter, $3 \mathrm{~m}$ long with 2.4-mm-thick internal fins. 
TABLE 2-54. Heat Generation Rates of Simulated PW-4b Waste Giass 72-68.

(After Mendel and Others, 1977.)

\begin{tabular}{c|c|c}
\hline BTU/hr-in & W/e & Approximate Age* \\
\hline 15.666 & 280 & 150 days \\
8.393 & 150 & 1 year (reference) \\
4.308 & 77 & 2 years \\
2.686 & 48 & 3 years \\
1.958 & 35 & 4 years \\
1.455 & 26 & 5 years \\
1.231 & 22 & 6 years \\
1.007 & 18 & 7 years \\
0.895 & 16 & 8 years \\
0.856 & 15.3 & 9 years \\
0.839 & 15.0 & 10 years \\
\hline
\end{tabular}

* Waste age reflects a reference scale assigned to a particular waste composition and is used strictly for comparative purposes.

An important property of waste glass, or any waste form, is its resistance to leaching by groundwater. Many specimens of various glass formulations have been tested (Mendel and Others, 1977) by the Soxhlet $\left(99^{\circ} \mathrm{C}, 1\right.$ atmosphere pressure), Paige $\left(23^{\circ}\right.$ to $99^{\circ} \mathrm{C}, 1$ atmosphere pressure), and modified International Atomic Energy Agency standard leach test $\left(23^{\circ} \mathrm{C}, 1\right.$ atmosphere pressure). The Soxhlet test employs hot, distilled water to accelerate water-glass reactions. The International Atomic Energy Agency test, which is used as a long-term test, requires that the leaching solution be periodically changed and sampled. These tests, while not representative of conditions which the glass (or any other waste form) will encounter in a mined geologic repository, do provide a convenient baseline for comparing the leach resistance of various waste giasses and identifying gross leachability problems. Glasses tested at Pacific Northwest Laboratory (Mendel and Others, 1977; Ross and Others, 1978) have also been leached at room temperature in solutions ranging from $\mathrm{pH} 1$ to 13 , followed by 24 hours of leaching in a Soxhlet apparatus. 
When leached under the relatively benign conditions which exist in the tests described above, borosilicate glasses exhibit comparatively low leach rates. Typical formulations, such as 72-68, exhibit initial longterm leachabilities of $\sim 10^{-5} \mathrm{gm} / \mathrm{cm}^{2} /$ day from as-formed $\mathrm{glass}$, with leach rate trailing off to $\sim 10^{-7} \mathrm{gm} / \mathrm{cm}^{2} /$ day after 2 to 3 weeks (Mendel and Others, 1977). Soxhlet testing of the four glass formulations listed in Table 2-51 revealed formulation 72-68 to have the lowest leach rate, while 77-107 and 77-260 formulations had intermediate values and 76-68 glass was the most leachable. In the long-term testing, 76-68 glass had better durability than 72-68 glass (Ross and 0thers, 1978).

A number of factors exist which may increase the leachability of nuclear waste glasses. Devitrification effects discussed in the previous section may increase the leachability of waste glass formulations, such as $72-68$, by an order of magnitude or more. These effects are directly related to storage temperature, with the most severe effects occurring at storage temperatures of $700^{\circ} \mathrm{C}$ in 72-68 glass. Leachability is approximately 7 times greater in 76-68 glass that has been maintained at $600^{\circ} \mathrm{C}$ to $750^{\circ} \mathrm{C}$ than in formulations fired at $550^{\circ} \mathrm{C}$ or less for extended periods. Tests with fully radioactive waste glass similar to formulation 72-68 (Bradley, 1978) indicate that cesium was the most leachable ion, followed in order of decreasing release by strontium, cobalt, antimony, manganese, piutonium, europium, rhodium, curium, and cerium. These results agree closely with data obtained from simulated waste glass formulations.

Two mechanisms control the leaching of ions from glass. The primary mechanism below $80^{\circ} \mathrm{C}$ (Mendel, 1978) is diffusion-controlled ion exchange. As cations are depleted from the surface layer, a silica-rich film develops which acts as a barrier, slowing the rate of leaching. The second mechanism is surface corrosion which erodes, and mechanically sloughs off, hydrated surface layers of the glass. At temperatures greater than $80^{\circ} \mathrm{C}$, corrosion usually controls glass leaching. In unaltered glass (Mendel and Others, 1977), diffusion mechanisms typically control leaching, while corrosion effects are dominant in devitrified glasses. 
When specimens of waste glass are subjected to hydrothermal testing (up to $350^{\circ} \mathrm{C}$ and 300 bars pressure), an entirely different reaction is observed. At temperatures above $2150^{\circ} \mathrm{C}$, glass reacts rapidly with the groundwater to form several crystalline species. This alteration front spreads throughout the glass at a rate determined by many factors, including temperature. The presence of a geologic medium usual1y enhances such reactions (Mende1, 1978). Hydrothermal alteration of glass and other waste forms is discussed in greater detail in Section 2.6.7.

Waste glass formulations have also undergone testing to determine their resistance to radiation damage over long time spans. Specimens of waste glass have been irradiated with doses up to $5 \times 10^{11}$ rads beta and gamma radiation with little effect (Mende1, 1978). Alpha radiation, which can also cause significant damage, has been tested in waste glass formulations. Tests in which specimens of glass have been subjected to integrated alpha doses of up to $4 \times 10^{18}$ a/g have yielded only minimal effects.

In many respects, glass appears to be a suitable form for the solidification of nuclear waste. However, many reactions of the waste with hot, pressurized groundwater and geologic media require quantification so that engineered barrier systems may be properly designed to minimize, and possibly eliminate, the detrimental effects of a waste glass canister breach.

\subsubsection{Tailored Ceramics}

Tailored ceramic waste forms provide an alternative to glass for the solidification of high-level liquid wastes that result from spent fuel reprocessing. Ceramic waste forms are designed to isolate fission product radionuclides on an atomic scale by incorporating them into the lattices of highly stable, crystalline minerals. Ideally, such minerals should be extremely resistant to decomposition and weathering effects.

A variety of crystalline waste forms have been proposed. Many of these have reached only a limited stage of development or are applicable only to very specialized wastes. In this section, three tailored ceramic waste forms which have received significant attention as candidates for 
high-level commercial waste solidification in the United States are described. These are the supercalcine ceramic, SYNROC, and the multiple barrier waste forms. Descriptions of other ceramic waste forms are given by Chikalla and Mendel (1979) and the National Academy of Engineering and the National Academy of Sciences (NAE and NAS, 1979).

2.6.5.1 Supercalcine. One of the more extensively developed of the ceramic nuclear waste forms is supercalcine. Supercalcine is so-named because, while sharing common processing steps with ordinary calcines, it provides a superior product when sintered at high temperatures (McCarthy, 1977a). This waste form is designed to isolate waste ions on an atomic level in the lattices of highiy stable crystalline phases. Emphasis was placed on the selection of phases analogous to minerals known to have survived eons of natural weathering in geologic environments.

A conceptual process stream for supercalcine-ceramic waste forms is shown in Figure 2-42. Selected additives are injected into the liquid high-level waste stream as liquid nitrates or as a colloidal suspension in the case of $\mathrm{SiO}_{2}$. These additives adjust the stoichiometry of the high-level waste to an elemental assemblage matching that of the desired crystalline end products. Liquid high-level waste is then calcined to renove water and nitrates, as described in Section 2.6.3. The resulting powder is crystallized at elevated temperatures to produce the desired phase assemblage, either by hot-pressing or by sintering pellets of arbitrary size at $1,000^{\circ}$ to $1,200^{\circ} \mathrm{C}$ (McCarthy and Davidson, 1976; McCarthy, 1977a). These temperatures provide rapid, thorough crystallization and densification of the supercalcine ceramic. Loss of volatile waste oxides is also minimized by the rapid crystallization of the ceramic phases.

Current supercalcine formulations were developed for waste loadings in excess of 50 wt\% (McCarthy, 1975a, 1977a). Consequently, additives to the waste stream must be minimai. Early sintering experiments with unaltered calcine (McCarthy and Davidson, 1975) suggested phase formulations which might fulfill the minimal additives requirements. Several additional properties are necessary in the supercalcine phase 


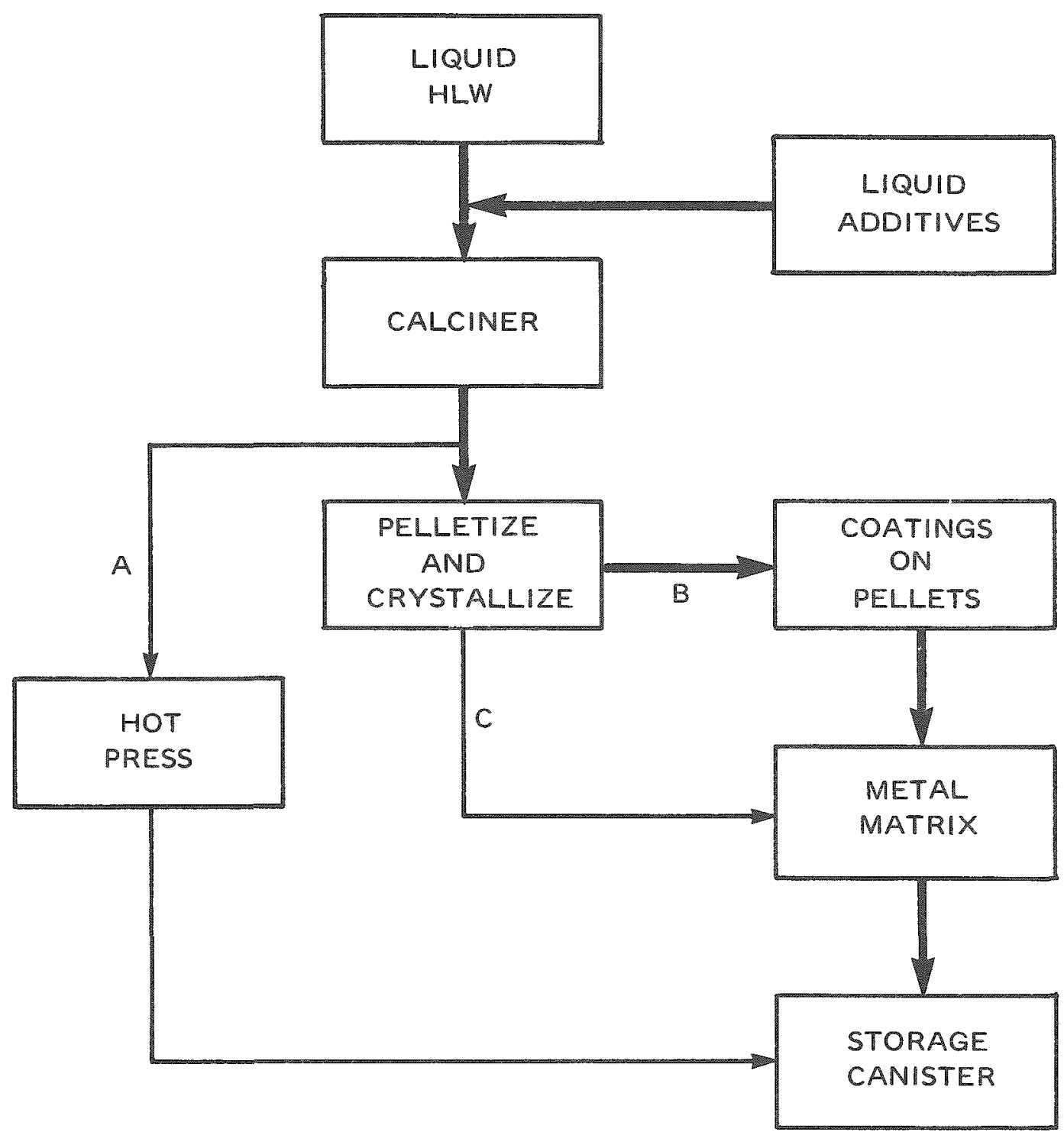

rjEB11/79-1

FIGURE 2-42. Conceptual Flow Diagram for Supercalcine Processing (after McCarthy, 1977a). Coated supercalcine ceramic pellets may also be placed in canisters alone, with no metal matrix addition to fill void spaces between the pellets. 
assemblage for successful high-level waste fixation. The properties are as follows (McCarthy, 1977a):

- Thermal Stability. No significant metal or metal oxide volatilization should occur during firings of several hours duration at crystallization temperatures of $1,000^{\circ}$ to $1,200^{\circ} \mathrm{C}$. The phases must also resist decomposition at waste storage temperatures of up to $800^{\circ} \mathrm{C}$ (due to the high waste loading). Such decomposition could result in enhanced leaching in the event of a canister breach in the hydrothermal environment of a flooded repository.

- Compatibility. Chemical reactions between two or more of the crystalline phases should not occur at storage temperatures over the thermal period of the repository. In addition, the phases should form swiftly in the complex high-level waste chemical mixture, preventing loss of volatile radionuclide species.

- Leachability. Leaching of the ceramic waste solid should be minimal over the range of temperature-pressure conditions present in the repository. Early criteria stated (McCarthy, 1977a) that the leaching resistance of supercalcines should be at least as high as that of the best high-level waste glasses tested under the same conditions.

Development of supercalcine formulations can be divided into three steps. First, a suite of crystalline phases must be selected for highlevel waste nuclide fixation. Second, the compatibility of fixation phases must be determined. Finally, formulations which approach complete simulations of high-level waste must be developed and tested. This process tends to be iterative rather than stepwise (McCarthy, 1977a).

\subsubsection{Chemistry and Phase Compositions of Prototype Supercalcines.} The prime objective of supercalcine development was fixation of both dangerous and troublesome high-level waste nuclides. Dangerous nuclides (McCarthy, 1977a) were considered to be those such as $137 \mathrm{Cs}$ and $90 \mathrm{Sr}$, which have relatively long half-lives and are biological hazards. Troublesome nuclides were defined as those whose oxides have high vapor pressures, such as molybdenum and ruthenium. None of the molybdenum in 


\section{RHO-BWI $-S T-7$}

high-level waste occurs as a radioisotope (Be11, 1973), and only 5.5\% of the ruthenium is radioactive (Johnston, 1980) at separation. The vapor oxides of these elements, besides being chemical toxins, tend to precipitate in cool areas which may contain particulates for nucleation sites (Christian, 1976), such as filters and off-gas piping, reducing filter lifetime and slowly clogging the off-gas system.

Several supercalcine chemistries have been investigated at The Pennsylvania State University. The first of these, based upon zirconia and zirconia/titania additives, proved to be generally unsuccessful (McCarthy, 1974). These formulations did not provide satisfactory cesium stabilization at high waste loadings (McCarthy, 1975b). When silica was added to any of these formulations, the rare-earth elements invariably crystallized in an apatite-structure phase (nominal stoichiometry $\left.\mathrm{Ca}_{2} \mathrm{RE}_{8}\left(\mathrm{SiO}_{4}\right)_{6} \mathrm{O}_{2}\right)$ upon sintering at high temperature.

More recent supercalcine formulations have been based upon an aluminosilicate chemistry. A primary reason for this choice is the fixation of cesium. The cesium aluminosilicate phase, pollucite, $\left(\mathrm{CaA}_{5} \mathrm{i}_{2} \mathrm{O}_{6}\right)$ was found to best fulfill this role in high waste loading applications. Three of these supercalcine formulations were prepared in engineeringscale batches by spray calcination at the Pacific Northwest Laboratory. Two of the spray-calcined supercalcines have been used extensively by researchers at The Pennsylvania State University and Pacific Northwest Laboratory as reference compositions. The phase assemblages and chemical compositions of these tailored ceramics, designated SPC-2 and SPC-4, are listed in Tables 2-55 to 2-58.

The formulations for SPC-2 and SPC-4, which are based on the PW-7 waste form, are very similar. Identical phase formulation models were used in their development. However, SPC-4 incorporated three significant modifications of the SPC-2 overall formulation (McCarthy, 1978a). The calcium and strontium additives are present only in the required amount, rather than in $40 \%$ excess as in SPC-2, and total $\mathrm{SiO}_{2}$ added to the mixture was reduced by $9 \%$. A more realistic rare-earth mixture was also used, with SPC-4 containing on $7 y 32 \%$ of the cerium present in the SPC-2 formulation (in SPC-2, the cerium concentration was too high). 
TABLE 2-55. Phase Formulation of Supercalcine SPC-2. (After McCarthy, 1977b.)

\begin{tabular}{|c|c|c|c|}
\hline $\begin{array}{l}\text { Millimoles } \\
\text { PW-7 }\end{array}$ & Proposed Phase Formulation & $\begin{array}{l}\text { Millimoles } \\
\text { Additives }\end{array}$ & \\
\hline $\left.\begin{array}{ll}100 & \mathrm{RE} \\
100 & \left(\mathrm{PO}_{4}\right)\end{array}\right\}$ & $\begin{array}{l}100 \operatorname{REPO}_{4}\left(M_{S S}\right) * \\
(R E=\text { Rare Earth Elements })\end{array}$ & $-\infty$ & \\
\hline $\left.\begin{array}{rl}257 & R E \\
2 & C d\end{array}\right\}$ & $32 \mathrm{Ca}_{2} \mathrm{RE}_{8}\left(\mathrm{SiO}_{4}\right)_{6} \mathrm{O}_{2}\left(\mathrm{~A}_{\mathrm{SS}}\right) *$ & $\begin{array}{r}62 \mathrm{Ca} \\
193 \mathrm{Si}\end{array}$ & \\
\hline $106 \mathrm{Zr}$ & 106 Tetragonal $\mathrm{ZrO}_{2}\left(\mathrm{~T}_{\mathrm{ss}}\right)^{*}$ & - & \\
\hline 95 Mo & $95 \mathrm{AEMoO}_{4}\left(S_{S S}\right) *$ & $20 \mathrm{sr}$ & \\
\hline $27 \mathrm{Sr}$ & & $21 \mathrm{Ca}$ & \\
\hline $27 \mathrm{Ba}$ & $(A E=$ Alkaline Earth Elements $)$ & -- & \\
\hline $6 \mathrm{Ru}$ & $6 \mathrm{RuO}_{2}$ & -- & \\
\hline $54 \mathrm{Cs}$ & & & \\
\hline $10 \mathrm{Rb}$ & $74(\mathrm{Cs}, \mathrm{Rb}, \mathrm{Na}) \mathrm{AlSi}_{2} \mathrm{O}_{6}(\mathrm{P})$ * & $148 \mathrm{Al}$ & \\
\hline $10 \mathrm{Na}$ & & $256 \mathrm{Si}$ & \\
\hline $100 \mathrm{Fe}$ & $(\mathrm{Fe}, \mathrm{Cr})_{2} \mathrm{O}_{3}+\mathrm{Ni}(\mathrm{Fe}, \mathrm{Cr})_{2} \mathrm{O}_{4}\left(\mathrm{SP}_{\mathrm{SS}}\right)^{*}$ & & \\
\hline $12 \mathrm{Cr}$ & & & \\
\hline $5 \mathrm{Ni})$ & & & \\
\hline & & $83 \mathrm{Ca}$ & \\
\hline & & $20 \mathrm{sr}$ & Required \\
\hline & & $74 \mathrm{Al}$ & \\
\hline & & $341 \mathrm{Si})$ & \\
\hline
\end{tabular}

$* M_{S S}=$ Monazite Structure Solid Solution: $A_{S S}=$ Apatite Structure Solid Solution: $T_{S S}=$ Tetragonal Solid Solution: $S_{S S}=$ Scheelite Structure Solid Solution; $P=$ Pollucite; $S P_{S S}=$ Spinel Structure Solid Solution.

**Extra additives to assure $C S$ and Mo retention $=67$ mi17imoles $C a ; 74$ millimoles A7: 198 millimoles Si. 
TABLE 2-57. Phase Formulation of Supercalcine SPC-4.

(After McCarthy, 1977b.)

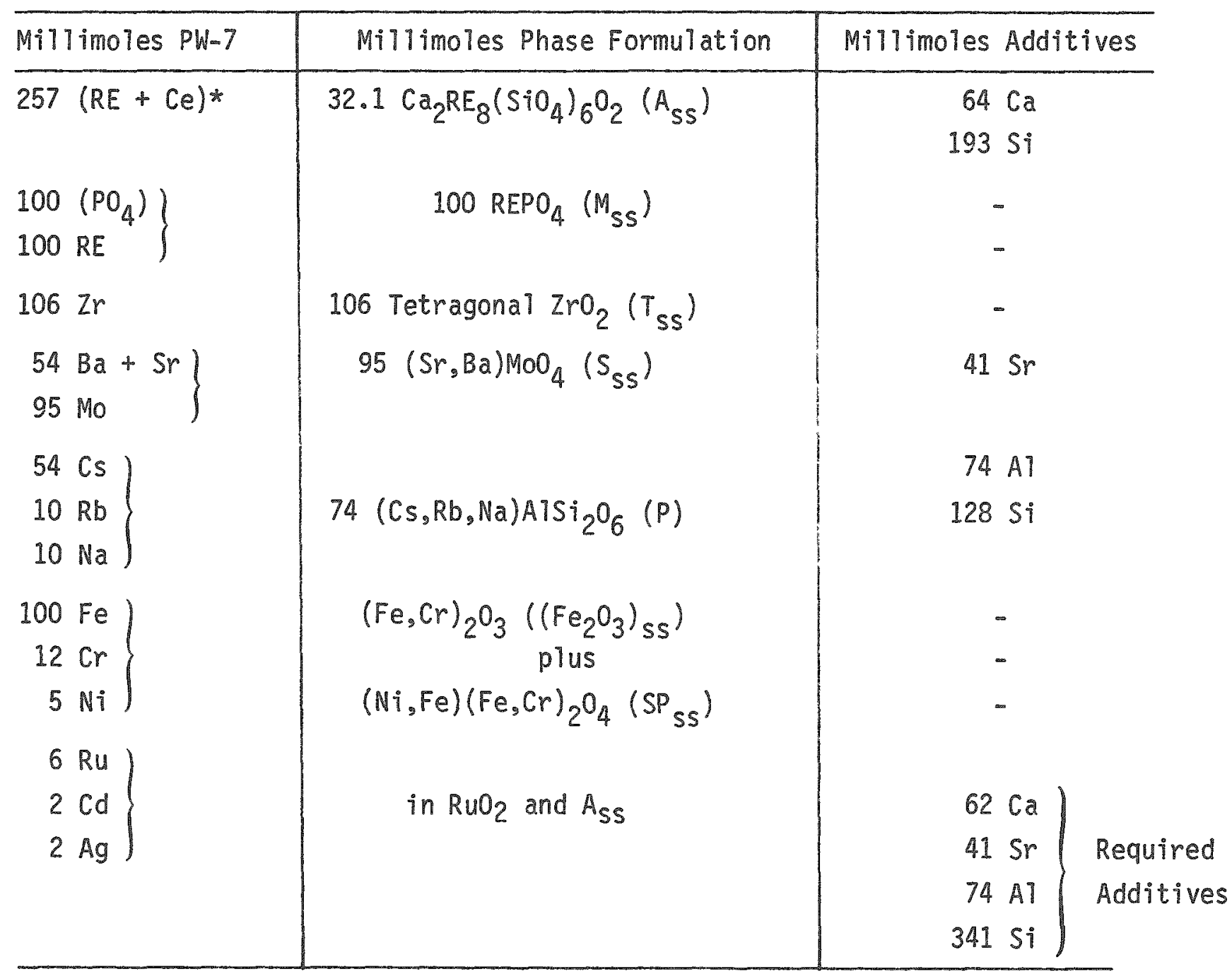

* Some $\mathrm{Ce}$ and RE are expected to crystallize with $\mathrm{Zr}$ in an $\mathrm{F}_{\mathrm{SS}}$ (fluorite-structure solid solution) phase during firings in air. If $S P C-4$ is fired in an inert or reducing atmosphere, the $F_{S S}$ phase may not crystallize. 
TABLE 2-58. Composition of Supercalcine SPC-4. (After McCarthy, 1977b.)

\begin{tabular}{|c|c|c|c|c|c|}
\hline Ion & Molarity & Oxide & $\begin{array}{l}9 \text { oxide per liter } \\
\text { of Calcined SPC-2 }\end{array}$ & \multicolumn{2}{|c|}{ Wt\% Oxide } \\
\hline \multicolumn{6}{|c|}{ From the Modified PW-7 Waste } \\
\hline $\mathrm{RE}^{\mathrm{a}}$ & 0.204 & $\mathrm{RE}_{2} \mathrm{O}_{3}$ & 34.07 & 20.4 & $(16.0)^{b}$ \\
\hline Gd & 0.153 & $\mathrm{Gd}_{2} \mathrm{O}_{3}$ & 27.69 & 16.6 & $(12.9)$ \\
\hline $\mathrm{Zr}$ & 0.106 & $\mathrm{ZrO}_{2}$ & 13.04 & 7.8 & $(6.1)$ \\
\hline $\mathrm{Fe}$ & 0.100 & $\mathrm{Fe}_{2} \mathrm{O}_{3}$ & 8.00 & 4.8 & $(3.7)$ \\
\hline$\left(\mathrm{PO}_{4}\right)$ & 0.100 & $\mathrm{P}_{2} \mathrm{O}_{5}$ & 7.10 & 4.3 & $(3.3)$ \\
\hline Mo & 0.095 & $\mathrm{MoO}_{3}$ & 13.68 & 8.2 & $(6.4)$ \\
\hline Cs & 0.054 & $\mathrm{Cs}_{2} \mathrm{O}$ & 7.61 & 4.6 & $(3.5)$ \\
\hline $\mathrm{Ba}$ & 0.027 & 820 & 4.13 & 2.5 & $(1.9)$ \\
\hline $5 r$ & 0.027 & sro & 2.81 & 1.7 & $(1.3)$ \\
\hline $\mathrm{Cr}$ & 0.012 & $\mathrm{Cr}_{2} \mathrm{O}_{3}$ & 0.91 & 0.5 & $(0.4)$ \\
\hline $\mathrm{Rb}$ & 0.010 & $\mathrm{Rb}_{2} \mathrm{O}$ & 0.94 & 0.6 & $(0.4)$ \\
\hline $\mathrm{Na}$ & 0.010 & $\mathrm{Na}_{2} \mathrm{O}$ & 0.31 & 0.2 & $(0.1)$ \\
\hline $\mathrm{Ru}^{\mathrm{C}}$ & 0.006 & $\mathrm{RuO}_{2}$ & 0.80 & 0.5 & $(0.4)$ \\
\hline Ni & 0.005 & N10 & 0.38 & 0.2 & $(0.2)$ \\
\hline cd & 0.002 & $\operatorname{cdo}$ & 0.26 & 0.2 & $(0.1)$ \\
\hline \multirow[t]{2}{*}{$\mathrm{Ag}$} & 0.002 & $\mathrm{Ag}_{2} \mathrm{O}$ & 0.23 & 0.1 & $(0.1)$ \\
\hline & & & $121.95 \mathrm{~g}$ & & \\
\hline \multicolumn{6}{|c|}{ Supercalcine Additives } \\
\hline $\mathrm{Ca}$ & 0.062 & $\mathrm{CaO}$ & 3.47 & 2.1 & $(1.6)$ \\
\hline $\mathrm{Sr}$ & 0.041 & Sro & 4.26 & 2.6 & $(2.0)$ \\
\hline A1 & 0.148 & $\mathrm{Al}_{2} \mathrm{O}_{3}$ & 7.55 & 4.5 & $(3.5)$ \\
\hline \multirow[t]{4}{*}{ Si } & 0.489 & $\mathrm{SiO}_{2}$ & 29.34 & 17.6 & $(13.8)$ \\
\hline & & & $166.58 \mathrm{~g}$ & $100.0 \%$ & \\
\hline & \multicolumn{3}{|c|}{ (73.2\% waste loading) } & & \\
\hline & \multicolumn{3}{|c|}{ other HLW Constituentsd } & & \\
\hline$U(N P, P U)$ & 0.1195 & $\mathrm{U}_{3} \mathrm{O}_{8}$ & 33.8 & & $(15.7)$ \\
\hline $\mathrm{Ru}^{\mathrm{C}}$ & 0.053 & $\mathrm{RuO}_{2}$ & 7.1 & & $(3.3)$ \\
\hline $\mathrm{Pd}$ & 0.032 & $P d 0^{2}$ & 3.9 & & $(1.8)$ \\
\hline Te & 0.012 & $\mathrm{TeO}_{2}$ & 1.9 & & $(0.9)$ \\
\hline \multirow[t]{3}{*}{ Rh } & 0.010 & $\mathrm{Rh}_{2} \mathrm{O}_{3}$ & 1.3 & & $(0.6)$ \\
\hline & & & $\overline{214.38 \mathrm{~g}}$ & & $(100.0 \%)$ \\
\hline & 179. & aste 10 & & & \\
\hline
\end{tabular}

$\mathrm{ARE}=0.133 \mathrm{Ad}+0.051 \mathrm{Ce}+0.014 \mathrm{La}+0.003 \mathrm{Pr}+0.002 \mathrm{Sm}+0.002$ others: 0.002 RE is a stand-in for Am + Cm.

bvalue in parentheses is the wit: of the oxide after addition of the appropriate amounts of $U, R U, P d, T e, R h$.

CRu concentration in the spray supercalcine SPC- 4 was $10 \%$ of the actual $P N-7$ value of $0.59 \mathrm{M}$. The addition of the remaining $0.053 \mathrm{M}$ is made after calcination.

dTese constituents were not included in the large batch of SPC-4 because of their expense or radioactivity. None require fixation additives. The only $\mathrm{PW}-7$ constituent not included above is $\mathrm{TC}$. 
Gadolinium and neodymium concentrations were increased 2.2 and 22 times respectively, with corresponding decreases in the other rare earth additives.

Elements such as uranium and ruthenium (in excess of $10 \%$ nomina? concentration) were not added to the engineering-scale preparations due to radioactivity or cost constraints. Full amounts of elements such as these were added to selected samples of SPC-2 and SPC-4 on a laboratory scale to produce a closer simulation of the actual waste. Additions of ruthenium $\left(\mathrm{as} \mathrm{RuO}_{2}\right.$ ) produced no observable changes in the phase assemblage other than allowing $\mathrm{RuO}_{2}$ to be detected by $X$-ray diffraction (Johnston, 1980).

In general, supercalcines crystallize according to the design phase mode1. Changes in the proportions of additives, or of the proportions of waste ions present in the high-level waste, did not change the suite of phases present (McCarthy, 1978a), although differences in relative phase abundances and unit cell sizes (of solid solutions) were observed. Such changes were most pronounced in SPC-4 when the approximately 16 wt\% $\mathrm{U}_{3} \mathrm{O}_{8}$ required by the $\mathrm{PW}-7$ formulation was added prior to crystallization. The fluorite structure solid solution $\left(F_{S S}\right)$ phase showed marked increases in both abundance and unit cell size, suggesting that uranium exists as $\mathrm{UO}_{2 \pm x}$ in supercalcine. Marked improvements in consolidation and weight loss behavior also occurred as a result of these substitutions.

A supercalcine formulation has also been developed for high sodium wastes, such as the $\mathrm{PW}-7 \mathrm{a}$ and $\mathrm{PW}-8 \mathrm{a}$ formulations discussed in Section 2.6.3. The high phosphate content simply results in the formation of more of the $\mathrm{M}_{\mathrm{SS}}$ phase, $\mathrm{REPO}_{4}$. Thus far, the only candidate phase for sodium fixation which is both refractory and acceptably leach resistant is nepheline, $\mathrm{NaAlSiO}_{4}$. Laboratory simulations of a supercalcine based on the $\mathrm{PW}-7 \mathrm{a}$ waste stream have yielded promising results (McCarthy, 1978b) in experiments at The Pennsylvania State University. The phases in this supercalcine, with the exception of nepheline, are very similar to those in SPC-2 and SPC-4. A phase formulation for one of these "dirty" supercalcines, 77-2 is listed in Table 2-59. 
TABLE 2-59. Phase Formulation of High-Sodium Supercalcine 77-2. (After McCarthy, 1977b.)

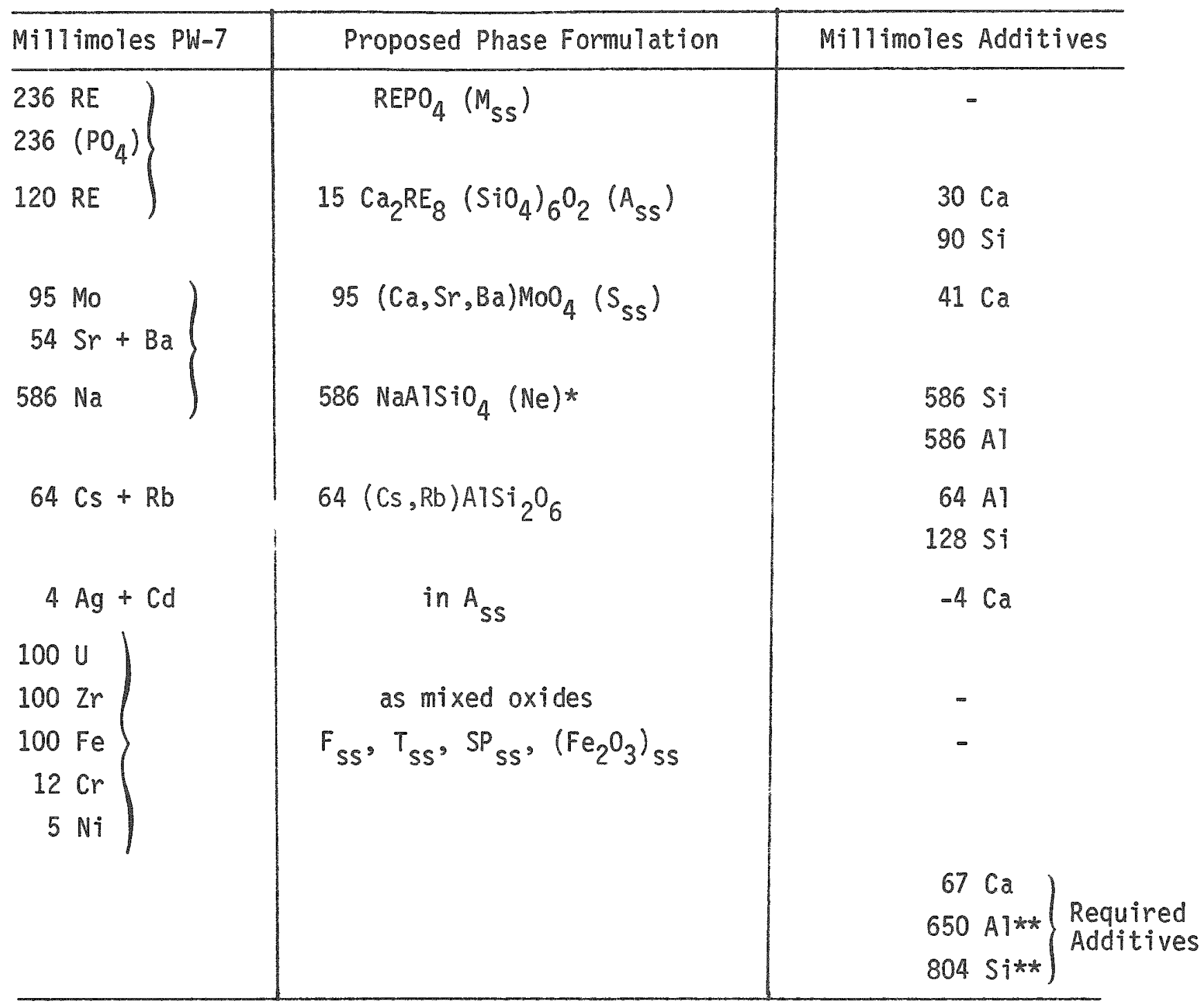

*Nephe line.

**Scouting experiments indicate 1.5 times these amounts required to prevent significant alkali volatilization during processing at $1,100^{\circ} \mathrm{C}$. 
2.6.5.3 Physical Properties of Supercalcine. The physical properties of sintered supercalcine powders compare favorably with those of other waste forms. The waste form is leach resistant, with Soxhlet leachabilities comparable to those of waste glass formulations (Rusin and Others, 1979). For instance, samples of SPC-4 + uranium subjected to Soxhlet extraction yielded bulk leachabilities of $8.4 \times 10^{-7} \mathrm{~g} / \mathrm{cm}^{2} /$ day (MCElroy and Others, 1979a) in 14-day tests. This figure is based on an estimated initial surface area of $200 \mathrm{~cm}^{2} / \mathrm{gm}$, which is approximately half that observed in similarly treated samples of SPC-2 at Pacific Northwest Laboratory (Rusin and Others, 1979). However, measured leachabilities are comparable to those observed from samples of SPC-2 similarly tested. A significant portion of the weight lost due to "leaching" actually is a result of physical weathering of the Soxhlet samples. Supercalcine provides superior resistance to hydrothermal leaching, particularly when compared to similarly treated waste glass. Results of such tests are described in Section 2.6.6.

Uncoated crystallized supercalcines exhibit bulk densities of 2.35 to $4.38 \mathrm{~g} / \mathrm{cm}^{3}$ (Rusin and Others, 1979), depending upon the method of pelletization employed and the crystallization temperature. Disc-pelletized specimens are usually the least dense, while the highest densities are recorded for hot-pressed samples. Impact resistance has yet to be determined.

The resistance of supercalcine to metamictization, the disordering of crystalline phases due to radiation damage, is largely untested. One set of tests, which simulated the a-dose which $80 \%$ waste-loaded supercalcine would experience in 200 years (Rusin and others, 1979), indicated that, under these conditions, the apatite-structure phase totally disappeared, becoming amorphous. The waste form also exhibited a density decrease of $0.07 \mathrm{~g} / \mathrm{cm}^{3}$ (from 4.19 to $4.12 \mathrm{~g} / \mathrm{cm}^{3}$ ) in these experiments. The fluorite and tetragonal structure phases were largely unaffected. The areas of radiation damage require further study, as such effects could decrease leach, volatility, or impact resistance.

Thermal decomposition, unless markedly increased by radiation damage, will probably not be a problem because the supercalcine phase assemblage, has high thermal stability. 
2.6.5.4 The Multiple Barrier Waste Form Concept. Supercalcine, glass marbles, and other waste forms have been envisioned as the central core of a multiple barrier waste form (Rusin and Others, 1978). Such a package would be designed to circumvent the inherent problems of specific waste forms by adding barriers about them within the canister itself. It would also provide a waste form more amenable to quality control, particulariy with respect to glass cast in canisters. A schematic of this concept is presented in Figure 2-43.

Supercalcine cores would be coated by chemical vapor deposition or other methods with successive layers of materials such as a-alumina over pyrolytic carbon, glass, or a commercial glaze. Superior coatings were produced by the duplex coatings, which were each roughly $50 \mathrm{~m}$ thick. Pellets of coated supercalcine show no detectable leaching in a Soxhlet test (Rusin and others, 1979). In fact, they show a small weight gain, probably due to hydration of the coating.

The metal matrix, which would be cast about the pellets in a canister, provides additional impact resistance and good thermal conductivity. Metals such as copper and aluminum have been studied for use as the matrix material. The matrix also acts as an additional barrier protecting the waste cores from groundwater attack. Casting metal in the canister allows the pelletized waste form to be immobilized as a monolithic block.

The multiple barrier waste form may prove to be overly complex for general use in high-level waste solidification, despite the payoffs in enhanced waste stability. Its overall stability, particulariy under conditions such as those which may exist in a repository in basalt, has not yet been determined. Should the multiple barrier waste form prove relatively impervious to the forces which may compromise its integrity in a repository, engineered barrier requirements in the repository may possibly be reduced. Such cost savings at the repository could offset higher waste processing costs. 

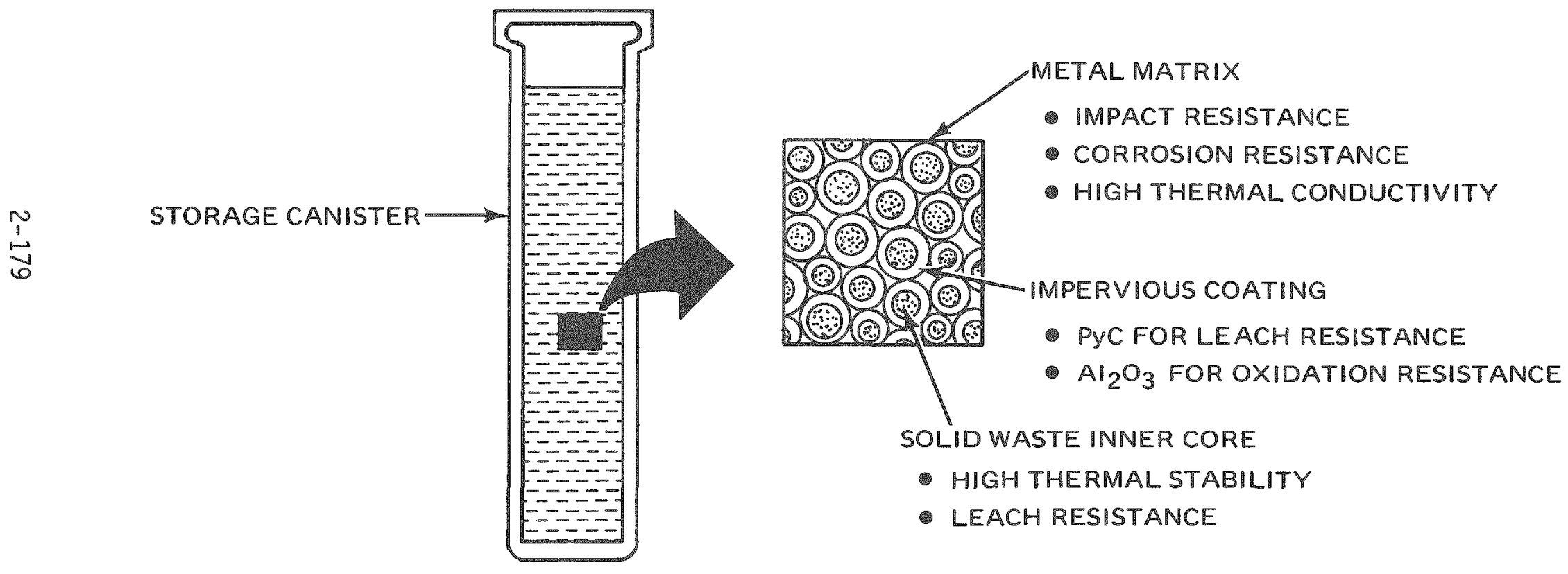

중
0
0
0
0
0
0
0
0

rjEB $1 / 80$

FIGURE 2-43. Multibarrier Concept for Isolating High-Level Waste (after Rusin and 0thers, 1978 ). 
2.6.5.5 SYNROC. Recently, an alternative ceramic nuclear waste form has been reported. This waste form, called SYNROC (Ringwood, 1978; Ringwood and Others, 1979), is based upon minerals which have existed for eons in geologic environments. In this instance the SYNROC concept is identical to that of supercalcine-ceramic, discussed in the previous section. However, early supercalcine phase compositions were largely determined by the composition of the waste stream to meet requirements of high waste loading and minimal additives. In the SYNROC concept, radioisotopes from fuel reprocessing are incorporated as di iute solid solutions in an arbitrarily chosen mineralogy. The waste stream additives, which constitute $90 \mathrm{wt} \%$ or more of the SYNROC matrix, determine the phase assemblage which forms during high-temperature processing.

Two SYNROC formulations have been developed for commercial nuclear waste and have undergone very limited testing. The phase and chemical compositions of these formulations are listed in Table 2-60. SYNROC A, an early formulation, is based upon an aluminosilicate-aluminotitanate chemistry. It contains six crystalline phases designed to isolate high-level waste radionuclides in dilute solid solution, as described in TabTe 2-61. Hydrothermal tests of SYNROC A samples doped with 1 to $3 \%$ of various simulated fission products were conducted in pure water and $10 \%$ $\mathrm{NaCl}$ solutions at 1,000 bars and at temperatures of up to $600^{\circ} \mathrm{C}$ (Ringwood and 0thers, 1979). These conditions, which are much more severe than those likely to be encountered in a repository (see Section 2.4) did not affect SYNROC $A$ when the reactant solution was water. Leucite and kalsilite partially decomposed at $400^{\circ}$ and $500^{\circ} \mathrm{C}$ from SYNROC $A$ when treated in the $10 \% \mathrm{NaCl}$ solution at 1,000 bars. These minerals completely disappeared in $600^{\circ} \mathrm{C}$ experiments, releasing all cesium in the waste to solution and producing sodalite $\left(\mathrm{Na}_{2}\left[\mathrm{NaATSiO}_{4}\right]_{6} \mathrm{Cl}_{2}\right)$ as a by-product.

Based upon results obtained in tests with SYNROC $A$, a simplified formulation, SYNROC $B$, was developed to rectify the "weaknesses" of SYNROC A (Ringwood and 0thers, 1979). As listed in Table 2-60, this ceramic contains only the hollandite, zirconolite, and perovskite phases. The waste ion sites for this formulation are also listed in 
TABLE 2-60. Phase and Chemical Compositions of SYNROC Ceramics.

(After Ringwood and Others, 1979.)

\begin{tabular}{|c|c|c|}
\hline & SYNROC A & SYNROC B \\
\hline Waste (Wt\%) & 10 & 10 \\
\hline Inert Additives (Wt\%) & 90 & 90 \\
\hline \multicolumn{3}{|c|}{ Compositions of Inert Additives (Wt\%) } \\
\hline $\mathrm{SiO}_{2}$ & 13 & - \\
\hline $\mathrm{TiO}_{2}$ & 33 & 57 \\
\hline $\mathrm{ZrO}_{2}$ & 10 & 11 \\
\hline $\mathrm{Al}_{2} \mathrm{O}_{3}$ & 16 & 10 \\
\hline $\mathrm{CaO}$ & 6 & 13 \\
\hline $\mathrm{BaO}$ & 17 & 9 \\
\hline $\mathrm{K}_{2} \mathrm{O}$ & 5 & - \\
\hline
\end{tabular}

\begin{tabular}{l|l|l} 
& \multicolumn{2}{|c}{ Phases Present* } \\
\hline $\mathrm{BaAl}_{2} \mathrm{Ti}_{6} \mathrm{O}_{16}$ (Hollandite) & $\times$ & $\times$ \\
$\mathrm{CaZrTi}_{2} \mathrm{O}_{7}$ (Zirconolite) & $x$ & $\times$ \\
$\mathrm{CaTiO}_{3}$ (Perovskite) & $\times$ & $\times$ \\
$\mathrm{BaAl}_{2} \mathrm{Si}_{2} \mathrm{O}_{8}$ (Ba Feldspar) & $\times$ & - \\
$\mathrm{KATSiO}_{4}$ (Kalsilite) & $\times$ & - \\
$\mathrm{KATSi}_{2} \mathrm{O}_{6}$ (Leucite) & $\times$ & - \\
\hline
\end{tabular}

*Varying proportions of these phases have been used in work reported to date. 
TABLE 2-61. Potential Radionuclide Substitutions in SYNROC A and SYNROC B Phases.a

(After Ringwood, 1978; Ringwood and Others, 1979.)

\begin{tabular}{|c|c|c|c|c|c|c|}
\hline & Hollandite & Zirconolite & Perovskite & Ba Feldspar & Kalsilite & Leucite \\
\hline SYNROC A & $\begin{array}{l}\mathrm{Na}, \mathrm{K}, \mathrm{Rb}, \mathrm{Cs}, \underline{\mathrm{Ba}}, \mathrm{Sr}, \\
\mathrm{Pb}, \mathrm{Co}, \mathrm{NiC}, \mathrm{CrC}, \mathrm{Fe}_{3} \\
\mathrm{MnC}, \mathrm{Mo}, \mathrm{Rh}, \mathrm{Ru}, \\
\mathrm{Sn}, \mathrm{Te}, \mathrm{IC}\end{array}$ & $\begin{array}{l}\mathrm{Sr}, \mathrm{Ba}, \mathrm{Pb}, \mathrm{Y}, \mathrm{REE}^{\mathrm{b}} \\
\mathrm{Bi}, \mathrm{Zr}, \underline{\mathrm{U}}, \mathrm{Th}, \mathrm{Ta}, \mathrm{Nb}, \\
\mathrm{Fe}^{\mathrm{C}}, \mathrm{MnC}, \mathrm{Na}\end{array}$ & $\begin{array}{l}\mathrm{Sr}, \mathrm{Ba}, \mathrm{Na}, \underline{\mathrm{REE}}, \mathrm{Y}, \\
\mathrm{Cd}, \mathrm{Cm}, \underline{\mathrm{Am}}, \underline{\mathrm{Pu}}, \mathrm{Nb} \\
\mathrm{Zr}, \mathrm{Mo}, \mathrm{Pu}, \mathrm{Rh}, \underline{\mathrm{U}}, \\
\mathrm{Sn}, \mathrm{Ru}, \mathrm{Fe}, \mathrm{Cr} C\end{array}$ & $\begin{array}{l}\mathrm{Ba}, \mathrm{Ca}, \mathrm{Pb}, \mathrm{Sr}, \mathrm{K}, \\
\mathrm{Na}, \mathrm{Rb}, \mathrm{Cs}\end{array}$ & $\underline{K}, \mathrm{Cs}, \mathrm{Rb}, \mathrm{Na}$ & $\mathrm{K}, \mathrm{Cs}, \mathrm{Rb}, \mathrm{Na}$ \\
\hline SYNROC B & $\begin{array}{l}\mathrm{Na}, \mathrm{K}, \underline{\mathrm{Rb}}, \underline{\mathrm{Cs}}, \underline{\mathrm{Ba}}, \mathrm{Sr}, \\
\mathrm{Pb}, \mathrm{Ca}, \mathrm{NiC}, \mathrm{Cr}, \\
\mathrm{MnC}, \mathrm{Mo}, \mathrm{Rh}, \mathrm{Ru}, \mathrm{Sn} \\
\mathrm{Zr}, \mathrm{Na}\end{array}$ & $\begin{array}{l}\mathrm{Sr}, \mathrm{Ba}, \mathrm{Pb}, \underline{\underline{\gamma}}, \underline{\mathrm{REE}^{\mathrm{b}}} \\
\underline{\mathrm{r}}, \underline{\mathrm{U}}, \mathrm{Th}, \mathrm{Ta}, \mathrm{Nb}, \mathrm{Fe}^{\mathrm{C}} \\
\mathrm{MnC}, \underline{\mathrm{Na}}\end{array}$ & $\begin{array}{l}\mathrm{Sr}, \mathrm{Ba}, \mathrm{Na}, \mathrm{REE}^{\mathrm{b}}, \mathrm{Y}, \\
\mathrm{Cd}, \mathrm{Cm}, \mathrm{Am}, \mathrm{Pu}_{\mathrm{u}} \mathrm{Nb}, \\
\mathrm{Zr}, \mathrm{Mo}, \mathrm{Pu}, \mathrm{Rh}, \mathrm{U}, \\
\mathrm{Sn}, \mathrm{Ru}, \mathrm{Fe}, \mathrm{Cr} C\end{array}$ & Not in SYMROC B & Not in SYMROC B & Not in SYMYROC B \\
\hline
\end{tabular}

In cases where an element may go into more than one phase, it is underlined in its preferred phase.

$c_{\text {Inerts from reprocessing. }}$ 
Table 2-61. Samples of SYNROC B doped with 1 to $3 \%$ of selected simulated radionuclides have also been subjected to hydrothermal tests similar to those described above for SYNROC A, but at temperatures up to $800^{\circ} \mathrm{C}$. No alteration or loss of simulated fission product ions were observed in these experiments (Ringwood and Others, 1979).

The preparation and testing of SPNROC formulations containing a full simulation of radioactive waste ions have not yet been reported. Tests with 1 to 3 wt\% of individual fission product oxides suggest that these ions will in fact go into solid solution in the expected phase (Ringwood and Others, 1979). However, tests with early supercalcine formulations (McCarthy, 1975b) indicated that fission product ions which were substituted comfortably into a given structure when the chemical assemblage was simple, did not do so when the full fission product mixture was present. In the phases into which the various fission product and transuranic ions substitute in a fult waste loading, accurate SYNROC must be determined to adequately characterize the prototypic ceramic.

SYNROC waste ceramics typically have been prepared by intimately mixing high-level waste and SYNROC solutions in the appropriate proportions, calcining and uniaxially cold-pressing the resultant powder to $70 \%$ theoretical density in a thick-walled nickel container. This canisterwaste combination is then sealed with a nickel lid and hot-pressed at $1,200^{\circ}$ to $1,300^{\circ} \mathrm{C}$, resulting in subsolidus crystallization of the SYNROC minerais. A somewhat reduced phase assemblage results in which some fission products such as ruthenium, tellurium, palladium, and added nickel are partial7y or totally reduced to a metallic state (Ringwood and others, 1979).

Much work remains to be accomplished in the development of these promising SYNROC formulations. For instance, determination of the maximum waste loading which the ceramic can tolerate before changing to another phase assemblage must be accomplished. As discussed above, SYNROC specimens containing complete or near-complete fission product mixtures must be prepared, characterized, and tested for stability. Hydrothermal tests of SYNROC in the presence of potential repository host 
rocks such as granite and basalt must also be performed. More work must be completed along these developmental lines before SYMROC may be considered for emplacement in a repository in basalt.

\subsubsection{Waste Form Performance in a Hydrothermal Environment}

As discussed in Section 2.5, radiogenic heat from buried waste is likely to produce near-hydrothermal conditions in the near-field repository environment. Since design of an effective engineered barrier system requires knowledge of waste form performance under both expected and worst case repository conditions, the hydrothermal stability of candidate waste forms must be investigated. Accordingly, the engineered barriers group of the Basalt Waste Isolation Project is gathering repositoryspecific data using simulated waste forms. To date, spent fuel and two alternate waste forms, borosilicate glass and supercalcine ceramic, have been tested over the temperature range $150^{\circ}$ to $300^{\circ} \mathrm{C}$ at 300 bars pressure. The preliminary resuits have provided a qualitative understanding of nuclear waste behavior which may be expected in a hydrothermal environment. These results, in conjunction with published data from other investigations, have been used to specify areas for careful, quantitative investigation.

2.6.6.1 Hydrothermal Reaction of Spent Fuel and Water. Dissolution of the radionuclides present in spent fuel may conceivabiy occur if the solid fuel comes in contact with groundwater at the high temperature and pressure conditions of a deep geologic repository. The extent of any such dissolution will be significantly influenced by the chemical composition of the groundwater, particularly its $\mathrm{pH}$. The oxidizing or reducing capacity of the repository environment will also affect dissolution rates, particularly for elements such as uranium, which can exist in either oxidized or reduced forms. The two most common ways of examining the oxidizing power of the environment are in terms of its oxidation-reduction potential (Eh) or its oxygen fugacity $\left(\mathrm{fO}_{2}\right)$. These are essentialiy equivalent, low $\mathrm{fO}_{2}$, and low Eh referring to reducing environments.

As discussed in Section 2.5, reducing conditions are expected shortly after closure of nuclear waste repository in basalt. In basalt, the 
oxygen fugacity is dictated by iron-bearing phases in the rock. In an oversimplified form, the controlling reaction may be written as:

$$
\begin{aligned}
& 3 \mathrm{Fe}_{2} \mathrm{SiO}_{4}+\mathrm{O}_{2} \leftrightarrows 2 \mathrm{Fe}_{3} \mathrm{O}_{4}+3 \mathrm{SiO}_{2} \text { 。 } \\
& \text { (fayalite) (hematite) (quartz) }
\end{aligned}
$$

At $65^{\circ} \mathrm{C}$ (ambient repository temperature), the oxygen fugacity is $10^{-67}$ atmospheres (Eugster and Wones, 1962). Under such highly reducing conditions, the stable uranium-bearing solid will probably be uraninite $\left(\mathrm{UO}_{2}\right)$.

No experiments have been performed with simulated spent fuel in which direct control of oxidation-reduction potential has been attempted. However, data from $\mathrm{UO}_{2}$ dissolution experiments (Lemoine, 1975; Langmuir, 1978) give an indication of the effects which oxidationreduction may have upon uranium leachability from spent fuel. Lemoine (1975) obtained the uranium solubility (in distilled water) versus temperature curve shown in Figure 2-44 using a platinum membrane and a

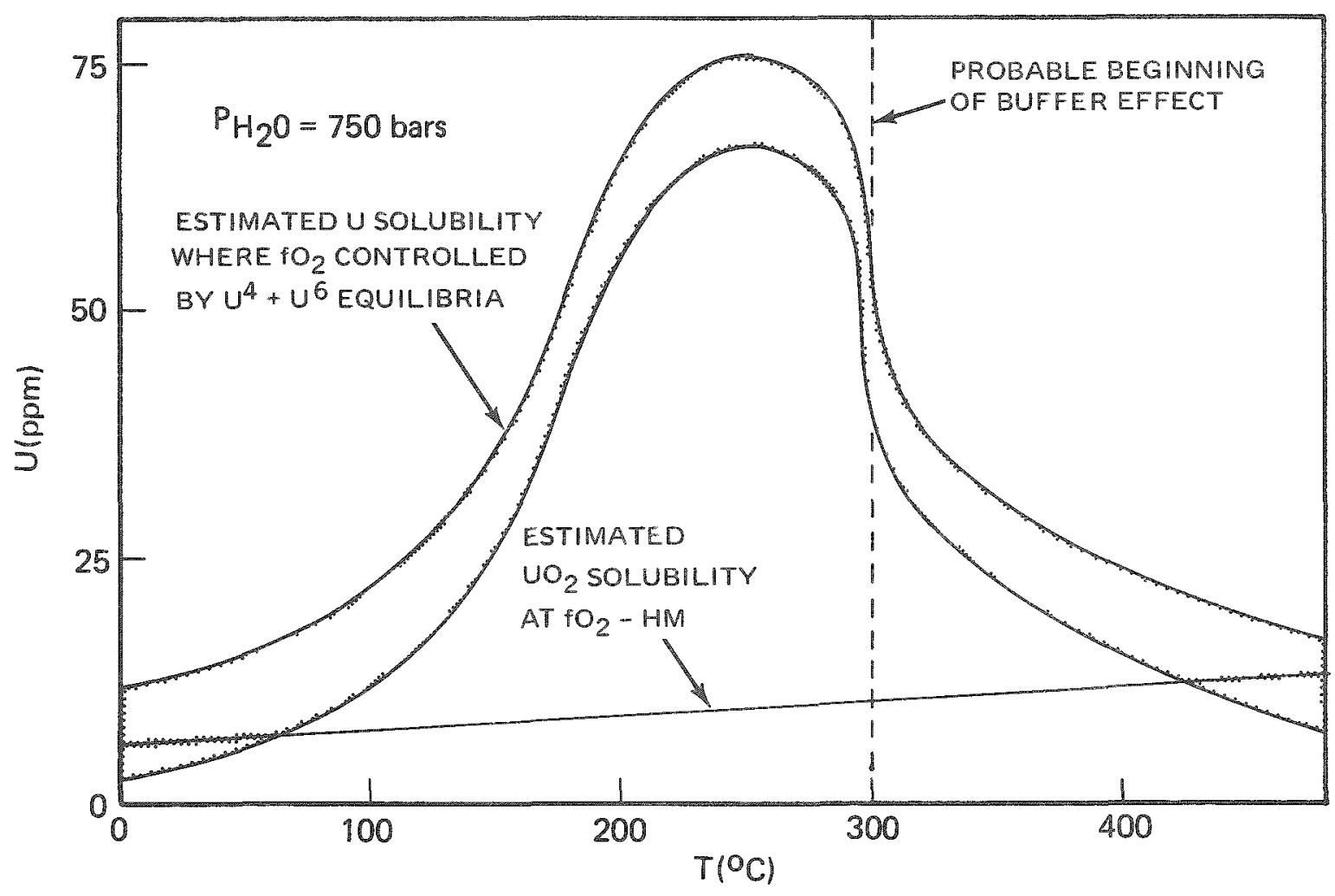

FIGURE 2-44. Solubility of $\mathrm{UO}_{2}$ in water as a Function of Temperature; $\mathrm{fO}_{2}$ in the Experiments Buffered by the Equilibrium between $\mathrm{U}_{2}$ and $\mathrm{UO}_{3}$ under Oxidizing Conditions (after Lemoine, 1975). Estimated $\mathrm{NO}_{2}$ solubility at hematite-magnetite $\mathrm{fO}_{2}$ plotted as dashed line. 
hematite-magnetite solid state buffer (Eugster and Wones, 1962) to fix the oxygen fugacity. Unfortunately, the solubility curve is not representative of constant oxygen fugacity, as is apparent for the maximum in the curve. Chou and Eugster (1978) demonstrated that the platinum membrane becomes inoperative below $300^{\circ} \mathrm{C}$, as shown in Figure $2-45$.

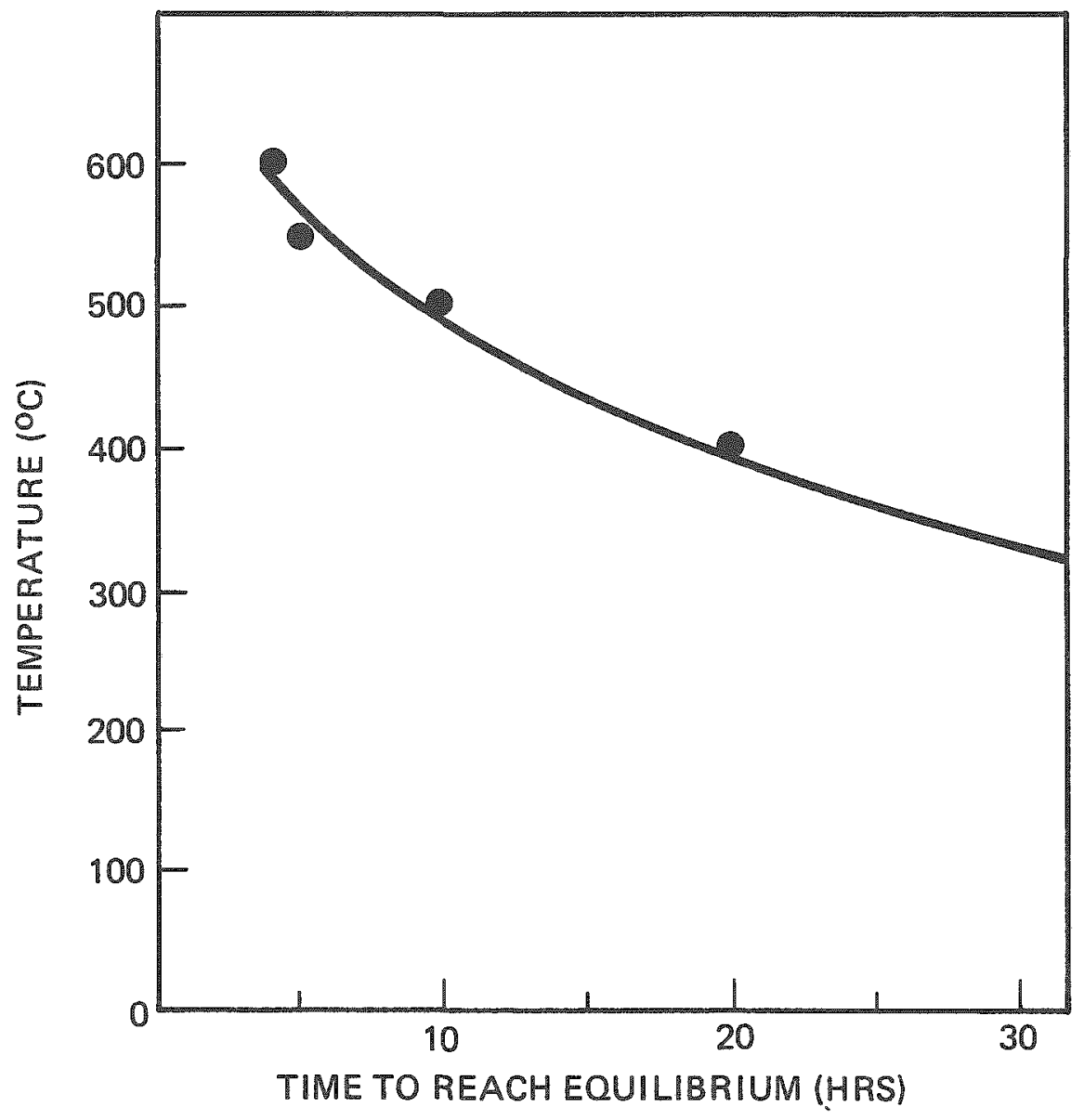

bcEB1/80

FIGURE 2-45. The Approach to Equilibrium Using a Hydrogen Diffusion Membrane (after Chou and Eugster, 1978).

Thus, in Lemoine's experiments, the uranium concentration in the distilled water below $300^{\circ} \mathrm{C}$ was controlled by oxygen present in the capsule rather than by the solid-state buffer. This portion of the curve may be representative of uranium solubilities in the repository immediately following closure, when the oxidation-reduction potential will be near that of atmospheric oxygen. At $300^{\circ} \mathrm{C}$ and above, the membrane was permeable, allowing the hematite-magnetite buffer to control the oxygen fugacity. The lower oxidation-reduction potential stabilized 
the relatively insoluble $\mathrm{UO}_{2}$ phase, as reflected by the rapid decrease in the concentration of uranium in solution above $300^{\circ} \mathrm{C}$.

Given the very low solubility of $\mathrm{UO}_{2}$, it is possible to extrapolate the results obtained at $300^{\circ} \mathrm{C}$ and higher temperatures by Lemoine (1975) to Tower temperatures, if a linear temperature dependency is assumed. This relationship is plotted as the dashed line in Figure 2-44. The estimated solubilities of $\mathrm{UO}_{2}$ at 500 bars pressure in the $65^{\circ}$ to $300^{\circ} \mathrm{C}$ temperature range are listed in Table 2-62. Note that while these estimates are conservative for distilled water, uranium solubility in a repository may be 10 to 100 times greater due to sulfate, carbonate, or fluoride complexation (Rich and Others, 1977: Langmuir, 1978).

Simulated spent fuel has been hydrothermaliy tested for leach resistance at The Pennsylvania State University. The composition of this synthetic spent fuel is described in Section 2.6.2.4. It is a finegrained, generally unconsolidated powder which, as discussed in Section 2.6.2.4, is a poor representation of actual spent fue 7 , since the latter is heterogeneous, coarse grained, and cohesive. However, the simulated waste is, at present, the only usable material for studies conducted in conventional laboratories. Results generated using this high surface area powder probably represent highly conservative (i.e., worst case) values for spent fuel leaching.

The results of preliminary experiments at $150^{\circ}$ to $300^{\circ} \mathrm{C}$ at 300 bars are listed in Table 2-63. Above $150^{\circ} \mathrm{C}$, cesium, rubidium, and molybdenum (and by analogy, technetium) were nearly totally leached from the synthetic spent fuel. These data are preliminary and may not be representative of the repository behavior of actual spent fuel. However, analyses of cooling water $\left(\sim 50^{\circ} \mathrm{C}\right)$ from storage pools tends to corroborate the observation that cesium is the most soluble element in actual spent fuel (from failed fuel pins). In these pools, which are mildly acidic ( $\mathrm{pH} 4.5$ to 5.5 ), about $72 \%$ of the radionuclides detected in solution are cesium, while strontium accounts for approximately $27 \%$ (Johnson, 1977). A small amount of 131 I has also been detected. Iodine-129, while not detected, should also be present. Ambient pressure jeach tests of actual light water reactor fuel by the Paige method (Katayama, 1976, 1979) also indicate that cesium, strontium, plutonium, 
TABLE 2-62. Estimated Solubility of Uraninite $\left(\mathrm{UO}_{2}\right)$ at 750 Bars Pressure and Low 0xygen Fugacity.

\begin{tabular}{c|c|c}
\hline Temperature $\left({ }^{\circ} \mathrm{C}\right)$ & Log Oxygen Fugacity $(\mathrm{atm})$ & Solubi7ity $(\mu \mathrm{g} / \mathrm{ml})^{\text {** }}$ \\
\hline 0 & -76.0 & 6 \\
25 & -68.5 & 6.4 \\
50 & -62.1 & 6.7 \\
75 & -56.6 & 7.1 \\
100 & -51.9 & 7.4 \\
125 & -47.8 & 7.8 \\
150 & -44.1 & 8.1 \\
175 & -40.9 & 8.5 \\
200 & -38.0 & 8.8 \\
225 & -35.5 & 9.2 \\
250 & -33.0 & 9.5 \\
300 & -28.9 & 10.2 \\
325 & -27.1 & 10.6 \\
350 & -25.5 & 10.9 \\
375 & -23.9 & 11.3 \\
400 & -22.6 & 11.6 \\
\hline
\end{tabular}

*0xygen fugacity controlled by hematite-magnetite buffer. $* *$ Estimated error $= \pm 5 \mu \mathrm{g} / \mathrm{ml}$. 
TABLE 2-63. Compositions of Residual Solutions from Experiments a Reacting Simulated Spent Fuel with Distilled Water at 300 Bars.

\begin{tabular}{|c|c|c|}
\hline Element & Dissolved Concentration $(\mu \mathrm{g} / \mathrm{ml})$ & Relative Percent Dissoived \\
\hline \multicolumn{3}{|c|}{ Temperature $=3000^{\circ} \mathrm{C}$} \\
\hline $\mathrm{Rb}$ & 33 & 100 \\
\hline Cs & 281 & 100 \\
\hline$s r$ & $N D^{b}$ & - \\
\hline Mo & 190 & 54 \\
\hline $\mathrm{U}$ & 3 & .004 \\
\hline others $c$ & ND & - \\
\hline \multicolumn{3}{|c|}{ Temperature $=200^{\circ} \mathrm{C}$} \\
\hline $\mathrm{Rb}$ & 44 & 100 \\
\hline Cs & 363 & 100 \\
\hline$s r$ & 1 & 1 \\
\hline Mo & 308 & 87 \\
\hline$u$ & 1 & .003 \\
\hline others & ND & - \\
\hline \multicolumn{3}{|c|}{ Temperature $=100^{\circ} \mathrm{C}$} \\
\hline $\mathrm{Rb}$ & 5 & 16 \\
\hline Cs & 51 & 19 \\
\hline$s r$ & 4 & 4 \\
\hline Mo & 25 & 7 \\
\hline$u$ & 10 & .01 \\
\hline $\mathrm{Ba}$ & 5 & 3.5 \\
\hline La & 1 & 0.8 \\
\hline $\mathrm{Nd}$ & ND & - \\
\hline $\mathrm{Zr}$ & ND & - \\
\hline Others & ND & \\
\hline
\end{tabular}

28 weeks duration: $10: 1$ water to solid ratio.

bNone detected by atomic absorption, atomic emission, or fluorometer.

$\mathrm{C}_{\mathrm{Ba}}, \mathrm{La}, \mathrm{Nd}$, and $\mathrm{Zr}$ were not detected in solution. 
curium, and uranium are leached from spent fuel at significant rates in deionized water. It should be noted that these latter tests were conducted with atmospheric oxygen content and therefore are not directly extendable to probable repository conditions.

The observed cesium and strontium solubilities in spent fuel correspond well with the phases in irridated $\mathrm{UO}_{2}$. Cesium has been observed as $\mathrm{Cs}_{2} \mathrm{O}, \mathrm{CsI}, \mathrm{Cs}_{2} \mathrm{MoO}_{4}$, and $\mathrm{Cs}_{2} \mathrm{U}_{2} \mathrm{O}_{7}$ (Cubicciotti and Sanecki, 1978). These phases are all highly water soluble, and tend to concentrate in the outer portions of the fuel pellet. Sro, which has a solubility of $0.23 \mathrm{ug} / \mathrm{ml}$ in water at $100^{\circ} \mathrm{C}$, has been observed both in the exterior portions of the fuel pellet and in the interior adjacent to the central void (Koizumi and Others, 1974).

In summary, the most leachable elements contained in spent fuel appear to be cesium, rubidium, molybdenum (and by analogy, technetium), and strontium. Cesium and strontium leached from unprotected spent fuel could represent a significant hazard during the thermal period of the repository. It should not, however, be difficult to retard migration of these elements with engineered barriers (Section 2.9). Molybdenum and technetium solubilities should be significantly smaller in a highiy reducing basalt environment than those obtained from the experiments under oxidizing conditions described above. If such is not the case, technetium release from spent fuel will present a significant problem throughout the repository's history. The release of long-7ived uranium and its toxic daughters will also be significantly influenced by the oxygen fugacity in the repository. Potential ramifications of this influence are discussed in more detail in Section 2.9 .

\subsubsection{Hydrothermal Reaction of Borosilicate Glass and Water.}

Borosilicate glass has been advanced as a leach-resistant waste form which could flexibly accommodate the variations in waste streams which arise from the reprocessing of commercial spent fuel. The use of glass as a waste form has created considerable controversy, with some researchers pointing to thermodynamic instability, potential leachability, and reactivity (Roy and Yoder in Carter, 1979; Ringwood, 1978) as disqualifying factors. Others cite low experimental ieach rates and persistent volranic glass as favorable evidence of the suitability of glass. The 
debates, plus a long history of glass waste form research, have resulted in a substantial body of waste glass performance data, allowing a more thorough treatment of borosilicate giass performance.

Various experimenters have subjected borosilicate glass formulations to hydrothermal testing. Most of this experimental work has been completed using PNL 76-68 glass. The composition of this glass, which was developed for a $\mathrm{PW}-7$ a waste stream (see Section 2.6.3) is given in Table 2-51. Selected results from long-term hydrothermal leach tests under oxidizing conditions ( $f_{02} \cong$ air) are shown in Table 2-64. These results cannot be quantitatively applied, because experimental conditions employed in gathering the data were insufficiently controlled. The resulting solution concentrations represent minimum amounts of dissolved material because of the precipitation of solids during sample c0ol down at the termination of the experiment.

The data in Table 2-64 clearly show that glass tends to release significant quantities of radionuclides at worst case repository temperatures $\left(300^{\circ} \mathrm{C}\right)$. It is also apparent that glass solubility decreases as temperature decreases. The dramatic decrease in dissolved radionuclide concentrations at low temperatures is somewhat misleading, however. The concentrations of dissolved silica, sodium, and boron (all glass network-formers) clearly indicate corrosion and degradation of the glass structure. This result implies that the concentrations of dissolved radionuclides will increase if the leach duration is increased even at low temperature. The net result suggests that, given sufficient time, glass will break down even at low temperature and ultimately release greater amounts of contained waste than indicated by the short-term experiments which have been conducted to date.

In order to predict the long-term leaching behavior of glass, it is necessary to perform experiments which lead to an understanding of the mechanisms by which glass dissolves. A mechanistic interpretation is a prerequisite for any quantitative extrapolation of experimental results to long geologic times. Various methods are used to enhance reaction rates and approach steady state dissolution kinetics. The first is to use relatively high temperatures (generally around $300^{\circ} \mathrm{C}$ ) and to assure that mechanistic information obtained at such temperatures can be extra- 
TABLE 2-64. Compositions of Residual Solutions from Experimentsa Reacting Simulated PNL 76-68 Glass in Distilled Water at 300 bars.

\begin{tabular}{|c|c|c|}
\hline Element & Dissolved Concentration ( $\mathrm{ug} / \mathrm{m} 1)$ & Relative Percent Dissolved \\
\hline \multicolumn{3}{|c|}{ Temperature $=3000^{\circ} \mathrm{C}$} \\
\hline $\mathrm{Rb}$ & 3 & 2 \\
\hline $\operatorname{cs}$ & 140 & 14 \\
\hline$S r$ & Nob & - \\
\hline Mo & 1,050 & 68 \\
\hline$u$ & 2.6 & .1 \\
\hline $\mathrm{Ba}$ & 1 & .1 \\
\hline$s i$ & 610 & 0.3 \\
\hline $\mathrm{Na}$ & 8,500 & 9.0 \\
\hline B & 15,000 & 52.0 \\
\hline Othersc & ND & - \\
\hline \multicolumn{3}{|c|}{ Temperature $=2000 \mathrm{C}$} \\
\hline$R b$ & ND & - \\
\hline $\operatorname{cs}$ & 10 & 1.0 \\
\hline$S r$ & ND & - \\
\hline Mo & 405 & 26 \\
\hline$u$ & 17 & .4 \\
\hline $\mathrm{Ba}$ & MD & - \\
\hline Si & 590 & 3.1 \\
\hline Na & 2,000 & 21.3 \\
\hline B & 1,600 & 53.8 \\
\hline others & ND & \\
\hline \multicolumn{3}{|c|}{ Temperature $=100^{\circ} \mathrm{C}$} \\
\hline $\mathrm{Rb}$ & ND & - \\
\hline $\operatorname{cs}$ & 6 & 0.6 \\
\hline $\sin$ & 1 & .01 \\
\hline Mo & 40 & 2.4 \\
\hline$u$ & 1.6 & .01 \\
\hline $\mathrm{Ba}$ & ND & - \\
\hline Si & 330 & 1.7 \\
\hline $\mathrm{Na}$ & 280 & 2.9 \\
\hline B & 90 & 3.0 \\
\hline others & ND & - \\
\hline
\end{tabular}

a4 months duration: $10: 1$ water to glass ratio.

bNone detected by atonic absorption, atomic emission, or fluoronetry

$\mathrm{Cla}, \mathrm{Nd}$, and $\mathrm{Zr}$ not detected in solution. 
polated down to more reasonable repository conditions. The geometry of glass within a canister can be scaled down by using small-diameter cylinders or spheres.

Dissolution rate experiments have been performed on glass spheres (McCarthy and Others, 1978a) and cylinders (Westsik and Turcotte, 1978) at temperatures near $300^{\circ} \mathrm{C}$ in distilled water. In these experiments, a 1.3-cm-diameter cylinder hydrated completely after 1 week at $350^{\circ} \mathrm{C}$ (Westsik and Turcotte, 1978). Extrapolation of these data using standard diffusion equations (Carslaw and Jaeger, 1959) indicates that a full 30.5-cm canister of solid glass would completely hydrate in 10 years. Even if this estimate is inaccurate by one order of magnitude, 10 to 100 years is a relatively brief span in terms of repository history. It can therefore be concluded that a waste glass cylinder will rapidiy hydrate in the event of a canister rupture under worst case repository conditions. The significance of this result is that inward diffusion of water is the preliminary step to leaching of the mobile constituents of the waste glass. Thus, favorable conditions for leaching of such components could be established rapidly if canisters were to rupture early in the life of a geologic repository. In order to delay mobilization of such elements, it would be necessary to provide a relatively impermeable engineered barrier such as a clay backfill.

McCarthy and Others (1978b) have performed semiquantitative electron microprobe analyses of borosilicate glasses which had been leached for 4 weeks at $300^{\circ} \mathrm{C}$ and 300 bars pressure. As can be seen from a scanning electron micrograph (Fig. 2-46), four attention zones and a rind of encrusted material are clearly visible after leaching under these conditions.

The nature of the zones and the diffusion phenomena which created them can be elucidated by plotting the microprobe analyses as a function of distance across the specimen. The data for each oxide analyzed are shown as the ratio of weight percentage divided by wt\% $\mathrm{SiO}_{2}$ in Figure $2-47$. It may be seen from this figure that uranium is depleted in the outer zones of the PNL 76-68 glass relative to silicon, indicating that it is leached faster than the latter, network-forming element. The same observation applies to molybdenum and also, by analogy, to technetium, 


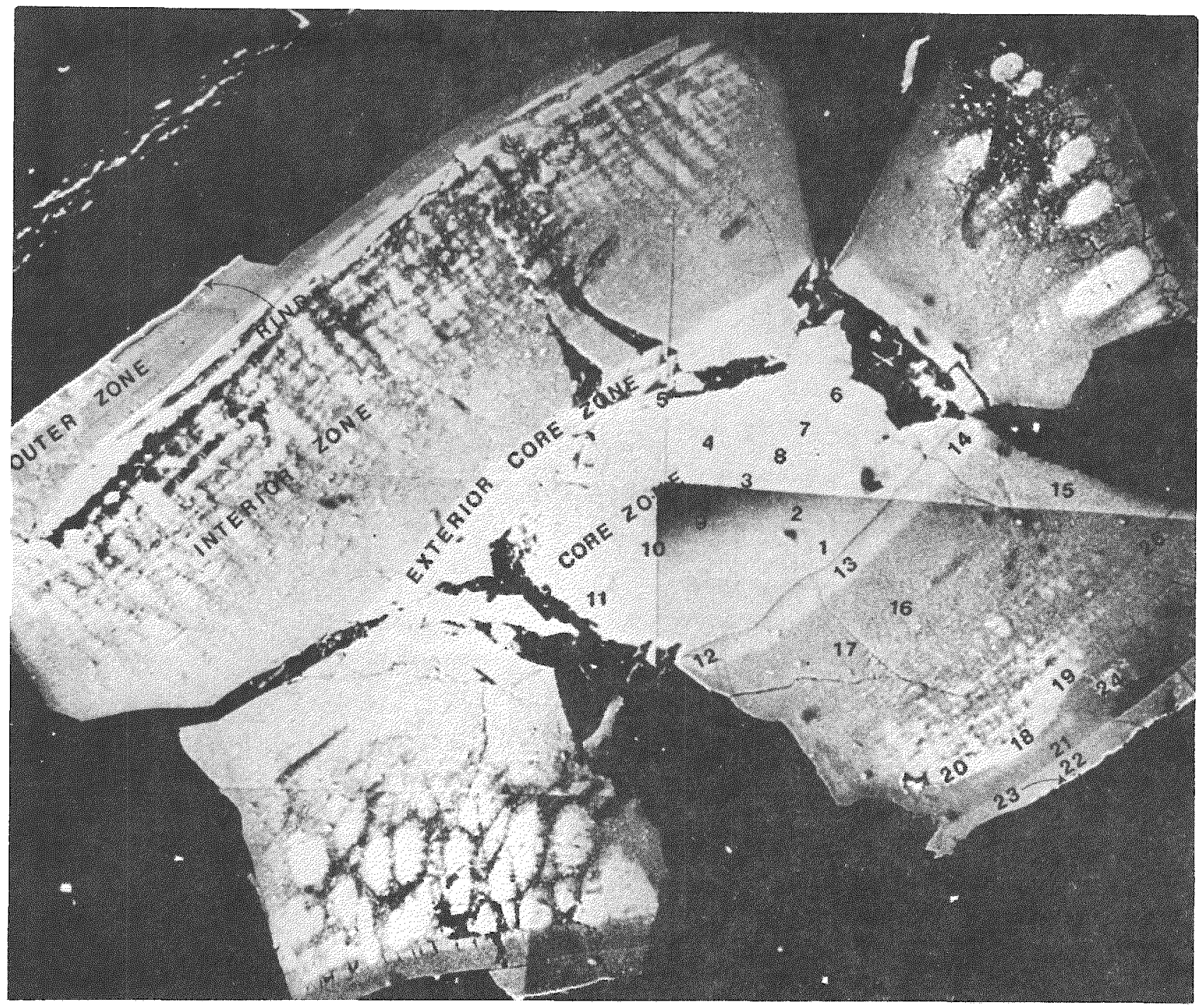

FIGURE 2-46. Scanning Electron Micrograph of a Section through the Product of a 4-Week Hydrothermally Treated Treatment of a PNL 76-68 G7ass Specimen (after McCarthy and Others, 1978b). 
RHO-BWI-ST-7
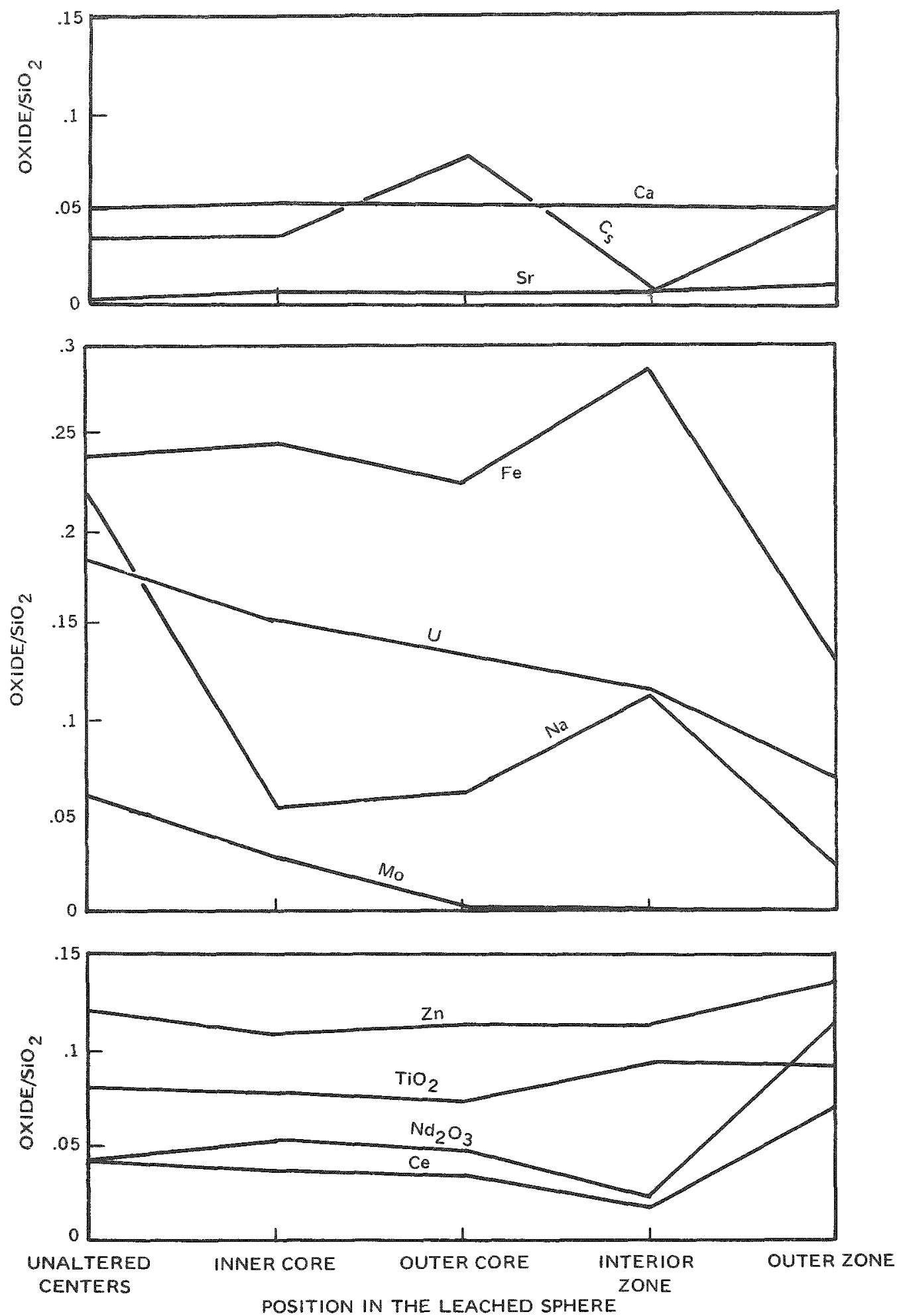

bc/80

FIGURE 2-47. Composition-Distance Profile for Leached PNL 76-68 Giass Sphere Shown in Figure 2-46. 
under the oxidizing conditions of the experiment. In contrast, the refractory oxides $\mathrm{Nd}_{2} \mathrm{O}_{3}, \mathrm{CeO}_{2}$, and $\mathrm{ZrO}_{2}$ show enrichment relative to silicon in the outer zone and depletion in the innermost regions of the sample. This may be explained by the low solubilities of these oxides in hydrothermal solutions: transfer from solid to solution is inhibited and oxide concentration builds up in the solid near its interface with the solution. FeO and $\mathrm{Na}_{2} \mathrm{O}$ appear to be leached more rapidly than $\mathrm{SiO}_{2}$ in the outer zone, but exhibit erratic behavior with peaks in the interior zone. This latter region of the specimen is largely crystalline, containing, however, sodium-iron metasilicates and opaque oxides. Crystaliization of the glass matrix leads to dramatic changes in the thermodynamic properties of the specimen and initiates any simple diffusion modes in the crystalline regions. Therefore, the behavior of sodium and iron cannot be quantitatively interpreted at this stage.

To this point, discussion of the hydrothermal leaching of waste glass has focused on the interior alteration zones. In the past, more attention has been directed at the thin, encrusting rind which is enriched in uranium and strontium (McCarthy and Others, 1978b; Westsik and Turcotte, 1978) and in potential actinide hosts (McCarthy and Others, 1978a). However, several lines of evidence point to this outermost rind being generated during cooking ("quenching") of the sample at the termination of the experiment. The rind is always the same thickness, regardless of the duration of the experiment, and it contains phases (e.g., actinite) and textures which are indicative of it being a quench phenomenon. Thus, the rind should not be relevant to repository conditions since it is an artifact of the experimental method, rather than a true dissolutionreaction zone.

The Group II elements strontium and calcium appear to dissolve at the same rate as silica, indicating a direct correspondence between siliconoxygen and Group II-oxygen bonds. If this correspondence extends to radium, also a Group II element, then radium release will aiso be directiy linked to the dissolution of the silicate network in the glass and will mimic the release of silica. 


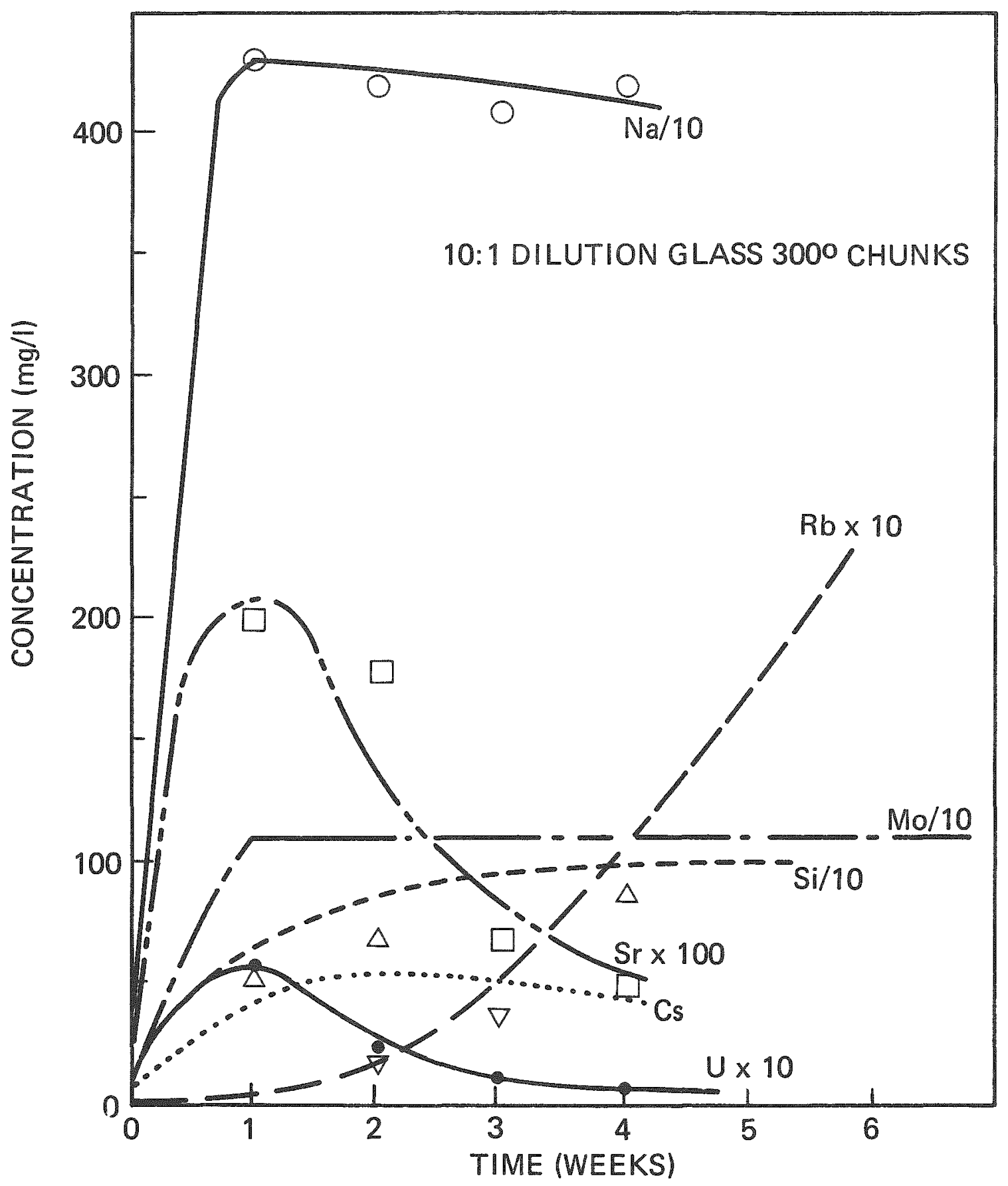

FIGURE 2-48. Solution Concentrations of Various Ions from PNL 76-68 Glass as a Function of Time at $3000^{\circ} \mathrm{C}, 300$ Bars in Deionized Water. 
Residual solutions arising from hydrothermal alteration of glass show continuous changes in composition with time for periods of up to 6 months at $300^{\circ} \mathrm{C}$. Figure $2-48$ represents a compilation of solution composition data extracted from the literature (Turcotte and Wald, 1978; McCarthy and others, 1978b). Data from experiments conducted at different laboratories under the same conditions are in agreement (Westsik and Turcotte, 1978).

Early solution trends are consistent with the data presented previousiy for the solid. The most leachable oxides appear to be those of sodium, molybdenum, uranium, and silicon. Lesser amounts of strontium (and calcium, which is not shown) are found in solution, with the solution concentrations changing with time in similar manner to that found for silicon. The trend for cesium is similar to that of sodium (also Group I). This finding is somewhat inconsistent with the results for the solid, in which cesium showed no consistent trend at all. This observation implies analytical difficulty with cesium in the glass.

The solution results also suggest early dissolution followed by precipitation and an approach to a steady state. The coincidence of cesium and uranium maxima with silica saturation verifies the contention of McCarthy and Others (1978b) that weeksite $(\mathrm{K}, \mathrm{Cs})_{2}\left(\mathrm{UO}_{2}\right)_{2}\left(\mathrm{Si}_{2} \mathrm{O}_{5}\right)_{3} \cdot 4 \mathrm{H}_{2} \mathrm{O}$ is a stable product of hydrothermal glass leaching experiments. Similarly, the coincidence of the maximum with molybdenum saturation can be attributed to powellite $(\mathrm{Ca}, \mathrm{Sr}) \mathrm{MOO}_{4}$ precipitation. Both of these solids have been identified following hydrothermal reactions of simulated waste glass, but their stability in equilibrium with the solid and solution at temperature, and pressure has been uncertain up to now. The solution data presented here confirm these stabilities and imply that uranium, strontium, and perhaps technetium will be at least partially immobilized, even under oxidizing conditions.

Oxide solubilities are almost always affected by changes in temperature. At this time, accurate estimations of solution composition limits are not available. However, a qualitative measure of the effect of temperature may be seen in Table 2-64. At this time it is unclear to what extent solution composition is controlled by kinetic and/or quenching phenomena and to what extent the composition differences reflect changes in equilibrium saturation values. However, it appears 
that at $100^{\circ}$ to $200^{\circ} \mathrm{C}$ very little hazardous material is leached from glass. It should be noted that the experiments on which this statement is based lasted only 28 days, and while oniy a small amount of "fission products" were dissolved, the borosilicate network was severely corroded. This may lead to a subsequent solution of the network modifying components, especially radium.

In summary, borosilicate glass appears to be more leach-resistant than spent fuel. Sodium, silicon, molybdenum (technetium), uranium, and cesium appear to be the most leachable elements in the waste glass under oxidizing conditions. Strontium and calcium are also leachable, but to a much lesser extent. Changes in oxidation potential, particularly to the extremely reducing conditions likely in a sealed repository in basalt, may significantly alter the results presented here. Although dissolution of borosilicate glass appears to be slow at temperatures less than $150^{\circ} \mathrm{C}$, some key radionuclides will be steadily released as a function of silicate network breakup. Unless fixed, these radionuclides may be concentrated as a migration front and represent a potential hazard requiring specific engineered barriers. Static or low flow conditions will allow some precipitation to occur, particularly of weeksite and powellite. Precipitation of these phases will reduce the solution concentrations of cesium, uranium, and perhaps technetium. The concentrations of radionuclides which remain in solution after precipitation are governed by temperature and the equilibrium constants for these phases. Further investigation of these phenomena are necessary to quantify waste species solubility for hazards determination.

2.6.6.3. Hydrothermal Reactions of Supercalcine and Water. Data on supercalcine-water reactions are considerably more limited than those for glass-water interactions. For example, there are no analytical data on both the leached solid and its accompanying liquid. Therefore, no mechanistic interpretations of supercalcine leaching are yet possible. However, some data on leaching of waste ions from prototype supercalcines at several temperatures are available. These data are presented in Table 2-65, together with glass leaching data under comparable conditions. As with glass leaching experiments, supercalcine experiments have been conducted on -6 to +10 mesh chunks, the chunks being broken from pressed, 
TABLE 2-65. Comparison of the Compositions of Residual Solutions from Experiments Reacting Alternative Waste Forms with Distilled Water at 300 Bars.

\begin{tabular}{|c|c|c|c|c|}
\hline \multicolumn{3}{|c|}{ Supercalcine (SPC-4). } & \multicolumn{2}{|c|}{ Glass (PNL 76-68) } \\
\hline Element & $\begin{array}{c}\text { Dissolved } \\
\text { Concentration }(\mu \mathrm{g} / \mathrm{m} 1)\end{array}$ & Relative \% & $\begin{array}{c}\text { Dissolved } \\
\text { Concentration } \mu \mathrm{g} / \mathrm{ml}\end{array}$ & Relative \% \\
\hline \multicolumn{5}{|c|}{ Temperature $=3000 \mathrm{C}$} \\
\hline $\mathrm{Rb}$ & 25 & 4.6 & 3 & 2 \\
\hline cs & 25 & 0.6 & 140 & 14 \\
\hline $\operatorname{sr}$ & 2.3 & 0.06 & ND & - \\
\hline Mo & 370 & 68 & 1,050 & 68 \\
\hline$u$ & - & - & 2.6 & .1 \\
\hline $\mathrm{Ba}$ & 6.1 & 0.3 & 1 & .1 \\
\hline si & 340 & 3.0 & 010 & 0.3 \\
\hline Na & 230 & 100 & 8,500 & 9.0 \\
\hline B & - & - & 15,000 & 52.0 \\
\hline others & ND* & - & ND & - \\
\hline \multicolumn{5}{|c|}{ Temperature $=2000 \mathrm{C}$} \\
\hline $\mathrm{Rb}$ & 30 & 0.6 & ND & $=$ \\
\hline Cs & 10 & 0.2 & 10 & 1.0 \\
\hline$s r$ & 0.5 & 0.1 & ND & - \\
\hline Mo & 83 & 1.8 & 405 & 26 \\
\hline$u$ & - & - & 17 & .4 \\
\hline$B q$ & ND & - & ND & - \\
\hline si & 110 & 1.0 & 590 & 3.1 \\
\hline $\mathrm{Na}$ & 27 & 18 & 2,000 & 21.3 \\
\hline$B$ & - & - & 2,600 & 53.8 \\
\hline others & ND & - & - & - \\
\hline \multicolumn{5}{|c|}{ Temperature $=100{ }^{\circ} \mathrm{C}$} \\
\hline $\mathrm{Rb}$ & ND & - & NO & - \\
\hline Cs & No & - & 6 & 0.6 \\
\hline Sr & NO & - & 1 & .01 \\
\hline Mo & 20 & 0.1 & 40 & 2.4 \\
\hline$u$ & - & - & 1 & .01 \\
\hline $\mathrm{Ba}$ & MD & - & ND & - \\
\hline si & 11 & 0.1 & 330 & 1.7 \\
\hline $\mathrm{Na}$ & ND & - & 280 & 2.9 \\
\hline B & - & - & ND & - \\
\hline others & ND & - & - & - \\
\hline
\end{tabular}


sintered pellets. At $200^{\circ}$ to $300^{\circ} \mathrm{C}$, solutions in contact with supercalcine contain less than $600 \mathrm{mg} / 2$ of fission products. This compares with a total of $1,100 \mathrm{mg} / \mathrm{l}$ obtained from identical experiments $\left(300^{\circ} \mathrm{C}\right.$, 300 bars, 4 weeks) on leaching of glass. Cesium, molybdenum, and nickel concentrations are noticeably lower in the solutions from supercalcine experiments than in glass leachates, while rubidium and barium show increases beyond "glass" values. Supercalcine also exhibits superior retention of metals associated with cladding wastes.

At $100^{\circ}$ to $200^{\circ} \mathrm{C}$, the experimental leachate compositions of glass and supercalcine are comparable. This rough equivalence has caused some investigators to conclude that glass and supercalcine will perform equaily well at low or moderate repository temperatures (Ross and 0thers, 1979). This conclusion must be viewed with caution. First, the near coincidence may be an artifact of experimental technique. Second, assuming that the solution compositions are approximately correct at moderate temperatures, water in contact with glass contains significant amounts of network forming components (silicon, aluminum) and shows indications of total network corrosion (sodium). This may imply that substantial amounts of soluble waste materials (e.g., cesium, radium) will be dissolved in geologic time from glass. Leachate for experiments with supercalcine does not contain large amount of network-forming components. This suggests that the long-term leach resistance of supercalcine may be greater than that of glass.

Waste form performance comparisons are hampered by the inability of experimenters to reach or demonstrate an approach to equilibrium. In contrast to glass-water data, supercalcine-water results do not show consistent trends with time even after experiments of 6 months' duration. The rather erratic behavior observed during hydrothermal leach tests of supercalcine ceramic is illustrated in Figure 2-49 (Ross and 0thers, 1979; Scheetz and Others in BWIP, 1979b). An early spike of dissolved solids is followed by a general decrease to significantly lower concentrations of dissolved material. The decrease is followed by a similar increase and decrease cycle. It is likely that the cycling can be explained by leaching of fresh supercalcine surfaces followed by stable phase precipitation. One hypothesis is that fresh surfaces of 


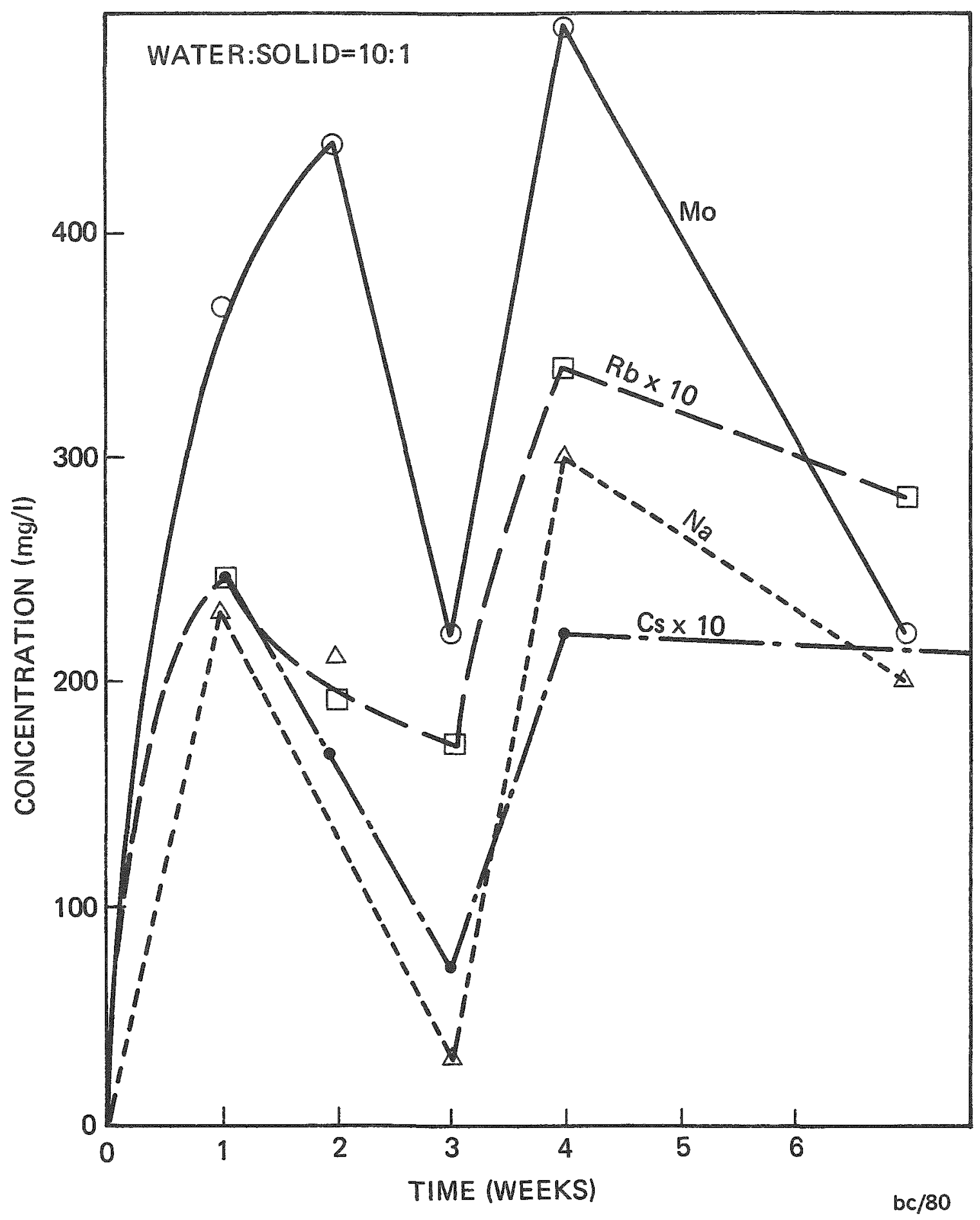

FIGURE 2-49. Waste Ion Concentrations in Solution as a Function of Time from Supercalcine-Ceramic SPC-4 at $3000^{\circ}$, 300 Bars in Deionized Water (after Ross and Others, 1979; Scheetz and others in BWIP, 1979b.) 
supercalcine dissolve more readily than solid phases precipitate. As the process continues, dissolution rates decrease and precipitation alters the solution concentrations. However, during this time, the chunk of supercalcine has become hydrated to an extent controlled by the diffusion of water in the collective solid. The hydration causes a volume expansion and a spalling of the hydrated layer, forming a fresh reactive surface. The newly exposed surface is readily dissolved and the concentration of dissolved solids again increases rapidly. Dissolution slows, precipitation dominates, and the concentration falls. If this hypothesis is correct, then available results of hydrothermal leach tests on supercalcine are likely to be misleauing. For instance, experiments of 3-weeks' duration are likely to produce artificially low concentrations of dissolved solids, giving rise to optimistic conclusions (see Fig. 2-49). It is suggested that long-term experiments leaching a fine powder $\left(<200\right.$ mesh) at $300^{\circ}$ to $400^{\circ} \mathrm{C}$ may provide more useful information.

It should be pointed out that the chief criticisms leveled at crystalline waste forms are related tu radioactive decay. Transmutation is the process wherein a given radionuclide (e.g., strontium) transforms to an entirely different element (e.g., zirconium) as a result of nuclear processes (decay or capture). Such transformations can alter both ionic size and charge, making direct substitution of daughter for parent element in a crystal structure difficult or impossible. For the above example, transmutation to zirconium results in a $0.33 \AA$ decrease in ionic radius and the addition of two units of charge. Perturbations of this magnitude are likely to destroy the original bonds and, depending on extent, give rise to dilute solid solution, tormation of antiphase domains, complete separation of phases, or metamictization.

Metamictization is the total disruption of a crystalline lattice which may arise from transmutation, but is more commonly associated with a-decay. crystals containing a-emitters (e.g., actinides) become metamict solids (i.e., amorphous to $X$-rays) by the displacement of elements on lattice sites. Displacement results either from direct collision with the a-particle or by recoil of the unstable nucleus and causes a random breakdown of the crystallographic order. crystal structures based on isolated tetrahedra linked by bridging metals (zircon, scheelite) are 
especially susceptible to metamictization. Both of these crystal structures occur as waste ion hosts in supercalcine. Thus, the possible detrimental effects of metamictization and transmutation or leach resistance must be considered.

In a crystalline waste form, both metamictization and transmutation will alter a phase which was selected for its stability and specifically engineered into the solid. Thus, changes in these desired phases or production of new phases may adversely affect the leach resistance demonstrated by the waste form in its unaltered state. Thus far, leach tests have not been performed on actual, waste-containing, supercalcine or SYNROC. However, it is possible to make several pertinent observations.

- Metamictization by $\alpha$-decay is likely to become important on $7 y$ after the thermal period ( 2500 years). This is likely because of the long half-lives of actinide elements and because elevated temperature tends to anneal the crystallographic damage caused by a-emission (Pabst, 1952).

- The resulting amorphous body will probably be more leachable than the original crystal because: (a) swelling usually occurs (Ewing and Haaker, 1979); (b) surface area may increase due to fracturing: and (c) the bonds are intrinsically weaker.

- Transmutation poses similar problems but includes the potential for new crystalline phase formation. In addition, transmutation is likely to occur during the thermal period when the potential for hydrothermal leaching is greatest.

- Quantitative estimates of increased leachability concurrent with radiation damage are presently impossible. However, conflicting results obtained on naturally damaged minerals (Mumpton and Roy, 1961; Lipova and Samoilova, 1973), indicate that the increases must be fairly small.

- Waste glasses will devitrify and crystallize during the thermal period (see Turcotte and Wald, 1978). Crystalline phases produced during devitrification will be subject to metamictization and transmutation and enhanced leachability. 
However, since leachability is enhanced by increased boron content of the glass, it is likely that glass will remain more leachable than crystalline waste forms.

In summary, hydrothermal leach tests performed on supercalcine ceramic clearly show the effects of disequilibrium. However, the data are sufficient to indicate that supercalcine is probably more resistant than glass at maximum repository temperatures $\left(200^{\circ}\right.$ to $\left.300^{\circ} \mathrm{C}\right)$. At lower temperatures, data comparisons reveal comparable concentrations of fission products in the leachate from supercalcine and glass. In contrast to results of glass experiments at lower temperatures, there is no evidence for general decomposition of the supercalcine host. This implies that supercalcine may be a more durable waste form. It is possible, though not certain, that transmutation and metamictization will increase the leachability of supercalcine ceramic. However, these processes will also be active in devitrified waste glass and it is likely that the borosilicate glass will be more adversely affected than supercalcine.

\subsubsection{A Comparison of Emplaced Nuclear Waste and Uranium Ore Body Toxicities}

Nuclear waste emplaced in a repository and uranium ore bodies are entities which differ in several ways. The most significant of these differences is the radionuclide inventory which is present in each. Wastes from nuclear fuel reprocessing contain mostly fission products (which are either inert or decay by beta and gamma emission) and small amounts of uranium, plutonium, and transuranics, as discussed in Section 2.6.3. The amount of uranium present in the waste depends upon the efficiency of the reprocessing operation, while plutonium content is dependent upon fuel burnup, fuel type, irradiation history, and reprocessing efficiency (only if plutonium is removed for reuse). Spent fuel is primarily $\mathrm{UO}_{2}$ containing $3.5 \mathrm{wt} \%$ fission products and 1 wt\% plutonium (see Section 2.6.2). Again, these parameters are dependent upon fuel burnup, reactor type (pressurized or boiling water), and irradiation history. 
Uranium ore, on the other hand, contains only uranium and its daughters radium, thorium, and radon as significant radionuclide hazards. Of these, radium, which is present in an equitibrium concentration with uranium, has the highest toxicity (Hamstra, 1975). The amount of uranium in commercially exploitable ore varies from 72 wt\% in pitchblende to $0.2 \mathrm{wt} \%$ in low grade ore. The ore deposits typically occur in coarse, clastic rocks (DOE, 1979C) such as sandstone.

Comparison of the hazards inherent in deeply buried nuclear waste and a "typical" uranium ore body presents a multifaceted problem. There are many methods by which the hazards posed by these entities may be evaluated (Voss, 1979). A few of these methods may be used with confidence, while others are not truly applicable to the problem. Such safety assessment techniques take into account factors such as quantity of radioactive material, decay constants, type and energy of decay, chemical and physical form, toxicity, pathways to man, and comparison of hazards and risks to other materials.

Accurate determination of the hazard presented by a repository or an ore body requires evaluation of the solubility (leachability) of the waste package or ore, changes in environment along the pathway to the biosphere which may cause sorption or precipitation of phases containing the radionuclides, solution flow rate and volume, and path length to the environment. Each of these factors is specific to the repository or ore body in question, making valid assessment of relative hazards difficult. The relatively uniform dispersion of $\mathrm{UO}_{2}$ throuahout the ore body as part of a permeable rock cannot be readily equated to a mine containing discrete packages of nuclear waste encased in a number of relatively impermeable barriers. This factor further complicates the issue.

One method of coming to grips with the problems that limited data can create in analyses such as those above is to consider the overa11 toxicity of the waste (Hamstra, 1975; Haug, 1975, 1976; Tonnessen and Cohen, 1977; Voss, 1979). Guidelines exist (NRC, 1979a; EPA, 1976) for the maximum or recommended concentration of radionuclides and chemicals in drinking water. This recommended concentration guide may be used to quantify the relative toxicity of various nuclear waste forms as a function of time. 
The overail toxicity of nuclear waste may be determined in several ways. Assume that a quantity of nuclear waste Q becomes totally dissolved in water. The quantity of water required to dilute the overall radionuclide package to safe levels is determined by the equation (Voss, 1979):

$$
\text { Hazard Measure }=H M=\sum_{i=1}^{n} Q_{i} / R_{C G} \text {, }
$$

where $Q_{i}$ is the quantity of each radionuclide, and $R C G_{i}$ is its maximum permissible concentration. This equation, when plotted as a function of time, gives a measure of relative toxicity of the waste as a function of time.

In order to compare nuclear waste from various fuel cycles and reprocessing options, and to compare wastes to uranium ore, a standard basis is required. This is typically accomplished by comparing equivalent volumes $(V)$ of waste, or by comparing the volume of waste, ore, etc. containing a unit quantity, such as a metric ton, of uranium meta1. The approach may be generalized further by comparing a volume of uranium ore containing a given amount of metal with the repository volume containing the spent fuel which originally contained said amount of uranium. In the case of reprocessing wastes, the amount of waste arising from the specified quantity of uranium metal is considered. This toxicity, or hazard index, is defined by the equation (Voss, 1979):

$$
\text { Hazard Index }=H I=\sum_{i=1}^{n} \frac{Q_{i} / V_{j}}{R_{C G}} .
$$

The hazard index and hazard measure may be converted to a dimensionless number by comparing the relative toxicities of two types of waste, or more typically, waste and a typical uranium ore body. This approach may also be used to compare the toxicity of emplaced nuclear waste to that of other commercially exploitable ores. The relative toxicity index (RTI), is derived from the following equation (Tonnessen and Cohen, 1977):

$$
\text { RTI = HM Waste/ } / M_{\text {Comparative base. }}
$$




\section{RHO-BWI-ST-7}

HM may be replaced by HI throughout this equation.

A plot of the relative toxicities of reprocessed nuclear waste, spent fuel, and uranium ore as a function of time is presented in Figure 2-50. This figure is based upon work by Haug $(1975,1976)$ and Tonnessen and Cohen (1977). Inherent in this figure are the following assumptions:

- Recommended concentration guides for the transuranics were determined by comparison to factors for 226Ra.

- The radioactive waste (or spent fuel) is immobilized in a solid matrix of low solubility.

- The waste canisters (20-cm-diameter) are placed in individual boreholes $10 \mathrm{~m}$ apart.

- The volume of rock containing the waste canisters is compared to an equal volume of low grade $238 \mathrm{U}$ ore $(0.2 \%)$, diluted to safe drinking water standards.

Significant differences between high-level waste and spent fuel are immediately apparent. The toxicity of high-level waste dips below that of uranium ore after about 1,000 years. Note that while high-level waste is less toxic than the ore after this time, the origin of hazards from the highlevel waste is quite different. The toxicity of this waste is a function of transuranic and $129 \mathrm{I}$ content. Spent fue 1 , on the other hand, is approximately one order of magnitude more toxic than the ore at 104 years after removal from the reactor, and at 106 years is still about three times more toxic. In this case, plutonium is the major hazard in the older waste, along with radium from uranium decay. Again, significant differences in the origin of the waste toxicity compared to that of the ore are apparent. Note also that the toxicity of the nuclear waste decreases to less than that of several important metal-bearing ores in a relatively short time-span.

Calculations of this sort are useful to provide a measure of "absolute" toxicity of a section of a nuclear waste repository and equivalent volumes of ore. However, they provide no measure as to the actual hazard which an emplaced repository may pose to a surrounding populace. Factors such as path length to the biosphere, transport time (dependent upon the failure rate, leach rate, groundwater flow, and retardation factors in the migration 
RHO-BWI-ST-7

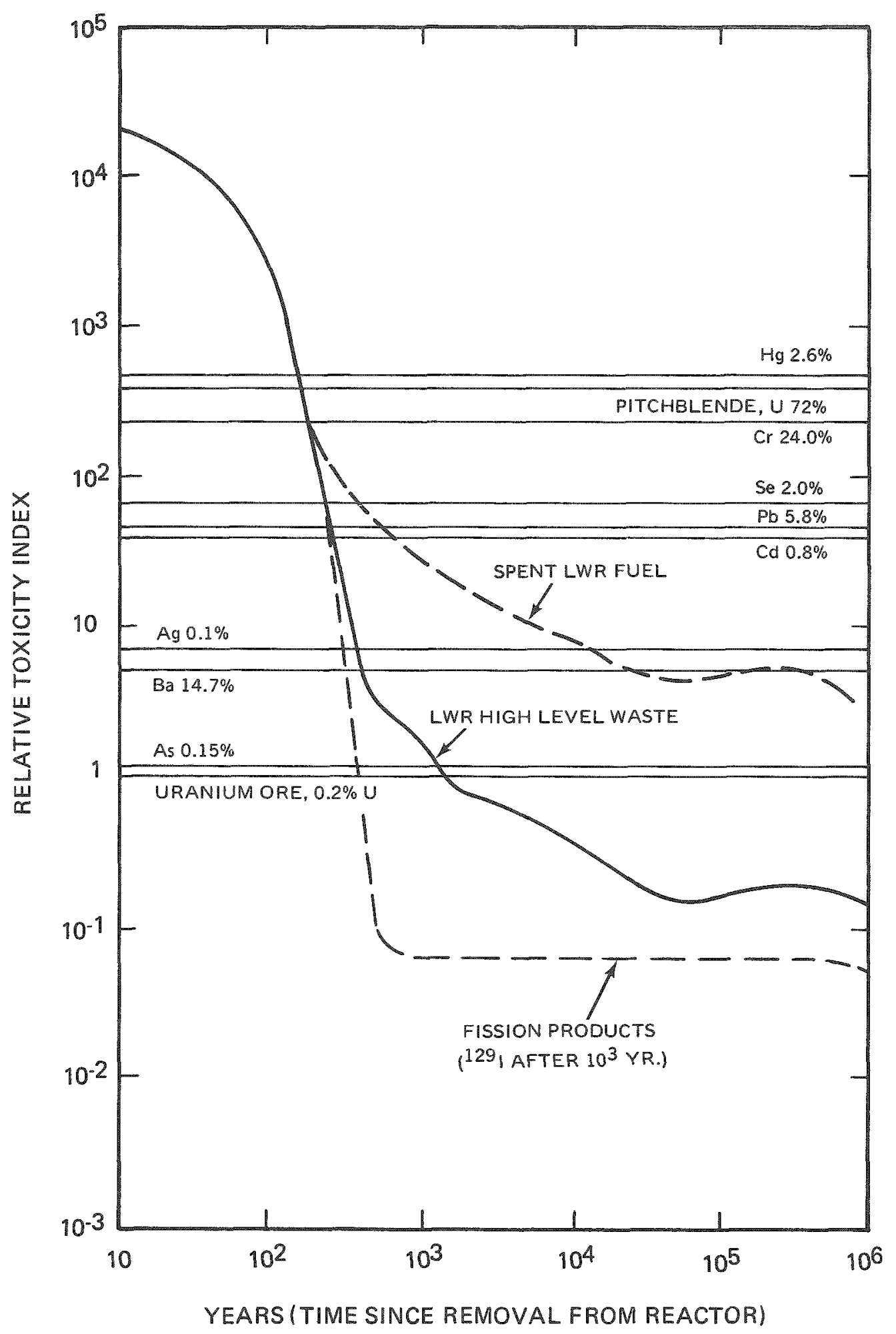

FIGURE 2-50. Relative Toxicities of Various Natural Ores to Nuclear Wastes Using Low-Grade Uranium Ore as a Basis for Comparison (after Haug, 1975, 1976; Tonnessen and Cohen, 1977). 
path), and decay time a 11 must be taken into account. The treatment presented in Figure 2-50 does, however, allow the toxicity of the waste to be compared to something which is not considered to be a hazard to man, or is an existing hazard over which man has no control.

\subsubsection{Thermal Properties of Waste Forms}

The thermal output of the waste form in the repository will influence dissolution reaction types and rates should water fill the repository under the pressures 7ikely to be present at depth. Overall thermal outputs of spent fuel and high level reprocessing wastes differ significantly over both the short and long term. Shown in Figure 2-51 are comparative thermal power generation curves for two conceptual waste canisters, one containing a single pressurized waste reactor fuel assembly, the other containing the waste (in vitreous form with $25 \%$ waste loading) from 2.5 metric tons (100 MW years) of spent uranium fuel (Ringwood, 1978; NAE and NAS, 1979). The heat generated per canister is initially greater for high-level waste, the thermal output of which is dominated by the decay of $90 \mathrm{Sr}$ and $137 \mathrm{Cs}$. After this period of time, the heat generated by an individual high-level waste canister is negligible for al1 practical purposes. Thermal output from spent fuel is also dominated by $90 \mathrm{Sr}$ and $137 \mathrm{Cs}$ decay during the early life time of the waste. Thereafter, its thermal output is a function of actinide element decay, principally 239pu (Cohen, 1977a). The thermal output of $239 \mathrm{Pu}$ peaks at approximately 104 years after fuel discharge, thereby producing a second, although minor, thermal output peak for spent fuel.

A more striking comparison can be made by comparing the heat generated by a quantity of spent fuel to that generated by the amount of high-level waste generated by reprocessing an identical quantity of spent fuel. This comparison (NAE and NAS, 1979) is shown in Figure 2-52. Note that 100 years after discharge, the heat generated by a quantity of spent fuel is aiready several times larger than the amount produced by highlevel waste from the same amount of fuel. Note also the relative ingestion hazard (calculated in a similar manner to toxicity indices discussed in Section 2.6.7) and radioactivity. 
RHO-BWI-ST-7

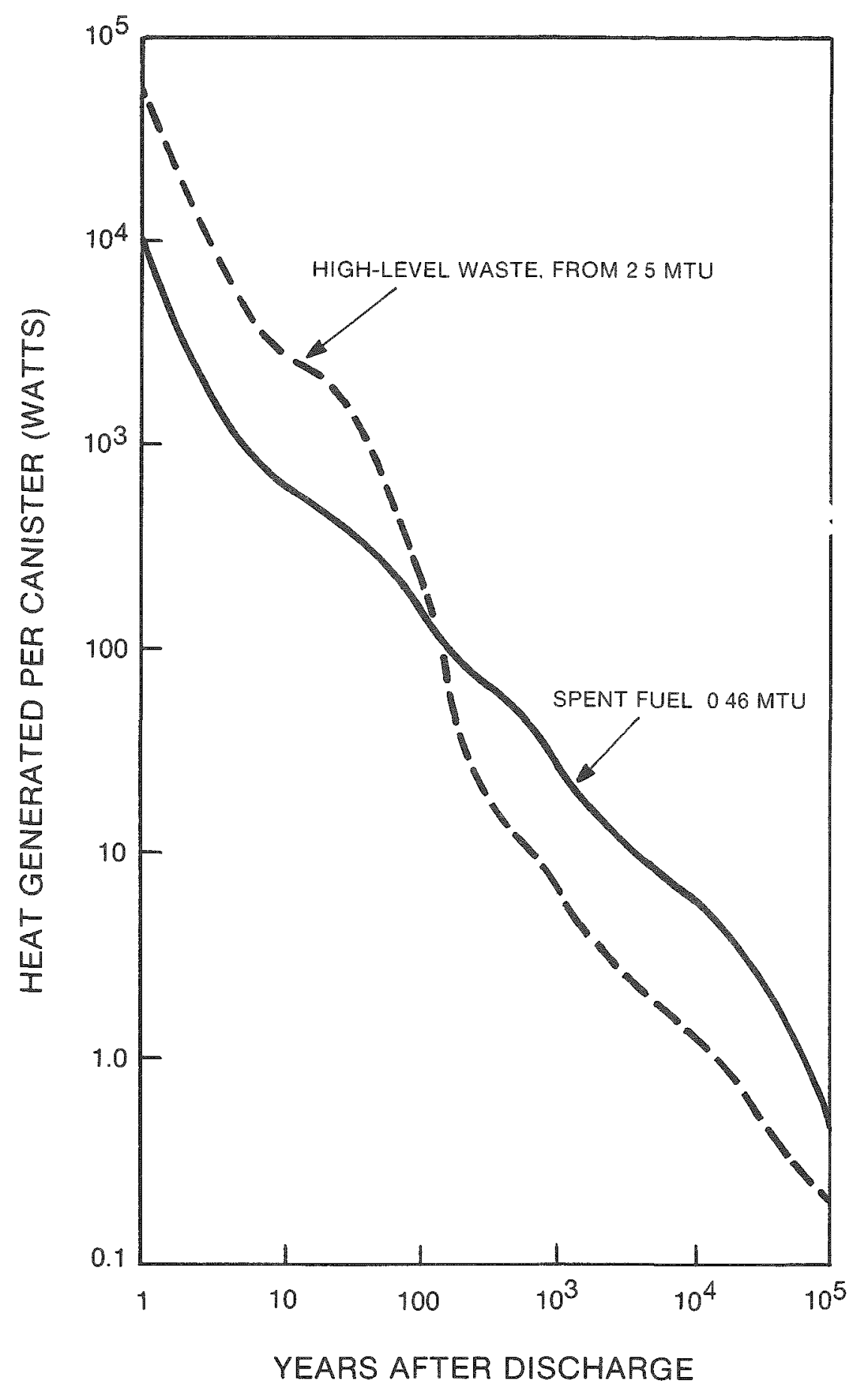

FIGURE 2-51. Thermal Power of a Spent Fuel Canister Containing One Pressurized Water Reactor Assembly Compared to a Canister of High-level Waste from Similar Fue 7 Containing 2.5 Metric Tons of Uranium (MTU) (after NAE and NAS, 1979). 


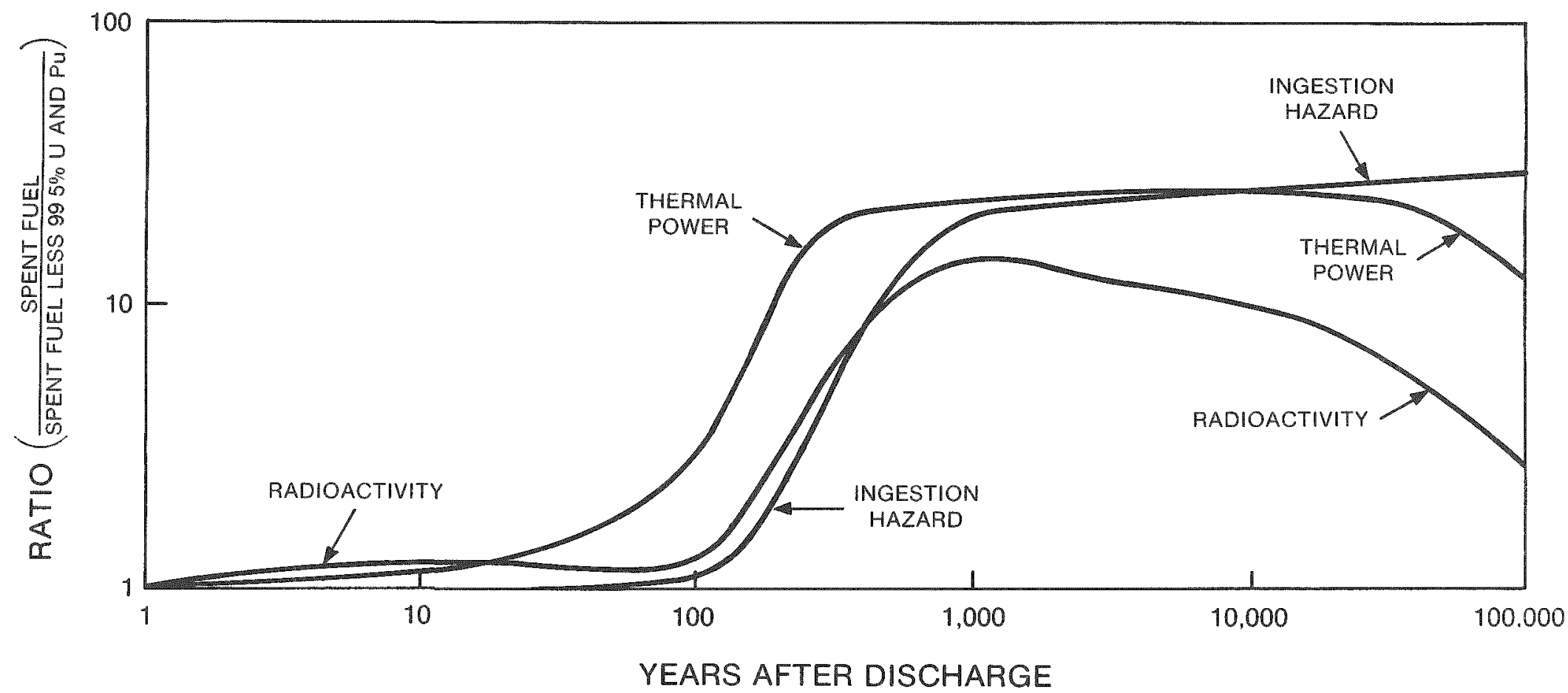

FIGURE 2-52. Comparison of the Characteristic Parameters of Unreprocessed and Reprocessed Spent Fuel. This figure shows that while essentially equal up to 100 years, thereafter the spent fuel assembilies are relatively more hazardous by a factor of about 20 (after NAE and NAS, 1979). 
The differences in thermal power generated by waste canisters significantly impact waste emplacement strategies. Due to its long thermal period, the amount of spent fuel which can be stored per unit area (in terms of thermal power generation), must be less than that of high-level waste in order to avoid exceeding maximum repository thermal loadings. Consequently, the high-level waste generated by reprocessing a given amount of spent fuel will require less repository area for its disposal than would the parent spent fuel.

The emplacement of waste canisters, and the thermal effects which they produce will be dependent upon the age of the waste and its configuration (waste loading). For instance, disassembling fuel assemblies and tripling the amount of spent fuel per canister will reduce the number of canisters by a factor of three. It will also produce a two-thirds reduction in the number of canisters stored per unit area, because the thermal power of the overal1 quantity of reference spent fuel remains the same.

UTtimately, the thermal loading capacity of the repository host rock and required barrier materials will determine the amount of heat per unit area which may be tolerated in a repository. The thermal loading capacities will aiso determine the amount of power per canister which may be tolerated, which will dictate the waste loading per canister and/or the extent to which the waste, be it spent fuel or reprocessing waste, must be aged before emplacement. Considerable research is still required to quantify these parameters for a repository in basalt.

\subsubsection{Considerations in the Development of Engineered Barrier Require- ments for Nuclear Waste Forms in a Basalt Environment}

Each of the waste forms discussed previously in this section will require some form of engineered barrier to prevent radionuclide release from any waste packages which fail early in the repository's history (the thermal period). The barrier system should also act to reduce radionuclide release from such failed canisters to acceptable levels in the time following the thermal period. As has been shown in previous sections, the various waste forms exhibit different stabilities under the variety of physical and chemical conditions which are possible in the repository. Consequently, different waste forms will require different 
engineered barriers to provide adequate safeguards against radionuclide release.

The characteristics of the three waste form types which impact barrier selection, both favorable and unfavorable, are summarized in Table 2-66. Spent fuel is the waste form which will probably require the most extensive engineered barrier development to meet requirements set forth in draft environmental regulations set by the U.S. Nuclear Regulatory Commission (NRC, 1980). These regulations demand a zero radionuclide release in the first 1,000 years of the repository's ifetime and a maximum one part in 105 per year release of the remaining radionuclide inventory thereafter. As was discussed in Section 2.6.2, many of the fission products in spent fuel are present as highly soluble phases, and a few are present as gases.

Limited testing has been conducted on waste forms under the types of pressure, temperature, and $\mathrm{pH}$ conditions expected in a repository in basalt during its operating lifetime. Details of these experiments are presented in Section 2.6.6. In summary, results to date confirm earlier estimates that spent fuel will probably require the most extensive barrier array to accommodate any waste package failure. The alkali metals, strontium, molybdenum, technetium, iodine, uranium and plutonium, can be leached from spent fuel under a variety of conditions. Leaching of the alkalis, strontium and molybdenum, has been observed under hydrothermal conditions. Uranium and plutonium leaching has been seen in ambient pressure and temperature in Paige-tests as well as in leaching of the elements mentioned above. These findings imply that barriers which not only function to fix ions such as cesium and strontium, but oxidized species of uranium and plutonium as well will be required while the repository is receiving waste and soon after closure. Defenses against complexed plutonium migration in the normally reducing conditions in an "equilibrium" repository may also be required.

Glass, while significantly more resistant to leaching, releases cesium, uranium, sodium, and molybdenum in rates greater than the dissolution of the glass network-formers under hydrothermal conditions. The apparent dissolution of the glass matrix-formers suggests that any fission products bound in the matrix will eventually be released in the 
TABLE 2-66. A Summary of Major Characteristics of Waste Forms.

\begin{tabular}{|c|c|c|}
\hline Form & Advantages & Disadvantages \\
\hline Spent Fue & $\begin{array}{l}\text { Reprocessing unneseccary } \\
\text { Unbreached cladding pro- } \\
\text { vides additional barrier }\end{array}$ & $\begin{array}{l}\text { Long thermal period (104 yr) } \\
\text { Fuel pellets highly leach- } \\
\text { able } \\
\text { Large actinide content } \\
\text { High resource potential } \\
\text { No control of spent fuel } \\
\text { properties } \\
\text { Limited data base } \\
\text { Poor hydrothermal stability }\end{array}$ \\
\hline Glass & $\begin{array}{l}\text { Tolerates variable waste } \\
\text { composition } \\
\text { Moderate waste loading } \\
\text { Fair hydrothermal sta- } \\
\text { bility } \\
\text { Short thermal period } \\
\text { Resists radiation damage } \\
\text { - Extensive data base }\end{array}$ & $\begin{array}{l}\text { Moderate thermal output } \\
\text { Glass network susceptible } \\
\text { to hydrothermal attack } \\
\text { Moderate leach rate } \\
\text { May devitrify, increasing } \\
\text { leachability }\end{array}$ \\
\hline $\begin{array}{l}\text { Supercalcine- } \\
\text { Ceramic }\end{array}$ & $\begin{array}{l}\text { High thermodynamic } \\
\text { stability } \\
\text { High waste loading } \\
\text { Very leach resistant } \\
\text { under hydrothermal cond- } \\
\text { ditions } \\
\text { Tolerates some waste } \\
\text { variation }\end{array}$ & $\begin{array}{l}\text { High thermal output* } \\
\text { Radiation damage possible } \\
\text { Transmutation effects on } \\
\text { crystal structures incom- } \\
\text { pletely defined } \\
\text { Limited data base }\end{array}$ \\
\hline
\end{tabular}


event of waste package failure, provided that they do not precipitate in insoluble phases.

Engineered barriers must be provided which will retard radionuclide migration in an environment where the $\mathrm{pH}$ is dominated by silicic acid dissolution (mildly acidic at peak repository temperatures) and the groundwater contains large amounts of dissolved silica should vitreous waste be stored in basalt. As the glass may dissolve slowly, barriers for retention of actinides contained in it may be required for long-term isolation. Barrier requirements for the operating and imnediate post-closure environment will probably be similar to spent fuel barrier requirements, although the quantity of barrier material required to stop actinides in the glass witl be greatly reduced due to the limited quantity of actinides present and the greater leach resistance of glass.

Much less information is available for supercalcine-ceramic and SYNROC. Limited hydrothermal tests suggest that small amounts of cesium, rubidium, sodium, and molybdenum will be leached from supercalcine at $3000 \mathrm{C}, 300$ bars, resulting primarily from leaching of a fresh surface, and hydration of the surface layers, followed by spalling which produces a fresh surface for leaching.

The ceramic waste forms appear to be much more leach resistant than glass. The limited tests which have been reported on SYNROC durability suggest that it can survive conditions far exceeding those likely in a repository. Even so, barriers for the above-mentioned radionuclides will probably be required to guard against waste package failure. The number of barriers required, the amount of material, and the type are topics presently under study. Preliminary results are shown in subsequent sections. Exacting tests under hydrothermal conditions at controlled Eh and $\mathrm{pH}$ in the ranges discussed in Section 2.5 will be required to more accurately specify barrier requirements in a basalt environment. The reactions of waste forms, water, minerals, and conceptual barrier materials will be described in greater detail in Section 2.9 .

Engineered barriers will be required to survive and function in temperature regimes which vary in both intensity and duration. As can be observed in Figure 2-51, high-level waste canisters (containing glass at $25 \%$ waste loading) initially emit about 5.5 times more heat than a 
pressurized water reactor canister. This heat load, which may vary as a function of waste loading and waste age, may require barrier materials which can survive and function at temperatures up to $4000 \mathrm{c}$. The maximum temperature conditions imposed by canisters of spent fuel will be lower $\left(\sim 220^{\circ} \mathrm{C}\right)$, but overall thermal effects will be of much longer duration.

A11 commercial nuclear waste forms that are now under consideration should be able to be emplaced in a repository located in basalt. Engineered barriers will be required for each waste form to minimize or eliminate radionuclide release within specified time periods, as discussed in Section 2.2. Because of differing thermal outputs and geochemical weaknesses, each waste form will require barrier materials that are somewhat different to minimize the effects of a canister or waste package failure. Currently, the largest body of data for waste form strengths and weaknesses exists for glass. Less is known about the reactions that may allow radionuclide release from spent fuel and supercalcine. Also, compositional and phase chemistry data on these waste forms are more limited. Data obtained from waste form developers, as well as repository specific reaction data gathered as a part of engineered barriers development work. will allow the development of specific barrier assemblages for each nuclear waste form in a repository in basalt.

\subsection{THE CANISTER AND OVERPACK}

\subsubsection{Introduction}

The functions of an engineered barrier system for a repository located in basalt were reviewed in Section 2.2. There it was proposed that a successfuily designed barrier system must rely on a system of physical and chemical barriers that function in a mutually supportive manner to achieve the required waste isolation. Given this design approach, it is important that the performance limits of candidate materials for the canister and overpack components of the barrier system be determined under conditions simulating the environment expected in a repository located in basalt. Further, these limits must be determined with sufficient accuracy to permit valid prediction of long-term behavior. 
Only in this way can reference canister and overpack materials eventually be selected with confidence. For this reason, a program has been initiated within the Basalt Waste Isolation Project which has as its objective the identification and testing of these reference materiais. This will entail, first, the selection of candidate materials, followed by mechanical and corrosion testing, and then selection of reference materials for barrier system design.

In this section, the approach used to select candidate alloys for testing is described. This approach includes a review of relevant corrosion literature from which materials that possess the potential for waste canister and overpack fabrication are identified. General criteria governing the selection of candidate alloys are then developed. From there, two criteria-corrosion resistance, as reported in the literature, and weldability--are used to screen and prepare a list of candidate a) loys for further testing.

\subsubsection{Survey of Materials Evaluation Studies}

\subsubsection{Introduction. Active programs are under way in Swedish,} Canadian, Belgian, and U.S. laboratories to select and qualify canister materials for use in several geologic repository environments. Progress made in this area is summarized in this section. Results of related Taboratory and engineering canister studies concerned with in-can giass melting and surface storage of spent fuel assemblies are also summarized along with corrosion data from recent geothermal energy investigations.

2.7.2.2 Swedish Studies. Swedish companies that build nuclear power installations organized the Nuclear Fuel Safety Project (KBS) in 1977 to meet the requirements called out in the "Stipulation Law" enacted by the Swedish parliament. In addition to extensive geologic studies, the KBS staff also pioneered the engineered barriers concept of nuclear waste disposal in geologic strata with particular attention to the development of high-integrity and high-performance canisters and backfills. Results, ideas, and philosophy of the Swedish engineered barrier development studies have been reported in various technical reports (KBS, 1978a, 
1978b, 1978c, 1978d, 1979) and in open 1iterature (Ah1ström, 1979; Larker, 1979; Mattsson, 1979; Ekbom and Others, 1979; and Pettersson, 1977).

The Swedish canister and backfill investigations are all keyed to a repository excavated $500 \mathrm{~m}$ below ground in igneous rock (granite). Plans are to place each canister, containing either high-level waste or spent fuel rods, in a vertical borehole embedded in a backfill of either pure bentonite or a mixture of quartz sand and bentonite. (The functions and properties of these backfill materials are covered in Section 2.8.) In the Swedish repository model the backfill will, after an initial unspecified period, become saturated with $\mathrm{pH} 7.0$ to 9.0 groundwater. Such groundwater will eventually come into contact with the exterior of the canister walls. In 211 cases, the highest temperature at the outer canister surface will be restricted to only $80^{\circ} \mathrm{C}$ or less. After 500 to 1,000 years the temperature is expected to fall to $40^{\circ}$ to $50^{\circ} \mathrm{C}$. The ability to limit the thermal load to low values, thereby minimizing the rate and extent of any hydrothermal reactions, is a fundamental tenet of the Swedish nuclear waste repository concept. Several methods are available to control the thermal load including extended surface storage of spent fuel before disposal or reprocessing, reduced loading of radionuclides in the high-level waste form, and increased dispersal of canisters in the repository.

For use in the Swedish repository regime, KBS scientists have proposed three alternative canister types. One, a lead-lined titanium container, is intended to contain high-level waste borosilicate glass while two others, metallic copper and a-alumina, are intended to contain spent fuel rods. The Swedish Corrosion Institute chartered a group of specialists to evaluate the corrosion resistance of these proposed canisters and to estimate their expected life under repository conditions.

The canister/backfill system proposed by the Swedes for disposal of high-level borosilicate glass is depicted in Figure 2-53. In this system the vitrified waste is put into a stainless steel liner can with walls 3-mm thick and placed in an inert-gas welded, lead-lined titanium canister. The titanium outer shell is unalloyed titanium (ATi-24 with a maximum of $0.002 \%$ hydrogen) with a wall thickness of $6 \mathrm{~mm}$. The inner 


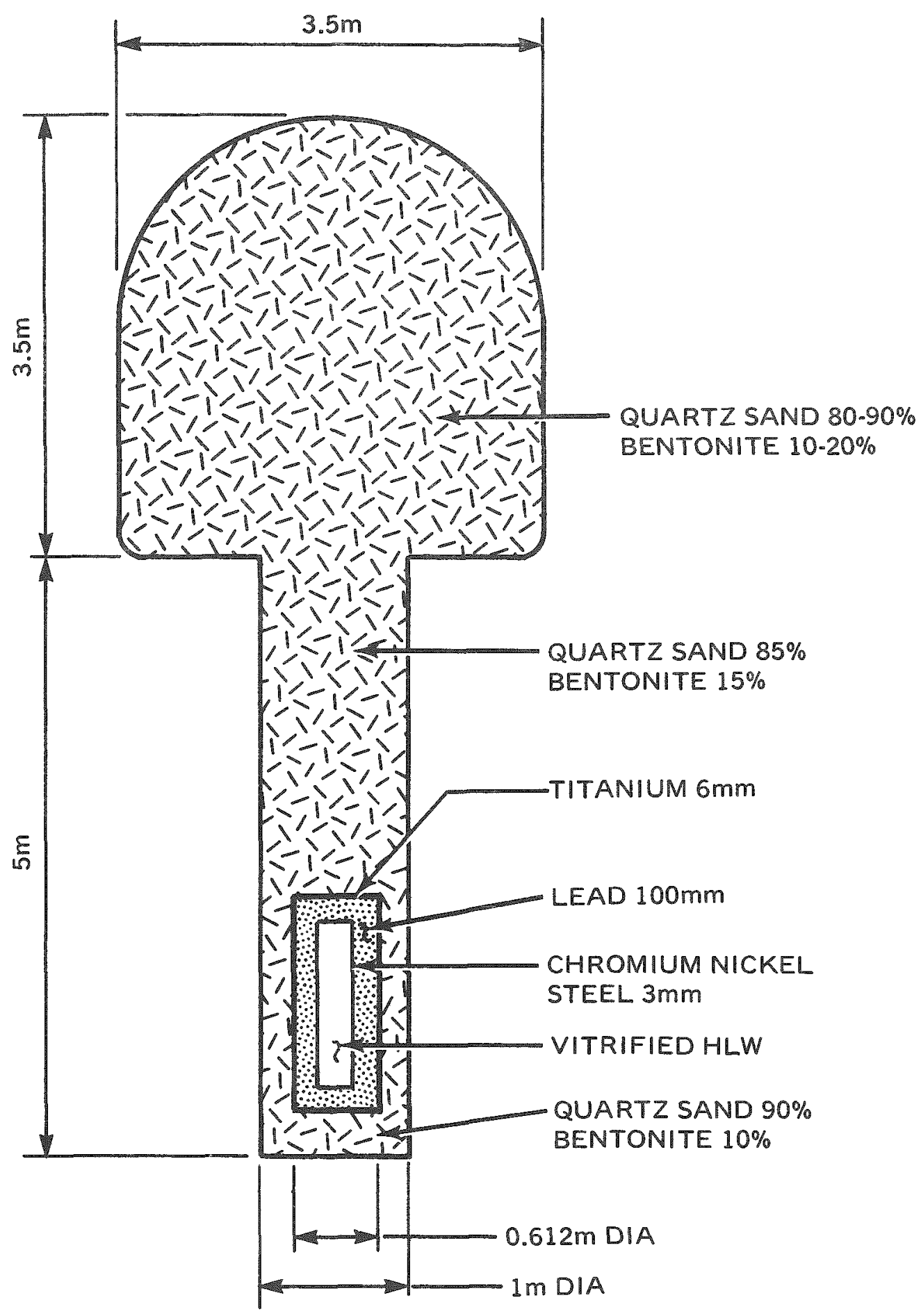

TITANIUM CANISTER WITH LEAD LINING

FIGURE 2-53. Swedish Titanium Canister-Backfill Concept for Geologic Disposal of Vitrified High-Level Waste (after Mattsson, 1979). 
oxygen-free lead (99.995\% lead) lining 100-mm thick with a grain size not less than $0.01 \mathrm{~m}$ to minimize creep. Lead-lined titanium canisters containing vitrified waste are placed in vertically drilled holes which are backfilled with quartz sand mixed with $10 \%$ bentonite (Fig. 2-53). Additional canister fabrication information is given by Ahlström (1979).

Findings regarding corrosion properties and the expected life of the lead-lined titanium canister have been reported (KBS, 1978d) and are summarized as follows:

- The life of the titanium outer shell was estimated to be at least 10,000 years based on a conservative value for general corrosion of $0.25 \mu \mathrm{m} /$ year.

- Pitting and crevice corrosion were considered unlikely in the geologic environment.

- Risk of delayed fracture because of hydrogen uptake was considered to be small but finite.

- The rate of localized attack on the lead would be determined by the availability of oxygen, but conservative calculations yield a lead-Tiner life of about 4,500 years.

- The complete canister was estimated to have a life of at least thousands of years, and probably tens of thousands of years.

The copper canister-backfill system proposed by the Swedes for disposal of spent nuclear fuel is illustrated in Figure 2-54. In this system single fuel rods from disassembled fuel assemblies are placed in a copper rack designed to hold 498 boiling-water reactor rods or 636 pressurized-water reactor rods. The rack and fuel rods are placed in a pure metallic copper canister made of oxygen-free high conductivity copper with walls $20 \mathrm{~cm}$ thick. The empty space between the fuel rods is backfilled with lead at $380^{\circ}$ to $400^{\circ} \mathrm{C}$. After cooling, the copper canister is closed with three consecutive lids, each electron-beam welded to the canister.

Fue 1 rods in the copper canister are embedded in lead to prevent canister deformation by internal and external stresses. Filled and sealed canisters are embedded in a backfill of highly compacted bentonite 


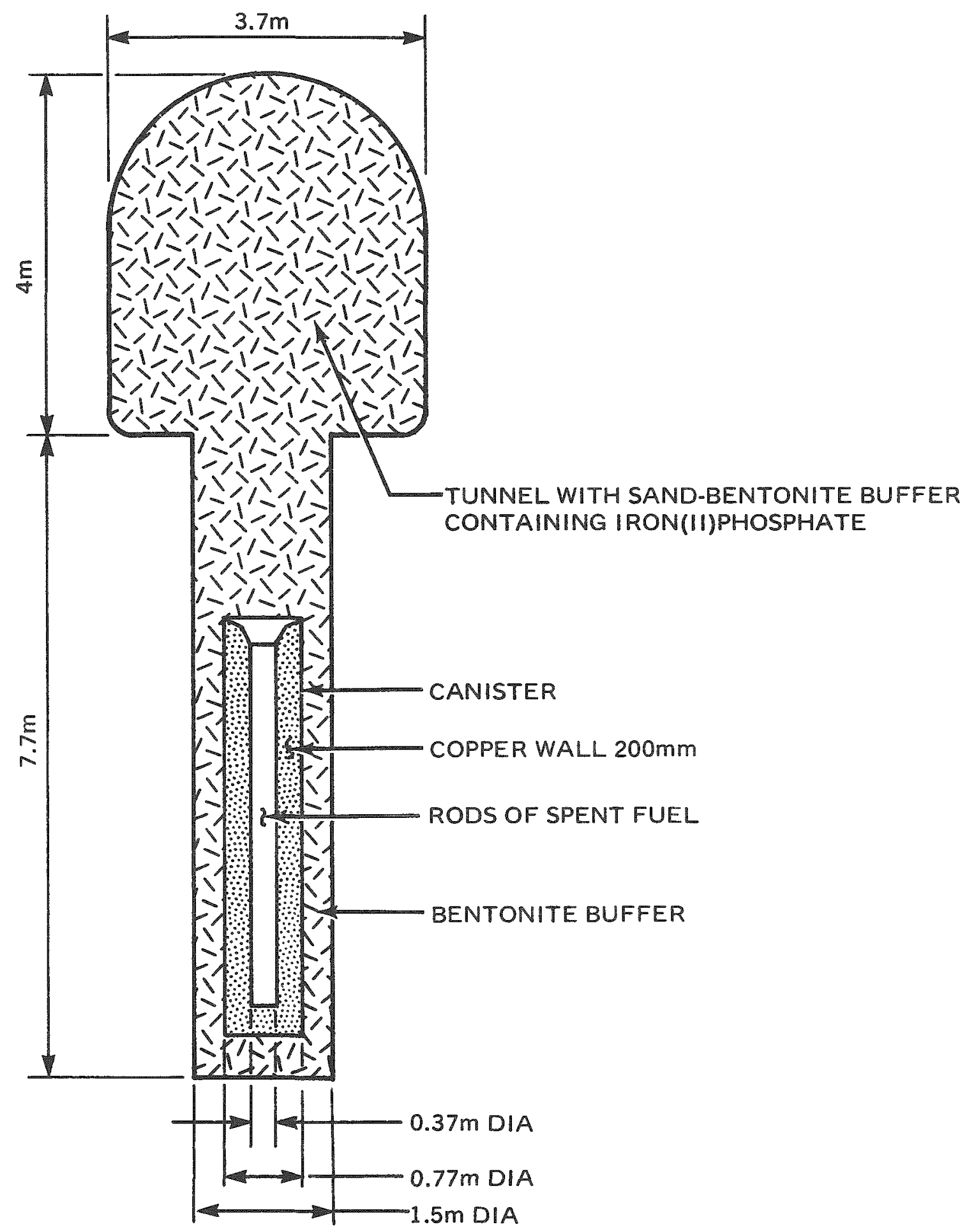

FIGURE 2-54. Swedish Copper Canister and Backfill Concept for Disposal of Spent Fuel Rods (after Mattsson, 1979). 
specially oxidized to limit its sulfide and organic matter content each to $200 \mathrm{mg} / \mathrm{kg}$ or less. Also, a small amount of $\mathrm{Fe}$ (II) phosphate is added to the sand-bentonite materiai used to plug repository tunnels (Fig. 2-54). The function of the $\mathrm{Fe}_{3}\left(\mathrm{PO}_{4}\right)_{2}$ is to remove atmospheric oxygen initially present in the sand-bentonite plug material.

After examination of the factors affecting corrosion of copper under proposed repository conditions, it was concluded at the Swedish Corrosion Institute that the only substances of importance are free oxygen and sulfides (KBS, 1978b). Using upper-limit values for the oxygen and sulfide ion sources and concentrations, the institute's scientists arrived at the conclusion that the proposed canister will last for hundreds of thousands of years.

Another system being studied by the Swedes for geologic disposal of spent fuel is depicted in Figure 2-55. This alternative involves enclosure of coiled spent fuel rods in high-purity alumina (minimum $99.8 \%$ $\mathrm{Al}_{2} \mathrm{O}_{3}$ ) canisters. Such canisters, formed by isostatic pressing at $100 \mathrm{MPa}$ and $1,350^{\circ} \mathrm{C}$ (Larker, 1979), have wall thicknesses of $100 \mathrm{~mm}$ and will be closed with a cap of alumina sintered onto the top leaving no detectable seam. Filled alumina canisters will be placed in holes filled with a bentonite-quartz sand buffer. In this disposal scheme, the maximum outside canister temperature will be $70^{\circ} \mathrm{C}$.

Corrosion of the alumina canisters is expected to occur by formation of either amorphous $\mathrm{Al}(\mathrm{OH})_{3}$ or crystalline gibbsite. Corrosion rates of 0.01 to $0.07 \mu \mathrm{m} /$ year in water at $\mathrm{pH} 7.0$ to 9.3 at $90^{\circ} \mathrm{C}$ have been measured. When alumina canisters are exposed to groundwater containing silicates even lower corrosion rates would be expected because of the formation of protective surface coatings (Mattsson, 1979).

An important point of concern about alumina canisters is the occurrence of delayed fracture. This phenomenon may occur if the alumina canister has sufficiently large surface defects and is under sufficiently high mechanical tension. Under these conditions surface defects may grow into slowly propagating cracks ultimately leading to fracture. Calculations and measurements indicate the largest residual stress in $\mathrm{Al}_{2} \mathrm{O}_{3}$ canisters, which have been produced to date is $38 \mathrm{Mn} / \mathrm{m}^{2}$, which corresponds to a largest surface defect of about $2.4 \mathrm{~mm}$. Such defects are easily detected by nondestructive testing methods (Mattsson, 1979). 
RHO-BWI-ST-7

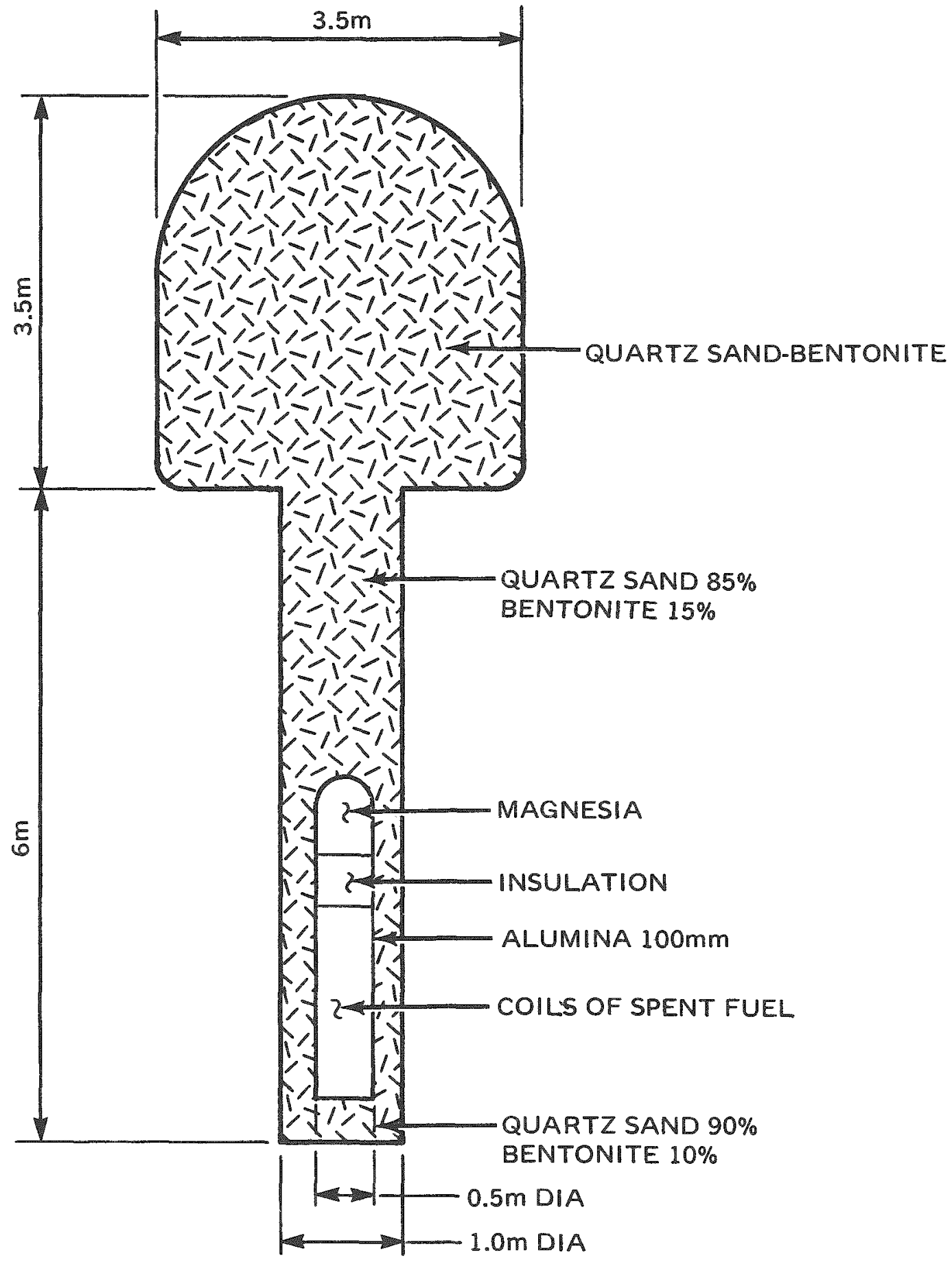

FIGURE 2-55. Swedish Aiumina Canister and Backfill Concept for Disposal of Spent Fuel Rods (after Mattsson, 1979). 
Available data suggests that the corrosion rate of alumina canisters under conditions in a repository located in granite (see Fig. 2-55) would be less than $0.1 \mu \mathrm{m} /$ year. With proper production control, it appears possible to avoid delayed fracture. However, the calculations of the expected life of an alumina canister under proposed Swedish repository conditions have not yet been completed and reported by the Swedish Corrosion Institute.

Fabrication of alumina canisters longer than $3 \mathrm{~m}$ is not possible with state-of-the-art isostatic pressing equipment. Ordinary light water reactor fuel rods are, however, closer to $4 \mathrm{~m}$ long. Satisfactory technology for rolling fuel rods, both irradiated and unirradiated, into spirals to reduce their length has been demonstrated by the Swedish firm ASEA (Ahiström, 1979). The need for complicated fuel rod length reduction equipment and procedures is a disadvantage in the use of alumina canisters. Investigations continue in Sweden to determine the need for such fuel rod length reduction and to develop techniques and equipment for making satisfactory 5-m-long alumina canisters.

Brief consideration was given in the Swedish KBS project to the development and testing of glass-ceramic canisters (Ahlström, 1979; Sundquist, 1979). Corrosion studies concentrated on the behavior of Corning Code 9617 glass-ceramic. This latter material is a composite of several phases--90\% beta spodumene $\left(\mathrm{Li}_{2} \mathrm{O}^{\circ} \mathrm{AT}_{2} \mathrm{O}_{3}{ }^{\circ} \times \mathrm{SiO}_{2}\right.$, where $\left.x=5-7\right)$, $3 \%$ rutile $\left(\mathrm{TiO}_{2}\right.$ ), $3 \%$ spinel ( $\mathrm{Mg}$ or $\mathrm{Zn}^{\cdot} \mathrm{Al}_{2} \mathrm{O}_{4}$ ), and residual glass. Corrosion tests of Corning Code 9617 glass-ceramic in water, $\mathrm{NaCl}$ solutions, and $\mathrm{H}_{2} \mathrm{O}$-bentonite-sand mixtures at $60^{\circ}$ to $180^{\circ} \mathrm{C}$ were made. These tests indicated a corrosion rate as low as $1.3 \mathrm{~mm}$ per 1,000 years was achievable. According to Ahlström (1979), the preliminary data indicated that the glass-ceramic would probably meet the requirements on a high-level waste canister. It was concluded, however, that this could not be verified within the short time schedule of the KBS project.

2.7.2.3 The Canadian Study. Cameron and Strathdee (1979) have noted that engineered containment is an integral part of the Canadian nuclear waste disposal program. Studies of corrosion-resistant metals and alloys, ceramic materials, and backfill materials are currently in 
progress at the Whiteshe11 Nuclear Research Establishment in Manitoba, Canada. Current emphasis in the Canadian program is on canisters for disposal of spent fuel assemblies. For this purpose, titanium, Inconel 625, and copper are considered to be leading canister materials.

2.7.2.4 The Belgian Study. The Commission of the European Communities in Brussels, Belgium, is concerned with evaluating various geologic formations including clays for disposal of nuclear waste. The corrosion of several candidate waste canister materials were studied under conditions simulating those expected in a repository located in a clay formation (Casteel and others, 1979). Corrosion measurements were made at $25^{\circ}$, $50^{\circ}, 100^{\circ}, 150^{\circ}, 200^{\circ}$, and $300^{\circ} \mathrm{C}$ on canister materials exposed to a moist atmosphere simulating that produced by pyrolysis of the clay at $300^{\circ} \mathrm{C}$. In situ corrosion tests in a geological clay formation were also conducted.

Casteel and co-workers evaluated the performance of the following listed materials in tests lasting up to 16. months: carbon stee1; chromised carbon steel; AISI 304; AISI 304L; AISI 316L; UHB 904 L (a $50 \mathrm{Fe} / 20 \mathrm{Cr} / 25 \mathrm{Ni} / 5 \mathrm{Mo}$ alloy); AISI 430; 2 ferritic steels with a low interstitial content; Inconel 600; Inconel 625; Incoloy 800; Ni 200; Hastelloy $C_{\text {; }}$ aluminum alloys: titanium; and Ti-Pd, Ti-AT, Ti-AT-Sn, and Ti-Al-U alloys. The time and temperature dependence of the corrosion phenomena was evaluated by measuring weight changes and observations were made by metallographic techniques.

In the series of ferritic and austenetic steels, UHB 904L and AISI $316 \mathrm{~L}$ were most resistant to preferential attack. Inconel 625 and Hastelloy $C$ both exhibited excellent resistance to localized corrosion as did titanium. Carbon steel and aluminum and its alloys were most susceptible to attack under the corrosion conditions tested.

2.7.2.5 Sandia Laboratories Study. Scientists at Sandia Laboratories have conducted corrosion studies to identify canister materials suitable for use under possible worst-case hydrothermal conditions in geologic repositories in bedded salt (e.g., Waste Isolation Pilot $\mathrm{Plant}$ ) and in seabed sediments (Braithwaite and Molecke, 1979). Candidate metallic alloys (Table 2-67) were selected for testing from a review of corrosion 
TABLE 2-67. Nominal Chemical Composition (Wt\%) of Candidate Canister Alloys--Sandia Laboratories.

(After Braithwaite and Molecke, 1979.)

\begin{tabular}{|c|c|c|c|c|c|c|c|c|c|}
\hline Alloy & C & $\mathrm{Mn}$ & Si & $\mathrm{Cr}$ & $\mathrm{Ni}$ & Mo & $\mathrm{Fe}$ & $\mathrm{Cu}$ & others \\
\hline 4130 Carbon Steel & $0.3 \mathrm{Ma}$ & 0.5 & 0.3 & 1.0 & - & 0.2 & $\mathrm{Bat}$ & - & - \\
\hline $2-1 / 4 \mathrm{Cr}-1$ Mo & 0.2 & 0.8 & 0.3 & 2.2 & - & 1.0 & $\mathrm{Bal}$ & - & - \\
\hline Naval Brass & - & - & - & - & - & - & - & 60.0 & $39.0 \mathrm{Zn} ; 1.0 \mathrm{Sn}$ \\
\hline$S S-304$ & $0.08 M$ & $2.0 \mathrm{M}$ & $1.0 M$ & 19.0 & 10.0 & - & Bal & - & - \\
\hline$S S-316$ & $0.08 M$ & $2.0 M$ & $1.0 M$ & 17.0 & 12.0 & 2.5 & Bat & - & - \\
\hline SS-Nitronic $50^{\circ}$ & $0.06 \mathrm{M}$ & 5.0 & $=$ & 22.0 & 13.0 & 2.25 & Bal & - & $0.2 \mathrm{Nb}, 0.2 \mathrm{v}$ \\
\hline SS-20cb3d & $0.07 \mathrm{M}$ & $2.0 M$ & $1.0 M$ & 20.0 & 34.0 & 2.5 & $\mathrm{Bal}$ & 3.5 & - \\
\hline SS-Ebrite 26-1e & $0.01 \mathrm{M}$ & $0.4 M$ & $0.4 M$ & 26.0 & $0.5 M$ & 1.0 & $\mathrm{Bal}$ & $0.2 M$ & - \\
\hline Inconel $625 f$ & 0.05 & 0.2 & 0.2 & 21.5 & 63.0 & 9.0 & 2.5 & - & $4.0 \mathrm{Nb} ; 0.2 \mathrm{Ti}$ \\
\hline Hastelloy $C-2769$ & - & - & - & 15.0 & 59.0 & 17.0 & 5.0 & - & $4 W$ \\
\hline Zircaloy 2 & 0.12 & - & - & 0.1 & 0.05 & - & - & - & $1.5 \mathrm{Sn}: 98.2 \mathrm{Zr}$ \\
\hline Titanium, C.P. & - & $\infty$ & $\infty$ & - & - & - & - & - & $99.5 \mathrm{Ti}$ \\
\hline Ticode-12h & 0.012 & - & - & - & 0.84 & 0.34 & 0.09 & - & $98.9 T i$ \\
\hline MP35N & - & - & - & 20.0 & 35.0 & 10.0 & - & - & $35.0 \mathrm{Co}$ \\
\hline
\end{tabular}

aM denotes maximum.

bu.S. Stee 1: CArmco Steel Corp: dCarpenter Technology Corp:

eAllegheny Ludlum Industries; fHuntington Alloys; gCabot Corp; hTIMET. 
experience with geothermal brines and seawater. Corrosion of these candidate materials was measured in synthetic seawater and brines representative of either water which might intrude into the proposed Waste Isolation Pilot Plant site by percolation through an overiying potash zone or dissolved, bedded salt at the $800-\mathrm{m}$ horizon of the proposed Waste Isolation Pilot Plant (Table 2-68). Table 2-69 summarized results of corrosion tests performed at $250^{\circ} \mathrm{C}$ and 5 to $7 \mathrm{MPa}$ in both deoxygenated and oxygenated solutions.

TABLE 2-68. Test Solutions for Canister Corrosion Studies--Sandia Laboratories.

(After Braithwaite and Molecke, 1979.)

\begin{tabular}{|c|c|c|c|}
\hline Ion & $\begin{array}{c}\text { Seawater } \\
\mathrm{mg} / \mathrm{l}\end{array}$ & $\begin{array}{c}\text { Brine } A \\
\mathrm{mg} / \mathrm{l}\end{array}$ & $\begin{array}{c}\text { Brine } B \\
\mathrm{mg} / \mathrm{l}\end{array}$ \\
\hline $\mathrm{Na}^{+}$ & 10,651 & 42,000 & 115,000 \\
\hline $\mathrm{K}^{+}$ & 380 & 30,000 & 15 \\
\hline $\mathrm{Mg}^{+2}$ & 1,272 & 35,000 & 10 \\
\hline $\mathrm{Ca}^{+2}$ & 400 & 600 & 900 \\
\hline$S r^{+2}$ & 13 & 5 & 15 \\
\hline $\mathrm{Cl}^{-}$ & 18,980 & 190,000 & 175,000 \\
\hline $\mathrm{SO}_{4}^{-2}$ & 884 & 3,500 & 3,500 \\
\hline$I^{-}$ & -5 & 10 & 10 \\
\hline $\mathrm{HCO}_{3}^{-}$ & 146 & 700 & 10 \\
\hline $\mathrm{Br}^{-}$ & 65 & 400 & 400 \\
\hline $\mathrm{BO}_{3}{ }^{-3}$ & - & 1,200 & 10 \\
\hline $\mathrm{pH}$ & 8.1 & 6.5 & 6.5 \\
\hline Total Dissolved & & & \\
\hline Solids: & $35 \mathrm{~g} / \mathrm{h} *$ & $306 \mathrm{~g} / \mathrm{l}$ & $297 \mathrm{~g} / \mathrm{h}$ \\
\hline
\end{tabular}

*arams per liter. 
TABLE 2-69. Corrosion Rates of Candidate Canister Materials

in Brines and Seawater at 2500C--Sandia Laboratories

(After Braithwaite and Molecke, 1979.)

\begin{tabular}{|c|c|c|c|c|c|}
\hline \multirow{3}{*}{ Materials } & \multicolumn{5}{|c|}{ Corrosion Rate $(\mathrm{mm} / \mathrm{y})$} \\
\hline & \multicolumn{3}{|c|}{ Deoxygenated Solutions $(P=5 \mathrm{MPa})$} & \multicolumn{2}{|c|}{ Oxygenated Solutions $(\mathrm{P}=7 \mathrm{MPa})$} \\
\hline & Brine Aa & Brine $B a$ & Seawatera & Brine $A^{b}$ & Seawater \\
\hline 1018 Mild Stee 7 & 1.7 & 0.07 & 0.4 & 7.0 & 11.0 \\
\hline Corten A Stee1 & 0.9 & 0.05 & 0.2 & & \\
\hline 2-1/4 Cr-1 Mo Stee 7 & $1.0 \mathrm{C}$ & $0.1 \mathrm{C}$ & 0.2 & & \\
\hline Lead & 0.5 & 0.3 & 0.3 & 1.2 & 1.0 \\
\hline Copper & 0.07 & 0.05 & 0.05 & 1.2 & 5.0 \\
\hline Naval Brass & 1.0 & & 1.0 & & \\
\hline 90-10 Cupronickel & 0.14 & & 0.07 & 0.4 & 0.7 \\
\hline SS-304L & 0.018 & 0.01 & 0.006 & & \\
\hline$S S-316 L$ & 0.015 & & 0.005 & & \\
\hline SS-Nitronic 50 & 0.008 & & 0.003 & & \\
\hline SS-20Cb3 & 0.007 & & 0.005 & $0.1 \mathrm{C}$ & \\
\hline SS-Ebrite $26-1$ & 0.016 & & 0.005 & 0.24 & \\
\hline Monet 400 & $c .03$ & & 0.1 & & \\
\hline Incoloy 825 & 0.006 & & 0.004 & & \\
\hline Incone1 600 & 0.009 & 0.007 & 0.005 & & 0.1 \\
\hline Inconel 625 & 0.005 & 0.001 & $0.012^{d}$ & & \\
\hline Haste1 loy C-276 & 0.007 & & 0.0015 & $0.06 \mathrm{~d}$ & $0.2^{d}$ \\
\hline Zircaloy 2 & 0.001 & & & & \\
\hline Titanium C.P. & 0.014 & & 0.012 & & \\
\hline TiCode-12 & 0.003 & & 0.001 & 0.0004 & 0.0006 \\
\hline
\end{tabular}

asee Table 2-68 for compositions.

$\mathrm{b}_{2}=600 \mathrm{mg} / \mathrm{l}$ in Brine $\mathrm{A}$ and $1,750 \mathrm{mq} / \mathrm{l}$ in seawater.

crevice corrosion. 
Predictably, the presence of substantial amounts of oxygen increases the corrosion rate of all the candidate alloys tested. Even under worst-case, brine-inundated, $250^{\circ} \mathrm{C}$ oxidizing environments, several of the candidate canister materials appear suitable for long-term service in a bedded salt or seabed geologic repository. Based on these initial corrosion rate results, published data, alloy costs, and availability, Sandia scientists have selected three prime candidate alloys for further comprehensive study. They are TiCode-12, Hastelloy C-276, and 90-10 Cupronickel. Inconel 625, Incoloy 825, and lead are considered alternate candidate alloys.

The Sandia scientists concluded that it appears possible to provide a high-level waste canister/overpack system that can survive the potentially corrosive environment of a repository located in salt for desired periods of time. Furthermore, they have concluded that a canister/ overpack can protect the high-level waste form from aqueous leaching (assuming an intruding leachant) during the period of greatest waste thermal output and greatest reactivity, which they estimate to be 300 to 400 years.

Braithwaite and associates at the Sandia Laboratories are actively continuing their studies of canister and overpack materials suitable for use in repositories sited in a bedded salt formation. Along with their initial scouting work, they have concentrated on evaluating the properties of TiCode-12, pure titanium $(T i-50 A)$, and a titanium-palladium alloy. These titanium materials appear to be particularly resistant to corrosion even by brine solutions and thus may also be the best choice for highly corrosion resistant canister or overpack materials for use in a Columbia Plateau basalt environment. Effects of radiation on the corrosion and other properties of the titanium-base alloys have also been studied by Braithwaite and Others (1980) and their conclusions are as follows:

- TiCode-12 has not been disqualified by any of the overtests conducted in this investigation.

- TiCode-12 and titanium-palladium are highly corrosion resistant alloys in hot brines. An increase in the solution's oxidizing potential increases the tenacity and effectiveness of the passivating $\mathrm{TiO}_{2}$ layer and decreases the corrosion rate. Higher temperatures 
increase the uniform corrosion rate, but pitting and crevice corrosion problems have not been encountered even at temperatures up to $300^{\circ} \mathrm{C}$. Crevice corrosion problems were observed at $250^{\circ} \mathrm{C}$ in cormercial purity titanium (Ti-50A), which makes it unacceptable as a candidate alloy.

- The primary effect of gamma radiation on corrosion is to produce oxidizing radiolysis products in solution. The primary longlived species are probably $\mathrm{OCT}^{-}$and $\mathrm{H}_{2} \mathrm{O}_{2}$. The production of these species along with the reduced species, $\mathrm{H}_{2}$, increases with increasing solute concentration, dose rate, and total dose. The corrosion rate of TiCode-12 in brine doubles in the presence of high dose rates of garma radiation $\left(10^{7} \mathrm{rads} / \mathrm{hr}\right)$.

- The ductility of TiCode-12 was unaffected by the test environment over a wide range of strain rate and environmental conditions in slow-strain rate stress-corrosion-cracking tests. Tests were conducted in dry salt and brine at $250^{\circ} \mathrm{C}$. Additional testing at room temperature was conducted on previously irradiated and hydrogen-charged materials.

- Whereas a ductile fracture morphology was typical of TiCode-12 exposed to dry salt and brines, the specimens exposed to hightemperature oxygenated brine and irradiated brine exhibited atypical regions. These regions were localized at the edges of the specimen and are characteristic of a less ductile fracture mechanism (i.e., quasi-cleavage). This change in fracture behavior warrants further investigation.

2.7.2.6 Battelle-Pacific Northwest Laboratory Studies. Westerman (1979) at the Pacific Northwest Laboratory has initiated a broad-based program to evaluate various materials for potential application as engineered barriers in several geologic repository environments. This program is an extension of Pacific Northwest Laboratory's task in the U.S. Department of Energy's spent-fuel handling and packaging program designed to develop an "advanced package" for spent fuel. Some of the candidate canister (and overpack) materials being considered by Westerman (1979) for containing spent fuel elements are listed in Table 2-70. They have noted 
that iron-base, copper-base, nickel-base, zirconium-base, titanium-base, lead, and ceramic materials can be considered as candidates for benign nonbrine applications; canisters and overpacks of moderate wall thicknesses constructed of these materials should meet the long-life requirements under these conditions.

TABLE 2-70. Candidate Materials for Long-Lived Spent Fuel Disposal Barrier Systems.

(After Westerman, 1979.)

\begin{tabular}{|c|c|}
\hline \multirow[t]{6}{*}{ Metals } & Ti alloys \\
\hline & Zr alloys \\
\hline & Ni alloys \\
\hline & $\mathrm{Pb}$ alloys \\
\hline & $\mathrm{Fe}$ alloys \\
\hline & $\mathrm{Cu}$ alloys \\
\hline \multirow[t]{8}{*}{ Ceramics } & $\mathrm{Al}_{2} \mathrm{O}_{3}$ (Alumina) \\
\hline & $2 \mathrm{Al}_{2} \mathrm{O}_{3} \cdot \mathrm{SiO}_{2}$ (Muilite) \\
\hline & $\begin{array}{l}\mathrm{Al}_{2} \mathrm{O}_{3}-\mathrm{ZrO}_{2}-\mathrm{SiO}_{2} \text { (Fused ZAS Refactory) } \\
\text { CaTiO } \mathrm{O}_{3} \text { perovskite }\end{array}$ \\
\hline & $\mathrm{CaO} \cdot \mathrm{ZrO}_{2} \cdot \mathrm{TiO}_{2}$ (Zirconolite) \\
\hline & $\mathrm{TiO}_{2}$ Rutile \\
\hline & $\mathrm{ZrO}_{2}$ (Zirconia CaO stabilized) \\
\hline & $\mathrm{ZrSiO}_{4}$ (Zircon) \\
\hline & TiC, SiC (Carbides) \\
\hline \multirow[t]{3}{*}{ Carbon } & Impervious graphite \\
\hline & Glassy carbon \\
\hline & Pyrolytic graphite \\
\hline GTasses & Wide variety \\
\hline
\end{tabular}


Slate and Maness (1978) at the Pacific Northwest Laboratory have conducted studies to determine the resistance of several candidate alloys for glass melter and canister fabrication in support of the laboratory's Nuclear Waste Fixation Program. The rate of attack by molten glass compositions varied with glass composition and alloy type and ranged from nil to severe. Oxidation at in-can melting temperatures was formed to contribute significantly to material degradation. Plastic yielding of the canister walls as the glass solidified and cooled was also measured.

The results of one series of exposures conducted by STate and Maness (1978) permit the qualitative prediction of the extent of glass waste/ metal interaction expected at repository temperatures. When exposed to a glass melt, $304 \mathrm{~L}$ stainless steel yielded corrosion rates that increased from $0.04 \mathrm{in} /$ year to $45 \mathrm{in} /$ year as the temperature was raised from $950^{\circ}$ to $1,150^{\circ} \mathrm{C}$. This trend suggests that at emplacement temperatures, the corrosion rate would be insignificant.

2.7.2.7 The Savannah River Laboratory Study. Research is also in progress at the Savannah River Laboratory to study glass-canister metaldry rocksalt interactions (Angerman and Rankin, 1978; Rankin, 1979). This study includes measurements of internal canister corrosion, from in-can melting of glass, as well as observations of long-term (up to 50,000 hours) dry salt-metal interactions. Initial results of this long-term canister corrosion and compatibility study using dry salt have been summarized by Rankin (1979) as follows:

"Candidate alloys to be used in fabricating canisters for solidified radioactive waste were exposed to salt from Carisbad, New Mexico, in a manner similar to that expected during final storage of waste-forms. There were no significant reactions of low carbon steel or Type 304L stainless steel at $80^{\circ}$ and $225^{\circ} \mathrm{C}$ in tests in unsealed or sealed capsules.

Other tests were carried out in sealed capsules at $600^{\circ} \mathrm{C}$. Under these conditions Type 304L stainless steel was attacked to a depth of 2 mils and low carbon steel was attacked up to 20 mils. This attack is attributed to exposure to the volatile components 
of the salt released by decrepitation. Storage conditions are being designed so that temperatures high enough to cause salt decrepitation will not occur. However, under proposed storage conditions, mechanisms exist, such as migration of brine in the salt to the warm canisters, that could lead to the concentration of the volatile components of the salt in the canister storage location. Additional tests are, therefore, planned to characterize the reaction between candidate canister alloys and the volatile components of the salt under proposed storage conditions. Specimens in sealed capsules will be heated to $300^{\circ} \mathrm{C}$ for one hour to decrepitate the salt. Then they will be heated for up to 50,000 hours at $80^{\circ}, 125^{\circ}$, and $225^{\circ} \mathrm{C}$."

\subsubsection{Geothermal Energy Studies. Increasing interest in geothermal} energy sources has motivated a number of studies to determine the corrosion behavior of various metals and alloys in hot brines (Shannon, 1977; Carter and MCCawley, 1978; Banning and Oden, 1973). Braithwaite and Molecke (1979) have noted that results of these corrosion studies are qualitatively applicable to the worst-case inundated conditions for a bedded salt repository. Metal corrosion in low-salt waters typical of hard-rock repositories is anticipated to be less than in brines or seawater. Hence, the data of Shannon, Carter and McCawley, and Banning and Oden are relevant worst case data and can be applied in selecting of canister and overpack materials for use in a nuclear waste repository in Columbia Plateau basalt.

Corrosion rates measured by Shannon (1978) in high-temperature synthetic geothermal brines under deoxygenated conditions are summarized in Tables 2-71, 2-72, and 2-73. This screening was performed in a refreshed autoclave apparatus (i.e., a procedure where the test solution is periodically replaced). Titanium-base alloys, nickel-base alloys, high chromium alloys, zirconium, Ebrite 26-1, and SS-446 were a11 resistant to the $250^{\circ} \mathrm{C}$ oxygen-free brine. Carter and McCawley (1978) observed similar corrosion behavior during in situ tests in the Salton Sea area of California. 
RHO-BWI $-S T-7$

TABLE 2-71. Nominal Composition (Wt\%) of Alloys Tested in Simulated High-Temperature Geothermal Brines.

(After Shannon, 1977)

\begin{tabular}{|c|c|c|c|c|c|c|c|c|c|c|c|c|c|c|c|}
\hline Carbon Steels & Carbon & $\operatorname{sen}$ & P & 5 & \$? & 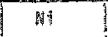 & $\mathrm{Cr}$ & 40 & M & $\mathrm{Cu}$ & Ee & H & 0 & Al & ather \\
\hline A570 sheet & 0.13 & 0.42 & 0.008 & $0.0: 7$ & -- & $\infty$ & $\ldots$ & $\rightarrow$ & - & $-\infty$ & $=$ & - & - & 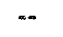 & \\
\hline As38 Fipe & 0.20 & 0.55 & 0.010 & 0.010 & 0.02 & 0.02 & 0.007 & 0.005 & - & $=$ & $R \in m^{* 4}$ & $\ldots$ & $-\infty$ & 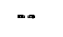 & \\
\hline SAE 1010 Tube & 0.10 & 0.30 & 0.007 & 0.020 & 0.009 & 0.04 & 0.009 & 0.010 & - & 0.02 & Ren & $\infty$ & $-\infty$ & $\infty$ & \\
\hline Alos Pipe & 0.20 & 0.55 & 0.10 & 0.012 & 0.15 & 0.09 & 0.04 & 0.010 & $-\infty$ & 0.03 & Ren & $\infty$ & $-\infty$ & $\infty$ & \\
\hline SAE 1010 Tubet & 0.03 & 0.27 & 0.017 & 0.006 & 0.095 & 0.03 & 0.039 & 0.005 & $\sim$ & 0.05 & Ren & $-\infty$ & om & $\infty$ & \\
\hline A538 Tube* & 0.23 & 0.71 & 0.010 & 0.019 & 0.15 & 0.25 & 0.010 & 0.007 & $-\infty$ & 0.608 & Re्षत & $\ldots$ & - & $\infty$ & \\
\hline \multicolumn{16}{|l|}{$\begin{array}{l}\text { Apl Grade he?1 } \\
\text { Cas?ng 3teels }\end{array}$} \\
\hline 675 & 0.44 & 1.86 & 0.008 & 0.17 & 0.21 & - & - & 0.21 & -- & -- & Rext & $-\infty$ & $\infty$ & $\infty$ & \\
\hline $\cos$ & $\cdots$ & - & 0.014 & 0.020 & -- & -- & -- & - & $-\infty$ & -+ & Rer & $\infty$ & $-\infty$ & - & \\
\hline Ј5 & $0.4 ?$ & 1.09 & 0.012 & 0.013 & 0.08 & 0.03 & 0.03 & $0 . m$ & $\cdots$ & $-\infty$ & Ren & -- & $-\infty$ & $\infty$ & \\
\hline K5E & 0.32 & 1.03 & 0.010 & 0.020 & 0.09 & 0.09 & 0.01 & 0.009 & -- & 0.07 & REx & $\infty$ & - & $-\infty$ & \\
\hline 160 & 0.29 & 1.22 & 0.021 & 0.033 & 0.07 & -- & - & -- & $-\cdots$ & $-\infty$ & Ren & $=$ & $\infty$ & $\infty$ & \\
\hline M8O & 0.28 & 1.20 & 0.010 & 0.012 & 0.13 & 0.08 & 0.04 & 0.01 & - & 0.12 & Rent & $\infty$ & - & $\infty$ & \\
\hline 0130 & - & $\cdots$ & 0.019 & 0.027 & -- & - & $\cdots$ & - & $\cdots$ & $\cdots$ & Rem & $\infty$ & $-\infty$ & $\infty$ & \\
\hline \multicolumn{16}{|l|}{ Chromiun Steeis } \\
\hline 4130 Tshes & 0.28 & 0.48 & 0.009 & 0.011 & 0.25 & 0.05 & 0.82 & 0.15 & $\infty$ & 13.997 & 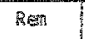 & $\infty$ & - & $\infty$ & \\
\hline -8rite 26-1 & 0.002 & 0.020 & 0.020 & 0.011 & 0.21 & 0.14 & 26.23 & 1.0 & 0.010 & 0.2020 & Rem & $\approx$ & $=$ & $=$ & \\
\hline 405 & 0.60 & 0.25 & 0.010 & 0.009 & 0.04 & 0.28 & 23.05 & 0.002 & $\infty$ & 0.051 & है बा & $\infty$ & $\cdots$ & 0.27 & \\
\hline 410 & 0.22 & 0.20 & 0.009 & 0.014 & 0.27 & 0.24 & 22.93 & 0.05 & - & 0.03 & Rem & $-\infty$ & $\infty$ & 0.08 & \\
\hline 430 & $0.05:$ & 0.24 & 0.012 & 0.039 & 0.29 & 0.34 & $\$ 5.89$ & 0.19 & $\infty$ & 0.87 & Ren & $\infty$ & $\infty$ & 0.05 & \\
\hline 486 & 0.057 & 0.45 & 0.014 & 0.011 & 0.22 & 0.29 & 23.20 & 0.06 & $\cdots$ & 0.05 & Ren & $=$ & $-\infty$ & 0.02 & \\
\hline 405 & 0.11 & 0.36 & 0.011 & 0.005 & 0.25 & 0.23 & 12.45 & 0.10 & $\infty$ & 0.04 & Rom & $\cdots$ & $\infty$ & 1.75 & \\
\hline 439 & 0.052 & 0.42 & 0.031 & 0.010 & 0.43 & 0.22 & 16.89 & 0.18 & - & 0.09 & Ren & $\approx$ & $\infty$ & 0.21 & \\
\hline $29 m 4 \times$ & $0.01 \max \mid$ & - & - & - & $-\infty$ & $\begin{array}{l}0.15 \\
\text { maa }\end{array}$ & 20 & 4 & $\begin{array}{l}0.03 \\
\text { max }\end{array}$ & $-\infty$ & Ren & - & $-\infty$ & $\cdots$ & \\
\hline $29-4-2 * \%$ & 0.01 max & - & - & + & $=-$ & 2 & 29 & 4 & $0.02 \mathrm{max}$ & - & Reta & - & $\infty$ & - & \\
\hline $26-15^{* t}$ & $0.05 \mathrm{max}$ & $-\infty$ & $-\infty$ & - & - & $0.05 \max$ & 26 & 1 & $0.04 \mathrm{mas}$ & - & $\operatorname{Ren}$ & $-\infty$ & $m$ & $\infty$ & $1.00 \mathrm{max} . \mathrm{T} \frac{\hat{s}}{3}$ \\
\hline $2-1 / 2 \mathrm{cr} .1 \mathrm{MO}$ & 0.12 & 0.50 & 0.012 & 0.014 & 0.22 & 0.32 & 2.14 & 2.05 & $-\infty$ & 0.18 & $8 \in$ & $\cdots$ & $-\infty$ & $=$ & \\
\hline $58 * 2$ & $0.03 \max$ & 2.5 & $-\infty$ & - & - & 24 & 20 & 6.5 & $-\infty$ & $\infty$ & Rer & $\infty$ & $\infty$ & 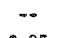 & \\
\hline E-8rite 20-1 Tuse* & 0.0 & 0.10 & 0.015 & 0.011 & 0.18 & 0.09 & 26.2 & 1.06 & $-\infty$ & 0.005 & Ren & $\cdots$ & $\infty$ & 0.05 & \\
\hline 410 Tabign & 0.13 & 0.39 & 0.010 & 0.009 & 0.51 & 0.33 & 11.80 & 0.03 & $\therefore$ & 6.93 & Rey & 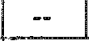 & $\infty$ & 0.17 & \\
\hline \multicolumn{16}{|l|}{ Titanism } \\
\hline $35=A$ & 0.28 & $-\infty$ & $-\infty$ & - & $\infty$ & - & - & $\infty$ & 0.011 & - & 0.04 & 0.036 & 0.03 & $-\infty$ & \\
\hline 15 ตร & 0.01 & $\infty$ & - & $-\infty$ & $\cdots$ & 1.5 & $\rightarrow$ & $\infty$ & 0.909 & - & 0.04 & $67 \mathrm{per}$ & 0.08 & $\infty$ & \\
\hline $0.2 P d$ & 10.63 & $-\infty$ & $-\infty$ & $-\infty$ & $-\infty$ & $\cdots$ & $\infty$ & $-\infty$ & 0.01 & - & 0.16 & 600 pom & 0.122 & $\infty$ & $0.18 \mathrm{Pd}$ \\
\hline $6 A 1-4 V * \pi$ & $-\infty$ & - & $-\infty$ & $\infty$ & - & $=$ & - & 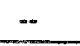 & - & $\infty$ & $-\infty$ & 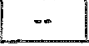 & $\ldots$ & 6 & $6 v$ \\
\hline \multicolumn{16}{|l|}{ Special Materiais } \\
\hline Hastelloy $\mathrm{C}-276^{*}$ & 0.02 & 1 & 0.03 & 0.03 & 0.05 & Rera & 18.5 & $15-17$ & -- & $-\infty$ & $4=7$ & $-\infty$ & -- & $\infty$ & พ3 $3-4.5, C 0$ \\
\hline Inconel 625 出k & 0.05 & 0.25 & $-\infty$ & 0.008 & 0.25 & 61 & 22.5 & 9 & $-\infty$ & - & 2.5 & $=$ & $\infty$ & 0.2 & $0.2^{\circ} \mathrm{TA}_{2} \mathrm{ACb}$ \\
\hline Inconel 6ogkt & 0.08 & 0.5 & $-\infty$ & $\cdots$ & 0.25 & 76 & 25.5 & $\infty$ & $\infty$ & 0.25 & 8 & -- & $\cdots$ & $\cdots$ & \\
\hline $\begin{array}{l}\text { Incoloy } 925 \text { n } \\
\text { Iireoniuta }\end{array}$ & 0.03 & 0.5 & -- & 0.015 & 0.25 & 42 & 21.5 & 3 & -- & 2.25 & 30 & - & $-\infty$ & 0.1 & $\begin{array}{l}\text { Ti } 0.2 \\
\text { Pure Crysta? }\end{array}$ \\
\hline
\end{tabular}


TABLE 2-72. Effect of A17oy Composition on Uniform Corrosion.

(After Shannon, 1977.)

\begin{tabular}{|c|c|c|c|c|c|c|}
\hline \multirow{2}{*}{ Alloy } & \multicolumn{6}{|c|}{ Corrosion Rate, in/yr (mm/yr) } \\
\hline & $1 \% \mathrm{NaCl}$ & \multicolumn{2}{|c|}{$5 \% \mathrm{NaCl}$} & $10 \% \mathrm{NaCl}$ & \multicolumn{2}{|c|}{$20 \% \mathrm{NaCl}$} \\
\hline A570 & $0.012(0.03)$ & 0.035 & $(0.9)$ & $0.043 \quad(1.1)$ & 0.11 & $(2.8)$ \\
\hline A538 Heat 1 & $0.011 \quad(0.3)$ & 0.024 & $(0.6)$ & $(0.9)$ & 0.11 & $(2.8)$ \\
\hline A53B Heat 2 & -- & 0.06 & $(0.4)$ & $0.023(0.6)$ & 0.13 & $(3.2)$ \\
\hline $\mathrm{C75}$ & $0.009 \quad(0.2)$ & 0.016 & $(0.4)$ & $0.007 \quad(0.2)$ & 0.08 & $(2.0)$ \\
\hline 1010 & $0.014(0.4)$ & 0.038 & $(1.0)$ & $0.041 \quad(1.0)$ & 0.14 & $(3.5)$ \\
\hline 4130 & -- & & & $0.007 \quad(0.2)$ & 0.091 & $(2.3)$ \\
\hline $2-1 / 4-1$ Mo & $0.003 \quad(0.08)$ & 0.023 & $(0.6)$ & $0.012(0.3)$ & 0.069 & $(1.8)$ \\
\hline 410 Heat 1 & $0.003 \quad(0.08)$ & 0.004 & $(0.1)$ & $0.030 \quad(0.8)$ & 0.14 & $(3.5)$ \\
\hline 410 Heat 2 & -- & 0.009 & $(0.2)$ & $0.020 \quad(0.5)$ & 0.15 & $(3.8)$ \\
\hline E-Brite $26-1$ Heat 1 & $0.002 \quad(0.05)$ & 0.0003 & $(0.01)$ & $0.0007(0.02)$ & 0.003 & $(0.08)$ \\
\hline E-Brite $26-1$ Heat 2 & -- & 0.0007 & $(0.02)$ & $0.0008(0.02)$ & 0.0006 & $(0.02)$ \\
\hline Hastelloy C-276 & $0.0009(0.02)$ & 0.0012 & $(0.03)$ & $0.0017(0.04)$ & 0.0015 & $(0.04)$ \\
\hline Incone1 625 & $0.0003(0.01)$ & 0.0001 & $(0.01)$ & $0.0002(0.01)$ & 0.0008 & $(0.02)$ \\
\hline Inconel 600 & $0.0006(0.02)$ & 0.0009 & $(0.02)$ & $0.0018(0.05)$ & 0.0015 & $(0.04)$ \\
\hline Incoloy 825 & $0.0004(0.01)$ & 0.0002 & $(0.01)$ & $0.0003(0.01)$ & 0.0018 & $(0.05)$ \\
\hline $29 \mathrm{Cr}-4-2$ & $0.003 \quad(0.08)$ & 0.0002 & $(0.01)$ & $0.0006(0.02)$ & 0.0005 & $(0.01)$ \\
\hline $6 x$ & $0.0004(0.01)$ & 0.0003 & $(0.01)$ & $0.0003(0.01)$ & 0.0013 & $(0.03)$ \\
\hline
\end{tabular}


TABLE 2-73. Comparison of Alternate Alloys with Carbon Steels in 0xygen-Free Brines $=6.89 \mathrm{MPa}$.

(Based on 11-Day Tests).

(After Shannon, 1977.)

\begin{tabular}{|c|c|c|c|c|}
\hline \multirow{3}{*}{ Alloy } & \multicolumn{4}{|c|}{ Corrosion Rate } \\
\hline & \multicolumn{2}{|c|}{$\begin{array}{c}2500 \mathrm{C}-1 \% \mathrm{NaCl} \\
\mathrm{pH} 4.8 \mathrm{H} \mathrm{s} 10 \mathrm{mg} / \mathrm{e}\end{array}$} & \multicolumn{2}{|c|}{$\begin{array}{c}250^{\circ} \mathrm{C}-20 \% \mathrm{NaCT} \\
\text { pH } 4.6\end{array}$} \\
\hline & $(\mathrm{in} / \mathrm{yr}$ & $(\mathrm{mm} / \mathrm{yr})$ & $(\mathrm{in} / \mathrm{yr})$ & $(\mathrm{mm} / \mathrm{yr})$ \\
\hline $\begin{array}{l}\text { Average of ten } \\
\text { carbon steels }\end{array}$ & 0.007 & 0.18 & 0.087 & 2.2 \\
\hline \multicolumn{5}{|l|}{ Chromium Alloys } \\
\hline $2-1 / 4 \mathrm{Cr} \cdot 1 \mathrm{MO}$ & 0.003 & 0.08 & 0.019 & 0.48 \\
\hline E-Brite 26-1 & 0.0006 & 0.02 & 0.0006 & 0.02 \\
\hline 405 & 0.0025 & 0.06 & 0.0098 & 2.5 \\
\hline 410 & 0.0014 & 0.04 & 0.120 & 3.0 \\
\hline 430 & 0.0017 & 0.04 & 0.0062 & 1.6 \\
\hline 446 & 0.0007 & 0.02 & 0.0008 & 0.02 \\
\hline 406 & 0.0022 & 0.06 & 0.017 & 0.43 \\
\hline 439 & 0.0014 & 0.04 & 0.015 & 0.38 \\
\hline $29 \mathrm{Cr}-4 \mathrm{MO}$ & 0.0006 & 0.02 & 0.0008 & 0.02 \\
\hline $29 \mathrm{Cr}-4 \mathrm{Mo}-2 \mathrm{Ni}$ & 0.0004 & 0.02 & 0.0008 & 0.02 \\
\hline $26 \mathrm{Cr}-1 \mathrm{Mo}-1 \mathrm{Ti}$ & 0.0006 & 0.02 & 0.0008 & 0.02 \\
\hline $6 x$ & 0.0001 & 0.003 & 0.0005 & 0.01 \\
\hline \multicolumn{5}{|l|}{ Nickel Alloys } \\
\hline Hastelloy C-276 & 0.0015 & 0.04 & 0.0005 & 0.01 \\
\hline Inconel 625 & 0.0002 & 0.005 & 0.0001 & 0.003 \\
\hline Inconel 600 & 0.0092 & 0.23 & 0.0004 & 0.01 \\
\hline Incoloy 825 & 0.0002 & 0.005 & 0.0003 & 0.008 \\
\hline \multicolumn{5}{|l|}{ Titanium Alloys } \\
\hline Ti $35 \mathrm{~A}$ & $<0.0002$ & $<0.005$ & $<0.0001$ & $<0.005$ \\
\hline Ti $1.5 \mathrm{Ni}$ & $<0.0002$ & $<0.005$ & $<0.0001$ & $<0.005$ \\
\hline $\mathrm{Ti} 0.2 \mathrm{Pd}$ & $<0.0002$ & $<0.005$ & $<0.0001$ & $<0.005$ \\
\hline Ti $6 \mathrm{~A}-4 \mathrm{~V}$ & $<0.0002$ & $<0.005$ & $<0.0001$ & $<0.005$ \\
\hline Zirconium & $<0.0001$ & $<0.005$ & $<0.0001$ & $<0.005$ \\
\hline
\end{tabular}


Attention is also called to the survey paper by Banning and Oden (1973), which presents an excellent compilation of corrosion data for most alloy systems in hot brines and seawater.

\subsubsection{Radiation Effects. Interactions between radiation and} crystalline solids can result in the creation of lattice imperfections: (1) by the introduction of chemical impurities through $(n, y)$ and $(n, \infty)$ reactions and atomic transmutation; and (2) by displacement of atoms from their equilibrium positions. The effects of these interactions on the physical and mechanical properties of metallic materials have been important to the development of nuclear technology and, hence, have been extensively studied. The results have been reported in reviews by Dienes and Vineyard (1957) and Billington and Crawford (1961).

Measurable radiation effects are usually only exhibited by metallic materials exposed to in-reactor environments, where the accumulated neutron radiation doses may reach as high as $10^{24} \mathrm{n} / \mathrm{cm}^{2}$ (Sutton and Leeser, 1954). Much lower neutron flux leve $1 \mathrm{~s}, w 10^{3} \mathrm{n} / \mathrm{cm}^{2} \cdot \mathrm{sec}$, associated with a typical 3-year-old pressurized water reactor spent fuel assembly (Davis, 1979), would not yield dose levels (during the period of geologic isolation) where radiation effects would be measurable. Hence, the major concern in evalution of nuclear waste isolation materials is the effect of the intense garma radiation on the corrosion resistance of canister/overpack materials.

Incident radiation can affect the corrosion resistance of metallic materials by affecting changes in: (1) the metal itself; (2) the protective layer; and/or (3) the corrodant. Researchers have concluded that gamma radiation principally affects the corrodant and does so by producing chemical changes (radiolysis) through excitation and ionization (Stobbs and Swallow, 1962; Byalobzheski, 1970; Wu, 1978). The primary radiolysis process in aqueous solutions is the decomposition of water to form short-lived radicals, $e_{a q} ; \mathrm{H}_{3} \mathrm{OH}$ and $\mathrm{HO}_{2}$, and the long-lived molecular products, $\mathrm{H}_{2}$ and $\mathrm{H}_{2} \mathrm{O}_{2}$. If in some manner the radiolytic $\mathrm{H}_{2}$ is continuously removed from the system, the oxidation potential of the solution will be increased. Conversely, in a closed system such as a sealed repository located in basalt where the hydrogen fugacity remains 
high (see Section 2.5), the radiolysis reaction will be suppressed and the oxidation potential will remain essentialiy unchanged. Under such conditions, radiation could have little effect on corrosion.

Under conditions where radiolysis can easily occur, however, the solution will generally exhibit oxidizing properties and the corrosion rate of metallic materials exposed to these solutions may increase, decrease, or remain essentially unchanged. Alloys, such as stainless steel and those of aluminum, titanium, and zirconium that are rendered passive by the presence of an adherent surface oxide film, should be little affected by oxidizing radiolysis products in aqueous solutions. The experimental study of the effect of gamma radiation on the corrosion of stainless steel in $3 \% \mathrm{NaCl}$ solution conducted by Byalobzheski (1970) showed that the corrosion rate was essentially unaffected after 1,200 hours exposure. Studies cited by Stobbs and Swallow (1962) in their review showed, similarly, that stainless steels in high-purity aqueous systems at temperatures up to $300^{\circ} \mathrm{C}$ and $\mathrm{pH}$ values around 10 are affected little by neutron irradiation.

Indicent gamma radiation can be beneficial in reducing crevice corrosion in stainless steels and other alloys that exhibit susceptibility to this form of attack (Wu, 1978). Crevice corrosion is initiated as a result of differential aeration. Oxygen within a crevice is consumed by reaction with the metal and, thus, becomes depleted relative to the surrounding solution. The metal surface within the crevice becomes more anodic than surrounding metal and pitting proceeds. Under irradiation, the radiolysis reaction promotes oxidizing conditions within the crevice and the differential aeration cell is removed.

Byalobzheski (1970) has reported in his review that radiation can slightly reduce or have no effect on the corrosion rate of aluminum exposed to aqueous solutions. Radiation slightly reduced the corrosion rate of aluminum alloys with nickel (up to $2 \%$ ), iron (about $0.5 \%$ ), and silicon $(0.90$ to $0.21 \%)$, as revealed by 700 -hour tests in a water-cooled reactor at $260^{\circ} \mathrm{C}$. In a 1,000 -hour test where aluminum was exposed at room temperature to a $3 \% \mathrm{NaCl}$ solution under gamma radiation of $4 \times 10^{15} \mathrm{eV} / \mathrm{cm}^{2} \cdot \mathrm{sec}$, the corrosion rate was unchanged. 
The corrosion resistance of zirconium and titanium, like aluminum, is determined by the tendency of these elements to passivation as a result of the formation of a dense oxide film on their surface. However, in reactor environments at higher temperatures the film on unalloyed zirconium starts to disintegrate, which leads to rapid corrosion. As a result, zirconium alloys, such as the zircaloys, which are covered with oxide films of greater stability, are used instead. According to Byalobzheski (1970) the corrosion resistance of these alloys should not be affected by gamma radiation. A study was conducted by Braithwaite and others (1980), in which titanium alloys were exposed to brine solutions and seawater at $90^{\circ} \mathrm{C}$ in a gamma field of $10^{7}$ rads. In this study, the general corrosion rate of TiCode-12 in seawater was unaffected by radiation and the rate only doubled in the brine solution.

Because of the absence of a protective oxide surface layer and the facilitation of the cathodic reaction by the oxidizing radiolysis products, the corrosion rate of carbon steel exposed to aqueous solutions should increase. This behavior was observed by Byalobzheski (1970). The corrosion rate of carbon steel increased $60 \%$ in distilled water, $80 \%$ in $0.5 \mathrm{~N} \mathrm{NaCl}$ solution, and $400 \%$ in $0.01 \mathrm{~N} \mathrm{H}_{2} \mathrm{SO}_{4}$ under garma irradiation $\left(4.0 \times 10^{15} \mathrm{eV} / \mathrm{cm}^{2} . \mathrm{sec}\right)$ after 1,000 hours at $20^{\circ} \mathrm{C}$. In other studies conducted by Byalobzheski, copper exhibited a marked increase in corrosion rate when exposed to $\mathrm{HCl}$ under gamma irradiation, which was also due to cathodic depolarization by the oxidizing radiolysis products. Samples of electrolytic copper were exposed to X-rays in a $1 \mathrm{~N} \mathrm{NaCl}$ solution. The corrosion rate increased by a factor of 4.5 for a 10-hour exposure where the total energy absorbed by the solution was equal to $0.37 \times 10^{16} \mathrm{eV} / \mathrm{cm}^{3}$.

\subsubsection{Evaluation of Previous Work}

The results of the Swedish studies showed that under their expected repository conditions $\left(80^{\circ} \mathrm{C}\right.$ temperature, granitic media, and associated groundwater) corrosion rates for titanium, copper, and alumina are very low. A panel of their corrosion experts concluded that properly designed canisters constructed of these materials can be expected to last from tens of hundreds to tens of thousands of years. The risk of surface-defectinitiated delayed fracture that may occur in their hot, isostatically-pressed 
alumina canister was evaluated and judged by the panel to be minimal, as was also the risk of the delayed fracture in titanium due to hydrogen uptake. The risk of delayed fracture in titanium is of concern, since the titanium alloy, TiCode-12, has been selected by the Basalt Waste Isolation Project as a prime candidate canister/overpack material. This phenomenon has been evaluated by Pettersson (1977). From his calculations for several hydrogen concentrations, it was concluded that the hydrogen concentration in titanium must be kept below $20 \mathrm{ppm}$ in order to minimize the risk of delayed fracture. This may be difficult to achieve, since hydrogen solubility in titanium has been determined by Patton and others (1971) to be $80 \mathrm{ppm}$ at $100^{\circ} \mathrm{C}$ and $30 \mathrm{ppm}$ at $45^{\circ} \mathrm{C}$. A source of hydrogen in the repository may be from the radiolysis of groundwater. More studies are needed before the risk of delayed fracture in Ticode-12 can be quantitatively assessed, especially since a significant hydrogen fugacity will exist in the repository.

Material screening studies conducted at Sandia Laboratories by Braithwaite and Molecke (1979) included a wide variety of alloys as potential candidates for waste canisters to be emplaced in bedded salt and sea beds. Included were alloys of iron, nickel, copper, titanium, and lead.

For their deoxygenated brine/seawater studies, the test coupons were sealed in quartz ampoules with the test solution and exposed in an autoclave for 2 to 8 weeks at temperature. For the experiments conducted under oxidizing conditions, the coupons were held in the autoclave in open-ended quartz tubes. Because of the short test duration, the use of unstressed specimens and stagnant test solutions (species used up in the corrosion process were not replaced), the corrosion rates measured may be non-conservative for service in brine and seawater environments.

The investigations by Shannon (1977) of the Pacific Northwest Laboratory in high-temperature deoxygenated brines yielded data that were in agreement with the Sandia corrosion data obtained in low-oxygen brines. Data from both the Sandia Laboratories and the Pacific Northwest Laboratory studies show that TiCode-12, Hastelloy C-276, Incoloy 825, Inconels 600 and 625, zirconium, and lead should be considered as candidate alloys for service in salt and seabed environments with 
TiCode-12 being a prime candidate. The ferritic alloys, 400 series, and chrome steels, while exhibiting good corrosion resistance, should probably be excluded from further consideration because they are susceptible to hydrogen embrittlement and difficult to weld.

The Belgian studies have yielded results that identify titanium, Inconel 625, and Hastelloy $C$ as candidate alloys for canisters to be emplaced in clay formations. Although the Canadian program has not yet yielded test results, its leading candidate canister materials are TiCode-12, Incone 1625 , and copper.

The results of studies by Slate and Maness (1978) of Pacific Northwest Laboratory showed that the in-can melting process for producing a glass waste form can be particularly aggressive to metallic materials. Reliance on the canister as a high-integrity barrier once it has been exposed to these process conditions appears to be unacceptable. An alternative would be to use a thin-walled container for the waste receptacle and to seal it in a high-integrity canister for disposal.

Tests at Savannah River Laboratory of up to 50,000-hour exposure are also under way to evaluate the interaction between dry salt and alloy specimens at temperatures of $80^{\circ}$ to $225^{\circ} \mathrm{C}$. Preliminary results show that attack of 304L stainless steel and low carbon steel by the dry salt is insignificant.

In general, the studies reviewed in Section 2.7 .2 yielded data that are conservatively applicable to the Basalt Waste Isolation Project engineered barriers development studies. Alloys of titanium, Inconel 600 and Inconel 625, Hastelloy C-276, Incoloy 825, zirconium, and 90-10 Cupronickel appear to be reasonable choices as candidates for canister and overpack materials for a repository in basalt. The corrosion rates of these alloys in the low ionic strength groundwater are expected to be low: however, the effect of gamma radiation must be determined. 


\subsubsection{General Criteria Governing the Selection of Candidate Canister and Overpack Materials}

In Section 2.2.4, the functions of an engineered barrier system for emplacement in a repository located in basalt were identified. The next step will be to develop engineered barrier performance criteria. These will be responsive to these function definitions and to the performance objectives for the engineered barrier system presently being proposed by agencies of the U.S. Government (EPA, 1979; NRC, 1980). Until these performance criteria are developed and formally approved for use, preliminary criteria are needed to act as a guide to canister/overpack materials selection and to allow the Basalt Waste Isolation Project materials evaluation program to proceed. These criteria are shown in Tables 2-74 and 2-75 and are used in Sections 2.7.6 and 2.7.9 to prepare a list of candidate canister and overpack alloys.

\subsubsection{The Canister as a Long-Lived Waste Isolation Barrier}

2.7.5.1 Historical. In national and international programs supporting the storage and disposal of nuclear waste, principal reliance for radionuclide containment has been placed on the canister. The canister has been regarded as a container of high integrity that must withstand the abuse of handling and transportation, must survive a period of interim storage, and then, once in the repository, must be quantitatively resistant to environmental degradation for a defined period of time. The design life requirements for the canister in national programs supporting waste management have changed from the initial 10-year maximum requirement in interim storage plus 90 days after disposal in a geologic repository (NRC, 1979b) to a 100-year interim storage requirement in a retrievable surface storage facility (ARHCO, 1974) to the present thousands of years' requirement for an engineered barrier system of which it is a component (NRC, 1980). With this change has come increased reliance on the canister as a waste isolation barrier for longer time periods, and it has been the principal motivation for initiation of many of the studies reviewed in the previous section. 


\section{TABLE 2-74. General Criteria Governing the Preliminary Selection of Candidate Canister Materials.}

$$
\text { Criterion }
$$

1. The canister material must be compatible with other components of the multiple barrier systam (including the waste form).*

2. The canister must meet the engineered barrier system longevity requirements.

3. The canister material must possess ase of fabrication.

4. The canister material must be readily available and cost effective.

5. The canister material must possess sufficient mechanical strength to permit handing, transportation, and retrieval.

6. The choice of material must meet the weight and size constraints for the canister.
Bases

A well-designed engineered barrier system will contain engineered barrier components that will function in a mutually supportive manner in concert with the basalt to effectively isolate waste from the biosphere. It is necessary that the canister material does not impair the ability of the other multiple barrier components to fulfill their functions.

The design life requirenent for the canister will be defined by proposed Federal engineered barrier performance guidelines (EPA, 1979; NRC, 1980) and the engineered barrier system concept selected. For a simple concept consisting of a canister and a tallored backfill, the design lite requirement would be the same as that for the engineered barrier system; i.e., 1,000 years. For a more complex system consisting of a canister and a buffer, overpack, and tailored of a canister and a buffer, overpack, and tailored backfill, that act to retard the intrusion and minimize the corrosiveness of the groundwater, a canister design iffe less than that for the engineered barrier system may be acceptable.

It is assumed that canisters will be delivered to the waste packaging facility ready for filling and closure. It is important that the canister possess ease of weldability to permit remote closure.

The selection of a canister material must not sericusly affect the metals market and must be available in sufficient quantities to present and future generations. The dependence on foreign sources for raw materials should be carefully evaluated in the selection of canister materials.

The canister must provide physical probection for the waste form during handling and transportation, and during any retrieval operations that may be necessary during the operational period of the repository.

The canister and waste form must not exceed the capacity of handling and transportation systems that support the repository in basalt. A material of moderate corrosion resistance may meet canister design life requirements by designing sufficiently thick wal's, but by so doing the material may be rendered unacceptable because of canister weight and size restrictions.

*The multiple barrier systen is comprised of the engineered barrier system and the natural barpiers (basalt, interbeds, etc.) 
TABLE 2-75. General Criteria Governing the Selection of Candidate Overpack Materials.

\begin{tabular}{l} 
Criterion \\
\hline 1. The overpack material must be \\
compatible with other components \\
of the multiple barrier system.
\end{tabular}

2. The overpack must meet the engineered barrier system longevity requirements.

3. The overpack material must possess aase of fabrication.

4. The overpack material must be readily available and must be selected to provide low cost.

5. The canister material must possess surficient mechanical strength to permit handing and retrieval.

6. The selection of overpack material must recognize the weight and size constraints for the overpacked canister and waste.
Bases

A well-designed engineered barrier system will contain barrier components that will function in a mutually supportive role, in concert with the basalt, to effectively isolate waste from the biosphere. It is necessary that the overpack material will not impair the ability of the other components of the multiple barpier system to fulfill their functions.

Proposed federal performance guidelines require that the engineered barrier system shall be designed to provide reasonable assurance of waste containment in a water-saturated repository for 1,000 years after repository closure. Depending on the barrier systen concept selected an overpack design life can range up to 1,000 years to provide protection for the canister.

Closure of the overpack will be done remotely and will probably be by welding, consequently the material must be selected on the basis of remote weldability.

The selection of an overpack material must not seriously affect the metals market and must be available in sufficient quantities to present and future generations. The dependence on foreign sources for raw materials should be carefully evaluated in the selection of overpack materials.

It is anticipated that the canister will be overpacked at the repository. The overpack must be sufficiently strong to permit emplacement and retrieval of the waste (if required).

The combination of overpack, canister, and waste form must not exceed the capacity of repository handing and transporter systems.

* The multiple barrier system is comprised of the engineered barrier system and the natural barrier systems (basalt, interbeds, etc). 
2.7.5.2 Canister Longevity. The longevity life requirement for the canister as a component of the enginerred barrier system for emplacement in a repository in basalt has not been fully defined. This must await the development and formal approval of barrier system performance criteria. For the present, however, it is sufficient to follow the U.S. Nuclear Regulatory Commission general guidelines (NRC, 1980) and consider an engineered barrier system design life of 1,000 years and allow the canister design life to vary with barrier system concept.

Presumably there are several engineered barrier system concept options available for achieving the design life requirements of 1,000 years. Extremes in barrier system complexity are shown in Figure 2-56. The relatively simple concept of Figure 2-56a consists of a waste canister located in an emplacement hole in the repository surrounded by a backfill, tailored to both retard the intrusion of groundwater and to modify the chemistry of the groundwater to provide a less corrosive environment for the canister. (The use of the retrieval sleeve shown is to aid in the retrieval of the canister, if required, during the operational period of the repository and would not constitute a long-lived barrier.) for this simple concept, the canister must bear the principal burden for radionuclide containment through the thermal period; hence, its design life must be equivalent to that of the barrier system. A canister material highly resistant to groundwater attack would therefore be necessary. Swedish investigators claim that their thick-walled copper spent fuel canister should last at least 5,000 years because of the inertness of copper in oxygen-free water in a repository located in granite (KBS, 19786). Titanium exhibits very low corrosion rates when exposed to dilute brines and seawater (Braithwaite and Molecke, 1979) and Shannon (1977). When exposed to basalt groundwater of lower ionic strength, corrosion rates are expected to be lower. Both copper and titanium, therefore, would have potential application as canisters for emplacement in basalt.

The more complex barrier system depicted in Figure 2-56b would allow the use of a less corrosion-resistant, less expensive material such as low carbon steel or a cast iron for the canister. For this concept, the overpack would provide protection for the canister through most or 211 of 


\section{RHO-BWI-ST -7}

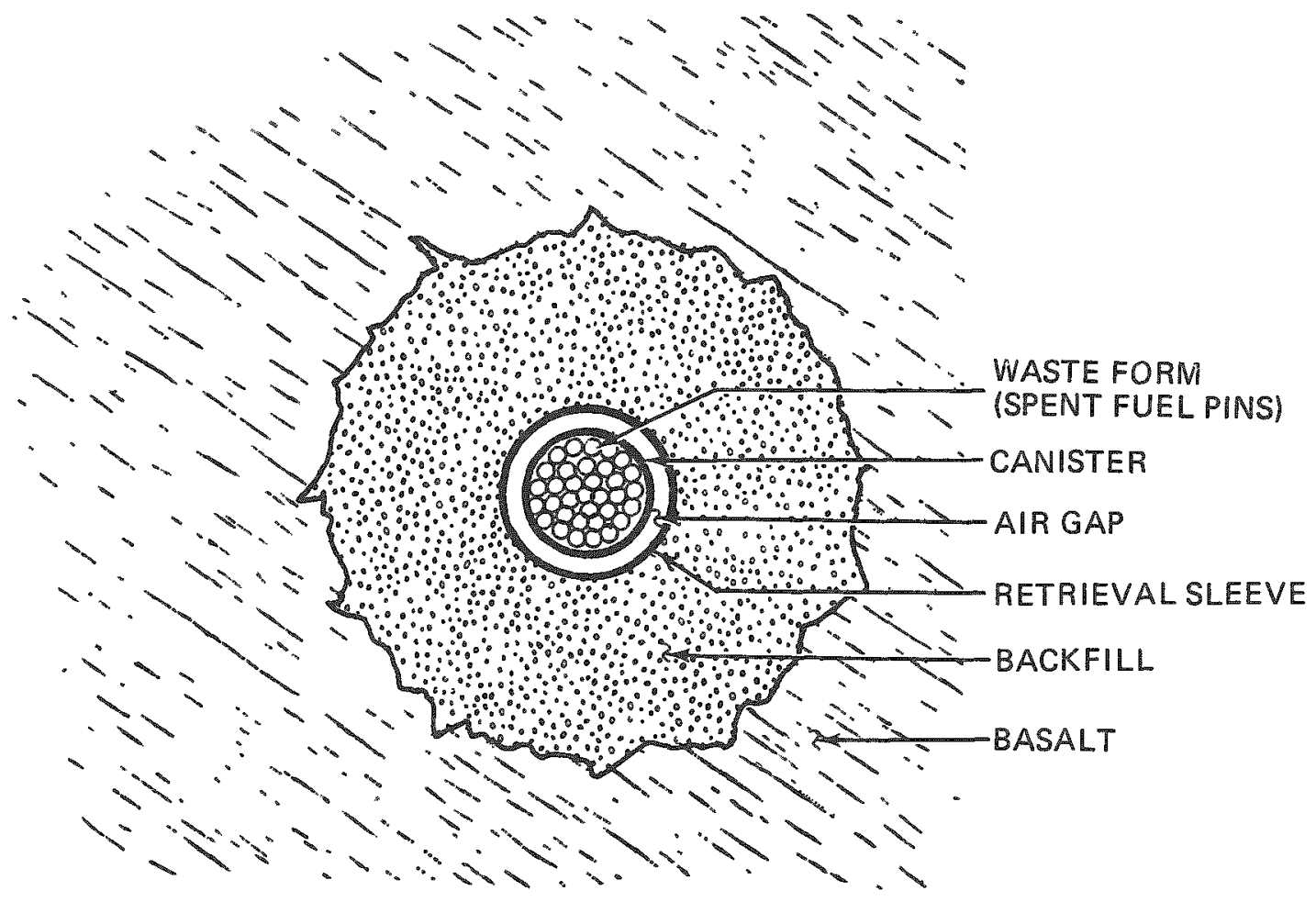

(A)

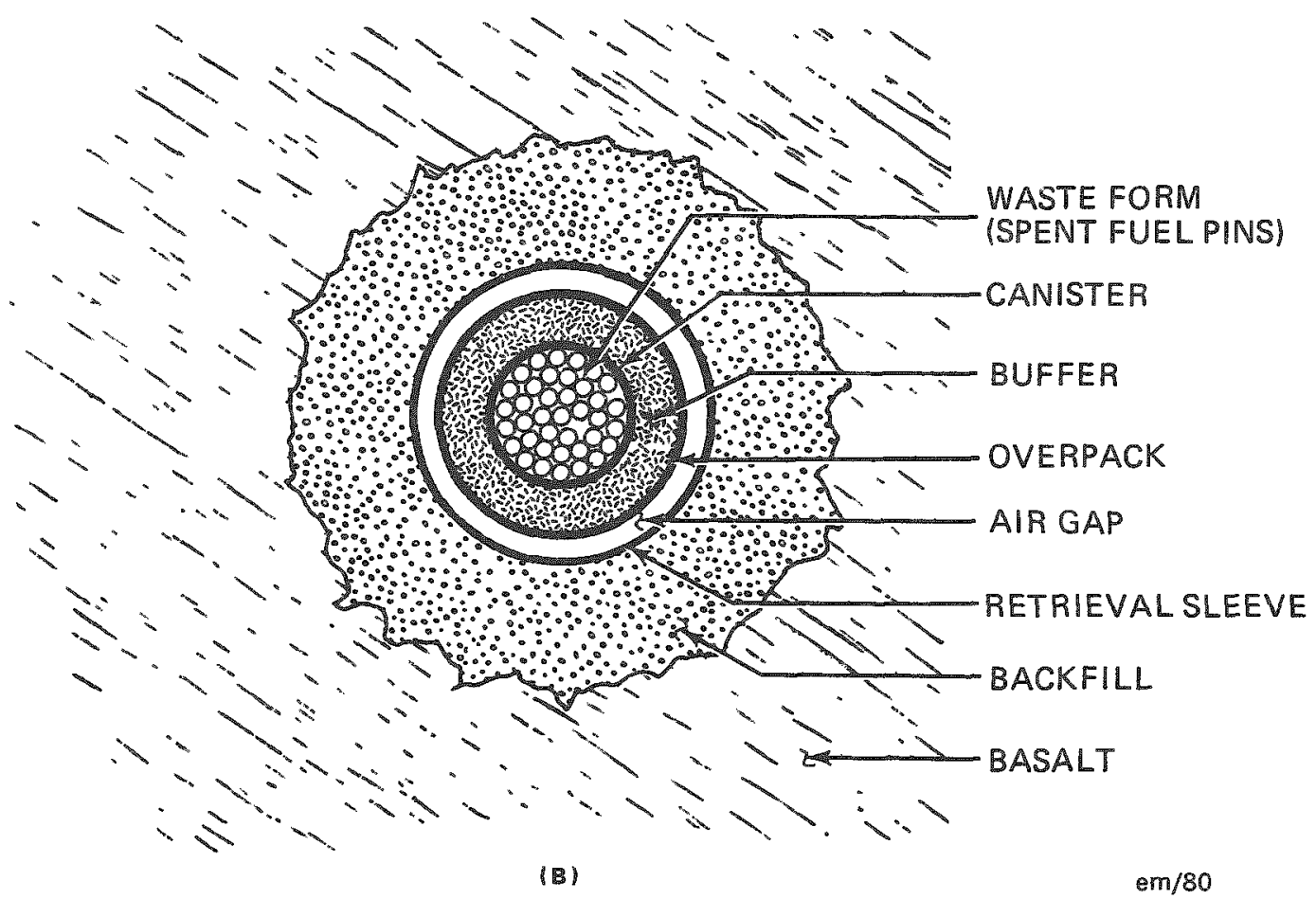

FIGURE 2-56. Engineered Barrier System Incorporating (a) Minimum Barrier Components and (b) Maximum Barrier Components. 
the barrier system design life of 1,000 years. In the event of a premature failure of the overpack, the local environment of the canister failure of the overpack, the local environment of the canister would be modified by the presence of a buffer material to adjust groundwater $\mathrm{pH}$ and oxygen fugacity and a tailored backfill to retard groundwater intrusion. (The functions of a tailored backfill and buffer are discussed in greater detail in Section 2.8). For this more complex barrier system a much shorter design life for the canister of perhaps 600 years can be considered. All components of this barrier system then would function in a mutually supportive manner to achieve the barrier system design life requirement of 1,000 years.

\subsubsection{Preliminary Selection of Candidate Canister Materials}

2.7.6.1 Introduction. A list of potentially useful materials for canister fabrication may include both metallic and normetallic materials. Metals are more susceptible to chemical attack than nonmetallics, but some materials in the latter group, such as graphite and ceramics, are far more susceptible to shock-induced fracture. Thus, the use of these materials for canisters appears to be unacceptable because of the canister handling requirements. The only exception to this may be the use of a hot-isotatic-pressing process to form heavy-walled ceramic spent fuel canisters, which Sweden has proposed (Mattsson, 1979). For the present, however, only metallic materials are being considered for canister fabrication by the Basalt Waste Isolation Project staff.

Normally, a materials evaluation program would be initiated by selecting a large number of potentially useful materials for screening tests to identify a few candidates for extensive evaluation. This might take several months to a year to accomplish. A more cost effective and timely approach is to use relevant corrosion studies conducted elsewhere and select candidate materials from these to initiate in-depth materials evaluation studies. This approach by the Basalt Waste Isolation Project permits an accelerated materials evaluation program that is compatible with overall project schedules. 


\section{RHO-BWI-ST-7}

This section of the report describes the approach taken to develop a list of candidate canister materials for in-depth evaluations. An initial selection of alloys is made from relevant corrosion studies taken from the literature. These are screened, using two of the criteria from Table 2-74, to develop a list of prime candidate alloys and a list of backup candidate a.7loys.

2.7.6.2 Initial Selection of Candidate Alloys. An initial selection of candidate alloys, potentially suitable for an engineered barrier system usable in a repository located in basalt, was made using relevant corrosion data developed by Braithwaite and Molecke (1979) and Shannon (1977). The alloys are shown in Table 2-76 together with their corrosion rates extracted from these two references. These alloys have also been selected by other major programs for further evaluation as potential canister materials. The last column in Table 2-76 shows the nominal canister wall thickness, based on the corrosion rates tabulated, that would be required for a 1,000-year canister design life. This design life is associated with the barrier system concept depicted in Figure 2-56 and represents the greatest challenge to materials selection to meet the guidelines of 10 CFR 60 (Draft 7) (NRC, 1980).

2.7.6.3 Preliminary Alloy Screening. In Table 2-74, general criteria are shown that will govern the selection of candidate canister materials. Of the six criteria proposed, data and information are availabie for two criteria, corrosion (longevity requirement) and weldability (ease of fabrication requirement), to permit their use for preliminary screenings of the list of alloys in Table 2-76. As additional data and information are developed, quantification of the general criteria and repeated screenings will identify reference alloys for the development of conceptualized engineered barrior systems. Waste/canister/groundwater interactions under hydrothermal conditions that may exist in a repository located in basalt are of particular importance. 
TABLE 2-76. Corrosion Rates at $250^{\circ} \mathrm{C}$ for Candidate

Canister Alloys in Simulated Brines and Seawater

(taken from Tables 2-69 and 2-71).

\begin{tabular}{|c|c|c|c|c|}
\hline \multirow[b]{2}{*}{ Alloy } & \multicolumn{4}{|c|}{ Corrosion Rate (in/yr/mm/yr) } \\
\hline & $\begin{array}{l}\text { Deoxygenated } 1 \% \mathrm{NaCl} \\
\text { Solutions with } 10 \mathrm{mg} / \mathrm{l} \mathrm{H}_{2} \mathrm{~S}\end{array}$ & $\begin{array}{l}\text { Deoxygenated } \\
1 \% \mathrm{NaCl} \text { Sol }\end{array}$ & $\begin{array}{l}\text { Deoxygenated } \\
\text { Seawater }\end{array}$ & $\begin{array}{l}\text { Wall Thickness Req'd } \\
\text { for } 1,000-y r \text { Life (in/mm) }\end{array}$ \\
\hline Titanium & $.0002 / .005$ & - & - & $0.2 / 5.1$ \\
\hline Zircaloy 2 & $.0001 / .0025$ & - & - & $0.1 / 2.5$ \\
\hline Inconel 625 & $.0002 / .005$ & $.0003 / .008$ & $.0005 / .013$ & $0.2 / 5.1$ \\
\hline Inconel 600 & $.0092 / .234$ & $.0006 / .015$ & $.0001 / .0025$ & $9.2 / 234$ \\
\hline Incoloy 825 & $.0002 / .005$ & $.0004 / .010$ & $.0002 / .005$ & $0.2 / 5.1$ \\
\hline Hastelloy $C-276$ & $.0015 / .038$ & $.0009 / .023$ & $.0006 / .015$ & $1.5 / 38.1$ \\
\hline Ebrite $26-1$ & $.0006 / .015$ & $.002 / .05$ & $.0002 / .005$ & $0.6 / 15.2$ \\
\hline SS-20Cb3 & - & - & $.0002 / .005$ & $0.2 / 5.1$ \\
\hline 90-10 Cupronickel & - & - & $.0028 / .071$ & $2.8 / 71.1$ \\
\hline Low Carbon Steel & $.007 / .178$ & $.011 / .279$ & $.012 / .304$ & $7.0 / 178$ \\
\hline
\end{tabular}


The wall thicknesses tabulated in Table 2-75 were used for the first of the two screenings. A wall thickness of 0.500 in was selected as that which would provide reasonable strength for a canister to meet design requirements. Those alloys requiring a corrosion allowance less than 0.500 in to meet the 1,000-year design life criterion were classified as prime candidates and the remainder were classified as backup candidates. Ebrite 26-1 and the 20Cb3 stainless steel were classified as backup alloys because of susceptibility to hydrogen embrittlement (Ebrite 26-1) and questionable stress corrosion cracking resistance (20cb3).

The candidate alloys surviving the first screening were next screened on the basis of weldability. For this screening, five welding processes were selected for their adaptability to remote processing. They were gas tungsten arc, gas metal arc, submerged arc, plasma arc, and laser beam. The weldability of each alloy was judged to lie on a scale ranging from readily weldable to very difficult to weld. The results are shown in Table 2-77. The judgment considered such parameters as sluggishness of weld puddle, cleanliness requirements, general tooling requirements, and extent of need for internal, external, and trailing cover gas. Cast iron was included in the weldability evaluation because of its potential as a low-cost canister material.

The results of the two screenings are shown in Table 2-78. The copper al7oy, 90-10 Cupronickel, was placed in the list of back-up alloys because of its poorer weldability. Further welding development using a process such as electron-beam welding may overcome its weldability problems. However, the electron-beam process may be a difficult process to operate and maintain remotely. For a description of each alloy in Table 2-78, see Tables 2-71 and 2-72.

Low carbon steel and cast iron are being considered by the Basalt Waste Isolation Project for engineered barrier system designs where the canister is protected by outer barrier components such as a buffer and overpack. These two materials are inexpensive, strong, and do not involve the commitment of scarce natural resources. The weldability of cast iron may be improved by using the resistance welding technique presently being developed by the Savannah River Laboratory for the remote closing of waste canisters. 
TABLE 2-77. Weldability of Candidate Canister Alloys for a Repository Located in Basalt.

\begin{tabular}{|c|c|c|}
\hline Alloy & $\begin{array}{l}\text { Welding Process } \\
\text { Available for } \\
\text { Remote Application }\end{array}$ & Weldability \\
\hline TiCode-12 & $(1)(4)(5)$ & Weldable with care \\
\hline Zircaloy 2 & $(1)(4)(5)$ & " 11 \\
\hline Inconel 625 & $(1)(2)(3)(4)(5)$ & Weldable \\
\hline Incone 1600 & $(1)(2)(3)(4)(5)$ & $"$ \\
\hline Incoloy 825 & $(1)(2)(3)(4)(5)$ & $"$ \\
\hline Hastelloy C-276 & $(1)(2)(3)(4)(5)$ & Weidable with care \\
\hline 90-10 Cupronickel & $(1)(2)(4)(5)$ & Difficult \\
\hline Low Carbon Steel & $(1)(2)(3)(4)(5)$ & Readily weldable \\
\hline Cast Irons & $(1)(2)$ & Very difficult \\
\hline SS 20Cb3 & $(1)(2)(3)(4)(5)$ & Weldable \\
\hline Ebrite 26-1 & $(1)(2)(3)(4)(5)$ & Weldable \\
\hline
\end{tabular}

*(1) Gas tungsten arc welding, (2) gas metal arc welding, (3) submerged arc welding, (4) plasma arc welding, (5) laser beam weiding.

TABLE 2-78. Preliminary List of Candidate Canister Alloys for a Repository Located in Basalt.

\begin{tabular}{l|l}
\hline Prime Candidates & Back-up Candidates \\
\hline TiCode-12 & SS 20Cb3 \\
Inconel 625 & Ebrite 26-1 \\
Incoloy 825 & Inconel 600 \\
Zircaloy 2 & Hastelloy C-276 \\
& 90 -10 Cupronickel \\
& Low Carbon Steel* \\
& Cast Iron* \\
& \\
\hline *These iron-base alloys are considered as prime candidates, \\
since they offer many advantages to a repository system. They \\
are inexpensive, strong, and do not involve the commitment of \\
carce natural resources, therefore are promising alloys for \\
canisters when protected by a buffer, overpack, and backfill.
\end{tabular}


The alloys listed as prime candidates in Table 2-78 are those that appear to have the greatest potential for qualifying as components of an engineered barrier system for emplacement in a repository located in basalt. As materials testing techniques advance and the performance of these alloys under geothermal conditions and radiation become better understood, further screening may change the position of some candidates between the two lists or eliminate some altogether.

Some important properties of each candidate alloy are reviewed in the following paragraphs.

TiCode-12

Commercial purity titanium exhibits excellent corrosion resistance in most natural, neutral, and oxidizing environments. Susceptibility of commercial purity titanium to crevice corrosion is reduced by alloying with $0.3 \%$ molybdenum and $0.8 \%$ nickel (TiCode-12). Protection from hydrogen embrittlement of the titanium alloys is provided by the $\mathrm{TiO}_{2}$ passivating layer, which is predicted from thermodynamic data to be stable in basalt groundwaters even under reducing conditions. Thus, TiCode-12 is expected to show superior resistance to environmental degradation in a repository located in basalt.

Inconel 625

The nickel-chromium alloy, Inconel 625, shows excellent resistance to corrosion and oxidation. The combination of nickel and chromium provides resistance to oxidizing solutions, whereas the high nickel and molybdenum content supplies resistance to anoxic environments. It is readily fabricated by common industrial practices and is weldable by several processess.

Incoloy 825

Incoloy 825 is a nickel-iron-chromium alloy developed to resist corrosion by seawater and by reducing environments, such as sulfuric and phosphoric acid solutions. Its chromium content provides resistance to a variety of oxidizing environments. It is a solid solution alloy and thus should be metallurgically stable throughout its design life as a waste 
canister. The alloy is readily fabricated, by both hot and cold working, and can be welded by several welding processes.

Zircaloy 2

Pure zirconium was first used in water-cooled reactors. Now a group of alloys, the zircaloys, are used for this service. The zircaloys provide greater strength and improved corrosion resistance in hightemperature water.

Zircaloy 2 derives its excellent corrosion resistance from an inert oxide film $\left(\mathrm{ZrO}_{2}\right)$ that is expected to be stable under anoxic conditions expected in a repository in basalt. Solutions containing fluoride iron in sufficient quantities can cause pitting in zircaloy 2. For this reason it may show marginal resistance to corrosion by fluoride-containing basalt groundwater. Zircaloy 2 is ductile and workable and can be fabricated by standard shop methods using the same techniques as those used for fabricating titanium. Its weldability is equal to that of titanium.

Carpenter 20Cb3

Carpenter $20 \mathrm{Cb} 3$ is a columbium stabilized stainless steel. It is normally used in the as-welded condition. It shows excellent resistance to both reducing and oxidizing acids. It is readily fabricated using conventional shop methods and can be welded by several weiding processes.

\section{Ebrite $26-1$}

Ebrite 26-1 is an election beam zone refined ferritic stainless steel. Compared to conventional 18-8 austenitic stainiess steels, it offers considerably higher yield strength. Its low levels of carbon and nitrogen provide greater ductility and toughness than that of conventional ferritic stainless steels. It possesses higher thermal conductivity and lower expansivity than austenitic stainless steeis, which combine to minimize distortion during welding. It is easity fabricated by conventional shop methods although its high purity requires care in welding to preserve its corrosion resistance.

Inconel 600

The nickel-chromium alloy, Inconel 600 , is a stable austenetic solid solution alloy. The chromium content provides corrosion resistance in 
oxidizing solutions while its nickel content provides corrosion resistance to reducing conditions. The alloy is highly resistant to flowing seawater. In quiet seawater, however, pitting may occur under surface deposits. With its high nickel content (72\%) it is immune to chlorideinduced stress corrosion cracking. Because of its ease of fabrication it is used extensively as a standard material of construction for nuclear reactors.

Haste110y $\mathrm{C}-276$

This nickel-base alloy is a modified Hastelloy $C$ with improved resistance to heat-affected zone attack in the as-welded condition. The alloy is resistant to strongly oxidizing solutions such as ferric and cupric chlorides. Its high nickel content makes it suitable for service in reducing environments. It has also performed well in seawater and brine service. Hastelloy $\mathrm{C}-276$ can be fabricated using conventional shop techniques and can be welded with most common welding processes. 90-10 Cupronickel

The copper-nickel alloys occupy a leading position in coastal and seawater cooling systems. They are resistant to stress corrosion cracking in marine environments. They also have wide application in brackish and fresh waters, where other copper alloys have failed. The copper-nickel alloys perform poorly in oxidizing solutions. These alloys do not harden rapidly, hence, can be fabricated by cold working techniques. They can be welded by most common joining processes, but the quality of the weld varies from one process to another.

Low Carbon Steel

Low carbon steel contains small amounts of manganese, sulphur, and phosphorus and generally less than $1 \%$ carbon. It is generally not considered a candidate for other than mildiy corrosive service. The two most important variables for low carbon steel corrosion by water are: (1) supply of dissolved oxygen; and (2) deposited protective film. The protectiveness of the film is influenced by the presence of dissolved salts in the water. Low carbon steel is readily fabricated and welded by conventional techniques. 
RHO-BWI-ST -7

\section{Cast Iron}

Cast iron is a generic name covering a range of irons such as gray cast iron, white cast iron, malleable cast iron, and nodular cast iron. Cast irons contain carbon in excess of the solubility in the austenite at the eutectic temperature. The corrosion resistance of gray cast iron is improved by the addition of nickel, chromium, and copper, singly or in combination. Chromium promotes corrosion resistance in oxidizing solutions, while nickel improves resistance to corrosion in reducing solutions. The weldability of cast irons by conventional means ranges from difficult to very difficult. However, joining by resistance welding holds some promise.

\subsubsection{The Overpack as a Long-Lived Waste Isolation Barrier}

There are three reasons why it may be desirable or, in some cases, necessary to enclose canisters in corrosion-resistant metallic or ceramic overpacks. First, any canister sufficiently damaged during shipment to the geologic repository site or while being handled at the repository will need to be overpacked prior to disposal. Second, a decision by the office of Nuclear Waste Isolation to develop a single waste canister for disposal in any geologic repository may require a site-specific overpack to meet compatibility criteria for emplacement in different media. Third, conservative repository design bases may dictate use of overpacks to ensure the integrity of the muitiple barrier system and thus comply with the general performance guidelines of 10 CFR 60 (Draft 7) (NRC, 1980). It was in response to this need for conservatism. that the operating philosophy for a conceptualized engineered barrier system was developed (Section 2.2). Consistent with this philosophy, the principal function of the overpack is to act as a physical barrier to the intrusion of groundwater during the thermal period in the repository. The design life for the overpack as a component of a barrier system would thus be 1,000 years, using the definition for the thermal period in the present text.

\subsubsection{Preliminary Selection of Candidate Overpack Materials.}

The selection procedures used to select canister materials in Section 2.7.6 are applicable to the preliminary selection of candidate 
alloys for overpacks. Hence, the lists in Table 2-79 contain most of the alloys listed in Table 2-78. Since the function of the overpack will be to protect the canister through the thermal period, the known inferior corrosion resistance of low carbon steel and cast iron relative to other alloys listed is sufficient to reject them as candidates for overpacks.

TABLE 2-79. Preliminary List of Candidate Overpack Alloys.

\begin{tabular}{l|l}
\hline Prime Candidates & Back-up Candidates \\
\hline TiCode-12 & SS 20Cb3 \\
Zircaloy 2 & Ebrite 26-1 \\
Inconel 625 & Inconel 600 \\
Incoloy 825 & Haste1 loy C-276 \\
& $90-10$ Cupronicke1 \\
\hline
\end{tabular}

Continued materials evaluation studies by the Basalt Waste Isolation Project will focus on the prime overpack candidates listed in Table 2-79. TiCode-12 remains the most promising alloy for service in both oxidizing and anoxic basalt groundwaters. Its favorable strength-to-weight ratio is an added incentive to fully evaluate it as both a canister and an overpack material. Zircaloy 2 is expected to exhibit a general corrosion resistance in basalt groundwater similar to TiCode-12. The demonstrated corrosion resistance of Inconel 625 and Incoloy 825 in relevant tests at Sandia Laboratories and Pacific Northwest Laboratory (see Section 2.7.2) also qualify them as prime candidates for further evaluation by the Basalt Waste Isolation Project.

Two other materials, ceranics and graphite, offer potential application as candidates for overpack fabrication. As discussed previousiy, both offer the greatest resistance to chemical degredation, but are far more susceptible to shock-induced fracture than metallic materials. Although they are not presently being considered for overpack fabrication, current programs being conducted elsewhere in which these materials are being evaluated will be monitored for application to the Basalt Waste Isolation Project. 
RHO-BWI-ST-7

\subsection{BACKFILL AND OTHER ENGINEERED BARRIERS}

\subsubsection{Introduction}

A fundamental premise of the multiple barrier concept is the development of a barrier system in which one barrier not only lends support to the functional capability of another barrier or $\mathrm{se}^{i}$ of barriers, but also provides redundant functional ability in the event of the failure of the other barrier. In the present multiple barrier system being considered by the Basalt Waste Isolation Project, the backfill has two major functions: (1) to minimize contact between the waste package and the host environment; and (2) to control release of radionuclides into the host environment within the recommended guidelines in the event of waste package failure. In Table 2-80, the functions of the backfill are correlated along with the chemical, mechanical, and physical properties of candidate materials which will be used to determine their relative acceptability.

The first function of the backfill can be divided into two parts. First, the backfi11 component is required to minimize contact between the waste package and groundwater because of the corrosive reaction which will take place, perhaps to a significant degree, over a 1,000-year period. The most important parameter here is the permeability of the material. Swelling pressure measures the ability of the backfill to fill voids in the space between the waste package and the bedrock. Second, the backfi11 must act as a shield to protect the canister from the impact of falling rock and undue stress resulting from. minor bedrock movement. The important parameters are bearing capacity, plasticity, and shear strength. These properties measure the ability of the backfill to keep the waste package in its emplacement position and to retain its physical integrity. Thermal conductivity is an important parameter since material fracturing could result from dehydration and shrinkage if the temperature buildup is excessive within the backfi11. The occurrence of fracturing could affect both the physical integrity and water-excluding ability of the backfill. 
TABLE 2-80. Functions and Functional Properties of the Backfil1 Component.

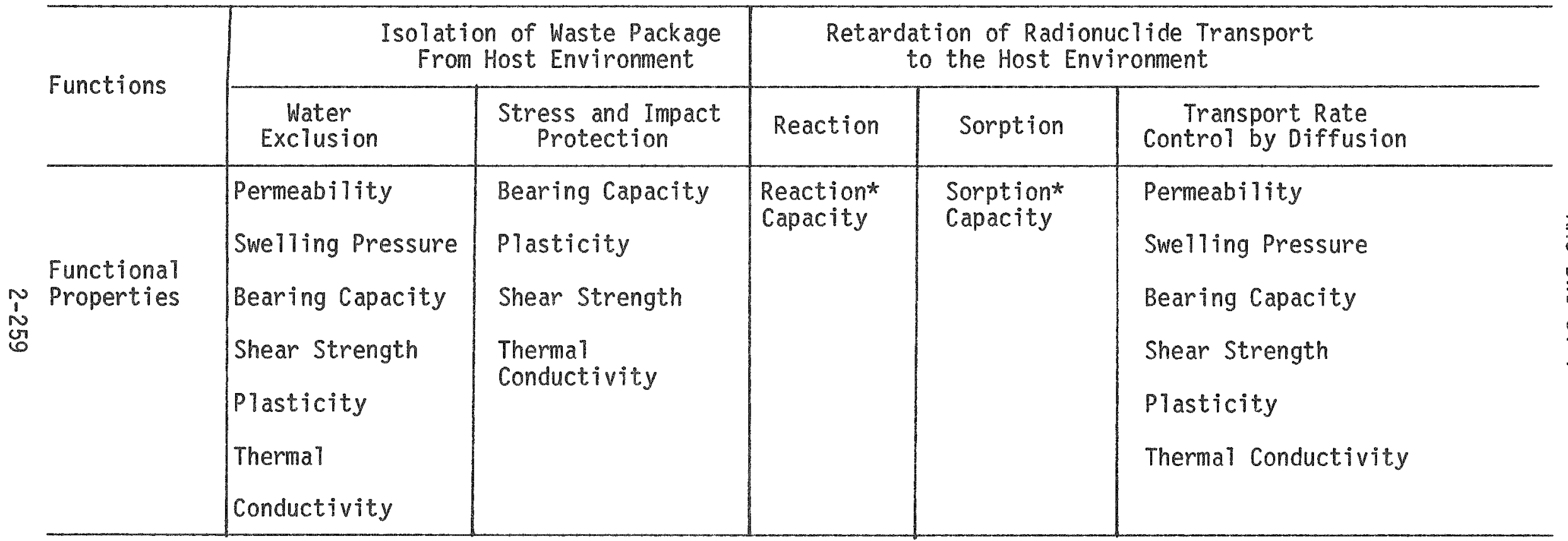

* Measured by distribution coefficients for radionuclides between liquids and solids. 
The second major function of the backfill, retardation of radionuclide migration, can be accomplished by the backfill via three principal mechanisms: (1) sorption; (2) reaction; and (3) diffusion control. Sorption and reaction capacities are strongly dependent on chemical properties of the backfill (backfill composition, the specific radionuclides, temperature), but diffusion controls the rate of radionuclide transport only under certain physical conditions. These conditions are most likely to occur in a dry, impermeable backfill or in a saturated backfill where the rate of groundwater flow is essentially zero. Due to the small thickness of the proposed backfill shell around the waste package, diffusion-controlled transport may prove to be the most effective means of radionuclide retardation. Consequentiy, the water-excluding properties of backfill components (permeability, swelling pressure, etc.) are significant parameters to consider in terms of radionuclide containment within the backfiti.

\subsubsection{Preliminary Backfill Material Candidates}

An optium backfill material is likely to be made up of several materials, since no single material has been found in the course of a literature search that can satisfy 211 of the functional requirements listed in Table 2-80. It is unlikely that a satisfactory single component will be found.

Two component types of candidate backfill materials have evolved on the basis of the functional requirements; a major component and a minor component. The major component makes up the buk of the backfiil and can be composed of more than one material. The best major component will satisfy a maximum number of the functional requirements. In addition to the functional properties listed above, two general constraints were applied to make up a preliminary candidate list. First, since backfill will be in direct contact with the geologic environment (basalt, secondary minerals, groundwater), it must remain in its functional state in that environment under ambient conditions during the time period of geologic control. Furthermore, backfill must be compatible with host rock and groundwater during the thermal period, when various chemical parameters are disturbed by the introduction of waste into the system (e.g., temperature, $\mathrm{pH}$, oxygen fugacity). The consequences of these 
constraints are that synthetic materials are eliminated as potential major components. Further preference is given to those natural materials presentiy found in the basait environment. Second, potential major component materials must be readily available in sufficient quantities to fill the bulk of the repository volume. Four potential major component candidates satisfy these two criteria and are evaluated more extensively below. They include: (1) bentonite; (2) bentonite-quartz sand; (3) crushed basalt; and (4) zeolites.

There is also a need for a minor backfill component that is specifically tailored for transport retardation (either by sorption or reaction) of key long-lived and potentially mobile radionuclides (e.g., ${ }^{129} \mathrm{I}$ and ${ }^{99} \mathrm{TC}$ ). Attention is focused on single phases, and the minor backfill component may be composed of several phases.

\subsubsection{Bentonite. Bentonite is a potential major backfill component} that has been extensively investigated by Swedish scientists. Ahlström (1979) characterized the mechanical properties of a reference bentonite of the type Volclay MX-80, which is mined in Wyoming and South Dakota. Very high density bentonite can be obtained by pressing bentonite powder into blocks under $100 \mathrm{MPa}$ of isostatic pressure. The bulk density of the water-saturated bentonite blocks ( $10 \%$ water) is about $2.3 \mathrm{~g} / \mathrm{cm}^{3}$ and about $1.75 \mathrm{~g} / \mathrm{cm}^{3}$ for compressed powder. If bentonite block is used to line a canister hole and bentonite powder is used to fill in the cracks between the blocks, the bulk density of the bentonite liner would be about $2.1 \mathrm{~g} / \mathrm{cm}^{3}$.

The density of bentonite is an important parameter because the mechanical properties of bentonite vary with density. Experimental studies on bentonites of varying densities indicate that bentonite with a density of $2.1 \mathrm{~g} / \mathrm{cm}^{3}$ will perform the following functions:

- The bearing capacity is sufficient to prevent appreciable subsidence of a copper canister (length $=4.7 \mathrm{~m}$, diameter $=5 \mathrm{~m}$, weight $=20,000 \mathrm{~kg}$ ). Swedish scientists (Ahiström, 1979) calculate that a density as low as 1.4 to $1.5 \mathrm{~g} / \mathrm{cm}^{3}$ will prevent canister subsidence for over a million years. 
- A significant swelling pressure allows bentonite to penetrate into and seal fissures which may exist at the beginning of canister emplacement or open up later. Pusch (1979) calculates the swelling pressure to be a approximately $5 \mathrm{MPa}$ at a density of $2.1 \mathrm{~g} / \mathrm{cm}^{3}$ (Fig. $2-57$ ).

- The hydraulic conductivity of $100 \%$ saturated bentonite, $2 \times 10^{-14} \mathrm{~m} / \mathrm{sec}(\mathrm{Fig} \cdot 2-58)$, is sufficiently low to impose a neglible flow rate in the backfill (approximately $1.9 \times 10^{-9} \mathrm{~m} / \mathrm{yr}$ if flow rate is governed by Darcy's Law). However, an appreciable flow rate will occur in the backfill toward the waste package until 100\% saturation is reached. After saturation and zero flow rate have occurred, transport of water and radionuclides will be diffusion-controlled. A conservative estimate of 15 to 50 years to completely saturate a 0.3-m-thick backfill has been calculated from Darcy's Law assuming a pressure gradient across the barrier of $10 \mathrm{MPa}$ (hydrostatic pressure). Fifteen to 50 years is a minimum range, since the calculation does not take into account the swelling pressure, which will increase in the bentonite during this time period, thereby reducing the pressure gradient and flow rate.

Few studies have been done to investigate the sorptive properties of bentonite. Ames and McGarrah (1979a) have studied the sorptive properties of secondary mineralization taken from the Pomona basalt flow on the Hanford Site. This material is not bentonite, but $X$-ray diffraction indicates that it is primarily smectite and is, therefore, a reasonable analog to bentonite. The results of these sorption experiments are shown in Tables 2-81 and 2-82. Two different solutions to solid ratios were used, and the radioisotope concentration in the 80 $\mathrm{ml}$ solution was twice that of the $10 \mathrm{ml}$ solution. The composition of the synthetic groundwater used is shown below the sorption data in Tables 2-81 and 2-82 (Ames and McGarrah, 1979b). The general sorption pattern does not change with temperature. The isotopes ${ }^{85} \mathrm{Sr},{ }^{137} \mathrm{Cs},{ }^{291} \mathrm{Am}$, and ${ }^{241} \mathrm{Pu}$ are strongly sorbed on the clay. The isotopes ${ }^{238} U$ and $237 \mathrm{~Np}$ are poorly sorbed, and ${ }^{99} \mathrm{TC}$ and ${ }^{125} \mathrm{I}$ are not sorbed at a11. 
RHO-BWI-ST-7

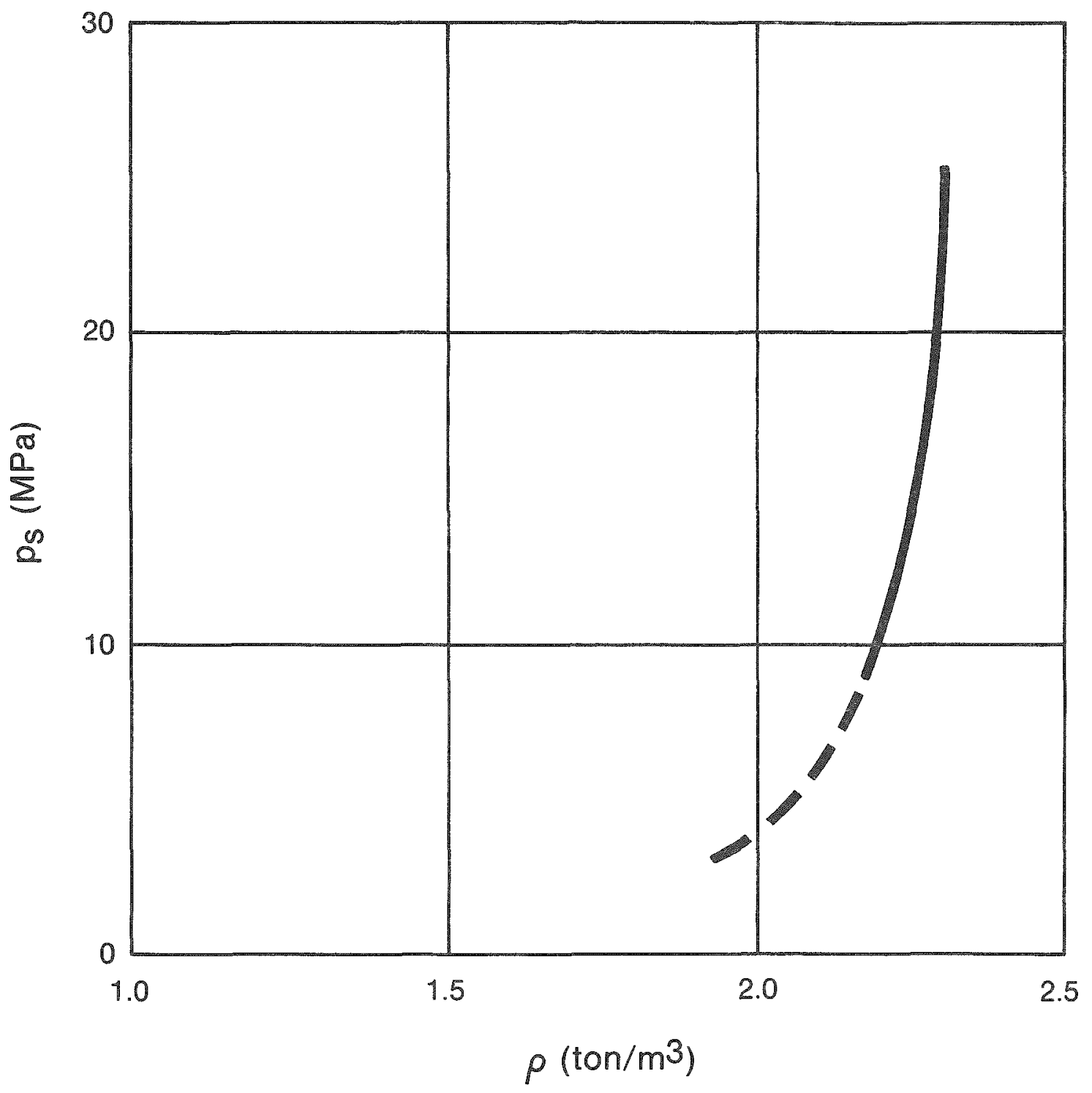

FIGURE 2-57. Variation in Swelling Pressure (PS) as a Function of Density (after Pusch, 1979). 
RHO-BWI-ST-7

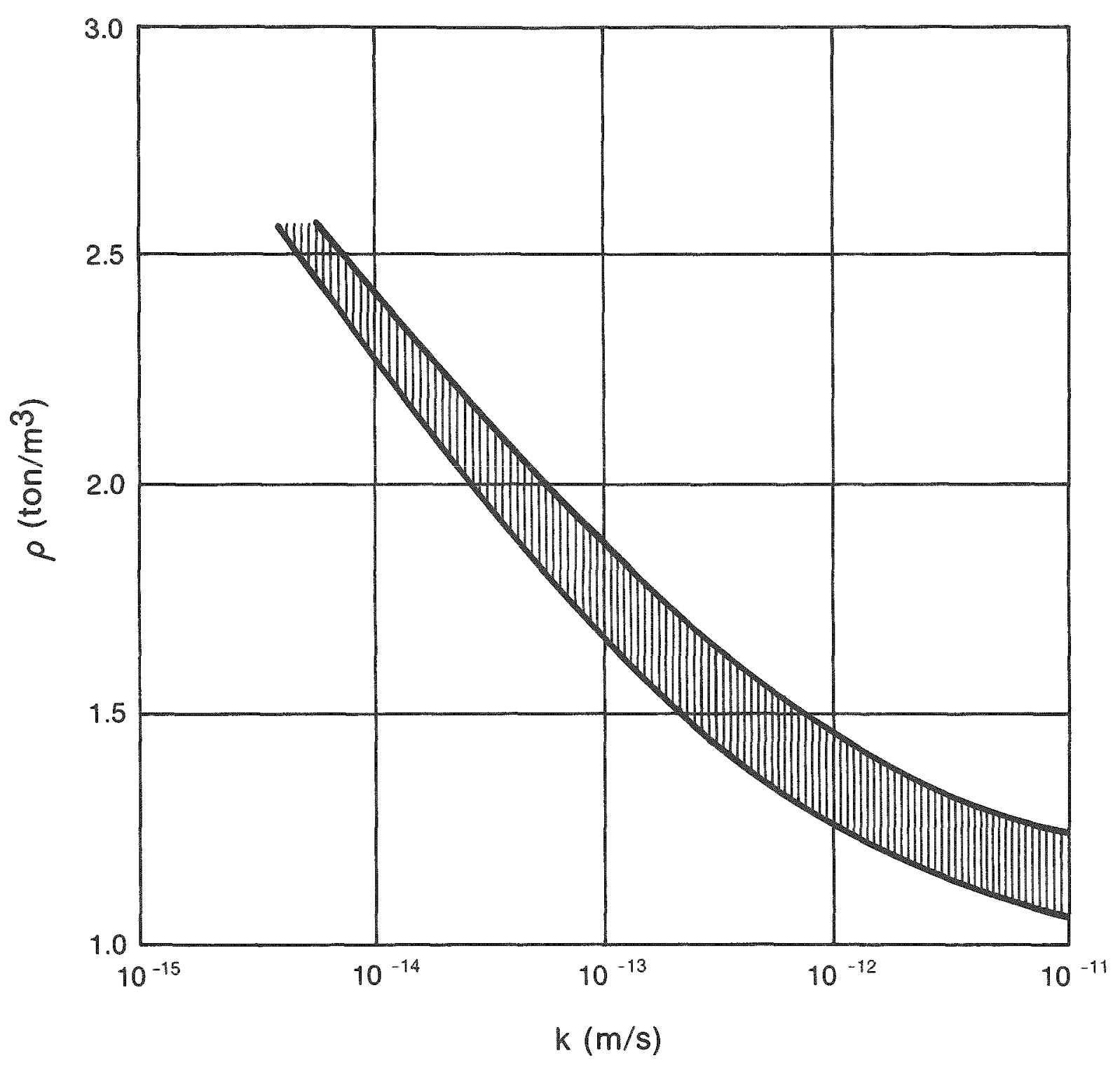

FIGURE 2-58. Variation in Permeability (k) as a Function of Density (after Pusch, 1979). 
TABLE 2-81 $230^{\circ} \mathrm{C} \mathrm{K} d^{\prime}$ Values for Fracture Mineralization and Synthetic Groundwater.*

(After Ames and McGarrah, 1979a.)

\begin{tabular}{l|c|c|c}
\hline \multirow{2}{*}{ Radionuclide } & \multicolumn{2}{|c|}{$K_{d^{\prime}(\mathrm{m} / / \mathrm{g})}$} & $\begin{array}{c}\text { Contact Time } \\
\text { (Days) }\end{array}$ \\
\cline { 2 - 4 } & $1 \mathrm{~g} / 10 \mathrm{~m} 7 * *$ & $1 \mathrm{~g} / 80 \mathrm{~m} 7 * *$ & 14 \\
\hline${ }^{75} \mathrm{Se}$ & $3.2 \pm 0.6$ & $18 \pm 3$ & 37 \\
& 0 & $7 \pm 2$ & 14 \\
${ }^{85} \mathrm{Sr}$ & $368 \pm 18$ & $881 \pm 35$ & 37 \\
${ }^{125} \mathrm{I}$ & $439 \pm 109$ & $745 \pm 55$ & 14 \\
& $3.3 \pm 0.3$ & $9.8 \pm 1.3$ & 37 \\
${ }^{137} \mathrm{Cs}$ & $3.3 \pm 0.2$ & $20 \pm 3$ & 14 \\
& $8,750 \pm 4,860$ & $42,100 \pm 7,000$ & 37 \\
$226_{\mathrm{Ra}}$ & $225,000 \pm 345,000$ & $35,100 \pm 3,300$ & 14 \\
& $117 \pm 0.3$ & $553 \pm 12$ & 37 \\
$237 \mathrm{~Np}$ & $46 \pm 1$ & $224 \pm 2$ & 14 \\
& $12 \pm 2$ & $50 \pm 1$ & 37 \\
$238_{\mathrm{U}}$ & $12 \pm 3$ & $49 \pm 6$ & 14 \\
$241_{\mathrm{Am}}$ & $14 \pm 4$ & $61 \pm 10$ & 14 \\
& $14,300 \pm 4,300$ & $17,300 \pm 4,000$ & 37 \\
$241_{\mathrm{Pu}}$ & $22,500 \pm 752$ & $76,400 \pm 32,000$ & 14 \\
& $2,740 \pm 3,100$ & $2,830 \pm 1,800$ & 37 \\
\hline
\end{tabular}

* Synthetic groundwater composition (Ames and McGarrah, 1979b)

Constituent Concentration (mg/l)

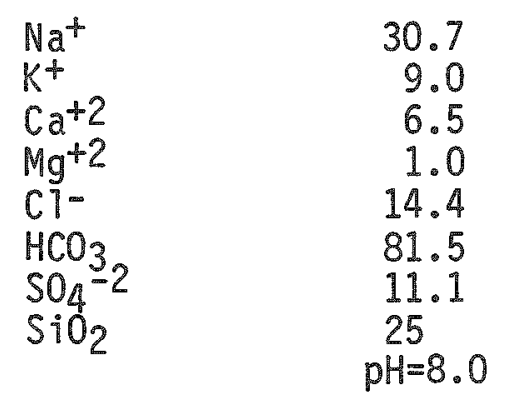

**Experimental solid-to-water ratio. 
TABLE 2-82. $600 \mathrm{C} K_{d}$ ' Values for Fracture Mineralization and Synthetic Groundwater.*

(After Ames and McGarrah, 1979a.)

\begin{tabular}{|c|c|c|c|}
\hline \multirow{2}{*}{ Radionuclide } & \multicolumn{2}{|c|}{$\mathrm{K}_{\mathrm{d}^{\prime}}, \mathrm{ml} / \mathrm{g}$} & \multirow{2}{*}{$\begin{array}{c}\text { Contact Time } \\
\text { (Days) }\end{array}$} \\
\hline & $1 \mathrm{~g} / 10 \mathrm{~m}]^{* *}$ & $1 \mathrm{~g} / 80 \mathrm{ml} * *$ & \\
\hline \multirow[t]{2}{*}{${ }^{75} \mathrm{Se}$} & $1.1 \pm 0.8$ & $7.1 \pm 4.7$ & 14 \\
\hline & 0 & $4.2 \pm 3.9$ & 37 \\
\hline \multirow[t]{2}{*}{${ }^{85} \mathrm{Sr}$} & $772 \pm 580$ & $906 \pm 46$ & 14 \\
\hline & $449 \pm 167$ & $997 \pm 14$ & 37 \\
\hline \multirow[t]{2}{*}{${ }^{99} \mathrm{TC}$} & 0 & 0 & 14 \\
\hline & 0 & 0 & 37 \\
\hline \multirow[t]{2}{*}{${ }^{125} \mathrm{I}$} & 0 & 0 & 14 \\
\hline & 0 & 0 & 37 \\
\hline \multirow[t]{2}{*}{${ }^{137} \mathrm{Cs}$} & $22,200 \pm 18,500$ & $15,300 \pm 4,300$ & 14 \\
\hline & $1,701 \pm 1,099$ & $17,000 \pm 1,000$ & 37 \\
\hline \multirow[t]{2}{*}{${ }^{226} \mathrm{Ra}$} & $212 \pm 17$ & $1,220 \pm 180$ & 14 \\
\hline & $90 \pm 7$ & $613 \pm 79$ & 37 \\
\hline \multirow[t]{2}{*}{${ }^{237} \mathrm{~Np}$} & $14 \pm 2$ & $63 \pm 5$ & 14 \\
\hline & $17 \pm 4$ & $66 \pm 21$ & 37 \\
\hline${ }^{238} \mathrm{U}$ & $25 \pm 13$ & $349 \pm 79$ & 14 \\
\hline \multirow[t]{2}{*}{${ }^{241}{ }_{A m}$} & $4,700 \pm 2,500$ & $16,200 \pm 1,400$ & 14 \\
\hline & $7,275 \pm 3,100$ & $20,000 \pm 7,400$ & 37 \\
\hline \multirow[t]{2}{*}{${ }^{241} \mathrm{Pu}$} & $767 \pm 288$ & $2,200 \pm 1,144$ & 14 \\
\hline & $1,536 \pm 750$ & $611 \pm 270$ & 37 \\
\hline
\end{tabular}

*Synthetic groundwater compositon ion.

Constituents Concentration (mg/l)

\begin{tabular}{|c|}
\hline $\begin{array}{l}\mathrm{Na}^{+} \\
\mathrm{K}^{+} \\
\mathrm{Ca}^{+2} \\
\mathrm{Mg}^{+2} \\
\mathrm{Cl}^{--} \\
\mathrm{HCO}_{3} \\
\mathrm{SO}_{4}{ }^{-2} \\
\mathrm{SiO}_{2}\end{array}$ \\
\hline
\end{tabular}

**Experimental solid-to-water ratio. 
Since these experiments were done under atmospheric conditions, the $\mathrm{K}_{d}$ 's of ${ }^{99} \mathrm{TC}$ and ${ }^{238} \mathrm{U}$ may be 1 arger under reducing conditions due to the reduction of technetium and uranium from the (VI) to the (IV) oxidation state.

Other studies have been done on bentonites under conditions different from the Hanford Site environment. Nowak (1979) has studied the sorption of ${ }^{152}$ Eu on clays, soils, and zeolite in brine solutions. Europium was chosen to simulate trivalent actinide behavior. The distribution coefficient for europium smectites was determined to be $200 \mathrm{ml} / \mathrm{g}$ or better. Allard and Beall (1979) have examined the sorption of americium as a function of $\mathrm{pH}$ and salinity. Specific data have not yet been published. Komarneni and Roy (1979) have begun an extensive study of the sorptive properties of a number of clay and zeolite phase (including montmorillonite) for cesium, rubidium, strontium, and uranium.

An analysis by Neretnieks (1978) indicates that transport of radionuclides through a 1 -m thickness of $100 \%$ water-saturated bentonite with a density of $2.1 \mathrm{~g} / \mathrm{cm}^{3}$ is primarily controlled by the rate of diffusion. The retention times of various nuclides for a 1-m-thick backfill layer are shown in Table 2-83. These calculations indicate that ${ }^{90} \mathrm{Sr},{ }^{137} \mathrm{Cs}$, and ${ }^{241} \mathrm{Am}$ wi11 have decayed below harmful levels by the time they escape the backfill barrier into the host rock.

Brookins (1979) has recently examined the uranium deposits of the Grants, New Mexico mineral belt to investigate the role and utility of clay minerals as backfill in waste repositories. The Grants, New Mexico uranium deposit is well suited to such a study because: (1) it is old (e.g., 135 to $145 \times 10^{6}$ years); (2) parts of the deposit have been remobilized and reprecipitated; (3) parts of the deposit have been destroyed by subsurface waters and the uranium disseminated; and (4) each type of uranium deposit has a rather diagnostic clay mineral suite and characteristic suite of elements associated with it. From his study, Brookins (1979) concludes that magnetite-bearing, montmorillonitechlorite-illite clay minerals are especially suitable backfill materials, particularly for low Eh conditions. Brookins (1979) notes that titanium-magnetites are especially effective in sorbing actinide and Tanthanide elements. 
TABLE 2-83. Retention Times in 1-Meter-Thick C1ay Barrier for Various Nuclides.

(After Neretnieks, 1978.)

\begin{tabular}{|c|c|c|c|}
\hline Nuclide & $\begin{array}{l}\text { Halflife } \\
\text { (Years) }\end{array}$ & $\begin{array}{c}\text { Retardation } \\
\text { Factor }\end{array}$ & $\begin{array}{c}\text { Retention Time } \\
\text { (Years) }\end{array}$ \\
\hline $90 s r$ & $2.77 \times 10^{1}$ & 600 & $1.3 \times 10^{4 *}$ \\
\hline${ }^{99} \mathrm{TC}$ & $212 \times 10^{5}$ & 1 & 22 \\
\hline 129 I & $1.7 \times 10^{7}$ & 1 & 22 \\
\hline${ }^{137} \mathrm{Cs}$ & $3.0 \times 10^{1}$ & 400 & $9 \times 10^{3}$ \\
\hline $226 \mathrm{Ra}$ & $1.602 \times 10^{3}$ & 800 & $1.8 \times 10^{4}$ \\
\hline${ }^{229} \mathrm{Th}$ & $7.34 \times 10^{3}$ & 1,000 & $2 \times 10^{4}$ \\
\hline $237 \mathrm{~Np}$ & $2.14 \times 10^{6}$ & 200 & $4.4 \times 10^{3}$ \\
\hline $239 p u$ & $2.44 \times 10^{4}$ & 1,200 & $2.6 \times 10^{4}$ \\
\hline $240 \mathrm{pu}$ & $6.58 \times 10^{3}$ & 1,200 & $2.6 \times 10^{4}$ \\
\hline $241_{\mathrm{Am}}$ & $4.33 \times 10^{2}$ & 4,000 & $9 \times 10^{4}$ \\
\hline $243 \mathrm{Am}$ & $7.95 \times 10^{3}$ & 4,000 & $9 \times 10^{4}$ \\
\hline
\end{tabular}

* Underlined retention times indicate that the radionuclide activity falls below harmful levels before escape from the backfill into the host environment. 
2.8.2.2 Bentonite-quartz Backfi17. A mixture of 80 to $90 \%$ quartz sand $\left(98 \% \mathrm{SiO}_{2}\right)$ and 10 to $20 \%$ bentonite powder has been proposed by the Swedish KBS project (Ah7ström, 1979; Mattsson, 1979) as a backfill for emplacement holes in which lead-titanium canisters containing high-level waste glass have been placed. Sand particles 0.062 to $2 \mathrm{~mm}$ in diameter sintered at a temperature of $1,400^{\circ} \mathrm{C}$ are suggested for this application. Restriction of the bentonite content has been suggested primarily as a means of increasing the thermal conductivity of the backfi11, thereby avoiding a temperature buildup that might threaten the functional integrity of the backfill. However, reduction of the bentonite content reduces the plasticity, ion exchange capacity, and density of the overall backfill component. The choice of 10 to $20 \%$ bentonite is considered sufficient to retain adequate functional ability of the total backfill.

Ah7ström (1979) has summarized the mechanical properties of a $10 \%$ bentonite-90\% quartz mixture from Swedish field and laboratory tests, which have revealed that:

- The maximum compacted density is 1.9 to $2.0 \mathrm{~g} / \mathrm{cm}^{3}$ at an optimum water content of 8 to $12 \%$.

- The bearing capacity of the mixture is sufficient to keep a leadtitanium canister in place ( 1.4 to $1.5 \mathrm{~g} / \mathrm{cm}^{3}$ is the minimum required density).

- Under confined swelling conditions, hydraulic conductivity of the mixture varies between $10^{-8}$ and $10^{-11} \mathrm{~m} / \mathrm{sec}$.

- When water content is 5 to $25 \%$, thermal conductivity is 0.3 to $1.7 \mathrm{~W} / \mathrm{m}^{\circ} \mathrm{C}$.

- Under confined swelling conditions, the swelling pressure exerted by the clay-quartz mixture is 0.3 to $1.5 \mathrm{MPa}$.

The retarding abilities of the 10\% clay-90\% quartz mixture were studied by Neretnieks (1977). Results are shown in Table 2-84. Retardation factors were calculated for the clay-quartz mixtures using Allard and Others' (1977) equilibrium data. Retardation factors were calculated assuming that diffusion is the migration-controlling process. It. *urns out that if the retardation factor $(R)$ is greater than the half life of a particular nuclide, then the nuclide will remain in the barrier 
TABLE 2-84. Retardation Factors in 1-Meter-Thick Clay/Quartz and Clinoptilolite Barriers for Various Nuclides.

(After Neretnieks, 1977.)

\begin{tabular}{|c|c|c|c|}
\hline \multirow[b]{2}{*}{ Nuclide } & \multirow[b]{2}{*}{$\begin{array}{l}\text { Half Life } \\
\text { (Years) }\end{array}$} & \multicolumn{2}{|c|}{ Retardation Factor, $R$} \\
\hline & & $\begin{array}{l}\text { 10\% Bentonite } \\
90 \% \text { Quartz Sand }\end{array}$ & Clinoptilolite \\
\hline $90 \mathrm{Sr}$ & $2.77 \times 10^{1}$ & $30^{2}$ & $600-1,400$ \\
\hline${ }^{99} \mathrm{TC}$ & $2.12 \times 10^{5}$ & 1 & 1 \\
\hline${ }^{129}$ I & $1.7 \times 10^{7}$ & 1 & 1 \\
\hline $137 \mathrm{Cs}$ & $3.0 \times 10^{1}$ & $20-30$ & $2,200-5,200$ \\
\hline $226 \mathrm{Ra}$ & $1.602 \times 10^{3}$ & $40-50$ & $600-1,400^{b}$ \\
\hline $229 \mathrm{Th}$ & $7.34 \times 10^{3}$ & $50-300$ & Unknown \\
\hline $237 \mathrm{~Np}$ & $2.14 \times 10^{6}$ & 10 & Unknown \\
\hline $239 \mathrm{pu}$ & $2.44 \times 10^{4}$ & $60-80$ & Unknown \\
\hline $240 \mathrm{pu}$ & $6.58 \times 10^{3}$ & $60-80$ & Unknown \\
\hline $241_{\mathrm{Am}}$ & $4.33 \times 10^{2}$ & $200-4,000$ & $1,000-30,000 \mathrm{C}$ \\
\hline $243 \mathrm{Am}$ & $7.95 \times 10^{3}$ & $200-4,000$ & $\underline{1,000-30,000 \mathrm{C}}$ \\
\hline
\end{tabular}

aUnderlined cases are retarded.

bFrom value of Sr.

CFrom value of Eu. 
longer than 30 half lives. This is sufficient time to reduce that radionuclide activity below hazardous levels. The values in Table 2-84 were calculated for a 1-m-thick barrier and assuming a diffusion coefficient of $1 \times 10^{-10} \mathrm{~m}^{2} / \mathrm{sec}$. They indicate that ${ }^{90} \mathrm{Sr},{ }^{137} \mathrm{Cs}$, and ${ }^{241} \mathrm{Am}$ are retarded by the clay-quartz barrier long enough to allow reduction of radioactive activity below harmful levels.

\subsubsection{Zeolites. Zeolites have been considered as a major backfill} component primarily because of their high cation exchange capabilities. Neretnieks (1977) experimentally determined distribution coefficients for cesium, strontium, europium, and uranium between zeolite (clinoptilolite) and synthetic groundwater. The groundwater composition was primarily a sodium chlorine bicarbonate with a pH of approximately 8.2 to 8.3 . Varying amounts of zeolite $(0.01$ to $10.0 \mathrm{~g})$ were ground up to less than 0.1 -mm-particle diameter and added to $30 \mathrm{ml}$ of groundwater that was preequilibrated with zeolite. The radioactive tracer was added and the mixture was shaken for 7 to 8 days at atmospheric pressure and $20^{\circ} \mathrm{C}$. These distribution coefficients were used to calculate retardation factors in a zeolite backfi11, listed in Table 2-84. A 1-m-thick zeolite barrier will retard transport of strontium, cesium, radium, and americium through the backfill into the host rock long enough for the activities of these radionuclides to fall below harmful levels. According to the calculations, if the retardation factor exceeds the half life of a radionuclide, the radionuclide will remain the the backfill in excess of 30 half lives. Note also that the retardation factors are an order of magnitude higher for clinoptilolite relative to bentonite/quartz. These values reflect the superior sorptive properties of zeolite. Consequently, Neretnieks (1977) estimates that a 0.2-m zeolite barrier will be as effective as a $1.0-\mathrm{m}$ bentonite/quartz barrier.

The mechanical properties of zeolite, however, are poor in comparison to bentonite or bentonite/quartz mixtures. Jacobsson (1977) reports that zeolites are highiy permeable and prone to cementation through chemical reaction with groundwater. Thus, zeolites are not suitable as a water excluding material. Also, if extensive cementation occurs, overall permeability decreases, but a zeolite barrier then becomes brittle, and therefore, subject to fracture. 
2.8.2.4 Basalt. Crushed basalt must be considered as a potential major backfill component because of its chemical reactivity, availability following an excavation of the repository, and the need to dispose of excavated basalt. Studies of the chemical retardation properties of basalt are discussed in other sections of this document. The most important discussions are sorption (Section 2.10) and basalt-water-waste reactions (Section 2.9). Basalt has a fairly high sorption capacity for cationic radionuclides (cesium, strontium, americium, plutonium) and under reducing conditions, it will strongly sorb technetium and neptunium. However, anionic radionuclides such as iodine and selenium are sorbed weakly, or not at all, on crushed basalt. It is likely that the basaltic glass and secondary mineral components of crushed basalt account for its high sorption capacity. Basalt has also been shown to react in hydrothermal conditions $\left(100^{\circ}\right.$ to $\left.300^{\circ} \mathrm{C}\right)$ to fix cationic radionuclides (cesium, strontium, rubidium, molybdenum) that were leached from a simulated waste form. These radionuclides appear to have entered the structures of the minerals pollucite, powellite, and plagioclase.

One potential difficulty in using basalt as a major backfill component is that colloids may form in groundwater in contact with basalt. Barney (1979) produced colloids in sorption experiments and raised the possibility that these colloids, which are very sma11, may act as carriers for radionuclides if the colloids can move through the groundwater. However, little is known about the transport of colloids. Furthermore, it is questionable whether colloids will form under repository conditions since the experimental procedure included sample agitation (a process unlikely to occur in the repository). If the agitation causes colloid formation, then colloids will not form in the repository.

2.8.2.5 Minor Backfill Components. The discussion of potential major backfill components indicates that certain key radionuclides, particularly anionic species, are not effectively retarded by these materials. Tailoring additives (i.e., backfill materials designed to retard specific radionuclides) are discussed below. 
Batch experiments done on a variety of mineral materials by Strickert and Others, (1978) and Fried and others (1978) to determine their capacity for sorbing pertechnetate $\left(\mathrm{TCO}_{4}{ }^{-}\right)$, iodide $\left(I^{-}\right)$, and iodate $\left(\mathrm{IO}_{3}\right)$ ions are summarized in Table 2-85. A quantity of crushed mineral or rock ( $0.39,60^{3}$ to 100 mesh) was added to $1 \mathrm{ml}$ of water that had been previously equilibrated with the mineral or rock. The water was also spiked with small amounts of pertechnetate and either iodide or iodate $\left(5 \times 10^{5}\right.$ disintegrations per minute). The vials were then shaken continuousiy for periods up to three days.

These data show that silicate rocks as well as other minerals such as apatite and anhydrite do not sorb appreciable amounts of either ${ }^{95}$ Tc or 131 I. On the other hand, copper, lead, or iron sulfides (e.g.s bournonite, galena, chalcopyrite) sorb $\mathrm{I}^{-}$and $\mathrm{IO}_{3}^{-}$ions very strongly. Bournonite also sorbs $\mathrm{TCO}_{4}$ strongly. There was evidence that reduction of $\mathrm{TCO}_{4}$ may occur by minerals containing $\mathrm{Cu}^{+}, \mathrm{Pb}^{+2}$, or $\mathrm{Fe}^{+2}$ ions. The large absorption of $I^{\text {* }}$ ions in minerals containing metals (e.g., copper, lead, iron) that form insoluble iodides suggests that iodide ions are coprecipitated or otherwise directly incorporated into the mineral lattice. Sorption of iodate ions coincided with sorption of iodide ions.

Bird and Lopata (1979) of the Canadian Whiteshell Nuclear Research Establishment have measured uptake of $\mathrm{SeO}_{4}^{-2}, \mathrm{TCO}_{4}$, and $\mathrm{I}^{-}$ions from pH 8 to 12 water by a variety of mineral oxides, suifides, phosphates, and carbonates, and for comparison, three silicates. Selenate and pertechnetate ions were both fixed to some extent by the minerals hydrocerussite, massicot, litharge, galena, cerussite, tenosite, cuprite, covelite, copper metal, apatite, calcite, sphalerite, smithsonite, and the silicates chlorite, labradorite, and augite. Selenate and pertechnetate ions are easily desorbed from the silicate minerals. Iodide ion, in contrast, was fixed in significant amounts only by copper metal and the two lead oxides, massicot and litharge.

of all the minerals studied by Bird and Lopata (1979), massicot (Pbo) and litharge (PbO) have the highest capacity for fixation of all three anions (Fig. 2-59). Greater than 95\% of each anion was removed from solution (measured on the $y$-axis) at molar ratios of anion/Pbo less than 
TABLE 2-85. Sorption of $\mathrm{TCO}_{4}^{-}, \mathrm{I}^{-}$, and $\mathrm{IO}_{3}^{-}$by Various Rocks and Minerals.

(After Strickert and Others, 1978; Fried and Others, 1978.)

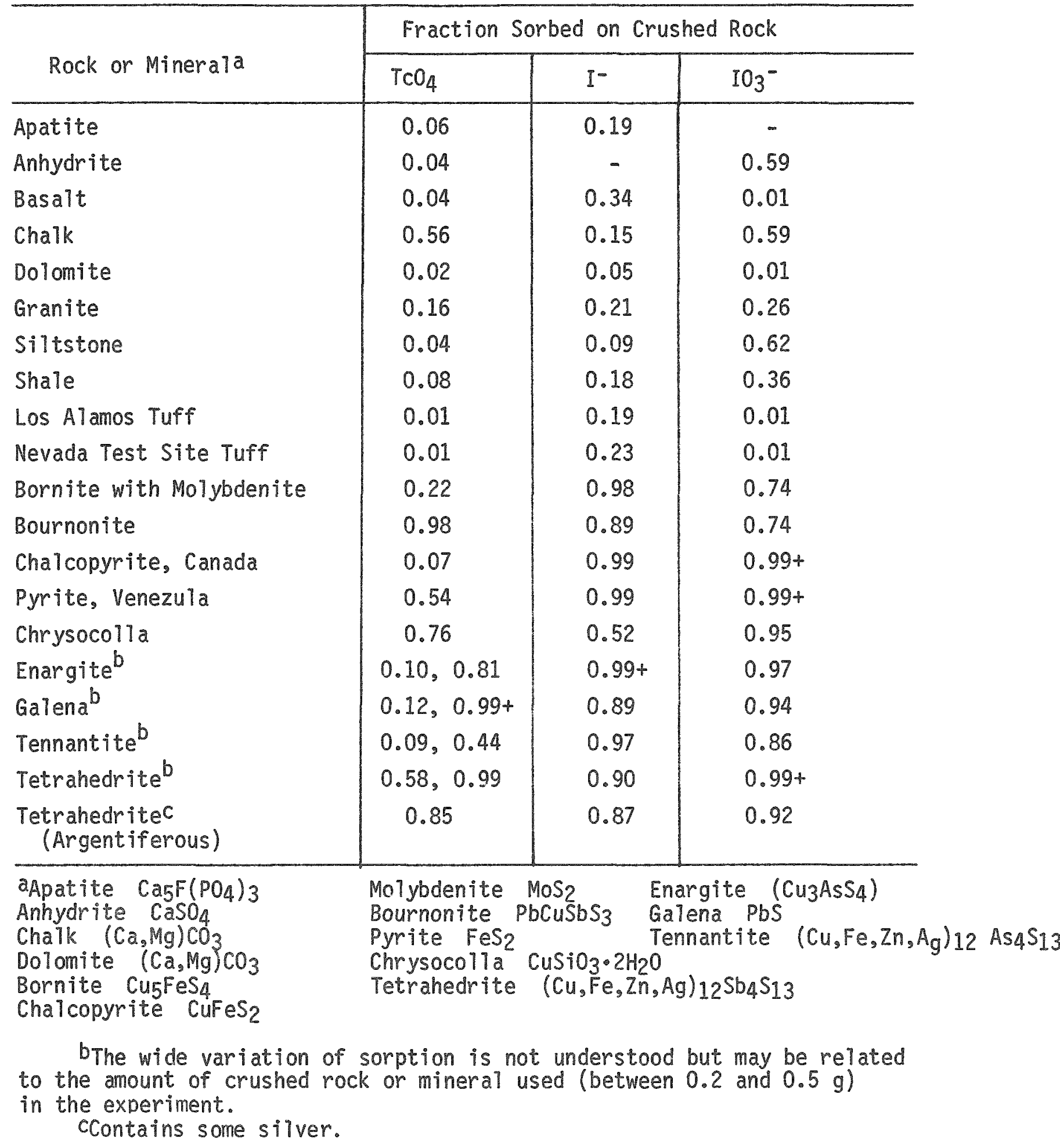


RHO-BWI-ST-7
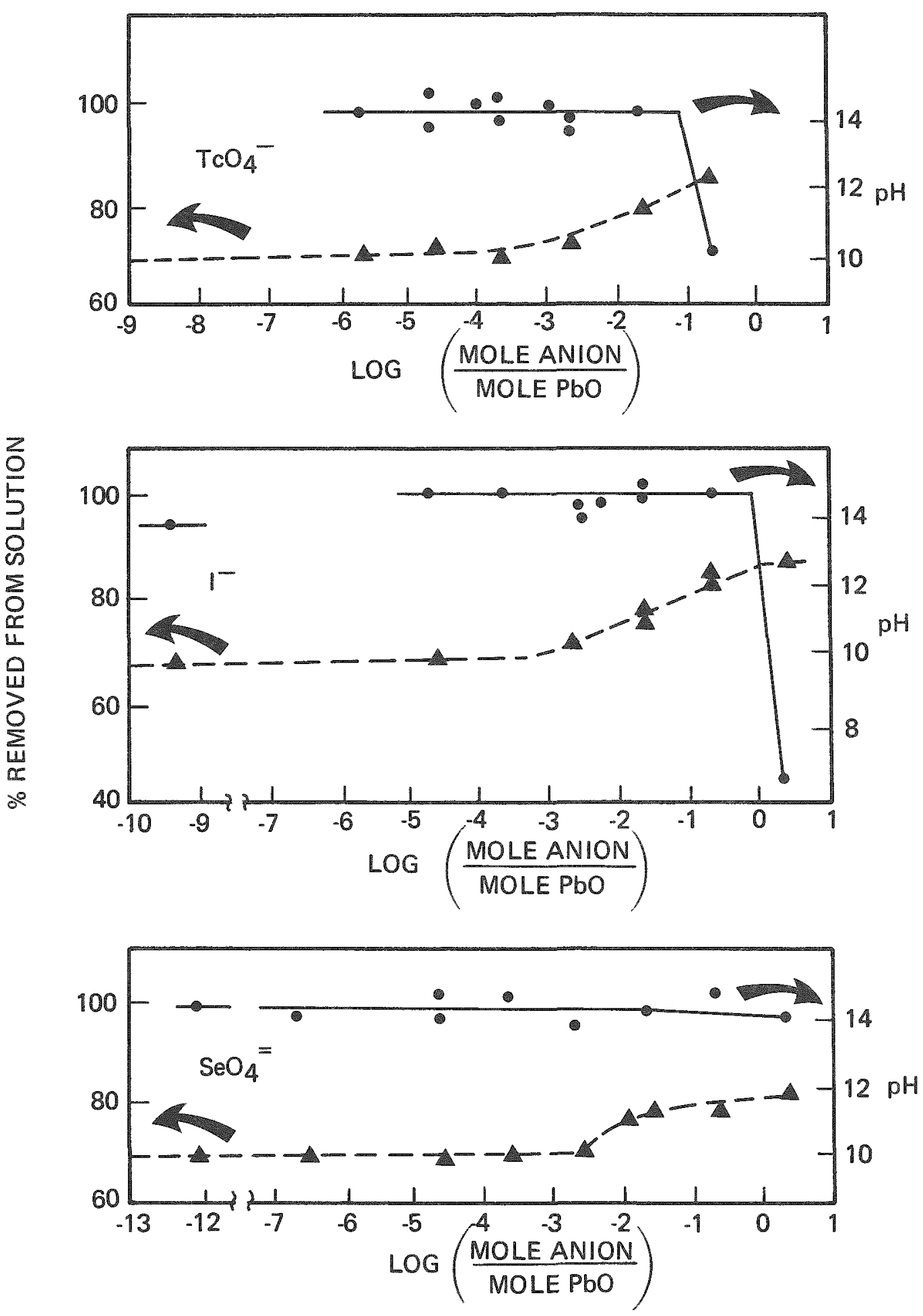

FIGURE 2-59. Fixation of $\mathrm{TCO}_{4}^{-}$and $\mathrm{SeO}_{4}^{-2}$ by $\mathrm{PbO}$ as a Function of Anion/Pbo Mole Ratio. Solid circles are measured percent removed: triangles are the measured $\mathrm{pH}$ or the solution in equilibrium with the solid (after Bird and Lopata, 1979). 
1:10 (all data points to the left of -1 on the $x$-axis). Note also that $\mathrm{pH}$ increases to the right as the anion/Pbo ratio increases. These data lead Bird and Lopata (1979) to postulate that new phases are being formed by the following reactions

or

$$
(X) \mathrm{PbO}+Y\left(\mathrm{H}_{2} \mathrm{O}\right)+(2 / \mathrm{C})(Y) A^{n-}=(X-Y) \mathrm{PbO}^{\circ}(Y) \mathrm{Pb}\left(\mathrm{A}^{\mathrm{n}-}\right){ }_{2} /+(2 Y) \mathrm{OH}^{-}
$$

where

$$
(X+Y) P b O+(2 X / n) A^{n-}+(X+Y) H_{2} \mathrm{O}=(X) P b\left(A^{n-}\right)_{2 / n} \cdot Y P b(O H)_{2}+(2 X) O H
$$

$A=\mathrm{TCO}_{4}{ }^{-}, I^{-}, \mathrm{SeO}_{4}{ }^{-2} ; n=1$ or $2 ;$ and $X$ and $Y$ are constants.

The addition of the anion to the system drives these reactions to the right, causing the formation of hydrated lead-anion compounds and $\mathrm{OH}^{-}$, which takes the anion out of solution and raises the $\mathrm{pH}$, respectively.

Fried and Others (1978) have reported some sorption data for uptake of $\mathrm{Np}(V)$ by various common rocks and minerals. The sorptive capacities were determined in batch experiments. A $10^{-4} \mathrm{M}$ solution of $\mathrm{Np}(\mathrm{V})$ was made up, and the $\mathrm{pH}$ was adjusted to approximately 7 with the addition of appropriate amounts of $\mathrm{HCl}$ and $\mathrm{LiOH}$. This solution was preequitibrated with the powdered rock or mineral of interest for 1 week at atmospheric pressure and room temperature. Subsequentiy, $2 \mathrm{ml}$ of this solution were mixed with $0.25 \mathrm{~g}$ of the powdered solid. The results are shown in Table 2-86, including the contact time, $\mathrm{pH}$ of the solution in contact with the solid, and the percentage of $\mathrm{Np}(\mathrm{V})$ sorbed. These were preliminary experiments and the results were not meant to represent equilibrium values. Nevertheless, they indicate'that azurite, apatite, siderite, limestone, and granite are potentially useful retardants for $\mathrm{Np}(\mathrm{V})$.

Ames (in press) has suggested use of the mineral ultramarine (1azurite) as a backfill material. Ultramarine may extract heavy metals that have an affinity for sulfur since a polysulfide is fixed within, and exists interstitially throughout the ultramarine structure. The polysulfide occurs in the center of a sodalite cage from which it cannot escape without destroying the bonds between atoms that hold the cage together. Sodium ions within the cage can be exchanged for other ions (i.e., $\mathrm{Ag}^{+}, \mathrm{Pb}^{+2}$ ). Uitramarine can be readily converted to the 
TABLE 2-86. Sorption of $\mathrm{Np}(V)$ from Water by

Various Rocks and Minerals.

(After Fried and Others, 1978.)

\begin{tabular}{l|c|c|c}
\hline Rock or Minera. & pH & $\begin{array}{c}\text { Contact } \\
\text { Time (Hr) }\end{array}$ & $\begin{array}{c}\% \mathrm{~Np}(\mathrm{~V}) \\
\text { Sorbed }\end{array}$ \\
\hline Chalocopyrite & $7 \pm 0.5$ & 3 & 0 \\
Galena & $7 \pm 0.5$ & 1 & 0 \\
Pyrite & $7 \pm 0.5$ & 2 & 0 \\
Magnetite & $7 \pm 0.5$ & 2 & 26 \\
Basalt & $7 \pm 0.5$ & 1 & 23 \\
Apatite & $7 \pm 0.5$ & 2 & 99 \\
Azurite & $7 \pm 0.5$ & 2 & 97 \\
Sandstone & $7 \pm 0.5$ & 3 & 46 \\
Shale & $9 \pm 0.5$ & 3 & 60 \\
Siderite & $7 \pm 0.5$ & 1.5 & 86 \\
Limestone & $9 \pm 0.5$ & 2.5 & 86 \\
Granite & $9 \pm 0.5$ & 4.0 & 83 \\
\hline
\end{tabular}

*Azurite is $2 \mathrm{CuCO}_{3} \cdot \mathrm{Cu}(\mathrm{OH})_{2}$; siderite is $\mathrm{FeCO}_{3}$; limestone is $\mathrm{CaCO}_{3}$; sandstone is a silicate minera1; all others are defined in the footnote in Table 2-85.

silver form at $90^{\circ} \mathrm{C}$ to yield a material which may be useful for immobilizing iodine as silver iodide within the ultramarine structure. Ultramarine may be useful for immobilization of a wide variety of radionuciides because of its unique reactivity. Also, since it is used commercially as a blue pigment, it is readily available and relatively inexpensive.

Many inorganic ion exchange materials have been synthesized and studied in the laboratory. Most of these are too expensive, unstable in the hydrothermal environment of the repository, or may react with the canister and therefore cannot be considered as backfill materials. There are, however, a few exceptions. Hydrous zirconia and zirconium phosphate were used by Hure and others (1958) to remove very dilute impurities in high-temperature reactor water. Hydrous zirconia is an anion exchanger and zirconium phosphate a cation exchanger. Both appear to be stable 
RHO-BWI-ST -7

under hydrothermal conditions. Very little change in their ion exchange properties was observed as the temperature was increased from ambient to $100^{\circ} \mathrm{C}$.

Zirconia appears to have unique anion exchange properties. Most inorganic exchangers will exchange only cations in alkaline solutions. However, zirconia has a measurable exchange capacity for anions even in neutral and slightly alkaline solutions. Since most of the mobile radionuclides in the waste are anionic (i.e., I, $\mathrm{SeO}_{4}^{-2}$, and $\mathrm{TCO}_{4}^{-}$), zirconia might be expected to remove these from contaminated groundwater.

Another type of synthetic ion exchanger which may be of use are titanates, $\mathrm{M}^{\mathrm{n}}\left(\mathrm{Ti}_{2} \mathrm{O}_{5}\right)_{n}$. Dosch (1978) did experiments to determine the ion exchange capacity of sodium titanates on strontium and cesium enriched salt cake. Sodium titanates were shown to be effective sorbers of not only strontium and cesium but also plutonium. A solution containing approximately $0.06 \mathrm{ppm}$ plutonium passed through a $60 \mathrm{ml}$ volume of sodium titanate, and no plutonium activity was detected above background in the solution afterwards. These experimental results indicate that sodium titanates may prove to be effective sorbents for plutonium and other actinides.

\subsubsection{Discussion}

The preliminary data base and the functional abilities of the candidate backfill components discussed above (bentonite, crushed basalt, zeolite, and sand) are sufficient to establish an order of preference among these materials. Attention is focused below primarily on the merits of single components rather than mixed components for the following reasons:

- With the exception of $10 \%$ bentonite-90\% quartz sand, very little information exists for the pertinent properties of mixed components except for the 10\% bentonite-90\% quartz sand mixture. The advantages of this particular mixture are discussed along with bentonite. 
- Although mixed backfill components are likely to be recommended for use in the repository system, the ratios and types of materials used will depend largely on design criteria (waste package type, waste package spacing, nearness of the backfill to the waste package, etc.). For example, Swedish scientists have recommended in one design scheme that pure bentonite be placed directly around the waste package and that a mixture of 10 to $20 \%$ bentonite- 80 to $90 \%$ quartz sand be placed in the tunnel above the waste package deposition hole.

A summary of preferred major backfill components is 1 isted in Table 2-87. The optimum backfill component is bentonite because of the variety of functional properties it possesses. More specifically, compacted bentonite, unlike the other materials considered, is characterized by two important properties, low permeability and large swelling capacity. Low permeability is an indispensable characteristic of a backfill material because two major functional requirements of the backfill barrier within the multiple barrier system cannot be satisfied otherwise. First, a backfill of low permeability and high swelling pressure will minimize water contact with the waste package. Second, it will put into effect a diffusion-controlled rate of radionuclide transport from the waste package to the host environment. Consequentiy, it is concluded that a significant proportion of backfill must be made up of bentonite.

Swedish scientists have expressed concern over the physical and chemical stability of pure bentonite in a repository environment at a temperature over $100^{\circ} \mathrm{C}$. This situation could occur near the canisterbackfill interface due to the poor thermal conductivity of pure bentonite. In order to avoid this problem, a backfill of $10 \%$ bentonite- $90 \%$ quartz sand has been proposed which allows a higher rate of heat-transport. since bentonite is the most important component of a backfi11, it is worthwhile to conside potential physical/chemical restrictions on the allowable proportion of bentonite in a backfill. It is clear from a comparison of pure bentonite versus $10 \%$ bentonite-90\% quartz sand properties that the clay-sand backfill is inferior. For example, the permeability and ability to retard radionuclide transport are lower in the clay-sand material. 
TABLE 2-87. Preliminary List of Preferred Backfi 11 Candidate Materials.

\begin{tabular}{|c|c|}
\hline Major Components & Functional Properties \\
\hline Bentonitet & $\begin{array}{l}\text { Permeability, swelling pressure, } \\
\text { sorption, plasticity, bearing } \\
\text { capacity }\end{array}$ \\
\hline Crushed Basalt** & $\begin{array}{l}\text { Sorption, swelling pressure, } \\
\text { reaction }\end{array}$ \\
\hline Zeolite & Sorption \\
\hline Sand & $\begin{array}{l}\text { Bearing capacity, themal } \\
\text { conductivity }\end{array}$ \\
\hline Minor Components & Sorption Potential \\
\hline Apatite: $\mathrm{Ca} 5(\mathrm{~F}, \mathrm{Cl}, \mathrm{OH})\left(\mathrm{PO}_{4}\right)_{3}$ & $\operatorname{Np}(V)$ \\
\hline Azurite: $\mathrm{Cu}_{3}\left(\mathrm{CO}_{3}\right)_{2}(\mathrm{OH})_{2}$ & $N p(V)$ \\
\hline UTtramarine: $\mathrm{Na}_{8}\left(\mathrm{ATSiO}_{4}\right)_{6} \mathrm{~S}_{2}$ & $\mathrm{SeO}_{4}^{-2}, \mathrm{I}^{-}$ \\
\hline Bournonite: $\mathrm{PbCuSbS}_{3}$ & $\mathrm{TCO}_{4}, \mathrm{I}^{-}$ \\
\hline Chalcopyrite: CuFeS2 & $\mathrm{I}^{-}, \mathrm{IO}_{3}^{-}$ \\
\hline Pyrite: $\mathrm{FeS}_{2}$ & $\mathrm{I}^{-}, \mathrm{IO}_{3}^{-}$ \\
\hline
\end{tabular}

*Mixtures of bentonite with crushed basalt, zeolite, or sand retain similar properties to bentonite alone, but permeability swelling pressure and sorption capacity decreases as the proportion of bentonite decreases. On the other hand, thermal conductivity increases as the bentonite decreases.

**Swelling pressure is minimal and results from minor amounts of secondary clay mineralization. 
Given the present understanding of the basalt environment and other reports concerning the chemical stability of montmorillonite, there is no convincing evidence that the montmorillonite will be altered above $100^{\circ} \mathrm{C}$. According to Deer and 0thers (1967), interlayer water is lost reversibly up to $300^{\circ} \mathrm{C}$ (see Fig. 2-31). However, structural water is not lost until $450^{\circ}$ to $500^{\circ} \mathrm{C}$. This suggests that structural alteration does not occur simply from heating below $300^{\circ} \mathrm{C}$. On the other hand, weaver (1979) has compiled studies on natural shale formations and laboratory experiments and has concluded that montmorillonite alteration can begin at temperatures as low as $50^{\circ} \mathrm{C}$. The principal alteration products are illite, and to a lesser extent, chlorite. Both the swelling ability and the cation exchange capacities of illite and chlorite are significantly less than montmori 1. 1onite. Such alteration will also increase the permeability of a bentonite backfill. Therefore, the implication is that chemical alteration will severely reduce the effectiveness of bentonite as a backfill.

These data must be considered in terms of the basalt environment existing at the Hanford Site. In order for montmorillonite to alter to illite, it is necessary to add potassium to the interlayer space and tetrahedral aluminum must be increased. Hower and others (1976) suggest the following simplified reaction to describe the alteration of montmorilionite:

$$
\text { Smectite }+A I \text { (III) }+K^{+}=I 17 i t e+S i(I V)+\text { Chiorite. }
$$

In this regard, it is important to note that the potassium content of Grande Ronde Basalt and Grande Ronde groundwater is extremely low $(\sim 1.7 \mathrm{wt} \%$ and $1.9 \mathrm{mg} / \mathrm{l})$. Therefore, this reaction is unlikely to occur in the Hanford basalt environment to a significant degree. Furthermore, there is no other reaction known to occur below $300^{\circ} \mathrm{C}$. This is substantiated by the fact that secondary mineralization in basalt fractures is dominated by smectites, with minor amounts of 111 ite and chlorite occurring.

The swelling ability of bentonite allows bentonite to fill a specific volume such as a borehole with the addition of water. It has also been demonstrated that bentonite will extrude into small fractures either by viscous flow or by expansion through uptake of water (Pusch, 1979). Consequentry, it is likely that the waste package can be effectively 
isolated from the basalt environment. However, there are potential problems involved with the swelling pressure of clay. For example, the effect of swelling pressure of clay on the stability of the surrounding basalt must be considered. At present, this does not appear to be a problem. If the density of the clay is $2.1 \mathrm{~g} / \mathrm{cm}^{3}$, which is as high a density as can be reasonabiy expected, maximum swelling pressure has been estimated at $10 \mathrm{MPa}$. Lithostatic pressure in the basalt at 1,000 m depth is $30 \mathrm{MPa}$. Lithostatic pressure near the borehole will probably be less due to fracture induced by the drilling, but is unlikely to fall below $10 \mathrm{MPa}$. However, this hypothesis has yet to be tested. If this is the case, then bentonite swelling pressure will not disturb the basalt fracture system.

Another potential problem which may affect the physical integrity of a bentonite backfill is the vaporization of interlayer water above $100^{\circ} \mathrm{C}$. In the event of this occurrence, steam channels could be formed which would provide a significantly greater and perhaps unacceptable increase in the rate of transport of radionuclides to the geologic environment. As described in Section 2.5, the vaporization temperature of water is strongly dependent on pressure. Even a small swelling pressure in the clay of $2 \mathrm{MPa}$ will raise the boiling point of water to approximately $200^{\circ} \mathrm{C}$. In the event that interlayer water does boil, it is unlikely that a sufficient mass or concentration of water exists in the bentonite to form a steam channel. However, this possibility remains to be tested.

It can be concluded from present evidence that bentonite will remain chemically and physically stable both in the ambient basalt environment and during the thermal period following repository completion. If this hypothesis holds true following site-specific experimentation, then no restrictions are needed concerning the proportion of bentonite in the backfill.

Crushed basalt, zeolite, and sand can be compared directly with each other. All of these materials are permeable and therefore cannot be considered as acceptable single component backfills. It is likely that a crushed and compacted form of each of these materials would supply adequate mechanical support to the waste package, although Jacobsson 
(1977) reports that zeolites tend to become cemented and brittle. Consequentiy, a backfill with a significant zeolite proportion would be susceptible to fracturing following minor bedrock movement.

Preliminary experiments involving basalt, groundwater, and various radionuciides indicate that basalt reacts (Section 2.9) to fix cesium, strontium, and rubidium and sorbs (Section 2.10) cesium, strontium, americium, and plutonium when it is weathered. Zeolites also have excellent sorption capacity for strontium, cesium, radium, and americium. In fact, zeolites are the most efficient sorbing agents of all the major backfill components considered. However, crushed basalt must be considered a better backfill component than zeolite for several reasons:

- The superior sorbing ability of zeolite applies to radionuclides which can probably be adequately sorbed by a combination of bentonite and basalt.

- Zeolites have a tendency to become cemented and brittle where crushed basalt does not.

- Crushed basalt would be readily available following excavation of the repository.

The least favored backfill component is quartz sand. Quartz sand is chemically inert and highly permeable. However, sand is recommended by the Swedish scientists as a dilutant to pure bentonite because of its relatively high thermal conductivity.

A list of preferred minor backfill components are also shown in Table 2-87. These phases were listed because they have shown a large sorption capacity for those radionuclides that cannot be prevented from reaching the host environment by any of the major backfill components. However, there are drawbacks to the sulfur-bearing phases. Dissolution of such phases could lead to the formation of aqueous sulfide or sulfate species which could corrode overpack and canister metals. The list is by no means complete and will be the subject of extensive future research. 
RHO-BWI-ST -7

\subsubsection{Other Engineered Barrier System Components}

2.8.4.1 Introduction. Canisters, overpacks, and backfills are presently considered to be the most important components of a multiple barrier system and considerable emphasis has been placed on them. However, several other components are also being considered as part of the system and are briefly summarized below.

2.8.4.2 Buffer. The engineered barrier system conceived by the Basalt Waste Isolation Project will be constructed of mutually supporting components that are intended to operate at specific times in repository history. This concept was developed after considering the need to contain the waste for thousands of years and the realization that the conditions in the area of the package will change drastically through time. Since the likely range of some conditions is broad (e.g., oxygen fugacity ranges from $10^{-.7}$ to $10^{-70} \mathrm{~atm}$ ), the long-term stability of a single encapsulation material is questionable. It is therefore more prudent to develop a time-phased system.

For instance, the canister is intended to provide long-term physical containment of the waste. However, under the Basalt Waste Isolation Project concept, the canister is not relied upon until the geology reestablishes control over the oxygen content of the environment. This is likely to be some time after operations and into the thermal period of repository history. In order to protect the canister from the corrosive environment likely to prevail during earfy repository history, resistant overpacks will probably be installed around the canister. If the system works properiy, no other barriers are required. However, to provide an additional margin of safety, a buffer material could be placed between the canister and overpack. Ideally, the buffer would moderate the $\mathrm{pH}$ and oxygen contents of the intruding groundwater to mitigate corrosive failure of the canister.

The stability fields for several elements and oxides of interest in the consideration of a repository in basalt are illustrated in Figure 2-60. The lines show the equilibrium conditions for oxidation of some metals which are candidate materials for either the canister or overpack. Also on the diagram is the oxygen frequency that will exist 
when oxygen control is reestablished by the basalt. It can be seen that the basalt will not cause either copper or nickel to oxidize or $\mathrm{TiO}_{2}$ to reduce. Rather, basalt promotes the stability of copper and nickel metals and maintains the passivity oxide coat on titanium metal.

However, if the resistant overpack fails eariy in repository history, the oxygen content of the system may not be yet under geologic control. In a worst case, the oxygen content may nearly equal that of air (log = 0.7). Under such oxygen-rich conditions 211 of the materials shown will readily oxidize. Therefore, steps should be taken to exert local control on the oxygen content of the environment immediately in contact with the canister. Conceptual7y, this can be accomplished with the buffer.

The oxygen atmosphere $\left(\mathrm{fO}_{2}\right)$ caused by the oxidation of graphite is shown in Figure 2-60. Of note is the near coincidence of this fugacity with that imposed by basalt and the position of the graphite- $\mathrm{CO}_{2}$ isobar relative to the isobars of candidate canister materials. Clearly, the graphite reaction is capable of consuming enough oxygen to promote the stability of copper and nickel. However, there are still many unanswered questions concerning the absolute effectiveness of a graphite buffer.

For instance, in order to reduce the local oxygen fugacity, graphite must react. As with many reactions, a quantum amount of thermal energy is required before reaction takes place. While the buffer is intended to operate when repository temperaiures are at their peak, it is as yet uncertain whether sufficient reaction will take place to warrant the inclusion of graphite as an oxygen fugacity buffer. Other material being considered as possible oxygen getters include metallic iron or titanium and finely powdered basalt.

As discussed in Section 2.5.3, groundwater pH is likely to vary as a function of temperature and flow rate. If an overpack breach occurs prior to or at the maximum pH depression, the canister could be exposed to a solution of $\mathrm{pH}=4$. Such acid solutions generally promote corrosion of both ceramics and metals. Therefore, a pH moderator is desirable.

Presentiy there are several materials being considered as possible candidates. Chief among these is $\mathrm{ATPO}_{4}$ because it has the potential to retard canister corrosion and precipitate transuranics in the event of a 
RHO-BWI -ST -7

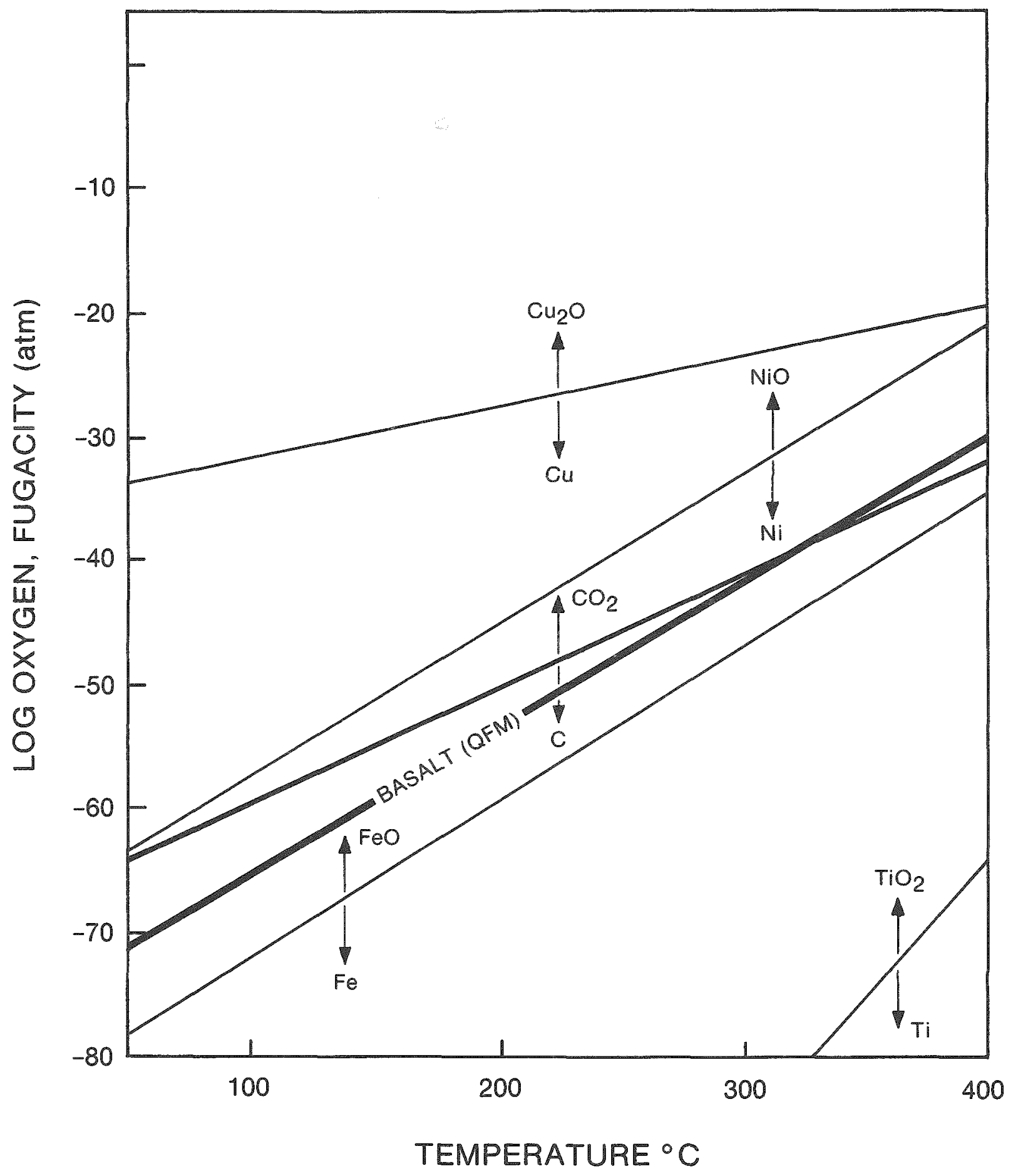

FIGURE 2-60. Stable Regions of Some Metals and Oxides Pertinent to Nuclear Waste Disposal in Basalt. 
canister failure. For instance, phosphates tend to moderate both acid and base solutions, generating moderate $\mathrm{pH}^{\prime} s$ by phosphoric acid dissociation. The anticipated result is extended canister life. In addition, phosphate is one of the best agents known for precipitating transuranics. Therefore, in the event of breached containment, dissolved phosphate wiil help immobilize the waste.

Another possible $\mathrm{pH}$ moderator is the carbonate family $\mathrm{Na}_{2} \mathrm{CO}_{3}, \mathrm{CaCO}_{3}$, etc.). Carbonate dissolution will raise $\mathrm{pH}$, producing a more basic solution. This will generally promote metallic canister life, especially carbon steels. However, in the event of breached containment, high pH and the presence of carbonate can increase the solubility of transuranics as complexants by as much as 8 to 10 orders of magnitude. Thus, if carbonate is used to buffer $\mathrm{pH}$, waste solubility could be promoted.

It is desirable to include a buffer between the canister and overpack to help protect the canister in the event of premature overpack failure. Two ways in which a buffer can inhibit canister corrosion are to depress the oxygen fugacity and to moderate or raise the pH of the intruding groundwater. It is yet to be determined whether effective measures can be taken. However, candidate buffer materials presently being considered include graphite, iron, titanium, carbonate, and phosphate.

It is recognized that only a limited amount of buffer can be contained between the canister and overpacks, and by the very nature of its operation, the buffer will be consumed. Therefore, the buffer is intended only to "buy time" until repository conditions are less severe. It is also implicit that a buffer will be effective only in the case of minor rupture of the overpack. Catastrophic failures cannot be mitigated by a buffer.

Other areas of concern which are likely to affect the final choice of buffer materials are heat capacity, thermal conductivity, ability to react spontaneousiy, ability to inhibit water flow, and the ability to immobilize dissolved waste. For these reasons, it is virtually certain that the buffer will be a composite material which may contain (at least in small amounts) many of the substances comprising the backfill. 
2.8.4.3 Sleeves. Some authors (Westerman, 1979; EPA, 1978) have advocated lining canister holes with metallic or ceramic sleeves. These hole liners would facilitate retrieval of canisters, if circumstances warrant such action, and that is usualiy regarded as their primary function. Properly designed, constructed, and installed hole sleeves could constitute an effective engineered barrier. Westerman (1979) suggests that massive shells of special cements, cast in place, for thermal and/or radiation protection, or impervious graphite vessels especially embedded in the surrounding rock might all be examples of hole sleeves which could act as highly effective barriers to radionuclide transport.

2.8.4.4 Grouts. Methods used to mine out holes to emplace canisters may induce fracture cracks in the basalt walls. Special grouts and grouting injection techniques may be deemed necessary to seal these cracks prior to waste emplacement. Properly constituted and emplaced grouts would provide a barrier to radionuclide transport.

2.8.4.5 Stabilizers. The major function of stabilizers would be to provide mechanical support for spent fuel assemblies inside the canister. Stabilizers would be chosen to fill in the void spaces in the spent fuel-canister assemblage. This would prevent movement of the spent fuel assemblage during emplacement of the waste package and increase the strength of the waste package. Materials which may be useful as space fillers are molten metal or powdered solids.

\subsection{WASTE-BASALT INTERACTIONS}

\subsubsection{Introduction}

Earlier sections have defined the environments that can potentially exist in proximity to a nuclear waste repository in basalt at Hanford. Environmental controls affecting waste/rock interactions unique to basalt are the combination of bulk chemistry, the presence of glass (hence, reactivity), and the low oxygen fugacity (hence, reducing conditions). These controls can prevail over the life of the repository and are generally favorable to the construction of a nuclear waste repository in basalt. Preliminary evidence, which indicates that basalt retards 
migration of hazardous materials by reaction and precipitation, is presented in the text that follows. However, in all cases discussed, data interpretations must be considered preliminary.

The hydrothermal interactions of each waste form with basalt will be discussed separately. For convenience, each discussion will focus on waste form performance during the operations and thermal and geologic control periods of repository history. For discussion purposes, general reference conditions for each time period are assumed.

$$
\begin{aligned}
& \text { Operations Period -- Oxidizing conditions }\left(\mathrm{fO}_{2}-10^{-.7} \mathrm{~atm}\right) \text {, } \\
& \text { maximum temperature }\left(300^{\circ} \mathrm{C}\right) \\
& \text { Thermal Period -- Variable oxygen }\left(10^{-.7}-10^{-47} \mathrm{~atm}\right) \text {, } \\
& \text { moderate maximum temperatures }\left(200^{\circ} \mathrm{C}\right. \text { to } \\
& 300^{\circ} \mathrm{C} \text { ) } \\
& \text { Geologic Control -- Reducing conditions }\left(\mathrm{fO}_{2}=10^{-47} \mathrm{~atm}\right) \text {, } \\
& \text { low temperatures }\left(\leq 100^{\circ} \mathrm{C}\right)
\end{aligned}
$$

\subsubsection{Spent Fuel-Basalt-Water Interactions}

As discussed in Section 2.6.1, the oxides comprising the greatest part of spent fuel ( $25 \%$ ) are uranium oxides. In all likelihood, both U(IV) and U(VI) oxides are present. However, the relative proportions of each are uncertain. In the short term, this ratio may be important because the aqueous solubilities of U(IV) and U(VI) are drastically different. Also important to the composition of spent fuel are oxides of cesium, strontium, rubidium, technetium and the element iodine.

\subsubsection{Repository Operations. During the operations period, tempera-} tures may reach the calculated maximum for the repository. However, even at $300^{\circ} \mathrm{C}$, under the minimum pressure associated with a hydrostatic leach situation, water remains a liquid. Thus, radionuclide migration is dependent on aqueous transport, and solubility limits are an important evaluation tool.

Under the oxidizing conditions expected during the operations period, uranium solubility is high. Estimates derived from Lemoine (1975) show concentrations of at least $75 \mu \mathrm{g} / \mathrm{ml}$ ( $\mathrm{Appm}$ ), and perhaps as high as 125 $\mu \mathrm{g} / \mathrm{ml}$, are to be expected (see Fig. 2-44). 
The radioisotopes of cesium and strontium $\left({ }^{137} \mathrm{Cs},{ }^{90} \mathrm{Sr}\right)$ are more soluble than uranium. Although these have short half lives, in the short term (operations period) both of these isotopes will comprise a significant portion of spent fuel. Thus, the near $100 \%$ extraction of cesium, rubidium, and molybdenum (see Section 2.6.6) represents an additional potential hazard. For instance, cesium concentrations from simulated waste-water leach experiments exceed maximum permissible concentration by nearly 9 orders of magnitude, and molybdenum (i.e., technetium) concentrations are too high by at least 4 orders of magnitude.

However, the mobility of uranium, cesium, rubidium, and molybdenum is significantly decreased by the presence of basalt (Table 2-88). For cesium and rubidium the mechanism is undoubtedly a reaction to form stable solids such as pollucite (Komarneni and Others, 1980). However, for polyvalent materials such as uranium or technetium, reduction may also contribute to stabilization. For instance, the solubility of $\mathrm{UO}_{3}$ at $250^{\circ} \mathrm{C}$ is at least $25 \mu \mathrm{g} / \mathrm{ml}$ while that of $\mathrm{UO}_{2}$ can only be as great as $8 \mu \mathrm{g} / \mathrm{ml}$ (estimated from Lemoine, 1975). Thus, dissolution and transport of the oxidized ions may be an inefficient means of transporting the radionuclides, since cooler and more reducing conditions will prevail within several tens of meters of the repository. This change in conditions is likely to result in massive precipitation and consequent decontamination of the groundwater. A quantitative estimate of resulting groundwater compositions will be presented in the discussion of the geologic control period of this section.

In summary, elements of high leachability in a basalt environment are uranium, cesium, strontium, rubidium, and molybdenum (i.e., technetium). It is likely that transuranics, iodine, and assorted decay products (e.g., radium, selenium) may exit the near-field repository region in amounts exceeding maximum permissible concentrations, if the fuel is directly exposed to water. Therefore, disposal of spent fuel requires a high-integrity canister/overpack system to isolate the waste from heated water. This canister must provide protection until temperatures are 
TABLE 2-88. Compositions of Residual Solutions from Experimentsa Reacting Simulated Spent Fuel in Distilled Water.

\begin{tabular}{|c|c|c|c|c|}
\hline \multicolumn{5}{|c|}{ Temperature $=300^{\circ} \mathrm{C}$} \\
\hline \multicolumn{3}{|c|}{ Spent Fuel (alone) } & \multicolumn{2}{|c|}{ Spent Fuel + Basalt } \\
\hline & $\mu \mathrm{g} / \mathrm{ml}$ & relative \% & $\mu \mathrm{g} / \mathrm{ml}$ & relative \% \\
\hline $\mathrm{Rb}$ & 33 & 100 & $N D^{b}$ & - \\
\hline Cs & 281 & 100 & ND & $=$ \\
\hline$S r$ & ND & - & ND & - \\
\hline Mo & 190 & 54 & ND & - \\
\hline$U$ & 3 & .004 & ND & - \\
\hline othersc & ND & - & ND & - \\
\hline \multicolumn{5}{|c|}{ Temper ature $=200^{\circ} \mathrm{C}$} \\
\hline & $\mu \mathrm{g} / \mathrm{ml}$ & relative \% & $\mu \mathrm{g} / \mathrm{ml}$ & relative \% \\
\hline $\mathrm{Rb}$ & 44 & 100 & ND & - \\
\hline Cs & 363 & 100 & 3 & 1 \\
\hline Sr & 1 & 1 & ND & - \\
\hline Mo & 308 & 87 & ND & - \\
\hline$u$ & 1 & .003 & ND & - \\
\hline others & ND & - & ND & - \\
\hline
\end{tabular}

as weeks duration: $10: 1$ water to solid ratio.

bNone detected by atomic absorption, atomic emission, or fluorometry.

$\mathrm{CBa}, \mathrm{La}, \mathrm{Nd}$, and $\mathrm{Zr}$ were not detected solution. 
below $100^{\circ} \mathrm{C}$. In addition, a backfill containing abundant basalt should be placed around the canister/overpack. Experiments at $200^{\circ}$ to $300^{\circ} \mathrm{C}$ indicate that a mass of crushed basalt equal to that of the spent fuel efficiently removes the cesium, rubidium, and molybdenum dissolved from spent fuel (see Table 2-88). Stabilization is by reaction to form pollucite, powellite, and some as yet unidentified phases. Incorporation of toxic material in these phases is irreversible and represents a major barrier to radionuclide migration. Thus, in the event of a breached canister/overpack, reaction should be encouraged. Reaction enhancement can be provided by encircling the canister with a high surface area material containing a large glassy component. However, it should be emphasized that if a breach occurs, some nuclides (notably ${ }^{129}$ I) may not be significantly delayed from reaching the biosphere. Therefore, if spent fuel is buried, heavy reliance must be placed on physical containment.

2.9.2.2 Thermal Period. During the thermal period, conditions will not be as conducive to spent fuel leaching as those encountered during the operations period. This change results primarity from the more reducing environment produced by oxygen equilibration with basalt phases ( $\mathrm{fO}_{2} \approx$ $10^{-67}$ atmospheres). For instance, experiments reacting simulated spent fuel and basalt produce a solution that contains 1/40 of the uranium concentration obtained from experiments leaching spent fuel (alone). This is largely a function of the precipitation of $\mathrm{UO}_{2}$ (as discussed earlier), which is a product in all experiments reacting spent fuel and basalt in groundwater.

The precipitation of $\mathrm{UO}_{2}$ is an encouraging result, implying control of uranium concentrations by $\mathrm{UO}_{2}$ equilibrium (at $200^{\circ}$ to $300^{\circ} \mathrm{C}$ the solubility limit is estimated at $\sim 5 \mu \mathrm{g} / \mathrm{ml}$ ). By inference, the solubilities of other transuranic elements will also be controlled by equilibrium with the tetravalent oxide; thus, maximum concentrations are likely to decrease by an order of magnitude. These concentrations will aiso decrease as a function of time.

2.9.2.3 Geologic Control. During the period of geologic control, conditions favoring spent fuel stability are optimum. It should be noted 
that these same conditions are likely to exist within several tens of meters of the repository during any portion of repository history.

Ambient conditions in a repository at Hanford are likely to include a temperature near $50^{\circ} \mathrm{C}$ and an oxygen content near $10^{-67}$ atmospheres. Figure 2-61 illustrates that under these conditions, the estimated $\mathrm{UO}_{2}$ solubility is approximately $0.02 \mu \mathrm{g} / 2(\approx 0.02 \mathrm{ppb})$ (Rich and 0thers, 1977; Sergergeva and 0thers, 1972). This concentration is about 5 orders of magnitude below maximum permissible concentration and strongly suggests that under undisturbed geologic conditions, uranium will not be released in hazardous amounts. By inference, neptunium, plutonium, americium, and curium may be similarly limited, although maximum permissible concentration limits on several of these isotopes are well below those for ${ }^{238} \mathrm{U}$.

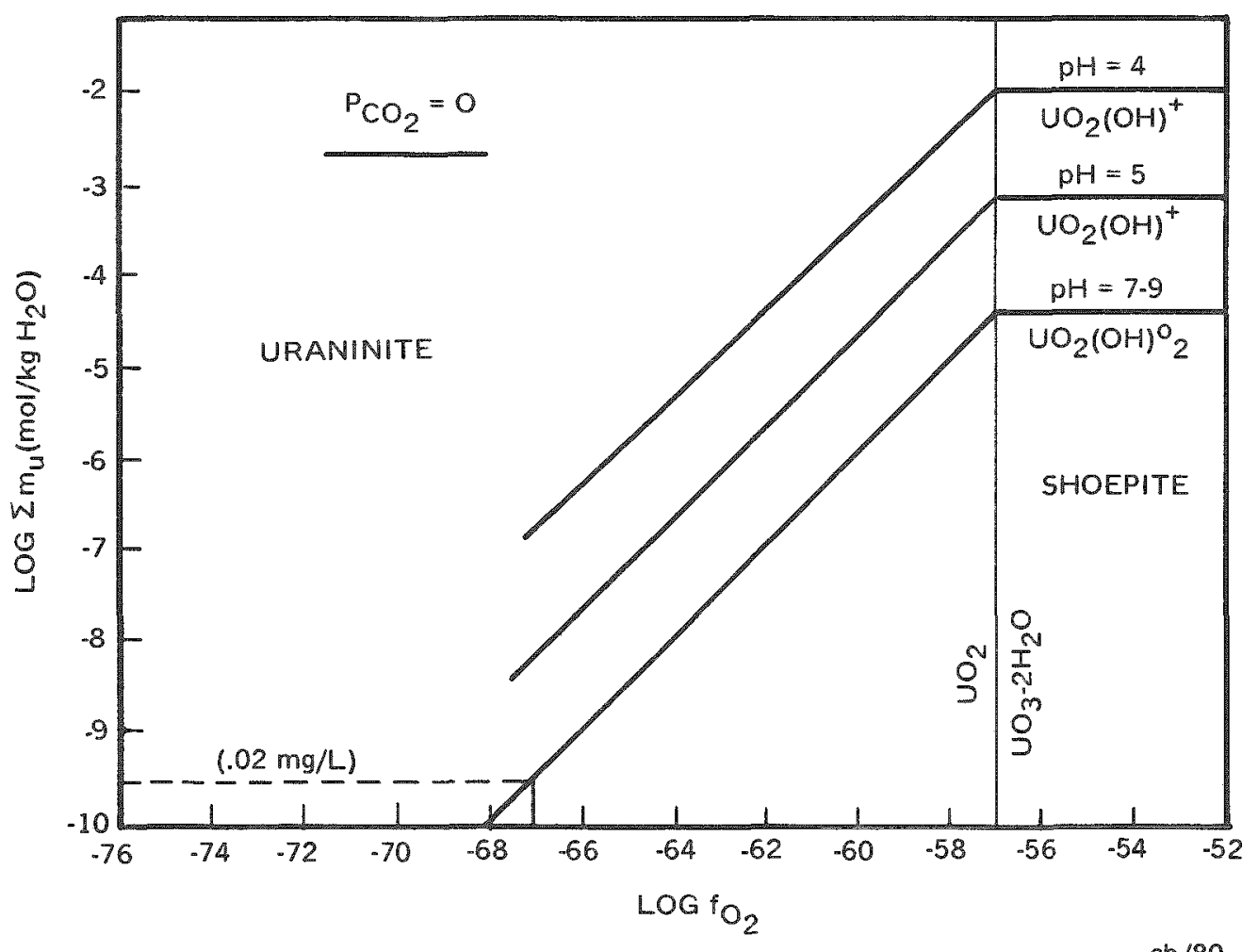

FIGURE 2-61. Solubility of $\mathrm{UO}_{2}$ as a Function of $\mathrm{pH}$ and 0xygen Content (after Rich and Others, 1977). 
These estimates must be tempered by the realization that they are preliminary and in some ways do not approximate actual repository conditions. For instance, $\mathrm{UO}_{2}$ solubility was measured in distilled water. Complexing agents such as $\mathrm{F}^{-}, \mathrm{Cl}^{-}, \mathrm{SO}_{4}{ }^{-2}$, and $\mathrm{CO}_{3}{ }^{-3}$ will affect uranium solubility and the presence of these agents in Hanford groundwater is known (Gephart and Others, 1979a). In addition, uranium solubility was measured using natural uranium outside of a strong radiation field. Reaction products of water resulting from the radiation emitted by spent fuel, however, may increase $\mathrm{UO}_{2}$ solubilities.

In the period of geologic control, the most abundant Group I radionuclide will be ${ }^{135} \mathrm{Cs}$. As discussed earlier, cesium is highly soluble but also highiy reactive with basalt. Present data are limited to a minimum temperature of $100^{\circ} \mathrm{C}$ (Table 2-89); they indicate total reaction and elimination of dissolved CS. It is presently unknown as to what extent cesium can be removed from solution by reaction with basalt at $50^{\circ}$ to $65^{\circ} \mathrm{C}$.

2.9.2.4 Summary. Spent fuel contains highly soluble cesium, strontium, rubidium, and molybdenum, which can be released from a breached canister. Present evidence indicates that virtually all of this material will react with basalt providing temperatures are $100^{\circ} \mathrm{C}$ or above and providing the contaminated solution is exposed to a mass of basalt at least equal to the mass of spent fuel leached. Reaction times are brief, reaching completion in one month.

The major component of spent fuel is uranium. Uranium solubility is highly dependent on oxygen content. Under oxidizing conditions at $250^{\circ}$ to $300^{\circ} \mathrm{C}$, uranium solubility exceeds maximum permissible concentration by 2 orders of magnitude. Under reducing conditions at $250^{\circ}$ to $300^{\circ} \mathrm{C}$, estimated uranium solubility is only 5 to 10 times above maximum permissible concentration limits. At $50^{\circ} \mathrm{C}$ under reducing conditions, uranium solubility appears to be 4 to 5 orders of magnitude below maximum permissible concentration. These data indicate that if a spent fuel canister/overpack is breached during the operations or thermal periods of repository history, high concentrations may be released from the 
TABLE 2-89. Compositions of Residual Solutions from Experiments Reacting Simulated Spent Fuel at $100^{\circ} \mathrm{C}^{*}$.

\begin{tabular}{c|c|c|c|c}
\hline \multicolumn{2}{c|}{ Spent Fue (alone) } & \multicolumn{2}{c}{ Spent Fuel + Basalt } \\
\hline & $\mu g / m 7$ & relative \% & $\mu g / m i$ & relative \% \\
\hline Rb & 5 & 16 & - & - \\
Cs & 51 & 19 & - & - \\
Sr & 4 & 4 & - & - \\
Mo & 25 & 7 & - & - \\
U & 10 & .01 & - & - \\
Ba & 5 & 3.5 & - & - \\
La & 1 & 0.8 & - & - \\
Nd & ND** & - & - & - \\
Zr & ND & - & - & - \\
\hline
\end{tabular}

$*_{4}$ weeks duration; $10: 1$ water to solid ratio.

** None detected by atomic absorption, atomic emission, or fluorometry.

canister. However, as the contaminated groundwater exits the thermal zone, uraninite precipitation may reduce dissolved uranium concentrations well below maximum permissible concentration. Similarly, during the period of geologic control, uranium concentrations in solution are likely to be limited by solubility and be below maximum permissible concentration. Using uranium as a gauge, neptunium, plutonium, and americium may be solubility limited as weil.

Highly toxic fission products of uranium (e.g., curium, radium, iodine) will not be solubility limited. Thus, containment of these radionuclides within the waste package environment is likely to depend heavily on a high integrity canister/overpack assemblage. In particular, ${ }^{129}$ I represents a problem because it is both unreactive and highiy mobile. Presently, it would appear that safe disposal of ${ }^{129}$ I requires either physical containment, massive dilution, or the development of an as yet unknown backfill component.

In summary, some toxic elements comprising spent fuel will be difficult to contain in the area of the waste package if a container fails. Therefore, a successful engineered barrier design should provide 
RHO-BWI-ST-7

a high-integrity canister/overpack assemblage that will last until temperatures return to $100^{\circ} \mathrm{C}$ or below. To mitigate premature canister overpack failure--especially during the operation and thermal periods--a high surface area backfill should be provided containing a mass of basalt equal to the mass of spent fuel leached. The total system relies most heavily on physical containment, but contains a chemical system designed to reduce the hazard potential in the event of premature container failure. The ultimate success of the chemical system requires a material development effort.

\subsubsection{Borosilicate Glass-Basalt-Water Interactions}

As discussed in Section 2.6.6, borosilicate glass has been advanced as a leach-resistant, alternative waste form in the event that spent fuel is reprocessed. The main attributes of glass are: high waste loading; the ability to easily accommodate variations in waste stream composition; and the well-developed nature of vitrification technology. The main criticisms of glass surround its long-term stability and its potential for leaching at temperatures much above $100^{\circ} \mathrm{C}$. The following paragraphs will discuss preliminary data obtained from experiments reacting simulated waste, basalt, and water. The data indicate that disposal of vitrified waste requires a less-extensive barrier system than spent fuel.

2.9.3.1 Operations and Thermal Periods. In the previous section on spent fuel, the operations and thermal periods of repository history were discussed separately. The principal parametric difference between these periods is the prevailing oxygen fugacity, which affects the solubilities of polyvalent nuclides. This phenomenon is discussed at length in the previous section. It can be assumed that uranium, technetium, neptunium, plutonium, and americium will be much more soluble under the oxidizing conditions prevaiting during early repository history. Further, it can be assumed that once dissolved, these radionuclides are likely to precipitate after a short transport distance. In contrast, uranium, technetium, neptunium, plutonium, and americium will not be as soluble under the reducing conditions expected for later repository history. With this difference clarified, the operations and thermal periods of repository history will now be discussed as a single topic. 
At temperatures in the range of $200^{\circ}$ to $300^{\circ} \mathrm{C}$ (during operations and thermal periods), glass release of cesium, strontium, molybdenum (i.e., technetium), and uranium are above maximum permissible concentration (Table 2-90). These concentrations are fairly reproducible from one laboratory to the next. However, in the presence of basalt, the data from similar experiments appear to be in disagreement (Table 2-91). The disparity in results is probably the result of different experimental procedures. The earlier discussion of how the water:rock ratio influences $\mathrm{pH}$ (see Section 2.5.3.1) may provide a partial answer to these divergent experimental results.

TABLE 2-90. Compositions of Residual Solutions from Experimentsa Reacting Simulated PNL 76-68 Giass in Distilled Water at $300{ }^{\circ} \mathrm{C}$.

\begin{tabular}{c|c|c|c|c}
\hline \multicolumn{3}{|c|}{ Glass (alone) } & \multicolumn{2}{|c}{ Comparison to MPC } \\
\hline & $\mu \mathrm{g} / \mathrm{ml}$ & relative $\%$ & $\mu \mathrm{g} / \mathrm{mlb} \mathrm{MPC}$ & isotope \\
\hline $\mathrm{Rb}$ & 3 & 2 & .003 & ${ }^{87} \mathrm{Rb}$ \\
$\mathrm{CS}$ & 140 & 14 & $2 \times 10^{3} ; 3 \times 10^{8}$ & ${ }^{135} \mathrm{Cs} ;{ }^{137} \mathrm{Cs}$ \\
$\mathrm{Sr}$ & $\mathrm{ND}^{\mathrm{C}}$ & - & - & ${ }^{90} \mathrm{Sr}$ \\
$\mathrm{Mo}$ & 1,050 & 68 & $2 \times 10^{6}$ & ${ }^{99} \mathrm{TC}$ \\
$\mathrm{U}$ & 2.6 & .1 & $1 ; 25 ; 3 \times 10^{3}$ & $238_{\mathrm{U},}{ }^{236} \mathrm{U},{ }^{234} \mathrm{U}$ \\
$\mathrm{Ba}$ & 1 & .1 & & \\
$\mathrm{La}$ & $\mathrm{ND}$ & - & - & \\
$\mathrm{Nd}$ & ND & - & - & \\
$\mathrm{Zr}$ & ND & - & - & \\
$\mathrm{B}$ & & & & \\
\hline
\end{tabular}

a4 months duration; $10: 1$ water to solid ratio; pressure $=300$ bars. bRatio of solution composition to approximate maximum permissible concentration. Values greater than 1 indicate a potential hazard.

CNot detected by atomic absorption, atomic emission. dMo related to Tc maximum permissible concentration.

The solubility of glass is highly dependent on solution pH. Neutral solutions ( $\mathrm{pH}=6$ to 8 ) result in minimum solubilities while acid solutions ( $\mathrm{pH}=3$ to 4 ) show the greatest increases (10-to 100-fold). Basic solutions ( $\mathrm{pH}=10$ ) show moderate increases $(3$-fold) (Hill and Grimwood, 1978). The experiments conducted at Pacific Northwest 
TABLE 2-91. Leachabilitya of Simulated PNL 76-68

Glass Using Distilled Water and in the Presence of Basalt (Near $300^{\circ} \mathrm{C}$ ).

\begin{tabular}{|c|c|c|c|c|c|c|}
\hline & \multicolumn{3}{|c|}{$\begin{array}{l}\text { The Pennsylvania } \\
\text { State Universityb }\end{array}$} & \multicolumn{3}{|c|}{ Pacific Northwest Laboratory ${ }^{C}$} \\
\hline & Glass & $\begin{array}{l}\text { Glass \& } \\
\text { Basalt }\end{array}$ & Net Change & Glass & $\begin{array}{c}\text { Glass \& } \\
\text { Basalt }\end{array}$ & Net Change \\
\hline$R b$ & 12 & 17 & $+5 \%$ & 16 & .06 & -15.4 \\
\hline Cs & 14 & 20 & $+6 \%$ & 6 & .04 & -5.96 \\
\hline$s r$ & $N D^{d}$ & .4 & $+4 \%$ & .2 & .05 & -.15 \\
\hline B & 80 & 88 & $+8 \%$ & 100 & 5.9 & -94.1 \\
\hline Mo & 68 & 59 & $-9 \%$ & 49 & .05 & -48.95 \\
\hline U & - & - & - & .1 & .002 & -.998 \\
\hline Si & 2.3 & 1.3 & $-1 \%$ & 2.2 & .07 & -2.13 \\
\hline
\end{tabular}

aExperiments one month in duration: concentrations reported as relative percent oxide (grams in liquid/grams in original solid).

bwater:rock $=20: 1$.

CWater:rock $=1: 1$.

dNot determined. 
Laboratory utilized a water:rock ratio equal to 1:1 (Ross and Mende?, 1979). This procedure will result in a minimum pH depression and a slow, steady dissolution of the glass. The water is not rapidly flooded with dissolved solid thus allowing the basalt to react with the water and produce a visible decrease in the concentration of dissolved material. In contrast, investigators at The Pennsyivania State University utilized a water:rock ratio approximating 20:1. This procedure wi11 result in a substantial pH depression (perhaps as low as pH:4; Bischoff and Dickson, 1976) and in a rapid dissolution pulse. Because the solution is flooded with a large amount of dissolved material, extractive processes such as reaction and precipitation are overwhelmed and obscured. Thus, basalt seemingly produces an increase in waste-glass solubility.

Both The Pennsylvania State University and Pacific Northwest Laboratory data sets have application to repository modeling. Under normal, undisturbed conditions, the repository water:rock ratio is likely to be small $(\leq 1: 1)$. Thus, during expected thermal conditions, the basalt, or a basalt-rich backfill can be expected to efficiently remove dissolved waste from contaminated groundwater and achieve results similar to those described earlier for spent fuel. However, under a rapidiy flowing regime such as might occur from increases in rock permeability or thermal convection (or both), enhanced glass solubilities may overwhelm the ability of basalt to mitigate release of radionuclides. Thus, an optimized engineered barrier system for borosilicate glass should attempt to minimize groundwater access and provide a means for $\mathrm{pH}$ moderation.

The period of repository history when temperatures could potentially approach $300^{\circ} \mathrm{C}$ is relatively brief (or non-existent), and at temperatures below $200^{\circ} \mathrm{C}$ glass solubility is markedly decreased. Data from McCarthy and Others (1978c) indicate that total dissolved fission products plus uranium decreases from $1,152 \mathrm{ug} / \mathrm{ml}$ at $300^{\circ} \mathrm{C}$ to $410 \mathrm{\mu g} / \mathrm{ml}$ at $200^{\circ} \mathrm{C}$. The potential for release of some radionuclides (notably strontium, cesium, uranium) from the canister at levels above maximum permissible concentration remains. Although no data of reacting glass and basalt at $200^{\circ} \mathrm{C}$ are available, direct comparison of leaching results indicates that the potential hazard posed by glass burial is 
certainly not as great as for spent fuel. In fact, glass compares favorably to tailored ceramic, at least in the short term (see Section 2.6.1).

In surmary, elements with leachabilities known to be sufficient to require containment during the operations and thermal periods of 2 repository in basalt are uranium, cesium, strontium, rubidium, and molybdenum (i.e., technetium). It is likely that neptunium, plutonium, and americium also require containment. However, in contrast to spent fuel, iodine is virtually absent; thus, one of the most troublesome problems--the inability to efficiently react, sorb, or retard jodine migration-needs not be addressed. A successful engineered barrier system should provide physical containment of the waste at least until temperatures fall below $200^{\circ} \mathrm{C}$. A reactive backfill containing a 1 arge basalt component should surround the canister/overpack assemblage. An optimized system should prevent or slow influx and recharge of groundwater, perhaps through a swelling.clay. In addition, pH moderation (i.e., a buffer) should be provided in the space between the canister and overpack. One preliminary candidate material is $\mathrm{Al}\left(\mathrm{PO}_{4}\right)$. The observation that borosilicate glass is less soluble than simulated spent fuel leads to the conclusion that an engineered system for glass will be less extensive, hence less costly than a similar system for spent fuel.

2.9.3.2 Geologic Control. At low temperatures $\left(100^{\circ} \mathrm{C}\right.$ or less), present leach data indicate that borosilicate glass may be as resistant as the more costly supercalcine (Rusin and 0thers, 1979; Scheetz and others, 1979). The data upon which this conclusion is based is presented in Table 2.65. It must be remembered that these results were obtained from relatively short-duration (i.e., less than one year) experiments and it is nearly certain that the data do not represent steady-state conditions. However, Figure $2-47$ can be used to make qualitative predictions.

The distribution of component oxides in a borosilicate glass sphere after hydrothermal leaching is illustrated in Figure 2-47. The vertical axis is the ratio of component oxide to $\mathrm{SiO}_{2}$, thus providing a relative gauge of oxide leaching versus framework degradation. The horizontal axis is the unscaled distance from the center of the sphere, with the 
Laboratory utilized a water:rock ratio equal to $1: 1$ (Ross and Mende?, 1979). This procedure will result in a minimum pH depression and a slow, steady dissolution of the glass. The water is not rapidly flooded with dissolved solid thus allowing the basalt to react with the water and produce a visible decrease in the concentration of dissolved material. In contrast, investigators at The Pennsylvania State University utilized a water: rock ratio approximating 20:1. This procedure will result in a substantial pH depression (perhaps as low as pH:4; Bischoff and Dickson, 1976) and in a rapid dissolution pulse. Because the solution is flooded with a large amount of dissolved material, extractive processes such as reaction and precipitation are overwhelmed and obscured. Thus, basalt seemingly produces an increase in waste-glass solubility.

Both The Pennsylvania State University and Pacific Northwest Laboratory data sets have application to repository modeling. Under normal, undisturbed conditions, the repository water:rock ratio is likely to be smal1 $(\leq 1: 1)$. Thus, during expected thermal conditions, the basalt, or a basalt-rich backfill can be expected to efficientiy remove dissolved waste from contaminated groundwater and achieve results similar to those described earlier for spent fuel. However, under a rapidiy flowing regime such as might occur from increases in rock permeability or thermal convection (or both), enhanced glass solubilities may overwhelm the ability of basalt to mitigate release of radionuclides. Thus, an optimized engineered barrier system for borosilicate glass should attempt to minimize groundwater access and provide a means for $\mathrm{pH}$ moderation.

The period of repository history when temperatures could potentially approach $300^{\circ} \mathrm{C}$ is relatively brief (or non-existent), and at temperatures below $200^{\circ} \mathrm{C}$ glass solubility is markedly decreased. Data from McCarthy and others (1978c) indicate that total dissolved fission products plus uranium decreases from $1,152 \mathrm{ug} / \mathrm{ml}$ at $300^{\circ} \mathrm{C}$ to $410 \mathrm{vg} / \mathrm{ml}$ at $200^{\circ} \mathrm{C}$. The potential for release of some radionuclides (notably strontium, cesium, uranium) from the canister at levels above maximum permissible concentration remains. Although no data of reacting $\mathrm{glass}$ and basait at $200^{\circ} \mathrm{C}$ are available, direct comparison of leaching results indicates that the potential hazard posed by glass burial is 
certainly not as great as for spent fuel. In fact, glass compares favorably to tailored ceramic, at least in the short term (see Section 2.6.1).

In summary, elements with leachabilities known to be sufficient to require containment during the operations and thermal periods of a repository in basalt are uranium, cesium, strontium, rubidium, and molybdenum (i.e., technetium). It is likely that neptunium, plutonium, and americium also require containment. However, in contrast to spent fuel, iodine is virtually absent; thus, one of the most troublesome problems--the inability to efficiently react, sorb, or retard iodine migration-needs not be addressed. A successful engineered barrier system should provide physical containment of the waste at least until temperatures fall below $200^{\circ} \mathrm{C}$. A reactive backfill containing a 1 arge basalt component should surround the canister/overpack assemblage. An optimized system should prevent or slow influx and recharge of groundwater, perhaps through a swelling.clay. In addition, pH moderation (i.e., a buffer) should be provided in the space between the canister and overpack. One preliminary candidate material is $\mathrm{Al}\left(\mathrm{PO}_{4}\right)$. The observation that borosilicate glass is less soluble than simulated spent fuel leads to the conclusion that an engineered system for glass will be less extensive, hence less costly than a similar system for spent fuel.

2.9.3.2 Geologic Control. At low temperatures $\left(100^{\circ} \mathrm{C}\right.$ or less), present leach data indicate that borosilicate glass may be as resistant as the more costly supercalcine (Rusin and Others, 1979; Scheetz and others, 1979). The data upon which this conclusion is based is presented in Table 2.65. It must be remembered that these results were obtained from relatively short-duration (i.e., less than one year) experiments and it is nearly certain that the data do not represent steady-state conditions. However, Figure $2-47$ can be used to make qualitative predictions.

The distribution of component oxides in a borosilicate glass sphere after hydrothermal leaching is illustrated in Figure 2-47. The vertical axis is the ratio of component oxide to $\mathrm{SiO}_{2}$, thus providing a relative gauge of oxide leaching versus framework degradation. The horizontal axis is the unscaled distance from the center of the sphere, with the 
origin representing the center. Cesium and Group II elements are shown to be dissolved at the same rate as silica. Thus, equilibrium compositions can be expected to contain greater amounts of strontium, cesium, and calcium (and radium) than short-lived experiments might indicate. Furthermore, congruency is a useful model for glass dissolution with respect to these radionuclides.

In contrast, uranium and molybdenum (i.e., technetium) are more readily dissolved than the framework. This result indicates that the mechanisms controlling dissolution of these radionuclides are their inherent solubilities and the diffusivity of water in glass. In contrast to Group II elements, congruent dissolution (relative to $\mathrm{SiO}_{2}$ ) is not a good model for these radionuclides. However, offsetting the seeming leachability of uranium and molybdenum in borosilicate glass is the capacity of basalt to extract these radionuclides from solution.

Al1 reliable experiments reacting borosilicate glass, water, and basalt have produced $\mathrm{UO}_{2}$ and powellite $\left(\mathrm{CaMOO}_{4}\right)$ as precipitates.

At $100^{\circ} \mathrm{C}$ there is no evidence of glass reaction with basalt detectable by $X$-ray analysis. However, experiments using highly soluble cesium compounds $\left(\mathrm{CsOH}, \mathrm{Cs}_{2} \mathrm{MOO}_{4}\right)$, water, and basalt produce pollucite at $100^{\circ} \mathrm{C}$ (Komarneni and others, 1980). Therefore, one may conclude that reaction between dissolved components of glass and basalt may take place at $100^{\circ} \mathrm{C}$, but the lack of dissolved material and (perhaps) sluggish reaction rates combine to yield an amount of product that is below $X$-ray detection limits ( $10 \%$ volume).

In any event, concentrations of rubidium, strontium, and uranium from residual solutions of preliminary experiments indicate that these elements may be released from the waste package at rates that are not hazardous once repository temperatures fall below $100^{\circ} \mathrm{C}$ (Table 2-92). Cesium and molybdenum (i.e., technetium) concentrations remain above maximum permissible concentration. This result differs from the results of similar experiments reacting spent fuel, basalt, and water. It seems likely that detectable amounts of cesium remained in solution in the glass experiments either because equilibrium was not obtained or because there was an insufficient amount of basalt with which to react. These 
contradictory results and the required interpretations must be confirmed by well-controlled experiments in which steady-state solution compositions have been reached.

TABLE 2-92. Compositions of Residual Solutions from Experiments* Reacting Simulated PNL 76-68 Glass in Distilled Water at $100^{\circ} \mathrm{C}$.

\begin{tabular}{|c|c|c|c|}
\hline Solution & $\begin{array}{l}\text { Glass } \\
\mu \mathrm{g} / \mathrm{ml}\end{array}$ & $\begin{array}{c}\text { Glass \& Basalt } \\
\mu \mathrm{g} / \mathrm{m}]\end{array}$ & $\begin{array}{c}\text { Comparison with MPC } \\
\text { Glass \& Basalt \& }(\mu \mathrm{g} / \mathrm{ml}) \\
M P C(\mu \mathrm{g} / \mathrm{ml})\end{array}$ \\
\hline $\mathrm{Rb}$ & $\mathrm{ND}^{* *}$ & ND & $=$ \\
\hline $\mathrm{Cs}$ & 6 & 8 & $100^{135} \mathrm{Cs} ; 2.3 \times 10^{6177} \mathrm{Cs}$ \\
\hline$S r$ & 1 & ND & - \\
\hline Mo & 40 & 20 & 1,000 \\
\hline U & 1.6 & ND & - \\
\hline $\mathrm{Ba}$ & ND & ND & - \\
\hline La & ND & ND & $=$ \\
\hline Nd & ND & ND & - \\
\hline $\mathrm{Zr}$ & ND & ND & - \\
\hline
\end{tabular}

* 300 bars at 4 months duration.

**Not detected by atomic absorption, atomic emission, or fluorometry.

2.9.3.3 Sumnary. Borosilicate glass is less leachable than simulated spent fuel and will require a less-extensive, hence less-expensive, engineered barrier system. Preliminary evidence indicates that the leachability of unprotected glass exceeds maximum permissible concentration at temperatures in excess of $200^{\circ} \mathrm{C}$. Radionuclides that are known to represent potential hazards during the operations and thermal periods include uranium, cesium, strontium, rubidium, and molybdenum (i.e., technetium). It is likely that neptunium, plutonium, and americium also represent potential hazards. However, it is possible that none of the transuranic elements will be released in hazardous amounts if a water-retarding backfill containing abundant basalt encloses the canister/overpack assemblage.

If repository temperatures are below $100^{\circ} \mathrm{C}$, preliminary evidence indicates a low probability for hazardous release of uranium, cesium, strontium, rubidium, and molybdenum (i.e., technetium), as long as a 
basalt-rich backfill is provided. This result raises the possibility that a successful engineered barrier system for glass may require only a reliable canister plus a basalt backfill.

\subsubsection{Supercalcine-Basalt-Water Interactions}

As discussed in Section 2.6, supercalcine ceramic has been advanced as perhaps the most leach resistant alternative waste form for waste from unreprocessed spent fuel (MCCarthy, 1978b). The main attributes of supercalcine are its predominantly crystalline habit, resistance to leaching at high $\left(300^{\circ} \mathrm{C}\right)$ temperatures, and high $(70 \%)$ waste loading. The main criticisms of supercalcine are its inflexibility to changes in waste stream composition, fabrication expense, and the complexity of the fabrication process. The following paragraphs will discuss preliminary data obtained from experiments reacting the simulated waste, basalt, and water. The data indicate that disposal of cormercial nuclear waste as a tailored ceramic may require a less-extensive barrier system than either spent fuel or borosilicate glass.

2.9.4.1 Operations and Thermal Periods. The operations and thermal periods will again be discussed as a single topic. A more detailed discussion of the inherent differences and resulting consequences of container failure during these periods is found in section 2.9.2.

In the presence of basalt, over the temperature range of $200^{\circ}$ to $300^{\circ} \mathrm{C}$, residual solutions from preliminary experiments contain cesium, rubidium, molybdenum (i.e., technetium) (Table 2-93). Although at $300^{\circ} \mathrm{C}$ the cesium and strontium concentrations represent less than $0.3 \%$ of the total cesium and strontium contained by the supercalcine, residual solution concentrations are above maximum permissible concentration. As with glass-basalt experiments, these results may imply incomplete reaction or insufficient basalt reactant. Given the results of spent fuel experiments, the reactive nature of cesium and strontium and the 1 arge concentration of cesium and strontium in supercalcine, it seems likely that a greater quantity of basalt-rich backfill will eliminate cesium and strontium from solution. Alternatively, given the evidence for low-temperature reaction (Komarneni and 0thers, 1980), the country rock may be relied upon to perform this service. 
TABLE 2-93. Compositions of Residual Solutions from Experimentsa Reacting Supercalcine ${ }^{b}$ and Basalt.

Temperature $=300^{\circ} \mathrm{C}$

\begin{tabular}{|c|c|c|c|c|c|}
\hline & \multicolumn{2}{|c|}{$\begin{array}{l}\text { Supercalcine } \\
\mu \mathrm{g} / \mathrm{ml} \quad \text { Relative } \%\end{array}$} & \multicolumn{2}{|c|}{$\begin{array}{l}\text { Supercalcine \& Basalt } \\
\mu \mathrm{g} / \mathrm{ml} \quad \text { Relative } \%\end{array}$} & $\begin{array}{c}\text { Comparison with MPC } \\
\mathrm{SPC}-4 \text { \& Basalt }(\mu \mathrm{g} / \mathrm{ml}) \\
\mathrm{MPC}(\mu \mathrm{g} / \mathrm{ml})\end{array}$ \\
\hline $\mathrm{Rb}$ & 25 & 4.6 & $N D^{C}$ & - & - \\
\hline Cs & 25 & 0.6 & 9 & 0.4 & $100^{135} \mathrm{Cs} ; 2.3 \times 10^{613 /} \mathrm{Cs}$ \\
\hline Sr & 2.3 & 0.06 & - & - & - \\
\hline Mo & 370 & 6.8 & 13 & 0.5 & 650 \\
\hline$u_{b}$ & - & - & - & - & - \\
\hline La & ND & - & ND & - & - \\
\hline Nd & ND & - & ND & - & - \\
\hline \multicolumn{6}{|c|}{ Temperature $=200^{\circ} \mathrm{C}$} \\
\hline & \multicolumn{2}{|c|}{$\begin{array}{l}\text { Supercalcine } \\
\mu \mathrm{g} / \mathrm{ml} \quad \text { Relative \% }\end{array}$} & \multicolumn{2}{|c|}{$\begin{array}{l}\text { Supercalcine \& Basalt } \\
\mu \mathrm{g} / \mathrm{ml} \quad \text { Relative } \%\end{array}$} & $\begin{array}{c}\text { Comparison with MPC } \\
\text { SPC-4 \& Basalt }(\mu \mathrm{g} / \mathrm{mi}) \\
M P C(\mu \mathrm{g} / \mathrm{ml})\end{array}$ \\
\hline $\mathrm{Rb}$ & 30 & 0.5 & 30 & 0.6 & $0.03^{87} \mathrm{Rb}$ \\
\hline Cs & 10 & 0.2 & 10 & 0.2 & $125^{135} \mathrm{cs} ; 2.3 \times 10^{6137} \mathrm{cs}$ \\
\hline$S r$ & 0.5 & .01 & 0.1 & 0.1 & $3.3 \times 10^{7}$ \\
\hline Mo & 83 & 1.5 & 100 & 1.8 & $5,000^{99} \mathrm{TC}$ \\
\hline$u^{b}$ & - & - & - & - & - \\
\hline La & ND & - & ND & - & - \\
\hline $\mathrm{Nd}$ & ND & - & ND & - & - \\
\hline
\end{tabular}

a300 bars pressure; 4 months duration.

b Formulation SPC-4.

CNot detected by atomic absorption, atomic emission or fluorometry. 
The high-temperature experimental results indicate that release of radionuclides from the waste package below maximum permissible concentration limits may be achievable if supercalcine is:

- Physically isolated from groundwater until oxygen fucacity is controlled by basalt equilibria

- Surrounded by a basalt-rich backfill.

The time required to re-establish basalt-oxygen equilibria is uncertain, but may be as short as 50 to 100 years. If this proves to be true, and if the preliminary data prove reliable, then an engineered barrier system for supercalcine may consist of only a lightweight canister and a basalt-rich backfill. The extent of the required backfill remains to be determined, but since supercalcine appears to be less leachable than glass, it is likely that a system for supercalcine would be more compact. 2.9.4.2 Geologic Control. At $100^{\circ} \mathrm{C}$, preliminary experiments indicate that leaching of supercalcine is small (even without basalt present). When crushed basalt is added to the system, concentration of cesium, rubidium, strontium, barium, molybdenum (i.e., technetium), lanthanum, or neodymium (i.e., actinides) in residual solutions are 2.11 well below limits set by maximum permissible concentration (Table 2-94). This result suggests that a system of supercalcine and basalt-rich backfill may be 217 that is required to prevent release of radionuclides to the biosphere.

2.9.4.3 Summary. Supercalcine ceramic is one alternative waste form that may facilitate safe storage of nuclear waste in the event that spent fuel is reprocessed. Preliminary data indicate that a backfill with a large component of basalt may limit release of toxic materials below maximum permissible concentration over the entire temperature range of the repository.

However, it is likely that supercalcine must be physically isolated from groundwater while the oxidizing conditions prevait. This is because the solubility of polyvalent nuclides (e.g., uranium, plutonium, neptunium, americium, technetium) will probably be unacceptably high and result in enhanced corrosion of the crystalline matrix. In addition, 
TABLE 2-94. Composition of Residual Solutions Reacting from Experiments ${ }^{a}$ on Supercalcine a and Distilled Water at $100^{\circ} \mathrm{C}, 300$ Bars.

\begin{tabular}{|c|c|c|c|c|c|}
\hline & \multicolumn{2}{|c|}{ Supercalcine } & \multicolumn{2}{|c|}{ Supercalcine \& Basalt } & \multirow{2}{*}{$\begin{array}{l}\text { Comparison with MPC } \\
\text { Supercalcine \& Basalt }(\mu \mathrm{g} / \mathrm{ml})\end{array}$} \\
\hline & $\mu \mathrm{g} / \mathrm{m}]$ & Relative \% & $\mu \mathrm{g} / \mathrm{ml}$ & Relative \% & \\
\hline $\mathrm{Rb}$ & $N^{C}$ & - & ND & - & $\operatorname{MPC}(\mu \mathrm{g} / \mathrm{m} 7)$ \\
\hline $\mathrm{Cs}$ & ND & - & ND & - & - \\
\hline$S r$ & ND & - & ND & - & - \\
\hline Mo & 20 & 0.1 & ND & - & - \\
\hline$u^{b}$ & - & - & - & - & - \\
\hline La & ND & - & ND & - & - \\
\hline Nd & ND & - & ND & - & - \\
\hline
\end{tabular}

a4 months duration.

bSPC-2 formulation.

CNone detected by atomic absorption, atomic emission or fluorometry. 
supercalcine is an inflexible waste form that may require a large fabrication expense. Future experiments witl precisely define expected performance levels and clarify the cost/benefits issue.

\subsubsection{Summary of Waste-Rock-Water Interactions and Implications for Siting a Repository in Basalt}

The following summary is based on the data presented in Sections 2.6 and 2.9. All conclusions are based on preliminary data and must be considered tentative. Careful quantitative experiments are presently under way and will permit more definitive statements to be made. Design requirements as presently conceived for an engineered barrier system are summarized for each waste form in Table 2-95. To date, there is no evidence that an acceptable waste package cannot be designed for any of the waste forms tested. However, reference to Table $2-95$ wil1 reveal that the systems may differ substantially in size and cost.

2.9.5.1 Spent Fuel/Basalt/Water Interactions. Spent fuel is the current waste form for the National Waste Terminal Storage Program. It is composed primarily of uranium (i.e., $295 \%$ ) with the remainder being fission products. Preliminary data indicate that cesium, strontium, and rubidium are readily extracted from spent fuel by heated aqueous solutions. In addition, spent fuel contains ${ }^{129} \mathrm{I}$, which is non-reactive and mobile in hydrogeologic systems.

However, the bulk of spent fuel is either relatively insoluble or highly reactive with basalt. Cesium, molybdenum, and rubidium, which are totally leached from simulated spent fuel, react with basalt to yield pollucite (nominally $\mathrm{CsA} 1 \mathrm{Si}_{2} \mathrm{O}_{6} \cdot \mathrm{nH}_{2} \mathrm{O}$ ) and powellite (nominally $\mathrm{CaMOO}_{4}$ ). Residual concentration of cesium, rubidium, and molybdenum are below detection limits after reaction with basalt. At temperatures below $100^{\circ} \mathrm{C}$, uranium (and by inference, transuranics) concentrations are limited to less than maximum permissible concentration. This result implies that if dissolved, uranium could not be transported far from the repository. However, the presence of $\mathrm{CO}_{3}^{-2}$ or $\mathrm{F}^{-}$greatly increases $\mathrm{vO}_{2}$ solubility. 
TABLE 2-95. Likely Engineered Barrier Design Requirements for Several Waste Forms.

\begin{tabular}{|c|c|c|c|c|}
\hline Waste Form & $\begin{array}{c}\text { Major } \\
\text { Advantages }\end{array}$ & $\begin{array}{c}\text { Major } \\
\text { Disadvantages }\end{array}$ & $\begin{array}{l}\text { Likely Barrier } \\
\text { Components Required }\end{array}$ & \\
\hline Spent Fue 1 & $\begin{array}{l}100 \% \text { waste loading } \\
\text { No fabrication expense }\end{array}$ & $\begin{array}{l}\text { Contains I, Cs, Rb, Mo, } \\
\text { Sr very leachable }\end{array}$ & $\begin{array}{l}\text { Special features to contain }{ }^{129} \text { I, } \\
\text { high integrity canister/overpack, } \\
\mathrm{pH} \& \mathrm{fO}_{2} \text { buffer, extensive backfill }\end{array}$ & \\
\hline Borosilicate Glass & $\begin{array}{l}\text { Does not contain I } \\
\text { Technologically feasible }\end{array}$ & $\begin{array}{l}\text { Questionable long-term } \\
\text { stability prone to leaching } \\
\text { at temperatures above } 100^{\circ} \mathrm{C} \\
\text { (Cs, Mo, Rb) }\end{array}$ & $\begin{array}{l}\text { Canister/overpack (to } 1000 \mathrm{C} \text { ) } \mathrm{pH} \\
\text { buffer, backfill, f0 } \mathrm{fO}_{2} \text { buffer(?) }\end{array}$ & 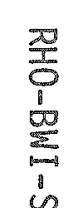 \\
\hline Supercalcine & $\begin{array}{l}\text { Leach resistance likely } \\
\text { Long term stability }\end{array}$ & $\begin{array}{l}\text { Complicated \& inflexible } \\
\text { fabrication process }\end{array}$ & $\begin{array}{l}\text { Canister/overpack (temperature } \\
1000_{-2000} \mathrm{C} \text { ) backfi } 11 \mathrm{pH} \text { and/or } \\
\mathrm{fO}_{2} \text { buffer (?) }\end{array}$ & $\sqrt{4}$ \\
\hline
\end{tabular}


An engineered barrier design for spent fuel must recognize the inherent difficulty of containing or immobilizing ${ }^{129}$ I. It seems most likely that heavy reliance must be placed on long-term physical isolation. Thus, it is likely that a high-integrity canister/overpack is required. Alternatively, a development effort to generate a backfill (or filler) component that will permanently immobilize ${ }^{129}$ I is required. The backfill should also contain a large component of basalt, feldspar, or similar material to remove dissolved cesium, rubidium, and strontium from contaminated groundwater. The mass of the basalt should approximately equal the mass of the spent fuel that might be leached.

\subsubsection{Borosilicate Glass/Basalt/Water Interactions. Borosilicate} glass is a waste form that might be fabricated if spent fuel is reprocessed. The extractive processes employed during reprocessing lead to wastes that are depleted in uranium and enriched in fission products compared to spent fuel. These compositions may be readily incorporated as a vitrified monolith using proven technology. The resulting product has been advanced as a relatively leach-resistant waste form, as long as repository temperatures are maintained below $100^{\circ} \mathrm{C}$.

On a relative basis, glass is less leachable than spent fuel over the temperature range $100^{\circ}$ to $300^{\circ} \mathrm{C}$. Thus, the total size of a system designed to isolate waste using a glass waste form is likely to be smaller than one designed for spent fuel.

Vitrified waste is essentially devoid of iodine. Therefore, the requirement for reliance on physical containment is not as great for glass waste packages as it is for spent fuel packages. The most soluble elements contained by glass appear to be cesium and molybdenum (i.e., technetium). However, these elements are known to be reactive with basalt and may be immobilized by using a basalt-rich backfill. However, present data are insufficient to specify the mass of basalt required.

Glass solubility is highly $\mathrm{pH}$ dependent. Since groundwater $\mathrm{pH}$ is largely a function of flow rate, steps should be taken to create stagnant conditions in the waste package environment. This may be accomplished by encircling the waste package in a water-retarding material such as swelling clay. 
At low temperatures $\left(\leq 100^{\circ} \mathrm{C}\right)$, borosilicate glass may be as leach resistant as tailored ceramics. However, this comparison is based on the results of short duration (<1 year) experiments. These same experiments indicate that the glass framework is slowly disintegrating. The implications for long-term performance are presently unclear, but preliminary data indicate that Group II elements (e.g., strontium, radium) are likely to be released. Additional low-temperature experimentation is required to evaluate the severity of the problem.

An engineered barrier system designed for borosilicate glass must include a canister/overpack system that wi 11 remain operative unit 1 temperatures approach $100^{\circ} \mathrm{C}$. Emplacement of a buffer material that will moderate $\mathrm{pH}$ is desirable. The buffer should be placed between the canister and overpack. A backfill rich in basalt, feldspar, or similar material should be placed around the canister/overpack assemblage. Surrounding this reactive backfill, it is advisable to place a waterretarding barrier, probably clay. The absolute amounts of these barriers are yet to be determined.

\subsubsection{Supercalcine/Basa1t/Water Interactions. Supercalcine is an} alternative waste form that might be fabricated in the event that spent fuel is reprocessed. However, variations in waste stream composition complicate the fabrication process.

As with borosilicate glass, supercalcine is virtually devoid of iodine, depleted in uranium, and enriched in fission products (relative to spent fuel). Preliminary evidence indicates that supercalcine ceramic is the most leach resistant of the waste forms tested over the range $100^{\circ}$ to $300^{\circ} \mathrm{C}$. As with glass, cesium, rubidium, and molybdenum (i.e., technetium) are the most soluble elements contained in supercalcine. Thus, a basalt-rich backfill is again recommended. However, given the leach resistance exhibited by supercalcine, dependence on physical isolation of the waste is likely to be less than for either glass or spent fuel. In fact, at some temperature between $100^{\circ}$ and $200^{\circ} \mathrm{C}$ supercalcine (SPC-2) ceases to be leached in detectable amounts. 
An engineered barrier system designed for spent fuel must include a canister/overpack assemblage that wi11 operate until temperatures fall somewhere below $200^{\circ} \mathrm{C}$. A reactive backfill containing a significant basalt component is advisable to mitigate the results of premature container failure. However, at this point it has not been determined how much backfill is required. Similarly, the need for a $\mathrm{pH}$ or $\mathrm{fO}_{2}$ buffer is of uncertain importance. However, it seems likely that an engineered barrier system designed for supercalcine is likely to require less space than one designed for borosilicate glass or spent fuel.

\subsubsection{Implications for Repository Siting in Basalt. While waste} package designs are necessarily specific to the waste form (they are designed to isolate), repository characteristics are of a more general nature and apply to all of the waste forms discussed above.

With geologic storage, the main transport medium for radioactive waste dispersal is groundwater. Therefore, it is natural that heavily fractured or otherwise porous horizons should be avoided. The mineralogy and chemistry of horizons should be considered. An ideal horizon would contain a large amount of glass because glass is the most reactive, therefore, most extractive phase in the basait. Other favorable phases are apatite (or phosphates in general) and magnetite. (Apatite is a known host for uranium; dissolved phosphates will precipitate transuranics: magnetite irreversibly sorbs $\mathrm{U}^{+6}, \mathrm{Pu}^{+6}$ and probablv $\mathrm{Am}^{+6}, \mathrm{ND}^{+6}$.)

Horizons associated with groundwater should naturally be avoided. However, it is realized that an aquifer must exist at some distance above or below the repository horizon. It is advisable that distance be maximized from groundwaters rich in $\mathrm{CO}_{3}^{-2}$ or $\mathrm{F}^{-}$. These complexing agents may increase uranium (and by inference neptunium, plutonium, and americium) solubilities by as much as 6 to 10 orders of magnitude.

\subsection{SORPTION STUDIES}

\subsubsection{Introduction}

The most likely mechanism for transport of nongaseous radionuclides to the biosphere is dissolution of the waste form and transport of the fission products and actinides in groundwater. Migration of the dissolved 
radionuclides will be retarded by adsorption on the overpack, backfil1, basalt, secondary minerals, or sediments which contact the contaminated groundwater. The most useful measure of the ability of the geologic materials to retard radionuclide migration is the distribution ratio $\left(K_{d}\right)$, which is defined as the ratio of the activity sorbed on the solid to that in solution. These ratios may not necessarily be equilibrium values since true equilibrium will not be attained in most laboratory experiments. Values of $k_{d}$ thus developed along with other relevant parameters (permeability, leach rate, radioactive decay, etc.) will be used to model radionuclide transport.

The specific objective of this work is to obtain distribution ratios between groundwaters and each of the geologic or engineered materials in or near a repository in basalt for radionuclides in spent fuel and processed waste form. Geologic materials include fresh basalt, secondary minerals from the Grande Ronde and upper basalt layers, interbed materials between basalt flows, Ringold sediments, and glaciofluvial sediments. Engineered materials include the canister, overpack, and backfil1.

The distribution ratios of radionuclides at trace concentrations in a geologic environment are controlled by a number of variables. Several of these are difficult to control in laboratory experiments. Because of these difficulties, $k_{d}$ values that are relevant to radionuclide migration in basalt formations and that are reproducible are not abundant in the literature. Variables affecting $K_{d}$ values that have been identified thus far include the following:

- Composition of the solid phase (elemental composition, phase composition)

- Physical characteristics of the solid phase (surface area, particle size, porosity)

- Chemical characteristics of the solid phase (cation and anion exchange capacity, solubility, hydrolysis, and other reactions with liquid phase, sorption isotherms)

- Composition of the liquid phase (cation and anion concentrations, pH, Eh, colloid content)

- Identity, chemical species, and concentration of the radionuclide

- Time 
- Temperature and pressure

- Radiation.

Each of these variables must be adjusted in the laboratory to simulate as closely as possible the conditions present in the groundwater pathway from the waste form to the biosphere.

In addition to providing essential information for modeling radionuclide migration, these data will be used to determine the needs and priorities for development of engineered barriers for specific radionuciides. Backfill materials will be designed to retard migration of radionuclides that are determined to be mobile in the geologic environment. Sorption experiments testing a variety of materials will be required to develop an optimum multibarrier system.

\subsubsection{Measurement Methods}

A11 variations of Taboratory sorption measurements can be classified as either closed (batch) or open (flow-through) experiments. The particular method used depends on the kind of information desired and the type of geologic material used in the experiment. For example, flowthrough techniques may not be practical when the permeability of the geologic material is very low, as in dense basalt, or when equilibrium is very slowly achieved.

There are many experimental designs available for $k_{d}$ measurements. However, the data derived from these experiments cannot always be applied. to actual conditions in or near a deep geologic repository. This is because $K_{d}$ 's are influenced by a number of experimental parameters, many of which are not we11 understood and/or are difficult to control. An excellent example of the difficulties encountered in obtaining reproducible sorption data was recently reported (Relyea and Serne, 1979). The results of batch $K_{d}$ measurements by nine different laboratories using identical rock samples and solutions were reported. A common experimental procedure was prescribed which was to be carefulty followed by each laboratory. Measured $k_{d}$ values varied over three orders of magnitude in some cases. Results for sorption of cesium, strontium, and plutonium on basalt from a synthetic basalt groundwater are shown in Table 2-96. 
TABLE 2-96. Comparison of $K_{d}$ Values Obtained by Nine Laboratories for Identical Controlled Experiments.

\begin{tabular}{c|c|c|c}
\hline \multirow{2}{*}{ Laboratory } & \multicolumn{3}{|c}{$K_{d, m i / g}$} \\
\cline { 2 - 4 } & Cesium & Strontium & Plutonium \\
\hline A & $401 \pm 21$ & $68 \pm 17$ & $8.8 \pm 3.4$ \\
B & $31 \pm 2$ & $41 \pm 6$ & $1,000 \pm 590$ \\
C & $265 \pm 4$ & $81 \pm 1$ & $13,000 \pm 8,000$ \\
D & $296 \pm 10$ & $55 \pm 2$ & $30 \pm 26$ \\
E & $290 \pm 70$ & $45 \pm 1$ & $580 \pm 12$ \\
F & $380 \pm 5$ & $89 \pm 5$ & $592 \pm 134$ \\
G & $453 \pm 12$ & $93 \pm 6$ & $312 \pm 66$ \\
H & $380 \pm 70$ & $92 \pm 3$ & $200 \pm 170$ \\
I & $255 \pm 7$ & $73 \pm 4$ & $89 \pm 17$ \\
\hline
\end{tabular}

The large differences in $k_{d}$ values were attributed to several uncontrolled parameters; method of tracer addition, solution/rock ratio, initial tracer concentration, solid-solution separation method, sample containers, and temperature. Therefore, in addition to the chemical and physical parameters which affect sorption, experimental technique can have a large effect on $k_{d}$ values. Several commonly used variations in experimental technique and their effects on $k_{d}$ measurement are given in Table 2-97.

2.10.2.1 High Temperature-Pressure Apparatus. High temperature $\left(>100^{\circ} \mathrm{C}\right)$ batch equilibration $K_{d}$ measurements are made using high-pressure vessels. Attempts have been made (Ames and McGarrah, 1979a) to measure radionuclide sorption on basalt using 300-ml capacity pressure vesseis made from Inconel 600. Samples of solution were taken at temperature and pressure with an Inconel sample line that extended below the liquid level in the vessel. 
TABLE 2-97. Effects of Various Procedures on $\mathrm{K}_{\mathrm{d}}$ Measurement.

\begin{tabular}{|c|c|}
\hline Procedural Variation & Effect on $k_{d}$ Measurement \\
\hline $\begin{array}{l}\text { Addition of tracers: } \\
\text { in solution } \\
\text { dry. }\end{array}$ & $\begin{array}{l}\text { Tracer solution may alter ground- } \\
\text { water composition. Dry tracer } \\
\text { compound will have minimum effect } \\
\text { on groundwater composition }\end{array}$ \\
\hline $\begin{array}{l}\text { Filtration of spiked ground-- } \\
\text { water }\end{array}$ & $\begin{array}{l}\text { Filtration will eliminate any } \\
\text { precipitated tracer (i.e.g } \\
\text { Pu(OH) }\end{array}$ \\
\hline $\begin{array}{l}\text { Pre-equilibration of ground- } \\
\text { water with geologic material }\end{array}$ & $\begin{array}{l}\text { Avoids changes in groundwater } \\
\text { composition due to sorption of } \\
\text { macrocomponents }\end{array}$ \\
\hline $\begin{array}{l}\text { Equilibration in various } \\
\text { containers }\end{array}$ & $\begin{array}{l}\text { Tracers sorb more strongly onto } \\
\text { some container materials than } \\
\text { others }\end{array}$ \\
\hline $\begin{array}{l}\text { Crushing and sieving of } \\
\text { the geologic material }\end{array}$ & $\begin{array}{l}\text { May change the surface area and } \\
\text { thus, the number of sorption sites }\end{array}$ \\
\hline $\begin{array}{l}\text { Solid-liquid separation } \\
\text { after equilibration: } \\
\text { centrifugation } \\
\text { filtration } \\
\text { ultrafiltration. }\end{array}$ & $\begin{array}{l}\text { May leave colloids in solution. } \\
\text { May leave colloids in solutions } \\
\text { and sorb tracer on filter } \\
\text { May sorb tracer on filter }\end{array}$ \\
\hline $\begin{array}{l}\text { Equilibration of various } \\
\text { tracer/solution/solid ratios }\end{array}$ & $\begin{array}{l}\text { If sorption isotherm is non- } \\
\text { linear, these ratios will affect } \\
K_{d}\end{array}$ \\
\hline $\begin{array}{l}\text { Measurement of container } \\
\text { wall sorption }\end{array}$ & $\begin{array}{l}\text { Correction may be important for } \\
\text { radionuclides which tend to } \\
\text { precipitate }\end{array}$ \\
\hline Agitation of the mixtures & $\begin{array}{l}\text { Vigorous agitation may produce } \\
\text { fines due to abrasion of solid } \\
\text { surfaces }\end{array}$ \\
\hline $\begin{array}{l}\text { Wet sieving of crushed geologic } \\
\text { material }\end{array}$ & $\begin{array}{l}\text { Removal of fines will reduce sur- } \\
\text { face area }\end{array}$ \\
\hline
\end{tabular}


Some vessels were lined with machined Teflon and others were used uniined. The liner reduced adsorption of strontium, cesium, iodine, and selenium on vessel walls at $150^{\circ} \mathrm{C}$, but had little effect on plutonium adsorption. Essentially all of the plutonium was sorbed on the vessel wal1s.

The necessity of using pressure vessels for sorption studies at elevated temperatures presents some special experimental problems in addition to wall adsorption of the tracer. Sampling the hot solution can lead to serious errors due to adsorption on sampling lines, precipitation of saturated solutes during cooling, and vaporization of solution components. Stirring is more difficult since either the mixture vessel must be stirred using a shaft which penetrates the vessel through a rotary seal (which usually leaks), or the entire vessel and furnace must be rocked or shaken. Separation of the solid and liquid phases is difficult since this must be done when the mixture is at the equilibration temperature. Consequently, there are little data in the literature on sorption of trace ions from solutions on solids at elevated temperature.

2.10.2.2 Flow-Through Pressure Vessels. In addition to the high temperature batch $K_{d}$ measurements, flow-through experiments at elevated temperatures are required. These experiments will simulate actual conditions near the repository more closely than will the static experiments. Since temperatures near the repository will of ten exceed $100^{\circ} \mathrm{C}$, pressure vessels will be required for these experiments. The apparatus used for such experiments must meet the following requirements:

- A constant temperature and pressure at the reaction zone of the apparatus

- A constant flow rate through the reaction zone

- A maximum temperature of $300^{\circ} \mathrm{C}$ and maximum pressure of 4,000 psig

- Filtration of eluate from the reaction zone

- Sampling of the eluate during removal at the temperature of the reaction zone

- Minimum radionuclide sorption on apparatus. 
Many equipment designs for flow-through sorption experiments at temperatures less than $100^{\circ} \mathrm{C}$ are available in the literature. However, none were found for sorption studies above $100^{\circ} \mathrm{C}$. Equipment for these experiments will have to be designed based on the experiences of hydrothermal flow-through equipment users, adapting the equipment to obtain sorption data.

2.10.2.3 Low Temperature Methods. Almost al1 radionuclide sorption studies to date have been conducted at ambient laboratory temperatures and pressures. The methods developed for these conditions have been tested extensively. Both batch and flow-through methods have been used. Batch equilibration methods have several advantages:

- They are simpler to design.

- A large number of experiments can be run simultaneousiy.

- Solids and liquids can be allowed to equilibrate for long periods of time when sorption reactions are slow.

- Solution flow rate is not a variable.

Flow-through methods may more closely simulate actual field conditions. Also, if more than one sorption reaction is important, or if more than one radionuclide species is being sorbed, flow-through experiments can sometimes distinguish among the species present. The composition of the solution in contact with the solid phase can be controlled since the solution is continually replenished. However, if the sorption reaction is slow, equilibrium will not likely be attained and the results of the experiments will be difficult to interpret.

The procedure for low-temperature batch $k_{d}$ measurements consists of contacting a weighed amount of solid material (normally crushed and sized) with a known volume of solution containing the tracer. After equilibration for a specified time, the solution is sampled to measure the change in tracer concentration. Sometimes the solid is also analyzed for the tracer. The $K_{d}$ value is then calculated from the parameters measured. Some of the detailed variations on the above procedure are listed in Table 2-97. 
For the flow-through experiments, columns of solid geologic media are prepared from either crushed material or undisturbed, solid, machined cores. Solutions containing the tracer are slowly pumped at a constant rate through the columns and the effluent analyzed for tracer concentration over a period of time. The distribution coefficient is calculated from the position of the tracer concentration peak in a plot of concentration versus column volumes of solution.

One of the difficulties in measuring $K_{d}$ values for basalt and clay minerals is separation of solids from the solution prior to tracer analysis. When basalt is equilibrated with groundwater solutions, colloids are formed which sorb cesium, strontium, neptunium, americium, and plutonium (Barney, 1979). If these colloids are not separated before analysis, an artificially low $\mathrm{K}_{\mathrm{d}}$ value will be calculated. A similar colloid generation problem was observed when nontronite clay was equilibrated with groundwater (Ames and McGarrah, 1979a). A $0.015 \mathrm{~m}$ filter appeared to remove the colloids from the clay-equilibrated solution; however, all colloids were not removed from basalt-equilibrated solutions with $0.010 \mu \mathrm{m}$ filters.

2.10.2.4 Recommended Measurement Methods. Batch experiments will be used for the vast majority of $K_{d}$ measurements because of their simplicity, the large number of experiments required, and the fact that many sorption reactions are expected to be slow. A lesser number of flow-through experiments will be conducted to simulate more closely the condition of flowing groundwater and to confirm batch $k_{d}$ values.

Some recommended procedures which can improve $k_{d}$ measurements are listed as follows.

- Tracer concentrations should be as low as possible to prevent precipitation. Sorption isotherms should be obtained to describe the effects of tracer/solution/solid ratios on $k_{d}$.

- Tracers should be added as solids to minimize the effect on groundwater composition.

- After the addition of tracer, the groundwater should be filtered to remove any undissolved tracer. 
- Solid geologic media should be pre-equilibrated with unspiked groundwater to saturate the media with macro-ions from the groundwater. This will prevent changes in groundwater composition due to sorption of the macro-ions on the solid media during the $\mathrm{K}_{\mathrm{d}}$ measurement.

- Sorption of the radionuclide on the walls of the container should be measured both in the presence of and the absence of solid geologic media.

- Solid-solution mixtures should be slowly agitated to prevent abrasion and the production of difficult to filter fines.

- Samples of the equilibrated groundwater should be filtered before analysis to remove any colloids. Ultrafiltration using membrane filters with openings of $0.003 \mu \mathrm{m}$ is recommended. Potential sorption of the radionuclide on the filter should be determined.

\subsubsection{Identification of Key Radionuclides}

Radionuclides have been identified which appear to pose the greatest potential threat to mankind during storage of radioactive wastes in a repository in basalt. Only the most hazardous radionuclides will be examined in the sorption work because of the large number of experiments required. The criteria used for selection of these radionuclides are as follows:

- Quantity of radionuclides present in light water reactor fuel 1,000 years after removal from the reactor (if the concentration of radionuclides in the spent fuel expressed in curies/metric ton of uranium was greater than $10^{-6}$, the radionuclide was considered to be a significant concentration).

- Biological toxicity (relative values from the recommended concentration guide were compared).

- Leach rate from the waste form (only those radionuclides which form anionic or neutral species or which have positive charges $\leq+2$ were considered significant since highly charged cations will form extremely insoluble hydrated solids at $\mathrm{pH}>8$ ).

- Transport rate to the biosphere (established by a worst case one-dimensional transport model for groundwater flow in basalt; Barney and Wood, 1980).

The first criterion can be applied using a table which lists the curies of radionuclides in light water reactor wastes from uranium fuels reprocessing as a function of time (Schneider and Platt, 1974). 
Table 2-98 shows that the following actinides and fission products will be present in significant concentrations in the waste form during the time that leaching and radionuclide migration is likely to occur $(>1,000$ years):

\begin{tabular}{|c|c|}
\hline Actinides and Daughters & Fission Products \\
\hline Americium & Technetium \\
\hline Plutonium & Zirconium \\
\hline Neptunium & Tin \\
\hline Curium & Cesium \\
\hline Uranium & Selenium \\
\hline \multirow[t]{5}{*}{ Thorium } & Samarium \\
\hline & Palladium \\
\hline & Iodine \\
\hline & Strontium \\
\hline & Radium \\
\hline
\end{tabular}

These are listed in approximate order of persistence in terms of curies/metric ton of uranium fuet.

The relative toxicity of these radionuclides can be estimated from the recommended concentration guide for water (NRC, 1979a). Recommended concentration guide values for the above radionuclides in decreasing order of toxicity are shown in Table 2-99.

The transport rate and relative leach rate of these elements are related to the chemical species formed under repository conditions. For example, elements which form anionic species in groundwater solution will be mobile because of the low anion exchange capacity of most geologic media. Technetium, selenium, and iodine each tend to form anionic species in groundwater solutions. Also, large cations with a relatively low charge tend to be more mobile.

Radionuclide species expected to be most mobile are $\mathrm{I}^{-}, \mathrm{TCO}_{4}^{-}$, $\mathrm{SeO}_{3}^{-2}, \mathrm{NpO}_{2}, \mathrm{Cs}^{+}, \mathrm{Sr}^{+2}, \mathrm{UO}_{2}^{+2}, \mathrm{Ra}^{+2}$, and $\mathrm{Sn}(\mathrm{OH})_{6}^{-2}$. Under strongly reducing conditions $\mathrm{Eu}^{+2}$ and $\mathrm{Sm}^{+2}$ may be formed and could be mobile. Metallic ions which exist in oxidation states greater than +2 when in 
TABLE 2-98. Light Water Reactor Plant Waste from Uranium Fuels Processing.*

(After Schneider and Platt, 1974.)

\begin{tabular}{|c|c|c|c|c|c|c|}
\hline \multicolumn{7}{|c|}{ Selected Actinides--Curies/Metric Ton of Uranium } \\
\hline Radionuclide & Separation & 1 Year & 10 Years & 100 Years & 1,000 Years & 10,000 Years \\
\hline${ }^{225} \mathrm{~Pa}$ & $3.48 \times 10^{-8}$ & $3.50 \times 10^{-8}$ & $4.22 \times 10^{-8}$ & $7.31 \times 10^{-7}$ & $6.94 \times 10^{-5}$ & $5.54 \times 10^{-3}$ \\
\hline${ }^{226} \mathrm{Ra}$ & $1.97 \times 10^{-8}$ & $2.85 \times 10^{-6}$ & $1.09 \times 10^{-7}$ & $1.11 \times 10^{-6}$ & $7.22 \times 10^{-5}$ & $2.91 \times 10^{-3}$ \\
\hline${ }^{229} \mathrm{Th}$ & $3.49 \times 10^{-8}$ & $3.50 \times 10^{-8}$ & $4.22 \times 10^{-8}$ & $7.31 \times 10^{-7}$ & $6.94 \times 10^{-5}$ & $5.53 \times 10^{-3}$ \\
\hline${ }^{230} \mathrm{Th}$ & $2.04 \times 10^{-5}$ & $2.05 \times 10^{-5}$ & $2.09 \times 10^{-5}$ & $3.42 \times 10^{-5}$ & $3.86 \times 10^{-4}$ & $3.74 \times 10^{-3}$ \\
\hline $233_{u}$ & $2.31 \times 10^{-7}$ & $1.84 \times 10^{-6}$ & $1.49 \times 10^{-5}$ & $1.47 \times 10^{-4}$ & $1.52 \times 10^{-3}$ & $1.56 \times 10^{-2}$ \\
\hline $234_{U}$ & $3.77 \times 10^{-3}$ & $3.95 \times 10^{-3}$ & $6.64 \times 10^{-3}$ & $2.56 \times 10^{-2}$ & $4.56 \times 10^{-2}$ & $4.45 \times 10^{-2}$ \\
\hline${ }^{237} \mathrm{~Np}$ & $3.40 \times 10^{-1}$ & $3.40 \times 10^{-1}$ & $3.41 \times 10^{-1}$ & $3.45 \times 10^{-1}$ & $3.67 \times 10^{-1}$ & $3.74 \times 10^{-1}$ \\
\hline $235_{\mathrm{NP}}$ & $1.76 \times 10^{1}$ & $1.76 \times 10^{1}$ & $1.75 \times 10^{1}$ & $1.74 \times 10^{1}$ & $1.60 \times 10^{1}$ & $7.10 \times 10^{0}$ \\
\hline${ }^{239} \mathrm{Pu}$ & $1.63 \times 10^{0}$ & $1.62 \times 10^{0}$ & $1.62 \times 10^{0}$ & $1.67 \times 10^{0}$ & $2.05 \times 10^{0}$ & $4.02 \times 10^{0}$ \\
\hline $240 p u$ & $2.37 \times 10^{0}$ & $2.63 \times 10^{0}$ & $4.52 \times 10^{0}$ & $8.90 \times 10^{0}$ & $8.25 \times 10^{0}$ & $3.28 \times 10^{0}$ \\
\hline $241_{A m}$ & $1.52 \times 10^{2}$ & $1.52 \times 10^{2}$ & $1.55 \times 10^{2}$ & $1.44 \times 10^{2}$ & $3.43 \times 10^{1}$ & $1.31 \times 10^{-1}$ \\
\hline $245_{\mathrm{Am}}$ & $1.76 \times 10^{1}$ & $1.76 \times 10^{1}$ & $1.75 \times 10^{1}$ & $1.74 \times 10^{1}$ & $1.60 \times 10^{1}$ & $7.10 \times 10^{0}$ \\
\hline${ }^{242} \mathrm{~cm}$ & $1.93 \times 10^{4}$ & $4.09 \times 10^{3}$ & $3.16 \times 10^{0}$ & $2.09 \times 10^{0}$ & $3.46 \times 10^{-2}$ & $5.24 \times 10^{-20}$ \\
\hline $245 \mathrm{~cm}$ & $2.76 \times 10^{-1}$ & $2.76 \times 10^{-1}$ & $2.76 \times 10^{-1}$ & $2.74 \times 10^{-1}$ & $2.56 \times 10^{-1}$ & $1.31 \times 10^{-1}$ \\
\hline \multicolumn{7}{|c|}{ Selected Fission Products Curies/Metric Ton of Uraniun } \\
\hline $3_{H}$ & $6.92 \times 10^{2}$ & $6.54 \times 10^{2}$ & $3.94 \times 10^{2}$ & $2.47 \times 10^{0}$ & $2.35 \times 10^{-22}$ & 0.00 \\
\hline${ }^{79} \mathrm{Se}$ & $3.98 \times 10^{-1}$ & $3.98 \times 10^{-1}$ & $3.98 \times 10^{-1}$ & $3.98 \times 10^{-1}$ & $3.94 \times 10^{-1}$ & $1.37 \times 10^{-1}$ \\
\hline${ }^{89} \mathrm{sr}$ & $9.72 \times 10^{4}$ & $7.48 \times 10^{2}$ & $7.05 \times 10^{-17}$ & 0.00 & 0.00 & 0.00 \\
\hline $90_{\mathrm{Sr}}$ & $7.68 \times 10^{4}$ & $7.50 \times 10^{4}$ & $6.01 \times 10^{4}$ & $6.53 \times 10^{3}$ & $1.50 \times 10^{-6}$ & 0.00 \\
\hline${ }^{93} \mathrm{Zr}$ & $1.46 \times 10^{0}$ & $1.46 \times 10^{0}$ & $1.45 \times 10^{0}$ & $1.46 \times 10^{0}$ & $1.46 \times 10^{0}$ & $1.45 \times 10^{0}$ \\
\hline${ }^{95} \mathrm{Zr}$ & $2.77 \times 10^{5}$ & $5.65 \times 10^{3}$ & $3.40 \times 10^{-12}$ & 0.00 & 0.00 & 0.00 \\
\hline${ }^{99} \mathrm{TC}$ & $1.43 \times 10^{2}$ & $1.43 \times 10^{1}$ & $1.43 \times 10^{2}$ & $1.43 \times 10^{1}$ & $1.43 \times 10^{1}$ & $1.39 \times 10^{1}$ \\
\hline${ }^{103}$ Ru & $8.83 \times 10^{4}$ & $1.48 \times 10^{2}$ & $1.54 \times 10^{-23}$ & 0.00 & 0.00 & 0.00 \\
\hline${ }^{106} \mathrm{Ru}$ & $4.10 \times 10^{5}$ & $2.06 \times 10^{5}$ & $4.15 \times 10^{2}$ & $4.58 \times 10^{-25}$ & 0.00 & 0.00 \\
\hline $107 \mathrm{Pd}$ & $1.10 \times 10^{-1}$ & $1.10 \times 10^{-1}$ & $1.10 \times 10^{-1}$ & $1.10 \times 10^{-1}$ & $1.10 \times 10^{-1}$ & $1.10 \times 10^{-1}$ \\
\hline $124 \mathrm{Sb}$ & $8.53 \times 10^{1}$ & $1.26 \times 10^{0}$ & $4.08 \times 10^{-17}$ & 0.00 & 0.00 & 0.00 \\
\hline${ }^{125} \mathrm{Sb}$ & $7.99 \times 10^{3}$ & $6.18 \times 10^{3}$ & $6.14 \times 10^{2}$ & $5.70 \times 10^{-8}$ & 0.00 & 0.00 \\
\hline 126 Sn & $5.46 \times 10^{-1}$ & $5.46 \times 10^{-1}$ & $5.46 \times 10^{-1}$ & $5.46 \times 10^{-1}$ & $5.42 \times 10^{-1}$ & $5.10 \times 10^{-1}$ \\
\hline $129 I$ & $3.74 \times 10^{-2}$ & $3.75 \times 10^{-2}$ & $3.75 \times 10^{-2}$ & $3.75 \times 10^{-2}$ & $3.75 \times 10^{-2}$ & $3.74 \times 10^{-2}$ \\
\hline${ }^{134} \mathrm{cs}$ & $2.15 \times 10^{5}$ & $1.53 \times 10^{5}$ & $7.30 \times 10^{3}$ & $4.47 \times 10^{-10}$ & 0.00 & 0.00 \\
\hline${ }^{135} \mathrm{Cs}$ & $4.96 \times 10^{-1}$ & $4.96 \times 10^{-1}$ & $4.96 \times 10^{-1}$ & $4.96 \times 10^{-1}$ & $4.95 \times 10^{-1}$ & $4.94 \times 10^{-1}$ \\
\hline $137 \mathrm{Cs}$ & $1.07 \times 10^{5}$ & $1.04 \times 10^{5}$ & $8.48 \times 10^{4}$ & $1.06 \times 10^{4}$ & $9.92 \times 10^{-6}$ & 0.00 \\
\hline${ }^{141} \mathrm{Ce}$ & $5.64 \times 10^{4}$ & $2.29 \times 10^{1}$ & 0.00 & 0.00 & 0.00 & 0.00 \\
\hline $144 \mathrm{Ce}$ & $7.71 \times 10^{5}$ & $3.16 \times 10^{5}$ & $1.04 \times 10^{2}$ & 0.00 & 0.00 & 0.00 \\
\hline${ }^{147} \mathrm{Pm}$ & $9.80 \times 10^{4}$ & $7.52 \times 10^{4}$ & $6.96 \times 10^{3}$ & $3.19 \times 10^{-7}$ & 0.00 & 0.00 \\
\hline${ }^{148} \mathrm{Pm}$ & $3.19 \times 10^{1}$ & $7.71 \times 10^{-2}$ & $2.15 \times 10^{-25}$ & 0.00 & 0.00 & 0.00 \\
\hline $151_{\mathrm{Sm}}$ & $1.47 \times 10^{3}$ & $1.46 \times 10^{3}$ & $1.36 \times 10^{3}$ & $6.46 \times 10^{2}$ & $5.12 \times 10^{-1}$ & 0.00 \\
\hline${ }^{152} \mathrm{EU}$ & $1.14 \times 10^{1}$ & $1.07 \times 10^{1}$ & $6.38 \times 10^{0}$ & $3.53 \times 10^{-2}$ & $9.45 \times 10^{-25}$ & 0.00 \\
\hline${ }^{154} \mathrm{Eu}$ & $6.76 \times 10^{3}$ & $6.47 \times 10^{3}$ & $4.38 \times 10^{3}$ & $8.89 \times 10^{1}$ & $1.05 \times 10^{-15}$ & 0.00 \\
\hline $153 \mathrm{EU}$ & $9.84 \times 10^{3}$ & $6.71 \times 10^{3}$ & $2.14 \times 10^{2}$ & $2.32 \times 10^{-13}$ & 0.00 & 0.00 \\
\hline
\end{tabular}

Assumptions: power 30 mb/metric ton, exposure 33,000 mb-days/metric ton, $3.3 \%$ enriched $V$, flux $2.92 \times 1013 \mathrm{n} / \mathrm{cm}^{2}-\mathrm{sec}$, spent fuel reprocessed 150 days after discharge, $0.50 \%$ fuel 10 ss to waste. 
TABLE 2-99. Recommended Concentration Guide Values (in Water) for Radionuclides in Liquid Water Reactor Plant Waste from Uranium Fuels Reprocessing

(After 10 CFR 20, 1979a.)

\begin{tabular}{l|r|r|r}
\hline Isotope & $\begin{array}{c}\text { Recommended } \\
\text { Concentration } \\
\text { Guide }\left(\mathrm{Ci} / \mathrm{m}^{3}\right)\end{array}$ & Isotope & $\begin{array}{c}\text { Recommended } \\
\text { Concentration } \\
\text { Guide }\left(\mathrm{Ci} / \mathrm{m}^{3}\right)\end{array}$ \\
\hline${ }^{226 \mathrm{Ra}}$ & $3 \times 10^{-8}$ & $241,243 \mathrm{Am}$ & $4 \times 10^{-6}$ \\
${ }^{129} \mathrm{I}$ & $6 \times 10^{-8}$ & $245 \mathrm{Cm}$ & $4 \times 10^{-6}$ \\
${ }^{90} \mathrm{Sr}$ & $3 \times 10^{-7}$ & $239,240 \mathrm{Pu}$ & $5 \times 10^{-6}$ \\
${ }^{230} \mathrm{Th}$ & $2 \times 10^{-6}$ & $154 \mathrm{Eu}$ & $2 \times 10^{-5}$ \\
${ }^{233} \mathrm{~Np}$ & $3 \times 10^{-6}$ & $233,234 \mathrm{U}$ & $3 \times 10^{-5}$ \\
${ }^{107 \mathrm{Pd}}$ & $3 \times 10^{-6}$ & $135 \mathrm{Cs}$ & $1 \times 10^{-4}$ \\
${ }^{126} \mathrm{Sn}$ & $3 \times 10^{-6}$ & $99 \mathrm{Tc}$ & $2 \times 10^{-4}$ \\
$79 \mathrm{Se}$ & $3 \times 10^{-6}$ & $151 \mathrm{Sm}$ & $4 \times 10^{-4}$ \\
& & $93 \mathrm{Zr}$ & $8 \times 10^{-4}$ \\
\hline
\end{tabular}

contact with groundwater are Am(III), Pu(IV), $\operatorname{Zr}$ (IV), Th(IV), and $\mathrm{Cm}$ (III). These ions form extremely insoluble hydrated oxides and wilt be immobile. The high $K_{d}$ values observed for these radionuclides reflect their inmobility. Combining all the criteria, the following list of radionuclides are of greatest importance.

\begin{tabular}{ll} 
Actinides & Fission Products \\
\hline Radium-226 & Iodine-129 \\
Neptunium-237 & Selenium-79 \\
Uranium-233,234 & Technetium-99 \\
PTutonium-239, 240, 242 & Cesium-135 \\
Americium-241, 243 & Strontium-90 \\
& Tin-126 \\
& Palladium-107 \\
& Zirconium-93
\end{tabular}


RHO-BWI - ST -7

\subsubsection{Results of Radionuclide Distribution Measurements}

Almost a17 radionuclide distribution measurements pertinent to migration from a deep repository in basalt have been made on crushed, fresh basalt at room temperatures. Very little work has been reported on radionuclide sorption onto secondary minerals or interbed materials. Sorption studies using these materials have just recently begun. However, geologic materials similar to secondary minerals (montmorillonite and other clays) and interbed materials (sandstone, tuff, etc.) found in Columbia Plateau basalt formations have been used in sorption experiments. A fairly large amount of sorption data are available for the upper sediments (Ringold and glaciofluvial sediments). A list of selected $K_{d}$ values is given at the end of this section.

2.10.4.1 Distribution Measurements on Basalt and Associated Secondary Minerals. Groundwater contaminated with radionuclides from breached containers may contact fresh basalt surfaces within or near the repository. These fresh surfaces may be exposed during tunnel excavation, or by fracturing basalt in or adjacent to the repository due to thermal or mechanical stress. The fresh basalt will act as a barrier to radionuclide migration by sorbing dissolved radionuclides. Natural fissures in basaltic rocks contain secondary minerals which result from weathering of the basalt. Secondary minerals which have been identified include smectite clay and the zeolites heulandite and clinoptilolite. Flow paths of groundwater in basalt formations are likely to be fissures which are lined with these materials. Sorption of radionuclides on these minerals will have a strong influence on migration.

Radionuclide sorption on crushed basalt at room temperature has been studied by a number of researchers. The results of an interlaboratory comparison of batch $\mathrm{K}_{\mathrm{d}}$ values for sorption of cesium, strontium, and plutonium on crushed basalt was given previously (Relyea and Serne, 1979). The values for cesium and strontium were reasonably consistent for most laboratories; however, the range of values for plutonium ( 8.8 to $13,000 \mathrm{~m} / \mathrm{g}$ ) indicates the difficulty in obtaining reproduceable $\mathrm{K}_{\mathrm{d}}$ values and illustrates the necessity of controlling all parameters which affect sorption. 
One important parameter which has often been neglected is time. Some radionuclides are sorbed very slowly by basalt and other crushed rocks (Barney, 1979). Neptunium sorption on basalt continues even after 218 days of equilibration. Strontium sorption requires about 75 days, and cesium about 10 days to reach a constant concentration. These slow reactions are probably due to changes in the composition of the solution and rock surface with time. The basalt slowly dissolves during contact with the groundwater and eventually colloidal particles are formed which contain silicon, iron, calcium, and aluminum. These particles sorb cesium, strontium, americium, and plutonium and must be filtered from solution using ultrafilters.

The dissolution of a crushed basalt (tholeitic from the MidAtlantic Ridge) in buffered solutions in atmospheres of oxygen and oxygen-free nitrogen was studied (Siever and Woodford, 1979). The concentration of dissolved elements versus time at pH 4.5 are given in Figure 2-62. The rate and extent of dissolution with oxygen excluded are much greater than with oxygen present for $\mathrm{Fe}^{+2}, \mathrm{Mg}^{+2}$, and $\mathrm{SiO}_{2}$. Dissolution in the presence of oxygen is slowed by the coating effect of $\mathrm{Fe}(\mathrm{OH})_{3}$ which appears on the surface after a few days. The dissolution can affect radionuclide sorption in several ways: $\mathrm{Fe}^{+2}$ can reduce radionuclides which have multiple oxidation states, the $\mathrm{Fe}(\mathrm{OH})_{3}$ precipitate formed in oxygen containing atmospheres can scavenge radionuclides, dissolved cations such as $\mathrm{Na}^{+}, \mathrm{Mg}^{+2}$, and $\mathrm{Ca}^{+2}$ can compete with radionuclides for sorption sites, and other reaction products formed on the solid surface can affect sorption.

Another important variable is the concentration of radionuclides in the groundwater solution during equilibration. If the sorption isotherm is linear, radionuclide concentration should have no effect on $k_{d}$ values. However, most sorption isotherms (sorption from solution) are shaped similar to that shown in Figure 2-63. If the sorption reaction conforms to this type of isotherm, $k_{d}$ values will decrease as the concentration of radionuclide increases. This behavior has been observed for sorption of cesium (Barney, 1979; Seitz and 0thers, 1979) and neptunium on basalt. A plot of $K_{d}$ values (28-day equilibration) versus cesium concentration is shown in Figure 2-64. Cesium sorption on basalt 
RHO-BWI-ST-7
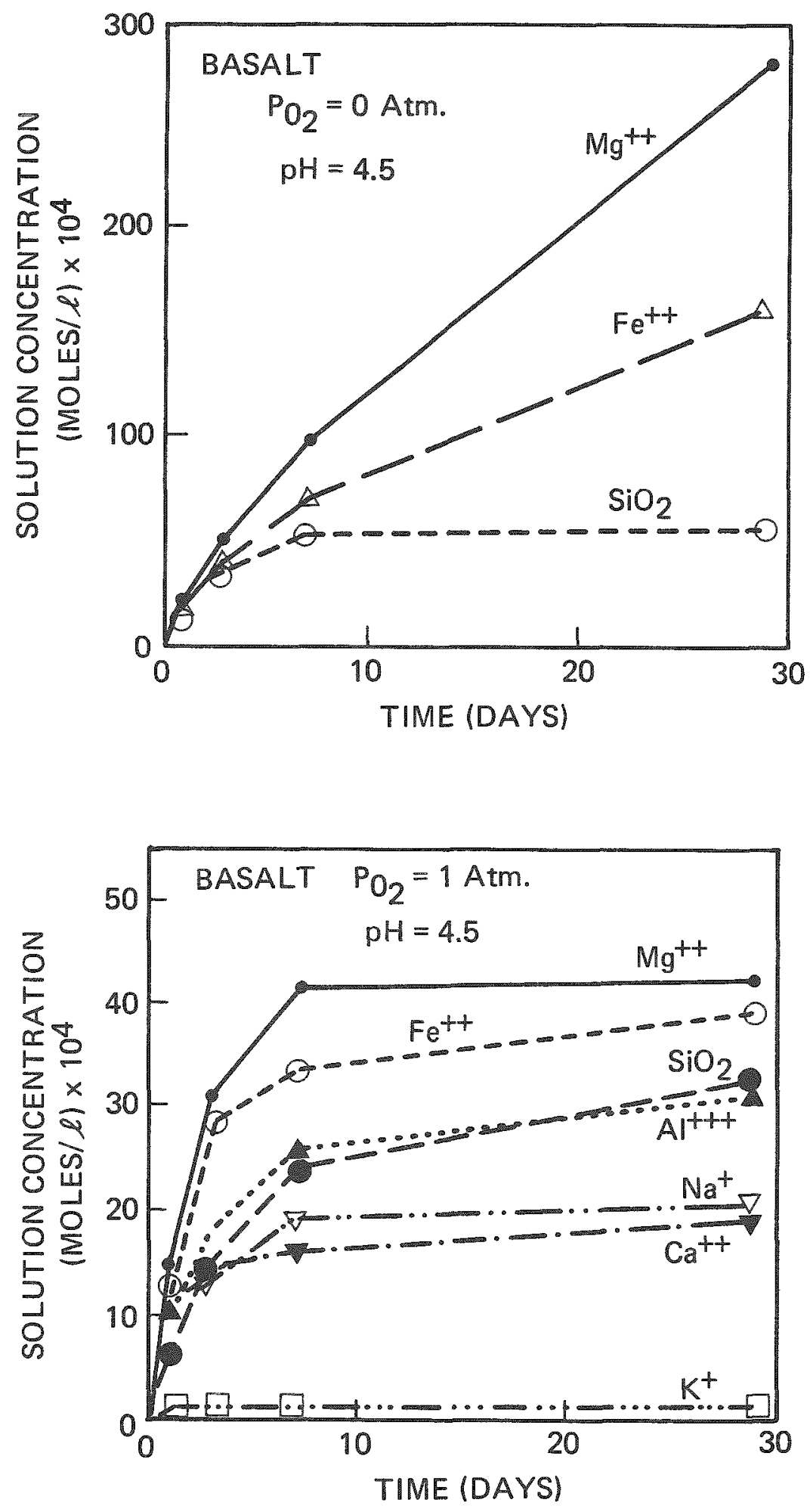

FIGURE 2-62. Dissolution of Crushed Basalt, pH 4.5 (after Siever and Woodford, 1979). 
shows significant dependence on cesium concentration in the range $10^{-10}$ to $10^{-5}$ cesium.

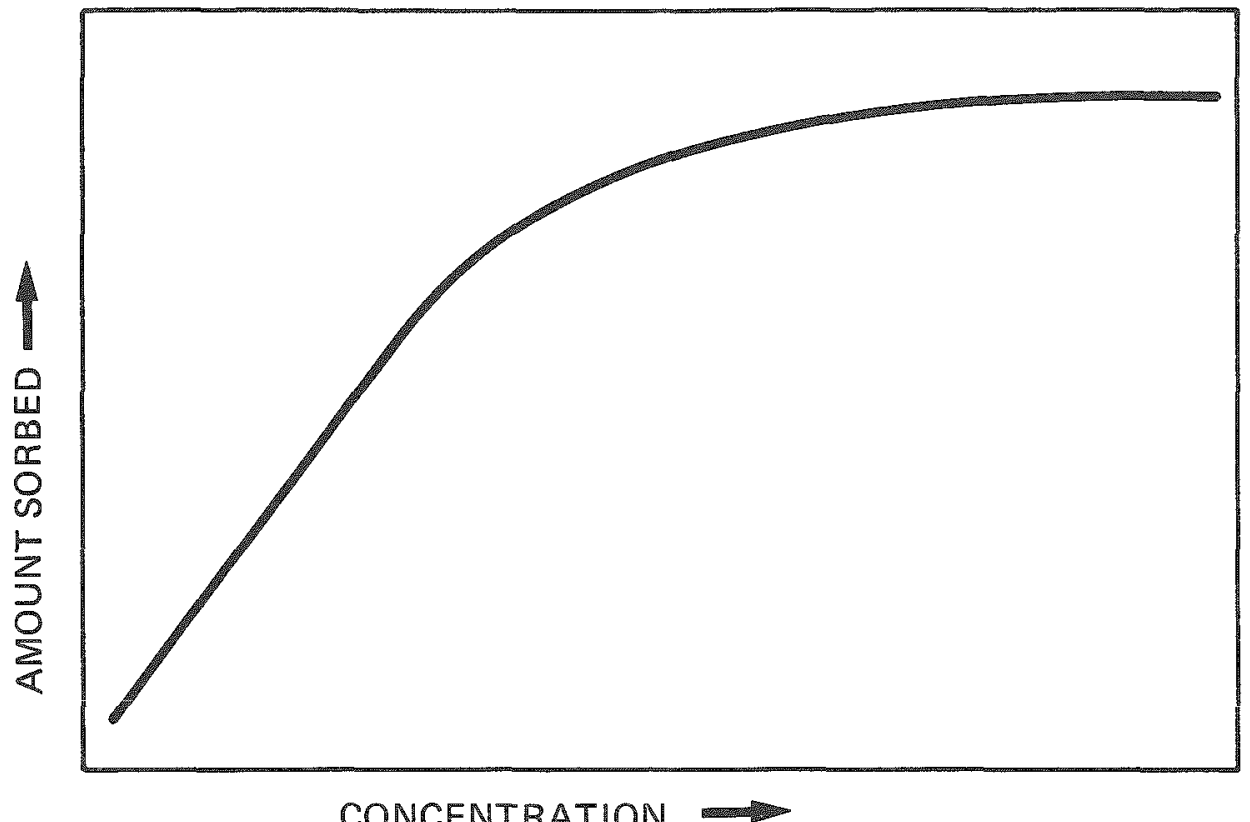

FIGURE 2-63. A Typical Sorption Isotherm for Sorption of a Solute from Solution.

The presence of oxygen in groundwater solutions during equilibration with basalt and other igneous rocks has been shown to strongly affect sorption of certain radionuclides. It has been shown (Bondietti and Francis, 1979) that when oxygen is excluded during equilibration of groundwater with Sentinel Gap basalt, sorption of technetium and neptunium is drastically increased (Fig. 2-65). The relatively mobile species, $\mathrm{TCO}_{4}{ }^{-}$and $\mathrm{NpO}_{2}{ }^{+}$, which are stable in solutions in contact with the atmosphere, are reduced to $\mathrm{TCO}_{2}$ and $\mathrm{NpO}_{2}$ by $\mathrm{Fe}(\mathrm{II})$ in the basait. The reduced species are relatively insoluble and therefore have lower mobilities. Other radionuclide species that might reasonably be affected by $\mathrm{Fe}(\mathrm{II})$ reduction include $\mathrm{UO}_{2}^{-2}, \mathrm{SeO}_{2}^{+2}$, and $\mathrm{Sn}(\mathrm{OH})_{6}^{-2}$.

The effects of temperature on radionuclide sorption on basalt have been studied by Ames and McGarrah (1979a). Sorption was measured at 3 temperatures--23 $3^{\circ}, 60^{\circ}$, and $150^{\circ} \mathrm{C}$. Table 2-100 shows typical $\mathrm{K}_{d}$ values for several radionuclides at these three temperatures (for 20- to 50-mesh Umtanum basalt, $1 \mathrm{~g}$ basalt/10 $\mathrm{ml}$ solution, and a 46- to 59-day equilibration time). 
RHO-BWI $-S T-7$

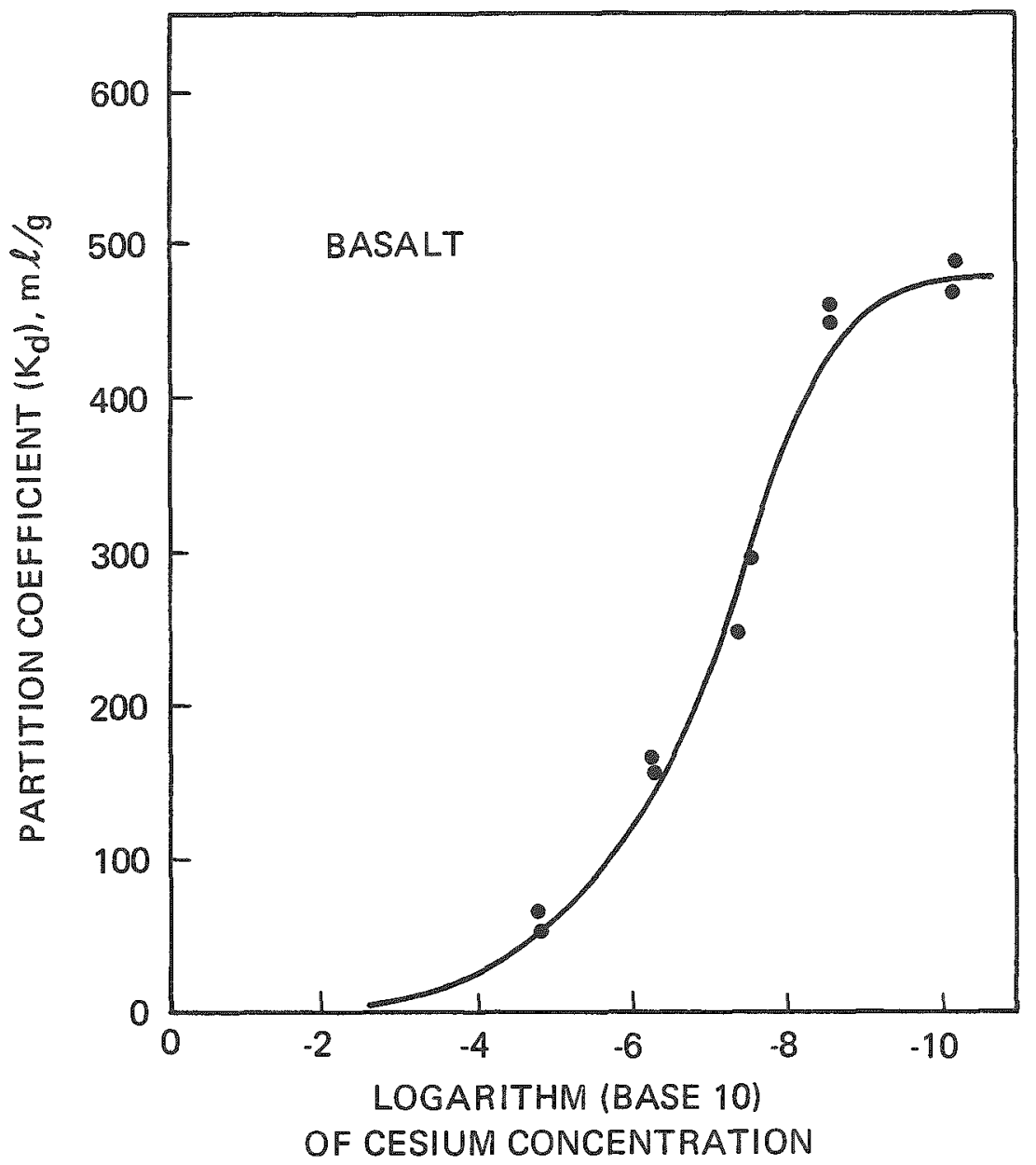

IN SOLUTION, M

FIGURE 2-64. Dependence of Cesium Sorption by Basalt on Cesium Concentration (after Seitz and Others, 1979).

TABLE 2-100. Effect of Temperature on $k_{d}$ Values $(\mathrm{ml} / \mathrm{g})$ for Umtanum Basalt.

\begin{tabular}{c|r|r|c}
\hline \multirow{2}{*}{ Radionuclide } & \multicolumn{3}{|c}{$\mathrm{K}_{\mathrm{d}, \mathrm{ml} / \mathrm{g}}$} \\
\cline { 2 - 4 } & \multicolumn{1}{|c|}{$23^{\circ} \mathrm{C}$} & $60^{\circ} \mathrm{C}$ & $150^{\circ} \mathrm{C}$ \\
\hline${ }^{75} \mathrm{Se}$ & 5 & 10 & 100 \\
${ }^{85} \mathrm{Sr}$ & 103 & 237 & 400 \\
${ }^{137} \mathrm{Cs}$ & 1,900 & 550 & 100 \\
${ }^{99} \mathrm{TC}$ & 13 & 36 & - \\
${ }^{125} \mathrm{I}$ & 2 & 0 & 0 \\
$237 \mathrm{~Np}$ & 10 & 13 & - \\
\hline
\end{tabular}



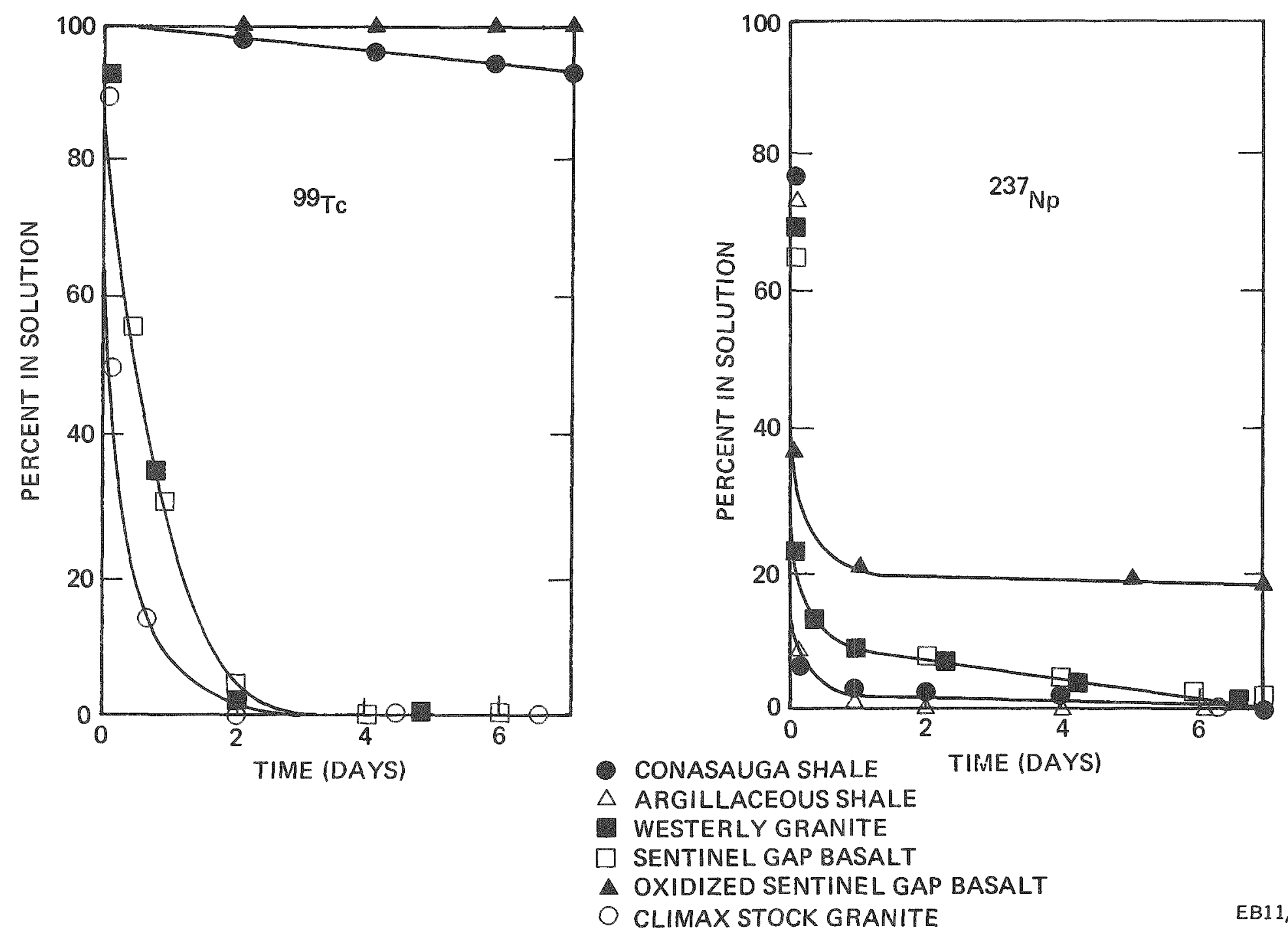
FIGURE 2-65. Sorption of (a) ${ }^{99} \mathrm{Tc}$ (Initiallv $\mathrm{TCO}^{-}{ }^{-}$) and (b) ${ }^{237} \mathrm{~Np}$ (initially $\mathrm{NpO}_{2}^{+}$) in
Rock-Water Systems Puraed of Dxygen (after Bondietti and Francis, 1979). 
Sorption of selenium and strontium increases as the temperature increases, whereas sorption of cesium decreases. Values of $k_{d}$ for technetium, iodine, and neptunium change little (taking into account experimental uncertainty) over this temperature range. The reasons for the observed effects of temperature on sorption are not understood because the mechanisms of these sorption reactions are not well known. The relationships between sorption and the variables that affect sorption are empirical and therefore cannot be extended outside the range of experimental measurements.

Ames and McGarrah (1979a) have also reported radionuclide sorption on basalts from different basalt flows underlying the Hanford Site. The objective was to compare sorption properties of these basalts which have different chemical and physical characteristics. Some relevant characteristics of these basalts (Umtanum, Flow $E$, and Pomona) are compared in Table 2-101.

TABLE 2-101. Characteristics of Three Columbia Plateau Basalts (20 to 50 Mesh).

\begin{tabular}{l|l|l|c}
\hline Characteristic & Umtanum & Flow E & Pomona \\
\hline $\begin{array}{l}\text { Surface area } \\
\text { (ethylene glycol) }\end{array}$ & $17.7 \pm 3.8 \mathrm{~m}^{2} / \mathrm{g}$ & $10.3 \pm 1.0 \mathrm{~m}^{2} / \mathrm{g}$ & $31.2 \pm 1.4$ \\
$\begin{array}{l}\text { Cation exchange } \\
\text { capacity }\end{array}$ & $1.7 \pm 0.1 \mathrm{meq} / 100 \mathrm{~g}$ & $4.7 \pm 0.2 \mathrm{meq} / 100 \mathrm{~g}$ & -- \\
Major minerals & $\begin{array}{l}\text { Plagioclase } \\
\text { Augite }\end{array}$ & $\begin{array}{l}\text { Plagioclase } \\
\text { Augite }\end{array}$ & $\begin{array}{l}\text { Plagioclase } \\
\text { Augite }\end{array}$ \\
$\begin{array}{l}\text { Wt\% groundmass } \\
\text { (including glass) }\end{array}$ & $37.5 \%$ & $13 \%$ & $26 \%$ \\
\hline
\end{tabular}

The sorption properties of these basalts were measurably different. Values of $K_{d}$ at $23^{\circ} \mathrm{C}, 1 \mathrm{~g}$ basalt/10 $\mathrm{ml}$ solution, and 83 days equilibration for 20 to 50 mesh basalts are given in Table 2-102.

Radionuclides which probably exist as anions in solutions (selenium, technicium, and iodine) are more strongly sorbed on Umtanum basalt than the other basalts. The Pomona flow appears to have the lowest affinity for anions. Flow $E$ basalt has the lowest affinity for those radionuclides that are cationic (strontium, cesium, radium, and neptunium). 
These relationships also hold true at other temperatures and basalt/ solution ratios.

TABLE 2-102. Comparison of $K_{d}$ Values $(\mathrm{ml} / \mathrm{g}$ ) for Three Columbia Plateau Basalts at $230^{\circ} \mathrm{C}$.

\begin{tabular}{l|c|c|c}
\hline Radionuclide & Umtanum & Flow E & Pomona \\
\hline $75 \mathrm{Se}$ & $4 \pm 0.4$ & $3 \pm 0.3$ & 0 \\
${ }^{85} \mathrm{Sr}$ & $105 \pm 3$ & $102 \pm 3$ & $137 \pm 7$ \\
${ }^{99} \mathrm{TC}$ & $12 \pm 3$ & $2 \pm 1$ & 0 \\
$125 \mathrm{I}$ & $3.1 \pm 0.5$ & $0.5 \pm 0.3$ & $0.5 \pm 0.4$ \\
$137 \mathrm{Cs}$ & $1,663 \pm 31$ & $753 \pm 79$ & $2,408 \pm 203$ \\
$226 \mathrm{Ra}$ & $64 \pm 3$ & $48 \pm 3$ & $54 \pm 2$ \\
$237 \mathrm{~Np}$ & $9 \pm 1$ & $4 \pm 0.3$ & $5 \pm 0.8$ \\
\hline
\end{tabular}

In addition to the batch sorption studies using crushed basalt, several workers have attempted flow-through experiments (Fried and others, 1976; Seitz and Others, 1979). Fried and 0thers (1976) have attempted to model the movement of pulutonium through fissures in basalt by passing plutonium containing solutions through an artificially produced fissure. The fissure was constructed of basalt from the Idaho Engineering Laboratory. Plutonium was introduced at the top of the fissure in a very small volume and then slowly eluted with water. After the water flow was stopped the rock surface was scanned to measure plutonium distribution along the fissure. Two areas of high concentration were found along the flow path of the fissure. There appeared to be a loosely bound, rapidly migrating component as well as a tightly bound plutonium component. Seitz and 0thers (1979) have measured the effect of cesium concentration on migration of ${ }^{137}$ CS through rock columns made from crushed Columbia Plateau basalt. The elution curves were shaped differently for different concentrations of cesium. Peak positions, peak heights, tailing, etc. were different depending on cesium concentration. More of the ${ }^{137} \mathrm{Cs}$ was eluted in solutions of higher cesium concentrations. The ${ }^{137} \mathrm{Cs}$ was also more rapidly eluted at higher cesium concentrations. A significant fraction of the ${ }^{137} \mathrm{Cs}$ is held up in the columns after passage of the main peak. This may be due to cesium diffusing into intergranular sites in the bulk of the rock. 
Preliminary studies of radionuclide sorption on secondary minerals occurring in Columbia Plateau basalts have been reported (Ames and McGarrah, 1979a). The secondary mineral sample was obtained from a large vug in the Pomona flow. Its main constituent is a green smectite clay with a relatively uniform chemical composition. Sorption of cationic radionuclides such as strontium, cesium, radium, and neptunium is much greater on this clay than on basalt. However, the clay appears to have a low affinity for anions such as technetium, iodine, and selenium.

Sorption of radionuclides on secondary mineral products from basalt-groundwater reactions are expected to be important. The contaminated groundwater flow path will more likely contain a greater abundance of these minerals than fresh basalt surfaces. In addition to sorption studies on pure secondary minerals, sorption on basalt samples which were altered by reaction with water has been examined (Barney, 1979). Fresh basalt samples were leached (artificially weathered) with hot, distilled water for six months under nitrogen to simulate alteration of basalt surfaces near a repository. Sorption measurements on altered basalt and fresh basalt (from the same original sample) were made under identical conditions. The results for cesium, strontium, neptunium, americium, and plutonium given in Table 2-103 show that these radionuclides are more strongly sorbed on the altered basalt.

TABLE 2-103. Sorption Properties of Fresh and Altered Basalt.

\begin{tabular}{c|c|c}
\hline \multirow{2}{*}{ Radionuclide } & \multicolumn{2}{|c}{$K_{d}$ values $(\mathrm{ml} / \mathrm{g})$ for } \\
\cline { 2 - 3 } & Fresh Basalt & Altered Basalt \\
\hline${ }^{137} \mathrm{Cs}$ & $350 \pm 35$ & $1,500 \pm 300$ \\
${ }^{85} \mathrm{Sr}$ & $108 \pm 20$ & $520 \pm 120$ \\
$237 \mathrm{~Np}$ & $10.4 \pm 0.8$ & $49 \pm 16$ \\
$241_{\mathrm{Am}}$ & $6 \pm 2$ & $18,000 \pm 17,000$ \\
$239_{\mathrm{Pu}}$ & $18 \pm 2$ & $2,000 \pm 200$ \\
\hline
\end{tabular}


Scanning electron photomicrographs of the altered basalt surface show that the glassy matrix of the basalt had been leached away, leaving a rough, crystalline surface with some coatings of alteration products (i.e., $\mathrm{Fe}_{2} \mathrm{O}_{3} \cdot x_{2} \mathrm{O}$ ) left behind. The increased surface area and/or the greater sorption capacity of the alteration products explain the increased affinity of radionuclides for the altered basalt.

In summarizing the information presently at hand on sorption of radionuclides on basalt and associated secondary minerals, one can list the following items:

- Fresh basalt surfaces react with groundwater to form new phases which, in turn, affect radionuclide sorption positively over long time periods.

- Sorption of technetium and neptunium on basalt is greatly enhanced when oxygen is excluded, possibly due to reduction by $\mathrm{Fe}(\mathrm{II})$.

- Anionic radionuclides such as iodine, selenium, and technetium are sorbed weakly on basalt and secondary minerals, whereas americium and plutonium are very strongly sorbed under all conditions thus far studied.

- Basalts from different flows show measurably different sorption properties. Three Columbia Plateau basalts show increasing cation sorption according to the order: Flow $E<$ Umtanum < Pomona.

- Sorption of cesium on basalt is a function of tracer concentration even at very low concentrations $\left(10^{-6}\right.$ to $\left.10^{-10} \mathrm{M}\right)$.

- Increasing the temperature decreases sorption of cesium and increases strontium and selenium sorption on basalt.

- Altered ("weathered") basalt and secondary minerals associated with basalt sorbed cationic radionuclides much more strongly than fresh basalt.

Much additional information must be obtained in order to fully model radionuclide sorption and migration. Additional materials such as naturally altered basalt and other secondary mineral deposits must be examined. Quantification of the effect of yariables such as temperature (up to $300^{\circ} \mathrm{C}$ ), time, oxygen concentration, radionuclide concentration, and surface area must be accomplished. 
2.10.4.2 Distribution Measurements on Interbed and Interflow Materials and Sediments. Understanding sorption of radionuclides on interbed and interfow materials is important since aquifers may exist in the more porous interbeds. A postulated flow path from the repository to the biosphere must include interbeds. Major components of interbed materials are known to include sandstone, tuff, diatomite, and clay. No sorption work has been performed on these Hanford site-specific interbed materials. However, sorption studies have begun on sandstone and tuff samples obtained from other locations.

Sorption properties of tuff samples taken from Los Aiamos, New Mexico and the Nevada Test Site have been extensively studied using both batch and flow methods. Wolfsberg and Others (1979) studied the sorption of strontium, cesium, barium, cerium, europium, iodine, molybdenum, ruthenium, antimony, plutonium, and americium on three Nevada Test Site tuffs from different depths. The batch method was used at $22^{\circ}$ and $70^{\circ} \mathrm{C}$. Radionuclides which exist as mono- and divalent cations such as strontium, cesium, and barium were strongly sorbed, especially on a sample containing mostly glass. Sorption of iodine, antimony, molybdenum, and uranium which were anionic or form soluble complexes was very low (near zero) and sorption of plutonium, americium, and europium was high. Sorption on the three tuff samples was markedly different due to their mineral composition. A glassy, partially welded, ash-flow tuff; a partially welded devitrified zeolitized tuff; and, an unwelded, crystalline tuff similar to a microgranite were used. Sorption at $70^{\circ} \mathrm{C}$ was generally greater than at $22^{\circ} \mathrm{C}$.

Radionuclide sorption on Nevada Test Site tuff samples has been studied using flow-through techniques by other researchers (Seitz and Others, 1979; Coles and Others, 1979). Cylindrical rock columns were cut from the tuff and sealed with epoxy in polyethylene tubes to prevent bypassing of the water around the rock. Radionuclides were added to the top of the column and rock equilibrated water passed through the column. The relative migration rate (distance traveled by the radionuclide divided by distance travelled by the water front) for americium through tuff was calculated. About $0.0009 \%$ of the americium was eluted from the column at a migration rate 0.06 times the travel rate of the water 
front. Coles and Others (1979) obtained effluent curves during flow-through experiments and concentration profiles in the rock column after passing groundwater solutions spiked with ${ }^{85} \mathrm{Sr}$ and ${ }^{95 \mathrm{~m}} \mathrm{TC}$ through Nevada Test Site tuff. Transport velocities (V), retardation factors $(R)$, and $K_{d}$ values were measured for three different cores. The results are shown in Table 2-104.

TABLE 2-104. Transport Velocities, Retardation Factors, and $K_{d}$ Values for Three Thirsty Canyon Tuff Samples.

(After Coles and Others, 1979.)

\begin{tabular}{|c|c|c|c|c|c|}
\hline Core \# & Radionuclide & $\begin{array}{c}\text { Flow Rate } \\
\mathrm{cm}^{3} / \mathrm{min}\end{array}$ & $\begin{array}{l}\text { Transport } \\
\text { Velocity } \\
\left(\mathrm{cm}^{3} / \mathrm{min}\right)\end{array}$ & $\begin{array}{l}\text { Retardation } \\
\text { Factor, R }\end{array}$ & $K_{d}, \mathrm{~cm}^{3} / \mathrm{g}$ \\
\hline \multirow[t]{2}{*}{5} & Tc & 0.0114 & 0.1035 & 1 & 0 \\
\hline & Sr & 0.0062 & $5.1 \times 10^{-5}$ & 110 & 13 \\
\hline \multirow[t]{2}{*}{6} & TC & 0.0152 & 0.01611 & 1 & 0 \\
\hline & $S r$ & 0.0113 & $2.8 \times 10^{-5}$ & 567 & 66 \\
\hline \multirow[t]{2}{*}{3} & TC & 0.0305 & 0.0335 & 1 & 0 \\
\hline & $S r$ & 0.0194 & $2.3 \times 10^{-5}$ & 928 & 108 \\
\hline
\end{tabular}

Strontium is strongly retained on the tuff. Although the $K_{d}$ values for technetium indicate no sorption, a fairly uniform concentration profile was found throughout the tuff after the flow-through experiment. This suggests that there may have been at least two forms of technetium in these systems--a mobile form which is not sorbed at all and a second form which is strongly retained by the tuff.

Flow-through sorption experiments have also been attempted using Los Alamos tuff by researchers at Argonne National Laboratories (Seitz and Others, 1979; Fried and Others, 1976, 1977). The transport velocity and retention factor (velocity of radionuclides/velocity of water) for strontium in Bandelier tuff were found to be $2.3 \times 10^{-4}$ and $2.66 \times 10^{-3} \mathrm{~cm} / \mathrm{min}$, respectively. Neptunium was not appreciably sorbed by this tuff. A sharp peak in the elution curve for neptunium occurs at less than two free column volumes. Similar results were obtained for 
$I^{-}$and $\mathrm{IO}_{3}{ }^{-}$. A tuff column $(7.8 \mathrm{~cm}$ long) was sectioned to measure the distribution of plutonium and americium after passing 1,000 pore volumes of water through the spiked column. The results are shown in Figure 2-66. The activity did not advance through the rock more than 1 or $2 \mathrm{~cm}$. The water advances about 25,000 times more rapidly through the pores of the tuff than plutonium or americium.

Relatively little information is available in the area of radionuclide sorption on sandstones. Coles and Others (1979) have reported distribution coefficients for radionuclide sorption from brine solution on 15 different sandstones. Sorption of cationic radionuclides (strontium, cesium) was less than might be expected for sorption from Hanford groundwater because of competition of brine cations for sorption sites. Values of $k_{d}$ for plutonium and cesium remained high since these are probabiy not cationic under the experimental conditions used. The sorption properties of Ohio barrier sandstone has been studied (Seitz and Others, 1978; Fried and Others, 1978). Flow-through column experiments were performed using rock equilibrated water spiked with either americium or neptunium. Americium was strongly sorbed. Less than $0.033 \%$ of the americium was eluted after 100 pore volumes of solution were passed through the column. Neptunium was weakly sorbed. About $61 \%$ of the neptunium was eluted with 100 pore volumes of solution.

A large amount of information is available in the literature on sorption of radionuclides on upper sediments at Hanford. Much of this work has been directed at prediction of waste movement in the vadose zone above the unconfined aquifer. No attempt to summarize this work will be made here since adequate reviews of this work are available (Routson, 1973; Benson, 1960).

Several general conclusions can be drawn from work thus far accomplished on radionuclide sorption on interbed materials (tuff and sandstone) and on upper sediments. They are follows:

- Anionic or neutrally-charged radionuclides (iodine, antimony, molybdenum, uranium, technetium) are sorbed very little, if at a11, on these materials.

- Radionuciides with high positive charges (plutonium, americium, cerium) are very strongly sorbed. 
RHO-BWI-ST-7

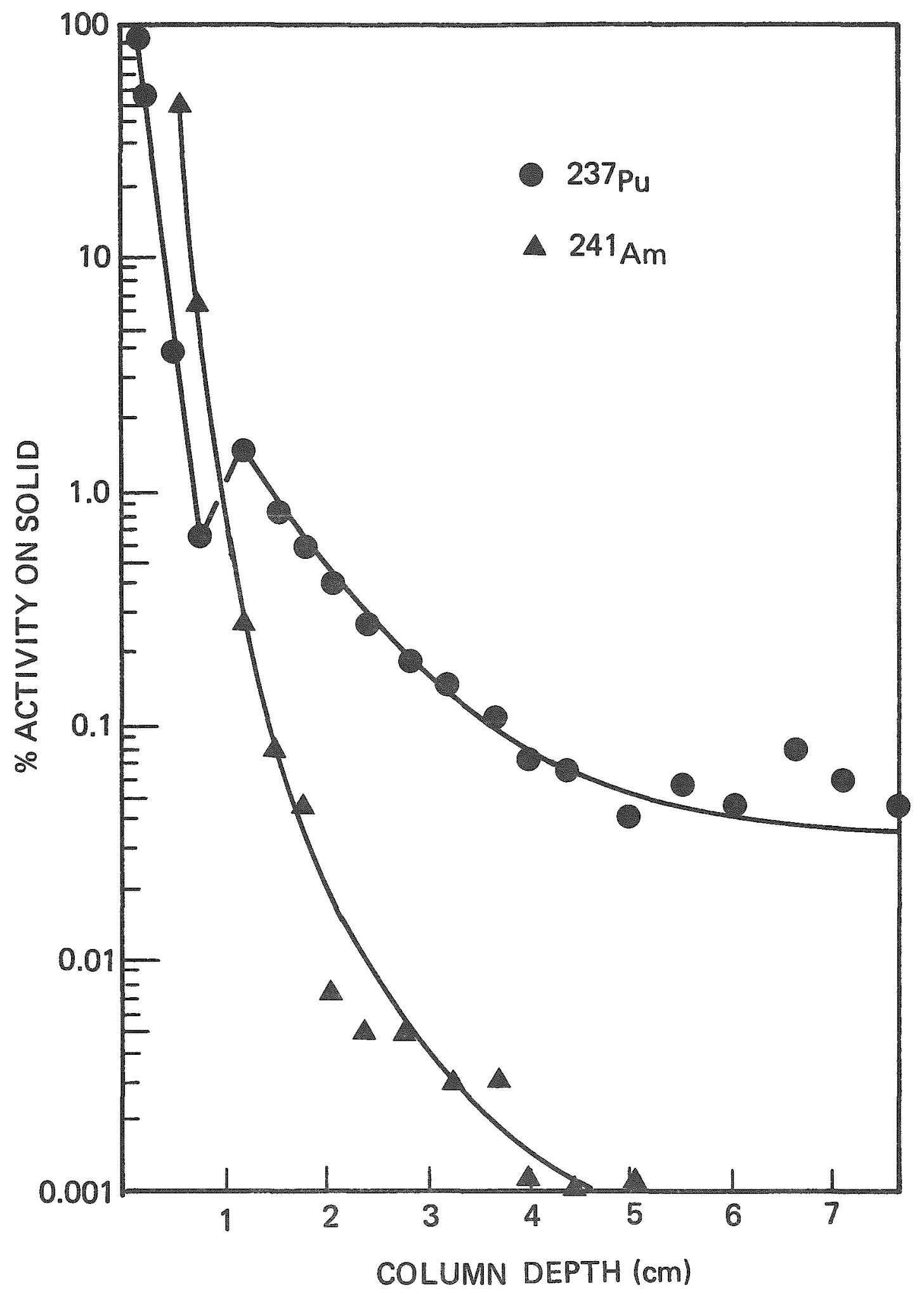

FIGURE 2-66. Relative Migration Rates for Plutonium and Americium in Los Alamos Tuff (after Fried and Others, 1976 and 1977 ). 
- If mica-like minerals are present, cesium can be selectively "fixed" on these.

- Flow-through experiments with technetium show that part of the technetium can be strongly sorbed on tuff.

Additional sorption information on site-specific interbed samples and upper sediment is needed. Sorption isotherms over the range of temperatures expected in the interbeds should be measured for all relevant radionuclides. Anoxic sorption measurement should be made on radionuclides with multiple oxidation states. Flowsthrough experiments are needed to identify radionuclides, which may exist as multiple species under repository conditions and to determine sorption mechanisms. After an extensive laboratory program is completed such that sorption equilibrium properties are well understood, field tests may be useful in demonstrating the veracity of the laboratory-determined $k_{d}$ values and transport models.

\subsubsection{Particulate Transport}

A possible mechanism for radionuclide transport from the repository is uptake of dissolved radionuclides onto suspended colloidal particulates and their subsequent transport through porous, geologic media. Another possibility is formation of colloidal, hydrous oxides of radionuclides by reaction of the waste form with water. Particulates may arise from erosion of rock material, mobilization of fine clay particles, or surface spalling of materials in the repository (waste matrix, canister, overpack, or backfill).

As radioactive particles move through the geologic formation, surrounding rock surfaces will compete for sorbed radionuclides. Also, particles and rock surfaces will interact to control the movement of particles. Eichholz (1979) has reported preliminary studies of these processes. He investigated the movement of labeled particles through columns simulating geological media that might occur near actual repository sites. In addition to other rocks, crushed basalt from Sentinel Gap, Washington was used as bed material for several experiments. The behavior of kaolin particles in columns of crushed basalt was studied using deionized water as the carrier. The labeled kaolin suspension was 
prepared by stirring kaolin in water and then activating the resulting solution in a reactor to provide an internal ${ }^{24} \mathrm{Na}$ tracer. Columns were made from 1.3-cm-diameter polycarbonate tubes $61 \mathrm{~cm}$ in length. The effective porosity was about $45 \%$ and the average effective pure diameter was approximately $70 \mu \mathrm{m}$. No significant amounts of kaolin were carried through the crushed rock columns when deionized water was used as the carrier. Less than $0.1 \%$ of the activity was recovered in a small peak at about one column volume. The activity of the labeled particles was highest at the top of the column and decreased steadily toward the bottom (Fig. 2-67).

When the carrier solution contained 500 to $1,250 \mathrm{mg} / \mathrm{l} \mathrm{NaCl}$, more kaolin particles passed through the column. The results are summarized in Table 2-105.

The first column void volume contains tracer which flows freely through the column and does not interact with the bed material. Part of this effect may be due to ionic ${ }^{24} \mathrm{Na}$ which is not bound to the kaolin. Maximum particulate flow was observed at $500 \mathrm{mg} / 2 \mathrm{NaCl}$, but higher concentrations actualiy increased particulate retention.

It can be concluded that fine suspended particles are likely to occur in deep aquifers near a repository site. Their size and shape depend on water quality. In high salt concentrations, colloidal aggregation occurs; however, migration of particles appears to be actually aided by moderately high sait concentrations. In "old" water containing appreciable concentrations of mineral ions, these ions may saturate sorption sites that may otherwise attract dispersed particulates.

\subsubsection{Effects of Radiation on Sorption}

Radiation from the waste canisters might be expected to cause chemical changes in their immediate surroundings which may affect the sorptive properties of the overpack, backfi11, and/or basalt. Radiation may cause changes in the chemical form or crystalline structure of these materials. In addition, radiolysis of the groundwater may yield products which could interact chemically with the dissoived radionuclides and/or the solid materials produced within the near field. No significant effect of radiation is expected in the far field because of low dose rates. 
RHO-BWI-ST -7

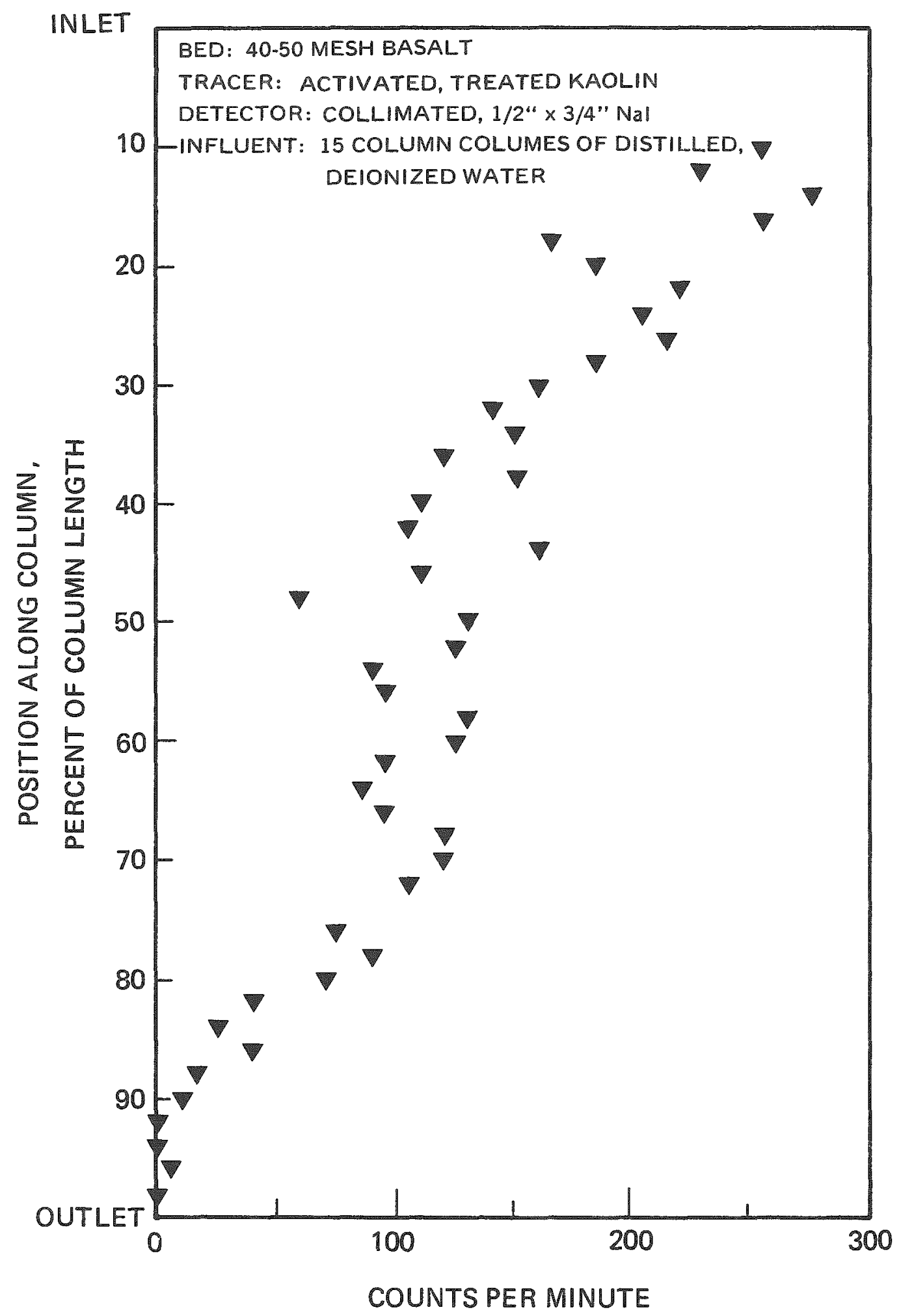

FIGURE 2-67. Distribution of Activated Kaolin throughout the Basalt Column after Particulate Flow Experiments (after Eichholz, 1979). 
TABLE 2-105. Migration of Kaolin Particles through Crushed Basalt Columns.

\begin{tabular}{c|c|c}
\hline $\begin{array}{c}\text { Added Salt } \\
\text { in Influent } \\
(\mathrm{mg} / \mathrm{l})\end{array}$ & $\begin{array}{c}\text { Percent of Tracer } \\
\text { Recovered in } \\
\text { First Pore Volume }\end{array}$ & $\begin{array}{c}\text { Percent of Tracer } \\
\text { Recovered after } \\
\text { First Pore Volume }\end{array}$ \\
\hline 0 & 1 & $\sim 1$ \\
500 & 0.6 & 83 \\
750 & 25 & 20 \\
1,250 & 1 & 15 \\
\hline
\end{tabular}

Preliminary results of batch-partitioning experiments using irradiated solutions and rock material have been reported (Seitz and others, 1979). Sorption of cesium, rubidium, and strontium on limestone was studied. The rock and groundwater tracer solutions were irradiated to test for effects near the solid waste. In addition, the traced groundwater was irradiated and contacted with non-irradiated rock to test for effects downstream from the solidified waste. Only results of the latter experiments were reported.

Solutions were given a dose of $07.5 \times 10^{7}$ rads prior to contact with the rock. This radiation dose is the same as that expected if the groundwater moves at a velocity of $12 \mathrm{~m}$ per year; the waste container is $15 \mathrm{~cm}$ in diameter and $244 \mathrm{~cm}$ long; the canister is steel $0.6 \mathrm{~cm}$ thick, the waste is aged 10 years, and initially generated 5,000 watts. The dose is the average expected in the initial 10 years of burial.

At this dose level, no effects were observed on sorption of the radionuclides. Partition coefficients were unchanged (within the limit of error for the experiments) when the irradiated, groundwater tracer solutions were contacted with limestone rock. Some additional research on radiation effects seems justified, however, using radionuclides with variable oxidation states since these would be most affected by radiolysis products of groundwater (i.e., $\mathrm{H}_{2}, \mathrm{O}_{2}, \mathrm{H}_{2} \mathrm{O}_{2}$, eic. ). If possible, irradiation of both rock and groundwater should occur simultaneously so that the effects of short-lived radiolysis products (radicals and other reactive species) on radionucidide sorption could be determined. 


\subsubsection{Summary}

The radionuclides which are of greatest concern in evaluating the safety of a nuclear waste repository in basalt are ${ }^{226} \mathrm{Ra},{ }^{237} \mathrm{~Np}, 233,234 \mathrm{U}$, $239,240,242 \mathrm{Pu}, 241,243 \mathrm{Am},{ }^{129} \mathrm{I},{ }^{79} \mathrm{Se},{ }^{99} \mathrm{TC},{ }^{135} \mathrm{Cs},{ }^{90} \mathrm{Sr},{ }^{126} \mathrm{Sn},{ }^{107} \mathrm{Pd}$, and ${ }^{93} \mathrm{Zr}$. These are present in the waste in substantial quantities after 1,000 years and have the greatest tendency to migrate from the repository. Overpack and backfill materials should be designed to retard the release of these radionuclides since they can be relatively mobile once they reach the geologic formation surrounding the repository.

The site for the repository should be selected so that sorption of radionuclides and flow path length are maximized. The reducing properties of the basalt will be important in determining the mobility of technetium, neptunium, and uranium. The reduced forms (TC(IV), Np(IV), and $U($ IV $)$ ) of these radionuclides are less mobile than the oxidized form normally found in solutions which are in contact with the atmosphere. $\mathrm{Fe}$ (II) in the basalt appears to be capable of reducing technetium and neptunium to immobile oxidation states.

Secondary minerals lining fissures in basalt have a higher sorption capacity than the basalt for most radionuclides. Therefore, to minimize radionuclide transport, the basalt formation chosen for the repository should have fissures which are lined (or preferably filled) with secondary minerals.

The repository should be placed as far away as practical from interflow and interbed units which are aquifers. These would Tikely be the main conduits for radionuclide transport from a breached repository to the biosphere. Results of preliminary sorption studies on interbed material (tuff and sandstone) show, however, that migration of some radionuclides will be strongly retarded in the interbeds.

A summary of $K_{d}$ values for key radionuclides is presented in Table 2-106. These values were selected from those obtained by Ames and MCGarrah (1979a) and by Wolfsberg and Others (1979, $K_{d}$ values for crushed tuff). It should be recognized that these values are valid only for the concentration ranges specified and are likely to be different at different tracer concentration and $\mathrm{pH}$. 
RHO-BWI-ST -7

TABLE 2-106. Selected $K_{d}$ Values.

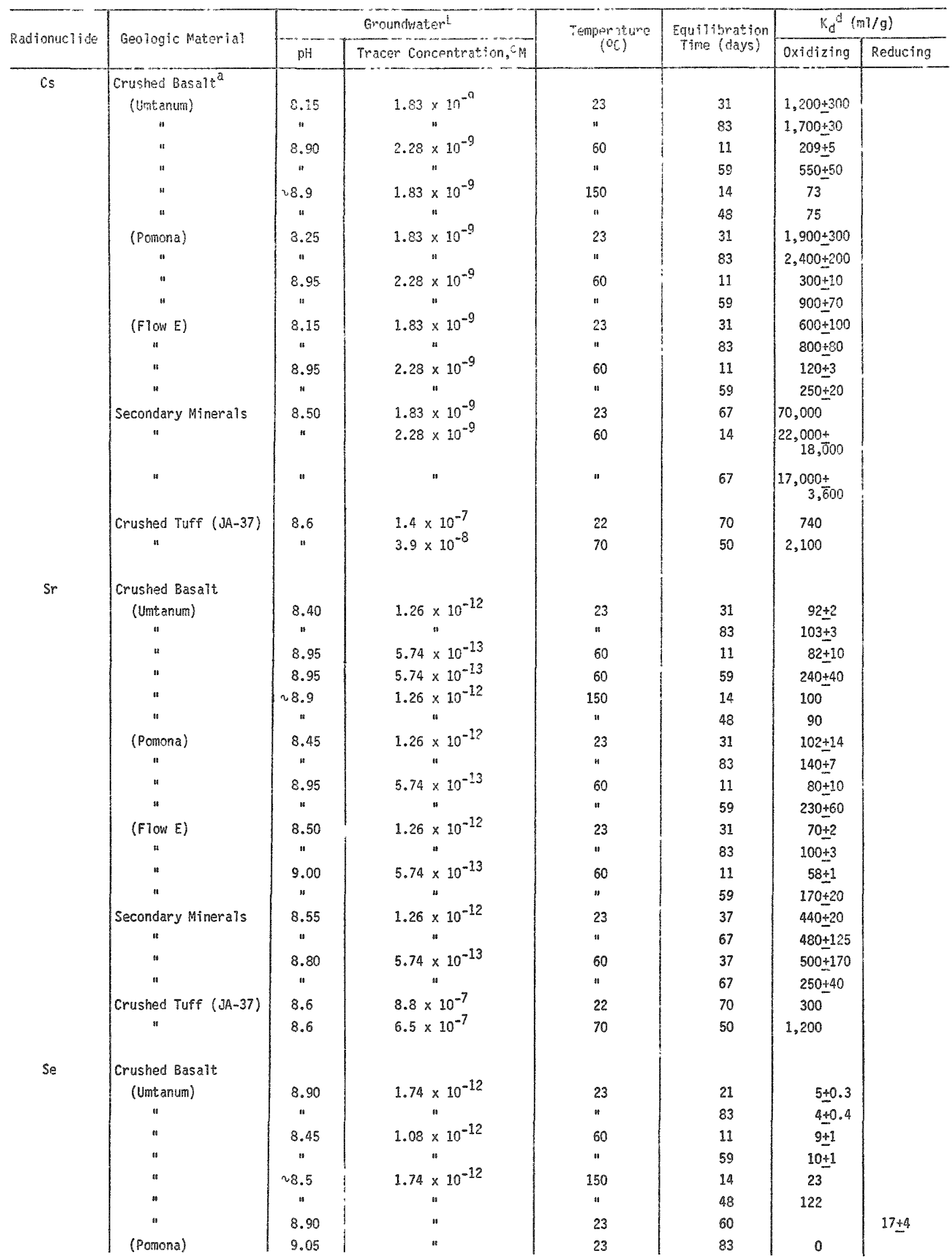




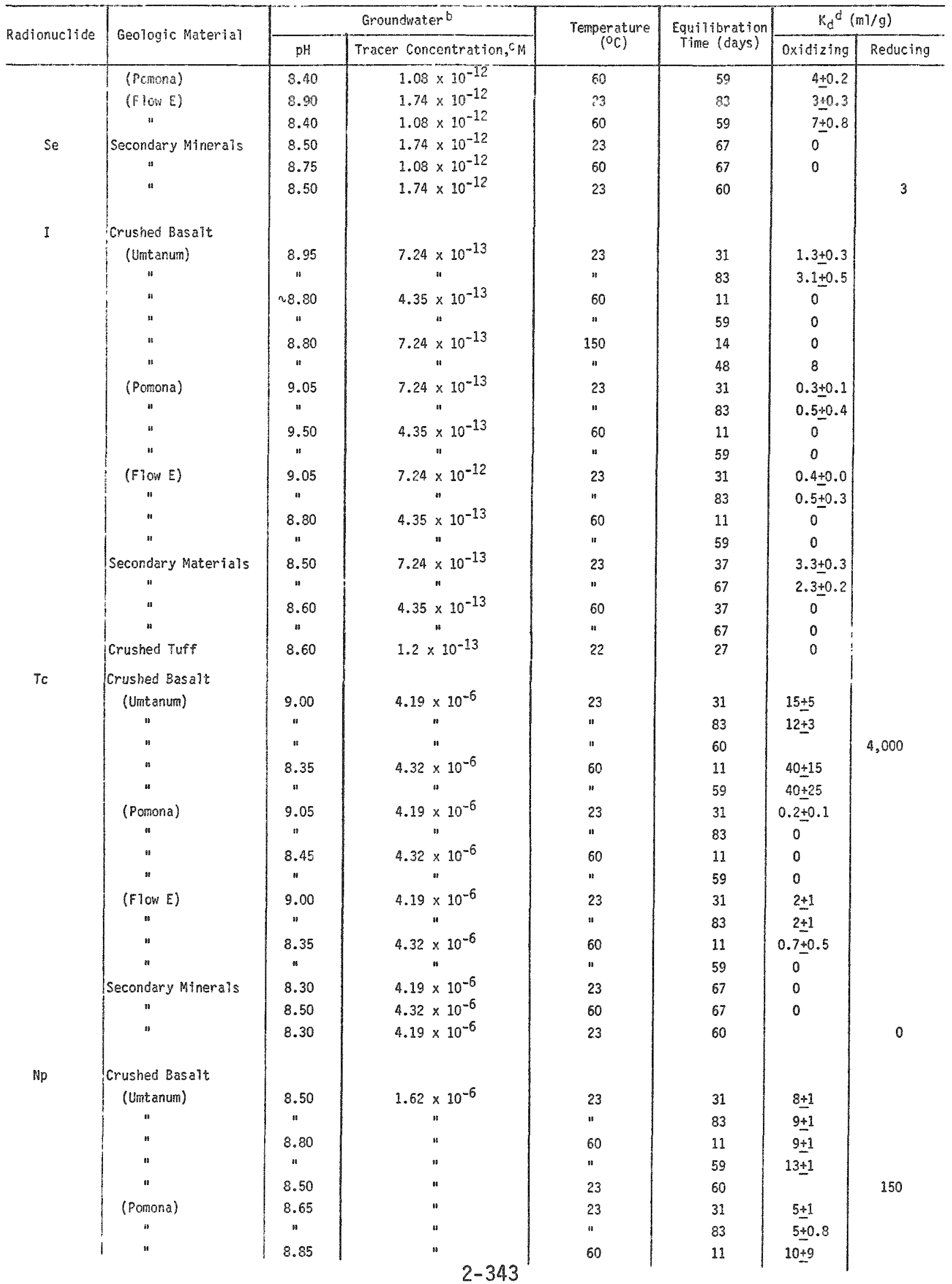


Table 2-106 (continued)

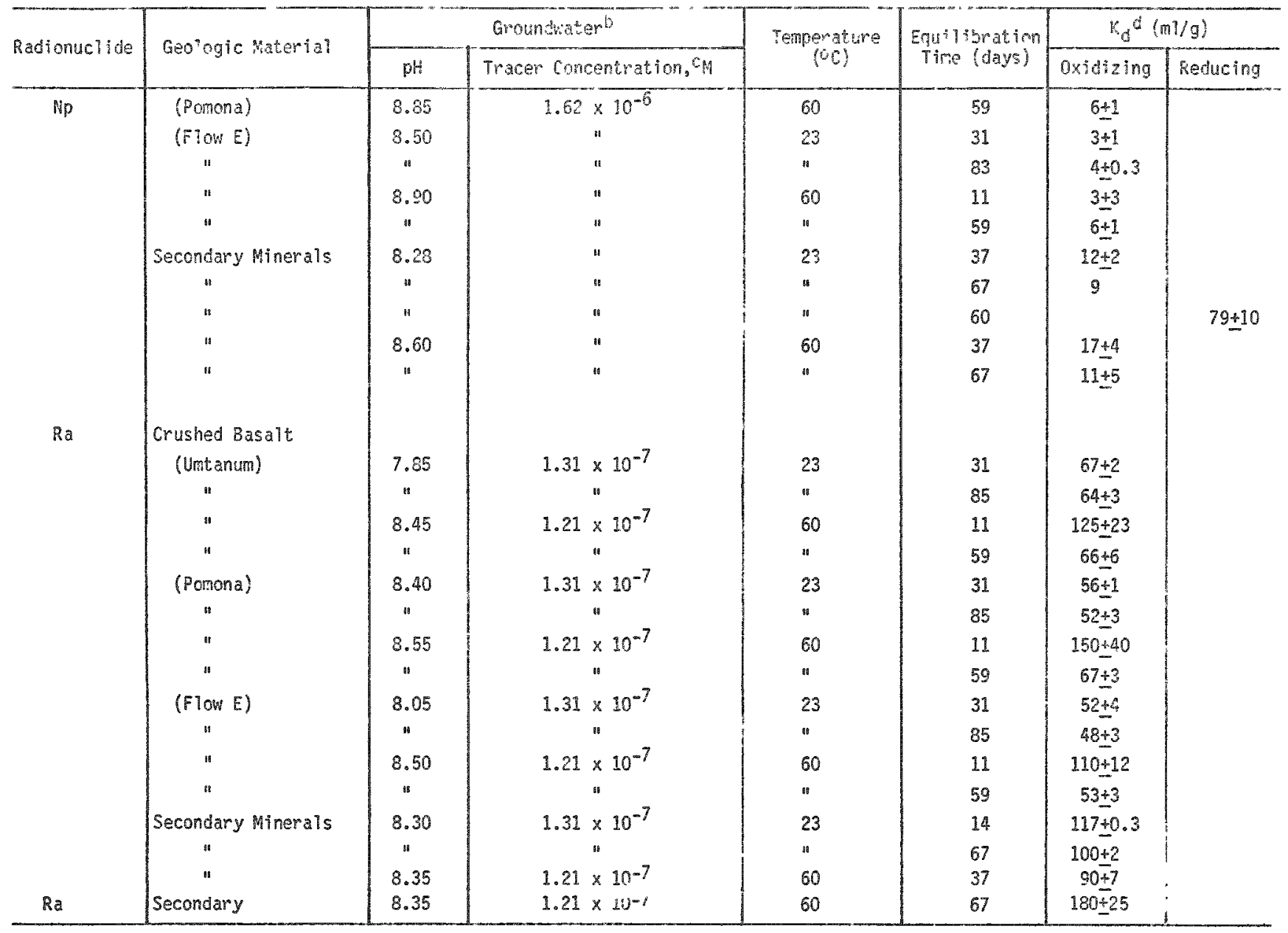

aparticle size range $20-50$ mesh.

bGroundwater compositions were as follows:

CInitial concentration (before equilibration). Solid/solution ratio was $1 \mathrm{~g} / 10 \mathrm{mi}$.

doxidizing $K_{d}$ values are for expewiments in aje reducing $K_{d}$ values are for experiments in law $0_{2}$ atmosphere ( $C_{2}$ partial pressure approximately $7.87 \times 10^{-7}$ atm.)

\begin{tabular}{c|c|c|c}
\hline \multicolumn{2}{|c|}{ Basalt and Secondary Hinerals } & \multicolumn{2}{|c}{ Crushed Tuff } \\
\hline Component & Concentration (mg/ $\mathrm{l})$ & Component & Concentration (mg/l) \\
\hline $\mathrm{Ma}^{+}$ & 30.7 & $\mathrm{Na}^{+}$ & 65 \\
$\mathrm{~K}^{+}$ & 9.0 & $\mathrm{~K}^{+}$ & 8.6 \\
$\mathrm{Ca}^{+2}$ & 6.5 & $\mathrm{Ca}^{+2}$ & 8.9 \\
$\mathrm{Mg}^{+2}$ & 1.0 & $\mathrm{Mg}^{+2}$ & 0.9 \\
$\mathrm{Cl}^{-}$ & 14.4 & $\mathrm{Cl}^{-}$ & 7.5 \\
$\mathrm{HCO}_{3}$ & 81.5 & $\mathrm{HCO}_{3}$ & 160 \\
$\mathrm{SO}_{4}$ & 11.1 & $\mathrm{SO}_{4}$ & 19 \\
$\mathrm{SiO}_{2}$ & 25 & $\mathrm{~F}^{-}$ & 2.3 \\
\hline
\end{tabular}


RHO-BWI-ST-7

\subsection{MODELING OF THE NEAR-FIELD ENVIRONMENT}

\subsubsection{Introduction}

In order to predict the long-term behavior of the engineered barrier system, it is necessary to understand the physical and chemical properties of the barriers and their environment throughout the life of the repository. Since it is not practical to perform experiments of more than a few months' or years' duration, the predictions of long-term behavior must rely on computer simulations that are rooted in precise short-term experimental results. This means that the modeling effort will facilitate the planning of hydrothermal experiments and barrier materials tests by identifying areas in which data are lacking or inadequate. When the short-term experiments can be satisfactorily modeled, the long-term simulations will provide input to far-field geosphere and biosphere transport modeis and risk assessment models.

For the purpose of this report, the behavior of the barrier system may be divided into those areas dependent on its chemical properties and those dependent on its physical properties. In the latter case, it will be necessary to know the thermal conductivities of the barriers in order to calculate heat flow and temperature gradients during the thermal period of the repository and to ensure that these are compatible with the mechanical and chemical stability of the system. The thermomechanical response of the barrier system to the heating-cooling cycle during this period will also be of great importance to its integrity. Thus far, however, the modeling effort has centered on the chemical behavior of the barrier system in the event of ingress of water into the repository. In this context it is necessary to evaluate the tendencies of different waste-form species towards immobilization within the engineered barriers and to determine which, if any, species can remain in solution. Immobilization can occur either by chemical precipitation or by sorption on surface or grain boundary sites within the barrier material. Available current data on sorptive processes were reviewed in Section 2.10 of this report. This section is directed mainly at dissolution and precipitation phenomena and their modeling in the near-field environment. 
Benson and Others (1979) have completed preliminary models of chemical interactions between groundwater and basalt and between groundwater, basalt, and spent fuel in the Pasco Basin. The simulations were performed using Wolery's (1979) Tocal equilibrium EQ3/EQ6 Code.

\subsubsection{The EQ3/EQ6 Mass Transfer Simulation Code}

The theoretical basis of the EQ3/EQ6 algorithm is the assumption that chemical changes occurring in an open system can be approximated by a series of equilibrium states. The code represents the following series of physical and chemical events, which are illustrated in Figure 2-68.

1. The program begins with a given amount of groundwater of known composition. This composition is examined by the EQ3 portion of the code to determine if any of the ionic species are supersaturated with respect to the mineral species in the data base. If so, the mineral phase is precipitated and the composition of the groundwater is recalculated to its equilibrium value.

2. The equilibrated water is brought into contact with a fixed amount of solid (rock or waste form or barrier material) as it flows through vesicles and fractures. It is assumed that the flow velocity is sufficiently low to allow chemical reactions to go to completion, thus attaining equilibrium in the water-solid system.

The EQ6 portion of the code determines which chemical reactions will occur and then recalculates the composition of the water. As in the first step, if any of the ionic species are supersaturated with respect to a mineral phase, that phase is precipitated out and a new aqueous composition is derived. Any precipitated solids are left behind and thus immobilized in the system.

3. The new $7 y$ equilibrated water flows through a fresh portion of the reacting solids and the entire process in Step 2 is repeated.

The precipitated phase(s) generated in Step 2 is physically separated from the groundwater derived in Step 2 and does not interact with the new segment of dissolving solids. This corresponds physically to the precipitation of secondary minerals on the sides of fractures and in vesicles. 


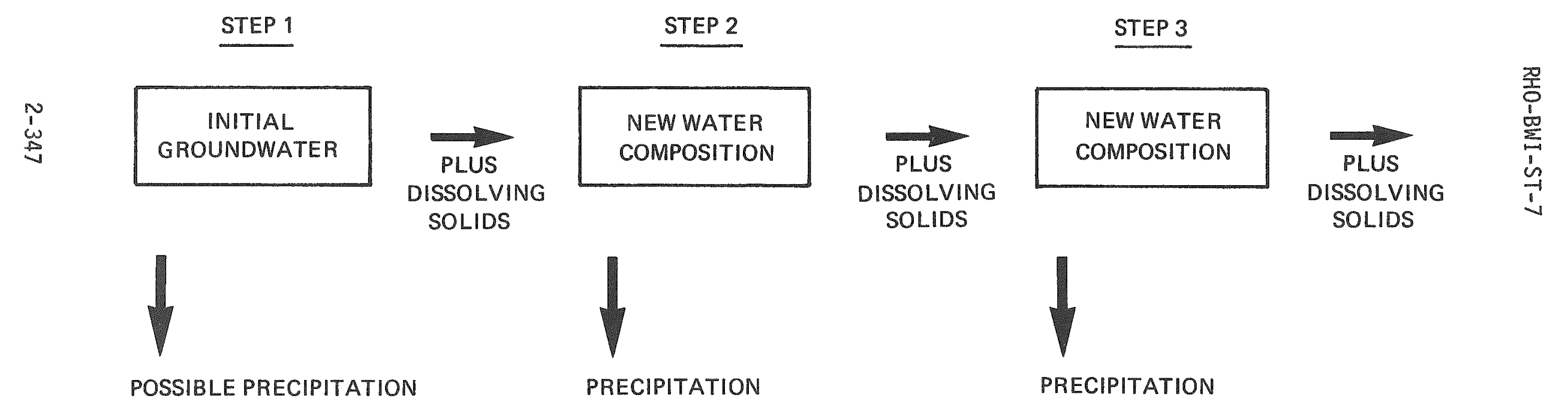

FIGURE 2-68. Local Equilibrium Mass-Transport as Modeled by the EQ3/EQ6 Mass Transfer Simulation Code. 


\section{RHO-BWI-ST-7}

Step 3 is repeated in the code as many limes as desired and each step is a closed system consisting of fresh reactant material and groundwater compositionally altered from chemical reaction in the previous step.

Each step in the progression is defined by an increasing extent of a reaction number $(Z)$ which represents the relative amount of reactant material converted by the aqueous phase. Output from the program for each step consists of the aqueous composition, $\mathrm{Eh}, \mathrm{pH}_{2} \mathrm{fO}_{2}$, and the identity, appearance, or disappearance of a precipitate phase.

This model has a number of advantages and disadvantages which need to be considered before the results can be realistically assessed. Its main attribute is that, because of the assumption of equilibrium, the only data required for a simulation run are the relative free energies of the aqueous and mineral species of interest. Many of the relevant free-energy data are well known and others can either be estimated or measured on a short time scale.

The main disadvantage of the method is that it models just one end member of the spectrum of possible chemical transport processes in nature. In the EQ3/EQ6 model it is assumed that fluid flow is sufficientiy slow for equilibrium to be reached at each point on the flow path. The other end member process which may be envisaged is one in which fluid flow is so rapid that there is no time for any reaction with the solid to take place. In practice, the observed precipitation and dissolution sequence will almost certainly depend both on equilibrium and rate or kinetic factors. A more sophisticated near-field model may, therefore, need to incorporate such factors as relative dissolution and precipitation rates. In addition, the near-field model will definitely need to incorporate the effects of radionuclide sorption in the engineered barrier system and on the host basalt.

The end-member equitibrium mode , with provision for sorption, may provide a good approximation to the processes occurring in a repository if the fluid-flow rate were indeed low enough for local equilibrium to be attained. In order to test the validity of this assumption, Benson and others (1979) have modeled the precipitation of secondary minerals in 
basalt in the Pasco Basin and correlated the predicted and observed groundwater chemistries and crystallization sequences.

\subsubsection{Groundwater-Basalt Interactions in the Pasco Basin}

For the purposes of modeling, a number of physical and chemical parameters were assumed which are simplifications of the real system. First, all simulations were done at temperature and pressure conditions of $25^{\circ} \mathrm{C}$ and 1 atmosphere even though repository site conditions (1,000-m depth) are estimated near $65^{\circ} \mathrm{C}$ and 100 atmospheres. This assumption was made because the thermodynamic data are best known at $25^{\circ} \mathrm{C}$ and the pressure and temperature dependencies of the mass transfer calculations are generally quite small. Secondly, the following assumptions about the Pasco Basin geology were made:

- The basalt host rock is chemically and physically homogeneous: i.e., the bulk composition, phase assemblages, and phase proportions are identical throughout the system.

- There is an effectively infinite reservoir of reactant phases.

- All basalts possess identical values of porosity, permeability, and tortuosity.

- There is a simple relationship between depth and the extent of the reaction. It is assumed that deeper groundwaters have passed through more basalt and hence, have reacted more than shall low groundwaters.

These assumptions are clearly simplifications of the real environment, but at this stage they are necessitated by the limitations of the program and by the availability of hydrologic and geologic information.

Reacting minerals of the basalt were taken to be clinopyroxene, plagioclase, feldspar, and glassy groundmass of the compositions given in Table 2-107. Although the code does not explicitly provide for the differing dissolution rates of the three reactant phases, they are implicitly accounted for by appropriate weighting of their proportions in the reacting assemblage. Thus, for example, the best agreement between observed and simulated products (discussed in more detail later) was obtained if plagioclase and groundmass were taken to dissolve much more readily than clinopyroxene. 
TABLE 2-107. Composition of Reactant Phases Used in EQ3/EQ6 Near-Field Simulations.

\begin{tabular}{l|c|c|c|c|c}
\hline Wt\% & Groundmass I & Groundmass II & Groundmass III & Plagioclase & Clinopyroxene \\
\hline $\mathrm{SiO}_{2}$ & 71.1 & 68.4 & 68.4 & 55.10 & 41.74 \\
$\mathrm{Al}_{2} \mathrm{O}_{3}$ & 13.5 & 13.0 & 13.0 & 26.95 & 1.97 \\
$\mathrm{FeO}_{\mathrm{MgO}}$ & 1.6 & 3.4 & 2.3 & -- & 16.63 \\
$\mathrm{CaO}$ & 0.5 & 0.5 & 0.5 & 0.60 & 16.43 \\
$\mathrm{Na}_{2} \mathrm{O}$ & 2.5 & 2.5 & 2.5 & 10.23 & 13.04 \\
$\mathrm{~K}_{2} \mathrm{O}$ & 1.2 & 1.2 & 1.2 & 5.26 & 0.25 \\
$\mathrm{Fe}_{2} \mathrm{O}_{3}$ & 2.5 & 6.3 & 6.3 & 0.47 & 0.01 \\
\hline
\end{tabular}

In all but one simulation the starting fluid composition was taken to be that of sierra snow and thus represented surface runoff. The fugacity of oxygen was set at 0.2 atmosphere and the partial pressure of carbon dioxide at 0.1 atmosphere. The composition of Columbia River water was used in one simulation to test the effect of an alternative recharge source on the model result. Initial fluid compositions used in the simulations are given in Table 2-108. Runs were not allowed to proceed past a $Z$ of 0.1 since the simulated $\mathrm{pH}$ at this extent of reaction usually exceeded the highest recorded field $\mathrm{pH}$ by at least two units.

The interrelationship between solution composition and the mineral phases which dissolve and precipitate during reaction of groundwater with basalt is illustrated schematically in Figure 2-69. The initial concentrations of all species other than $\mathrm{H}_{2} \mathrm{O}$ are extremely low in Sierra snow (Table 2-108). Total carbon is shown to be higher than the $1.6 \mathrm{mg} / \mathrm{l}$ in Sierra snow because, at a carbon dioxide pressure of 0.1 atmosphere, additional carbon as carbon dioxide dissolves in the water prior to contact with basalt. As the basalt dissolves, the concentrations of most elements except carbon, which has low abundance in basalt, increase steadily. The silicon content of the groundwater continues to increase until the solution becomes saturated in a silicate phase, in this case $\mathrm{SiO}_{2}$ (cristobalite). Thereafter, further dissolution is accompanied by cristobalite crystallization with a resulting net decrease in the concentration of silicon in solution. The silicon content of the 
solution decreases during cristobalite precipitation until the fluid is no longer saturated in $\mathrm{SiO}_{2}$. Cristobalite then stops precipitating. Thereafter, further dissolution of the basalt results in a linear increase in the silicon content of the solution. This trend continues until the solution becomes saturated in cristobalite again or until another silicate, probabiy smectite or clinoptilolite, precipitates. Thereafter, silicon would remain constant or decrease as before.

At the beginning of the simulation, most of the carbon is present in solution as dissolved $\mathrm{CO}_{2}$. As the extent of reaction progress increases, the $\mathrm{CO}_{2}$ present reacts with $\mathrm{OH}^{-}$ions in solution via the equilibria:

$$
\begin{aligned}
& \mathrm{CO}_{2}+\mathrm{OH}^{-} \rightleftarrows \mathrm{HCO}_{3}^{-} \\
& \mathrm{HCO}_{3}+\mathrm{OH}^{-} \rightleftarrows \mathrm{CO}_{3}^{-2}+\mathrm{H}_{2} \mathrm{O} \text {. }
\end{aligned}
$$

TABLE 2-108. Surface-Water Compositions $(\mathrm{mg} / \mathrm{l})$ Used as the Initial Groundwater Composition in the EQ3/EQ6 Near-Field Simulations.

\begin{tabular}{|c|c|c|}
\hline \multirow{2}{*}{ Composition } & \multicolumn{2}{|c|}{ Sample } \\
\hline & Sierra Snow & Columbia River \\
\hline $\mathrm{pH}$ & 4.9 & 8.7 \\
\hline $\mathrm{SiO}_{2}$ & 0.051 & 2.0 \\
\hline c & 1.4 & 8.3 \\
\hline $\mathrm{Cl}^{-}$ & 0.19 & 6.6 \\
\hline $\mathrm{SO}_{4}^{-2}$ & 0.2 & 8.1 \\
\hline $\mathrm{Na}$ & 2.37 & 1.2 \\
\hline k & 0.041 & 0.5 \\
\hline $\mathrm{Ca}$ & 0.082 & 0.15 \\
\hline $\mathrm{Mg}$ & 0.0071 & 3.7 \\
\hline $\mathrm{Fe}^{+3 *}$ & ND* & ND* \\
\hline
\end{tabular}

(After Brown and Skau, 1975; Apps and Others, 1979.) 


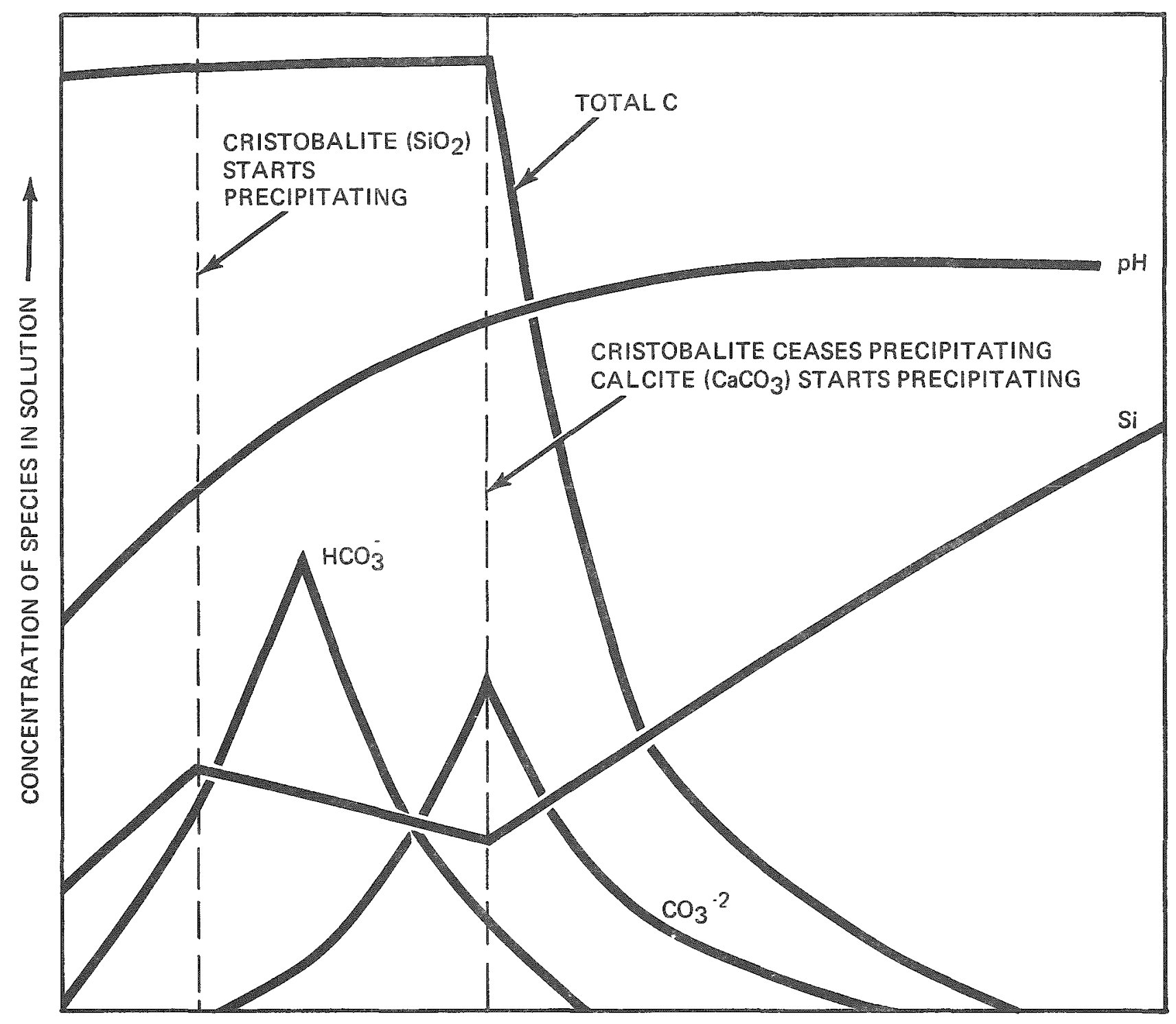

REACTION PROGRESS (Z)

FIGURE 2-69. Solution Species Concentrations and Solids Precipitating during Reaction of Groundwater with Basalt. Extent of reaction (2) and species concentrations are shown schematically. 
As the concentration of $\mathrm{OH}^{-}$ions in solution increases due to reaction with basalt, equilibrium is driven to the right, producing the $\mathrm{HCO}_{3}{ }^{-}$shown in the left-hand side of Figure 2-69. At increasingly higher values of $\mathrm{pH}$, however, equilibrium (2) dominates and further reaction converts the $\mathrm{HCO}_{3}{ }^{-}$generated into $\mathrm{CO}_{3}{ }^{-2}$. These competing reactions produce the maximum in $\mathrm{HCO}_{3}$ content shown in Figure 2-69. With large amounts of $\mathrm{CO}_{3}^{-2}$ being generated with increasing extent of reaction (and $\mathrm{OH}^{-}$content), the solution eventually becomes saturated in calcite $\left(\mathrm{CaCO}_{3}\right)$, which precipitates during further reaction. For the purposes of illustration, the point at which calcite starts to precipitate has been shown on Figure 2-69 as corresponding to the point at which cristobalite ceases forming. As calcite precipitates, the total carbon content of solution decreases dramatically due to its immobilization in the solid phase.

The simulation may be run to any desired extent of reaction. It is generally halted, however, at the point where $\mathrm{pH}$ (which increases during reaction) exceeds the observed values of $\mathrm{pH}$ by 1 to 2 units.

\subsubsection{Results of Groundwater-Basalt Simulations}

The behavior of species for which analytical and thermodynamic data are available have been calculated by Benson and others (1979) in their simulations of basalt-groundwater interactions. The compositions of actual and simulated groundwaters are listed in Table 2-109 and compared at three arbitrary depth categories; shallow, intermediate, and deep. Average concentrations of the aqueous species as well as pH are listed together with the range of reported values. The depth ranges from which the analyzed water samples were taken are shown next to the analyses. Below each actual composition is an average simulated composition for the group of runs which most nearly approximated the natural compositions, the range of ionic species concentration, and the range of $Z$ values at which the aqueous compositions were derived.

A number of aqueous species show concentration trends with increasing depth which are reproduced by simulations when correlated with increasing extent of reaction 2 . For example, $\mathrm{SiO}_{2}$ and $\mathrm{Na}$ values increase in both actual and simulated groundwaters. Also, pH increases with depth 
TABLE 2-109. Simulated Groundwater Compositions which Best Reproduce Actual Groundwater Compositions as a Function of Increasing Depth or Extent of Reaction ( $Z$ )

(After Benson and Others, 1979.)

\begin{tabular}{|c|c|c|c|c|c|c|c|c|c|c|c|}
\hline Type & $\operatorname{Depth}(m)$ or $Z$ & pH & $\mathrm{SiO}_{2}$ & $c$ & $\mathrm{Cl}^{-}$ & $\mathrm{SO}_{4}^{-2}$ & $\mathrm{Na}$ & k & $\mathrm{Ca}$ & $\mathrm{Mg}$ & $\mathrm{Fe}^{+3}$ \\
\hline Actual & $\begin{array}{l}150-300 \\
\text { (shat low) }\end{array}$ & $\begin{array}{l}7.7 \\
7.3-8.3\end{array}$ & $\begin{array}{l}45 \\
39-50\end{array}$ & $\begin{array}{l}25 \\
17-37\end{array}$ & $\begin{array}{l}5 \\
3-6\end{array}$ & $\begin{array}{l}13 \\
10-18\end{array}$ & $\frac{11}{5-21}$ & $\begin{array}{l}2.8 \\
1.5-5.2\end{array}$ & $\begin{array}{l}23 \\
23-24\end{array}$ & 9 & $\begin{array}{l}0.008 \\
0.003-0.016\end{array}$ \\
\hline Simulated & $\begin{array}{l}0.0024- \\
0.0075(2)\end{array}$ & $\begin{array}{l}6.9 \\
6.1-7.6\end{array}$ & $\begin{array}{l}26 \\
22.3- \\
26.8\end{array}$ & $\begin{array}{l}38 \\
34.8- \\
38.8\end{array}$ & $=$ & - & $\stackrel{16}{9.23-21.1}$ & $\begin{array}{l}2.8 \\
1.5-2.2\end{array}$ & $\begin{array}{l}31.5 \\
16.4-42.9\end{array}$ & $\begin{array}{l}0.145 \\
0.19 \mathrm{E}-06- \\
0.496\end{array}$ & $\begin{array}{l}0.16 E-05 \\
0.16-07 \\
0.40 E-05\end{array}$ \\
\hline Actual & $\begin{array}{l}300-500 \\
\text { (intermediate) }\end{array}$ & $\begin{array}{l}8.3 \\
7.6-8.8\end{array}$ & $\begin{array}{l}62 \\
52-75\end{array}$ & $\begin{array}{l}38 \\
29-56\end{array}$ & $\begin{array}{l}18 \\
3.8-81\end{array}$ & $\begin{array}{l}14 \\
0-50\end{array}$ & $\begin{array}{l}62 \\
16-122\end{array}$ & $\begin{array}{l}11.3 \\
5.4-17\end{array}$ & $\begin{array}{l}14 \\
0.8-44\end{array}$ & $\begin{array}{l}5.7 \\
0.15\end{array}$ & $\begin{array}{l}0.05 \\
0.03-0.08\end{array}$ \\
\hline Simulated & $0.02(z)$ & $\begin{array}{l}9.4 \\
(9.2-9.5)\end{array}$ & $\begin{array}{c}24.2 \\
(13.8- \\
34.6)\end{array}$ & $\begin{array}{l}11.5 \\
(8.8- \\
14.2)\end{array}$ & - & - & $\begin{array}{l}10.0 \\
(0.003- \\
20.0)\end{array}$ & $\begin{array}{l}22.5 \\
(14.6= \\
30.3)\end{array}$ & $\begin{array}{l}2.1 \\
(1.09-10) \\
3.10)\end{array}$ & $\begin{array}{l}4.2 \\
(0.16 \mathrm{E}-10- \\
8.385)\end{array}$ & $\begin{array}{l}0.000 \\
(0.0002-n .000\end{array}$ \\
\hline Actual & $\begin{array}{c}900-1,150 \\
\text { (deep) }\end{array}$ & $\begin{array}{l}10.0 \\
9.7-10.3\end{array}$ & $\begin{array}{l}43 * \\
43 *\end{array}$ & $\begin{array}{l}28 \\
23-35\end{array}$ & $\begin{array}{l}117 \\
94-148\end{array}$ & $\begin{array}{l}48 \\
10-108\end{array}$ & $\begin{array}{l}206 \\
176-250\end{array}$ & $\begin{array}{l}3.6 \\
1.9-5.9\end{array}$ & $\begin{array}{l}0.9 \\
0.6-1.3\end{array}$ & $\begin{array}{l}0.56 \\
0-2.0\end{array}$ & $\begin{array}{l}0.30 \\
0-0.65\end{array}$ \\
\hline Simulated & $\begin{array}{l}0.0125 \\
0.0200(z)\end{array}$ & $\begin{array}{l}9.6 \\
(8.9-10.5)\end{array}$ & $\begin{array}{c}37.6 \\
(22.6- \\
56.4)\end{array}$ & $\begin{array}{l}8.9 \\
(1.03- \\
15.6)\end{array}$ & - & $\because$ & $\begin{array}{l}38 \\
(30.3- \\
47.1)\end{array}$ & $\begin{array}{c}0.91 E-03 \\
(0.0013- \\
0.42 E-04)\end{array}$ & $\begin{array}{l}2.94 \\
(1.43- \\
3.76)\end{array}$ & $\begin{array}{c}0.65 \mathrm{E}-10 \\
(0.51 \mathrm{E}-12- \\
0.19 \mathrm{E}-09)\end{array}$ & $\begin{array}{c}0.92 E-03 \\
(0.35 E-93- \\
0.0013)\end{array}$ \\
\hline
\end{tabular}

All values except $\mathrm{pH}$ are expressed as $\mathrm{mg} / \mathrm{h}$.

*Value corrected to $25^{\circ} \mathrm{C}$, assuring cristobalite saturation in order to provide valid comparison with $25^{\circ} \mathrm{C}$ simulation runs. 
and $Z$. $K$ values maximize at intermediate depths and $Z$ in both types. On the other hand, the actual total carbon concentrations are essentially constant at all depths, but simulated carbon concentrations decrease with increasing 2 . This is due to the fact that calcite precipitates in most simulation runs, producing a loss of carbon in the fluid, but calcite appears only rarely in the secondary mineralization of basalt. This may be the result of the apparent readiness of natural groundwaters to be supersaturated with respect to calcite, but not to precipitate this phase (Benson and Others, 1979). Thus, in this respect, the evolution of natural groundwaters may involve some chemical disequilibrium.

Major differences between actual and simulated groundwater occur principaily in the concentrations of iron and magnesium. These arise from differences in the crystallization sequences between observed and simulated groundwater-basalt interactions. For example, in the simulations, iron oxides (either hematite or magnetite) were commoniy calculated to precipitate soon after dissolution of the basalt begins. However, the natural secondary mineral assemblages rarely contain these iron oxides. This feature results in the natural groundwater being substantially richer in iron than the simulated groundwater.

The most common order of crystallization of solids generated by the EQ3/EQ6 code was iron oxide (hematite or magnetite), gibbsite, kaolinite, smectite or B-cristobalite, clinoptilolite, calcite. The most abundant natural minerals were calcite, kaolinite and $\beta$-cristobalite (Table 1-110). Smectite and clinoptilolite were calculated to be minor phases. Differences between the observed and calculated mineral assemblages apart from those discussed above center around the abundances of smectite (a clay mineral) and clinoptilolite (a zeolite). In altered basalts these two phases are found to be the most abundant, whereas in the simulations, they were found to be of lesser importance (Table 2-110). Gibbsite and kaolinite precipitate in the simulations but do not occur in the observed secondary mineral assemblages. 
TABLE 2-110. Moles of Secondary Minera Ts Produced in Simulated Basalt-Groundwater Reactions $(z=0.02)$.

(After Benson and Others, 1979.)

\begin{tabular}{l|l|l|l}
\hline \multirow{2}{*}{ Mineral } & \multicolumn{3}{|c}{ Reactant Proportions* } \\
\cline { 2 - 4 } & Run 346 & Run 345 & Run 272 \\
\hline Magnetite $\left[\mathrm{Fe}_{3} \mathrm{O}_{4}\right]$ & $0.1 / 1 / 1$ & $100 / 10 / 1$ & $1 / 10 / 1$ \\
Gibbsite $\left[\mathrm{A}(\mathrm{OH})_{3}\right]$ & $0.196 \mathrm{E}-03$ & $0.130 \mathrm{E}-02$ & $0.383 \mathrm{E}-04$ \\
Calcite $\left.\mathrm{CaCO}_{3}\right]$ & $0.190 \mathrm{E}-04$ & $0.513 \mathrm{E}-05$ & $0.261 \mathrm{E}-02$ \\
Kaolinite $\left[\mathrm{Al}_{4} \mathrm{Si}_{4} \mathrm{O}_{10}(\mathrm{OH})_{8}\right]$ & $0.201 \mathrm{E}-02$ & $0.321 \mathrm{E}-02$ & $0.315 \mathrm{E}-02$ \\
B-Cristoba7ite $\left[\mathrm{SiO}_{2}\right]$ & $0.247 \mathrm{E}-02$ & $0.730 \mathrm{E}-03$ & $0.379 \mathrm{E}-02$ \\
Clinoptilo & $0.312 \mathrm{E}-02$ & $0.177 \mathrm{E}-02$ & $0.119 \mathrm{E}-02$ \\
Smectite $(\mathrm{ZeO} 7 \mathrm{Cl}$ ay) & $0.348 \mathrm{E}-03$ & -- & $0.172 \mathrm{E}-03$ \\
\hline
\end{tabular}

*Clinopyroxene/plagioclase/groundmass.

Benson and Others (1979) have suggested a number of alterations in the algorithm which may improve correlations between the simulated and observed basalt-groundwater interactions. They include the following:

- Calcite could be removed from the program as a possible precipitate, thus removing it as a possible carbon sink. In order to prevent unacceptably high calcium concentrations in the aqueous fluid, a phosphorous component would be added to the reactant assemblage (in the groundmass) thus allowing a calcium phosphate phase to be a precipitate. Also, another calcium-rich phase, mordenite, which is found at depth in the real system, should be added to the data base.

- No chlorine or sulphur values were actually computed in the simulated groundwaters. This is because chlorine- and sulphur-bearing mineral phases are not included in the data base nor have chlorine or sulphur been determined in the original groundwater compositions. These values and the mineral phases gypsum $\left(\mathrm{CaSO}_{4} \cdot 2 \mathrm{H}_{2} \mathrm{O}\right)$ and halite $(\mathrm{NaCl})$ should be added to the data base. Gypsum has been observed in the actual system.

- Smectite and clinoptilolite are characterized by large ion exchange capacities. The current code needs to be modified to include sorption processes. 
Other discrepancies between actual and simulated data are not easily explained and include the following: (1) the occurrence of two secondary minerais in the simulated crystallization sequence, gibbsite and kaolinite, which are not observed in the actual system; and (2) the differences between the proportions of secondary minerals that are produced in the simulated as opposed to the actual system; e.g., the relatively large proportion of B-cristobalite and small proportions of smectite and clinoptilolite produced.

The inability of the model to predict solution and solid compositions exactly is probably due to a combination of reasons. First, at the low temperatures involved $\left(\sim 65^{\circ} \mathrm{C}\right)$ reaction rates are slow and the assumption that chemical equilibrium is attained is unlikely to be completely correct. In addition, there are uncertainties in the current thermodynamic data base (see Section 2.11.8) that can cause appreciable discrepancies between observed and simulated compositions even if local equilibrium is attained.

Given the uncertainties in the available thermodynamic data and the likely influence of variable reaction rates, it must be concluded that the agreement between observed and simulated assemblages is encouraging. It is reasonable to expect that mass transfer processes within the repository could be modeled with a fair degree of accuracy using the local equilibrium approach with the modifications suggested above.

\subsubsection{Waste-Basalt-Groundwater Interactions}

The modeling of interactions between wasteforms, basalt, and groundwater is, in principle, readily performed using the EQ3/EQ6 code. If such interactions were to occur in the repository, they would arise from ingress of water into the near-field environment and failure of backfi11, overpack, and canister materiais. Thus, as shown in Figure 2-68, the code should be used in a flow-through mode to predict the consequences of barrier failure. The steps illustrated in Figure 2-68 would be used to model the flow-through process as follows:

1. Reaction of groundwater with basalt

2. Removal from basalt and reaction with barrier system components 
3. Flow from barrier system and reaction with waste form

4. Removal from waste form and reaction with barrier system components on exit

5. Reaction with basalt outside the barrier system.

A complete simulation of this type cannot be performed at present because of the lack of thermodynamic data for most of the elements in commercial nuclear waste. This is particulariy true of the actinides and many of the fission products, including cesium, strontium, and technetium. There are also, at present, only limited data on the precise nature of the phases present in potential waste forms, particularly in spent fuel (see Section 2.6).

As a first approximation to the type of interactions that might be obtained in the system described above, Benson and others (1979) have performed simulations involving groundwater, basalt, and spent fuel where the latter two components are mixed homogeneously together. The proportions of oxides in the spent fuel used by Benson and Others (1979) in the simulations are shown in Table 2-111.

TABLE 2-111. Mole Fractions of Principal Oxides in Light Water Reactor Fuel Cycle Waste Used in Groundwater/ Basalt/Spent Fuel Near-Field Simulations.

(After Benson and Others, 1979.)

\begin{tabular}{l|l}
\hline Oxide & Mole Fraction \\
\hline $\mathrm{PuO}_{2}$ & 0.00768 \\
$\mathrm{UO}_{2}$ & 0.98854 \\
$\mathrm{Cs}_{2} \mathrm{O}$ & 0.00188 \\
$\mathrm{SrO}$ & 0.00191 \\
\hline
\end{tabular}

The reactant phase assemblage was made up in the proportions clinopyroxene:plagioclase: groundmass:spent fuel equals 1:10:1:10. The permitted precipitates included hematite, gibbsite, kaolinite, smectite, clinoptilolite, $\beta$-cristobalite, strontianite, celestite, and uranium solid and aqueous species whose thermodynamic properties have been collected by Langmuir (1978). Calcite precipitation was permitted in one simulation. 


\subsubsection{Results}

In simulations where calcite formulation was depressed, clinoptilolite precipitated first followed by the uranium-bearing phases uranophane $\left[\mathrm{Ca}\left(\mathrm{UO}_{2}\right)_{2}\left(\mathrm{SiO}_{3} \mathrm{OH}\right)_{2}\right]$ and coffinite (USiO 4$)$. Uranium increases in solution until these phases precipitate (Fig. 2-70). Coffinite precipitates immediately after a steep drop in $\mathrm{fO}_{2}$.

Addition of plutonium species to the data base resulted in a numerical instability due to a rapid drop in $\mathrm{fO}_{2}$. The simulation aborted at this point. This problem has been resolved and future simulations involving dissolution and precipitation of plutonium-bearing phases are planned. No cesium-bearing phase was observed to precipitate in the simulations. This is because only data for relatively soluble cesium compounds are currently available. In practice, the insoluble cesium silicate pollucite ( $\mathrm{CsAlSi}_{2} \mathrm{O}_{6} \cdot \mathrm{nH}_{2} \mathrm{O}$ ) is observed to precipitate during hydrothermal experiments (Komarneni and Others, 1980).

\subsubsection{Future Work}

The near-field model simulations completed to date illustrate areas of study in which further research must be concentrated. First, an attempt will be made to rectify the deficiencies in the model of the evolution of current Hanford groundwater. Second, the major emphas is will shift from modeling the groundwater-rock interaction in the Pasco Basin system as a whole to modeling the chemical reactions occurring between rock-groundwater-waste in the near canister region.

Two processes other than local equilibrium which may have significant effects on the chemical relationships in the basalt-waste system are sorption and dissolution kinetics. Consideration of these processes will require modification of the algorithm and expansion of the data base. The conceptual limitations of the present code may require adoption of an additional new code to accormodate these processes. Modeling of kinetically-controlled reactions, for example, requires the introduction of a time parameter into the algorithm. The extension of the code to include sorption and reaction kinetics will require expansion of the current data base. Sorption experiments for basalt and the alteration products of basalt are aiready under way (see Section 2.10) and will be 
RHO-BWI-ST-7

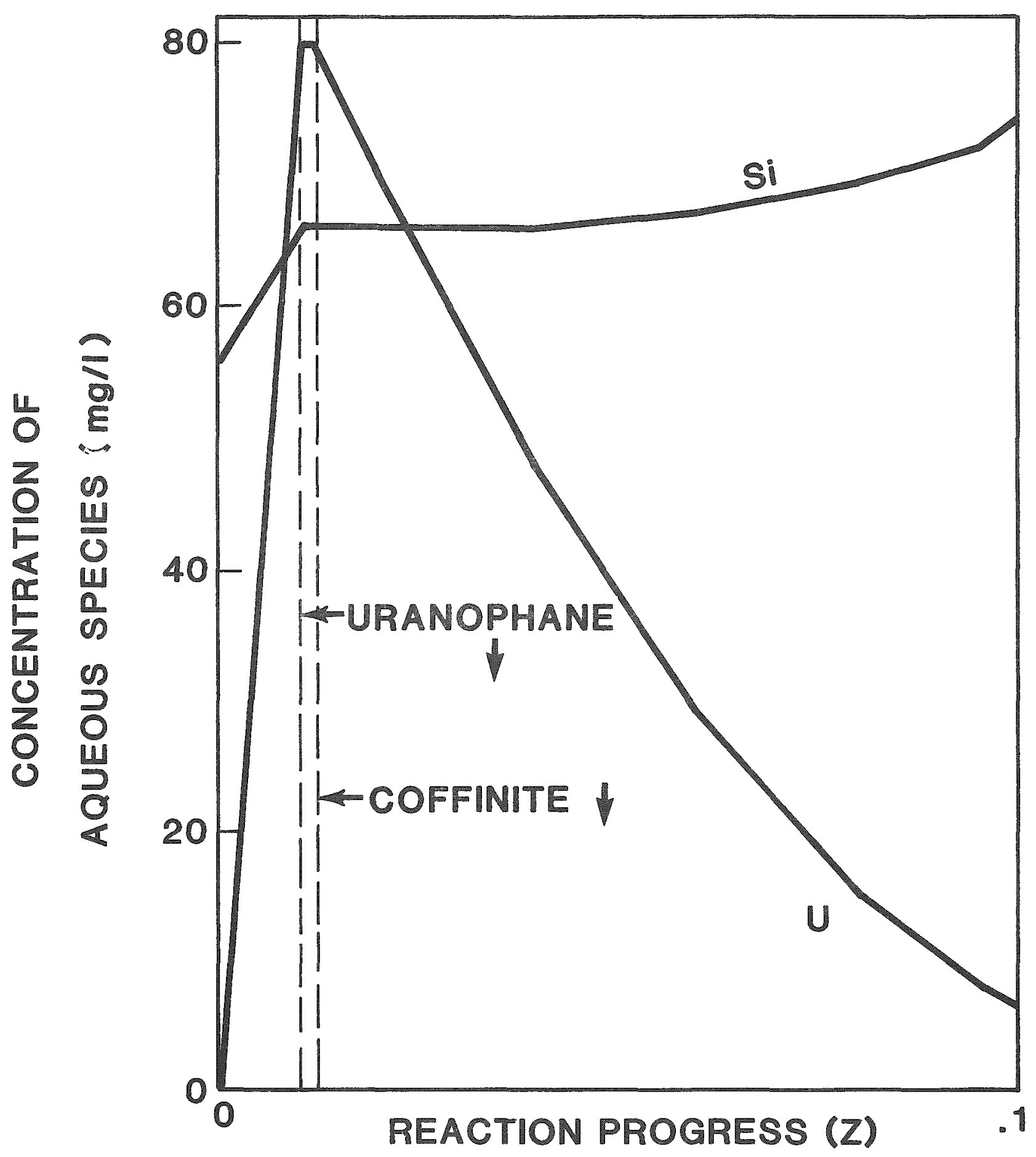

FIGURE 2-70. Dissolution of Spent Fuel and Basalt by Groundwater in Spent Fuel/Basalt/Groundwater Near-Field Simulations. 
performed in such a way that they interface with sorption algorithms being developed for the code. There is also a need for some understanding of the processes involved in the dissolution of basalt minerals so that relative reaction rates can be included in the simulations.

The spent fuel-basalt-groundwater results reported above were performed only for uranium and cesium components in the waste form. These simulations were limited by the current lack of adequate thermodynamic data for most of the important radionuclides. One task is to review the literature, gather thermodynamic data for all important radionuclide species (both aqueous and solid), and identify data that are missing and must be experimentally derived. Second, sorption data for radionuciides on the secondary minerals found in the system--smectite, silica, clinoptilolite, and mordenite--must be acquired. Third, the dissolution rate data for the primary reactant phases; i.e., the waste form, the canister, and the basait and secondary mineral phases must be obtained. These data must be derived for a temperature range likely to occur under repository conditions. This effort will initially highlight the areas in which experimental thermodynamic, dissolution, and sorption data are required before the modeling effort can advance. Experiments will then be performed to supplement the data base as required.

The near-field model will be used to simulate flow-through systems involving waste, basalt, canister, overpack, and backfill materials. The results will serve as input to the flow-through hydrothermal experiments which will be started in fiscal year 1982. The model will pinpoint areas where experiments are required and these experiments will provide a means of checking and improving the model. When the model can accurately simulate flow-through experiments under the range of conditions that are expected in the repository, it will be possible to make valid predictions of the long-term chemical behavior of the near-field environment.

\subsubsection{Thermodynamic Data Base Development}

The elements of the data base for the EQ3/EQ6 code include thermodynamic data for minerals and aqueous species along with mass balance relationships, and acid-base and redox equations which control 
the $\mathrm{fO}_{2}, \mathrm{pH}$, and $\mathrm{Eh}$ of the aqueous phase. Thermodynamic data for common rock-forming minerals make up the initial data base. Sources for these data were taken from Helgeson and Others (1978). Not inciuded in the initial data base are the compositions or free energies of formation of the two major secondary minerals found in the Pasco Basin basalts, smectite and clinoptilolite. These two secondary minerals represent structures with large solid solution capabilities. Thus, average compositions of these minerals are given in Table 2-112 together with the range in both weight percent and mole percent. In the mole percent column, $\mathrm{Fe}^{+2} / \mathrm{Fe}^{+3}$ is indicated by dividing the total abundance of iron oxide between $\mathrm{Fe}_{2} \mathrm{O}_{3}$ and $\mathrm{FeO}$ based on wet chemical data. The $\Delta \mathrm{G}_{f}^{\circ}, 298.15$ has not been determined experimentally for these minerals. Therefore in order to make the simulation, Benson and Others (1979) reviewed the literature concerning free energy extrapolation methods. They calculated $\Delta G_{f}^{\circ}, 298.15$ of average smectite and clinoptilolite using a modified version of the approximation method developed by Tardy and Garreis (1974). The approximation methods, although not very reliable, do appear to give free energy estimates which yield reasonable agreement between observed and simulated secondary mineral assemblages. Benson and others (1979) obtained values of $\Delta G_{f}^{0} 298.15$ of $1,239.58 \mathrm{kc} / \mathrm{mol}$ for average smectite and $-8305.4 \mathrm{kc} / \mathrm{mol}$ for clinoptilolite.

The agreement between observed and simulated assemblages using, in part, estimated free-energy data suggests that a similar approach could provide some preliminary data for elements for which compound data are currently lacking. In particular, one may take advantage of the analogous chemicai behavior of some actinide and lanthanide elements to estimate data for the former from those of the latter. Brookins (1978) suggested, for example, that analogies may be drawn between europium and americium and between americium and curium. Use of such analogs could enable construction of a preliminary data base, which would be updated as information from the hydrothermal experiments became available. 
TABLE 2-112. Chemical Composition of Average Hanford Smectite and CTinoptilolite.

\begin{tabular}{|c|c|c|c|c|}
\hline \multirow{2}{*}{ Component } & \multicolumn{2}{|c|}{ Smectite } & \multicolumn{2}{|c|}{ Clinoptilolite } \\
\hline & Wt\% & Mole\% & wt\% & Mole\% \\
\hline $\mathrm{SiO}_{2}$ & $50.20 \pm 3.76$ & 3.64 & $68.51 \pm 2.28$ & 29.84 \\
\hline $\mathrm{Al}_{2} \mathrm{O}_{3}$ & $5.88 \pm 2.30$ & .296 & $12.34 \pm 0.45$ & 3.17 \\
\hline $\mathrm{Fe}_{2} \mathrm{O}_{3}$ & $24.07 \pm 5.51$ & .358 & $0.13 \pm 0.07$ & .021 \\
\hline FeO & - & .199 & - & - \\
\hline $\mathrm{CaO}$ & $1.67 \pm 1.32$ & .139 & $1.13 \pm 0.50$ & .527 \\
\hline $\mathrm{BaO}$ & $0.06 \pm 0.08$ & .001 & $0.42 \pm 0.10$ & .072 \\
\hline $\mathrm{Na}_{2} \mathrm{O}$ & $1.68 \pm 0.81$ & .228 & $3.09 \pm 0.62$ & 1.305 \\
\hline $\mathrm{K}_{2} \mathrm{O}$ & $1.26 \pm 1.16$ & .074 & $3.02 \pm 0.99$ & .839 \\
\hline MgO & $6.93 \pm 4.18$ & 1.12 & $0.02 \pm 0.01$ & .013 \\
\hline $\mathrm{H}_{2} \mathrm{O}$ & 8.25 & 1.00 & 11.34 & 16.47 \\
\hline
\end{tabular}


-

- 
RHO-BWI-ST-7

\subsection{BOREHOLE PLUGGING}


○

- 


\subsection{BOREHOLE PLUGGING}

\subsection{INTRODUCTION}

One important feature that will determine the success of a repository located in basalt is the ability to seal the facility at the end of the operational period. The technology required to develop this capability must be explored in sufficient depth to ensure the safety and licensability of the repository as well as the isolation of waste components from man. In order to achieve this objective, a borehole plugging study is being conducted by the engineered barriers group of the Basalt Waste Isolation Project to develop, test, and demonstrate materials, equipment, and techniques for plugging the various man-made openings (boreholes, shafts, and tunnels) in and around the repository. These plugs are intended to:

- Severely restrict groundwater transport of toxic materials by both physical and chemical retardation

- Isolate water-bearing zones from the repository in order to maximize the travel time of migrating radionuclides

- Provide structural strength to maintain the stability of the plug zone and prevent subsidence

- Exhibit compatibility with the host geology and geologic environment in basalt

- Exhibit longevity for the required period of isolation.

The U.S. Nuclear Regulatory Commission (NRC, 1980) has recent7y proposed licensing procedures for disposal of high-level radioactive wastes at geologic repositories. The proposed ruling sets forth requirements applicable to submitting a license application for such a facility. Several of these requirements relate to repository sealing. If it is assumed that an exploratory shaft is required for detailed in situ characterization of the potential repository site, assurance must be given in the site characterization report that excavation of such a facility will not make the site unsealable. At the time that the license 
application for construction of the repository is made, design considerations intended to facilitate decommissioning of the repository are to be identified. It is assumed that considerations made to facilitate sealing the repository at decommissioning will be a key part of this design. The updated license application for operation should resolve questions not answered during the construction authorization review process. It is assumed reasonable that assurance that the repository can be sealed should be provided as part of this process. Finalily, the license application for closure should detail the results of tunnel and shaft sealing experiments.

The Basait Waste Isolation Project borehole plugging study will develop designs for plugging boreholes, shafts, and tunnels in or near a nuclear waste repository in basalt. The objectives of this study, which are compatible with U.S. Nuclear Regulatory Commission requirements given above, are:

- To evaluate the natural environment where boreholes, shafts, or tunnels may penetrate the geologic units in or near a repository in basalt

- To identify and test candidate plug materials that are compatible with existing and anticipated site-specific environmental conditions

- To develop methods and equipment for plug emplacement

- To verify the design for the engineered plug system through a series of field tests and demonstrations in basalt.

In order to achieve these objectives, major emphasis in the Basalt Waste Isolation Project borehole plugging program has been placed on the use of localiy available natural materials that exhibit longevity ( 10,000 years) and are compatible with the expected plug environment. The physical and chemical characteristics of this environment will greatly influence the choice of potential plug materials, which will, in turn, influence the selection of plug placement equipment and wil1 ultimately determine plug system design. Thus, characterization of the 
plug environment and the choice of materials of known longevity in this expected environment are of critical importance to the success of the Basalt Waste Isolation Project borehole plugging program.

The structural integrity of the plug designs developed will be provided by the ability of the plugs to resist or accomnodate deformation over time. While deformable, plastic materials will provide some physical continuity, engineering practice requires that more rigid plug components capable of transmitting the loads that may be imposed upon large plugs be employed. The Basalt Waste Isolation Project recognizes that currently the best technology for providing structural strength requires the use of man-made cements, and the question of their longevity in a geologic environment will require extensive testing. On the other hand, natural self-cementing basalts being developed by the Basalt Waste Isolation Project are easily demonstrated to possess chemical stability in a basalt environment, but the use of such materials will require a research and development effort to document their structural properties. As a result, both man-made and natural cements are being investigated in the Basalt Waste Isolation Project borehole plugging program. Either one or both of these material types may be incorporated in final plug designs as a result of further material development.

Candidate mixtures of the borehole plugging materials are being evaluated in a comprehensive physical and geochemical laboratory testing program. Mixtures selected for testing are based upon needed engineering properties in multiphase plugs and have application in plugging all sizes of man-made accesses (boreholes, shafts, and tunnels). Machinery selected to suit the environmental conditions, depths, diameters, and orientations of the accesses in a nuclear waste repository located in basalt are undergoing study. The most recently completed work has been the deveiopment of preconceptual designs for borehole, tunnel, and shaft-plugging systems. These designs have been aimed at fulfilling the following preliminary criteria:

- Establishing a design lifetime of 10,000 years 
- Ensuring a maximum total seepage of $1 \mathrm{~m}^{3} / \mathrm{yr}$ through shaft and tunnel plugs after saturation

- Reducing waste leakage to below permissible levels assuming maximum credible amounts of radionuclide in solution in the repository

- Sustaining a thermomechanical loading cycle from a 500C temperature change

- Producing a bond with tunnel or borehole walls to resist maximum credible axial forces.

In order to fulfill these criteria, designers of plugs must take into account the depth of disturbance of the wall rock created by borehole or tunnel excavation. This disturbance alters the permeability of the wall rock and affects the permeability of the plug-rock interface. Idealized models, based on the conditions such plugs are expected to encounter, were used to analyze the performance of monolithic plug elements for a variety of designs and conditions. Based on such calculations, combinations of plug elements (creating multiple-zone plug schemes) were devised to provide plugs that afforded superior performance over a wide range of repository environment conditions. A suite of "optimum" multiple-zone plug designs was chosen from those that were tested. Because many variables such as repository design, site location, exact hydrologic conditions, etc. are yet to be determined, these designs are being treated as preconceptual for the present.

The plug design for tunnels includes zones of concrete and mortared basalt blocks, interrupted at intervals along their length by seepage cutoff collars of clay/sand slurry. The cutoff collars extend across the entire plug cross section and into the wall rock extending through the disturbed rock zone and into the undisturbed rock zone. Basalt blocks with mortared joints satisfy the requirements for structural support and long-term stability. The blocks would be hand masoned with cement mortar that is tentatively selected for use pending further evaluation of a ground basalt mortar. The design for shafts shows zones of concrete and of compacted clay/sand mixtures. Seepage cutoff collars used in the 
shaft are made of concrete. Preliminary calculations suggest a plug length of about $300 \mathrm{~m}$ may be acceptable if the disturbed rock zone around the plugs is properly controlled during and after excavation. The scheme for plugging boreholes includes alternating zones of (1) gravel and unhydrated, compressed bentonite pellets in a hydrated bentonite originally introduced as a slurry and (2) zones of cement grout.

In the Basalt Waste Isolation Project borehole plugging program, laboratory testing, materials selection, machinery development, and modeling of borehole plugs is coupled with a graduated series of field tests and demonstrations designed to test scale-up factors for materials and machines as well as elements of long-term performance in the in situ environment that cannot be simulated in the laboratory. The first of these tests, the shallow borehole plugging test, will involve the plugging of shallow boreholes under dry conditions. This test will yield engineering data on borehole plugging machines, materials, techniques, and on parameters such as plug/wall rock bonding and fracture filling around plugs. The shallow borehole plugging test is scheduled for completion during fiscal year 1983. A second plugging field test, which will probably take place within the Near-Surface Test Facility at Hanford, will consist of two parts: (1) the plugging of sma11-diameter horizontal and vertical boreholes under wet conditions; and (2) the plugging of a large-diameter vertical shaft penetrating the Near-Surface Test Facility from the surface. Data from this test will be used to define techniques and materials for fitting small-diameter boreholes under adverse (wet) conditions and techniques to seal repository access shafts.

An advanced field demonstration will be used to demonstrate the emplacement of prototype plugs and seals in the expected repository environment and for long-term observation of plug performance characteristics. This test has two distinct parts with parallel schedules. The first part is the deep remote plugging of a selected 
smal1-diameter vertical core hole and is scheduled for completion in the 1980 's. The second consists of plugging of tunnels and shafts in a subsurface test facility. The emplacement of plugs in the subsurface test area is scheduled to start in the early 1990's.

Based upon the results of the Basalt Waste Isolation Project borehole plugging program to date, it appears feasible to design a composite plug system that employs natural and manufactured materials capable of satisfactorily sealing a nuclear waste repository in basalt.

\subsection{CONCEPTS}

\subsubsection{System of Borehole Plugging}

The final sealing of a nuclear waste repository in basalt will require the backfilling and plugging of a variety of man-made openings in and around the repository (Fig. 3-1). The primary function of plugs designed for repository sealing is to prevent the migration of unacceptable concentrations of radionuclides to the biosphere. To fulfill their primary function, the plugs must provide a variety of secondary functions, including mechanical support for the surrounding rock, maintenance of their own physical integrity, minimization of water movement ( low permeability), and retardation of radionuclide migration (sorption and/or reaction). The multiple functions required of the plugs, coupled with the need for reliability, will probably require the emplacement of multiple, composite plugs. In addition, different types of openings, such as shafts, tunnels, and small-diameter boreholes, will require different plug designs and plugging techniques. The result is a relatively complex system of plugs for repository sealing.

\subsubsection{General Methodology for Borehole Plug Validation}

The sealing and plugging of commercial boreholes and shafts is an old and highly developed technology. In addition to the mining and petroleum industries, plugging techniques have been developed in the fields of 


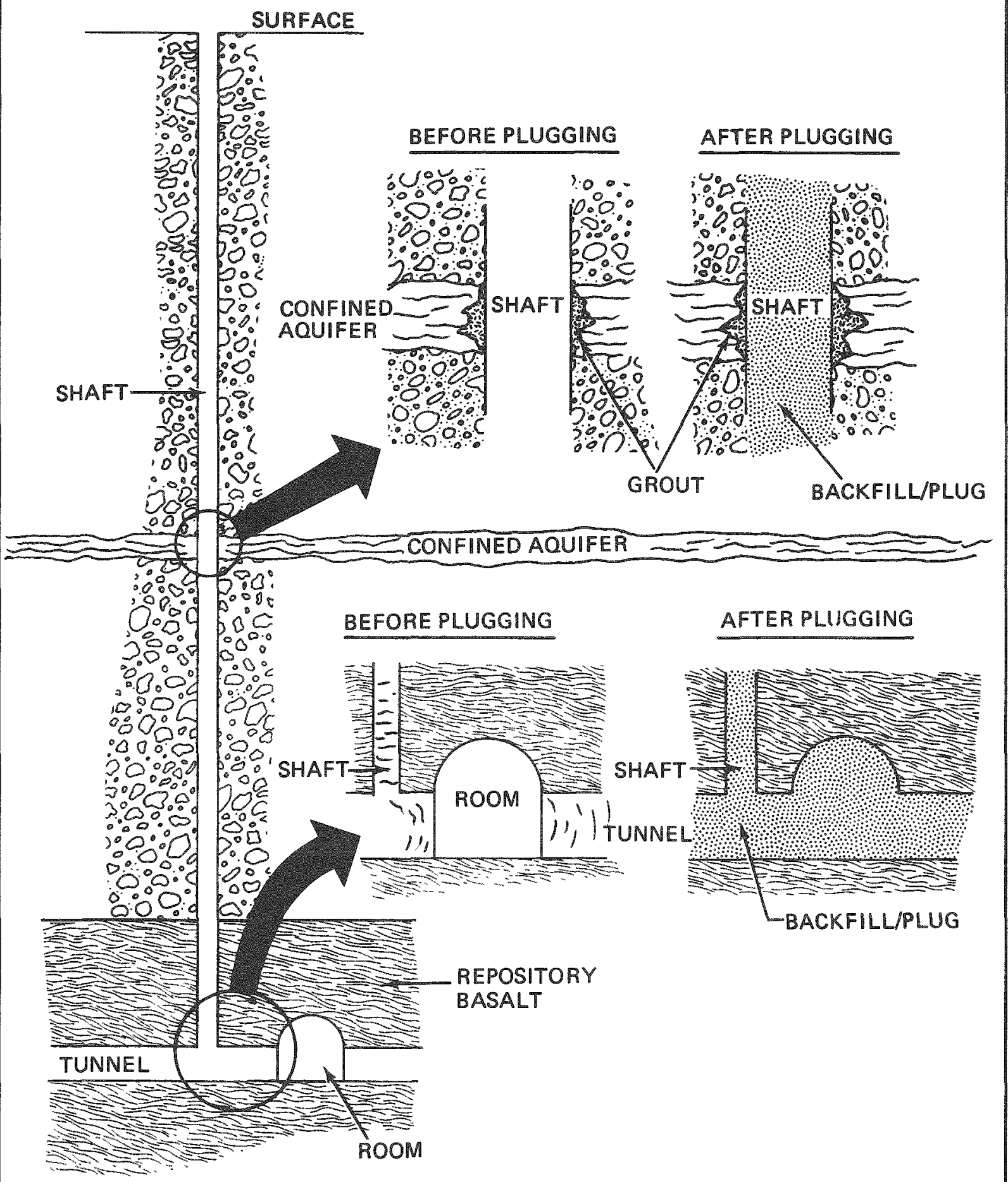

$\sin / 80$

FIGURE 3-1. Schematic of Repository Plugging. 
hazardous chemical disposal and underground nuclear weapons testing. An extensive review of commercial borehole plugging technology is presented by the Office of Nuclear Waste Isolation (ONWI, 1979).

A major difference between normal commercial sealing and plugging techniques and the requirement for sealing a nuclear waste repository is the greater time period over which the repository seals must remain effective. Periods of 50 to 100 years are considered long term in normal engineering design considerations. On the other hand, seals for nuclear waste repositories must remain effective over periods on the order of $10^{5}$ years, a requirement that casts severe doubt upon the utility of most commercially used sealing and plugging materials. Concrete, in one form or another, has the longest recorded survival history of commonily used man-made materials. The survival history for concrete is, however, only on the order of 2,000 years and, in many cases, the environment in which the concrete has survived may have been much less harsh than that expected around a nuclear waste repository, particularly during the thermal period (see Section 2.5). Because of the strong need for plugging materials with documented survival histories at least as great as the required containment time, the Basalt Waste Isolation Project materials selection process has concentrated upon natural geological materials with proven longevity. Concrete has been retained in early parts of the study because of the amount of design data and experience that exists for concrete; however, either its long-term stability under repository conditions must be demonstrated or other materials of proven longevity must be found to fill the design role normally filled by concrete.

An early effort in borehole plugging was made at the conclusion of Project Salt Vault at Lyons, Kansas. Atomic Energy Commission No. 1 Well, drilled through the Hutchinson salt, was plugged with expanding portland cement grout. The concrete section within the salt was saturated with sodium chioride and 3-m sections of epoxy resin were used to cap the top and bottom of the salt interval (Eilers, 1974). A borehole near the Waste Isolation Pilot Plant site in New Mexico was plugged in October 1977 principally to test quality control procedures 
under field conditions (Gurlick, 1978), and a field test of a deep plug in a small-diameter core hole, the Bell Canyon test, is currently under way (Burns, 1979).

Efforts are under way to demonstrate repository plugging at Sandia Laboratories and at the Stripa site in Sweden. These programs provide a starting point for the Basalt Waste Isolation Project. A literature search has been made to identify candidate plug materials and emplacement techniques and is reported in this chapter. Candidate types of machinery and possible adaptations of existing machinery have been identified. Information gathered to date is being adapted to the specific problem of sealing a repository in the Columbia Plateau basalt.

Testing and verification of plugging techniques and concepts require full-scale tests under repository conditions, thus, the Basalt Waste Isolation Project laboratory program will run parallel with a series of in situ tests of gradually increasing size and complexity. The laboratory programs will evaluate the geochemical compatibility of the host rock and plug materials, characterize interactions between materials, determine interaction kinetics and products, suggest modifications to the composition of the plug material, and determine the physical properties of proposed plug materials and systems including mechanical strength, bond strength between rock and plug materials, and permeabilities of materials and systems. The laboratory program will aiso test and evaluate the core samples from the in situ tests. Since grouting or other injection techniques are commonly used to seal aquifers and strengthen fragile strata during the excavation of a shaft, the laboratory program must include testing of these materials with respect to overall seal performance and compatibility with the plug materials. These experiments wi11 lead to recommendations of materials that are acceptable for use as borehole plugs. Tests to be carried out on the core samples from the in situ experiments include determinations of mechanical strength of the plug and the plug-to-host rock bond strength, permeability of the plug system, radionuclide sorption characteristics of the plug material, and the plug-to-host rock system. In situ tests include large-scale permeability measurements, measurement of the migration of tracer levels of short-lived isotopes, and evaluation of emplacement 
techniques, emplacement machinery, monitoring instrumentation, and grouting techniques. Aiso included in this task is the development of monitoring equipment capable of cableless transmission through approximately $1 \mathrm{~km}$ of the earth's crust. A more detailed description of these various tasks is found in Sections 3.3 through 3.7 .

Decision theory methodology has been used with the information gathered in the Basalt Waste Isolation Project's borehole plugging program to select materials, machines, and systems for sealing a repository in basait in concert with the appropriate acceptance and performance criteria established by various U.S. regulatory agencies. These criteria are soon to be released to the public. The proposed repository seal system must be demonstrated to meet or exceed these criteria. Consideration will also be given to other important constraints such as practicality and economics when proposing a plug system that will meet the regulatory criteria. A more thorough discussion of the criteria and constraints is found in the following section.

\subsubsection{Borehole Plug--Generalized Criteria and Constraints}

Acceptance and performance criteria for the tunnel, shaft, and borehole seals exist in draft form (NRC, 1980). The sealing of boreholes and shafts to guarantee the integrity of a nuclear waste repository has yet to be accomplished. Therefore, draft criteria have been written to allow for technology development. Because of retrievability requirements, the repository is likely to be open for some 50 years after waste capacity has been reached--this allows for several generations of seal materials and techniques to be developed-each advanced technology to supercede the previous one. For instance, first generation technology is likely to propose the use of grouts and cements as primary seals, along with a mixture of clay and crushed material previously removed from the borehole or shaft. In the intervening 75 to 100 years when the repository is being filled and when retrievability must be possible, technology, which today seems unproven or impracticable, might become pedestrian. Thus, it may well be feasible to "weld" the repository seal into a solid plug using highmenergy laser beams or to melt the original rock into a plug that is not differentiable from the undisturbed 
stratum. Since advanced technologies will surely be developed, those involved in the borehole plugging task must keep abreast of a multitude of disciplines. Developments in fields other than those directly related to borehole plugging may have applications in the sealing of a repository and thus must be followed.

Practicality and economic constraints will certainly limit the application of many advanced technologies. In the case of plugging smal1 diameter boreholes where the seal must be emplaced under remote conditions, ease of operation and workability of the machines and materials will be major constraints. The larger diameter of the access shafts and tunnels will allow personnel and machinery to work at the surface of the seal and the principal constraints will likely be economic rather than spatial.

The general criterion that applies to the repository seals is that they be fully redundant to the other engineered barriers. Their design must provide reasonable assurance that the release rate of radionuclides to the biosphere will be consistent with the applicable environmental standards set by the U.S. Environmental Protection Agency and other regulatory agencies and wi 11 be as low as reasonably achievable. Although not specifically called out in the draft criteria, it appears as if these assurances must be good for periods on the order of $10^{5}$ years.

The borehole plugging task is inextricably related to the other phases of the repository construction. Excavation of the shafts, tunnels, and rooms must not be carried out using techniques that wi11 cause massive fracture of the rock or provide alternate paths for radionuclide migration that are impossible or impractical to seal. Included in these considerations should be grouts and concretes, which are used to seal aquifers and stabilize strata that have little structural stability. While these grouting techniques are necessary, the materials used must not synergistically interact with the proposed plug materials or fail in such a way as to compromise an otherwise acceptable seal.

One of the proposed criteria (NRC, 1980) requires remote, in situ monitoring of the seal. This criterion requires the development of equipment to do this monitoring. Since cable transmission of data would 
compromise the shaft seal, cableless transmission devices capable of transmitting through approximately a kilometer of the earth's crust or more must be developed if this criterion is to be met. Devices to measure radiation levels, water content, water flow rates, padionuclide content of the aquifers, and any migrating water, are anticipated as necessary. In genera1, the instruments will provide in situ testing and verification of the seal performance against the seal design. A certain amount of redundancy and independence is required by the proposed criteria to guarantee that information will be meaningful and assured in case of an unforeseen instrument failure. As previously discussed, the long-term reliability of these devices must be demonstrated and their use must not compromise the integrity of the seal.

Preliminary selection criteria for determining the suitability of materiais as borehole plugs are discussed in Section 3.4 and itemized in tables in that section. Factors covered by these criteria are listed in Table 3-1. Section 3.5 covers the criteria used for the selection of emplacement machinery.

\subsection{DESCRIPTION OF THE ENVIRONMENT}

The physical and chemical characteristics of a plug enviromment will greatly influence the choice of materials, which will in turn influence the selection of plug placement equipment and will aiso uitimately determine plug system designs. Sections 2.3, 2.4, and 2.5 detait the geotectonic, groundwater, and physical and chemical charecteristics of the deep basalts within the Columbia Plateau. The following subsections summarize the aspects of the natural environment (geotectonic, physical, and chemical) most likely to affect plug designs, plug systems, and plug stability. While much of this chapter strives to incorporate the general state-or-art in borehole plugging, this section will only address the specific environment existing at Hanford.

\subsubsection{Plug Environment}

The plug environment is controlled by: (1) the ambient geologic environment at the Hanford Site: (2) the proposed location and depth of the repository: and (3) the alteration of the natural environment because 
RHO-BWI-ST-7

TABLE 3-1. Generalized Physical Characteristics of Basalt.

Unconfined Compressive Strength

- $300 \mathrm{MPa}$

- Not changed significantly at low confining pressures

- Compressive strength increases at confining pressures greater than $20 \mathrm{MPa}$

Density

- Assumed $2.8 \mathrm{gm} / \mathrm{cm}^{3}$ as preliminary average value

Elastic Constants

- Young's Modulus $=70 \mathrm{GPa}$

- Poisson's Ratio $=0.25$

- Do not change appreciably in range of existing and projected rock temperatures $\left(500\right.$ to $\left.200^{\circ} \mathrm{C}\right)$

Thermal Expansion

$6.6 \times 10^{-6} /{ }^{\circ} \mathrm{C}$

- Insignificant variation for 0 to $3000^{\circ} \mathrm{C}$ range

- Dense basalt has higher coefficient than vesicular basalt

Thermal Conductivity

- $0.01 \mathrm{~W} / \mathrm{cm}^{\circ}{ }^{\circ} \mathrm{C}$, from static tests, $100^{\circ}$ to $3000^{\circ} \mathrm{C}$ range

- Value increases in transient tests

Stress Field in Rock

- In situ vertical stress to overburden pressure is predicted to be in the range of 28 to $47 \mathrm{MPa}$ at a depth of 1.0 to $1.7 \mathrm{~km}$

- Horizontal stress is between $1 / 2$ and $1-1 / 2$ times the vertical stress. 
of both the excavation of the repository and the storage of radioactive waste. Conditions important to borehole plugging include rock strength of basalt, bedding attitudes, the position of aquifers, permeabilities of flows and interflow units, lithostatic pressure, potential maximum hydrostatic pressure, regional subsidence and horizontal stresses, the parameters of potential earthquakes, general fracture patterns within flows (flow top, entablature, and colonnade), temperature of the host rock, geochemistry of the groundwater, and secondary minerals filling basalt fractures and other natural openings.

\subsubsection{Geotectonic Environment}

The Hanford Site lies within the Pasco Basin (Section 2.3), a structural basin developed in a thick sequence of tholeijtic basalt flows that form the Columbia Plateau. The Pasco Basin is bordered on the north, west, and south by east-west to northwest-trending asymmetric anticlines that deform the Columbia River Basalt Group of middle to late Miocene age. The basalts of the Columbia River Basalt Group are estimated to have a minimum thickness of $1.7 \mathrm{~km}$ in the Pasco Basin where they overlie older basalts of 0ligocene to Eocene age (Deju and Others, 1977). A complete review of the geology of the Columbia Plateau is given by Myers/Price and Others (1979).

Poorly consolidated Pliocene fluvial and lacustrine deposits of the Ringold Formation overlie the basalt sequence. The Ringold Formation is overlain by unconsolidated coarse-grained sediments deposited by late Pleistocene glacial floods. The flood gravel is, in turn, overlain by a thin veneer of loess and dune sand. The sedimentary deposits range from 0 to about $1 \mathrm{~km}$ in thickness (Deju and Dthers, 1978a).

Individual basalt flows range from a few meters to more than $60 \mathrm{~m}$ thick and are separated from adjacent flows by vesicular and, in many cases, brecciated, interflow zones and occasionally by sedimentary interbeds. Sedimentary interbeds are largely restricted to the upper part of the section. It is anticipated that the proposed repository will be in a basalt flow with a minimum thickness of $30 \mathrm{~m}$ at a depth of 1.0 to $1.7 \mathrm{~km}$ below the ground surface. Several flows within the Grande Ronde Basalt (Ledgerwood and others, 1978) meet these conditions in the Hanford area. 
Studies of focal mechanisms (few of which are well constrained) by Malone (1978) indicate that earthquakes in the Columbia Plateau occur in response to a horizontally directed compressive stress field. The maximum principal horizontal stress varies through an arc of about $60^{\circ}$ to 800 ( $N 300 \mathrm{~W}$ or $N 400 \mathrm{~W}$ to $N 300 \mathrm{E}$ or $N 400 \mathrm{E}$ ). If folding is currentiy active the rate must be very low, as indicated by the absence of deformed Pleistocene deposits. Faults, where they do occur in the Pasco Basin and surrounding ridges, are generally spatially related to the steep limb of anticlines. Most investigators consider the faults to be subordinate to folds and an expression of the same compressional events (Bentley, 1977; B lume and Associates, 1971; Brown, 1968; Myers/Price and Others, 1979).

Triangulation and leveling surveys indicate that the Columbia Plateau is currently subsiding at an average rate of approximately $1 \mathrm{~mm}$ per year (Tillison, 1970). It appears that this deformation may be caused by regional compression, as discussed above.

The Milton-Freewater earthquake of July 1936 had a Richter magnitude of 5.75 and a Modified Mercalli (MM) intensity VII. No historic earthquake greater than this has been recorded in the Columbia Plateau. Seismic studies indicate that the maximum anticipated earthquake in the Hanford area would probably occur on the Saddle Mountains or the Rattlesnake-Wallula structure, have an MM intensity of VIII, and produce an expected maximum ground acceleration of $0.25 \mathrm{~g}$ (Deju and Others, 1977). Rockwell Hanford Operations is currently conducting studies that may impact the selection of a design basis earthquake for a repository at the Hanford Site.

\subsubsection{Physical Environment}

The physical properties of basalt considered most pertinent to borehole plugging are known from laboratory testing of intact basalt specimens and are shown in Table 3-1; however, the bulk properties of the rock mass are known with much less certainty.

Basalt flows in the Columbia Plateau are essentially fractured (jointed) throughout the bulk of their thickness. Fractures in the 
colonnade portions of flows are generally vertical and planar, while those in the entablature tend to be more irregular and, in many cases, form fan-like surfaces. Subhorizontal, slightly undulatory fracture planes occur within some flows, particularly along contacts between the entablature and colonnade. Flow tops generally are less dense because of the presence of vesicles and brecciation and, within boreholes, have walls that are generally more irregular than within dense, interior parts of the flow.

The groundwater data collected in the Pasco Basin thus far indicate that water-bearing units in this area can be commoniy broken into three systems: (1) the unconfined; (2) the uppermost confined; and (3) the lower confined aquifer systems. The presence of porous interflow zones up to several feet thick in the Grande Ronde Basalt suggests that flow contacts may be potential aquifers. Groundwater movement in basait sequences is primarily through permeable interflow and interbed zones, although some sequences of flows are tight and relatively impermeable. Flow tops and bases are considerably more porous and may be more permeable than either the entablature or colonnade, which appear to be essentialiy impermeable at depth because of tightness of fractures and the presence of fracture fillings. Permeabilities within the interflow zones will depend upon both the degree to which the vesicles are interconnected and the extent to which they are filled with secondary minerals.

Insufficient data have been collected from the lower confined aquifer system to describe the spatial variation of the potentiometric surface. More data must be collected before the potentiometric relationships can be understood with reasonable certainty.

Hydrautic characteristics of the unconfined, uppermost confined and lower confined aquifer systems have been summarized elsewhere (ERDA, 1975; ARHCO, 1976; Gephart and Others in BWIP, 1978; Ledgerwood and Deju, 1976; Newcomb, 1969). A comprehensive report on the hydrology of the Pasco Basin is presented by Gephart and Others (1979b). The values of horizontal conductivity for interbeds in the uppermost confined system are two to three orders of magnitude greater than the values of vertical hydraulic conductivity. Within flows (colonnades and entablatures), vertical hydrautic conductivity is greater than the horizontal component 
(Ledgerwood and Deju, 1976) because of the orientation of cooling fractures. The vertical hydraulic conductivities of the flows, however, are generally much smaller than the horizontal hydraulic conductivities of interbeds (Ledgerwood and Deju, 1976). Therefore, under a given hydrologic gradient, more water will flow through the interbeds than through the flows. The hydraulic conductivity of the top of the Umtanum basalt is $10^{-6}$ to $10^{-10} \mathrm{~cm} / \mathrm{sec}$; within the entablature and colonnade it is $10^{-8}$ to $10^{-12} \mathrm{~cm} / \mathrm{sec}$. The permeability along fractures at depth is not known.

The geochemistry of the groundwater under the Hanford Site has been summarized elsewhere (Deju, 1978b; LaSala and Doty, 1971; ARHCO, 1976; Gephart and Others in BWIP, 1978; Gephart and Others, 1979a). The estimated composition of groundwater from the Grande Ronde Basalt is shown in Table 3-2 and is considered to be representative of the ambient repository environment (see Section 2.4). A discussion of Eh and $\mathrm{pH}$ in the repository environment is presented in Section 2.5 .

TABLE 3-2. Estimated Composition of Groundwater from the Lower Confined Aquifer (Grande Ronde) at $45^{\circ} \mathrm{C}$.

\begin{tabular}{l|c}
\hline Element & $\mathrm{mg} / \mathrm{l}$ \\
\hline $\mathrm{Na}^{+}$ & 250 \\
$\mathrm{Ca}^{+2}$ & 1.3 \\
$\mathrm{Mg}^{+2}$ & 0.04 \\
$\mathrm{Cl}^{-}$ & 148 \\
$\mathrm{SO}_{4}^{-2}$ & 108 \\
$\mathrm{HCO}_{3}^{-}$ & 25 \\
$\mathrm{CO}_{3}^{-2}$ & 21 \\
$\mathrm{~K}^{+}$ & 1.9 \\
$\mathrm{H}_{3} \mathrm{SiO}_{4}^{-}$ & 145 \\
$\mathrm{~F}^{-}$ & 37 \\
\hline $\mathrm{pH}$ & 10.1 \\
$\mathrm{Eh}$ & Reducing, precise \\
& values not well \\
& documented but \\
& probabiy in the range \\
& -0.50 to -0.54 $\mathrm{V}$. \\
\hline
\end{tabular}


Secondary minerals (zeolites, clay minerals, quartz, calcite, iron oxide, pyrite, etc.) are present in fractures and other openings in basalt flows (see Section 2.3). These secondary minerals have sorption properties that would tend to inhibit the migration of radionuclides and their presence reduces the permeability of the basalt. Benson (1978) reported that clinoptilolite, smectite, and silica in vesicies and smectite in fractures are the most common secondary minerals in basalts in the deeper portion of the Pasco Basin.

$01 d e r$ temperature measurements from wells range from $50^{\circ}$ to $55^{\circ} \mathrm{C}$ at the depth of the Umtanum basalt (Raymond and Tillson, 1968). However, more recent measurements from the central portions of the basin indicate temperatures as high as $66^{\circ} \mathrm{C}$ (see Section 2.5). Temperatures maxima near storage canisters in the repository, however, may be on the order of $300^{\circ} \mathrm{C}$ (Hardy and Others, 1978).

In engineering design, the hydrostatic pressure is usually taken as the depth below the water table times the unit weight of water. Assuming this to be the case beneath the Hanford site, the water pressure at depths of 1.0 to $1.7 \mathrm{~km}$ (that may act on borehole plugs) will be on the order of 10 to $17 \mathrm{MPa}$.

Many measurements of the in situ stress beneath the earth's surface show that the vertical component is approximately the weight of the overburden (1ithostatic). If the folding in the Columbia Plateau is active, there may be a principal horizontal stress greater than the vertical stress. In lieu of data from in situ measurements at the Hanford Site, upper bounds on the horizontal stress can be estimated from a compilation of previous stress measurements by cook (1977). At depths of 1.0 to $1.7 \mathrm{~km}$, the vertical stress resulting from the mass of overlying rock would be on the order of 28 to $47 \mathrm{MPa}$ and, based upon the assumption that the horizontal stresses fall in the typical range of 1/2 to 1-1/2 times the vertical stress, the horizontal stresses should fall in the range of $14 \mathrm{MPa}$ to $70 \mathrm{MPa}$. 


\subsubsection{Additional Characterization of the Plug Environment}

The successful long-term functioning of any plug depends on its compatibility with physical and chemical conditions existing at the time of plug placement and with changes in these parameters during the life of the plug. An initial discussion of some aspects of the physical and chemical environment that will affect the design of plug systems was presented in the previous section together with the assumed values of physical and chemical parameters expected to exist in the repository and access shafts, tunnels, and related boreholes. These values are based on available data.

However, many presently unforeseen conditions may occur within the man-made openings that will exist when the plugs are installed. Some of these changes will be introduced as a result of the design, construction, and operation of the repository; they may invalidate initial assumptions or require that these assumptions be aitered. Some of the studies needed to provide additional data for minimizing uncertainties in future plug design can be formulated on the basis of the following discussion.

3.3.4.1 Vertical Boreholes. Many of the man-made openings that will require plugging are existing, small-diameter boreholes. Many of these holes were drilled before the need existed to document downhole conditions. The condition of these holes is uncertain because of possible events such as caving, corrosion, and heaving. Thus, before a plug is designed and installed in an existing borehole, conditions in that hole must be determined through the use of techniques such as downhole logging and photography. In many cases the hole may require cleaning or reaming prior to plugging.

Many problems will be encountered in documenting borehole wall conditions, designing an appropriate plug, and documenting the condition of plugs placed in vertical boreholes. Most problems are related to the geometry of the openings. Most vertical boreholes have small diameters, and most plug seats will be located several thousand meters below the surface. This combination of circumstances will require remote operations for determining in situ conditions, placing the plugs, quality checks on plug materials, and tests required to determine the performance of the plugs after placement. 
3.3.4.2 Horizontal Boreholes. Horizontal boreholes will be drilled ahead of tunnel excavations. If the rock is in good condition, the entire borehole will be mined out as the tunnel is advanced. If the exploration encounters substandard rock, the tunnel will not necessarily be extended in that direction, in which case a plug will have to be placed in the horizontal borehole to maintain the integrity of the repository.

Data collected in horizontal holes will be obtained more easily and probably will be of better quality than data from vertical holes, because the time from drilling to plug installation will be shorter, and plugs will be installed from a few tens to a few hundreds of feet from the operators. Plug seat data will still need to be obtained by core logging, interpretation of cuttings, and geophysical logging.

3.3.4.3 Tunnels and Shafts. Methods to be used in excavating tunnels and shafts have not been finalized. Therefore, certain assumptions about the condition of the openings, the presence of linings, and the condition of the rock adjacent to the opening have been made. These assumptions are the basis of the preliminary selection of plug materials, plug placement equipment, and the location of plugs in man-made openings. Investigators working in tunnels and shafts can be physically present at the plug seat to inspect the opening, wall rock, and other conditions. Destructive and nondestructive testing methods can be used to determine the condition of the rock at the wall surface and for some distance into the wall. Thus, many of the uncertainties inherent in plugging small boreholes will not exist when working in tunnels and shafts.

It has become apparent that a single environmental model is inadequate to deal with all man-made openings that are to be plugged and that plug materials and plugging machinery must be specific to the type of opening to be plugged. Thus, four plug types and the environments to which each will be subjected are presented in Table 3-3 (Taylor and others, 1979). 
TABLE 3-3. Preliminary Definition of Plug Types and Plug Environments.

(After Taylor and Others, 1979.)

\begin{tabular}{|c|c|c|c|c|}
\hline Parameter & $\begin{array}{c}\text { Boreholes That Start } \\
\text { at the Surface }\end{array}$ & $\begin{array}{c}\text { Boreholes That Start } \\
\text { in the Subsurface }\end{array}$ & Tunnels & Shafts \\
\hline \multicolumn{5}{|c|}{ Description of Openings } \\
\hline Characterization & $\begin{array}{l}\text { Boreholes considered in } \\
\text { this category start at } \\
\text { the surface and are } \\
\text { drilled into the sub- } \\
\text { surface, generally using } \\
\text { well drilling equipnent } \\
\text { Water wells } \\
\text { Exploratory boreholes } \\
\text { Core holes } \\
\text { Rotary rock-bit drilled } \\
\text { holes. }\end{array}$ & $\begin{array}{l}\text { The man-made openings in } \\
\text { this category are gen- } \\
\text { erally bored out of tun- } \\
\text { nels or shafts in the } \\
\text { subsurface. They will } \\
\text { generally be bored by } \\
\text { drilling equipment } \\
\text { developed for use in the } \\
\text { mining or mineral ex- } \\
\text { ploration industry: } \\
\text { Exploratory holes } \\
\text { drilled in advance of } \\
\text { tunnels } \\
\text { Grout holes } \\
\text { Anchor bolt holes } \\
\text { Canister storage holes } \\
\text { Other. }\end{array}$ & $\begin{array}{l}\text { Repository tunnels will } \\
\text { generally all be exca- } \\
\text { vated within one repos- } \\
\text { itory flow. There will } \\
\text { probably be more cubic } \\
\text { yards of material exca- } \\
\text { vated from tunnels than } \\
\text { from shafts or bored } \\
\text { holes. Tunnels may } \\
\text { include: } \\
\text { Haul tunnels } \\
\text { Ventilation tunnels } \\
\text { Placement tunnels. }\end{array}$ & $\begin{array}{l}\text { Shafts are those that are } \\
\text { excavated from the surface } \\
\text { facilities to the storage } \\
\text { and haul tunnels at depth. } \\
\text { These may include: } \\
\text { Ventilation shafts } \\
\text { Manways } \\
\text { Hoists (skips) for } \\
\text { waste rock from tunnel } \\
\text { excavation } \\
\text { Elevators for canisters } \\
\text { and equipment. }\end{array}$ \\
\hline $\begin{array}{l}\text { Dimensions at } \\
\text { Plug Depth }\end{array}$ & $\begin{array}{l}\text { Diameter } \\
\text { Smallest: NX core, } 7.6 \mathrm{~cm} \\
\text { Average: } 22 \mathrm{~cm} \\
\text { Largest: about } 25 \mathrm{~cm} \text {. } \\
\text { Depth } \\
\text { T,000-1,500 m. } \\
\text { Taper (reduction) } \\
\text { The dianeters listed } \\
\text { pate are those antici- } \\
\text { depths. At the surface, } \\
\text { these holes are generally } \\
\text { 20 to } 30 \mathrm{~cm} \text { or larger, } \\
\text { and are tapered by per- } \\
\text { iodic reductions in size. }\end{array}$ & $\begin{array}{l}\frac{\text { Diameter }}{\text { Core holes: } 7-11 \mathrm{~cm}} \\
\text { Percussion drilled } \\
\text { holes: } 8-14 \mathrm{~cm} \\
\text { Canister storage holes: } \\
60-100 \mathrm{~cm} \\
\text { Depth } \\
\text { Core holes } 9-100 \mathrm{~m} \\
\text { Percussion holes: } 1.5 \text { - } \\
8 \mathrm{~m} \\
\text { Canister storage holes: } \\
1.5-10 \mathrm{~m} \text { (or more). } \\
\text { Taper } \\
\text { Most holes drilled in the } \\
\text { subsurface will be so } \\
\text { short that there will be } \\
\text { no reductions. }\end{array}$ & $\begin{array}{l}\text { Diameter } \\
\text { Haulways: } 6.0-7.5 \mathrm{~m} \\
\text { Storage: } 6.0-7.5 \mathrm{~m} \\
\text { Ventilation: } 2.0-7.5 \mathrm{~m} \text {. } \\
\text { Recent verbal information } \\
\text { indicates that a } 10 \mathrm{~m} \text { dia- } \\
\text { meter is a possibility. } \\
\text { Length } \\
\text { Depth }(1) \\
\text { Haulways: } 3-8 \mathrm{~km} \\
\text { Placement: up to } 5 \mathrm{~km} \\
\text { Ventilation: } 3-8 \mathrm{~km} \text {. } \\
\text { Taper } \\
\text { No reductions anticipated. }\end{array}$ & $\begin{array}{l}\text { Diameter } \\
\text { Designers option: at } \\
\text { present must assume } \\
6-7.5 \mathrm{~m} \text {. } \\
\text { Recent verbal information } \\
\text { indicates that a 9-m dia- } \\
\text { meter is possible. } \\
\text { Depth } \\
\text { 1,000-1,500 m } \\
\text { Taper } \\
\text { None anticipated. }\end{array}$ \\
\hline
\end{tabular}


Table 3-3 (continued)

\begin{tabular}{|c|c|c|c|c|}
\hline Parameter & $\begin{array}{c}\text { Boreholes That Start } \\
\text { at the Surface }\end{array}$ & $\begin{array}{c}\text { Boreholes That start } \\
\text { in the subsurface }\end{array}$ & Tunnels & Shafts \\
\hline $\begin{array}{l}\text { Access at Time } \\
\text { of Plugging }\end{array}$ & \multicolumn{2}{|c|}{$\begin{array}{l}\text { No access by man: access by drill tools, } \\
\text { drill rods, drill tubing, and remotely } \\
\text { operated instruments. }\end{array}$} & \multicolumn{2}{|c|}{$\begin{array}{l}\text { Unlimited access by man using hand tools. } \\
\text { Access for equipment is limited by the } \\
\text { diameter and the geometry of the openings. }\end{array}$} \\
\hline $\begin{array}{l}\text { Conditions Before } \\
\text { During. and After } \\
\text { Plugging }\end{array}$ & $\begin{array}{l}\text { Before } \\
\text { Cased or uncased } \\
\text { Possibly dry } \\
\text { Filled with water } \\
\text { Filled with drill mud } \\
\text { Filled with caved wall } \\
\text { rock } \\
\text { During } \\
\text { Plug may be placed in } \\
\text { the dry or wet hole } \\
\text { conditions depending } \\
\text { on the prior hole his- } \\
\text { tory } \\
\text { Need plug systems to } \\
\text { work in either wet or } \\
\text { dry holes } \\
\text { After } \\
\text { ultimately, the plug and } \\
\text { backfill materials will } \\
\text { become saturated with } \\
\text { groundwater. }\end{array}$ & $\begin{array}{l}\text { Before } \\
\text { Probably wet and } \\
\text { making water with } 900 \text { - } \\
1,400 \text { m hydrostatic } \\
\text { head ( } 9-14 \text { MPa). } \\
\text { Holes that do not en- } \\
\text { counter permeable } \\
\text { parts of a flow would } \\
\text { not be candidates for } \\
\text { Ticensed plugs. } \\
\text { Only those subsuriace } \\
\text { holes which encounter } \\
\text { adverse hydrologic } \\
\text { condilions may have to } \\
\text { be plugged. } \\
\text { During } \\
\text { Hole may be dry or wet } \\
\text { Failed part of the } \\
\text { hole can probably be } \\
\text { installed in a hole } \\
\text { made dry before plug } \\
\text { placement. } \\
\text { After } \\
\text { UTtimately. the plug and } \\
\text { backfill materials will } \\
\text { becone saturated with } \\
\text { groundwater. }\end{array}$ & $\begin{array}{l}\text { Before } \\
\text { Dry, possibly lined in } \\
\text { some places, some wall } \\
\text { rock treatment is to } \\
\text { be expected. } \\
\text { During } \\
\text { Dry } \\
\text { Aicer } \\
\text { Ulitimately, the plug and } \\
\text { backifil materials will } \\
\text { become saturated with } \\
\text { groundwhter. }\end{array}$ & $\begin{array}{l}\text { Before } \\
\text { Dry, possibly lined in } \\
\text { some places, some wall } \\
\text { rock treatnent is to } \\
\text { be expected. } \\
\text { During } \\
\text { Dry } \\
\text { After } \\
\text { Uitimately, the plug and } \\
\text { backfill materials will } \\
\text { become saturated with } \\
\text { groundwater. }\end{array}$ \\
\hline
\end{tabular}


Table 3-3 (continued)

\begin{tabular}{|c|c|c|c|c|}
\hline Parameter & $\begin{array}{c}\text { Boreholes That Start } \\
\text { at the Surface }\end{array}$ & $\begin{array}{c}\text { Boreholes That Start } \\
\text { in the Subsurface }\end{array}$ & Tunnels & Shafts \\
\hline Casing or Linings & $\begin{array}{l}\text { The holes will have one or } \\
\text { more strings of pipe } \\
\text { (probably cemented) near } \\
\text { the surface. Most holes } \\
\text { will be uncased at the } \\
\text { bottom. At repository } \\
\text { depth, it is anticipated } \\
\text { that the hole will either } \\
\text { be open or will have not } \\
\text { more than one casing } \\
\text { string at the plug seat. }\end{array}$ & $\begin{array}{l}\text { Exploratory holes, drilled } \\
\text { ahead of tunnels, will } \\
\text { probably have no casing } \\
\text { at the time of plugging. } \\
\text { other holes (grout holes, } \\
\text { core holes, rockbolt } \\
\text { holes) will probably be } \\
\text { filled with grout at the } \\
\text { time of closure. Most of } \\
\text { the material in these } \\
\text { holes will be designated } \\
\text { as backfill and will be } \\
\text { abandoned (filling not } \\
\text { removed and replaced with } \\
\text { plug). }\end{array}$ & $\begin{array}{l}\text { It is anticipated that } \\
\text { most tunnels will be } \\
\text { unlined; however, some } \\
\text { linings must be antici- } \\
\text { pated in places along } \\
\text { the bores. } \\
\text { Shotcrete } \\
\text { Gunite } \\
\text { Steel ribs backed } \\
\text { with grout } \\
\text { Reinforced }\end{array}$ & $\begin{array}{l}\text { Shafts will have lining, } \\
\text { stairs, elevator track, or } \\
\text { other improvements. Un- } \\
\text { lined or undeveloped portions } \\
\text { of shafts will be rare. }\end{array}$ \\
\hline \multicolumn{5}{|c|}{ Plug Categorization } \\
\hline $\begin{array}{l}\text { Class I plugs } \\
\text { CTass I plugs are } \\
\text { primary license } \\
\text { plugs; they can be } \\
\text { considered an ana- } \\
\text { log of Category I } \\
\text { facilities in } \\
\text { nuclear plant } \\
\text { design. }\end{array}$ & \multicolumn{3}{|c|}{$\begin{array}{l}\text { Prior to placing class } 1 \text { plugs in man-made openings, the permeability } \\
\text { and the condition of the wall rock adjacent to the plug must be known. } \\
\text { Probably all previous construction will be removed from the plug seat, } \\
\text { or it will be studied and certified as being compatible with the plug- } \\
\text { ging method. Any altered disturbed wall rock will probably be removed } \\
\text { prior to placing the plug, or the plugging method must be certified } \\
\text { compatible with sealing any altered or disturbed rock. class I plugs } \\
\text { will probably consist of a series of individual plugs in order to pro- } \\
\text { vide multiple barriers and safety in case of partial failure of any } \\
\text { component. }\end{array}$} & \\
\hline $\begin{array}{l}\text { Class II plugs } \\
\text { These plugs will } \\
\text { be placed through- } \\
\text { out the system; } \\
\text { failure of a Class } \\
\text { II plug allows the } \\
\text { material from with- } \\
\text { in the repository } \\
\text { to reach Class I } \\
\text { plugs. }\end{array}$ & \multicolumn{4}{|c|}{$\begin{array}{l}\text { The design and placement of Class I plugs will be similar to class I } \\
\text { plugs. The only difference will be in their positions within the } \\
\text { system. }\end{array}$} \\
\hline
\end{tabular}


Table 3-3 (continued)

\begin{tabular}{|c|c|c|c|c|}
\hline Parameter & $\begin{array}{c}\text { Boreholes That Start } \\
\text { at the Surface }\end{array}$ & $\begin{array}{c}\text { Boreholes That Start } \\
\text { in the Subsurface }\end{array}$ & Tumnels & Shafts \\
\hline $\begin{array}{l}\text { Class III Plugs } \\
\text { These plugs will } \\
\text { be primarily des- } \\
\text { igned to fill space } \\
\text { and provide struc- } \\
\text { tural integrity } \\
\text { within the reposi- } \\
\text { tory. They may } \\
\text { also be designed } \\
\text { to provide bar- } \\
\text { riers to waste } \\
\text { migration, but } \\
\text { their function } \\
\text { as barriers will } \\
\text { be a secondary } \\
\text { function. }\end{array}$ & \multicolumn{4}{|c|}{$\begin{array}{l}\text { Class III plugs may be placed against permeable rock, against casing, cenent, or linings. } \\
\text { The main purpose of class III plugs is to fill place or provide structural strength. } \\
\text { Secondary purpose may include inhibiting circulation of water, providing ion exchange } \\
\text { capacity, providing other multiple barriers to the migration of waste, or providing } \\
\text { other beneficial functions. } \\
\text { Backfill may be considered a class III application, or it may ultimately become a } \\
\text { separate category. }\end{array}$} \\
\hline \multicolumn{5}{|c|}{ Description of Wall and Wall Rock } \\
\hline $\begin{array}{l}\text { Wall Rock } \\
\text { Surrounding } \\
\text { Repository } \\
\text { Openings } \\
\text { Glaciof luvial } \\
\frac{\text { Sediments ffor }}{\text { Class III }} \\
\frac{\text { plugs or back- }}{\text { IiTfonTy) }}\end{array}$ & $\begin{array}{l}\text { Varies-will encounter all } \\
\text { formations from the surface } \\
\text { to the tunnel depth of the } \\
\text { hole. } \\
\text { Wells are generally cased } \\
\text { or comented through these. }\end{array}$ & $\begin{array}{l}\text { Varies--each subsurface } \\
\text { borehole would be designed } \\
\text { for one type of wall rock. } \\
\text { Not applicable }\end{array}$ & $\begin{array}{l}\text { By definition, all tumnels } \\
\text { will be in the repository } \\
\text { flow. } \\
\text { Not applicable }\end{array}$ & $\begin{array}{l}\text { Shafts will penetrate all } \\
\text { formations in the strati- } \\
\text { graphic section to repos- } \\
\text { itory depth. } \\
\text { Noncohesive layers, water } \\
\text { charged and highly permeable } \\
\text { below the water table. Con- } \\
\text { sists of gravels and sands. } \\
\text { shaft lining and wall rock } \\
\text { treatment is anticipated. }\end{array}$ \\
\hline
\end{tabular}




\section{Table 3-3 (continued)}

\begin{tabular}{|c|c|c|c|c|}
\hline Parameter & $\begin{array}{c}\text { Boreholes That Start } \\
\text { at the Surface }\end{array}$ & $\begin{array}{c}\text { Boreholes That Start } \\
\text { in the Subsurface }\end{array}$ & Tunnels & Shafts \\
\hline $\begin{array}{l}\text { Ringold Formation } \\
\text { TClass II plugs } \\
\text { or backfill only) }\end{array}$ & $\begin{array}{l}\text { Wells penetrating to re- } \\
\text { pository depth are generally } \\
\text { cased and cemented through } \\
\text { the Ringold Formation. }\end{array}$ & $\begin{array}{l}\text { Occurs both above and } \\
\text { below the water table. } \\
\text { Consists of cohesive and } \\
\text { noncohesive layers of } \\
\text { sand, silt, and clay. } \\
\text { Most layers are cemented; } \\
\text { a few may be uncemented } \\
\text { or plastic. }\end{array}$ & Not applicable & $\begin{array}{l}\text { Occurs both above and below the } \\
\text { water table. Consists of co- } \\
\text { hesive and noncohesive layers } \\
\text { of sand, silt and clay. Most } \\
\text { layers are cemented, a few may } \\
\text { be uncemented or plastic. Shaft } \\
\text { lining and some formation } \\
\text { grouting is anticipated. }\end{array}$ \\
\hline $\begin{array}{l}\frac{\text { Ellensburg }}{\text { Formation }} \\
\text { (class III plugs } \\
\text { or backfil1 only) }\end{array}$ & $\begin{array}{l}\text { Hole may be cased or un- } \\
\text { cased through layers of } \\
\text { Ellensburg sediment, most } \\
\text { are cased. Uncased holes } \\
\text { can be expected to be over- } \\
\text { sized through sedimentary } \\
\text { interbeds (eroded by } \\
\text { drilling fluid, some caving } \\
\text { possible). Most layers are } \\
\text { known as aquifers and can } \\
\text { be expected to produce water. }\end{array}$ & Not applicable & Not applicable & $\begin{array}{l}\text { Shaft lining is anticipated at } \\
\text { time of backfill or plug place- } \\
\text { ment. Formation grouting } \\
\text { (behind lining) is anticipated } \\
\text { to control water during exca- } \\
\text { vations. }\end{array}$ \\
\hline
\end{tabular}


Table 3-3 (continued)

\begin{tabular}{|c|c|c|c|c|}
\hline Parameter & $\begin{array}{c}\text { Boreholes That Start } \\
\text { at the Surface }\end{array}$ & $\begin{array}{c}\text { Boreholes That Start } \\
\text { in the Subsurface }\end{array}$ & Tunnels & Shafts \\
\hline \multicolumn{5}{|l|}{ Hydrology } \\
\hline$\frac{\text { Groundwater }}{\text { in Wall Rock }}$ & $\begin{array}{l}\text { It can be assumed that holes } \\
\text { to be plugged will penetrate } \\
\text { all three aquifer zones: the } \\
\text { unconfined, the upper-con- } \\
\text { fined, and the lower-confined } \\
\text { aquifers. Licensed plugs } \\
\text { will probably be placed in } \\
\text { aquicludes or aquifuges } \\
\text { within the lower aquifer } \\
\text { zone, in or adjacent to the } \\
\text { repository flow. }\end{array}$ & $\begin{array}{l}\text { Each hole drilled from tun- } \\
\text { nels or shafts in the sub- } \\
\text { surface will probably only } \\
\text { penetrate one aquifer, if } \\
\text { any. }\end{array}$ & $\begin{array}{l}\text { Tunnels will be mined from } \\
\text { rock generally classed as } \\
\text { an aquiclude or as an aqui- } \\
\text { fuge located within the } \\
\text { repository flow in the } \\
\text { lower confined aquifer } \\
\text { zone. }\end{array}$ & $\begin{array}{l}\text { Shafts will penetrate all three } \\
\text { aquifer zones. Groundwater } \\
\text { conditions will vary depending } \\
\text { on the adjacent wall rock. }\end{array}$ \\
\hline Permeability & $\begin{array}{l}\text { Because the holes will pene- } \\
\text { trate essentially all flows } \\
\text { in the section, they will } \\
\text { also penetrate aquifers. At } \\
\text { the time of plugging, many } \\
\text { of the aquifers will be iso- } \\
\text { lated from the holes by } \\
\text { casing or cemented casing. } \\
\text { some aquifers can be antici- } \\
\text { pated in the lower uncased } \\
\text { sections of the hole prior } \\
\text { to plugging. }\end{array}$ & $\begin{array}{l}\text { Grout holes drilled from } \\
\text { shafts will probably be } \\
\text { drilled into permeable } \\
\text { zones. They will be used } \\
\text { to inject grout to lower } \\
\text { the permeability. This } \\
\text { grout may be considered } \\
\text { a Class III backfill for } \\
\text { that type of hole. Explor } \\
\text { ation holes, drilled } \\
\text { ahead of tunnels, will } \\
\text { only be backfilled if } \\
\text { they intersect substandard } \\
\text { rock. This rock would } \\
\text { probably be defined on the } \\
\text { basis of its permeability. }\end{array}$ & $\begin{array}{l}\text { By definition, the tunnels } \\
\text { should only be constructed } \\
\text { through relatively imper- } \\
\text { meable rock. The reposi- } \\
\text { tory flow will be selected } \\
\text { on the basis of its being } \\
\text { an aquiclude or an aqui- } \\
\text { fuge. It can be antici- } \\
\text { pated that an exploratory } \\
\text { hole will be drilled ahead } \\
\text { of all of the tunnels to } \\
\text { intersect any potential } \\
\text { permeable rock within the } \\
\text { repository flow. If perm- } \\
\text { eable rock is encountered, } \\
\text { it is assumed that the tun- } \\
\text { nel will not be driven } \\
\text { through that zone. }\end{array}$ & $\begin{array}{l}\text { It is assumed that the perme- } \\
\text { ability of the wall rocks inter- } \\
\text { sected by shafts will vary } \\
\text { cansiderably. Permeable rock } \\
\text { can be anticipated within the } \\
\text { upper confined aquifer (in and } \\
\text { above the Vantage Member). In } \\
\text { the lower portion of the shafts, } \\
\text { permeability should be limited } \\
\text { to flow contacts. Where the } \\
\text { shaft intersects the repository } \\
\text { flow, the rock should be } \\
\text { relatively impermeable. }\end{array}$ \\
\hline
\end{tabular}


Table 3-3 (continued)

\begin{tabular}{|c|c|c|c|c|}
\hline Parameter & $\begin{array}{c}\text { Boreholes That Start } \\
\text { at the Surface }\end{array}$ & $\begin{array}{l}\text { Boreholes That Start } \\
\text { in the subsurface }\end{array}$ & Tunnels & Shafts \\
\hline Hydrostatic Head & $\begin{array}{l}\text { The increase of hydrostatic } \\
\text { head with depth is no prob- } \\
\text { lem by itself. problems may } \\
\text { result from differential head } \\
\text { that exists between the wall } \\
\text { rock and the hole or between } \\
\text { permeable zones at various } \\
\text { depths within the hole. }\end{array}$ & $\begin{array}{l}\text { Hydrostatic head will in- } \\
\text { crease with depth. Any } \\
\text { hole drilled from the re- } \\
\text { pository tunnels or shafts } \\
\text { has a probability of en- } \\
\text { countering water in perm- } \\
\text { eable rock. Since tunnels } \\
\text { and shafts will be dry } \\
\text { during construction, any } \\
\text { water intersected by holes } \\
\text { drilled from them would be } \\
\text { at a higher hydrostatic } \\
\text { pressure. At repository } \\
\text { depth, this head differ- } \\
\text { ential could be as much as } \\
15 \text { MPa. }\end{array}$ & $\begin{array}{l}\text { Hydrostatic head in the wall } \\
\text { rock will be a function of } \\
\text { repository depth and the } \\
\text { piezometric presure of the } \\
\text { lower confined aquifer. It } \\
\text { will probably be at least } \\
7 \text { mp bilt probably not more } \\
\text { than } 14 \text { Mpa. Thus, during } \\
\text { mining and storage, differ- } \\
\text { ential head between the } \\
\text { water in the wall rock and } \\
\text { the amosphere in the tun- } \\
\text { nels will be high. Nor- } \\
\text { mally, the high head will be } \\
\text { compensated by the low per- } \\
\text { meablities so that the tun- } \\
\text { nels can be kept dry. How- } \\
\text { ever, once the repository } \\
\text { is closed, the high head in } \\
\text { the wall rocks will be a } \\
\text { driving force to saturate } \\
\text { any open space left in the } \\
\text { tumels. }\end{array}$ & $\begin{array}{l}\text { The hydrostatic head will in- } \\
\text { crease with depth. Since the } \\
\text { shafts will penetrate many perm- } \\
\text { eable zones on their way to the } \\
\text { repository flow, water flows } \\
\text { at various hydrostatic heads } \\
\text { are anticipated. Thus, some } \\
\text { water control measures will } \\
\text { be required. }\end{array}$ \\
\hline
\end{tabular}

groundwater through rock, plugs, and backfill in the repository zone. 
Table 3-3 (continued)

\begin{tabular}{|c|c|c|c|c|}
\hline Parameter & $\begin{array}{c}\text { Boreholes That Start } \\
\text { at the Surface }\end{array}$ & $\begin{array}{c}\text { Boreholes That Start } \\
\text { in the Subsurface }\end{array}$ & Tunnels & Shafts \\
\hline$\frac{\text { Geochemical }}{\text { Conditions }}$ & $\begin{array}{l}\text { Static Conditions } \\
\text { It can be assumed that any } \\
\text { borehole drilled from the } \\
\text { surface will have been in- } \\
\text { active for a period of time } \\
\text { bef ore plugging and will be } \\
\text { at static conditions. } \\
\text { Above the water table, } \\
\text { the hole will be filled } \\
\text { with air, and it can be } \\
\text { anticipated that the } \\
\text { conditions will be oxi- } \\
\text { dizing with an excess of } \\
\text { con in any groundwater } \\
\text { adhering to the walls or } \\
\text { interconnecting frac- } \\
\text { tures. } \\
\text { At the water table, the } \\
\text { upper few meters of the } \\
\text { aquifer may be charged } \\
\text { with oxygen and co } \\
\text { Below the water table it } \\
\text { is not anticipated that } \\
\text { the water would be sat- } \\
\text { urated with either oxy- } \\
\text { gen or con. At some } \\
\text { depth, Eh conditions } \\
\text { will become reducing } \\
\text { and pH conditions will } \\
\text { become neutral or basic. } \\
\text { At repository depth, a } \\
\text { reducing Eh and basic } \\
\text { pH is anticipated. }\end{array}$ & $\begin{array}{l}\text { Normally, any hole drilled } \\
\text { from the subsurface would } \\
\text { encounter only one set of } \\
\text { Eh and pH conditions. } \\
\text { Refer to the columns on } \\
\text { tunnels and shafts for } \\
\text { conditions at point where } \\
\text { borehole may be made. }\end{array}$ & $\begin{array}{l}\text { Conditions within the } \\
\text { dall Rock } \\
\text { Prior to tunnel excava- } \\
\text { tion, wall rock should } \\
\text { be saturated, and the } \\
\text { groundwater chemistry } \\
\text { in the wall rock would } \\
\text { have a reducing Eh and } \\
\text { a neutral to moderately } \\
\text { basic pH. } \\
\text { Arter excavations, air } \\
\text { in the tunnels will be } \\
\text { against the wall rock. } \\
\text { Oxygen can be expected } \\
\text { to permeate any openings } \\
\text { and will become dissol- } \\
\text { ved in water in capi- } \\
\text { llary openings Thus, a } \\
\text { zone of the wall rock } \\
\text { around the tunnel will } \\
\text { shift to oxidizing con- } \\
\text { ditions and possibly } \\
\text { have a lower pl due to } \\
\text { dissolved co. s. Since } \\
\text { water in the wall rocks } \\
\text { will be under a high } \\
\text { head and will be mig- } \\
\text { rating toward the tunnel, } \\
\text { the depth of this change } \\
\text { will be a function of the } \\
\text { velocity of groundwater } \\
\text { approaching the tunnel } \\
\text { and the diffusion of oxy- } \\
\text { gen and con back into the } \\
\text { water. }\end{array}$ & $\begin{array}{l}\text { Geochemical conditions will } \\
\text { vary from the surface to repos- } \\
\text { itory depth as explained in the } \\
\text { column under boreholes that } \\
\text { start from the surface. Geo- } \\
\text { chemical conditions in the wall } \\
\text { rock prior to excavation, during } \\
\text { operations, and after closure } \\
\text { will be similar to the scenario } \\
\text { discussed under tunnels. }\end{array}$ \\
\hline
\end{tabular}


Table 3-3 (continued)

\begin{tabular}{|c|c|c|c|c|}
\hline Parameter & $\begin{array}{c}\text { Boreholes That Start } \\
\text { al the Surface }\end{array}$ & $\begin{array}{l}\text { Boreholes That start } \\
\text { in the Subsurface }\end{array}$ & Tunnels & Shafts \\
\hline $\begin{array}{l}\text { Geochemical } \\
\frac{\text { Conditions }}{\text { (continued) }}\end{array}$ & $\begin{array}{l}\text { Conditions During Drilling } \\
\text { During drilling with } \\
\text { air, groundwater in (or } \\
\text { adjacent to) the hole } \\
\text { would become saturated } \\
\text { with both oxygen and C. } 0_{2} . \\
\text { When drilling with water } \\
\text { or drilling mud, the } \\
\text { drilling fluid returns to } \\
\text { the surface and is held } \\
\text { for a time in setting } \\
\text { tanks. Thus, the dril- } \\
\text { ling fluid would probably } \\
\text { be saturated with oxygen. } \\
\text { Many drilling fluids have } \\
\text { a ph control so that they } \\
\text { are moderately to highly } \\
\text { basic. }\end{array}$ & & $\begin{array}{l}\text { Condition after closure } \\
\text { The only oxygen remaining in } \\
\text { the tunnel after closu" } \\
\text { will be traped in the pore } \\
\text { spaces in the backfill or } \\
\text { plugs. This will soon be } \\
\text { used up and the geochemical } \\
\text { conditions will either re- } \\
\text { turn to those existing be- } \\
\text { fore the repository was exca- } \\
\text { vated or will be at equili- } \\
\text { brium with the geochemical } \\
\text { conditions in the backfill or } \\
\text { plug material. }\end{array}$ & \\
\hline $\begin{array}{l}\text { Plugs and Plug } \\
\text { Seats in Grande } \\
\text { Ronde Basalt }\end{array}$ & \multicolumn{4}{|c|}{$\begin{array}{l}\text { Assumption } \\
\text { It is assumed that all Class I and II plugs will be placed in and adjacent to the } \\
\text { repository flow in Grande Ronde Basalt. Class III plugs and backfill may also be } \\
\text { used here. } \\
\text { Major Concerns } \\
\text { Groundwater appears to be the only significant medium available for transport of } \\
\text { radionuclides out or the repository zone once the repository is closed. Thus, } \\
\text { groundwater and its movements are of major concern to the program. Within this } \\
\text { study major areas of concern are: } \\
\text { Groundwater movement through the plug } \\
\text { G Groundwater movement at the plug-wall rock interface } \\
\text { Groundwater movement through damaged or altered rock ("disturbed rock") } \\
\text { adjacent to the plug. } \\
\text { Objectives } \\
\text { The program should lead to a plug design that: } \\
\text { - Will have a permeability equal to or less than that which existed in the } \\
\text { rock prior to excavation } \\
\text { - Is predictable through time } \\
\text { - Can be tested and shown effective. }\end{array}$} \\
\hline
\end{tabular}


Table 3-3 (continued)

\begin{tabular}{c|c|c|c|c|}
\hline Parameter & $\begin{array}{c}\text { Boreholes That start } \\
\text { at the Surface }\end{array}$ & $\begin{array}{c}\text { Boreholes That Start } \\
\text { in the Subsurface }\end{array}$ & Tunnels \\
\hline
\end{tabular}

\section{Columbia River} Basati (CTass I, II and III plugs and backfill)

General

Description

$\stackrel{\omega}{0}$
The Columbia River basalt consists of flood basalt flows that range from a few tens of meters to about $100 \mathrm{~m}$ thick. It is assumed for this project that the flows at repository depth will be essentially of uniform thickness across the repository.

By definition, the attitude of the repository flow will be near horizontal (less than $5^{\circ}$ dip). This precludes locating the repository near the steeply dipping anticlines and faults associated with those folds.

The repository will be below the water table; thus by derinition, it will be in saturated rock. The basalt flows are relatively impermeable. Permeability (which will produce water at an opening) is normally found only in interflow zones at flow contacts, if at all.

At repository depth two major types of jointing are found. Near the base of the flow, a zone called the colonnade is characterized by vertical columnar joints. Above the colonnade, in a zone called the entablature, the joints fan and intersect with random dips and strikes.

Examination of the core indicates that joints cut the core every 6 to $24 \mathrm{~cm}$ in the thicker flows. Most joints are cemented with smectite, zeolite, and silica minerals with minimum amounts of pyrite minerals formed from groundwater-wall-rock reactions. 
Table 3-3 (continued)

\begin{tabular}{|c|c|c|c|c|}
\hline Parameter & $\begin{array}{c}\text { Boreholes That Start } \\
\text { at the Surface }\end{array}$ & $\begin{array}{l}\text { Boreholes That Start } \\
\text { in the Subsurface }\end{array}$ & Tunnels & Shafts \\
\hline $\begin{array}{l}\text { Physical } \\
\text { Characteristics } \\
\text { of Basalt } \\
\text { Note: The ranges } \\
\text { express uncertainty, } \\
\text { variation in test } \\
\text { results or changes } \\
\text { due to depth. Where } \\
\text { only one value is } \\
\text { given, it was the } \\
\text { value selected by } \\
\text { the cited authority } \\
\text { as being a reason- } \\
\text { able, average, or } \\
\text { representative } \\
\text { value. }\end{array}$ & 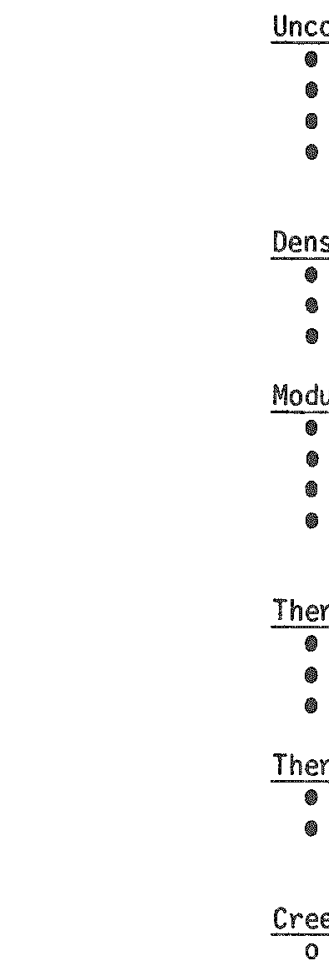 & 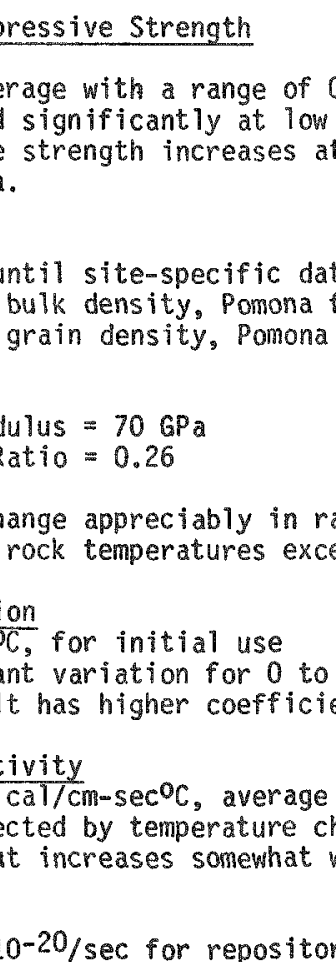 & $\begin{array}{l}\text { ures } \\
\text { ssures greater } \\
\text { and forecasted } \\
\text { anisters. } \\
\text { ar basalt. } \\
\text { of } \\
\text { basalt. }\end{array}$ & \\
\hline
\end{tabular}


Table 3-3 (continued)

\begin{tabular}{|c|c|c|c|c|}
\hline Parameter & $\begin{array}{l}\text { Boreholes That Start } \\
\text { at the Surface }\end{array}$ & $\begin{array}{l}\text { Boreholes That Start } \\
\text { in the Subsurface }\end{array}$ & Tunnels & Shafts \\
\hline \multirow[t]{4}{*}{$\begin{array}{l}\text { Physical } \\
\frac{\text { Characteristics }}{\text { of Basalt }} \\
\text { (continued) }\end{array}$} & \multicolumn{4}{|c|}{$\begin{array}{l}\text { Stress Field in Rock } \\
\text { Earlier work is cited to generalize that the vertical stress approximates } \\
\text { the lithostatic load and that major and minor horizontal stresses range } \\
\text { from } 1 / 2 \text { to } 1-1 / 2 \text { times the vertical. Thus, until in situ values are } \\
\text { determined, the following approximations (based on a repository between } \\
1,000 \mathrm{~m}-1,500 \text { m depth) are suggested. } \\
\begin{array}{ll}\text { - Vertical stress } & 28-74 \mathrm{MPa} \\
\text { - Horizontal stress } & 14-70 \mathrm{MPa} \text {. }\end{array}\end{array}$} \\
\hline & \multicolumn{4}{|c|}{ Hydraulic Conductivities of Basalt } \\
\hline & \multicolumn{4}{|c|}{$\begin{array}{l}\text { - } 10^{-7}-10^{-13} \mathrm{~cm} / \mathrm{sec} \text { reported from recent tests in Grande Ronde Basalt. } \\
\text { Fracture permeability - no applicable values found. }\end{array}$} \\
\hline & \multicolumn{4}{|c|}{$\begin{array}{l}\text { Pore Water/Groundwater } \\
\text { Use sample analysis from Deju (1978) or Ames (1978) for initial model, } \\
\text { better analyses will probably become available to supercede this } \\
\text { preliminary data. } \\
\text { pH various measurements, } 9.6-9.9 \text {. } \\
\text { En assumed reducing; precise values not well documented. }\end{array}$} \\
\hline \multicolumn{5}{|l|}{$\frac{\text { Disturbed }}{\text { Rock }}$} \\
\hline Definition & \multicolumn{4}{|c|}{$\begin{array}{l}\text { General Discussion } \\
\text { When openings are made in stressed rock, the rock is of ten displaced } \\
\text { toward the opening (a zone of lower stress) by creep, induced fracture, } \\
\text { or adjustments in the existing joints and fractures. } \\
\text { The problem can be made worse by irregular openings, excessive blasting } \\
\text { or poor workmanship. } \\
\text { At some depth in the rock, the rock strength will equal the inward force } \\
\text { and the in situ stresses will be bridged around the opening. The wall } \\
\text { rock acts as an arch to carry the in situ stress; thus, the forces pushing } \\
\text { the rock toward the hole are compensated. } \\
\text { The point where this compensation occurs marks the extent and thickness } \\
\text { of disturbed rock. } \\
\text { For smooth, regular openings in competent rock, this depth of stress } \\
\text { compensation may be only a fraction of a hole diameter from the } \\
\text { opening-wall rock interface. }\end{array}$} \\
\hline
\end{tabular}




\section{Table 3-3 (continued)}

\begin{tabular}{|c|c|c|c|c|}
\hline Parameter & $\begin{array}{c}\text { Boreholes That Start } \\
\text { at the Surface }\end{array}$ & $\begin{array}{l}\text { Boreholes That Start } \\
\text { in the Subsurface }\end{array}$ & Tunnels & Shafts \\
\hline$\frac{\text { Definition }}{\text { (continued) }}$ & \multicolumn{4}{|c|}{$\begin{array}{l}\text { For incompetent rocks, the depth of compensation may be several hole } \\
\text { diameters into the wail. } \\
\text { For rock that behaves plastically (i.e., shale, salt), there is no depth } \\
\text { of compensation. The walls will continue to move until the hole has } \\
\text { been closed. } \\
\text { The compressive strength of basalt is high when compared with the anti- } \\
\text { cipated stress conditions in the wall rock (see Physical characteristics } \\
\text { of Basalt). } \\
\text { The depth of disturbed rock will be a function of the roundness of the } \\
\text { opening, the regularity of the opening, the present fracture strength } \\
\text { of fracture fillings, and the construction methods used to excavate } \\
\text { the rock. }\end{array}$} \\
\hline $\begin{array}{l}\text { Means of } \\
\text { Minimizing } \\
\text { Disturbed } \\
\text { Rock }\end{array}$ & \multicolumn{4}{|c|}{$\begin{array}{ll}\text { No special problems are anticipated in small diameter } & \text { Openings should be circular or elliptical. Stress corpensa- } \\
\text { boreholes. The small diameter, roundness of the opening, } & \text { tion in the wall rock occurs on a circular or elliptical } \\
\text { and the ratio of the strength of basalt to the stress } & \text { surface paralleling the axis of the opening. Square corners } \\
\text { present in the rock combined with the other factors indi- } & \text { or irregular reentrants move the surface of stress compensaw } \\
\text { cate a minimum depth of disturbed rock. } & \text { of disturbed rock. Blasting should be carefully controlled. } \\
\text { Orilling fluids that attack the secondary minerals in } & \text { Line drilling along the planned outline of the opening allows } \\
\text { cooling joints or fractures should be avoided. } & \text { Tor relief of blasting stress and promotes a regular opening. } \\
& \text { thanding machines induce less fracturing in the wall rock }\end{array}$} \\
\hline
\end{tabular}


Table 3-3 (continued)

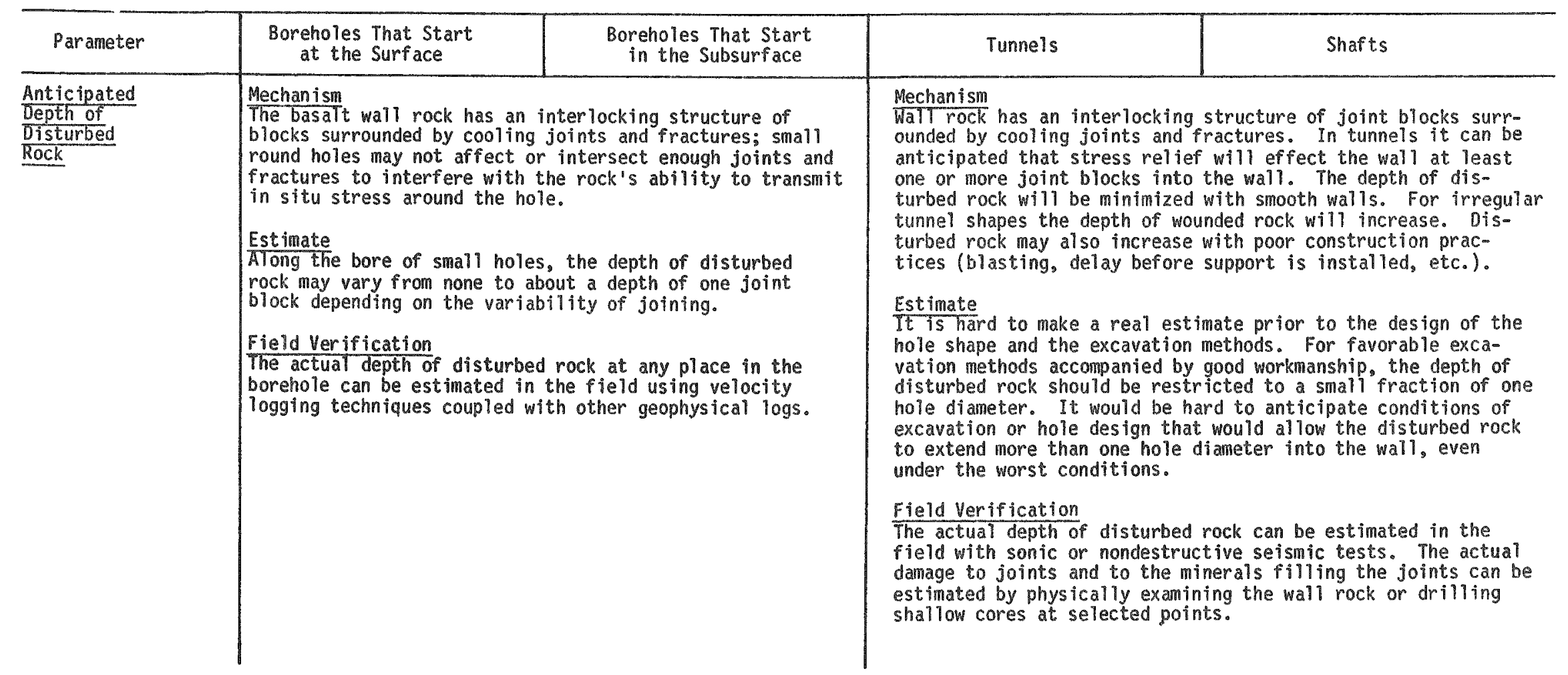


Table 3-3 (continued)

\begin{tabular}{|c|c|c|c|c|}
\hline Parameter & $\begin{array}{c}\text { Boreholes That Start } \\
\text { at the Surface }\end{array}$ & $\begin{array}{l}\text { Boreholes That start } \\
\text { in the Subsurface }\end{array}$ & Tunnels & Shafts \\
\hline $\begin{array}{l}\text { Remedial } \\
\text { Treatment } \\
\text { Available } \\
\text { Prior to Plug } \\
\text { Placement }\end{array}$ & \multicolumn{2}{|c|}{$\begin{array}{l}\text { Underreamers may be used to locally enlarge sec. } \\
\text { tions of the hole to remova altered or disturbed } \\
\text { wall rock. As hole size increases, the potential } \\
\text { for deeper disturbed rock also increases. Thus, } \\
\text { at some hole sizes, underreamers will not be able } \\
\text { to remove all the disturbed rock. The hole could } \\
\text { be enlarged to remove the disturbed rock. } \\
\text { In vertical holes, various drilling muds could } \\
\text { be used to produce hydrostatic pressure to avoid } \\
\text { additional damage. pressurized muds could also } \\
\text { be used in horizontal holes; however, this would } \\
\text { require drilling through a packing tox. } \\
\text { Methods of squeezing cement, clay slurries, or } \\
\text { other material into disturbed rock are available. } \\
\text { The problem would be to select a material and em- } \\
\text { placement compatible with predictabie behavior } \\
\text { through time. }\end{array}$} & \multicolumn{2}{|c|}{$\begin{array}{l}\text { Sections of disturbed rock could be carefully } \\
\text { removed by enlarging the hole. Various geo- } \\
\text { metries of enlargements could be used to en- } \\
\text { hance wall support. } \\
\text { Any method of removing disturbed rock should } \\
\text { also incorporate a method of immediately apply- } \\
\text { ing temponary support which could remain until } \\
\text { the plug is placed. }\end{array}$} \\
\hline \multicolumn{5}{|c|}{ Changes in the Subsurface Geochermical Environment } \\
\hline $\begin{array}{l}\text { Impact of } \\
\text { Manmade } \\
\text { Openings on } \\
\text { Geochemistry }\end{array}$ & $\begin{array}{l}\text { At repository depth, } \\
\text { changes should be minimum. } \\
\text { The holes will be wet until } \\
\text { plugged: therefore, any } \\
\text { potential geochenical } \\
\text { change would be induced } \\
\text { by the drilling fluid or } \\
\text { by the plugging method. }\end{array}$ & $\begin{array}{l}\text { Any holes that may be } \\
\text { sealed with Class I or II } \\
\text { plugs would probably be } \\
\text { sealed soon after they } \\
\text { were drilled. During most } \\
\text { of this time, there would } \\
\text { be an inflow of ground- } \\
\text { water from the wall rock } \\
\text { that would flush the bore- } \\
\text { hole and keep the geochen- } \\
\text { ical conditions essential- } \\
\text { ly as they were before the } \\
\text { hole was drilled. }\end{array}$ & $\begin{array}{l}\text { During Mining and storage } \\
\text { The atmosphere inside the } \\
\text { tunnels will be oxidizing. } \\
\text { minerals in the wall rocks } \\
\text { will be exposed to oxi- } \\
\text { dizing conditions. Some } \\
\text { desiccation of secondary } \\
\text { minerals in the joints and } \\
\text { fractures may be antici- } \\
\text { pated. }\end{array}$ & $\begin{array}{l}\text { The conditions in the upper } \\
\text { parts of the shafts will be } \\
\text { similar to those discussed } \\
\text { with the upper parts of } \\
\text { vertical boreholes. } \\
\text { The significant environmental } \\
\text { changes, from the standpoint } \\
\text { of plug placement, will occur } \\
\text { deep in the shafts near the } \\
\text { repository flow. For condi- } \\
\text { tions at this depth refer to } \\
\text { the column on tunnels. }\end{array}$ \\
\hline
\end{tabular}


Table 3-3 (continued)

\begin{tabular}{|c|c|c|c|c|}
\hline Parameter & $\begin{array}{c}\text { Boreholes That Start } \\
\text { at the Surface }\end{array}$ & $\begin{array}{l}\text { Boreholes That Start } \\
\text { in the Subsurface }\end{array}$ & Tunnels & Shafts \\
\hline$\frac{\text { Impact of }}{\text { Manmade }}$ & & $\begin{array}{l}\text { During placenent of the } \\
\text { plug, it may be necessary } \\
\text { to install a class III } \\
\text { plug as a water control } \\
\text { agent in the extremity of } \\
\text { the hole. Thus, any geo- } \\
\text { chemical changes that } \\
\text { would occur at the plug } \\
\text { seat would occur after the } \\
\text { water is stopped and dur- } \\
\text { ing the time the hole is } \\
\text { in place. }\end{array}$ & $\begin{array}{l}\text { Due to differential head, } \\
\text { wail rocks and joints will } \\
\text { remain charged with water. } \\
\text { The impact of changes in } \\
\text { the wall rock will be a fun- } \\
\text { ction of whether the oxygen } \\
\text { and other dissolved gases } \\
\text { can penetrate into the wall } \\
\text { faster than the water } \\
\text { migrates toward the tunnel. }\end{array}$ & \\
\hline$\frac{\text { Impact of }}{\text { Plugs and }}$ & \multicolumn{2}{|c|}{$\begin{array}{l}\text { The impact of plugging material will vary with } \\
\text { depth and with the aquifer system. }\end{array}$} & \multicolumn{2}{|c|}{$\begin{array}{l}\text { The permeability of the wall rock will be low. } \\
\text { This will inhibit the exchange of pore fluid } \\
\text { and any possible geochemical changes. }\end{array}$} \\
\hline
\end{tabular}

The significant areas for licensed plugs are in the repository flow and adjacent flows. For any significant geochemical change to occur there must be comunications between the fluids and the pore space in the rock.

There is more chance of chemical change in plugs placed in boreholes, because the mass of plugs will be relatively small compared to the area of interface with the wall rock.

\begin{tabular}{l|l}
\hline Impact of & $\begin{array}{l}\text { Most boreholes will not } \\
\text { intersect the tunnels or } \\
\text { Gaste on the } \\
\text { Geochemical } \\
\text { Environment } \\
\text { repositace openings of the } \\
\text { they will be separated } \\
\text { from the waste by natural } \\
\text { and engineered barriers. } \\
\text { The waste must migrate } \\
\text { through both engineered } \\
\text { and natural barriers before } \\
\text { it can come into contact } \\
\text { with the borehole and } \\
\text { atter the geochemical en- } \\
\text { vironment of the borehole. }\end{array}$
\end{tabular}

Plugs placed in holes dritied from tunnels could be affected by the geochemistry of the waste if that waste escapes through the canister, thermal overpack, in the tunnels.

The probability for a plug being influenced by the geochemistry of the waste material would be slightly higher in storage cumnels than it would be in the haul tunnels.
The mass of the plug material will be large compared with the area where the plugs are in contact with the wall rock.

The area where adjacent plugs contact each other will be large when compared with similar areas in small boreholes.

The probability of the geochemistry of the water af fecting plugs in tumels appears higher than the probability in boreholes or shafts.
Plugs or backfill in shafts would probably be separated from the waste material by several engineered barriers.

$$
\text { (n) }
$$


Table 3-3 (continued)

\begin{tabular}{|c|c|c|c|c|}
\hline Parameter & $\begin{array}{c}\text { Boreholes That Start } \\
\text { at the Surface }\end{array}$ & $\begin{array}{c}\text { Boreholes That Start } \\
\text { in the Subsurface }\end{array}$ & Tunnels & Shafts \\
\hline $\begin{array}{l}\text { Impact of Heat } \\
\text { TAssume static } \\
\text { rock temperature } \\
\text { now } 50-550 \mathrm{c} \text { some } \\
\text { parts of reposi- } \\
\text { tory may rise to } \\
\text { 20006 during early } \\
\text { isolation.) }\end{array}$ & $\begin{array}{l}\text { Most of the vertical } \\
\text { boreholes to be plugged } \\
\text { under this category will } \\
\text { be at some distance from } \\
\text { the repository shafts and } \\
\text { tunnels. The effects of } \\
\text { heat will vary from bore- } \\
\text { hole to borehole and must } \\
\text { be considered on a site } \\
\text { specific basis. }\end{array}$ & $\begin{array}{l}\text { The subsurface boreholes } \\
\text { drilled from storage } \\
\text { tunnels will probably be } \\
\text { in the zone of maximum } \\
\text { heat changes during the } \\
\text { repository life. Any } \\
\text { boreholes drilled from } \\
\text { transportation tunnels } \\
\text { will probably be further } \\
\text { removed from the heat } \\
\text { sources and will be less } \\
\text { affected by the heating } \\
\text { and cooling of the repo- } \\
\text { sitory rock. For further } \\
\text { discussions, refer to } \\
\text { comments under the tun- } \\
\text { nel column. }\end{array}$ & $\begin{array}{l}\text { The tunnels will extend } \\
\text { from near the waste canis- } \\
\text { ters to areas remote from } \\
\text { the waste. Thus, the rate } \\
\text { of change will vary from } \\
\text { place to place and from } \\
\text { storage tunnels to haul } \\
\text { tunnels. } \\
\text { Storage tunnels will have } \\
\text { the maximum change of temp- } \\
\text { erature during the life of } \\
\text { the repository. Haul tun- } \\
\text { nels will intersect storage } \\
\text { tunnels and will have a } \\
\text { relatively high range of } \\
\text { heat conditions during the } \\
\text { repository life. Away from } \\
\text { the storage areas, the im- } \\
\text { pact of the cyclic heat } \\
\text { change will diminish. } \\
\text { It can be anticipated that } \\
\text { class II plugs will be } \\
\text { placed nearer to the waste } \\
\text { and will be subjected to } \\
\text { a greater temperature } \\
\text { change during the heating } \\
\text { and cooling. } \\
\text { At least some of the class } \\
\text { I plugs will be remote from } \\
\text { the storage areas where the } \\
\text { heat change will be only } \\
\text { moderate. }\end{array}$ & $\begin{array}{l}\text { The shafts will probably be } \\
\text { some distance fron heat sources. } \\
\text { since the heat dissipates radi- } \\
\text { ally through rock, the impact } \\
\text { on shafts will be less than the } \\
\text { impact on tunnels. }\end{array}$ \\
\hline
\end{tabular}


Table 3-3 (continued)

\begin{tabular}{|c|c|c|c|c|}
\hline Parameter & $\begin{array}{c}\text { Boreholes That Start } \\
\text { at the Surface }\end{array}$ & $\begin{array}{c}\text { Boreholes That Start } \\
\text { in the Subsurface }\end{array}$ & Tunnels & Shafts \\
\hline \multicolumn{5}{|c|}{ Summary of the State of Practice } \\
\hline $\begin{array}{l}\text { Purpose of } \\
\text { Backfill in } \\
\frac{\text { Current Prac- }}{\text { Eice (known) }} \\
\frac{\text { repository }}{\text { applications) }}\end{array}$ & $\begin{array}{l}\text { Most vertical boreholes, by } \\
\text { state law, are required to } \\
\text { be plugged when they are } \\
\text { abandoned. This plugging } \\
\text { is basically for the pro- } \\
\text { tection of aquifers or, } \\
\text { in some cases, economic } \\
\text { resources (petroleum, } \\
\text { evaporates, minerals). }\end{array}$ & $\begin{array}{l}\text { Construction Experience } \\
\text { Most holes drilled from } \\
\text { underground openings will } \\
\text { be for grouting, explora- } \\
\text { tion, or anchor bolts. } \\
\text { Grout holes are normally } \\
\text { plugged with the same } \\
\text { grout that is injected in } \\
\text { the wall rock to improve } \\
\text { its strength or to control } \\
\text { water. } \\
\text { Anchor bolt or rockbolt } \\
\text { holes are often grouted to } \\
\text { improve the bond between } \\
\text { the bolt and the wall rock. } \\
\text { Exploration holes, drilled } \\
\text { from mines, are seldom } \\
\text { backfilled unless they } \\
\text { present a problem by } \\
\text { making water. In this } \\
\text { case, they are grouted. }\end{array}$ & $\begin{array}{l}\text { Dams } \\
\text { Diversion tunnels are of- } \\
\text { ten sealed with tapered } \\
\text { concrete plugs. } \\
\text { Extensions of penstock tun- } \\
\text { nels are often sealed with } \\
\text { concrete plugs. } \\
\text { Exploratory tunnels are } \\
\text { backfilled, plugged, and/or } \\
\text { grouted. } \\
\text { Mines } \\
\text { Many openings in mines are } \\
\text { backfilled to prevent sub- } \\
\text { sidence. } \\
\text { Some mine backfill is for } \\
\text { the purpose of disposing } \\
\text { of cailings. } \\
\text { Sone shafts or tunnels are } \\
\text { plugged for aquifer pro- } \\
\text { tection. } \\
\text { Plugs are placed in inac- } \\
\text { tive shafts for water } \\
\text { control. }\end{array}$ & $\begin{array}{l}\text { Mines } \\
\text { Parts of shafts are back- } \\
\text { filled to prevent caving } \\
\text { and subsidence when the } \\
\text { shafts are abandoned. } \\
\text { Water-tight plugs are placed } \\
\text { in abandoned shafts for } \\
\text { aquifer protection. }\end{array}$ \\
\hline
\end{tabular}


Table 3-3 (contrimed)

\begin{tabular}{|c|c|c|c|}
\hline Parameter & $\begin{array}{c}\text { Boreholes That Start } \\
\text { at the Surface }\end{array}$ & $\begin{array}{c}\text { Boreholes That start } \\
\text { in the Subsurface }\end{array}$ & Toland 1 \\
\hline $\begin{array}{l}\text { Materials Used } \\
\text { in current } \\
\text { Practice }\end{array}$ & 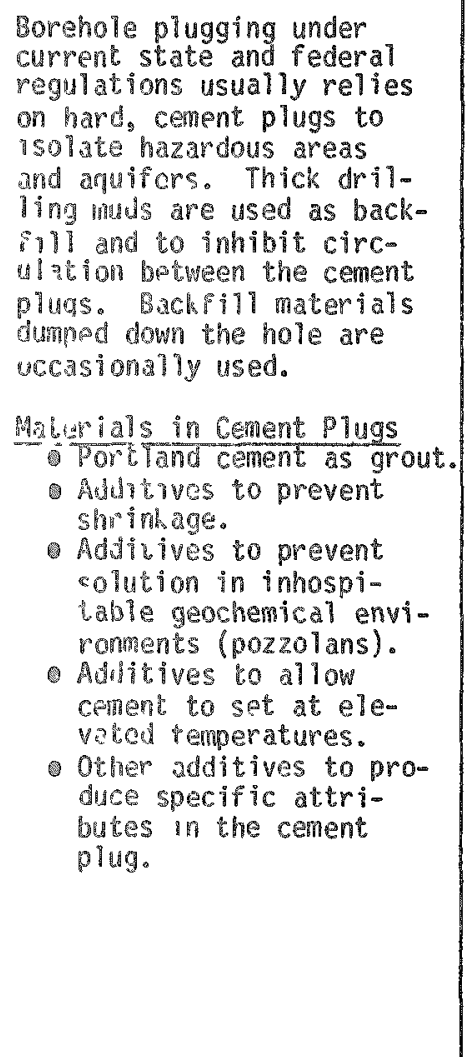 & 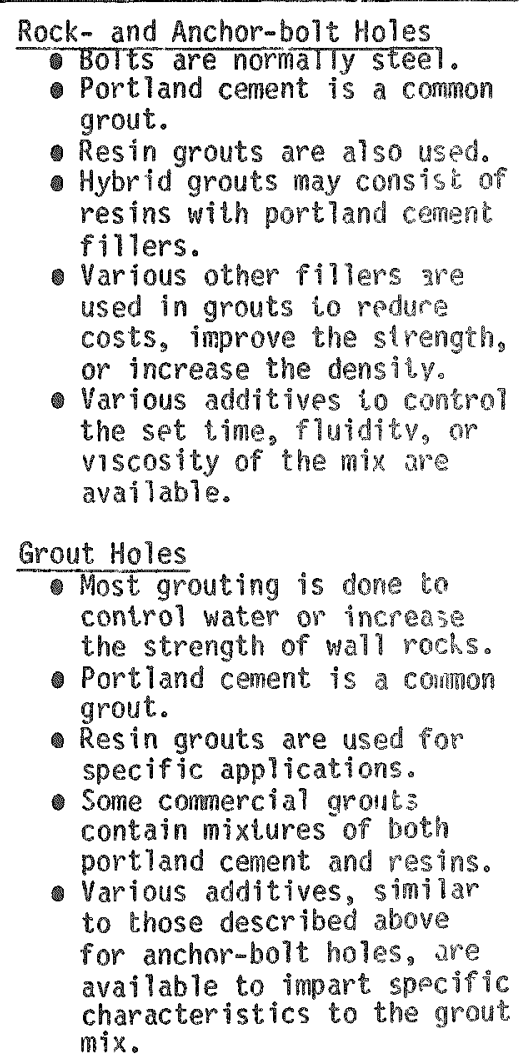 & 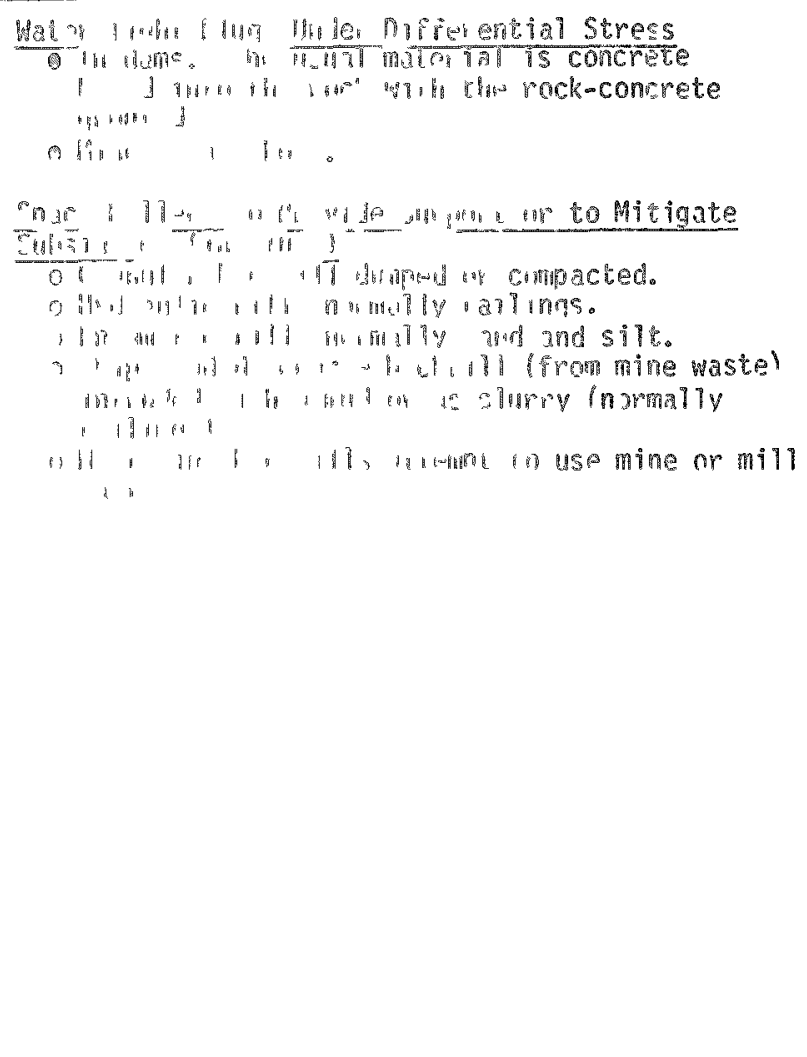 \\
\hline
\end{tabular}


Table 3-3 (continued)

\begin{tabular}{|c|c|c|c|c|}
\hline Parameter & $\begin{array}{l}\text { Boreholes That Start } \\
\text { at the Surface }\end{array}$ & $\begin{array}{c}\text { Boreholes That Start } \\
\text { in the Subsurface }\end{array}$ & Tunnels & Shafts \\
\hline$\frac{\text { Materials Used }}{\frac{\text { incurrent }}{\text { Practice }}}$ & $\begin{array}{l}\text { Materials in orillina Mud } \\
\text { Drilling muds are based } \\
\text { on bentonite, a thixo- } \\
\text { tropic clay in fresh } \\
\text { water } \\
\text { For saline waters, at- } \\
\text { tapulgite clay is the } \\
\text { thixotropic material. } \\
\text { Various fibrous mater- } \\
\text { ials are used to inhi- } \\
\text { bit lost circulation. } \\
\text { Starch or polymers are } \\
\text { used to seal the wall } \\
\text { rock and to build an } \\
\text { impermeable wall cake. } \\
\text { Sodiun hydroxide or } \\
\text { other caustics are used } \\
\text { to maintain a basic pH. } \\
\text { Many other additives } \\
\text { are used to impart } \\
\text { specific characteris- } \\
\text { bics to the drilling } \\
\text { mud. }\end{array}$ & & & \\
\hline
\end{tabular}


Table 3-3 (continued)

\begin{tabular}{|c|c|c|c|c|}
\hline Parameter & $\begin{array}{c}\text { Boreholes That Start } \\
\text { at the Surface }\end{array}$ & $\begin{array}{c}\text { Boreholes That Start } \\
\text { in the subsurface }\end{array}$ & Tunne Is & Shafts \\
\hline $\begin{array}{l}\text { Equipment Used } \\
\text { in Current } \\
\text { State-of-Prac- } \\
\text { tice }\end{array}$ & $\begin{array}{l}\text { The list of standard } \\
\text { equipment is too long to } \\
\text { describe. sone constraints } \\
\text { are listed: } \\
\text { oil drilling industry } \\
\text { has the capability to } \\
\text { plug holes to about } 40 \mathrm{~cm} \\
\text { diameter at repository } \\
\text { depth. } \\
\text { The water well drilling } \\
\text { industry has the capa- } \\
\text { bility to drill or plug } \\
\text { holes to about } 1 \text { m in } \\
\text { dianeter to about } 200 \mathrm{~m} \\
\text { depth. } \\
\text { The construction indus- } \\
\text { try has the capability } \\
\text { to drill and plug } \\
\text { larger diameter holes } \\
\text { with specialized equip- } \\
\text { ment at essentially any } \\
\text { depth. }\end{array}$ & $\begin{array}{l}\text { Most of the equipment for } \\
\text { subsurface hole plugging } \\
\text { has been developed by the } \\
\text { mining or construction } \\
\text { industries. Some oil- } \\
\text { field tools may be adap- } \\
\text { ted to work with mining } \\
\text { industry drills for } \\
\text { subsurface plugging. }\end{array}$ & $\begin{array}{l}\text { The mining industry has } \\
\text { developed methods for } \\
\text { backfilling tumnels and } \\
\text { stopes that could be } \\
\text { adapted to class II } \\
\text { plugs. } \\
\text { Water-tight bulkheads or } \\
\text { tunnel plugs have been } \\
\text { developed by both the } \\
\text { mining and construction } \\
\text { industries. These are } \\
\text { normally based on concrete } \\
\text { plugs with a final grout } \\
\text { seal at the plug-wall rock } \\
\text { interface. } \\
\text { The most significant } \\
\text { problems are anticipated } \\
\text { in producing a seal in the } \\
\text { crown of tunnels. } \\
\text { concrete placing and } \\
\text { grouting equipnent is } \\
\text { within the current state- } \\
\text { of-practice. }\end{array}$ & $\begin{array}{l}\text { Sharts are routirely } \\
\text { backfilled in bolh the } \\
\text { mining and construction } \\
\text { industries. Concrete } \\
\text { placement equiprint, } \\
\text { backfill compacting } \\
\text { equipment and materials } \\
\text { handing equipment are } \\
\text { available. }\end{array}$ \\
\hline
\end{tabular}


Table 3-3 (continued)

\begin{tabular}{|c|c|c|c|}
\hline Parameter & $\begin{array}{l}\text { Boreholes That Start } \\
\text { at the Surface }\end{array}$ & Tunnels & Shafts \\
\hline $\begin{array}{l}\text { Applicability } \\
\text { of the State- } \\
\text { of Practice to } \\
\text { the Repository } \\
\text { Program Plugs }\end{array}$ & $\begin{array}{l}\text { Cementing or grouting equipment is available } \\
\text { to make stateof-practice sealing possible. } \\
\text { The problem here is in predicting the } \\
\text { behavior of the cement or grout material } \\
\text { through time. } \\
\text { To allow the cement or grout behavior (through } \\
\text { time) to be predicted, a mix must be developed } \\
\text { that will hydrate to make minerals that can } \\
\text { be predicted through time. Thus, the problem } \\
\text { with cements or grouts concerns mix design and } \\
\text { licensing rather than construction and } \\
\text { placement. } \\
\text { With some modifications, existing construction } \\
\text { equipment could be adapted to compact soil-like } \\
\text { material into relative impermeable plugs. } \\
\text { Mixtures of natural materials could be designed } \\
\text { for both raliability through time and for their } \\
\text { ability to be compacted into impermeable plugs. } \\
\text { The problems, then, would be finding methods of } \\
\text { testing and certifying the plug through time. }\end{array}$ & $\begin{array}{l}\text { The comments on predicting } \\
\text { the stability of cement or } \\
\text { grout in boreholes are also } \\
\text { applicable to problems in } \\
\text { tunnels. Using mixtures of } \\
\text { natural materials designed } \\
\text { as impermeable embankments, } \\
\text { shows promise for back- } \\
\text { filling tunnels. } \\
\text { No major problems are fore- } \\
\text { seen for backfilling the } \\
\text { bottom two-thirds of tun- } \\
\text { nels with impermeable, } \\
\text { natural, soil-like mater- } \\
\text { ial. Most problems will } \\
\text { come in backfilling the } \\
\text { upper portions of the tun- } \\
\text { nels (the crown) where } \\
\text { space is restricted and } \\
\text { the last material must be } \\
\text { emplaced. } \\
\text { Backfill or plugs, using } \\
\text { mixtures of soil-ilike mater- } \\
\text { ial would require a great } \\
\text { deal of handwork to complete } \\
\text { the crown portion of the } \\
\text { plug. }\end{array}$ & $\begin{array}{l}\text { The comments on predicting } \\
\text { the stability of cement or } \\
\text { grout listed in the borehole } \\
\text { column are also applicable to } \\
\text { a discussion of cements or } \\
\text { grouts in shafts. Problems } \\
\text { experienced in compacted soil- } \\
\text { like materials in the cromn } \\
\text { portion of tunnels will not be } \\
\text { applicable to shafts. } \\
\text { The main problems in compac- } \\
\text { ting material in shafts will } \\
\text { be producing a seal with un- } \\
\text { even rock, and removing lin- } \\
\text { ings as compaction continues, } \\
\text { and to operate at the bottom } \\
\text { of a shaft where all backfill } \\
\text { material must be lowered over } \\
\text { the heads of the workers. }\end{array}$ \\
\hline
\end{tabular}




\section{RHO-BWI-ST-7}

\subsection{SELECTION OF CANDIDATE PLUG MATERIALS}

\subsubsection{Introduction}

The selection of materials for repository seals (plugs) is one of the most critical steps in the development of a borehole plugging system. The plugs will function as designed, throughout the long containment time necessary for high-level nuclear waste disposal, only if the materials chosen are highly compatible with the chemical and physical environment in which the plugs must exist. In addition, the materials selected will strongly influence the selection of emplacement machinery and plug design.

In the past, borehole plugging techniques have been developed principally by the petroleum industry. Various plugging techniques have aiso been developed for mine closure, chemical waste disposal, hydrothermal energy development, and nuclear testing development. Most previous work in burchole plugging has utilized cements or concretes (e.g., Ei7ers, 1973): however, Martin (1975) has investigated the possibility of using compacted natural, earthen materials, Roy and white (1975) and Roy and others $(1975,1976$ ) have investigated using hydrothermal transport to plug boreholes, and Black and others (1975) and Los Alamos Scientific Laboratory (1975) have investigated the possibility of using earth melting to seal boreholes. An excellent review of current borehole plugging technology has been prepared by D'Appolonia Consulting Engineers (1979).

Within the Basalt Waste Isolation Project borehole plugging program, a list of preferred candidate plugging materials has been selected for use in the laboratory testing program and in preconceptual design studies. The long functional life required of plug materials places great emphasis on chemical stability in the plug environment and proven longevity. Consequentiy, the list of preferred candidate materials is heavily weighted toward nalurally occurring geologic materials. of the man-made materials considered, concrete has the longest recorded survival history ( 2,000 years): however, its documented survival history is considerably shorter than the required isolation time and its stability under expected repository conditions has not been documented. It has been retained for the present because of its utipity in construction and 
the existing wealth of information on its properties. Either the long-term stability of concretes under repository conditions must be demonstrated or materials of proven longevity must be found to fill the role normally filled by concrete.

\subsubsection{Materials Selection Methodology}

The initial selection of candidate borehole plugging materials for a nuclear waste repository in basalt was reported by Taylor and 0thers (1979). In the initial selection process a list of potential borehole plugging materials was prepared on the basis of literature review and the combined experience of the authors. The list was intended to be a representative sampling of material types rather than a comprehensive list of all possible materials. The list of potential plug materials was passed through a series of selection screens (Table 3-4) designed to identify candidate plug materials that: (1) have a high probability for successful use in plugs; (2) have a high probability of acceptance based upon U.S. Nuclear Regulatory Commission criteria; and (3) could be used in the initial laboratory test program. The list of preferred candidate plug materials resulting from the initial selection process is presented in Tabie 3-5.

Subsequentiy, the material selection process outlined by Taylor and others (1979) was refined and verified to produce a materials selection process more firmly grounded in decision analysis and with as much objectivity as possible. The primary objectives of continued evaluation of the selection process and of the application of decision analysis to the problem are: (1) to correct deficiencies in logic in the original selection scheme; (2) to develop a method that avoids the use of weighting and rating factors and cutoff values: (3) to re-examine the initial comprehensive list of materials with a different approach; (4) to more completely document the steps of the process (specifically the steps used in the decision analysis); and (5) to develop an analytical approach that can be generalized and applied to materials selection problems pertaining to backfill and canister hole plugs. 
TABLE 3-4. Characteristics of Starting Materials (Ground to -200 Mesh).

\begin{tabular}{|c|c|c|c|c|c|c|c|}
\hline Material & $\begin{array}{l}\text { Sample } \\
\text { No. }\end{array}$ & $\begin{array}{c}\text { Density } \\
\text { pa }\end{array}$ & $\begin{array}{l}\text { Density } \\
\text { ob range }\end{array}$ & Particle Sizec & $\operatorname{BET}\left(m^{2} / g\right)^{d}$ & Color & Mineral Phasese \\
\hline Basalt & $A-76$ & 2.88 & 2.68 to 2.72 & $-\infty$ & & Dk. Gray & $L, A, M$ \\
\hline $\begin{array}{l}\text { Bentonite } \\
\text { Oregon } \\
\text { Oregon } \\
\text { Wyoming } \\
\text { Shurgel } \\
\text { Aquagel }\end{array}$ & $\begin{array}{l}A-60 \\
A=61 \\
A-04 \\
A=03 \\
A=05\end{array}$ & $\begin{array}{l}2.70 \\
2.67 \\
2.44 \\
2.47 \\
2.46\end{array}$ & $\mid \begin{array}{l}2.2 \text { to } 2.7 \\
2.2 \text { to } 2.7 \\
2.2 \text { to } 2.7 \\
2.2 \text { to } 2.7 \\
2.2 \text { to } 2.7\end{array}$ & $\begin{array}{l}2.9 \\
2.9 \\
7.3 \\
5.9 \\
4.9\end{array}$ & $\begin{array}{l}90 \\
90 \\
25\end{array}$ & $\begin{array}{l}\text { Brown } \\
\text { Brown } \\
\text { Lt. Gray } \\
\text { Lt. Gray } \\
\text { Lt. Gray }\end{array}$ & $\begin{array}{l}M t \\
M t \\
M t\end{array}$ \\
\hline $\begin{array}{l}\text { Clay } \\
\text { Ringold }\end{array}$ & $\begin{array}{l}A-77 \\
\text { Rin-D }\end{array}$ & 2.71 & 2.6 to 2.7 & 2.6 & 45 & Brown & \\
\hline $\begin{array}{l}\text { Sand } \\
\text { Glaciof Juvial }\end{array}$ & $A-79$ & 2.64 & -- & $-\infty$ & & Dk. Gray & $L, A, Q$ \\
\hline $\begin{array}{l}\text { Quartz } \\
\text { Sitica Flour }\end{array}$ & A-84 & 2.68 & 2.65 & 3.1 & & White & $Q$ \\
\hline $\begin{array}{l}\text { Zeolite } \\
\text { Oregon } \\
\text { Oregon }\end{array}$ & $\begin{array}{l}A=59 \\
A=73\end{array}$ & $\begin{array}{l}2.30 \\
2.20\end{array}$ & $\mid \begin{array}{lll}2.0 & \text { to } & 2.4 \\
2.0 & \text { to } & 2.4\end{array}$ & $\begin{array}{l}2.6 \\
2.6\end{array}$ & 40 & $\begin{array}{l}\text { Buff } \\
\text { Buff }\end{array}$ & $\mathrm{C}, \mathrm{H}$ \\
\hline $\begin{array}{l}\text { Portland Cements } \\
\text { Type II } \\
\text { Type V } \\
\text { Pozzolan }\end{array}$ & $\begin{array}{l}A-75 \\
A-01 \\
A-02\end{array}$ & $\begin{array}{l}3.26 \\
3.16 \\
3.15\end{array}$ & $\begin{array}{l}3.15 \\
3.15 \\
-.=\end{array}$ & $\begin{array}{l}4.2 \\
5.7 \\
32\end{array}$ & & $\begin{array}{l}\text { Gray } \\
\text { Gray } \\
\text { Gray }\end{array}$ & \\
\hline $\begin{array}{l}\text { Hydrothermal Cements } \\
\text { Fondu } \\
\text { Secar }\end{array}$ & $\begin{array}{l}A-74 \\
A-83\end{array}$ & $\begin{array}{l}3.34 \\
3.06\end{array}$ & -- & $\begin{array}{l}4.1 \\
3.3\end{array}$ & & $\begin{array}{l}\text { Dk. Brown } \\
\text { White }\end{array}$ & \\
\hline $\begin{array}{l}\text { ameasured experim } \\
\text { bfrom literature } \\
\text { cFisher subsieve } \\
\text { dsurface area mea } \\
\text { efound by X-ray }\end{array}$ & $\begin{array}{l}\text { ntally w } \\
\text { g/ } \mathrm{cm}^{3} \text { ). } \\
\text { nalysis } \\
\text { urement. } \\
\text { ffractio }\end{array}$ & $\begin{array}{l}\text { th the py } \\
\text { microns). } \\
\text { and petr }\end{array}$ & $\begin{array}{l}\text { ycnometer }(\mathrm{g} / \mathrm{c} \\
\text { rographic anal }\end{array}$ & & $\begin{array}{l}=\text { Labradorit } \\
=\text { Augite } \\
=\text { Ti-Fe Magn } \\
\text { tt }=\text { Montmori] } \\
=\text { Ouartz }\end{array}$ & tite & $\begin{array}{l}\text { Clinoptilolite } \\
\text { Heulandite. }\end{array}$ \\
\hline
\end{tabular}


TABLE 3-5. Preferred Candidate Plug Materials.

\begin{tabular}{|c|c|}
\hline Material & Desirable Attributes \\
\hline Basalt & $\begin{array}{l}\text { Relatively impermeable as a solid } \\
\text { plug } \\
\text { Good strength for engineering } \\
\text { purpose } \\
\text { Low (but some) ion exchange } \\
\text { potential and moderate sorption } \\
\text { capacity } \\
\text { Low cost, high availability }\end{array}$ \\
\hline $\begin{array}{l}\text { Quartz (only as a } \\
\text { solid plug for } \\
\text { small boreholes) }\end{array}$ & $\begin{array}{l}\text { Impermeable } \\
\text { Good strength } \\
\text { Chemically stable } \\
\text { Low cost }\end{array}$ \\
\hline Smectite clays & $\begin{array}{l}\text { Very impermeable } \\
\text { High ion exchange potential and } \\
\text { sorption capacity } \\
\text { Chemically stable } \\
\text { Low cost, readily available }\end{array}$ \\
\hline Clinoptilolite & $\begin{array}{l}\text { High ion exchange potential and } \\
\text { sorption capacity } \\
\text { chemically stable } \\
\text { Low cost, readily available }\end{array}$ \\
\hline $\begin{array}{l}\text { Steatite (only as a } \\
\text { solid plug for } \\
\text { small boreholes) }\end{array}$ & $\begin{array}{l}\text { Low permeability } \\
\text { Good strength } \\
\text { Low cost }\end{array}$ \\
\hline $\begin{array}{l}\text { Grouts } \\
\text { portland cements } \\
\text { hydrothermal cements }\end{array}$ & $\begin{array}{l}\text { Low permeability } \\
\text { High adaptability } \\
\text { Low cost, readily available }\end{array}$ \\
\hline $\begin{array}{l}\text { Concretes } \\
\text { portiand cements and } \\
\text { aggregate } \\
\text { hydrothermal cements } \\
\text { and aggregate }\end{array}$ & $\begin{array}{l}\text { Good strength } \\
\text { Low permeability } \\
\text { High adaptability } \\
\text { Low cost, readily available }\end{array}$ \\
\hline
\end{tabular}


Evaluation of the overall physical and chemical properties of a material requires consideration of all relevant properities of the material. To the extent possible, it is desirable to evaluate candidate plug materials without deciding on the relative importance of the various attributes. To this end a dominance analysis was applied to the material selection process. The concept of dominance in decision analysis (also referred to as efficiency) used in this modified materiais selection process dates back to the classic work of Pareto (1897) on welfare economics. This work has been utilized successfully in a variety of evaluation problems involving multiple attributes (e.g., Ford and others, 1979: Keeney, 1973). The interested reader is referred to Holloway (1979) for an elementary discussion of dominance, or Keeney and Raiffa (1976) for a more advanced presentation. other relevant work is presented in Zeleny (1973).

The constraints on the selection of materials are substantial because a plugging system must maintain its functional capabilities for thousands of years without human intervention. In addition, this study was restricted to considerating materials that do not require the collection of substantial amounts of new data.

These considerations resulted in the following objectives for the materials selection process:

- Selected materials must be compatible with the natural environment expected in the basalt repository shafts, tunnels, and boreholes.

- Selected materials must have a documented history of survival for a period of time on the order of that expected for the containment lifetime of the repository.

- Selected materials must be sufficientily documented so that relevant physical and chemical properties can be specified.

- Selected materials should provide, in a superior manner, at least one of the three functions (inhibit fluid flow, inhibit radionuclide migration, or provide structural integrity needed in a plugging system). 
- Selected materials should be practical to use. This requires consideration of a variety of concerns, including cost, availability, ease of placement, etc.

Note that the first three objectives must be met by any selected material. If either of the first two objectives are not met by a material, conservative engineering practice dictates that the material not be used. If the third objective is not met, consideration of the material is outside the scope of the study. The last two objectives differ from the first three in that materials might meet these objectives to differing degrees and still be acceptable as potential plug materials.

In choosing appropriate material properties to measure how well a material meets the fourth objective listed above, it is necessary to keep in mind that materials will be evaluated with respect to three different potential functions in plugs. Obviously, the properties used to measure how well materials inhibit fluid flow are different than those used to measure how well they provide structural integrity.

Analys is of multiple properties are needed to completely assess the ability of a material to perform one of these functions, and all of these properties are considered together when evaluating the overall ability of a material to perform one of the functions. Because the relative importance of the various properties will depend to some extent on details of plug system design (not yet determined), specific statements of a property's relative importance are avoided as much as possibie when carrying out the evaluation.

The first four objectives listed above are qualitatively different and are considered to be more significant than the last objective (which is that materials should be practical to use). There are two reasons for this: first, it is difficult to judge now what will become "practical" over the 50 to 100 years that are likely to elapse before a basalt repository is permanently sealed. Second, "practicality" is relative. In some people's view, there cannot be large-scale use of nuclear power until the terminal waste isolation problem is solved, and without such use of nuclear power there may be severe dislocations in the economy of 
the United States. If the latter is correct, cost and availability become secondary factors in selecting candidate plug materiais.

For this reason, the overall evaluation of a material in the modified selection process has three sequential parts:

- Assurance that the three mandatory objectives are met

- Determination of how well the physical and chemical properties suit the material's capability to carry out one or more of the three plug functions

- Qualitative consideration of the various practicality issues to determine whether these issues have sufficient importance to alter the evaluation based oniy on physical and chemical properties (carried out under the second part above).

In this three-part process, the initial evaluation of the desirabitity of a material is based only on physical and chemical properties. Thus, if anyone should disagree with the assessment as to what is "practical, "he would still be able to use much of the analysis.

\subsubsection{Materials Selection Process}

The considerations discussed in Section 3.4.2 led to the development of a seven-step materials selection process. This process is outtined in Figure 3-2, and the relationship of these seven steps to the four steps of a formal decision analysis is illustrated in Table 3-6.

The initial list of potential candidate plug materials assembled by Taylor and 0thers (1979) was reviewed as part of Step 1, development of an initial list of materials. The initial list was found to be generally acceptable, but was modified by removing materials that are considered onty as additives to major plug components. It is felt that additives may be best evaluated once major plug components, design, and environmental parameters are better known. The list of potential candidate plug materials considered in the revised selection process is given in Table $3-7$. 


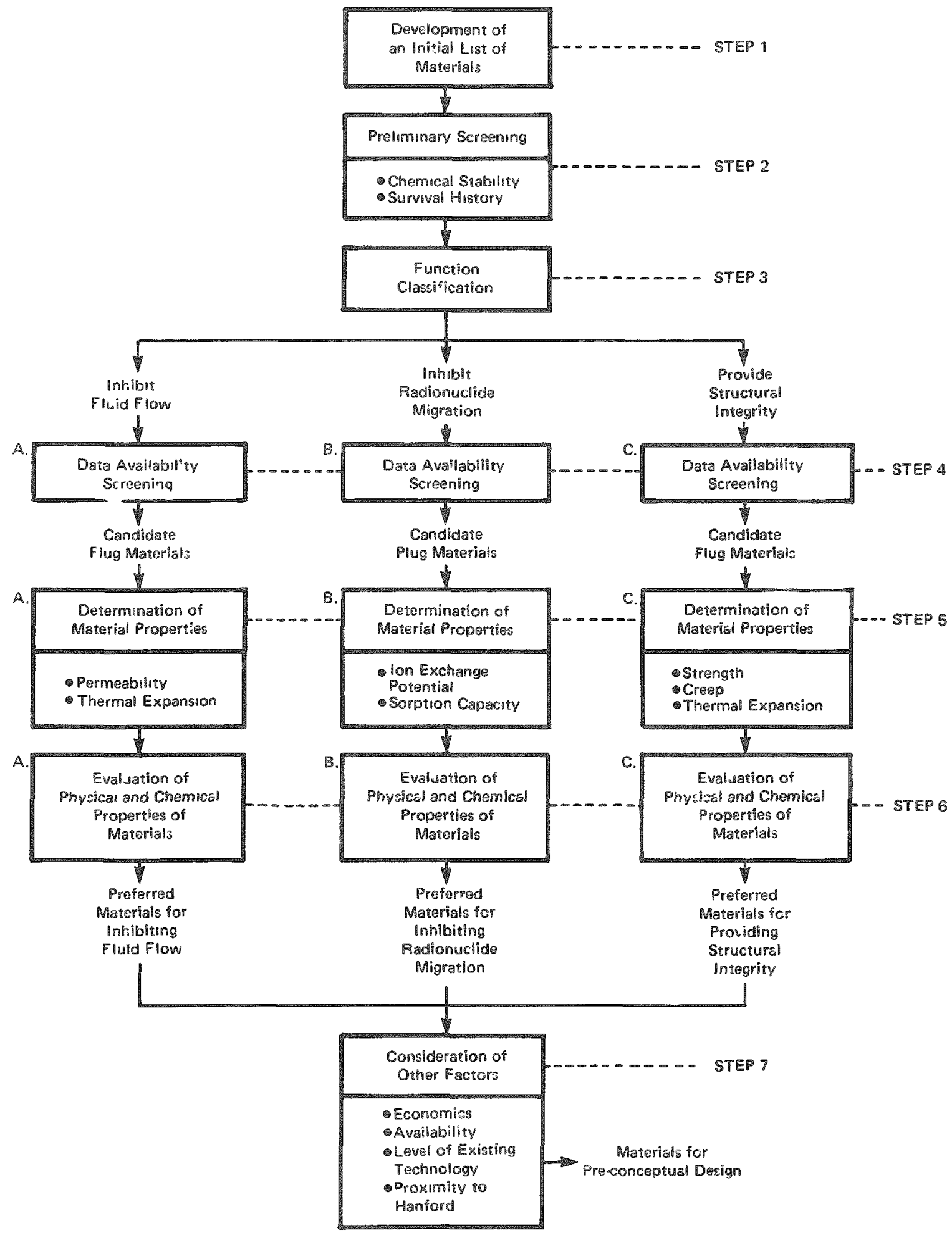

FIGURE 3-2. Materials Selection Process. 
TABLE 3-6. Decision Analysis and the Selection of Candidate Plug Materials.

\begin{tabular}{|c|c|c|c|}
\hline \multicolumn{2}{|c|}{$\begin{array}{l}\text { Steps in the Modified } \\
\text { Selection Process } \\
\text { for Materials }\end{array}$} & $\begin{array}{c}\text { Equivalent Steps(s) } \\
\text { Formal Decision } \\
\text { Analysis }\end{array}$ & Discussion \\
\hline & $\begin{array}{l}\text { Development of an } \\
\text { initial list }\end{array}$ & $\begin{array}{l}\text { Structuring the } \\
\text { problem }\end{array}$ & $\begin{array}{l}\text { It is necessary to decide on } \\
\text { an initial list of materials } \\
\text { from the many thousands that } \\
\text { might potentially meet the } \\
\text { selection process objectives }\end{array}$ \\
\hline & $\begin{array}{l}\text { Preliminary } \\
\text { screening }\end{array}$ & $\begin{array}{l}\text { Structuring the } \\
\text { problen }\end{array}$ & $\begin{array}{l}\text { Materials are evaluated to } \\
\text { see if they meet two primary } \\
\text { objectives--compatibility } \\
\text { with the natura? environment } \\
\text { and a documented history of } \\
\text { survival }\end{array}$ \\
\hline 3. & $\begin{array}{l}\text { Function } \\
\text { classification }\end{array}$ & $\begin{array}{l}\text { Structuring the } \\
\text { problem }\end{array}$ & $\begin{array}{l}\text { Materials are classified by } \\
\text { function--inhibiting fluid } \\
\text { flow inhibiting radio- } \\
\text { nuclide migration, or pro- } \\
\text { viding structural integrity }\end{array}$ \\
\hline 4. & $\begin{array}{l}\text { Data availability } \\
\text { screening }\end{array}$ & $\begin{array}{l}\text { Structuring the } \\
\text { problem }\end{array}$ & $\begin{array}{l}\text { Materials are evaluated to } \\
\text { see if they meet a third } \\
\text { objective--data availability }\end{array}$ \\
\hline 5. & $\begin{array}{l}\text { Determination of } \\
\text { material } \\
\text { properties }\end{array}$ & $\begin{array}{l}\text { Estimating } \\
\text { attribute levels }\end{array}$ & $\begin{array}{l}\text { Relevant material properties } \\
\text { are determined for all } \\
\text { materials that meet the above } \\
\text { objectives, and numerical } \\
\text { attribute levels are } \\
\text { assigned after determining } \\
\text { attribute scales }\end{array}$ \\
\hline 6. & $\begin{array}{l}\text { Evaluation of } \\
\text { physical and } \\
\text { chemical proper- } \\
\text { ties of materials }\end{array}$ & $\begin{array}{l}\text { Determining evalua- } \\
\text { tion (utility) } \\
\text { function and } \\
\text { evaluation of } \\
\text { alternatives }\end{array}$ & $\begin{array}{l}\text { The various attributes used } \\
\text { to measure the physical and } \\
\text { chemical properties of } \\
\text { materials are combined to } \\
\text { determine the overall } \\
\text { suitability of a material } \\
\text { for carrying out a plug } \\
\text { function }\end{array}$ \\
\hline & $\begin{array}{l}\text { Consideration of } \\
\text { other factors }\end{array}$ & $\begin{array}{l}\text { Evaluation of } \\
\text { alternatives }\end{array}$ & $\begin{array}{l}\text { The degree to which a } \\
\text { material is practical to use } \\
\text { (based on cost, avallability, } \\
\text { and other factors) is } \\
\text { evaluated in this step }\end{array}$ \\
\hline
\end{tabular}


TABLE 3-7. Materials for Consideration.

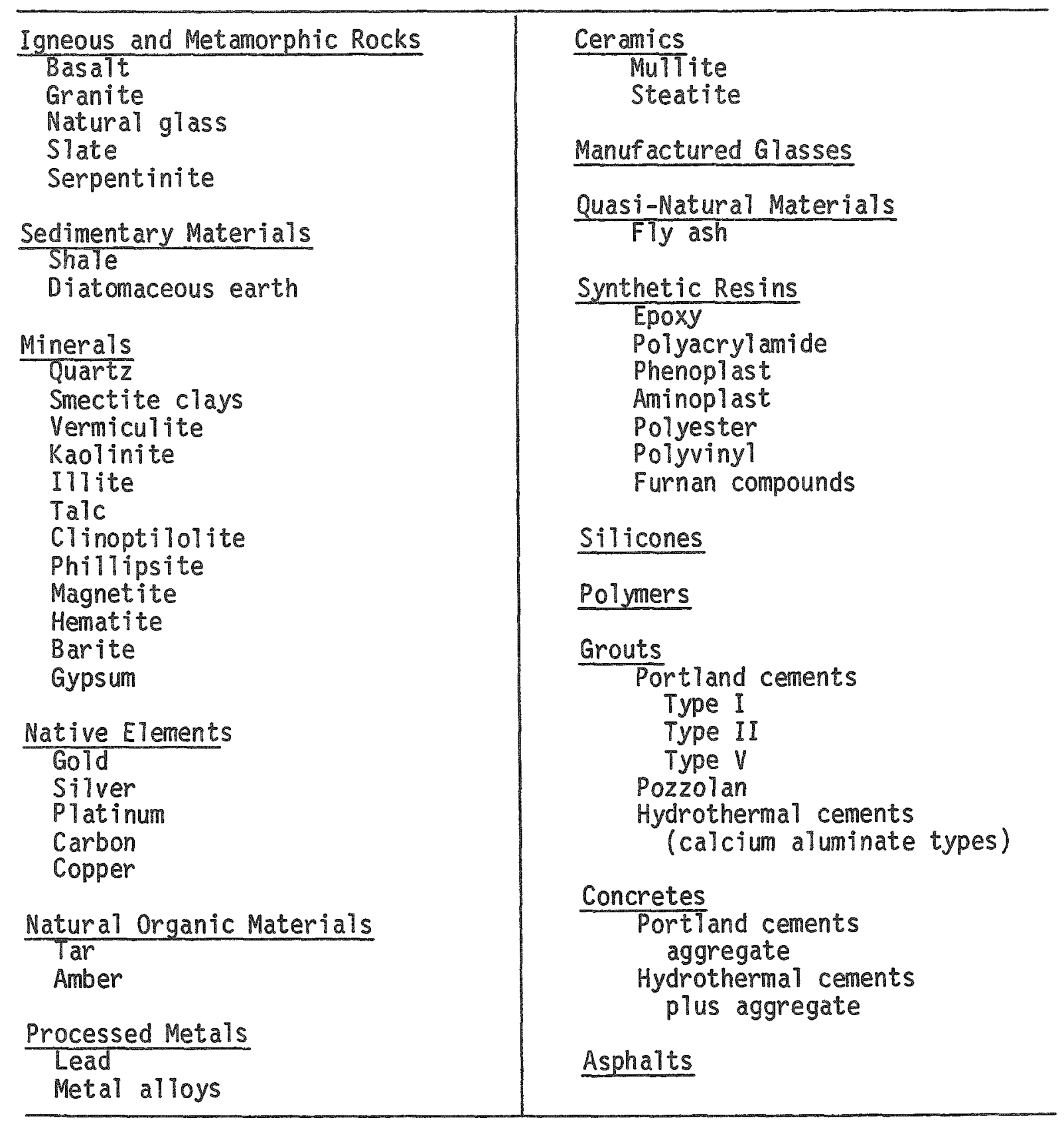


The original materials selection process described in Taylor and others (1979) was found to be highly sensitive to several major factors. In the original selection process, one of these factors, chemical stability, was incorporated into the general weighting and rating scheme used in that process. In the current approach, these major factors are consolidated into an initial screening procedure (Step 2) that eliminates materials found to be unacceptable on the basis of one or both of the following criteria:

- The material is chemically unstable in the repository environment with respect to expected $\mathrm{pH}$ and Eh conditions.

- The material has an insufficiently documented history of survival to assure its stability for periods on the order of thousands of years.

This screen assesses the fundamental chemical compatibility of materials with the repository and geologic environment. It aiso assesses their documented history of survival through time and their ultimate acceptability as plug materials in plugs that must be demonstrated, with a high degree of assurance, to be capable of lasting for thousands of years. The latter constraint greatly diminishes the acceptability of many man-made materials.

In Step 3, the remaining materials are classified by three major functions: (1) to inhibit fluid flow: (2) to inhibit radionuclide migration; and (3) to provide structural integrity. Materials that can serve more than one function are classified under all relevant categories. Note that the function classification used here is different than that defined by Tayior and others (1979), which separates materials into potential major plug components and additives. In the current selection process, only potential major plug components are considered; additives are not included in this process because the objective is to select candidate materials for testing that are potential major components for preconceptual plug designs. Additives will be present only in very small amounts and will be tailored to highly specific conditions: they will fulfill a separate, special function and are best evaluated at a later date after major plug components, design, and environmental parameters are better known. 
The function classification is necessary because the evaluation process must be somewhat different for each class of materials. In particular, the relevant material properties that need to be considered during evaluation of a material depend on the function for which the material will be used. For example, the ion exchange potential of a material is not important if the material is to be used to inhibit fluid flow; however, if its function is to inhibit radionuclide migration, then ion exchange potential is very important.

This classification of materials anticipates plug design to some extent because materials are categorized according to their projected ability to perform a certain function in the plug. However, such a classification at this stage in the selection process overcomes a major problem of the original screening process developed in Taylor and others (1979). In that process, the relative merits and properties of materials that are to serve fundamentaliy different functions in a plug had to be compared in a series of complex screens. As a result, the serious problems of comparing "apples" with "oranges" were greatly increased.

Classification of materials according to the three functions outlined in this section, and the evaluation of each group separately under each classification, enable the selection of properties that measure the performance of a material with respect to a specific function. Thus, materials can be ranked under each classification in accordance with their ability to perform that function as defined by a list of properties relevant to that function. In general, like quantities are being compared by the process.

The data availability screen (Step 4) is individually applied to data available for the various attributes used to rank materials in each function classification in Step 5. Materials for which large data bases have been accumulated are more predictable than materials for which fewer data are available. It was not within the scope of this work to expand the data base with respect to specific properties of materials listed under each of the three function $c l$ assifications. This would require new research and laboratory experimentation for those materials having little-known physical and chemical properties. 
The data availability screen eliminates materials for which data are judged inadequate; university and company libraries, textbooks, scientific journals, and professional reports are consulted to evaluate their relevant properties within the time constraints of the testing program. For a material to pass this screen does not require that every property discussed under each function classification in the next step be completely defined in the literature. Materials that are similar to other well-documented materials, or materials that have properties that are well-documented and similar to those discussed in the next section, are considered as having sufficient, available information to assign attribute values on the basis of professional judgment or analogy. However, those materials that lack sufficient, pertinent data on properties of concern or lack well-documented analogs are eliminated by this screen.

Obviously, as new data become available, the evaluation produced by this screen may change. It should be re-emphasized that the evaluation is made with respect to data considered pertinent to the basalt borehole plugging problem and to material properties. Thus, some materials (particularly man-made ones) are eliminated even though they have relatively large, but inappropriate, data bases with respect to their known properties.

Step 5 is the determination of relevant material properies. A wide variety of chemical and physical properties is potentially relevant for evaluating the desirability of a material for use in borehole, shaft, or tunnel plugs. Selecting the appropriate material properties requires that the primary purpose of the materials selection process (i.e., to select materials for inclusion in programs of continued evaluation and testing) be kept clearly in mind. The objective is not to define the large number of properties for each material that will be required in the selection of final designs for plugs. Many properties of a material will be important in deciding on a specific plug design that best utilizes that material. However, during the initial evaluation of whether a material should be considered for use in a plug, only a few critical material properties that will be important regardless of the exact design 
of the plug should be considered. The following questions were pertinent in developing procedures used in Steps 5 and 6:

- What material properties should be considered?

- What attributes (evaluation measures) should be used to measure each important material property?

- How should the attribute levels be determined for each material property?

- How should the different attributes be combined to arrive at a single overall evaluation of the chemical and physical properties of each material?

The number and type of material properties considered should be limited to those that will fundamentally characterize the suitability of materials under each function classification. The list of selected material properties under each $c$ lassification is based on parameters for which adequate data exist in the literature and for which a direct evaluation of the material's impact on potential plug design can be made. The impact of certain properties on the final performance of a plug is ambiguous. These properties were not used in the evaluation of materials under each function classification.

3.4.3.1 Properties of Materials to Inhibit Fluid Flow. Permeability is the primary measure of the ability of a material to inhibit fluid flow. Many factors affect permeability, and a range of values for permeability is commonly cited in the literature for any given material. In addition, other physical properties of a material can directly affect the bulk permeability of a plug. One of these, thermal expansion, is inciuded on the list of properties used to evaluate the ability of a material to inhibit fluid flow. Materials with coefficients of thermal expansion similar to that of basalt are more suitable for plugs than materials that have greatly different coefficients of thermal expansion. Separation at the plug/wall rock interface and induced fracturing of the plug or basalt should be less likely to occur during the heating and cooling cycles of the containment period of a repository where the plug has a coefficient of thermal expansion similar to that of basalt. Fracturing induced by 
materials that have thermal expansion coefficients greatly different than basalt could drastically and adversely affect the bulk permeability of the plug/host rock system.

Other potentially relevant factors, such as modulus of elasticity and plasticity index, were considered for use as evaluation measures, but the significance of these factors is difficult to determine unless a specific plug design is being evaluated. For instance, very high elasticity could either be detrimental or beneficial in a plug material, depending on the plug's proposed use. Both properties could influence the long-term ability of a plug to restrict fluid flow: however, because the impacts of these factors are unclear (high plasticity, for example, may be desirable in some plug designs to maintain impermeability and undesirable in others), they are not used to evaluate and rank materials. These factors, of course, will be considered once actual plug design is under way.

The two selected factors (permeability and thermal expansion) along with chemical stability assessed in Step 2 (pH and Eh compatibility with the environment), are the bases for determining the overall potential of a material for inhibiting fluid flow in this evaluation.

\subsubsection{Properties of Materials to Inhibit Radionuclide Migration.} Under this function classification, the suitability of those materials that will inhibit the migration of radionuclides (although not necessarily a fluid containing them) was evaluated. In addition to low permeability, a large capacity to exchange ions with the environment is the most important mechanism by which plug materials can heip control the migration of radionuclides in solution; ion exchange potential and sorption capacity are two primary indicators of this abiitity.

Ion exchange potential is a measure of the ability of a material to set free and replace ions in its structure with ions in solution in contact with the material. Materials with high ion exchange potentials may have the capacity for freeing ions from their lattice structure and replacing them with (and thus immobilizing) migrating radionuclides. Sorption capacity is a measure of the general ability of a material to entrap ions migrating in solution; the actual sorption mechanism for any 
given material can reflect several phenomena, including van der Waals bonding, the filling of vacant lattice spaces in crystal structure, the entrapment of ions by the host because of unsatisfied bonds along crystal edges (edge effects), as well as actual ion exchange (as described above). Generally, the distribution coefficient ( $K_{d}$ value), which gives a relative measure of the sorption capacity of a material, is a collective, somewhat qualitative assessment of these various phenomena.

Both ion exchange potential and sorption capacity are temperature dependent; for most materials, these factors decrease with increasing temperature. However, thermal stability is not included as a third attribute under this function classification because the temperature at plug seats is assumed to be less than $100^{\circ} \mathrm{C}$. Within this expected temperature range, the ion exchange potentials and sorption capacities for most materials are not greatly affected, and thermally induced changes in their properties that might affect ion exchange potential or sorption capacity are expected to be minor. Chemical changes could also adversely alter the ability of a material to block migrating radionuclides. (Step 2 eliminated materials that are chemically unstable in the anticipated environment.)

Chemical precipitation was considered as another possible mechanism for inhibiting radionuclide migration. However, in general, materials that have the ability to precipitate migrating radionuciides and to form stable mineral products are not candidates for major plug components. They would be present in plugs in very small amounts as additives and, therefore, are not considered in this selection process. Thus, ion exchange potential and sorption capacity, in conjunction with chemical stability (evaluated in step 2 of the selection process), are the basis for determining the overall ability of a material for inhibiting radionuclide migration in this evaluation.

\subsubsection{Properties of Materials to Provide Structural Integrity.}

Structural integrity of the plug will be provided primarily by its ability to resist or accommodate deformation over time. Because materials that provide other important functions of inhibiting fluid flow and radionuclide migration may be rather easily deformed, it is necessary to separately evaluate materials suitable for providing the plug with 
requisite structural integrity during the containment period of the repository. While deformable, plastic materiais will provide some physical continuity, engineering practice indicates that in large openings (shafts and tunnels) such materials will need to be buttressed by more rigid plug components capable of transmitting the various loads that may be imposed on large plugs. Thus, the factors for evaluating the ability of a material to provide structural integrity include strength (in unconfined compression), creep (as a measure of a material's long-term behavior), and its coefficient of thermal expansion. The last factor measures the compatibility of the candidate plug material with the host rock and the natural environment. Materials that have thermal expansion properties similar to basalt are preferred. Again, note that chemical compatibility with the environment is evaluated during Step 2 of this selection process.

Other properties that might help measure a material's ability to provide structural integrity (such as consolidation, compressibility, plasticity, and elasticity) are, in part, design dependent. Under differing circumstances, high or low values of each may be desirable or undesirable. Thus, these properties can not be used in the present phase of materials selection.

In order to evaluate the physical and chemical properties of materials under each function classification, all attributes of the material are considered together in step 6. To the extent possible, the desirability of candidate plug materials would be evaluated without assigning specific relative importance to each of the various attributes. This procedure is desirable because the importance of the different factors depends in part on features of plug design that have not yet been determined. For example, the importance that should be attached to having high ion exchange capacity depends on the degree to which this mechanism will be used to trap radionuclides in the plug. This has not yet been determined. In addition, the approach used herein avoios the weighting factors and cutoff values applied in the original selection process dascribed in Taylor and Others (1979). 
RHO-BWI-ST-7

The evaluation procedure used here is dominance analysis, which does not require any assignment of relative importance to the various properties. In Section 3.7 of this report, the application of dominance analysis to the current materials selection process is described in detail; this application resulted in a list of materials ranked from most to least preferred in each function classification. This list catagorizes materials by the relative desirability of their physical and chemical properties; however, all materials in each function classification are not precisely rank-ordered for two reasons. First, because each attribute scale has only a few different levels, several materials have the same levels for all attributes. Thus, these materials will always rank the same, regardless of what procedure is used to combine the various attributes. Second, because only dominance concepts are used in the evaluation and no statements are made about the exact relative importance of the various material properties, it is not always possible to decide which of any two materials in question has the most desirable physical and chemical properties.

In most cases, the first of these two reasons resulted in materials being ranked as equally preferable. There are only two situations in the set of three lists (one for each of two function classifications) for which additional information about the relative importance of attributes could lead to a more detailed ranking of the materials. Both of these situations involve materials that are ranked relatively low, and hence a more detailed evaluation that would require assessment of the relative importance of each attribute was not necessary.

In addition to chemical and physical properties, several other factors are important in determining the final list of preferred candidate materials to be used in testing programs and preconceptual piug design schemes. These factors include economic availability compatiblity with various borehole diameters (ranging from several centimeters to as much as $10 \mathrm{~m}$ ) and, in the case of natural materials, proximity to the Hanford Site.

Each material ranked on the three lists derived from Step 6 for the three function classifications is evaluated in Step 7 with respect to these other factors. A final list of preferred candidate materials 
(Table 3-5) is based on the physical and chemical properties evaluated in Step 6 and these other factors.

From the beginning of the selection process through Step 6 , the evaluation procedure considered the physical and chemical properties of the materials on the original list and also considered the potential for determining these properties. Step 7 addresses other limitations on the uses of materials. For example, certain materials that have desirable chemical and physical properties from performing certain plug functions may be very costiy (the precious metals are a good example). In other instances, materials that have desirable physical and chemical properties may only be appropriate for consideration as plugs in certain diameter holes (e.g., the use of machined quartz or ceramic plugs for small diameter boreholes).

With the exception of Step 4, Step 7 is more qualitative and judgmental than the other steps in the evaluation. This subjectivity is necessary because questions of cost and availability are dependent on factors of plug environment and design that have not yet been determined. In addition, the meaning of these terms is relative and depends on available alternatives at the time of actual plug placement. While it is almost certainly out of the question to use gold to plug a shaft or tunnel, it might be feasible to use it as part of a plugging system for a small borehole. Whether gold is, in fact, too costly for this application depends partly on what alternatives to its use are available. If, for example, no other material had physical and chemical properties that were as suitable for a particular plugging function in a borehole, and if the plugging program required the performance of function, then it is conceivable that a costly material would be used. In Step 7, the assessment that the cost will preclude the use of an expensive material is essentialiy an assessment that the hypothetical chain of events discussed will not come to pass.

\subsubsection{Conclusion}

The final list of preferred candidate materials (see Table 3-5) produced by the refined decision process is very similar to that 
presented by Taylor and 0thers (1979), although the technique used is quite different. This process serves as a validation of the earlier list that was used as a basis for chemical and physical testing.

The reorganization of function classifications and more complete definition of attributes in this new approach makes it possible to compare materials that will have like applications in plug design and to discriminate between and rank them on a common basis. The restructuring of the selection process also provides a framework for this type of analysis during future work on materials selection for repository backfill and canister hole plugs. New initial lists of materials tailored to backfill and canister hole plug problems could be developed, and the various attribute scales can be adjusted to reflect the more extreme physical and chemical conditions that may exist in the near-field environment of the waste storage canisters. It would probably be necessary to add to the list of material properties under the various function classifications if the selection scheme were modified to evaluate potential backfill and canister hole plug materials. For example, the thermal stability ranges of various materials may be a critical property in the near-field environment.

\subsection{EMPLACEMENT MACHINES}

The proper choice of plug emplacement machinery is an important part of the overall Basalt Waste Isolation Project borehole plugging program. The most favorable plug material will be useless if it cannot be emplaced practically in the desired form. The high performance standards required of repository seals require that plug placement machinery be specific to both the plug material and the type of opening being plugged (i.e., shafts, tunnels, boreholes.)

An additional constraint on machinery selection results from repository licensing requirements. It seems certain that reasonable assurance that the repository can be sealed will be required prior to the issuance of an operating license. Existing schedules for licensing do not allow sufficient time for an extensive research and development program. Therefore, plug designs developed for licensing must utilize either existing machinery or modifications of existing machinery. 


\subsubsection{Candidate Machines}

Sealing and backfilling techniques and machines have been developed for a wide range of industrial applications. A report on the current status of industrial cementing techniques, mine sealing practices, and research concepts has been presented by D'Appolonia Consulting Engineers (1979). In addition, an extensive review of excavation techniques and decommissioning of underground facilities was presented by Analytical Sciences Corporation (1979).

Taylor and Others (1979) developed a list of candidate machines for the sealing of a nuclear waste repository in basalt, after a detailed review of the literature, with particular emphasis on dam construction technology, mine stowing techniques, oil and gas well drilling, and plugging techniques. The candidate machinery was chosen for six broad classifications of plug materials: cohesive soil; rock; non-cohesive soils; concrete and cement grout; soil cement; and grout slurries. In addition, the machines were chosen for three plug environments in basalt: tunnels; shafts; and boreholes. The list of candidate borehole plugging machinery is given in Table 3-8.

\subsubsection{Machine Selection}

In order to evaluate the candidate borehole plugging machines, Taylor and Others (1979) rated each of the candidate machines on the basis of availability, dimensional versatility, experience, documentation, mechanical complexity, operational complexity, waterproof operation, density control, process monitoring, and performance monitoring. Ratings of 0 to 3 were established for machine performance over a possible range of minimal to superior performance for each factor. A matrix format, with a weighting scheme to balance the relative importance of the various factors, was used to evaluate the candidate machines. On the basis of this evaluation a list of preferred candidate plugging machines was derived (Table 3-9) and the preferred machines were grouped into classes on the basis of the evaluation. Classes $A$ and $B$ were preferred machines, and $C$ lass $C$ machines were those that would be carried forward into design studies only if they incorporated a unique feature later found to be essential. 
TABLE 3-8. Candidate Borehole Plugging Machinery. (After Taylor and Others, 1979.)

\begin{tabular}{|c|c|c|c|c|c|c|c|c|c|c|c|c|c|c|}
\hline \multirow[b]{2}{*}{$\begin{array}{l}\text { General } \\
\text { Machine } \\
\text { Type }\end{array}$} & \multirow[b]{2}{*}{$\begin{array}{l}\text { Specific } \\
\text { Machine } \\
\text { Type }\end{array}$} & \multirow[b]{2}{*}{ Description } & \multirow[b]{2}{*}{ Plug Use Proposed } & \multicolumn{7}{|c|}{$\begin{array}{l}\text { Work Product } \\
\text { Capability }\end{array}$} & \multicolumn{3}{|c|}{$\begin{array}{l}\text { Hole } \\
\text { Type }\end{array}$} & \multirow[b]{2}{*}{ Suppliers } \\
\hline & & & & 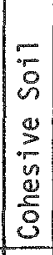 & 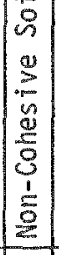 & $\mid$ & : & 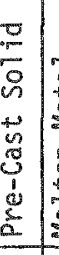 & 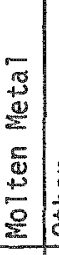 & : & \begin{tabular}{|c|}
2 \\
0 \\
0 \\
0 \\
0 \\
0 \\
0 \\
0 \\
\end{tabular} & $\frac{n}{4} \frac{5}{5}$ & $\frac{\infty}{2}$ & \\
\hline \multirow[t]{3}{*}{$\begin{array}{l}\text { Plate } \\
\text { Compactor }\end{array}$} & $\begin{array}{l}\text { Down-Hole } \\
\text { Hammer Drill }\end{array}$ & $\begin{array}{l}\text { Mining drills include per- } \\
\text { cussion-rotary, down-hole } \\
\text { hammer drills. A carbide- } \\
\text { drill bit is followed by a } \\
\text { hammer unit near the end of } \\
\text { the drill rods. The drill } \\
\text { bit is rapidly hammered and } \\
\text { indexed in rotation with } \\
\text { each blow. }\end{array}$ & $\begin{array}{l}\text { Replace drill bit with tamp- } \\
\text { ing foot (or tri-cone roller). } \\
\text { Single foot for } 60 \text { cm dia. } \\
\text { borehole; ganged units for } \\
>60 \text { cmm dia. boreholes, shafts. } \\
\text { Might use horizontal in } \\
\text { tunnel arch lift. }\end{array}$ & $x$ & $x$ & & $x$ & $x$ & & & $x$ & $x$ & $x$ & $\begin{array}{l}\text { Acker } \\
\text { Mobile orill } \\
\text { Ingersoll-Rand }\end{array}$ \\
\hline & $\begin{array}{l}\text { Pile-Driver } \\
\text { Hammer }\end{array}$ & $\begin{array}{l}\text { Steam, air, or diesel-driven } \\
\text { hammers are used with cranes } \\
\text { in free-hanging or rigida } \\
\text { leads suspensions, to drive } \\
\text { steel pipe or H-piles into } \\
\text { soil. }\end{array}$ & $\begin{array}{l}\text { These hammers may be run into } \\
\text { boreholes or shafts on wire- } \\
\text { lines to tamp earth-fill or } \\
\text { dry-mix concrete such as for } \\
\text { "Franki"-piles, or to hammer } \\
\text { solid plugs in place. }\end{array}$ & $x$ & $x$ & & $x$ & $x$ & & & $x$ & $x$ & $x$ & $\begin{array}{l}\text { L.B. Foster } \\
\text { Foundation } \\
\text { Equipment } \\
\text { Vulcan }\end{array}$ \\
\hline & $\begin{array}{l}\text { Sheet-Pile } \\
\text { Hammer }\end{array}$ & $\begin{array}{l}\text { High-frequency air, electric } \\
\text { or diesel hammers used to } \\
\text { drive Z-type or other inter- } \\
\text { locking flat steel sheets } \\
\text { into soil for cofferdams, } \\
\text { groundwater cutoff, etc. }\end{array}$ & $\begin{array}{l}\text { As above, but higher frequency } \\
\text { may be better for non-cohesive } \\
\text { soils, and rather than densify } \\
\text { dry-mix concrete by ramming, } \\
\text { might be better for densifying } \\
\text { wet-mix concrete by penetration } \\
\text { vibration. }\end{array}$ & & $x$ & & & $x$ & & & $x$ & $x$ & $x$ & $\begin{array}{l}\text { Atlas-Copco } \\
\text { L.B. Foster } \\
\text { MKT }\end{array}$ \\
\hline $\begin{array}{l}\text { Plate } \\
\text { Compactor }\end{array}$ & $\begin{array}{l}\text { Impact } \\
\text { Tamper }\end{array}$ & $\begin{array}{l}\text { Man-operated, usually com- } \\
\text { prising a cylindrical ram } \\
\text { with a flat tamping foot } \\
\text { attached, powered by air or } \\
\text { gasoline engine, tamps } \\
\text { multiple strokes/minute. }\end{array}$ & $\begin{array}{l}\text { Compact } 10-\mathrm{cm} \text { lifts of soil or } \\
\text { concrete in shafts of suitable } \\
\text { diameter, and in areas of } \\
\text { shafts and tunnels not acces- } \\
\text { sible to larger tractor } \\
\text { compactors }\end{array}$ & $x$ & $x$ & & $x$ & & & & & $x$ & $x$ & $\begin{array}{l}\text { Ingersoll-Rand } \\
\text { MBW Inc. } \\
\text { Atlas-Copco } \\
\text { Hacker }\end{array}$ \\
\hline
\end{tabular}


Table 3-8 (continued)

\begin{tabular}{|c|c|c|c|c|c|c|c|c|c|c|c|c|c|c|}
\hline \multirow[b]{2}{*}{$\begin{array}{l}\text { General } \\
\text { Machine } \\
\text { Type }\end{array}$} & \multirow[b]{2}{*}{$\begin{array}{l}\text { Specific } \\
\text { Machine } \\
\text { Type }\end{array}$} & \multirow[b]{2}{*}{ Description } & \multirow[b]{2}{*}{ Plug Use Proposed } & \multicolumn{7}{|c|}{$\begin{array}{c}\text { Work Product } \\
\text { Capability }\end{array}$} & \multicolumn{3}{|c|}{$\begin{array}{l}\text { Hole } \\
\text { Type }\end{array}$} & \multirow[b]{2}{*}{ Suppliers } \\
\hline & & & & 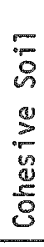 & $\mid \begin{array}{c}0 \\
0 \\
2 \\
0 \\
0 \\
9 \\
\\
0 \\
1 \\
0 \\
0 \\
2\end{array}$ & \begin{tabular}{|}
$\mid$ \\
3 \\
3 \\
0 \\
5 \\
\end{tabular} & 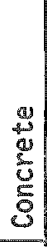 & 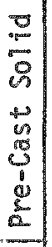 & 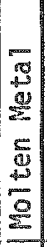 & $\frac{2}{25}$ & 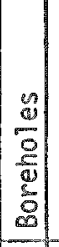 & 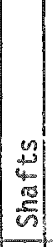 & $\frac{n}{\Xi}$ & \\
\hline & Vibrating & $\begin{array}{l}\text { Man-operated, usually of a } \\
0.6 \text {-m } \times 0.5-m \text { steel plate } \\
\text { an engine-driven eccentric } \\
\text { weight is mounted on. Unit } \\
\text { is pushed along manually. }\end{array}$ & & $x$ & $x$ & & $x$ & & & & & $x$ & $x$ & $\begin{array}{l}\text { Essick } \\
\text { Wacker }\end{array}$ \\
\hline & Pressure & $\begin{array}{l}\text { Proposed in earlier borehole } \\
\text { plug research comprising a } \\
\text { down-hole unit held in place } \\
\text { by rods or packers equipped } \\
\text { with a hydraulic ram and } \\
\text { plate for compressing soil } \\
\text { layer beneath. }\end{array}$ & $\begin{array}{l}\text { Compact incremental lifts } \\
\text { of soil fill in boreholes } \\
\text { to } 60 \mathrm{~cm} \pm \text { diameter. }\end{array}$ & $x$ & $x$ & & & & & & $x$ & & & $\begin{array}{l}\text { Halliburton } \\
\text { Services } \\
\text { Mobile Drill }\end{array}$ \\
\hline $\begin{array}{l}\text { Pol Ter } \\
\text { Compactor }\end{array}$ & $\begin{array}{l}\text { Pneumatic- } \\
\text { Tire }\end{array}$ & $\begin{array}{l}\text { Articulated row of weighted } \\
\text { ballast boxes, each on sepa- } \\
\text { rate pneumatic tire, drawn } \\
\text { by tractor to compact earth- } \\
\text { fill. }\end{array}$ & $\begin{array}{l}\text { Compact } 15-\mathrm{cm} \text {-thick lifts } \\
\text { of cohesive soil in tunnel } \\
\text { plugs - must be supplemental } \\
\text { by use of smaller machine } \\
\text { when clearances are } \\
\text { insufficient. }\end{array}$ & $x$ & $x$ & & & & & & & $x$ & $x$ & Hyster \\
\hline & "Sheepsfoot" & $\begin{array}{l}\text { Cylindrical steel drum with } \\
\text { projecting steel knobs, drawn } \\
\text { by tractor. Drum can be } \\
\text { weighted; i.e.s sand and } \\
\text { water. compacts earth fill. }\end{array}$ & & $x$ & & & & & & & & $x$ & $x$ & Cacerpillar \\
\hline
\end{tabular}


Table 3-8 (continued)

\begin{tabular}{|c|c|c|c|c|c|c|c|c|c|c|c|c|c|c|}
\hline \multirow[b]{2}{*}{$\begin{array}{c}\text { General } \\
\text { Machine } \\
\text { Type }\end{array}$} & \multirow[b]{2}{*}{$\begin{array}{l}\text { Specific } \\
\text { Machine } \\
\text { Type }\end{array}$} & \multirow[b]{2}{*}{ Description } & \multirow[b]{2}{*}{ Plug Use Proposed } & \multicolumn{7}{|c|}{$\begin{array}{l}\text { Work Product } \\
\text { Capability }\end{array}$} & \multicolumn{3}{|c|}{$\begin{array}{l}\text { Hole } \\
\text { Type }\end{array}$} & \multirow[b]{2}{*}{ Suppliers } \\
\hline & & & & 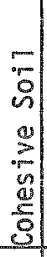 & \begin{tabular}{l|}
0 \\
8 \\
0 \\
2 \\
0 \\
0 \\
\\
\\
$\frac{1}{5}$ \\
\end{tabular} & $\mid$ & 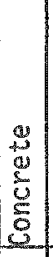 & $\mid \begin{array}{c}0 \\
\cdots \\
0 \\
0 \\
0 \\
0 \\
0 \\
0 \\
1 \\
0 \\
0 \\
0 \\
\end{array}$ & 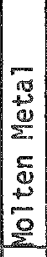 & 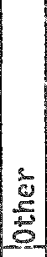 & $\mid \begin{array}{l}2 \\
\frac{2}{2} \\
\frac{2}{2} \\
\frac{2}{2} \\
0\end{array}$ & $\mid$\begin{tabular}{|c|}
2 \\
$\frac{2}{4}$ \\
$\frac{6}{2}$ \\
\end{tabular} & $\frac{n}{\sum^{\frac{a}{E}}}$ & \\
\hline & Grid-Roller & $\begin{array}{l}\text { Waffle-surfaced steel drums, } \\
\text { comprising the wheels of a } \\
\text { self-propelled, highly ma- } \\
\text { neuverable compactor: used on } \\
\text { earth fills. Compacting } \\
\text { weight includes tractor. }\end{array}$ & & $x$ & $x$ & & & & & & & $x$ & $x$ & Hyster \\
\hline & Smooth-Drum & $\begin{array}{l}\text { Smooth-steel drums mounted } \\
\text { to front and rear axles of } \\
\text { tractor, for base-course } \\
\text { of road construction (rock) } \\
\text { or asphalt layer. Drum } \\
\text { weighted, compactor load } \\
\text { includes tractor. }\end{array}$ & & $x$ & $x$ & & & & & & & $x$ & $x$ & $\begin{array}{l}\text { Essick } \\
\text { Hyster }\end{array}$ \\
\hline $\begin{array}{l}\text { Roller } \\
\text { Compactor }\end{array}$ & $\begin{array}{l}\text { Vibratory } \\
\text { Drum }\end{array}$ & $\begin{array}{l}\text { Steel drum with engine on } \\
\text { draw-bar to drive an } \\
\text { eccentric weight within } \\
\text { drum for dynamic impact. } \\
\text { Drawn by tractor, for } \\
\text { earth fills and rock fills. }\end{array}$ & $\begin{array}{l}\text { Compact } 30-c m \text { lifts of } \\
\text { non-cohesive soil or rock } \\
\text { in tunnel or shaft plugs. } \\
\text { Must be supplemented with } \\
\text { small compactor machines } \\
\text { where clearances are } \\
\text { insufficient. }\end{array}$ & & $x$ & & & & & & & $x$ & $x$ & $\begin{array}{l}\text { Caterpillar } \\
\text { Essick } \\
\text { Hyster } \\
\text { Hacker }\end{array}$ \\
\hline & Tri-Cone & $\begin{array}{l}\text { Adaptation of standard } \\
\text { tri-cone bits for drilling } \\
\text { rock, incorporating } 3 \text { cone- } \\
\text { shaped rollers, in a cast } \\
\text { housing, revolving about a } \\
\text { common center (axis of } \\
\text { drill rods). }\end{array}$ & $\begin{array}{l}\text { Earlier research proposed } \\
\text { modifying roller design } \\
\text { for compactive efficiency } \\
\text { rather than cutting intent. } \\
\text { could be used to compact } \\
\text { soil materials in deep bore- } \\
\text { holes with diameters to } \\
24 \mathrm{~cm} \pm \text {. }\end{array}$ & $x$ & $x$ & & & & & & $x$ & & & $\begin{array}{l}\text { Acker } \\
\text { Mobile Drill }\end{array}$ \\
\hline
\end{tabular}


Table 3-8 (continued)

\begin{tabular}{|c|c|c|c|c|c|c|c|c|c|c|c|c|c|}
\hline \multirow[b]{2}{*}{$\begin{array}{l}\text { General } \\
\text { Machine } \\
\text { Type }\end{array}$} & \multirow[b]{2}{*}{$\begin{array}{l}\text { Specific } \\
\text { Machine } \\
\text { Type }\end{array}$} & \multirow[b]{2}{*}{ Description } & \multirow[b]{2}{*}{ Plug Use Proposed } & \multicolumn{6}{|c|}{$\begin{array}{c}\text { Work Product } \\
\text { Capability }\end{array}$} & \multicolumn{3}{|c|}{$\begin{array}{l}\text { Hole } \\
\text { Type }\end{array}$} & \multirow[b]{2}{*}{ Suppliers } \\
\hline & & & & 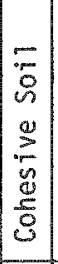 & 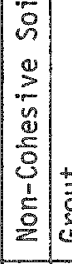 & 这 & 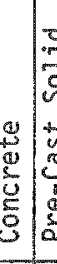 & 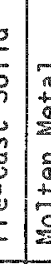 & & $\frac{\mathscr{0}}{0}$ & $\mid$ & $\stackrel{\frac{n}{g}}{\frac{2}{5}}$ & \\
\hline $\begin{array}{l}\text { Materials } \\
\text { Handling }\end{array}$ & $\begin{array}{l}\text { Concrete } \\
\text { Batch Buckets }\end{array}$ & $\begin{array}{l}\text { Typical1y } 0.8-\text { to } 2.5-\mathrm{m}^{3} \\
\text { buckets suspended from } \\
\text { cranes or wire-line trams, } \\
\text { with pneumatic or manual } \\
\text { operated bottom-dump. }\end{array}$ & $\begin{array}{l}\text { Transferring material from } \\
\text { ground surface down into } \\
\text { boreholes and shafts, or } \\
\text { horizontally along tunnel } \\
\text { plugs. }\end{array}$ & $x$ & $x$ & x & $x$ & & & $x$ & $x$ & $x$ & \\
\hline & $\begin{array}{l}\text { Transfer } \\
\text { Hoppers and } \\
\text { Conveyor } \\
\text { Betts }\end{array}$ & & $\begin{array}{l}\text { Large steel hoppers to be } \\
\text { located near plug construc- } \\
\text { tion in tunnels, to be top- } \\
\text { loaded by end-dump trucks } \\
\text { dumping off raised ramps-- } \\
\text { material bottom discharged } \\
\text { from hoppers onto conveyor } \\
\text { belts, to plug lift or } \\
\text { into buckets. }\end{array}$ & $x$ & $x$ & $x$ & $x$ & & & & & $x$ & $\begin{array}{l}\text { R. A. Hanson } \\
\text { Kaiser Engineers }\end{array}$ \\
\hline & $\begin{array}{l}\text { Rotary } \\
\text { Drilling } \\
\text { Mud Plant } \\
\quad- \\
\text { Reverse } \\
\text { Circulation }\end{array}$ & $\begin{array}{l}\text { Multi-pond mud pit, exca- } \\
\text { cavated or fabricated, mud- } \\
\text { pump, water swivel, drill } \\
\text { rods (with special bottom } \\
\text { joint fitted with tamping } \\
\text { foot). }\end{array}$ & $\begin{array}{l}\text { Mud from pit gravity flows } \\
\text { into borehole, pea gravel } \\
\text { or similar added to flow } \\
\text { at borehole collar; mud } \\
\text { transports pea gravel down } \\
\text { hole to plug, and returns } \\
\text { through drill pipe to mud } \\
\text { pump at surface. prill } \\
\text { pipe automaticaliy or } \\
\text { manually tamps gravel to } \\
\text { form gravel and mud plug. }\end{array}$ & $x$ & $x$ & & & & & $x$ & & & \\
\hline
\end{tabular}


Table 3-8 (continued)

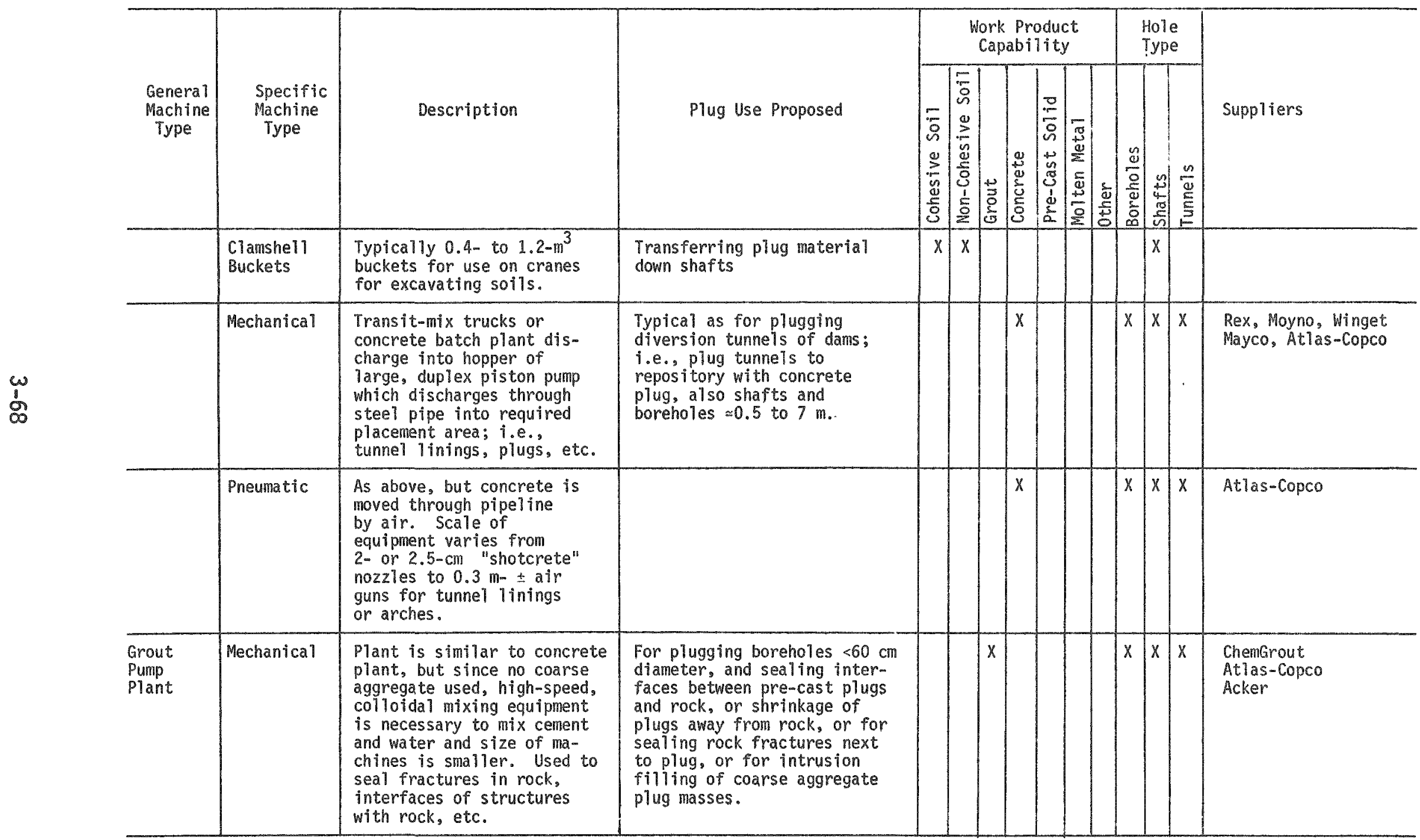


Table 3-8 (continued)

$\omega$
$b$

\begin{tabular}{|c|c|c|c|c|c|c|c|c|c|c|c|c|}
\hline \multirow[b]{2}{*}{$\begin{array}{l}\text { General } \\
\text { Machine } \\
\text { Type }\end{array}$} & \multirow[b]{2}{*}{$\begin{array}{l}\text { Specific } \\
\text { Machine } \\
\text { Type }\end{array}$} & \multirow[b]{2}{*}{ Description } & \multirow[b]{2}{*}{ Plug Use Proposed } & \multicolumn{6}{|c|}{$\begin{array}{l}\text { Work Product } \\
\text { Capability }\end{array}$} & \multicolumn{2}{|c|}{$\begin{array}{l}\text { Hole } \\
\text { Type }\end{array}$} & \multirow[b]{2}{*}{ Suppliers } \\
\hline & & & & $\begin{array}{l}7 \overline{3} \\
\overline{9} \\
0 \\
0 \\
0 \\
0\end{array}$ & $\begin{array}{l}5 \\
0 \\
2 \\
0 \\
0 \\
0 \\
0 \\
1 \\
0 \\
0 \\
2\end{array}$ & 势 & 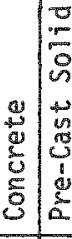 & 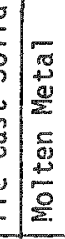 & $\mid$ & 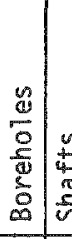 & (c) & \\
\hline \multirow[t]{2}{*}{$\begin{array}{l}\text { Electro- } \\
\text { Osmosis }\end{array}$} & We 17-Point & $\begin{array}{l}\text { Practical applications include } \\
\text { dewatering and densifying } \\
\text { fine-grained soil. Typically, } \\
\text { a driven, metal rod is the } \\
\text { anode and a well point is the } \\
\text { cathode - pore water is in- } \\
\text { duced to flow to the well } \\
\text { point where it is removed and } \\
\text { soil is consolidated. }\end{array}$ & $\begin{array}{l}\text { Place fine-grained material } \\
\text { as wet slurry, remove water } \\
\text { by electro-osmosis and } \\
\text { densify plug. }\end{array}$ & $x$ & $x$ & & & & & & & Not a stock item \\
\hline & $\begin{array}{l}\text { Fracture- } \\
\text { Sealing }\end{array}$ & $\begin{array}{l}\text { Reported to be used in Sweden } \\
\text { to seal fractures in } \\
\text { repository rock by driving } \\
\text { bentonite slurry up to } 1 \mathrm{~m} \\
\text { into exposed fracture. }\end{array}$ & Same as in description. & $x$ & & $x$ & & & & $x: x$ & $x \mid x$ & Research Technique \\
\hline $\begin{array}{l}\text { Mine } \\
\text { Stowing }\end{array}$ & Pneumatic & $\begin{array}{l}\text { An electric motor-driven, air } \\
\text { compressor unit on skids with } \\
\text { a waste-charging hopper, } \\
\text { called a pneumatic stower, } \\
\text { discharges waste into a pipe } \\
\text { line where it is discharged } \\
\text { onto the face from side-- } \\
\text { discharge sections in the } \\
\text { pipe. }\end{array}$ & Same as in description. & $x$ & $x$ & & & & & & $x$ & Brieden, Germany \\
\hline $\begin{array}{l}\text { Mine } \\
\text { Stowing }\end{array}$ & Hydrautic & $\begin{array}{l}\text { High-pressure water jets are } \\
\text { used to sluice waste into } \\
\text { pipelines, from where it is } \\
\text { discharged onto the face } \\
\text { from side-discharge sections } \\
\text { in the pipe. Slurry pumps } \\
\text { may be used if increase in } \\
\text { hydraul ic head is needed. } \\
\text { Water is drained away from } \\
\text { fill. }\end{array}$ & Same as in description. & & $x$ & & & & & & $x$ & \\
\hline
\end{tabular}


Table 3-8 (continued)

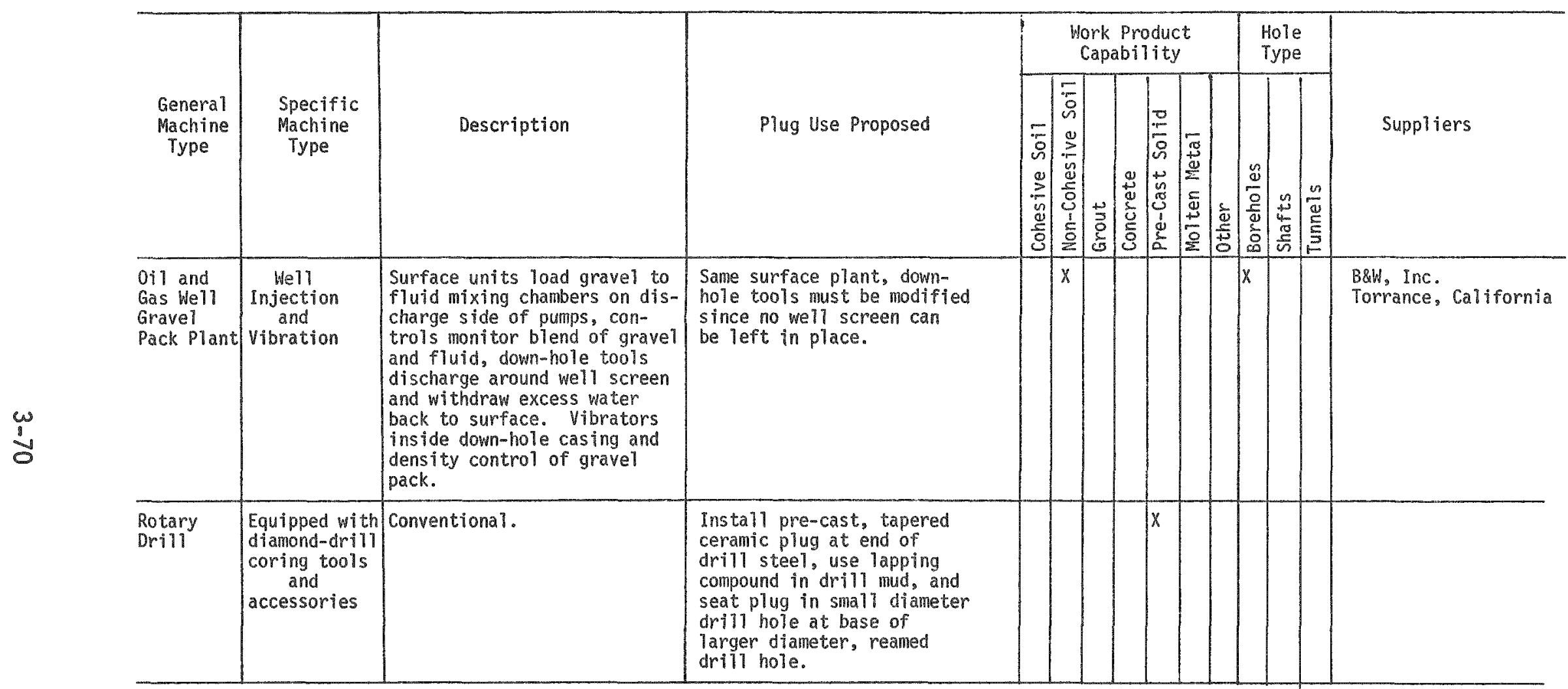


RHO-BWI-ST-7

TABLE 3-9. Results of Matrix Ratings.

\begin{tabular}{|c|c|c|}
\hline & Class & Machine \\
\hline \multirow[t]{3}{*}{ Tunnels } & A & Portable compactors for earth dams \\
\hline & B & Concrete pump system for tunnels \\
\hline & $c$ & $\begin{array}{l}\text { Earth dam heavy equipment } \\
\text { Hammer drill-tampers, on } \\
\text { tunnel jumbos* } \\
\text { Mine stowing plant hydrauilic } \\
\text { Mine stowing plant pneumatic }\end{array}$ \\
\hline \multirow[t]{3}{*}{ Shafts } & A & Portable compactors for earth dams \\
\hline & B & Concrete wireline or pump systems \\
\hline & c & Pile driving hammer-tampers \\
\hline \multirow[t]{2}{*}{ Boreholes } & A & $\begin{array}{l}\text { 1. } 0 i 1 \text { and gas well gravel pack } \\
\text { plant* } \\
\text { 2. Rotary drilling, } \\
\text { Reverse circulation mud plant* } \\
\text { 3. Grout pump system (foundation-type) }\end{array}$ \\
\hline & B & $\begin{array}{l}\text { 1. Down-hole hammer drill-tamper* } \\
\text { 2. Tri-cone rock bit } \\
\text { (with earth rollers)* }\end{array}$ \\
\hline
\end{tabular}

* Machine requires modification. 
During preconceptual design studies, the preferred candidate plugging machinery was evaluated in terms of plug material to be emplaced and plug category. The results of this evaluation, based upon literature, experience, and engineering judgment are presented in Figures 3-3 through 3-9. The comparison matrices divide material-machine combinations into three broad categories: schemes that are most feasible, but which still require demonstration; schemes considered possible at this time which require little or no modification; and unproven schemes that would require extensive modification of existing equipment or design and demonstration of new equipment.

\subsection{LABORATORY TESTING}

Extensive physical and geochemical testing of candidate plug materials is necessary to determine whether these materials are suitable for inclusion in plug designs. Physical testing must determine parameters that affect plug performance such as permeabilities, swelling pressures, compressive strengths, and bond strength, as well as physical properties such as cohesiveness, plasticity, and compactibility that will determine whether or not the materials can be emplaced in the desired form. Geothermical testing must indicate whether or not the candidate plug materials are stable under expected repository conditions. This includes reactions induced by heat or pressure, reactions between plug materials and groundwater, plug materials and host rock, and between piug components. The physical properties of a material are irrelevant if it alters to another material under operating conditions.

\subsubsection{Geochemical Testing}

Materials used in plugging boreholes must be stable in the plug environment over time periods that are long ( $10^{4}$ to $10^{6}$ years) by any human standard of comparison. When engineered into plugs, these materials must block radionuclide migration to the biosphere as part of the overall containment function of the repository. One process that could lead to unacceptable levels of radionuclide migration to the biosphere during the containment period of the repository is chemical 


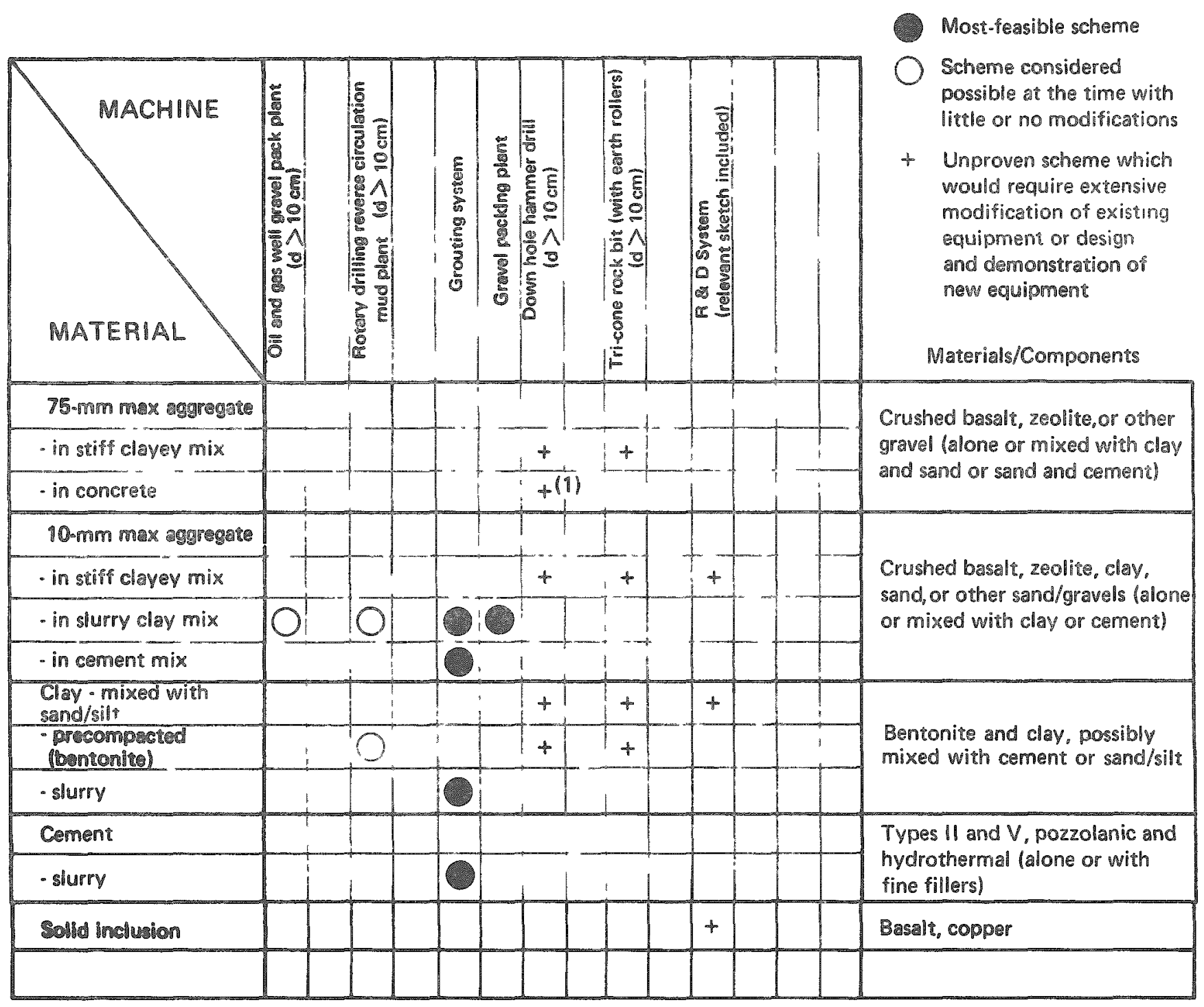

NOTES:(1)Dry mix concrete

FIGURE 3-3. Boreholes Drilled from the Surface. 


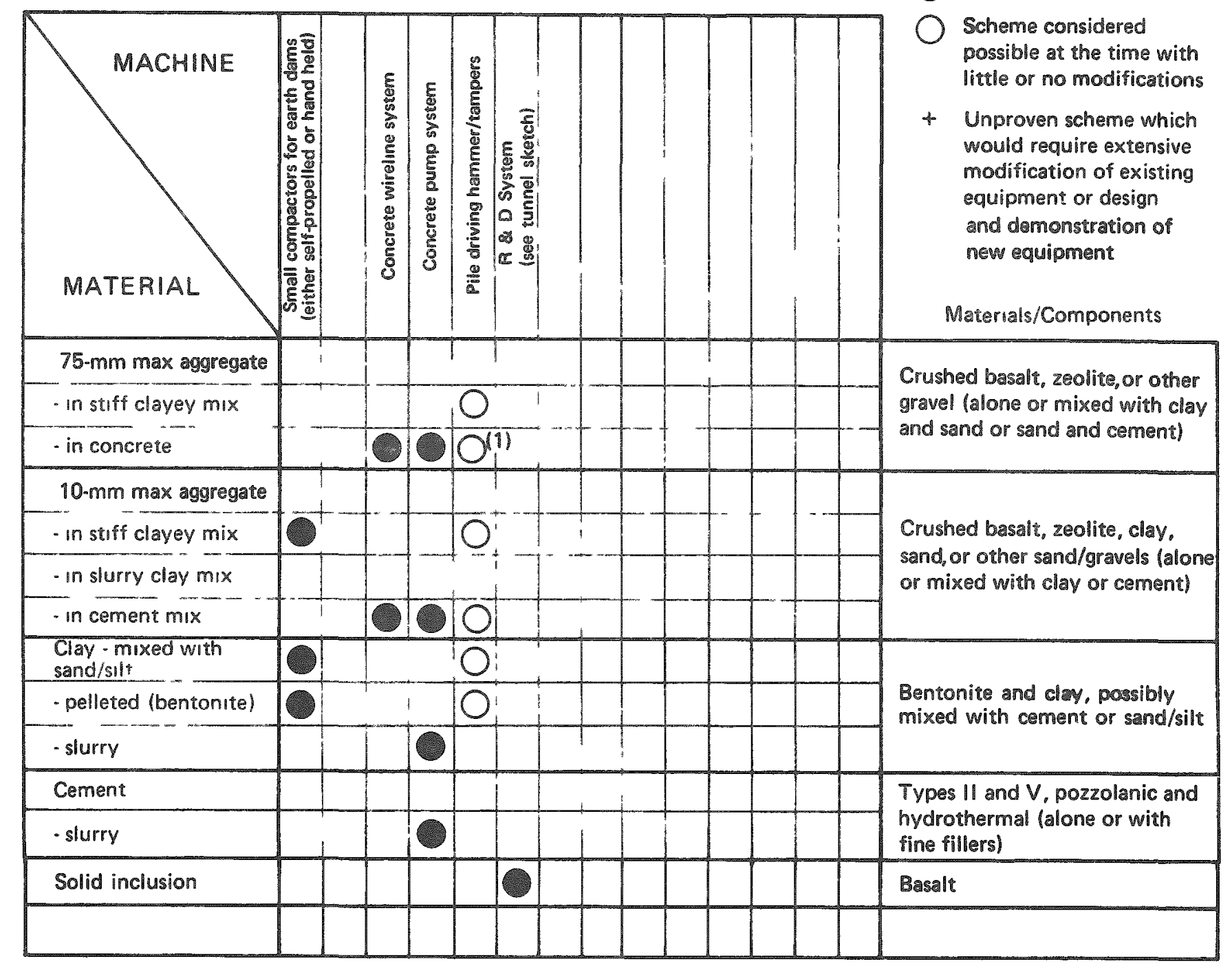

NOTES: 11 DOY mix concrete

FIGURE 3-4. Shafts. 


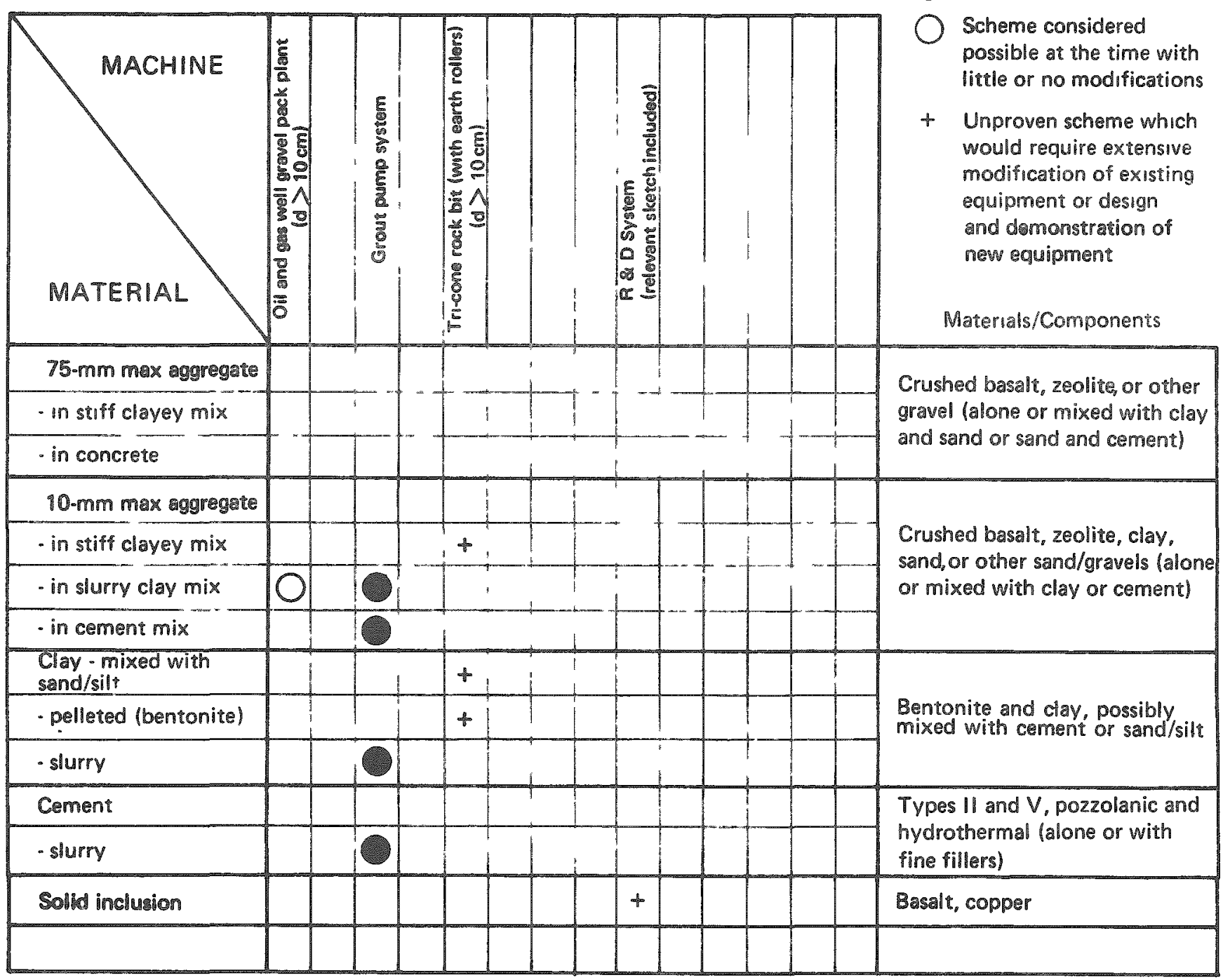

FIGURE 3-5. Subsurface Boreholes (Plug Far from Large Working Area). 


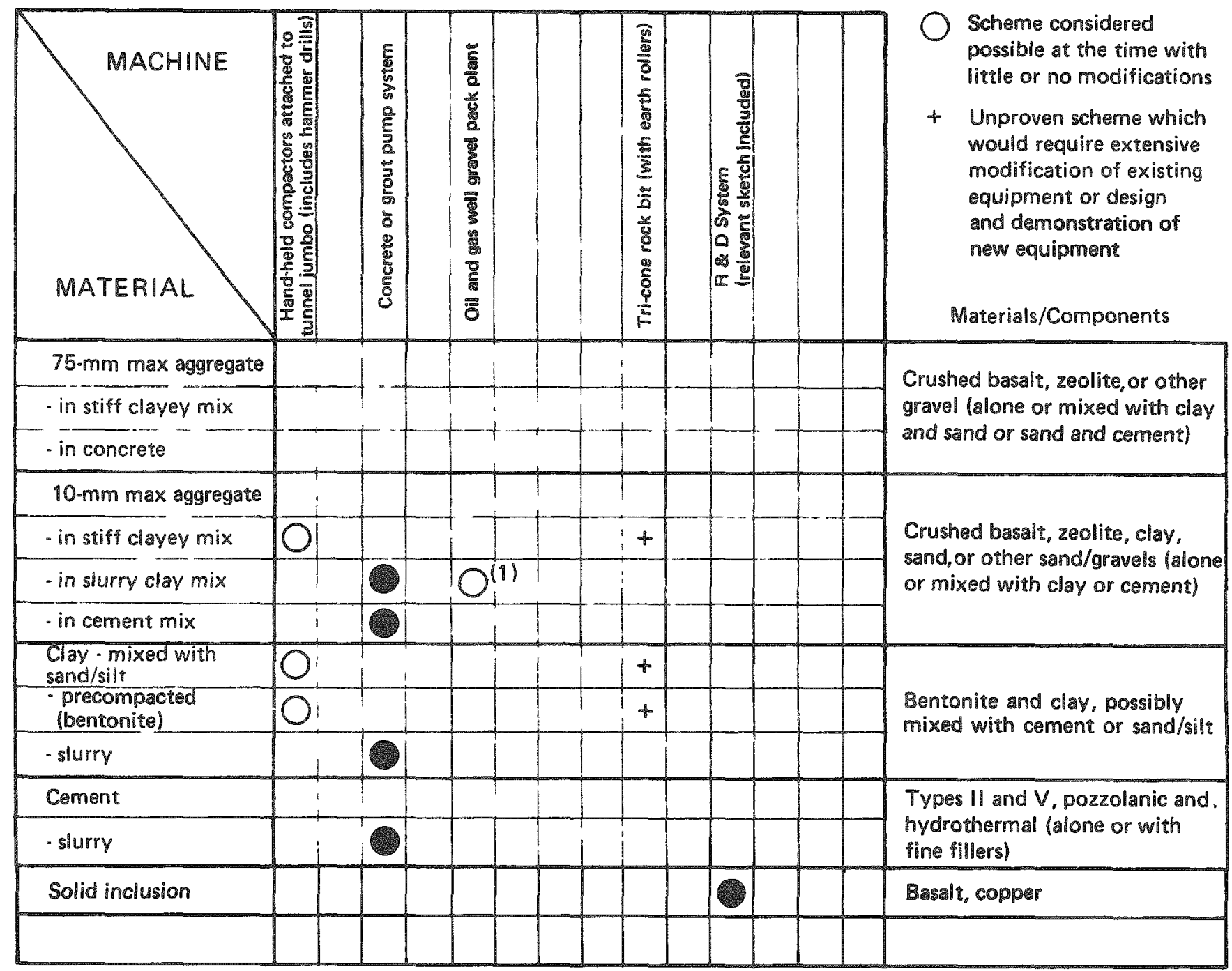

NOTES: (1)Holes below horizontal

FIGURE 3-6. Subsurface Boreholes (Plug near to Large Working Area). 
lost-feasible scheme

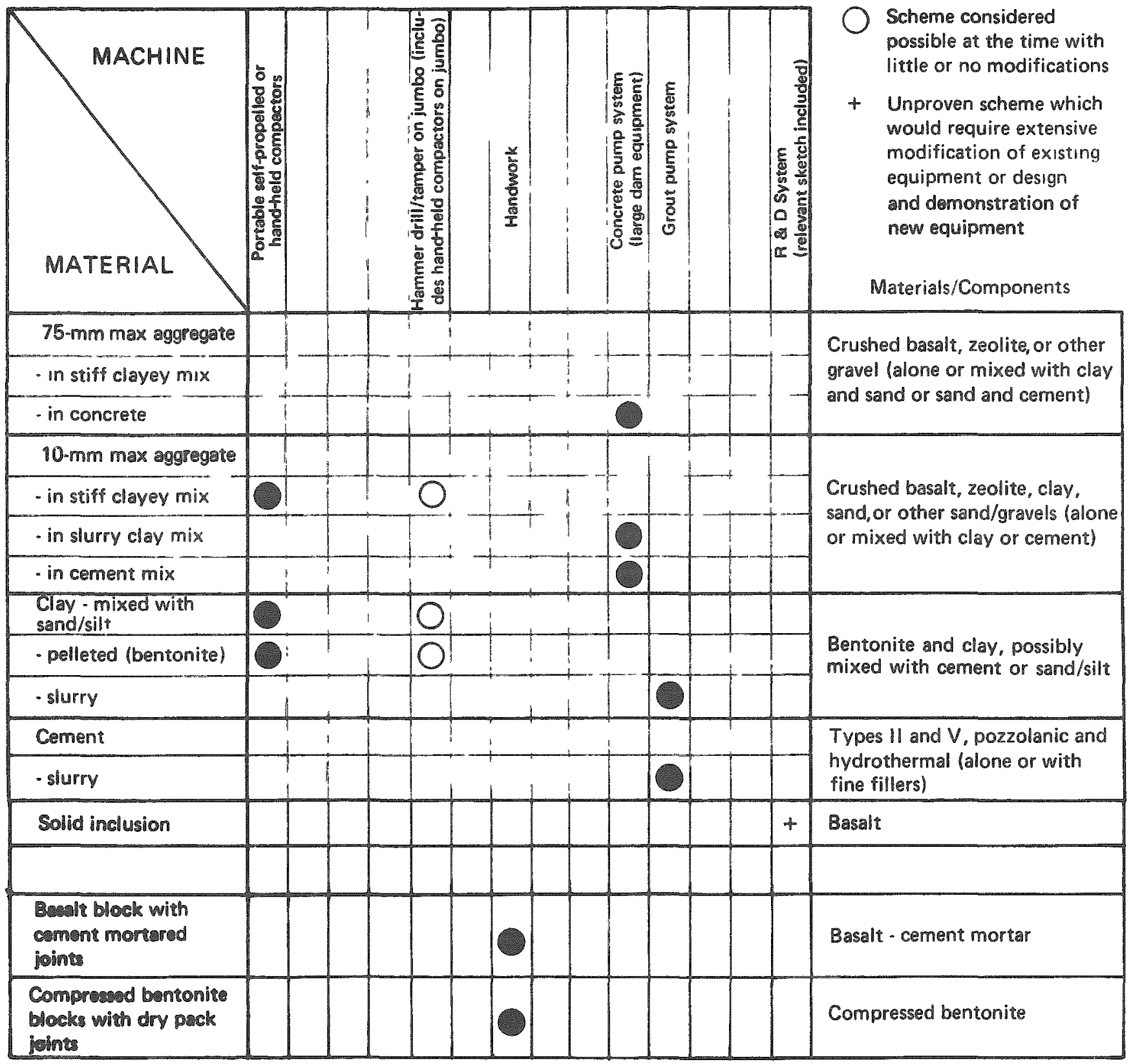

FIGURE 3-7. Sma11 Tunnel. 


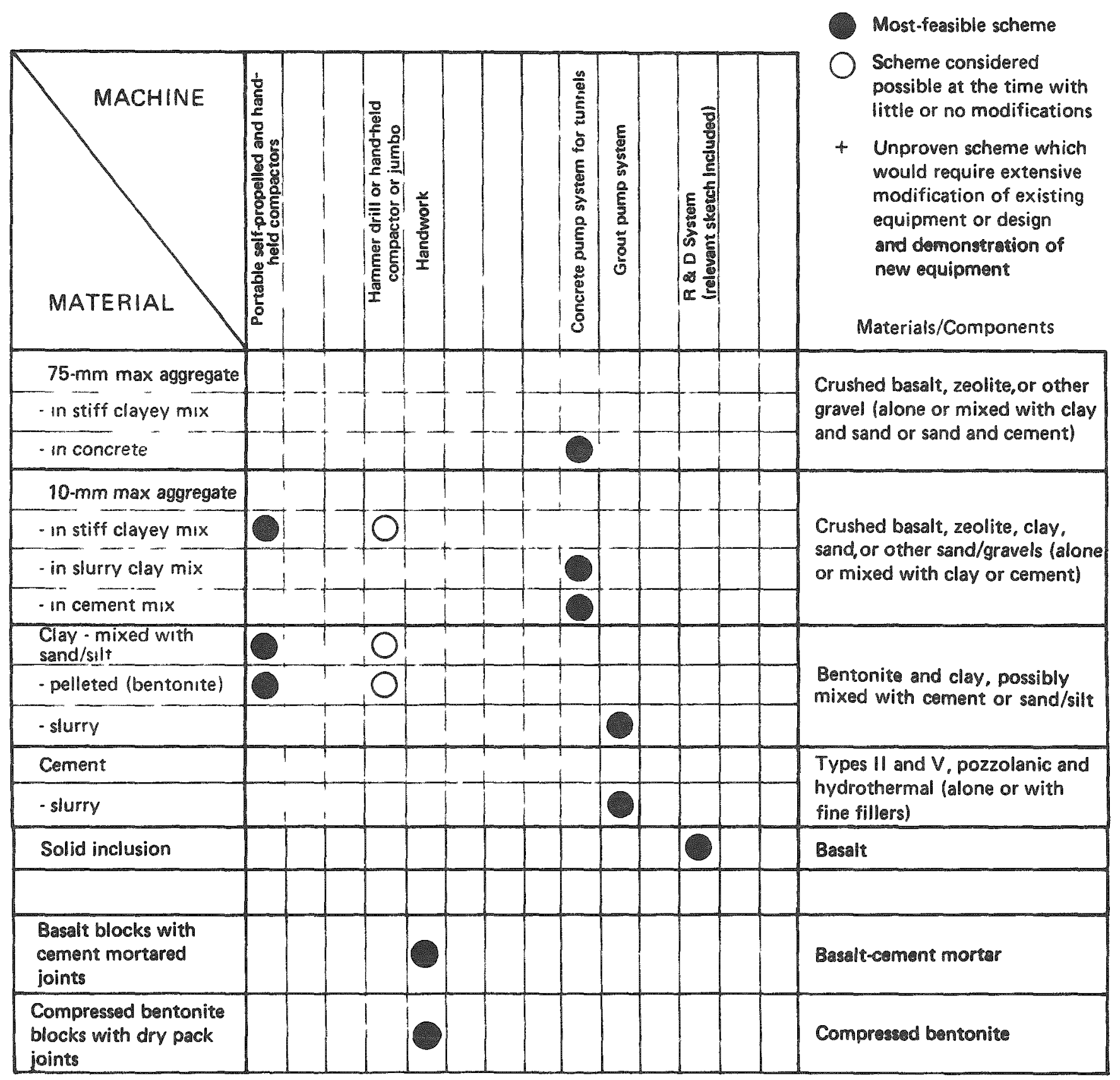

FIGURE 3-8. Large Tunnel with Short Plug. 


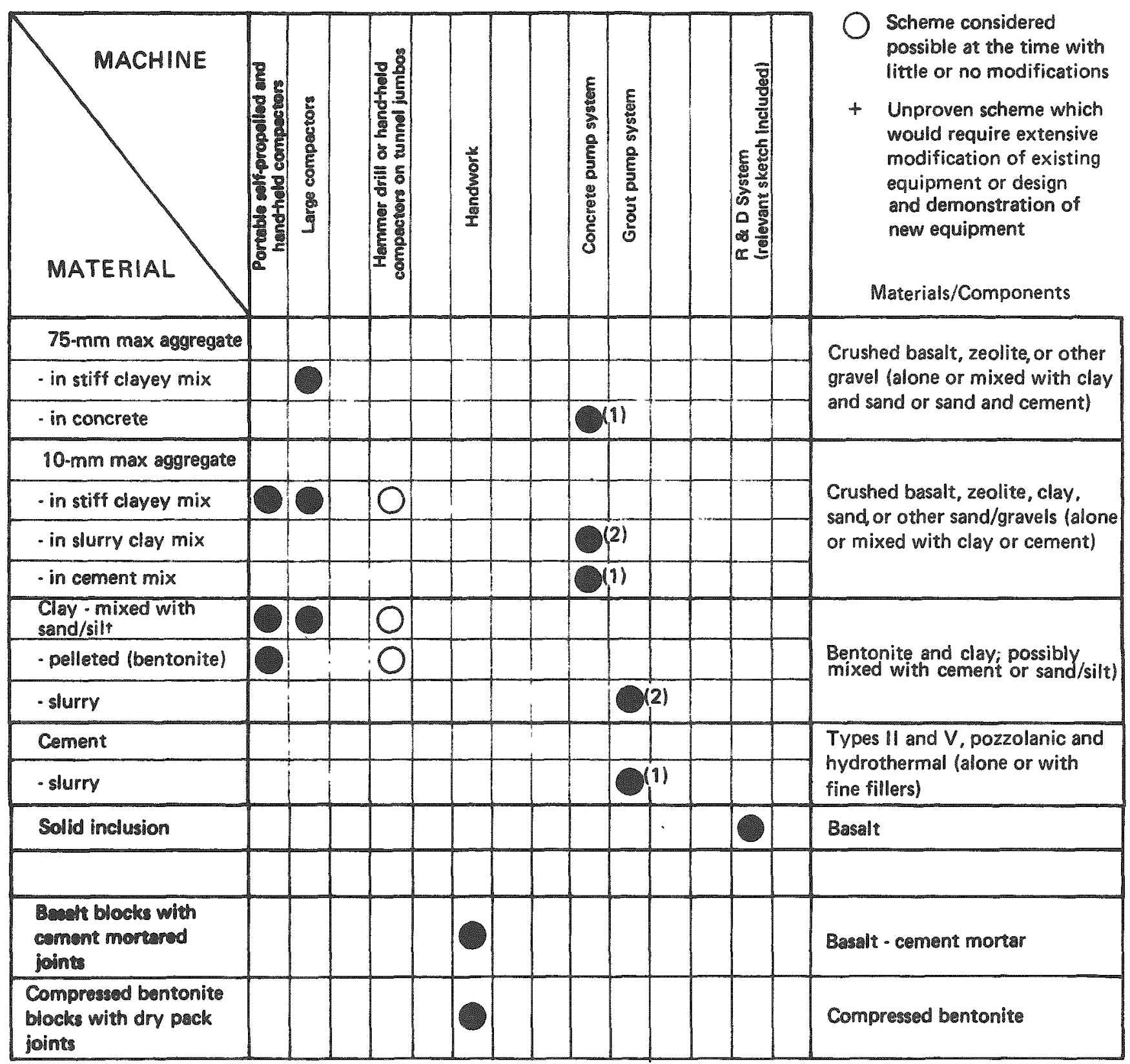

NOTES: (1) or (2) Designates one machine/material combination in a multiple machine machine/material requirement for the monolithic plug

FIGURE 3-9. Large Tunnel with Long Plug. 
deterioration of plug materials because of reactions between the materials themselves or reactions with their surroundings.

The objectives of the preliminary geochemical screening tests, carried out at Stanford Research Institute in Palo Alto, California, were to: help define the behavior of candidate plug materials in the plug environment; provide data on the relative stability and reactivity of candidate plug materials; and identify the most promising materials for consideration in future studies involving plug system design and advanced testing programs.

Fourteen materials used in the physical testing program were chosen for the preliminary geochemical testing. These materials and the various combinations used for the preliminary tests are given in Tabie 3-10. It should be noted that in both the geochemical and physical testing, materials from the Hanford Site or the northwestern United States have been used wherever possible.

Materials used in the geochemical tests, with the exception of several tests involving only basalt, were finely ground $(-200$ to +325 mesh) to increase reaction rates during the tests. Test mixtures were prepared by combining materials in equal proportions by weight. Tests were carried out with simulated Hanford groundwater (Section 2.4) and at a water:rock ratio of 10:1 (by weight). Actual test samples are listed in Table 3-11. The great majority of screening tests were carried out at $250^{\circ} \mathrm{C}$ and $3.9 \mathrm{MPa}$, the saturation pressure of steam at that temperature. All materials and mixtures of materiais listed in Table 3-10 were tested under these conditions for periods of 1,2 , and 3 months. The tests were carried out in a large volume $(11.4 \mathrm{l}$ ) autoclave with the individual samples encapsulated in Teflon sample bottles. Similar tests were carried out with six samples at $150^{\circ} \mathrm{C}$ and $0.5 \mathrm{MPa}$ and several tests were carried out in a smaller autoclave at $250^{\circ} \mathrm{C}$ and $34.5 \mathrm{MPa}$ in order to test for pressure effects. In addition, several tests were carried out in a stirred autoclave to test the effects of agitation upon reaction rates.

Test samples were characterized prior to testing by $X$-ray powder diffraction analysis, BET surface area analysis, Fisher subsieve analysis, and scanning electron microscopy. Results of the pretest characterization are presented in Table 3-4. 
TABLE 3-10. Materials and Materials Mixtures for Preliminary Hydrothermal Screening Tests.

\begin{tabular}{|c|c|}
\hline Basalt ${ }^{2}$ Samples & $\begin{array}{l}\text { Bulk Basalt } \\
\text { Coarse-Grained Basalt } \\
\text { Fine-Grained Basalt } \\
\text { Basalt/Sandb }\end{array}$ \\
\hline Soil Materials & $\begin{array}{l}\text { Oregon Bentonite } \\
\text { Wyoming Bentonite } \\
\text { Ringold Clayc }^{c} \\
\text { Oregon Zeolited } \\
\text { Processed Bentonite }\end{array}$ \\
\hline$\frac{\text { Soil Materials }}{\text { Mixtures }}$ & $\begin{array}{l}\text { Oregon Bentonite/Sand } \\
\text { Wyoming Bentonite/Sand } \\
\text { Ringold Clay/Sand } \\
\text { Oregon Bentonite/Zeolite } \\
\text { Wyoming Bentonite/Zeolite }\end{array}$ \\
\hline 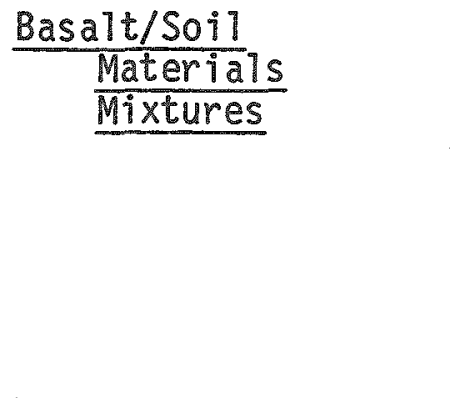 & $\begin{array}{l}\text { Basalt/Oregon Bentonite } \\
\text { Basalt/Wyoming Bentonite } \\
\text { Basalt/Ringold Clay } \\
\text { Basalt/Sand/Oregon Bentonite } \\
\text { Basalt/Sand/Wyoming Bentonite } \\
\text { Basalt/Sand/Ringold Clay } \\
\text { Basalt/Zeolite/Oregon Bentonite } \\
\text { Basalt/Zeolite/Wyoming Bentonite } \\
\text { Basalt/Zeolite/Ringold Clay }\end{array}$ \\
\hline$\frac{\frac{\text { Cement/Soil }}{\text { Materia7s/Basalt }}}{\frac{\text { Mixtures }}{\text { Mint }}}$ & $\begin{array}{l}\text { Portland Cement Type II/Sand/Basalt } \\
\text { Portland Cement Type V/Sand/Basalt } \\
\text { Portland Pozzolan Cement/Sand/Basalt } \\
\text { Hydrothermal Cement (1)/Sand/Basalt } \\
\text { Hydrothermal Cement (2)/Sand/Basalt } \\
\text { Portland Cement Type II/Zeolite/Basalt } \\
\text { Portland Cement Type V/Zeolite/Basalt } \\
\text { Portland Pozzolan Cement/Zeolite/Basalt } \\
\text { Hydrothermal Cement (1)/Zeolite/Basalt } \\
\text { Hydrothermal Cement (2)/Zeolite/Basalt }\end{array}$ \\
\hline
\end{tabular}

${ }^{A} \mathrm{AT}$ basalt samples used in these preliminary tests are Pomona basalt from the Near-Surface Test Facility. Umtanum basalt will be used in the advanced tests.

bGlaciofluvial sand from the Hanford Site.

Cprimarily smectite clay.

dPrimarily the mineral clinoptilolite. 
RHO-BWI-ST-7

TABLE 3-11. Specimens Used in the Geochemical Testing Program.

\begin{tabular}{|c|c|c|c|}
\hline $\begin{array}{l}\text { Sample } \\
\text { ID wa. }\end{array}$ & Composition & Dupportions ${ }^{\alpha}$ & Description \\
\hline 1 & Basa:t & - & Single piece, polished race \\
\hline 2 & Basale & - & $-10 / 4,40$ mesht \\
\hline 3 & Basalt & $\cdots$ & - \\
\hline 4 & Basalu/card & $\therefore: 1$ & -- \\
\hline 5 & Basalt/onegon bentorite & $1: 1$ & Bentonite -325 mesh \\
\hline 6 & Basalt/wyonng bentonite & $1: 1$ & Bentonite -325 mesh \\
\hline 7 & Eusalt/shurgel & $1: 1$ & $\begin{array}{l}\text { Shu*get }-325 \text { mesh } \\
\text { (processed benton ite) }\end{array}$ \\
\hline 8 & Easalt/Aquagel & $1: 12$ & $\begin{array}{l}\text { Aquagel }-325 \text { mesh } \\
\text { (processed bentonite) }\end{array}$ \\
\hline 9 & Basalt/Ringold ciay" & $1: 1$ & clay -325 mesh \\
\hline 10 & Basa't/sans/oregon benton tze & $1: 1: 1$ & Bentonite -325 mesh \\
\hline 11 & Basalt/sand/Wyoming bentonte & $1: 1: 1$ & Bentonite -325 thesh \\
\hline 12 & Basalt/sand/Ringold clay & $1: 1: 1$ & clay -325 mesh \\
\hline 33 & Basalt/zeolite/oregon berton the & $1: 1: 1$ & Eeofite, bentonite -325 mesh \\
\hline 14 & Basaltzeoltiterycring bentonite & $1: 1: 1$ & leolite, bentonite -325 mesh \\
\hline 15 & Basalt/zeolite/Ringold clay & $1: 1: 1$ & Zeolite, clay -325 mesh \\
\hline 16 & oregon bentorite & & -325 wesh \\
\hline 3 & Wyoniog bentonite & & -325 mesh \\
\hline 18 & orggon bentonitelsand & $1: 1$ & Bentonite -325 mesh \\
\hline 19 & Wyor'ng bentontte/sand & $1: 1$ & Bentonte -325 mesh \\
\hline 20 & oregon kenantelzeglite & $\therefore: 1$ & Both -325 mesh \\
\hline 21 & Wyoning bentonite/zeolite & $1:{ }^{n}$ & Both -325 mesh \\
\hline $2 e^{2}$ & Oregon zeolite & & -325 mesh \\
\hline 23 & Rimgold clay & & -325 resh \\
\hline 24 & Ringold clay/sand & $2: 1$ & c1ay -325 mesh \\
\hline 25 & Fondu/sand/basalt & $1: 1: 1$ & $\begin{array}{l}\text { Fondu a hydrotherwal cenent } \\
\text { (brand none) }\end{array}$ \\
\hline 26 & Stear/sand/basalt & $1: 1: 1$ & $\begin{array}{l}\text { Secaw = hydrothemal cement } \\
\text { (brand name) }\end{array}$ \\
\hline 27 & $\begin{array}{l}\text { (Portland pozzlan coment } \\
+ \text { sand)/basalt }\end{array}$ & $1: 1$ & \\
\hline 28 & $\begin{array}{l}\text { (Portiand Type If coment } \\
\text { + sard) basale }\end{array}$ & $:: 1$ & \\
\hline 29 & $\begin{array}{l}\text { (Portland Type y cement } \\
\text { * sant)/basalt }\end{array}$ & $\pm: 1$ & \\
\hline 30 & (Fondu + zeolite) basate & $1: 1$ & \\
\hline 31 & $\begin{array}{l}\text { (Portiand pozzolan cenert } \\
\text { * zeolite)/basa? }\end{array}$ & $:: 1$ & \\
\hline 32 & $\begin{array}{l}\text { (Portiand Typa II cament } \\
+ \text { zeolite)/basalt }\end{array}$ & $1: 1$ & 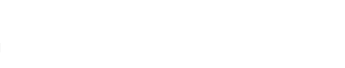 \\
\hline 33 & $\begin{array}{l}\text { Porsland Type V cenent } \\
+200 \mathrm{ntel} \text { basalt }\end{array}$ & $: 1$ & 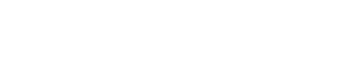 \\
\hline 34 & $\begin{array}{l}\text { (Portland Type V cerent } \\
+ \text { silica ftourl/basalt }\end{array}$ & $1: 1$ & 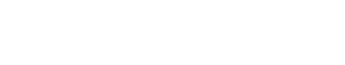 \\
\hline 35 & Basalt core t concrete & & 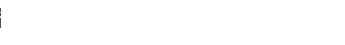 \\
\hline 36 & $\begin{array}{c}\text { (TXI chem con cement: } \\
\text { Lassen'e)/sand }\end{array}$ & $1: 1$ & $\begin{array}{l}\text { TXI chem com = pomeland } \\
\text { cement with shminiage } \\
\text { compensat ing agent } \\
\text { (brand nane); }\end{array}$ \\
\hline & & -- & $\begin{array}{c}\text { Lassenite = natural pozzolar } \\
\text { additive (brand nane) }\end{array}$ \\
\hline 37 & $\begin{array}{l}\text { (Pontland Type V cement } \\
+ \text { sillica flowr } t \\
\text { plastiment/sand }\end{array}$ & $2: 1$ & $\begin{array}{l}\text { Plastiment = organic water } \\
\text { reductrg retarder agent } \\
\text { (brand name) }\end{array}$ \\
\hline 38 & $\begin{array}{c}\text { (Portiand pozzotan cenert } \\
+ \text { silica flourl/sand }\end{array}$ & $1: 1$ & 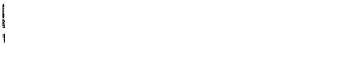 \\
\hline 39 & $\begin{array}{c}\text { (Portiland Type } V \text { cerent } \\
+ \text { Lassenite }) / \text { sand }\end{array}$ & $1: 1$ & 1 \\
\hline
\end{tabular}


Characterization of the experimental run products is incomplete: however, initial results indicate that the candidate plug materials are generally unreactive under the test conditions. This result is not a complete surprise, considering the careful selection process carried out prior to testing. Montmorillonite formed in all samples containing basalt (Section 2.9). The results of X-ray diffraction analysis of solid materials from static, $250^{\circ} \mathrm{C}$ tests involving single natural materials are presented in Table 3-12. Analys is of Sample No. 3 illustrates the formation of montmorilionite from basalt and the disappearance of the unknown phase from Sample No. 22 (Oregon zeolite) probably represents the formation of one homogeneous zeolite phase. The formation of an unknown phase in the Wyoming bentonite (No. 17) and the Ringold clay (No. 23) is of particular interest. A single unidentified peak $(d=3.18 \AA)$ appeared in these samples as a result of 3 months' treatment. The presence of a single, strong peak may indicate the presence of a micaceous mineral (paragonite?) that has formed from the clays as a result of hydrothermal reaction. If this is the case, the formation of paragonite would set an upper-temperature limit for the use of sodium-bentonites within a repository. It is very important to identify the phase and deliniate the conditions and kinetics of its formation.

Preliminary runs in a stirred autoclave $\left(250^{\circ} \mathrm{C}, 3.9 \mathrm{MPa}\right)$ indicate that crushed Columbia River basalt, in the presence of simulated groundwater, undergoes a self-cementing reaction. In runs of 2-week duration, approximately one half of the basalt in the autoclave was cemented into a hard, durable mass. The self-cementation, similar to that described for reaction between sea water and basalt (Bischoff and Dickson, 1976), is apparently a result of dissolution of the glassy phase within the basalt and precipitation of silica (amorphous?). This reaction offers the possibility of producing natural cements from repository materials of known long-term stability. Efforts are currently under way to determine the exact nature and kinetics of the cementing reaction and to produce pieces of self-cemented basalt sufficiently large for physical testing. 
TABLE 3-12. Cement Curing Procedures.

A. Wet-curing at standard temperature $\left(230^{\circ} \mathrm{C}\right)$

- Specimen wet-cured 24 hours within the mold, then removed and cured in a moist room before testing, for non-expansive or quick-hardened, cement mortars.

- Specimen wet-cured 7 days within the mold, then removed and cured in a moist room before testing, for expansive cement mortar.

B. Wet-curing at elevated temperature, initial curing for 24 hours within the mold followed by one of the following curing alternatives:

- In boiling water for 72 hours at $1000^{\circ} \mathrm{C}$.

- In an autoclave for 72 hours at $2000 \mathrm{C}$.

\subsubsection{Physical Testing}

The physical testing program was designed: (1) to help select individual materials and mixtures from the list of preferred candidate materials for further testing and use in preconceptual design schemes to plug boreholes, shafts, and tunnels leading to a repository in basalt; and (2) to provide quantitative experimental data on the thermomechanical response of selected mixtures under simulated repository conditions. Candidate materials for physical testing included natural cohesive and non-cohesive granular earth materials, portland cements, hydrothermal cements, and some standard cement additives. These materials are the same as those tested during the concurrent geochemical testing program, and Table 3-10 presents a detailed listing of the various individual materials used in both testing programs. Various aspects of the physical testing program required different proportions of components in various test mixtures and also required different sample and particle sizes from the geochemical testing program.

For the purpose of the physical testing program, mixtures made from the candidate materials listed in Table 3-10 are classified into three main categories: (1) cementitious mixtures; (2) compacted natural earth 
materials; and (3) clay slurries. These mixtures were tested in two phases. During an initial phase of screening tests, all preferred candidate materials and mixtures that fell into one of the three generic categories were examined, and the most promising mixtures were selected for further examination in the subsequent phase of preliminary tests. During the preliminary tests, specific, promising candidate materials and mixtures selected on the basis of the screening tests were examined in greater detail.

\subsubsection{Cementitious Mixtures. Candidate cementitious mixtures for} plugging man-made accesses to a repository in basalt should be characterized by a good working ability, low permeability, good bonding properties, and long-term integrity and durability. In related research, portland cements were recommended by Eilers and Spangle (1973) as the primary sealant for boreholes because of portland cement's proven permanence, low porosity, and good bond strength to formation material. Preferred portland cements included Types II and $V$ because of sulfate resistance, and Chem Com expanding cements because of their ability to provide a compressive self-stressing effect against confining walls, thus resulting in a higher bond strength to formation material. The best performing Chem Com cement was reported to be El Toro Chem Com from Southwestern Portland Cement Company. This cement is no longer available. TXI Chem Com made by Texas Industries was considered next best in performance characteristics, and it was evaluated in this study.

Boa (1978) included fly ash and natural high-silica pozzolans in his selection of candidate grouts for plugging. These additives improve the impermeability of cement mixtures and the addition of natural or artificial pozzolan in mixtures should also reduce bleeding and segregation, lower the heat of hydration and thermal shrinkage, and improve chemical resistance and long-term integrity and durability of the cementitious material. In this study, preference is given to natural, high-silica pozzolan because of its documented history of survival. In addition, natural, high-silica pozzolan has been found to provide cementitious mixtures that have greater sulfate resistance than fly ash (Mather, 1977). Accordingly, this study includes: premixed portland 
pozzolan cement containing $15 \%$ (by weight) expanded shale and a natural calcined, high-silica volcanic ash (Lassenite), which was added to various cement mixtures during the batching process.

To improve workability of fresh grout or concrete, several additives were used. One additive (Plastiment) was a water-reducing retarder agent which, when introduced in small quantities, causes a reduction of the required water and provides a stronger, denser product. Another additive was small amounts of finely ground aluminum powder that reacted with the alkaline constituents of portland cement to produce hydrogen gas. This resulted in an early expansion of cementitious mixtures prior to setting and improved the contact of fresh cement mixtures against irregular surfaces.

Cement mixtures to be placed near the waste repository should also have enough thermal stability to withstand cyclic temperature increases caused by the storage of radioactive wastes. Conventional portland cement mixtures are reported not to be stable at elevated temperatures (Roy and 0thers, 1975). Under elevated pressure and temperature conditions, the original highly cementitious calcium silicate hydrates into crystalline lime that has lower strength and higher permeability. A feasibility study by Roy and others (1975) on hydrothermal transport indicated that the addition of finely ground silica flour to conventional portiand cement produces a thermodynamically stable phase, tobermorite, which results in a denser, stronger final product. To minimize deterioration of cement mixtures at elevated temperature, the following two alternatives were examined during this phase of the testing program: (1) the addition of finely ground silica to portland cements (both a -325 mesh silica flour and a high silica pozzolan); and (2) the use of calcium aluminate cements (Fondu and Secar). In the second case, the main component is calcium aluminate as distinguished from calcium silicate in portland cements; no free lime is liberated either during hydration or heat exposure in calcium aluminate cements. Fine and coarse aggregates used in all cement mixtures were chosen for their ready availability and proximity to the Hanford Site; they include crushed and naturally graded sands and gravels and crushed basalt. 
Screening tests for cementitious materiais included: (1) the determination of unit weight, specific gravity, percentage of absorption, grain size distribution, anu inorganic impurities content for candidate sands: (2) the consistency and setting time of freshly mixed cementitious mixtures; (3) the early volume change and the restrained shrinkage or expansion of candidate mixtures; and (4) the unconfined compressive strength at 7 days and 28 days of hardened 5 -cm cubes of cement mortar, cured using one of the methods presented in Table 3-12.

The procedures used during physical testing included the American Society for Testing and Materials and the U.S. Army Corps of Engineers standards and modified standard procedures. The list of standard procedures is given in Table 3-13, and procedures for curing of cements are given in Table $3-12$.

Experimental values of the compressive strength of 5 -cm cement mortar cubes, which were tested at ambient temperature after being cured at $23^{\circ}, 100^{\circ}$, or at $200^{\circ} \mathrm{C}$ (Table $3-14$ ), are plotted in Figure $3-10$ (a and b) for nine candidate cement mixtures. Descriptions of the mixture components, water/cement ratios, setting times, and compressive strengths are summarized in Table 3-14. Calcium aluminate cement (Fondu), portland pozzolan cement, portland cement Type II with a natural pozzolan added, and TXI Chem Com cement (with or without pozzolan) show a substantial deterioration in structural strength when subjected to elevated temperature. Portiand cement Type $V$ mixed with a high-silica pozzolan (Lassenite) and Secar cement are stable and exhibit no significant change in strength with increasing curing temperature. However, strengths developed by mixtures of portiand cement Type $V$ plus Lassenite are about $35 \%$ higher than strengths developed by mixtures of secar cement. On the basis of data indicating high structural strength, the addition of finely ground silica powder to portland cements appears to be highly desirable in mixtures designed for use in plug locations where temperatures may be high (greater than $100^{\circ} \mathrm{C}$ ).

Large variations in reactivity were observed between the various grades of aluminum powder tested. Whereas $0.070 \%$ of -325 mesh unpolished aluminum powder by weight of cement was necessary to eliminate early 
TABLE 3-13. Testing Procedures Applied to Cementitious Mixtures.

\begin{tabular}{|c|c|}
\hline ASTM C-29a & Unit weight of aggregate \\
\hline ASTM C-128a & Specific gravity and absorption of fine aggregate \\
\hline ASTM $\mathrm{C}-40 \mathrm{a}$ & Inorganic impurities \\
\hline ASTM D-422b & Particle size analysis of soil \\
\hline ASTM C-230a & $\begin{array}{l}\text { Specification for flow table for use in test of } \\
\text { hydraulic cement }\end{array}$ \\
\hline ASTM C-191C & Setting time by vicat needle \\
\hline ASTM C-827a & Early volume change of cementitious mixtures \\
\hline CRD C-588d & $\begin{array}{l}\text { Restrained expansion of cement mortars: U.S. } \\
\text { Army Corps of Engineers method }\end{array}$ \\
\hline Modified ASTM C-109a & $\begin{array}{l}\text { (1) Compressive strength of expansive or } \\
\text { shrinkage-compensating cement mortars. (2) } \\
\text { Compressive strength of non-expansive and } \\
\text { rapid-hardening cement mortars. (3) Effect of } \\
\text { heat exposure on the compressive strength of wet } \\
\text { cement mortars. Modifications include variations } \\
\text { in curing procedures described in the text. }\end{array}$ \\
\hline
\end{tabular}

aASTM (1977).

DASTM (1978).

CASTM (1973).

dU.S. Army Corps of Engineers (1978). 
TABLE 3-14. Summary of Test Results for Cement Mortars Cured at Elevated Temperatures.

\begin{tabular}{|c|c|c|c|c|c|c|c|c|c|}
\hline \multirow{2}{*}{$\begin{array}{l}\text { Mixture } \\
\text { Number }\end{array}$} & \multirow{2}{*}{$\begin{array}{l}\text { Cement } \\
\text { Description }\end{array}$} & \multirow{2}{*}{$\begin{array}{l}\text { Sand } \\
\text { Description }\end{array}$} & \multirow{2}{*}{$\begin{array}{l}\text { Additive } \\
\text { Description }\end{array}$} & \multicolumn{2}{|c|}{$\begin{array}{c}\text { Water Cement } \\
\text { Ratio } \\
\end{array}$} & \multicolumn{2}{|c|}{ Setting Time } & \multicolumn{2}{|c|}{$\begin{array}{l}\text { Unconfined Strength } \\
\text { (MPa) }\end{array}$} \\
\hline & & & & $W / c$ & $\begin{array}{l}\text { W/Ct } \\
\text { silica }\end{array}$ & Initial & Final & $\begin{array}{l}\text { Curing at } \\
t=100^{\circ} \mathrm{C}\end{array}$ & $\begin{array}{l}\text { Curing at } \\
t=200^{\circ} \mathrm{C}\end{array}$ \\
\hline 612 & Fondu & $\begin{array}{l}\text { Glaciof luvial } \\
\text { sand }\end{array}$ & NA* & 0.40 & NA & $2: 00$ & $3: 30$ & 33.9 & 24.6 \\
\hline 613 & Secar & $\begin{array}{l}\text { Glaciofluvial } \\
\text { sand }\end{array}$ & NA & 0.51 & NA & $1: 40$ & $2: 50$ & 32.4 & 35.6 \\
\hline 614 & $\begin{array}{l}\text { Portl and } \\
\text { Type V }\end{array}$ & $\begin{array}{l}\text { Glaciof luvial } \\
\text { sand }\end{array}$ & Silica flour & 0.57 & 0.37 & $2: 45$ & $4: 00$ & 50.1 & 106.1 \\
\hline 615 & $\begin{array}{l}\text { Portiand } \\
\text { Pozzol an }\end{array}$ & $\begin{array}{l}\text { Glaciof luvial } \\
\text { sand }\end{array}$ & Silica flour & 0.56 & 0.36 & $2: 15$ & $3: 45$ & 53.3 & 101.7 \\
\hline 616 & TXI & $\begin{array}{l}\text { Glaciof luvial } \\
\text { sand }\end{array}$ & NA & 0.47 & NA & $1: 40$ & $3: 35$ & 38.3 & 16.7 \\
\hline 619 & $\begin{array}{l}\text { Portl and } \\
\text { Type V+ } \\
\text { Lassenite }\end{array}$ & $\begin{array}{l}\text { Glaciof luvial } \\
\text { sand }\end{array}$ & NA & 0.49 & NA & $3: 15$ & $5: 15$ & 48.3 & 47.8 \\
\hline 620 & $\begin{array}{c}\text { TXI }+ \\
\text { Lassenite }\end{array}$ & $\begin{array}{l}\text { Glaciofluvial } \\
\text { sand }\end{array}$ & NA & 0.50 & NA & $1: 30$ & $3: 45$ & 43.6 & 22.2 \\
\hline 621 & $\begin{array}{l}\text { Portl and } \\
\text { Type } V\end{array}$ & $\begin{array}{l}\text { Glaciofluvial } \\
\text { sand }\end{array}$ & $\begin{array}{l}\text { Silica flour } \\
+ \text { Plastiment }\end{array}$ & 0.49 & 0.32 & $3: 00$ & $6: 30$ & 53.0 & 116.3 \\
\hline 622 & $\begin{array}{l}\text { Port land } \\
\text { Type V } \\
\text { Lassenite }\end{array}$ & $\begin{array}{l}\text { Glaciofluvial } \\
\text { sand }\end{array}$ & Plastiment & 0.45 & NA & & & 56.1 & 53.2 \\
\hline 623 & $\begin{array}{l}\text { Portl and } \\
\text { Type V }\end{array}$ & $\begin{array}{l}\text { Glaciofluvial } \\
\text { sand }\end{array}$ & $\begin{array}{l}\text { Silica flour } \\
+ \text { Plastiment } \\
+ \text { Al Powder }\end{array}$ & 0.50 & 0.33 & & & 58.5 & 111.0 \\
\hline 624 & $\begin{array}{l}\text { Portl and } \\
\text { Type II } \\
\text { Lassenite }\end{array}$ & $\begin{array}{l}\text { Glaciofluvial } \\
\text { sand }\end{array}$ & NA & 0.53 & NA & $1: 50$ & $4: 20$ & 40.6 & 31.8 \\
\hline 625 & $\begin{array}{l}\text { Portl and } \\
\text { Pozzol an }\end{array}$ & $\begin{array}{l}\text { Glaci of luvial } \\
\text { sand }\end{array}$ & NA & 0.45 & NA & & & 60.9 & 33.1 \\
\hline
\end{tabular}




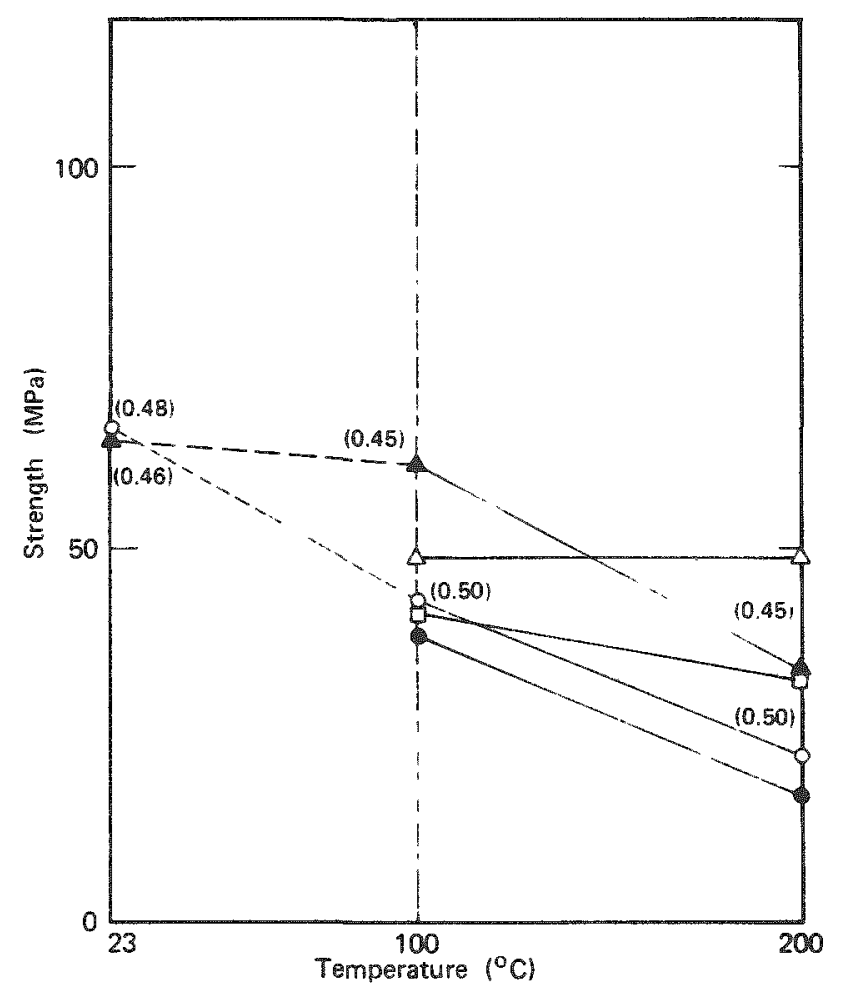

(a)

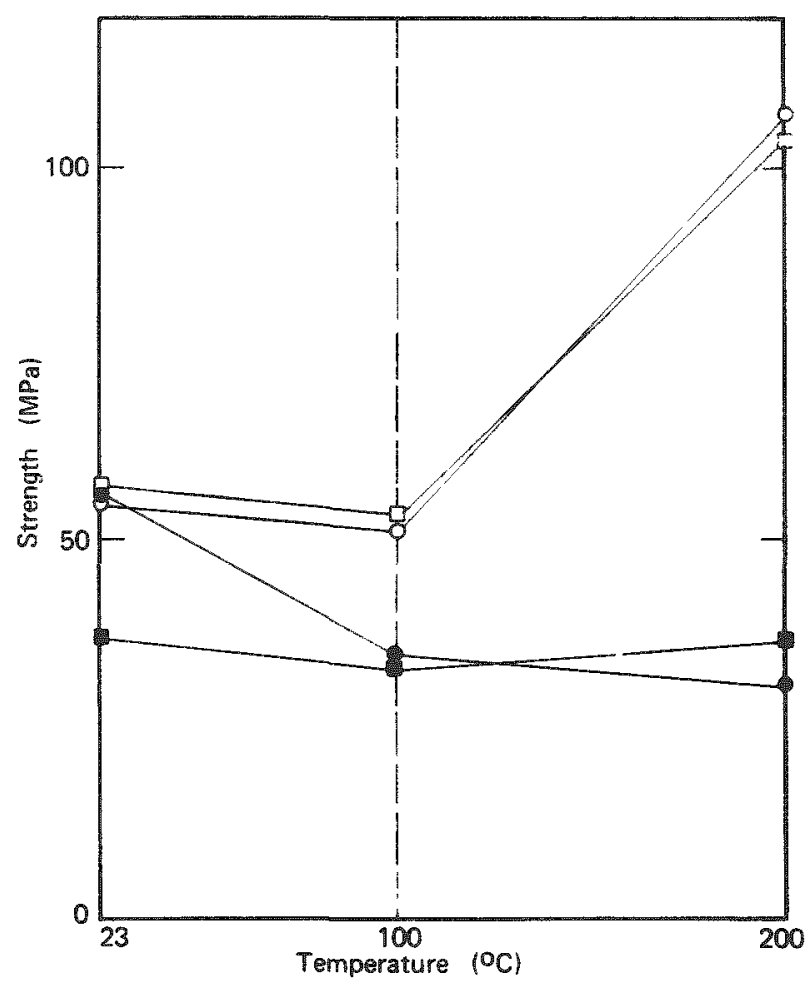

(b)
EXPLANATION

- Portland Pozzolan Cement

- TXI Chem Com plus Lassenite

- TXI Chem Com

- Portland Cement Type II plus Lassenite $\triangle$ Portland Cement Type $V$ plus Lassenite

NOTE:

Water-cement ratios are plotted in parentheses near data point when not uniform for the same candidate mixture at different curing temperature.

\section{EXPLANATION}

- Fondu Cement

- Secar Cement

- Portland Cement Type $V$ plus Silica

c Portland Pozzolan Cament plus Silica

FIGURE 3-10. Compressive Strength of Cement Mortar Mixtures Cured at Elevated Temperatures. 
shrinkage in portland cement Type $V$ mixtures, $0.03 \%$ of -325 polished, leafing-type aluminum powder was found to produce $8 \%$ free expansion in cement mixtures (Figure 3-11). Initial testing of cement mortars containing unpolished aluminum powder indicated that for the same consistency, an increase in the aluminum powder ratio required an increase in the water/cement ratio (thus causing increased bleeding and segregation and a less dense mortar), and an acceleration of the set of the mixture. The use of a water-reducing retarder agent, Plastiment, which can reduce the amount of water required for a given cement consistency and also retard the rate of stiffening, is expected to significantly improve the expansive characteristics and structural behavior of mixtures containing aluminum powder. Experimental compressive strength values for specimens cured at elevated temperatures, which contain both a water-reducing agent and aluminum powder, indicated that no additional deterioration was caused by either the addition of a water-reducing agent or aluminum powder (Figure 3-12). On the contrary, there was a slight increase in structural strength. Values of unit weight, specific gravity, percentage of absorption, and inorganic impurities of glaciofluvial sand, crushed basalt, and crushed zeolite are given in Figure 3-13. The grain size distribution curves of these three candidate sands relative to two grading limit curves proposed by ASTM C-33 (ASTM, 1977) for sand used in mortar and concrete are given in Figure 3-13. The basalt and zeolite sands had to be crushed to conform to the American Society of Testing and Materials requirements. The glaciofluvial sand and the crushed-basalt sand have similar physical properties and are recommended for cement mixtures. Crushed zeolite appears to be a porous and weak aggregate. A large amount of breakdown was observed during blending of this material.

Comparative values for water/cement ratios and compressive strengths, together with mixture designs, are given in Table 3-15. Three cement mixtures were cured at $100^{\circ} \mathrm{C}$ and at $200^{\circ} \mathrm{C}$ using the same cements and additives but containing different aggregates. Experimental strength values are plotted on Figure 3-13. Cement mortars mixed with glaciofluvial sand and crushed basalt developed very similar strengths. 


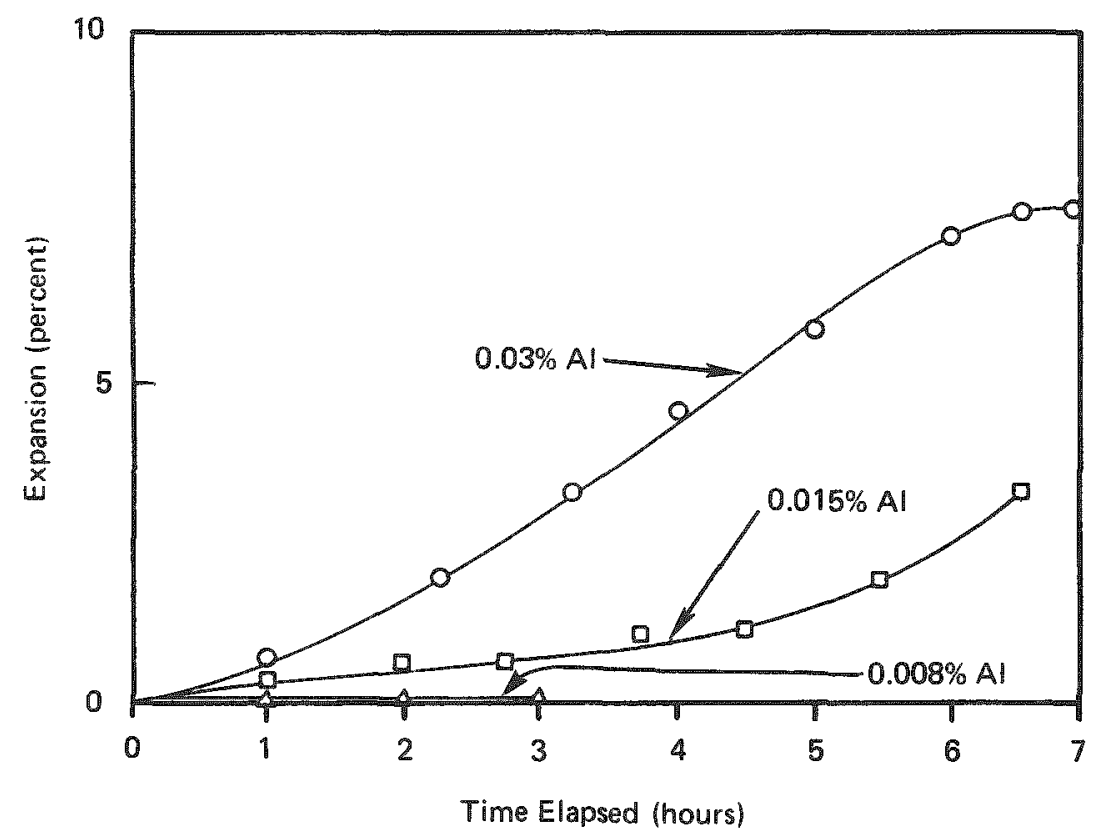

FIGURE 3-11. Effect of Increasing the Content of -325 Mesh, Polished, Leafing-Type Aluminum Powder on Expansion Characteristics of Fresh Grout.

Cement mortar mixed with crushed zeolite had an extremely weak structural strength. The amount of water used with crushed zeolite aggregate tomaintain the same consistency was twice that used for either crushed basalt or glaciofluvial sand. This demand for water and the weak structural strength suggests a very porous cement mortar. The use of crushed zeolite in cement is not desirable, based on low-strength results and high water demand for a given consistency. The results of tests on mortars made with either glaciofluvial or crushed basalt were very similar and indicate a strong, dense, competent material. The screening test results for cementitious mixtures led to the selection of materials for more detailed performance test evaluations on the basis of workability, volume change, and structural strength for mixtures to be placed at locations where temperatures are expected to be low (less than $100^{\circ} \mathrm{C}$ ) and on the basis of workability, volume change, structural strength, and thermal stability for mixtures to be placed at locations where high temperatures are expected (greater than $100^{\circ} \mathrm{C}$ ). A list of 


\section{RHO-BHI-ST-7}

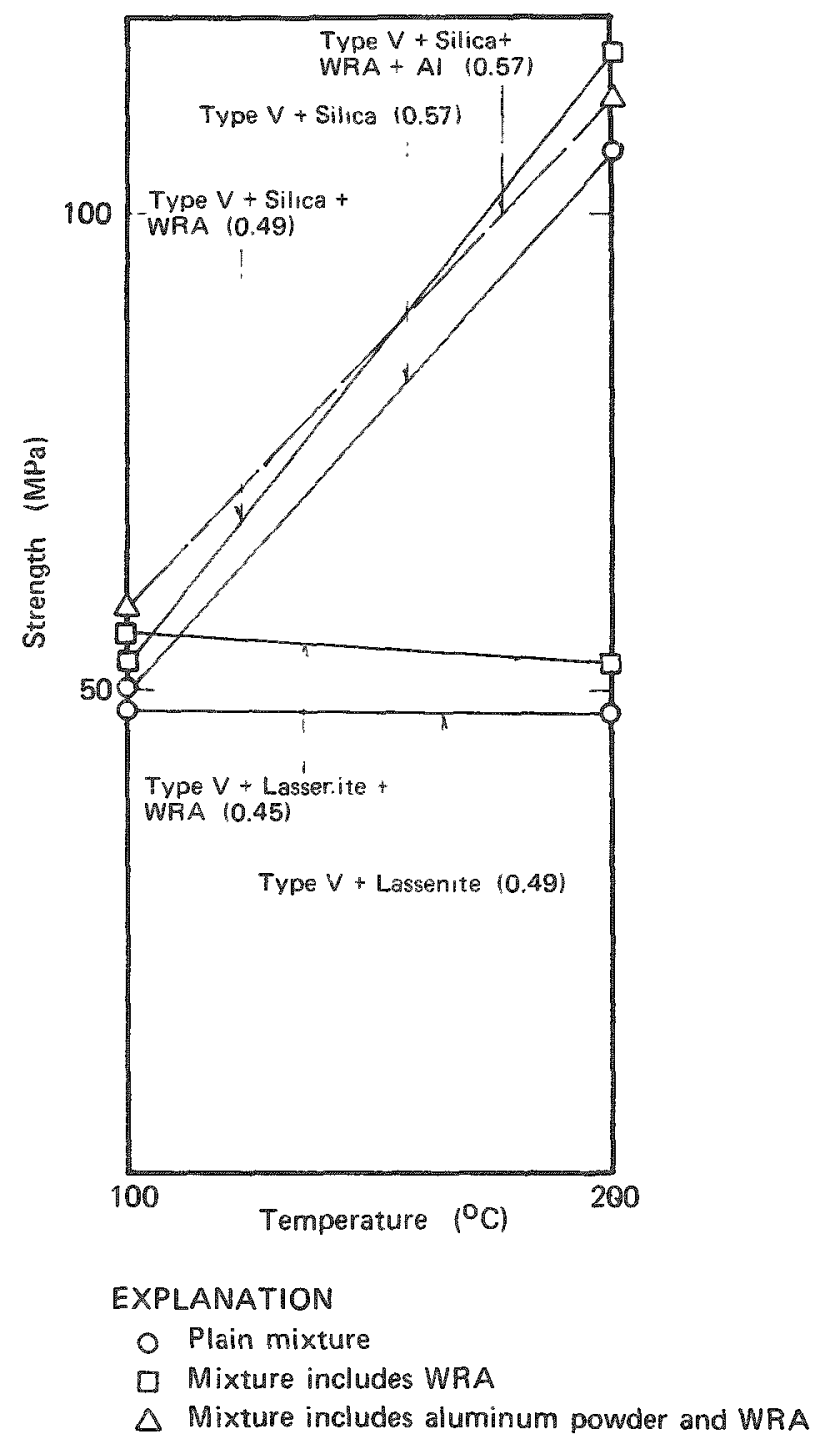

FIGURE 3-12. Compressive Strength of Cement Mixtures Containing a Water-Reducing Agent (Plastiment) and Aluminum Powder at Elevated Curing Temperatures. 


\section{RHO-BWI-ST -7}

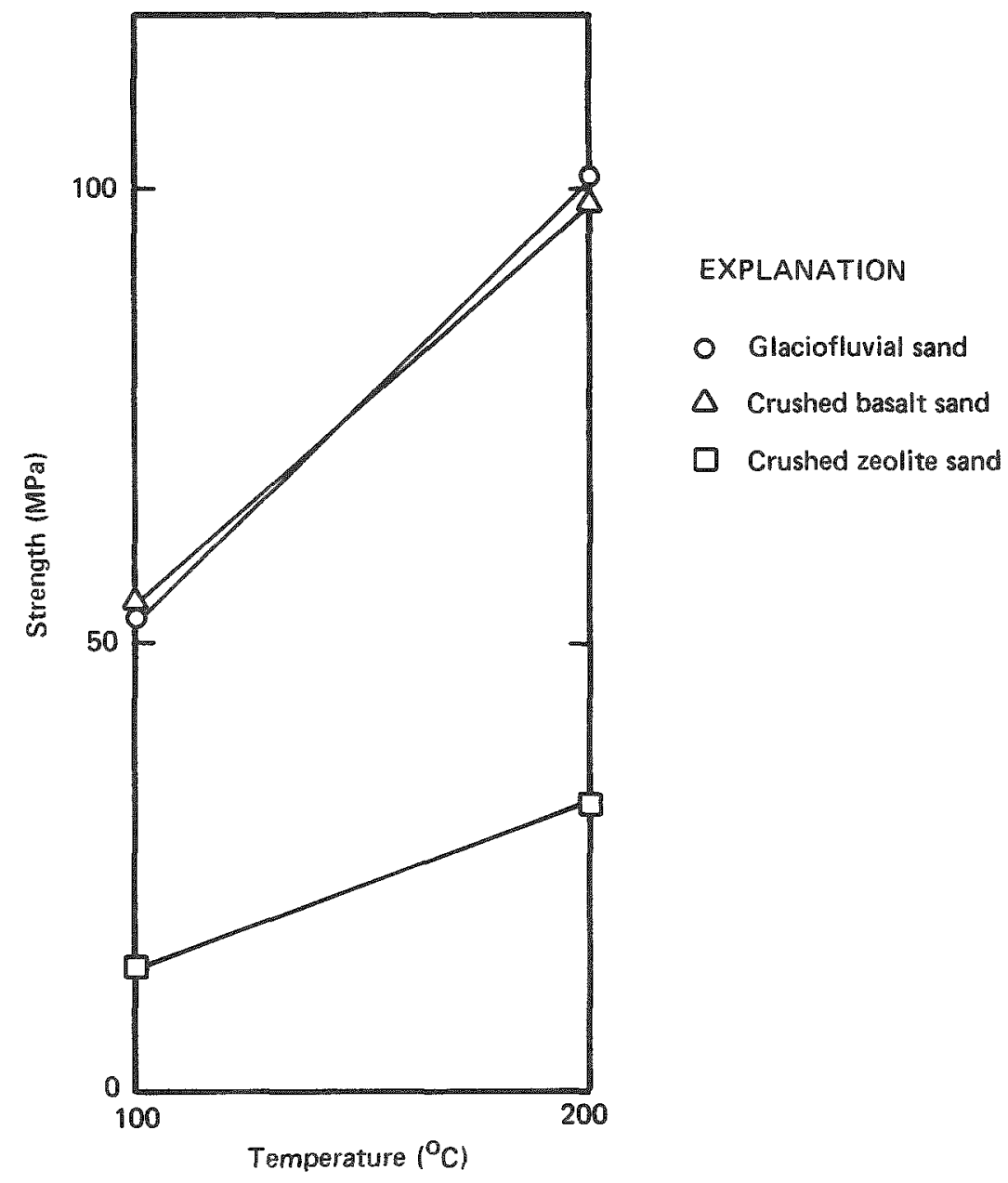

FIGURE 3-13. Performance of Cement Mixtures Containing Portland Type V, Silica Flour and Three Types of Fine Aggregate. 
TABLE 3-15. Summary of Test Results for Portland Pozzolan Cement Mortars Containing Different Aggregate Types.

\begin{tabular}{|c|c|c|c|c|c|c|}
\hline \multirow{2}{*}{$\begin{array}{l}\text { Mixture } \\
\text { Number } \\
\text { BBPP }=\text { PT }\end{array}$} & \multirow{2}{*}{$\begin{array}{l}\text { Components } \\
\text { Description }\end{array}$} & \multirow{2}{*}{$\begin{array}{c}\text { Additive } \\
\text { Description }\end{array}$} & \multicolumn{2}{|c|}{$\begin{array}{c}\text { Water Cement } \\
\text { Ratio }\end{array}$} & \multicolumn{2}{|c|}{$\begin{array}{c}\text { Unconfined } \\
\text { Compression (MPa) }\end{array}$} \\
\hline & & & $W / C$ & $\begin{array}{c}W / C \\
+ \text { silica }\end{array}$ & $\begin{array}{c}\text { Boiling Water } \\
\text { Curing } \\
100^{\circ} \mathrm{C}\end{array}$ & $\begin{array}{l}\text { Autoclave } \\
200^{\circ} \mathrm{C}\end{array}$ \\
\hline 615 & $\begin{array}{l}\text { Portland } \\
\text { Pozzolan/ } \\
\text { Glaciofluvial } \\
\text { Sand }\end{array}$ & Silica flour & 0.56 & 0.36 & 53.3 & 101.7 \\
\hline 617 & $\begin{array}{c}\text { Portland } \\
\text { Pozzolan/ } \\
\text { Crushed Basalt }\end{array}$ & Silica flour & 0.56 & 0.36 & 54.3 & 98.1 \\
\hline 618 & $\begin{array}{c}\text { Portland } \\
\text { Pozzolan/ } \\
\text { Crushed Zeolite }\end{array}$ & Silica flour & 1.39 & 0.88 & 14.9 & 21.7 \\
\hline
\end{tabular}

TABLE 3-16. Materials Used in Performance Tests for Cementitious Mixtures.

\begin{tabular}{l|l}
\hline Cementitious Materials & $\begin{array}{l}\text { Portland Type } V \text { cement and silica flour (high } \\
\text { temperature locations: } T \geq 1000 \mathrm{C}) \\
\text { Portland Type } V \text { cement and lassenite (moderate } \\
\text { temperature locations: } T \leq 1000 \mathrm{C})\end{array}$ \\
\hline Fine Aggregates & $\begin{array}{l}\text { TXI Chem Com cement and lassenite (10w } \\
\text { temperature locations: } T \leq 500 \mathrm{C})\end{array}$ \\
\hline Coarse Aggregates & $\begin{array}{l}\text { Glaciofluvial sand or crushed basalt sand } \\
\text { (from the Hanford Site) }\end{array}$ \\
\hline Additives & $\begin{array}{l}\text { Minus } 2.5 \text { cm crushed river gravel or crushed } \\
\text { basalt gravel (from the Hanford Site) }\end{array}$ \\
\hline
\end{tabular}


materials employed in performance tests is given in Table 3-16. Performance tests of candidate grout and concrete mixtures included: standard index tests of freshly prepared cementitious mixtures; (2) density, porosity, volume change, and strength determinations of hardened mixtures included: (1) standard index test of freshly prepared cementitious mixtures; (2) density, porosity, volume change, and strength determinations of hardened mixtures; and (3) model testing, including the determination of the permeability and bond strength of cementitious mixtures and basalt host rock.

Two types of plug/basalt models were prepared: one using a clean basalt surface and the other using a mud-contaminated basalt surface. In both cases freshly mixed grout or concrete was emplaced in holes drilled down the center of a piece of basalt core. The mud-contaminated models, representing the worst case of an uncleaned borehole, were coated with a bentonite slurry ( $8 \%$ by weight of Shurgel) prior to grout or concrete emplacement. In both cases the model plugs were cured for 72 hours under the steam pressure of water at $100^{\circ} \mathrm{C}$. Bond strengths between cement plugs were determined by end loading the plugs in a large hydraulic press and measuring maximum loading force during plug extrusion. Measurements were made both at room temperature and at $100^{\circ} \mathrm{C}$.

Permeability tests of cement plug/basalt (host rock) models were carried out inside a conventional triaxial cell using the falling head method. A pressure differential of $0.05 \mathrm{MPa}$ for concrete plugs and $0.03 \mathrm{MPa}$ for grout plugs was applied between the top and the bottom of the full surface of the composite samples, corresponding to an approximate value of 70 for the hydraulic gradient. The permeability measurement, thus, represents an average permeability for the entire plug/basalt model.

Test results are given for each cementitious mixture on Figures 3-14 to $3-19$.

Oven-dry densities of grout composed of Chem Com TXI cement plus lassenite (G-TXI-L) and grout composed of portland cement Type $V$ plus lassenite $(G-V-L)$ were found to be the same $\left(1.64 \mathrm{~g} / \mathrm{cm}^{3}\right)$, while a 


\section{RHO-BWI-ST-7}

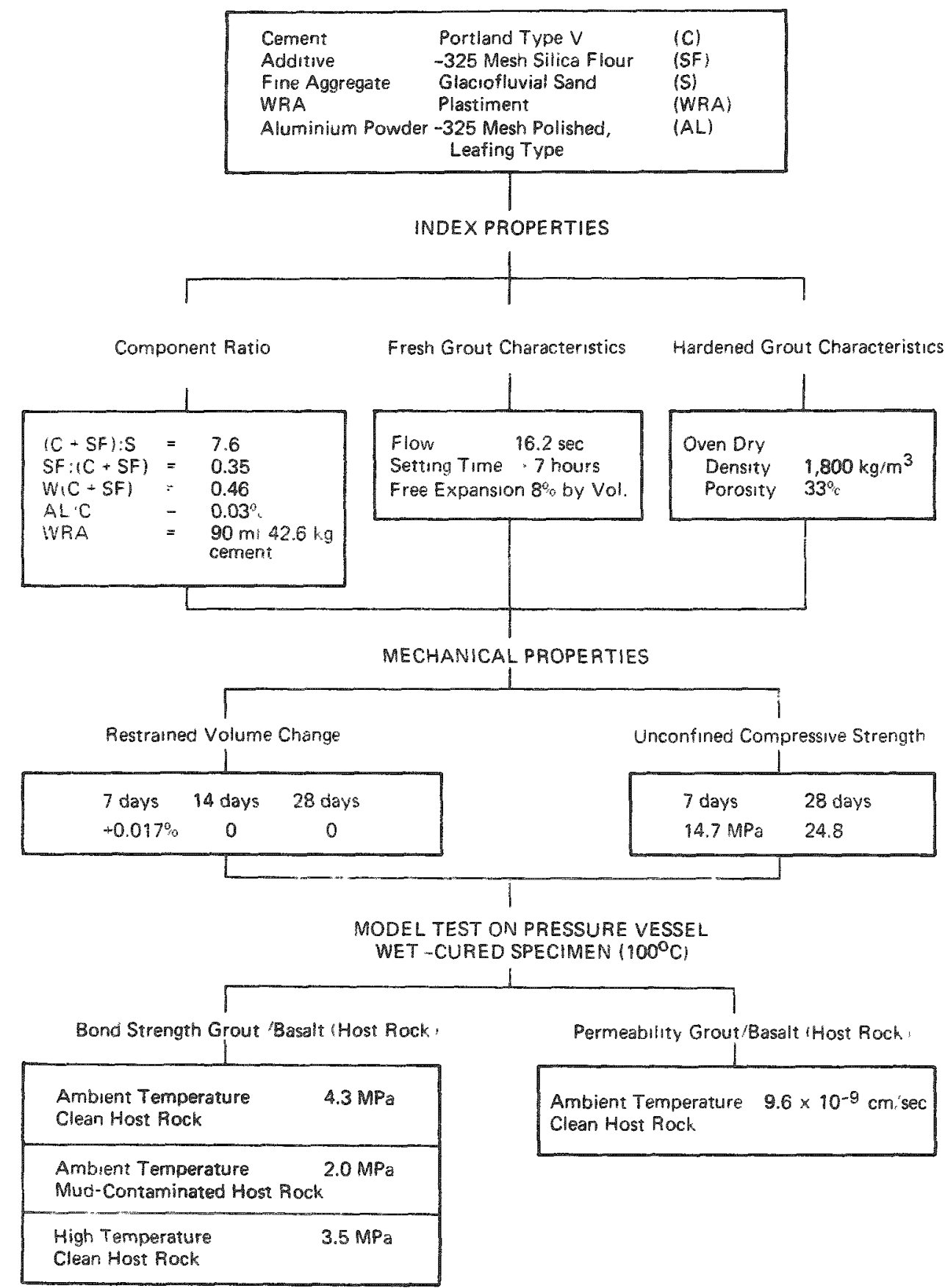

FIGURE 3-14. Summary of Grout Performance for High Temperature Locations $\left(T \geq 100^{\circ} \mathrm{C}\right)$. 
RHO-BWI-ST - 7

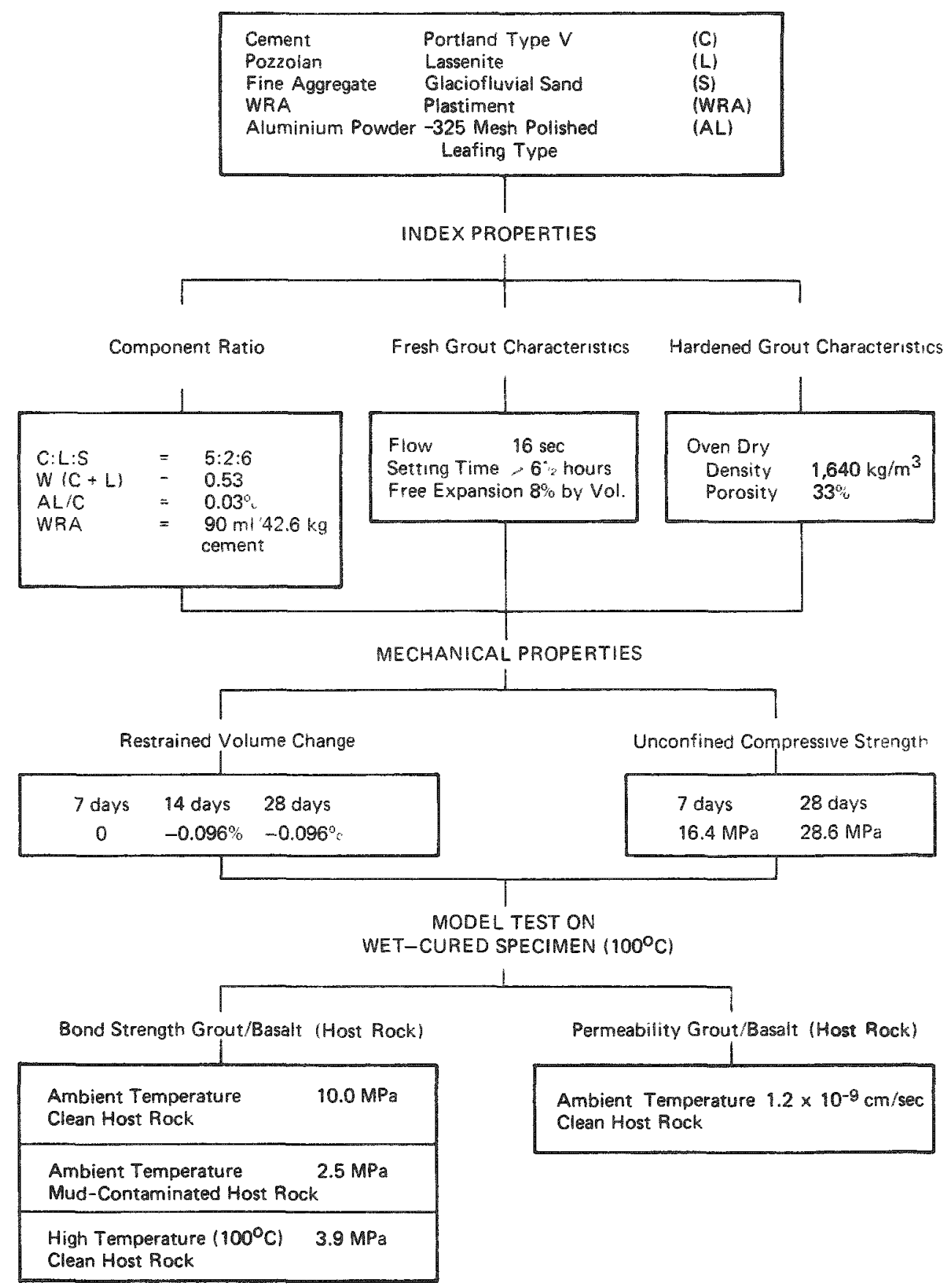

FIGURE 3-15. Summary of Grout Performance for Moderate Temperature Locations ( $T \leq 1000 \mathrm{C})$. 


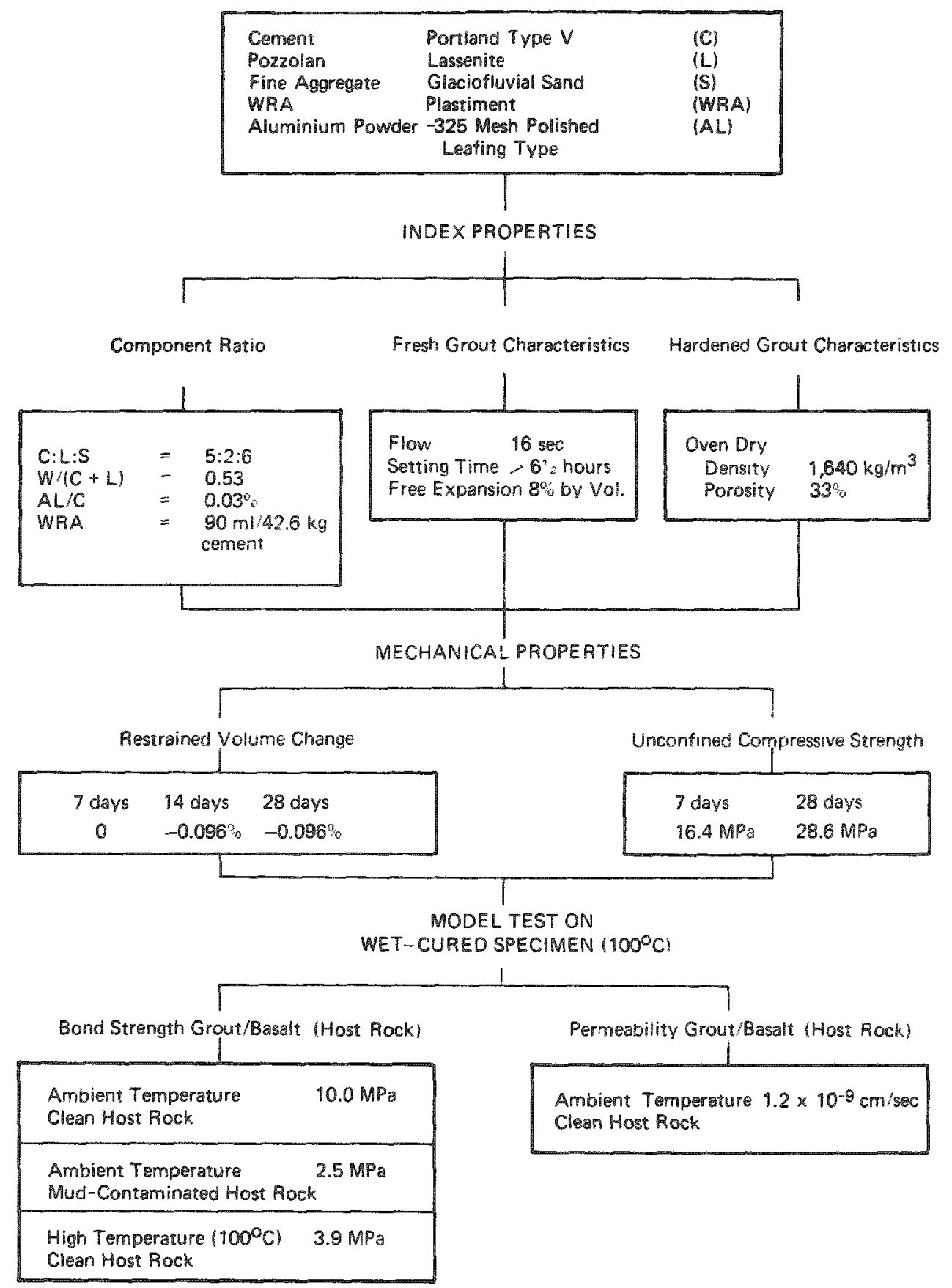

FIGURE 3-16. Summary of Grout Performance: Expansive Grout for Relatively Low Temperature Locations ( $T \leq 500 \mathrm{C}$ ). 
RHO-BWI-ST-7

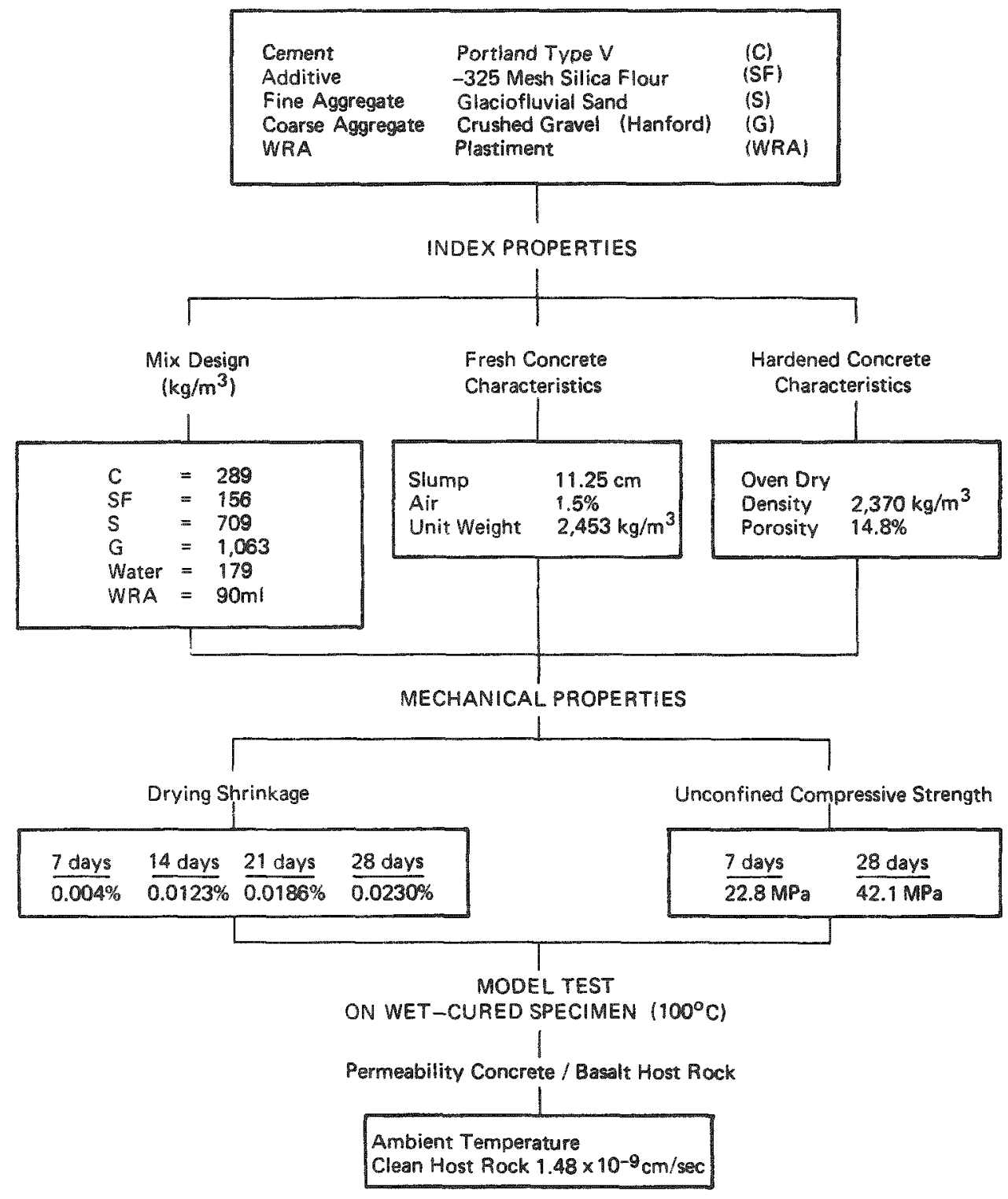

FIGURE 3-17. Summary of Concrete Performance for High Temperature Locations ( $T \geq 1000 \mathrm{C}$ ). 


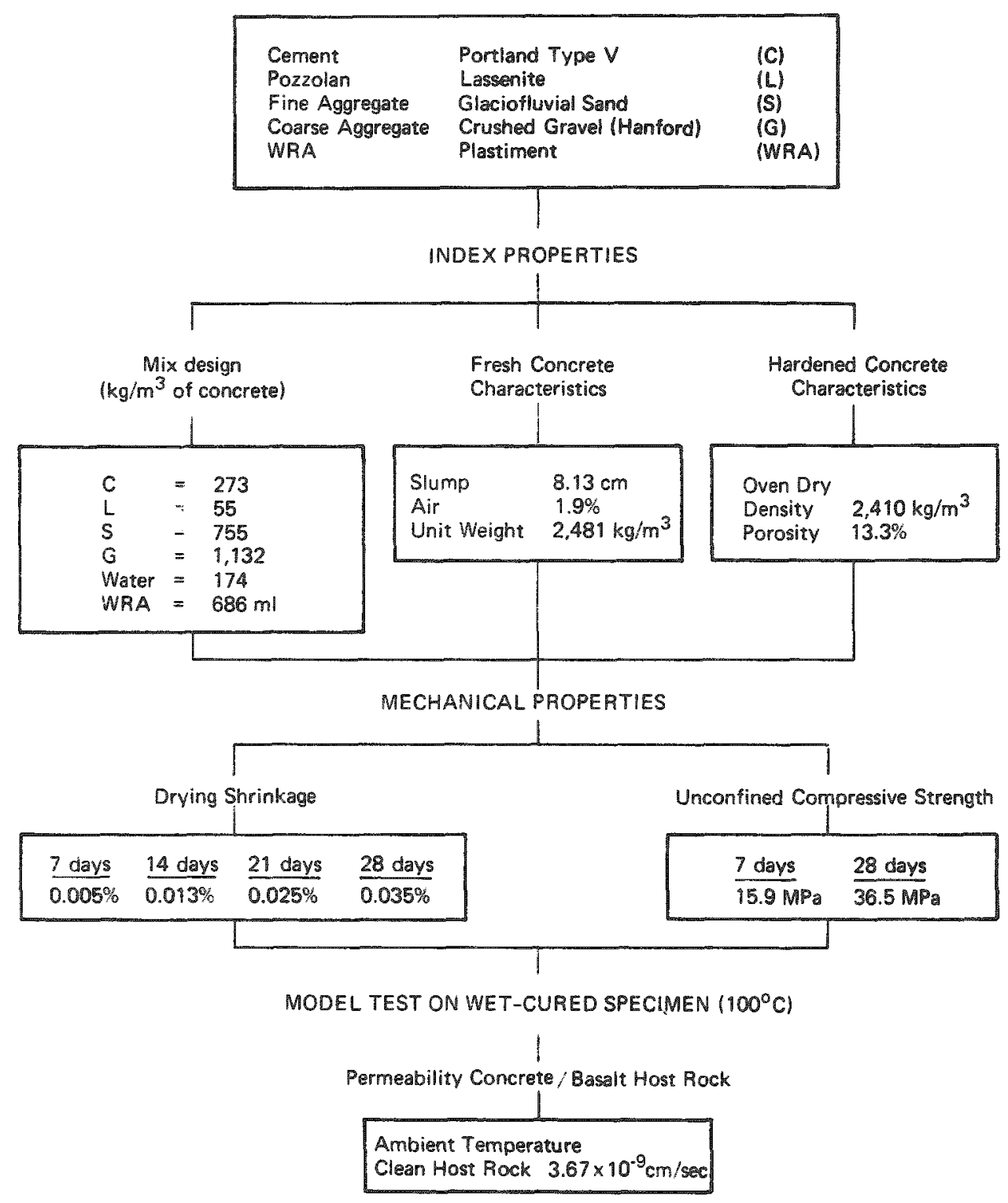

FIGURE 3-18. Summary of Concrete Performance for Moderate Temperature Locations $(T \leq 1000 \mathrm{C})$. 


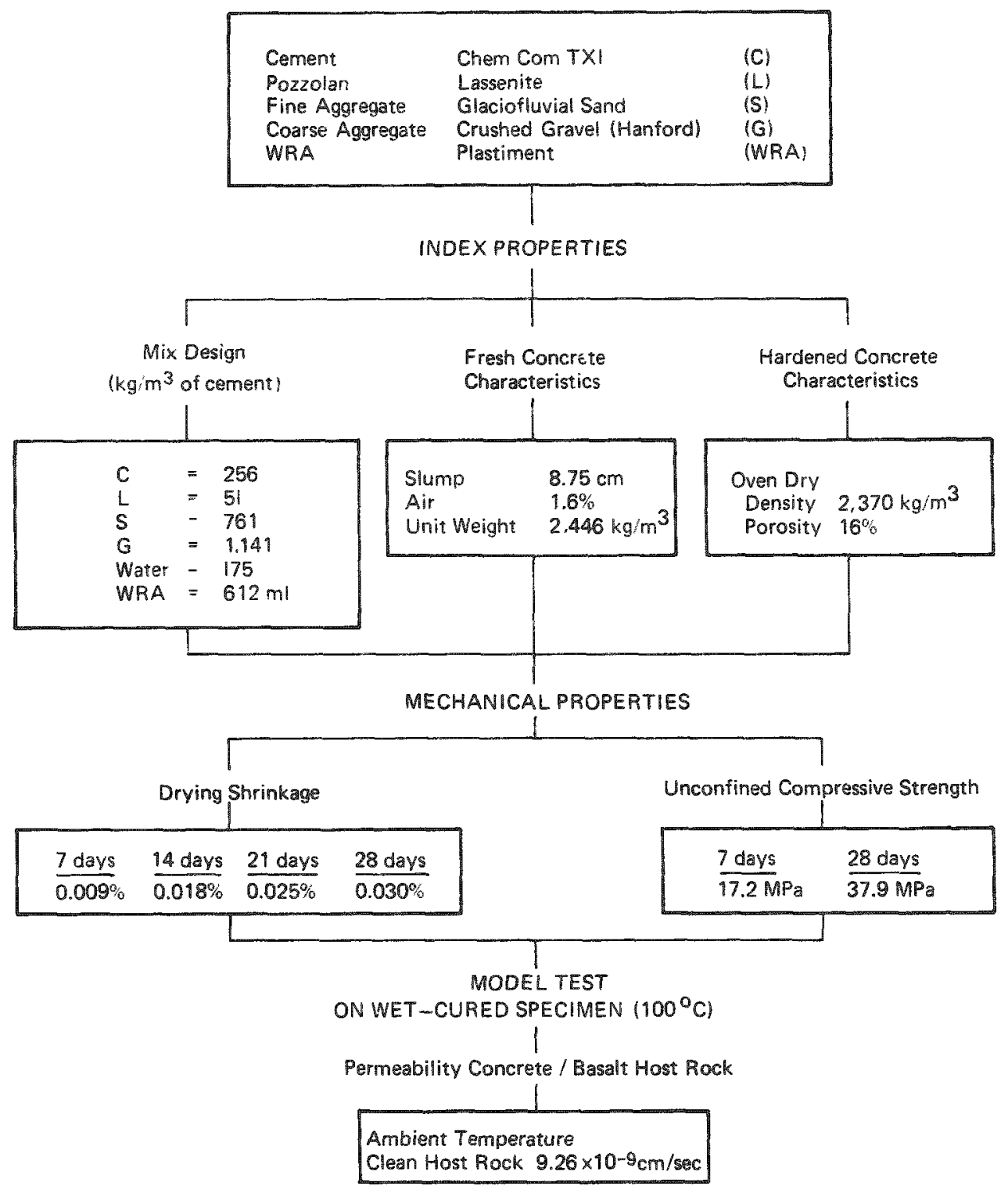

FIGURE 3-19. Summary of Concrete Performance Expansive Concrete for Low Temperature Locations $(T \leq 50 \circ \mathrm{C})$. 
significant difference in porosity was observed (42.3\% for G-TXI-L and $33 \%$ for $G-V-L)$. Data on water cement ratios indicated that porosity data were consistent. Thus, oven-dry densities may be misleading. An explanation may be the difference in specific gravity between Chem Com TXI and portland cement Type $V$. The high value of oven-dry density for the grout composed of portland cement Type $V$ plus silica flour $(G-V-S)$ is due to the high specific gravity of the silica flour $\left(2.65 \mathrm{~g} / \mathrm{cm}^{3}\right)$ when compared with the specific gravity of Lassenite $\left(2.43 \mathrm{~g} / \mathrm{cm}^{3}\right)$.

The restrained volume change of G-TXI-L grout did not meet the non-shrink grout requirements specified in the Corps of Engineers "Handbook for Concrete and Cement" CRD C-588 (U.S. Army Corps of Engineers, 1978), because a slight shrinkage (0.05\%) was observed after 28 days of wet curing. This shrinkage cannot be explained by the addition of Lassenite because the presence of a pozzolan in a cement mixture generally decreases the shrinkage. Further testing is needed to refute or confirm this result. The 28-day restrained shrinkage result for $G-V-L$ was found to be twice that for the G-TXI-L. Nonetheless, it is considerably lower than that reported earlier for portland cement Type $V$ mortar without an additive, even though a higher water/cement ratio was used. It may be possible to obtain a non-shrink grout by adding a slightly greater amount of aluminum powder and/or Plastiment and/or Lassenite in the G-V-L mix. No shrinkage was observed for G-V-S grout, indicating that the addition of finely ground aluminum powder tends to reduce the shrinkage behavior of cement mixtures.

Compressive strength measurements at 28 days of grout cylinders under standard curing and testing temperatures were found to be $39.2 \mathrm{MPa}$ for G-TXI-L, 28.6 MPa for $G-V-L$, and $24.8 \mathrm{MPa}$ for $G-V-S$. These values are within the design range needed by plugs to restrain the expected lithostatic and thermomechanical loading forces at plug-seat depths.

Grout plug/basalt (host rock) bond strengths measured at standard temperature are significantiy higher for G-TXI-L (10.8 MPa) and G-V-L $(10.0 \mathrm{MPa})$ than for G-V-S $(4.3 \mathrm{MPa})$. The high values and the similarity in bond strengths for $G-V-L$ and $G-T X I-L$ are promising and tend to confirm the proportion studies conducted during screening tests. 
Significantly lower bond strengths were obtained for models with mud-contaminated drill hole walls, which suggests that in actual practice, boreholes should be flushed before plugging.

Comparisons of bond strengths obtained at standard temperature with bond strengths obtained at high temperature $\left(100^{\circ} \mathrm{C}\right)$ indicate an increase in bond strength with increasing temperature. Percentage deterioration of bond strength is $19 \%$ for $G-V-S, 61 \%$ for $G-V-L$, and $88 \%$ for G-TXI-L. Once again, the addition of silica flour greatly improved the high-temperature performance of the cement mixtures. Note that these bond strengths take into account shrinkage of grout plugs caused by 48-hour oven curing prior to testing.

Model plugs composed of portland cement Type $V$ have a reported permeability of less than $10^{-8} \mathrm{~cm} / \mathrm{sec}$, which is surprisingly low considering the relatively high porosity of these mixtures. The model plug composed of Chem Com TXI cement is somewhat more permeable $(3.5 \times$ $10^{-8} \mathrm{~cm} / \mathrm{sec}$ ). It should be remembered that each model plug was subjected to a 72-hour curing period in an autoclave at $100 \mathrm{C}$ prior to testing. This procedure was chosen to accelerate the curing of the grout mixtures in order to meet project time constraints. As mentioned earlier, cement mixtures containing Chem Com TXI cement exhibited a deterioration in structural strength when cured at an elevated temperature. Consequently, lower permeability may be expected for mixtures cured at ambient temperature.

The mixture containing portland cement Type $V$ plus silica flour $(C-V-S)$ had a slightly higher slump $(11.43 \mathrm{~cm})$ than the other concrete mixtures. This should be considered when comparing performance results of the various concrete mixtures. Thus, for a lower slump, C-V-S may have a higher density and strength and lower permeability.

Once again concrete mixtures containing Chem Com TXI cement plus Lassenite (C-TXI-L) had a higher porosity. Porosity and density data for the three concrete mixtures seemed consistent and were characteristic of relatively dense concretes. 
As in the case of the grout, the concrete mixture containing Chem Com TXI cement does not exhibit the expected expansive behavior but shows a slight shrinkage $(0.03 \%)$ after the standard 28 -day dry curing. In fact, no significant difference in volume change was observed between the three concrete mixtures. As in the case of the grout, C-V-S exhibited the lowest shrinkage, while the concrete mixture containing portland cement Type $V$ plus Lassenite $(C-V-L)$ had the highest.

The "28-day" compressive strength measurements for concrete cylinders were $42.1 \mathrm{MPa}$ for $C-V-S, 37.9 \mathrm{MPa}$ for $C-T X I-L$, and $36.5 \mathrm{MPa}$ for $C-V-L$. Concretes containing silica flour appear to have the greatest structural strength, even when cured under standard temperatures.

The results of permeability tests on concrete plug/basalt host rock models confirm the results obtained on model grout plugs. C-TXI-L is slightly more permeable $\left(9.26 \times 10^{-9} \mathrm{~cm} / \mathrm{sec}\right)$ than $C-V-L\left(3.7 \times 10^{-9}\right.$ $\mathrm{cm} / \mathrm{sec}$ and $\mathrm{C}-\mathrm{V}-\mathrm{S}\left(1.5 \times 10^{-9} \mathrm{~cm} / \mathrm{sec}\right)$. The permeability obtained for $C-V-S$ is on the order of the permeability of the basalt core container. This result suggests that it will be possible to design a concrete plug with the similar hydraulic characteristics to those reported for basalt flows at the Hanford Site.

3.6.2.2 Compacted Earth Materials. The feasibitity of using compacted earth materials to plug boreholes has been previously examined by Martin (1975) for shale and montmorillonite/quartz sand mixtures. Buffer materials composed of quartz sand and bentonite and highly compressed bentonite blocks have been proposed by workers in Sweden (KBS, 1979) to seal canister storage holes. In addition to blocking radioactive waste migration in groundwater, compacted sandy clay mixtures are expected to provide ion exchange and sorption capabilities to help retard the migration of radionuclides through the plug system in yet two other ways.

In preliminary physical testing, emphasis was placed on materials readily available in the proximity of the Hanford Site. Compacted earth materials used in plugs should combine low permeability with low compressibility, have a high shear strength, and form a good bond with surrounding rocks. In a sand/clay mixture, impermeability is provided by 
the clay fraction while low compressibility and a high shear strength are obtained by increasing the sand fraction. However, the addition of t.00 much sand will impair the impermeability of the mixture. Preliminary screening tests were designed to evaluate the values and the sensitivity of selected mechanical properties (permeability and strength) to various sand/clay ratios in order to select optimum mixtures for later testing of hydraulic properties.

Compacted earth materials evaluated during the screening test and the sources for these materials are listed in Table 3-17. Samples for testing included mixtures of clays and glaciofluvial sand (in order to examine the properties of different clay/sand ratios) and skip-graded, coarse-crushed basalt in clay/sand mixtures (to ascertain the effect of a coarse aggregate on mixtures of fine-grained materials).

Screening tests for compacted natural materials included: (1) grain size analysis, specific gravity, and relative density of non-cohesive granular materials; (2) grain size analysis, specific gravity, Atterberg limits on clays; (3) moisture/density relationships in mixtures after impact compaction; (4) swelling pressure under conditions of zero volume change on mixtures compacted at maximum dry density and at the optimum water content; and (5) determination of stress-strain relationships under unconfined compression for candidate mixtures compacted to the maximum dry density at the optimum water context.

The procedures used in testing compacted earth materials included both standard published procedures given in Table 3-18. Special test methods used in this study that have no published reference are described in more detail here.

Minimum density is first determined on an oven-dried sample by pouring the sample into a cylindrical mold $(7 \mathrm{~cm}$ in diameter by $12.7 \mathrm{~cm}$ high) through a $2.5-\mathrm{cm}$ diameter pouring spout of a funnel. The sample is poured into the mold using a spiral motion from the outside toward the center until the mold is filled to overflowing capacity. The excess material is then struck off and the weight of the material is recorded. This procedure is repeated a minimum of three times, and an average minimum density value is calculated. 
TABLE 3-17. Natural Materials Used in Screening

Tests on Compacted Earth Materials.

\begin{tabular}{|c|c|}
\hline $\begin{array}{c}\text { Materials } \\
\text { Seven Candidate Clayey Soils }\end{array}$ & $\begin{array}{c}\text { Source } \\
\text { Pasco Basin }\end{array}$ \\
\hline Oregon bentonite ( -200 mesh) & Teaque Mineral Industries \\
\hline Oregon bentonite $(-20$ to +160 mesh $)$ & Teaque Mineral Industries \\
\hline Wyoming bentonite & Baroid National Brand \\
\hline Glaciofluvial sand & Hanford Site \\
\hline $\begin{array}{l}\text { Fine-crushed zeolite } \\
\qquad(-2.6 \mathrm{~mm})\end{array}$ & Teaque Mineral Industries \\
\hline $\begin{array}{l}\text { Fine-crushed basalt } \\
(-4.6 \mathrm{~mm})\end{array}$ & Hanford Site \\
\hline $\begin{array}{l}\text { Coarse-crushed basalt } \\
(-1.9 \mathrm{~cm})\end{array}$ & Hanford Site \\
\hline
\end{tabular}

The same volume mold is used to determine the maximum density. A porous stone is placed on the bottom of the mold, and the mold is filled with water to one-third of its capacity. The oven-dried soil is then added to fill the mold to within $3.8 \mathrm{~cm}$ of the top. A porous stone is placed on the upper end of the sample, and a spring is placed on the porous stone so that when the mold cap is bolted in place, there is a surcharge equivalent to $141 \mathrm{~g} / \mathrm{cm}^{2}$. A vacuum of about $0.1 \mathrm{MPa}$ is then applied to the lower end of the mold, and the upper end is open to the atmosphere. The mold is then vibrated at a frequency of approximately 30 impact vibrations per minute, and the energy expended is approximately 2

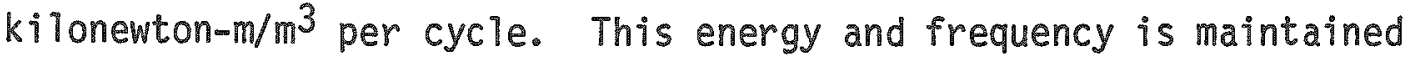
until all excess water is removed from the mold and no further reduction in height can be observed. The height and weight of the sample are recorded, and the maximum dry density is calculated after the sample is oven dried.

A method was designed to standardize the compaction process to be used on sand/clay and sand/clay/coarse aggregate mixtures throughout the testing program. This method is sensitive to a maximum particle diameter 
TABLE 3-18. Testing Procedures Applied to Compacted Earth Materials.

\begin{tabular}{|c|c|}
\hline ASTM $D-422^{a}$ & Particle size analysis of soils \\
\hline ASTM C-128b & $\begin{array}{l}\text { Specific gravity and absorption of } \\
\text { fine aggregate }\end{array}$ \\
\hline $\begin{array}{l}\text { Special test } \\
\text { method (see test) }\end{array}$ & $\begin{array}{l}\text { Maximum/minimum density of non- } \\
\text { cohesive granular material }\end{array}$ \\
\hline ASTM D-854a & Specific gravity of soils \\
\hline ASTM D-423a & Liquid limit of soils \\
\hline ASTM D-424a & Plastic limit of soils \\
\hline ASTM D-427a & Shrinkage factors of soils \\
\hline $\begin{array}{l}\text { Special test } \\
\text { method (see text) }\end{array}$ & $\begin{array}{l}\text { Moisture/density relation of } \\
\text { soil using a } 4.5-\mathrm{kg} \text { rammer and a } \\
45-\mathrm{cm} \text { drop (tested in a } 6.25-\mathrm{cm} \\
\text { diameter mold) }\end{array}$ \\
\hline $\begin{array}{l}\text { Test method suggested by } \\
\text { the International Society } \\
\text { for Rock Mechanics }\end{array}$ & $\begin{array}{l}\text { Determination of the swelling } \\
\text { pressure under conditions of } \\
\text { zero volume change }\end{array}$ \\
\hline ASTM D-2166a & $\begin{array}{l}\text { Unconfined compressive strength of } \\
\text { cohesive soils }\end{array}$ \\
\hline
\end{tabular}

aASTM (1978).

bASTM (1977). 
in a sample when testing the strength and the swelling of soil samples with standard laboratory soil testing equipment. During compaction, densification is achieved by impacting the 5 -cm diameter tamper foot of a standard $4.5-\mathrm{kg}$ rammer concentrically into a mold with a diameter of $6.35 \mathrm{~cm}$. Impact, height, and the number of lifts compacted in each sample are the same as for ASTM D-1557 standard procedure (ASTM, 1978). The only difference between the two procedures is the size of the mold, which is $10.16 \mathrm{~cm}$ in diameter in ASTM D-1557. Comparative tests were carried out on a pure clay specimen and on a $-1.9-\mathrm{cm}$ coarse-crushed basalt/sand/clay mixture using both compaction methods. No significant difference was observed for the optimum water content. A greater densification is obtained in the 6.35 -cm-diameter mold for both mixtures, and the difference in maximum dry density between the two compactive methods is greater for 1 arger, maximum aggregate size, indicating that good, standardized campaction can be obtained on coarse aggregate mixtures.

Tests were performed to determine the index properties of four candidate clays: two Oregon bentonites; one Wyoming bentonite; and the Ringold clay $D$. Results are presented in Figure 3-20a. Relationships between liquid limit and plasticity index (Fig. 3-20b) and values of activity (Fig. 3-20c) are given for various clay minerals. In the following discussion, clay activity, as defined by Skempton (1953), is the ratio of the plasticity index to the amount of the clay fraction (defined as the percentage dry weight of the $-2-m m$ fraction of the sample). Wyoming bentonite has a high plasticity index and a very high activity. The two oregon bentonites exhibit significantly lower values for these properties. As shown on Figure 3-20b, the candidate Wyoming bentonite has the characteristics of a sodium montmorilionite, while the two Oregon bentonites are similar to a calcium montmorillonite. Results from geochemical testing also indicate that oregon bentonite contains more calcium than Wyoming bentonite. This distinction is important because the sodium form of montmorillonite exhibits considerably less permeability than the calcium form. Results given by Grim (1962) show that when $50 \%$ sodium bentonite is present in a quartz sand, the resuiting 
(a) Index properties of candidate clays

\begin{tabular}{|l|c|c|c|c|c|c|c|c|}
\hline Clay Description & $\begin{array}{c}\text { Liquid } \\
\text { Limit } \\
(\mathrm{LL})\end{array}$ & $\begin{array}{c}\text { Plastic } \\
\text { Limit } \\
\text { (LP) }\end{array}$ & $\begin{array}{c}\text { Plastic } \\
\text { Index } \\
(\mathrm{Ip})\end{array}$ & $\begin{array}{c}\text { Shrinkage } \\
\text { Limit } \\
(\%)\end{array}$ & $\begin{array}{c}\% \text { of soll } \\
\text { finer than } \\
-74 \mu m\end{array}$ & $\begin{array}{c}\% \text { of soil } \\
\text { finer than } \\
2 \mu \mathrm{m}\end{array}$ & $\begin{array}{c}\text { Activity } \\
\text { Ip } \\
(\%<2 \mu)\end{array}$ & $\begin{array}{c}\text { Specific } \\
\text { Gravity } \\
\left(\mathrm{g} / \mathrm{cm}^{3}\right)\end{array}$ \\
\hline Wroming bentonite & 5531 & 336 & 5195 & $0 ?$ & 9803 & $\leq 98$ & $\geq 53$ & 277 \\
\hline $\begin{array}{l}\text { Oregon bentorite } \\
-200 \text { mesh }\end{array}$ & 21269 & 381 & 1746 & 896 & 9921 & $\leq 99$ & $\geq 176$ & 285 \\
\hline $\begin{array}{l}\text { Oregon bentonite } \\
\text { 20 to 160 mesh }\end{array}$ & 2096 & 410 & 16858 & 847 & 9813 & $\leq 98$ & $\geq 172$ & 273 \\
\hline Ringold clay D & 639 & 231 & 408 & 1975 & 9458 & 26 & 157 & 271 \\
\hline Ringold clay C & 446 & 258 & 188 & - & - & - & - & - \\
\hline
\end{tabular}

(b) Liquid limit versus plasticity index from various clay minerals (from Grum, 1962)

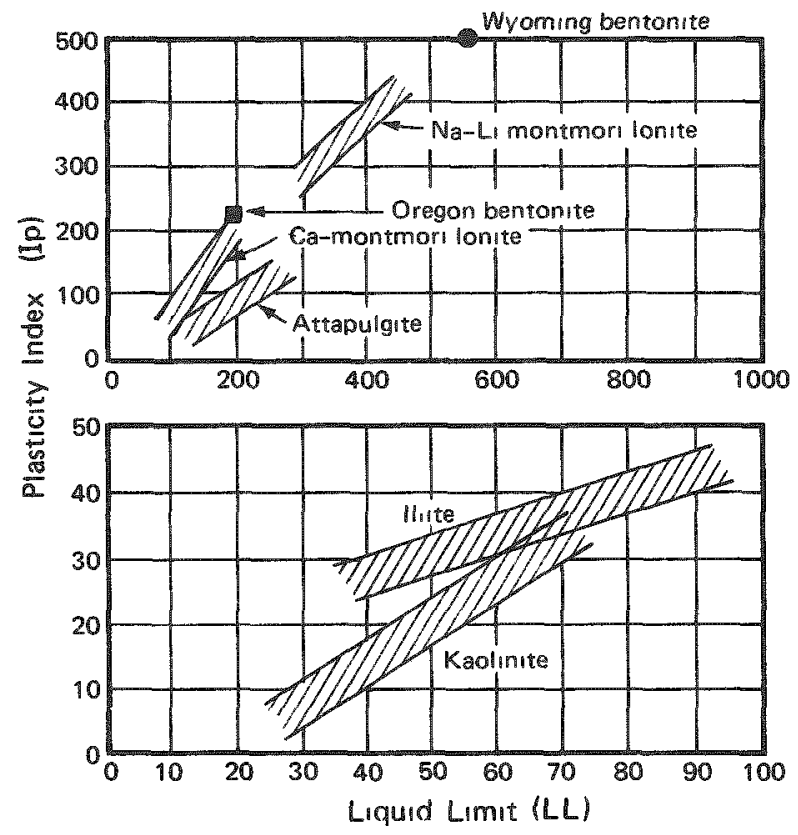

(c) Activity of clay minerals (from Kezdi, 1974)

\begin{tabular}{|l|c|}
\hline TYPE OF MINERAL & $\begin{array}{c}\text { ACTIVITY } \\
\text { Ip/Clay Content }\end{array}$ \\
\hline Quartz & $0-$ \\
Calcite & 0.18 \\
Muscovite & 0.23 \\
Kaolinite & 0.46 \\
IIlite & 0.90 \\
Ca-montmorillonite & 1.5 \\
Na-montmorillonite & 7.5 \\
\hline
\end{tabular}

FIGURE 3-20. Index Properties of Various Clay Minerals. 
clayey mixture is essentially impervious, while for the same proportions, mixtures made with calcium bentonite have a permeability coefficient of $5 \times 10^{-7} \mathrm{~cm} / \mathrm{sec}$. Although analytical data are not available, Ringold clay $D$ is also thought to be primarily composed of smectite clay, which exhibits an activity between 1 and 7 (Mitche11, 1976). However, the high percentage of silt present in this soil material and its high shrinkage factor could affect the bond strengths of candidate plug mixtures containing this materiat.

Compaction, unconfined compression, and swelling tests were carried out on candidate cohesive mixtures for various clay/sand sample ratios using glaciofluvial sand as aggregate and Wyoming bentonite, Oregon bentonite, or Ringold clay $D$ as binding materials. These tests were designed to evaluate the variation in mechanical properties with the amount of clay (versus sand) present in the mixture. Figure 3-21 gives the compaction curves for 12 candidate clay mixtures composed of the various clays and glaciofluvial sand, with the proportion of sand ranging from 10 to $70 \%$ by weight when mixed with the bentonites and from 10 to $50 \%$ when mixed with Ringold clay. The Oregon and Wyoming bentonite/sand mixtures have similar swelling response, as shown in Figure 3-22. The swell pressure at constant volume is negligible for clay contents less than or equal to $10 \%$. For clay contents ranging from 10 to $70 \%$, an almost exponential increase of swell pressure is observed with increasing clay content. For clay content of $70 \%$, swe 17 pressures as high as $2 \mathrm{MPa}$ were developed. For bentonite content more than or equal to $50 \%$, the swell pressure developed by a confined specimen was such that it was found difficult to constrain it perfectly; a small amount of expansion occurred during the night which had to be corrected the next morning by increasing the loading pressure. As noted by Martin (1975), a small expansion during the test can have a large influence on the measured value of the swell pressure. Therefore, the measured swell pressures should be considered as minimum and approximate. Swelling pressure of Ringold clay/sand mixtures was not studied except for a clay content equal to $10 \%$ where no swelling was observed. However, a lower swelling pressure is expected for Ringold clay (versus bentonites) considering the high silt content of Ringold clay. 


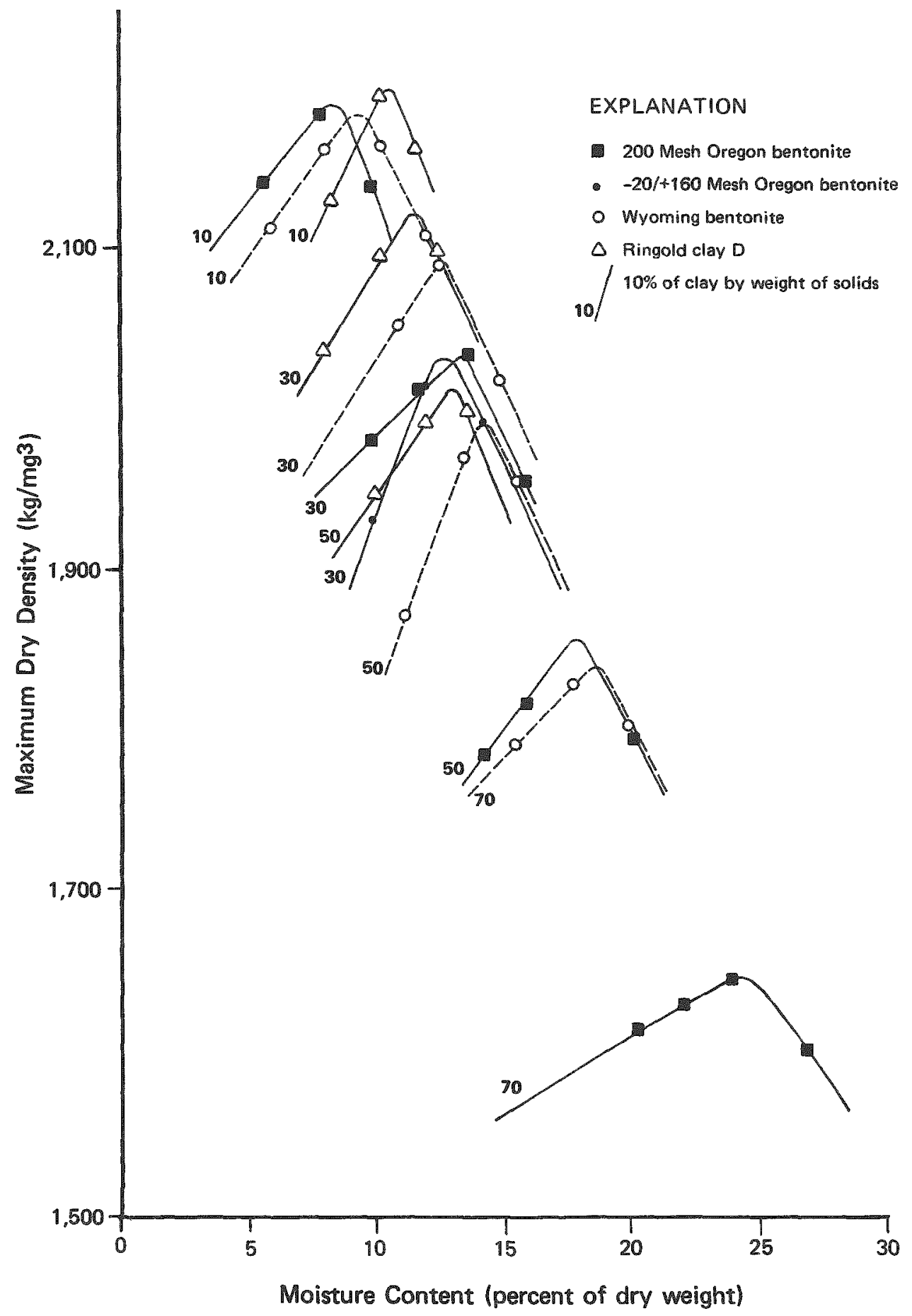

FIGURE 3-21. Compaction Curves for Candidate Clay/Sand Mixtures. 
Unconfined compressive tests, including the determination of stress-strain relationships and maximum compressive strengths, were performed on the 10 candidate mixtures compacted at maximum dry density and optimum water content. These tests were designed to evaluate the strength behavior of clay/sand mixtures. In general, high strength and stiffness would be desirable in compacted soil mixtures used in plug designs because the plug material should provide restraint to the surrounding wall rock, which may be under lithostatic and thermomechanical loads. The behavior of this material should be as elastic as possible to maintain the best possible contact with the wall rock.

Curves showing the variation in unconfined compressive strength and the variation in Young's modulus with varying clay content are presented in Figures 3-23 and 3-24. Young's modulus is taken as the tangent to the stress-strain curve as $1 \%$ strain. A notable result was the observed difference in behavior between bentonite/sand mixtures and Ringold clay/sand mixtures. For a clay content of $10 \%$, the bentonite mixtures developed strengths 10 times higher and a Young's modulus 8 times greater than Ringold clay/sand mixtures. This result shows the exceptionally high strength of bentonite clays. As expected, mixtures containing Oregon bentonite developed higher strength and have greater stiffness than those containing Wyoming bentonite. Data published by Grim (1962) indicate that the calcium form of montmorillonite gives the highest strength of a11 clays when mixed with sand. For clay contents varying from 10 to $50 \%$, strength and stiffness increased with increasing clay content. For $\mathrm{clay}$ contents varying from 50 to $70 \%$, a slight decrease was observed for both parameters with increasing clay content. Maximum values of strength and Young's modulus were observed for a clay content of 50\%. Compressive strength and Young's modulus are exceptionally high, and and unconfined compressive strength of $2.9 \mathrm{MPa}$ with a Young's modulus of $80 \mathrm{MPa}$ were observed for one Oregon bentonite/sand mixture.

Skip-graded, coarse-crushed basalt/sand/clay mixtures with potential use in backfill were designed and tested. Materials in these mixtures 


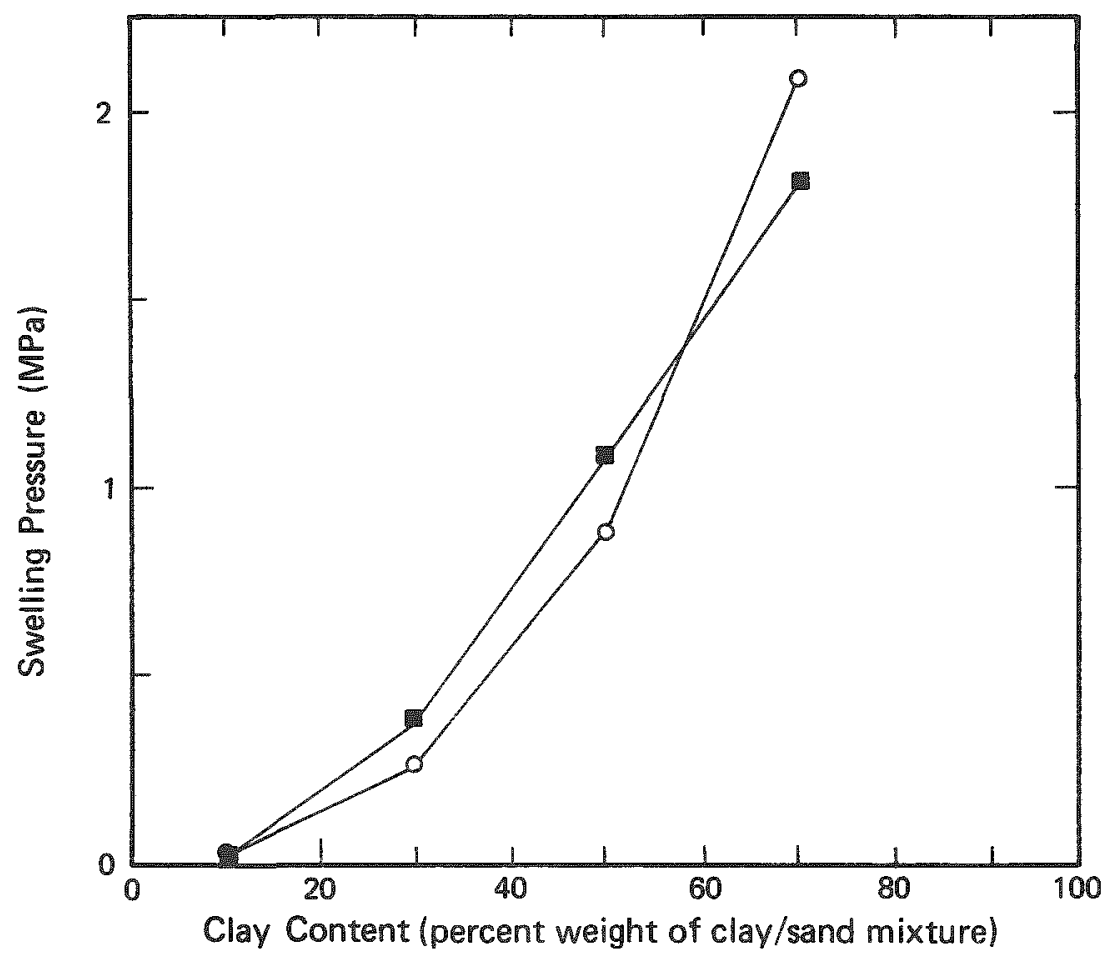

EXPLANATION

- Wyoming bentonite

Oregon bentonite

FIGURE 3-22. Swelling Pressure of Bentonite/Sand Mixtures.

were composed of $-1.9 \mathrm{~cm}$ coarse-crushed basalt, glaciofluvial sand, and various clays. A clay/sand ratio of $50 \%$ was chosen to provide an essentially impervious and self-healing binder. The following three mixtures were tested; the proportions of the various components are given as weight percents in parentheses:

- Coarse-crushed basait (68\%)/Oregon bentonite (16\%)/glaciofluvial sand $(16 \%)$. In this mixture, the coarse aggregate/sand/clay ratio was selected so that the bentonite/sand mixture filled the void spaces within the aggregate when compacted at its maximum density. This sample simulated a grain-support framework and was intended to combine relatively low permeability with low compressibility. 


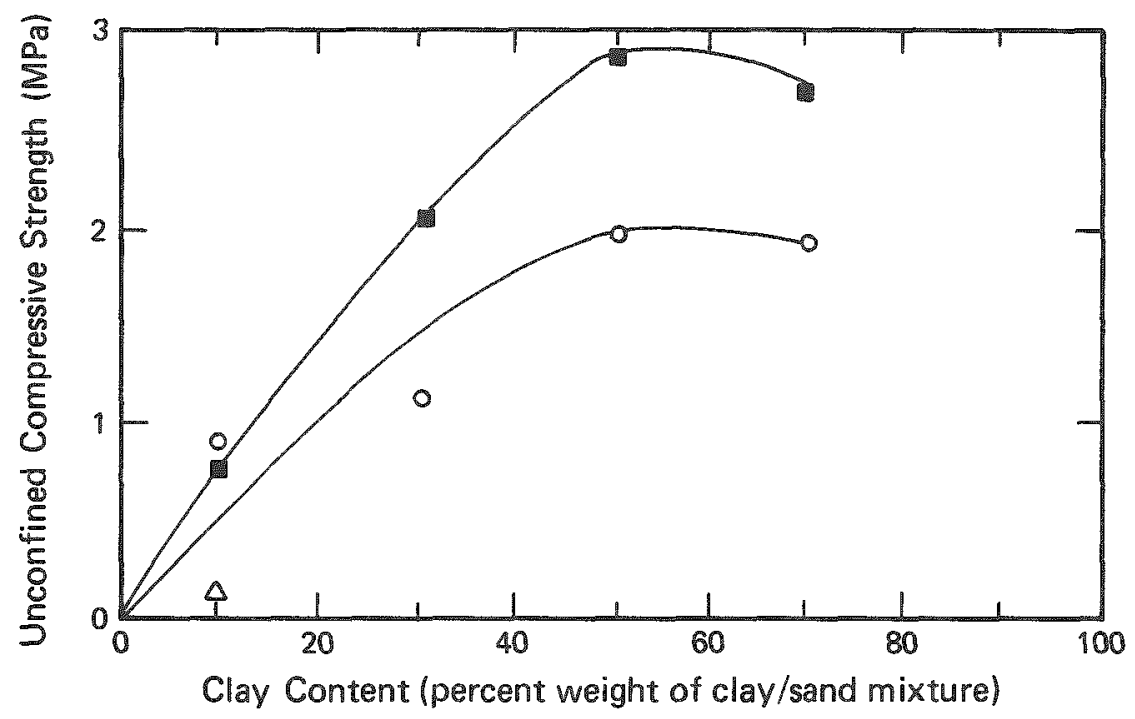

EXPLANATION

- Wyoming bentonite

Oregon bentonite

$\triangle$ Ringold clay D

FIGURE 3-23. Unconfined Compressive Strength of Clay/Sand Mixtures.

- Coarse-crushed basalt (66\%)/crushed zeolite (17\%)/Ringold clay (17\%). In this mixture, crushed zeolite and Ringold clay were substituted for glaciofluvial sand and Oregon bentonite, respectively. The purpose of this substitution was to examine the possibility of using a clay available near the Hanford Site in combination with a material having a very high ion exchange potential. This mixture is intended for use in backfill designed to retard radionuclide migration and, at the same time, provide some structural strength.

- Coarse-crushed basalt (50\%)/glaciofluvial sand (25\%)/Wyoming bentonite (25\%). In this mixture, the coarse aggregatel sand/clay ratio was designed with a high percentage of clay in order to simulate a matrix support fabric (with clay as the matrix). This mixture is designed primarily to be an almost impervious backfill that has substantial self-healing potential. 


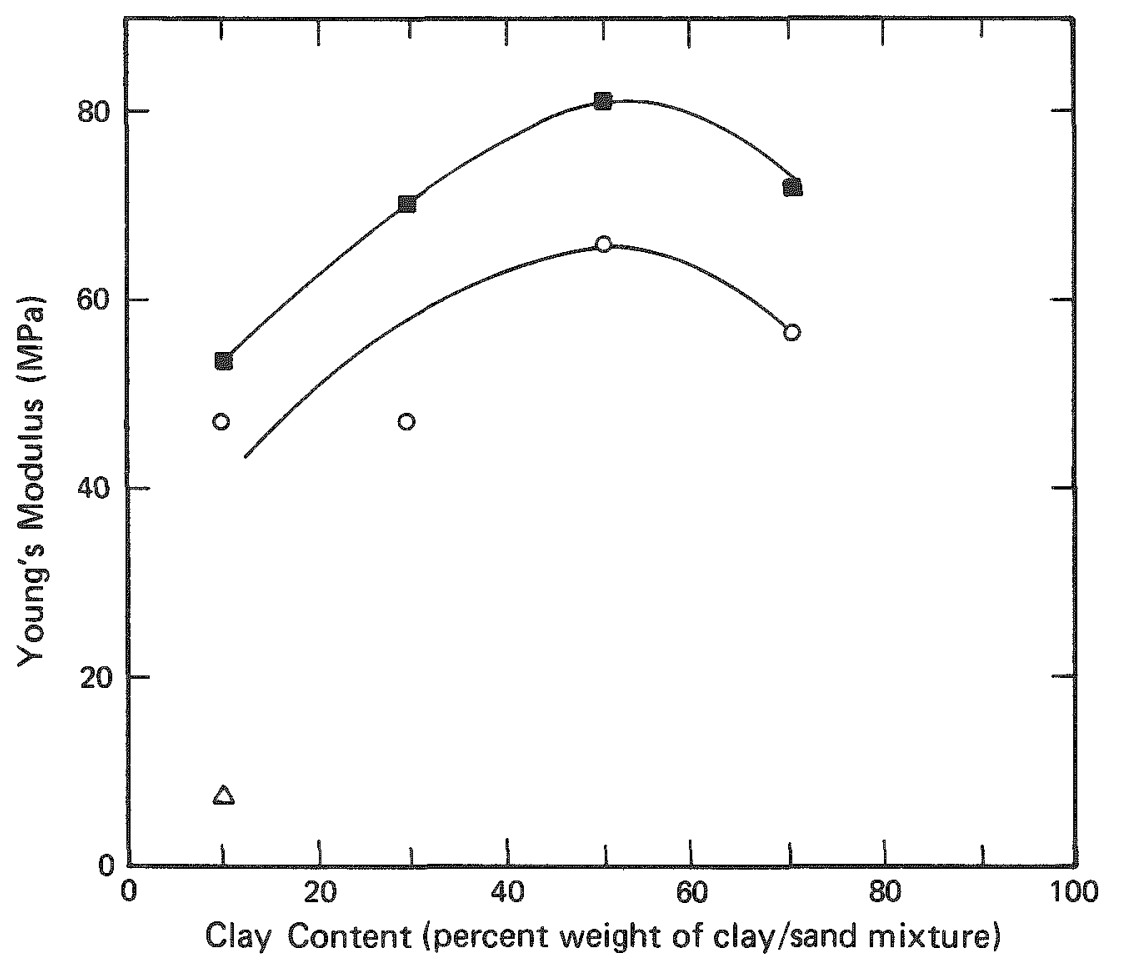

EXPLANATION

- Wyoming bentonite

Oregon bentonite

$\triangle$ Ringold clay D

FIGURE 3-24. Young's Modulus of Clay/Sand Mixtures.

The most effective compaction and maximum unconfined compressive strength results were obtained for the Wyoming bentonite/glaciofluvial sand/coarse-crushed basalt mixture. A maximum dry density of 2,266 $\mathrm{kg} / \mathrm{m}^{3}$ (at an optimum water content of $9.3 \%$ ) and an unconfined compressive strength of $1.45 \mathrm{MPa}$ were measured for this sample. A somewhat lower maximum dry density $\left(2,195 \mathrm{~kg} / \mathrm{m}^{3}\right)$ and an unconfined compressive strength (half that of the first mixture) were measured for the mixture 
of Oregon bentonite, glaciofluvial sand, and coarse-crushed basalt. As expected, an even lower density was obtained for the Ringold clay/ zeolite/coarse-crushed basalt mixture $\left(2,066 \mathrm{~kg} / \mathrm{m}^{3}\right)$ principally because of the high porosity and low specific gravity of the crushed zeolite. However, this density is still with a range judged representative of multiple-purpose engineered fills. Moreover, the unconfined compressive strength developed by this last mixture was appreciable.

A comparison of clay activity values showed that Wyoming bentonite has characteristics close to a sodium montmorillonite while Oregon bentonite has characteristics close to a calcium montmorillonite. Consequent7y, Wyoming bentonite mixtures are expected to have higher compressibility, lower shear strength, and lower permeability. Index tests performed on candidate non-cohesive granular materials indicated that glaciofluvial sand and crushed basalt are the most desirable aggregates for use in skip-graded aggregate/clay mixtures. Both offer acceptable grain-size distrubution and structural strength. In contrast, crushed zeolite appears to be a weak aggregate, but would be acceptable for use in backfill where an increase in ion exchange potential and sorption capacity are considered desirable. Relatively good densities were achieved by impact compaction of bentonite/sand mixtures for clay contents lower than or equal to $50 \%$ in the case of Wyoming bentonite and $30 \%$ in the case of Oregon bentonite. Unconfined compressive strength on clay/sand samples indicated that bentonite/sand mixtures had considerably higher strength than Ringold clay/sand mixtures. Swelling pressures of compacted bentonite/sand mixtures at constant volume were negligible for a clay content of $10 \%$, but swell pressures increased exponentially to values reaching $2 \mathrm{MPa}$ when the clay content increased to $70 \%$. If fractured, swelling pressure behavior may provide compacted plug materials with cohesive, self-healing properties. Results of compaction and compression tests on skip-graded aggregate/clay mixtures show best density and strength for mixtures containing 25\% Wyoming bentonite, $25 \%$ glaciofluvial sand, and $50 \%-1.9 \mathrm{~cm}$, coarse-crushed basalt. Density in the range of multiple-purpose engineered fills and appreciable strength were also obtained for mixtures composed of Ringold clay, crushed 
zeolite, and crushed basalt; however, significantly lower values were obtained for these properties in mixtures containing Ringold clay and crushed zeolite.

Except for the elimination of six fine-grained sediments from the Pasco Basin, no further screening was attempted in the first phase of physical testing. Some of the materials and mixtures that survived the screening tests may be more or less suitable than others as potential plug components. However, no definitive arguments were found to justify not testing those mixtures remaining after the screening tests on compacted earth materials. Peformance tests included model tests of the bond strength and permeability of miniature compacted soil plug and consolidation tests on compacted sandy clay mixtures. Consolidation tests were made using ASTM D-2435 method "One-Dimensional Consolidation of Soil Materials" (ASTM, 1978). Bond strength tests were carried out using the same procedures as for bond strength determinations on concrete plug/basalt (host rock) models. Models of compacted earth plugs were constructed in a manner similar to that used for grout and cement models. Soil components were dry mixed and sufficient water was added to dampen the mixture to optimum water content. Soil placement was performed by compacting the soil materials in the $6.35-\mathrm{cm}$ diameter hole drilled into the basalt core in five equal layers (three layers for permeability tests); this placement would give a total length of compacted soil not exceeding $12.5 \mathrm{~cm}(7.62 \mathrm{~cm}$ for permeability tests), such that $95 \%$ of maximum dry density was achieved using the compacting method described above.

Special sample holders were designed for the permeability testing of the miniature soil plugs, which have a $15.24-\mathrm{cm}$ diameter base and cap plates. The cap plate has a recessed $7.62-\mathrm{cm}$ diameter 0 ring and a $6.35-\mathrm{cm}$ diameter porous stone through which channels ( $3 \mathrm{~mm}$ in diameter) are drilled and machined such that communication exists between the porous stones and hydraulic fittings screwed into the plate. The base plate and cap plate were placed on the bottom and top, respectively, of the dressed surface of the basalt (host rock) core containing the compacted soil materials. As in the case of cement plugs, permeability 
was determined using the falling head method. However, to avoid particle migration, only a $0.003 \mathrm{MPa}$ pressure differential was applied between the top and the bottom of the compacted plug, corresponding to an approximate hydrautic gradient of 4.

Only one permeability test was completed within the time limit of the initial physical testing program. A model plug composed of $10 \%$ oregon bentonite and $90 \%$ glaciofluvial sand was observed to have a permeability of $9.5 \times 10^{-8} \mathrm{~cm} / \mathrm{sec}$. This value is somewhat higher than that desired in laboratory testing of permeability, which should be near the permeability reported for incact basalt. Actual field placement of a similar plug in a borehole, shaft, or tunnel should result in a still nigher in situ permeability.

The four other permeability model tests were still not completely saturated by the end of this testing period. In the case of mortar or concrete plugs, saturation times varied between one and two weeks for permeabilities less than $10^{-8} \mathrm{~cm} / \mathrm{sec}$. Saturation times for soil plugs composed of $10 \%$ Oregon bentonite and $90 \%$ glaciofluvial sand were more than twice as long ( 4 weeks) for a sample with a permeability almost 10 times greater. This clearly shows the slowness of the hydration process in bentonite mixtures. For the mixture with $10 \%$ Wyoming bentonite and $90 \%$ glaciofluvial sand, 42 days were insufficient to obtain complete saturation of the model plug.

Accordingly, mixtures containing 50\% Wyoming bentonite may require more than 200 days to complete the saturation process. Note that the hydrautic gradient chosen for model tests is approximately 400 times greater than the assumed long-term vertical gradient and 4,000 times greater than the assumed long-term horizontal gradient in or near the repository. Thus, a 100-m-long plug of compacted Wyoming bentonite and sand (with a clay content of 50\%) submitted to the same hydraulic gradient used in laboratory model testing should require more than 1,000 years to achieve saturation. Futhermore, clay/sand mixtures with $50 \%$ Wyoming bentonite are expected to be essentially impervious as stated by Grim (1962), although no experimental data are available to confirm this. These observations confirm the relatively good performance of compacted clay/sand plugs as seepage barriers. 
Results of bond strength tests carried out at ambient temperature on soil plugs compacted in clean basalt (host rock) cores are given on Figure 3-25 for Wyoming bentonite, Oregon bentonite, and Ringold Unit D clay, each mixed with glaciofluvial sand. Clay content ranged from 10 to $70 \%$. Highest bond strengths were observed for oregon bentonite/sand mixtures for all clay contents, closely followed by bond strengths obtained for Wyoming bentonite/sand mixtures. Ringold Unit D clay/sand mixtures had significantly lower bond strengths, particularly for clay content less than $50 \%$. The shapes of curves plotted on the basis of experimental values for bond strength are similar for all three types of clay. The variation in curve shapes for clay content varying from 10 to $50 \%$ indicates a change in the physical nature of the bond between the compacted soil plug and the basalt (host rock). This change is interpreted as a transition from an essentially frictional to an essentially cohesive bond. Comparison of unconfined compressive strength values for clay/sand mixtures and variations is the residual friction angle of sodium-montmorilionite-quartz sand mixtures (Kenney, 1967) supports this hypothesis and indicates that the minimum bond strength value for clay/ sand mixtures should occur between 10 and $20 \%$ clay. Further testing is needed to precisely locate this minimum.

This hypothesis of a transition in bond nature from frictional to cohesive seems to be in agreement with the shapes of curves giving the change in bond strength with the percent of sliding deformation. Typical curves given in Figure $3-26$ for $10 \%$ clay content ratios of Wyoming bentonite and sand show a relatively slow differential increase in bond strength until the peak value is reached, which is followed by a slow decrease in strength (residual bond strength). These curves also show a greater differential increase in bond strength followed by a sharp loss of cohesion for clay content greater than 10\%. Note that for all clay percentages, significant residual bond strength was observed after the peak bond strength was achieved, indicating only a partial destruction of the bond under large sliding deformations. Other data not included in this report indicted that the bond strength is strongly dependent on 
RHO-BWI-ST-7

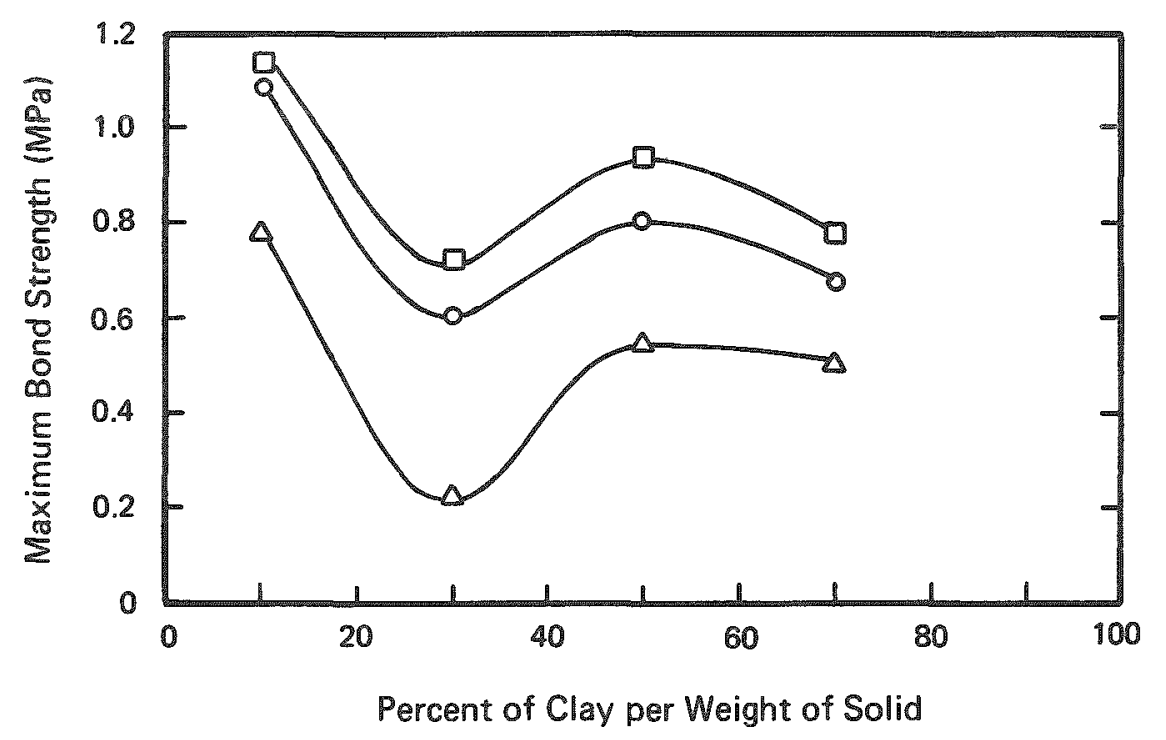

EXPLANATION

- Wyoming bentonite

$\square$ Oregon bentonite

$\triangle$ Ringold clay

FIGURE 3-25. Bond Strength of C Tay/Sand Mixtures at Ambient Temperatures.

percent compaction. Bond strengths of Oregon bentonite/sand mixtures (for a clay content of 10\%) exhibited a $70 \%$ decrease when soil plugs compacted at $95 \%$ and at $87 \%$ were compared.

The results of bond strength measurements for soil plugs compacted at ambient temperature in a mud-contaminated basalt (host rock) core and soil plugs compacted at high temperature $\left(100{ }^{\circ} \mathrm{C}\right)$ in a clean basalt (host rock) core for two different clay contents of 10 and $50 \%$ are summarized in Table 3-19. In general, the contamination of the simulated borehole walls in the basalt piece produced a decrease in bond strength. Percent deterioration was found to be greater for higher clay content. 


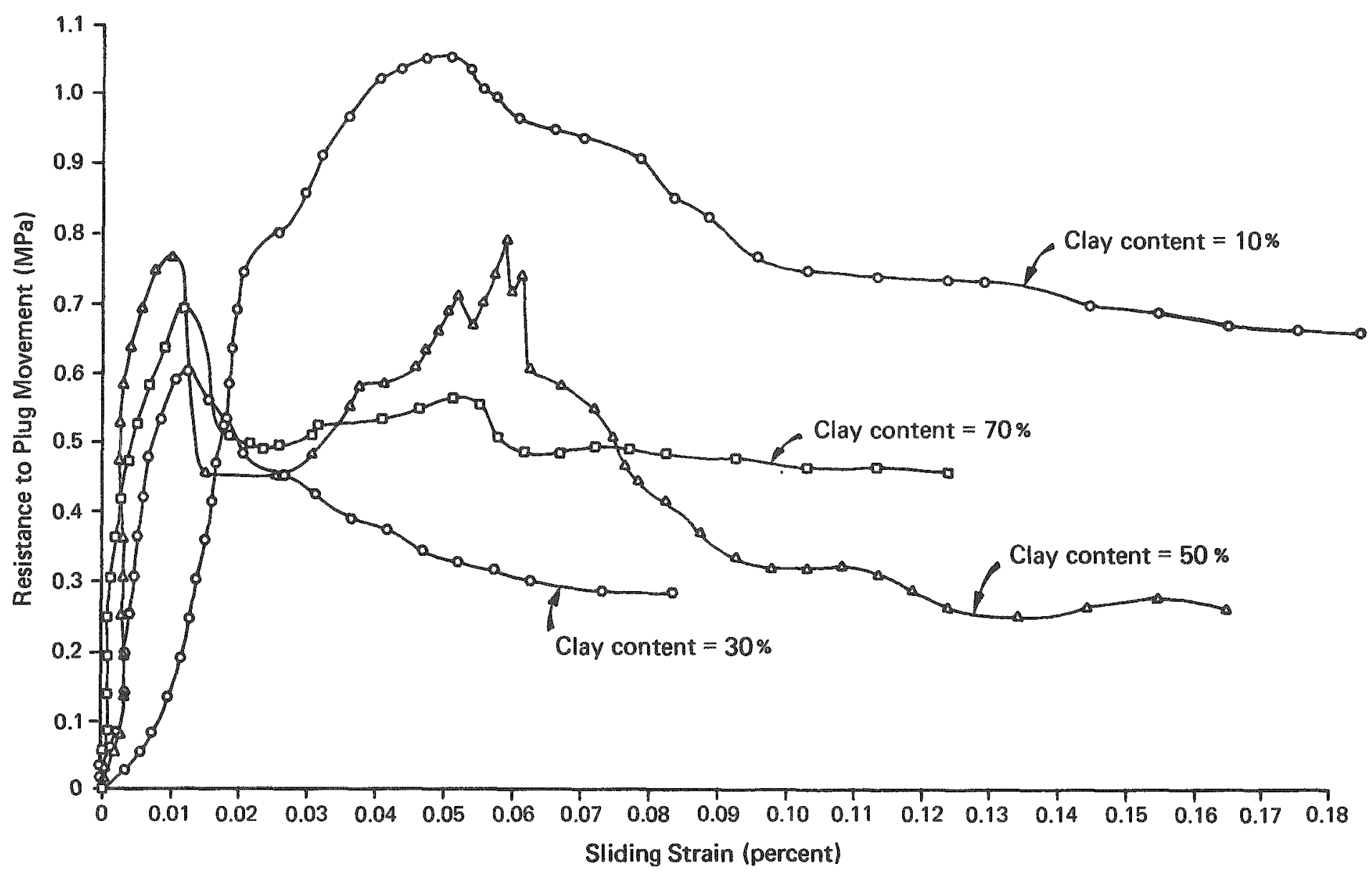

FIGURE 3-26. Bond Strength STidina Strain Curves for Clay/Sand Mixtures Containing Wyoming Bentonite and Glaciofluvial Sand. 
TABLE 3-19. Summary of Bond Strength Data for Selected Clay/Sand Mixtures.

\begin{tabular}{|c|c|c|c|}
\hline $\begin{array}{l}\text { Mixture } \\
\text { Components }\end{array}$ & $\begin{array}{c}\text { Bond Strength } \\
\text { Q Ambient } \\
\text { Ternperature } \\
\mathrm{MPa}\end{array}$ & $\begin{array}{l}\text { Bond Strength } \\
\text { a Ambient } \\
\text { Temperature on } \\
\text { Mud-Contaminated } \\
\text { Host Rock (MPa) }\end{array}$ & $\begin{array}{l}\text { Bond Strength } \\
0100 \mathrm{C}(\mathrm{MPa})\end{array}$ \\
\hline $\begin{array}{l}10 \% \text { Wyoming bentonite } \\
90 \% \text { Glaciofluvial sand }\end{array}$ & 0.11 & 0.67 & $\approx 7 *$ \\
\hline $\begin{array}{l}50 \% \text { Wyoming bentonite } \\
50 \% \text { Glaciofluvial sand }\end{array}$ & 0.80 & 0.30 & 0.51 \\
\hline $\begin{array}{l}10 \% \text { Oregon bentonite } \\
90 \% \text { Glaciofluvial sand }\end{array}$ & 0.11 & 0.10 & $\approx 7 *$ \\
\hline $\begin{array}{l}50 \% \text { Oregon bentonite } \\
50 \% \text { Glaciofluvial sand }\end{array}$ & 0.94 & 0.45 & 0.27 \\
\hline $\begin{array}{l}10 \% \text { Ringold clay } \\
90 \% \text { Glaciofluvial sand }\end{array}$ & 0.78 & 0.46 & 0.63 \\
\hline $\begin{array}{l}50 \% \text { Ringold clay } \\
50 \% \text { Glaciofluvial }\end{array}$ & 0.54 & 0.37 & $?$ \\
\hline
\end{tabular}

*Model plug left for 12 hours in basalt block in oven at $100^{\circ} \mathrm{C}$ prior to testing. Bond strength values are approximate and are obtained from pressure gauge indication of a hydraulic jack. 
Experimental values for bond strength obtained at high temperature $\left(100^{\circ} \mathrm{C}\right)$ indicated a net deterioration of the bond for a clay content of $50 \%$. This may be due to shrinkage of the clay fraction in the compacted soil plug: testing at high temperature was made without attempting to maintain moisture content in the plug.

An exceptionally high bond strength (7 MPa) was observed for bentonite/sand mixtures containing 90\% glaciofluvial sand. In this test, the miniature plug/basalt host rock models were left for 12 hours in a conventional oven at $100^{\circ} \mathrm{C}$ prior to testing. Accordingly, no comparison of bond strengths was attempted between mixtures containing various percentages of clay because different curing methods were applied. Note that bond strengths obtained for bentonite mixtures containing $10 \%$ sand were approximately twice those observed for grout plug/basalt (host rock) models at high temperature. These high bond strengths are significant and may be the result of cementation between the basalt core walls and the compacted soil plug. Further testing is needed to confirm this result.

Curves showing variations in void ratio with variations in consolidation pressure are given in Figures 3-27 and 3-28 for oregon bentonite/glaciofluvial sand mixtures having clay contents of 10 and $50 \%$. Oregon bentonite mixtures with a clay content of $10 \%$ had a low compressibility. Under consolidation pressures ranging from 3 to $6.4 \mathrm{MPa}$, the compression index was only 0.02 . However, the unloading part of the consolidation curve exhibits a hysteresis that suggests the potential for separation at the interface between the soil plug and borehole wall after cyclic loading. Such cyclic loading could be produced by thermal cycles in the repository environment because of radioactive waste decay. By contrast, the Oregon bentonite mixture with a clay content of $50 \%$ exhibited a higher compressibility: a compression index of 0.105 was computed for consolidation pressures ranging from 3 to $6.4 \mathrm{MPa}$. However, in this case the unloading part of the consolidation curve indicates a strong swelling potential for this mixture. Void ratio values more than or equal to the initial void ratio of the compacted mixture were observed for consolidation pressures less than or equal to 3 MPa during loading 


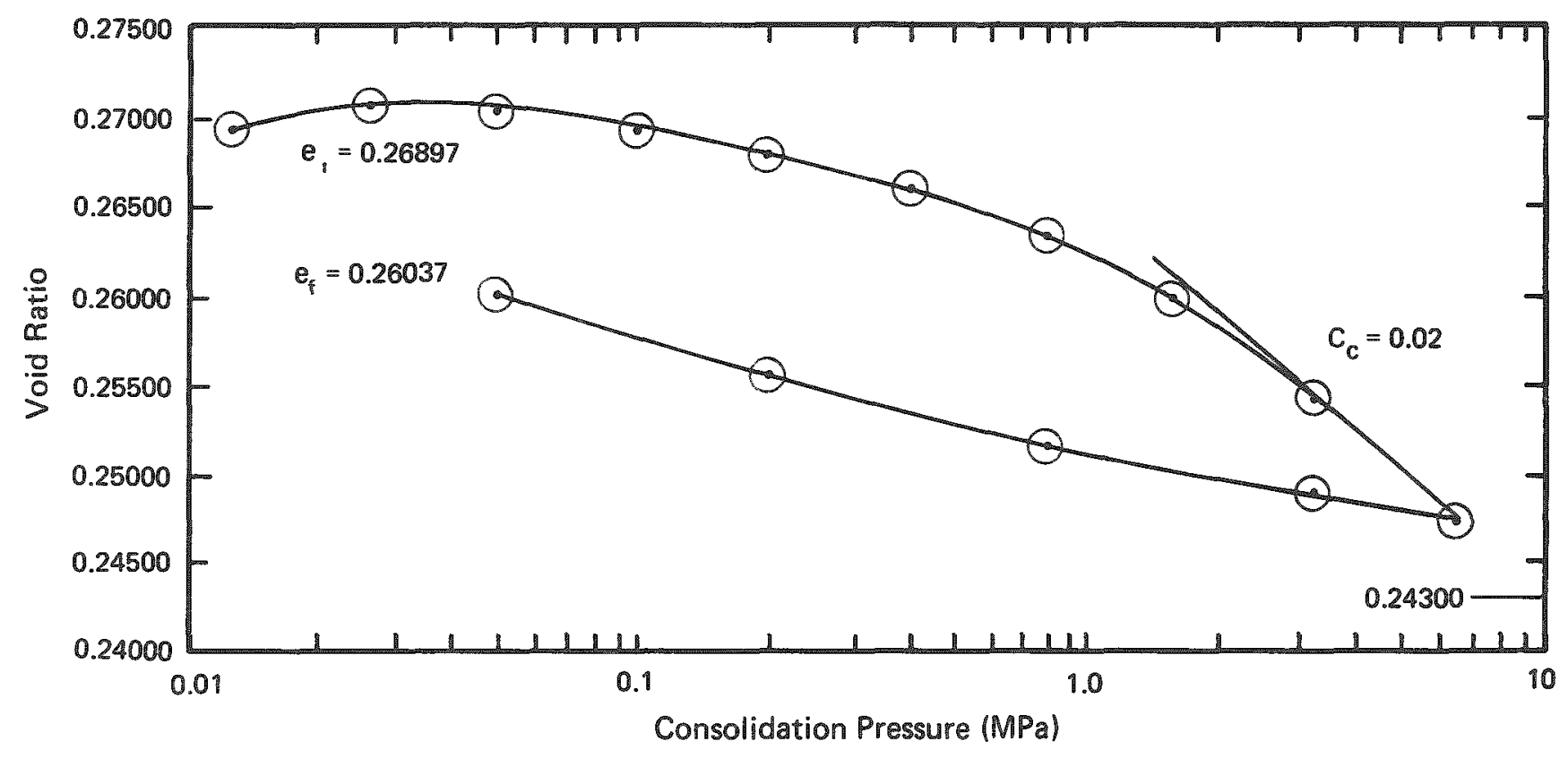

\footnotetext{
EXPLANATION

$e_{i}=$ Mutual void ratio

$e_{f}=$ Final void ratio

$\mathrm{C}_{\mathrm{c}}=$ Compression index (for loading pressure ranging from 3.2 to $6.4 \mathrm{MPa}$ )
}

FIGURE 3-27 Consolidation Curve of Clay/Sand Mixtures Containing 10\% Oregon Bentonite and $90 \%$ Glaciof Tuvial Sand. 


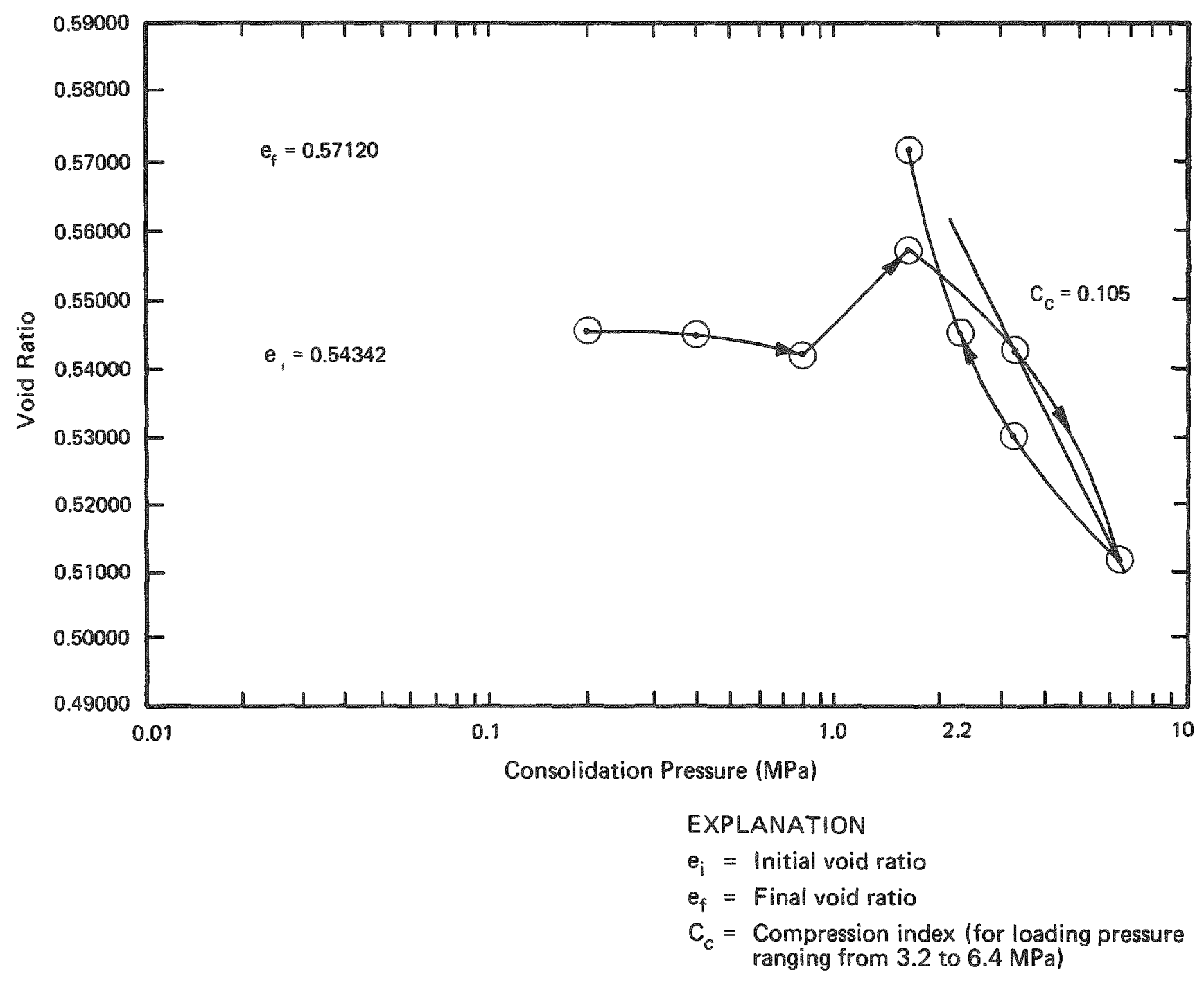

FIGURE 3-28. Consolidation Curves of Clay/Sand Mixtures Containing 60\% Oregon Bentonite and 50\% Glaciofluvial Sand. 
and less than or equal to $2.2 \mathrm{MPa}$ during unloading. This result suggests that, even after cyclic loading, a tight contact between the soil plug and borehole wall should be expected. For unloading pressures less than 2.2 $\mathrm{MPa}$, the confined plug should exert a self-stressing pressure against the walls because of swelling of the plug material. This result is considered promising but should be confirmed and extended by testing the long-term swelling potential of sand/clay mixtures under elevated temperature conditions.

\subsubsection{Clay Slurries. The primary objective of evaluating clay} slurries is to determine the most suitable slurry for use in conjunction with crushed basalt gravel. Such material would derive its strength from a framework of crushed basalt in grain-to-grain contact; the slurry would be intruded into framework voids to act as an impermeable filler which would inhibit fluid migration as well as adding to the ion exchange potential and sorption capacity of this type of plug material. Premixed combinations of clay siurries and gravel or coarse-crushed basalt should have the same low permeability, enhanced ion exchange potential, and sorption capacity as slurry/aggregate mixtures produced by injection of a slurry into a coarse granular framework. Premixed materials make it possible to use slurries containing sand and natural clay that were found to be unsuitabie for slurry injection during screening tests and thereby allow for a wider variety of plug materials. The sand and clay can occupy a significant portion of the void space between coarse gravel or basait aggregate as well as be incorporated into the grain-to-grain contacts of the structural framework itself. Consequentiy, the relative proportions of components in premixed slurry/aggregate samples can be more varied than for slurry/aggregate samples can be more varied than for slurry injection samples.

Preliminary screening tests of clay slurries included: determination of the densities of fresh slurries using a container of known weight and volume; determination of the flow properties of slurries by measuring the time of discharge of a specified volume of slurry from a standardized 
flow cone; and evaluation of the thixotropic properties of slurries by measuring the shear strength of the slurry at increasing time using a laboratory vane shear test.

For complete dispersion of solids, a linear relationship can be demonstrated between slurry density and solids content, as shown by Figure 3-29. The slope of this straight line, as drawn through a plot of experimental data points, is a function of the specific gravity of the solids. Note that the point corresponding to a slurry containing $15 \%$ Aquagel was plotted at a density lower than was expected because of the presence of several air voids in the sample used for the density determination. For the slurry in which solids consisted of $98 \%$ Ringold clay and $2 \%$ Wyoming bentonite, there was a great deal of scatter in the test results because of the difficulty encountered when attempting to obtain a representative sample for density determination. This difficulty was primarily caused by the high silt content of Ringold clay from Unit $D$; the solids rapidly settled whenever agitation of the slurry ceased, thereby effectively reducing the solids content of the slurry. Thus, it was difficult to produce a consistent slurry when using Ringold clay. With the exception of these discrepancies, the test results do show the linear relationship between slurry density and solids content. The slurries consisting of Shurgel and Aquagel produced the greatest densities.

In conjunction with tests to determine slurry densities, the same slurry mixtures were used to determine the flow properties (viscosity) of slurries at various solids contents by measuring the time required for a given volume of slurry to flow out of a test funnel. It should be noted that the flow time of water at $25^{\circ} \mathrm{C}$ was approximately 8.3 seconds. Tests performed to monitor consistency indicated that test repeatability was reasonable (about t0.20 second). As shown in Figure 3-30, for slurries with solids consisting of Shurgel, Aquage1, or Wyoming bentonite, the viscosity is close to that of water for solids content less that $6 \%$. The viscosity increased rapidly for solids content above $6 \%$. For solids content greater than $9 \%$ (the consistency of heavy drilling mud), the slurries became too viscous to flow through the cone used for this test. 
RHO-BWI-ST-7

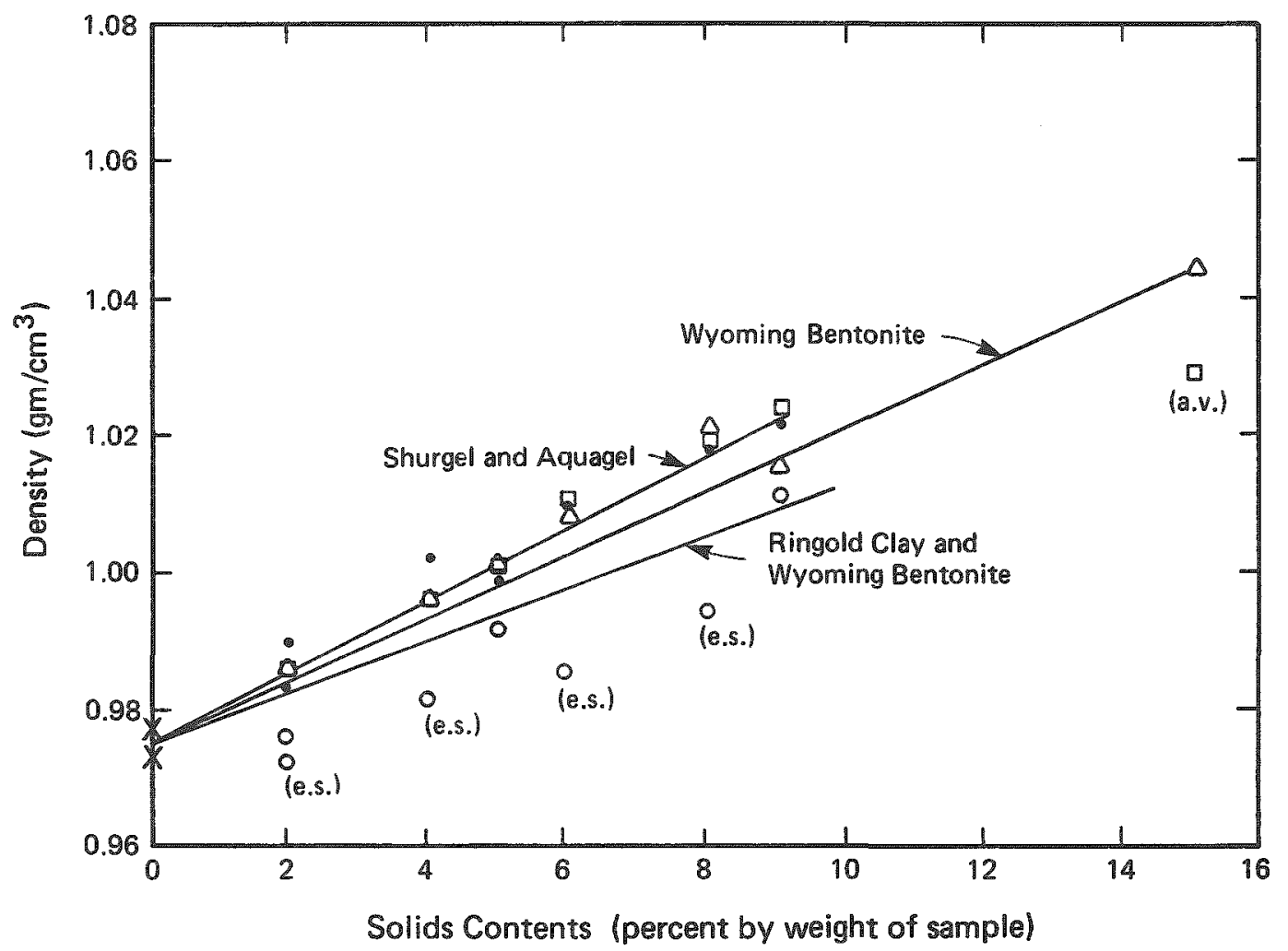

EXPLANATION
$\times$ Water alone
Shurgel
0 Aquagel
$\triangle$ Wyoming bentonite
$0 \quad 98 \%$ Ringold clay
$2 \%$ Wyoming bentonite
(e.s.) Excess silt
(a.v.) Air void

FIGURE 3-29. Densities of Clay STurries. 
RHO-BWI-ST-7

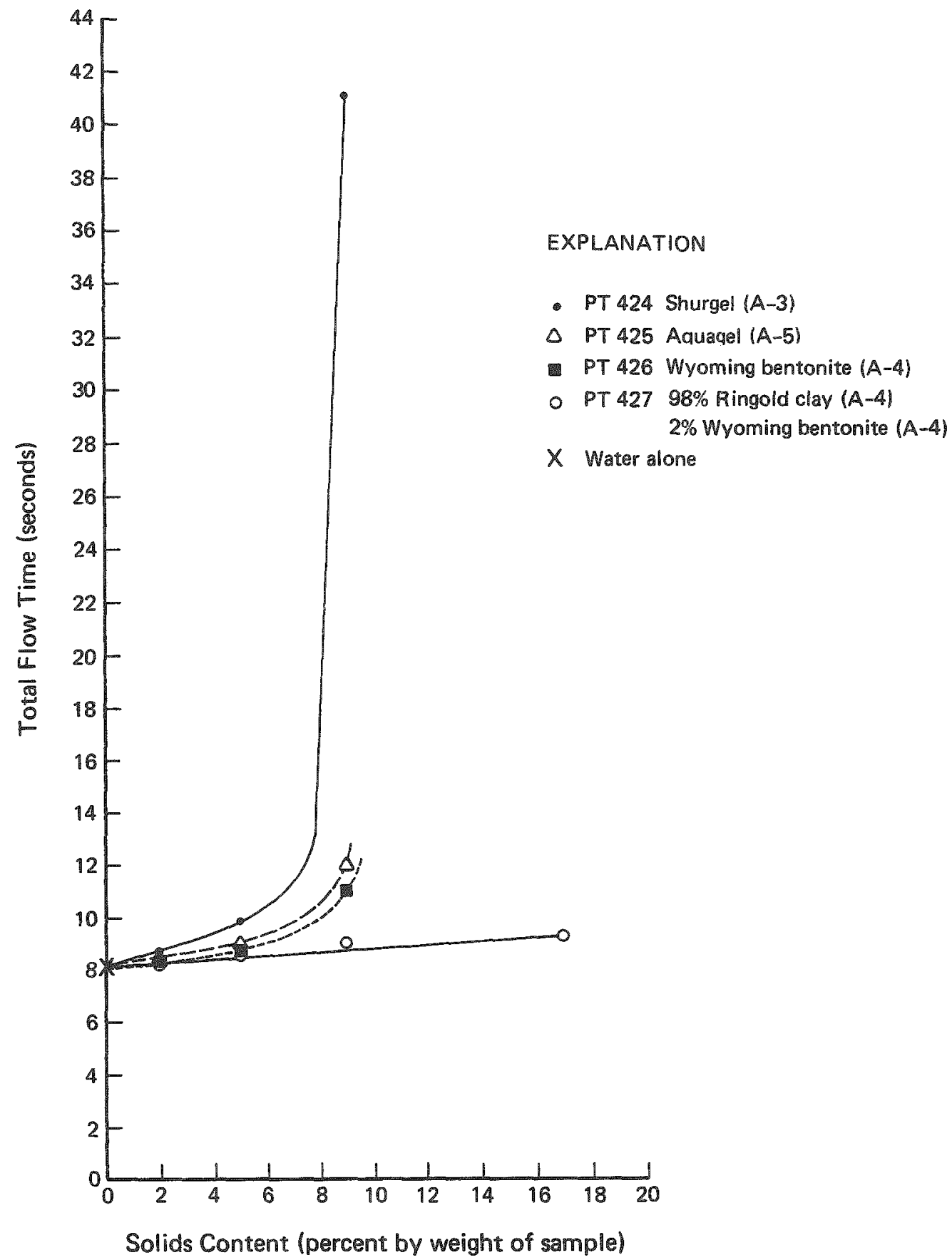

FIGURE 3-30. Flow Time of Clay Slurries. 
The slurry containing Shurgel increased in viscosity (with increase in solids content) much more rapidly than slurries containing either Aquagel or Wyoming bentonita, both of which increased equally in viscosity with increasing solids content. However, the slurry that contained 98\% Ringold clay and $2 \%$ Wyoming bentonite maintained a viscosity close to that of water for all solids contents tested, including solids contents as high as $17 \%$. This result confirms the instability of this mixture as a permanent suspension in a slurry because of the rapid settling of solids upon cessation of mixing.

After evaluating the results of tests for slurry densities and flow properties, it was possible to select slurry mixtures that received further testing with respect to thixotropic (shear strength) properties. In a attempt to quantify test results, laboratory vane shear tests were performed. However, the test apparatus was not sensitive enough to measure the low shear strength associated with the slurries, and qualitative descriptions given in Table 3-20 must be used to present the results of these tests. Each time a vane shear test was performed on a slurry sample, the sample condition was monitored by taking a solids content specimen from the sample (Fig. 3-31 and 3-32). These specimens were taken by scraping some slurry from the top of the sample with a spoon. It was this procedure that produced indentations and holes in the surface of samples, as noted in Table 3-20. These indentations and holes are considered a valid basis for an initial qualitative comparison of shear strength because the slope stability of the cut of any material is a function of its shear strength.

The descriptions given in Table 3-20 are presented to illustrate the following test results: (1) for solid contents less than $6 \%$, no apparent shear strength was developed by any of the slurries tested; (2) 7 days after being mixed, apparent shear strength was only developed by slurries containing $6 \%$ and $8 \%$ Shurgel and $8 \%$ Aquage 7 ; (3) the slurry containing $6 \%$ Shurgel developed apparent shear strength after a period of 3 days, while the slurry containing $8 \%$ Shurge 1 developed apparent shear strength after a period of only 24 hours; and (4) the slurry containing $8 \%$ Shurgel 
TABLE 3-20. Qualitative Results of Thixotropy Tests on Clay Siurries.

\begin{tabular}{|c|c|c|c|c|c|}
\hline \multicolumn{2}{|c|}{ Slurry Design } & As Mixed & 1 Day & 3 Days & 7 Days \\
\hline \multirow{4}{*}{ Shurgel } & $2 \%$ Solids & Low viscosity liquid & Low viscosity liquid & Low viscosity liquid & Low viscosity liquid \\
\hline & $4 \%$ Solids & Low viscosity liquid & Low viscosity iquid & Poderate viscosity liquid & $\begin{array}{l}\text { Moderate to high } \\
\text { viscosity liquid }\end{array}$ \\
\hline & $6 \%$ Solids & Low viscosity liquid & $\begin{array}{l}\text { Moderate to high } \\
\text { viscosity liquid }\end{array}$ & $\begin{array}{l}\text { Some shear strength apparent } \\
\text { by indentation left in } \\
\text { surface of sample }\end{array}$ & $\begin{array}{l}\text { Increased shear strength } \\
\text { indicated by deeper indentation } \\
\text { left in surface of sample }\end{array}$ \\
\hline & $8 \%$ solids & $\begin{array}{l}\text { Very high viscosity } \\
\text { Iiquid }\end{array}$ & $\begin{array}{l}\text { Some shear strength } \\
\text { apparent by indentation } \\
\text { left in surface of sample }\end{array}$ & $\begin{array}{l}\text { Increased shear strength } \\
\text { indicated by deeper } \\
\text { indentation left in surface } \\
\text { of sample. }\end{array}$ & $\begin{array}{l}\text { Greater shear strength } \\
\text { indicated by hole left } \\
\text { in surface of sample }\end{array}$ \\
\hline \multirow{4}{*}{$\begin{array}{l}\text { byoming } \\
\text { Bentonite }\end{array}$} & $2 \%$ Solids & Low viscosity liquid & Low viscosity liquid & & $\begin{array}{l}\text { Cloudy water; solids } \\
\text { at bottom of container }\end{array}$ \\
\hline & $4 \%$ Solids & Low viscosity liquid & Los viscosity & & $\begin{array}{l}\text { Low to moderate viscosity } \\
\text { iqquid; some setting of solids }\end{array}$ \\
\hline & $6 \%$ Solids & Low viscosity liquid & $?$ & & Moderate to high \\
\hline & $8 \%$ Solids & Low viscosity liquid & Moderate viscosity liquid & & High viscosity liquid \\
\hline \multirow{4}{*}{ Aquagel } & $2 \%$ Solids & Low viscosity liquid & Low viscosity liquid & & $\begin{array}{l}\text { Cloudy water; solids at } \\
\text { bottom of container }\end{array}$ \\
\hline & $4 \%$ Solids & Low viscosity iiquid & Low viscosity & & $?$ \\
\hline & $6 \%$ Solids & Low viscosity liquid & $?$ & & $\begin{array}{l}\text { Moderate to high } \\
\text { viscosity liquid }\end{array}$ \\
\hline & $8 \%$ solids & Low viscosity liquid & $\begin{array}{l}\text { Moderate to high } \\
\text { viscosity liquid }\end{array}$ & & $\begin{array}{l}\text { Some shear strength apparent } \\
\text { by indentation left in } \\
\text { surface of sample }\end{array}$ \\
\hline \multirow{4}{*}{$\begin{array}{l}\frac{\text { Bingoid }}{\text { Clay } 98 \%} \\
\text { w/Shurgel } 2 \%\end{array}$} & 2\% Solids & Essentially cloudy water & $\begin{array}{l}\text { Clear water; solids at } \\
\text { bottom of container }\end{array}$ & & $\begin{array}{l}\text { Clear water; solids at } \\
\text { bottom of container }\end{array}$ \\
\hline & $4 \%$ Solids & Essentially cloudy water & Cloudy water & & $\begin{array}{l}\text { Clear water; solids at } \\
\text { bottom of container }\end{array}$ \\
\hline & $6 \%$ Solids & Essentially cloudy water & Cloudy water & & $\begin{array}{l}\text { Clear water: solids at } \\
\text { bottom of container }\end{array}$ \\
\hline & 8\% Solids & Essentially cloudy water & Cloudy water & & $\begin{array}{l}\text { Clear water; solids at } \\
\text { bottom of container }\end{array}$ \\
\hline
\end{tabular}


RHO-BWI $-S T-7$
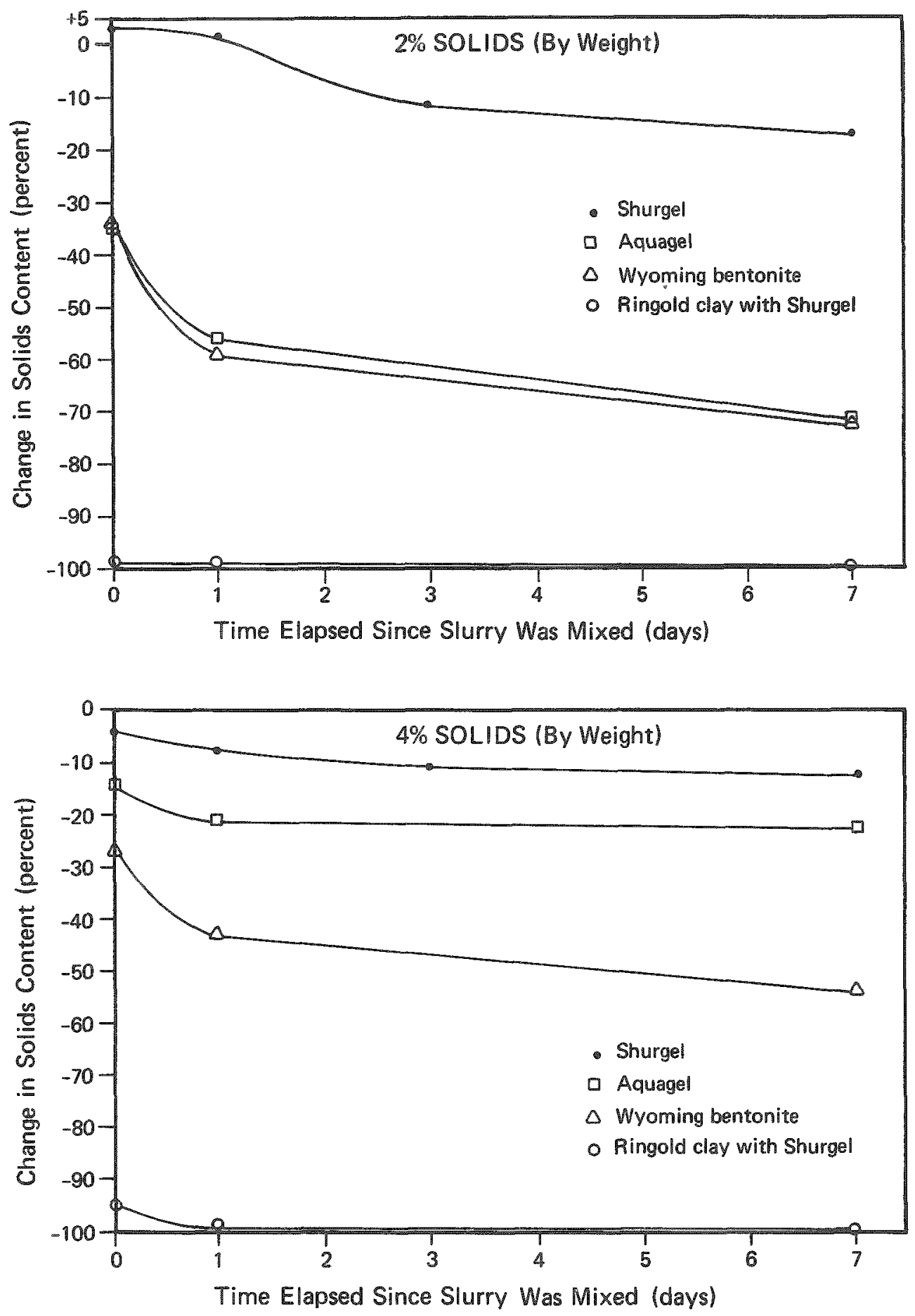

FIGURE 3-31. Variation of Solids Content $(2 \%$ and $4 \%)$ of Clay Slurries. 
RHO-BWI-ST-7
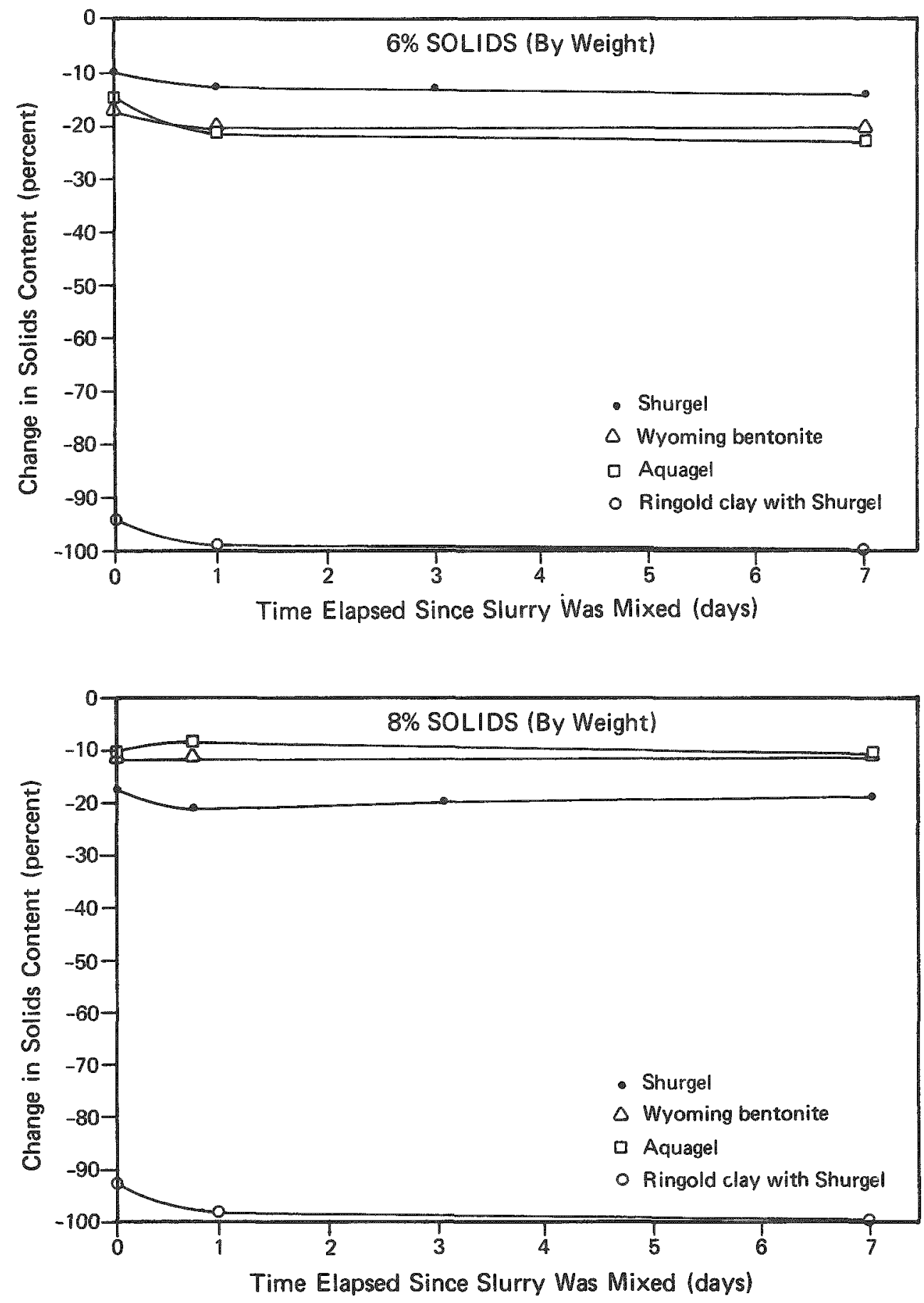

FIGURE 3-32. Variation of Solids Content $(6 \%$ and $8 \%)$ of Clay Slurries. 
developed sufficient shear strength after a period of 7 days to maintain vertical sides of a groove in the sample. However, this shear strength was still too small to be measured with the laboratory vane shear apparatus (the minimum measurable shear strength is $1.4 \mathrm{~g} / \mathrm{cm}^{2}$ ). These results indicate that, in terms of shear strength, slurries should contain at least $9 \%$ by weight of solids and the greatest strength will be developed by slurries containing Shurget.

These results were further substantiated by data obtained by continuous monitoring of thixotropy tests; these results are shown on Figure 3-31 and 3-32. The change in solids content for a sample, as shown by these figures, is given as the percent change from the original solids content of that sample; that is, $-10 \%$ indicates that at the surface of the sample, there were 10\% fewer solids than when the sample was originally prepared. These figures illustrate the extent to which the solids in a slurry remained "suspended" throughout the slurry or "settled" towards the bottom of the sample. The results indicate that Shurgel solids essentially remained suspended throughout the sample for all solids contents tested, whereas in the mixture of $98 \%$ Ringold Clay with $2 \%$ Shurge1, solids settled to the bottom of the sample for all solids contents tested (Table 3-20). The slurries containing Aquagel and Wyoming bentonite exhibited significant settling of solids for mixtures containing $2 \%$ solids, but for solids contents of $6 \%$ and $8 \%$, the solids essentially remained suspended throughout the sample.

Screening tests indicated that a slurry containing 6 to $8 \%$ by weight Shurgel (processed bentonite) exhibits the best properties of workability, stability, and thixotropy. Therefore, this slurry was adopted for further study in performance testing and was combined with fine-crushed zeolite $(-4.6 \mathrm{~mm})$ from Oregon, Ringold clay from Unit $D$, and precompressed bentonite pellets to form a variety of samples. Crushed basalt gravel $(-1.9 \mathrm{~cm})$ used in these tests was from the Hanford Site. Test mixtures are listed in Tables $3-21$ and 3-22. Percentages listed on these tables indicate percentage of solids by weight. All materials, except Shurgel, were mixed in an air-dried condition. Shurgel was prepared as a slurry which contained the percent solids by weight given in parentheses on Tables 3-21 and 3-22. 
TABLE 3-21. Summary of Data and Test Results for Preplacement and Slurry Injection of Aggregate.

\begin{tabular}{|c|c|c|c|c|}
\hline Mixture & Density & Porosity & Bond Strength & Compressibility \\
\hline $\begin{array}{l}\text { PT } 42 \mathrm{C} \text { I } \\
98 \% \text { crushed } \\
\text { basalt gravel } \\
2 \% \text { Shurgel } \\
\text { (7\% s? urry) }\end{array}$ & 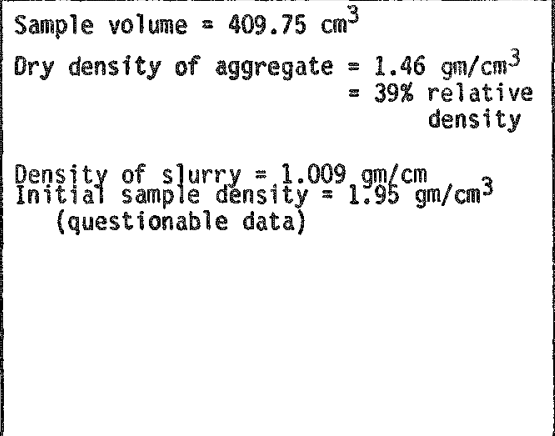 & $\begin{array}{l}\begin{array}{l}\text { Assurne } \\
\text { Gasalt }=2.84: G_{S}=0.98(2.84) \\
+0.02(2.75)\end{array} \\
\text { Shurgel }=2.75: G_{S}=2.84 \\
\text { Since } \\
\begin{array}{l}\text { Sample density }=\left(n+(1-n) G_{S}\right)_{u} \\
1.95 \mathrm{gm} / \mathrm{cm}^{3}=(n+(1-n) \\
\qquad 2.84)\left(1.0 \mathrm{gm} / \mathrm{cm}^{3}\right)\end{array} \\
\frac{\text { Therefore }}{n=0.48}\end{array}$ & $\begin{array}{l}\text { Sample slumped out of } \\
\text { steel mold. } \\
\text { Rubber membranes were not } \\
\text { used inside steel mold. }\end{array}$ & No test possible \\
\hline $\begin{array}{l}\text { PT } 428 \text { II" } \\
98 \% \text { Crushed } \\
\text { basalt grave } 1 \\
2 \text { Shurgel } \\
(7 \% \text { slurry) }\end{array}$ & $\begin{array}{l}\text { Sample volume }-419.09 \mathrm{~cm}^{3} \\
\text { Ory density of aggregate }=1.54 \mathrm{gm}^{\mathrm{cm}} \mathrm{cm}^{3} \\
=68 \% \text { relative } \\
\begin{array}{r}\text { Density of slurry }=1.010 \mathrm{gm} / \mathrm{cm}^{3} \\
\text { Initial sample density }=1.95 \mathrm{gm} / \mathrm{cm}^{3}\end{array}\end{array}$ & 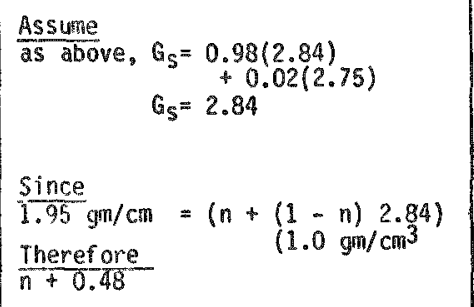 & $\begin{array}{l}\text { Sample slumped out of steel } \\
\text { mold after plug res istance } \\
\text { reached } 0.002 \mathrm{~kg} / \mathrm{cm} 2 \text {. } \\
\text { Rubber membrane was not } \\
\text { used inside steel mold. }\end{array}$ & Mo test possible \\
\hline $\begin{array}{l}\text { PT } 428 \text { III } \\
98 \% \text { Crushed } \\
\text { basalt gravel } \\
2 \text { Shurgel } \\
\text { (7\% slurry) }\end{array}$ & $\begin{aligned} & \text { Sample volume }+378.66 \mathrm{~cm}^{3} \\
& \text { Dry density of aggregate }= 1.63 \mathrm{~m} / \mathrm{cm}^{3} \\
& \begin{array}{r}100 \% \\
\text { relative } \\
\text { density }\end{array} \\
& \text { Density of slurry }=1.033 \mathrm{gm} / \mathrm{cm}^{3} \\
& \text { Initial sample density }=2.07 \mathrm{gm} / \mathrm{cm}^{3}\end{aligned}$ & 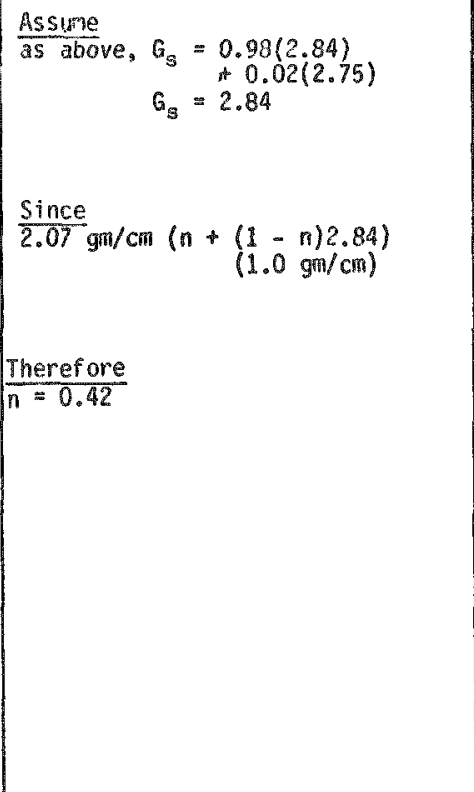 & $\begin{array}{l}\text { No test possible } \\
\text { Rubber membrane was used } \\
\text { inside mold } \\
\text { - Triaxial conpressive } \\
\text { strength test pending. }\end{array}$ & 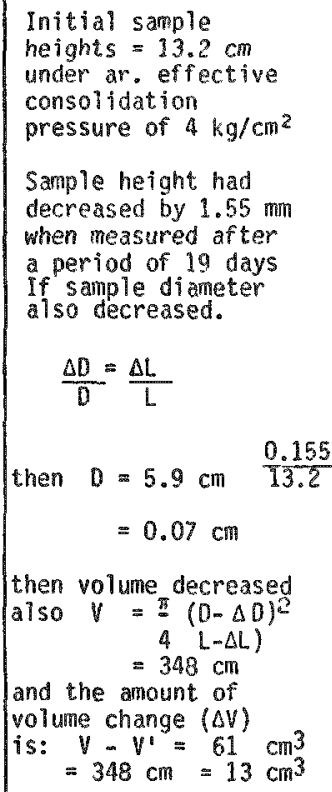 \\
\hline
\end{tabular}


TABLE 3-22. Summary of Data and Test Results for Premixed Slurry and Aggregate.

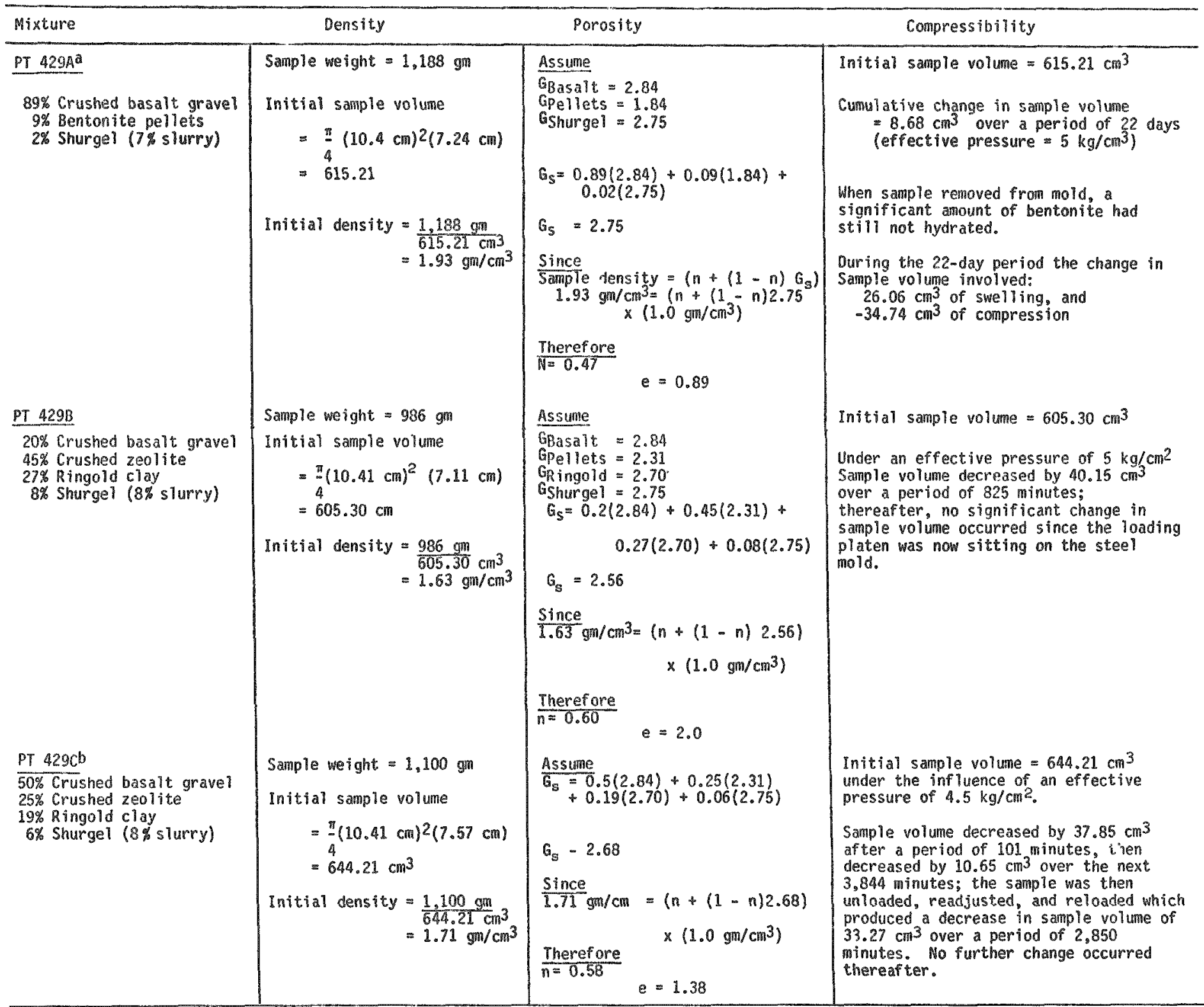

a Channeling of sample due to particle migration, no test possible for permeability.

Using effective pressure of $0.09 \mathrm{MPa}$, back pressure $=0.51 \mathrm{MPa}$, and $K=1.2 \times 10^{\circ} \mathrm{cm} / \mathrm{sec}$. 
The two attempts at determining the bond strength of slurry/aggregate mixtures that involved injection proved futile. In both instances, the sample essentially slumped out of the steel mold under the influence of its own weight, which indicated that very little cohesive or frictional force was available to resist sample movement. The lack of cohesion was attributed to the inability of the Shurgel clay particles to interact with the walls of the mold, while the lack of significant granular frictional resistance on the wall was attributed to the low relative density of the aggregate as well as the lubrication of aggregate particles when coated with slurry. However, this lack of cohesion and friction was not exhibited by the samples themseives, since they were capable of supporting their own weight when the split steel mold was disassembled from around them.

Some important observations on strength characteristics were made when a sample of premixed slurry and aggregate (sample PT 429A, Table 3-22) was removed from the steel consolidometer. This sample was essentially the same composition as slurry injection samples, except that it contained bentonite pellets and had undergone a period of consolidation. Because of swelling of the bentonite and simultaneous consolidation the sample was very tightly squeezed within the steel consolidometer; it did not slump out of the container under the influence of its own weight as other, similar samples had. This sample was, in fact, very difficult to dig out of the container. In addition, bonding between gravel grains was significantiy greater than that exhibited by samples prepared by slurry injection. It appears that hydration and swelling of the bentonite pellets, in conjunction with sample consolidation, had an important influence of the cohesive strength of the mixture.

From test results shown in Tables 3-21 and 3-22, inconsistencies resulted due to problems with maintaining pressures and measuring changes in sample height. However general data trends indicate that compressibility of the various mixtures increased with increasing porosity. With respect to sample PT 429A (Tab7e 3-22), the relationship between porosity and compressibility is difficult to evaluate because test results were strongly influenced by swelling of the bentonite 
pellets. The volume changes experienced by this sample alternated between swelling and compression, partly because of the bentonite and partly because of the cell pressure regulator that allowed the effective consolidation pressure to fluctuate between 0.1 and $0.48 \mathrm{MPa}$. However, the capacity of bentonite to swell did appear to offset the effect of consolidation. Test results for premixed slurry/aggregate samples PT $429 \mathrm{~B}$ and PT $429 \mathrm{C}$ indicate that an increase in the percentage of fine aggregate wi 11 produce an increase in porosity and an attendant increase in compressibility. In addition to the high porosity of these mixtures (which, in turn, affects compressibility), D'Appolonia and Ryan (1979) present data showing that compressibility of a slurry/aggregate (structurai framework) is decreased. One other consideration mentioned earlier is the low strength and breakdown of crushed zeolite, which will also increase the compressibility of mixtures. As shown on Tables 3-21 and $3-22$, only one permeability test was fully completed. The sample (PT 429C) incorporated premixed slurry, coarse aggregate, and fine aggregate that was consolidated under an effective pressure of $0.45 \mathrm{MPa}$ and then subjected to a falling head permeability test with the effective pressure reduced to $0.1 \mathrm{MPa}$. The coefficient of permeability was determined to be $10^{-8} \mathrm{~cm} / \mathrm{sec}$, which is consistent with results presented by D'Appolonia and Ryan (1979) for such a mixture.

Based on preliminary test results for clay slurries, the following conclusions can be made: the bond strength of a slurry/aggregate mixture was greatiy enhanced when bentonite pellets were added and the mixture was subjected to consolidation; compressibility of a slurry/aggregate mixture increased as its porosity increased and percent coarse aggregate decreased; and for slurry mixtures containing $6 \%$ bentonite by weight, the permeability should be on the order of $10^{-8} \mathrm{~cm} / \mathrm{sec}$.

\subsection{PRECONCEPTUAL PLUG DESIGN}

The construction and operation of a subsurface repository in the Columbia $\mathrm{Plateau}$ basalt will require man-made openings for exploration, access shafts and tunnels, and storage areas. The diameters of these man-made openings, which are collectively referred to as boreholes, may 
range from $5 \mathrm{~cm}$ for existing vertical exploration holes to 6 or $7 \mathrm{~m}$ for shafts and tunnels (upper limits of 9 to $10 \mathrm{~m}$ are expected). When the repository is decommissioned, these boreholes will be sealed or plugged to preserve the integrity of the repository.

The materials and system (integration of plug materials, plug emplacement machines, and monitoring) selected for the borehole plug must be compatible (stable) with the physical and chemical properties of the surrounding repository rock and its geologic environment. The plug system will be emplaced by machines and techniques that will provide a suitable degree of confidence in the security and durability of the plug.

The purpose of the plug system is to prevent the migration of harmful amounts of radioactive waste to the biosphere. To prevent this migration along man-made openings, it is likely that a variety of materials and series of multiple plug barriers will be used. The materials considered include hard rock and noble metals, soil and portland cement concretes, natural cements, grouts, clay, sand, gravel, and mixtures of these. Each material or mixture of materials will contribute one or more favorable attributes to complement and preserve the integrity of the surrounding repository rock.

During the development of preconceptual plugging schemes, an attempt was made to anticipate some of the generally known probiem areas. For example, rock undergoes stress changes and loosening for some finite distance back from the wall surface of an underground excavation. The amount of stress change and loosening is dependent on the diameter of the excavated opening, the physical properties of the rock mass, excavation methods, stress field, and other factors. Therefore, the plugging schemes presented in this section include remedial grouting and excavation of cutoff collars along the plug length just prior to plugging. These measures are designed to mitigate possible seepage flows that would bypass the plug through the weakened wall rock.

Because of the problem of weakened wall rock, the difficulties of demonstrating complete effectiveness of any grouting cutoff scheme, and the possibility of damage to remedial measures because of subsidence above the repository excavation, it is believed that vertical shafts that 
directly enter the repository may provide a more probable flow path to the biosphere and thus are undesirable. The shafts should be excavated at some distance from the repository and should be connected to the repository by tunneis. Consequently, even if the permeability of the wall rock could not be restored to its in situ condition, the resistance to flow through and around a plug constructed in the tunnel and shaft could be greater than the resistance to flow through overhead, intact rock separating the repository and the biosphere.

An initial assumption here is that smal1-diameter boreholes do not cause significant stress change or loosening of surrounding rock and thus do not contribute to an increase in the in situ permeability in the surrounding rock. Consequentiy, it may be acceptable to penetrate the proposed repository area with boreholes. Such a conclusion presupposes that the methods of plugging boreholes developed in this program are found to be satisfactory.

\subsubsection{Candidate Plugging Schemes}

A major thrust of the borehole plugging program is to provide preconceptual designs for up to four plug systems that are estimated to be available on a near-term basis ( 5 years). The identification process for candidate schemes has consequent7y been weighted toward technologies where the necessary production machinery is commercially available and demonstrated on plug-like materials in operations similar to anticipated plugging operations. This methodology has thus far resulted in the "preferred" candidate machinery already described. It seems prudent, however, to continue a parallel identification, discussion, and evaluation of a category of plug systems that involve new research and deveiopment technologies.

It is possible that, in certain situations, multiple-zoned plugs will be used. A multiple-zoned plug is divided along the length of plug into separate zones of different types of material. The zones may change completely from one type of material to another (e.g., concrete to earth) or material in adjacent zones may be of similar type (e.g., earth, but of different physical properties, such as permeability and density). Such zoning is designed to make use of special properties of individual 
material types so that the overall performance of the zoned plug achieves all the design objectives of waste isolation plugs in basalt.

In the discussions that follow, each zone of a multiple plug will be considered as a separate individual plug. The material in that zone is essentially uniform along its length. Similar placement techniques are employed from one end of the plug to the other; however, some exceptions may occur in tunnel plugging where constricted working room for men and machines near the top or crown of the tunnel may make it desirable to reduce maximum sizes of material particles, such as the maximum size aggregate in concrete, and may require special types of machines for placement in the reduced space.

Selection of candidate plugging materials is discussed in Section 3.4 and selection of candidate machinery is discussed in Section 3.5. The following is a list of material preparations and mixtures used for preconceptual schemes.

\section{Material}

75-mm maximum aggregate

- In a stiff clay mixture

- In concrete

10-mm maximum aggregate

- In a stiff clay mixture

- In a slurry clay mixture

- In a cement mixture

Clay mixed with sand and silt

- Pelleted (bentonite)

- Slurry

Cement

- Slurry
Material Components

Crushed basalt, zeolite, or other gravel

- Alone or mixed with clay, silt, and sand

- Sand and cement.

Crushed basalt, zeolite, or other gravel

- Alone or mixed with clay, silt, and sand

- With sand and cement.

Bentonite, Ringold clay, or other clay

- Alone or mixed with cement; or

- Sand and silt.

Types II and $V$, pozzolanic, and hydrothermal

- Alone

- With fine fillers.

Taylor and others (1979) defined three categories of plug: those to go in boreholes; those in shafts; and those in tunnels. For the purposes 
of this report, this division has been further divided into subcategories. The new divisions are as follows:

- Boreholes Originating at the Surface--Holes not large enough for a man to get down and work in, a maximum of $1 \mathrm{~m}$ in diameter.

- Shafts--Vertical holes large enough for a man to get down, larger than about $1 \mathrm{~m}$ diameter $(1 \mathrm{~m}$ may be hazardous for deep situations, but actual shaft sizes are expected to be significantiy larger).

- Boreholes Originating Underground--Holes not large enough for a man to work in: about 0 to $1 \mathrm{~m}$ in diameter.

i) Plug to be placed at a distance (greater than $3 \mathrm{~m}$ ) from a large working area.

ii) Plug to be placed near (about 0 to $3 \mathrm{~m}$ ) a large working area.

- Tunnels--Horizontal holes greater than about $1 \mathrm{~m}$ in diameter.

i) Smail Tunnels--Tunnels in which it would not be practical to use heavy, earth-moving equipment because of the lack of headroom, about 1 to $6 \mathrm{~m}$ in diameter.

ii) Large Tunnels--Tunnels in which there is sufficient headroom to use heavy, earth-moving equipment; tunnel diameter of greater than $6 \mathrm{~m}$ but less than $10 \mathrm{~m}$. The actual use of such equipment further depends on plug length.

a. Large Tunnels having Short Plugs--The use of heavy, earth-moving equipment is probably impractical for plugs less than about $25 \mathrm{~m}$ in length.

b. Large Tunnels having Long Plugs--Plugs that are long enough to warrant the use of heavy, earth-moving equipment.

These proposed subdivisions could present additional problems in machine selection and operating personnel safety and efficiency, if opening sizes vary with the depths contemplated. It is expected that the 
actual sizes of the holes to be plugged will be narrower than those described above, with the anticipated range of sizes as follows:

- Boreholes originating at surface--50 $\mathrm{mm}$ to $600 \mathrm{~mm}$ diameter

- Shafts- $-4.5 \mathrm{~m}$ to $8 \mathrm{~m}$ diameter

- Boreholes originating underground--50 $\mathrm{mm}$ to $300 \mathrm{~mm}$ diameter

- Tunne $15--3$ m to $10 \mathrm{~m}$ diameter.

The plugs in boreholes originating at the surface will freqently be placed at a distance from the ground surface. Therefore, the placement and compaction of materials, inspection of the plug, and quality control will be difficult. The system chosen to construct the plugs should preferably be one that has been shown by experiment and practical use to be capable of producing a plug of the necessary characteristics. The only available systems identified at present that partially meet this requirement are those used in the completion of deep oil and gas wells; i.e., the gravel pack and grout systems. Other schemes have been identified; however, they would require considerably more development (Figures 33-35). It is anticipated that pressure grouting may be used to help reseal the disturbed basalt around the hole. Similarly, underreamed cutoffs may be effective in sealing off the disturbed basalt. If the plug is to be set at a position other than at the bottom of the hole, then a structural backfill could be placed in the hole up to the desired plug location. If this backfill is permeable, it may be necessary to place a sealing or filter layer above the backfill to prevent the plug material from moving into the backfill.

The problems associated with non-slurry materiais in boreholes are significantly reduced in shafts because of the increased size of shafts and the fact that men can get down to the plug locations to operate and repair equipment and to inspect the plug construction. Also, because of the increased size, compaction equipment that is presently available and has a proven record of providing suitable compaction can be used. An example of such equipment would be a hand-held power tamper. It is anticipated that the full range of preferred candidate materials could be used with the possible combinations of materials and machines shown in accompanying matrices. 


\begin{tabular}{|c|c|}
\hline Materials & Equipment \\
\hline $\begin{array}{l}\text { 10-mm aggregate with clay or bentonite } \\
\text { slury (possibly with compressed, dry } \\
\text { bentonite pellets) }\end{array}$ & $\begin{array}{l}\text { Reverse or normal circulation } \\
\text { mud system }-\mathrm{R} \text { \& } \mathrm{D} \text { concept }\end{array}$ \\
\hline
\end{tabular}

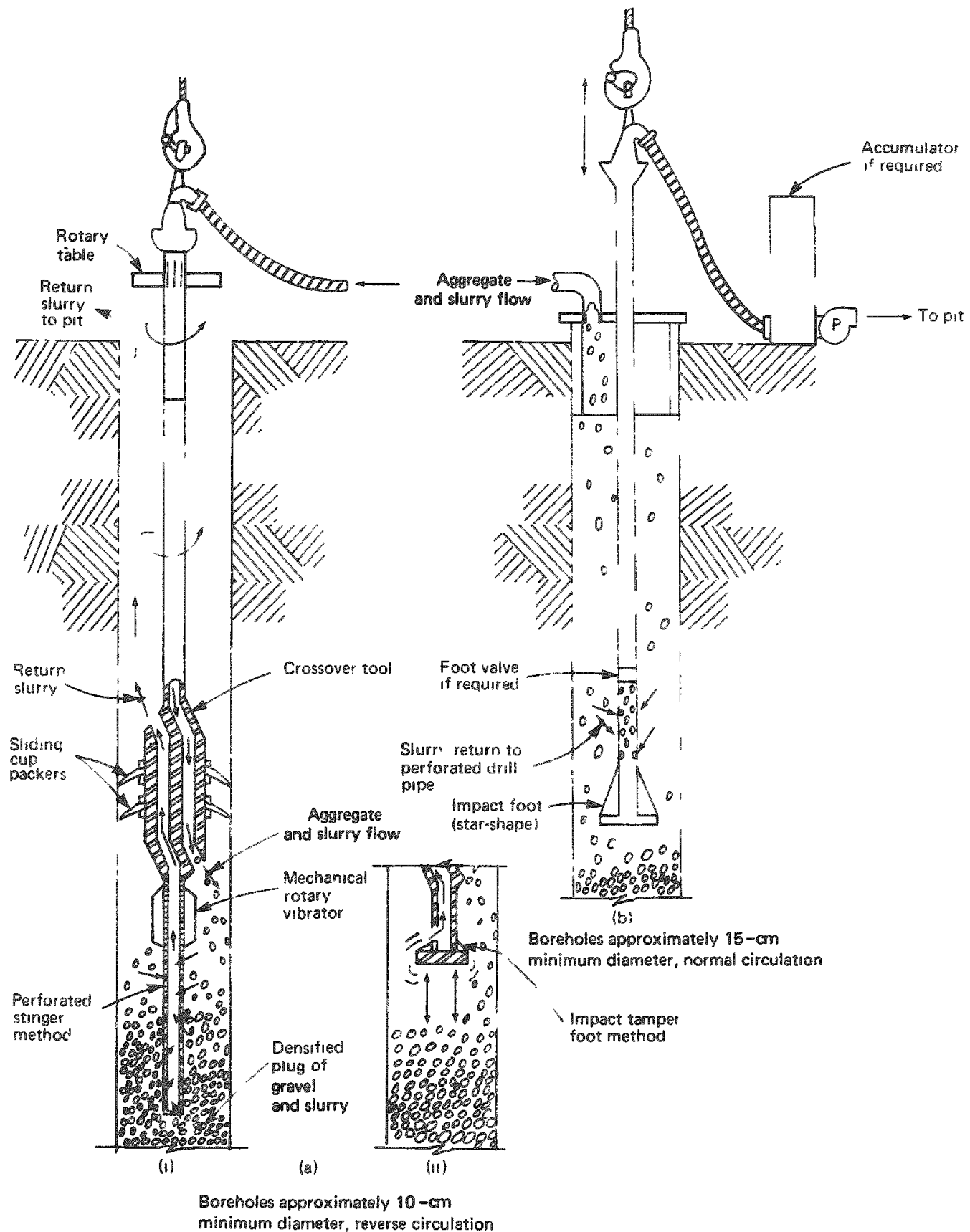

FIGURE 3-33. Boreholes from the Surface. 


\begin{tabular}{|c|c|}
\hline Material & Equipment \\
\hline $\begin{array}{l}\text { Precompacted clay mixed } \\
\text { with sand and silt }\end{array}$ & As shown - R \& D concept \\
\hline
\end{tabular}
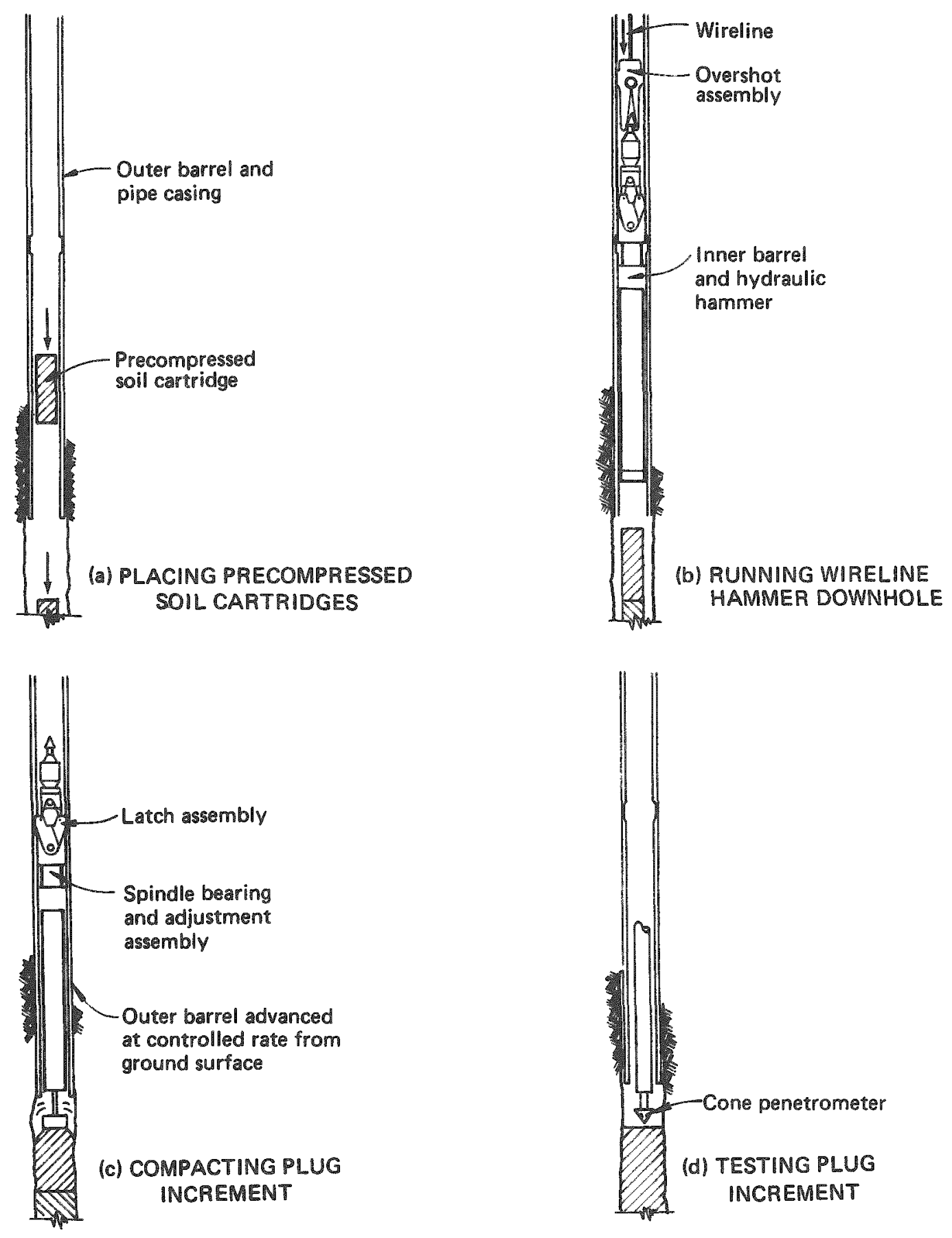

FIGURE 3-34. Boreholes Drilled from the Surface: Precompressed Soil Plug Scheme for Boreholes. 


\section{RHO-BWI -ST-7}

PLUG SYSTEM

\begin{tabular}{|c|c|}
\hline Materials & Equipment \\
\hline $\begin{array}{l}\text { Pracompacted copper powder } \\
\text { and phosphorous }\end{array}$ & As shown $-\mathrm{R}$ \& $\mathrm{D}$ concept \\
\hline
\end{tabular}

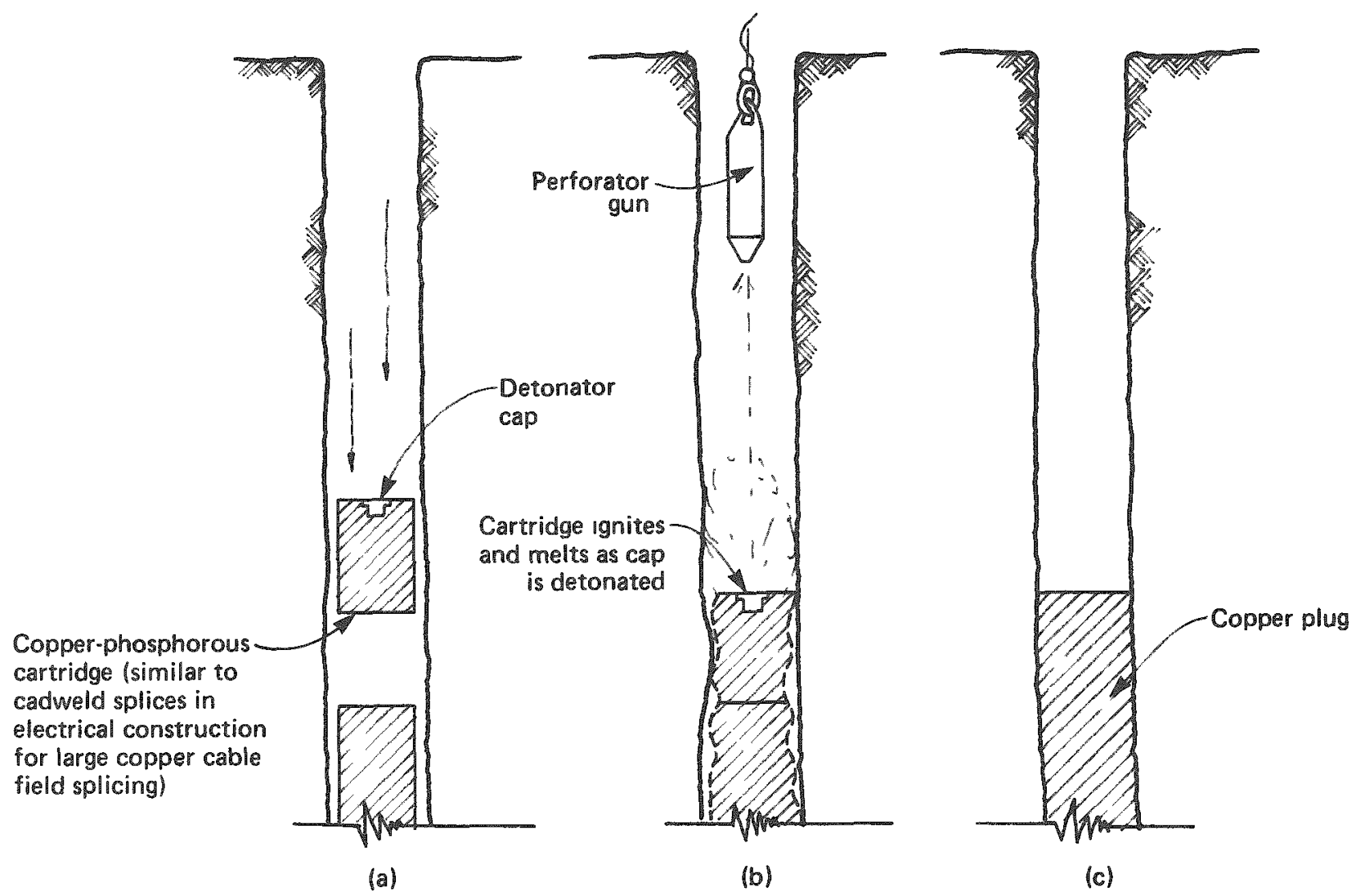

FIGURE 3-35. Boreholes Drilled from the Surface:

Copper Plug for Boreholes. 
One of the problems anticipated during shaft construction will be the protection of the workers during material feeding and compaction operations. Some sort of protective enciosure must be designed, such as that shown schematically in Figures 3-36 to 3-38. A second problem will be the sealing of the damaged basalt. Pressure grouting may only be a partial solution. The placement and compaction of either the slurry materials or the stiff clayey materials will be relatively straightforward. The slurry materials can be vibrated to produce a dense plugging material. Most of the compaction of the stiff materials can be done with small, self-propelled compactors. Compaction around the walls and into irregularities, such as cutoffs, will be done with hand-held power tampers. It should be noted that this is expected to be a difficult problem area.

The problems associated with boreholes originating underground will be similar to those encountered in the construction of plugs in boreholes originating at the surface. If the horizontal holes are inclined slightily downward, similar solutions to those used on surface holes can be employed. If the holes are inclined upward and a slurry mixture is selected, a packer would have to be used to prevent the slurry from running out of the hole. When boreholes do not extend long distances from man-sized work areas, a wider variety of materials and equipment can be utilized for plugging operations than is possible in boreholes that do extend for long distances. These holes can be plugged with either a pumped slurry or a stiff clayey mix. A placement scheme for the pump slurry is as shown in Figure 3-39. A schematic of the placement technique for the stiff clayey $\operatorname{mix}$ is shown in Figure 3-40. Also shown are the methods for material delivery. The compaction should be carried out in small increments, the specific size of which should be confirmed by field tests on the actual plug material using the actual compaction device.

Small tunnels are those for which it would be impractical to employ large tractor-driven rollers for the compaction of earthen materials because of the lack of headroom. In this case, earthen materials would be compacted with small, self-propelled or hand-held power tampers. Concrete-type materials could be used, and a medium-size pump system 


\begin{tabular}{|l|l|}
\hline Materials & Equipment \\
\hline $\begin{array}{l}\text { Clay/sand mixture (with or without } 10 \mathrm{~mm} \\
\text { aggregate pelleted bentonite) }\end{array}$ & $\begin{array}{l}\text { Small compactors } \\
\text { Working platform } \\
\text { Wireline delivery system }\end{array}$ \\
\hline
\end{tabular}

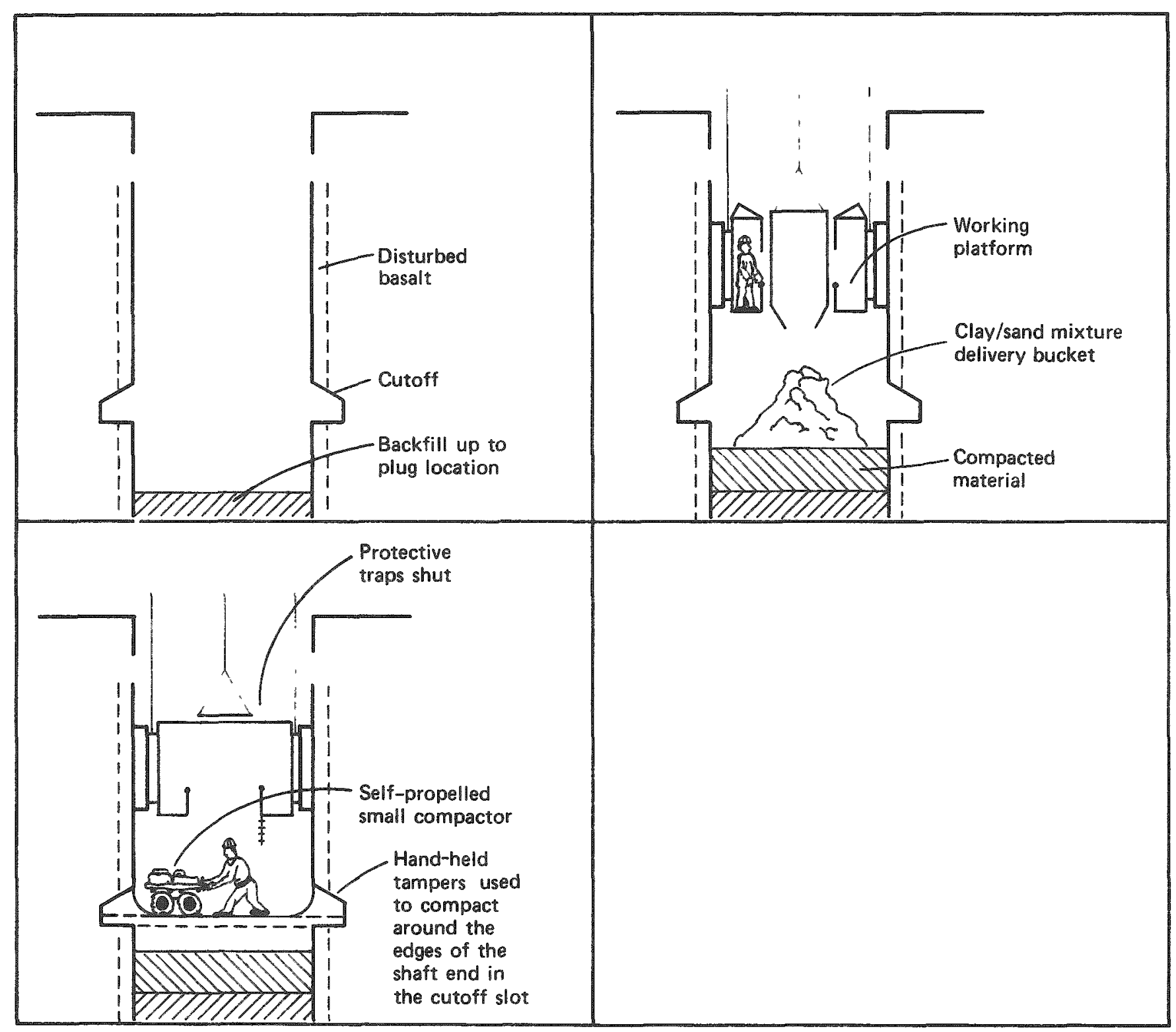

FIGURE 3-36. Stiff Clay/Sand Plug for Shafts. 
RHO-BWI-ST-7

\section{PLUG SYSTEM}

\begin{tabular}{|c|c|}
\hline Materials & Equipment \\
\hline Concrete with $75-\mathrm{mm}$ or $10-\mathrm{mm}$ aggregate & $\begin{array}{l}\text { Concrete wireline system } \\
\text { Working platform }\end{array}$ \\
\hline
\end{tabular}

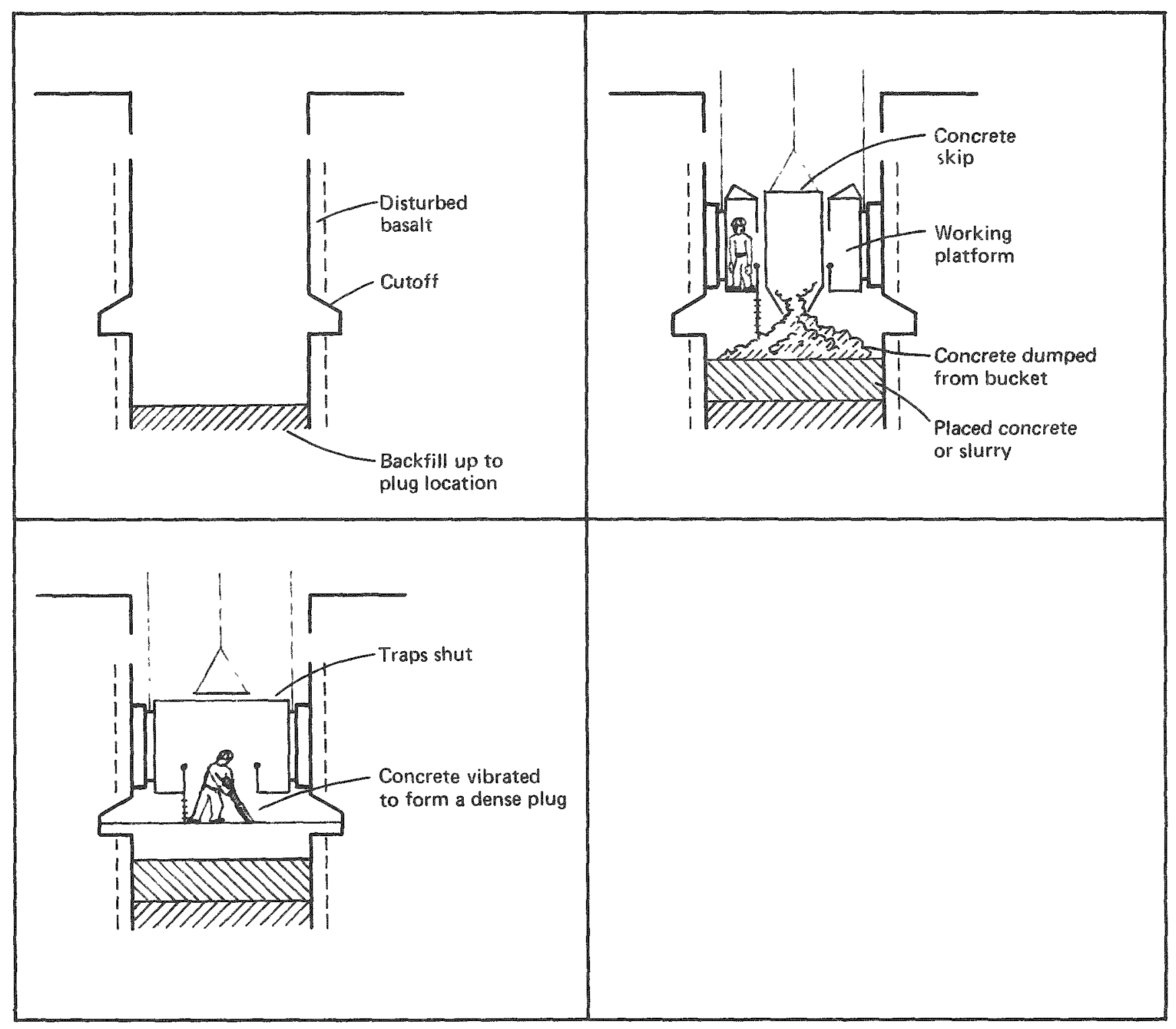

FIGURE 3-37. Concrete Plug (1) for Shafts. 
RHO-BWI-ST-7

PLUG SYSTIM

\begin{tabular}{|c|c|}
\hline Materials & Equipment \\
\hline $\begin{array}{l}\text { 75.mm or 10-mm } \\
\text { aggregate concrete } \\
\text { Cement slurry } \\
\text { Clay slurry }\end{array}$ & $\begin{array}{c}\text { Concrete pump } \\
\text { Working platrorm }\end{array}$ \\
\hline
\end{tabular}

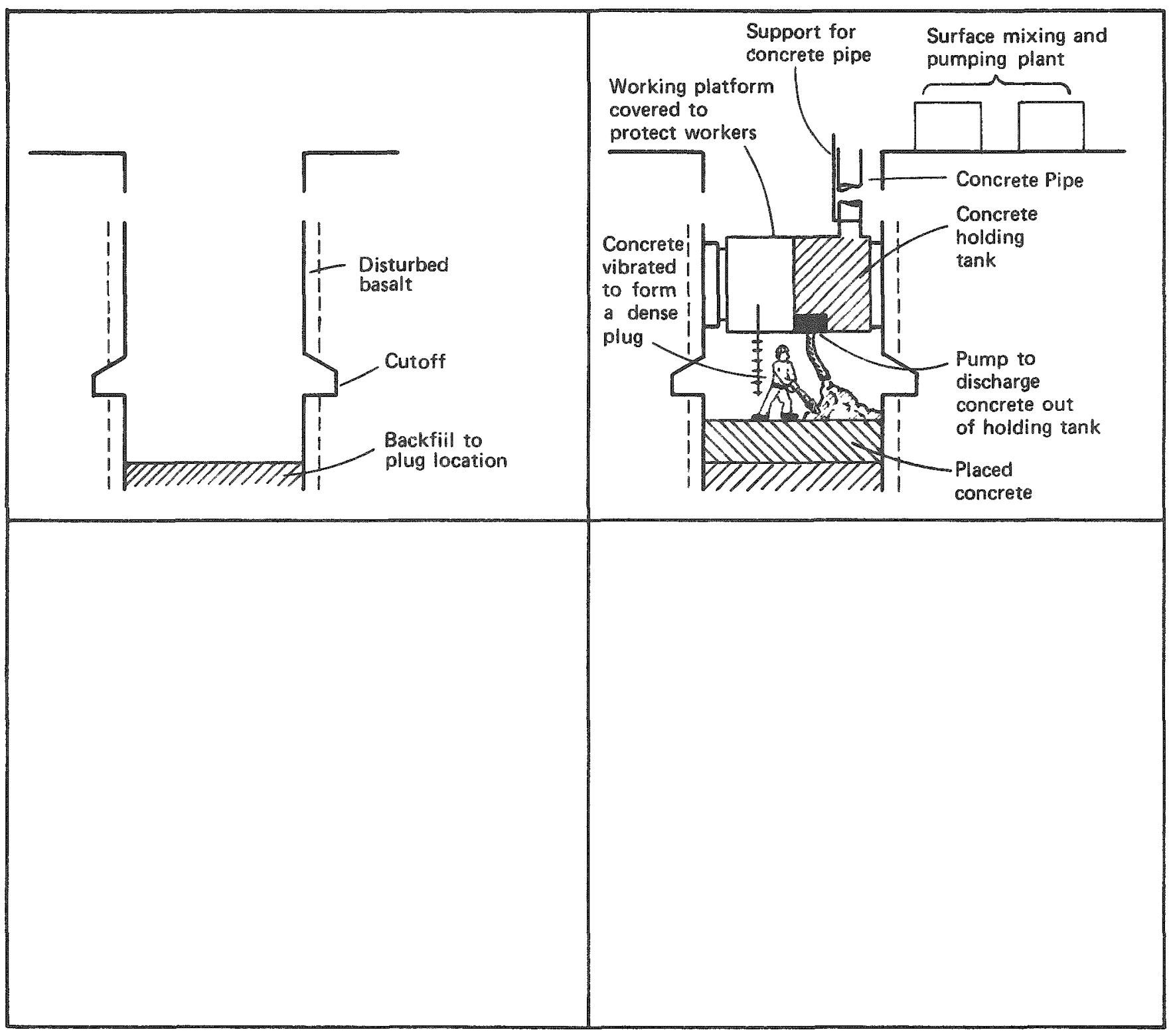

FIGURE 3-38. Concrete Plug (2) for Shafts. 


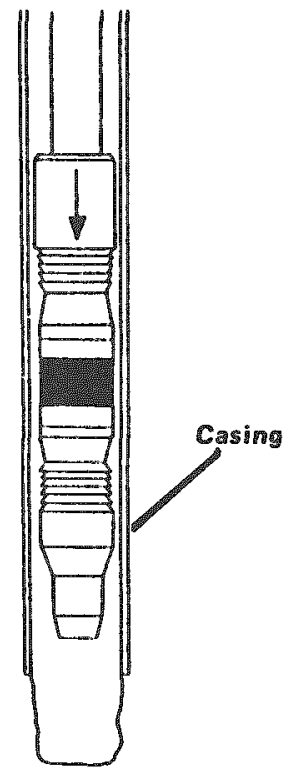

(A)

Cement retainer run down to the bottom of the hole
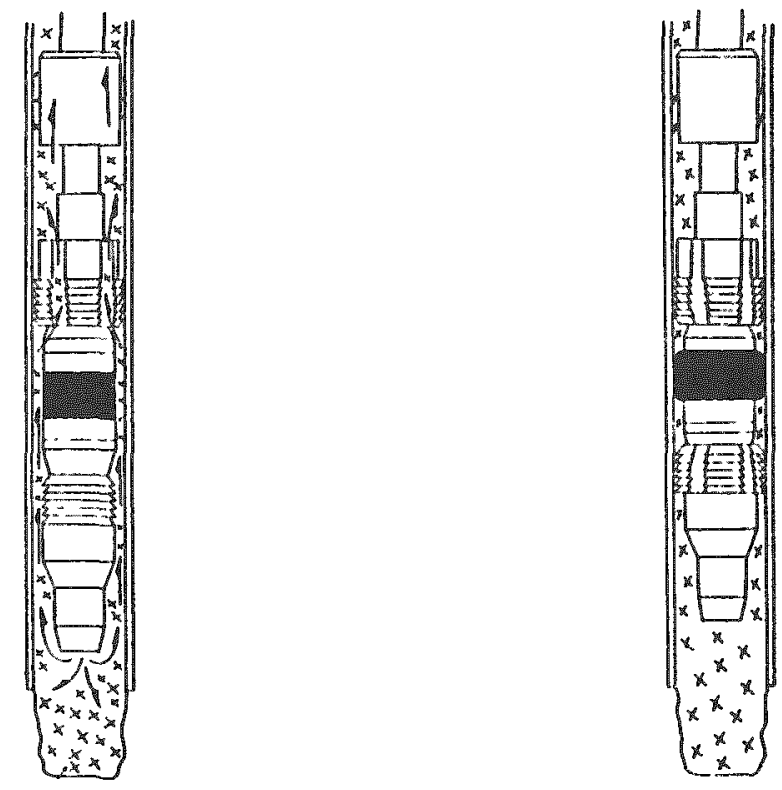

(B)

(C)

Grout pumped down and around retainer
Retainer retracted to its final setting depth

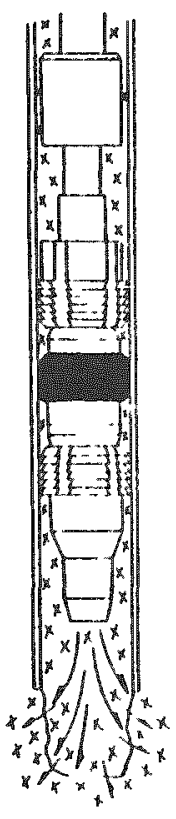

(D)

Reteiner set and the grout pressured into the rock fissures

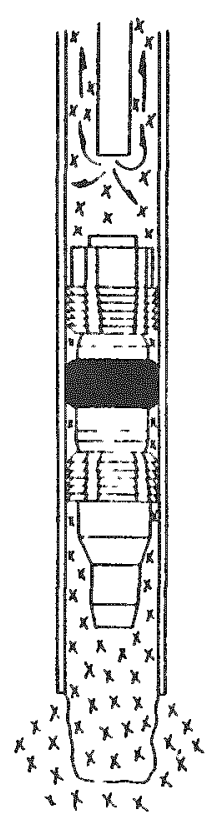

(E)

Tubing removed leaving the retainer

FIGURE 3-39. Boreholes Drilled from the Surface: the Use of a Cement Retainer Plug in Cased Hole. 


\begin{tabular}{|c|c|}
\hline Materials & Equipment \\
\hline $\begin{array}{l}\text { Stiff clavey material, with } \\
\text { or without } 10 \mathrm{~mm} \text { aggregate }\end{array}$ & $\begin{array}{l}\text { Hand-held power compactor } \\
\text { operated from tunnel jumbo, } \\
\text { or horizontal hammer tamper } \\
\text { as shown }-\mathrm{R} \& \mathrm{D} \text { concept }\end{array}$ \\
\hline
\end{tabular}

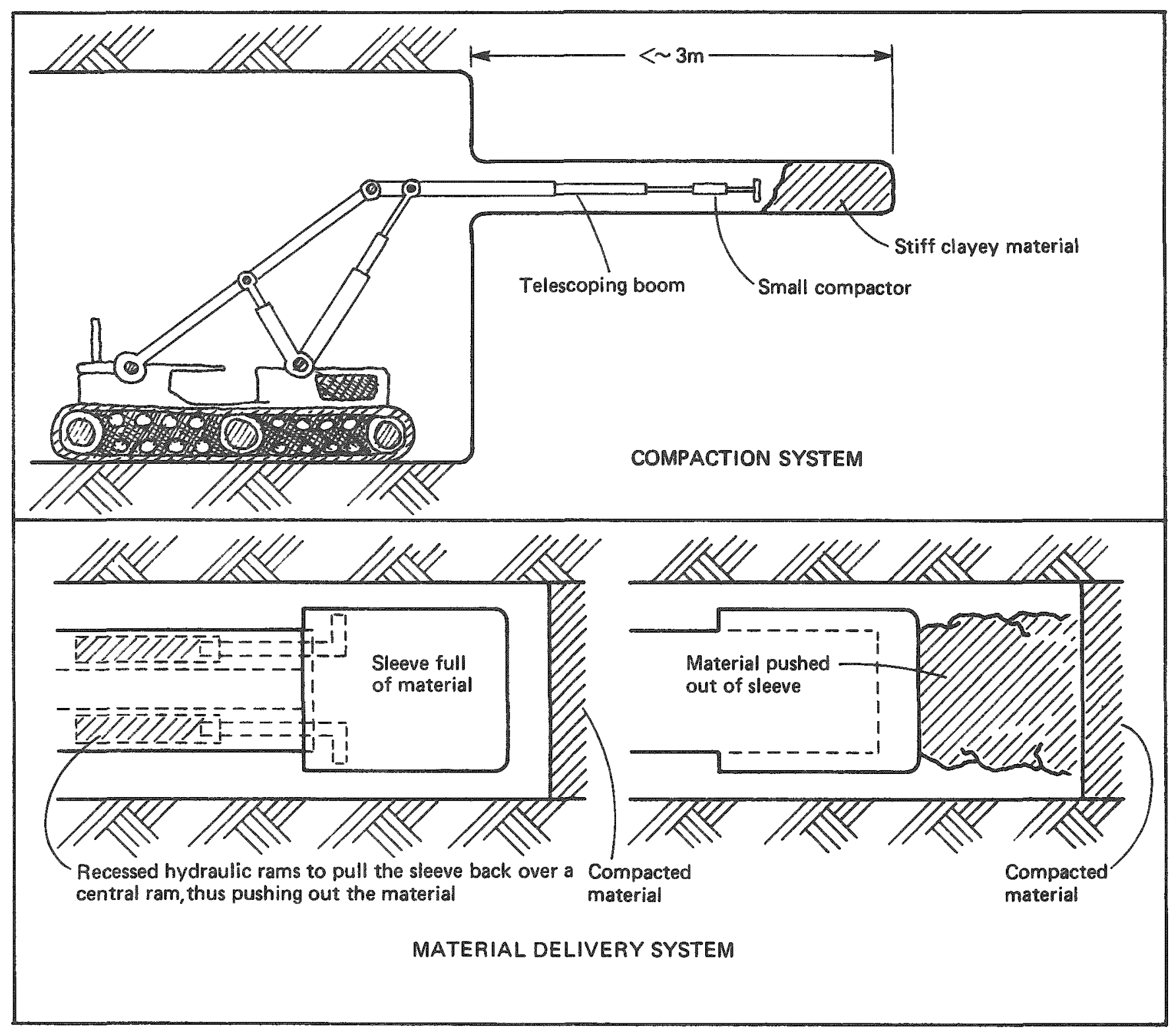

FIGURE 3-40. Boreholes Originating Underground (Plug near to Large Working Area). 
would be employed. Research and development work might demonstrate the feasibility of solid inclusion plugs, such as basalt and copper. The use of large rolling equipment is probably impractical for short, earthen plugs. These plugs, like those in small tunnels, could be constructed with smal1, hand-held power tampers. Again, concrete might be employed, or solid inclusion plugs might be feasible. For long-plugs, large, tractor-drawn, rolling equipment could be used effectively to construct the lower part of an earth plug. The upper part of the plug could be constructed in the same way as a small tunnel by using self-propelled or hand-held power tampers. If concrete is selected as the plug material, a large-scale concrete pump could be used, or solid inclusion plugs might be feasible.

It is anticipated that bulkheads wi11 sometimes be used as permanent material supports during plug construction. It is possible that the bulkheads will be made of a degradable material, but this will not necessarily affect the performance of the plug. The bulkheads will all be constructed perpendicular to the flow through the plug so they will not provide a path for seepage through the plug. The bulkheads can be constructed of materials that react with the plug environment to produce geochemically stable reaction products, such as aluminum, which occupy a volume that is equal to (or greater than) that volume occupied by the original material. These reaction products will be prevented from moving by the plug and by the structural backfill on either side of the plug, and consequently, no large voids will be created by the alteration of bulkhead materials, precluding any loss of structural support.

A11 of the schemes shown in the matrices and identified as "mostfeasible schemes" or "schemes considered possible at this time with little or no modification" are considered available plug schemes. Plug systems representative of the third category of relative capability are considered research and development schemes. The available monolithic plug schemes can be simply categorized in machine and material combinations (detailed later and illustrated in Fig. 3-36 to 3-49 alona with research and development schemes; preconceptual multiple-zoned plug schemes are illustrated in Fig. 3-50 to 3-54). 


\section{RHO-BWI-ST-7}

\section{PLUC SVITEM}

\begin{tabular}{|l|c|}
\hline Materials & Equipment \\
\hline $\begin{array}{l}10-\mathrm{mm} \text { aggregate in clay slurry } \\
10-\mathrm{mm} \text { aggregate in cement slurry } \\
\text { Clay slurry } \\
\text { Cament slurry }\end{array}$ & $\begin{array}{c}\text { Pumping equipment at surface } \\
\text { Mixing equipment at surface }\end{array}$ \\
\hline
\end{tabular}

(a) Plug placed at an intermediate (b) Plug placed at the position in the hole
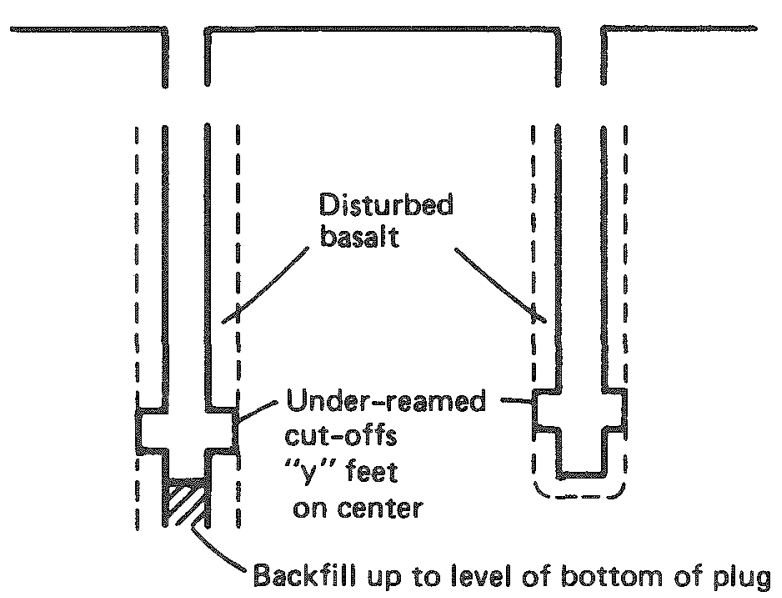

Pumping and mixing unit

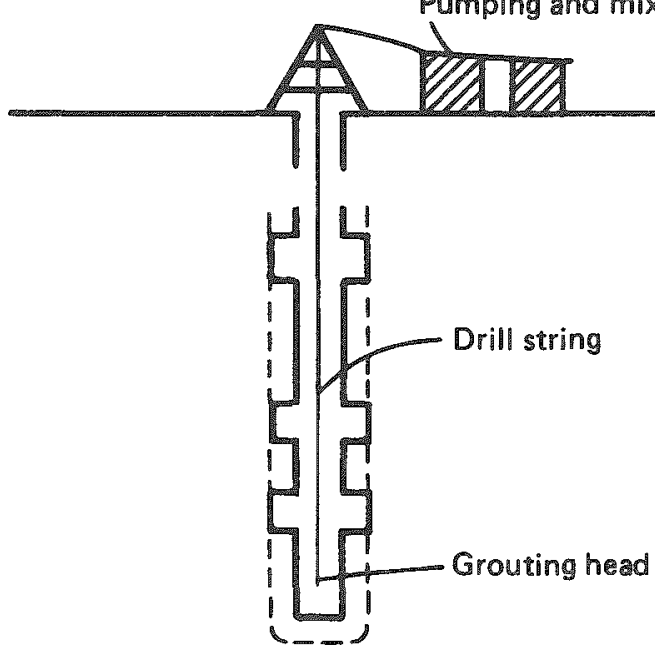

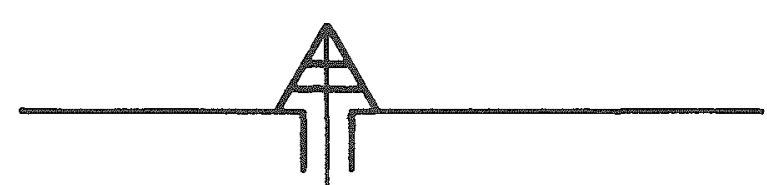

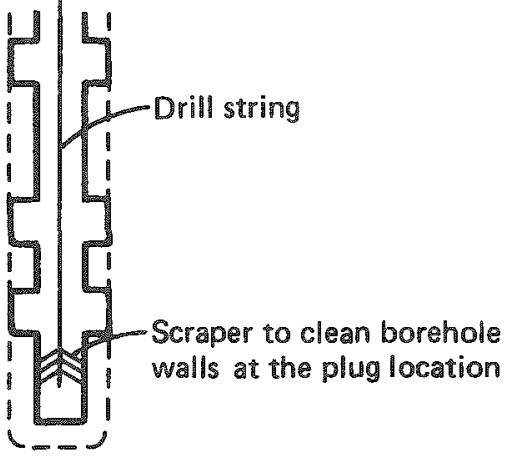

NOTE: Grouting sequence as shown on accompanying figure

FIGURE 3-41. Boreholes Drilled from the Surface. 


\section{PLUG SYSTEM}

\begin{tabular}{|c|c|}
\hline Materials & Equipment \\
\hline 10 -mm maximum aggregate in clay slurry mixture & Gravel-packing plant \\
\hline
\end{tabular}

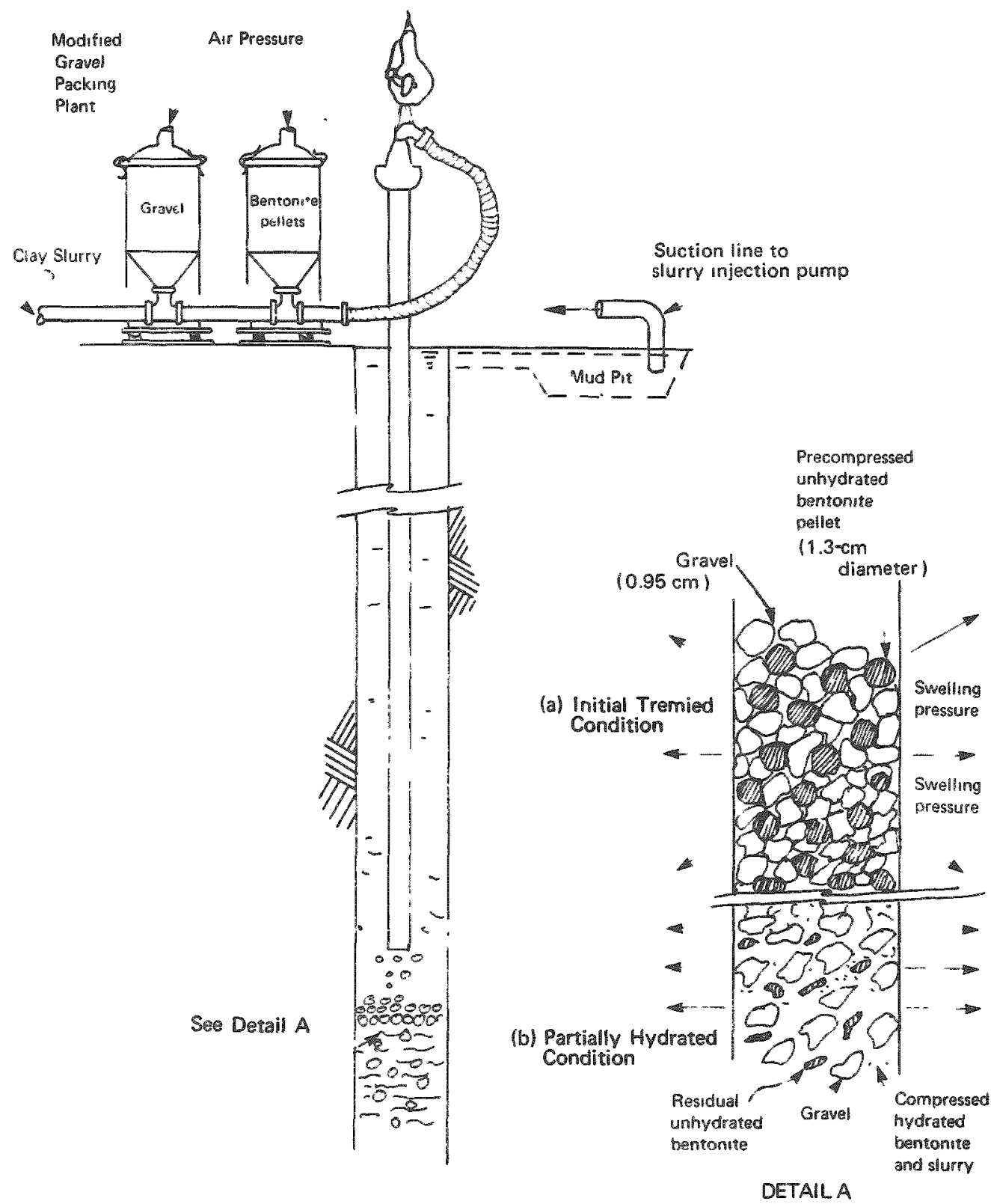

FIGURE 3-42. Boreholes Drilled from the Surface: Borehole Plug of Pre-Compressed Bentonite Pellets with Gravel Pack. 


\begin{tabular}{|c|c|}
\hline Materials & Equipment \\
\hline Basalt & $\begin{array}{l}\text { Rotary drill as shown, } \\
\text { P \& D concept }\end{array}$ \\
\hline
\end{tabular}

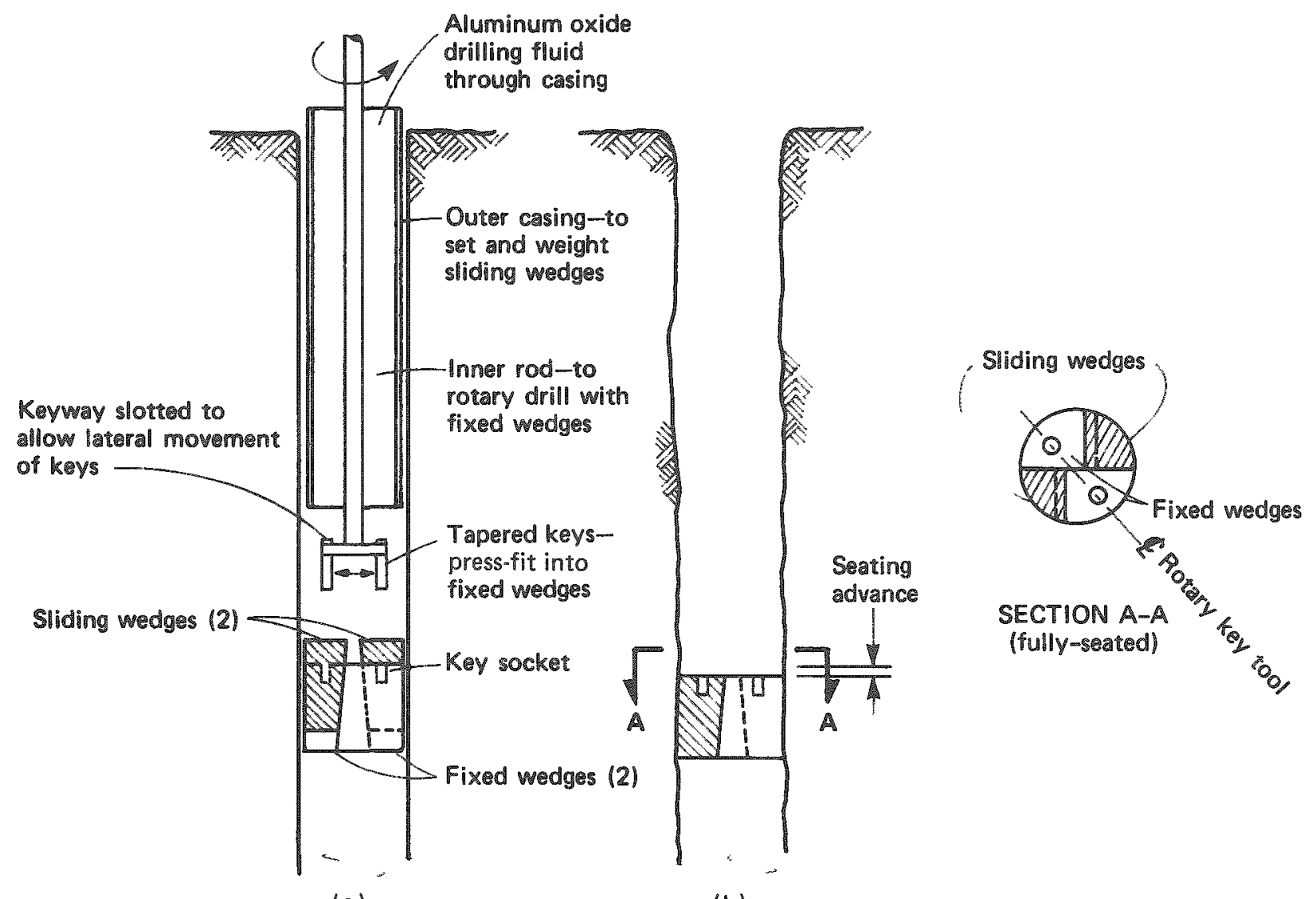

(a)

(b)

Exploded view of setting tools and plug; plug in retracted-diameter position.
Plug set and tools withdrawn, ready for inserting another plug in series.

(wedges shown in section)

FIGURE 3-43. Boreholes Drilled from the Surface: Basalt Plug for Boreholes. 


\section{PLUG SYSTEM}

Materials

Pelletized lead, lead alloys, or lead minerals:

copper, salt, sulfur, natural glass, or basalt fragments.
Equipment

As shown - R \& D concept

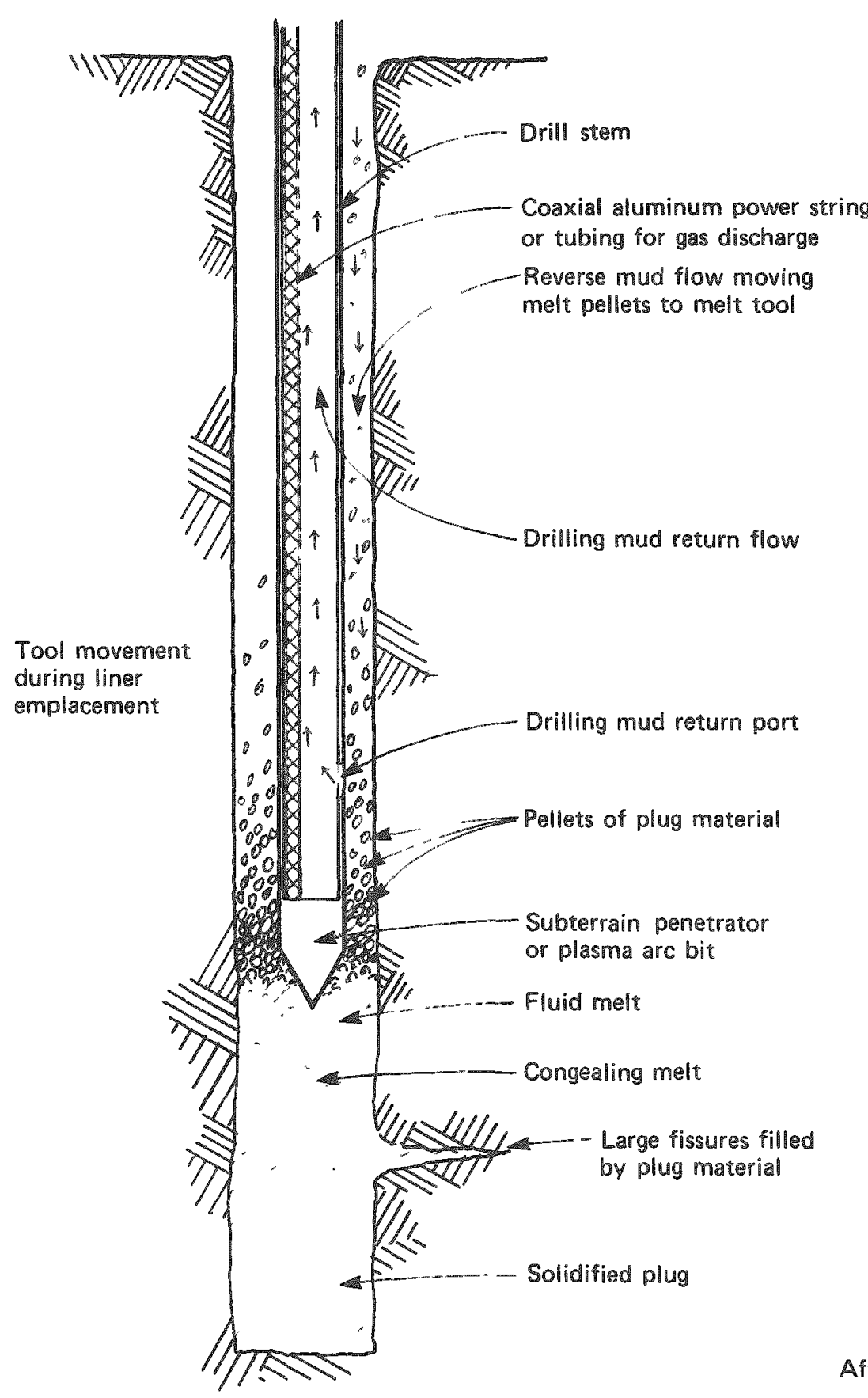

After Altsheimer (1976)

FIGURE 3-44. Boreholes Drilled from the Surface:

Continuous Melt Plug for Boreholes. 
RHO-BWI-ST-7

PLUG SYSTEM

\begin{tabular}{|c|c|}
\hline Materials & Equipment \\
\hline $\begin{array}{l}\text { Stiff clays (with or without } 10-\mathrm{mm} \text { aggregate) } \\
\text { Bentonite pellets }\end{array}$ & $\begin{array}{l}\text { Small compactors } \\
\text { Material feed system }\end{array}$ \\
\hline
\end{tabular}

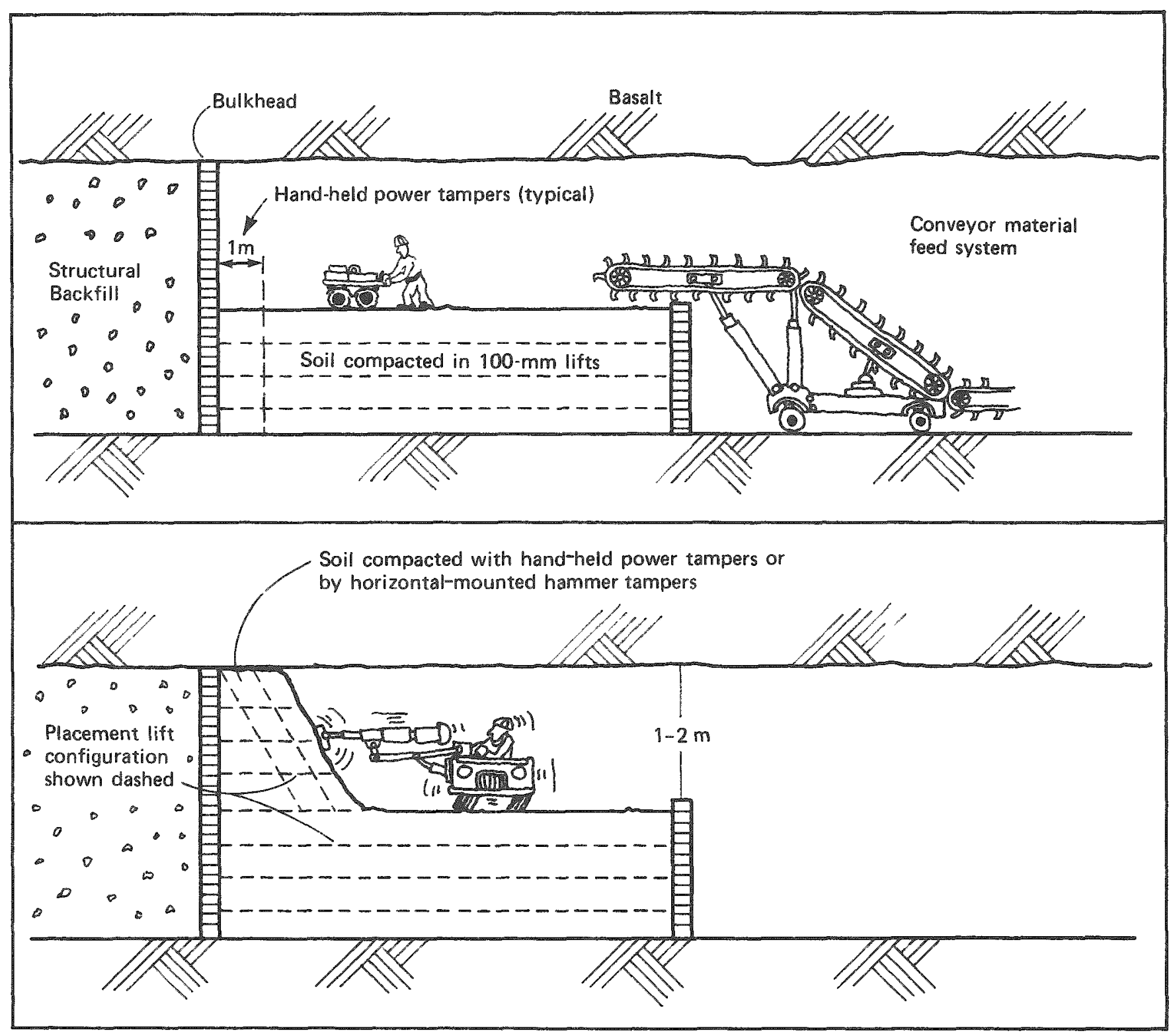

FIGURE 3-45. Smal1 Tunnel. 


\section{PLUG SYSTEM}

\begin{tabular}{|l|l|}
\hline Material & Equipment \\
\hline $\begin{array}{l}\text { Basalt block or precomposed bentonite blocks } \\
\text { with cemant or bentonite mortared joints }\end{array}$ & $\begin{array}{l}\text { Hand work } \\
\text { Material feed system }\end{array}$ \\
\hline
\end{tabular}

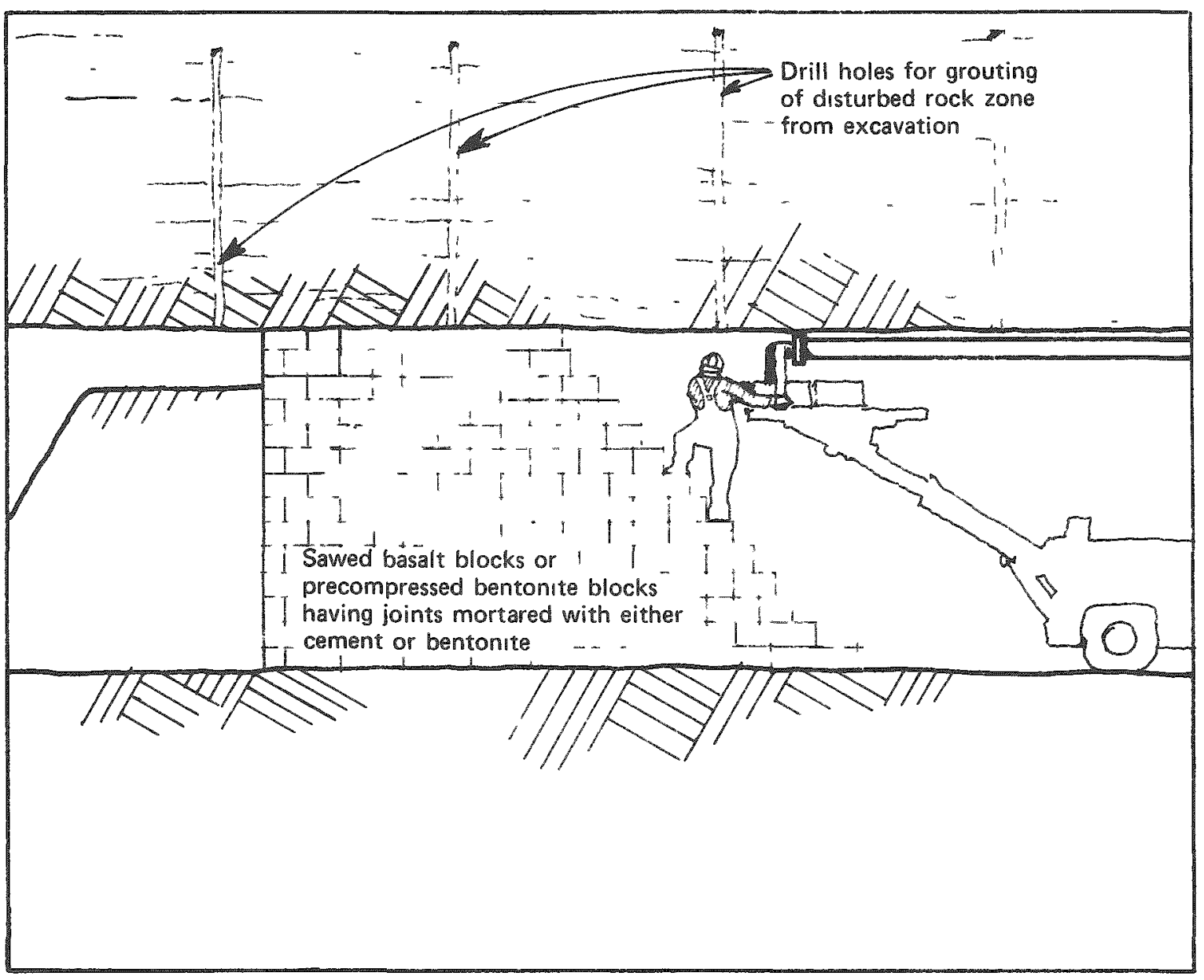

FIGURE 3-46. Masoned B lock Plugs for Tunnels. 


\section{PLUG SYSTEM}

\begin{tabular}{|l|c|}
\hline Materials & Equipment \\
\hline $\begin{array}{l}\text { Concrete with 10-mm or 75-mm aggregate } \\
\text { Clay slurry with 10-mm aggregate }\end{array}$ & Concrete pump system \\
\hline $\begin{array}{l}\text { Cement slurry } \\
\text { Clay slurry }\end{array}$ & Grout pump svstem \\
\hline
\end{tabular}

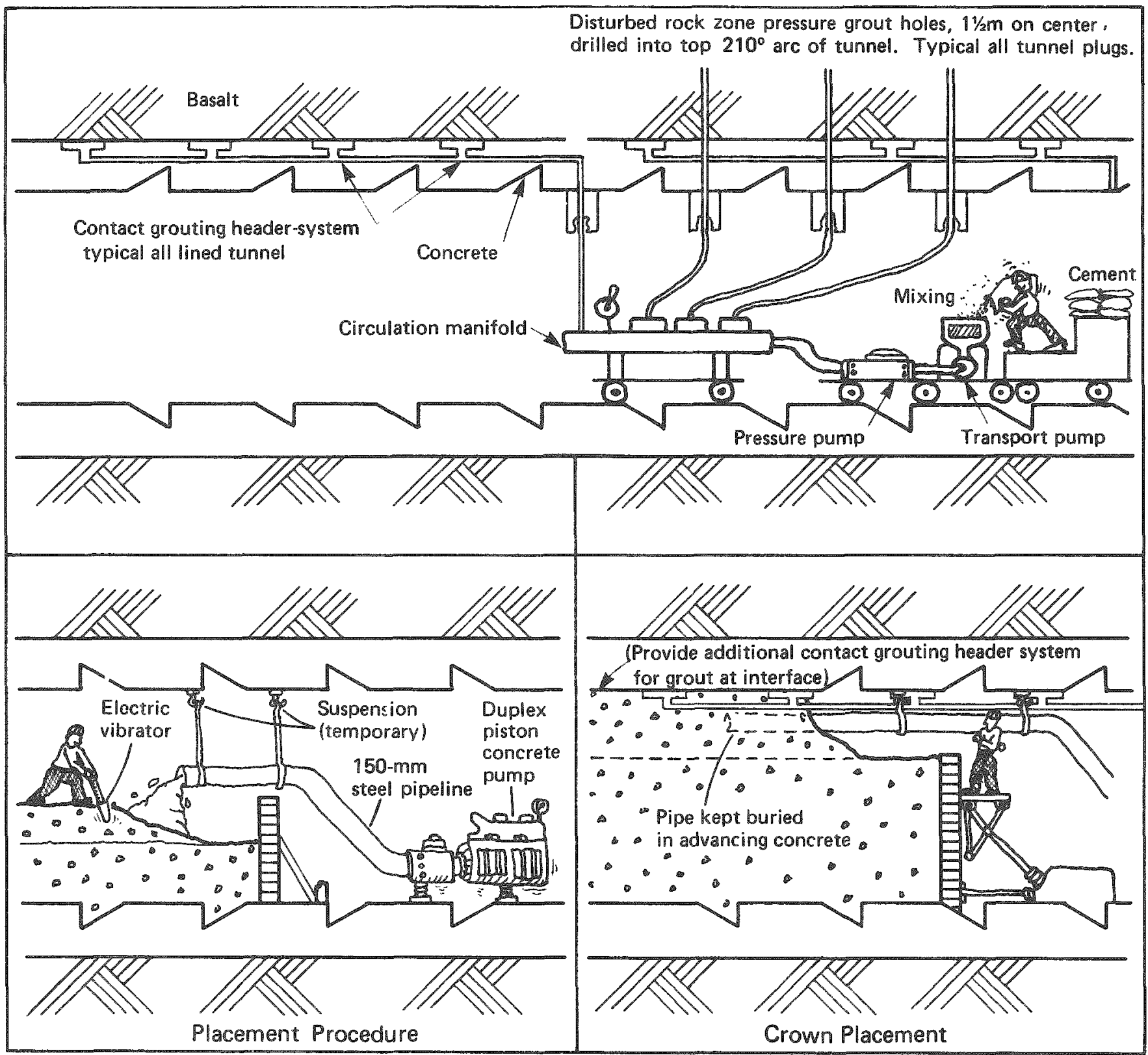

NOTES: The procedure for the placement of the concrete in an unlined tunnel will be similar to a lined tunnel. In case of soil plug (e.g.clay slurry with $10-\mathrm{mm}$ aggregate), no liner is left in tunnel wall rock. Pressure grouting of disturbed wall rock in this case may be with a clay grout and contact grouting will be with a clay slurry.

FIGURE 3-47. Large Tunne?. 


\begin{tabular}{|c|c|}
\hline Materials & Equipment \\
\hline Clay/sand mixture with or without aggregate & $\begin{array}{l}\text { Large earth rollers, supplemented with } \\
\text { small compactors and tampers }\end{array}$ \\
\hline
\end{tabular}

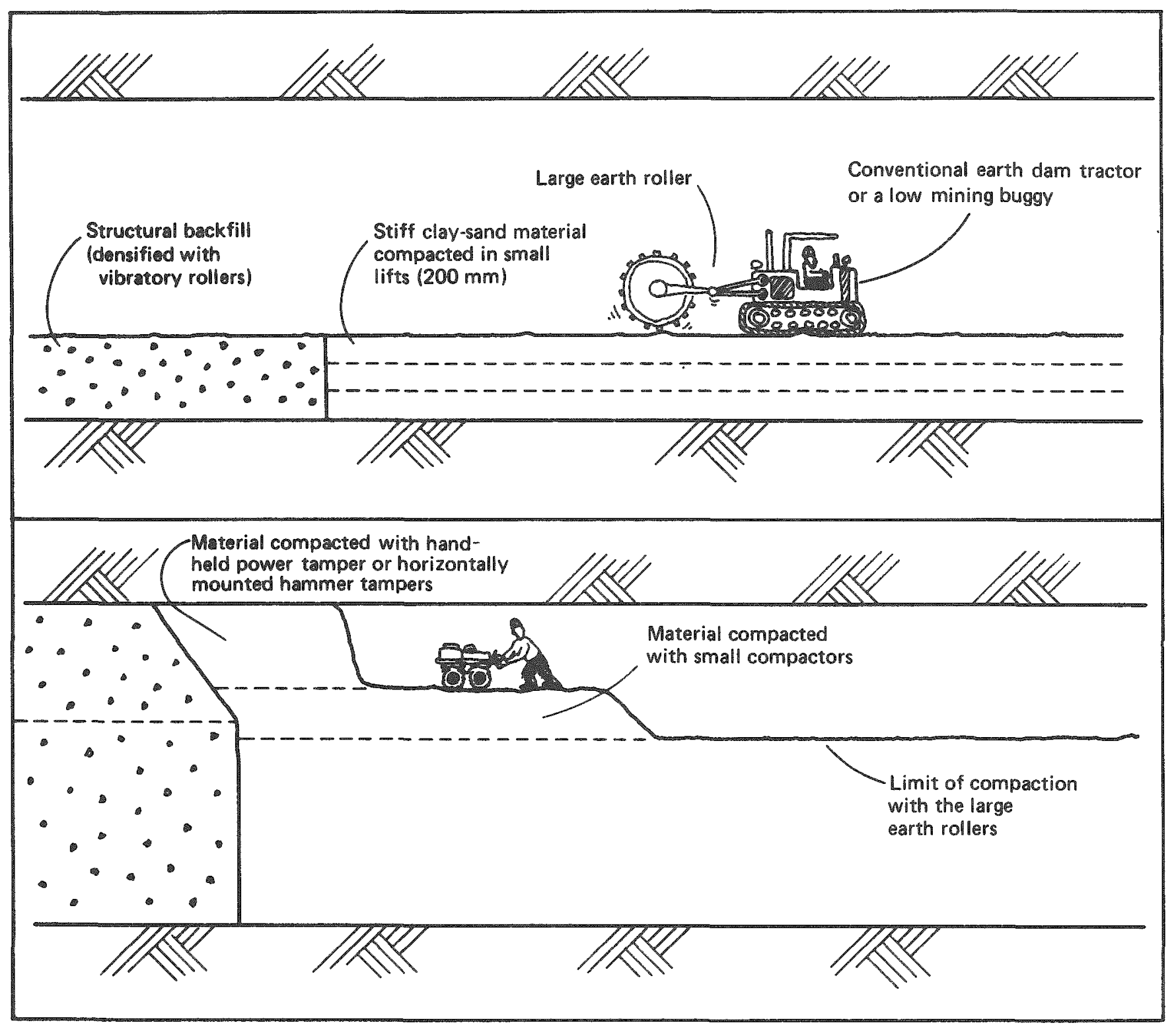

FIGURE 3-48. Large Tunnel with a Long Plug. 


\begin{tabular}{|c|c|}
\hline Material & Equipment \\
\hline Solid inclusion of basalt & As shown $-\mathbb{R}$ \& $\mathrm{D}$ concept \\
\hline
\end{tabular}

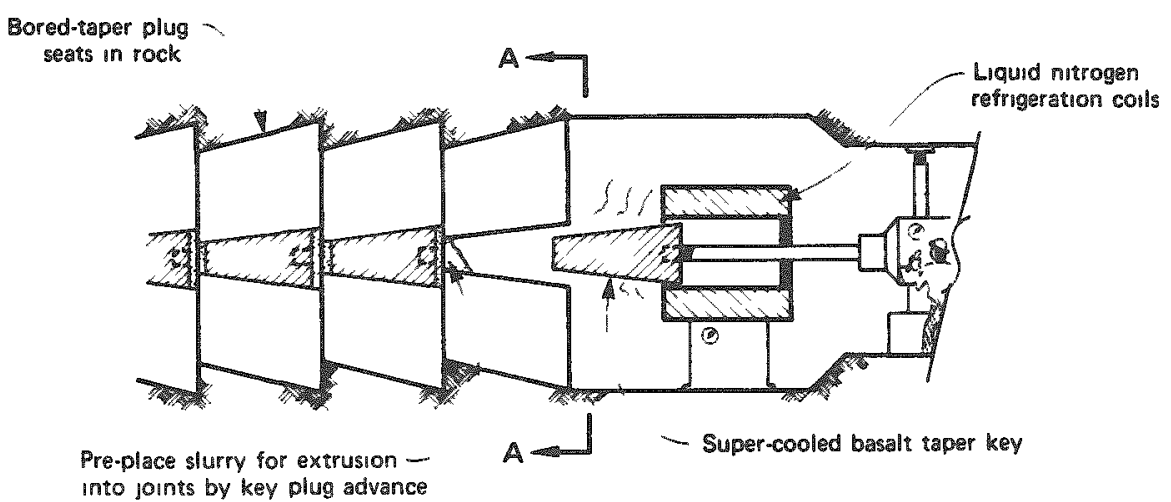

NOTES Basalt plug cylinder segments machined irom solid basalt

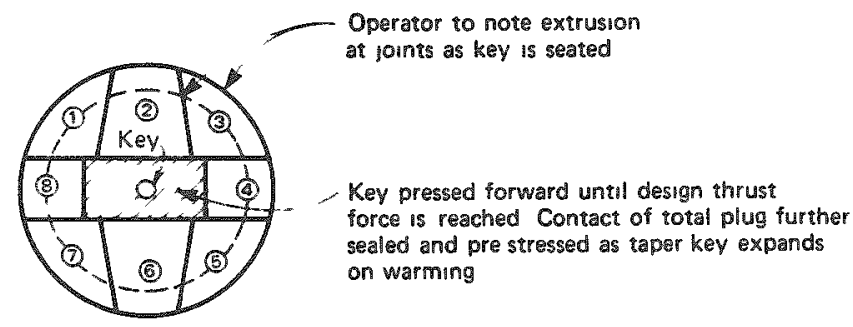

SECTIONA A

(a) CRYOGENIC PLUG

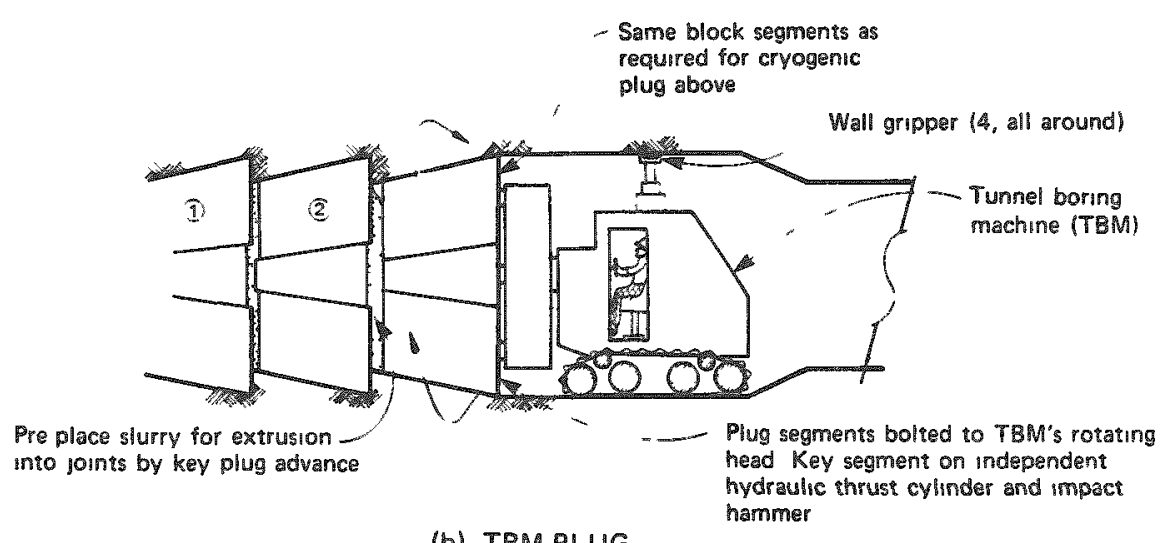

FIGURE 3-49. Solid Basalt Rock Plugs for Tunnels and Shafts. 


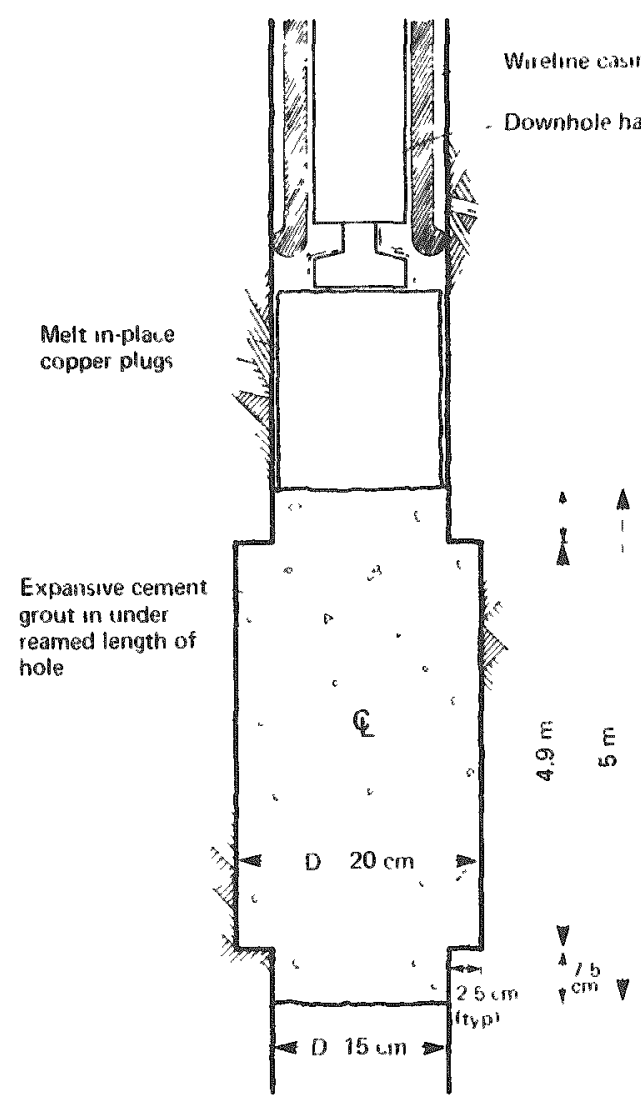

ITYPICAL PLUG INTERVALI

(a)
4 mounted in rotating mounted in rotel

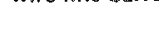

NOTES

The followng expermental dot al a neaded

Determine shrukage $A R$ for cylinder of copper couling trom molten state to ambient temperdure

2 Determine static or impact energy needed to expand copper cylender back to make cuntact with wall rock what should maximum iength of plug be between expanson intervals?

3. What wall stress is produced if a heat cycle of $200 \mathrm{C}$ maximum temperatur acts on the plug?

COPPER AND GROUT PLUG (BOREHOLES)

METAL SHOT AND GROUT PLUG

FIGURE 3-50. Multiple-Zone Metal and Cement Grout Plugs for Boreholes. 


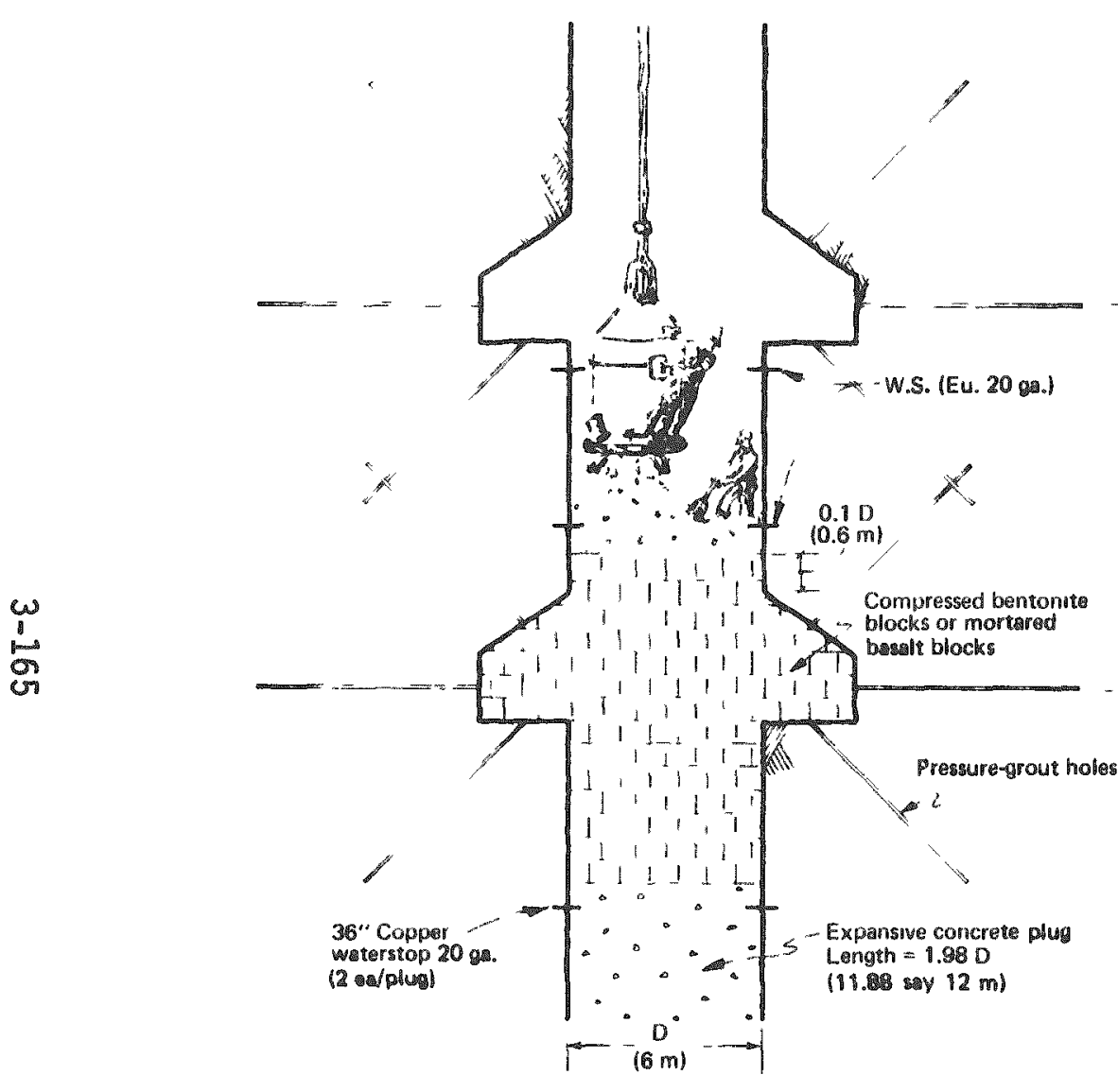

(a)

Multiple - Zone Concrete and Bentonite or Basalt Block Plug

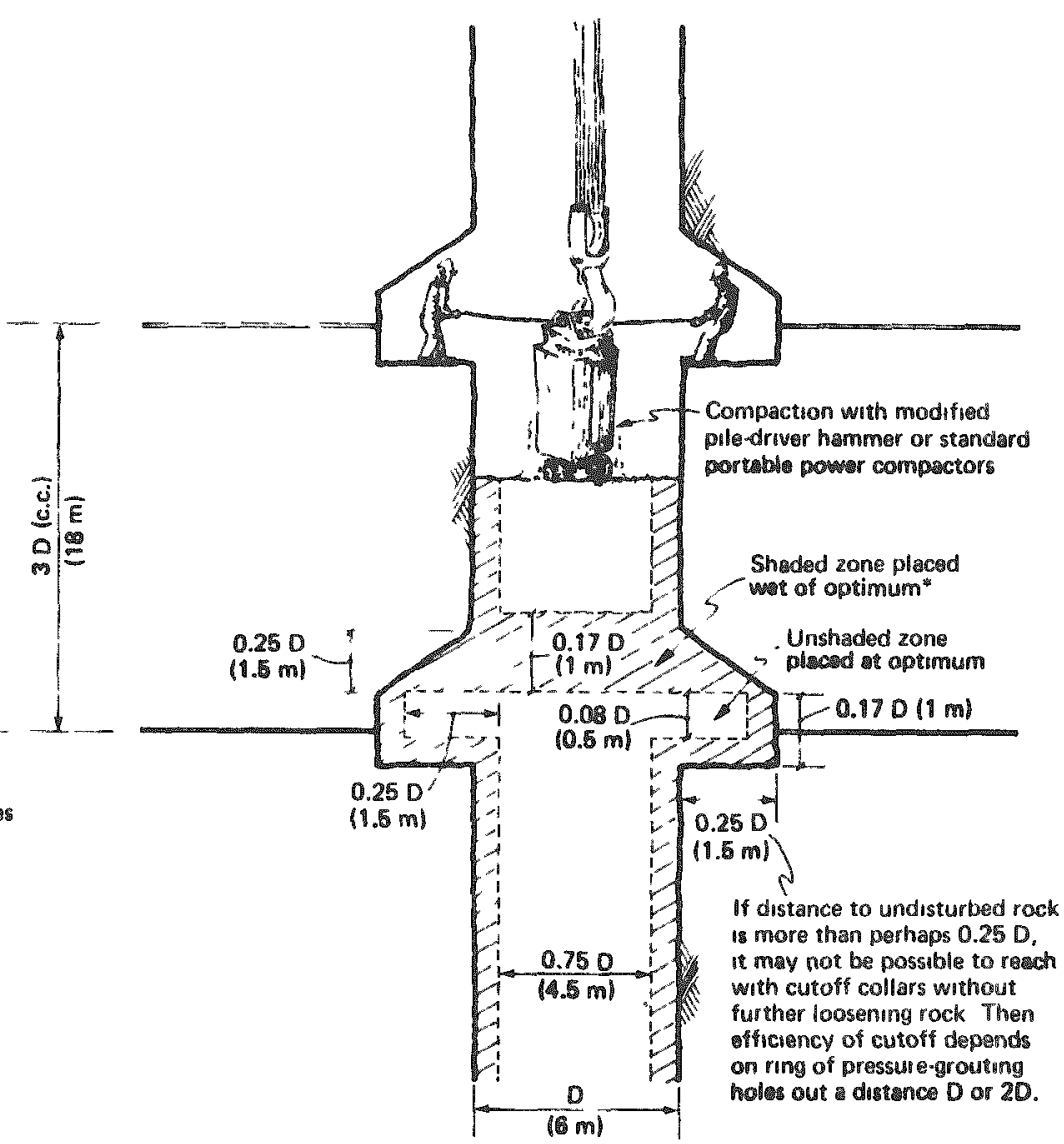

(b)

"Soil compacted at a monsture content in excess of that required to get maximum dry densty at a given offort

FIGURE 3-51. Multiple-Zone, Concrete and Block, and Zoned Earth Plugs. 


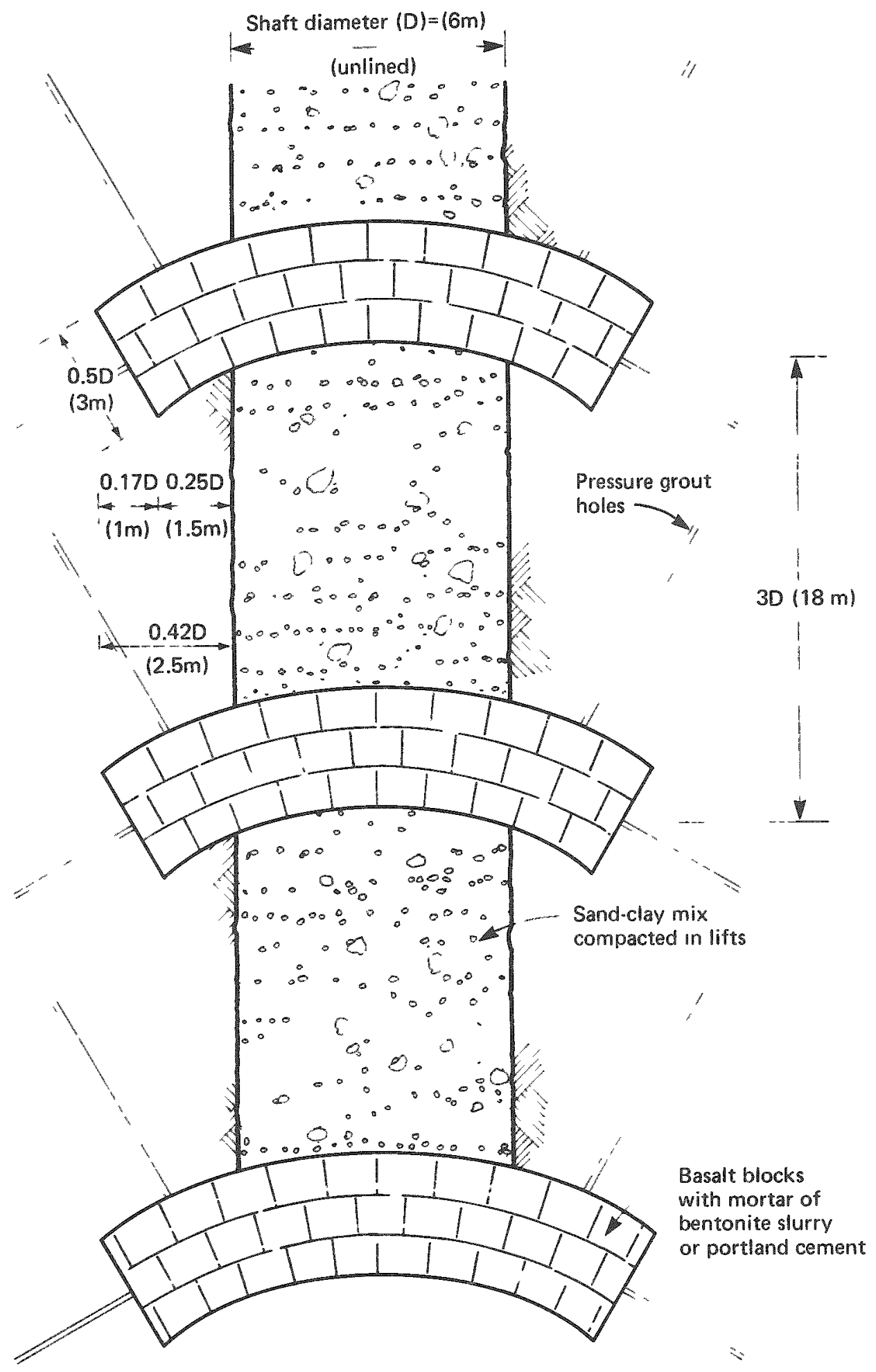

FIGURE 3-52. Multiple-Zone, Mortared Block Arch and Concrete Plug. 


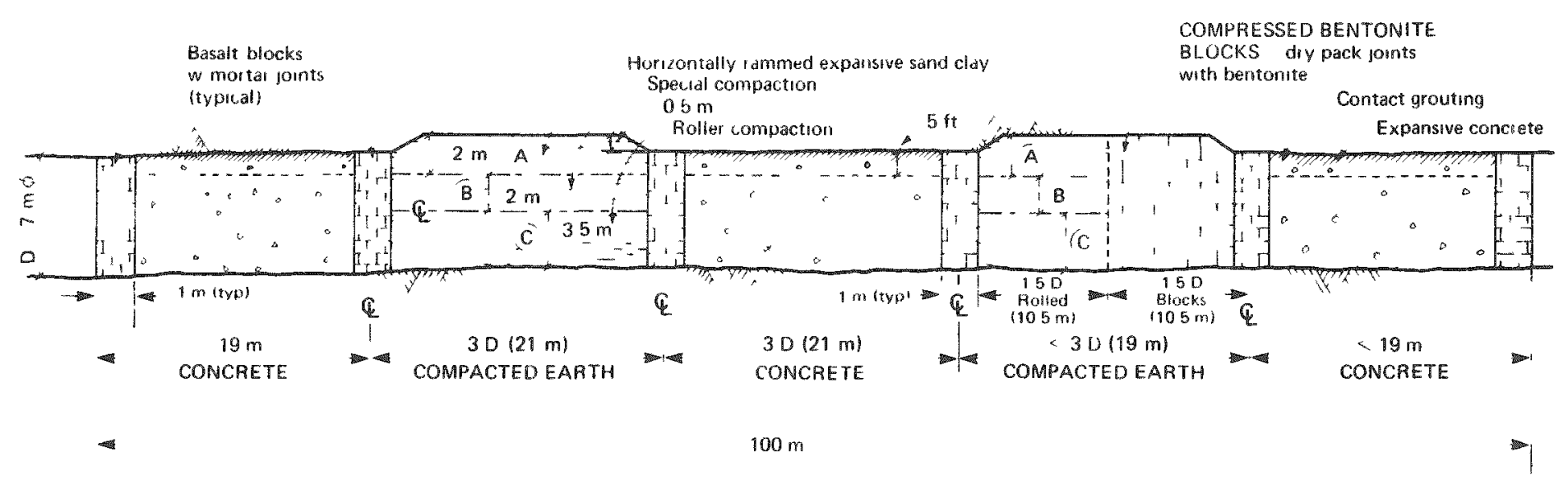

(a) Multıple zone, compacted soll/concrete plugs

$D=$ Tunnel diameter $=7 \mathrm{~m} \phi$ (unlined)

$\stackrel{\omega}{\stackrel{2}{2}}$

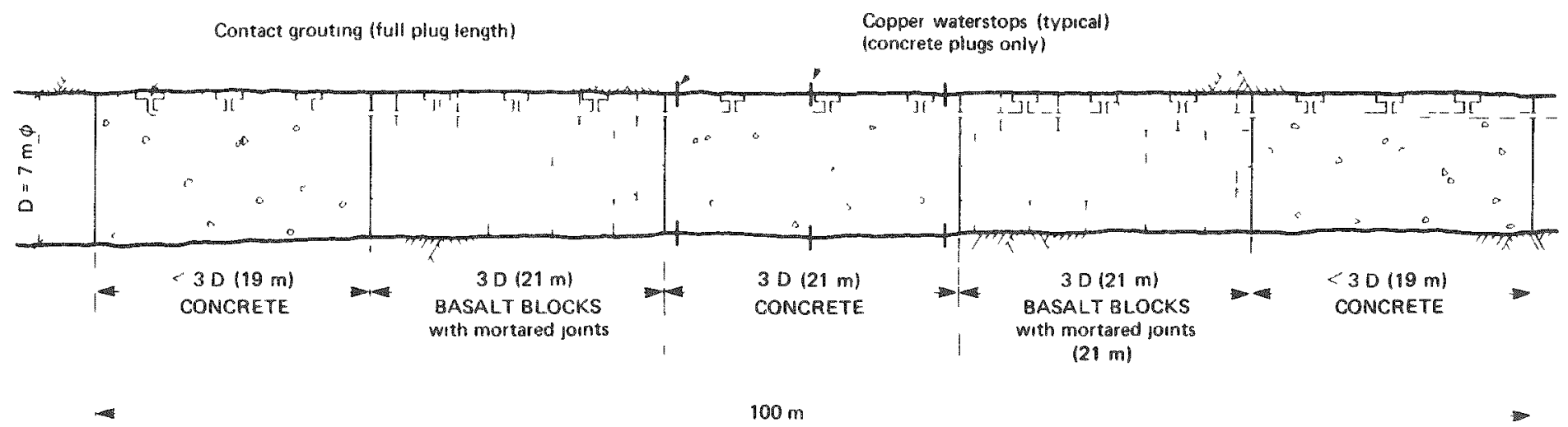

(b) Multiple-zone, basalt blocks/concrete/soil plug

FIGURE 3-53. Multiple-Zoned Plugs for Tunnels. 


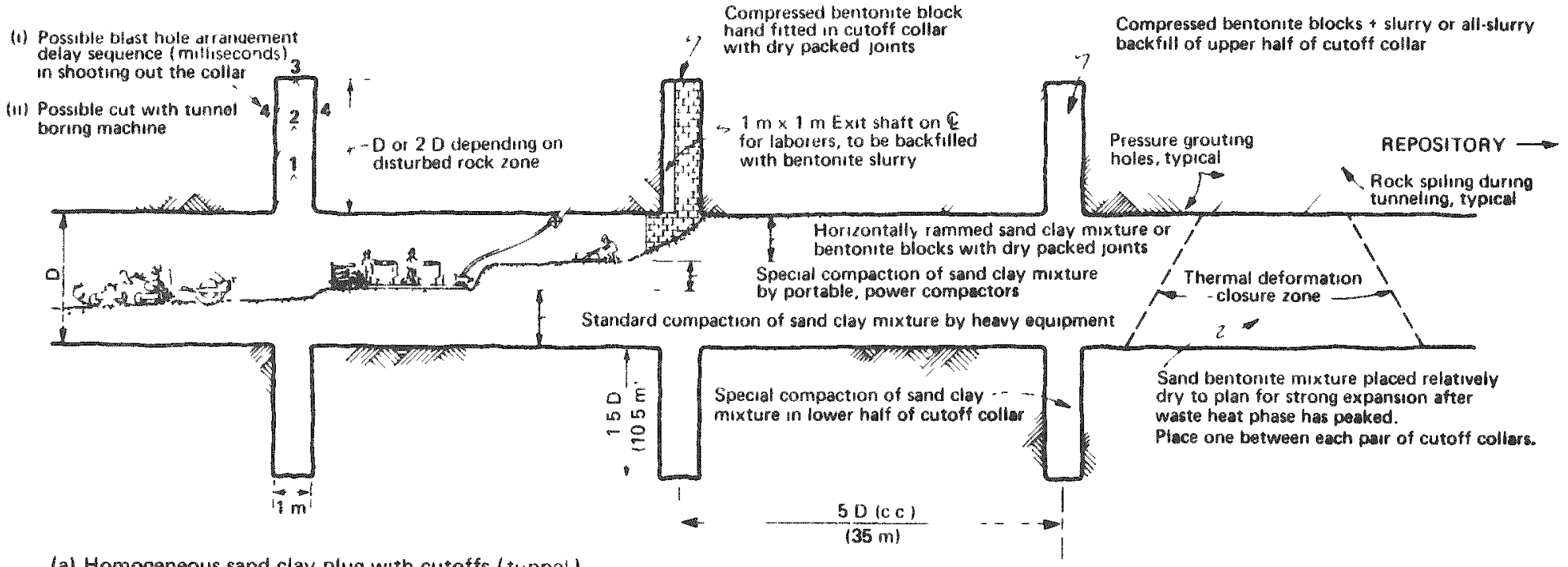

(a) Homogeneous sand clay plug with cutoffs (tunnel)

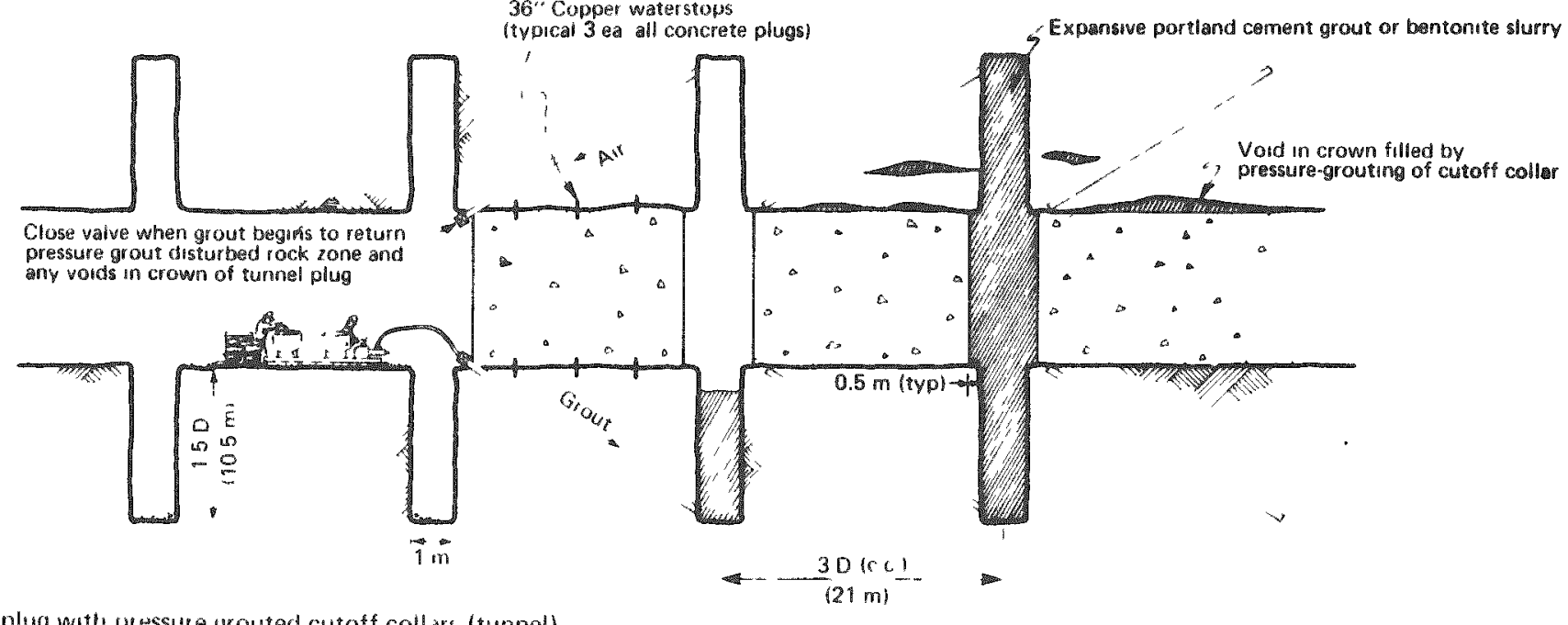

FIGURE 3-54. Multiple-Zoned Pluas with Cutoffs for Tunnels. 
- Boreholes originating at the surface
(a) $10 \mathrm{~mm}$ aggregate in a clay slurry
(b) $10 \mathrm{~mm}$ aggregate in a cement slurry
Placement System
Concrete pump
(c) Cement slurry
(d) Clay slurry
(e) Clay slurry with or without pea grave1
Concrete pump
Grout pump
Grout pump
Reverse or normal
circulation mud

- Shafts (Fig. 3-36 to 3-38, and Fig. 3-49)
Materials
(a) $75 \mathrm{~mm}$ or $10 \mathrm{~mm}$ aggregate concrete
(b) $75 \mathrm{~mm}$ or $10 \mathrm{~mm}$ aggregate concrete
(c) Clay slurry
(d) Cement slurry
(e) Stiff clay (with or without $10 \mathrm{~mm}$ aggregate)
(f) Pelleted bentonite and aggregate
Placement System Wireline/vibration Concrete pump/ vibration
Grout pump
Grout pump
Wireline/small compactors Wireline/smal1 compactors

- Borehole Originating Underground

i) With the plug at a distance from a larger working area (Fig. 3-33 to $3-44$ )
Materials
(a) $10 \mathrm{~mm}$ aggregate in a clay slurry
(b) $10 \mathrm{~mm}$ aggregate in a cement slurry
(c) Cement slurry
(d) Clay slurry
Placement System
Concrete pump
Concrete pump
Grout pump
Grout pump
ii) With the plug near a larger working area
(Fig. 3-33 to 3-44)
(a) As for i) Materials
(b) Stiff clay (with or without
$10 \mathrm{~mm}$ aggregate)
(c) Pelleted bentonite and aggregate
Placement System
Small compactor mounted on a jumbo
Small compactor mounted on a jumbo

- Tunnels (Fig. $3-45$ to $3-47$ and Fig. 3-49)

i) Small Tunnels
Materials
(a) $75 \mathrm{~mm}$ or $10 \mathrm{~mm}$ aggregate concrete
(b) Clay slurry
Placement System Concrete pump vibration Grout pump


(c) Cement slurry Grout pump

(d) Stiff clay (with or without Small compactors $10 \mathrm{~mm}$ aggregate)

iia) Large tunnels with short plugs (Fig. $3-45$ to $3-47$ and Fig. 3-49)

(a) Same as for i) $(a-d)$

Placement System

iib) Large tunnels with long plugs (Fig. 3-46 to 3-49)

(a) Same as for i) (a-d)

(b) Stiff clay with aggregate

up to $75 \mathrm{~mm}$

Placement System -.---Large rolling equipment

The preconceptual multiple-zoned plug schemes, Figures 3-50 to 3-54, represent various combinations of the monolithic plug schemes illustrated in Figures 3-33 to 3-49.

The available schemes devised and discussed in this report must be recognized as being preconceptual and in need of analytical and field demonstration of their viability. Some of the schemes, such as the placing of concrete plugs in large-diameter lined tunnels, are conventional civil construction methods that are closely akin to the anticipated operation needed for waste isolation plugs. However, the materials and performance specifications for the latter are much more demanding and the enviroment is more difficult. Experience with earthmoving and with compaction processes developed for engineered filts lends some level of confidence toward the viability of these schemes for waste isolation plugging: however, the technology transfer to the constricted space and difficult environment of basalt borehole plugging is an order of magnitude more uncertain than for concrete plugs.

\subsubsection{Analysis of Plugging Schemes}

The numerous preconceptual plugging schemes identified in Section 3.6.1 were developed with a general knowledge of the problems that could arise during various stages of plug design, construction, and performance. 
Implicit in the development of these schemes was the assumption that, among the schemes, acceptable ones could be chosen for plugging boreholes, shafts, and tunnels. Acceptable plugs would be those that could be shown, by analysis, to satisfy the criteria of core barrier performance, plug-wall rock interface performance, support performance, disturbed zone performance, and long-term integrity. By incorporating various aspects of plug design, construction, and costs into these performance criteria, a comprehensive evaluation of the acceptability of the preconceptual plugging schemes has been made.

Three approaches were used in evaluating the relative acceptability of the plugging schemes. The first approach, technical analysis, incorporated numerical and probabilistic analyses not only to evaluate the anticipated performance characteristics of the plugging schemes, but also to confirm the validity of the assumption that an acceptable plug could be chosen at a11. For the second approach, dominance analysis, rating matrices, and decision analysis techniques were used to rate the relative strengths and weaknesses of the plugging schemes. In the third approach, expert judgment, a questionnaire format was used to obtain the judgment of experienced evaluators relative to the feasibility and performance of the preconceptual plugging schemes. Finally, the results of these three analysis techniques were compared, major discrepancies were reconciled, and a consensus was reached as to the most acceptable plugging schemes.

In the absence of specific design criteria, engineering judgment was used to define the many design parameters, making possible a limited technical analysis of the preconceptual plugging schemes. It was determined that the most productive analysis could be performed by developing several different models to evaluate what are considered the most important aspects of plug design, such as thermal stresses in the plug, sliding stability of the plug, and water flow out of the repository. For each model, parameters (such as plug diameter hydrautic gradients along the plug, and plug rigidity) were assumed to be constant or varied over a limited range of values, since these could be estimated with the greatest degree of confidence. Using these models, it was 
possible to evaluate the effect of parameters, such as plug permeability, plug shear strength, and the zone of disturbed basait around the plug, such as plug length and the use of cutoff collars extending into the zone of disturbed basalt. Even though limited in scope, these models proved to be valuable for illustrating the plug design and construction parameters that will have the greatest impact on plug performance.

3.7.2.1 Design Criteria. For plug design, specific design criteria are useful to help identify the best plug configurations prior to the evaluation of the repository as a whole. It has been proposed that the plug be designated as Class I, II, and III*, defined roughily as follows:

- Class I: Primary barrier to flow of contaminated groundwater out of the repository; plug should be able to withstand the maximum design load and remain functional.

- Class II: Same capabilities as a Class I plug, but farther from the repository or back-up plug.

- Class III: Generally capable of reducing flow through boreholes and providing structural support.

These definitions are not sufficiently specific for engineering design, so identification of several design criteria for the preconcentual studies was made to facilitate design. These criteria are not necessarily recommended design limits; they are useful for selecting preferred candidate plugging schemes.

Three possible design criteria for flow that can be used in the design process:

- Allowable seepage through the plug, plug-basalt interface, and damaged wall rock. This approach would specify a maximum annual seepage rate. Note that any instability of the plug that causes

*These definitions are conceptualized after U.S. Nuclear Regulatory Commission definitions for licensing nuclear reactors. In Regulatory Guide 1.29, Seismic Category I structures are defined as those which should be designed to withstand a Safe Shutdown Earthquake (SSE) and remain functional. 
cracking or failure will increase seepage. Thus, this criterion implies a condition of plug stability. A possible allowable seepage might be $1 \mathrm{~m}^{3} /$ year for 10,000 years.

- Seepage travel time through the plug, plug-basalt interface, and damaged wall rock. This approach would specify how long it must take for one drop of water to traverse the plug. A travel time of 10,000 years has been suggested. This is a more restrictive criterion than that above.

- Equivalent undisturbed basalt flow resistance. The piug should be able to resist flow at least as well as the intact rock. The length of the plug may be limited by the distance of the repository from the biosphere. That distance might be defined as the distance from the repository to the nearest potential aquifer resource above the repository, or the distance to the biosphere could also be taken as the distance to the ground surface.

The ultimate criteria of this type would be based upon allowable radioactive contaminant escape. This criteria would specify the amount of radioactive material that could allowably pass through the plug over a period of 1 year. The design would include the ability of certain potential plug materials to retard radioactive materials. Insufficient data on sorptive properties are available at this time to facilitate use of this criterion in preconceptual design. For the present case, we will use the first criterion, which is easier to define than the third. The second and third may prove to be excessively conservative because neither criterion considers the sorptive capabilities of the plug and the second criterion does not consider distance to the biosphere.

The plug may meet the previous flow design criteria and have only a factor of safety (defined as strength/stress) of 1 for stability. Because of the variation in soil or rock parameters in any mass and because of our inexact knowledge of the geology, hydrology, and other parameters, it is necessary to use a higher factor of safety. Because no 
stability criteria for plug design have been recommended in research to date, the following will be used for modeling:

Material

Intact Basalt

Basalt Joints

A71 Plug Components

\section{Factor of Safety}

at Time of Plugging

1.5

2

2
Long-Term Factor

of Safety

1

2

1.5

3.7.2.2 Effects of Construction and Support Methods. Some wall rock will be disturbed and destressed as a result of the excavation. Two processes will affect the extent of disturbance and may cause loosening of rock blocks and radial inward movement of the disturbed zone. They are stress relief and loosening and overbreak caused by energy transfer into the rock by the construction process (such as blasting). The presence of the disturbed zone may have important implications for plug design. First, if loosening occurs, permeability may increase in the disturbed zone. Also, loosening may decrease the wall rock stiffness and strength. The resulting material properties are expected to influence plug placement techniques and potential stress concentration locations over the life of the repository.

Because of the decrease in confining pressure parallel to the tunnel, shaft, or borehole wall, permeability may increase in the zone of stress relief. In Figure 3-55, the zones of interest are outlined for three stress conditions. Tangential boundary stresses may also locally decrease, particularly where the horizontal and vertical in situ stresses are very different, and potentially increase permeability to flow in the direction perpendicular to the tunnel, shaft, or borehole axis.

Permeability of sandstones has been shown to increase by a factor of 2 (Wyble, 1958) when the confining pressure decreases from $35 \mathrm{MPa}$ to $0 \mathrm{MPa}$. Similar results were found by Nelson (1976) for fractured sandstone. In basalt, the same level of increase in permeability for a single fracture was found by Iwai (1976) for a confining pressure decrease from 20 to $5 \mathrm{MPa}$; however, permeability increased by $10^{2}$ between 5 and $0 \mathrm{MPa}$. In addition to stress relief, mechanical energy 


\section{RHO-BWI-ST-7}

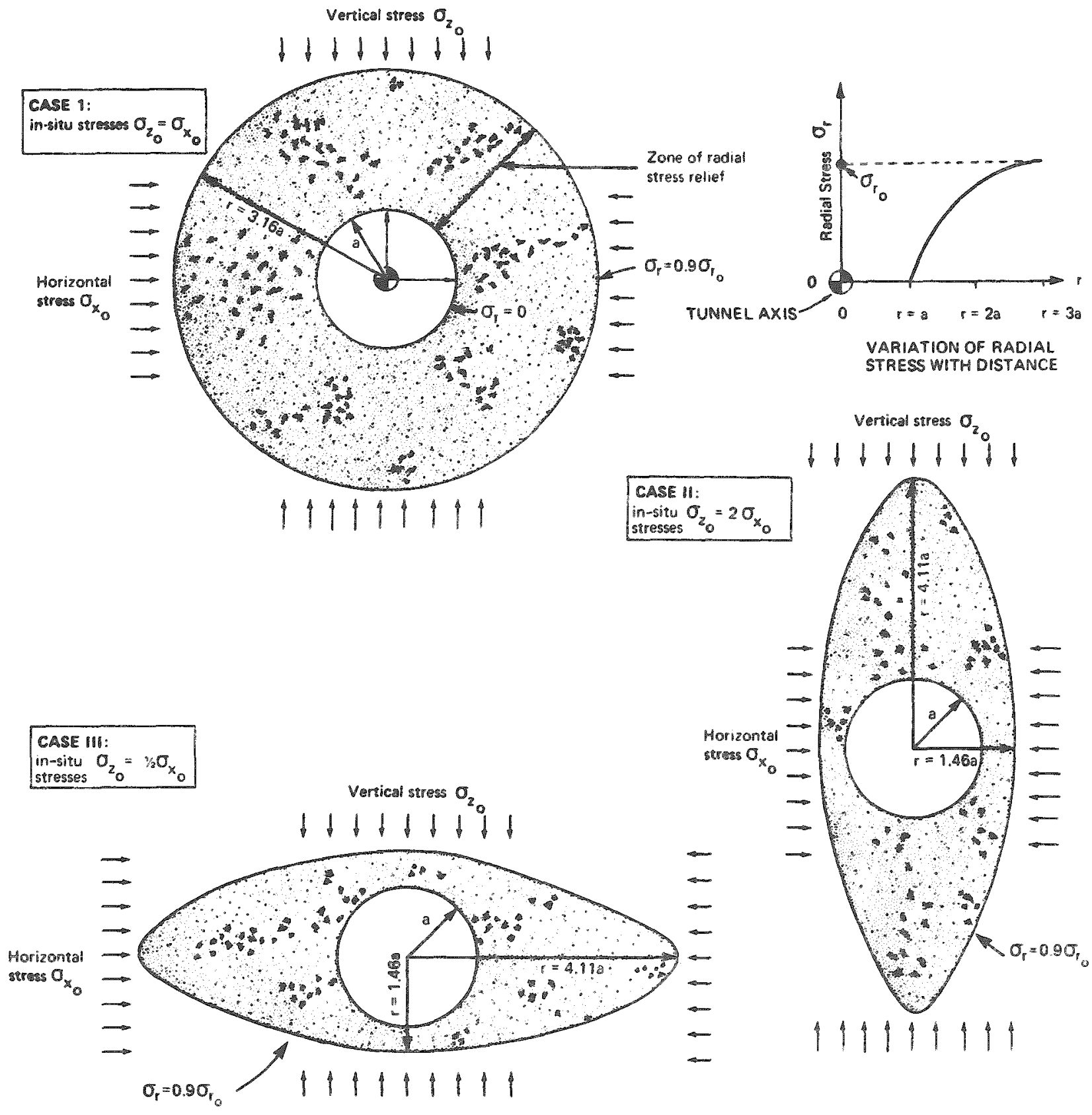

NOTES: Direction of increased permeability is parallel to axis of plug. This may lead to increased flow around the plug and bypassing it.

Stresses perpendicular to tunnel axis:

$$
\begin{aligned}
& \sigma_{x}=\text { horizontal stress } \\
& \sigma_{z}=\text { vertical stress } \\
& \sigma_{r}=\text { radial stress }
\end{aligned}
$$

FIGURE 3-55. Zone of Elastic Stress Relief. 
transferred into the rock by the excavation process (e.g., blasting) may loosen the rock and open or create new fractures. Any source of increase in fracture aperture, $e$, will increase the fracture rock permeability, $k_{f}$. The relation between those two factors is of the form $k_{f}=e_{3}$ (Goodman, 1976), so that the combined effects of stress relief and mechanical loosening may have a potentially significant impact on basalt permeability. This impact must be considered in plug analysis.

As noted above, there are two sources of loosening in tunnel and shaft construction. One is deformation because of stress relief prior to and during support placement (see Fig. 3-56). The second source is mechanical loosening caused by energy transferred into the rock by the excavation process. Careful excavation and construction techniques can minimize both sources of loosening. Presupport by pre-grouting or by the use of spiling reinforcement can be an effective way to limit stressrelief deformations (see Fig. 3-56). Placing supports as close to the face as possible can also reduce deformation, but some deformation will occur before support placement as the stress is reduced due to an approaching face. Mechanical loosening can be controlled by careful excavation. For example, for dri11 and blast operations, short lengths of advance, reduced charges in perimeter holes, controlled deviation of blast hole drilling, and possibly prenotched drillholes will all help maintain the integrity of the rock. Hardy and Hocking (1978) recommend that the zone of non-linear deformation be kept to a thickness of $1 / 6$ the diameter of the opening. Careful monitoring during excavation at intervals along the excavation length may be necessary to demonstrate this.

Once the construction techniques are identified, the modeling program would benefit from: (1) existing or pilot scale field data on the use of those methods in basalt; and (2) good engineering-geology-type descriptions of the basalt (rock quality data, strike and dip of joint sets, roughness of fractures). With this information, it may be possible to estimate the extent and degree of loosening for site-specific cases.

A discussion of some of the problems resulting from the presence of the disturbed zone may clarify why an understanding of this zone is 


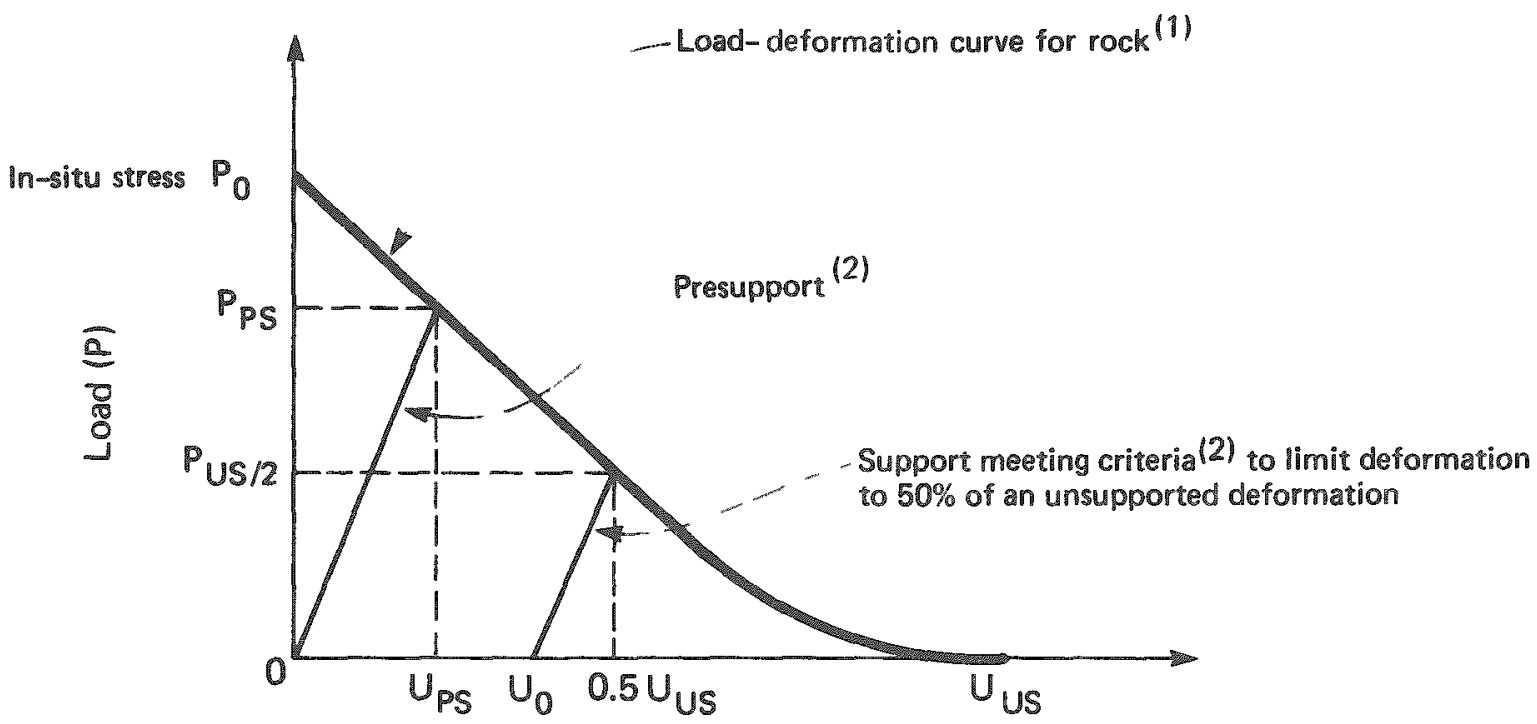

Deformation (u)

NOTES: (1) The load-deformation curve is shown for a tunnel in good rock wnich may stand unsupported. At equilibrium, the unsupported rock $(P=0)$ will have displaced by the amount $u=u_{u s^{\circ}}$

(2) Presupports are placed before any deformation occurs (at $u=0$ ). Due to the presupports finite stiffness, some displacement $\left(u=u_{p s}\right)$ occurs after support placement.

13) A support meeting criteria for $50 \%$ of the unsupported deformation is shown. It is placed a few feet behind the face, with some deformation $\left(u=u_{0}\right)$ having already occurred. The final displacements, including elastic compression of the supports, are $u=0.5 u_{u s}$. (Note: This is an example only only and not a recommendation for allowable deformation.)

After Schwartz and Einstein (1978)

FIGURE 3-56. Relation between Support Types and Possible Deformation Criteria. 
important. If the disturbed zone is not treated prior to plugging, the effectiveness of the plugging scheme to retard flow will be diminished by flow bypassing the plug. In shafts or vertical boreholes (where there is only a limited vertical distance to an overhead aquifer from the repository), this material could provide a "relatively high" permeability flow path between the repository and nearby aquifers. Remedial measures, such as grouting, may not be effective in reducing the permeability of the disturbed zone beyond perhaps $10^{-6}$ to $10^{-7} \mathrm{~cm} / \mathrm{sec}$. (Intact mass basalt has a reported permeability of $10^{-9} \mathrm{~cm} / \mathrm{sec}$.) Rock joint openings with permeabilities of $\sim 10^{-6}$ to $10^{-7} \mathrm{~cm} / \mathrm{sec}$ are likely to be less than 50 microns (Woodward-Clyde Consultants, 1977). Grouting may be possible with a fine clay or chemical grout, but cement grout particles are too large to penetrate such small openings.*

\subsubsection{Numerical Analysis of Plug Seepage Control and Thermomechanical}

Performance. Preliminary numerical analysis involving closed form solutions was used to provide some insight into the effect of the zone of disturbed rock around an opening to be plugged, including an estimate of the lengths of plug necessary to achieve seepage control, and the potential benefit of constructing cutoff collars that protrude from the plug into the zone of disturbed rock. A closed-form solution to the combined problem of thermomechanical behavior of a hard plug and the surrounding rock is used to evaluate the bond strength and confinement required for the plug to offset thermal stresses. Finally, in a critical review of these analyses, the limitations of closed-form solutions that treat separately the thermal, mechanical, and fluid dimensions of the problem and that assume gross simplifications (such as homogeneity, isotropy, and linear elasticity) are discussed. The allowable quantity of flow per year, as described in design criteria for flow, was used for

$*$ Based on grout particle sizes (as documented in Lenzini and Bruss, 1975). Note that soils of permeability 10-6 to $10-8$ have flow channels of much smaller cross-sectional area than rock joints having the same permeability. Thus, $K=10^{-5} \mathrm{~cm} / \mathrm{sec}$ is usually the minimum permeability for a groutable soil. 
the seepage analysis, and a factor of safety of 1.5 was used for the sliding stability analysis. Thermally induced stresses were computed then compared with the compressive strength of the plug. All the analyses are for an assumed diameter tunnel of $7 \mathrm{~m}$.

The quantity of water flowing through the plug system was computed using Darcy's law for flow through a porous media which states:

$$
Q=k i A
$$

where:

$Q=$ quantity of flow

$k=$ coefficient of hydrautic conductivity

$i=$ hydraulic gradient

$A=$ cross-sectional area.

For this analysis, flow was considered to be through the plug and disturbed basalt around the plug only, neglecting any flow through the undisturbed basalt. This is a valid assumption if the permeability of the plug and/or disturbed rock is significantly greater than that of the undisturbed rock.

The worst case condition for flow moving out of the repository is assumed to be a pressure head of $160 \mathrm{~m}$ of water, as shown in Figure 3-57. The flow is assumed to be steady-state, which means that the head has remained constant over a long enough period of time for the flow to stabilize, the plug is saturated, and phase changes are neglected. (The value of $160 \mathrm{~m}$ of pressure head is approximately the saturation pressure of steam at $200^{\circ} \mathrm{C}$ ).

The permeability of undisturbed basalt is estimated to range from $10^{-13}$ to $10^{-3} \mathrm{~cm} / \mathrm{sec}$ with an assuned value of $10^{-9} \mathrm{~cm} / \mathrm{sec}$ for the basalt formation in which the repository will be constructed. Work by Iwai (1976) on the permeability of fractured basalt shows minimal changes

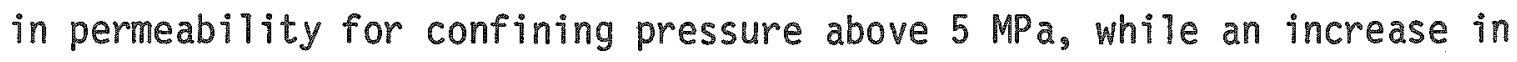
permeability by 2 orders of magnitude occurred when confining pressures were decreased from $5 \mathrm{MPa}$ to $0 \mathrm{MPa}$. This would result in a permeability 
TUNNEL

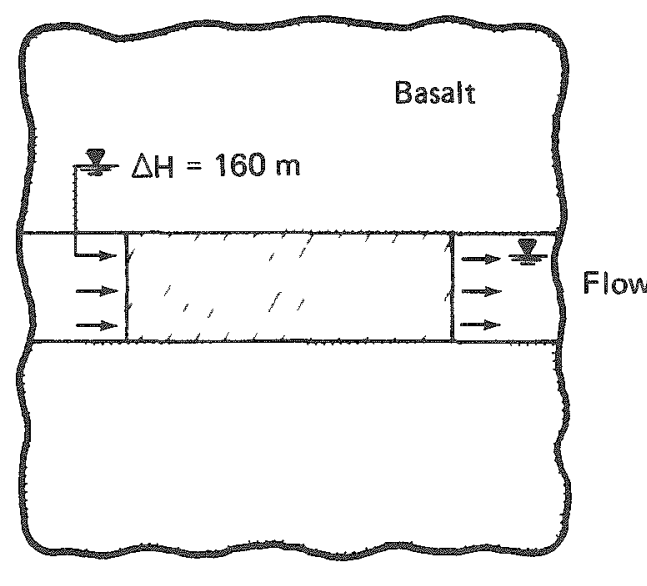

PROBLEM:

Flow out of repository

due to hot water.

NOTE: $\triangle H$ is the differential

fluid pressure head acting across the plug, expressed in an equivalent height of water column at one end of the plug-typical, all modeling conditions.

\section{DESCRIPTION:}

During rewatering, at far end of plug, head equals a few meters. The repository (almost full) heats up: $P_{\text {sat, for water/steam system }}$ (a) $200^{\circ} \mathrm{C} \approx 160 \mathrm{~m}$ of water. Use post-plugging material parameters. Ignore temperature effect on materials.

\section{CONSEOUENCES:}

Possibly unacceptable

flow rate. Possible

piping in plug.

FIGURE 3-57. Modeling Conditions No. 1. 
of $10^{-7} \mathrm{~cm} / \mathrm{sec}$ for fractured basalt with low confining pressures; if the permeability was greater than $10^{-7} \mathrm{~cm} / \mathrm{sec}$, grouting might be able to reduce the permeability to $10^{-7} \mathrm{~cm} / \mathrm{sec}$. The thickness of the zone of fractured basalt around a plug is expected to depend greatly upon the construction techniques used for excavating and shoring of the tunnel; however, the stress relief around a circular opening can be approximated by the theory of elasticity (Timoshenko and Goodier, 1951).

For a uniform elastic material, a reduction in confining pressure from $28 \mathrm{MPa}$ to less than $5 \mathrm{MPa}$ would occur throughout a zone that has a thickness of less than $5 \%$ of the diameter of the tunnel; however, this reduction can oniy be considered to be the minimum estimate of the depth of rock disturbance since existing fractures, non-linear mechanics, and construction methods are not taken into account. Recognizing that the depth of disturbed rock is so difficult to evaluate, values ranging from 0 to 2 times the tunnel diameter were investigated in a parametric study.

Two values of permeability of the plug material were considered. The values of $10^{-8}$ and $10^{-9} \mathrm{~cm} / \mathrm{sec}$ both fall within the range of permeabilities for concrete and laboratory-compacted clay. If a plug has a permeability on the order of $10^{-7} \mathrm{~cm} / \mathrm{sec}$, any flow would occur predominantly through the plug because of its larger cross-sectional area compared with the zone of disturbed rock.

The length of a uniform plug required to 7 imit seepage to $1 \mathrm{~m}^{3} /$ year without cutoffs for varying depths of the disturbed rock zone are shown in Figure 3-58 for a plug permeability of $10^{-9} \mathrm{~cm} / \mathrm{sec}$. Computations show that the length of plug necessary to meet the $1 \mathrm{~m}^{3}$ /year criteria, assuming no disturbed rock zone surrounding that plug, would be $2 \mathrm{~m}$, and for a plug permeability of $10^{-8} \mathrm{~cm} / \mathrm{sec}$ the plug would have to be $20 \mathrm{~m}$ long. The computation also shows that flow through a plug of either permeability is minimal compared with flow through the disturbed basait. For a disturbed zone equal to the diameter of the plug (e.g., 21 m outer diameter boundary), a length of about $1,600 \mathrm{~m}$ would be necessary for either plug.

These results indicate the importance of reducing the permeability of the disturbed zone and that it is not really useful to require the 


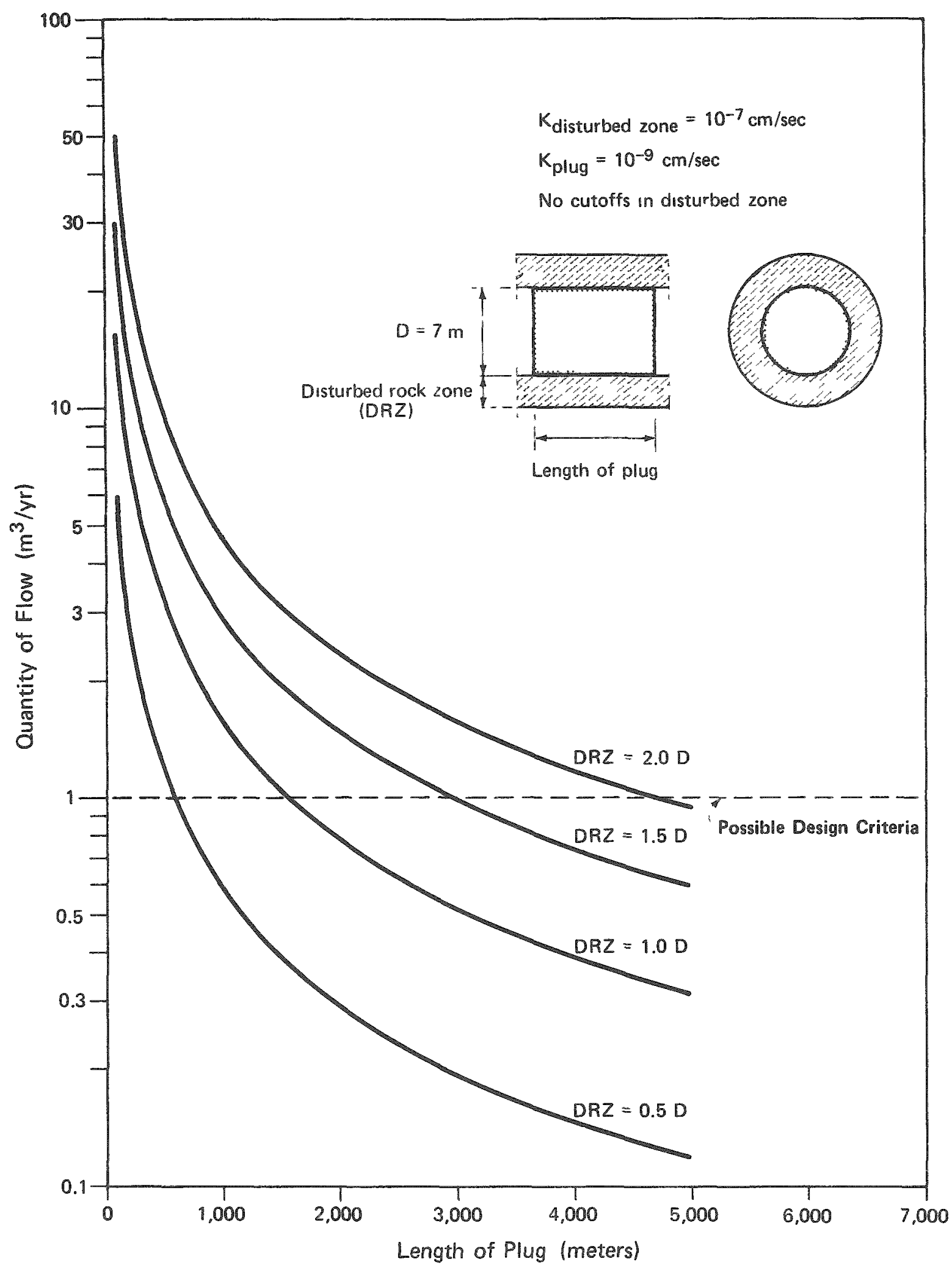

FIGURE 3-58. Flow through Plug of Permeabitity $10^{-9} \mathrm{~cm} / \mathrm{sec}$. 
permeability of the plug material to be more than an order of magnitude less than can be expected for the rock surrounding the plug. One way to reduce flow through a disturbed rock zone may be by installing cutoffs. Figures 3-59 and 3-60 show the results of computations evaluating the effectiveness of cutoffs equal to one-tenth the total length of a plug. For a disturbed zone equal to the plug diameter, the necessary length of a plug with cutoffs is reduced to approximately 150 and $840 \mathrm{~m}$ for the respective permeabilities.

As summarized in Figure 3-61, the thickness and permeability of the disturbed zone are the major factors that influence the amount of flow. The results presented are based on a tunnel diameter of $7 \mathrm{~m}$. Flow through a 5-m tunnel would be approximately half and through a 10-m tunnel approximately twice that for the 7-m tunnel.

The method used to assess the sliding stability of a plug was to compute the factor of safety against sliding (i.e., the shear strength of a possible failure surface divided by the stresses induced on it). For the purpose of these closed form solutions, the fallure surface was assumed to be the tunnel-plug interface, with the shear strength of the plug considered the controlling factor. The shear strength of disturbed basalt has not been established, but it is judged to be greater than the plug material strength.

The maximum driving force is assumed to be a pressure head of $1,000 \mathrm{~m}$ of water against the outside of the plug $(1,000 \mathrm{~m}$ of water yields a pressure of $9.8 \mathrm{MPa}$ ). This models a condition in which the shaft fills with water before the repository has rewatered or significantly pressurized.

The shear strength of the plug, rock, and plug-rock bond all depend upon the confining pressure. The strength increases with increasing confinement uniess the confining pressure becomes so great that it changes the mechanical properties of the material (e.g.g by breaking down its structure). The confining pressure of the plug is extremely difficult to estimate because it depends upon the support of the opening, amount of disturbance in the rock, plug material, temperature, time, and 
RHO-BWI-ST-7

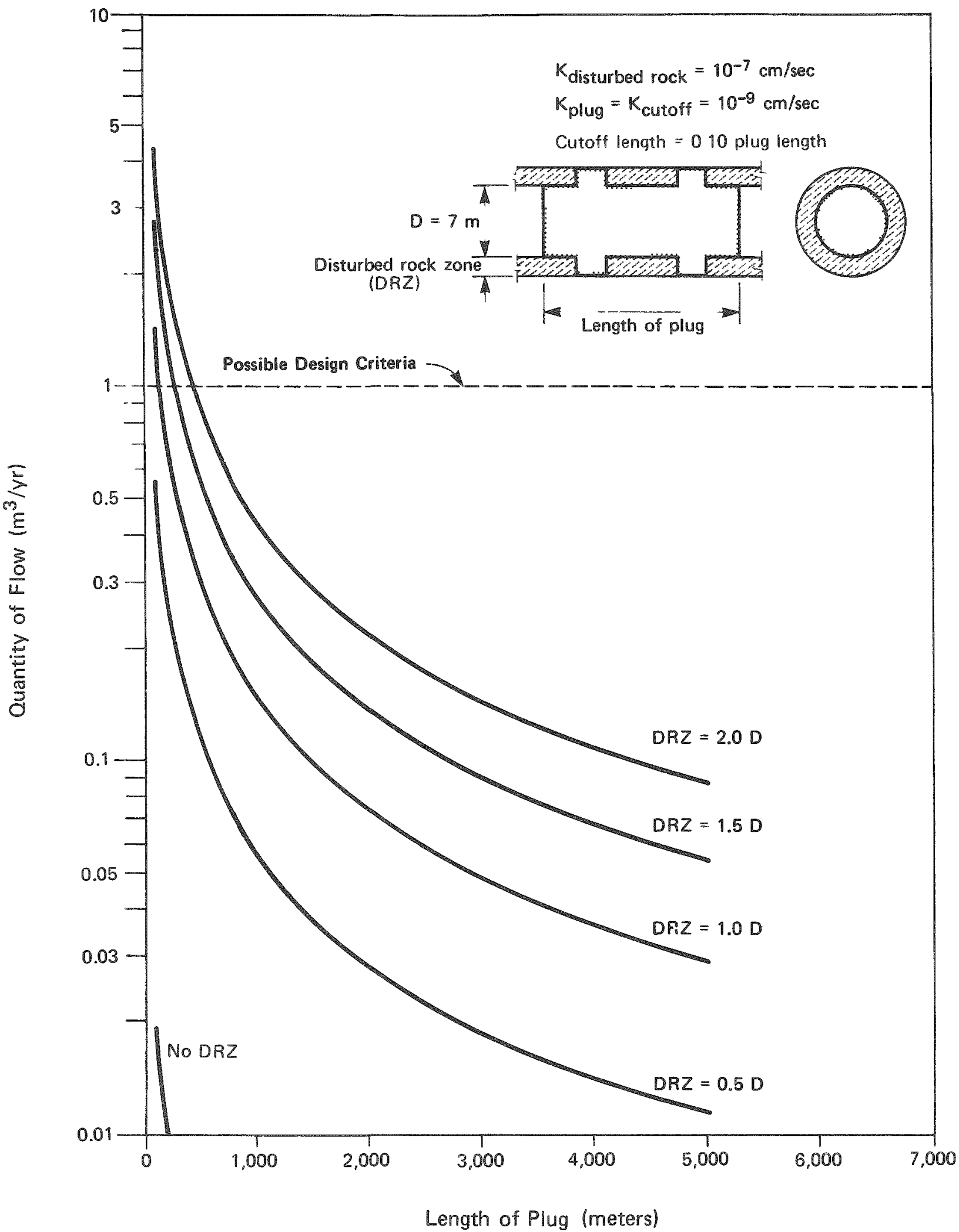

FIGURE 3-59. Flow through Plug of Permeability $10-9 \mathrm{~cm} / \mathrm{sec}$ with Cutoffs. 
RHO-BWI-ST-7

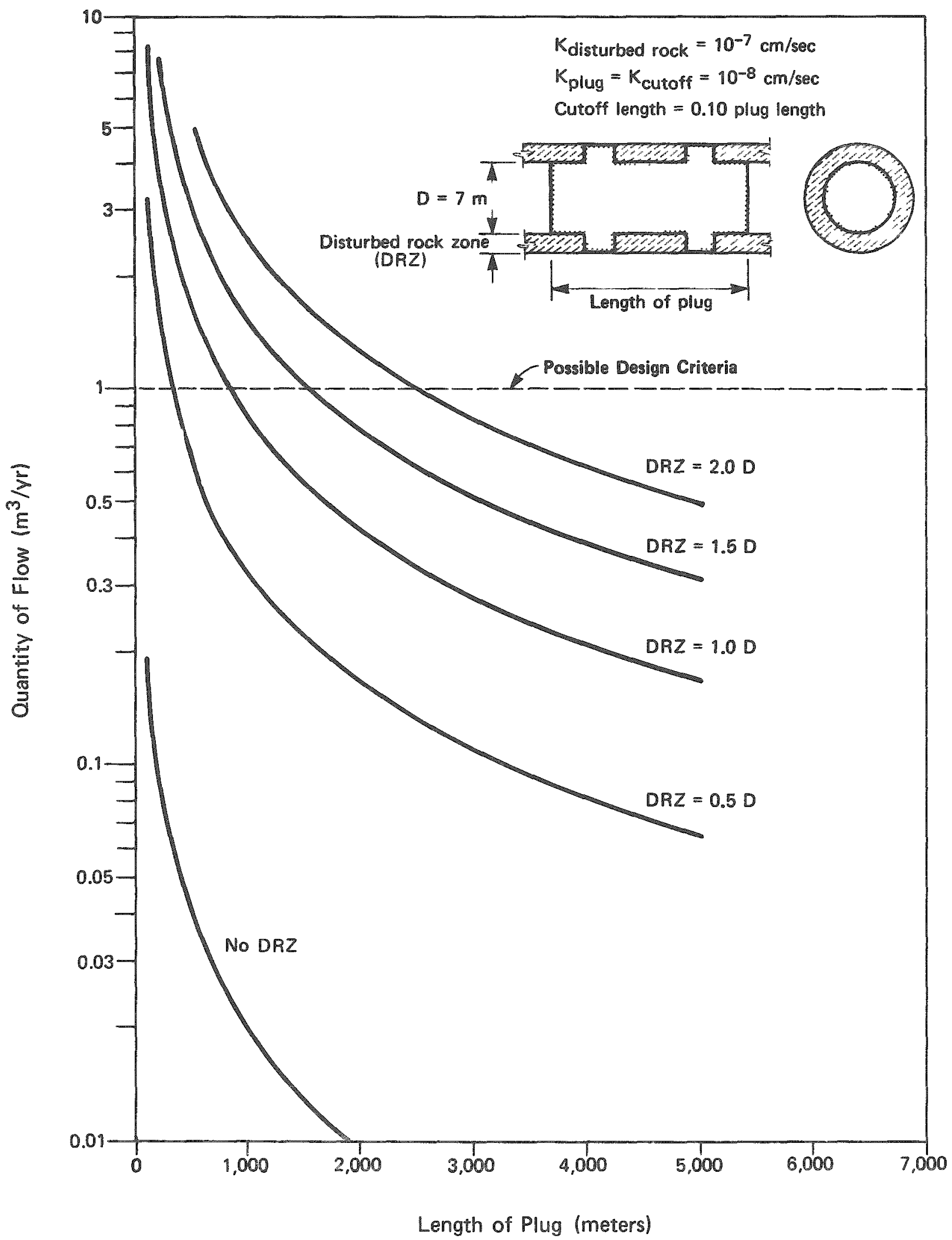

FIGURE 3-60. Flow through Plug of Permeability $10-8 \mathrm{~cm} / \mathrm{sec}$ with Cutoffs. 
RHO-BWI-ST-7

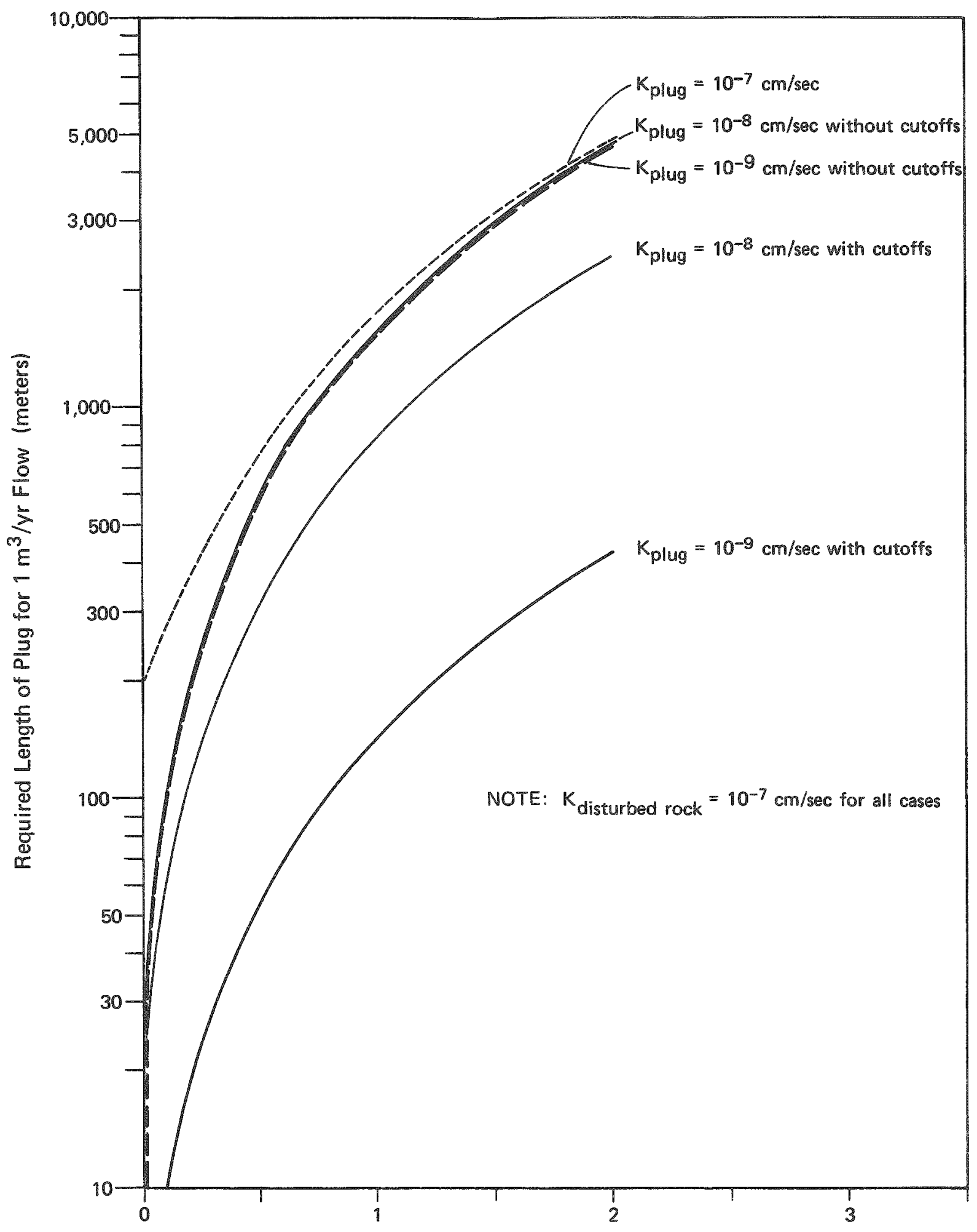

Ratio of Disturbed Zone to Hole Diameter

FIGURE 3-61. Length of Plug (Idealized Numerical Model). 
method of placement. There is no simple way to evaluate the plug confining pressure, so a nominal value for plug shear strength has been used.

A representative value of the unconfined compressive strength of concrete is $30 \mathrm{MPa}$. The shear strength with no confinement (Troxel1 and others, 1968) is approximately $12 \%$ of this or $3.6 \mathrm{MPa}$. The necessary length of plug for a 7-m diameter tunnel with a factor of safety of 1.5 is only $7.15 \mathrm{~m}$. This value is extremely conservative unless the force between the plug and tunnel wall is tensile, which could occur due to plug shrinkage (as in concrete curing) or temperature drop.

Clearly, more detailed analyses of the strength of the plug must be made; however, based on this analysis, it does not appear that sliding failure of the plug will be the critical design factor. Analysis of the induced strains must also be done to check that flow paths are not established through shear zones within the plug.

An evaluation of the thermomechanical response of a plug and its environment was made using differential linear thermoelasticity to describe the behavior of the plug and the surrounding rock. The elastic solutions are developed for a confined plug representing the case of a shaft plug or the case of a confined tunnel plug, where confinement is provided by an engineering designed structure and for an unconfined plug simulating the case of a tunnel plug with its end free to move. A numerical application is given in the case of a concrete plug. The term "confined" means that no axial movement of the plug is allowed. The subscripts " $p$ " for plug and "R" for surrounding rock are used to differentiate plug and surrounding rock elastic constants.

In the modeling of elastic behavior of the plug-host rock medium, the plug and surrounding rock are assumed to be perfectiy homogeneous, isotropic, and elastic and can be mathematically described using the theory of differential linear elasticity. When determining thermal stresses, the temperature change is taken as uniform and equal to $50^{\circ} \mathrm{C}$ throughout the plug and the host rock. Final solutions for the elastic, host rock-plug problem are provided using the Saint Venant principle; 
i.e., the solutions for the elastic stress field distribution caused by the lithostatic stress field around a circular hole are superimposed onto the solutions for the thermoelastic stress field induced in the plug and its environment by a uniform increase in temperature.

The thermoelastic stress field for the plug-host rock system is determined using equations developed by Timoshenko and Goodier (1951) to describe the thermal response of the plug (a long solid cylinder) and the thermal response of the surrounding rock (a long, thick-wall hollow cylinder). The condition of radial displacement compatibility at the plug-rock interface provides the necessary equation to resolve the problem.

The lithostatic stress with the basalt at a depth of $1,000 \mathrm{~m}$ is assumed to be hydrostatic and is estimated to be $28 \mathrm{MPa}$ prior to repository excavation. Moreover, both shafts and tunnels are assumed to be $7 \mathrm{~m}$ in diameter for the purposes of this analysis. Elastic solutions for the stress distribution around a circular hole have been given by Obert and Duval (1967) for long shafts or tunnels. Numerical analys is using a $28 \mathrm{MPa}$ hydrostatic, lithostatic stress field leads to a uniform tangential stress of $56 \mathrm{MPa}$ at the hole boundary as shown in Figure 3-62.

A solution for the thermal stresses in a confined elastic plug and its environment is based on an assumed condition of radial displacement continuity at the interface plug-wa11 rock. The numerical analysis in the case of a concrete plug leads to the curves shown in Figure 3-63. For an increase in temperature of $50^{\circ} \mathrm{C}$, the radial and tangential stresses inside the plug reach $34.2 \mathrm{MPa}$. However, the confining axial stress ${ }^{\sigma} z_{p}$ is $28.7 \mathrm{MPa}$. Therefore, the plug is only submitted to a stress differential of $5.5 \mathrm{MPa}$. The isotropic part of the stress field $(28.7 \mathrm{MPa}$ ) is certainiy not strong enough to cause a failure of the concrete by crushing, while the stress differential is less than $20 \%$ of the unconfired compression strength of the concrete $(30 \mathrm{MPa})$.

In the analysis of thermal stresses in an unconfined elastic plug, it was assumed that no forces are acting at the end of the plug to restrain axial movement. As in the case of the confined plug, the state of stress is the same everywhere in the plug. 


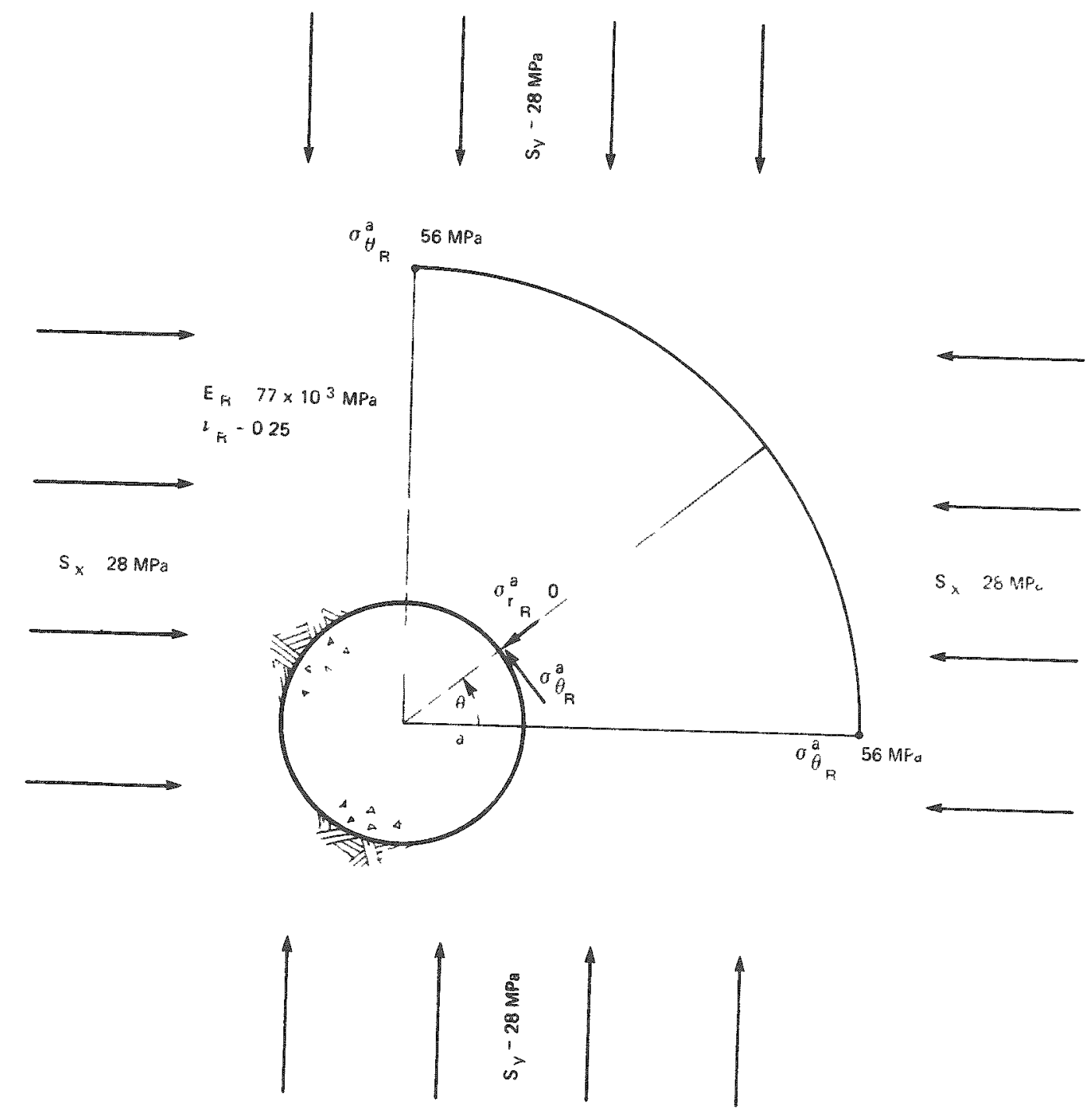

NOTE

Elastic solution for a homogeneous isotropic elastic basalt medum under hydrostanc lithostatic stress At the plug/wall rock interface

$$
\sigma_{\theta}^{a}=56 \mathrm{MPa} \text { for all } \theta \text { and } T_{\mathrm{R}}^{a} \theta_{\mathrm{B}} \quad 0
$$

FIGURE 3-62. Stress Distribution around Tunnel and Shaft. 
RHO-BWI-ST-7
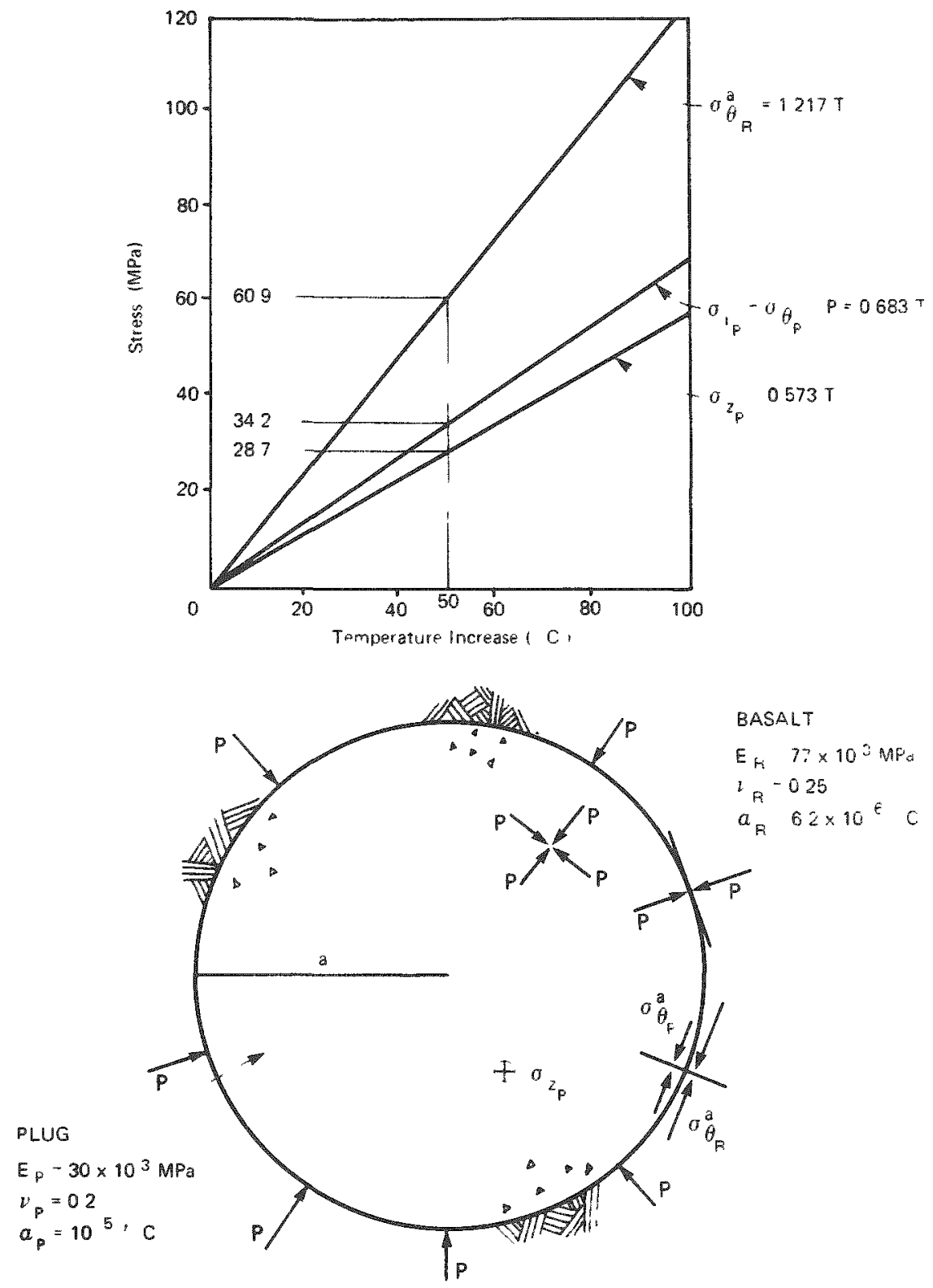

Pluq Transwersal Cross Section

FIGURE 3-63. Thermoelastic Response of a Confined Concrete PIug. 
The numerical analysis in the case of an unconfined concrete plug leads to the curves shown in Figure $3-64$. For a $50^{\circ} \mathrm{C}$ increase in temperature the radial and tangential stresses inside the plug reach the value of $29.7 \mathrm{MPa}$. As no confinement is provided, the radial stress must be directly compared with the unconfined compressive strength of the concrete $(30 \mathrm{MPa})$, so that the resulting safety factor is on the order of 1.0 .

To avoid any differential axial movement at the plug-rock interface, the bond strength between the plug and the wall rock should be strong enough to resist the thermal shear stresses induced by the difference in thermal expansion properties of the plug and the rock. As shown in Figure 3-64 (curve "b"), for an increase in temperature of $50^{\circ} \mathrm{C}$ the required bond strength reaches $11.2 \mathrm{MPa}$, which is more than twice the expected value of the bond strength of concrete (approximately $5 \mathrm{MPa}$, based on laboratory test data).

Elastic solutions for the thermomechanical stress field in the surrounding rock were obtained by superposition of the stress associated with the lithostatic stress field and the thermal stress induced by temperature increase. Solutions for a confined and an unconfined plug are very similar so that the analysis for an unconfined plug can be applied as an approximation for a confined plug.

Results for the superposition of thermal and lithostatic stresses are given on Figure 3-65. For a $28 \mathrm{MPa}$ hydrostatic lithostatic stress field and a temperature increase of $50{ }^{\circ} \mathrm{C}$, radial and tangential stress at the boundary plug-rock are given by

$$
\sigma_{r_{R}}^{\mathrm{a}}=29.7 \mathrm{MPa} ; \sigma_{\theta_{R}}^{\mathrm{a}}=121.3 \mathrm{MPa} \text {. }
$$

The stress deviator $\sigma_{r_{R}}^{a}-\sigma_{\theta_{R}}^{a}$ (i.e., 91.6 MPa) is approximately a third of the assumed basalt unconfined compressive strength (218 MPa). However, in this computation, the deterioration of the rock by stress relief and loosening is not taken in consideration, and the assumption of 
RHO-BWI-ST-7

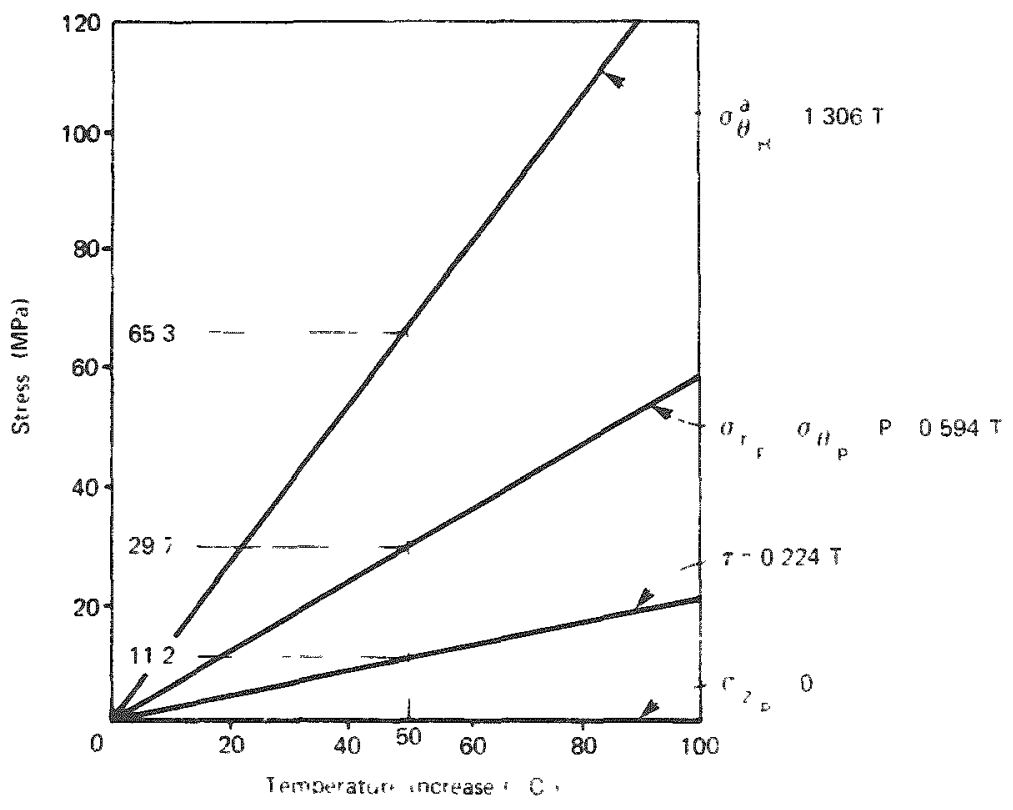

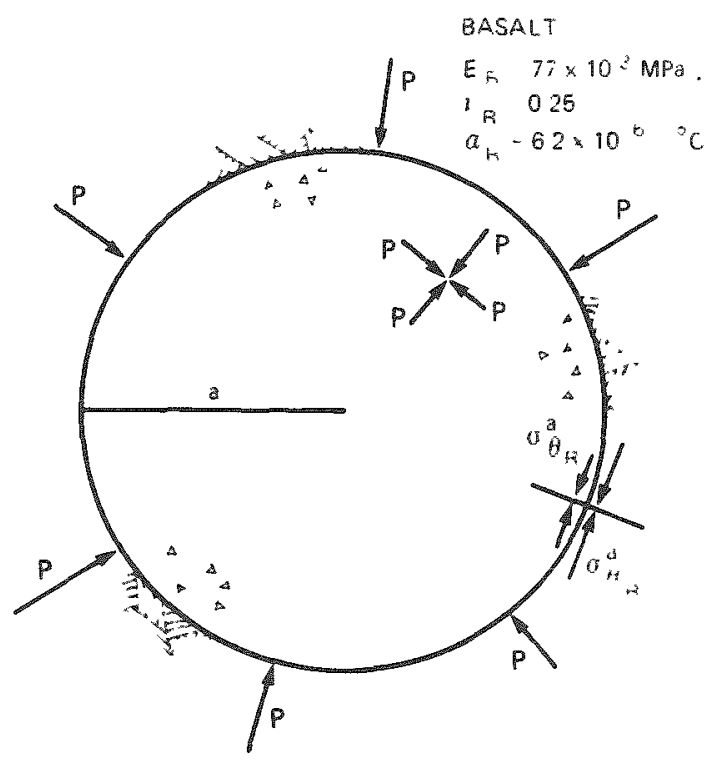

Plug Transuersat Cross Section

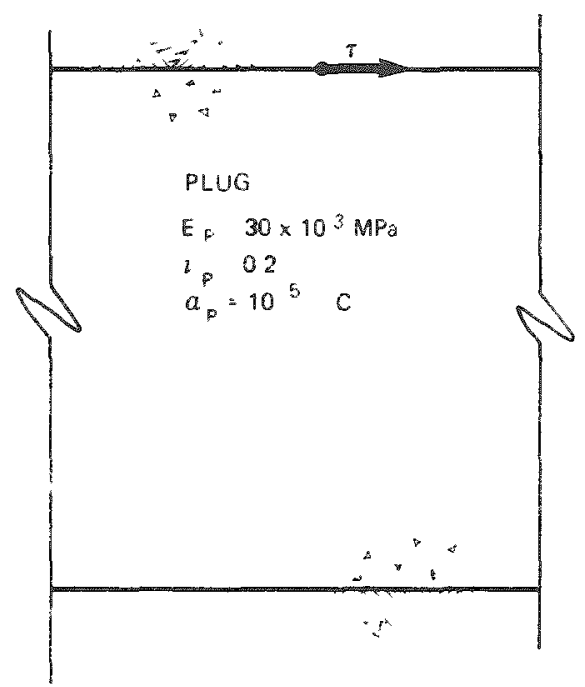

Par of Pha Longrudinal Closs Swaten

FIGURE 3-64. Thermoelastic Response of an Unconfined Concrete Plug. 


\section{RHO-BWI-ST-7}
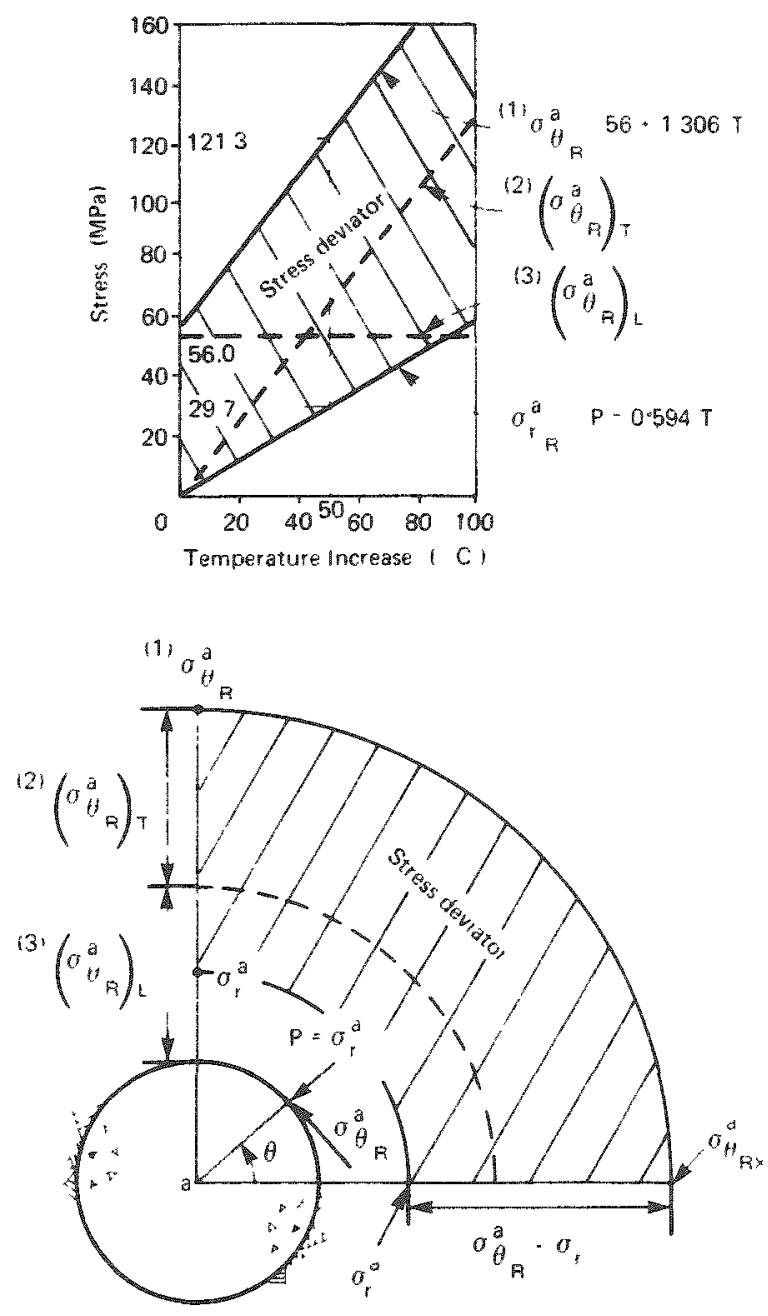

NOTES

(1) $a_{\theta}^{a}$ Total tangential stress in the rock at the plug wal rock nierfact $a_{\theta}^{a}\left(o_{\theta}^{a}\right)_{T}+\left(o_{A B}^{a}\right)$.

(2) $\left(\sigma_{\theta}^{a}{ }_{\mathrm{A}}\right)_{T}$ - Tangential stress in the rock at the plug wall rock interface caused by thernomectianical loadina

(3) $\left(\sigma_{0}^{a}\right)_{R}$ - Tangential stress in the rock at the plug wall rock interface caused by ithostatic stress reluef

FIGURE 3-65. Thermomechanical Stresses in the Surrounding Basalt Rock at the Plug Interface. 
a hydrostatic state of stress in the repository before mining is not the most conservative assumption. Calculations not reported here show that for a high horizontal lithostatic stress ( $S x=50 \mathrm{MPa}, \mathrm{Sz}=28 \mathrm{MPa}$ ), the stress deviator of the tangential compressive stress at the rock-plug interface reaches $158 \mathrm{MPa}$.

3.7.2.4 Dominance Analysis. Using the results of the extended dominance analysis, various superior performing monolithic plug schemes can be incorporated into multiple-zone plug systems to secure an improved, overall plug performance, a result not achievable with monolithic plugs alone. Note that these multiple-zone plug systems will not necessarily coincide with the multiple-zone plug schemes discussed up to this point.

Radionuclides can potentially migrate past a plug (Fig. 3-66) in any one or a combination of the following three ways:

- By migration through the plug

- By migration through the plug-rock interface

- By migration through the disturbed rock surrounding the plug.

In the actual case, all three paths would probably contribute toward any total migration that might occur. A well-designed plug system would minimize the extent of flow paths available (e.g., low permeability, good plug-wa11 rock contact and integration of plug materials into any disturbed rock surroundings) and must be stress and strain compatible with the host rock to maintain its performance under lithostatic and thermomechanical stress changes that may occur after construction.

Comparing the performance of two plug schemes can be done by comparing expected values, or the range of values, for the design parameters and judging the final impact of this variation on the overall plug performance. Evaluation of design parameters (Table 3-23) for various types of plugs led to the selection of five design functions that describe total plug performance over the range of plug environments (i.e., tunnels, shafts, and boreholes). The design functions are: (1) core barrier performance; (2) plug-wall rock performance; (3) disturbed zone cutoff performance; (4) mechanical stability performance; and (5) long-term integrity. 


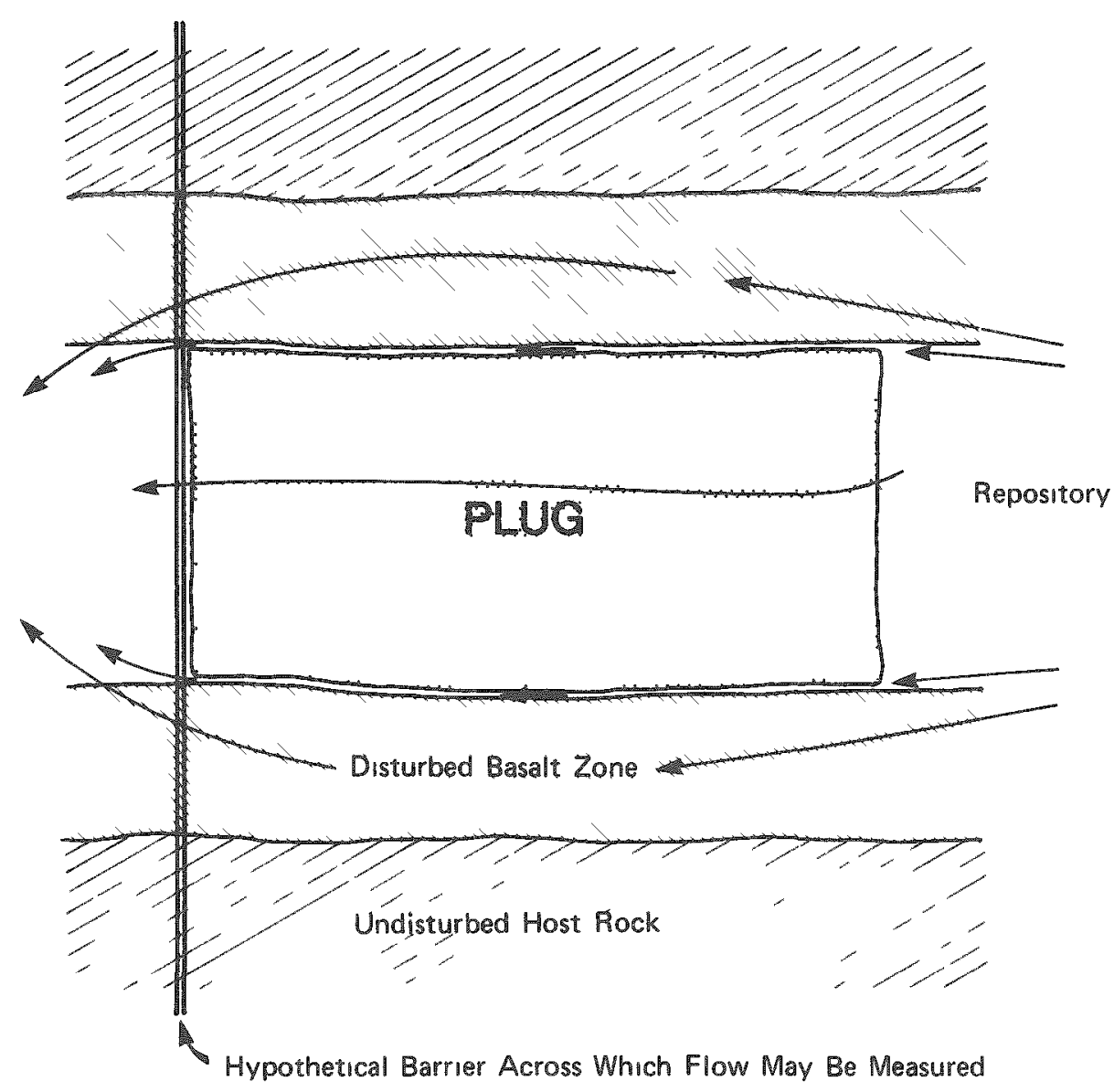

FIGURE 3-66. Migration of Radionuclides across a Hypothetical Plug.

Plug schemes were subjected to an extended dominance analysis and each scheme was rated on its ability to fulfill each of the five design functions. The extended dominance analysis results in groups of plug schemes identified as Group $A$, Group $B$, etc. The alternatives in Group $A$ are preferred to the alternatives in Groups $B, C$, etc. The alternatives in Group $B$ are preferred to those in Groups C, D, etc. Within each group a complete ordering is not possible. However, for some alternatives, it may be possible to list alternatives in the same group that are always preferred. The results of the dominance analysis are presented in Tables 3-24 through 3-26 and are discussed below. 
TABLE 3-23. Proposed Value of Design Parameters.

\begin{tabular}{|c|c|c|c|c|c|c|c|c|c|c|c|}
\hline \multirow[b]{2}{*}{$\begin{array}{l}\text { Plug } \\
\text { Materials }\end{array}$} & \multicolumn{11}{|c|}{$\begin{array}{c}\text { Design } \\
\text { Parameters }\end{array}$} \\
\hline & $\begin{array}{l}\text { Porasity } \\
(\%)\end{array}$ & $\begin{array}{c}\text { Permeability } \\
(\mathrm{cm} / \mathrm{sec})\end{array}$ & $\begin{array}{c}\text { Cation } \\
\text { Exchange } \\
\text { Capacity } \\
(\text { meq/100g) }\end{array}$ & $\begin{array}{l}\text { Young's } \\
\text { Modulus } \\
\text { (MPa) }\end{array}$ & $\begin{array}{l}\text { Poisson's } \\
\text { Ratio }\end{array}$ & $\begin{array}{l}\text { Thermal } \\
\text { Expansion } \\
\left({ }^{\circ} \mathrm{C}\right)\end{array}$ & $\begin{array}{l}\text { Unconfined } \\
\text { Compressive } \\
\text { Strength } \\
\text { (MPa) }\end{array}$ & $\begin{array}{l}\text { Compression } \\
\text { Index } \\
\text { (c) }\end{array}$ & $\begin{array}{l}\text { Bond } \\
\text { Strength } \\
\text { (MPa) }\end{array}$ & $\begin{array}{l}\text { Swelling } \\
\text { Pressure } \\
\text { (MPa) }\end{array}$ & $\begin{array}{l}\text { Density } \\
(q / c c)\end{array}$ \\
\hline Busalt & 1.24 & $10^{-9}$ & $4 / 9.3$ & $>>10^{3}$ & 0.25 & $\begin{array}{l}6.2 \\
10^{-6}\end{array}$ & 288 & $N A *$ & 30 & NA & 2.78 \\
\hline $\begin{array}{l}\text { Concrete (75 mam } \\
\text { maximum aggregate) }\end{array}$ & $25 / 30$ & $\frac{10^{-7}}{10^{-8}}$ & $<40$ & $\frac{2010^{3}}{4010^{3}}$ & $\frac{0.15}{0.20}$ & $10^{-5}$ & $30 / 40$ & NA & $3 / 10$ & NA & $2.2 / 2.5$ \\
\hline $\begin{array}{l}\text { Concrete (10 mum } \\
\text { maximum aggregate) }\end{array}$ & $25 / 30$ & $\frac{10^{-8}}{10^{-9}}$ & $<40$ & $\frac{2010^{3}}{4010^{3}}$ & $\frac{0.15}{0.20}$ & $10^{-5}$ & $30 / 40$ & NA & $3 / 10$ & NA & $1.5 / 2.0$ \\
\hline Cement slurry & $25 / 30$ & $\frac{10^{-7}}{10^{-8}}$ & $<40$ & $\frac{2010^{3}}{3010^{3}}$ & $\frac{0.15}{0.20}$ & $10^{-5}$ & $20 / 30$ & $\mathbb{N A}$ & $3 / 10$ & NA & $1.5 / 2.0$ \\
\hline $\begin{array}{l}\text { Stiff clayey mixture } \\
\text { (75 man maximum } \\
\text { dggregate) }\end{array}$ & $20 / 30$ & $\frac{10^{-7}}{10^{-8}}$ & $20 / 80$ & $40 / 60$ & $\frac{0.20}{0.40}$ & $?$ & $1 / 3$ & 0.05 & $0.5 / 1$ & $0 / 3$ & $2.2 / 2.4$ \\
\hline $\begin{array}{l}\text { Stiff clayey mixture } \\
\text { (10 max maxum } \\
\text { aggregate) }\end{array}$ & $20 / 30$ & $\frac{10^{-8}}{10^{-9}}$ & $20 / 80$ & $40 / 60$ & $\frac{0.20}{0.40}$ & $?$ & $1 / 3$ & 0.05 & $0.5 / 1$ & $0 / 3$ & $2.2 / 2.4$ \\
\hline $\begin{array}{l}\text { Clay mixed with } \\
\text { sand and silt }\end{array}$ & $25 / 35$ & $<10^{-8}$ & $60 / 100$ & $40 / 60$ & $\frac{0.30}{0.50}$ & $?$ & $1 / 3$ & 0.7 & $0.2 / 1$ & $0 / 3$ & $1.8 / 2.2$ \\
\hline $\begin{array}{l}\text { Soil bentonite } \\
\text { slurry }\end{array}$ & $30 / 35$ & $\frac{10^{-7}}{10^{-9}}$ & $60 / 100$ & $\begin{array}{l}\text { Very } \\
\text { Smail }\end{array}$ & $\frac{0.30}{0.50}$ & $?$ & $\begin{array}{l}\text { Very } \\
\text { Small }\end{array}$ & $1 / 3$ & 0 & 0 & $1.6 / 1.9$ \\
\hline $\begin{array}{l}\text { Basalt block with } \\
\text { mortared joints }\end{array}$ & 5 & $\frac{10^{-8}}{10^{-9}}$ & $4 / 9.3$ & $\frac{70 \quad 10^{3}}{75 \quad 10^{3}}$ & 0.25 & $>10^{-6}$ & $?$ & NA & $3 / b$ & $\mathbb{N A}$ & 2.7 \\
\hline $\begin{array}{l}\text { Compressed bentonite } \\
\text { blocks, dry sack } \\
\text { joints with bentonite }\end{array}$ & 20 & $<10^{-9}$ & $>80$ & 60 & $\frac{0.30}{0.50}$ & $?$ & 5 & 1 & 0.5 & $>3$ & 2.2 \\
\hline
\end{tabular}

*NA $=$ nonapplicable. 
TABLE 3-24. Summary of Dominance Computations for Tunnels.

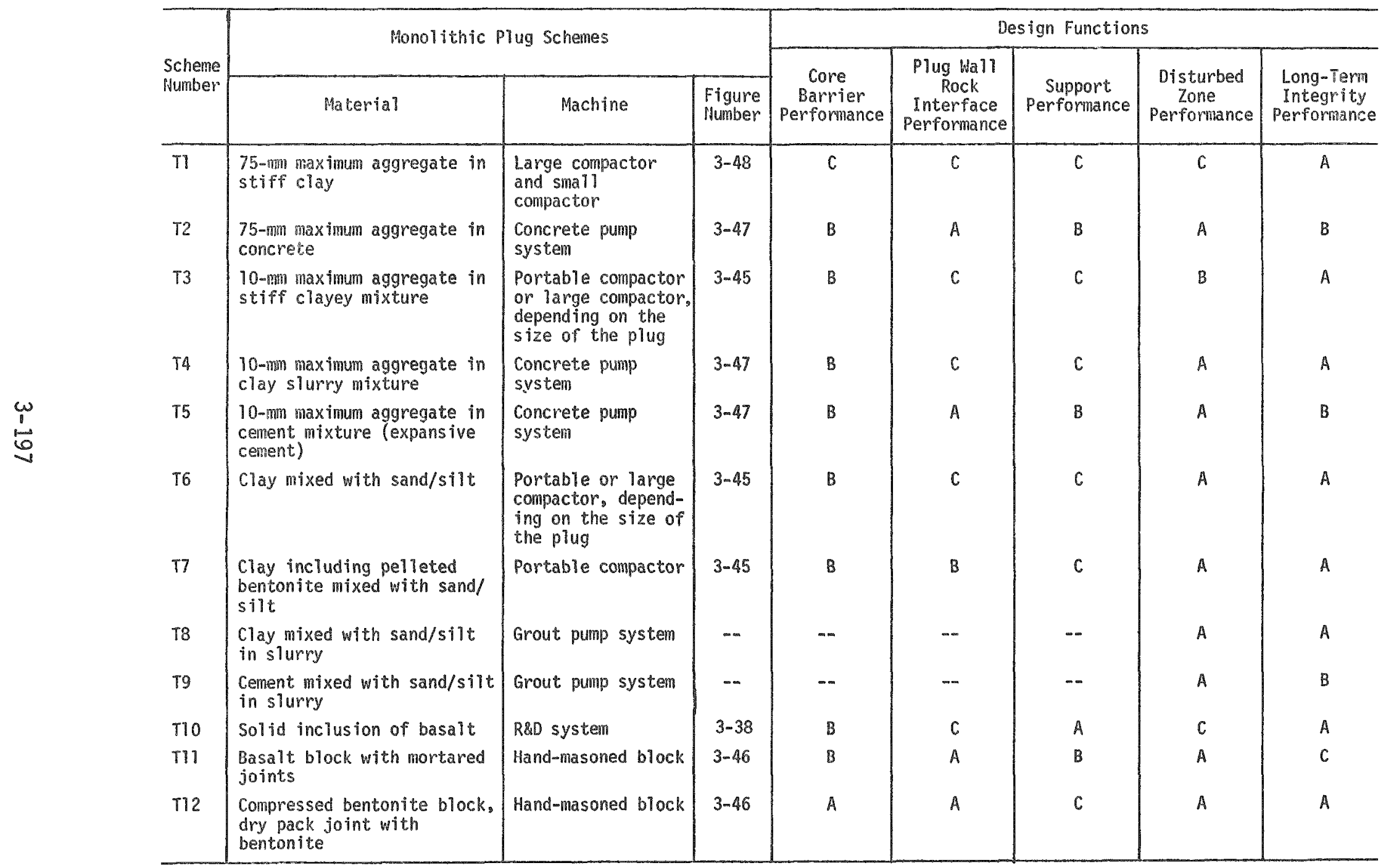


TABLE 3-25. Summary of Dominance Computations for Shafts.

\begin{tabular}{|c|c|c|c|c|c|c|c|c|}
\hline \multirow{3}{*}{$\begin{array}{l}\text { Scheme } \\
\text { Rumber }\end{array}$} & \multicolumn{3}{|c|}{ Monolithic Plug Schemes } & \multicolumn{5}{|c|}{ Design Functions } \\
\hline & & & & \multirow{2}{*}{$\begin{array}{c}\text { Core } \\
\text { Barrier } \\
\text { Performance }\end{array}$} & \multirow{2}{*}{$\begin{array}{c}\text { Plug Wall } \\
\text { Rock } \\
\text { Interface } \\
\text { Performance }\end{array}$} & \multirow[b]{2}{*}{$\begin{array}{c}\text { Support } \\
\text { Performance }\end{array}$} & \multirow{2}{*}{$\begin{array}{l}\text { Disturbed } \\
\text { Zone } \\
\text { Performance }\end{array}$} & \multirow{2}{*}{$\begin{array}{l}\text { Long-Term } \\
\text { Integrity } \\
\text { Performance }\end{array}$} \\
\hline & Material & Prâchine & $\begin{array}{l}\text { Figure } \\
\text { Number }\end{array}$ & & & & & \\
\hline S1 & $\begin{array}{l}\text { 75-minaxinum aggregate in } \\
\text { concrete }\end{array}$ & $\begin{array}{l}\text { Concrete wireline } \\
\text { system }\end{array}$ & $3-33$ & $\varepsilon$ & B & B & $\mathrm{c}$ & 8 \\
\hline$\$ 2$ & $\begin{array}{l}\text { 75-mm maximum aggregate in } \\
\text { concreie }\end{array}$ & $\begin{array}{l}\text { Concrete pump } \\
\text { system }\end{array}$ & $3-34$ & E & B & B & $\mathrm{c}$ & B \\
\hline$\$ 3$ & $\begin{array}{l}\text { 10-mm maximum aggregate in } \\
\text { stiff clayey mixture }\end{array}$ & Smal1 compactor & $3-42$ & c & B & B & D & A \\
\hline 54 & $\begin{array}{l}\text { 10-mm maximum aggregate in } \\
\text { cement mixture }\end{array}$ & $\begin{array}{l}\text { Concrete wireline } \\
\text { system }\end{array}$ & $3-33$ & D & B & $A$ & B & B \\
\hline$\$ 5$ & $\begin{array}{l}\text { 10-min maximum aggregate in } \\
\text { cement mixture }\end{array}$ & $\begin{array}{l}\text { Concrete pump } \\
\text { system }\end{array}$ & $3-34$ & D & B & A & B & B \\
\hline 56 & Clay mixed with sand/silt & Sma11 compactor & $3-42$ & A & A & B & c & A \\
\hline$\$ 7$ & $\begin{array}{l}\text { Clay including pelleted } \\
\text { bentonite mixed with sand/ } \\
\text { silt }\end{array}$ & Small compactor & $3-42$ & A & A & B & C & A \\
\hline$\$ 8$ & $\begin{array}{l}\text { Clay mixed with sand/silt } \\
\text { in slurry }\end{array}$ & $\begin{array}{l}\text { Concrete pump } \\
\text { system }\end{array}$ & $3-34$ & c & B & C & B & A \\
\hline s9 & Solid inclusion of basalt & R\&D system & $3-37$ & C & B & B & E & A \\
\hline$\$ 10$ & $\begin{array}{l}\text { Basalt block with mortared } \\
\text { joints }\end{array}$ & Hand-masoned block & $3-48$ & D & B & B & C & c \\
\hline 511 & $\begin{array}{l}\text { Compressed bentonite block, } \\
\text { dry pack joint with } \\
\text { bentonite }\end{array}$ & Hand-masoned block & $3-48$ & B & A & B & A & A \\
\hline$\$ 12$ & Cement slurry & $\begin{array}{l}\text { Concrete pump } \\
\text { system }\end{array}$ & $3-34$ & $\mathrm{E}$ & B & B & C & B \\
\hline
\end{tabular}


TABLE 3-26. Summary of Dominance Computations for Boreholes.

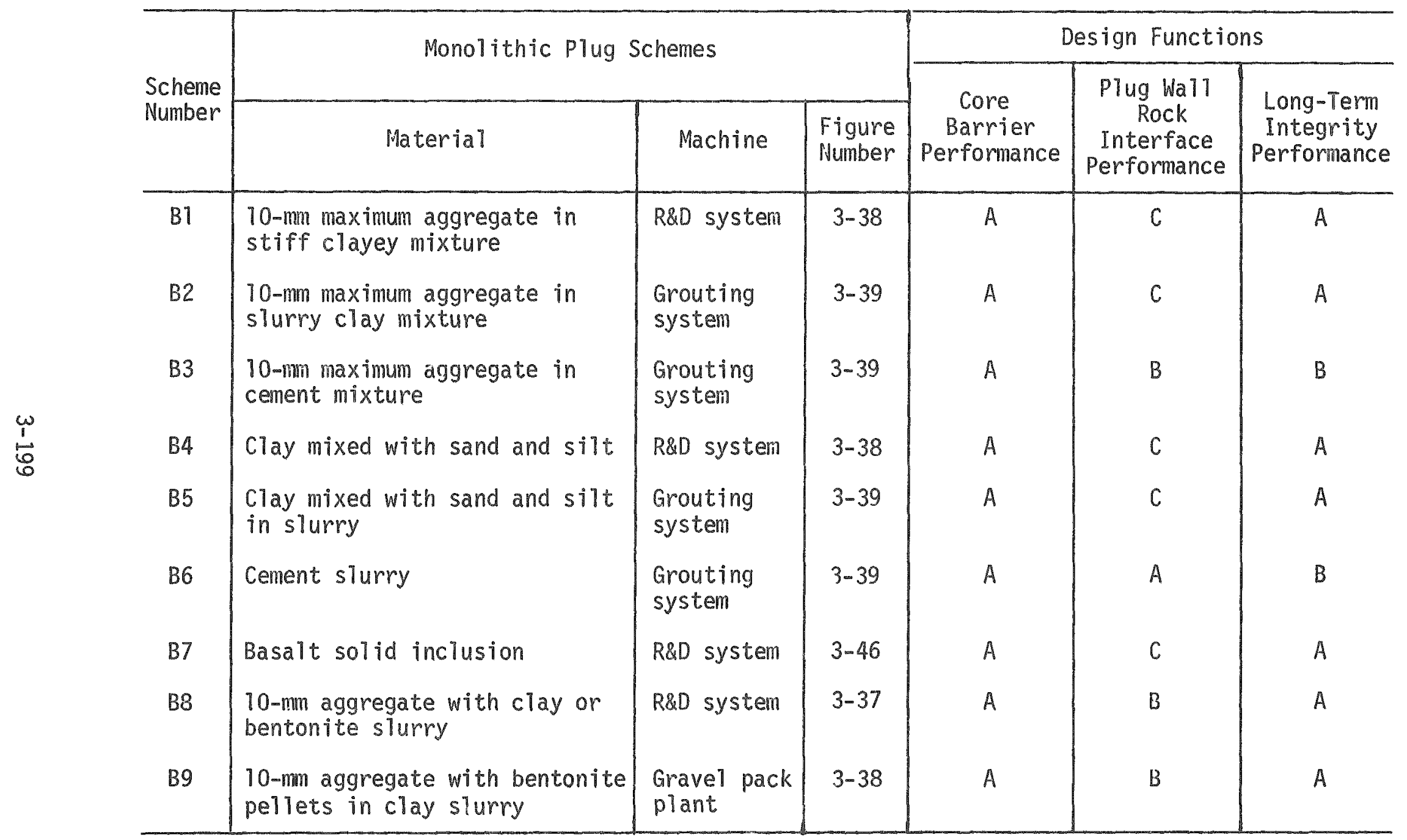


Resuits of the dominance analysis (Table 3-24) show that a superior, common performer for the combined first two design functions (core barrier performance and plug-wall rock interface performance) is a scheme employing either compressed bentonite blocks or concrete.

The next required design function is support performance. The most dominant scheme employs a solid, basalt inclusion, which is considered a research and development scheme not presently viable. The next level of dominance is shared by a concrete scheme and a basalt block masonry scheme. In view of a superior concrete rating for the combined first two categories (though shared by basalt blocks in the second category), concrete might be considered the leading choice for suiting the first three design functions.

In the fourth design function of disturbed rock zone treatment, there is a wide range of possibilities in the same top dominance group. However, depending on specific design details, some schemes within the group may or may not be dominated by the other schemes. It appears, though, that in cutoff collar treatments, pumped clay/sand/silt slurry mixtures or clay/aggregate mixtures, or compressed bentonite blocks, provide the more superior choices. (Pressure grouting of rock fractures has been presumed for all designs, whether or not cutoff collars are used.)

In the fifth design function of long-term integrity, compacted earth and clay slurries dominate. If concrete is used to a large extent to meet a number of the other design functions, particularly the support function, it seems necessary to consider compacted earth schemes as backup elements. However, a zoned plug of concrete and earth elements may be difficult to construct, and it will be especially difficult to obtain good compaction and contact of earth materials at the top of tunnels. It appears that basalt block schemes are penalized heavily in the analyses input because of proposed cement mortar joints and, therefore, are rated low. Judgment suggests that the penalty may actually be too severe in view of the small volume of mortar joints included in such schemes. 
In any case, considering the self-cementing properties of finely ground basalt (as determined during the geochemical test program), it might be reasonable to specify a few zones using basalt blocks with basalt mortared joints as a redundant feature to any concrete zones. This scheme might be easier to construct in tunnels and would secure improved long-term integrity features in the multiple-zone plug design. It should be noted, though, that the geochemical tests were carried out at elevated temperatures as an alternative to long-term testing for reactions. Consequentiy, it would be necessary to check the self-cementing property at ambient temperatures, or to plan on curing the mortared block installation in the tunnel at some elevated temperature. Cement mortar will be tentatively selected at this point, though ground basalt mortar is at least recommended for future investigation.

Inspection of Table 3-25 shows that compacted earth schemes (or compressed bentonite blocks) rate high for the first two design functions of core barrier performance and plug-wa11 rock interface performance.

In the third design function of support performance, concrete schemes dominate, while in the fourth design function of disturbed rock zone treatment, concrete is a midrange possibility dominated by compressed bentonite blocks. The principal design plan for disturbed rock zone treatment in shafts is to excavate cutoff collars through the disturbed rock zone, and to backfill them with a seepage barrier material. In the shaft configuration, a cutoff collar excavation would undermine an annulus of loosened disturbed rock zone, so the excavation would have to be done in partial, arc segments with backfilling of excavated segments before excavating adjoining arc segments (much like special techniques for pulling pillars in coal mines). The cutoff collar backfill in shafts then, unlike tunnels, must carry a potentially significant load. This is not realiy recognized in the data input to the dominance analysis for shafts and the compressibility of bentonite blocks might permit progressive loosening of the disturbed rock zone. The preferred choice of plug scheme for design functions three and four is concrete.

In the fifth design function, long-term integrity, compacted earth schemes dominate and concrete schemes are in a midrange. Considering the 
makeup of the multiple-zone plug thus far envisioned for the shaft, compacted earth is already a major feature of the plug and concrete, even if it suffers some degradation in quality with time; it could still perform its design functions to some extent, and so the plugs as a whole are expected to perform in an acceptable manner.

Inspection of Table 3-26 quickly reveals two potential zones for a multiple-zone plug that has superior performances over all the design functions necessary to borehole pligs.

The gravel and clay slurry with bentonite pellets rate among the highest in core barrier performance and long-term integrity performance, while cement grout is dominant in plug-wall rock interface performance.

\subsubsection{Expert Evaluation and Judgment}

In order to expand the base of engineering judgment upon which the analysis of plug schemes is founded, it was necessary to consult experts in the areas of tunneling and plugging. Using a consensus of their evaluations and comments, in combination with results of the previous technical and dominance analyses, final designs were developed for preconceptual plugging systems.

Following preliminary trials, which resulted in modifications in the evaluation forms and procedure, three experienced evaluators were chosen for final evaluation of the proposed schemes. The three evaluators were chosen on the basis of their long experience and familiarity with three different aspects of tunneling and plugging so as to evaluate each scheme from their respective points of view. Evaluator 1 was a heavy construction and tunneling specialist with over 35 years of field and design experience with dams and tunnels. Evaluator 2 was a civil engineering design specialist with some 40 years of design and field experience. Evaluator 3 was a geology specialist with about 25 years of field and design experience. These three evaluators thus represent about 100 years of experience in three fields considered most pertinent to the evaluation of the proposed schemes.

The evaluators were presented with a total of 19 proposed schemes: 10 monolithic and 9 multiple-zone plug schemes. Separate meetings were held 
with each evaluator; hence, their expressed views were independent of one another. Each evaluator was first briefed on the purpose of the meeting and the objectives of the evaluation process. Next, they were told to consider the particular environment (e.g., deep underground repository), loading conditions, (e.g., hydraulic, thermal, dynamic) and time frame of the probiem (thousands of years). Following these preliminaries, each evaluator was presented with the proposed plug schemes, one at a time (and not in the same order with different evaluators). They were asked to study the scheme prior to filling in the evaluation form. The procedure was repeated for each scheme.

It was expected that the respondents would not always agree on anticipated performance and properties of plug components. Such disagreements could occur whether or not the evaluators were equally informed about the plug schemes and whether or not they had comparable experience judgments about untried schemes, and it was felt the responses were bound to vary. The first type of interpersonal disagreement would be reconciled by discussion between the participants; however, the second kind could arise because one evaluator may be better informed or more experienced with a particular plug component than others. In this case, the views of the more knowledgeable evaluator could be weighed more heavily. However, the assumption was made that all evaluators were equally informed about the various plug components and their expressed views were equally weighed. This assumption could be relaxed, if necessary, without changing the procedure. The evaluation procedure further assumed that respondents would not disagree on any question in a major way. Such an assumption was reasonable, since it was understood that any major disagreements could be resolved in subsequent discussions between evaluators.

It was found during the evaluation process that the three evaluators were reluctant to make any response to questions dealing with overall radionuclide absorptive/retentive properties, even though they were rurnished with some limited, qualitative data concerning materials performance. Therefore, their overall rating of any scheme did not 
consider this question. A fourth evaluator, with a background in radiochemistry, was asked to evaluate in this area, but the results did not present much additional basis for discrimination between schemes.

A conservative approach was adopted to analyze the questionnaire results. Any scheme that received an overall rating of $D$ by any evaluator would be considered least desirable, since the experience of that evaluator suggested some significant reservations about its feasibility or performance. Any scheme that received at least an $A$ or $B$ overall rating by each of the evaluators would be considered mostpreferred schemes. It is felt that no hard distinction can be made between $A$ and $B$ ratings because at least one evaluator was generally reluctant to give any scheme better than a $B$ overall rating (understandably, because every scheme is untried yet and the available data is relatively scant). On this basis, schemes were rated as shown in Table 3-27. These results are in reasonably good agreement with the dominance analysis evaluation of the plug schemes.

- Boreholes--The cement-grout/clay-gravel slurry with bentonite pellets for boreholes matches exactly.

- Tunnels--For tunnels, the evaluators preferred monolithic concrete plugs, and the next choice included concrete and basalt block. The latter choice, plus clay-sand slurry cutoff collars, was the preferred choice of the previous analysis. It is felt that long-term integrity considerations make it imperative to go with the multiple-zone concept.

The construction-specialist evaluator had some detailed comments on how the cutoff collars might be constructed and his concerns indicated that some careful thought will have to be given to final design of this feature. Generally, he discussed excavating and filling each collar in segments. The staff felt this concept was necessary for shafts but considered that natural arching would allow a single excavation and a single backfilling operation for tunnel cutoff collars without causing excessive, additional disturbance of the tunnel wall rock. 
TABLE 3-27. Judgmental Evaluation of Candidate Monolithic and Multiple-Zone Plugs by Professionals.

\begin{tabular}{|c|c|c|c|c|}
\hline \multirow{2}{*}{\multicolumn{2}{|c|}{ "Most Preferred" Schemes }} & Boreholes & Tunnels & Shafts \\
\hline & & & 7 & 15 \\
\hline \multicolumn{2}{|c|}{ "Second Most Preferred" Schemes } & 2,5 & 8,10 & 13,14 \\
\hline \multicolumn{2}{|c|}{ "Least Preferred" Schemes } & 4 & $6,9,11,12$ & 16,17 \\
\hline \multicolumn{2}{|c|}{ Reference key } & \multirow{2}{*}{\multicolumn{3}{|c|}{ General Plug Description }} \\
\hline $\begin{array}{c}\text { Scheme } \\
\text { No. }\end{array}$ & $\begin{array}{c}\text { Reference } \\
\text { Figure }\end{array}$ & & & \\
\hline $\begin{array}{l}1 \\
2 \\
3\end{array}$ & $\begin{array}{l}3-39 \\
3-33 \\
3-42\end{array}$ & \multirow{9}{*}{\multicolumn{3}{|c|}{$\begin{array}{l}\text { Cement grout } \\
\text { clay-gravel slurry } \\
\text { clay-gravel slurry with bentonite } \\
\text { pellets } \\
\text { Cement grout/melt-in-place metal } \\
\text { cement grout/compacted metal } \\
\text { pellets } \\
\text { compacted earth } \\
\text { concrete } \\
\text { Basalt block masonry } \\
\text { compacted earth/bentonite blocks/ } \\
\text { basalt blocks/concrete } \\
\text { Concrete/basalt blocks } \\
\text { compacted earth core/clay-slurry or } \\
\text { bentonite blocks cutoff collars } \\
\text { concrete/clay-slurry or cement } \\
\text { cutoff collars } \\
\text { Compacted earth } \\
\text { Concrete } \\
\text { Concrete/bentonite blocks or basalt } \\
\text { blocks } \\
\text { cutoff collars } \\
\text { Compacted earth } \\
\text { compacted earth/basalt cutoff } \\
\text { collars }\end{array}$}} \\
\hline $\begin{array}{l}4 \\
5\end{array}$ & $\begin{array}{l}3-50 \\
3-50\end{array}$ & & & \\
\hline $\begin{array}{l}6 \\
7 \\
8 \\
9\end{array}$ & $\begin{array}{c}3-45, \quad 3-48 \\
3-47 \\
3-46 \\
3-53\end{array}$ & & & \\
\hline 10 & $3-53$ & & & \\
\hline 11 & $3-54$ & & & \\
\hline 12 & $3-54$ & & & \\
\hline $\begin{array}{l}13 \\
14\end{array}$ & $3-37, \frac{3-36}{3-38}$ & & & \\
\hline 15 & $3-51$ & & & \\
\hline $\begin{array}{l}16 \\
17\end{array}$ & $\begin{array}{l}3-51 \\
3-52\end{array}$ & & & \\
\hline
\end{tabular}


- Shafts-For shafts, the evaluators considered a multiple-zone plug of concrete with a compressed bentonite block or basalt block cutoff collar as the most preferable scheme. Monolithic plugs of compacted earth or concrete were their next choice. Previous technical ratings favored a multiple-zone plug of compacted earth with a concrete collar cutoff. This was based on the staff concern for increasing the disturbance effects in the shaft borehole wall if the cutoff collar were built of compressible material; e.g., the bentonite blocks, so there was some reluctance to adopt such a design, and the basalt block cutoff collar was more acceptable for this reason. On the other hand, there was some concern with the long-term integrity of that design because a major structural component, the concrete in the shaft proper, does not have the best rating for this design function. The mortar for the basalt blocks could also be a further long-term integrity problem as discussed for tunnels. on the basis of long-term integrity performance, therefore, there seems to be less risk with taking the compacted earth with concrete collar cutoff preferred in the previous analysis.

\subsubsection{Preconceptual Plugging Systems}

From an analysis of the preconceptual plugging schemes by evaluation specialists who have many years' experience and familiarity in different aspects of tunneling and plugging, a series of recommendations pertaining to plug design has been developed. These recommendations were geared towards practical, available plugging schemes that could be expected to satisfactorily perform five functions: (1) core barrier performance; (2) plug-rock interface performance; (3) disturbed rock zone cutoff performance; (4) mechanical stability performance; and (5) long-term stability. Based on a consensus of these plug design recommendations, preconceptual plugging systems for tunnels, shafts, and boreholes have been developed.

Although the analyses provided some insight into the order of magnitude required for various plug design parameters, the analyses were limited by the quantity and quality of data available and by the 
simplicity of the models that were used. More detailed analyses will require sophisticated models that can be utilized and revised during the course of repository excavation, backfilling, and sealing with the input for these models initially consisting of available field and laboratory test data and assumed values. Confirming or revising the available data and the assumed values will require timely installation and extensive use of instrumentation to monitor: (1) basalt behavior during the excavation of tunnels and shafts, as well as during the waste storage period; (2) quality of plug materials and placement procedures; and (3) plug performance. Consequently, plugging system designs must incorporate not only plug materials and placement techniques, but also instrumentation to monitor plug conditions and exercise quality control.

\subsubsection{Machines and Materials. In order to combine the plugging} schemes that were identified as currently possible with the materials and designs recommended in Section 3.7 .2 , the most effective preconceptual plugging systems will consist of multiple-zoned plugs. Each plug zone witl be designed to perform one or more of the key design functions (i.e., core-barrier performance, plug-rock interface performance, disturbed rock zone cutoff performance, mechanical stability performance, and long-term stability) that apply to the given plug environment (i.e., tunnels, shafts, or boreholes). A discussion of the preconceptual plugging systems designed for each of the three plug environments follows.

As shown in Figure 3-67, this design incorporates the following features:

- Concrete with copper flashing to satisfy the requirements of core barrier, plug rock interface and support performance. The concrete would be placed in 1.5 m lifts using a concrete pump and 20 - to $30-\mathrm{cm}$ diameter steel pipe. The upper flashing would be installed in the basalt just prior to concrete placement.

- Basalt blocks, with mortared joints, to satisfy the requirements of support performance and long-term stability. The blocks would be hand-masoned with cement mortar tentatively selected at 


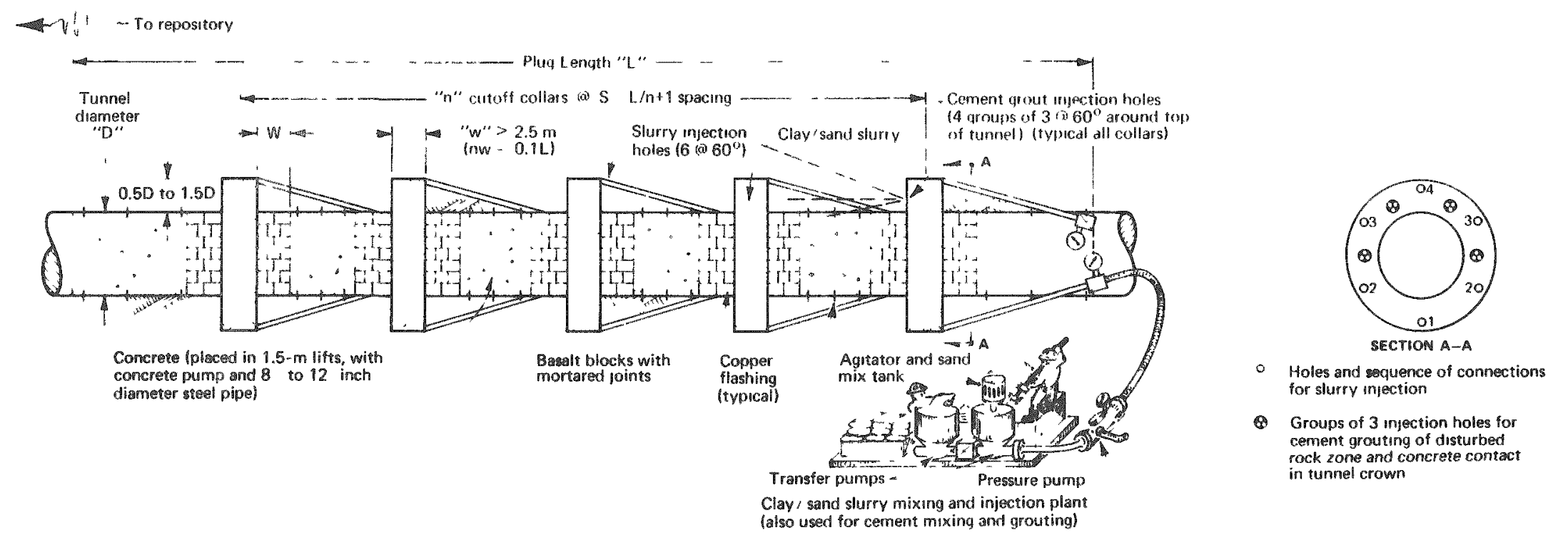

$w$
1
0
0

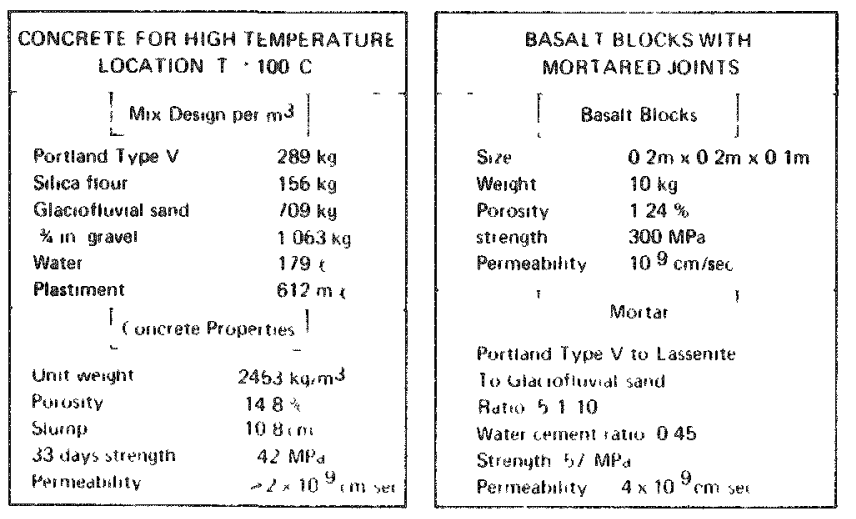

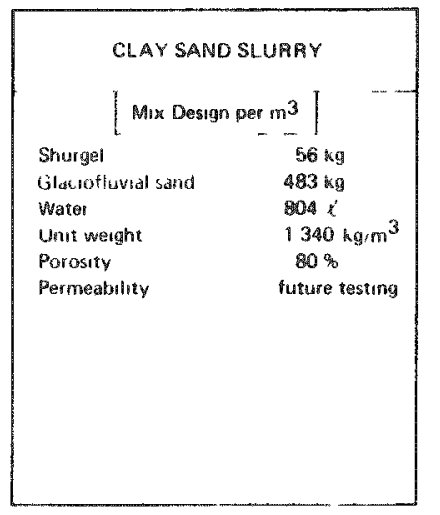

\begin{tabular}{|c|c|}
\hline \multicolumn{2}{|c|}{$\begin{array}{l}\text { CONCRETE FOR LOW TEMPERATURE } \\
\text { LOCATION } T<100^{\circ} \mathrm{C}\end{array}$} \\
\hline \multicolumn{2}{|c|}{ Mix Design per $\mathrm{m}^{3}$} \\
\hline Portland Type V & $273 \mathrm{~kg}$ \\
\hline Lassentre & $55 \mathrm{~kg}$ \\
\hline Giaciofluvial sand & $755 \mathrm{~kg}$ \\
\hline $3 / 4$ in gravel & $1132 \mathrm{~kg}$ \\
\hline Water & $174 x$ \\
\hline Plastiment & $689 \mathrm{mk}$ \\
\hline \multicolumn{2}{|c|}{ Concrete Propervies } \\
\hline Unut wesghe & $2481 \mathrm{~kg} \mathrm{~m}^{3}$ \\
\hline Porosity & $133 \%$ \\
\hline Stump & $83 \mathrm{~cm}$ \\
\hline 25 davs strength & $36 \mathrm{~b} \mathrm{MPa}_{\mathrm{a}}$ \\
\hline Permeabulity & $<4 \times 10^{9} \mathrm{~cm}$ sec \\
\hline
\end{tabular}

FIGURE 3-67. Preconceptual Design of Tunnel Plugs. 
this point, although ground-basalt mortar is at least recommended for future investigation. Using basalt blocks in combination with concrete is beijeved to provide a reasonable degree of redundancy to this design.

- clay-sand slurry to satisfy the requirements for disturbed rock zone treatment. Cutoff collars would be excavated into the disturbed rock zone, and injection holes would be drilled so that the slurry could be pumped, under pressure, into the cutoff collars after placement of the basalt blocks (see Fig. 3-67).

- Cement grout for treatment of disturbed rock zone and the zone of contact between the concrete plug and the tunnel crown. Injection holes will be drilled from the cutoff collar recesses and the grout pumped, under pressure, to seal off fractures in the disturbed rock zone as we 71 as any gaps that exist between the concrete plug and the tunnel crown.

Preliminary calculations suggest that a plug length of $300 \mathrm{~m}$ may be acceptable depending on assumptions for in situ and disturbed rock properties, radioactive waste conditions and criteria, and other factors.

As shown in Figure $3-68$, this plugging system design incorporates the following features:

- Concrete to satisfy the requirements of support performance and disturbed rock zone treatment. In particular, the concrete will provide support to the disturbed rock zone during the excavation and construction of the cutoff collars using the segmental procedure shown in Figure 3-68, thereby minimizing continued disturbance of this rock zone. The concrete would be placed in lifts using a surface pump, steel pipe and holding tank arrangement as shown in Figure 3-68.

- Sandy clay to satisfy the requirements of core barrier and plug rock interface performance, as well as long-term stability. The sandy clay would be transported and placed in lifts, using essentialiy the same apparatus as was used for the concrete, 


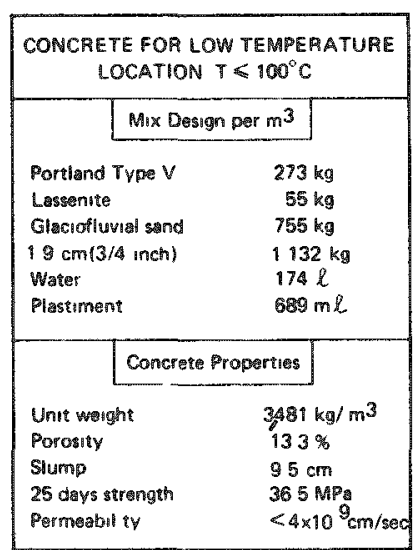

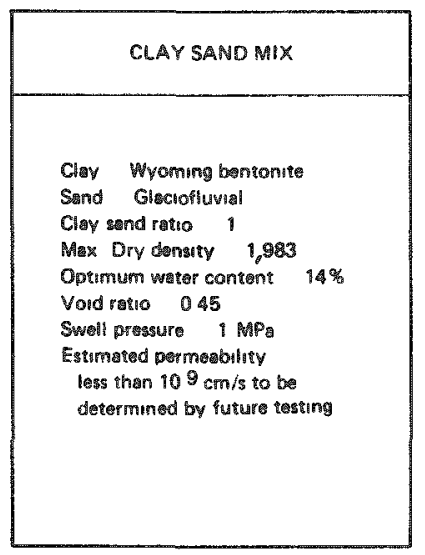

CONCRETE FOR HIGM TEAPE RATURE LOCATION $T \geq 100^{\circ} \mathrm{C}$

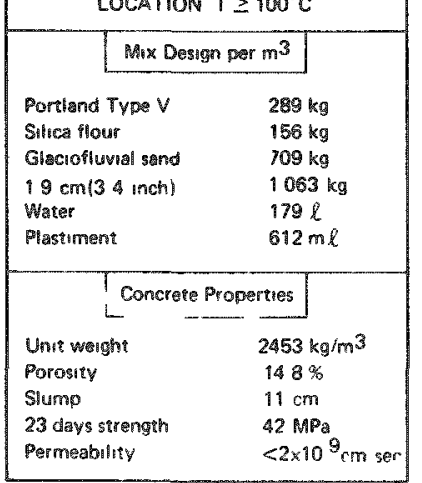

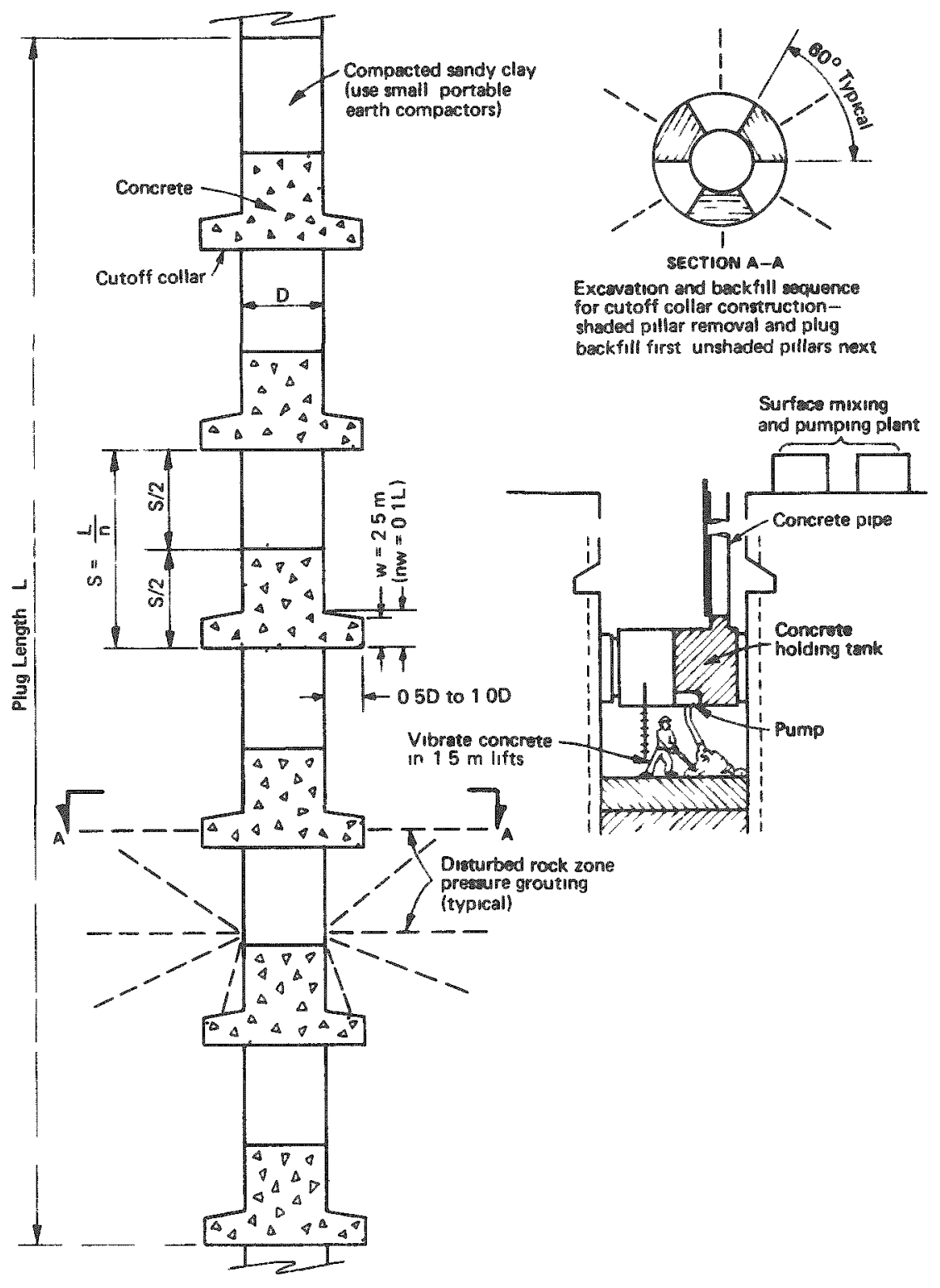

FIGURE 3-68. Preconceptual Design of Shaft Plugs. 
then compacted by a self-propelled small compactor (hand-held tampers would be used to compact near the sides of the shaft). Using the compacted sandy clay in combination with concrete would provide this design with a reasonable degree of redundancy.

- Cement grout for treatment of disturbed rock zone and zone of contact between concrete in the cutoff collar and the top of the cutoff collar recess. Injection holes would be drilled into the sides of the shaft as well as into the sides of the cutoff collar recess (see Fig. 3-68). The grout would be pumped, under pressure, to seal off fractures in the disturbed rock zone as well as any gaps that exist between the concrete and the cutoff collar recess.

As with the tunnel plug, preliminary calculations suggest that a plug length of $300 \mathrm{~m}$ may be acceptable.

As shown in Figure 3-69, this plugging system design incorporates the following features:

- Gravel and clay slurry with compressed bentonite pellets to satisfy the requirements of core barrier performance and long-term stability. The gravel and bentonite pellets would be mixed with clay slurry at the ground surface and pumped, under pressure, through a steel pipe. As the bentonite pellets hydrate, the mixture will swell against the sides of the borehole; also, clay within the slurry will seal off fractures along the borehole walls.

- Cement grout to satisfy the requirements of plug-wall rock interface performance and to incorporate a reasonable level of redundancy into the plug system. The grout would be pumped, under pressure, through the same steel pipe as the gravel-slurry-pellet mixture, thereby allowing for a continuous plugging operation.

As with the tunnel plug, preliminary calculations suggest that a plug length of $300 \mathrm{~m}$ may be acceptable. 


\begin{tabular}{|c|c|}
\hline \multicolumn{2}{|c|}{$\begin{array}{l}\text { GROUT FOR LOW TI MPE PAIURE } \\
\text { LOTATION T. 100? }\end{array}$} \\
\hline Mix Des & Mix Destinn ner m3 3 \\
\hline Portland Type V & $602 \mathrm{~kg}$ \\
\hline Lassente & $241 \mathrm{kq}$ \\
\hline Sand & $723 \mathrm{~kg}$ \\
\hline Water & $447 k$ \\
\hline WHA & $125 k$ \\
\hline AI powder & $180 \mathrm{q}$ \\
\hline \multicolumn{2}{|c|}{ Trout Properties } \\
\hline Unit weeght & $2,013{\mathrm{~kg} / \mathrm{m}^{3}}^{3}$ \\
\hline Porastey & 338 \\
\hline Flow & 16 Acc \\
\hline \multirow{2}{*}{$\begin{array}{l}28 \text { daws strength } \\
\text { Pormeabslity }\end{array}$} & $29 \mathrm{MPa}$ \\
\hline & $1 \times 10^{9} \mathrm{~cm} / \mathrm{sec}$ \\
\hline
\end{tabular}

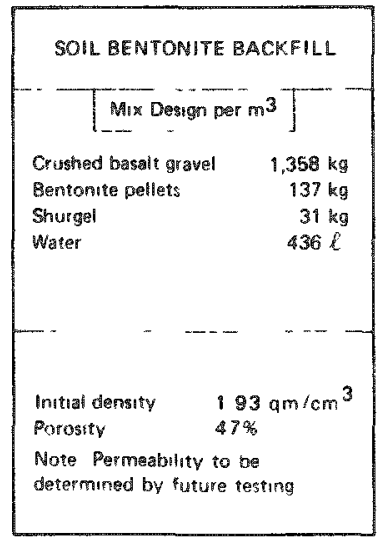

GROUT KOR HIGH TEMPERATURE

\begin{tabular}{|c|c|}
\hline \multicolumn{2}{|c|}{ Mix Design per $\mathrm{m}^{3}$} \\
\hline Portland Type $v$ & $586 \mathrm{~kg}$ \\
\hline Sifica flour & $315 \mathrm{~kg}$ \\
\hline Glacrofluvial sand & $772 \mathrm{~kg}$ \\
\hline Water & $414 ?$ \\
\hline$W R A$ & 1226 \\
\hline Al nowder & $176 \mathrm{~g}$ \\
\hline Grout $\mathrm{Pr}$ & opertses \\
\hline Urit weaght & $2082 \mathrm{~kg} \mathrm{~m}^{3}$ \\
\hline Porospty & 33 o \\
\hline Flow & $16 ? A_{G C}$ \\
\hline 28 day strenugth & $248 \mathrm{MPa}$ \\
\hline Permeability & $86 \times 10^{6} \mathrm{~cm}$ ser \\
\hline
\end{tabular}

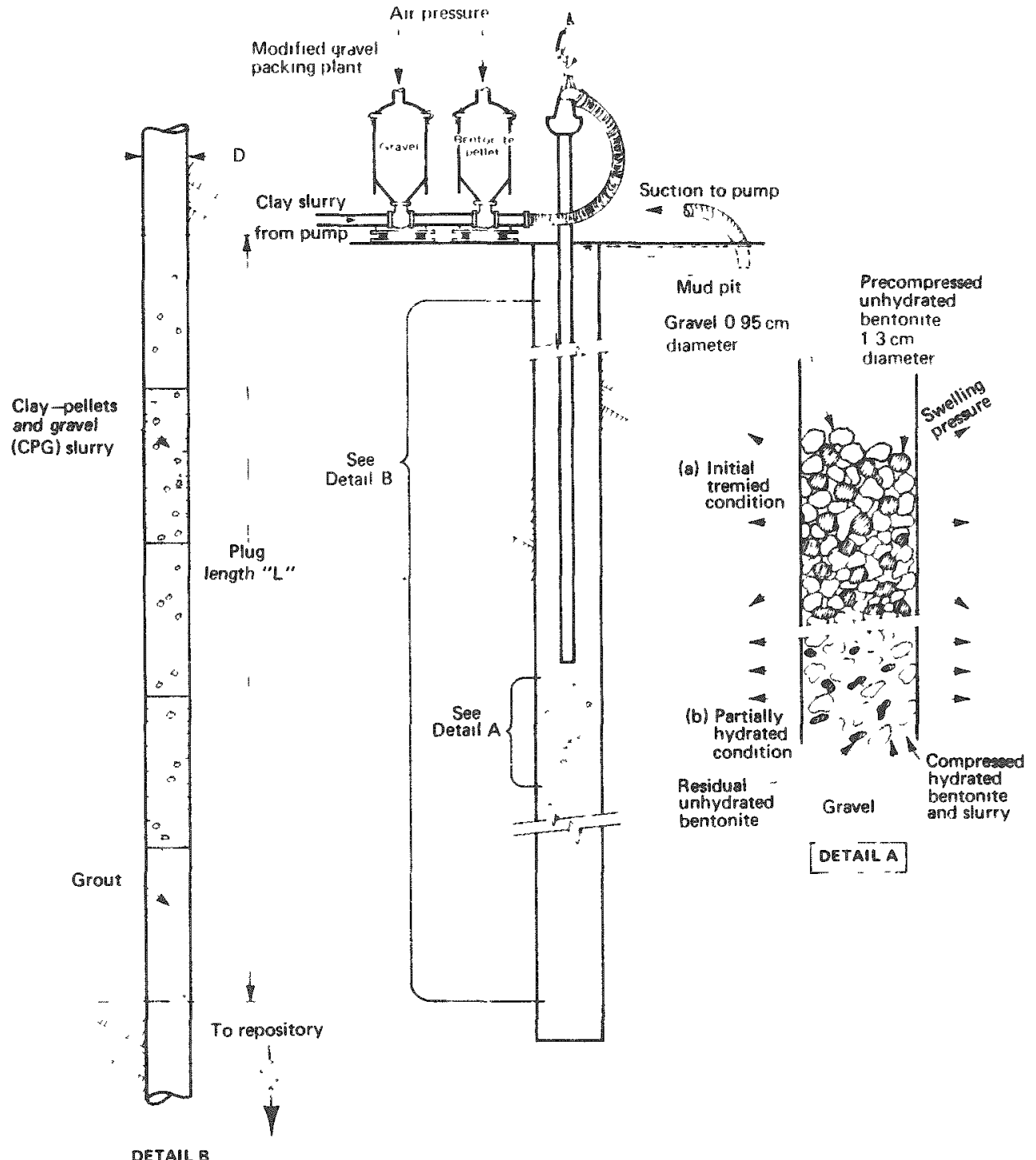

FIGURE 3-69. Preconceptual Design of Borehole Plugs. 
3.7.4.2 Conclusions. The materials and equipment proposed for the preconceptual plugging systems are considered practical, available, and effective combinations that can satisfactorily perform the required design functions. By using multiple-zone plug designs, it was possible to utilize the most desirable properties of a variety of materials and to incorporate a reasonable level of redundancy into the designs. Based on preliminary calculations, it is assumed that a plug length of $300 \mathrm{~m}$ would be acceptable.

\subsection{BOREHOLE PLUGGING FIELD TESTS}

Field tests of plug materials and plug designs are necessary to demonstrate that a repository for high-level nuclear waste in basalt can be sealed in an acceptable manner. In the Basalt Waste Isolation Project borehole plugging program, laboratory testing, materials selection, machinery development, and modeling of borehole plugs are coupled with a graduated series of field tests and demonstrations. The tests and demonstrations are designed to test both materials and emplacement techniques under scaled-up in situ conditions and to validate plug models through real-time monitoring of piug behavior. The test sequence will consist of the shallow borehole plugging test, the second borehole plugging test, and the advanced field demonstration. The advanced field demonstration will consist of two parts: the deep remote plugging of a selected smali-diameter vertical core hole; and the plugging of tunnels and shafts in a subsurface test facility.

\subsubsection{Shallow (First) Borehole Plugging Test}

The shallow (first) borehole plugging test will involve the plugging of shallow boreholes under dry conditions. Plug materials recommended by the preconceptual design study will be emplaced into instrumented boreholes ranging in depth between 12 and $46 \mathrm{~m}$. This test will yieid engineering data on borehole plugging machines and techniques and on parameters such as plug-wall rock bonding, fracture filling around boreholes, plug permeabilities, swelling pressures, and thermomechanical response. Subsequent to testing, several of the plugs will be overcored 
and the recovered material will be used for further laboratory testing and characterization. The test will be carried out in the state of Washington both on Gable Mountain and near the Near-Surface Test Facility, because of the occurrence of dry basalt at or near the surface and because of easy access to Near-Surface Test Facility facilities. The shallow borehole plugging test is scheduled for completion in fiscal year 1983.

\subsubsection{Second Borehole Plugging Test}

The second borehole plugging test, which will probably be carried out within the Near-Surface Test Facility, will consist of two parts: the plugging of small-diameter horizontal and vertical boreholes under wet conditions; and (2) the plugging of a large-diameter shaft penetrating the Near-Surface Test Facility from the surface. The test wi11 require excavation of a test room within the Near-Surface Test Facility for the small-diameter boreholes and to receive the surface shaft.

The shaft will be excavated by backreaming of a borehole drilled from the surface. The first part of the test will evaluate techniques and materials for the plugging of boreholes against water pressure. This is important because of the possibility that exploratory boreholes drilled ahead of repository excavation wi 11 encounter bad rock zones that must be sealed, both to allow continued excavation and to preserve repository integrity. The shaft plugging test will allow testing of materials and machines in the emplacement of preconceptual or conceptual plug schemes for shafts and will provide engineering data on parameters such as permeability, plug-wall rock bond strength, and mechanical properties of plugs under in situ conditions. Sections of the plugs and plug-wall rock interface will be recovered through coring and used for continued laboratory characterization and testing. The second borehole plugging test is scheduled for completion in fiscal year 1986.

\subsubsection{Advanced Field Demonstration}

An advanced field demonstration will be used to test the emplacement of prototype plugs and seals in the expected repository environment and 
for long-term monitoring of plug performance characteristics. This test has two distinct parts with parallel schedules. The first part is the deep, remote plugging of a selected smali-diameter vertical core hole and is scheduled for completion in the late 1980's. The second consists of plugging tunnels and shafts in a subsurface test facility and is scheduled to start in the eariy 1990's.

The plugging of a deep core hole, approximately 1,000 m deep and 12 to $15 \mathrm{~cm}$ in diameter is probably the most difficult technical problem involved in repository sealing. The hole must be characterized and prepared remotely prior to plugging and all plugging operations including quality assurance procedures and instrumentation must be carried out remotely. An existing core hole on the Hanford Site will be selected and characterized through the use of cores, geophysical logs, and down hole photography for the deep remote plugging test. Subsequently, plugs and monitoring instrumentation will be emplaced under carefully controlled conditions. Recovery of intact plugs will be virtually impossible, therefore, the instrumentation must be carefully designed for long-term monitoring.

The plugging of tunnels and shafts will take place in a subsurface test facility, either part of an exploratory shaft complex or in a test area adjoining the repository. Testing will allow the emplacement and monitoring of prototype seais under repository conditions and will allow the evaluation of the effect of the disturbed rock zone and various schemes, such as grouting and cutoffs, for blocking flow within the disturbed zone.

\subsubsection{Conclusions}

The iterative interaction of a graduated series of borehole plugging field tests with laboratory and modeling studies should facilitate the design of a set of viable borehole plug designs for the sealing of a nuclear waste repository in basalt. 
RHO-BWI-ST- 7

4.0 REFERENCES 
RHO-BWI-ST - 7

\subsection{REFERENCES}

Additon, M. K. and Sei1, R. 0, 1979, Columbia River basalt reference sample: RHO-SA-93, Rockwell Hanford Operations, Richland, Washington.

Ah1ström, P.E., 1979, Ceramic and pure-metal canisters in buffer meta1: NUREG/CP-0005, U.S. Nuclear Regulatory Commission, Washington, D.C., p. 287-316.

Allard, B. and Beal1, G. W., 1979, Chemical reactions in the bedrockgroundwater system of importance for the sorption of actinides: in Proceedings, the Material Research Society's International Symposium on the Scientific Basis for Nuclear Waste Management, Boston, Massachusetts.

A1lard, B., Kipatsi, H., and Rydberg, J., 1977, Sorption of long-1ived radionuclides in clay and rock, part 1: KBS-55, Swedish Nuclear Fuel Safety Project Report, AB Atomenergi, Stockholm, Sweden.

Altseimer, J. H., 1976, Technical and cost analysis of rock-melting systems for producing geothermal we17s: LA-6555-MS, Los Alamos Scientific Laboratories, Los Alamos, New Mexico, 41 p.

Ames, L. L. (in press) Hanford basalt flow mineralogy: PNL-2847, Pacific Northwest Laboratory, Richland, Washington.

Ames, L. L. and McGarrah, J. E., 1979a, Geomedia-radionuclide distribution coefficient, fiscal year 1979 annual report: PNL-3146, Pacific Northwest Laboratory, Richland, Washington.

Ames, L. L. and McGarrah, J. E., 1979b, A waste overpack material specific for iodine and selenium removal from circulating groundwater: BNIR-425, Battelle, Pacific Northwest Laboratory, Richland, Washington.

Analytical Sciences Corporation, 1979, Information base for waste repository design: NUREG/CR-0495, U.S. Nuclear Regulatory Commission, Hashington, D.C.,.V. 1 . 
Andrews, M. G., Freeburn, H. R., and Wenisen, W. D., 1979, The performance of combustion engineering fuel in operating PWRs: in Proceedings, the American Nuclear Society Topical Meeting on LWR Fuel Performance, Portland, Oregon.

Angerman, C. L. and Rankin, W. N., 1978, Durability of containers for storing solidified radioactive wastes: Materials Performance, $v .17$, p. 9-18.

Anonymous, 1979, World 1ist of nuclear power plants: Nuclear News, v. 22, p. 69-87.

ANS, 1979, American nuclear society policy statements: Nuclear News, November, 1979.

Apps, J., Doty, B., Doty, S., Galbraith, R., Kearns, A., Kohrt, B., Lons, J., llonroe, A., Narasimhan, T. N., Nelson, P., Wilson, C. R., and Witherspoon, P. A., 1979, Geohydrologic studies for nuclear waste isolation at the Hanford Reservation: LBL-8764, Lawrence Berkeley Laboratory, Earth Science Division, Berkeley, California, v. 2.

ARHCO, 1974, Retrievable surface storage facility alternative concepts engineering studies: ARH-2888 REV, Atlantic Richfield Hanford Company and Kaiser Engineers, Richland, Washington.

ARHCO, 1976, Preliminary feasibility study on storage of radioactive wastes in Columbia River basalts: ARH-ST-137, Atlantic Richfield Hanford Company, Richland, Washington.

Asaro, F., Miche1, H. V., and Myers, C. W., 1978, A statistical evaluation of some Columbia River basalt chemical analyses: RHO-BWI-ST-3, Rockwell Hanford Operations, Richland, Washington. 
ASTM, 1973, Annual book of ASTM standards: Part 9 - Cement, 1ime, gypsum: American Society of Testing and Materials, Philadelphia, Pennsylvania.

ASTM, 1977, Annual book of ASTM standards: Part 14 - Concrete and mineral aggregates: American Society for Testing and Materials, Philadelphia, Pennsylvania.

ASTM, 1978, Annual book of ASTM standards: Part 19 - Natural building stones, soil and rock, peats, mosses, and humus: American Society for Testing and Materials, Philadelphia, Pennsylvania.

Banham, M. F., Causer, R., Fudge, A. J., and Murphy, L., 1968, Investigation of the distribution of radioactive fission product nuclei in irradiated fuel specimens by precision gamma-ray scanning: AERE-R-5864, United Kingdom Atomic Energy Agency, Harwe11, United Kingdom.

Banning, L. H. and Oden, L. L., 1973, Corrosion resistance of metals in hot brines: A Titerature review: IC8601, U.S. Bureau of Mines, Washington, D.C.

Barnes, M. W. and Scheetz, B. E., 1979, Laboratory alteration of a Columbia River basalt by hot groundwater: An application to deep geological disposal of nuclear waste: Geological Society of America Bulletin, no. 11, p. 384.

Barney, G. S., 1979, The kinetics and reversibility of radionuclide sorption reactions with basalt, granite, and argillite: RHO-SA-80, Rockwell Hanford Operations, Richland, Washington.

Barney, G. S. and Wood, B. J., 1980, Identification of key radionuclides in a nuclear waste repository in basalt: RHO-BWI-ST-9, Rockwel1 Hanford Operations, Richland, Washington. 
Batch, J.M. and Heath, C. A., 1979, U.S. program for disposal of radioactive wastes: in Proceedings, International Symposium on the Underground Disposal of Radioactive Waste, IAEA-SM-243/77, International Atomic Energy Agency and OECD Nuclear Energy Agency, Otaniemi (Helsinki), Finland.

Be11, M. G., 1973, ORIGEN - the ORNL isotope generation and depletion code: ORNL 4628, Oak Ridge National Laboratory, Oak Ridge, Tennessee.

Benson, D. W., 1960, Review of soil chemistry research at Hanford: HW-67201, General Electric Company, Richland, Washington.

Benson, L. V., 1978, Secondary minera1s, oxidation potentials, pressure of temperature gradients in the Pasco Basin of Washington State: RHO-BWI-C-34, Rockwell Hanford Operations, Richland, Washington.

Benson, L. V., Carnahan, D. J., Apps, J. A., Mouton, C. A.s Corrigan, D. J., Frisch, C. J., and Shomura, L. K., 1978, Basalt alteration and basalt-waste interaction in the Pasco Basin of Washington State: LBL-8532, Lawrence Berkeley Laboratory, Berkeley, California.

Benson, L. V., Mouton, L. S. Frisch, C. J., Stolzman, R. A., and Corrigan, D. J., 1979, A study of rock-water-nuclear waste interactions in the Pasco Basin, Washington: LBL-9677, Lawrence Berkeley Laboratory, Berkeley, California.

Bentley, R. D., 1977, Stratigraphy and structure of the Yakima Basalt and structural evolution of the Yakima ridges on the western Columbia Plateau: in Proceedings, Geological Excursion in the Pacific Northwest, Geological Society of America Annual Meeting, Seattle, Washington, p. 339-389.

Billington, D. S. and Crawford, J. H., 1961, Radiation damage in solids: University Press, Princeton, New Jersey. 
Bird, G.W. and Lopata, V. J., 1979, Solution interaction of nuclear waste anions with selected geological materials: in Proceedings, the Materials Research Society's International Symposium on the Scientific Basis for Nuclear Waste Management, Boston, Massachusetts.

Bischoff, J. L. and Dickson, F. W., 1976, Seawater basalt interactions at $200^{\circ} \mathrm{C}, 500$ bars--implication for origin of sea-floor heavy metal deposits and regulation of seawater chemistry: Earth Planet Science Letter, v. 25, p. 385-397.

Bischoff, J. L. and Seyfried, W. E., 1978, Hydrothermal chemistry of seawater from $25^{\circ} \mathrm{C}$ to $350^{\circ} \mathrm{C}$ : American Journal of Science, v. 278, p. 338-860.

Black, D. L., Blankenship, W. P., Fernandes, R., Hak7, A. R., Holder, C. A., Holman, R. R., Spurrier, F. R., and Wright, M. K., 1975, A study of borehole plugging in bedded salt domes by earth melting technology: WANL-TME-2870, Westinghouse Electric Corporation, Astronuclear Laboratory, Pittsburgh, Pennsylvania, 219 p.

Blackwe11, D. D., 1978, Heat flow and energy loss in the western United States: Geological Society of America Memoir 152, Smith, R. and Easton, G., eds., p. 175.

Blume and Associates, 1971, A summary report, seismic evaluation and development of ground acceleration and response spectra for FFTF site: JABE-WADCO-03, prepared for WADCO, Richland, Washington.

Boa, J. A., Jr., 1978, Borehole plugging program (waste disposal) report 1: Initial investigations and preliminary data: Miscellaneous Paper C-78-1, U.S. Army Engineer Waterways Experiment Station, Vicksburg, Mississippi, $16 p$.

Bondietti, E. A. and Francis, C.W., 1979, Geologic migration potentials of Technetium-99 and Neptunium-237: Science, no. 203, p. 1337-1340. 
Bonner, W. F., Blair, H. T., and Romero, L. S., 1976, Spray calcination of nuclear wastes: BNWL-SA-5764, Battelle, Pacific Northwest Laboratory, Richland, Washington.

Bradley, D. J., 1978, Leaching of fully radioactive high-level waste glass: PNL-2664, Pacific Northwest Laboratory, Richland, Washington.

Braithwaite, J.W. and Molecke, M. A., 1979, Nuclear waste canister corrosion studies pertinent to geologic isolation: SAND 74-1935J, Sandia Laboratories, Albuquerque, New Mexico.

Braithwaite, J. W., Magnani, N. J., and Munford, J.W., 1980, Titanium alloy corrosion in nuclear waste environments: in Proceedings, Corrosion 80, Chicago, I17inois, paper no. 213.

Brookins, D. G., 1978, Geochemical constraints on accumulation of actinide critical masses for stored nuclear waste in natural rock repositories: ONWI-17, Office of Nuclear Waste Isolation, Columbus, Ohio.

Brookins, D. G., 1979, Clay minerals suitable for overpack in waste repositories: evidence from uranium deposits: in Proceedings, the Materials Research Society's International Symposium on Scientific Basis for Nuclear Waste Management, Boston, Massachusetts.

Brown, D. J., 1959, Subsurface geology of the Hanford separations area: HW-61780, General Electric Company, Richland, Washington.

Brown, D. J. and Ledgerwood, R. K., 1973, Stratigraphy and structure of the Vakima Basalt in the Pasco Basin, Washington: Oregon Department of Geology and Mineral Industries BuT7etin No. 77, p. 171-181.

Brown, J. C. and Skau, C. M., 1975, Chemical composition of snow in the east central Sierra Nevada: Cooperative Report Series No. AG-2, Desert Research Institute, Reno, Nevada. 
Brown, R. E., 1968, A study of reported faulting in the Pasco Basin: BNWL-662, Battelle, Pacific Northwest Laboratory, Richland, Washington.

BWIP, 1978, Staff, Basalt Waste Isolation Program annual report-fiscal year 1978: RHO-BWI-78-100, Rockwe11 Hanford Operations, Richland, Washington.

BWIP, 1979a, Staff, Basalt Waste Isolation Program second quarterly report-fiscal year 1979: RHO-BWI-79-100 2Q, Rockwel1 Hanford Operations, Richland, Washington.

BWIP, 1979b, Staff, Basalt Waste Isolation Project annual report-fiscal year 1979: RHO-BWI-79-100, Rockwell Hanford Operations, Richland, Washington.

Bya lobzheski, A. V., 1970, Radiation corrosion: AEC-tr-7096, Atomic Energy Commission, Washington, D.C.

Cameron, D. J. and Strathdee, 1979, Materials aspects of nuclear waste disposal in Canada, in Proceedings of an international symposium on ceramics in nuclear waste management, Chikal1a, T. D. and Mendel, J. E., eds.: CONF-790420, U.S. Department of Energy, Washington, D.C.

Camp, V. E., 1976, Petrochemical stratigraphy and structure of the Columbia River basalt, Lewiston Basin area, Idaho-Washington: Ph.D. thesis, Washington State University, Pul7man, Washington.

Camp, V. E., Price, S. M., and Reidel, S. P., 1978, Descriptive summary of the Grande Ronde Basalt type section, Columbia River Basalt Group: RHO-BWI-LD-15, Rockwell Hanford Operations, Richland, Washington.

Carslaw, H. S. and Jaeger, J. C., 1959, Conduction of heat in solids: Oxford University Press, London, England. 
Carter, L. J., 1979, Academy squabbles over radwaste report: Science, v. 205, p. 287-289.

Carter, J. P. and McCawley, F. X., 1978, In situ corrosion tests in Salton Sea geothermal brine environments: Journal of Metals, p. 11-15.

Castee1, F., Tas, J., Maets, J., and Brabers, M. J., 1979, Corrosion of materials in clay environment: in Proceedings, the Materials Research Society's International Symposium on Scientific Basis for Nuclear Waste Management, Boston, Massachusetts.

Chika11a, T. D. and Mendel, J. E., eds., 1979, Proceedings of an international symposium on ceramics in nuclear waste management: CONF-790420, U.S. Department of Energy, Washington, D.C.

Chou, I. and Eugster, H. P., 1978, Diffusion of hydrogen through platinum membranes at high pressures and temperatures: Geochimica et Cosmochimica Acta, v. 42, p. 281-288.

Christian, J. D., 1976, Process behavior and control or Ru and Ce, in Controlling airborne effluents from fuel cycle plants: in Proceedings, American Nuclear Society-AIChE meeting, August 5 and 6, 1976, Section 2.1-2.34.

Clark, R. G. and Reynolds, A. W., 1979, Uranium market forecasts: in Proceedings, Uranium Industry Seminar, Grand Junction, Colorado, October 12, 1979.

Cleveland, J.M., 1970, The chemistry of plutonium: Gordon and Breach Science Publishers, New York, New York, 653 p.

Cohen, B. L., 1977a, High-level radioactive waste from light water reactors: Reviews of Modern Physics, v. 49, p. 1-9. 
Cohen, B. L., 1977b, The disposal of radioactive wastes from fission reactors: Scientific American, v. 236, p. 21-31.

Coles, D. G., weed, H. C., and Tewhey, J. D., 1979, Geochemical studies of sorption and transport of radionuclides in rock media: NCD-WP-79-147, Lawrence Livermore Laboratory, Livermore, California.

Cook, N. G., 1977, An appraisal of hard rock for potential underground repositories of radioactive wastes: LBL-7004, Lawrence Berkeley Laboratory, Berkeley, California, 15 .

Cubicciotti, D. D. and Jones, R. L., 1978, Stress corrosion crack initiation sites in zirconium alloys exposed to iodine vapor: Journal of Electrochemical Society, v. 125, p. 1001-1002.

Cubicciotti, D. D. and Sanecki, J. E., 1978, Characterization of deposits on inside surfaces of LWR cladding: Journal of Nuclear Materials, v. 78, p. 96-111.

D'Appolonia Consulting Engineers, 1979, The status of borehole plugging and shaft sealing for geologic isolation of radioactive waste: ONWI-15, Office of Nuclear Waste Isolation, Columbus, Ohio, 1979.

D'Appolonia, D. S. and Ryan, C. R., 1979, Soil-bentonite slurry trench cut-off walls: Geotechnical Exhibition and Technical Conference, Chicago, I17inois, $112 \mathrm{p}$.

Davies, J. H. and Ewart, F. T., 1971, The chemical effects of composition changes in irradiated oxide fuel materials: Journal of Nuclear Materials, v. $41, p .143-155$.

Davis, R. B., 1979, Data report for the nondestructive examination of Turkey Point spent fuel assembl ies B02, B03, B17, B41, and B43: TC-1284, Hanford Engineering Development Laboratory, Richland, Washington. 
Deer, W. A., Howie, R. A., and Zussman, J., 1967, Rock-forming minerals: Longmans, Green and Co., London, England, v. 1-5.

DeHalas, D. R. and Horn, G. R., 1963, Evolution of uranium dioxide structure during irradiation of fuels rods: Journal of Nuclear Materials, v. 8, p. 207-220.

Deju, R. A., 1978a, Evaluation of basalt flows as a waste isolation medium: RHO-BWI-SA-14, Rockwell Hanford Operations, Richland, Washington.

Deju, R. A., 1978b, Preliminary analysis of some waters from the confined aquifers underlying the Hanford Site: RHO-BWI-LD-12, Rockwell Hanford Operations, Richland, Washington, $22 p$.

Deju, R. A. and Summers, W. K., 1975, Conductivity of saturated sedimentary rocks in the Hanford Reservation: ARH-C-0007, AtTantic Richfield Hanford Company, Richland, Washington.

Deju, R. A. and Fecht, K. R., 1979, Preliminary description of hydrologic characteristics and contaminant transport potential of rocks in the Pasco Basin, south-central Washington: RHO-BHI-LD-20, Rockwe11 Hanford Operations, Richland, Washington.

Deju, R. A., Eddy, P. A., Grutzeck, M. W., and Myers, C. W., 1977, Environmental factors needed to establish the geotechnical feasibility of storing radioactive waste in Columbia River basalt: RHO-ST-8, Rockwell Hanford Operations, Richland, Washington.

Deju, R. A., Ledgerwood, R. K., and Long, P. E., 1978a, Reference waste form, basalts, and ground-water systems for waste interaction studies: RHO-BWI-LD-11, Rockwell Hanford Operations, Richland, Washington. 
Deju, R. A., Board, M. P., Gephart, R. E., and Myers, C. W., 1978b, Structural considerations in the design of a repository to store radioactive waste in basalt formations: RHO-SA-10, Rockwe11 Hanford Operations, Richland, Washington.

Dienes, G. J. and Vineyard, G. H., 1957, Radiation effects in solids: Interscience Publishers, New York, New York and London, England.

DOE, 1979a, Technology for commercial radioactive waste management: DOE/ET-0028, U.S. Department of Energy, Washington, D.C., V. 1.

DOE, 1979b, Annual report to congress, 1978, forecast: DOE/EIA-0713/3, U.S. Department of Energy, Energy Information Administration, Washington, D.C., V. 3.

DOE, 1979C, Statistical data of the uranium industry: Grand Junction office: GJ0-100, U.S. Department of Energy, Grand Junction, Colorado.

DOE and USGS, 1979, Earth science technical plan for mined geologic disposal of radioactive waste: TID-29018 (Draft 2), U.S. Department of Energy and U.S. Geological Survey, Washington, D.C.

DOE and USGS, 1980, Earth science technical plan for disposal of radioactive waste in a mined repository: DOE/TIC-11033 (Draft), U.S. Department of Energy and U.S. Geological Survey, Washington, D.C.

Dosch, R. G., 1978, Use of titanates in decontamination of defense waste: SAND-78-0710, Sandia Laboratories, Albuquerque, New Mexico, 64 p.

Eichho 1z, G. G., 1979, Subsurface migration of radioactive waste materials by particulate transport, annual progress report 1978-1979: School of Nuclear Engineering, Georgia Institute of Technology, Atlanta, Georgia. 
Eilers, L. H., 1973, Borehole sealing final report: ORNL/SUB-73/15966, Dow Chemical Company, Dowe11 Division, Tulsa, OkTahoma, $101 \mathrm{p}$.

Eilers, L. H., 1974, Sealing AEC \#1 wel1, Lyons, Kansas, final report: ORNL/SUB-74/33542, Dow Chemical Company, Dowell Division, Tulsa, OKlahoma, $45 \mathrm{p}$.

Eilers, L. H. and Spangle, L. G., 1973, Borehole sealing: ORNL/SUB/1596673/1, Union Carbide Corporation, Nuclear Division, Oak Ridge, Tennessee, $110 \mathrm{p}$.

Ekbom, L. B., Hannerz, K., Henrikson, S., 1979, Corrosion studies on copper and titanium-lead canisters for nuclear waste disposal: in Proceedings, International Symposium on the Underground Disposal of Radioactive Wastes, IAEA-SM-243/77, Internationai Atomic Energy Agency and OECD Nuclear Energy, Otaniemi (Helsinki), Finland.

EPA, 1976, National interim primary drinking water regulations: EPA-570/ 9-76-003, Office of Water Supply, U.S. Environmental Protection Agency, Washington, D.C.

EPA, 1979, Radiation protection programs, subpart B-environmenta 1 standards for disposa 1: 40 CFR 191 (Draft 7), Code of Federal Regulations, U.S. Environmental Protection Agency, Washington, D.C.

ERDA, 1975, Environmental statement - waste management operations, Hanford Reservation, Richland, Washington: WASH-1538, U.S. Energy Research and Development Administration, Richland, Washington, v. 2.

ERDA, 1976, Alternatives for managing wastes from reactors and post-fission operations in the LWR fuel cycle: ERDA-76-43, U.S. Energy Research and Development Administration, Washington, D.C., V. 1 .

Eugster, H. P. and Wones, D. R., 1962, Stability relations of the ferrugenous biotite, annite: Journal of Petrology, v. 3, p. 82-125. 
Ewart, F. T. and Taylor, R. G., 1976, The chemical effects of composition changes in irradiated oxide fuel materials II--fission product segregation and chemical equilibria: Journal of Nuclear Materials, v. 61, p. 254-270.

Ewing, R. C. and Haaker, R. F., 1979, The metamict state: radiation damage in crystalline materials: in Abstract with Programs, Internal Symposium on Ceramics in nuclear waste management, Chika1la, T. D. and Mendel, J. E., eds.: CONF-790420, U.S. Department of Energy, Washington, D.C.

Fecht, K. R., 1978, Geology of the Gable Mountain-Gable Butte area: RHO-BWI-LD-5, Rockwel1 Hanford Operations, Richland, Washington.

Ford, C. K., Keeney, R. L., and Kirkwood, C. W., 1979, Evaluating methodologies--a procedure and application to nuclear power plant siting methodologies: Management Science, $v .25, p .1-10$.

Fried, S. M., Friedman, A. M., Hines, J. J., Atcher, R. W., Quarterman, L. A., and Volesky, A., 1976, Annual report for fiscal year 1976 on project ANO115A: The migration of plutonium and americium in the lithosphere: ANL-76-127. Argonne National Laboratory, Argonne, I17inois.

Fried, S. M., Friedman, A. M., Atcher, R. W., and Hines, J. J., 1977, Retention of americium in plutonium by rock: Science, v. 196, p. 1087-1089.

Fried, S. M., Friedman, A. M., Cohen, D., Hines, J. J., and Strickert, R. Gos 1978, The migration of long-lived radioactive processing wastes in selected rocks--annual report to the office of waste hardling: ANL-78-46, Argonne National Laboratory, Argonne, I1linois.

Garrels, R. M. and Christ, C. L., 1965, Solutions, minerals and equilibria: Freeman Cooper and Company, San Francisco, California.

Gephart, R. E., Deju, R. A., and Eddy, P. A., 1979a, Geophysical logging and hydrologic testing of deep basalt flows in the Rattlesnake Hills well number one: RHO-BWI-ST-1, Rockwell Hanford Operations, Richland, Washington. 
Gephart, R. E., Arnett, R. C., Baca, R. G., Leonhart, L. S., and Spane, F. A., Jr., 1979b, Hydrologic studies within the Columbia Plateau: An integration of current knowledge: RHO-BWI-ST-5, Rockwell Hanford Operations, Richland, Washington.

Glover, S. L., 1936, Preliminary report on petroleum and natural gas in Washington: Washington Division of Geology Report of Investigation No. 4., 0lympia, Washington.

Greene, E. M., 1979, Spent fuel for waste storage programs: HEDL-TC-1374, Hanford Engineering Development Laboratory, Richland, Washington, 106 p.

Grim, R. E., 1962, Applied clay mineralogy: McGraw-Hil1, New York, New York, $422 p$.

Gurlick, C. W., Jr., 1978, Borehole plugging--materials development program: SAND 78-0715, Sandia Laboratories, Albuquerque, New Mexico, 19 p.

Hajash, A. J., 1975, Hydrothermal processes along mid-ocean ridges: An experimental investigation: Contributions to Mineralogy and Petrology, v. 53, p. $205-226$.

Hamstra, J., 1975, Radiotoxic hazard measure for buried solid radioactive waste: Nuclear Safety, v. 16, p. 180-189.

Hardy, M. P. and Hocking, G., University of Minnesota and Dames \& Moore, 1978, Numerical modeling of rock stresses within a basalt nuclear waste repository: Phase II - parametric design studies: RHO-BHI-C-23, Rockwell Hanford Operations, Richland, Washington, 303 p.

Haug, H. 0., 1975, Production, disposal, and relative toxicity of long-lived fission products and actinides in the radioactive wastes from nuclear fuel cycles: KFK-2022, Kernforschungszentrum, Karlsruhe, West Germany. 
Haug, H. 0., 1976, Relative toxicity and long-term problems of actinidebearing wastes from fuel reprocessing: CONF-761020, in Proceedings, the Symposium on Waste Management, Tucson, Arizona, p. 262-271.

Helgeson, H. C., Delany, J. M., Nesbitt, H. W., and Bird, D. K., 1978, Summary and critique of the thermodynamic properties of rock-forming minerals: American Journal of Science, v. 278 A, p. 229.

Hi11, M. D. and Grimwood, P. D., 1978, Preliminary assessment of the radiological protection aspects of disposal of high-level waste in geologic formations: National Radiological Protection Board-R69, Harwel1, Didcot, Oxon, England.

Holloway, C. A., 1979, Decision making under uncertainty: Prentice-Ha11, Englewood Cliffs, New Jersey, 522 p.

Hower, J., Eslinger, E. V., Hower, M. E., and Perry, E. A., 1976, Mechanism of burial metamorphism of argillaceous sediments: 1. Mineralogical and chemical evidence: Geological Society of America Bulletin, v. 87, p. $725-737$.

Hoyt, R. C. and Rhee, B. W., 1979, Review of the literature for dry reprocessing oxide, metal, and carbide fuel - the airox, rahyd, and carbox pyrochemical processes: ESG-DOE-13277, Rockwell International, Energy Systems Group, Canoga Park, California.

Huebner, J. S. and Sato, M., 1970, The oxygen fugacity-temperature relationships of manganese and nickel compounds: American Mineralogist, v. 55, p. 934-956.

Hure, J. R., Platzen, R., Bitte1, R., Foure, J., and Wey, R., 1958, Investigation of some mineral exchangers which are usable in high temperature water: in Proceedings, Second U.N. Conference on Peaceful Uses of Atomic Energy, v. 28, Basic Chemistry in Nuclear Energy, p. 31-47. 
IRG, 1979, Report to the President by the Interagency Review Group on nuclear waste management: TID-29442, U.S. Department of Energy, Washington, D.C.

Iwai, K., 1976, Fundamental studies of fluid flow through a single fracture: Ph.D. thesis, University of California, Berkeley, California.

Jacobsson, A., 1977, A short review of the formation, stability, and cementing properties of natural zeolites: KBS Technical Report No. 27, Swedish Nuclear Fuel Safety Project, Stockholm, Sweden.

Jeffrey, B. M., 1967, Microanalysis of inclusions in irradiated $\mathrm{UO}_{2}$ : Journal of Nuclear Materials, v. 22, p. 33-40.

Johnson, A. B., 1977, Behavior of spent nuclear fuel in water pool storage: BNWL-2256, Batte11e, Pacific Northwest Laboratory, Richland, Washington, $85 \mathrm{p}$.

Johnston, R. G., 1980, 0xides containing ruthenium in nuclear waste disposa 1: Ph.D. thesis, The Pennsylvania State University, University Park, Pennsylvania.

Jones, M. G. and Landon, R. D., 1978, Geology of the Nine Canyon map area: RHO-BWI-LD-6, Rockwe11 Hanford Operations, Richland, Washington.

Katayama, Y. B., 1976, Leaching of irradiated LWR fuel in deionized and typical ground water: BNWL-2057, Battelle, Pacific Northwest Laboratory, Richland, Washington.

Katayama, Y. B., 1979, Spent LWR fuel 1each tests: PNL-2982, Pacific Northwest Laboratory, Richland, Washington.

KBS, 1978a, Changes of creep properties for a lead casing as a result of mechanical damage: KBS-85, Swedish Nuclear Fuel Safety Project, AB Atomenergi, Stockholm, Sweden. 
KBS, 1978b, Copper as canister material for non-processed spent nuclear fuel - evaluation from corrosion point of view: KBS-90, Swedish Nuclear Fuel Safety Project, AB Atomenergi, Stockholm, Sweden.

KBS, 1978c, Preliminary corrosion studies of glass-ceramic code 9617 and a sealing frit for nuclear waste canisters: KBS-93, Swedish Nuclear Fuel Safety Project, AB Atomenergi, Stockholm, Sweden.

KBS, 1978d, Lead-titanium canister for vitrified high-level waste from reprocessing-evaluation from corrosion point of view: KBS-107, Swedish Nuclear Fuel Safety Project, AB Atomenergi, Stockholm, Sweden.

KBS, 1979, Alumina as canister material for unreprocessed nuclear waste-evaluation with respect to corrosion: KBS-118, Swedish Nuclear Fuel Safety Project, AB Atomenergi, Stockholm, Sweden.

Keeney, R. L., 1973, A decision analysis with multiple objectives: The Mexico City airport: Bell Journal of Economics and Management Science, v. 4, p. 101-117.

Keeney, R. L. and Raiffa, H., 1976, Decisions with multiple objectives: Preferences and Value Tradeoffs: John WiTey and Sons, New York, New York.

Kenney, T. C., 1967, The influence of mineralogical composition on the residual strength of natural soils: in Proceedings, 0slo Geotechnical Conference on the Shear Strength Properties of Natural Soils and Rocks, v. 1, p. 123-129.

Kezdi, A., 1974, Handbook of soil mechanics: Elsevier Scientific Pubiishing Company, New York, New York, 187 p.

Koizumi, M., Satoh, M., and Noro, K., 1974, Phase study on solid fission products, $\mathrm{Ba}, \mathrm{Sr}$ and $\mathrm{Zr}$ in oxide fue1: Journal of Nuclear Materials, $v .51$, p. 90-94. 
Komarneni, S. and Roy, R., 1979, Superoverpack: tailor-made mixtures of zeolites and clays: in Proceedings, the Materials Research Society's International Symposium on the Scientific Basis for Nuclear Waste Management, Boston, Massachusetts.

Komarneni, S., Scheetz, B. E., McCarthy, G. J., The Pennsyivania State University, and Coons, W. E., 1980, Hydrothermal interactions of cesium and strontium phases from spent unreprocessed fuel with basait phases and basalts: RHO-BWI-C-70, Rockwe11 Hanford Operations, Richland, Washington.

Krauskopf, K. B., 1967, Introduction to geochemistry: McGraw-Hi11, New York, New York, 721 p.

Lamb, K. M. and Cole, H. S., 1979, Development of a pelletized waste form for high-Tevel ICPP zirconia wastes: ICP-1185, Allied Chemical Corporation, Idaho Fal1s, Idaho, 32 .

Langmuir, D., 1978, Uranium solution-mineral equilibria at low temperature: Geochimica et Cosmochimica Acta, v. 42, p. 547-569.

Larker, H. T., 1979, Densification of calcines and direct containment of spent nuclear fuel in ceramics by the ASEA hot isostatic pressing techniques: in Proceedings, International Symposium on Ceramics in Nuclear Waste Management, Cincinnati, Ohio.

LaSala, A. M. and Doty, G. C., 1971, Preliminary evaluation of hydrologic factors related to radioactive waste storage in basaltic rocks at the Hanford Reservation, Washington: U.S. Geological Survey Open-File Report.

Lava1, W. N., 1957, Stratigraphy and structural geology of portions of south-central Washington: Ph.D. thesis, University of Washington, Seattle, Washington. 
Ledgerwood, R. K. and Deju, R. A., 1976, Hydrogeology of the uppermost confined aquifers underlying the Hanford Reservation: ARH-SA-253, Atlantic Richfield Hanford Company, Richland, Washington.

Ledgerwood, R. K., Myers, C. W., and Cross, R. W., 1978, Pasco Basin stratigraphic nomenclature: RHO-BWI-LD-1, Rockwe 11 Hanford Operations, Richland, Washington.

Leitnaker, J. M., 1974, Applications of thermodynamics for predicting and understanding the performance of fast breeder reactor oxide fuels: Journal of Nuclear Materials, v. 51, p. 95-105.

Lemoine, A., 1975, Contribution a T'etude du comportement de $\mathrm{UO}_{2}$ en miliere aqueux a' haute temperature et haute pression: Ph.D. thesis, Université de Nancy 1, Nancy, France, $111 \mathrm{p}$.

Lindemer, T. B., 1977, Measurement and interpretation of $\mathrm{CO}$ and $\mathrm{Kr}+\mathrm{Xe}$ in irradiated $\mathrm{ThO}_{2}$-containing HTGR fuel particles: Journal of American Ceramics Society, v. 60, p. 409-416.

Long, P. E., 1978, Characterization and recognition of intraflow structures, Grande Ronde Basalt: RHO-BWI-LD-10, Rockwell Hanford Operations, Richland, Washington.

Long, P. E., Ledgerwood, R. K., Myers, C. W., Reidel, S. P., Landon, R. D., and Hooper, P. R., 1980, Chemical stratigraphy of Grande Ronde Basalt, Pasco Basin, south-central Washington: RHO-BWI-SA-32, Rockwell Hanford Operations, Richland, Washington.

Mackin, J. H., 1961, A stratigraphic section in the Yakima Basalt and the Ellensburg Formation in south-central Washington: Washington Division of Mines and Geology Report of Investigations No. 19, 01ympia, Washington. 
Martin, R. T., 1975, Feasibility of sealing boreholes with compacted natural earthen material, volumes I, II, III: ORNL/SUB-3960/2, (MIT Research Report 75-28), Massachusetts Institute of Technology, Cambridge, Massachusetts, $76 \mathrm{p}$.

Mather, K., 1977, Minimize alkali-silica reaction: U.S. Army Engineer Waterways Experiment Station, Vicksburg, Mississippi, 4 p.

Mattsson, E., 1979, Corrosion resistance of canisters for final disposition of spent nuclear fuel, in Scientific basis for nuclear waste management: McCarthy, G. J., ed., Plenum Press, New York, New York, pp. 271-281.

McCarthy, G. J., 1974, Advanced waste forms research and development: progress report 1975-1: C00-2510-1, The Pennsylvania State University, University Park, Pennsylvania, 48 p.

McCarthy, G. J., 1975a, Radioactive waste management: the nuclear waste form: Earth and Mineral Sciences, v. 45, p. 17-20.

McCarthy, G. J., 1975b, Advanced waste forms research and development, first quarterly report: C00-2510-6, The Pennsylvania State University, University Park, Pennsylvania, $38 \mathrm{p}$.

McCarthy, G. J., 1977a, High-Tevel waste ceramics: Materials considerations, process simulation, and product characterization: Nuclear Technology, v. 32, p. 92-105.

McCarthy, G. J. 1977b, Advanced waste forms research and development, comprehensive progress report: C00-2510-12, The Pennsylvania State University, University Park. Pennsylvania, p. 14-17.

McCarthy, G. J., 1978a, Crystal chemistry and phase formation in developmental supercalcine: C00-2510-14, The Pennsylvania State University, University Park, Pennsylvania. 
McCarthy, G. J., 1978b, Supercalcine, in Quarterly progress report, research and development activities, waste fixation program, July through September 1977: PNL-2265-3, McE7roy, J. L., ed., Pacific Northwest Laboratory, Richland, Washington, p. 19-21.

McCarthy, G. J. and Davidson, M. T., 1975, Ceramic nuclear waste forms: I, crystal chemistry and phase formation: American Ceramics Society Bulletin, v. 54, p. $782-786$.

McCarthy, G. J. and Davidson, M. T., 1976, Ceramic nuclear waste forms: II, a ceramic-waste composite prepared by hot-pressing: Bulletin of American Ceramic Society, v. 55, .p. 190-194.

McCarthy, G. J., Scheetz, B. E., Komarneni, S., Barnes, M., Smith, C. A., Lewis, J.F., and Smith, D. K., The Pennsyivania State University, 1978a, simulated high-level waste-basalt interaction experiments. First interim progress report: RHO-BWI-C-12, Rockwell Hanford Operations, Richland, Washington.

McCarthy, G. J., Scheetz, B. E., Komarneni, S., and Smith, D. K., The Pennsylvania State University, 1978b, Reaction of water with a simulated high-level nuclear waste glass at $300^{\circ} \mathrm{C}, 300$ bars: RHO-BWI-C-35, Rockwell Hanford Operations, Richland, Washington.

McCarthy, G. J., Scheetz, B. E., Komarneni, S., Barnes, M., Smith, C. A., Smith, D. K., and Lewis, J. F., The Pennsylvania State University, 1978c, simulated high-level waste-basalt interaction experiments. Second interim progress report: $\mathrm{RHO}-\mathrm{BWI}-\mathrm{C}-16$, Rockwel] Hanford Operations, Richland, Washington.

McElroy, J. L., 1974a, Quarterly progress report, research and development activities, waste fixation program: BNWL-1841, Battelle, Pacific Northwest Laboratory, Richland, Washington, p. 28-29. 
MCETroy, J. L., 1974b, Quarterly progress report, research and development activities, waste fixation program: BNWL-1871, Battelle, Pacific Northwest Laboratory, Richland, Washington, p. 23.

McE7roy, J.L., 1975, Quarteriy progress report, research and development activities, waste fixation program, January through March 1975: BNWL-1908, Battelle, Pacific Northwest Laboratory, Richland, Washington, p. 34.

McE1roy, J. L., 1976, Quarterly progress report, research and development activities, waste fixation program: BNWL-1994, Battelle, Pacific Northwest Laboratory, Richland, Washington, p. 2.10.

McElroy, J. L. and Burns, R. E., Pacific Northwest Laboratory, 1979, Nuclear waste management status and recent accomplishments: EPRI NP-1087, Electric Power Research Institute, Palo Alto, California, 75 p.

McE1roy, J. L., Mende1, J. E., Bonner, W. F., and Henry, M. H., 1979a, Quarterly progress report, research and development activities, highlevel waste immobilization program: January through December 1978: PNL-2999, 1, 2, 3, 4, Pacific Northwest Laboratory, Richland, Washington.

Megerth, F. H., 1969, Zircaloy-clad $\mathrm{UO}_{2}$ fuel rod evaluation program. GEAP-5746, General Electric Company, San Jose, California.

Mendel, J. E., 1978, The storage and disposal of radioactive waste as glass in canisters: PNL-2764, Pacific Northwest Laboratory, Richland, Washington, $73 \mathrm{p}$.

Mende 1, J. E., Ross, W. A., Roberts, F. P., Katayama, Y. B., Westsik, J.H., Jr., Turcotte, R. P., Wald, J.W., and Bradley, D. J., 1977. Annual report on the characteristics of high-level waste glasses: BNWL-2252, Battelle, Pacific Northwest Laboratory, Richland, Washington, $99 \mathrm{p}$. 
Mitche11, J.K., 1976, Fundamentals of soil behavior: Wiley and Sons, New York, New York, 422 p.

Miyashiro, A., 1973, Metamorphism and metamorphic belts: Halsted Press, John Wiley and Sons, New York, New York.

Morris, J.C. and Stumm, W. L., 1967, Redox equilibria and measurement of potentials in the aquatic environment, in Equilibrium concept in natural water systems: Advances in Chemistry Series Ho. 67. American Chemical Society, Washington, D.C.

Mumpton, F. A. and Roy, R., 1961, Hydrothermal stability of the zirconthorite group: Geochimica et Cosmochimica Acta, v. 21, p. 217-238.

Myers, C. W. 1973, Yakima Basalt flows near Vantage, and from core holes in the Pasco Basin, Washington: Ph.D. thesis, University of California at Santa Cruz, Santa Cruz, California.

Myers, C. W., Price, S. M., Caggiano, J. A., Cochran, M. P., Czimer, W. J., Davidson, N. J., Edwards, R. C., Fecht, K. R., Holmes, G. E., Jones, M. G., Kunk, J. R., Landon, R. D., Ledgerwood, R. K., Lillie, J. T., Long, P. E., Mitche11, T.H., Price, E. H., Reidel, S. P., and Tallman, A. M., 1979, Geologic studies of the Columbia Plateau: a status report: RHO-BWI-ST-4, Rockwell Hanford Operations, Richland, Washington.

NAE and NAS, 1979, Solidification of high-level radioactive wastes: NUREG/CR-0895, National Academy of Engineering and National Academy of Sciences, Washington, D.C., 250 p.

Neretnieks, I., 1977, Retardation of escaping nuclides from a final reposi. tory: KBS Technical Report No. 30, Swedish Nuclear Fuel Safety Project, AB Atomenergi, Stockholm, Sweden.

Neretnieks, I., 1978, Transport of oxidants and radionuclides through a clay barrier: KBS Technical Report No. 27. Swedish iluclear Fuel Safety Project, AB Atomenergi, Stockhoim, Sweden. 
Newcomb, R. C., 1969, The Columbia River group: Its tectonic structure in Washington, Oregon, and Idaho: in Gilmour, E. H. and Stradiing, D., eds., Proceedings of the Second Columbia River Basalt Symposium, Eastern Washington State College Press. Cheney, Washington, p. 173-175.

Newcomb, R. C., 1972, Quality of the ground water in basalt of the Columbia River group, Washington, Oregon and Idaho: U.S. Geological Survey WaterSupply Paper 1999-N.

Nowak, E. J., 1979, The backfill as an engineered barrier for nuclear waste management: in Proceedings, the Materials Research Society's International Symposium on the Scientific Basis for Nuclear Waste Management, Boston, Massachusetts.

NRC, 1979a, Standards for protection against radiation: 10 CFR 20, Code of Federal Regulations, U.S. Nuclear Regulatory Commission, Washington, D.C.

NRC, $1979 \mathrm{~b}$, Policy relating to the siting of fuel reprocessing plants and related waste management facilities - domestic licensing of production and utilization facilities: 10 CFR 50, Code of Federal Regulations, U.S. Nuclear Regulatory Commission, Washington, D.C.

NRC, 1980, Disposal of high-level radioactive wastes in geologic repositories - performance objectives and technical criteria: 10 CFR 60 (Draft 7), Code of Federal Regulations, U.S. Nuclear Regulatory Commission, Washington, D.C.

Obert, L. and Duva11, W. I., 1967, Rock mechanics and the design of structures in rock: John Wiley and Sons, Inc., New York, New York.

O'Boyle, D. R., Brown, F. L., and Sanecki, J. E., 1969, Solid fission product behavior in uranium-plutonium oxide fuel irradiated in a fast neutron flux: Journal of Nuclear Materials, v. 29, p. 27-42. 
0i, N. and Naito, K., 1964, Relocation of fission products and Pu in irradiated $\mathrm{UO}_{2}$ pellets: Nuclear Science Technology, v. 2, p. 284.

01 ander, D. R., 1976, Fundamental aspects of nuclear reactor fuel elements: TID-26711, U.S. Energy Research and Development Administration, Washington, D.C., V. 1, 613 p.

ONWI, 1979, Criteria for the geological disposal of nuclear wastes interim waste package performance and acceptance criteria: ONWI-33(3) (Draft), Office of Nuclear Waste Isolation, Battelle Columbus Laboratories, Columbus, Ohio, July 1979.

Pabst, A., 1952, The metamict state: American Mineralogist, v. 37, p. $137-152$.

Packer, D. R. and Petty, M. H., Woodward-Clyde Consultants, 1979, Magnetostratigraphy of the Grande Ronde Basalt, Pasco Basin, Washington: RHO-BWI-C-46, Rockwe 11 Hanford Operations, Richland, Washington.

Pareto, V., 1897, Cours d'Economie Politique: Rouge, Lausanne, France, 2 volumes.

Patton, N. E., Hickman, B. S., and Leslie, D. H., 1971, Behavior of hydrogen in $\alpha$-phase Ti-Al alloys: Metallurgical Transactions, v. 2, p. 2791-2796.

Pettersson, K., 1977, Calculation of the risk of delayed failure for titanium, in Study of suitability of titanium as a corrosion-resistant cladding for nuclear fuel waste by Henriksson, S.: KBS-11. Swedish Nuclear Fuel Safety Project, AB Atomenergi, Stockholm, Sweden.

Poncelet, C. G., 1965, Burnup physics of heterogeneous reactor lattices: WCAP-606, Westinghouse Atomic Power Division, Pittsburgh, Pennsylvania, $173 p$. 
Price, S. M., 1974, A geochemical classification of dikes of the Grande Ronde swarm, Columbia River basalt: ARH-SA-202, Atlantic Richfield Hanford Company, Richland, Washington.

Price, S. M., 1977, An evaluation of dike-flow correlations indicated by geochemistry, Chief Joseph dike swarm, Columbia River basalt: Ph.D. thesis, University of Idaho, Moscow, Idaho.

Price, S. M., 1978, An evaluation of dike-flow correlations indicated by geochemistry, Chief Joseph swarm, Columbia River basalt: RHO-SA-59, Rockwell Hanford Operations, Richland, Washington.

Pusch, R., 1979, Highly compacted sodium bentonite for isolating rockdeposited radioactive waste products: Nuclear Technology, $v .45$, p. $153-157$.

Rankin, W. N., 1979, Canister compatibility with Carlsbad salt: in Proceedings, the Materials Research Society's International Symposium on Scientific Basis for Nuclear Waste Management, Boston, Massachusetts.

Raymond, J.R. and Tillson, D. D., 1968, Evaluation of a thick basalt sequence in south-central Washington: geophysical and hydrological exploration on the Rattlesnake Hills deep stratigraphic test well: BNWL-776, Battelle, Pacific Northwest Laboratory, Richland, Washington, 126 p.

Reidel, S. P., 1978, Stratigraphy and petrogenesis of the Grande Ronde Basalt in the lower Salmon and Adjacent Snake River Canyons: RHO-SA-62, Rockwell Hanford Operations, Richland, Washington.

Relyea, J.F. and Serne, R. J., 1979, Controlled sample program publication number 2: interlaboratory comparison of batch $K_{d}$ values: PNL-2872, Pacific Northwest Laboratory, Richland, Washington. 
Rich, R. A., Holland, H. D., and Peterson, U., 1977, Hydrothermal uranium deposits: Elsevier, Amsterdam, The Netherlands.

Ringwood, A. E., 1978, Safe disposal of high-level nuclear reactor wastes: A new strategy: Australian National University Press, Canberra, Australia, $63 \mathrm{p}$.

Ringwood, A. E., Kesson, S. E., Ware, N. G., Hibberson, W., and Major, A., 1979, Immobilization of high-Tevel nuclear reactor wastes in SYNROC: Nature, v. 278, p. 219-223.

Robie, R. A., Hemingway, B. S., and Fisher, J. R., 1978, Thermodynamic properties of minerals and related substances at 298.15K and 1 bar and at higher temperatures: Geological Society of America Bulletin no. 1452.

Ross, W. A., Bradley, D. J., Bunnel, L. R., Gray, W. J., Katayama, Y. B., Mellinger, G. B., Mendel, J. E., Roberts, F. P., Turcotte, R. P., Wa1d, J. W., Weber, W. E., and Westsik, J. H., Jr., 1978, Annual report on the characterization of high-level waste glasses: PNL-2625, Pacific Northwest Laboratory, Richland, Washington, $55 \mathrm{p}$.

Ross, W. A. and Mende1, J. E., 1979, Annual report on the development and characterization of solidified forms for high-level wastes: PNL -3060 , Pacific Northwest Laboratory, Richland, Washington, 89 p.

Ross, W. A., Turcotte, R. P., Mende], J. E., and Rusin, J. M., 1979, A comparison of glass and crystalline waste materials: PNL-SA-7530, Pacific Northwest Laboratory, Richland, Washington.

Routson, R. C., 1973, A review of studies on soil-waste relationships on the Hanford Reservation from 1944-1967: BNWL-1464, Battelle, Pacific Northwest Laboratory, Richland, Washington. 
Roy, D. M. and White, W. B., 1975, Borehole plugging by hydrothermal transport, a feasibility report: ORNL/SUB-4091/1, The Materials Research Laboratory, The Pennsylvania State University, University Park, Pennsylvania, $252 p$.

Roy, D. M., White, W. B., Grutzeck, M. W., Sweet, J. R., and Oyefesobi, D., 1975, Borehole plugging by hydrothermal transport, an interim report on experimental studies: ORNL/SUB-4091/2, the Materials Research Laboratory, The Pennsylvania State University, University Park, Pennsylvania, $95 \mathrm{p}$.

Roy, D. M., White, W. B., Grutzeck, M. W., Sweet, J. R., and Oyefesobi, D., 1976a, Borehole plugging by hydrothermal transport, final report: ORNL/SUB-4091/3, The Materials Research Laboratory, The Pennsylvania State University, University Park, Pennsylvania, $78 p$.

Roy, D. M., White, E. L., Langton, C. A., and Zimmerman, K. G., 1976b, Hydrated calcium aluminosilicate cements for hydrothermal bonding, in Cement and concrete research, v. 8: Pergamon Press, New York, New York, p. 509-512.

Rusin, J. M., 1980, A review of glass-ceramic waste forms: in Proceedings, Aiternate Nuclear Waste Forms and Interactions in Geologic Media--a Workshop, May 13-15, Gatlinberg, Tennessee.

Rusin, J. M., Lokken, R. O., Lukacs, J. M., Sump, K. R., Browning, M. F., and McCarthy, G. J., 1978, Muttibarrier waste forms part I, development: PNL-2668-1, Pacific Northwest Laboratory, Richland, Washington.

Rusin, J. M., Gray, W. J., and Wald, J. W., 1979, Multibarrier waste forms part II, characterization and evaluation: PNL-2668-2, Pacific Northwest Laboratory, Richland, Washington.

Russe11, I. C., 1903, A geological reconnaissance in central Washington: U.S. Geological Survey Bulletin No. 108. 
Sari, C., Walker, C. T., and Schumacher, G., 1979, Solubility and migration of Ba in oxide fuel: Journal of Nuclear Materials, v. 79, p. 244-259.

Schmincke, H. V., 1964, Petrology, paleocurrents and interbedded Yakima Basalt flows, south-central Washington: Ph.D. thesis, The John Hopkins University, Baltimore, Maryland.

Schneider, K. J., and Platt, A. M., 1974, High-level waste management alternative, V. 1: BNWL-1900, Battelle, Pacific Northwest Laboratory, Richland, Washington.

Schwartz, C.W. and Einstein, H. H., 1978, Improvement of ground support performance by full consideration of ground displacements: Transportation Research Record No. 684, Transportation Research Board, National Academy of Sciences, Washington, D.C., P. 14-20.

Seitz, M. G., Rickert, P. G., Fried, S.M., Friedman, A. M.s and Steindler, M. J., 1978, Studies of nuclear-waste migration in geologic media, annual report. November 1979-0ctober 1977: ANL-78-8, Argonne National Laboratory, Argonne, I17inois.

Seitz, M. G., Rickert, P.G., Fried, S. M., Friedman, A. M., and Steindler, M. J., 1979, Transport of radionuclides in geologic media-annual report: ANL-79-30, Argonne National Laboratory, Argonne, I11 inois.

Sergergeva, E. I., Nikitin, A. A., Khodakovskiy, I. L., and Naumov, G. B., 1972. Experimental investigation of equilibira in the system $\mathrm{UO}_{3}-\mathrm{CO}_{2}-\mathrm{H}_{2} \mathrm{O}$ in $25-200^{\circ} \mathrm{C}$ temperature interva 1: Geochemistry International, $v .9$, p. $900-910$.

Shannon, D. W., 1977, Geochemical engineering program - progress report for the period ending December 1977: PNL-2736, Pacific Northwest Laboratory, Richland, Washington. 
Siever, R. and Woodford, N., 1979, Dissolution kinetics and the weathering of mafic minerals: Geochimica et Cosmochimica Acta, v. 43, p. 717-724.

Skempton, A. W., 1953, The colloidal "activity" of clay: in Proceedings of the third International Conference of Soil Mechanics, Part 1, p. 55-61.

Slate, S. C. and Maness, R. F., 1978, Corrosion experience in nuclear waste processing at Battelle-Northwest: Materials Performance, v. 17, 13-21.

Smith, G. 0., 1901, Geology and water resources of a portion of Yakima County, Washington: U.S. Geological Survey Water-Supply Paper No. 55.

Smith, G. 0., 1903, Geology and physiography of central Washington: U.S. Geological Survey Professional Paper No. 19.

Smith, R. M. and Martel1, A. E., 1976, Critical stability constants. v. 4: Inorganic complexes: Plenum Press, New York, New York.

Sofer, G. A. and Woods, K. N., 1979, Nondestructive examination of Exxon nuclear fuel in LWR reactors: in Proceedings, the American Nuclear Society Topical Meeting on LWR Fuel Performance, Portiand, Oregon, American Nuclear Society, Chicago, Illinois, p. 39-48.

Stobbs, J. J. and Swallow, A. J., 1962, Effects of radiation on metallic corrosion: Metallurgic Reviews, v. 7, no. 25.

Strickert, R., Friedman, A. M., and Fried, S., 1978, The sorption of technetium and iodine radioisotopes by various minerals: Transcripts, American Nuclear Society, v. 28, p. 365-366.

Summers, W. K. and Deju, R. A., 1974, Final report: A preliminary review of the regional hydrology of the Hanford Reservation: ARH-C-5, Atlantic Richfield Hanford Company, Richland, Washington. 
Summers, W. K. and Schwab, G. E., 1978, Bib7iography of the geology and ground water of the basalts of the Pasco Basin, Washington: RHO-BWI-C-15, Rockwell Hanford Operations, Richland, Washington.

Summers, W. K. and Weber, P. A., 1978, Data for wells penetrating basalts in the Pasco Basin area, Washington: RHO-BWI-C-19, Rockwe 11 Hanford Operations, Richland, Washington.

Sundquist, J. D., 1979, Preliminary corrosion test of a glass-ceramic candidate for a nuclear waste canister, in Scientific basis for nuclear waste management, McCarthy, G. J., ed.: Plenum Press, New York, New York, p. 289-296.

Sutton, C. R. and Leeser, D. 0., 1954, Radiation effects in reactor materials: Nucleonics, v. 12, no. 9.

Swanson, D. A., 1967, Yakima Basalt of the Tieton River area, south-central Washington: Geological Society of America Bulletin no. 78, p. 1077-1110.

Swanson, D. A., Wright, T. L., Hooper, P. R., and Bentley, R. D., 1979, Revisions in stratigraphic nomenclature of the Columbia River Basalt Group: U.S. Geological Survey Bulletin 1457-H.

Ta11man, A. M., Fecht, K. R., Marratt, M. C. and Last, G. V., 1979, Geology of the separations area, Hanford Site, south-central Washington: RHO-ST-23, Rockwell Hanford Operations, Richland, Washington.

Tardy, Y. and Garrels, R. M., 1974, A method of estimating Gibbs free energies of formation of larger silicates: Geochimica et Cosmochimica Acta, v. 38, p. 1101-1116.

Tatman, J. B., 1972, Geochemical variation of Columbia River basalts beneath the Hanford Reservation, Washington: ARH-2610, Atlantic Richfield Hanford Company, Richland, Washington. 
Taylor, C. L., Anttonen, G. J., O'Rourke, J. E., and Niccum, M. R., Woodward-Clyde Consultants, 1979, Borehole plugging of man-made accessess to a basalt repository: A preliminary study: RHO-BWI-C-49, Rockwell Hanford Operations, Richland, Washington.

Thomas, E., 1962, Stabilization of rock by bolting: in Reviews in engineering geology - I, Flehr and Legget, eds., Geological Society of America, p. $257-280$.

Tillson, D. D., 1970, Analysis of crustal changes in the Columbia Plateau area from contemporary triangulation and leveling measurements: BNWL-CC-2174, Batte11e, Pacific Northwest Laboratory, Richland, Washington.

Timoshenko, S. and Goodier, J. N., 1951, Theory of elasticity: Second edition, McGraw-Hi11, New York, New York.

Todd, D. K., 1959, Ground water hydrology: John Wiley and Sons, Inc., New York, New York.

Tonnessen, K. A. and Cohen, J. J., 1977, Survey of naturally occurring hazardous materials in deep geologic formations: A perspective on the relative hazard of deep burial of nuclear wastes: UCRL-52100, Lawrence Livermore Laboratory, Livermore, California.

Turcotte, R. P. and Wa1d, J.W., 1978, Devitrification behavior in a zinc borosilicate nuclear waste glass: PNL-2247, Pacific Northwest Laboratory, Richland, Washington.

U.S. Army Corps of Engineers, 1978, Handbook for Concrete and Cement (2 volumes): Waterways Experiment Station, Vicksburg, Mississippi.

Voss, J. W., 1979, Safety indices and their application to nuclear waste management safety assessment: PNL-2727, Pacific Northwest Laboratory, Richland, Washington, $67 \mathrm{p}$. 
Wald, J. W. and Westsik, J.H., 1979, Devitrification and leaching effects in HLW glass - comparison of simulated and fully radioactive waste glass, in Proceedings of an international symposium on ceramics in nuclear waste management, Chikalla, T. D. and Mendel, J. E., eds.: CoNF-790420, U.S. Department of Energy, Washington, D.C.

Ward, A. W., Jr., 1976, Petrology and chemistry of the Huntzinger Flow, Columbia River basalt, Washington: ARH-SA-272, Atlantic Richfield Hanford Company, Richland, Washington.

Waring, G. A., 1913, Geology and water resources of a portion of southcentral Washington: U.S. Geological Survey Water-Supply Paper No. 316.

Waters, A. C., 1961, Stratigraphic and 7ithologic variations in the Columbia River basalt: American Journal of Science, v. 259, p. 583-611.

Weaver, C. E., 1979, Geothermal alteration of clay minerals and shales: diagenesis: ONWI-21, Office of Nuclear Waste Isolation, Columbus, Ohio.

Westerman, R. E., 1979, Preliminary conceptual designs for advanced packages for the geologic disposal of spent fuel: PNL-2990, Pacific Northwest Laboratory, Richland, Washington.

Westsik, J. H. and Turcotte, R. P., 1978, Hydrothermal reactions of nuclear. waste solids - a preliminary report: PNL-2759, Pacific Northwest Laboratory, Richland, Washington.

Winkler, H. G. F., 1974, Petrogenes is of metamorphic rocks: Springer-Verlag, New York, New York.

Wolfsberg, K., Bayhurst, B. F., Crowe, B. M., Erda1, B. R., Lawrence, F. D., Norris, A. E., and Smyth, J. A., 1979, Sorption-desorption studies on Tuff 1. Initial studies with samples from the J-13 drill site, Jackass Flats, Nevada: LA-7480-MS, Los Alamos Scientific Laboratory, Los Alamos, New Mexico. 
Wolery, T., 1979, Calculation of chemical equilibrium between aqueous solution and minerals: The EQ3/6 software package: UCRL-52658, Lawrence Livermore Laboratory, Livermore, California.

Woodward-Clyde Consultants, 1977, Preliminary geologic site selection factors for the NWTS program: Y/OWI/SUB-76-16531/1, Union Carbide Corporation, Division Office of Waste Isolation, Oak Ridge, Tennessee, p. 39.

Wright, T. L., Grolier, M. J., and Swanson, D. A., 1973, Chemical variations related to the stratigraphy of the Columbia River basalt: Geological Society of America Bulletin no. 84, p. 371-386.

Wu, C. S., 1978, Sensitization, intergranular attack, stress corrosion cracking, and irradiation effects on the corrosion of iron-chromium-nicke] alloys: ORNL/TM-6311, Oak Ridge National Laboratory, Oak Ridge, Tennessee.

Wyble, D. 0., 1958, Effect of applied pressure on the conductivity, porosity, and permeability of sandstones: Petroleum Transactions, AIME, v. 213, p. 430-432.

Zeleriy, M., 1973, Compromise programming, in Multiple criteria decision making, Cochrane, J. L. and Zeleny, M., eds.: University of South Carolina Press, Columbia, South Carolina, p. 262-301. 